\title{
Focused Feasibility Study for Surface Soil at the Main Pits and Pushout Area, J-Field Toxic Burning Pits Area, Aberdeen Proving Ground, Maryland
}

\author{
IIso \\ $9661809 \cap \mathrm{NH}$ \\ वᄏ1190习习
}

Environmental Assessment Division

Argonne National Laboratory

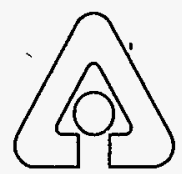

Operated by The University of Chicago, under Contract W-31-109-Eng-38, for the 


\section{Argonne National Laboratory}

Argonne National Laboratory, with facilities in the states of Illinois and Idaho, is owned by the United States Government, and operated by the University of Chicago' under the provisions of a contract with the Department of Energy.

- This technical memo is a product of Argonne's Énvirónmental A'ssessment Division (EAD). For information on the division's scientific and engineering activities, contact:

Director, Environmental Assesșment Division

Argonne National Laboratory

Argonne, Illinois 60439-4815

Telephone (708) 252-3107

Presented in this technical memo are preliminary results of ongoing work or work that is more limited in scope and depth than that described in formal reports issued by the EÁD.

-Publishing support services were provided by Argonne's Information and Publishing Divișion (for more information, see IPD's home page: http:/(www.ipd.anl.gov/).

\section{Disclaimer}

This report was prepared as an account of wōk sponsored by an agency of. the United States Government. Neither the United States Government nor any agency thereof, nor any, of their employees, makes any warranty, express or implied, or assumes any legal liability or responsibility for the accuracy, completenesss, or usefulness of any information, apparatus, product, or process disclosed, or, represents that its use would not infringe privately owned rights. Reference herein to any specific commercial product, process, or.service by trade name, trademark, manufacturer, or otherwise, does not necessarily constitute or imply its endorsement, recommendation, or favoring by the United States Government or any agency thereof. The views and opinions of authors.expressed herein do not necessarily state or reflect those of the United Siates Government or any agency thereof.

Reproduced directly from the best available copy. Available to DOE and DOE contractors from the Office of Scientific and Technical Information, P.O. Box 62, Oaḱ Ridge, TN 37831; prices available from (423) $576-8401$

Available to the public from the National Technical Information Senvice, U.S. Department of Commerce, 5285 Port Royal Road, Springfield, VA 22161. 


\section{Focused Feasibility Study for Surface Soil at the Main Pits and Pushout Area, J-Field Toxic Burning Pits Area, Aberdeen Proving Ground, Maryland}

by

T. Patton, P. Benioff, C. Biang, J. Butler, W. Davies, R. Haffenden, J. Hayse, I. Hlohowskyj, L. Martino, L. Poch, E. Portante, J. Quinn, C.-Y. Yuen, Y.-Y. Wang, and G. Williams

Environmental Assessment Division,

Argonne National Laboratory, 9700 South Cass Avenue, Argonne, Illinois 60439

June 1996

Work sponsored by U.S. Army Aberdeen Proving Ground, Directorate of Safety, Health, and Environment 
This report is printed on recycled paper. 


\section{DISCLAIMER}

Portions of this document may be illegible in electronic image products. Images are produced from the best available original document. 



\section{CONTENTS}

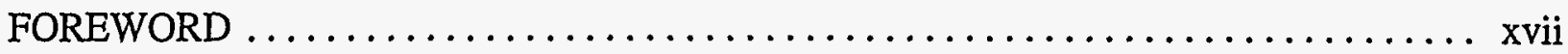

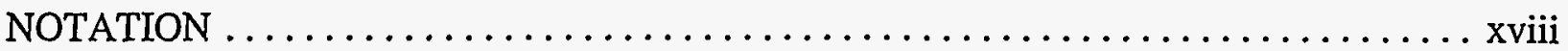

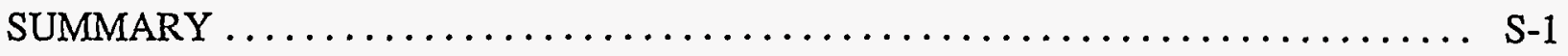

S.1 Introduction $\ldots \ldots \ldots \ldots \ldots \ldots \ldots \ldots \ldots \ldots \ldots \ldots \ldots \ldots \ldots \ldots$, S -1

S.2 Focused Feasibility Study Approach $\ldots \ldots \ldots \ldots \ldots \ldots \ldots \ldots \ldots \ldots \ldots \ldots$, S-2

S.3 Interim Remedial Action Objectives $\ldots \ldots \ldots \ldots \ldots \ldots \ldots \ldots \ldots \ldots \ldots$, S-2

S.3.1 Objectives and Scope $\ldots \ldots \ldots \ldots \ldots \ldots \ldots \ldots \ldots \ldots \ldots \ldots \ldots \ldots \ldots \ldots \ldots \ldots, 2$

S.3.2 Preliminary Remediation Goals $\ldots \ldots \ldots \ldots \ldots \ldots \ldots \ldots \ldots \ldots$ S -3

S.4 Potentially Applicable Technologies $\ldots \ldots \ldots \ldots \ldots \ldots \ldots \ldots \ldots \ldots \ldots \ldots$ S-4

S.5 Description of Alternatives $\ldots \ldots \ldots \ldots \ldots \ldots \ldots \ldots \ldots \ldots \ldots \ldots \ldots \ldots \ldots, \mathrm{S}-4$

S.5.1 Alternative 1: No Action ......................... S-7

S.5.2 Alternative 2: Limited Removal and Disposal, and In-Situ Containment .... S-7

S.5.3 Alternative 3: Removal and Short-Term Storage ............... S-7

S.5.4 Alternative 4: Removal, On-Site Treatment, and Limited Disposal ........ S-8

S.5.5 Alternative 5: Removal, Off-Site Treatment, and Disposal ........... S-8

S.6 Identification of Final Alternatives $\ldots \ldots \ldots \ldots \ldots \ldots \ldots \ldots \ldots \ldots \ldots$ S 8

S.7 Evaluation Summary and Comparative Analysis $\ldots \ldots \ldots \ldots \ldots \ldots \ldots \ldots$ S -9

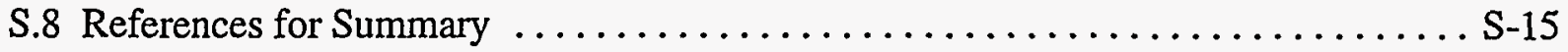

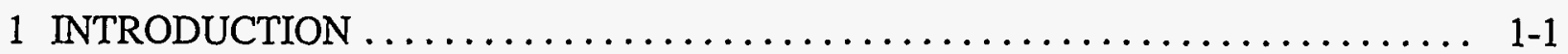

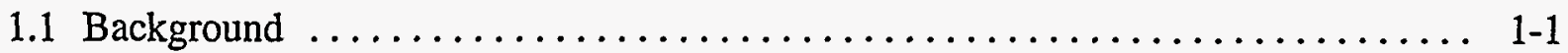

1.2 Purpose of this Report $\ldots \ldots \ldots \ldots \ldots \ldots \ldots \ldots \ldots \ldots \ldots \ldots \ldots \ldots \ldots \ldots \ldots \ldots \ldots \ldots \ldots \ldots, 1-1$

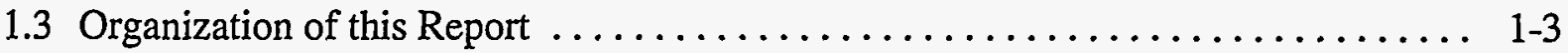

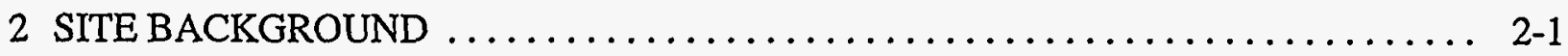

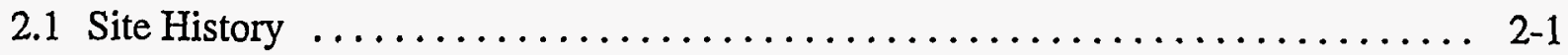

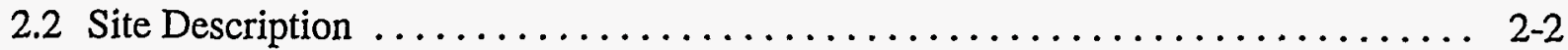

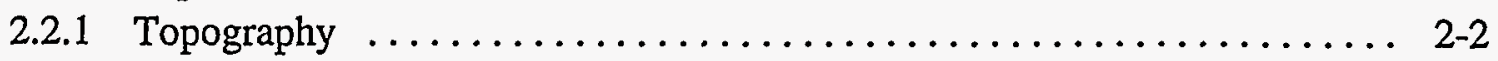

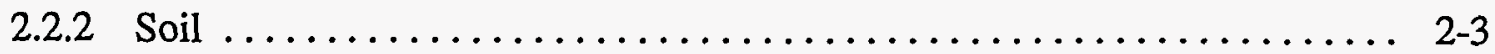

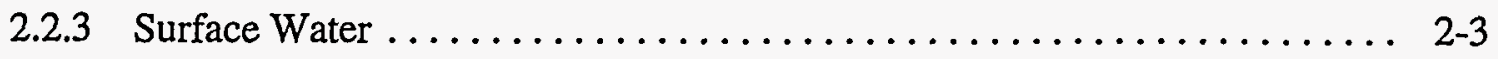

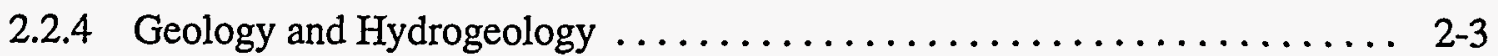

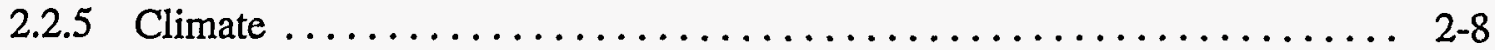

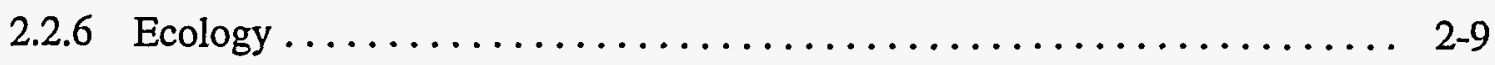

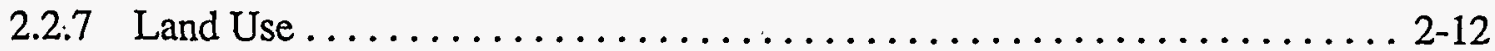

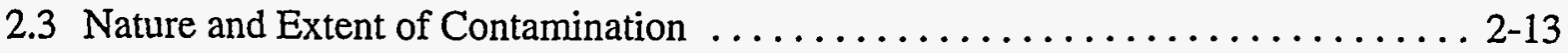

2.3 .1 Soil $\ldots \ldots \ldots \ldots \ldots \ldots \ldots \ldots \ldots \ldots \ldots \ldots \ldots \ldots \ldots \ldots \ldots \ldots \ldots \ldots \ldots \ldots \ldots, 2-13$ 


\section{CONTENTS (Cont.)}

2.3.2 Groundwater .............................. 2-19

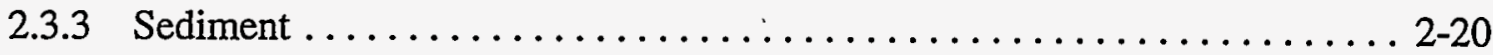

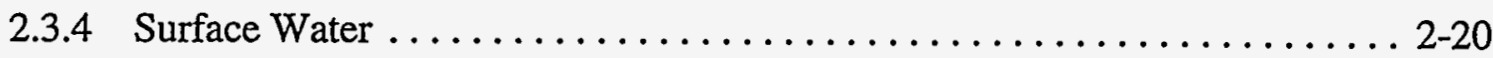

2.4 Contamination Sources and Release Mechanisms . . . . . . . . . . . . 2-20

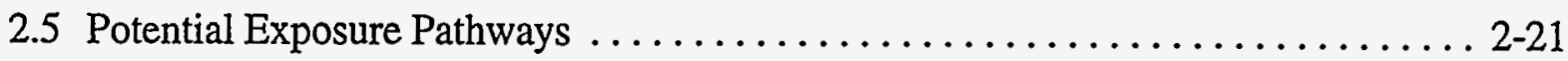

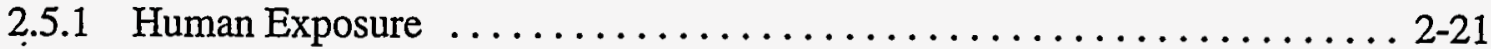

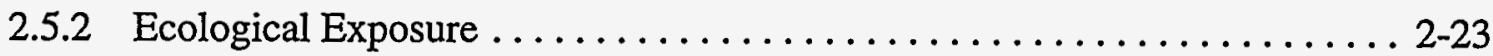

2.6 Contaminants of Concern . . . . . . . . . . . . . . . . . . . . . . 2-23

2.6.1 Human Health Contaminants of Concern ................. 2-23

2.6.2 Contaminants of Ecological Concern ................... 2-27

2.7 Concurrent Studies . . . . . . . . . . . . . . . . . . . . . . . . . . . . . 2-29

2.7.1 Remedial Investigation ........................... 2-29

2.7.2 Human Health Risk Assessment ...................... 2-30

2.7 .3 Ecological Risk Assessment . . . . . . . . . . . . . . . . . 2-30

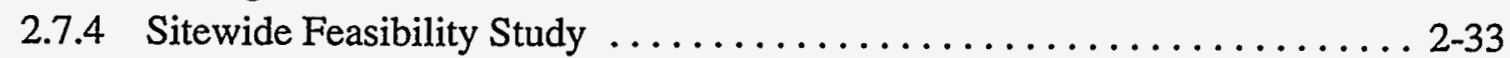

3 INTERIM REMEDIAL ACTION OBJECTIVES . . . . . . . . . . . . . 3-1

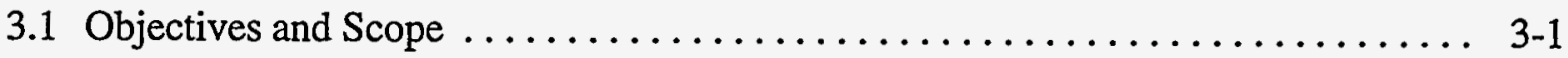

3.2 Compliance with Regulatory Requirements . . . . . . . . . . . . . . . . . . 3-3

3.3 Interim Preliminary Remediation Goals . . . . . . . . . . . . . . . . 3-7

4 IDENTIFICATION AND SCREENING OF TECHNOLOGIES . . . . . . . . . 4-1

4.1 Criteria for Identifying and Screening Technologies $\ldots \ldots \ldots \ldots \ldots \ldots \ldots \ldots$. . . .

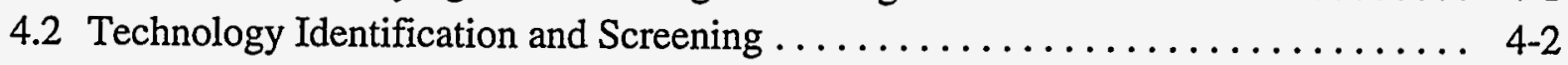

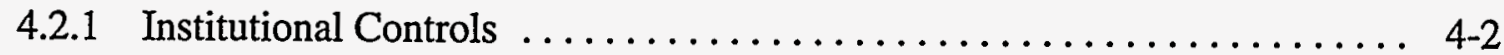

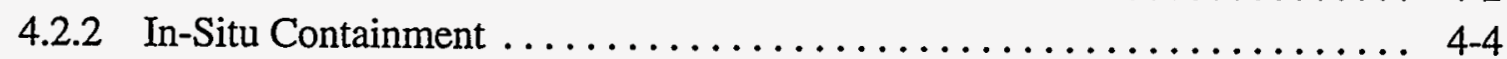

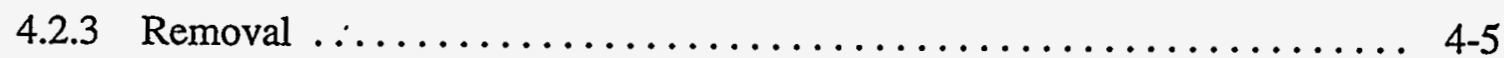

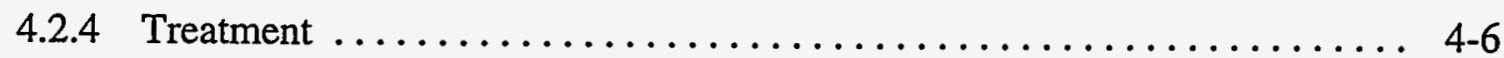

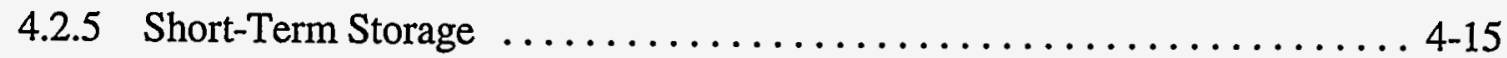

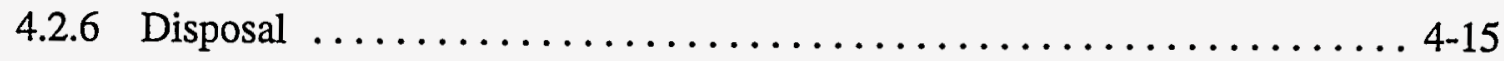

4.3 Potentially Applicable Technologies $\ldots \ldots \ldots \ldots \ldots \ldots \ldots \ldots \ldots \ldots \ldots$. . . . . . . .

5 DEVELOPMENT AND SCREENING OF PRELIMINARY

ALTERNATIVES $\ldots \ldots \ldots \ldots \ldots \ldots \ldots \ldots \ldots \ldots \ldots \ldots \ldots \ldots \ldots \ldots \ldots \ldots \ldots$

5.1 Criteria for Developing Alternatives $\ldots \ldots \ldots \ldots \ldots \ldots \ldots \ldots \ldots \ldots \ldots \ldots$

5.2 Identification of Preliminary Alternatives $\ldots \ldots \ldots \ldots \ldots \ldots \ldots \ldots \ldots \ldots \ldots$ 


\section{CONTENTS (Cont.)}

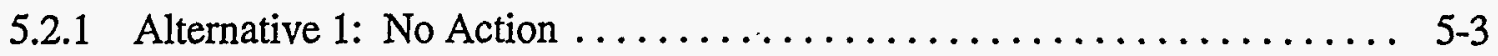

5.2.2 Alternative 2: Limited Removal and Disposal,

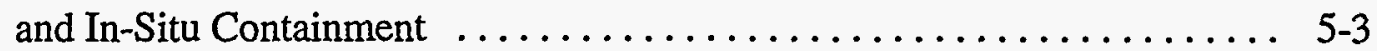

5.2.3 Alternative 3: Removal and Short-Term Storage ............. 5-3

5.2.4 Alternative 4: Removal, On-Site Treatment, and

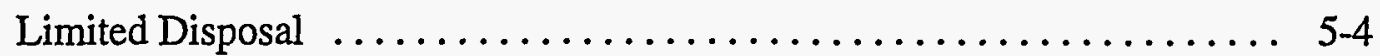

5.2.5 Alternative 5: Removal, Off-Site Treatment, and Disposal ......... 5-4

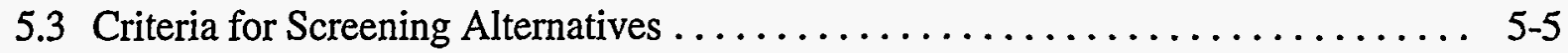

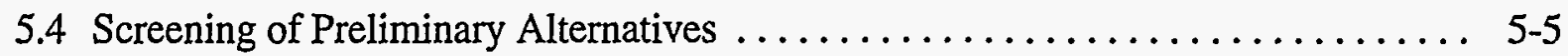

5.4.1 Alternative 1: No Action $\ldots \ldots \ldots \ldots \ldots \ldots \ldots \ldots \ldots \ldots \ldots \ldots \ldots, 5-5$

5.4.2 Alternative 2: Limited Removal and Disposal,

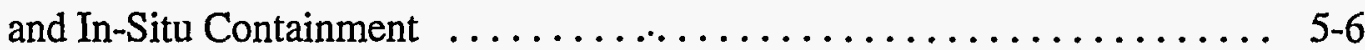

5.4.3 Alternative 3: Removal and Short-Term Storage ............. 5-7

5.4.4 Alternative 4: Removal, On-Site Treatment, and

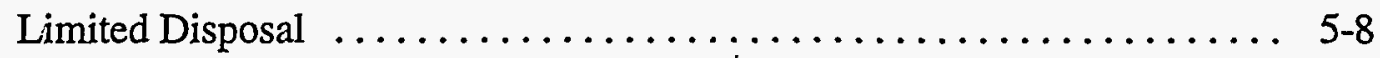

5.4.5 Alternative 5: Removal, Off-Site Treatment, and Disposal ......... 5-10

5.5 Screening Summary and Identification of Final Alternatives $\ldots \ldots \ldots \ldots \ldots .5-11$

6 DESCRIPTION OF FINAL ALTERNATIVES $\ldots \ldots \ldots \ldots \ldots \ldots \ldots \ldots \ldots . \ldots \ldots$

6.1 Alternative 1 : No Action $\ldots \ldots \ldots \ldots \ldots \ldots \ldots \ldots \ldots \ldots \ldots \ldots \ldots \ldots, 6.1$

6.2 Alternative 2: Limited Removal and Disposal, and In-Situ Containment ....... 6-2

6.2 .1 Limited Removal $\ldots \ldots \ldots \ldots \ldots \ldots \ldots \ldots \ldots \ldots \ldots \ldots, 6.2$

6.2 .2 Disposal $\ldots \ldots \ldots \ldots \ldots \ldots \ldots \ldots \ldots \ldots \ldots \ldots \ldots \ldots \ldots \ldots \ldots \ldots, 6,4$

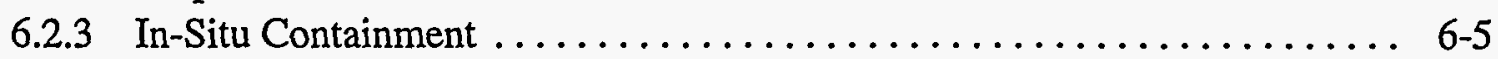

6.2 .4 Shoreline Stabilization $\ldots \ldots \ldots \ldots \ldots \ldots \ldots \ldots \ldots \ldots \ldots \ldots \ldots, 6,5$

6.3 Alternative 3: Removal and Short-Term Storage $\ldots \ldots \ldots \ldots \ldots \ldots \ldots \ldots$ 6.6. 6

6.3 .1 Removal .................................. $6-6$

6.3.2 Storage Facility Construction $\ldots \ldots \ldots \ldots \ldots \ldots \ldots \ldots \ldots \ldots \ldots, 6,8$

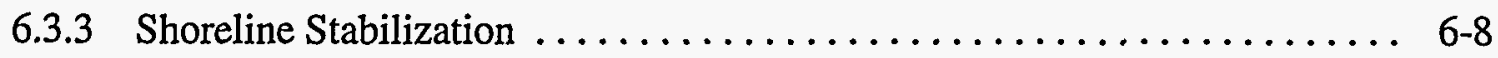

6.4 Alternative 4: Removal, On-Site Treatment, and Limited Disposal .......... 6-9

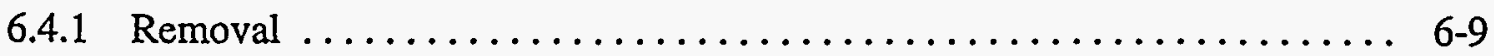

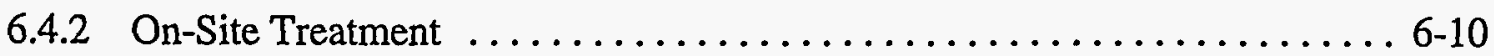

6.4.3 Limited Disposal ................................. 6-12

6.5 Alternative 5: Removal, Off-Site Treatment, and Disposal $\ldots \ldots \ldots \ldots \ldots \ldots$ 6-13

6.5 .1 Removal .................................... $6-13$

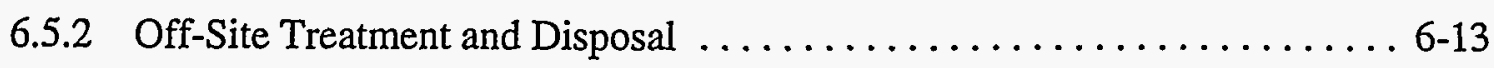




\section{CONTENTS (Cont.)}

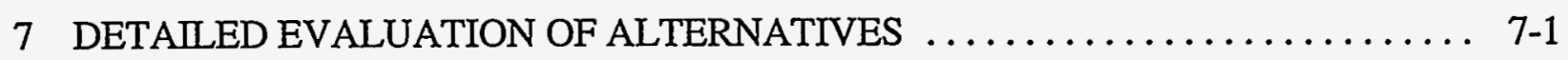

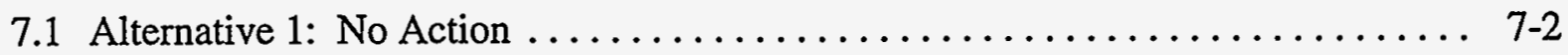

7.1.1 Overall Protection of Human Health and the Environment $\ldots \ldots \ldots \ldots \ldots$ 7-2

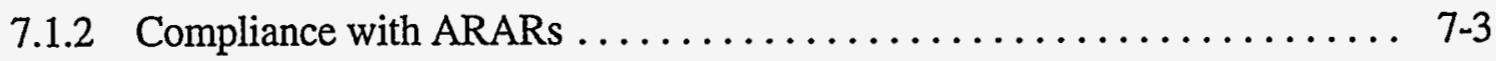

7.1.3 Long-Term Effectiveness and Permanence $\ldots \ldots \ldots \ldots \ldots \ldots \ldots \ldots \ldots$ 7-3

7.1 .4 Reduction of Toxicity, Mobility, or Volume ............... 7-4

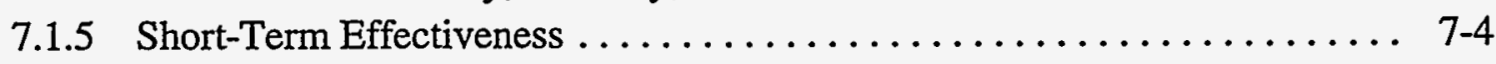

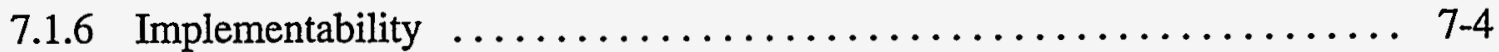

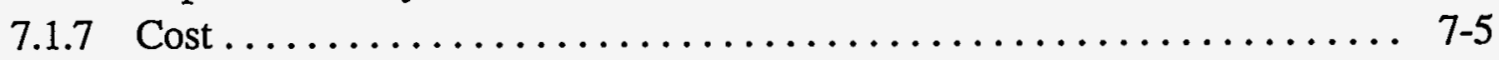

7.2 Alternative 2: Limited Removal and Disposal, and In-Situ Containment . . . . . 7-5

7.2.1 Overall Protection of Human Health and the Environment . . . . . . . . 7-5

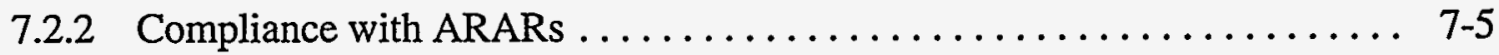

7.2.3 Long-Term Effectiveness and Permanence $\ldots \ldots \ldots \ldots \ldots \ldots \ldots \ldots$ 7-6

7.2.4 Reduction of Toxicity, Mobility, or Volume .............. 7-7

7.2 .5 Short-Term Effectiveness ........................ 7-7

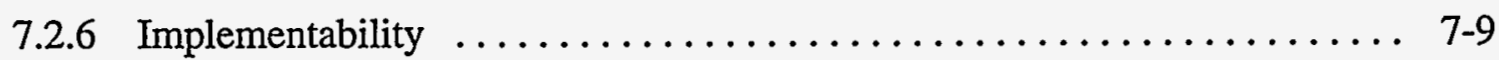

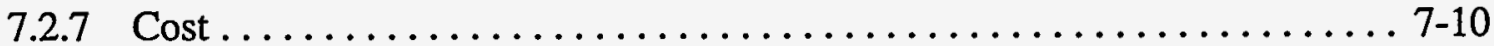

7.3 Alternative 3 : Removal and Short-Term Storage $\ldots \ldots \ldots \ldots \ldots \ldots \ldots \ldots$ 7-13

7.3.1 Overall Protection of Human Health and the Environment . . . . . . . 7-13

7.3 .2 Compliance with ARARs . . . . . . . . . . . . . . . . . $7-13$

7.3.3 Long-Term Effectiveness and Permanence ............... 7-14

7.3.4 Reduction of Toxicity, Mobility, or Volume . . . . . . . . . . . . 7-15

7.3.5 Short-Term Effectiveness . . . . . . . . . . . . . . . . . . $7-15$

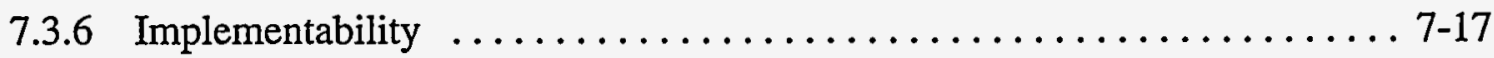

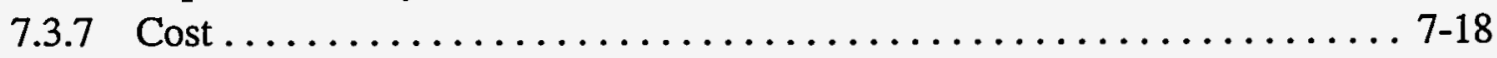

7.4 Alternative 4: Removal, On-Site Treatment, and Limited Disposal . . . . . . . . 7-21

7.4.1 Overall Protection of Human Health and the Environment . . . . . . . 7-21

7.4 .2 Compliance with ARARs ...................... 7-21

7.4.3 Long-Term Effectiveness and Permanence $\ldots \ldots \ldots \ldots \ldots \ldots \ldots \ldots \ldots .22$

7.4.4 Reduction of Toxicity, Mobility, or Volume . . . . . . . . . . . 7-23

7.4 .5 Short-Term Effectiveness . . . . . . . . . . . . . . . . . . 7-23

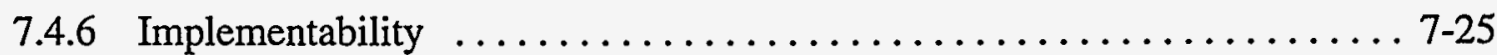

7.4 .7 Cost ................................... 7-26

7.5 Alternative 5: Removal, Off-Site Treatment, and Disposal . . . . . . . . . 7-28

7.5.1 Overall Protection of Human Health and the Environment . . . . . . . 7-28

7.5 .2 Compliance with ARARs . . . . . . . . . . . . . . . . . . $7-28$

7.5.3 Long-Term Effectiveness and Permanence . . . . . . . . . . . . . . . . 7-29

7.5.4 Reduction of Toxicity, Mobility, or Volume ............... 7-30 


\section{CONTENTS (Cont.)}

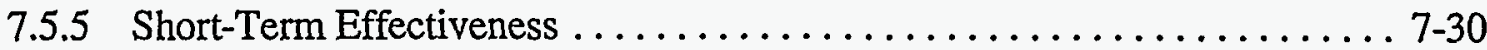

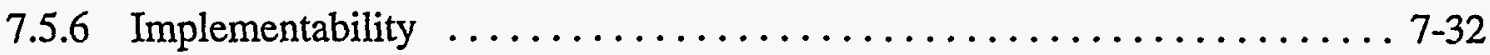

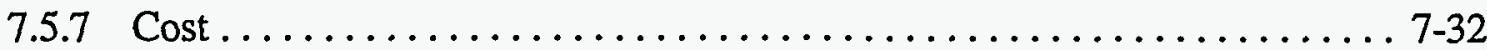

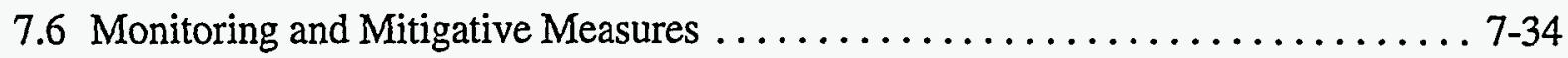

8 COMPARATIVE ANALYSIS OF ALTERNATIVES $\ldots \ldots \ldots \ldots \ldots \ldots \ldots, 8-1$

8.1 Threshold Criteria $\ldots \ldots \ldots \ldots \ldots \ldots \ldots \ldots \ldots \ldots \ldots \ldots \ldots \ldots \ldots . .6 .1$

8.1.1 Overall Protection of Human Health and the Environment .......... 8-1

8.1 .2 Compliance with ARARs ............................ 8 8

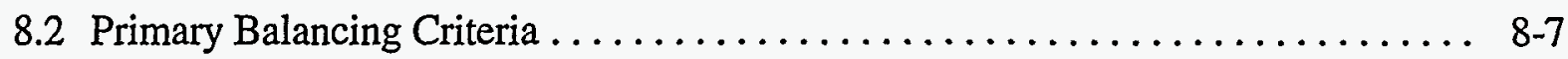

8.2.1 Long-Term Effectiveness and Permanence $\ldots \ldots \ldots \ldots \ldots \ldots \ldots \ldots$ 8-7

8.2 .2 Reduction of Toxicity, Mobility, or Volume ................ 8 $8-8$

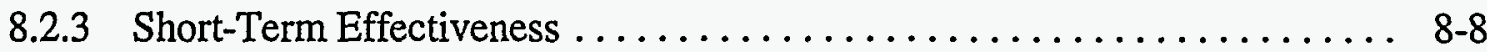

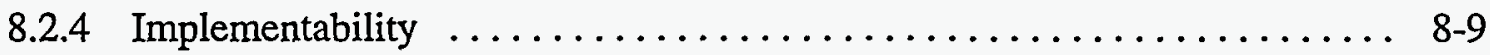

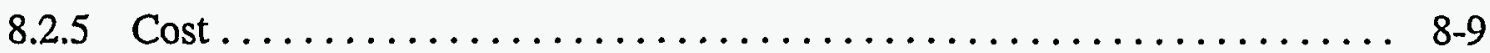

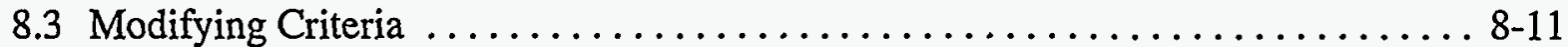

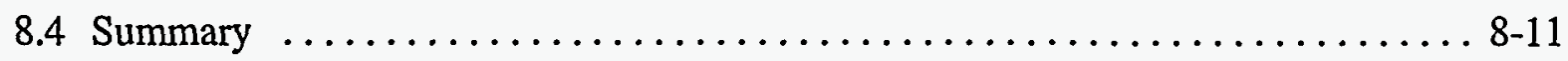

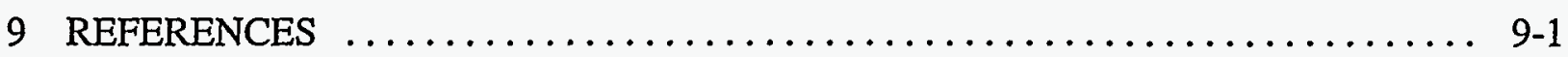

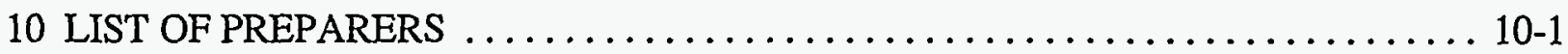

APPENDIX A: Vadose Zone Model of Metal Transport for the Toxic Burning

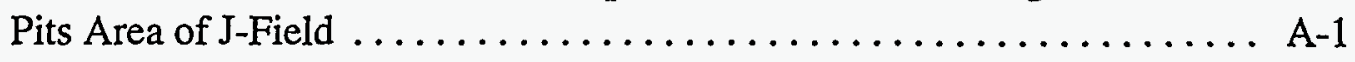

APPENDIX B: Applicable or Relevant and Appropriate Requirements ........... B-1

APPENDIX C: Sampling Data for the Toxic Burning Pits Area

January 1993 - June $1995 \ldots \ldots \ldots \ldots \ldots \ldots \ldots \ldots \ldots \ldots \ldots \ldots \ldots \ldots \ldots \ldots$

APPENDIX D: Characterization of the Toxic Burning Pits Area $\ldots \ldots \ldots \ldots \ldots \ldots$ D-1

APPENDIX E: Ecological Risk Assessment Modeling Methods $\ldots \ldots \ldots \ldots \ldots \ldots$ E-1

APPENDIX F: Determining Interim Remedial Action Costs $\ldots \ldots \ldots \ldots \ldots \ldots \ldots$ F-1

APPENDIX G: English/Metric — Metric/English Equivalents ............... G-1 


\section{TABLES}

S.1 Estimated Areas and Volumes of Contaminated Surface Soil at the Main Pits and Pushout Area

S.2 Risk-Based Interim Preliminary Remediation Goals for Surface Soil

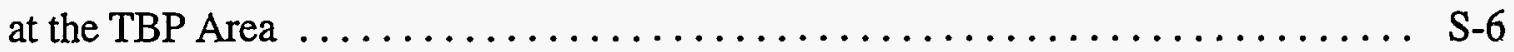

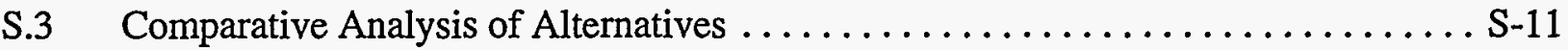

2.1 Bird Species of Special Federal and State Concern Reported at APG $\ldots \ldots \ldots \ldots$ 2-11

2.2 Mean and Maximum Background Soil Concentrations of Metals Reported for Off-Site Areas Surrounding APG

2.3 Potential Human Exposure Pathways at the TBP Area under Current Land-Use Conditions

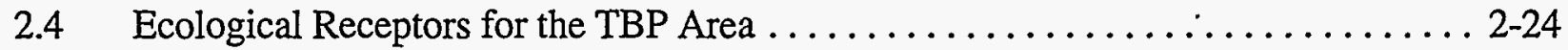

2.5 Identification of Human Health-Based Contaminants of Concern for Soil in the TBP Area $\ldots \ldots \ldots \ldots \ldots \ldots \ldots \ldots \ldots \ldots \ldots \ldots \ldots \ldots \ldots \ldots \ldots \ldots .25$

2.6 Contaminants of Ecological Concern for TBP Area Soils $\ldots \ldots \ldots \ldots \ldots \ldots \ldots$ 2-29

2.7 Identification of Preliminary Ecological Contaminants of Concern for the TBP Area

3.1 Estimated Areas and Volumes of Contaminated Surface Soil at the Main Pits and Pushout Area

3.2 Human Health-Based Interim Preliminary Remediation Goals for Surface Soil at the TBP Area ............................ 3-7

3.3 Ecological Effects Quotient Risk Estimates of Soil Contaminant Concentrations for Selectèd Ecological Receptors at the TBP Area

3.4 Estimated Surface Soil Contaminant Concentrations Necessary to Achieve a No-Effects Level for Selected Ecological Receptors that Use the TBP Area 


\section{TABLES (Cont.)}

3.5 Ecological Risk-Based Interim Preliminary Remediation Goals for Soils

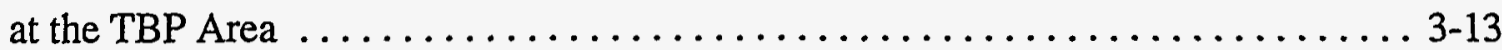

3.6 Risk-Based Interim Preliminary Remediation Goals for Surface Soil at the TBP Area $\ldots \ldots \ldots \ldots \ldots \ldots \ldots \ldots \ldots \ldots \ldots \ldots \ldots \ldots \ldots . \ldots \ldots \ldots .14$

4.1 Summary of Screening Analysis for Institutional Controls $\ldots \ldots \ldots \ldots \ldots \ldots$ 4-3

4.2 Summary of Screening Analysis for In-Situ Containment $\ldots \ldots \ldots \ldots \ldots \ldots$ 4-5

4.3 Summary of Screening Analysis for Removal $\ldots \ldots \ldots \ldots \ldots \ldots \ldots \ldots$ 4 6

4.4 Summary of Screening Analysis for In-Situ Treatment Technologies $\ldots \ldots \ldots \ldots$ 4-7

4.5 Summary of Screening Analysis for Ex-Situ Treatment Technologies . . . . . . . 4-10

4.6 Summary of Screening Analysis for Biological Treatment $\ldots \ldots \ldots \ldots \ldots \ldots \ldots$ 4-14

4.7 Summary of Screening Analysis for Short-Term Storage $\ldots \ldots \ldots \ldots \ldots \ldots \ldots$ 4-16

4.8 Summary of Screening Analysis for Disposal $\ldots \ldots \ldots \ldots \ldots \ldots \ldots \ldots \ldots \ldots, 4-17$

4.9 Summary of Potentially Applicable Technologies $\ldots \ldots \ldots \ldots \ldots \ldots \ldots \ldots$ 4-18

5.1 Screening Results for Preliminary Alternatives $\ldots \ldots \ldots \ldots \ldots \ldots \ldots \ldots \ldots, 12$

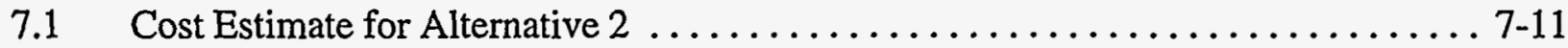

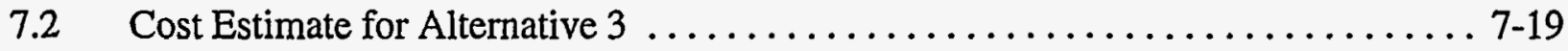

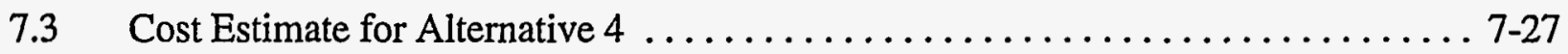

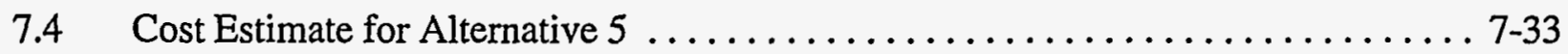

7.5 Major Monitoring and Mitigative Measures for Action Alternatives ......... 7-35

8.1 Comparative Analysis of Alternatives $\ldots \ldots \ldots \ldots \ldots \ldots \ldots \ldots \ldots \ldots . \ldots .2$ 


\section{TABLES (Cont.)}

8.2 Comparative Costs for Cleanup Activities under

Alternatives $2,3,4$, and 5

A.1 $\quad \mathrm{K}_{\mathrm{d}}$ Values and Results $\ldots \ldots \ldots \ldots \ldots \ldots \ldots \ldots \ldots \ldots \ldots \ldots \ldots \ldots \ldots \ldots \ldots \ldots \ldots \ldots \ldots$

A.2 Inorganic Materials of Concern $\mathrm{K}_{\mathrm{d}}$ Values $\ldots \ldots \ldots \ldots \ldots \ldots \ldots \ldots \ldots \ldots \ldots \ldots \ldots$

B.1 State Regulations and To-Be-Considered Requirements for J-Field $\ldots \ldots \ldots \ldots$ B-3

B.2 Federal Regulations and To-Be-Considered Requirements for J-Field -

Potential Contaminant-Specific Requirements ................... B-11

B.3 Federal Regulations and To-Be-Considered Requirements for J-Field -

Potential Location-Specific Requirements

B.4 Federal Regulations and To-Be-Considered Requirements for J-Field -

Potential Action-Specific Requirements

C.1 Index to Data Tables for the J-Field TBP Area $\ldots \ldots \ldots \ldots \ldots \ldots \ldots \ldots$ C-4

C.2a Volatile Organics Analyses for Surface Water, April $1993 \ldots \ldots \ldots \ldots \ldots$. . . . . 6

C.2b Volatile Organics Analyses for Surface Water, September 1993 . . . . . . . . . C C-8

C.2c Volatile Organics Analyses for Surface Water, February $1994 \ldots \ldots \ldots \ldots$. . . . C-10

C.2d Volatile Organics Analyses for Surface Water, May $1994 \ldots \ldots \ldots \ldots \ldots$. . . . . 13

C.3a Semivolatile Organics Analyses for Surface Water, April 1993 . . . . . . . . . . C-14

C.3b Semivolatile Organics Analyses for Surface Water, September 1993 . . . . . . . . C-17

C.3c Semivolatile Organics Analyses for Surface Water, May 1994 . . . . . . . . . . C-19

C.4a Inorganic Analyses for Surface Water, September $1993 \ldots \ldots \ldots \ldots \ldots \ldots$ C-21

C.4b Inorganic Analyses for Surface Water, May $1994 \ldots \ldots \ldots \ldots \ldots \ldots \ldots \ldots$ C-23 


\section{TABLES (Cont.)}

C.5a Pesticide and Polychlorinated Biphenyl Analyses

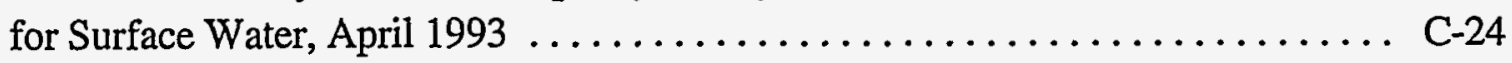

C.5b Pesticide and PCB Analyses for Surface Water, September 1993 . . . . . . . . C C-26

C.5c Pesticide and PCB Analyses for Surface Water, May $1994 \ldots \ldots \ldots \ldots \ldots$ C-28

C.6a General Chemistry Analyses for Surface Water, May $1994 \ldots \ldots \ldots \ldots \ldots$. . . . . 29

C.6b Explosive Compounds Analyses for Surface Water, May 1994 . . . . . . . . . . . C C-30

C.6c Chemical Warfare Agent Degradation Products and Organosulfur Compounds Analyses for Surface Water, April 1993 ..................... C-31

C.7a Volatile Organics Analyses for Sediment Borings, April $1994 \ldots \ldots \ldots \ldots \ldots$. . . . 32

C.7b Volatile Organics Analyses for Sediment Borings, June 1995 . . . . . . . . . . C-38

C.8a Semivolatile Organics Analyses for Sediment Borings, April 1994 . . . . . . . . . C-40

C.8b Semivolatile Organics Analyses for Sediment Borings, June 1995 . . . . . . . . C-53

C.9a Inorganic Analyses for Sediment Borings, April $1994 \ldots \ldots \ldots \ldots \ldots \ldots$. . . . 55

C.9b Inorganic Analyses for Sediment Borings, June $1995 \ldots \ldots \ldots \ldots \ldots \ldots$ C 60

C.10 Pesticide and PCB Analyses for Sediment, June $1995 \ldots \ldots \ldots \ldots \ldots \ldots$ C-62

C.11 Explosive Compounds Analyses for Sediment, June $1995 \ldots \ldots \ldots \ldots \ldots \ldots$ C-63

C.12 CWA Degradation Products and Organosulfur Compounds Analyses for Sediment, June $1995 \ldots \ldots \ldots \ldots \ldots \ldots \ldots \ldots \ldots \ldots \ldots \ldots \ldots \ldots . \ldots \ldots$

C.13a Volatile Organics Analyses for Soil Borings, January $1993 \ldots \ldots \ldots \ldots \ldots$. . . 65

C.13b Volatile Organics Analyses for Soil Borings, January $1994 \ldots \ldots \ldots \ldots \ldots$. . . 71

C.13c Volatile Organics Analyses for Soil Borings, May 1994 .............. C-77 


\section{TABLES (Cont.)}

C.13d Volatile Organics Analyses for Soil Borings, May 1995 .............. C-91

C.14a Semivolatile Organics Analyses for Soil Borings, January 1993 . . . . . . . . . C-102

C.14b Semivolatile Organics Analyses for Soil Borings, January 1994 . . . . . . . . . C-116

C.14c Semivolatile Organics Analyses for Soil Borings, May $1994 \ldots \ldots$. . . . . . . . C C-126

C.14d Semivolatile Organics Analyses for Soil Borings, May 1995 . . . . . . . . . . . C-142

C.15a Inorganic Analysis for Soil Borings, January 1993 . . . . . . . . . . . . . . C C-160

C.15b Inorganic Analyses for Soil Borings, January $1994 \ldots \ldots \ldots \ldots \ldots \ldots \ldots$ C-165

C.15c Inorganic Analyses for Soil Borings, $1994-1995$. . . . . . . . . . . . . . . C-169

C.15d Inorganic Analysis for Soil Borings, May $1995 \ldots \ldots \ldots \ldots \ldots \ldots \ldots \ldots$ C-176

C.16a Pesticide and PCB Analyses for Soil Borings, January $1993 \ldots \ldots \ldots \ldots \ldots$. . . . 188

C.16b Pesticide and PCB Analyses for Soil Borings, May $1995 \ldots \ldots \ldots \ldots \ldots \ldots \ldots$. . . 193

C.17 On-Site Analytical Suite Results for Soil Borings, December 1993-May 1994 ................................ C-195

C.18 Explosive Compounds Analyses for Soil Samples, May 1995 . . . . . . . . . . . C-198

C.19 CWA Degradation Products and Organosulfur Compound Analyses

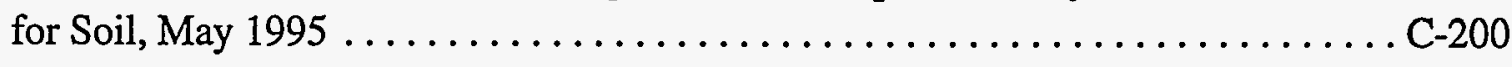

C.20 Dioxin and Total Petroleum Hydrocarbons Analyses

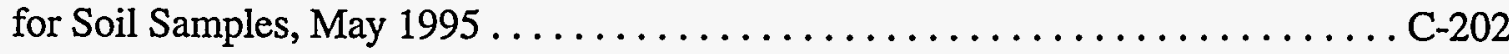

C.21a Volatile Organics Analyses for Groundwater, May $1994 \ldots \ldots \ldots \ldots \ldots$. . . . C-203

C.21b Volatile Organics Analyses for Groundwater in Piezometer Located

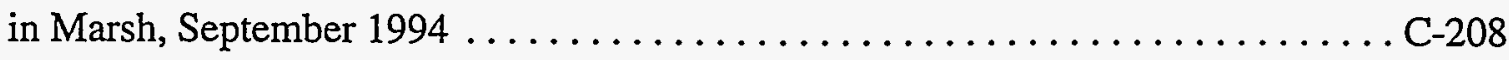

C.22 Semivolatile Organics Analyses for Groundwater, May 1994 ............ C-211 


\section{TABLES (Cont.)}

C.23 Inorganic Analyses for Groundwater, May $1994 \ldots \ldots \ldots \ldots \ldots \ldots \ldots \ldots$ C 215

C.24 General Chemistry Analyses for Groundwater, May $1994 \ldots \ldots \ldots \ldots \ldots \ldots$. C-220

C.25 Pesticide and PCB Analyses for Groundwater in the

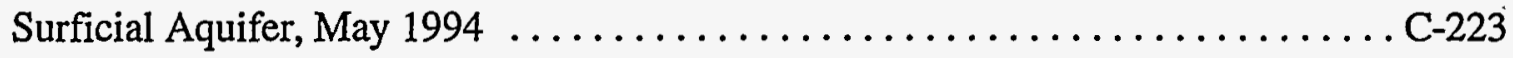

C.26 Explosive Compounds Analyses for Groundwater in the Surficial Aquifer, June 1994

C.27 Radiochemistry Analyses for Groundwater, June $1994 \ldots \ldots \ldots \ldots \ldots \ldots$. . -225

D.1 Summary of On-Site Aralytical Methods and

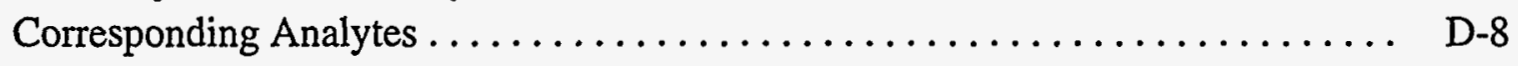

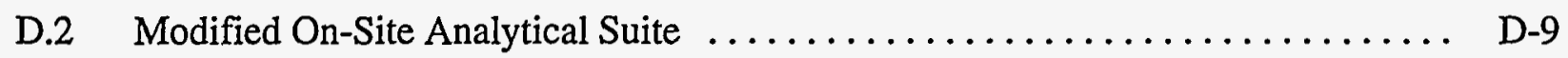

D.3 Results of the Field-Portable X-Ray Fluorescence Analysis at the TBP Area .... D-12

D.4 Analytical Results for Selected Metals in Soil $\ldots \ldots \ldots \ldots \ldots \ldots \ldots \ldots \ldots$ D-19

D.5 Toxicity Characteristic Leaching Procedure Results for Selected Metals in Soil . . . . . . . . . . . . . . . . . . . .

D.6 Analytical Results for Selected Volatile Organic Compounds, in Southern Main Pit Soil . . . . . . . . . . . . . . . . . . . . D 25

D.7 Analytical Results for Selected Metals in Southern Main Pit Soil . . . . . . . . D-27

D.8 Analytical Results for Polychlorinated Biphenyls and Total Petroleum Hydrocarbons in Southern Main Pit Soil ............ D-28

D.9 Analytical Results for Selected Metals in Surface Water Samples Collected in May 1994

D.10 Summary of Volatile Organics Analyses for Surface Water ........... D-35

D.11 Contract Laboratory Program Analytical Suite $\ldots \ldots \ldots \ldots \ldots \ldots \ldots$ D-37 


\section{TABLES (Cont.)}

D.12 Analytical Results for Selected Volatile Organic Compounds in Groundwater, 1994

D.13 Construction Data and Summary of Volatile Organic Compounds

Detected in J-Field Marsh Piezometers in 1994

D.14 Analytical Results for Selected Inorganics in Groundwater, 1994

D-42

E.1 Exposure Routes Evaluated for Ecological Receptors at the TBP Area

E.2 Exposure Point Concentrations of Contaminants of

Ecological Concern for the TBP Area

E.3 Species-Specific Exposure Factors Used to Model the Applied

Daily Dose for Ecological Receptors that Use the TBP Area

E.4 Soil-to-Plant Transfer Factors Used to Model the Applied Daily

Dose for Ecological Receptors that Use the TBP Area

E.5 Species-Specific NOAEL Benchmark Values Used to Estimate the

Environmental Effects Quotient

G.1 English/Metric Equivalents

G-3

G.2 Metric/English Equivalents

G-3

\section{FIGURES}

S.1(a) Contaminated Surface Soil, 0-6 in., to Be Addressed by the Proposed Action at the TBP Area

S.1(b) Contaminated Surface Soil, 6-24 in., to Be Addressed by the Proposed Action at the TBP Area 


\section{FIGURES (Cont.)}

1.2 Locations of Principal Site Features at J-Field $\ldots \ldots \ldots \ldots \ldots \ldots \ldots \ldots \ldots$

2.1 Locations of Main Features and Monitoring Wells at the TBP Area $\ldots \ldots \ldots \ldots$ 2-2

2.2 Generalized Hydrogeologic Cross Section and Direction of Groundwater Flow at J-Field TBP Area $\ldots \ldots \ldots \ldots \ldots \ldots \ldots \ldots \ldots \ldots . \ldots \ldots . .4$

2.3 Estimated Contaminated Area at Depth Interval 0-6 in. with Heavy Metal

Concentration Levels above Mean Background

2.4 Estimated Contaminated Area at Depth Interval 6-24 in. with Heavy Metal

Concentration Levels above Mean Background

2.5 Estimated Contaminated Area at Depth Interval 0-6 in. with Heavy Metal

Concentration Levels above Maximum Background ................ 2-18

2.6 Estimated Contaminated Area at Depth Interval 6-24 in. with Heavy Metal

Concentration Levels above Maximum Background ................ 2-18

2.7 Estimated Contaminated Area at Depth Interval 2-4 ft with Heavy Metal

Concentration Levels above Mean Background ................... 2-19

3.1 Contaminated Surface Soil, 0-6 in., to Be Addressed by the Proposed

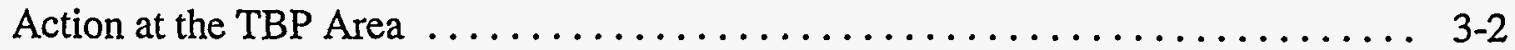

3.2 Contaminated Surface Soil, 6-24 in., to Be Addressed by the Proposed

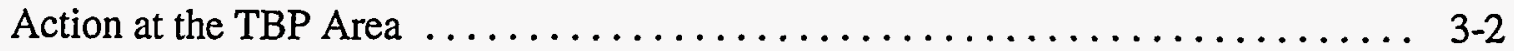

6.1 Location of In-Situ Containment Area and Shoreline Stabilization,

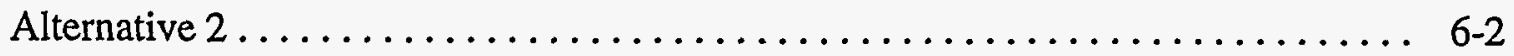

6.2 Location of Fenced Work Zone and Proposed Storage Facility, Alternative $3 \ldots \ldots$ 6-9

6.3 Location of Fenced Work Zone and Proposed Treatment Facility

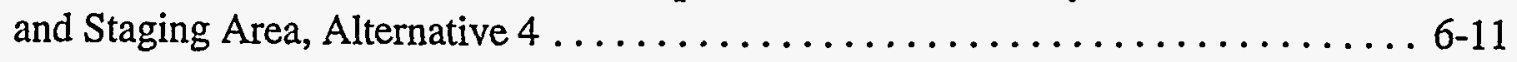

6.4 Process Flowchart for the Soil Washing/Leaching Facility $\ldots \ldots \ldots \ldots \ldots \ldots 6-12$ 


\section{FIGURES (Cont.)}

A.1 Concentration Profiles for Lead Using a $\mathrm{K}_{\mathrm{d}}$ Value

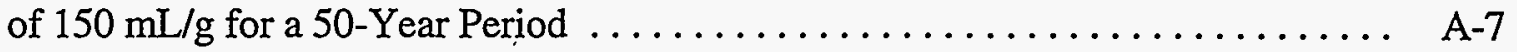

A.2 Concentration Profiles for Cadmium Using a $\mathrm{K}_{\mathrm{d}}$ Value of $15 \mathrm{~mL} / \mathrm{g} \ldots \ldots \ldots$ A.8

A.3 Concentration Profiles for Zinc Using a $\mathrm{K}_{\mathrm{d}}$ Value of $5.0 \mathrm{~mL} / \mathrm{g} \ldots \ldots \ldots \ldots$ A-9

D.1 Location of Passive and Active Soil-Gas Measurements

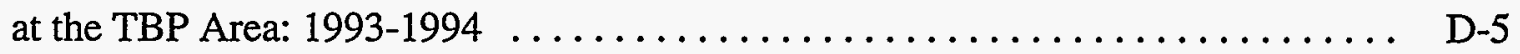

D.2 Locations of Active Soil-Gas Sampling at the TBP Area $\ldots \ldots \ldots \ldots \ldots \ldots$ D-6

D.3 Locations of In-Situ X-Ray Fluorescence Measurements at the TBP Area . . . . . . D-11

D.4 Locations of Surface Soil Samples Collected at the TBP Area since 1993 . . . . . D D-16

D.5 Locations of Soil Borings at the TBP Area $\ldots \ldots \ldots \ldots \ldots \ldots \ldots \ldots \ldots$ D-23

D.6 Distribution of Polychlorinated Biphenyls at the TBP Area $\ldots \ldots \ldots \ldots \ldots$ D-29

D.7 Locations of Surface Water and Sediment Samples and Sediment Borings

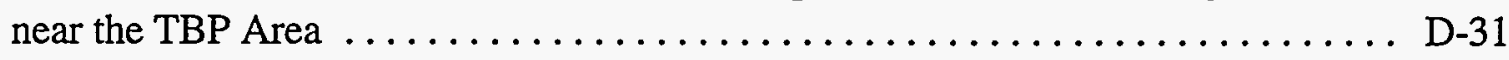

D.8 Potential Contamination Sources at the TBP Area $\ldots \ldots \ldots \ldots \ldots \ldots \ldots$ D-36 


\section{FOREWORD}

Argonne National Laboratory acknowledges Mr. Larry Thebeau and Mr. Prakash Ramaswamy of ICF Kaiser Engineers, Inc., for the development of Alternative 2 (Limited Removal and Disposal, and In-Situ Containment) for this focused feasibility study. Mr. Thebeau and Mr. Ramaswamy prepared Sections 4.2.2, 5.2.2, 6.2, 7.2.7, and F.1. 


\section{NOTATION}

The following is a list of acronyms, initialisms, chemical abbreviations, and units of measure used in this document.

\section{ACRONYMS AND INITIALISMS}

$\mathrm{ADD}$

$\mathrm{AE}$

ANL

AOC

APG

ARAR

ART

ASTM

AWQC

BRA

CAMU

CCMAS

CERCLA

CFR

CLP

CMS

$\mathrm{COC}$

COEC

COMAR

CRC

CRQL

CSTA

CWA

DANC

DNAPL

DOE

DOT

DRE

DSHE

DW applied daily dose

assimilation efficiency

Argonne National Laboratory

area of concern

Aberdeen Proving Ground

applicable or relevant and appropriate requirement

Alternative Remedial Technologies, Inc.

American Society for Testing and Materials

ambient water quality criteria

baseline risk assessment

Corrective Action Management Unit

Construction Cost Management Analysis System

Comprehensive Environmental Response, Compensation, and

Liability Act (as amended)

Code of Federal Regulations

Contract Laboratory Program

corrective measures study

contaminant of concern

contaminant of ecological concern

Code of Maryland Regulations

Chemical Rubber Company

contract-required quantitation limit

Combat Systems Test Activity

chemical warfare agent

decontaminating agent, noncorrosive

dense, nonaqueous-phase liquid

U.S. Department of Energy

U.S. Department of Transportation

destruction/removal efficiency

Directorate of Safety, Health, and Environment (U.S. Army)

dry weight 
EEQ

EMD

EO

EP

EPA

ERA

ERT

FEMA

FFS

FR

FS

GPR

HAZMAT

HE

HFA

HW

IRA

IRD

LDR

LEL

MCL

MCR

MDNR

MSL

NCP

NOAA

NOAEL

NPDES

NPL

NR

O\&M

O\&P

$\mathrm{OB} / \mathrm{OD}$

ODC

OSAS environmental effects quotient

Environmental Management Division (U.S. Army)

Executive Order

extraction procedure

U.S. Environmental Protection Agency

ecological risk assessment

Emergency Response Team

Federal Emergency Management Agency

focused feasibility study

Federal Register

feasibility study

ground-penetrating radar

hazardous materials

high explosives

Human Factors Applications, Inc.

hazardous waste

interim remedial action

interim remedial design

land disposal restriction

lower explosive limit

maximum contaminant level

maximum credible release

Maryland Department of Natural Resources

mean sea level

National Oil and Hazardous Substances Pollution Contingency Plan

National Oceanic and Atmospheric Administration

no observed adverse effects level

National Pollutant Discharge Elimination System

National Priorities List

National Resources

operation and maintenance

overhead and profit

open burning/open detonation

other direct cost

on-site analytical suite 
OSHA

OSWER

PL

PRG

QC

RACER

RCRA

RFI

RI

RME

ROD

SARA

SPTF

SVE

SWMU

TAL

TBC

TBP

TCL

TCLP

TDS

TSCA

TSD

UCL

USATHAMA

USC

USGS

UV

UXO

WPP

XRF
Occupational Safety and Health Administration

Office of Solid Waste and Emergency Response

Public Law

preliminary remediation goal

quality control

Remedial Action Cost Engineering and Requirements System

Resource Conservation and Recovery Act

RCRA facility investigation

remedial investigation

reasonable maximum exposure

Record of Decision

Superfund Amendments and Reauthorization Act of 1986

soil-to-plant transfer factor

soil-vapor extraction

solid waste management unit

target analyte list

to-be-considered requirement

Toxic Burning Pits

target compound list

toxicity characteristic leaching procedure

total dissolved solids

Toxic Substances Control Act

treatment, storage, and disposal

upper confidence limit

U.S. Army Toxic and Hazardous Materials Agency

United States Code

U.S. Geological Survey

ultraviolet

unexploded ordnance

white phosphorus burning pits

$\mathrm{X}$-ray fluorescence 


\section{CHEMICAL ABBREVIATIONS}

BHC

BTEX

$\mathrm{CAH}$

DCE

11DCE

12DCE

DDD

DDE

DDT

DNAPL

EDTA

GA

GB

GD

HD

LNAPL

PAH

PCB

PEH

PETN

RDX

SVOC

111TCE

112TCE

TCLEA

TCLEE

TNT

TPH

TRCLE

VOC

$\mathrm{VX}$ benzene hexachloride

benzene, toluene, ethylbenzene, and xylenes

chlorinated aliphatic hydrocarbon

dichloroethylene

1,1-dichloroethylene

1,2-dichloroethylene

4,4'-dichlorodiphenyldichloroethane

4,4'-dichlorodiphenyldichloroethylene

4,4'-dichlorodiphenyltrichloroethane

dense nonaqueous-phase liquid

ethylenediamine tetraacetic acid

ethyl N,N-dimethyl phosphoramidocyanidate (tabun)

isopropyl methylphosphonofluoridate (sarin)

pinacolyl methylphosphonofluoridate (soman)

sulfur mustard

light nonaqueous-phase liquid

polyaromatic hydrocarbon

polychlorinated biphenyl

petroleum hydrocarbon

pentaerythritol tetranitrate

hexahydro-1,3,5-trinitro-1,3,4-triazine

semivolatile organic compound

1,1,1-trichloroethane

1,1,2-trichloroethane

1,1,2,2-tetrachloroethane

tetrachloroethylene

trinitrotoluene

total petroleum hydrocarbon

trichloroethylene

volatile organic compound

methylphosphonothioic acid 


\section{UNITS OF MEASURE}

$\begin{array}{llll}\mathrm{cm} & \text { centimeter(s) } & \mathrm{L} & \text { liter(s) } \\ { }^{\circ} \mathrm{F} & \text { degree(s) Fahrenheit } & \mathrm{m}^{3} & \text { cubic meter(s) } \\ \mathrm{ft} & \text { foot (feet) } & \mathrm{mg} & \text { milligram(s) } \\ \mathrm{ft}^{2} & \text { square foot (feet) } & \mathrm{mi} & \text { mile(s) } \\ \mathrm{gal} & \text { gallon(s) } & \mathrm{mm} & \text { millimeter(s) } \\ \mathrm{gpm} & \text { gallon(s) per minute } & \mathrm{ng} & \text { nanogram(s) } \\ \mathrm{h} & \text { hour(s) } & \mu \mathrm{g} & \text { microgram(s) } \\ \mathrm{in} . & \text { inch(es) } & \mathrm{ppm} & \text { part(s) per million } \\ \mathrm{kg} & \text { kilogram(s) } & \mathrm{s} & \text { second(s) } \\ \mathrm{km} & \text { kilometer(s) } & \mathrm{V} & \text { volt(s) } \\ \mathrm{kW} & \text { kilowatt(s) } & \mathrm{yd}^{3} & \text { cubic yard(s) }\end{array}$




\title{
FOCUSED FEASIBILITY STUDY FOR SURFACE SOIL AT THE MAIN PITS AND PUSHOUT AREA, J-FIELD TOXIC BURNING PITS AREA, ABERDEEN PROVING GROUND, MARYLAND
}

\author{
SUMMARY
}

\section{S.1 INTRODUCTION}

The Environmental Management Division of Aberdeen Proving Ground (APG), Maryland, is conducting a remedial investigation and feasibility study of the J-Field area at APG pursuant to the Comprehensive Environmental Response, Compensation, and Liability Act, as amended (CERCLA). J-Field is located within the Edgewood Area of APG in Harford County, Maryland. Since World War II, activities in the Edgewood Area have included the development, manufacture, testing, and destruction of chemical agents and munitions. These materials were destroyed at $\mathrm{J}$-Field by open burning/open detonation. Portions of J-Field continue to be used for the detonation and disposal of unexploded ordnance (UXO) by open burning/open detonation under authority of the Resource Conservation and Recovery Act.

J-Field is almost flat and is covered by open fields, woods, and nontidal marshes. It encompasses about 460 acres at the southern end of Gunpowder Neck Peninsula. The peninsula is surrounded by tidal estuaries on three sides - Gunpowder River to the west and Chesapeake Bay to the south and east.

The Toxic Burning Pits (TBP) area, one of the designated areas of concern at J-Field, is located on about 9 acres in the southern portion of J-Field. This area was used to dispose of bulk chemical wastes, drummed chemical wastes, high explosives, various chemical agents, and chlorinated solvents. The TBP location contains several potential source areas of contamination, including five burning pits, a pushout area, a storage area, a disposal area, and a demolition area.

Results from the remedial investigation (Yuen et al. 1996) indicate that the principal contaminant sources at the TBP area are surface and subsurface soils associated with the two main pits and the pushout area. Surface soil is the environmental medium of greatest concern; soil contaminants include heavy metals and organic compounds. These contaminants may be released by surface runoff, precipitation infiltration, and gaseous emission of volatile organic compounds. Contaminant transport from these sources has resulted in contamination of sediments and surface water in the marsh-pond ecosystem that borders the pushout area and the southern boundary of the site. Surface water and sediments are contaminated primarily with heavy metals; some organic compounds have also been detected. 
This report presents the focused feasibility study (FFS) for the TBP area at J-Field. The purpose of this study is to develop and evaluate potential remedial action alternatives to address surface soil contamination at three source areas within the J-Field TBP area: the northern main pit, the southern main pit, and the pushout area. Other source areas and contaminated media at the TBP area are outside the scope of this interim remedial action and will be addressed as part of the longterm remediation for J-Field.

\section{S.2 FOCUSED FEASIBILITY STUDY APPROACH}

The initial task of the FFS was to develop remedial action objectives and define the scope of the proposed action given the information available from the remedial investigation, human health and ecological risk assessments, and earlier investigations. Interim preliminary remediation goals (PRGs) were developed for each contaminant of concern (COC) on the basis of risk to human and ecological receptors and probable future land use. The objectives and scope (Section S.3) guided the subsequent tasks of identifying and screening remedial action technologies (Section S.4), assembling and screening preliminary remedial action alternatives (Sections S.5 and S.6), conducting treatability studies, and evaluating the final remedial action alternatives. The last step in the evaluation process was a comparative analysis of alternatives (Section S.7).

\section{S.3 INTERIM REMEDIAL ACTION OBJECTIVES}

\section{S.3.1 Objectives and Scope}

The overall objectives of the proposed interim remedial action at the TBP area of J-Field are to:

- Reduce exposure of human and environmental receptors to surface contamination in three source areas: the northern main pit, the southern main pit, and the pushout area;

- Minimize the potential for contaminant migration via sediment transport from these areas;

- Minimize the potential for contaminant migration via downward leaching through these areas; and

- Support long-term site remediation. 
Three source areas of contamination at the TBP area are the subject of this FFS: the northern main pit, the southern main pit, and the pushout area. Two additional pits in the pushout area have been filled in and are partially covered by soil pushed out from the main pits. Preliminary results of human health and ecological risk assessments (ICF Kaiser Engineers 1995a; Hlohowskyj et al. 1996) indicate that contaminated surface soil in these areas should be addressed to protect human health and the environment. An interim remedial action could be implemented that would achieve the objectives stated above.

Preliminary area and volume estimates for these areas are presented in Table S.1. Figure S.1 shows the areas with metal concentrations that exceed the mean regional background as reported by ICF Kaiser Engineers (1995b). The figure also includes areas with levels of contaminants that exceed the interim PRGs reported in Table S.2. The interim PRGs developed for surface soils at the TBP area (Section S.5) were used to determine which source areas should be cleaned up as part of the interim action and which could be appropriately left in their current condition until further action is taken at the site as part of the long-term remediation for J-Field.

\section{S.3.2 Preliminary Remediation Goals}

For the TBP area, human health-based interim PRGs for soil were developed by using the risk-based soil concentrations derived by the U.S. Environmental Protection Agency (EPA) Region III. EPA Region III derives the risk-based values by following the Superfund risk assessment guidelines (EPA 1989a,b) and standard default assumptions (EPA 1991a); the values are based on carcinogenic and noncarcinogenic effects of ingesting "industrial" soil (as opposed to residential soil).

Two approaches were employed to develop ecological risk-based interim PRGs for the TBP area: (1) use of the contaminant uptake models developed for the ecological risk assessment to backcalculate acceptable surface soil concentrations and (2) use of the human health-based interim PRGs for $\mathrm{COCs}$ for which uptake modeling was not performed. In this latter approach, risk reduction for ecological resources is considered to be directly correlated with the reduction of contaminant concentrations or with removal of contaminated media. Thus, reducing surface soil contaminant concentrations to the levels of the human health risk-based interim soil PRGs would also reduce risk for ecological resources. In both approaches, each derived interim soil PRG was screened against the regional background soil concentration of that contaminant, and the greater of the two values was selected as the interim PRG.

Table S.2 integrates the ecological and human health risk-based PRGs and presents an overall list of preliminary interim soil PRGs for the TBP area. The identified interim soil PRG for each COC is the lower of the human health and ecological risk-based interim PRGs. These interim PRGs are initial guidelines and are not intended to set final cleanup levels or to establish that cleanup to meet these goals is warranted (EPA 1991b, 1994). 
TABLE S.1 Estimated Areas and Volumes of Contaminated Surface Soil at the Main Pits and Pushout Area

\begin{tabular}{lccc}
\hline $\begin{array}{c}\text { Contaminated } \\
\text { Surface Soil Interval }\end{array}$ & $\begin{array}{c}\text { Contaminants of } \\
\text { Concern }\end{array}$ & Area $\left(\mathrm{ft}^{2}\right)$ & Volume $\left(\mathrm{yd}^{3}\right)$ \\
\hline 0-6 in. & Metals, organics & 218,300 & 4,043 \\
& Metals, organics & 208,600 & 11,590 \\
\hline
\end{tabular}

a See Figure S.1 for location of excavation area.

\section{S.4 POTENTIALLY APPLICABLE TECHNOLOGIES}

Remedial technology types and process options that are potentially applicable to addressing contaminated soil at the TBP area were identified and screened on the basis of effectiveness, implementability, and cost and for applicability to specific site conditions in accordance with EPA guidance (1988). The current understanding of contaminants and conditions at the site suggested that the general response actions that could be implemented to achieve the project objectives (Section S.3) are institutional controls, in-situ containment, removal, treatment, short-term storage, and disposal. Specific application of these technologies to site conditions was evaluated to determine which would be most appropriate for interim remedial action at the TBP area. The technology types retained through the screening process include institutional controls (access restriction, ownership and use or deed restriction, and monitoring); in-situ containment (surface control diversions, vertical barriers, and caps); removal (excavation, and clearing and grubbing); ex-situ treatment (stabilization/ fixation, soil washing, soil leaching, incineration, and thermal desorption); short-term storage (on-site open and closed structures); and disposal (off-site land-based facility). These technologies were combined to develop preliminary interim remedial action alternatives for the TBP area.

\section{S.5 DESCRIPTION OF ALTERNATIVES}

Preliminary alternatives for remediating surface soil at the TBP area were developed and screened in accordance with CERCLA, EPA guidance (1988), and the National Oil and Hazardous Substances Pollution Contingency Plan (EPA 1990). Five preliminary alternatives were developed and screened on the basis of implementability, effectiveness, and cost. These alternatives are described briefly in the following subsections. 


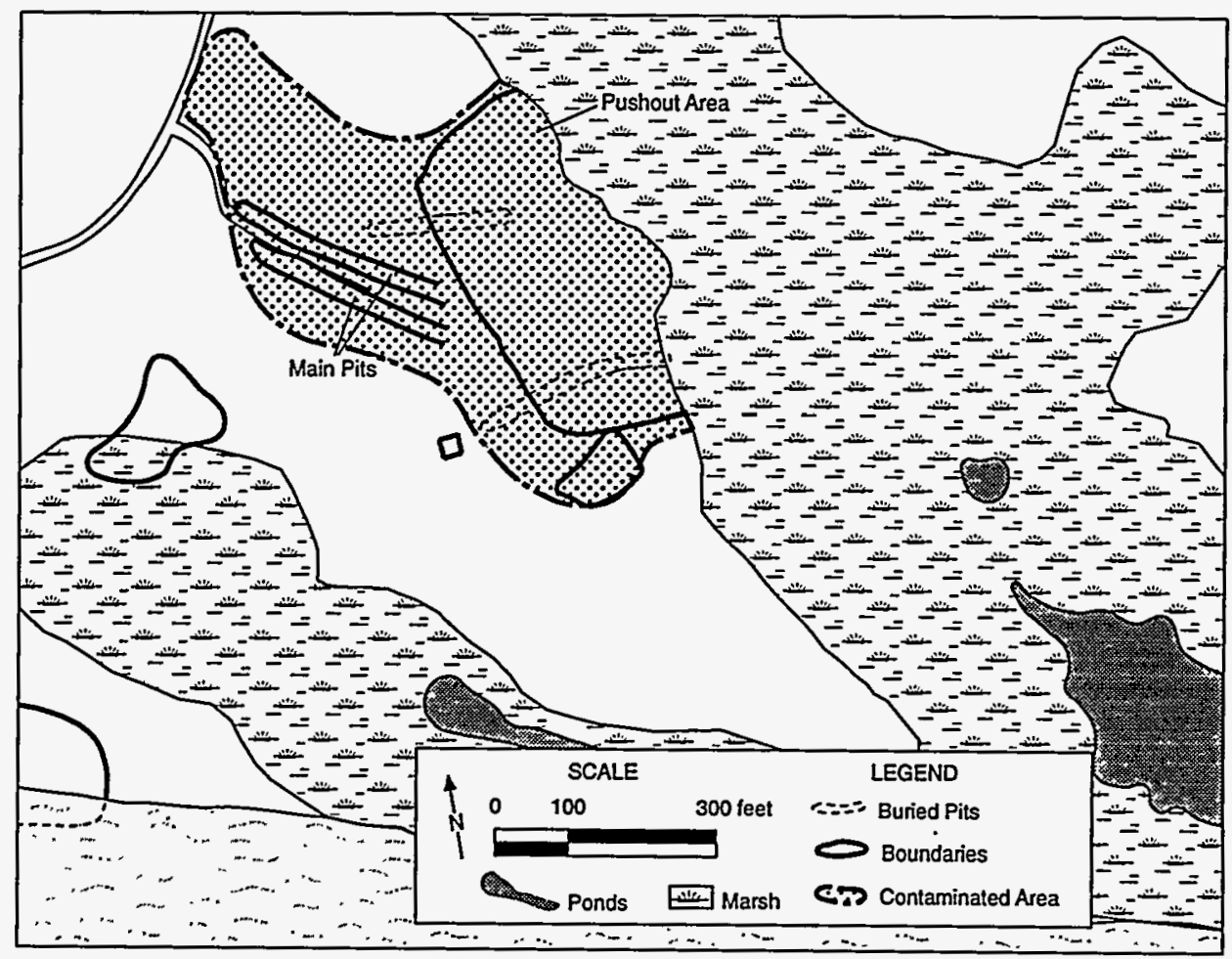

FIGURE S.1(a) Contaminated Surface Soil, 0-6 in., to Be Addressed by the Proposed Action at the TBP Area

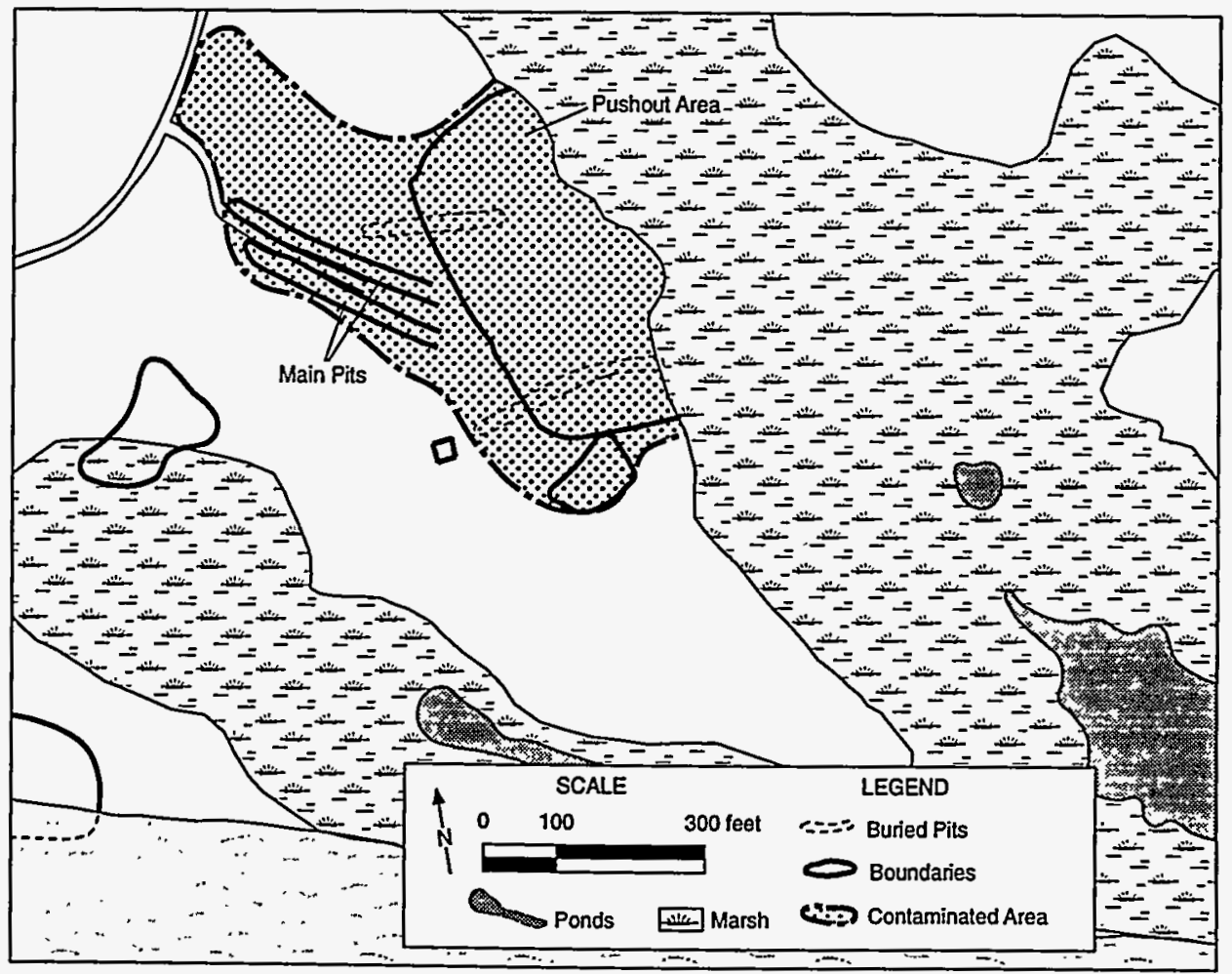

FIGURE S.1(b) Contaminated Surface Soil, 6-24 in., to Be Addressed by the Proposed Action at the TBP Area 
TABLE S.2 Risk-Based Interim Preliminary Remediation Goals (PRGs) for Surface Soil at the TBP Area

\begin{tabular}{|c|c|}
\hline Contaminant & Interim PRG $(\mathrm{mg} / \mathrm{kg})$ \\
\hline \multicolumn{2}{|c|}{ Volatile and semivolatile organic compounds } \\
\hline Trichloroethene & $1.3^{\mathrm{a}}$ \\
\hline 2-Methylnaphthalene & $N A^{b}$ \\
\hline \multicolumn{2}{|l|}{ Explosive } \\
\hline Nitroglycerin & NA \\
\hline \multicolumn{2}{|l|}{ Inorganic materials } \\
\hline Aluminum & $7,940^{\mathrm{c}}$ \\
\hline Antimony & $3.7^{\mathrm{a}}$ \\
\hline Arsenic & $3.8^{\mathrm{d}}$ \\
\hline Barium & $64.4^{\mathrm{a}}$ \\
\hline Beryllium & $1.3^{\mathrm{d}}$ \\
\hline Cadmium & $0.34^{\mathrm{c}}$ \\
\hline Chromium & $16.7^{\mathrm{c}}$ \\
\hline Cobalt & $25.0^{\mathrm{a}}$ \\
\hline Copper & $100^{\mathrm{a}}$ \\
\hline Cyanide & $1.0^{\mathrm{a}}$ \\
\hline Lead & $58.7 / 400^{\mathrm{e}}$ \\
\hline Mercury & $0.04^{c}$ \\
\hline Selenium & $0.20^{c}$ \\
\hline Silver & $2.0^{\mathrm{a}}$ \\
\hline Zinc & $37.0^{\mathrm{c}}$ \\
\hline
\end{tabular}

a Interim PRG is ecological risk-based (see Table 3.5).

b $\mathrm{NA}=$ No interim PRG developed. Insufficient data to develop ecological risk-based interim PRG, and no EPA Region III human health-based PRG has been developed (see Table 3.2).

c Ecological risk-based PRG value is below mean background concentration; interim PRG is mean background concentration.

d Interim PRG is human health-based (see Table 3.2).

e The ecological risk-based PRG is $58.7 \mathrm{mg} / \mathrm{kg}$ (see Table 3.5). EPA currently recommends a soil cleanup value of $400 \mathrm{mg} / \mathrm{kg}$ for residential land use (see Table 3.2). The cleanup goal for lead has been as high as $1,000 \mathrm{mg} / \mathrm{kg}$ at other APG sites (Wrobel 1995). 


\section{S.5.1 Alternative 1: No Action}

Alternative 1 is included to provide a baseline for comparison with the other action alternatives. Under this alternative, the site would continue to operate under restricted access. Current conditions of the contaminated surface soil would continue. The baseline condition of the J-Field TBP area would include only minor maintenance activities, such as mowing and monitoring.

\section{S.5.2 Alternative 2: Limited Removal and Disposal, and In-Situ Containment}

Under Alternative 2, contaminated surface soil in the two main pits and pushout area would be contained in place with a protective soil cover. Limited excavation and disposal would be implemented to address contaminated soil in the main pits (specifically arsenic and polychlorinated biphenyls [PCBs]).

The "risk-reduction cover" would involve placing a geotextile fabric over the vegetationcleared surface (about 5 acres) and covering it with a layer of soil sufficient to raise the site topography above the 100 -year floodplain. The soil layer would be stabilized with a vegetative cover. Runoff from the area would be diverted by surface grading controls. Erosion of contaminated soil from the portion of the pushout area in contact with the marsh would be mitigated by installing a vertical barrier. Because the soil layer would be emplaced incrementally in 2-ft layers, UXO screening most likely would not be required for this component. A UXO survey would be required for the limited excavation component, especially if conventional equipment were used. The area of excavation would be limited, so hand removal methods could be used (if the density of metal contacts present is high). The limited disposal component under Alternative 2 would involve shipping about $400 \mathrm{yd}^{3}$ of soil to a permitted off-site facility for treatment (stabilization and possibly incineration) and disposal.

Stabilization of the shoreline to the south of the TBP area would also be implemented as part of this alternative. Installation of a boulder riprap berm would reduce the potential for long-term erosion along the shoreline.

\section{S.5.3 Alternative 3: Removal and Short-Term Storage}

Under Alternative 3, contaminated surface soil in the two main pits and pushout area that exceeds soil cleanup criteria would be removed and transported to an on-site, short-term storage facility, where it would be stored until final remediation is addressed at J-Field.

Soil would be excavated to a depth of $2 \mathrm{ft}$ from the source areas with standard earthmoving equipment, such as front-end loaders, scrapers, and backhoes. The excavation area would be 
surveyed for.UXO in the upper 2 to $4 \mathrm{ft}$. Approximately $16,000 \mathrm{yd}^{3}$ of soil would be removed. The short-term storage facility would be constructed adjacent to the Prototype Building to minimize the distance the material would have to be transferred. The short-term facility would be a modular building consisting of fabric walls. The base of the structure would require the construction of a bermed and drained concrete or asphalt pad equipped with a leachate collection system. An air infiltration system might also be required.

\section{S.5.4 Alternative 4: Removal, On-Site Treatment, and Limited Disposal}

Under Alternative 4, contaminated soil in the two main pits and pushout area that exceeds soil cleanup criteria would be removed and treated by soil washing/leaching to reduce the volume of waste for off-site disposal.

The removal component of Alternative 4 would be similar to that of Alternative 3; however, the excavated soil would be transported to an on-site soil washing/leaching treatment facility, which would be constructed adjacent to the Prototype Building. For the conceptual design, it was estimated that $16,000 \mathrm{yd}^{3}$ of soil would be treated. After removal and treatment, the cleaned material would either remain on-site to be used as fill (pending a treatability variance or CERCLA waiver) or be shipped to an off-site solid waste disposal facility, in accordance with the State of Maryland's preference. Limited disposal under Alternative 4 would involve shipping recovered lead, scrap metal, and other (nonhazardous) refuse, as necessary, to an off-site facility (smelter and/or municipal landfill). A portion of the soil from the southern main pit, contaminated with PCBs, would also be sent off-site for treatment and disposal.

\section{S.5.5 Alternative 5: Removal, Off-Site Treatment, and Disposal}

Under Alternative 5, contaminated soil in the two main pits and pushout area that exceeds soil cleanup criteria would be removed and transported to an off-site treatment and disposal facility.

The removal component of Alternative 5 would be similar to that of Alternative 3; however, the excavated soil would be temporarily staged on-site following excavation, then transported to an off-site treatment and disposal facility.

\section{S.6 IDENTIFICATION OF FINAL ALTERNATIVES}

On the basis of the screening analysis for preliminary alternatives, all five of the preliminary alternatives were retained for detailed analysis. Although the no-action alternative (Alternative 1) would not be protective of human health and the environment in the long term, it was 
retained through this screening to provide a basis for comparison with the remaining action alternatives during the subsequent detailed analysis. Alternatives 2 and 3 were retained because they offer low-cost options for reducing risk; however, Alternative 3 it is not considered effective in the long term and would thus require an additional action at a future date. Alternatives 4 and 5 were retained because they offer permanent solutions to surface soil contamination; however, these alternatives are fairly costly.

\section{S.7 EVALUATION SUMMARY AND COMPARATIVE ANALYSIS}

Table S. 3 provides the comparative analysis of the five remedial action alternatives. The analysis is summarized as follows.

All of the final remedial action alternatives for the TBP area, except for the no-action alternative (Alternative 1), satisfy the threshold criteria for protecting human health and the environment and complying with regulatory requirements, with waivers as appropriate. Overall protectiveness would be comparable for Alternatives 2, 4, and 5 . Alternative 3 is protective in the short term but would require an additional component (e.g., off-site treatment and disposal) to be as protective as Alternatives 4 and 5 .

Only Alternatives 2, 4, and 5 are expected to provide a permanent solution that would ensure protection for a very long time; however, long-term effectiveness under Alternative 2 could be affected by the potential for flooding. It is possible that the soil washing/leaching treatment under Alternative 4 would be more protective than Alternative 5 if, at some future date, the stabilized/ solidified waste were to be exposed to the environment and the contaminants leached. However, appropriate design and good engineering practices would minimize the likelihood of such an occurrence.

Each action alternative would reduce contaminant mobility. Under Alternative 2, waste toxicity and volume would be only somewhat reduced. Under Alternative 3, waste volume would not be affected. Under Alternative 4, waste volume would decrease. Waste volume would increase under Alternative 5 because of the addition of cement and fly ash to stabilize the waste. Treatment methods under Alternatives 2, 4, and 5 would reduce contaminant toxicity; under Alternative 4, metals would be recovered and recycled.

The short-term effectiveness of Alternatives 2 through 5 would be comparable. The overall risk to the general public would be higher for Alternative 5 because it involves off-site transport of a large volume of contaminated soil. Environmental impacts at the TBP area from excavation and construction activities would be common for all action alternatives, and comparable impacts would be expected. Mitigative measures would be used to minimize potential short-term impacts. 
Emplacement of the "risk-reduction cover" under Alternative 2 would be straightforward, as would construction of the storage facility under Alternative 3. Implementing Alternative 4 would also be fairly straightforward, although additional studies would be required to refine the soil washing/leaching treatment system design and cost estimates. The chemical stabilization/solidification treatment that would be performed off-site under Alternative 5 is fairly well established and would not require further development before implementation.

Alternative 2 has the lowest overall estimated cost ( $\$ 1.8$ million) of the action alternatives; however, this estimate only includes projected costs for the next 30 years and is not directly comparable to Alternatives 3,4 , and 5 (for excavation to $2 \mathrm{ft}$ ). Alternative 5 is considered more costeffective than Alternative 4 for site cleanup. The estimated total cost of Alternative 5 is $\$ 10.5$ million (for excavation to $2 \mathrm{ft}$ ), and it would provide a similar level of overall effectiveness as Alternative 4, which would cost an estimated $\$ 13.1$ million. 
TABLE S.3 Comparative Analysis of Alternatives

\begin{tabular}{|c|c|c|c|c|}
\hline $\begin{array}{l}\text { Altemative 1: } \\
\text { No Action }\end{array}$ & $\begin{array}{l}\text { Altemative 2: } \\
\text { Limited Removal and Disposal, and } \\
\text { In-Situ Containment }\end{array}$ & $\begin{array}{l}\text { Altemative 3: } \\
\text { Removal and Short-Term Storage }\end{array}$ & $\begin{array}{c}\text { Altemative 4: } \\
\text { Removal, On-Site Treatment, } \\
\text { and Limited Disposal }\end{array}$ & $\begin{array}{c}\text { Altemative 5: } \\
\text { Removal, Off-Site Treatment, } \\
\text { and Disposal } \\
\end{array}$ \\
\hline \multicolumn{5}{|c|}{ Overall Protection of Human Health and the Environment } \\
\hline $\begin{array}{l}\text { Would not ensure protection of } \\
\text { human health and the cnviron- } \\
\text { ment in the long term. Source } \\
\text { areas would not be removed or } \\
\text { treated, and exposures could } \\
\text { increase over time. }\end{array}$ & $\begin{array}{l}\text { Engineering and mitigative measures } \\
\text { would be employed during the } \\
\text { remedial action period so that no } \\
\text { significant adverse impacts would } \\
\text { occur to the general public or environ- } \\
\text { ment. Worker exposures would be } \\
\text { similarly controlled to levels within } \\
\text { health-protective limits. Long-term } \\
\text { exposures would be minimized by } \\
\text { removing "hot spots" (arsenic and } \\
\text { PCBs) from the main pits and by } \\
\text { covering remaining contaminated soil } \\
\text { with a protective soil cover. }\end{array}$ & $\begin{array}{l}\text { Generally similar to Alternative } 2 \text {. } \\
\text { Long-term exposures would be } \\
\text { minimized by removing and storing } \\
\text { contaminated soil from the main pits } \\
\text { and pushout area for about } 5 \text { years. At } \\
\text { the end of that time, an additional } \\
\text { component (e.g., off-site treatment and } \\
\text { disposal) would be needed to ensure } \\
\text { long-term protection. }\end{array}$ & $\begin{array}{l}\text { Generally similar to Alternatives } 2 \\
\text { and } 3 \text {. Long-term exposures would } \\
\text { be minimized by removing and } \\
\text { treating contaminated soil from the } \\
\text { main pits and pushout area. }\end{array}$ & $\begin{array}{l}\text { Generally similar to Altematives } 2,3 \text {, } \\
\text { and } 4 \text {. Treatment and disposal of a } \\
\text { large volume of contaminated soil } \\
\text { would be conducted off-site; therefore, } \\
\text { the overall risk of exposure to the } \\
\text { general public would be higher than } \\
\text { that for Alternatives } 2,3 \text {, and } 4 \text {. }\end{array}$ \\
\hline \multicolumn{5}{|l|}{ Compliance with ARARs } \\
\hline $\begin{array}{l}\text { Would not meet all ARARs, } \\
\text { including the corrective action } \\
\text { requirements of RCRA and } \\
\text { TSCA. In addition, would not } \\
\text { satisfy the CERCLA-mandated } \\
\text { preference for remedies that } \\
\text { reduce contaminant toxicity, } \\
\text { mobility, or volume } \\
\text { through treatment. }\end{array}$ & $\begin{array}{l}\text { Would meet all pertinent ARARs } \\
\text { (with waivers as appropriate), } \\
\text { including those that address protection } \\
\text { of endangered species and habitats, } \\
\text { floodplains, and wetlands. } \\
\text { Implementing Alternative } 2 \text { might } \\
\text { require preparation of a sediment and } \\
\text { erosion control plan. }\end{array}$ & $\begin{array}{l}\text { Same as Altemative } 2 \text {. The on-site } \\
\text { storage facility would be operated to } \\
\text { ensure compliance with RCRA. }\end{array}$ & $\begin{array}{l}\text { Same as Alternatives } 2 \text { and } 3 \text {. The } \\
\text { on-site treatment facility would be } \\
\text { operated to ensure compliance } \\
\text { with RCRA. }\end{array}$ & $\begin{array}{l}\text { Same as Alternatives } 2,3 \text {, and } 4 \text {, with } \\
\text { additional disposal requirements that } \\
\text { would be met, including RCRA } \\
\text { hazardous waste generator. }\end{array}$ \\
\hline
\end{tabular}


TABLE S.3 (Cont.)

\begin{tabular}{|c|c|c|c|c|}
\hline $\begin{array}{l}\text { Alternative 1: } \\
\text { No Action } \\
\end{array}$ & $\begin{array}{c}\text { Altemative 2: } \\
\text { Limited Removal and Disposal, and } \\
\text { In-Situ Containment }\end{array}$ & $\begin{array}{c}\text { Alternative 3: } \\
\text { Removal and Short-Term Storage } \\
\end{array}$ & $\begin{array}{c}\text { Alternative 4: } \\
\text { Removal, On-Site Treatment, } \\
\text { and Limited Disposal } \\
\end{array}$ & $\begin{array}{c}\text { Alternative 5: } \\
\text { Removal, Off-Site Treatment, } \\
\text { and Disposal } \\
\end{array}$ \\
\hline \multicolumn{5}{|c|}{ Long-Term Effectiveness and Permanence } \\
\hline $\begin{array}{l}\text { Current exposures and impacts } \\
\text { would continue and could } \\
\text { increase over time because of } \\
\text { continued contaminant migra- } \\
\text { tion. Existing institutional } \\
\text { controls would continue to limit } \\
\text { access to site workers and other } \\
\text { authorized personnel, thereby } \\
\text { reducing risk to the general } \\
\text { public. }\end{array}$ & $\begin{array}{l}\text { More protective than Alternatives } 1 \\
\text { and } 3 \text { because contaminated soil } \\
\text { would be partially removed; the } \\
\text { remaining soil then would be covered } \\
\text { to reduce exposure of human and } \\
\text { environmental receptors to surface } \\
\text { contamination. Soil cleanup criteria } \\
\text { would be applied to the removal of } \\
\text { soils and to the delineation of the area } \\
\text { to be covered. }\end{array}$ & $\begin{array}{l}\text { More protective than Alternative } 1 \\
\text { because contaminated soil would be } \\
\text { removed and stored in an enclosed } \\
\text { facility to provide an interim solution } \\
\text { for risk posed by contaminated surface } \\
\text { soil. Soil cleanup criteria would be } \\
\text { applied as appropriate to the removal } \\
\text { of soils, so the action would reduce } \\
\text { contaminant concentrations remaining } \\
\text { in soil to the most protective } \\
\text { levels practicable. }\end{array}$ & $\begin{array}{l}\text { More protective than Alternatives } 1 \\
\text { and } 3 \text { because contaminated surface } \\
\text { soil would be removed and treated } \\
\text { (soil washing/leaching) to provide a } \\
\text { permanent solution for risk posed } \\
\text { by contaminated surface soil. Soil } \\
\text { cleanup criteria would be applied as } \\
\text { appropriate to the removal of soils, } \\
\text { so the action would reduce contami- } \\
\text { nant concentrations remaining in } \\
\text { soil to the most protective } \\
\text { levels.practicable. }\end{array}$ & $\begin{array}{l}\text { Similar to Altemative } 4 \text {, except that } \\
\text { exposure of stabilized/solidified waste } \\
\text { to the environment could result in } \\
\text { contaminants leaching from the waste } \\
\text { over time. }\end{array}$ \\
\hline \multicolumn{5}{|c|}{ Reduction of Toxicity, Mobility, or Volume } \\
\hline $\begin{array}{l}\text { Toxicity, mobility, and volume } \\
\text { of contaminated soil would } \\
\text { not change. }\end{array}$ & $\begin{array}{l}\text { The in-situ containment component } \\
\text { would significantly reduce contam- } \\
\text { inant mobility. Contaminant volume } \\
\text { would be somewhat reduced by the } \\
\text { limited removal and disposal } \\
\text { component. Contaminant toxicity } \\
\text { would not be reduced. }\end{array}$ & $\begin{array}{l}\text { Short-term storage of soil in an on-site } \\
\text { facility would significantly reduce } \\
\text { contaminant mobility. An estimated } \\
16,000 \mathrm{yd}^{3}(27,200 \text { tons) of soil would } \\
\text { be stored on-site for about } 5 \text { years. } \\
\text { Contaminant toxicity and volume } \\
\text { would not be reduced. }\end{array}$ & $\begin{array}{l}\text { Chemical treatment of soil by soil } \\
\text { washing/leaching would signif- } \\
\text { icantly reduce contaminant mobility } \\
\text { and volume. An estimated } \\
16,000 \text { yd }^{3} \text { ( } 27,200 \text { tons) of soil } \\
\text { would be treated on-site by soil } \\
\text { washing/leaching. This process } \\
\text { could reduce original soil volume by } \\
\text { about } 94 \% \text {; the remaining } 6 \% \text { could } \\
\text { then be sent off-site for disposal. } \\
\text { Toxicity of PCBs would be reduced. } \\
\text { Lead toxicity would not be reduced; } \\
\text { however, the metal would be } \\
\text { removed and recycled. }\end{array}$ & $\begin{array}{l}\text { Chemical treatment of soil with the } \\
\text { stabilization/solidification technology } \\
\text { would significantly reduce contaminant } \\
\text { mobility. An estimated } 16,000 \mathrm{yd}^{3} \\
\text { ( } 27,200 \text { tons) of soil would be treated } \\
\text { off-site by chemical stabilization/ } \\
\text { solidification. This process could } \\
\text { increase the original soil volume and } \\
\text { weight by as much as } 30 \% \text { and } 60 \% \text {, } \\
\text { respectively. This would result in a } \\
\text { total treated volume of about } \\
20,800 \text { yd }{ }^{3} \text { and total weight of about } \\
35,360 \text { tons to be placed in a landfill. } \\
\text { Contaminant toxicity would } \\
\text { not be reduced. }\end{array}$ \\
\hline
\end{tabular}


TABLE S.3 (Cont.)

\begin{tabular}{|c|c|c|c|c|}
\hline $\begin{array}{l}\text { Altemative 1: } \\
\text { No Action }\end{array}$ & $\begin{array}{c}\text { Alternative 2: } \\
\text { Limited Removal and Disposal, and } \\
\text { In-Situ Containment } \\
\end{array}$ & $\begin{array}{l}\text { Alternative 3: } \\
\text { Removal and Short-Term Storage }\end{array}$ & $\begin{array}{c}\text { Alternative 4: } \\
\text { Removal, On-Site Treatment, } \\
\text { and Limited Disposal } \\
\end{array}$ & $\begin{array}{c}\text { Alternative 5: } \\
\text { Removal, Off-Site Treatment, } \\
\text { and Disposal } \\
\end{array}$ \\
\hline \multicolumn{5}{|l|}{ Short-Term Effectiveness } \\
\hline $\begin{array}{l}\text { Current exposures and adverse } \\
\text { impacts would continue. Existing } \\
\text { institutional controls would } \\
\text { continue to limit access to site } \\
\text { workers and other authorized } \\
\text { personnel, thus reducing risks to } \\
\text { the general public. Short-term } \\
\text { risks to site workers and the } \\
\text { environment as a result of } \\
\text { monitoring and maintenance } \\
\text { activities are considered low. }\end{array}$ & $\begin{array}{l}\text { Exposures would be lower than for } \\
\text { Alternatives } 3,4 \text {, and } 5 \text {, which } \\
\text { involve large-scale excavation. } \\
\text { Mitigative measures would still be } \\
\text { required in the short term because of } \\
\text { particulate and VoC emissions } \\
\text { associated with removal and trans- } \\
\text { portation activities. No adverse } \\
\text { impacts to the general public are } \\
\text { expected from contaminant releases } \\
\text { during implementation of this } \\
\text { altemative. Soil, vegetation, and } \\
\text { wildlife disturbances would be } \\
\text { significant during soil excavation } \\
\text { activities. An estimated } 5 \text { acres would } \\
\text { be affected. Most impacts to biota } \\
\text { would be temporary. Surface water } \\
\text { impacts associated with the } \\
\text { construction of a berm along the } \\
\text { pushout-marsh boundary would be } \\
\text { minimal (and localized). Surface } \\
\text { water input would be reduced, but } \\
\text { reduction in erosion and transport of } \\
\text { soils into the marsh would be a } \\
\text { benefit to the marsh ecosystem. } \\
\text { Mitigative measures would be } \\
\text { implemented to minimize impacts to } \\
\text { air quality and those associated with } \\
\text { noise levels. }\end{array}$ & $\begin{array}{l}\text { Exposures could be higher than } \\
\text { Alternatives } 1 \text { and } 2 \text { in the short term } \\
\text { because of particulate and VOC } \\
\text { emissions associated with removal, } \\
\text { transportation, and storage activities. } \\
\text { Mitigative measures would be } \\
\text { implemented to minimize potential } \\
\text { human health and environmental } \\
\text { impacts. Risks to a site worker would } \\
\text { increase compared to Alternative I; } \\
\text { however, worker health and safety } \\
\text { precautions would be used to control } \\
\text { exposures. No adverse impacts to the } \\
\text { general public are expected from } \\
\text { contaminant releases during imple- } \\
\text { mentation of this alternative. Soil, } \\
\text { vegetation, and wildlife disturbances } \\
\text { would be significant during soil } \\
\text { excavation activities. An estimated } \\
5 \text { acres would be affected. Most } \\
\text { impacts to biota would be temporary. } \\
\text { Activities are not expected to affect } \\
\text { threatened or endangered species. } \\
\text { Mitigative measures would be } \\
\text { cmployed to minimize impacts to } \\
\text { surface water resources (including the } \\
\text { adjacent marsh), air quality, and those } \\
\text { associated with noise levels. }\end{array}$ & Similar to Altemative 3 . & $\begin{array}{l}\text { Similar to Altematives } 3 \text { and } 4 \text {, except } \\
\text { that overall risk to the general public } \\
\text { would be higher because this alter- } \\
\text { native would involve the off-site } \\
\text { transport of a large volume of } \\
\text { contaminated soil. Additional } \\
\text { mitigative measures would be } \\
\text { implemented to reduce related impacts. }\end{array}$ \\
\hline
\end{tabular}


TABLE S.3 (Cont.)

\begin{tabular}{|c|c|c|c|c|}
\hline $\begin{array}{l}\text { Alternative 1: } \\
\text { No Action }\end{array}$ & $\begin{array}{c}\text { Alternative 2: } \\
\text { Limited Removal and Disposal, and } \\
\text { In-Situ Containment }\end{array}$ & $\begin{array}{l}\text { Altemative 3: } \\
\text { Removal and Short-Term Storage }\end{array}$ & $\begin{array}{l}\text { Alternative 4: } \\
\text { Removal, On-Site Treatment, } \\
\text { and Limited Disposal } \\
\end{array}$ & $\begin{array}{c}\text { Alternative 5: } \\
\text { Removal, Off-Site Treatment, } \\
\text { and Disposal } \\
\end{array}$ \\
\hline \multicolumn{5}{|l|}{ Implementability } \\
\hline $\begin{array}{l}\text { Minimum site operations } \\
\text { (monitoring and maintenance) } \\
\text { would continue with the use of } \\
\text { readily available resources. }\end{array}$ & $\begin{array}{l}\text { Fairly straightforward to implement. } \\
\text { Resources are readily available for } \\
\text { UXO screening, soil removal, in-situ } \\
\text { containment, and shoreline } \\
\text { stabilization. }\end{array}$ & $\begin{array}{l}\text { Fairly straightforward to implement. } \\
\text { Resources are readily available for } \\
\text { UXO screening, soil removal, and } \\
\text { on-site storage. Short-term storage } \\
\text { facilities are available as kits and } \\
\text { can be customized to meet } \\
\text { project specifications. }\end{array}$ & $\begin{array}{l}\text { Similar to Alternative } 3 \text {. Soil } \\
\text { washing/leaching has been used at } \\
\text { several hazardous waste sites and } \\
\text { probably would not require further } \\
\text { development before it could be } \\
\text { implemented at the TBP area. } \\
\text { Further bench-scale testing would } \\
\text { be required to refine and optimize. } \\
\text { the design of the treatment system. }\end{array}$ & $\begin{array}{l}\text { Similar to Alternatives } 3 \text { and } 4 \text {. } \\
\text { Chemical stabilization/solidification is } \\
\text { an established technology and would } \\
\text { not require further development before } \\
\text { it could be implemented. }\end{array}$ \\
\hline \multicolumn{5}{|l|}{ Cost } \\
\hline $\begin{array}{l}\text { The total cost would be the } \\
\text { lowest in the short term (about } \\
\$ 3 \text { million over a } 10 \text {-year } \\
\text { period), but the comparative } \\
\text { level of effectiveness would be } \\
\text { low. In addition, the cost could } \\
\text { be potentially higher than the } \\
\text { action alternatives over the long } \\
\text { term because conditions could } \\
\text { worsen over time, necessitating } \\
\text { an expensive expanded response } \\
\text { in the future. }\end{array}$ & $\begin{array}{l}\text { The total cost would be about } \\
\$ 1.8 \text { million, the lowest of all the } \\
\text { action alternatives. This cost, } \\
\text { however, reflects only O\&M costs for } \\
\text { the next } 30 \text { years. Because } \\
\text { contaminated soil would remain in } \\
\text { place, O\&M costs would likely } \\
\text { extend indefinitely into the future. } \\
\text { Repairs associated with the } \\
\text { catastrophic effects of a 100-year } \\
\text { flood (should such occur) are not } \\
\text { reflected in this estimate. }\end{array}$ & $\begin{array}{l}\text { The total cost would be about } \\
\$ 5.0 \text { million (for } 16,000 \mathrm{yd}^{3} \text { of soil), } \\
\text { the second lowest of all the action } \\
\text { alternatives. This cost, however, does } \\
\text { not include the cost of an additional } \\
\text { component (off-site treatment and } \\
\text { disposal) that would be needed to } \\
\text { ensure long-term protectiveness and } \\
\text { permanence. Therefore, while this } \\
\text { alternative would achieve project } \\
\text { objectives of reducing exposures and } \\
\text { minimizing contaminant migration at a } \\
\text { low cost, it is considered the least cost- } \\
\text { effective because additional } \\
\text { components would be required when } \\
\text { the } 5 \text {-year storage period ended. }\end{array}$ & $\begin{array}{l}\text { The total cost would be about } \\
\$ 13.0 \text { million (for } 16,000 \mathrm{yd}^{3} \\
\text { of soil), which is the highest of } \\
\text { the action alternatives. The soil } \\
\text { washing/leaching component would } \\
\text { account for } 86 \% \text { of the total direct } \\
\text { cost of this alternative. }\end{array}$ & $\begin{array}{l}\text { The total cost would be about } \\
\$ 10.5 \text { million (for } 16,000 \mathrm{yd}^{3} \text { of soil), } \\
\text { which is lower than Alternative } 4 \text { for } \\
\text { the same overall level of effectiveness. } \\
\text { Off-site treatment and disposal would } \\
\text { account for } 85 \% \text { of the total direct cost } \\
\text { of this alternative. }\end{array}$ \\
\hline
\end{tabular}




\section{S.8 REFERENCES FOR SUMMARY}

- Hlohowskyj, I., et al., 1996, Remedial Investigation Report for J-Field, Aberdeen Proving Ground, Maryland, Volume 2: Ecological Risk Assessment, draft prepared by Argonne National Laboratory, Argonne, Ill., for U.S. Army, Aberdeen Proving Ground, Md., Directorate of Safety, Health, and Environment.

ICF Kaiser Engineers, 1995a, J-Field Toxic Burn Pits Baseline Human Health Risk Assessment, draft prepared for U.S. Army Environmental Center, Aberdeen Proving Ground, Md., Aug.

ICF Kaiser Engineers, 1995b, Reference Sampling and Analysis Program at the U.S. Army Aberdeen Proving Ground, Soil, Sediment, and Surface Water Reference Data Report, prepared for U.S. Army Environmental Center, Aberdeen Proving Ground, Md., July.

U.S. Environmental Protection Agency, 1988, Guidance for Conducting Remedial Investigations and Feasibility Studies under CERCLA, Interim Final, EPA/540/G-89/004 (OSWER Directive 9355.3-01), Office of Emergency and Remedial Response, Washington, D.C., Oct.

U.S. Environmental Protection Agency, 1989a, Risk Assessment Guidance for Superfund, Vol. I, Human Health Evaluation Manual, Part A, EPA/540/1-89/002, Office of Emergency and Remedial Response, Washington, D.C., Dec.

U.S. Environmental Protection Agency, 1989b, Risk Assessment Guidance for Superfund, Vol. II, Environmental Evaluation Manual, EPA/540/1-89/001, Office of Emergency and Remedial Response, Washington, D.C., March.

U.S. Environmental Protection Agency, 1990, "National Oil and Hazardous Substances Pollution Contingency Plan; Final Rule (40 CFR Part 300)," Federal Register, 55(35):6154-6176, Feb. 21.

U.S. Environmental Protection Agency, 1991a, Human Health Evaluation Manual, Supplemental Guidance: Standard Default Exposure Factors, OSWER Directive 9285.6-03, Office of Emergency and Remedial Response, Washington, D.C., March 25.

U.S. Environmental Protection Agency, 1991b, Risk Assessment Guidance for Superfund, Vol. 1, Human Health Evaluation Manual, Part B, Development of Risk-Based Preliminary Remediation Goals, EPA/540/R-92/003, Office of Emergency and Remedial Response, Washington, D.C., Dec.

U.S. Environmental Protection Agency, 1994, Revised Interim Soil Lead Guidance for CERCLA Sites and RCRA Corrective Action Sites, OSWER Directive 9355.4-12, Office of Emergency and Remedial Response, Washington, D.C., Aug. 
Wrobel, J., 1995, personal communication from Wrobel (Directorate of Safety, Health, and Environment, U.S. Army Aberdeen Proving Ground, Md.) to L. Martino (Argonne National Laboratory, Argonne, III.), July 15.

Yuen, R., et al., 1996, Remedial Investigation Report for J-Field, Aberdeen Proving Ground, Maryland, Volume 1: Remedial Investigation Results, draft prepared by Argonne National Laboratory, Argonne, Ill., for U.S. Army, Aberdeen Proving Ground, Md., Directorate of Safety, Health, and Environment. 


\section{INTRODUCTION}

\subsection{BACKGROUND}

The Environmental Management Division (EMD) of Aberdeen Proving Ground (APG), Maryland, is conducting a remedial investigation and feasibility study (RI/FS) of the J-Field area at APG pursuant to the Comprehensive Environmental Response, Compensation, and Liability Act, as amended (CERCLA). J-Field is located within the Edgewood Area of APG in Harford County, Maryland (Figure 1.1). Since World War II, activities in the Edgewood Area have included the development, manufacture, testing, and destruction of chemical agents and munitions. These materials were destroyed at J-Field by open burning/open detonation (OB/OD). Portions of J-Field continue to be used for the detonation and disposal of unexploded ordnance (UXO) by OB/OD under authority of the Resource Conservation and Recovery Act (RCRA).

J-Field is almost flat and is covered by open fields, woods, and nontidal marshes. It encompasses about 460 acres at the southern end of the Gunpowder Neck Peninsula (Figure 1.1). The peninsula is surrounded by tidal estuaries on three sides - Gunpowder River to the west and Chesapeake Bay to the south and east.

The Toxic Burning Pits (TBP) area, one of the designated areas of concern (AOCs) at $\mathrm{J}$-Field, is located on about 9 acres in the southern portion of J-Field (Figure 1.2). This area was used to dispose of bulk chemical wastes, drummed chemical wastes, high explosives, various chemical agents, and chlorinated solvents. The TBP location contains several potential source areas of contamination, including five burning pits (two main pits and the methylphosphonothioic acid [VX], mustard, and liquid smoke pits), a pushout area, a storage area, a disposal area, and a demolition area.

\subsection{PURPOSE OF THIS REPORT}

The purpose of this focused feasibility study (FFS) is to develop and evaluate potential remedial action alternatives to address surface soil contamination at three source areas within the J-Field TBP area: the northern main pit, the southern main pit, and the pushout area. The FFS report documents this process; its purpose is to provide sufficient information to support an informed decision regarding an appropriate interim remedial action for these areas. 


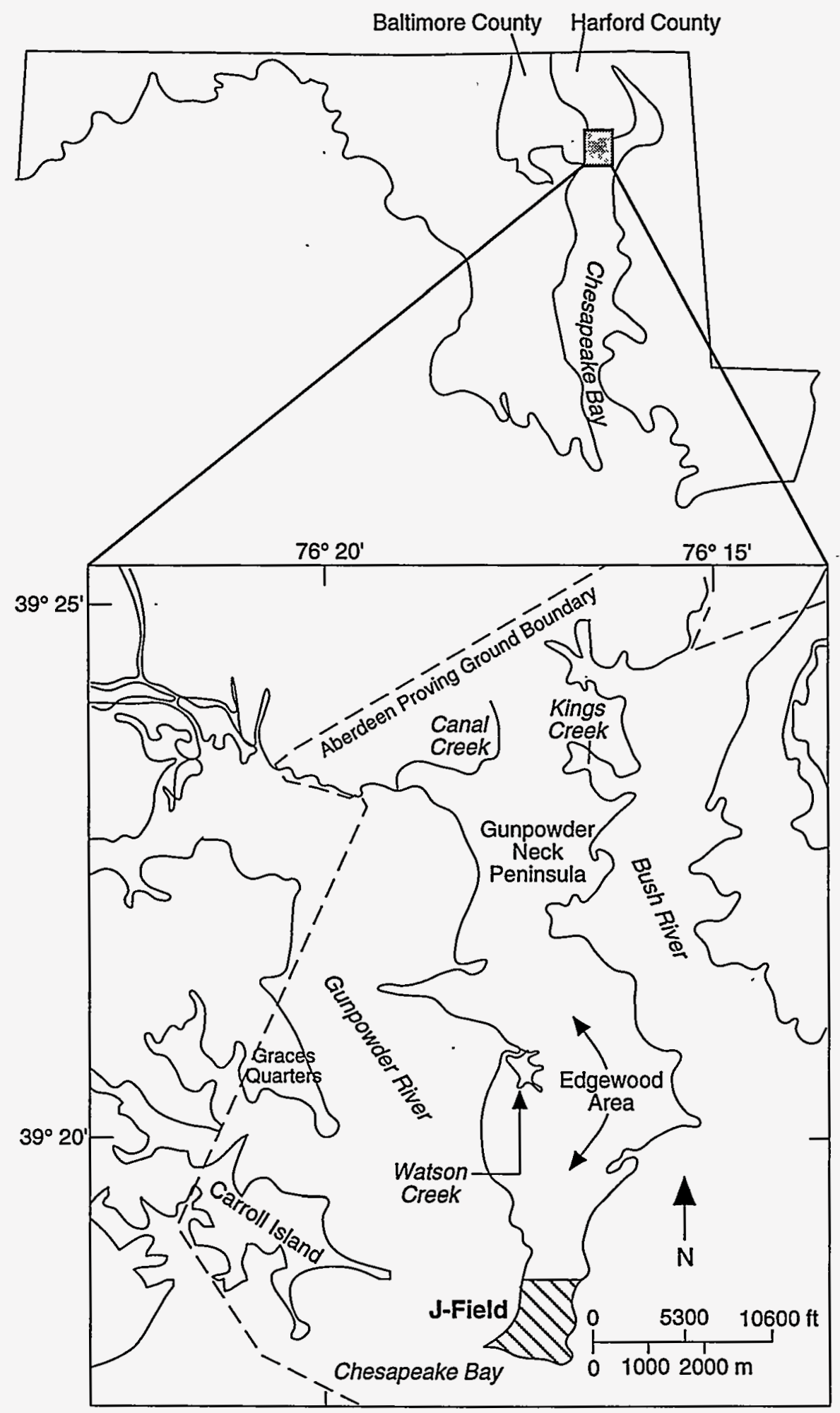

FIGURE 1.1 Location of J-Field in the Edgewood Area at APG 


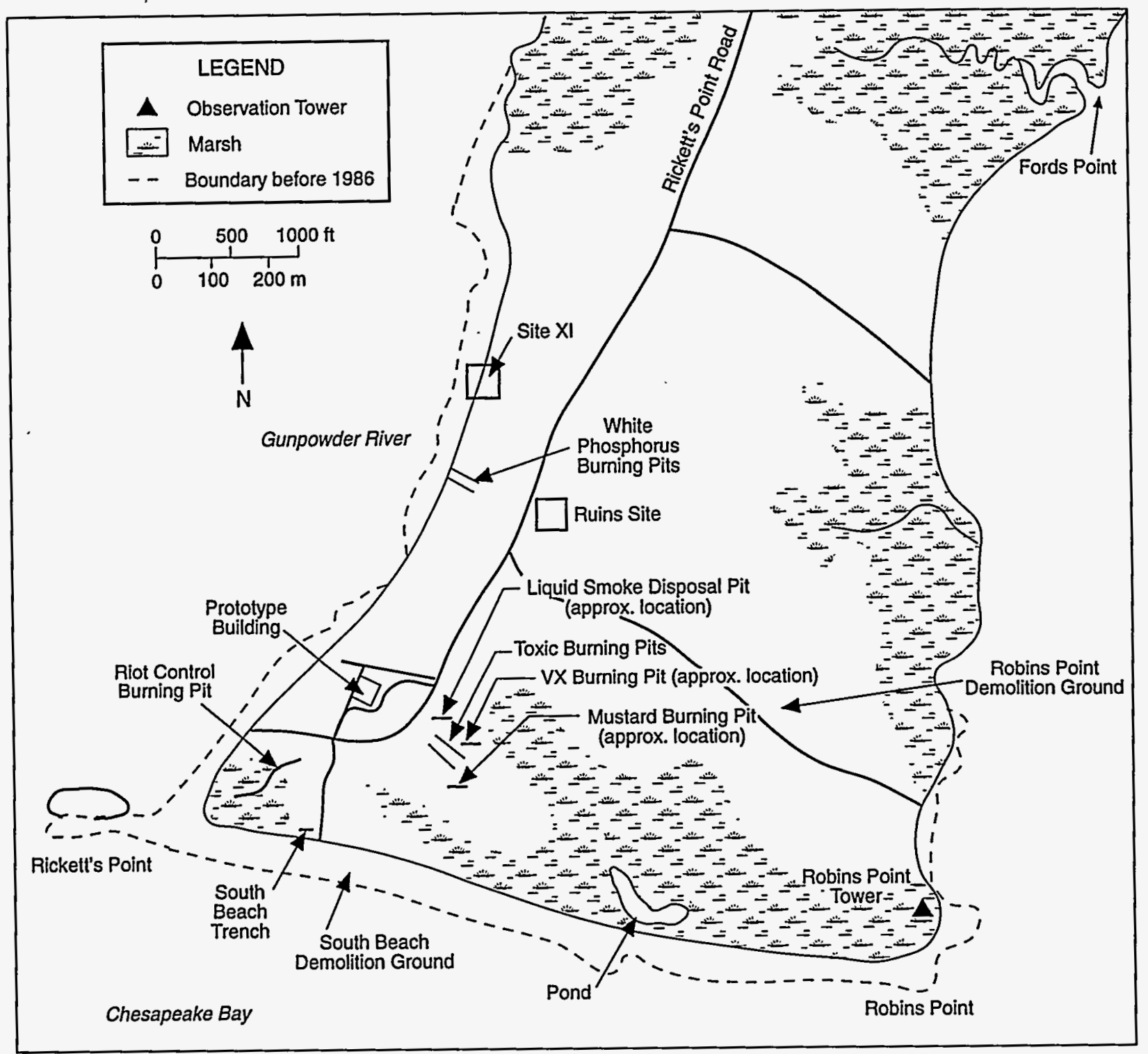

\section{FIGURE 1.2 Locations of Principal Site Features at J-Field}

\subsection{ORGANIZATION OF THIS REPORT}

Section 1 of this report presents background information and summarizes the purpose of the proposed action within the context of the RI/FS process. Section 2 describes the site history and environmental setting. The environmental setting includes site topography, soil, surface water, geology and hydrogeology, groundwater, climate, ecology, and land use. Also provided are an overview of available information about the nature and extent of contamination at the TBP area and a discussion of exposure pathways. Contaminants of concern (COCs) are also identified in Section 2.

Section 3 describes the overall objectives of the interim remedial action. Other site aspects discussed include applicable or relevant and appropriate requirements (ARARs), to-be-considered requirements (TBCs), and the development of interim preliminary remediation goals (PRGs). In 
Section 4, potentially applicable technologies are screened on the basis of effectiveness, implementability and cost, and site-specific conditions. Section 5 describes and screens the preliminary interim remedial action alternatives.

Section 6 provides a detailed description of the final interim remedial action alternatives. These alternatives are evaluated in Section 7 against nine general criteria: overall protection of human health and the environment; compliance with ARARS; long-term effectiveness and performance; reduction of contaminant toxicity, mobility, and volume through treatment; short-term effectiveness; implementability; and cost. The discussion of state and community acceptance has been deferred and will be addressed in the Responsiveness Summary prepared for the Record of Decision (ROD) for the site. Section 8 presents a comparative analysis.

All references cited in this report are listed in Section 9, and a list of preparers is given in Section 10. Appendix A evaluates potential metal transport via leaching through the unsaturated zone at the TBP area. Appendix B provides tables summarizing preliminary identification of ARARs and TBCs for J-Field. Appendix C consists of data summary tables for the TBP area. Appendix D describes the RI characterization activities and sampling results at the TBP area. Appendix E explains the uptake model and approach used to develop ecological-based interim PRGs. The methodology and assumptions used to determine the costs of the interim remedial action alternatives are presented in Appendix F. Appendix G gives conversion factors between metric and English units of measure. 


\section{SITE BACKGROUND}

\subsection{SITE HISTORY}

Disposal operations at the TBP area began in the 1940s and continued until about 1980 . The pits were used most extensively between the late 1940s and 1960s. Items disposed of included bulk chemical wastes, drummed chemical wastes, high explosives (HE) (by OB/OD), nerve agents, incapacitating agents (also known as riot-control agents), chlorinated solvents, and blister agents (Nemeth 1989).

Information from interviews, sampling, geophysical surveys, and analysis of historical aerial photographs indicates that five disposal pits were used at the TBP area (Figure 2.1). The two existing (or main) burning pits, each covering an area of about $4,500 \mathrm{ft}^{2}$, were most actively used for the disposal of various chemical agents and explosives. These pits are referred to as the northern and southern main pits in this report and are the only visible open pits in this area. Two other burning pits (the VX and mustard pits, Figure 2.1) are buried. The liquid smoke disposal pit, a small pit measuring $4 \times 6 \mathrm{ft}$, has also been reported (Nemeth 1989); however, its specific location is not clear. In the HE demolition ground, near the southern edge of the site (Figure 2.1), HE munitions were disposed of by detonation (Nemeth 1989). The TBP storage area, a fenced area near the southwestern end of the mustard pit, was used for storage, as evidenced by historical aerial photographs taken in the 1960s (U.S. Army 1965). A scrap metal mound has been observed in the field near the southwestern portion of the site, adjacent to the marsh. This area (the TBP southwestern suspect burning area, Figure 2.1) was probably active in the 1950 s and 1960s, as indicated by historical aerial photographs, and may have been used for burning and/or demolition. A small square pit, measuring about $3.5 \times 4.25 \mathrm{ft}$, lies between the southwestern suspect burning area and monitoring well P9. This feature is believed to be the liquid smoke disposal pit.

Procedures for open burning in the TBP area involved placing 3-4 $\mathrm{ft}$ of wood dunnage in a pit, placing the materials to be burned on top of the dunnage, adding fuel oil, and igniting it. Scrap metal items were removed and reburned in the same manner. Large metal items were recovered and disposed of as scrap. The depths of the pits were maintained by pushing burned soil and ash out toward the adjacent marsh. The areas where this material now resides are referred to collectively as the "pushout" area (Figure 2.1). The pushout area associated with the four burning pits occupies about $100,000 \mathrm{ft}^{2}$ and extends more than $100 \mathrm{ft}$ into the marsh (Sonntag 1991). Currently, the pushout area shows obvious signs of disturbance, including an uneven surface, areas of bare ground, and disposal debris (e.g., rebar, sheet metal, and rusted pipes).

An agent known as DANC (decontaminating agent, noncorrosive) was commonly used to decontaminate scrap metal contaminated with mustard, Lewisite, and VX (Nemeth 1989). DANC 


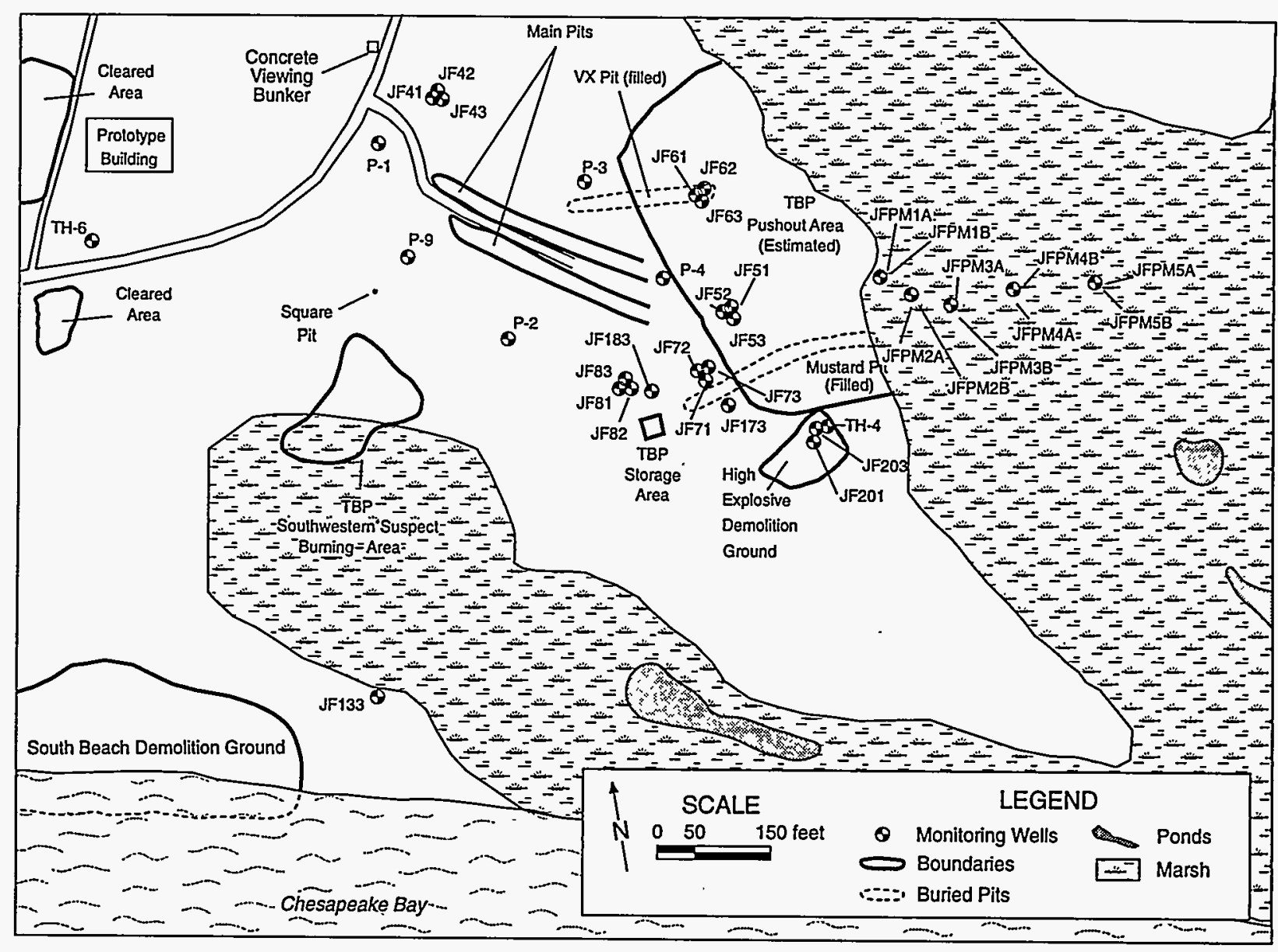

FIGURE 2.1 Locations of Main Features and Monitoring Wells at the TBP Area

is an organic $\mathrm{N}$-chloroamide compound in solution with 1,1,2,2-tetrachloroethane (TCLEA); it typically contains $90-95 \%$ (by weight) TCLEA.

\subsection{SITE DESCRIPTION}

\subsubsection{Topography}

J-Field is nearly flat, with a maximum relief of about $10 \mathrm{ft}$. The elevation in the TBP area ranges from about $14 \mathrm{ft}$ above mean sea level (MSL) near the main pits to bay level at the shore. The adjacent marsh and freshwater pond are at an elevation of about $5 \mathrm{ft}$ above MSL during wet periods. 


\subsubsection{Soil}

The APG was not mapped in the most recent Harford County soil survey (Smith and Matthews 1975). However, a previous survey by Perkins and Winant (1927) includes the APG. Their map indicates that the surface of J-Field comprises fairly equal areas of Elkton silt loam, Sassafras loam, and tidal marshes, with minor areas of Sassafras silt loam. Smith and Matthews (1975) describe the Elkton soil as slowly permeable and poorly drained. The Sassafras soils are moderately permeable and well drained. The tidal marsh soil is sandy to clayey, with peat or muck.

\subsubsection{Surface Water}

Surface water features at J-Field include freshwater marshes, a marsh pond, and two unnamed streams that discharge into the Bush River (Figure 1.1). The freshwater marsh and pond along the southern shore near the TBP area are separated from Chesapeake Bay by sandy beaches. Because the beach acts as a dam, this marsh typically has water levels about $2 \mathrm{ft}$ above high tide (Hughes 1993a). The large pond in this marsh has a maximum depth of about $5 \mathrm{ft}$. Other large marshes are present along J-Field's eastern and western shores. Water levels in these marshes are tidal influenced (Hughes 1993b). The streams along the eastern coast of J-Field are also affected by tides. Discharge is minimal except during heavy rainfalls (Hughes 1993a). The TBP area is located within the 100-year floodplain (Federal Emergency Management Agency [FEMA] 1986).

A tidal measuring station, located on Pooles Island (about $1 \mathrm{mi}$ southeast of J-Field), shows that the difference between the mean high tide and the mean low tide is about $1.2 \mathrm{ft}$ (National Oceanic and Atmospheric Administration [NOAA] 1993). The average level of the surrounding estuaries at Pooles Island is about $0.9 \mathrm{ft}$ above MSL (Hughes 1993c). Vroblesky et al. (1989) determined an average bay level of $1.5 \mathrm{ft}$ above MSL at an APG site north of J-Field. Hughes (1993b) suggested that the bay level measured by Vroblesky et al. was higher because the tide station for the study was located on an inland creek and not in the bay or estuary.

The depth of water in the Gunpowder River and Chesapeake Bay proper within $0.5 \mathrm{mi}$ of J-Field's shores is generally shallower than $12 \mathrm{ft}$ below mean lower low water (NOAA 1993). ${ }^{1}$

\subsubsection{Geology and Hydrogeology}

The stratigraphy at J-Field consists of Pleistocene sediments of the Talbot Formation underlain by Cretaceous sediments of the Patapsco Formation (Potomac Group). The Pleistocene deposits are divided into three main units: a surficial, unconfined aquifer of interbedded sand, clay,

1 "Mean lower low water" refers to the mean of the lower of the two daily low tides. 
and silt; a confining unit of sandy and silty clay; and confined sand and gravel aquifer (Hughes 1993a). On the basis of current knowledge of contaminant distribution, groundwater studies have focused on the surficial aquifer. The generalized stratigraphy in the TBP area is shown in Figure 2.2.

The deeper Talbot deposits fill a paleochannel eroded into the Patapsco sediments. Pleistocene paleochannels are common in the region (Kerhin et al. 1988), and similar features have been identified at other APG study areas (Lorah and Clark 1992; Vroblesky et al. 1989; Oliveros and Vroblesky 1989). Hughes (1991, 1992, 1993a) performed a marine seismic survey around the J-Field peninsula to determine the offshore extent of the geologic units. The seismic data suggest that the confining unit and the confined aquifer pinch out against the sides of a southwest-trending paleochannel. The width of this feature is approximately $1 \mathrm{mi}$.

Several monitoring wells were installed in the TBP area during the field investigations conducted at J-Field (Figure 2.1). One TH-series well (TH4) was installed near the TBP area by the U.S. Army Toxic and Hazardous Materials Agency (USATHAMA) during a 1977 environmental survey. Five additional wells (P1-4, 9) were installed by Princeton Aqua Science (1984). These wells

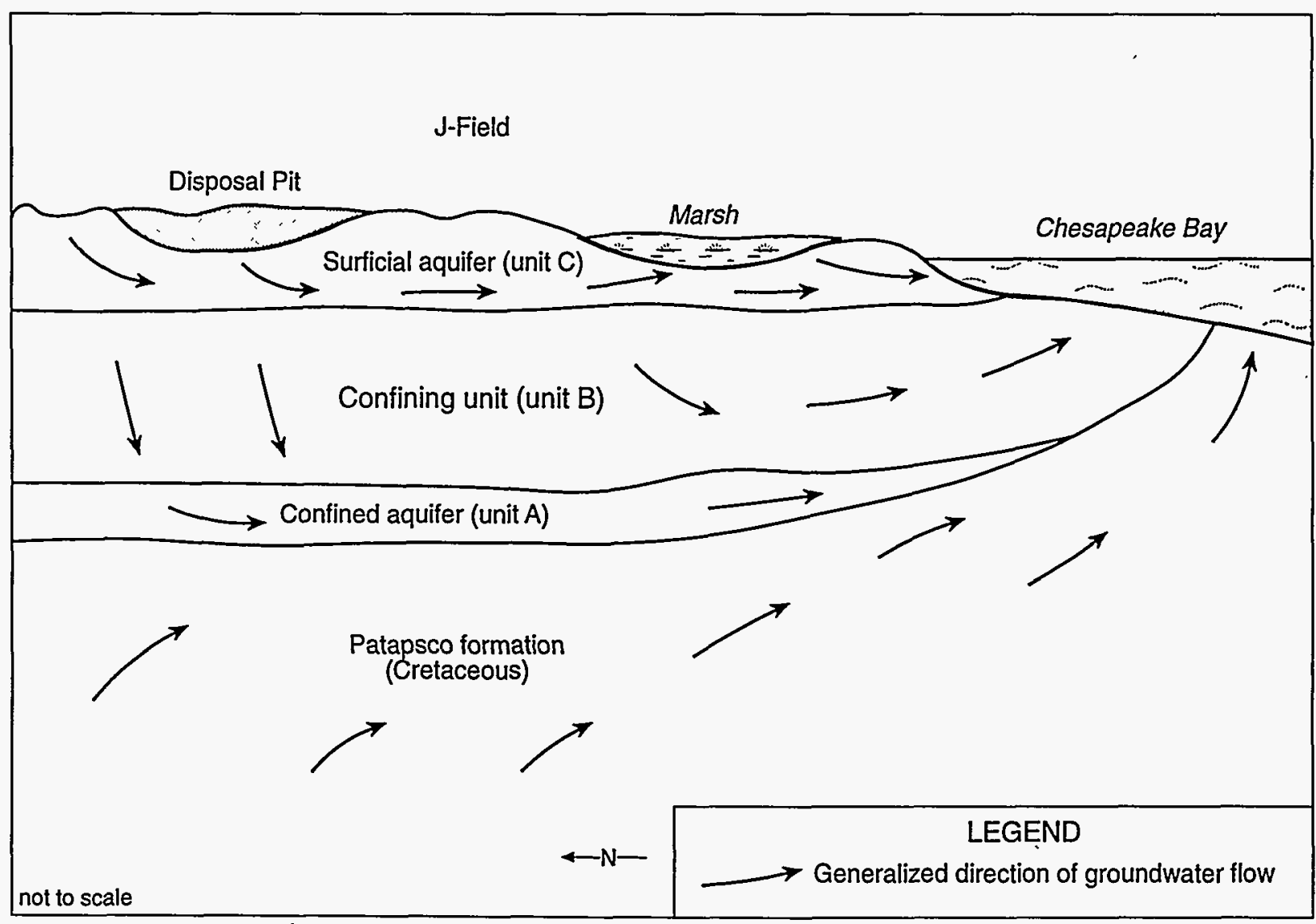

FIGURE 2.2 Generalized Hydrogeologic Cross Section and Direction of Groundwater Flow at J-Field TBP Area (Source: Modified from Hughes 1993a) 
are all screened in the surficial aquifer to a maximum depth of $20 \mathrm{ft}$; they do not penetrate the confining unit.

The U.S. Geological Survey (USGS) installed five monitoring well nests (JF4-JF8), each consisting of three wells, in each of the three main Pleistocene units (Hughes 1993a). The well screens range in length from 3 to $5 \mathrm{ft}$. Hughes estimated hydraulic conductivities for these units based on slug tests performed in these and other J-Field monitoring wells.

In 1993, well JF173 was installed southeast of the main pits to monitor for dense, nonaqueous-phase liquids (DNAPLs) at the base of the surficial aquifer. The well is screened over a 5-ft interval, ranging from a depth of 26 to $31 \mathrm{ft}$ (Patton 1994). Well JF183 was installed for use as a pumping well for the pumping test conducted in 1994; it is screened across the entire depth of the surficial aquifer.

In early 1996, wells JF201 and JF203 were installed adjacent to well TH4. Well JF203 is shallow, installed to replace the sediment-filled TH4. Well JF201 was installed to a depth of $165 \mathrm{ft}$ to assess the confined aquifer.

\subsubsection{Surficial Aquifer}

The surficial aquifer is composed of medium- to fine-grained sand with interbedded clay (Hughes 1993a). The sand is generally red to gray in color; the clay is dark to light gray. The sandy facies are commonly silty or clayey. Hughes suggests that these sediments were deposited in an estuarine or marginal marine system during a period of higher sea level. A 10-ft vertical exposure of this unit can be viewed along the coast west of the TBP area. Here the stratigraphy is mainly reddish silt with fine sand. A 1-ft clay layer is also present. The depositional units appear to be continuous along the $50-\mathrm{ft}$ length of the 10 -ft-high cliff.

The total thickness of the surficial aquifer in the TBP area ranges from 30 to $40 \mathrm{ft}$. The USGS data suggest a basal contact elevation of 25-31 ft below MSL. Clay or silt units with thicknesses of up to $8 \mathrm{ft}$ have been logged within this unit.

The hydraulic conductivity of the surficial aquifer has been estimated in several ways. Hughes (1993a) measured it to be in the range of $1.0 \times 10^{-4}$ to $3.7 \times 10^{-4} \mathrm{~cm} / \mathrm{s}(0.29$ to $1.04 \mathrm{ft} / \mathrm{day})$, with a median of $2.4 \times 10^{-4} \mathrm{~cm} / \mathrm{s}(0.69 \mathrm{ft} /$ day). These values are typical of silty sand or silt (Freeze and Cherry 1979). Because of the problems inherent in slug testing of wells, the results often underestimate the horizontal conductivity (Bradbury and Muldoon 1990; Hughes 1993b). During calibration of a draft modeling study, a value of $2.8 \times 10^{-3} \mathrm{~cm} / \mathrm{s}(8 \mathrm{ft} /$ day $)$ was assigned to this unit (Hughes 1993b). A pump test at well JF183, installed in 1994, indicated a hydraulic conductivity 
of $1.9 \times 10^{-3} \mathrm{~cm} / \mathrm{s}$ (5.3 ft/day) (Quinn 1995). This value is consistent with a silty to clean sand (Freeze and Cherry 1979).

Despite the available data, the permeability of the surficial aquifer at the TBP area and throughout most of $J$-Field is uncertain. Because of the arrangement of interbedded facies, the permeability of the surficial aquifer varies over several orders of magnitude laterally and vertically. Any measurement of permeability is highly spatially dependent because of location-specific stratigraphy and well construction factors, including the depth interval of the well screen.

The flow rate produced by the pump test well was low. A yield of 2 gpm could not be sustained during a step drawdown test. The constant-rate pump test was completed with a flow rate of $1 \mathrm{gpm}$.

Continuous-head recordings available from the USGS for the 1993 water year indicate that the head in the surficial aquifer in the TBP area is more than $6 \mathrm{ft}$ above MSL during a wet springtime and approximately $1 \mathrm{ft}$ below MSL during August and September, when high evapotranspiration rates prevail.

The surficial aquifer receives most of its recharge by infiltration of precipitation; however, during dry periods, water levels in wells may be slightly lower than bay level (Hughes 1993a). A flow reversal may take place during these periods, with flow from the tidal estuaries providing recharge to the aquifer.

Under Maryland Code of Regulations 26.08.02.09, the surficial aquifer at J-Field is classified as a Type I(b) aquifer (Lemaster 1995). A Type I(b) aquifer has a transmissivity between 1,000 and $10,000 \mathrm{gal} / \mathrm{day} / \mathrm{ft}$, a permeability greater than $100 \mathrm{gal} / \mathrm{day} / \mathrm{ft}^{2}$, and natural water with a total dissolved solids concentration of between 500 and $1,500 \mathrm{mg} / \mathrm{L}$.

\subsubsection{Confining Unit}

The confining unit contains silty and sandy clay with shell fragments and varying amounts of organic matter. The clay is dark gray or olive gray in color. Hughes (1993a) interprets the sediment to be an estuarine deposit.

The basal contact elevation of the confining unit in the TBP area ranges from $64 \mathrm{ft}$ to deeper than $145 \mathrm{ft}$ below MSL (according to logs for well JF201). The thickness of this unit in the TBP area ranges from $35 \mathrm{ft}$ in the northwestern portion of the area to greater than $125 \mathrm{ft}$ in the southeastern portion. The thickness apparently depends on the depth of paleochannel erosion into the Potomac Group. 
Slug tests performed by Hughes (1993a) on three wells in this unit yielded hydraulic conductivity values of less than $3 \times 10^{-6}$ to $7.0 \times 10^{-5} \mathrm{~cm} / \mathrm{s}(0.01-0.20 \mathrm{ft} / \mathrm{day})$, with a median value of $1.8 \times 10^{-5} \mathrm{~cm} / \mathrm{s}(0.05 \mathrm{ft} /$ day). These values fall into the typical range of fine-grained materials (Freeze and Cherry 1979). Hughes (1993c) suggests that the slug test generally provides an estimate of horizontal conductivity, so the vertical conductivity may be much less. A value of $1.8 \times 10^{-6} \mathrm{~cm} / \mathrm{s}$ $\left(5 \times 10^{-3} \mathrm{ft} /\right.$ day) used by Hughes (1993b) is comparable to that of Vroblesky et al. (1989), who modeled a nearby clay-filled estuarine paleochannel with a vertical hydraulic conductivity of $6.8 \times 10^{-8} \mathrm{~cm} / \mathrm{s}\left(2 \times 10^{-4} \mathrm{ft} /\right.$ day $)$.

\subsubsection{Confined Aquifer}

The confined aquifer consists of gravelly sand with some clay and clayey sand. The confined aquifer is a fluvial deposit that blankets the bottom of a paleochannel identified by marine seismic and exploratory borings.

The thickness of the confined aquifer cannot be determined with USGS cluster well data because the confined aquifer monitoring wells do not fully penetrate the aquifer. Data from a deep USGS exploratory boring located near cluster JF8 (Figure 2.1) indicate that the base of the confined aquifer near the pits is about $120 \mathrm{ft}$ below MSL (Hughes 1993a).

Slug tests were performed in four J-Field wells screened in the confined aquifer (Hughes 1993a). Hydraulic conductivity values determined for two wells completed in permeable portions of the aquifer were $3.9 \times 10^{-2}$ and $3.2 \times 10^{-1} \mathrm{~cm} / \mathrm{s}$ (110 and $930 \mathrm{ft} /$ day), with a median of $1.3 \times 10^{-1} \mathrm{~cm} / \mathrm{s}$ (390 ft/day). Hydraulic conductivity values determined for two other wells screened in fine-grained zones were $1.1 \times 10^{-3}$ and $1.8 \times 10^{-2} \mathrm{~cm} / \mathrm{s}(3.2$ and $52 \mathrm{ft} /$ day), with a median of $3.9 \times 10^{-3} \mathrm{~cm} / \mathrm{s}$ (11 ft/day).

\subsubsection{Cretaceous Sediments}

The Cretaceous Patapsco Formation sediments beneath J-Field are alluvial deposits of interbedded fine-grained sand and massive clay (Hughes 1993a). The Cretaceous clays are differentiated from Pleistocene clays by color in the USGS stratigraphic logs. Rather than the dark and olive gray of the confining unit, the Patapsco clays vary among reddish brown, light gray, white, light red, and olive yellow. The top of the Cretaceous sediments dips from $105 \mathrm{ft}$ below MSL in the western portion of J-Field to $157 \mathrm{ft}$ in the east (Hughes 1993a). Interpretation of gamma logs of the exploratory boreholes suggests that the sands range from 2 to $30 \mathrm{ft}$ thick and that the clays range from 5 to $45 \mathrm{ft}$ thick. Stratigraphic cross sections suggest that the various lenses are highly discontinuous laterally (Hughes 1993a). The Cretaceous deposits are underlain by metamorphic rock at a depth of about $800 \mathrm{ft}$. 


\subsubsection{General Groundwater Flow}

Field measurements of heads at J-Field indicate that groundwater flow is generally from topographically high areas to topographically low areas, such as marshes and estuary discharge areas (Hughes 1993a). In the TBP area, the water table has a local high in the area between the main pits and the Prototype Building. No pumping stresses are imposed on the Talbot aquifers at or in the vicinity of J-Field. The nearest pumping wells are $4 \mathrm{mi}$ away, across the Gunpowder River (Hughes 1993a).

A comparison of the heads of wells screened in the three Pleistocene units indicates a downward gradient, suggesting leakage from the surficial aquifer into the confining unit and confined aquifer (Hughes 1993a). However, in wetlands and estuaries, flow is assumed to be vertically upward as groundwater flows from the deeper units to the discharge areas. The vertical head gradient within the surficial aquifer currently cannot be determined because only one well is screened in the surficial aquifer at each USGS well nest.

Hughes (1993a) describes the head distribution pattern in the confining unit and the confined aquifer as generally similar to that of the surficial aquifer. A low lateral head gradient was observed, so lateral flow is minimal. Discharge is believed to occur through the confining unit into the estuaries. During dry periods, flow reversals occur as the heads in the surficial aquifer fall slightly below those in the confined aquifer.

The tide in the bay influences water levels in some wells screened in the surficial aquifer at J-Field. The degree of influence depends on the distance from the shore and the presence of finegrained confining or semiconfining units within the surficial aquifer. Continuous-head data are available from USGS for two wells (JF63 and JF43) in the TBP area. Stratigraphic logs for these wells indicate that they are screened in and overlain by fine sand (Hughes 1993a). The heads do not demonstrate the two highs and lows per day expected for tidally influenced wells. These data suggest that the distance from the shore to the TBP area is sufficient to negate tidal influence.

Hughes (1993a) did not observe tidal effects in wells screened in the confining unit. The confined aquifer, however, exhibited a strong tidal influence in continuous water-level data from six confined-aquifer monitoring wells. The heads fluctuate over a range of about $0.75 \mathrm{ft}$. Over a two-day period, the water levels in the wells show a high degree of similarity independent of distance from the shoreline. The head changes are therefore attributed to tidal loading on the confined aquifer.

\subsubsection{Climate}

The Harford County area has a continental-type climate with significant temperature contrasts between winter and summer (Smith and Matthews 1975). The average daily high and low 
are $65^{\circ} \mathrm{F}$ and $42^{\circ} \mathrm{F}$, respectively. The average annual temperature is about $54^{\circ} \mathrm{F}$. The average annual precipitation of 45 in./year is distributed fairly uniformly throughout the year.

\subsubsection{Ecology}

Ecological surveys were conducted at J-Field as part of the overall site ecological risk assessment (ERA), and the results of these surveys are presented in the draft ERA report (Hlohowskyj et al. 1996). The following subsections (2.2.6.1 through 2.2.6.4) summarize the ecological setting of the TBP area on the basis of the results presented in that report.

\subsubsection{Terrestrial Habitats}

Terrestrial habitats at the TBP area include grassland and forested plant communities and represent less than $0.02 \%$ of the available terrestrial habitat at J-Field. The area immediately surrounding the main pits comprises disturbed habitats consisting exclusively of mowed and unmowed grassland with patches of bare ground. The areas of bare ground are located mainly in the pushout area, where a variety of disposal debris, such as rebar, sheet metal, and rusted pipes, is present. The grassland is bordered to the south, east, and north by marsh habitat, with a narrow band of upland forest occurring between the marsh and grassland habitat along the southern and southeastern boundary of the area. Dominant woody species in the forested habitats include black gum, sycamore, sweetgum, red and white oaks, and black tupelo.

\subsubsection{Freshwater Habitats and Wetlands}

The freshwater marsh southeast of the main pits and largely surrounding the pushout area is the major nontidal freshwater habitat in the southern portion of the Edgewood Peninsula. No other freshwater habitats are present at the main pits and pushout area. A large freshwater pond occurs near the center of the marsh. The pond is classified as an intertidal estuarine permanently flooded wetland (Hlohowskyj et al. 1996). The areal extent of the pond varies seasonally with changes in the water table and precipitation periods, averaging about 2.5 acres. No permanent surface water connections exist between the pond and Chesapeake Bay, although occasional connection is possible during very high tides and during extremely heavy rains. The marsh is classified as an intertidal estuarine wetland irregularly flooded by tides (Hlohowskyj et al. 1996). Common reed, the dominant plant species (Van Lonkhuyzen 1994), forms floating mats in some parts of the marsh. Palustrine forested and scrub/shrub seasonally flooded wetlands are also present along portions of the perimeter of the marsh, particularly along the southern and northern boundaries of the TBP area. 


\subsubsection{Fish and Wildlife}

More than 40 mammal, 22 reptile, and 15 amphibian species have been reported from the APG (USATHAMA 1993), and many of these species may occur at J-Field and use portions of the TBP main pits and pushout area.

Small mammals that have been collected from the TBP area include the white-footed mouse, meadow vole, and short-tailed shrew. Red fox and feral house cats have been observed at the TBP area, while bats have been observed flying over the site (Hlohowskyj et al. 1996). Although white-tailed deer, raccoon, muskrat, gray squirrel, and eastern chipmunk may occasionally forage at the site, the main pits and pushout area provide little or no habitat for these species.

The main pits and pushout area may provide seasonal or year-round habitat for a variety of reptile and amphibian species, primarily the American toad, northern spring peeper, spotted salamander, eastern box turtle, and a number of snake and lizard species; however, use of the main pits and pushout area by these species is most likely limited. In contrast, the marsh and pond represent good habitat for a variety of reptiles and amphibians, including bullfrog, leopard frog, eastern painted turtle, and common snapping turtle. The surrounding wooded areas also provide habitat for a variety of species.

Although more than 40 species of fish have been reported to occur in the APG area, most of these species are found in Chesapeake Bay and the Gunpowder and Bush Rivers. Fish collected from the marsh pond adjacent to the pushout areas include the bluespotted sunfish, banded killifish, spottail shiner, and golden shiner (Hlohowskyj et al. 1996).

The APG site is located along the Atlantic Flyway, a major migration corridor used by birds in spring and autumn. Because of the presence of the flyway and the diversity of habitat types in the vicinity, more than 140 species of birds have been reported from the APG (USATHAMA 1993), and many may use J-Field as foraging or nesting habitat. Qualitative auditory and visual surveys of birds were conducted in all seasons at the TBP area, and more than 110 species were reported from the site (Hlohowskyj et al. 1996). Birds reported for the area included mourning doves, American robins, eastern bluebirds, eastern kingbirds, and a variety of sparrows. Hawks that are known to nest in the J-Field area and may use the TBP area include the American kestrel and red-tailed hawk. Although osprey are known to nest at J-Field, it is unlikely that the osprey would feed on any of the fish species collected to date from the pond, primarily because of the small size of the fish.

A large variety of waterfowl occurs in the areas surrounding J-Field. The State of Maryland has designated Pooles Island, located about $1.5 \mathrm{~km}(1 \mathrm{mi})$ south of the Edgewood Peninsula and the TBP area, as a "Colonial Waterbird Nesting Site" (McKegg 1992). In addition, the open water areas north of the J-Field site have been identified by the state as a "Historic Waterfowl Staging and Concentration Area" (McKegg 1992). Waterfowl and shorebirds that have been reported from the 
area and observed in the vicinity of the TBP area include mallard, tundra swan, wood duck, and great blue heron (Hlohowskyj et al. 1996). The small size of the pond, however, probably limits its use by large numbers of shorebirds or waterfowl.

\subsubsection{Threatened and Endangered Species}

No mammals, amphibians, or reptiles identified on the State of Maryland's rare, threatened, and endangered list have been reported for the J-Field area (Maryland Department of Natural Resources [MDNR] 1992). The bobcat, classified as in need of conservation by Maryland (MDNR 1992), has been reported for the general vicinity of APG (USATHAMA 1993) but not for the J-Field site. The eastern harvest mouse, listed by Maryland as endangered, historically has been reported for the area, but is now considered extirpated from the state (MDNR 1992). A number of bird species reported from the APG are state-listed species (MDNR 1992), including the barn owl (watchlist), sora (highly rare), dark-eyed junco (rare), and northern harrier (rare), and the grassland habitats at the pushout area and adjacent marsh provide suitable habitat for these species. The darkeyed junco and the northern harrier were observed at the TBP area during the avian surveys conducted at the site. Table 2.1 identifies state and federally listed bird species that have been reported for APG.

TABLE 2.1 Bird Species of Special Federal and State Concern Reported at APG

\begin{tabular}{llll}
\hline \multicolumn{1}{c}{ Common Name } & \multicolumn{1}{c}{ Scientific Name } & \multicolumn{1}{c}{ State Status ${ }^{\mathrm{a}}$} & Federal Status \\
\hline Bald eagle & Haliaeetus leucocephalus & Endangered & Threatened \\
Common barn owl & Tyto alba & Watchlist & Not listed \\
Common moorhen & Gallinula chloropus & Needs conservation & Not listed \\
Dark-eyed junco & Junco hyemalis & Rare & Not listed \\
Golden-crowned kinglet & Regulus satrapa & Rare & Not listed \\
Loggerhead shrike & Lanius ludovicianus & Endangered & C2 \\
Northern harrier & Circus cyanus & Rare & Not listed \\
Peregrine falcon & Falco peregrinus & Endangered & Endangered \\
Sharp-shinned hawk & Aegolius acadicus & Highly rare & Not listed \\
Sora & Porzana carolina & Highly rare & Not listed \\
Yellow-bellied sapsucker & Sphyrapicus varius & Historical & Not listed \\
Yellow-rumped warbler & Dendroica coronata & Uncertain & Not listed \\
\hline \multirow{2}{*}{ Source: MDNR (1992). } & & & \\
b C2 = Federal candidate for listing as a threatened or endangered species. &
\end{tabular}


Several federally listed species are known to occur at the APG and may forage in suitable habitats near the TBP area (MDNR 1992; Wolflin 1992; USATHAMA 1993) (Table 2.1). The peregrine falcon is federally listed as endangered. No suitable habitat for the peregrine falcon occurs at the Edgewood Peninsula or the J-Field site; however, this species may be an occasional visitor to the area, especially during migration. The loggerhead shrike is a federal category 2 species that has been reported for APG and may forage in the TBP area. A federal category 2 species is a candidate for listing as either threatened or endangered. Neither the peregrine falcon nor the loggerhead shrike were observed at the TBP area during the avian surveys at the site.

APG supports the most significant concentration of bald eagles (federally listed as threatened) on the northern Chesapeake Bay (Wolflin 1992). A bald eagle nest site is located approximately $1.5 \mathrm{~km}(1 \mathrm{mi})$ north of the J-Field site. Occupation by the bald eagle is light to moderate on Pooles Island and the shoreline areas of the Edgewood Peninsula (Wolflin 1992). The bald eagle may forage on waterfowl at the marsh and pond adjacent to the pushout area but is unlikely to use the immediate TBP area because of the absence of suitable habitat and because of human activities at the site and surrounding areas.

\subsubsection{Land Use}

The lower portion of the Edgewood Peninsula is generally dedicated to a military test range, with no resident population and only a limited number of site workers; however, the range fields offer restricted, seasonal accessibility to a limited number of hunters. Upland game hunting and bow hunting of deer and woodchuck are allowed along the northern border of (but not within) J-Field and farther north on the peninsula. Blinds for hunting deer with guns are scattered throughout the peninsula, including several locations in the northern portion of J-Field. However, the J-Field blinds are no longer available to hunters; hunting and trapping are no longer allowed within the J-Field boundary (Wrobel 1994). Seasonal hunting of migratory waterfowl is permitted along the entire shoreline of J-Field.

Although most of the AOCs are no longer used for OB/OD, a portion of the Robins Point Demolition Ground is currently active and is operating under interim status under RCRA. An open burning pan located $50 \mathrm{~m}$ west of the Prototype Building and an open detonation area at the White Phosphorus Pits area are also being used for emergency disposal operations.

Recent remedial activities at $\mathrm{O}-$ Field have required rerouting Robins Point Road through $\mathrm{N}-$, D-, and I-Fields; the firing range; and H-Field; thus making J-Field less accessible. These changes in the main access route to J-Field will most likely preclude any future development of the $\mathrm{J}$-Field site in the near term. In the long term, disturbances due to testing at $\mathrm{H}$ - and I-Fields make development of the J-Field site unlikely. 


\subsection{NATURE AND EXTENT OF CONTAMINATION}

The following subsections summarize what is currently known about the nature and extent of contamination at the TBP area. Because the focus of this report is to address contaminated surface soil in the main pits and pushout area, the discussion of soil is most detailed. Site characterization data collected from 1993 to 1995 are presented in Appendix C. Appendix D, which is based on the draft RI report (Yuen et al. 1996), provides more details (including locations of samples) on the results of the RI at the TBP area.

\subsubsection{Soil}

As part of the J-Field RI, soil samples have been collected from the TBP area and analyzed for various constituents. This discussion is divided into sections for the northern main pit, the southern main pit, and the pushout area east of the main pits to describe the contaminants found at each area. Two additional pits, the VX pit and the mustard pit, occur within the pushout area. These pits have been filled in and are partially covered by soil pushed out from the main pits. A brief discussion of these pits is included in Section 2.3.1.3.

\subsubsection{Northern Main Pit}

Soil borings ranging in depth from 4 to $12 \mathrm{ft}$ were drilled in six locations (JBP2-W, JBP2-C, JBP2-E, TBNPBOR1, TBNPBOR2, and TBNPBOR3; see Figure D.5) within the northern main pit as part of the RI. Samples taken from the borings indicate that contamination in the pit is not homogeneous. In general, contamination is higher in the western portion of the pit than in the eastern portion. The highest levels of volatile organic compound (VOC) contamination occur in sample TBNPBOR3 at the depth interval between 4 and $10 \mathrm{ft}$. Contaminants include acetone (up to $6,000 \mu \mathrm{g} / \mathrm{kg}$ at 8-10 ft), tetrachloroethylene (TCLEE) (up to $750 \mu \mathrm{g} / \mathrm{kg}$ at $6-8 \mathrm{ft}$ ), chlorobenzene (up to $23,000 \mu \mathrm{g} / \mathrm{kg}$ at $4-6 \mathrm{ft}$ ), ethyl benzene (up to $6,600 \mu \mathrm{g} / \mathrm{kg}$ at $6-8 \mathrm{ft}$ ), toluene (up to $4,200 \mu \mathrm{g} / \mathrm{kg}$ at $6-8 \mathrm{ft}$ ), and total xylenes (up to $46,000 \mu \mathrm{g} / \mathrm{kg}$ at 6-8 ft). Other VOCs, present at lower concentrations, include 1,1-dichloroethylene (11DCE), 12DCE, chloroform, TCLEA, and trichloroethylene (TRCLE). Semivolatile organic compounds (SVOCs) were also highest in sample TBNPBOR3 and include bis(2-ethylhexyl) phthalate (up to $1,900 \mu \mathrm{g} / \mathrm{kg}$ at $6-8 \mathrm{ft}$ ), 2-methylnaphthalene (up to $2,100 \mu \mathrm{g} / \mathrm{kg}$ at $6-8 \mathrm{ft}$ ), and naphthalene (up to $1,800 \mu \mathrm{g} / \mathrm{kg}$ at $6-8 \mathrm{ft}$ ).

Metal contamination in soil underlying the northern main pit reflects a similar pattern as exhibited by the VOCs: contamination is highest in the western and central portions of the pit. The highest levels of heavy metal contamination occur in the upper $4 \mathrm{ft}$ of soil. Metals include arsenic (up to $2,290 \mathrm{mg} / \mathrm{kg}$ ), cadmium (up to $77 \mathrm{mg} / \mathrm{kg}$ ), chromium (up to $240 \mathrm{mg} / \mathrm{kg}$ ), copper (up to $7,120 \mathrm{mg} / \mathrm{kg}$ ), lead (up to $4,790 \mathrm{mg} / \mathrm{kg}$ ), and zinc (up to $17,800 \mathrm{mg} / \mathrm{kg}$ ). In general, concentrations 
of these metals decrease with depth, although elevated concentrations of metals were detected at depths of up to $12 \mathrm{ft}$. Toxicity characteristic leaching procedure (TCLP) analyses indicate high leachate levels of arsenic (155-216 $\mu \mathrm{g} / \mathrm{L})$, lead $(1,620-26,500 \mu \mathrm{g} / \mathrm{L})$, and cadmium $(16.4-187 \mu \mathrm{g} / \mathrm{L})$. The soil is therefore considered hazardous (i.e., characteristically toxic) with respect to lead and cadmium.

Low levels of PCBs ( $<10 \mathrm{mg} / \mathrm{kg}$ at 0-2 ft) and dioxin/furan compounds $(<5 \mu \mathrm{g} / \mathrm{kg}$ at $4-6 \mathrm{ft}$ ) were also detected in the western portion of the northern main pit. One sample (TBNPBOR3) had a total petroleum hydrocarbon (TPH) concentration of $19,000 \mathrm{mg} / \mathrm{kg}$ at 4-6 ft.

\subsubsection{Southern Main Pit}

Soil borings ranging in depth from 4 to $10 \mathrm{ft}$ were drilled in five locations (JBP1-W, JBP1-E, JHDP-C, TBSPBOR1, and TBSPBOR2; see Figure D.5) within the southern main pit as part of the RI. In general, the highest levels of VOC contamination are in the eastern portion of the pit. Although no VOC contamination was present at the surface, VOC concentrations were found to generally increase with depth. The highest concentrations of VOCs, found in the eastern portion of the pit, include 12DCE $(8,400 \mu \mathrm{g} / \mathrm{kg}$ at $10 \mathrm{ft})$, trans-12DCE $(3,220 \mu \mathrm{g} / \mathrm{kg}$ at $6 \mathrm{ft})$, 1,1,2-trichloroethane (112TCE) $(8,540 \mu \mathrm{g} / \mathrm{kg}$ at $6 \mathrm{ft})$, TCLEA $(3,270,000 \mu \mathrm{g} / \mathrm{kg}$ at $6 \mathrm{ft})$, TCLEE $(25,700 \mu \mathrm{g} / \mathrm{kg}$ at $6 \mathrm{ft}), \operatorname{TRCLE}(263,000 \mu \mathrm{g} / \mathrm{kg}$ at $6 \mathrm{ft})$, and vinyl chloride $(302 \mu \mathrm{g} / \mathrm{kg}$ at $6 \mathrm{ft})$. SVOCs were highest in the upper $2 \mathrm{ft}$; these include $N$-nitrosodiphenylamine (up to $950 \mu \mathrm{g} / \mathrm{kg}$ ), hexachloroethane (up to $580 \mu \mathrm{g} / \mathrm{kg}$ ), and pyrene (up to $580 \mu \mathrm{g} / \mathrm{kg}$ ).

In general, heavy metals contamination is lower in the southern main pit than in the northern main pit; the highest levels occur in the upper $4 \mathrm{ft}$ of soil. Metals include arsenic (up to $28.2 \mathrm{mg} / \mathrm{kg}$ ), cadmium (up to $7 \mathrm{mg} / \mathrm{kg}$ ), copper (up to $366 \mathrm{mg} / \mathrm{kg}$ ), lead (up to $831 \mathrm{mg} / \mathrm{kg}$ ), and zinc (up to $1,240 \mathrm{mg} / \mathrm{kg}$ ). In general, metal concentrations decreased with depth in the southern main pit.

PCBs (e.g., Aroclor 1254) were found in the upper $4 \mathrm{ft}$ in the eastern portion of the southern main pit (in sample JBP1-E, collected by Weston, Inc., in 1993). Sampling indicates a fairly localized area of PCB contamination in the surface soil.

\subsubsection{Pushout Area East of Main Pits}

Surface soil samples collected by Weston, Inc., in 1992 indicate that VOC contamination is present in the upper $1 \mathrm{ft}$ of the pushout area soil; these include acetone (up to $1,460 \mu \mathrm{g} / \mathrm{kg}$ ), TCLEA (up to $13,200 \mu \mathrm{g} / \mathrm{kg}$ ), and TRCLE (up to $26,000 \mu \mathrm{g} / \mathrm{kg}$ ). SVOCs were also detected: hexachloroethane (up to $498 \mu \mathrm{g} / \mathrm{kg}$ ), phenanthrene (up to $311 \mu \mathrm{g} / \mathrm{kg}$ ), and pyrene (up to $215 \mu \mathrm{g} / \mathrm{kg}$ ). Figure D.4 shows the locations of all samples collected within the pushout area. 
Sampling in the pushout area also indicates that concentrations of heavy metals in the upper $4 \mathrm{ft}$ exceed background concentrations (Table 2.2). The eastern portion of the pushout area exhibits the highest concentrations, although elevated concentrations were found throughout. In the upper $2 \mathrm{ft}$, metals include arsenic (up to $41 \mathrm{mg} / \mathrm{kg}$ ), copper (up to $4,320 \mathrm{mg} / \mathrm{kg}$ ), and lead (up to $94,000 \mathrm{mg} / \mathrm{kg}$ ). TCLP analyses indicate that pushout area soil is hazardous with respect to lead. The vertical extent of metal contamination in soil is related to the thickness of the pushout material and increases toward the marsh. In general, metal concentrations decrease with depth.

Low levels of PCBs (Aroclor 1248, up to $3 \mathrm{mg} / \mathrm{kg}$ in sample JBPMA) were found in the upper $1 \mathrm{ft}$ (Figure D.6). Low levels of pesticides were also found in the upper $1 \mathrm{ft}\left(4,4^{\prime}\right.$-dichlorodiphenyltrichloroethane [DDT], up to $177 \mu \mathrm{g} / \mathrm{kg}$ in sample JBPMA). No explosives were detected in the surface soil samples.

Within the pushout area are two buried pits: the VX pit and the mustard pit (Figure 2.1). These pits were delineated during the RI by aerial photographic analysis (Yuen et al. 1996) and geophysical surveys (Daudt et al. 1994; Davies et al. 1995). Four surface soil samples (OT16A,

TABLE 2.2 Mean and Maximum

Background Soil Concentrations of Metals

Reported for Off-Site Areas

Surrounding APG

\begin{tabular}{lcc}
\hline & & \\
& & \\
& & \\
\cline { 2 - 2 } Metal & Mean & Maximum \\
\cline { 2 - 3 } & & \\
Aluminum & 7,940 & 17,300 \\
Antimony & 3.14 & $<9.8$ \\
Arsenic & 2.57 & 5.29 \\
Barium & 43.6 & 125 \\
Beryllium & 0.44 & 1.42 \\
Calcium & 534 & 1,980 \\
Chromium & 16.8 & 68.9 \\
Copper & 8.72 & 27.5 \\
Iron & 12,300 & 23,500 \\
Lead & 21.6 & 117 \\
Magnesium & 1,010 & 3,920 \\
Manganese & 276 & 1,140 \\
Mercury & 0.04 & $<0.14$ \\
Nickel & 8.37 & 24.1 \\
Potassium & 384 & 1,700 \\
Selenium & 0.21 & 0.497 \\
Zinc & 37 & 242 \\
\hline
\end{tabular}

Source: ICF Kaiser Engineers (1995a). 
OT16B, OT19A, and OT19B; see Figure D.4) were collected from two locations near the VX pit. Five borings (VXBOR1-VXBOR5; see Figure D.5), ranging in depth from 4 to $16 \mathrm{ft}$, were drilled into the VX pit as part of the RI. The nature of contamination at the VX pit was only partially characterized due to the potential presence of UXO (especially in the area of VXBOR3 and VXBOR4). On the basis of available data, the bottom of the VX pit is inferred to be about 4-6 $\mathrm{ft}$ below the ground surface.

Soil samples from the VX pit indicate that contamination is highest at the disposal center within the pit (near borings VXBOR3 and VXBOR4). In this area, surface soil is contaminated with moderate to high levels of heavy metals (including copper, up to $343 \mathrm{mg} / \mathrm{kg}$; lead, up to $262 \mathrm{mg} / \mathrm{kg}$; and zinc, up to $1,629 \mathrm{mg} / \mathrm{kg}$ ), low levels of chlorinated ethenes and ethanes, petroleum-related compounds (including benzene, up to $42 \mu \mathrm{g} / \mathrm{kg}$; ethyl benzene, up to $2,900 \mu \mathrm{g} / \mathrm{kg}$; and xylenes, up to $2,300 \mu \mathrm{g} / \mathrm{kg}$ ), low levels of dioxins and furans, low levels of pesticides, 1,4-dithiane (a chemical warfare agent [CWA] degradation product), and phthalates. The vertical extent of contamination is estimated to be deeper than $6 \mathrm{ft}$. Near the disposal center, in areas near the western end of the pit, metal contamination is limited to the upper $2 \mathrm{ft}$, while organic contamination is minimal. The TPH content is high at depth.

Five surface soil samples (CLP6 [0-6 in.], CLP6 [6-24 in.], CLP7 [0-6 in.], CLP7 [6-24 in.], and CLP7 [24-48 in.]; see Figure D.4) were collected at two locations near the mustard pit. Three borings (HBOR1-HBOR3; see Figure D.5), ranging in depth from 10 to $16 \mathrm{ft}$, were drilled near the mustard pit (because of the potential presence of UXO, no borings were taken from within the pit). The bottom of the mustard pit is estimated to be about 4-6 ft below the ground surface.

Soil samples from the mustard pit indicate that heavy metals (including arsenic, up to $16 \mathrm{mg} / \mathrm{kg}$; copper, up to $204 \mathrm{mg} / \mathrm{kg}$; lead, up to $4,960 \mathrm{mg} / \mathrm{kg}$; and zinc, up to $896 \mathrm{mg} / \mathrm{kg}$ ) are present, especially in the upper $2 \mathrm{ft}$. Contamination decreases with depth and was not detected below $6 \mathrm{ft}$ in the three borings. Very low levels of petroleum-related compounds and phthalates were detected in the upper $2 \mathrm{ft}$. Low levels of chlorinated ethanes and ethenes were detected in surface and subsurface soil. Low levels of CWA degradation products (diisopropylmethyl phosphonate and 1,4-dithiane) were also detected in samples taken at a depth of $6 \mathrm{ft}$.

\subsubsection{Summary}

Figures 2.3 and 2.4 illustrate the extent of metal contamination at two depth intervals (0-6 in. and 6-24 in., respectively), which exceeds the mean background values given in Table 2.2. The figures take into account the concentrations of several metals, including aluminum, arsenic, barium, cadmium, chromium, copper, lead, mercury, and zinc. The extent of contamination at these depth intervals is reduced when compared to maximum background values (Figures 2.5 and 2.6). Figure 2.7 shows an estimated area at $2-4 \mathrm{ft}$, which was inferred from limited soil sampling in the 


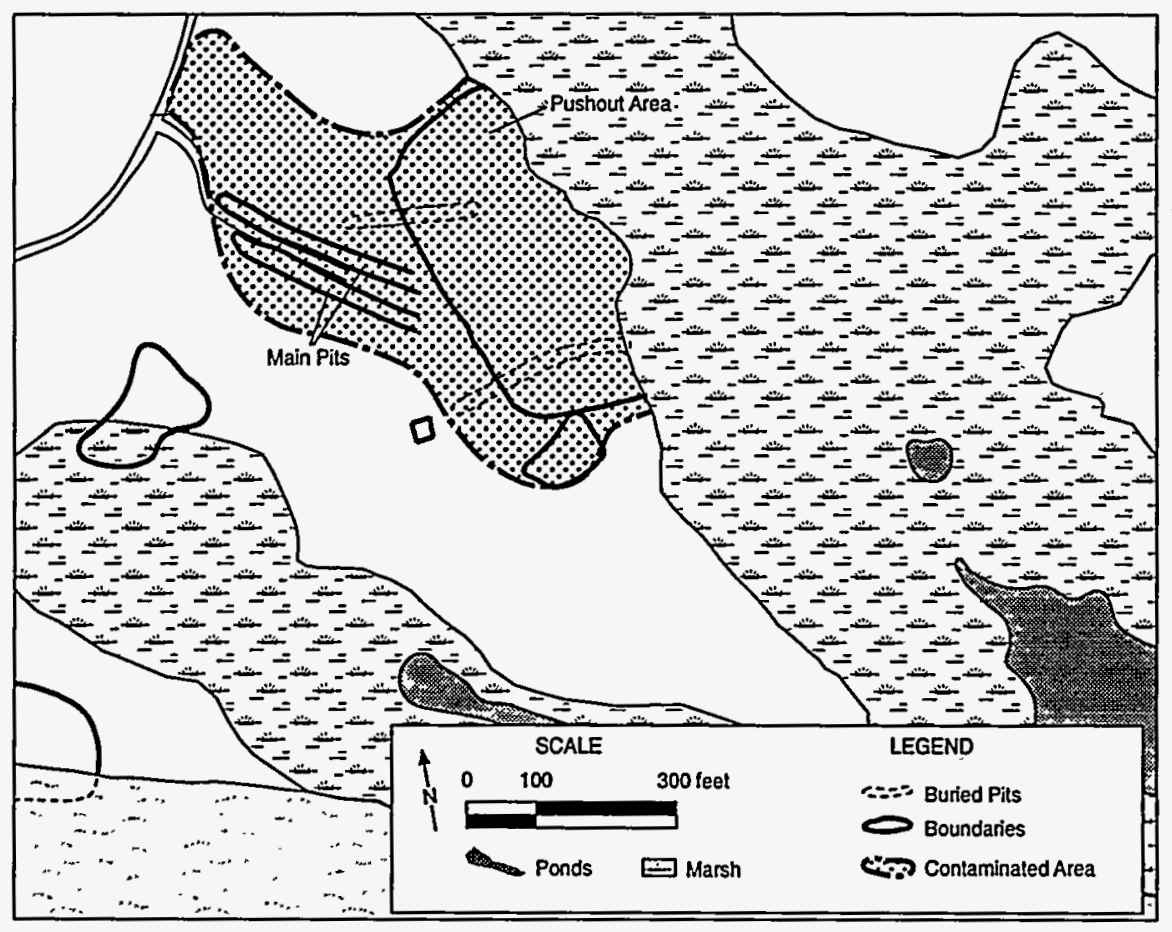

FIGURE 2.3 Estimated Contaminated Area at Depth Interval 0-6 in. with Heavy Metal Concentration Levels above Mean Background

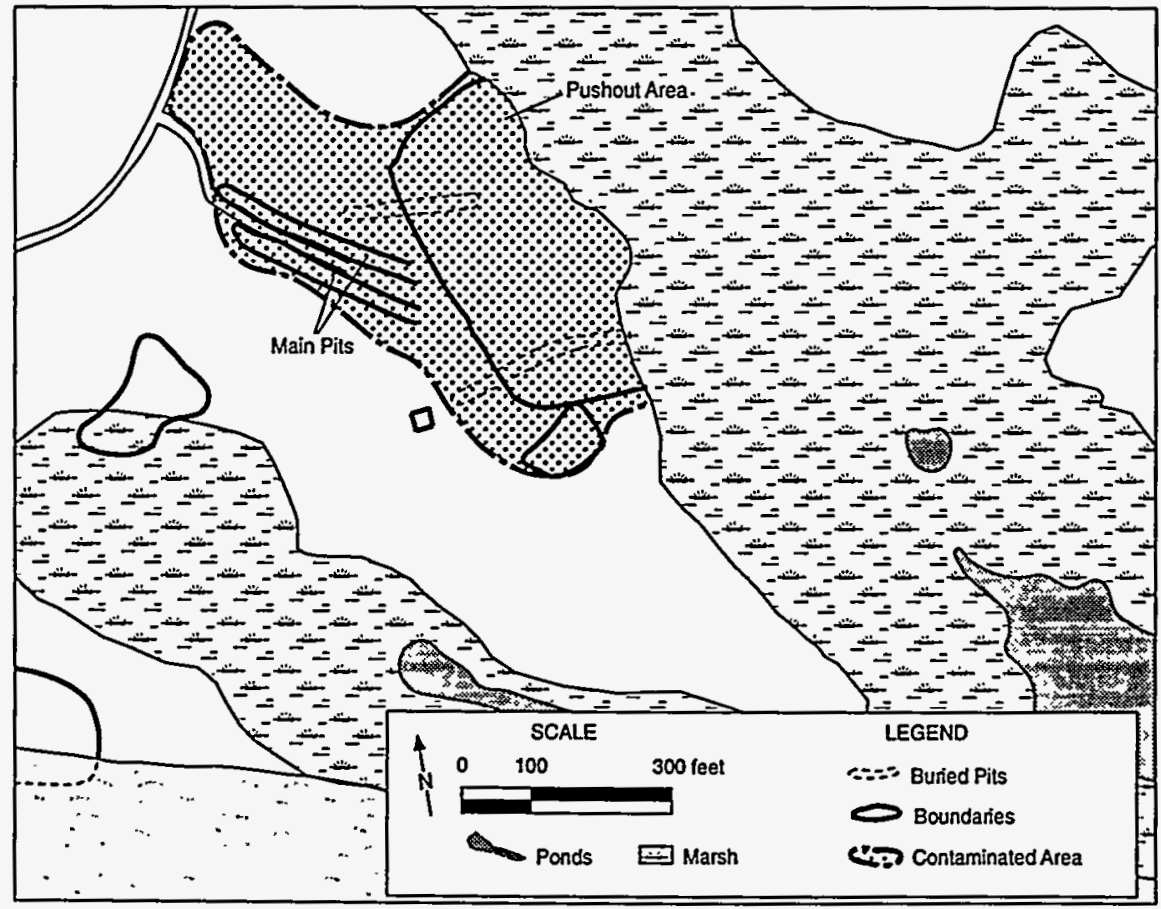

FIGURE 2.4 Estimated Contaminated Area at Depth Interval 6-24 in. with Heavy Metal Concentration Levels above Mean Background 


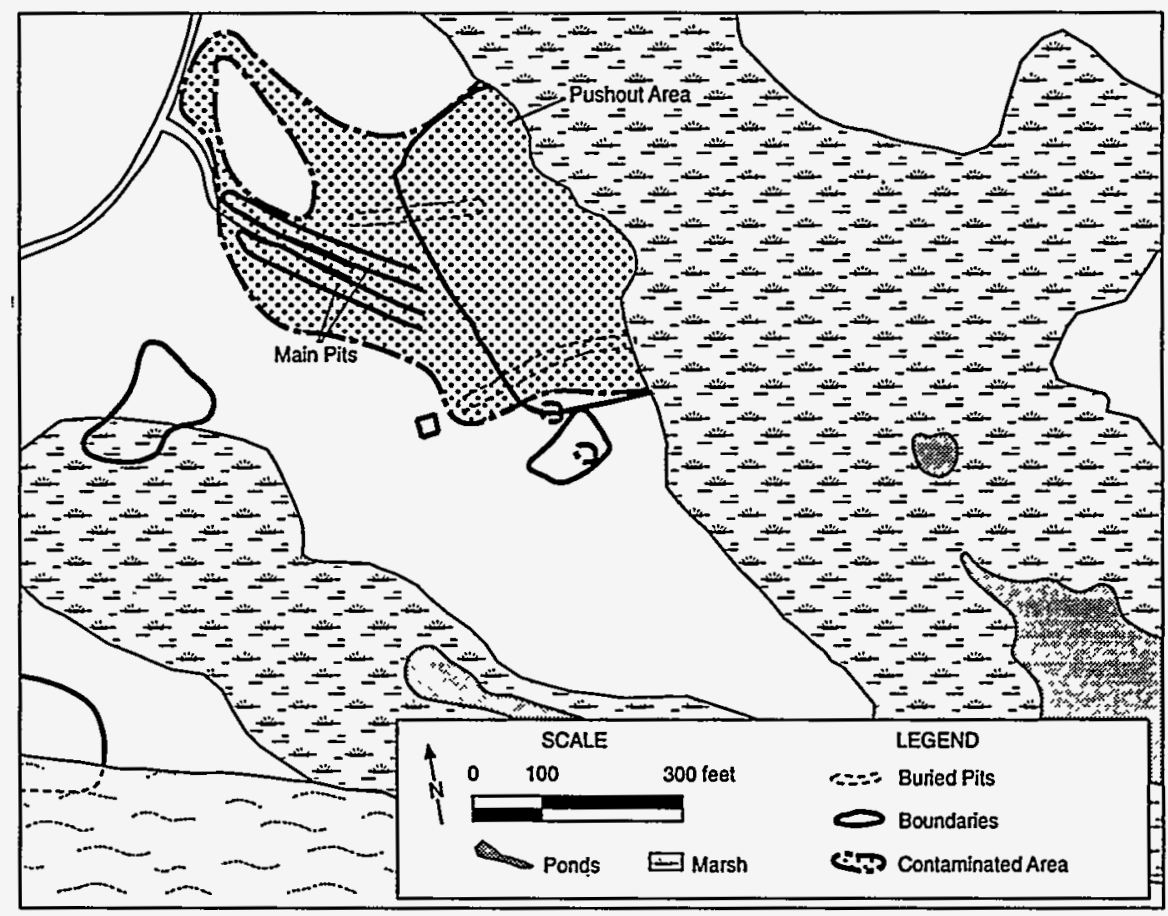

FIGURE 2.5 Estimated Contaminated Area at Depth Interval 0-6 in. with Heavy Metal Concentration Levels above Maximum Background

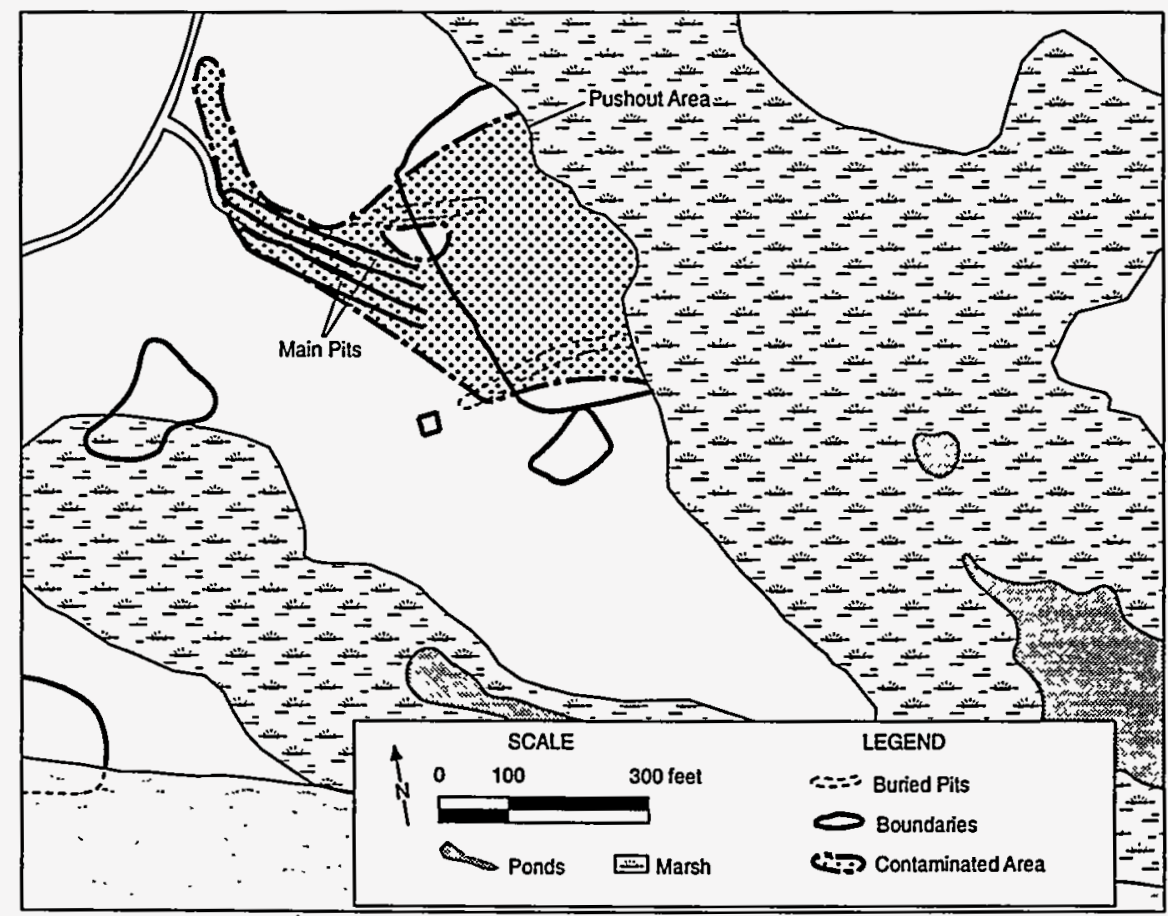

FIGURE 2.6 Estimated Contaminated Area at Depth Interval 6-24 in. with Heavy Metal Concentration Levels above Maximum Background 


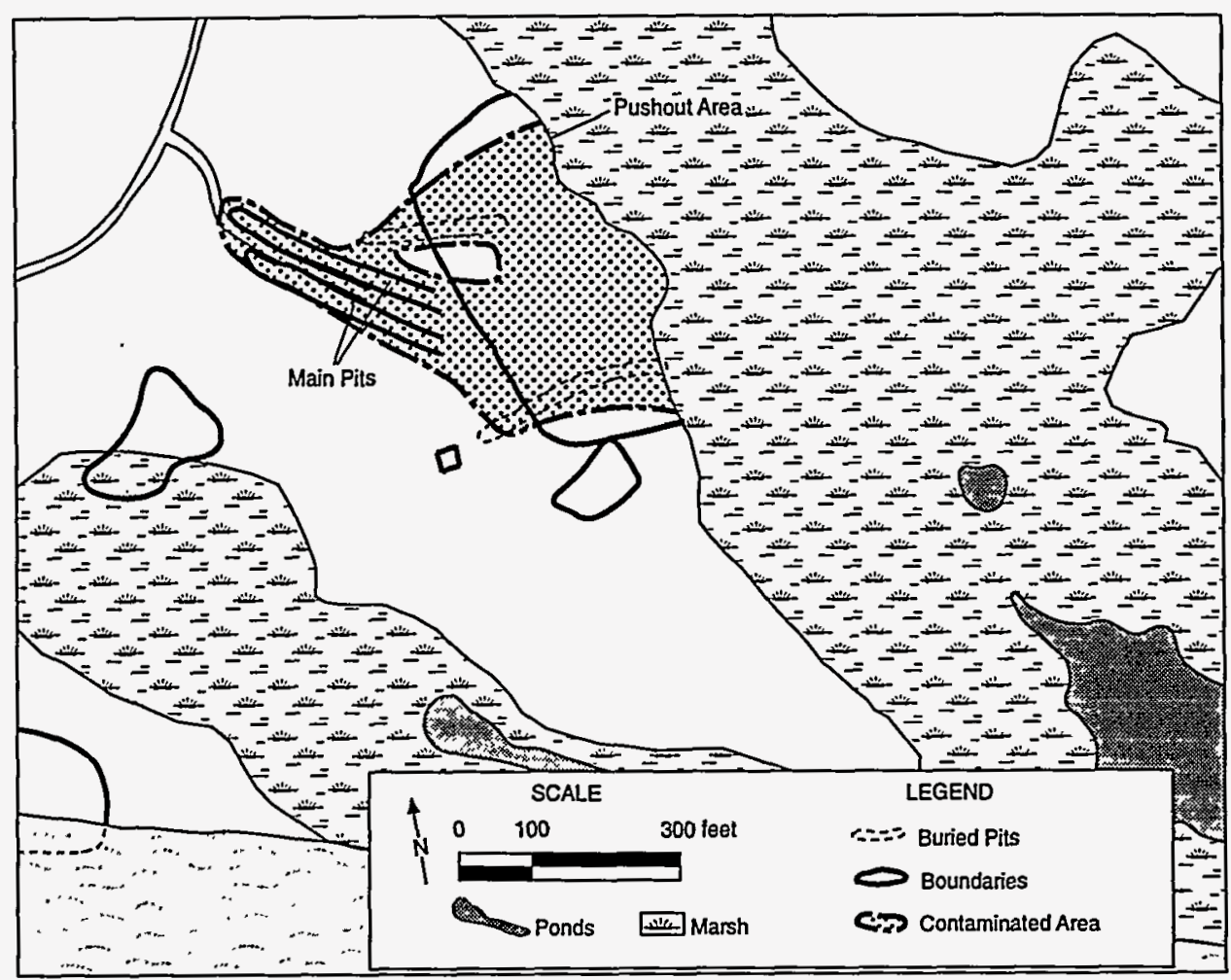

FIGURE 2.7 Estimated Contaminated Area at Depth Interval 2-4 ft with Heavy Metal Concentration Levels above Mean Background

interval of 2-4 ft. This estimate also considered the contamination present in the overlying soil and the likelihood for contaminant mobility. At the interval of $2-4 \mathrm{ft}$, VOC contamination is also present (and may also be present in low concentrations in the interval of $0-2 \mathrm{ft}$ ).

\subsubsection{Groundwater}

Groundwater in the surficial aquifer in the TBP area is contaminated primarily with VOCs, particularly TCLEA (up to $260,000 \mu \mathrm{g} / \mathrm{L}$ in well JF83), $112 \mathrm{TCE}$ (up to $2,000 \mu \mathrm{g} / \mathrm{L}$ in well JF83), 12DCE (up to $37,000 \mu \mathrm{g} / \mathrm{L}$ in piezometer JFPM1A), TRCLE (up to $41,000 \mu \mathrm{g} / \mathrm{L}$ in well JF83), TCLEE (up to 3,400 $\mu \mathrm{g} / \mathrm{L}$ in well P-3), and vinyl chloride (up to 3,200 $\mu \mathrm{g} / \mathrm{L}$ in piezometer JFPM1A). Wells JF73 and JF83 and piezometer JFPM1A are located downgradient and about 200 to $400 \mathrm{ft}$ from the two main pits. 


\subsubsection{Sediment}

Sediment samples were collected from the marsh as part of the RI (Yuen et al. 1996; see Figure D.7). Marsh sediments adjacent to the pushout area show significantly high levels of heavy metals in the upper $2 \mathrm{ft}$ of the sediment column, including arsenic (up to $14 \mathrm{mg} / \mathrm{kg}$ ), lead (up to $1,780 \mathrm{mg} / \mathrm{kg}$ ), copper (up to $515 \mathrm{mg} / \mathrm{kg}$ ), and zinc (up to $3,410 \mathrm{mg} / \mathrm{kg}$ ). These contaminants correlate well with those found in the pushout area, suggesting that erosion via surface runoff is the mechanism of transport for these contaminants. Low levels of organic contaminants were also detected, including 4,4'-dichlorodiphenyldichloroethane (DDD) (up to $22 \mu \mathrm{g} / \mathrm{kg}$ ), 4,4'-dichlorodiphenyldichloroethylene (DDE) (up to $16 \mu \mathrm{g} / \mathrm{kg}$ ), 12DCE ( $45 \mu \mathrm{g} / \mathrm{kg}$ ), TRCLE (up to $29 \mu \mathrm{g} / \mathrm{kg}$ ), and vinyl chloride (up to $18 \mu \mathrm{g} / \mathrm{kg}$ ). In one surface sediment sample (TPSED1), 2,4-dinitrotoluene was

found at a concentration of $2,110 \mu \mathrm{g} / \mathrm{kg}$. A variety of polyaromatic hydrocarbons (PAHs), including fluorene $(410 \mu \mathrm{g} / \mathrm{kg}$ ), chrysene $(1,200 \mu \mathrm{g} / \mathrm{kg}$ ), pyrene (up to $1,800 \mu \mathrm{g} / \mathrm{kg}$ ), anthracene (up to $280 \mu \mathrm{g} / \mathrm{kg}$ ), and the benzo- series (up to $2,300 \mu \mathrm{g} / \mathrm{kg}$ ), were found at a depth of $2-4 \mathrm{ft}$ in sample SEDBOR7-1 (Figure D.7).

\subsubsection{Surface Water}

Surface water samples from the adjacent marsh were also collected as part of the RI (Figure D.7). The samples were analyzed for organic compounds (VOCs, SVOCs, pesticides, and polychlorinated biphenyls [PCBs]) and inorganic materials (metals and cyanide). Several VOCs have been detected in the surface water, suggesting that contamination is migrating from the pit (source) areas via groundwater to the marsh. The organic contaminants detected include 12DCE (up to $1,700 \mu \mathrm{g} / \mathrm{L}$ ), TRCLE (up to $3,615 \mu \mathrm{g} / \mathrm{L}$ ), $112 \mathrm{TCE}$ (up to $138 \mu \mathrm{g} / \mathrm{L}$ ), and TCLEA (up to $4,348 \mu \mathrm{g} / \mathrm{L}$ ). SVOCs, pesticides, and PCBs were not detected. Lead (up to $1,590 \mu \mathrm{g} / \mathrm{L}$ ), copper (up to $525 \mu \mathrm{g} / \mathrm{L}$ ), and zinc (up to $4,040 \mu \mathrm{g} / \mathrm{L}$ ) were also detected in several samples. The elevated concentrations of metals indicate that contamination has migrated to the marsh, most likely by surface runoff from the TBP and pushout areas.

\subsection{CONTAMINATION SOURCES AND RELEASE MECHANISMS}

Potential contamination sources identified in the RI include the two main pits, the mustard and VX pits, and their associated pushout areas; and a storage area, a disposal area, and an HE demolition area (Yuen et al. 1996; Figure 2.1). As described in the RI, surface and subsurface soil samples collected at the storage area did not indicate the presence of contamination. Soils from the $\mathrm{HE}$ demolition area showed concentrations of some metals above mean background levels but below maximum background levels (Table 2.2). The sources of contamination at the TBP area are the two main pits, the pushout area, the two buried pits within the pushout area (VX and mustard pits), and 
the disposal area. The disposal area has not yet been fully characterized and is therefore not included in this FFS.

Release of contaminants from their primary source is most likely through lateral dispersion, surface runoff, leaching, and vertical infiltration. The lateral dispersion was enhanced by the pushout operations after each disposal/decontamination activity. Surface runoff is an important release mechanism for contaminants in the surface soil, especially in the pushout area. Leaching and infiltration are also important release mechanisms because fuel, liquid wastes (e.g., chlorinate solvents), and decontaminating agents (e.g., bleach and DANC) were used in the pits. These contaminants have been detected in groundwater downgradient of the site. A modeling study to evaluate the transport of metals through the vadose zone at the TBP area is presented in Appendix A.

\subsection{POTENTIAL EXPOSURE PATHWAYS}

\subsubsection{Human Exposure}

Even under current conditions of restricted site access, a number of potential human exposure pathways have been identified at the J-Field study area (ICF Kaiser Engineers 1994b). These pathways, summarized in Table 2.3, include the exposure routes of dermal contact, ingestion of soil and water, and inhalation of vapors and particulate matter. The most likely human receptors include site workers, trespassers, or persons fishing along the J-Field shoreline. Because J-Field is situated in a restricted area with a wide range of physical security measures (including patrols by military police), the likelihood of trespassing at J-Field is considered low. However, the trespasser scenario is being retained in this study to comply with U.S. Environmental Protection Agency (EPA) guidance (1991a) requiring consideration of trespassers in the baseline risk assessment (BRA). Hunters are no longer considered likely human receptors because hunting at J-Field has been banned (Wrobel 1994).

Preliminary investigations indicate that the potential for most human exposure pathways at J-Field ranges from no (or negligible) potential for significant exposure to low potential (ICF Kaiser Engineers 1994b). Incidental soil ingestion and/or dermal contact with soil by on-site individuals may have a low to moderate potential for significant exposure because of the elevated chemical concentrations detected in surface soil in the vicinity of the TBP area. In addition, incidental ingestion and/or dermal contact with contaminated surface water or sediments has an unknown potential for significant exposure because of the limited data currently available. Infrequent contact with these media (surface soil, sediments, and surface water) and the use of protective clothing by on-site workers during remediation activities would be expected to prevent significant exposures. 
TABLE 2.3 Potential Human Exposure Pathways at the TBP Area under Current Land-Use Conditions

\begin{tabular}{|c|c|c|}
\hline Medium & Chemical Release Source & Exposure Pathway/Receptor ${ }^{\mathfrak{a}}$ \\
\hline $\begin{array}{l}\text { Soil } \\
\text { (surface, subsurface) }\end{array}$ & $\begin{array}{l}\text { Previous dumping and disposal } \\
\text { activities } \\
\text { Aerial deposition from past explosions } \\
\text { and fires }\end{array}$ & $\begin{array}{l}\text { Incidental ingestion and/or dermal } \\
\text { contact with surface soil by } \\
\text { personnel working at site, persons } \\
\text { fishing, and trespassers }\end{array}$ \\
\hline Groundwater & $\begin{array}{l}\text { Leaching of chemicals from } \\
\text { contaminated soil and buried wastes }\end{array}$ & $\begin{array}{l}\text { Although groundwater is } \\
\text { contaminated, no exposure pathway } \\
\text { exists because there is currently no } \\
\text { human uses of groundwater at this } \\
\text { site or in downgradient areas }\end{array}$ \\
\hline $\begin{array}{l}\text { Surface water/ } \\
\text { sediments }\end{array}$ & $\begin{array}{l}\text { Groundwater discharge to Gunpowder } \\
\text { River, Bush River, or Chesapeake Bay } \\
\text { Surficial runoff of chemicals from } \\
\text { disposal areas }\end{array}$ & $\begin{array}{l}\text { Incidental ingestion and/or dermal } \\
\text { contact by site workers, persons } \\
\text { fishing, and trespassers }\end{array}$ \\
\hline $\begin{array}{l}\text { Food chain } \\
\text { (fish/shellfish) }\end{array}$ & $\begin{array}{l}\text { Uptake from food sources that have } \\
\text { bioaccumulated chemicals } \\
\text { Uptake of chemicals from exposure to } \\
\text { contaminated media }\end{array}$ & $\begin{array}{l}\text { Ingestion of contaminated fish and } \\
\text { shellfish caught by local fishermen } \\
\text { from the Gunpowder River, Bush } \\
\text { River, or Chesapeake Bay near } \\
\text { J-Field }\end{array}$ \\
\hline $\begin{array}{l}\text { Air } \\
\text { (vapor-phase, } \\
\text { particulate matter) }\end{array}$ & $\begin{array}{l}\text { Volatilization from subsurface wastes } \\
\text { or soil } \\
\text { Volatilization of chemicals from } \\
\text { groundwater that has discharged to } \\
\text { surface water } \\
\text { Wind erosion of contaminated surface } \\
\text { soil from disposal areas and spills } \\
\text { Dispersion and deposition of dust from } \\
\text { destruction of explosive materials at } \\
\text { Robins Point Demolition Ground }\end{array}$ & $\begin{array}{l}\text { Inhalation of contaminated dust and } \\
\text { vapors by site workers, persons } \\
\text { fishing along the J-Field shoreline, } \\
\text { and trespassers }\end{array}$ \\
\hline
\end{tabular}

a Hunters are no longer considered likely human receptors because hunting at J-Field has been banned (Wrobel 1994).

Source: Adàpted from ICF Kaiser Engineers (1994b). 
For the purpose of an interim remedial action, it is assumed that the most likely human exposure pathway is incidental ingestion of contaminated surface soil by site workers at the TBP area.

\subsubsection{Ecological Exposure}

Of the 35 species of aquatic and terrestrial biota identified as ecological receptors for the J-Field site (Hlohowskyj et al. 1995), 17 are appropriate for evaluation of ecological exposure and risk at the TBP area (Table 2.4). Exposure routes identified and evaluated in the J-Field ERA include exposure to and uptake from soil, surface water, and sediment.

For this FFS, contaminated surface soils represent the ecological media of concern at the TBP area and may affect 11 of the 17 receptors identified for this area (Table 2.4). The principal exposure pathways to the ecological receptors at the site are the incidental ingestion of contaminated soil by terrestrial biota, root uptake of contaminants by vegetation, and food-chain transfer of contaminants to higher trophic levels. This latter pathway represents the major contaminant route to the birds of prey that may use the site. For example, soil contaminants may be taken up by vegetation, which in turn is consumed by mice, which constitute a large portion of the diet of the red-tailed hawk.

\subsection{CONTAMINANTS OF CONCERN}

\subsubsection{Human Health Contaminants of Concern}

COCs for soil were selected for the TBP area according to U.S. Environmental Protection Agency (EPA) Region III guidance for Superfund sites (EPA 1993a, 1995). Maximum chemical concentrations detected during the ongoing RI and earlier investigations of the TBP area were screened against EPA risk-based concentrations. EPA Region III guidance includes a database, updated semiannually, of approximately 600 contaminants in air, drinking water, fish tissue, and soil (EPA 1995). Risk-based concentrations for each contaminant were derived for the above exposure pathways corresponding to a hazard quotient of 1 , or a lifetime cancer risk of $10^{-6}$, by using protective default exposure scenarios and the best available toxicity information (EPA 1993a).

Table 2.5 includes the maximum levels of all surface soil contaminants detected at least once in the TBP area. The maximum concentrations for surface soil (defined as $0-2 \mathrm{ft}$ in depth) were screened against EPA's risk-based concentrations. Chemicals with maximum concentrations exceeding the risk-based concentrations were identified as COCs for surface-soil-related pathways 
TABLE 2.4 Ecological Receptors for the TBP Area

\begin{tabular}{|c|c|c|c|}
\hline Receptor & Habitat Type & $\begin{array}{c}\text { Occurrence at the } \\
\text { TBP Area }\end{array}$ & $\begin{array}{c}\text { Exposure } \\
\text { Point Media }\end{array}$ \\
\hline Grasses (Andropogon spp.) & Upland & $\begin{array}{l}\text { Pushout area, } \\
\text { main pits area }\end{array}$ & Soil \\
\hline Maple (Acer spp.) & Upland & $\begin{array}{l}\text { Southern portion } \\
\text { of area }\end{array}$ & Soil \\
\hline Common reed & Wetlands & Marsh & Sediment \\
\hline $\begin{array}{l}\text { Phytoplankton and } \\
\text { zooplankton }\end{array}$ & Quiet surface waters & Pond, marsh & Surface water \\
\hline Golden shiner & Quiet surface waters & $\begin{array}{l}\text { Pond, marsh, and } \\
\text { marsh edges }\end{array}$ & Surface water \\
\hline Leopard frog & Quiet surface waters & $\begin{array}{l}\text { Marsh and pond } \\
\text { margins }\end{array}$ & Surface water \\
\hline Great blue heron & $\begin{array}{l}\text { Surface waters and } \\
\text { wetlands }\end{array}$ & $\begin{array}{l}\text { Marsh and pond } \\
\text { margins }\end{array}$ & Surface water \\
\hline American kestrel & Semi-open grasslands & $\begin{array}{l}\text { Pushout area, } \\
\text { main pits area }\end{array}$ & $\begin{array}{l}\text { Soil and } \\
\text { surface water }\end{array}$ \\
\hline Red-tailed hawk & $\begin{array}{l}\text { Wetlands, grasslands, } \\
\text { and forests }\end{array}$ & Entire area & $\begin{array}{l}\text { Soil and } \\
\text { surface water }\end{array}$ \\
\hline American robin & $\begin{array}{l}\text { Wetlands, grasslands, } \\
\text { and forests }\end{array}$ & Entire area & $\begin{array}{l}\text { Soil and } \\
\text { surface water }\end{array}$ \\
\hline Tree swallow & $\begin{array}{l}\text { Grasslands with wooded } \\
\text { edges or nearby woodlots }\end{array}$ & Entire area & $\begin{array}{l}\text { Soil and } \\
\text { surface water }\end{array}$ \\
\hline Mallard duck & $\begin{array}{l}\text { Wetlands with nearby } \\
\text { grasslands }\end{array}$ & $\begin{array}{l}\text { Pond, marsh, and } \\
\text { pushout area }\end{array}$ & $\begin{array}{l}\text { Soil, surface } \\
\text { water, and } \\
\text { sediment }\end{array}$ \\
\hline White-tailed deer & $\begin{array}{l}\text { Old fields, grasslands, } \\
\text { and forests }\end{array}$ & Entire area & $\begin{array}{l}\text { Soil and } \\
\text { surface water }\end{array}$ \\
\hline Muskrat & $\begin{array}{l}\text { Surface waters and } \\
\text { wetlands }\end{array}$ & Marsh, pond & $\begin{array}{l}\text { Surface water } \\
\text { and sediment }\end{array}$ \\
\hline White-footed mouse & All upland habitats & Entire area & $\begin{array}{l}\text { Soil and } \\
\text { surface water }\end{array}$ \\
\hline Eastern cottontail & $\begin{array}{l}\text { Upland habitats and } \\
\text { marsh edges }\end{array}$ & Entire area & $\begin{array}{l}\text { Soil and } \\
\text { surface water }\end{array}$ \\
\hline Red fox & $\begin{array}{l}\text { Wetlands, grasslands, } \\
\text { and forests }\end{array}$ & Entire area & $\begin{array}{l}\text { Soil and } \\
\text { surface water }\end{array}$ \\
\hline
\end{tabular}


TABLE 2.5 Identification of Human Health-Based Contaminants of Concern for Soil $(0-2 \mathrm{ft})$ in the TBP Area

\begin{tabular}{|c|c|c|c|}
\hline Chemical & $\begin{array}{l}\text { Maximum } \\
\text { Concentration }^{\mathrm{a}} \\
(\mathrm{mg} / \mathrm{kg})\end{array}$ & $\begin{array}{c}\text { Risk-Based } \\
\text { Concentration } \\
\text { (mg/kg) }\end{array}$ & $\begin{array}{c}\text { Contaminant } \\
\text { of Concern }\end{array}$ \\
\hline \multicolumn{4}{|l|}{ Volatile organic compounds } \\
\hline Acetone & 0.02 & 200,000 & No \\
\hline Benzene & 0.1 & 200 & No \\
\hline 2-Butanone & 0.037 & $1,000,000$ & No \\
\hline Carbon disulfide & 0.038 & 200,000 & No \\
\hline Chlorobenzene & 0.1 & 41,000 & No \\
\hline Chloroform & 0.05 & 940 & No \\
\hline 11DCE & 0.10 & 9.5 & No \\
\hline trans-12DCE & 0.17 & 18,000 & No \\
\hline Methylene chloride & 0.10 & 760 & No \\
\hline TCLEA & 2.5 & 29 & No \\
\hline TCLEE & 1.0 & 110 & No \\
\hline Toluene & 0.05 & 410,000 & No \\
\hline TRCLE & 2.8 & 520 & No \\
\hline Xylenes & 0.05 & $1,000,000$ & No \\
\hline \multicolumn{4}{|c|}{ Semivolatile organic compounds } \\
\hline Benzo(b)fluoranthene & 1.25 & 7.8 & No \\
\hline Benzo(k)fluoranthene & 1.25 & 78 & No \\
\hline Bis(2-chloroethyl)ether & 1.25 & 5.2 & No \\
\hline Diethylphthalate & 1.25 & $1,000,000$ & No \\
\hline Fluorene & 1.25 & 82,000 & No \\
\hline Hexachlorobenzene & 3.1 & 3.6 & No \\
\hline Hexachloroethane & 1.25 & 410 & No \\
\hline 2-Methylnaphthalene & 1.25 & $N A^{c}$ & Yes \\
\hline 2-Methylphenol & 1.25 & 100,000 & No \\
\hline 4-Methylphenol & 1.25 & 10,000 & No \\
\hline N-Nitrosodiphenylamine & 0.95 & 1,200 & No \\
\hline Phenol & 1.25 & $1,000,000$ & No \\
\hline Pyrene & 1.25 & 61,000 & No \\
\hline 2,4,6-Trichloroaniline & 7.9 & 170 & No \\
\hline \multicolumn{4}{|l|}{ Pesticide/PCB } \\
\hline Aroclor 1248 & 0.57 & $0.74^{d}$ & No \\
\hline \multicolumn{4}{|l|}{ Explosives } \\
\hline Nitroglycerin & 15.3 & NA & Yes \\
\hline
\end{tabular}


TABLE 2.5 (Cont.)

\begin{tabular}{|c|c|c|c|}
\hline Chemical & $\begin{array}{c}\text { Maximum } \\
\text { Concentration } \\
(\mathrm{mg} / \mathrm{kg})\end{array}$ & $\begin{array}{c}\text { Risk-Based } \\
\text { Concentration }^{\mathrm{b}} \\
(\mathrm{mg} / \mathrm{kg})\end{array}$ & $\begin{array}{c}\text { Contaminant } \\
\text { of Concern }\end{array}$ \\
\hline \multicolumn{4}{|l|}{ Inorganic materials } \\
\hline Aluminum & 22,600 & $1,000,000$ & No \\
\hline Antimony & 501 & 820 & No \\
\hline Arsenic & 1,440 & 3.8 & Yes \\
\hline Barium & 1,580 & 140,000 & No \\
\hline Beryllium & 1.38 & 1.3 & Yes \\
\hline Cadmium & 35.5 & 1,000 & No \\
\hline Calcium & 36,000 & $-^{e}$ & No \\
\hline Chromium & 878 & 10,000 & No \\
\hline Cobalt & 108 & 120,000 & No \\
\hline Copper & 4,320 & 82,000 & No \\
\hline Cyanide & 120 & 41,000 & No \\
\hline Iron & 154,000 & 610,000 & No \\
\hline Lead & 94,200 & $400^{f}$ & Yes \\
\hline Magnesium & 3,880 & $-{ }^{e}$ & No \\
\hline Manganese & 633 & 10,000 & No \\
\hline Mercury & 3.6 & 610 & No \\
\hline Molybdenum & 6.9 & 10,000 & No \\
\hline Nickel & 84.5 & 41,000 & No \\
\hline Potassium & 1,460 & $-^{e}$ & No \\
\hline Selenium & 7.12 & 10,000 & No \\
\hline Silver & 41.9 & 10,000 & No \\
\hline Sodium & 521 & $-^{e}$ & No \\
\hline Thallium & 19.3 & $160^{g}$ & No \\
\hline Vanadium & 32.7 & 14,000 & No \\
\hline Zinc & 17,800 & 610,000 & No \\
\hline
\end{tabular}

a Maximum detected concentrations for surface soil samples (0-2 $\mathrm{ft}$ in depth). These values are taken from currently available data, excluding non-Contract Laboratory Program data collected by Weston.

b From EPA (1995), for "industrial" soil.

c $\mathrm{NA}=$ not available.

d Risk-based concentrations for PCB isomers are based on Aroclor mixtures.

e Risk-based concentrations for these compounds are not available due to low toxicity.

f EPA currently recommends a soil lead cleanup value of $400 \mathrm{mg} / \mathrm{kg}$ for residential land use but site-specific pharmacokinetic modeling for nonresidential (adult) screening, when riecessary (EPA 1994).

g A risk-based concentration was not available for the class of thallium compounds, so the value for thallium sulfate was used instead. 
of human exposure. In addition, except for several inorganic materials commonly found in soil (noted on Table 2.5), chemicals without a risk-based concentration were also included as COCs.

Although this approach is intended for use in BRAs (EPA 1993a), it is a conservative screening methodology that should be appropriate for identifying human health COCs for interim remedial action at the TBP area. The risk-based concentrations were derived by using conservative default exposure scenarios (EPA 1991a) and the most recent reference doses and carcinogenic potency slopes. Consequently, the risk-based concentrations "represent relatively protective environmental conditions at which EPA would typically not take action" (EPA 1993a). EPA Region III's risk-based screening approach was also used to select COCs at J-Field for determining soil concentrations that would be protective of human health, especially for site remediation workers (ICF Kaiser Engineers 1994a).

In addition, the COC screening methodology assumes a scenario of surface exposures to site personnel and remediation workers (i.e., the use of maximum surface soil concentrations and ingestion of industrial soils). This approach is not intended to take into account potential contaminant leaching to the groundwater. In that case, soil screening levels for groundwater use (recently developed by EPA) would be used to screen for COCs. Because the available soil screening levels for transfers from soil to groundwater are often orders of magnitude lower, there would be additional COCs to evaluate if the groundwater pathway were considered (e.g., VOCs). Similarly, human health-based interim PRGs would be correspondingly lower. However, the surface exposure scenario developed in this report is appropriate for a removal action, supplemented by a BRA and sitewide FS that considers potential contaminant leaching to groundwater.

\subsubsection{Contaminants of Ecological Concern}

The contaminants of ecological concern (COECs) in soils were identified for the TBP area by using data collected as part of the RI for J-Field (Yuen et al. 1996). These contaminants were identified by comparing measured soil concentrations with a number of chemical-specific factors, including background concentrations and screening benchmark values. The detection frequency, capacity to bioaccumulate or bioconcentrate, and importance as a micro- or macronutrient were also considered in the selection process. The procedure for selecting the COECs follows the general approach recommended by EPA in the Human Health Evaluation Manual (EPA 1989a) and EPA Region III guidance for identifying COCs (EPA 1993a) and is consistent with the screening approach used for the TBP area human health risk assessment (see Section 2.6.1 and ICF Kaiser Engineers 1995b).

Contaminant characterization data for soil were first evaluated with respect to analytical methods, detection limits, quality control (QC) samples, and blanks. Details regarding this portion 
of the screening process are presented in the J-Field ERA report (Hlohowskyj et al. 1996). The following steps were then performed, in order, by using the remaining soil data for the TBP area:

- The detection frequency of each contaminant was evaluated, and all contaminants with detection frequencies of $0 \%$ were eliminated from further consideration in the ERA.

- Contaminant concentrations were compared to reported background concentrations (ICF Kaiser Engineers 1995a). The one-tailed nonparametric MannWhitney test (Zar 1984) was employed to test for similarity between background and site concentrations, and contaminants were retained for further screening if they were found to significantly $(p<0.05)$ exceed background concentrations. However, if the sample size for a contaminant from a particular site and medium was less than or equal to 3 , a statistical comparison was not possible. In these instances, the maximum reported concentration was compared directly to the maximum reported background concentration, and a contaminant was retained for further screening if the reported maximum concentration exceeded the maximum background level.

- Chemical contaminants were compared to screening values. These values represent media concentrations considered to be protective of biota. Contaminants present at maximum concentrations exceeding screening concentrations were retained as the final COECs.

- Chemicals that were present at maximum concentrations within background levels but greater than the screening values were retained as final COECs.

Background concentrations used in the screening process are those identified for the region (ICF Kaiser Engineers 1995a). Soil screening values were obtained from a number of sources, including the EPA Region III screening levels, Opresko et al. (1994), Will and Suter (1994), NOAA/HAZMAT (undated), and the open scientific literature. Although soil benchmarks considered protective of human health are available (e.g., EPA 1993a), these were not used in the screening process.

The contaminants identified as the final COECs and carried through the remainder of the ERA were those with maximum concentrations that exceeded background and/or screening level concentrations. The screening process also considered essential plant and animal nutrients and bioconcentration and bioaccumulation potential. The final list of COECs for the TBP area soils is presented in Table 2.6. 
TABLE 2.6 Contaminants of Ecological Concern for TBP Area Soils

\begin{tabular}{lll}
\hline Acetone & Cobalt & Nickel \\
Aluminum & Copper & Nitroglycerin \\
Antimony & Cyanide & N-Nitrosodiphenylamine \\
Aroclor 1248 & 1,1-Dichloroethene & Phenol \\
Arsenic & Diethyl phthalate & Potassium \\
Barium & Fluorene & Selenium \\
Benzene & Hexachlorobenzene & Silver \\
Benzo(b)fluoranthene & Hexachloroethane & 1,1,2,2-Tetrachloroethane \\
Benzo(k)fluoranthene & Iron & 2,4,6-Trichloroaniline \\
Beryllium & Lead & Trichloroethene \\
Bis(2-chloroethyl)ether & Magnesium & Vanadium \\
2-Butanone & Mercury & m \& p Xylene \\
Cadmium & 2-Methylnaphthalene & Zinc \\
Carbon disulfide & 2-Methylphenol & \\
Chromium & 4-Methylphenol & \\
\hline
\end{tabular}

\subsection{CONCURRENT STUDIES}

\subsubsection{Remedial Investigation}

The suspected contamination sources at the TBP area include the two main pits, the VX and the mustard pits, and their associated pushout areas; and a storage area, a disposal area, and an HE demolition ground. The specific location of the liquid smoke disposal pit is uncertain. Because the two main pits are visible at the surface today, their extent is easy to determine. Examination of historical aerial photographs indicates that their extent has not changed significantly over time. The remaining pits (VX, mustard, and liquid smoke) have been buried. The approximate locations of the VX and mustard pits have been identified with the aid of historical aerial photographs. The results of ground-penetrating radar (GPR) surveys conducted in the area of the VX pit correlate well with the location identified in the aerial photographs. Additional geophysical surveys and soil sampling will be conducted to verify the locations of all other pits and associated unloading zones, which are considered potential groundwater contamination sources.

Characterization of the TBP area is continuing so that long-term remedial alternatives may be developed for the entire site during the FS. The nature and extent of soil contamination in the remaining pits, the storage area, the disposal area, and demolition area are currently under investigation as part of the RI. 


\subsubsection{Human Health Risk Assessment}

Human health risk assessments were recently conducted for J-Field (ICF Kaiser Engineers 1995a, 1996). The J-Field risk assessment focuses on potential exposure to chemical contaminants at hazardous waste disposal areas within J-Field, except for soil, surface water, and sediment at the TBP area, which were evaluated in a separate report (ICF Kaiser Engineers 1995a). Draft reports of these assessments have been released for public comment. The objective of the risk assessment is to determine the potential for and extent of human health risks resulting from contaminants at $\mathrm{J}$-Field. Human exposures to chemical contaminants detected at $\mathrm{J}$-Field or migrating from the waste disposal sites were evaluated specifically for the following environmental media: groundwater, soil, air, surface water, and sediment.

The approach for conducting the human health risk assessment at J-Field is outlined by ICF Kaiser Engineers (1994b). The preliminary list of potential receptors and human exposure pathways (which is based on a review of the site background and history) was reevaluated. Because the scope of the human health risk assessment is broad, additional field and laboratory data from the RI were needed to fully characterize the potential for human health risks. The data generated during the RI at J-Field were analyzed statistically to determine the significance of chemical concentration data. After the collection and statistical analysis of data, the BRA was performed to estimate human health impacts resulting from past activities at J-Field. Human health risks for each complete pathway were evaluated according to EPA guidance for BRAs (EPA 1989a,b). A similar approach was used for the TBP area baseline human health risk assessment (ICF Kaiser Engineers 1995a), which evaluated soil, surface water, and sediment data.

As stated in EPA guidance, risk-based remediation goals are initial guidelines that need to be reviewed and possibly modified upon completion of the BRA or when additional information is available.(EPA 1991b). To reduce uncertainties and support the development of final remediation goals, the review should include exposure assumptions, future land use, and media and contaminants of potential concern.

\subsubsection{Ecological Risk Assessment}

An ERA (Hlohowskyj et al. 1996) was recently completed for the TBP area. This risk assessment included the following:

- Evaluations of species abundance and community composition that used quantitative and qualitative surveys of wetland and upland vegetation and terrestrial and aquatic invertebrate and vertebrate biota; 
- Quantitative evaluations of physiological parameters of soil invertebrates, such as enzyme activity and respiration rates;

- Quantitative evaluations of processes mediated by soil invertebrates, such as litter decomposition and nitrogen mineralization; and

- Toxicity tests of site soils, sediments, and surface waters on a variety of invertebrates, vertebrates, and plants.

Surveys of the aquatic invertebrate community at the TBP area marsh and pond showed a diverse community representing a wide variety of taxa. Except in the site nearest the pushout area, the benthic fauna in the pond and marsh represented communities expected to occur in such habitats. The fish community was dominated by two species, one of which was present in very large numbers. No fish collected exhibited any external evidence (lesions, ulcers, fin rot, exopthalamus) of contaminant effects or other environmental stressors.

The vertebrate surveys showed a very diverse bird community inhabiting or using the site; more than 100 species were identified. No individuals exhibited any obvious external abnormalities. Four amphibian species and four native mammal species (white-footed mouse, meadow vole, short-tailed shrew, and red fox) were collected or observed, and none of the specimens exhibited any external abnormalities (lesions or tumors).

The survey results showed reduced invertebrate abundance in the disturbed soils of the area. Total macroinvertebrate numbers, bacterial and fungal biomass, and nematode numbers were significantly lower, particularly at the pushout area, than those measured at on-site and off-site reference areas. The trophic structure of the nematode community at the pushout area was also different from that observed at the reference area.

The activity of several bacterial and fungal nutrient-acquiring enzymes in the pushout area was significantly lower than that at the reference site. Enzyme activity was significantly and negatively correlated with the total metal content of the soil. Substrate-induced respiration and soil nitrogen dynamics were also lower in the pushout area than in the reference location.

Toxicity testing of aquatic media showed no acute toxicity of surface water from the pond or marsh, but chronic toxicity was indicated for surface water from the marsh. This toxicity was restricted to surface water collected from the marsh immediately next to the pushout area; it was manifested as growth inhibition of the floating vascular plant Lemna and reduced survival and growth in larval fish. No chronic toxicity was detected for surface water from the pond. Toxicity testing of sediments indicated bacterial (Microtox) inhibition, and some tests showed an increase in mortality of the amphipod Hyalella. The sediments exhibiting toxic effects were all collected from along the boundary between the pushout area and the marsh. No toxicity was detected in sediments 
collected from the pond. The distribution of the measured surface water and sediment toxicity suggests that the toxicity of these media is a result of contaminated surface soil and precipitation running off from the pushout area to the marsh. Testing of groundwater from the surficial aquifer at the TBP area showed both acute and chronic toxicity to a variety of test organisms, including zooplankton, vascular plants, amphibians, and larval fish.

Soils from the TBP area had lethal and sublethal effects on earthworms and vegetation. Soils from the southern main pit and the pushout area resulted in nearly $100 \%$ mortality in earthworms, and significant weight loss in worms was detected in soil mixtures containing more than $25 \%$ of site soil. Toxicity testing evaluating seedling emergence, growth, and survival in lettuce showed seedling emergence rate $\leq 2.5 \%$ for soils from the pushout area and southern main pit and seedling emergence rate $<75 \%$ from other areas of the TBP area.

Risk estimation based on uptake modeling (Appendix E) indicates that the soil contamination at the TBP poses a substantial risk to several receptors. Aluminum, antimony, arsenic, cadmium, chromium, cyanide, lead, mercury, selenium, and zinc were each found to pose an extreme risk (environmental effects quotient [EEQ] > 100) for at least one modeled ecological receptor. However, the exposure point concentrations used to model the uptake of particular contaminants were frequently based on the maximum detected concentrations for the site. In actuality, the concentrations to which receptors would likely be exposed at the site range from levels much lower than the exposure point concentrations (e.g., minimum detected values) to the maximum detected concentration. Thus, the results present a conservative view of risks likely to be incurred from contamination at the site (i.e., more likely to detect risks).

Extreme and moderate risks from soil contamination are indicated to terrestrial vegetation from 7 soil contaminants, and moderately high to extreme risk is indicated to a variety of terrestrial receptors for 13 COECs. Extreme risks were identified for $8 \mathrm{COECs} \mathrm{(7} \mathrm{metals} \mathrm{and} \mathrm{cyanide)} \mathrm{and}$ 3 receptor species, while moderate to high risks were identified for 11 COECs (10 metals and cyanide). Low risks were identified for only two COECs, chromium and trichloroethene. The large number of receptors for which high or extreme risks were identified, together with the results of the effects assessment, supports the risk characterization that soil from the TBP area poses a high risk to ecological resources.

The EEQ and weight-of-evidence approaches for risk estimation indicate that the TBP area poses a high risk for adverse ecological impacts. This risk is associated primarily with contaminated soils in the pushout area and pits and is related primarily to heavy-metal concentrations rather than PCBs, pesticides, VOCs, or SVOCs. The contaminated soils of the pushout area are also the probable primary source of the contamination and high risk identified in surface water and sediment along the marsh-pushout area boundary (Hlohowskyj et al. 1996). The lack of suitable benchmark values for several of the receptor species precluded the calculation of EEQ risk values for a number 
of the organic COECs. However, the absence of these risk estimates does not affect the conclusion that the TBP area soils pose a high risk for adverse ecological impacts.

The high risk identified for the TBP area may be significant at a local scale for most terrestrial wildlife that use the site. Adverse impacts were identified for several ecological variables and across multiple taxa and trophic levels. These impacts should largely be restricted to biota that occur within the TBP area boundaries and not extend to other areas of J-Field or APG. However, potential impacts on wide-ranging biota may affect wildlife populations that are not restricted to the $\mathrm{J}$-Field boundary. The use of the site by migratory waterfowl and avian predators, such as the redtailed hawk and American kestrel, is of particular concern. Consequently, the TBP area poses risks that would be ecologically significant, given the potential importance of the surrounding marsh to waterfowl and the implications that impacts on raptor populations could have on control of prey populations in the J-Field area.

\subsubsection{Sitewide Feasibility Study}

A sitewide FS is being conducted for J-Field. The purpose of the FS is to gather sufficient information to develop and evaluate alternative remedial actions to address contamination at J-Field AOCs, including the TBP area groundwater. 
2-34

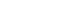




\section{INTERIM REMEDIAL ACTION OBJECTIVES}

\subsection{OBJECTIVES AND SCOPE}

The overall objectives of the proposed interim remedial action at the TBP area of J-Field are to:

- Reduce exposure of human and environmental receptors to surface contamination in three source areas: the two main pits and pushout area,

- Minimize the potential for contaminant migration via sediment transport from these areas,

- Minimize the potential for contaminant migration via downward leaching through these areas, and

- Support long-term site remediation.

The source areas of contamination at the TBP area are described in Section 2.4. Three of these source areas are the subject of this FFS: the northern main pit, the southern main pit, and the pushout area (Figure 2.1). Preliminary results of human health and ecological risk assessments (Section 2.7) indicate that contaminated surface soil in these areas should be addressed to protect human health and the environment. An interim remedial action could be implemented that would achieve the objectives stated above.

Technologies that could be applied to address contaminated surface soil in the main pits and pushout area are discussed in Section 4. Figures 3.1 and 3.2 show the areas of surface soil contamination to be addressed by the proposed action. Preliminary area and volume estimates for these areas are presented in Table 3.1. Volumes apply only to the excavation scenarios proposed under Alternatives 3, 4, and 5. Area of contamination applies to all the action alternatives, including

TABLE 3.1 Estimated Areas and Volumes of Contaminated Surface Soil at the Main Pits and Pushout Area

\begin{tabular}{cccc}
\hline $\begin{array}{c}\text { Contaminated } \\
\text { Surface Soil Interval }\end{array}$ & Contaminants of Concern & Area $\left(\mathrm{ft}^{2}\right)$ & Volume $\left(\mathrm{yd}^{3}\right)$ \\
\hline 0 to 6 in. & Metals, organics & 218,300 & 4,043 \\
6 to 24 in. & Metals, organics & 208,600 & 11,590 \\
\hline
\end{tabular}

a See Figure 3.1 for location of excavation area. 


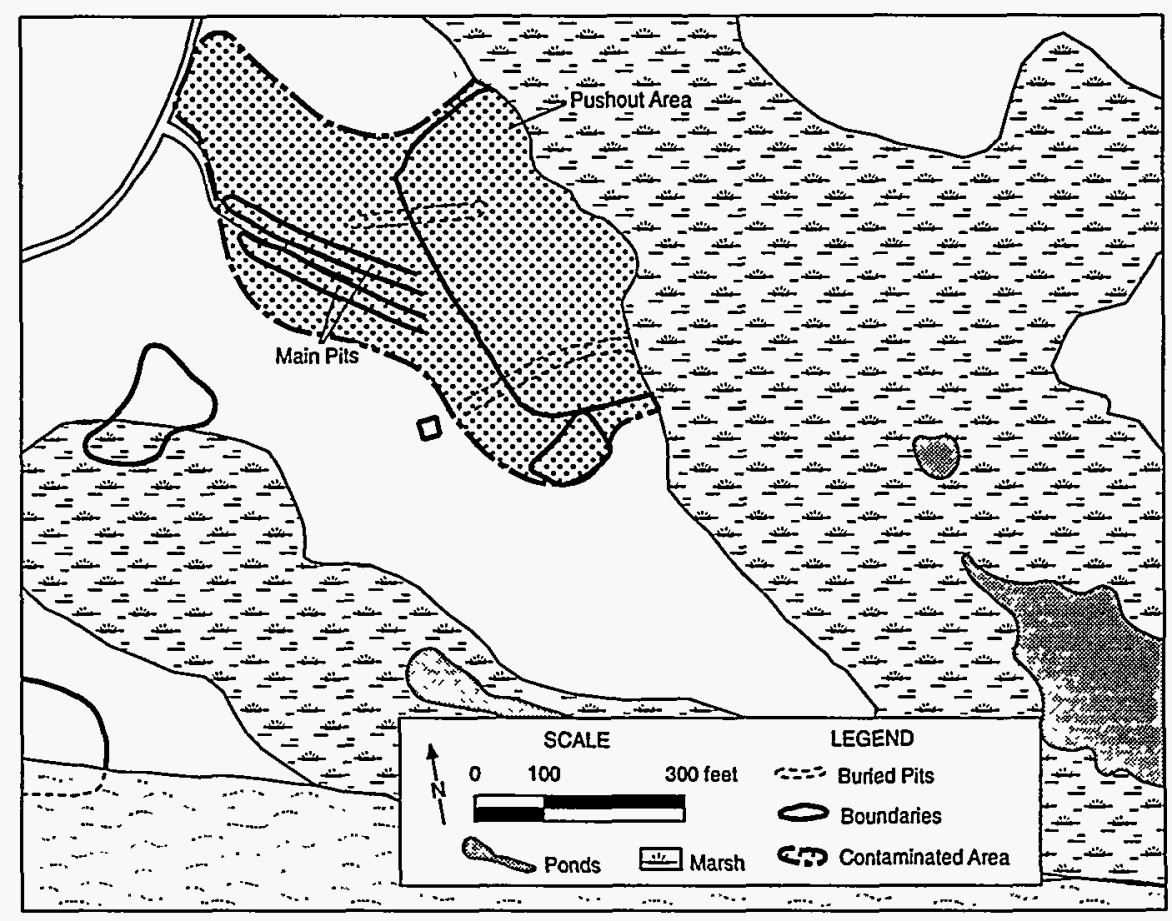

FIGURE 3.1 Contaminated Surface Soil, 0-6 in., to Be Addressed by the Proposed Action at the TBP Area

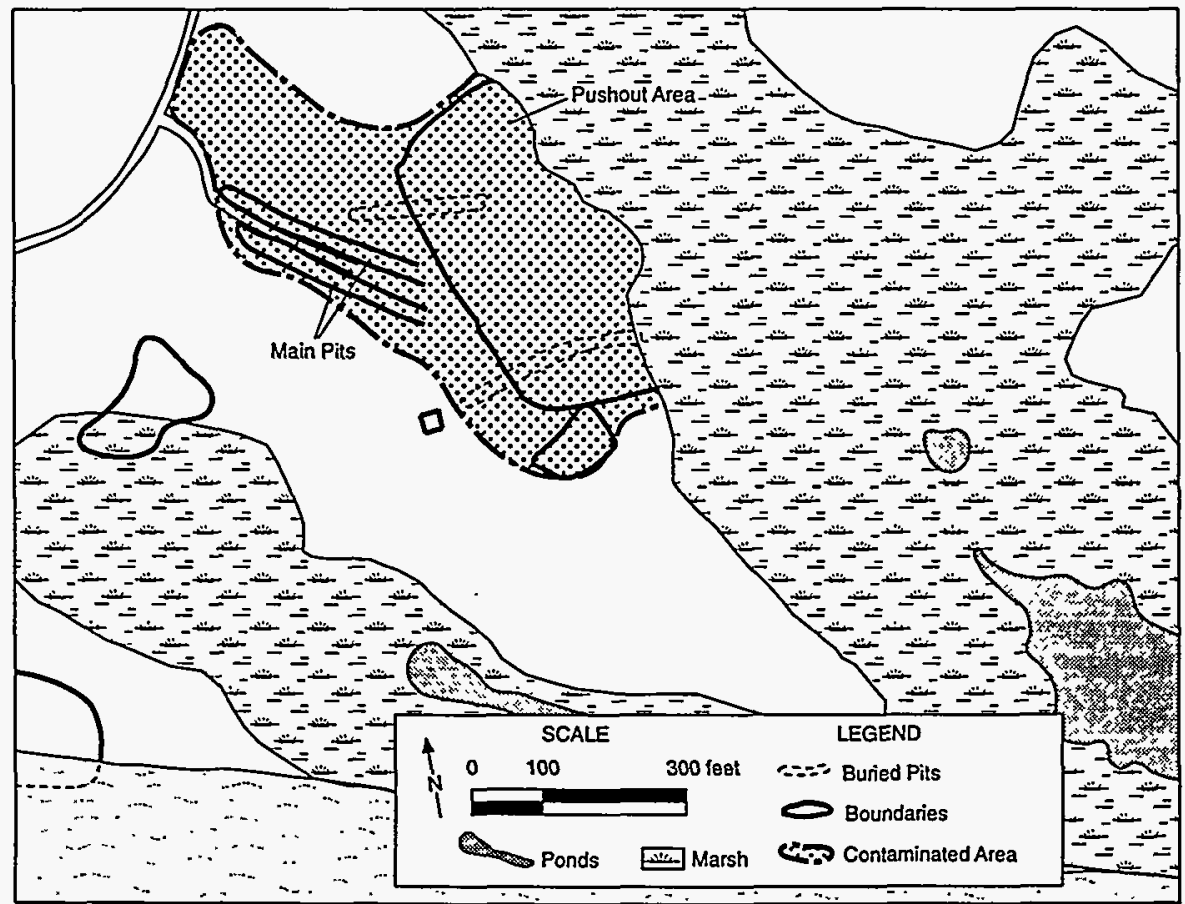

FIGURE 3.2 Contaminated Surface Soil, 6-24 in., to Be Addressed by the Proposed Action at the TBP Area 
the covering of soil as proposed in Alternative 2 and the excavation scenarios proposed under Alternatives 3, 4, and 5. The areas depicted in Figures 3.1 and 3.2 represent the areas with metal concentrations exceeding the mean regional background as reported by ICF Kaiser Engineers (1995a). The methodology used to derive this estimate is presented in Section 2.3. The areas depicted in the figures also cover the areas with levels of contaminants exceeding the interim PRGs reported in Table 3.5. The interim PRGs developed for surface soils at the TBP area (Section 3.3) were used to determine which source areas at the TBP area should be addressed as part of the interim action and which could be appropriately left in their current condition until further action is taken at the site as part of the long-term remediation for J-Field. Other source areas and contaminated media (groundwater, surface water, sediment, and subsurface soils) at the TBP area are outside the scope of this interim remedial action and will be addressed as part of the long-term remediation for J-Field (Section 2.7.4).

\subsection{COMPLIANCE WITH REGULATORY REQUIREMENTS}

In accordance with Section 121 of CERCLA and the National Oil and Hazardous Substances Pollution Contingency Plan (NCP), the proposed action would be implemented in accordance with ARARs. Identification of ARARs is site-specific and is defined as follows:

- Applicable requirements are cleanup standards, standards of control, and other substantive environmental protection requirements, criteria, or limitations promulgated under federal or state environmental or facility siting laws that specifically address a hazardous substance, pollutant, contaminant, remedial action, location, or other circumstance at a CERCLA site. Only those state standards that are identified by a state in a timely manner and that are more stringent than federal requirements may be applicable.

- Relevant and appropriate requirements are cleanup standards, standards of control, and other substantive environmental protection requirements, criteria, or limitations promulgated under federal or state environmental or facility siting laws that, while not "applicable" to a hazardous substance, pollutant, contaminant, remedial action, location, or other circumstances at a CERCLA site, address problems or situations sufficiently similar to those encountered at the CERCLA site that their use is well suited to the particular site. Only those state standards that are identified by. a state in a timely manner and that are more stringent than federal requirements may be relevant and appropriate.

As described in EPA guidance, ARARs can be divided into three categories: contaminantspecific, location-specific, and action-specific. Contaminant-specific ARARs address certain chemical species or classes of contaminants and relate to the allowable limits of contaminant 
concentrations in various environmental media.(soil, groundwater, surface water, air). Locationspecific ARARs are based on the specific setting and nature of the site, such as location in a floodplain and proximity to wetlands. Action-specific ARARs relate to specific response actions (i.e., excavation or soil washing/leaching) that are proposed for implementation at the site.

In addition to ARARs, the NCP provides for the use of other advisories, criteria, or guidance TBCs. These are advisories, criteria, and standards that are issued by the federal or state regulatory body but not legally binding because they have not been properly promulgated. The identification of TBCs is not mandatory; however, they are to be used as appropriate to complement the ARARs.

Potential ARARs for the proposed action at the TBP area are identified on the basis of the nature of contamination, the site location, and the proposed activities (including both federal and State of Maryland requirements). A comprehensive list of potential ARARs is presented in Appendix B.

The NCP acknowledges the EPA's policy of responding by distinct operable unit at a site rather than waiting to take one consolidated response action (EPA 1990a). Therefore, this interim action has a limited scope, and requirements are ARARs only when they pertain to the issues to be addressed and the specific activities to be conducted under the interim action. For instance, this interim action addresses only the excavation and removal of contaminated soils and does not concern groundwater remediation, which is within the scope of a concurrent RI/FS. The interim action would also contribute to improving migration of contaminants to surface waters but does not address surface water remediation. Therefore, Appendix B does not address ARARs outside the scope of soil excavation, treatment, and disposal.

Appendix B identifies federal and state location-specific requirements for permitting and approvals for activities taking place in wetlands and floodplains (e.g., the movement of soils, grading, and fill discharge). Location-specific requirements also address impacts on wildlife and cultural, historic, or archeological sites.

Federal standards and guidelines are available for only a few of the soil contaminants of concern at the J-Field TBP area: metals (e.g., lead), dioxin, and PCBs. These soil contaminants are governed by RCRA and the Toxic Substances Control Act (TSCA), respectively. The management and disposal of soils contaminated with lead or arsenic are governed by the Maryland RCRA program. No Maryland State PCB standards or guidelines are established; therefore, federal standards for management and disposal of PCB-contaminated soils would be contaminant-specific ARARs.

Under RCRA regulations, any waste that fails the TCLP is a characteristic hazardous waste. The soil in the TBP area was analyzed and found to be characteristically hazardous for lead and 
arsenic (i.e., the TCLP extract exceeded $5 \mathrm{mg} / \mathrm{L}$ ). Because the operations at the TBP ceased before 1979, if the soil is left in place and no current actions are taken that constitute treatment, storage, or disposal as defined by RCRA, RCRA land disposal restriction (LDR) regulations would not be applicable to the TBP. However, if lead-or arsenic-contaminated characteristic hazardous waste is to be excavated and land-disposed, it must meet the RCRA LDR regulations and, thereunder, must be treated to meet an extraction procedure (EP) or TCLP concentration of less than $5 \mathrm{mg} / \mathrm{L}$ prior to disposal. Therefore, Maryland's EPA-authorized RCRA program regulations and standards will govern any activities concerning excavated contaminated soils, including any storage, treatment, or disposal activities.

The EPA recognized early on that RCRA constituent-contaminated soil is different than hazardous wastes generated in a process (as-generated wastes) and that treatment of soil should also be different. Therefore, the treatment standards for soil were delayed until May 8, 1992. An additional 1-year extension was granted and has since expired. Therefore, hazardous waste soil is now subject to the same treatment standards as as-generated wastes.

In the proposed Phase II LDR rule, the EPA included provisions to establish constituentspecific treatment standards for soils contaminated with hazardous wastes. However, after receiving a number of comments, the EPA issued a subsequent Federal Register Notice (58 FR 59,976, November 12,1993) that announced its intention to not include soil LDRs in the Phase II LDR final rule. In the preamble of the Phase II LDR final rule, the EPA reiterated its position that "treatment . standards for as-generated wastes are generally inappropriate or unachievable for soils contaminated with hazardous wastes" (59 FR 47,980, September 19, 1994). Now the EPA has issued its proposed Hazardous Waste Identification Rule - Media (61 FR 18,779, April 29, 1996).

This proposed rule would establish modified LDR treatment requirements and modified permitting procedures for higher-risk contaminated media that remain subject to hazardous waste regulations and give the EPA and any state authorized to implement the Hazardous Waste Identification Rule - Media the authority to remove certain lower-risk contaminated media from regulations as a hazardous waste, including minimum technological requirements. Once adopted, this rule would govern the storage, treatment, and disposal of hazardous waste-contaminated soils at remediation sites overseen by either the EPA or an authorized state. As proposed, this rule would also supersede the Corrective Action Management Unit (CAMU) regulations. Therefore, adoption of this rule would affect the management of any hazardous waste soils excavated after the rule's effective date.

However, until a new regulation is finalized, Maryland RCRA regulations, including LDRs, will apply to any hazardous waste soils excavated for storage, treatment, or disposal. Upon excavation, any soils that are hazardous wastes by definition (i.e., either characteristic waste due to lead contamination) must be stored pursuant to RCRA storage regulations and treated and disposed of pursuant to RCRA LDR regulations. Under the Phase II Universal Treatment Standards, hazardous 
constituents other than those that cause wastes to exhibit a characteristic are "underlying hazardous constituents." These underlying hazardous constituents may also have to be treated to specified maximum concentrations prior to land disposal. Underlying hazardous constituents are defined as any constituent listed in 40 Code of Federal Regulations (CFR) 268.48, except zinc, that can reasonably be expected to be present at the point of generation of the hazardous waste at a concentration above the constituent-specific Universal Treatment Standard [40 CFR 268.2(i)]. Therefore, if any constituent listed in 40 CFR 268.48 is expected to be present in the waste soil in excess of the listed treatment standard concentration, it must also be treated before land disposal can take place.

In light of the uncertainty surrounding the treatment of hazardous waste soils, the EPA has presumed that a treatability variance will be used to comply with LDRs for the disposal of contaminated soil. EPA has published several guides for soils subject to treatability variances, including alternative treatment standards (EPA 1990b). The contaminated soil will need to be treated to meet either the concentration range or the percent reduction range for each hazardous constituent listed. A threshold concentration is used to determine which alternative standard to apply. The concentration range would be applied if the waste sample constituent concentration exceeded the threshold, and the percent reduction range would be applied if the threshold were not exceeded.

If an alternative cannot meet the identified ARARs, it may be assessed to determine whether the alternative meets the grounds for invoking a CERCLA waiver provision. The waiver provisions allow an alternative to not attain all ARARs where the alternative is an interim measure that will become part of a total remedial action that will attain ARARs [40 CFR $3000.430(f)(1)(\mathrm{ii})(\mathrm{C})]$.

TSCA regulations set forth standards for PCB-contaminated soils once they are excavated and there is a need to manage, store, treat, and dispose of them. TSCA also addresses cleanup standards and guidelines for contaminated soil left in place. Under TSCA regulations, materials contaminated with PCBs in concentrations exceeding $50 \mathrm{ppm}(\mathrm{mg} / \mathrm{kg})$ must be stored in specially designed facilities, and disposal must be either by incineration or in a chemical waste landfill at an EPA-approved facility. Under EPA's PCB spill cleanup policy (40 CFR Part 761 [Subpart G]) for spills of materials contaminated with greater than $50 \mathrm{ppm}$ PCBs in restricted-access areas, soil within the spill area must be excavated and backfilled with soil containing PCBs in concentrations less than $25 \mathrm{ppm}$.

The PCB spill cleanup policy (40 CFR 761.120) applies only to spills taking place after the effective date of the regulation and is not a mandatory standard; therefore, the policy is not an ARAR but a TBC. However, according to EPA guidance, the policy sets forth the standards and guidelines that are used by EPA to determine PRGs for CERCLA sites (EPA 1990a). No state standards or guidelines exist for PCB-contaminated soils. 
PCBs have been found to contaminate soils at the TBP area in concentrations exceeding $50 \mathrm{ppm}$; therefore, TSCA regulations for the management, storage, treatment, and disposal of PCBs will govern interim actions concerning such PCB-contaminated soil, and the PCB spill cleanup policy will be an important TBC in determining the cleanup standard.

\subsection{INTERIM PRELIMINARY REMEDIATION GOALS}

The development of risk-based PRGs early in the RI/FS process can aid in identifying appropriate remedial action alternatives at a site. The site-specific information required to develop risk-based PRGs usually consists of (1) the COCs, (2) the concentrations of the COCs by medium, (3) the human and ecological receptors, and (4) the probable future land use. For the TBP area, human health-based interim PRGs for soil were developed by using the EPA Region III derived risk-based soil concentrations (Table 3.2). EPA Region III derives the risk-based values following

TABLE 3.2 Human Health-Based Interim

Preliminary Remediation Goals (PRGs)

for Surface Soil at the TBP Area

\begin{tabular}{l} 
Contaminant \\
\hline $\begin{array}{c}\text { Interim PRG } \\
(\mathrm{mg} / \mathrm{kg})\end{array}$ \\
$\begin{array}{l}\text { Semivolatile organic compound } \\
\text { 2-Methylnaphthalene }\end{array}$ \\
Explosive \\
Nitroglycerin \\
Inorganic materials \\
Arsenic \\
Beryllium \\
Lead \\
\hline $\begin{array}{l}\mathrm{NA} \\
\text { a }\end{array}$ \\
NA = Not available: \\
b Human health-based interim PRG for arsenic is \\
based on the EPA Region III risk-based concen- \\
tration for arsenic as a carcinogen. The noncar- \\
cinogenic concentration for arsenic is $610 \mathrm{mg} / \mathrm{kg}$. \\
c EPA (1994) currently recommends a soil lead \\
cleanup value of 400 mg/kg for residential land \\
use but site-specific pharmacokinetic modeling \\
for nonresidential adult screening, when \\
necessary.
\end{tabular}


the Superfund risk assessment guidelines (EPA 1989a) and standard default assumptions (EPA 1991a); the values are based on carcinogenic and noncarcinogenic effects of ingestion of "industrial" soil (as opposed to residential soil). The interim PRGs for the TBP area are initial guidelines and are not intended to set final cleanup levels or establish that cleanup to meet these goals is warranted (EPA 1991b, 1994).

EPA has not developed risk-based soil concentrations for ecological resources similar to the human health-based PRGs. Two approaches were employed to develop ecological risk-based interim PRGs for the TBP area: (1) use of the contaminant uptake models developed for the ERA to back-calculate acceptable surface soil concentrations and (2) use of the human health-based interim PRGs for COCs for which uptake modeling was not performed. In this latter approach, risk reduction for ecological resources is considered to be directly correlated with the reduction of contaminant concentrations or with removal of contaminated media. Thus, reducing surface soil contaminant concentrations to the levels of the human health risk-based interim soil PRGs would also reduce risk for ecological resources. In both approaches, each derived interim soil PRG was screened against the regional background soil concentration of that contaminant, and the greater of the two values was selected as the interim PRG.

In the ERA for J-Field (Hlohowskyj et al. 1996), uptake modeling was used to estimate a daily uptake or dose (the applied daily dose [ADD]) for each COEC. Potential risk to an ecological receptor was estimated by comparing the modeled $\mathrm{ADD}$ value with a benchmark value representing a safe daily uptake. The ratio of the ADD to the benchmark value is termed the environmental effects quotient (EEQ) and is analogous to the hazard quotient used for estimating human health risks. For a particular contaminant, a potential risk is indicated for all values of the EEQ exceeding 1.00. Details regarding the uptake models and estimation of the EEQ are presented in Appendix E. It was possible to develop EEQ risk estimates only for those contaminants for which suitable benchmark values were available.

For the TBP area, the J-Field ERA modeled contaminant uptake and developed EEQ risk estimates for terrestrial vegetation and 11 vertebrate receptor species. Risk estimates exceeding values of 1.00 were identified for aluminum, antimony, arsenic, barium, cadmium, chromium, cobalt, copper, cyanide, lead, mercury, selenium, silver, zinc, and trichloroethene for terrestrial vegetation and six of the modeled terrestrial receptors (Table 3.3). To derive the ecological riskbased interim PRG values, the uptake models were used to identify contaminant surface soil concentrations that would limit the EEQ risk values for each receptor species to less than 1.00 , and the lowest estimated soil concentration among all the receptors was selected as the interim PRG value. The species-specific interim surface soil PRGs derived for the TBP area are shown in Table 3.4. 
TABLE 3.3 Ecological Effects Quotient Risk Estimates of Soil Contaminant Concentrations for Selected Ecological Receptors at the TBP Area ${ }^{\mathrm{a}, \mathrm{b}}$

\begin{tabular}{|c|c|c|c|c|c|c|c|}
\hline \multirow[b]{2}{*}{ Contaminant } & \multicolumn{7}{|c|}{ Ecological Effects Quotient } \\
\hline & Vegetation & $\begin{array}{c}\text { White-Footed } \\
\text { Mouse }\end{array}$ & $\begin{array}{c}\text { Eastern } \\
\text { Cottontail } \\
\end{array}$ & $\begin{array}{c}\text { White-Tailed } \\
\text { Deer }\end{array}$ & $\begin{array}{c}\text { American } \\
\text { Robin }\end{array}$ & $\begin{array}{c}\text { American } \\
\text { Kestrel }\end{array}$ & $\begin{array}{c}\text { Red-Tailed } \\
\text { Hawk }\end{array}$ \\
\hline Aluminum & $N^{c}$ & 97.1 & 263 & 12.7 & 2.02 & 0.01 & 0.13 \\
\hline Antimony & 100 & 50.7 & 138 & 5.98 & $\mathrm{NA}$ & NA & NA \\
\hline Arsenic & 144 & 113 & 352 & 16.6 & 2.59 & 0.06 & 0.67 \\
\hline Barium & 1.60 & 4.50 & 24.2 & 1.01 & 9.90 & 0.03 & 0.23 \\
\hline Cadmium & 3.60 & 24.8 & 110 & 3.88 & 5.94 & 0.02 & 0.13 \\
\hline Chromium & 251 & 1.21 & 3.61 & 0.15 & 7.30 & 0.03 & 0.35 \\
\hline Cobalt & 4.30 & $\mathrm{NA}$ & NA & NA & NA & NA & NA \\
\hline Copper & 43.2 & 3.79 & 19.1 & 0.80 & 9.40 & 0.03 & 0.22 \\
\hline Cyanide & NA & 46.3 & 125 & 5.24 & $\mathrm{NA}$ & NA & NA \\
\hline Lead & 942 & 103 & 507 & 21.3 & 1,527 & 5.20 & 40.4 \\
\hline Mercury & $\mathrm{NA}$ & 16.2 & 117 & 5.53 & 68.2 & 0.20 & 1.19 \\
\hline Selenium & 7.10 & 51.0 & 139 & 5.99 & 12.1 & 0.06 & 0.33 \\
\hline Silver & 21.0 & $\mathrm{NA}^{-}$ & NA & NA & NA & NA & NA \\
\hline Trichloroethene & $\mathrm{NA}$ & 1.37 & 3.46 & 1.02 & NA & $\mathrm{NA}$ & $\mathrm{NA}$ \\
\hline Zinc & 1,780 & 3.94 & 22.8 & 0.96 & 981 & 3.29 & 20.1 \\
\hline
\end{tabular}

a EEQ values exceeding 1.00 indicate potential risk to an ecological receptor. Values between 1.0 and 10 indicate low potential risk, values between 10 and 50 indicate moderate potential risk, values between 50 and 100 indicate high potential risk, and values exceeding 100 are indicative of extreme potential risk to ecological receptors.

b EEQ values are shown only for those contaminants of ecological concern for which the EEQ values exceeded 1.00 for at least one receptor.

c $\mathrm{NA}=\mathrm{A}$ suitable benchmark value for this contaminant is not available for this receptor, and it is not possible to calculate an EEQ value at this time. 
TABLE 3.4 Estimated Surface Soil Contaminant Concentrations Necessary to Achieve a No-Effects Level (100\% Risk Reduction) for Selected Ecological Receptors that Use the TBP Area ${ }^{a}$

\begin{tabular}{|c|c|c|c|c|c|c|c|}
\hline \multirow[b]{2}{*}{ Contaminant } & \multicolumn{7}{|c|}{ Surface Soil Contaminant Concentration ( $\mathrm{mg} / \mathrm{kg}$ ) } \\
\hline & Vegetation & $\begin{array}{c}\text { White-Footed } \\
\text { Mouse }\end{array}$ & $\begin{array}{c}\text { Eastern } \\
\text { Cottontail }\end{array}$ & $\begin{array}{c}\text { White-Tailed } \\
\text { Deer }\end{array}$ & $\begin{array}{l}\text { American } \\
\text { Robin }\end{array}$ & $\begin{array}{c}\text { American } \\
\text { Kestrel }\end{array}$ & $\begin{array}{c}\text { Red-Tailed } \\
\text { Hawk }\end{array}$ \\
\hline Aluminum & $N R^{b}$ & $N P^{c}$ & NP & NP & 11,084 & NR & NR \\
\hline Antimony & 5.00 & 9.55 & 3.36 & 80.1 & $N^{d}$ & NA & NA \\
\hline Arsenic & 10.0 & 12.3 & 9.7 & 82.3 & 556 & NR & NR \\
\hline Barium & 1,000 & 349.4 & 64.4 & 1,557 & 159 & NR & NR \\
\hline Cadmium & 10.0 & 1.4 & 0.316 & 9.1 & 6.0 & NR & NR \\
\hline Chromium & 3.50 & 727 & 242 & NR & 120 & NR & NR \\
\hline Cobalt & 25.0 & NA & $\mathrm{NA}$ & $\mathrm{NA}$ & $\mathrm{NA}$ & $\mathrm{NA}$ & $\mathrm{NA}$ \\
\hline Copper & 100 & 1,137 & 224 & NR & 459 & NR & NR \\
\hline Cyanide & $\mathrm{NA}$ & 2.59 & 0.96 & 22.9 & $\mathrm{NA}$ & NA & $\mathrm{NA}$ \\
\hline Lead & 100 & 900 & 181 & 4,358 & 58.7 & 18,083 & 2,323 \\
\hline Mercury & $\mathrm{NA}$ & 0.221 & 0.029 & 0.637 & 0.052 & NR & 3.0 \\
\hline Selenium & 1.00 & NR & NR & 1.18 & NR & NR & NR \\
\hline Silver & 2.00 & NA & NA & $\mathrm{NA}$ & NA & NA & NA \\
\hline Trichloroethene & NA & 1.3 & $\mathrm{NP}$ & 1.9 & NA & NA & NA \\
\hline Zinc & 10.0 & 4,516 & 776 & NR & 16.7 & 5,393 & 878 \\
\hline
\end{tabular}

a For each contaminant and receptor, the soil concentration identified will give a modeled applied daily dose to the ecological receptor that limits the ecological effects quotient (EEQ) to less than 1.00 , resulting in a potential $100 \%$ reduction in risk.

b NR = Current levels of soil contamination pose no risk to the receptor as determined by the modeled uptake and a resultant EEQ value less than 1.00 .

c $\mathrm{NP}=$ Because of contaminant uptake from exposure routes from media other than soil, a $100 \%$ risk reduction is not possible from remediation of soil alone.

d NA = Suitable benchmarks for this contaminant are not available for this receptor, and it is not possible to calculate an EEQ value or an interim PRG at this time. 
The ecological risk-based PRGs should be used with care. Because of the assumptions and uncertainties associated with the uptake models used to predict $A D D$ values, the PRG values for some receptors may be greatly overprotective. The uptake models use a COEC exposure point concentration that is either the maximum concentration reported from the TBP area or the $95 \%$ upper confidence limit (UCL) of all the reported concentrations. For most of the contaminants, the maximum reported concentration was used as the exposure point concentration for the uptake modeling. The use of either value as the exposure point concentration is consistent with EPA Region III guidance (Davis 1994) and results in a very conservative modeled daily contaminant uptake. For the uptake modeling, the exposure point concentration is assumed to be homogeneously distributed across the entire site, and the resultant EEQ risk estimate represents the potential risk to ecological receptors from a uniform, sitewide contaminant concentration. In reality, the actual occurrence and distribution of the exposure point concentration (maximum or 95\% UCL) is restricted to specific locations within the TBP area, such as the pits and trenches, and concentrations at most locations within the TBP area are much lower than the exposure point concentrations. Thus, the EEQ risk estimates are likely greatly overestimated, and the ecological risk-based PRGs are likely greatly overprotective for most if not all the contaminants and receptors.

Modeling contaminant uptake also requires exposure factor information on species-specific ecological and physiological parameters, such as body weight, ingestion rate, and diet. In contrast to the exposure factor data available for human health risk assessments, species-specific exposure factors for ecological receptors are largely unavailable. The exposure factors used to estimate contaminant uptake, and the benchmark values used to calculate the EEQs, were either (1) speciesspecific but not population specific, (2) not species-specific but from related taxa, or (3) developed with empirically derived allometric equations. Each of these sources adds to the uncertainty of the $\mathrm{ADD}$ and $\mathrm{EEQ}$ risk estimates and the interim PRGs.

Additional uncertainty with the uptake modeling that may affect the PRG values is related to the assumptions regarding contaminant transfer between trophic levels and contaminant assimilation. The $\mathrm{ADD}, \mathrm{EEQ}$, and $\mathrm{PRG}$ values were all derived assuming $100 \%$ contaminant transfer and assimilation; however, for most biota, it is unlikely that contaminant transfer or assimilation is $100 \%$ efficient. So, this assumption likely overestimates the true degree of contaminant uptake by the modeled receptors and, thus, the $\mathrm{ADD}$ and $\mathrm{EEQ}$; therefore, the PRG values are probably overprotective.

The final uncertainty associated with the contaminant models that may result in overly protective PRGs is the nature of the benchmark values used for estimating the EEQ risk values. The benchmark values used were reported in the literature to produce no observable adverse effects in the exposed species. However, benchmark values specific to the species of concern at the TBP area were not available for all the COECs, and benchmark values were extrapolated between species as necessary. In some cases, uncertainty factors (Davis 1994) were used to minimize uncertainty 
associated with benchmark extrapolations between species of the same class and between species of different classes (Appendix E).

For each COEC, the lowest PRG among those developed for all the receptors was chosen as the interim ecological risk-based PRG (Table 3.5). For some COECs, the interim PRG soil concentrations are less than the reported regional background concentrations, and attaining the PRGs for some COECs would require remediation.to below background levels. For those COECs with interim PRGs below background levels, the background concentrations were selected as the ecological risk-based interim soil PRGs. However, remediation to background levels would produce risk reductions in excess of $97 \%$ for all the COECs except aluminum (Table 3.5). Regional background aluminum concentrations are indicated to pose a high risk to ecological resources. However, remediation to background levels of this COEC would result in a 64\% reduction in the current risk level identified for the TBP area.

For those contaminants with insufficient available data to model an ADD, calculate an EEQ risk estimate, and derive an ecological risk-based interim soil PRG, the human health-based interim soil PRGs were used as the default ecological risk-based interim PRGs.

Table 3.6 integrates the ecological and human health risk-based PRGs and presents an overall list of preliminary interim soil PRGs for the TBP area. The identified interim soil PRG for each COC is the lower of the human health and ecological risk-based interim PRGs presented in Tables 3.2 and 3.5, respectively. These interim soil PRGs are initial guidelines and are not intended to set final cleanup levels or establish that cleanup to meet these goals is warranted (EPA 1991b, 1994). Rather, they provide a basis for the initial evaluation of remedial alternatives and for the development of remedial boundaries at the TBP area. 
TABLE 3.5 Ecological Risk-Based Interim Preliminary Remediation Goals (PRGs) for Soils at the TBP Area

\begin{tabular}{|c|c|c|c|c|c|}
\hline Contaminant & $\begin{array}{l}\text { Ecological Risk-Based } \\
\text { Interim PRG (mg/kg) for } \\
100 \% \text { Risk Reduction }{ }^{\mathrm{a}}\end{array}$ & $\begin{array}{c}\text { Current } \\
\text { EEQ } \\
\text { Risk Level }^{\mathrm{b}}\end{array}$ & $\begin{array}{c}\text { Mean Background } \\
\text { Soil Concentration } \\
(\mathrm{mg} / \mathrm{kg})\end{array}$ & $\begin{array}{l}\text { Background } \\
\text { EEQ } \\
\text { Risk Level }\end{array}$ & $\begin{array}{c}\text { Current Risk Reduction } \\
\text { by Using Background- } \\
\text { Based PRG (\%) }\end{array}$ \\
\hline Aluminum & $N P^{c}$ & 263 & 7,940 & 99.4 & 64.1 \\
\hline Antimony & 3.7 & 137 & $3.14^{d}$ & 0.08 & $>100^{c}$ \\
\hline Arsenic & 9.7 & 352 & 2.57 & 0.71 & $>100$ \\
\hline Barium & 64.4 & 24.2 & 43.6 & 0.68 & $>100$ \\
\hline Cadmium & 0.32 & 110 & 0.34 & 1.07 & 99.0 \\
\hline Chromium & 3.5 & 251 & 16.7 & 4.79 & 98.1 \\
\hline Cobalt & 25.0 & 4.3 & 7.25 & 0.29 & $>100$ \\
\hline Copper & 100 & 43.2 & 8.72 & 0.09 & $>100$ \\
\hline Cyanide & 1.0 & 125 & $N A^{f}$ & 0.67 & $>100$ \\
\hline Lead & 58.7 & 1,527 & 21.6 & 0.40 & $>100$ \\
\hline Mercury & 0.03 & 117 & 0.04 & 1.67 & 98.6 \\
\hline Selenium & 0.05 & 139 & 0.20 & 4.12 & 97.0 \\
\hline Silver & 2.0 & 21 & $0.31^{d}$ & 0.16 & $>100$ \\
\hline Trichloroethene & 1.3 & 3.46 & NA & NA & NA \\
\hline Zinc & 10.0 & 1,780 & 37.0 & 3.70 & 99.8 \\
\hline
\end{tabular}

a Predicted contaminant soil concentration necessary to limit the ecological effects quotient (EEQ) to less than 1.00 , resulting in a potential $100 \%$ risk reduction.

b Predicted EEQ risk values estimated by using current contaminant levels detected in soils at the TBP area.

c Greatest risk was identified for the eastern cottontail (Table 3.3). Because of the contaminant uptake via ingestion of drinking.water, a $100 \%$ risk reduction is not possible for this species from soil remediation alone. Remediation to background levels will result in a $64 \%$ risk reduction for this species. Similarly, $100 \%$ risk reduction from soil remediation is not possible for the white-tailed deer or the white-footed mouse. Remediation to background aluminum concentrations would result in a $100 \%$ risk reduction for the American robin but risk reductions of only $56 \%$ and $64 \%$ for the white-tailed deer and white-footed mouse, respectively.

d Reported background concentrations were all below detection limits; mean background concentrations were estimated by using one-half the reported method detection limits (ICF Kaiser Engineers 1995a).

c Risk reduction is greater than $100 \%$ when the background EEQ value is less than 1.00 , while risk reduction equals $100 \%$ when the EEQ equals 1.00 .

f. $\mathrm{NA}=\mathrm{Benchmark}$ value is not available, so estimation of $\mathrm{EEQ}$ is not possible at this time. 
TABLE 3.6 Risk-Based Interim Preliminary Remediation Goals (PRGs) for Surface Soil at the TBP Area

\begin{tabular}{|c|c|}
\hline Contaminant & Interim PRG (mg/kg) \\
\hline \multicolumn{2}{|c|}{ Volatile and semivolatile organic compounds } \\
\hline Trichloroethene & $1.3^{\mathrm{a}}$ \\
\hline 2-Methylnaphthalene & $N A^{b}$ \\
\hline \multicolumn{2}{|l|}{ Explosive } \\
\hline Nitroglycerin & NA \\
\hline \multicolumn{2}{|l|}{ Inorganic materials } \\
\hline Aluminum & $7,940^{\mathrm{c}}$ \\
\hline Antimony & $3.7^{\mathrm{a}}$ \\
\hline Arsenic & $3.8^{\mathrm{d}}$ \\
\hline Barium & $64.4^{2}$ \\
\hline Beryllium & $1.3^{\mathrm{d}}$ \\
\hline Cadmium & $0.34^{c}$ \\
\hline Chromium & $16.7^{c}$ \\
\hline Cobalt & $25.0^{\mathrm{a}}$ \\
\hline Copper & $100^{a}$ \\
\hline Cyanide & $1.0^{\mathrm{a}}$ \\
\hline Lead & $58.7 / 400^{e}$ \\
\hline Mercury & $0.04^{c}$ \\
\hline Selenium & $0.20^{c}$ \\
\hline Silver & $2.0^{\mathrm{a}}$ \\
\hline Zinc & $37.0^{c}$ \\
\hline
\end{tabular}

a Interim PRG is ecological risk-based (see Table 3.5).

b $N A=$ No interim PRG developed. Insufficient data to develop ecological risk-based interim PRG, and no EPA Region III human health-based PRG has been developed (see Table 3.2).

c Ecological risk-based PRG value is below mean background concentration; interim PRG is mean background concentration.

d Interim PRG is human health-based (see Table 3.2).

e The ecological risk-based PRG is $58.7 \mathrm{mg} / \mathrm{kg}$ (see Table 3.5). EPA currently recommends a soil cleanup value of $400 \mathrm{mg} / \mathrm{kg}$ for residential land use (see Table 3.2). The cleanup goal for lead has been as high as $1,000 \mathrm{mg} / \mathrm{kg}$ at other APG sites (Wrobel 1995). 


\section{IDENTIFICATION AND SCREENING OF TECHNOLOGIES}

Alternative interim remedial actions for the TBP area at J-Field were developed by identifying remedial technology types and process options that are potentially applicable to addressing contaminated soil. The technologies considered in selecting interim remedial action alternatives for contaminated soil in the TBP area include those identified in the NCP (EPA 1990a). These technology types and process options were screened for applicability to the site in accordance with EPA guidance (EPA 1988).

\subsection{CRITERIA FOR IDENTIFYING AND SCREENING TECHNOLOGIES}

The criteria for identifying potentially applicable technology types and process options are provided in EPA guidance (EPA 1988) and the NCP (EPA 1990a). Technologies identified in this section were screened on the basis of site-specific conditions and the current understanding of the TBP area at J-Field. Section 121 of the Superfund Amendments and Reauthorization Act of 1986 (SARA) identifies a strong statutory preference for remedial actions that are highly reliable and provide long-term protection. The primary requirements for a selected remedy are that it protects human health and the environment and meets the objectives of the proposed action in a cost-effective manner. Additional selection criteria include the following:

- In preferred remedies, the principal element is treatment to permanently or significantly reduce the toxicity, mobility, or volume of hazardous substances, pollutants, or contaminants.

- Where practical treatment technologies are available, off-site transport and disposal without treatment is the least preferred alternative.

- Permanent solutions and alternative treatment technologies or resource recovery technologies should be addressed and used to the maximum extent practicable.

These criteria have been considered in identifying and screening technologies to determine the appropriate components of remedial action alternatives for the TBP area.

The remedial action objectives for the TBP area are described in Section 3. The current understanding of contaminants and conditions at the site suggests the general response actions that could be implemented to achieve these objectives are institutional controls, in-situ containment, removal, treatment, short-term storage, and disposal. Specific application of these technologies to site conditions was evaluated to determine which would be most appropriate for interim remedial 
action at the TBP area. These technologies were screened on the basis of effectiveness, implementability, and cost, as defined by the following factors:

- Effectiveness - in terms of protecting human health and the environment in both the short term and the long term;

- Implementability - in terms of technical and administrative feasibility and resource availability; and

- Cost - in a comparative manner (i.e., low, moderate, or high) for technologies of similar performance and/or implementability.

These screening criteria were applied only to the technologies and general response actions being evaluated; combinations of technologies to address site-specific contamination problems were evaluated after the technologies were assembled into alternatives. This evaluation is presented in Section 5 .

The no-action response was also included in this evaluation to provide a baseline for comparison; it is evaluated as an alternative in Sections 5 and 7 . The technology types and process options identified for the other response actions were screened for applicability to address contaminated soils at the TBP area. Potentially applicable technologies are discussed in Section 4.3, and the results of the screening process are presented in Table 4.9.

\subsection{TECHNOLOGY IDENTIFICATION AND SCREENING}

\subsubsection{Institutional Controls}

Institutional controls are measures that preclude or minimize public exposure by limiting access to or use of contaminated areas. Institutional controls include measures to restrict access, such as security guards or fencing, ownership and use or deed restrictions, and monitoring. Institutional controls do not reduce contaminant toxicity, mobility, or volume, but they can reduce the potential for exposure to contaminated material.

Access to the Edgewood down range area (including J-Field) is controlled by security guards and is limited to authorized personnel. Vehicular access to J-Field is controlled by a locked gate. These measures mitigate potential public exposure to contamination. However, these measures are not as effective at mitigating exposure of wildlife to contamination on-site. Fencing around the TBP area would not control exposures to wildlife, especially small and burrowing mammals and birds. 
The U.S. Army has custody of the site and is expected to maintain this custody and accountability into the future. This measure controls public exposures to on-site contamination by restricting access and use.

An extensive environmental monitoring program is currently in place as part of the RI. Additional monitoring will be employed during future response actions. This measure can support the mitigation of potential exposures to humans and wildlife by providing data on the nature and extent of contamination and the effectiveness of primary control measures such as containment or removal. Future monitoring activities for the TBP area and other J-Field AOCs will be discussed in the FS report.

The screening analysis for institutional controls is summarized in Table 4.1. On the basis of effectiveness, implementability, and cost, all institutional controls currently in place have been retained. Fencing of the TBP area is not recommended. The most significant control at the site is land ownership. As long as the U.S. Army maintains custody of the APG site, the potential for significant public exposure will remain low because land use can be controlled and access to

\section{TABLE 4.1 Summary of Screening Analysis for Institutional Controls}

\begin{tabular}{|c|c|c|c|}
\hline $\begin{array}{c}\text { Institutional } \\
\text { Control Measure }\end{array}$ & Effectiveness & Implementability & Cost \\
\hline Access restriction & $\begin{array}{l}\text { Entry to the Edgewood down range area } \\
\text { (which includes J-Field) is controlled by } \\
\text { security guards. Vehicular access to the site is } \\
\text { controlled by a locked fence. These measures } \\
\text { are effective at mitigating potential public } \\
\text { exposure to on-site contamination; however, } \\
\text { they are less effective at mitigating potential } \\
\text { exposures to wildlife. Fencing around the TBP } \\
\text { area would not control exposures to wildlife } \\
\text { and is not recommended. }\end{array}$ & $\begin{array}{l}\text { Fences, guards, and other } \\
\text { such measures are easy to } \\
\text { implement, and resources } \\
\text { are readily available. }\end{array}$ & Low \\
\hline $\begin{array}{l}\text { Ownership and } \\
\text { use or deed } \\
\text { restrictions }\end{array}$ & $\begin{array}{l}\text { The U.S. Army has custody of APG and is } \\
\text { expected to maintain this custody and } \\
\text { accountability into the future. }\end{array}$ & $\begin{array}{l}\text { Ownership and use or deed } \\
\text { restrictions are easy to } \\
\text { implement, and resources } \\
\text { are readily available. }\end{array}$ & Low \\
\hline Monitoring & $\begin{array}{l}\text { An extensive monitoring program is currently } \\
\text { in place as part of the RI. Additional } \\
\text { monitoring will be employed during future } \\
\text { response actions and will support mitigation } \\
\text { of potential exposures to humans and wildlife. }\end{array}$ & $\begin{array}{l}\text { Monitoring is easy to } \\
\text { implement, and resources } \\
\text { are readily available. }\end{array}$ & Moderate \\
\hline
\end{tabular}


contaminated areas can be restricted. Additional control measures would be needed to reduce the potential for significant exposure of wildlife.

\subsubsection{In-Situ Containment}

In-situ containment involves technologies that confine contamination to its current locations in the soil. These technologies reduce contaminant mobility and the associated potential for exposure, but they do not reduce contaminant toxicity or volume. In-situ containment technologies that address contamination in surface soils include surface controls/diversions, vertical barriers, and caps/covers.

Surface controls/diversions are used to divert surface runoff around contaminated areas to minimize the potential for contaminant resuspension. Graded contours, swales, and berms can effectively control surface water runon and runoff and can limit the mobility of contaminants. These measures alone, however, may not be effective for surface water bodies (e.g., marsh) that are hydrologically connected to the surficial aquifer system or other surface water bodies. Therefore, vertical barriers may also be needed. In addition, erosion of contaminated soil from the portion of the pushout area in contact with the marsh could be mitigated by installing a vertical barrier.

A contaminated area can be encapsulated by placing barriers on top (caps/covers). Capping (e.g., a RCRA-engineered cap) of soil could effectively reduce airborne emissions (e.g., VOCs), precipitation-enhanced percolation and leaching, and contaminant resuspension via surface water runoff. This method would limit exposures of humans and wildlife to contamination in the surface soils. A stabilized surface would be required prior to cap placement and would most likely necessitate some grading and excavation. Therefore, a UXO survey would also be required over the area to be capped. In-situ capping of the main pits and pushout areas could prove difficult to implement, and the effectiveness of the cap would be constrained by the shallow water table and its proximity to the marsh. In addition, because the J-Field site is a designated floodplain, measures would be required to minimize the potential for damage from flood water. These measures would include shoreline stabilization and building the cap to elevations above flood level.

An alternative to an engineered cap is a protective soil cover, referred to here as a "riskreduction cover." The risk-reduction cover also would be effective at minimizing contaminant mobility and limiting exposures at the surface. Under this option, a geotextile membrane would be laid over the contaminated area and covered with soil. This approach could be implemented with little or no UXO screening.

The screening analysis for in-situ containment is summarized in Table 4.2. On the basis of effectiveness, implementability, and cost, the in-situ containment technologies (surface controls/ diversions, vertical barriers, and caps/covers) have been retained. 
TABLE 4.2 Summary of Screening Analysis for In-Situ Containment

\begin{tabular}{|c|c|c|c|}
\hline $\begin{array}{l}\text { In-Situ } \\
\text { Containment } \\
\text { Measure } \\
\end{array}$ & Effectiveness & Implementability & Cost \\
\hline $\begin{array}{l}\text { Surface controls/ } \\
\text { diversions }\end{array}$ & $\begin{array}{l}\text { Could effectively reduce contaminant } \\
\text { mobility at the site. Such measures alone, } \\
\text { however, might not be effective for the } \\
\text { marsh because of its hydrological } \\
\text { connection to the surficial aquifer. }\end{array}$ & $\begin{array}{l}\text { Could be implemented with } \\
\text { conventional equipment and } \\
\text { procedures, and resources are } \\
\text { readily available. }\end{array}$ & Low \\
\hline Vertical barriers & $\begin{array}{l}\text { Could effectively reduce contaminant } \\
\text { mobility at the site, especially in ground- } \\
\text { water and in places where the pushout area } \\
\text { is in contact with the marsh. }\end{array}$ & $\begin{array}{l}\text { Could be implemented with } \\
\text { conventional equipment and } \\
\text { procedures, and resources are } \\
\text { readily available. }\end{array}$ & $\begin{array}{l}\text { Low to } \\
\text { moderate }\end{array}$ \\
\hline Caps/covers & $\begin{array}{l}\text { Could effectively limit airborne emissions } \\
\text { (e.g., VOCs), precipitation-enhanced } \\
\text { percolation and leaching, and contaminant } \\
\text { resuspension via surface water runoff. } \\
\text { Because J-Field is designated as a flood- } \\
\text { plain, measures would be required to } \\
\text { minimize damage from flood waters. }\end{array}$ & $\begin{array}{l}\text { Could be implemented with } \\
\text { conventional equipment and } \\
\text { procedures, and resources are } \\
\text { readily available. UXO survey } \\
\text { might be required. }\end{array}$ & $\begin{array}{l}\text { Low to } \\
\text { moderate }\end{array}$ \\
\hline
\end{tabular}

\subsubsection{Removal}

Removal of contaminated material can limit contaminant mobility and volume at the affected source area and can facilitate treatment and disposal that could reduce contaminant toxicity, mobility, and volume.

Excavation with conventional earth-moving equipment (e.g., bulldozers, backhoes, and front-end loaders) could effectively remove soil in the main pits and pushout area at the TBP area. The area of excavation would have to undergo a UXO survey, and the soil would have to be monitored for CWAs during excavation.

Soil also could be removed by hand if the density of metal contacts is high or if only limited excavation is required. Human Factors Applications, Inc. (HFA) surveys have shown that conventional earth-moving equipment could be used in areas with metal contact densities of 1 to 28 contacts per $100-\mathrm{ft}^{2}$ area.

Contaminated vegetation can also be removed by standard clearing and grubbing methods to reduce exposures and limit biotic transport. 
The screening analysis for removal is summarized in Table 4:3. On the basis of this evaluation, these technologies have been retained as potentially applicable to address surface soil contamination in the TBP area.

\subsubsection{Treatment}

\subsubsection{In-Situ Physical/Chemical Treatment Technologies}

Several in-situ physical/chemical treatment technologies are available for treating soil contaminated with metals, SVOCs, and PCBs (VOCs are present only at depth and will not be addressed by the proposed interim remedial action). These technologies include soil flushing, stabilization/solidification, vitrification, and electrokinetic processing. The main advantage of in-situ treatment is that it allows soil to be treated without being excavated and transported, resulting in potentially significant cost savings. However, in-situ treatment generally requires longer time periods to be effective, and there is less certainty about the uniformity of treatment because of the variability in soil characteristics and because the efficacy of the process is more difficult to confirm (EPA 1994). For the TBP area, UXO screening and removal would have to precede in-situ treatment.

The screening analysis of potential in-situ treatment technologies is discussed in the following subsections and is summarized in Table 4.4 .

Soil Flushing. Soil flushing is the extraction of contaminants from the soil with water or other suitable aqueous solutions. This method is applicable to coarse-grained soils contaminated with

\section{TABLE 4.3 Summary of Screening Analysis for Removal}

\begin{tabular}{|c|c|c|c|}
\hline $\begin{array}{l}\text { Removal } \\
\text { Measure }\end{array}$ & Effectiveness & Implementability & Cost \\
\hline Excavation & $\begin{array}{l}\text { Could remove the source of } \\
\text { contamination to limit contaminant } \\
\text { mobility and volume and to reduce } \\
\text { related exposures. It could also facilitate } \\
\text { treatment and disposal. }\end{array}$ & $\begin{array}{l}\text { Could be implemented with } \\
\text { conventional equipment and } \\
\text { procedures, and resources are } \\
\text { readily available. UXO surveys and } \\
\text { CWA screening would be required. }\end{array}$ & $\begin{array}{l}\text { Moderate to } \\
\text { high }\end{array}$ \\
\hline $\begin{array}{l}\text { Clearing and } \\
\text { grubbing }\end{array}$ & $\begin{array}{l}\text { Could effectively remove vegetation } \\
\text { from source areas to reduce related } \\
\text { exposures and limit biotic transport. }\end{array}$ & $\begin{array}{l}\text { Could be implemented with } \\
\text { conventional equipment and } \\
\text { procedures, and resources are } \\
\text { readily available. }\end{array}$ & Low \\
\hline
\end{tabular}


TABLE 4.4 Summary of Screening Analysis for In-Situ Treatment Technologies

\begin{tabular}{|c|c|c|c|}
\hline $\begin{array}{l}\text { Treatment } \\
\text { Technology }\end{array}$ & Effectiveness & Implementability & Cost \\
\hline Soil flushing & $\begin{array}{l}\text { Applicable to soils contaminated with } \\
\text { SVOCs and metals; would not address } \\
\text { soils with PCB contamination. Effec- } \\
\text { tiveness is limited by variability in } \\
\text { permeability across the TBP area. The } \\
\text { potential for mobilizing contaminants } \\
\text { beyond the capture zone is also a } \\
\text { concern. }\end{array}$ & $\begin{array}{l}\text { Implementation limited by variable } \\
\text { soil conditions and low-permeability } \\
\text { soil that could impede percolation } \\
\text { and contact with reagents. Presence } \\
\text { of UXO may also be a constraint. }\end{array}$ & $\begin{array}{l}\text { Moderate } \\
\text { to high }\end{array}$ \\
\hline $\begin{array}{l}\text { Stabilization/ } \\
\text { solidification }\end{array}$ & $\begin{array}{l}\text { Effective at limiting mobility of metals } \\
\text { only; therefore, only applicable to soils } \\
\text { in the pushout area. Contaminant } \\
\text { mobility would be reduced, but } \\
\text { contaminant toxicity would not. } \\
\text { Volume of contaminated material } \\
\text { would increase. Long-term effec- } \\
\text { tiveness uncertain due to the } \\
\text { unpredictable effects of weathering, } \\
\text { groundwater infiltration, and physical } \\
\text { disturbance (e.g., local detonations). }\end{array}$ & $\begin{array}{l}\text { Implementation limited by scattered } \\
\text { nature of contamination. Proximity } \\
\text { to marsh and presence of UXO may } \\
\text { also be constraints. }\end{array}$ & $\begin{array}{l}\text { Moderate } \\
\text { to high }\end{array}$ \\
\hline $\begin{array}{l}\text { In-situ } \\
\text { vitrification }\end{array}$ & $\begin{array}{l}\text { Applicable to soils contaminated with } \\
\text { organics and metals. Toxicity and } \\
\text { mobility of organics and metals would } \\
\text { be reduced; volume would not. }\end{array}$ & $\begin{array}{l}\text { Somewhat difficult to implement } \\
\text { because of the innovative nature of } \\
\text { this technology. Implementation } \\
\text { limited by high organic content in } \\
\text { soil. Presence of UXO may also be a } \\
\text { constraint. }\end{array}$ & $\begin{array}{l}\text { Moderate } \\
\text { to high }\end{array}$ \\
\hline $\begin{array}{l}\text { Electrokinetic } \\
\text { processing }\end{array}$ & $\begin{array}{l}\text { Could reduce the area of contamination } \\
\text { to be addressed by mobilizing metals } \\
\text { and some organics with an electric } \\
\text { current applied across the site. Studies } \\
\text { indicate a period of } 10 \text { years may be } \\
\text { required to concentrate contaminants. } \\
\text { The potential for mobilizing contam- } \\
\text { inants beyond the capture zone is a } \\
\text { concern. Would not be effective at } \\
\text { mobilizing particulate lead from } \\
\text { pushout area soils. }\end{array}$ & $\begin{array}{l}\text { Somewhat difficult to implement } \\
\text { because of the innovative nature of } \\
\text { this technology. Presence of UXO } \\
\text { may also be a constraint. }\end{array}$ & $\begin{array}{l}\text { Moderate } \\
\text { to high }\end{array}$ \\
\hline
\end{tabular}


SVOCs and metals. PCBs would not be removed by this process. Extraction fluids are passed through soil by using an injection or infiltration process, recovered, and recycled when possible. Recovered groundwater and fluids laden with desorbed contaminants may require treatment to meet appropriate discharge standards before release to wastewater treatment facilities or receiving streams. Treatment of the recovered fluids results in process sludges and residual solids, such as spent carbon and spent ion exchange resin, which must be appropriately treated before disposal. Air emissions of VOCs from recovered fluids would be collected and treated, as appropriate, to meet applicable regulatory standards.

The effectiveness of soil flushing is limited at sites, like the TBP area, with lowpermeability soils. The permeability of soils in the TBP area varies laterally and vertically over several orders of magnitude because of the arrangement of interbedded facies, making any estimates of effectiveness difficult. In addition, the potential for immobilizing contaminants beyond the capture zone and introducing surfactants to the subsurface is of general concern. Soil flushing is considered a developing technology. For these reasons, soil flushing has been rejected from further consideration.

Stabilization/Solidification. In stabilization/solidification technologies, a fixing or stabilizing agent is mixed into the soil to create a product that is stable and resistant to leaching. In this process, additives are mixed directly into contaminated soil by conventional backhoes or equipment specifically designed for in-situ chemical injection and mixing. This technology effectively reduces the mobility of contaminants through both physical and chemical means. In-situ stabilization/solidification is considered most effective for immobilizing metals; therefore, it could only be applied in situ to fix contaminated soil at the pushout area. SVOC- and PCB-contaminated soil would have to be addressed by implementing an additional treatment technology.

The long-term effects of weathering (e.g., freeze-thaw cycles, acid precipitation, and wind erosion), groundwater infiltration, and physical disturbance (e.g., local detonations) could significantly affect the integrity of the stabilized mass, potentially reducing the long-term effectiveness of this technology. Contaminant mobility would be reduced, but contaminant toxicity would not. In addition, the volume of contaminated material would increase. For these reasons, stabilization/ solidification has been rejected from further consideration.

In-Situ Vitrification. In-situ vitrification uses an electric current to melt soil or other earthen materials at 'extremely high temperatures $\left(2,900\right.$ to $\left.3,650^{\circ} \mathrm{F}\right)$ and thereby immobilize most inorganics (metals) and destroy organics (VOCs, SVOCs, and PCBs) by pyrolysis. To initiate the process, graphite electrodes are placed on the surface of the soil so that current can flow in the soil beyond the boiling temperature of water to the melting point of soil. The molten soil zone grows downward and outward. A vacuum-pressurized hood is placed over the vitrification zone to contain 
and process any contaminants emanating from the soil during vitrification. The vitrification product is a chemically stable, leach-resistant glass and crystalline material similar to obsidian or basalt. Metals are incorporated within the vitrified product. Water vapor and organic pyrolysis combustion products are captured and drawn into an off-gas treatment system that removes particulates and other contaminants from the gas.

The in-situ application of this technology is considered innovative for waste treatment and has only been operated for test and demonstration purposes. For this reason, in-situ vitrification has been rejected from further consideration.

Electrokinetic Processing. Electrokinetic processing is an in-situ transport process that uses electric current to decontaminate soils contaminated with metals and some organics (polar species), such as phenol. The effectiveness of this technology is based on its ability to concentrate contaminants within a small area, thus reducing the area of contamination to be addressed. The application of electric current produces an acid in the anode compartment that sweeps across the soil, desorbing contaminants from the surface of soil particles and initiating electromigration of contaminants toward the respective electrodes. To initiate the process, anode and cathode series are inserted or laid on the ground, and a current is established across the electrodes. A conditioning fluid is introduced at the electrodes. A recent bench-scale study indicates that the time required to concentrate contamination in the TBP area could be as long as 10 years (Peters 1995). In addition, this process would not be effective at removing particulate lead, which makes up a significant proportion of contamination in the pushout area (U.S. Department of Energy [DOE] 1993/1994; EPA 1993b,d). For these reasons, electrokinetic processing has been rejected from further consideration.

\subsubsection{Ex-Situ Physical/Chemical Treatment Technologies}

Several ex-situ physical/chemical treatment technologies are available for treating soil contaminated with metals, SVOCs, and PCBs. These technologies include stabilization/fixation, vitrification, soil washing, soil leaching, oxidation/reduction, dehalogenation, incineration, and thermal desorption. The main advantages of ex-situ treatment are that it generally requires shorter time periods than in-situ treatment and that it affords more certainty about the uniformity of treatment because of the ability to homogenize, screen, and continuously mix the soil. However, ex-situ treatment requires excavation of soils, leading to increased costs and engineering for equipment, the necessity of UXO surveying, possible permitting, and material handling (EPA 1994).

The screening analysis of potential ex-situ treatment technologies is discussed in the following subsections and summarized in Table 4.5. 
TABLE 4.5 Summary of Screening Analysis for Ex-Situ Treatment Technologies

\begin{tabular}{|c|c|c|c|}
\hline $\begin{array}{l}\text { Treatment } \\
\text { Technology }\end{array}$ & Effectiveness & Implementability & Cost \\
\hline $\begin{array}{l}\text { Stabilization/ } \\
\text { fixation }\end{array}$ & $\begin{array}{l}\text { Effective at limiting mobility of metals } \\
\text { and PCBs; applicable to soils from the } \\
\text { pushout area and southern main pit. } \\
\text { Contaminant mobility would be reduced, } \\
\text { but contaminant toxicity would not. Final } \\
\text { waste volume would increase. }\end{array}$ & $\begin{array}{l}\text { Could be implemented with } \\
\text { readily available equipment } \\
\text { and materials. }\end{array}$ & Moderate \\
\hline Vitrification & $\begin{array}{l}\text { Effective at reducing toxicity of organics } \\
\text { and metals. Volume would be reduced. } \\
\text { Applicable to soils contaminated with } \\
\text { organics and metals. }\end{array}$ & $\begin{array}{l}\text { Could be implemented with } \\
\text { readily available equipment } \\
\text { and materials. }\end{array}$ & High \\
\hline Soil washing & $\begin{array}{l}\text { Effective at reducing toxicity, mobility, } \\
\text { and volume of metals and SVOCs (and } \\
\text { possibly PCBs); applicable to soils in the } \\
\text { northern main pit and pushout area. }\end{array}$ & $\begin{array}{l}\text { Could be implemented with } \\
\text { readily available equipment } \\
\text { and materials. }\end{array}$ & $\begin{array}{l}\text { Low to } \\
\text { moderate }\end{array}$ \\
\hline Soil leaching & $\begin{array}{l}\text { Effective at reducing toxicity, mobility, } \\
\text { and volume of metals and SVOCs; } \\
\text { applicable to soils in the northern main pit } \\
\text { and pushout area. }\end{array}$ & $\begin{array}{l}\text { Could be implemented with } \\
\text { readily available equipment } \\
\text { and materials. }\end{array}$ & Moderate \\
\hline Reduction/oxidation & $\begin{array}{l}\text { Effective at reducing contaminant toxicity, } \\
\text { mobility, and volume; applicable to soils } \\
\text { contaminated with metals only. }\end{array}$ & $\begin{array}{l}\text { Could be implemented with } \\
\text { readily available equipment } \\
\text { and materials. }\end{array}$ & Moderate \\
\hline Dehalogenation & $\begin{array}{l}\text { Effective at reducing toxicity, mobility, } \\
\text { and volume of PCBs and halogenated } \\
\text { SVOCs; applicable only to soils in the } \\
\text { main pits. }\end{array}$ & $\begin{array}{l}\text { Could be implemented with } \\
\text { readily available equipment } \\
\text { and materials. }\end{array}$ & Moderate \\
\hline Incineration & $\begin{array}{l}\text { Effective at reducing contaminant volume; } \\
\text { toxicity and mobility would not be } \\
\text { reduced. Bottom ash would require further } \\
\text { treatment by stabilization. May be required } \\
\text { to treat PCB-contaminated soil (depending } \\
\text { on concentrations). }\end{array}$ & $\begin{array}{l}\text { Could be implemented with } \\
\text { readily available equipment } \\
\text { and materials. }\end{array}$ & $\begin{array}{l}\text { Moderate } \\
\text { to high }\end{array}$ \\
\hline $\begin{array}{l}\text { High-temperature } \\
\text { thermal desorption }\end{array}$ & $\begin{array}{l}\text { Effective at reducing toxicity, mobility, } \\
\text { and volume of organics only; applicable to } \\
\text { soils in the main pits. }\end{array}$ & $\begin{array}{l}\text { Could be implemented with } \\
\text { readily available equipment } \\
\text { and materials. }\end{array}$ & Moderate \\
\hline
\end{tabular}


Stabilization/Fixation. In stabilization/fixation technologies, a fixing or stabilizing agent is mixed into the soil to create a product that is stable and resistant to leaching. This process involves mixing reagents with contaminated soil in a mixing vessel, such as a pug mill, to immobilize the contaminants and solidify the waste. This technology effectively reduces the mobility of contaminants through both physical and chemical means. Stabilization/fixation is considered effective for immobilizing metals and PCBs; therefore, it could only be applied to soils excavated from the pushout area and southern main pit. SVOC-contaminated soil may have to be addressed by implementing an additional treatment technology (e.g., if treatment codes are exceeded).

The predominant fixing agents currently in use are Portland cement, lime/fly ash, Portland cement/fly ash, and Portland cement/sodium silicate. Gypsum, bentonite, and zeolites could also be used, as could a number of proprietary agents. Chemical stabilization with cement and fly ash is an established practice for treating hazardous waste and has been retained as potentially applicable to address surface soil contamination in the TBP area.

Ex-Situ Vitrification. Ex-situ vitrification is designed to encapsulate inorganic contaminants rather than reduce inorganic contaminant concentration. This process involves electrically heating contaminated material to temperatures high enough to cause it to melt. Vitrification is applicable to a full range of contaminants. Inorganic contaminants are encapsulated in the vitrified mass; organic contaminants are destroyed because of the high temperatures achieved during processing. Organic off-gases and some volatile metal contaminants would have to be controlled and treated during process operation. The vitrified product is a chemically stable, leach-resistant glass or crystalline material similar to obsidian or basalt, ready for disposal. This technology is not considered cost-effective for the small volume of soils to be treated at the TBP area; on this basis, ex-situ vitrification has been rejected from further consideration.

Soil Washing. Soil washing is an aqueous-based process that reduces soil contamination through the use of particle size separation. This technology is applicable to soils contaminated with metals, SVOCs, and possibly PCBs. The effectiveness of soil washing is based on the finding that most organic and inorganic contaminants tend to bind, either chemically or physically, to the fine-grained fraction of the soil matrix (clay, silt, and organic soil particles). Washing processes that separate the fine particles (silt and clay) from the coarser material (sand and gravel) separate and concentrate the contaminants into a smaller volume of soil that can be further treated or disposed of.

Gravity separation is an effective method for removing high or low specific gravity particles, such as lead. Attrition scrubbing removes adherent contaminant films from coarser particles. The clean, larger fraction can be returned to the site for use as clean fill. The washing agent and soil fines are residuals from this process that would require further treatment (e.g., through soil 
leaching). A bench-scale study has indicated that density separation is effective at removing metals from the sand fraction of TBP area pushout soils (Alternative Remedial Technologies, Inc. [ART] 1995). An additional study is needed to evaluate the efficacy of treating the fine-grained fraction through chemical extraction (soil leaching). On the basis of this preliminary study, it is estimated that a volume reduction of $94 \%$ may be achievable. For this reason, this technology type has been retained.

Soil Leaching. Soil leaching is a chemical process used to remove metals that remain in the fine sand, silt, and clay soil particles after the soil washing and separation process. Sand and fines are leached in separate parallel circuits with an acid solution. The effectiveness of soil leaching is achieved through dissolving smaller metallic particles and ionic metals remaining in the soil. A final step may include precipitation of metals from the leaching solution for recovery and recycling. Soil leaching is applicable to soils contaminated with metals and possibly SVOCs. PCB-contaminated soil would have to be addressed by implementing an additional treatment technology; however, these soils constitute a small fraction of the TBP area soils to be treated. On this basis, soil leaching has been retained.

Reduction/Oxidation. Reduction/oxidation (redox) reactions chemically convert contaminants to nonhazardous or less toxic compounds that are more stable, less mobile, and/or inert (EPA 1994). The oxidizing agents most commonly used for treatment are ozone, hydrogen peroxide, hypochlorites, chlorine, and chlorine dioxide. Chemical redox is applicable to soils contaminated with metals. SVOC- and PCB-contaminated soil would have to be addressed by implementing an additional treatment technology. This technology is not considered cost-effective for soils with high contaminant concentrations (because of the large amounts of oxidizing agent required); on this basis, chemical redox has been rejected from further consideration.

Dehalogenation. Dehalogenation is a decomposition process (e.g., base-catalyzed decomposition or glycolate) designed to remediate soils contaminated with chlorinated organic compounds (especially PCBs and halogenated SVOCs). During the dehalogenation process, contaminated soil is screened, processed with a crusher and pug mill, and mixed with sodium bicarbonate. The mixture is heated in a rotary reactor to decompose and partially volatilize the contaminants. The effectiveness of this technology is limited in soils with high clay and moisture content. In addition, it is only applicable to a small portion of the soils to be excavated at the TBP area. On this basis, dehalogenation has been rejected from further consideration.

Incineration. Waste material can be incinerated by rotary kiln, fluidized bed, slagging, and liquid injection incinerators. Rotary kiln and fluidized bed incineration are typically used to destroy 
organic contaminants. Rotary kilns are refractory-lined, slightly inclined, rotating cylinders that function as a combustion chamber and operate at temperatures up to $1,800^{\circ} \mathrm{F}$. Waste is introduced at the high end, and ash is collected from the bottom end. Flue gases pass through a secondary chamber and control equipment before exiting to the atmosphere. Fluidized-bed incinerators contain a bed of sized granular refractory material in a refractory-lined vesssel. Waste is injected onto the bed and incinerated as air is forced up through the bed at a velocity sufficient to fluidize the burning material.

Incineration technologies do not reduce the toxicity or mobility of inorganic constituents; they do reduce the total waste volume but produce an ash residue. Heavy metals can produce a bottom ash that requires further treatment by stabilization, although volatile metals would leave the combustion unit with the flue gases and would require the installation of gas cleaning systems for removal. In addition, given the small volume of soil to be treated, this option would only be applied at an off-site facility. Waste transport would result in an increased risk of transportation accidents and related impacts, the magnitude of which would depend on the waste volume and type, mode of transportation, and facility location. Given the high costs associated with transportation and treatment, incineration is not considered cost-effective. However, this option has been retained because it may be required to treat PCB-contaminated soil (depending on concentrations, incineration may be the required treatment).

High-Temperature Thermal Desorption. High-temperature desorption involves heating wastes to temperatures of 600 to $1,000^{\circ} \mathrm{F}$. It is applicable to soils contaminated with SVOCs and PCBs. In the treatment process, a carrier gas or vacuum system transports volatilized water and organics to the gas treatment system. Some volatile metals may also be removed. Contaminants are removed from the gas stream and disposed of. Bench-scale studies would be required to determine the effectiveness of organics removal. Thermal desorption is only applicable to a small portion of the soils to be excavated at the TBP area, but it is considered a cost-effective treatment for PCBcontaminated soil. On this basis, this option has been retained.

\subsubsection{Biological Treatment Technologies}

Several biological technologies are available for treating contaminated soil. Biological treatment technologies use living organisms, such as bacteria or fungi, to detoxify or immobilize contaminants in waste. These technologies are applied primarily for converting organic contaminants into nontoxic products. Bioremediation has also been used to degrade inorganic contaminants, such as nitrates, and it can be used to detoxify or immobilize certain metals by changing their oxidation state. The SVOC- and PCB-contaminated soils in the main pits are candidates for bioremediation. 
Biological treatment technologies can be implemented as either in-situ or ex-situ processes. The advantage of in-situ treatment is that it allows soil to be treated without being excavated and transported, resulting in a significant cost savings. However, in-situ treatment generally requires longer time periods, and there is less certainty about the uniformity of treatment because of the variability in soil characteristics and because the efficacy of the process is more difficult to confirm (EPA 1994). Ex-situ treatment generally requires shorter time periods; however, it requires excavation of soils, leading to increased costs and engineering for equipment, the necessity of UXO surveying, possible permitting, and material handling/worker exposure considerations (EPA 1994).

The screening analysis of potential biological treatment technologies is discussed in the following subsections and is summarized in Table 4.6.

In-Situ Bioremediation. In-situ bioremediation is a destructive technique aimed toward stimulating microorganisms in the soil to grow and use the contaminants as a food and energy source by creating a favorable environment for the microorganisms. Generally, this means providing some combination of oxygen, nutrients, and moisture and controlling the temperature and $\mathrm{pH}$. Sometimes, microorganisms adapted for degradation of specific contaminants can be applied to enhance the process. This technology is applicable to soils contaminated with organics (e.g., PCBs); it is not applicable to soils contaminated with metals.

A recent treatability study has shown that sufficient numbers of microorganisms suitable for removal of the organic COCs are present; however, the low permeability of the soil would limit the effectiveness of in-situ bioremediation (Huang 1994).

Because in-situ bioremediation is only applicable to a small portion of the soils to be excavated at the TBP area, it has been rejected from further consideration.

TABLE 4.6 Summary of Screening Analysis for Biological Treatment

\begin{tabular}{llll}
\hline $\begin{array}{c}\text { Biological Treatment } \\
\text { Technology }\end{array}$ & \multicolumn{1}{c}{ Effectiveness } & \multicolumn{1}{c}{ Implementability } & Cost \\
\hline In-situ bioremediation & $\begin{array}{l}\text { Applicable to soils contaminated with } \\
\text { organics; would not address metals } \\
\text { contamination in the pushout area. }\end{array}$ & $\begin{array}{l}\text { Implementation limited by } \\
\text { low-permeability soil that } \\
\text { could impede aeration of } \\
\text { soils. }\end{array}$ & Moderate \\
Ex-situ bioremediation & $\begin{array}{l}\text { Applicable to soils contaminated with } \\
\text { organics; would not address metals } \\
\text { contamination in the pushout area. }\end{array}$ & $\begin{array}{l}\text { Can be implemented with } \\
\text { conventional equipment and } \\
\text { procedures. }\end{array}$ & Moderate \\
\hline
\end{tabular}


Ex-Situ Bioremediation. Ex-situ bioremediation technologies include slurry-phase and solid-phase processes applicable to soils contaminated with organics (e.g., PCBs). Slurry-phase methods, such as batch treatment in a reactor, might be effective because operating parameters could be closely controlled. Solid-phase methods, such as placing in piles, have the advantage of low setup costs. Metals would not be addressed through either treatment.

A recent treatability study reported that significant numbers of microorganisms, including methanotrophs and biphenyl degraders (that are appropriate for degrading organics), are present and that ex-situ bioremediation by using bulking agents might be effective. Another treatability study has indicated that significant numbers of heterotrophs suitable for degradation of chlorinated organics may also be present (Huang 1994).

Because ex-situ bioremediation is only applicable to a small portion of the soils to be excavated at the TBP area, it is not considered a cost-effective treatment. Therefore, ex-situ bioremediation has been rejected from further consideration.

\subsubsection{Short-Term Storage}

Short-term storage involves isolating contaminated material to protect human health and the environment until the material can be treated and/or permanently disposed of. This technology typically involves constructing an engineered facility to minimize the potential for contaminant migration. Short-term storage would not reduce contaminant toxicity or volume, but it could reduce contaminant mobility and potential exposures. Such facilities also could be developed to support cleanup activities. The storage facility could be an enclosed structure or an outdoor area with a gravel pad or other base and covers, such as tarpaulins. These options could be applied either on-site or at an off-site facility.

The screening analysis of short-term storage is summarized in Table 4.7. Use of an off-site facility would require that the material be transported off-site and that an appropriate facility be available. Waste transport would result in an increased risk of transportation accidents and related impacts, the magnitude of which would depend on the waste volume and type, mode of transportation, and facility location. No suitable off-site facility exists for short-term storage of site waste, and none is likely to become available in the near future. Therefore, only the on-site application has been retained.

\subsubsection{Disposal}

Disposal options for contaminated soil involve confinement for permanent disposition. The only disposal option considered for the waste resulting from site remediation at the TBP area is 
TABLE 4.7 Summary of Screening Analysis for Short-Term Storage

\begin{tabular}{llll}
\hline $\begin{array}{c}\text { Short-Term } \\
\text { Storage Facility }\end{array}$ & \multicolumn{1}{c}{ Effectiveness } & \multicolumn{1}{c}{ Implementability } & Cost \\
\hline $\begin{array}{l}\text { Open and enclosed } \\
\text { structures }\end{array}$ & $\begin{array}{l}\text { Could effectively protect human } \\
\text { health and the environment in the } \\
\text { short term by reducing contaminant } \\
\text { mobility and limiting exposures. The } \\
\text { off-site application of this option has } \\
\text { been rejected on the basis of } \\
\text { potential increased risk to workers } \\
\text { and the general public due to } \\
\text { increased likelihood of exposures } \\
\text { associated with waste transportation. }\end{array}$ & $\begin{array}{l}\text { The on-site application could be } \\
\text { easily implemented with readily } \\
\text { available resources. Such facilities } \\
\text { also could be developed to } \\
\text { support cleanup activities. An } \\
\text { appropriate storage facility is not } \\
\text { currently available off-site, and it } \\
\text { is unlikely that such a facility } \\
\text { would become available in the } \\
\text { near future. }\end{array}$ & $\begin{array}{l}\text { Low to } \\
\text { moderate }\end{array}$ \\
\hline
\end{tabular}

off-site land-based facilities. Material determined to be hazardous under RCRA could be shipped to a permitted facility; nonhazardous material could be shipped to a sanitary or demolition landfill. Related requirements are presented in Appendix B (Table B.4).

Under RCRA regulations (40 CFR Part 261), a solid waste is considered to be a regulated hazardous waste if it is not otherwise excluded from regulation as a hazardous waste and either exhibits any of the characteristics identified in Subpart $C$ of this regulation (a "characteristic hazardous waste") or is listed in Subpart D of the regulation (a "listed hazardous waste"). Waste determined to be hazardous as defined by RCRA must be disposed of according to the requirements of 40 CFR Parts 264 and 268 (see Appendix B). In addition, the LDRs promulgated by EPA in 40 CFR Part 268 preclude the disposal of certain contaminants without prior treatment. The LDRs would apply to any TBP area soils regulated under 40 CFR Part 268, and land disposal of such waste would require that appropriate treatment standards be met. The treatment standards are based on contaminant concentrations in the waste, the treatment technology used, or waste characteristics after treatment. Untreated soils from the TBP area pushout area may be categorized as hazardous waste code D008 under 40 CFR Part 261 (Subpart C) because of the high lead concentrations. These soils would require treatment by stabilization to satisfy LDRs prior to disposal. PCB-contaminated soils would also require treatment prior to disposal. If TBP area soils are found to be regulated under TSCA (e.g., if concentrations of PCBs exceed $50 \mathrm{ppm}$ in unrestricted-access areas), these soils may require incineration prior to disposal. If PCB-contaminated soils are not regulated under TSCA (i.e., if concentrations are less than $50 \mathrm{ppm}$ ), they would undergo stabilization prior to disposal.

The implementability of land disposal at an off-site facility is affected by the availability of suitable sites for disposal of APG waste. Special pricing through an on-site contractor at APG could keep disposal costs down relative to off-site contractors, thereby making disposal a cost-effective option. 
The screening analysis of the disposal option is summarized in Table 4.8. On the basis of this evaluation, the disposal option has been retained.

\subsection{POTENTIALLY APPLICABLE TECHNOLOGIES}

Potentially applicable technologies for remediation of the TBP area are summarized in Table 4.9. This summary is based on the screening analysis presented in Section 4.2. The technology types that have been retained through this analysis were used to develop preliminary interim remedial action alternatives for the TBP area. These alternatives are identified in Section 5.

TABLE 4.8 Summary of Screening Analysis for Disposal

\begin{tabular}{llll}
\hline Disposal Option & \multicolumn{1}{c}{ Effectiveness } & Implementability & Cost \\
\hline $\begin{array}{l}\text { Off-site, land- } \\
\text { based disposal }\end{array}$ & $\begin{array}{l}\text { Provides protection of environment } \\
\text { and reduces exposures. Treatment of } \\
\text { contaminated soils would be required } \\
\text { prior to disposal. }\end{array}$ & $\begin{array}{l}\text { Subtitle C and D landfills are } \\
\text { available in the eastern region } \\
\text { of the United States (e.g., } \\
\text { Virginia and Pennsylvania). }\end{array}$ & Moderate \\
\hline
\end{tabular}


TABLE 4.9 Summary of Potentially Applicable Technologies

\begin{tabular}{|c|c|c|c|}
\hline $\begin{array}{l}\text { General } \\
\text { Response } \\
\text { Action } \\
\end{array}$ & Technology Type & $\begin{array}{c}\text { Evaluation } \\
\text { Result } \\
\end{array}$ & Comments \\
\hline No action & Not applicable & Retained & $\begin{array}{l}\text { Would provide a baseline for } \\
\text { comparison with action } \\
\text { alternatives. }\end{array}$ \\
\hline \multirow[t]{3}{*}{$\begin{array}{l}\text { Institutional } \\
\text { control }\end{array}$} & Access restriction & Retained & $\begin{array}{l}\text { Could effectively limit entry to } \\
\text { contaminated areas and could be } \\
\text { used to support other response } \\
\text { actions. }\end{array}$ \\
\hline & $\begin{array}{l}\text { Ownership and use or deed } \\
\text { restrictions }\end{array}$ & Retained & $\begin{array}{l}\text { Could minimize exposures to site } \\
\text { contaminants by limiting use of } \\
\text { contaminated areas and could be } \\
\text { used to support other response } \\
\text { actions. }\end{array}$ \\
\hline & Monitoring & Retained & $\begin{array}{l}\text { Could provide data useful for } \\
\text { minimizing exposures and could be } \\
\text { used to support other response } \\
\text { actions. }\end{array}$ \\
\hline \multirow[t]{3}{*}{$\begin{array}{l}\text { In-situ } \\
\text { containment }\end{array}$} & Surface control diversions & Retained & $\begin{array}{l}\text { Could limit contaminant mobility } \\
\text { by directing surface runoff from } \\
\text { contaminated areas and could be } \\
\text { used to support other response } \\
\text { actions. }\end{array}$ \\
\hline & Vertical barriers & Retained & $\begin{array}{l}\text { Could limit contaminant mobility } \\
\text { by impeding groundwater } \\
\text { discharge to the marsh and by } \\
\text { minimizing erosion of contam- } \\
\text { inated soil from the pushout area. }\end{array}$ \\
\hline & Caps/covers & Retained & $\begin{array}{l}\text { Could limit airborne emissions, } \\
\text { precipitation-enhanced percolation } \\
\text { and leaching, and contaminant } \\
\text { resuspension via surface water } \\
\text { runoff. }\end{array}$ \\
\hline \multirow[t]{2}{*}{ Removal } & Excavation & Retained & $\begin{array}{l}\text { Could effectively remove the } \\
\text { source of contamination and could } \\
\text { be readily implemented. UXO } \\
\text { survey would be required. }\end{array}$ \\
\hline & Clearing and grubbing & Retained & $\begin{array}{l}\text { Could effectively remove } \\
\text { vegetation from the site to support } \\
\text { overall cleanup activities. }\end{array}$ \\
\hline
\end{tabular}


TABLE 4.9 (Cont.)

\begin{tabular}{|c|c|c|c|}
\hline $\begin{array}{l}\text { General } \\
\text { Response } \\
\text { Action }\end{array}$ & Technology Type & $\begin{array}{c}\text { Evaluation } \\
\text { Result }\end{array}$ & Comments \\
\hline \multirow[t]{4}{*}{$\begin{array}{l}\text { In-situ } \\
\text { treatment }\end{array}$} & Soil flushing & Rejected & $\begin{array}{l}\text { Difficult to implement because of } \\
\text { limitations due to site conditions. } \\
\text { Ineffective for removing PCBs. }\end{array}$ \\
\hline & Stabilization/solidification & Rejected & $\begin{array}{l}\text { Difficult to implement because of } \\
\text { limitations due to site conditions. } \\
\text { Ineffective for limiting mobility of } \\
\text { PCBs. }\end{array}$ \\
\hline & Vitrification & Rejected & $\begin{array}{l}\text { Difficult to implement because of } \\
\text { innovative nature of technology } \\
\text { and site conditions. }\end{array}$ \\
\hline & Electrokinetic separation & Rejected & $\begin{array}{l}\text { Difficult to implement because of } \\
\text { innovative nature of technology } \\
\text { and site conditions. Ineffective at } \\
\text { mobilizing particulate lead. }\end{array}$ \\
\hline \multirow[t]{6}{*}{$\begin{array}{l}\text { Ex-situ } \\
\text { treatment }\end{array}$} & Stabilization/fixation & Retained & $\begin{array}{l}\text { Could reduce contaminant mobility } \\
\text { but increases volume. Would } \\
\text { require an engineered treatment } \\
\text { facility. }\end{array}$ \\
\hline & Vitrification & Rejected & $\begin{array}{l}\text { Could reduce contaminant toxicity } \\
\text { and mobility; volume would not be } \\
\text { reduced. Would require an } \\
\text { engineered treatment facility; not } \\
\text { considered cost-effective. }\end{array}$ \\
\hline & Soil washing & Retained & $\begin{array}{l}\text { Could reduce contaminant toxicity, } \\
\text { mobility, and volume. Could be } \\
\text { implemented on-site. }\end{array}$ \\
\hline & Soil leaching & Retained & $\begin{array}{l}\text { Could reduce contaminant toxicity, } \\
\text { mobility, and volume. Would } \\
\text { facilitate recovery of lead for } \\
\text { recycling. Could be implemented } \\
\text { on-site. }\end{array}$ \\
\hline & Reduction/oxidation & Rejected & $\begin{array}{l}\text { Could reduce toxicity, mobility, } \\
\text { and volume (for metals only). Not } \\
\text { considered cost-effective. }\end{array}$ \\
\hline & Dehalogenation & Rejected & $\begin{array}{l}\text { Could reduce toxicity, mobility, } \\
\text { and volume (for chlorinated } \\
\text { organic compounds only). } \\
\text { Effectiveness limited by site } \\
\text { conditions. }\end{array}$ \\
\hline
\end{tabular}


TABLE 4.9 (Cont.)

\begin{tabular}{|c|c|c|c|}
\hline $\begin{array}{l}\text { General } \\
\text { Response } \\
\text { Action } \\
\end{array}$ & Technology Type & $\begin{array}{c}\text { Evaluation } \\
\text { Result }\end{array}$ & Comments \\
\hline \multirow[t]{2}{*}{$\begin{array}{l}\text { Ex-situ } \\
\text { treatment } \\
\text { (cont.) }\end{array}$} & Incineration & Retained & $\begin{array}{l}\text { Could reduce contaminant toxicity, } \\
\text { mobility, and volume (for } \\
\text { organics). Would require an } \\
\text { engineered treatment facility. }\end{array}$ \\
\hline & Thermal desorption & Retained & $\begin{array}{l}\text { Could reduce contaminant toxicity, } \\
\text { mobility, and volume (for } \\
\text { organics). }\end{array}$ \\
\hline \multirow[t]{2}{*}{$\begin{array}{l}\text { Biological } \\
\text { treatment }\end{array}$} & In-situ bioremediation & Rejected & $\begin{array}{l}\text { Could reduce contaminant toxicity, } \\
\text { mobility, and volume (for } \\
\text { organics). Effectiveness limited } \\
\text { by site conditions. }\end{array}$ \\
\hline & Ex-situ bioremediation & Rejected & $\begin{array}{l}\text { Could reduce contaminant toxicity, } \\
\text { mobility, and volume (for } \\
\text { organics). Not considered } \\
\text { cost-ffective. }\end{array}$ \\
\hline $\begin{array}{l}\text { Short-term } \\
\text { storage }\end{array}$ & Open and closed structures & Retained & $\begin{array}{l}\text { Could effectively reduce } \\
\text { contaminant mobility in the short } \\
\text { term and support cleanup activities. }\end{array}$ \\
\hline Disposal & Land-based facility & Retained & $\begin{array}{l}\text { Could effectively provide } \\
\text { protection of environment and } \\
\text { reduce exposures. Treatment } \\
\text { required prior to disposal. }\end{array}$ \\
\hline
\end{tabular}




\section{DEVELOPMENT AND SCREENING OF PRELIMUNARY ALTERNATIVES}

Preliminary alternatives for remediating surface soil in the J-Field TBP area were developed and screened in accordance with CERCLA, EPA guidance (EPA 1988), and the NCP (EPA 1990a). Five preliminary alternatives, including no action, were developed on the basis of the criteria presented in Section 5.1. These alternatives, identified and described in Section 5.2, were then screened on the basis of the criteria defined in Section 5.3. Each of the five preliminary alternatives was passed through the screening analysis presented in Section 5.4; they are identified as final alternatives and listed in Section 5.5. These final alternatives are further developed and described in Section 6 and evaluated in detail in Section 7. The preferred alternative will be identified in the proposed plan for this interim remedial action.

\subsection{CRITERIA FOR DEVELOPING ALTERNATIVES}

EPA has established an approach for developing remedial action alternatives that are appropriate to the site-specific conditions (EPA 1988, 1990a). In this approach, the scope, characteristics, and complexity of the site are considered in developing a range of alternatives that would be protective of human health and the environment. This protection can be achieved by eliminating, reducing, and/or controlling risks posed by each pathway at a site. Two major categories of response, containment and treatment, are considered in developing remedial action alternatives:

- Containment involves little or no treatment but protects human health and the environment by preventing or controlling exposures to contaminants through engineering measures and by using institutional controls as necessary to ensure the continued effectiveness of a response; and

- Treatment ranges from alternatives that use treatment as the primary element of the response to address the principal threat(s) posed by a site to alternatives that use treatment to reduce the toxicity, mobility, or volume of contaminated material to the maximum extent feasible, minimizing the need for long-term management.

As stated in Section 121(b) of CERCLA, as amended, the most preferred alternatives (1) represent permanent and cost-effective solutions for protecting human health and the environment; (2) permanently and significantly reduce the toxicity, mobility, or volume of contaminated material; and (3) apply alternative treatment or resource recovery technologies to the extent possible. Least preferred alternatives involve the transport and disposal of waste off-site without treatment. 
A no-action alternative is also included to provide a baseline for comparison with other alternatives. For the analysis in this FFS, the baseline condition of the J-Field TBP area would include only minor maintenance activities, such as mowing and monitoring.

\subsection{IDENTIFICATION OF PRELIMINARY ALTERNATIVES}

Technologies potentially applicable to managing contaminated surface soil at the J-Field TBP area are identified and screened in Section 4 (Table 4.9). On the basis of this screening, various technologies were identified as potential components of remedial action alternatives for the site. These technologies have been incorporated into five preliminary alternatives:

- Alternative 1: No Action;

- Alternative 2: Limited Removal and Disposal, and In-Situ Containment;

- Alternative 3: Removal and Short-Term Storage;

- Alternative 4: Removal, On-Site Treatment, and Limited Disposal; and

- Alternative 5: Removal, Off-Site Treatment, and Disposal.

In-situ containment is the primary emphasis of Alternative 2, and source control through removal is the primary emphasis of Alternatives 3, 4, and 5 .

The J-Field site would remain secured, and existing institutional controls, such as ownership and use or deed restrictions, are implicitly included in each action alternative during the cleanup period. These controls are also included for the no-action alternative. Controls, such as monitoring, would be increased as needed. Each alternative would require various support activities before implementation, including the design and construction of staging areas, procurement of appropriate equipment, and development of contingency plans and operational controls to minimize contaminant releases. Site preparation activities would include clearing and grubbing contaminated areas, conducting UXO surveys, constructing access roads, and emplacing site perimeter dikes for surface water control. Shoreline stabilization has been included only for Alternatives 2 and 3 . Because Alternatives 4 and 5 involve total removal of contaminated surface soil, shoreline stabilization was not included as a component. 


\subsubsection{Alternative 1: No Action}

Alternative 1 is included to provide a baseline for comparison with the other action alternatives. Under this alternative, the site would continue to operate under restricted access. Current conditions of the contaminated surface soil would continue.

\subsubsection{Alternative 2: Limited Removal and Disposal, and In-Situ Containment}

Under Alternative 2, contamination in the two main pits and the pushout area would be contained in place with a protective cover. Limited excavation and disposal would be implemented to address contaminated soil in the main pits.

The "risk-reduction cover" would involve placing a geotextile fabric over the vegetationcleared surface (about 5 acres [218,000 $\left.\mathrm{ft}^{2}\right]$ ), which would then be covered by a layer of soil sufficient to raise the site topography above the 100-year floodplain. The soil layer would be stabilized with a vegetative cover. Runoff from the area would be diverted by surface grading controls. Erosion of contaminated soil from the portion of the pushout area in contact with the marsh would be mitigated by installing a vertical barrier. Because the soil layer would be emplaced incrementally in 2-ft layers, UXO screening most likely would not be required for this component. A UXO visual survey would be required for the limited excavation component. Because the area of excavation is limited, hand removal methods may be used (depending on the density of metal contacts present). The limited disposal component under Alternative 2 would involve shipping about $400 \mathrm{yd}^{3}$ of soil to a permitted off-site facility for treatment (stabilization and possibly incineration) and disposal.

Stabilization of the shoreline about $2,000 \mathrm{ft}$ to the south of the TBP area would also be implemented as part of this alternative. A UXO survey would be conducted by a two-man clearance team. Installation of a boulder riprap berm would reduce the potential for long-term erosion along the shoreline.

\subsubsection{Alternative 3: Removal and Short-Term Storagé}

Under Alternative 3, contaminated surface soil in the two main pits and pushout area that exceed soil cleanup criteria would be removed and transported to an on-site, short-term storage facility, where it would be stored until final remediation is addressed at J-Field.

Soil would be excavated to a depth of $2 \mathrm{ft}$ from the source areas with standard construction equipment, such as front-end loaders, scrapers, and backhoes. The excavation area would be surveyed for UXO in the upper 2 to $4 \mathrm{ft}$. Approximately $16,000 \mathrm{yd}^{3}$ of soil would be removed. 
Runoff from the area would be diverted by surface grading controls. Following excavation, the area would be backfilled with clean soil. The short-term storage facility would be constructed adjacent to the Prototype Building to minimize the distance over which the material would have to be transferred. This location is the highest topographic area at J-Field. The short-term facility would be a modular building consisting of fabric walls. The base of the structure would require the construction of a bermed and drained concrete or asphalt pad equipped with a leachate collection system. An air infiltration system may also be required.

Stabilization of the shoreline about 2,000 $\mathrm{ft}$ to the south of the TBP area would also be implemented as part of this alternative. A UXO survey would be conducted by a two-man clearance team. Installation of a boulder riprap berm would reduce the potential for long-term erosion along the shoreline.

\subsubsection{Alternative 4: Removal, On-Site Treatment, and Limited Disposal}

Under Alternative 4, contaminated soil in the two main pits and pushout area that exceeds soil cleanup criteria would be removed and treated by soil washing/leaching to reduce the volume of waste for off-site disposal.

The removal component of Alternative 4 would be similar to that of Alternative 3; however, the excavated soil would be transported to an on-site soil washing/leaching treatment facility, which would be constructed adjacent to the Prototype Building (though I- and H-Fields are other potential sites). For the conceptual design, it was estimated that $16,000 \mathrm{yd}^{3}$ of soil would be treated. A portion of the soil from the southern main pit, contaminated with PCBs, would be sent off-site for treatment and disposal. After removal and treatment, the cleaned material would either remain on-site to be used as fill or be shipped to an off-site solid waste disposal facility, in accordance with the State of Maryland's preference. Limited disposal under Alternative 4 would involve shipping recovered lead, scrap metal, and other (nonhazardous) refuse, as necessary, to an off-site facility (smelter and/or municipal landfill).

\subsubsection{Alternative 5: Removal, Off-Site Treatment, and Disposal}

Under Alternative 5, contaminated soil in the two main pits and pushout area that exceeds soil cleanup criteria would be removed and transported to an off-site treatment and disposal facility.

The removal component of Alternative 5 would be similar to that of Alternative 3; however, the excavated soil would be temporarily staged on-site following excavation, then transported to an off-site treatment and disposal facility. 


\subsection{CRITERIA FOR SCREENING ALTERNATIVES}

The five preliminary alternatives were evaluated for applicability to remediating the J-Field TBP area on the basis of three general criteria: effectiveness, implementability, and cost. The effectiveness of an alternative is defined by its overall ability to protect human health and the environment in both the short term and long term. Measures of effectiveness include (1) reduction of potential long-term impacts to human health and the environment; (2) reduction of contaminant toxicity, mobility, or volume through treatment; (3) control of potential impacts to human health and the environment during the action period; (4) timeliness; and (5) consistency with regulatory requirements.

The implementability of an alternative is defined by its technical and administrative feasibility and availability of resources. Technical feasibility refers to the ability to construct, reliably operate, and meet technology-specific regulations for process options until the remedial action is complete. It also addresses the operation, maintenance, replacement, and monitoring of the technical components of an alternative, as appropriate; potential constraints associated with the site environment are also considered. Administrative feasibility addresses the acceptability of an alternative by other agencies and groups and pertinent environmental requirements, such as permits, as appropriate. Resource availability addresses the resources required to implement specific components of an alternative and the ability to obtain them.

The cost of an alternative is considered only in a comparative manner at the screening stage by comparing general estimates for each alternative to evaluate relative cost. This comparison helps decision makers to determine whether the cost of one alternative is much greater than that of another alternative of similar effectiveness and implementability. If the cost of an alternative is inordinately excessive compared to the effectiveness it provides, that alternative can be screened from further consideration.

\subsection{SCREENING OF PRELIMINARY ALTERNATIVES}

\subsubsection{Alternative 1: No Action}

Under Alternative 1, the TBP area would remain unchanged. Activities that would continue under the no-action alternative include maintenance and periodic monitoring. 


\subsubsection{Effectiveness}

Alternative 1 would not involve any treatment to reduce the toxicity, mobility, or volume of contaminated surface soil at the TBP area, and it would not provide for a timely or permanent response to the contamination problem. In addition, certain regulatory requirements would not be met. The potential for exposures of wildlife, trespassers, and site workers would continue in the short term and could increase over time if contaminants were released to other media (groundwater, surface water, sediment, or air). Potential long-term health impacts to site workers and the general public would be low as a result of institutional controls; however, adverse impacts to wildlife would be expected due to continued exposure.

\subsubsection{Implementability}

Minimum site operations, including maintenance activities (e.g., mowing) and monitoring, would continue with readily available resources.

\subsubsection{Cost}

Costs associated with Alternative 1 (baseline conditions) include those for continuing the general maintenance and security of the site. Monitoring activities would also be included. Annual costs are estimated to be about $\$ 300,000$.

\subsubsection{Alternative 2: Limited Removal and Disposal, and In-Situ Containment}

\subsubsection{Effectiveness}

The effectiveness of the soil cover could be limited by the shallow water table and its proximity to the marsh and by the potential for flooding, because portions of the TBP area are located within the 100-year floodplain (FEMA 1986). Other factors that could limit the effectiveness of the soil cover include the activities of burrowing animals present at the site and growth of deeprooted vegetation on the soil cover. Engineering controls (e.g., contouring and landscaping) and maintenance could effectively alleviate these limitations. Regular maintenance and monitoring would be necessary to maintain long-term effectiveness. Some repair might be necessary if the soil cover were to deteriorate. 


\subsubsection{Implementability}

Alternative 2 could be implemented with readily available resources. Technical feasibility of the in-situ containment component and shoreline stabilization would be high. Timeliness would be affected by the potential presence of UXO, which would require labor-intensive removal methods for the localized areas. However, localized removal would take considerably less time than full excavation and removal or excavation and on-site treatment.

Approximately $60 \%$ of the site is above the 100 -year floodplain; another $20 \%$ is above the 5 - $\mathrm{ft}$ contour and would only require 2 to $3 \mathrm{ft}$ of cover to exceed the 100-year floodplain line. The remaining $20 \%$ would have to be raised 6 to $7 \mathrm{ft}$ to exceed the 100 -year floodplain line. The edge of the cover along the marsh would be engineered as a berm that would be covered by geotextile fabric and rock riprap to protect against erosion from the 100 -year flooding.

The disposal component of Alternative 2 would be relatively straightforward. About $400 \mathrm{yd}^{3}$ of contaminated soil would be sent off-site for treatment and disposal.

\subsubsection{Cost}

The estimated cost of in-situ containment would be about $\$ 2$ million. This cost includes site preparation activities (clearing and grubbing, UXO surveying, constructing and improving roads, and limited excavating), construction of the soil cover, limited disposal, direct and indirect costs, remedial design costs, and project management. The cost of Alternative 2 would be comparable to Alternative 3 and lower than Alternatives 4 and 5.

\subsubsection{Alternative 3: Removal and Short-Term Storage}

\subsubsection{Effectiveness}

Alternative 3 would not include a treatment component; therefore, contaminant toxicity, mobility, and volume would not be reduced through treatment. However, potential exposures to wildlife, trespassers, and site workers would be reduced through removal of surface soil. The storage component of this alternative would provide for short-term protection, but it would not be protective in the long term.

Short-term risks to on-site workers and the general public would be significant for Alternative 3 because of the removal component. Risks include those related to the potential for encountering UXO and airborne emissions. Potential short-term environmental impacts, mainly a 
result of excavation and grading activities, include disturbance to the soil, temporary increases in fugitive dust emissions and ambient noise level, increased sediment transport to the adjacent marsh, and displacement or loss of vegetation and wildlife habitat. Mitigative measures to reduce these impacts are discussed in Section 7.4.

\subsubsection{Implementability}

Implementing the removal component of Alternative 3 would be relatively straightforward with regard to the availability of resources. Technical feasibility of the on-site storage component and shoreline stabilization would be high. Contaminated surface soil from the main pits and pushout area could be excavated with standard equipment and readily available materials. Timeliness would be affected by the potential presence of UXO, which will require time-consuming surveys in the upper 2 to $4 \mathrm{ft}$. Implementing the on-site, short-term storage component would also be straightforward. The storage facility could be built by on-site workers with assistance from the manufacturer's technical representative.

\subsubsection{Cost}

The estimated cost of removal and on-site, short-term storage would be about $\$ 5$ million. This cost includes site preparation activities (clearing and grubbing, UXO surveying, extending electric service, and constructing and improving roads), excavation, construction of the storage facility, transporting material to a storage facility, landscaping the excavation area, direct and indirect costs, remedial design costs, and project management. For this estimate, operation of the facility was assumed to be 5 years. The cost of Alternative 3 would be comparable to Alternative 2 and lower than Alternatives 4 and 5. Although the costs associated with Alternative 3 are lower than those for Alternatives 4 and 5 , they do not represent the total cost of long-term remediation. Shortterm storage following excavation is only a temporary measure to limit exposures to contaminated surface soil; this action would have to be followed by treatment and disposal at some point in the future.

\subsubsection{Alternative 4: Removal, On-Site Treatment, and Limited Disposal}

\subsubsection{Effectiveness}

8

Excavating contaminated surface soil at the TBP area would reduce potential impacts to human health and the environment in a timely manner and would reduce the potential for contaminant migration. Subsequent treatment of the waste (via soil washing/leaching) would reduce 
contaminant toxicity, mobility, and volume over the short and long term. Alternative 4 satisfies the statutory preference for treatment as a principal element of the remediation.

Recent treatability studies (ART 1995) have shown that through a combination of physical separation treatment and chemical extraction (leaching) of sand and fines, a volume reduction of about $94 \%$ may be achieved. The remaining $6 \%$ would consist of oversize material $(>2 \mathrm{~mm})$ that may require disposal as a hazardous waste. These studies were based on achieving interim PRGs for metals. Final remediation goals would have to be determined before further studies are conducted so that total effectiveness could be accurately assessed.

Short-term risks to site workers and the general public would be significant for Alternative 4 because of the removal component. Risks include those related to the potential for encountering UXO and airborne emissions. Potential short-term environmental impacts, mainly a result of excavation and grading activities, include disturbance to the soil, temporary increases in fugitive dust emissions and ambient noise level, increased sediment transport to the adjacent marsh, and the displacement or loss of vegetation and wildlife habitat. Mitigative measures to reduce these impacts are discussed in Section 7.4.

\subsubsection{Implementability}

Implementing the removal component of Alternative 4 would be relatively straightforward with regard to the availability of resources. Contaminated surface soil from the main pits and pushout area could be excavated with standard equipment and readily available materials. Timeliness would be affected by the potential presence of UXO, which will require time-consuming surveys in the upper 2 to $4 \mathrm{ft}$. Implementing the on-site treatment component (soil washing/leaching) and limited disposal (recovered lead and scrap metal) would also be straightforward.

\subsubsection{Cost}

The estimated cost of removal, on-site treatment, and limited disposal would be about $\$ 13$ million. This cost includes site preparation activities (clearing and grubbing, UXO surveying, extending electric service, and constructing and improving roads), excavation (to $2 \mathrm{ft}$ ), construction of the soil washing/leaching facility, transporting and loading material into the facility, landscaping the excavation area, direct and indirect costs, remedial design costs, and project management. The estimate given here is based on a $94 \%$ reduction in soil volume; that is, $6 \%$ of washed soil volume and all PCB-contaminated soil would be sent off-site. The cost of Alternative 4 is the highest of all the action alternatives. 


\subsubsection{Alternative 5: Removal, Off-Site Treatment, and Disposal}

\subsubsection{Effectiveness}

Excavating contaminated surface soil at the TBP area would reduce potential impacts to human health and the environment in a timely manner and would reduce the potential for contaminant migration. Subsequent treatment of the waste (off-site) would reduce contaminant toxicity, mobility, and volume over the short and long term. Alternative 5 satisfies the statutory preference for treatment as a principal element of the remediation but does not satisfy the statutory preference for on-site treatment; instead, it involves the transport of a large volume of soil to an offsite facility for treatment.

Short-term risks to site workers and the general public would be significant for Alternative 5 because of the removal component. Potential short-term risks to the general public would also exist because of the off-site transport of untreated hazardous material. Risks include those related to the potential for encountering UXO and airborne emissions. Potential short-term environmental impacts, mainly a result of excavation and grading activities, include disturbance to the soil, temporary increases in fugitive dust emissions and ambient noise level, increased sediment transport to the adjacent marsh, and the displacement or loss of vegetation and wildlife habitat. Mitigative measures to reduce these impacts are discussed in Section 7.4.

Leachability tests have been conducted on surface soils ( 0 to $4 \mathrm{ft}$ ) in the pushout area (Peters 1995). Test results indicate that soil fails the TCLP requirements for hazardous waste with respect to lead. Waste determined to be hazardous as defined by RCRA ( 40 CFR Part 261) must be disposed of according to the requirements of 40 CFR Parts 264 and 268. Because of the high lead concentrations, untreated soils from the TBP pushout area would be categorized as waste code D008 under 40 CFR Part 268 (Subpart D). These soils would require treatment by stabilization before disposal. The semivolatile components most likely will not present a disposal problem for the soils excavated from the main pits (and volatiles are present mainly at depths greater than $2 \mathrm{ft}$ ). However, PCB-contaminated soils (found in the southern main pit) would also require treatment before disposal. Depending on concentrations, the PCB-contaminated soils would undergo either stabilization (if less than $50 \mathrm{ppm}$ ) or incineration (if greater than $50 \mathrm{ppm}$ ). These technologies have been demonstrated to be effective and acceptable for treating hazardous soils before disposal.

\subsubsection{Implementability}

Implementing the removal component of Alternative 5 would be relatively straightforward with regard to the availability of resources. Contaminated surface soil from the main pits and pushout area could be excavated with standard equipment and readily available materials. Timeliness 
would be affected by the potential presence of UXO, which will require time-consuming surveys in the upper 2 to $4 \mathrm{ft}$. Implementing the off-site treatment and disposal components would also be straightforward. Off-site facilities are available to handle the type and volume of waste that would be generated.

\subsubsection{Cost}

The estimated cost of removal, off-site treatment, and disposal would be about $\$ 11$ million. This cost includes site preparation activities (clearing and grubbing, UXO surveying, and constructing and improving roads), excavation (to $2 \mathrm{ft}$ ), construction of a temporary staging area, landscaping the excavation area, direct and indirect costs, remedial design costs, and project management. The cost of Alternative 5 is higher than Alternatives 1 through 3 but less than Alternative 4.

\subsection{SCREENING SUMMARY AND IDENTIFICATION OF FINAL ALTERNATIVES}

The results of the screening analysis for the preliminary alternatives are summarized in Table 5.1. Information for each alternative was evaluated relative to EPA's screening criteria of effectiveness, implementability, and cost.

Although it would not be protective of human health and the environment in the long term, the no-action alternative (Alternative 1) was retained through this screening to provide a basis for comparison with the remaining action alternatives during the subsequent detailed analysis. Alternative 3 was retained because it offers a low-cost option for reducing risk; however, it is not considered effective in the long term and would thus require an additional action at a future date.

On the basis of the screening analysis, all five preliminary alternatives were retained. 
TABLE 5.1 Screening Results for Preliminary Alternatives

\begin{tabular}{|c|c|c|c|}
\hline Alternative & Effectiveness & Implementability & Cost \\
\hline $\begin{array}{l}\text { Alternative 1: } \\
\text { No Action }\end{array}$ & $\begin{array}{l}\text { Exposures to humans and wildlife at the } \\
\text { contaminated areas would continue, and } \\
\text { migration could result in increased } \\
\text { exposures over time. No treatment } \\
\text { would be implemented to reduce } \\
\text { toxicity, mobility, or volume of } \\
\text { contaminated material; no permanent } \\
\text { solution would be achieved; and certain } \\
\text { regulatory requirements would not be } \\
\text { met. }\end{array}$ & $\begin{array}{l}\text { Standard practices and equipment } \\
\text { would be used to conduct general } \\
\text { maintenance activities and maintain } \\
\text { current institutional controls, such as } \\
\text { access restriction and monitoring. }\end{array}$ & $\begin{array}{l}\text { Annual costs estimated to be } \\
\$ 300,000 \text {. The baseline costs would } \\
\text { probably increase with inflation. }\end{array}$ \\
\hline $\begin{array}{l}\text { Alternative 2: } \\
\text { Limited Removal } \\
\text { and Disposal, and } \\
\text { In-Situ Containment }\end{array}$ & $\begin{array}{l}\text { More protective in the long term than } \\
\text { Alternative } 1 \text {. Short-term impacts to } \\
\text { workers would be higher than for } \\
\text { Alternative } 1 \text { because of the potential } \\
\text { for exposures during construction and } \\
\text { grading activities. Exposures would be } \\
\text { reduced in the short term, and this } \\
\text { alternative could be implemented in a } \\
\text { timely manner. Factors limiting the } \\
\text { effectiveness of the cover include the } \\
\text { activities of burrowing animals and } \\
\text { growth of deep-rooted vegetation. } \\
\text { Regular maintenance and monitoring } \\
\text { would be required. }\end{array}$ & $\begin{array}{l}\text { Installation of the protective cover } \\
\text { would be relatively straightforward } \\
\text { and could be implemented with } \\
\text { readily available resources. The } \\
\text { presence of UXO could affect the } \\
\text { timeliness of implementation. For the } \\
\text { limited excavation and (off-site) } \\
\text { disposal component, transport and } \\
\text { disposal of waste material generated } \\
\text { from grading activities would be } \\
\text { relatively straightforward. Installation } \\
\text { of riprap berm at the shoreline would } \\
\text { also be straightforward. }\end{array}$ & $\begin{array}{l}\text { Total estimated cost is } \$ 2 \text { million. } \\
\text { More expensive than Alternative } 1 \\
\text { but less than other action alternatives } \\
\text { ( } 4 \text { and } 5 \text { ). Comparable in cost to } \\
\text { Alternative } 3 .\end{array}$ \\
\hline
\end{tabular}


TABLE 5.1 (Cont.)

\section{Alternative}

Alternative 3:

Removal and Short-

Term Storage

\section{Alternative 4: \\ Removal, On-Site \\ Treatment, and \\ Limited Disposal}

Effectiveness

More protective in the short term than

Alternative 1 because it would reduce potential exposures to humans and wildlife through removal. No treatment would be implemented to reduce contaminant toxicity, mobility, or volume. Alternative 3 would not be protective in the long term and would require an additional action at a future date. Potential risks to human health and the environment would be significant in the short term because of the removal component but would be reduced in the long term. Good engineering practices and mitigative measures would be implemented to minimize impacts.

More protective than Alternatives 1 through 3 in the long term because contaminated soil would be removed from the source areas and treated. The statutory preference for treatment as a principal element of remediation would be met. Contaminant toxicity, mobility, and volume would be reduced. Potential risks to human health and environment would be significant in the short term because of the removal component but would be reduced in the long term. Good engineering practices and mitigative measures would be implemented to minimize impacts.

\author{
Implementability
}

Removal and storage would be relatively straightforward and could be implemented with readily available resources and standard procedures. The presence of UXO could affect the timeliness of implementation. Installation of riprap berm at the shoreline would also be straightforward.

Removal and treatment would be relatively straightforward and could be implemented with readily available resources and standard procedures. The presence of UXO could affect the timeliness of implementation.
Total estimated cost is $\$ 5$ million but does not include costs of long-term remediation. More expensive than Alternative 1 but less than other action alternatives ( 4 and 5 ).

Comparable in cost to Alternative 2.
Total estimated cost is $\$ 13$ million. Alternative 4 is the highest of all the action alternatives. 


\begin{tabular}{|c|c|c|c|}
\hline 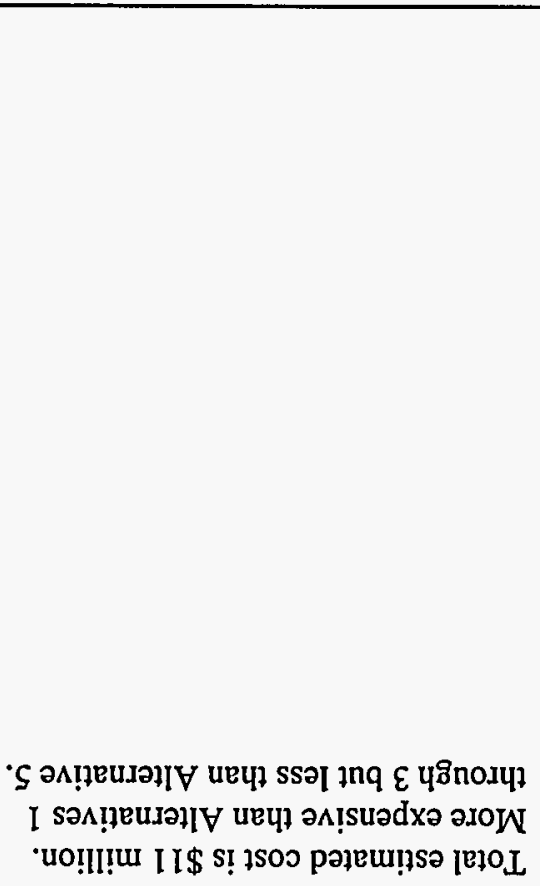 & 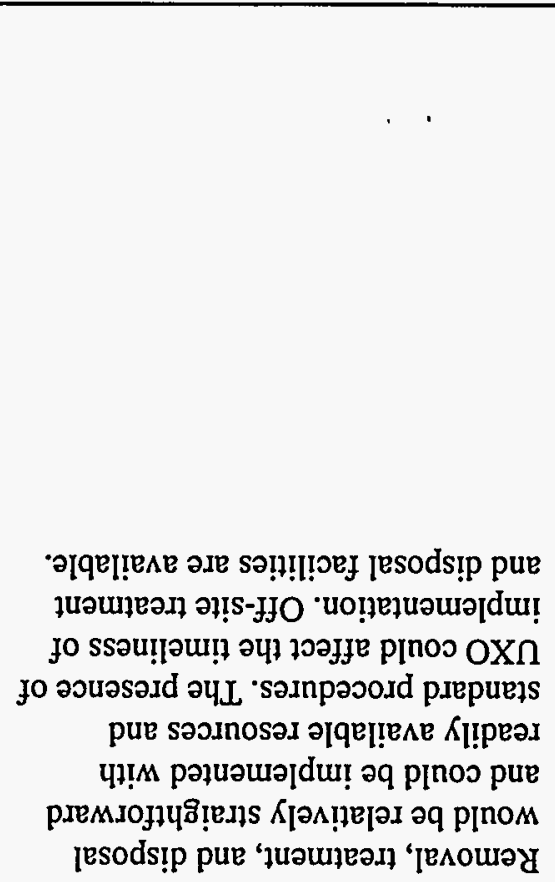 & 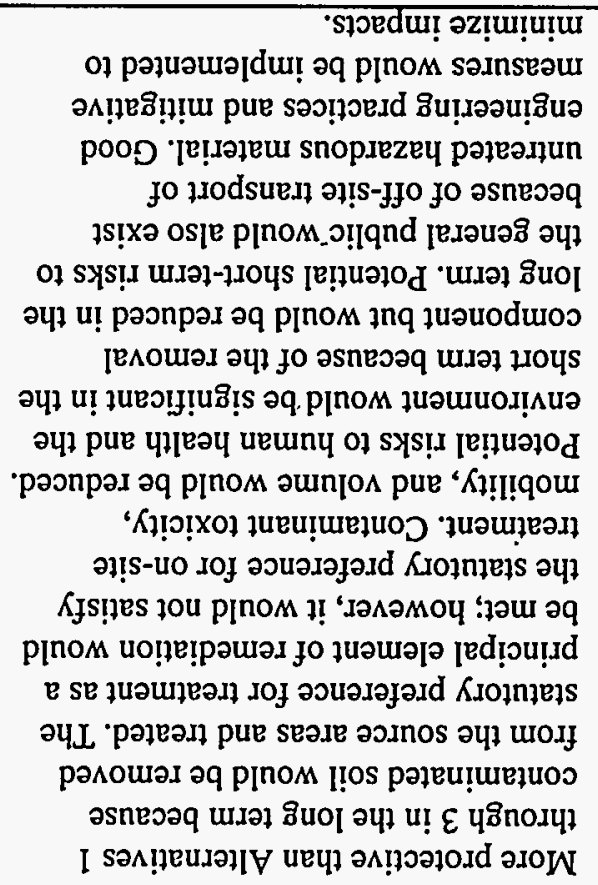 & 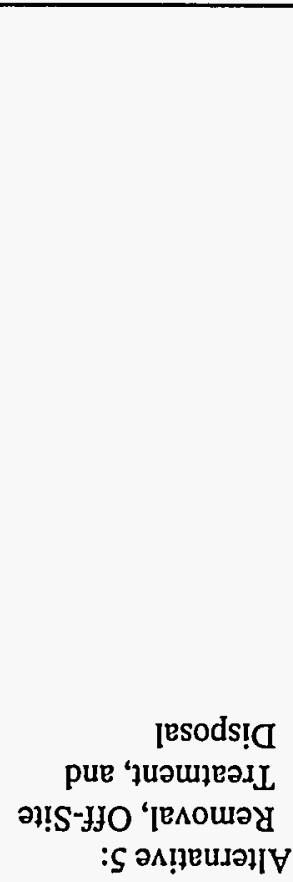 \\
\hline 7 SOD & 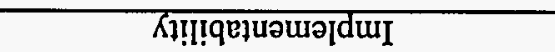 & 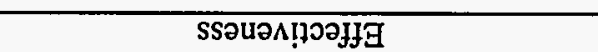 & 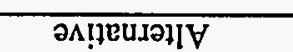 \\
\hline
\end{tabular}

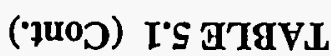




\section{DESCRIPTION OF FINAL ALTERNATIVES}

Five interim remedial action alternatives for the J-Field TBP area main pits and pushout area were retained through the screening process:

- Alternative 1: No Action;

- Alternative 2: Limited Removal and Disposal, and In-Situ Containment;

- Alternative 3: Removal and Short-Term Storage;

- Alternative 4: Removal, On-Site Treatment, and Limited Disposal; and

- Alternative 5: Removal, Off-Site Treatment, and Disposal.

The components of these alternatives are described in Sections 6.1 through 6.5. Under Alternative 2, contaminated soil would be contained in place with a protective cover. Under Alternative 3, contaminated surface soil would be removed through excavation and placed in a shortterm storage facility. Under Alternatives 4 and 5, contaminated surface soil would be removed through excavation and treated (either on-site or off-site). Treated soil under Alternative 4 would be returned to the site to be used as fill (pending a treatability variance or CERCLA waiver as described in Section 3.2) or disposed of as nonhazardous waste. Metal scrap and metals recovered from the soil washing and leaching processes would be sent to an off-site smelter, and PCB-contaminated soil would be sent to an off-site treatment and disposal facility. Under Alternative 5, all contaminated soil would be sent off-site for disposal. Because contaminated soil would remain on-site under Alternatives 2 and 3, shoreline stabilization would be an additional component as a measure to control erosion of the peninsula south of the TBP area. Engineering procedures and equipment presented in the following sections are provided to compare the feasibility of the alternatives. Final design components, procedures, and equipment selection will be developed during the remedial design phase and will incorporate information developed during the course of detailed design.

\subsection{ALTERNATIVE 1: NO ACTION}

The no-action alternative is included as a final alternative to provide a baseline for comparison with the action alternatives. Under this alternative, no action would be taken at the TBP area, and contaminated surface soil would remain in place. Institutional control measures (described in Section 4.2.1), including access restriction, ownership and use or deed restrictions, and monitoring, would remain in effect at the area. 


\subsection{ALTERNATIVE 2: LIMITED REMOVAL AND DISPOSAL, AND IN-SITU CONTAINMENT}

\subsubsection{Limited Removal}

Under Alternative 2, approximately $400 \mathrm{yd}^{3}$ of contaminated surface soil would be removed from the two main pits, and the 5-acre area encompassing the main pits and pushout areas would be contained in place (Figure 6.1). An estimated $350 \mathrm{yd}^{3}$ of arsenic-contaminated soil would be removed from the northern main pit. The removal would include excavation of soil containing arsenic levels that exceed the EPA Region III noncarcinogenic, industrial risk-based concentration of $610 \mathrm{mg} / \mathrm{kg}$. Confirmation samples would be collected in unexcavated soil to determine whether arsenic has been removed to levels below this criterion.

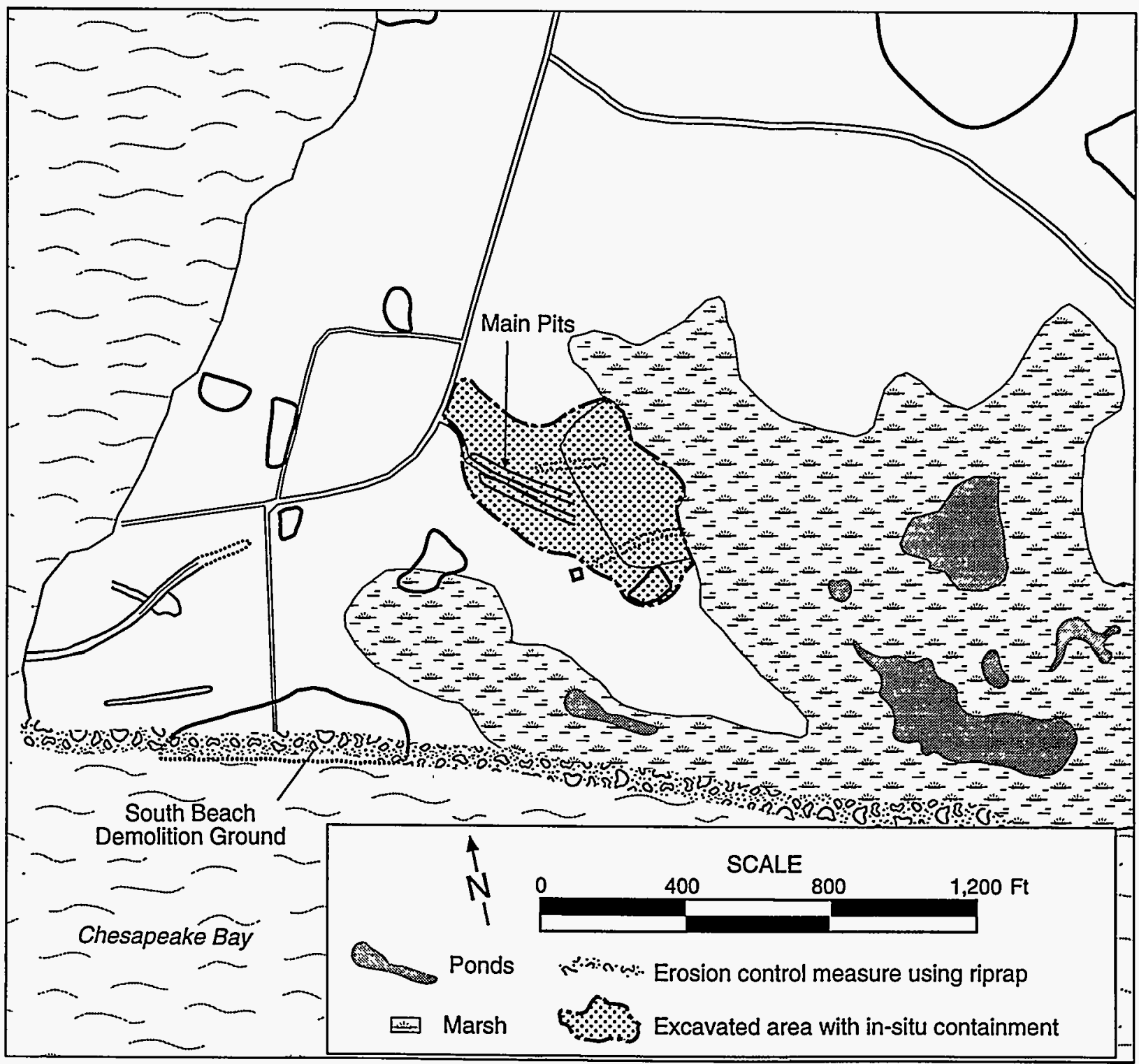

FIGURE 6.1 Location of In-Situ Containment Area and Shoreline Stabilization, Alternative 2 
At the southern main pit, arsenic concentrations were below the risk-based concentration of $610 \mathrm{mg} / \mathrm{kg}$. However, PCBs (Aroclor 1248) were detected at a concentration of $143 \mathrm{mg} / \mathrm{kg}$ in a sample collected at a depth of $2 \mathrm{ft}$ from boring JBP1-E, which is at the western section of the pit (see Figure D.6). Soil would be excavated at this boring. Confirmatory analyses would be performed on the unexcavated soil to ensure that PCB concentrations were below the ARAR value of $50 \mathrm{mg} / \mathrm{kg}$. It is estimated that about $17 \mathrm{yd}^{3}$ of PCB-contaminated soil would be removed from the southern main pit. The site would be prepared by personnel performing a visual UXO inspection of the excavation area, grubbing and clearing vegetation in the excavation area, constructing a temporary staging area, and improving existing access roads. A work zone would be designated with temporary fencing. Access routes would be established by relying on the U.S. Army's ordnance avoidance procedures. After excavation activities were completed, the areas would be backfilled with clean soil and prepared for the emplacement of the protective cover.

\subsubsection{UXO Screening}

The UXO screening effort for Alternative 2 would consist of visually inspecting the two main pits and conducting a UXO survey along the southern shoreline of the Gunpowder Neck Peninsula where erosion control measures would be implemented. The UXO survey for the main pits does not include the use of metal detection devices because the amount of buried metal debris is expected to be high. A UXO supervisor, however, would be on-site throughout the remediation effort. The survey of the shoreline would be conducted by a two-man UXO clearance team with handheld excavation tools, active electromagnetic induction detectors, and passive ferromagnetic detectors. The total area to be surveyed would be $24,000 \mathrm{ft}^{2}$ ( $8 \mathrm{ft}$ wide by $3,000 \mathrm{ft}$ long), to a depth of $2 \mathrm{ft}$ below the surface.

As metal contacts were identified, the following activities would be carried out:

- Explosive-, chemical-, propellant-, or pyrotechnic-loaded UXO would be marked with a yellow survey marker; work would cease; and Emergency Notification Procedures would be implemented immediately; and

- Nonexplosive-loaded ordnance components, including armor-piercing projectiles, empty ejection munitions, and spent rocket motors (separated from warheads), and nonexplosive-loaded training munitions would be segregated for pickup by the U.S. Army Technical Escort personnel.

Other metal debris that is not ordnance-related would not be removed. 


\subsubsection{Site Preparation}

Following the initial UXO survey, site preparation activities would begin, including grubbing and clearing vegetation, constructing a temporary staging area, and improving existing access roads. Vegetation, which consists mainly of grass and Phragmites, would be removed from the entire 5-acre area. The access road would be repaired and resurfaced. The final surfacing of the road would occur after the remediation of the main pit areas is completed and all equipment is demobilized. Construction and improvement of roads would require the placement of $525 \mathrm{yd}^{3}$ of fill and gravel obtained from an off-site location.

\subsubsection{Excavation}

At the northern main pit, $2 \mathrm{ft}$ of soil would be removed from the entire pit (approximately $350 \mathrm{yd}^{3}$ ). An additional $10 \mathrm{yd}^{3}$ from boring TBPNPBOR1 would be removed because the arsenic concentration $(2,290 \mathrm{mg} / \mathrm{kg})$ in a sample collected from a depth of $4 \mathrm{ft}$ exceeds the industrial riskbased concentration. At the southern main pit, $17 \mathrm{yd}^{3}$ would be excavated from boring JBP1-E because Aroclor 1248 was detected at a concentration of $143 \mathrm{mg} / \mathrm{kg}$.

\subsubsection{Mitigation and Monitoring}

During remediation activities, good engineering practices and mitigative measures would be implemented to control both contaminant releases and potential exposures to workers and the general public. All workers engaged in soil removal activities would be required to wear an appropriate level of personal protective equipment. Work zones would be clearly delineated and monitored to ensure worker safety. Equipment and personnel would be decontaminated before leaving the area. Monitoring and mitigative measures for Alternative 2 are summarized in more detail in Section 7.6. Erosion control measures to be implemented include engineering the soil cover as a berm along the pushout-marsh boundary.

\subsubsection{Disposal}

Soil from the northern main pit would be placed directly into 20 -yd $\mathrm{d}^{3}$ rolloffs. Approximately 20 rolloffs would be required for disposal of arsenic-contaminated soil. PCBcontaminated soil would likely be containerized in 55-gal U.S. Department of Transportation(DOT-) and TSCA-approved drums. Approximately 68 drums would be needed for containerizing the excavated soil. One trailer would be required for transportation off-site. If PCB-contaminated soil is required to be incinerated and containerized, a temporary staging area would be constructed in the work zone. Because the PCB-contaminated soil meets the definition of PCBs and PCB items 
that may be stored temporarily for up to 30 days [40 CFR 761.65 (c)(I)(iii)], design specifications of PCB storage areas are not required [40 CFR 761.65(c)(I)].

Soil in the northern main pit has been characterized as Toxicity Characteristic for Lead (D008) under RCRA. The soil would require stabilization prior to land disposal. In addition, because the soil is from a National Priorities List (NPL) site, the soil must be disposed of at a facility that can accept CERCLA wastes. Soil from the northern main pit would be transported to a RCRA Subtitle C Landfill for stabilization and final disposal.

Soil in the southern main pit would be containerized in 55-gal drums and transported to a TSCA-approved incinerator. If the moisture content and PCB concentrations are low (i.e., below $500 \mathrm{ppm}$ ), the PCB-contaminated soil can be disposed of in a chemical waste landfill that meets the requirements of $40 \mathrm{CFR} 761.75$.

Remediation-derived wastes, such as personal protection equipment, decontamination water, debris, and scrap metal, would be characterized and disposed of accordingly (e.g., incineration, stabilization). Because remediation-derived wastes that are RCRA-hazardous would not be stored on-site for more than 90 days, the generator is not required to construct a storage facility that meets the standards of 40 CFR Parts 264 or 265, and the generator is not required to meet the permit requirements of 40 CFR Part 270. Likewise, because remediation-derived wastes that are regulated under TSCA because of PCB concentrations are not expected to be stored on-site for more than 30 days, the generator is not required to construct a PCB storage facility that meets the standards of 40 CFR 761.65(c)(I). The number of 55-gal drums for disposal of remediationderived waste is not expected to exceed 20.

\subsubsection{In-Situ Containment}

Once the excavation was completed, the excavated areas would be backfilled with clean soil. The backfill soil would be tested to ensure that it is "clean" prior to use. The 5-acre $\left(218,000-\mathrm{ft}^{2}\right)$ area would be covered with geotextile fabric and then clean soil to an elevation of just about the 100-year floodplain $(7.5 \mathrm{ft}$ ), compacted (by standard construction equipment), regraded, covered with topsoil, and seeded (the end result would be a natural grass habitat).

\subsubsection{Shoreline Stabilization}

Shoreline stabilization would include removing debris from the shoreline and placing a fabric liner and riprap over an area $8 \mathrm{ft}$ wide by $3,000 \mathrm{ft}$ long along the southern shoreline (Figure 6.1). After the area has been surveyed for UXO, riprap would be transported by truck to the shore via the unnamed road that extends south from Robins Point Road to the South Beach 
Demolition Ground. Front-end loaders (or comparable equipment) would be used to place riprap along the shoreline. The trucks would drive over the riprap to compact it into the sand as the wall is built along the shoreline.

\subsection{ALTERNATIVE 3: REMOVAL AND SHORT-TERM STORAGE}

\subsubsection{Removal}

Under Alternative 3, approximately $16,000 \mathrm{yd}^{3}$ of contaminated surface soil would be removed from the two main pits and pushout area to achieve permanent source control and long-term protection of human health and the environment (Figures 3.1 and 3.2). Removal activities would be carried out with standard construction equipment and procedures. Removal activities at the TBP area would begin with a visual surface UXO survey; subsurface UXO surveys would be conducted as required. The site would be prepared by grubbing and clearing vegetation, constructing and/or improving access roads, and extending electric service to the storage facility location. A work zone would be designated with temporary fencing. Access routes would be established by relying on the U.S. Army's ordnance avoidance procedures.

\subsubsection{UXO Screening}

The work zone would be surveyed for UXO in the upper 2 to $4 \mathrm{ft}$. The total area to be surveyed would be $218,000 \mathrm{ft}^{2}$. The survey would be conducted by two-man UXO clearance teams with handheld and mechanical excavation tools, active electromagnetic induction detectors, and passive ferromagnetic detectors.

As metal contacts were identified and removed from the excavation area, the following activities would be carried out:

- Explosive-, chemical-, propellant-, or pyrotechnic-loaded UXO would be marked with a yellow survey marker; work would cease; and Emergency Notification Procedures would be implemented immediately;

- Nonexplosive-loaded ordnance components, including armor-piercing projectiles, empty ejection munitions, and spent rocket motors (separated from warheads), and nonexplosive-loaded training munitions would be segregated for pickup by the U.S. Army Technical Escort personnel; and 
- Miscellaneous metallic debris would be collected, drummed, and stored at the Prototype Building until it was shipped to an off-site smelter.

Metal contacts would be marked and removed at each depth interval. Removal of metal contacts might proceed during soil excavation to limit "double handling" of the soil.

\subsubsection{Site Preparation}

Following the initial UXO survey, site preparation activities would begin, including clearing and grubbing vegetated areas, constructing access roads and staging areas, and extending electric service to the site. Site preparation would require clearing and grubbing an estimated 5 acres $\left(218,000 \mathrm{ft}^{2}\right)$ of vegetation. Construction and improvement of access roads connecting the excavation area with the storage facility would require clearing an area of about $15,000 \mathrm{ft}^{2}(15 \mathrm{ft}$ by $1,000 \mathrm{ft}$ ). Construction of roads would require placing approximately $525 \mathrm{yd}^{3}$ of fill and gravel base obtained from an off-site location. Vegetation, which consists mainly of grass and Phragmites, would be removed from these areas, drummed, and characterized to determine appropriate handling. Electric service would be extended to J-Field; power needs for the storage facility would be $440 \mathrm{~V}$ at 580 $600 \mathrm{~kW}$.

\subsubsection{Excavation}

Excavation and transport of the soil from the TBP area would be accomplished by using standard earthmoving equipment. After excavation, soil would be placed in trucks and transported to the storage facility. A fleet of three trucks, each with a $32-\mathrm{yd}^{3}$ capacity, would be required. The soil would most likely require dewatering before being loaded onto the trucks. If needed, belt filter presses would be used to dewater soils through a combination of gravity draining and compression between two filter cloth belts. The water resulting from this process would be collected and characterized to determine the appropriate method of disposal. Once the excavation activities were completed, the excavated pit would be backfilled with clean soil. Backfilling activities might be necessary intermittently as the excavation proceeds to prevent sidewall collapse and water infiltration. Additional clean soil would be brought in from off-site to be used as backfill as necessary. The excavated area would be regraded, covered with topsoil, and seeded.

\subsubsection{Mitigation and Monitoring}

During remediation activities, good engineering practices and mitigative measures would be implemented to control both contaminant releases and potential exposures to workers and the general public. All workers engaged in soil removal activities would be required to wear an 
appropriate level of personal protective equipment. Work zones would be clearly delineated and monitored to ensure worker safety. Equipment and personnel would be decontaminated before leaving the area. Monitoring and mitigative measures for Alternative 3 are summarized in more detail in Section 7.6. Dust control measures would include spraying water, covering stockpiles, and covering loads during transport. Erosion control measures would be used to mitigate impacts to both the air and surface water. For air, these measures would include wetting loose material and minimizing construction stockpiles; for surface water, these measures would include isolating work areas with berms, covering stockpiles, and possibly using temporary vegetative covers. An air monitoring program would be implemented for the period of the remediation activities. Biomonitoring would also be employed to assess the impact of excavation activities on biota in the adjacent marsh.

\subsubsection{Storage Facility Construction}

The excavated soil would be stored in an area adjacent to the Prototype Building (Figure 6.2) in a building consisting of fabric-covered steel arch trusses. Buildings of this type are relatively inexpensive, are durable enough for extended time periods, and can be erected quickly. In addition, they can cover a large area free of interior supports, are weather tight, and can be easily dismantled. A liner and leachate collection system would probably be needed to meet the RCRA waste pile regulations. The design of this type of structure could be patterned after a design for a similar soil storage project performed by the U.S. Army Corps of Engineers in Winfield, West Virginia. The foundation of the storage building would consist of a bottom layer of $3 \mathrm{ft}$ of impermeable clay, a leachate collection system, and a type $\mathrm{K}$ concrete pad $1 \mathrm{ft}$ thick with an area of about $48,000 \mathrm{ft}^{2}$ for $16,000 \mathrm{yd}^{3}\left(25,000 \mathrm{ft}^{2}\right.$ for $\left.4,000 \mathrm{yd}^{3}\right)$. Concrete barriers (like those used for highway median dividers) would be placed around the inside perimeter to protect the walls from the trucks and bulldozers piling the soil, and an air scrubber system would be installed to filter any VOCs emitted during the storage period. An excavation of about $5 \mathrm{ft}$ would be needed to accommodate the foundation required for the storage facility. The soil removed from this excavation could then be used to backfill the excavated contaminated area.

\subsubsection{Shoreline Stabilization}

Shoreline stabilization would include removing debris from the shoreline and placing a fabric liner and riprap over an area $8 \mathrm{ft}$ wide by 3,000 $\mathrm{ft}$ long along the southern shoreline (Figure 6.1). After the area has been surveyed for UXO, riprap would be transported by truck to the shore via the unnamed road that extends south from Robins Point Road to the South Beach Demolition Ground. Front-end loaders (or comparable equipment) would be used to place riprap along the shoreline. The trucks would drive over the riprap to compact it into the sand as the wall is built along the shoreline. 


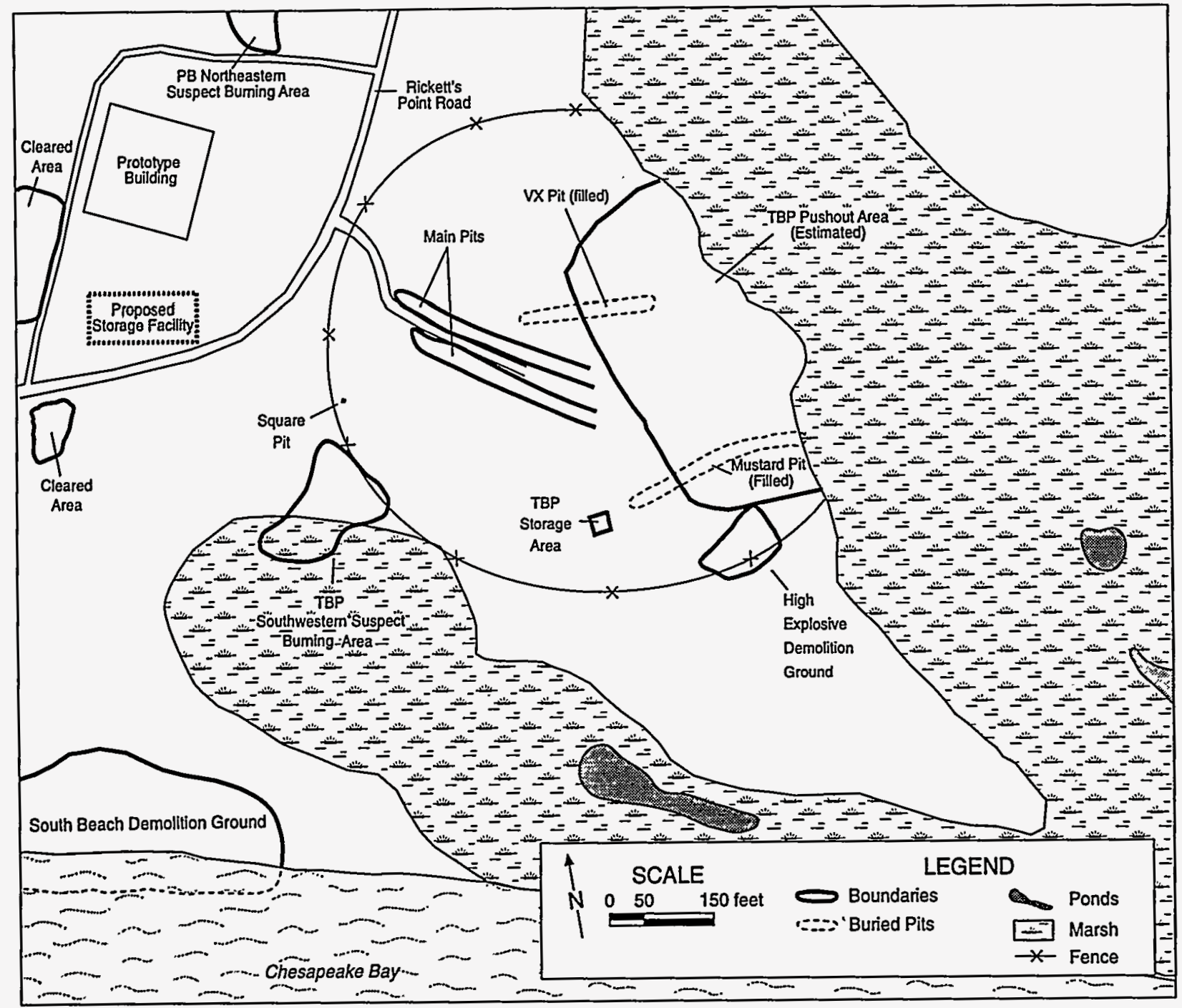

FIGURE 6.2 Location of Fenced Work Zone and Proposed Storage Facility, Alternative 3

\subsection{ALTERNATIVE 4: REMOVAL, ON-SITE TREATMENT, AND LIMITED DISPOSAL}

\subsubsection{Removal}

Under Alternative 4, contaminated surface soil would be removed to a depth of $2 \mathrm{ft}$ from the two main pits and pushout area in the same manner as described for Alternative 3 (Section 6.2.1). The area to be excavated is shown in Figures 3.1 and 3.2. Electric service would be extended to J-Field; power needs for a $15 \mathrm{ton} / \mathrm{h}$ soil washing/leaching facility would be $440 \mathrm{~V}$ at $580-600 \mathrm{~kW}$. A temporary staging area for excavated soil would be constructed in the work zone. Contaminated soil awaiting treatment would be stockpiled on a bermed and drained concrete or asphalt pad (about 
$48,000 \mathrm{ft}^{2}$ ) and covered with plastic laminate to control dust and vapor emissions. Treated soil would be staged at a separate location (in the clean zone) until analytical testing was performed to verify that treatment goals had been achieved. The pad would be decontaminated following remedial activities and would remain in place at the site. Once the excavation and treatment activities were completed, the excavated pit would be backfilled with clean soil. The excavated area would be regraded, covered with topsoil, and seeded.

\subsubsection{On-Site Treatment}

\subsubsection{Metals- and Semivolatile-Contaminated Soil}

Under Alternative 4, a soil washing/leaching facility would be constructed on-site to treat all contaminated soils except those contaminated with PCBs. The approximate location of the facility is shown in Figure 6.3. The facility would be constructed on a concrete pad, about 100 by $200 \mathrm{ft}$ in area. This area would require clearing and grading before the concrete foundation and necessary utilities (i.e., electricity) are installed. Water used in the process would be trucked to the site.

The soil washing/leaching facility would be used to treat metals- and semivolatilecontaminated soils (approximately $16,000 \mathrm{yd}^{3}$ ) by (1) physically separating metallic fragments; (2) physically separating soil into various size fractions (coarse sand and gravel, fine sand, and silt and clay); (3) chemically removing metals bound to sand, silt, and clay; and (4) precipitating metals out of the wash for recovery. PCB-contaminated soil, if found, would be excavated and sent off-site for treatment and disposal (see Section 6.4.2.2). The preliminary conceptual design of the soil washing/leaching facility (Figure 6.4) is based on a bench-scale study that used J-Field TBP area soil (ART 1995).

The treated soil product would be placed in a pile located adjacent to the treatment plant. Treated soil would be sampled and analyzed to ensure that treatment goals had been met. Soil failing analysis might be reprocessed. Soil meeting treatment goals would be either returned to the excavated area once all excavation activities were completed (pending a treatability variance or CERCLA waiver) or disposed of as nonhazardous waste.

Delivery trucks would travel on clean access roads to eliminate the need for vehicle decontamination. Vehicles would be decontaminated, as required, before leaving the work zone.

Operation of the soil washing/leaching facility would require supervision, laborers, and laboratory and maintenance personnel. The soil washing/leaching plant would operate for 8 months, assuming a throughput of 15 tons per hour and 6-day work weeks (10-hour shifts). 


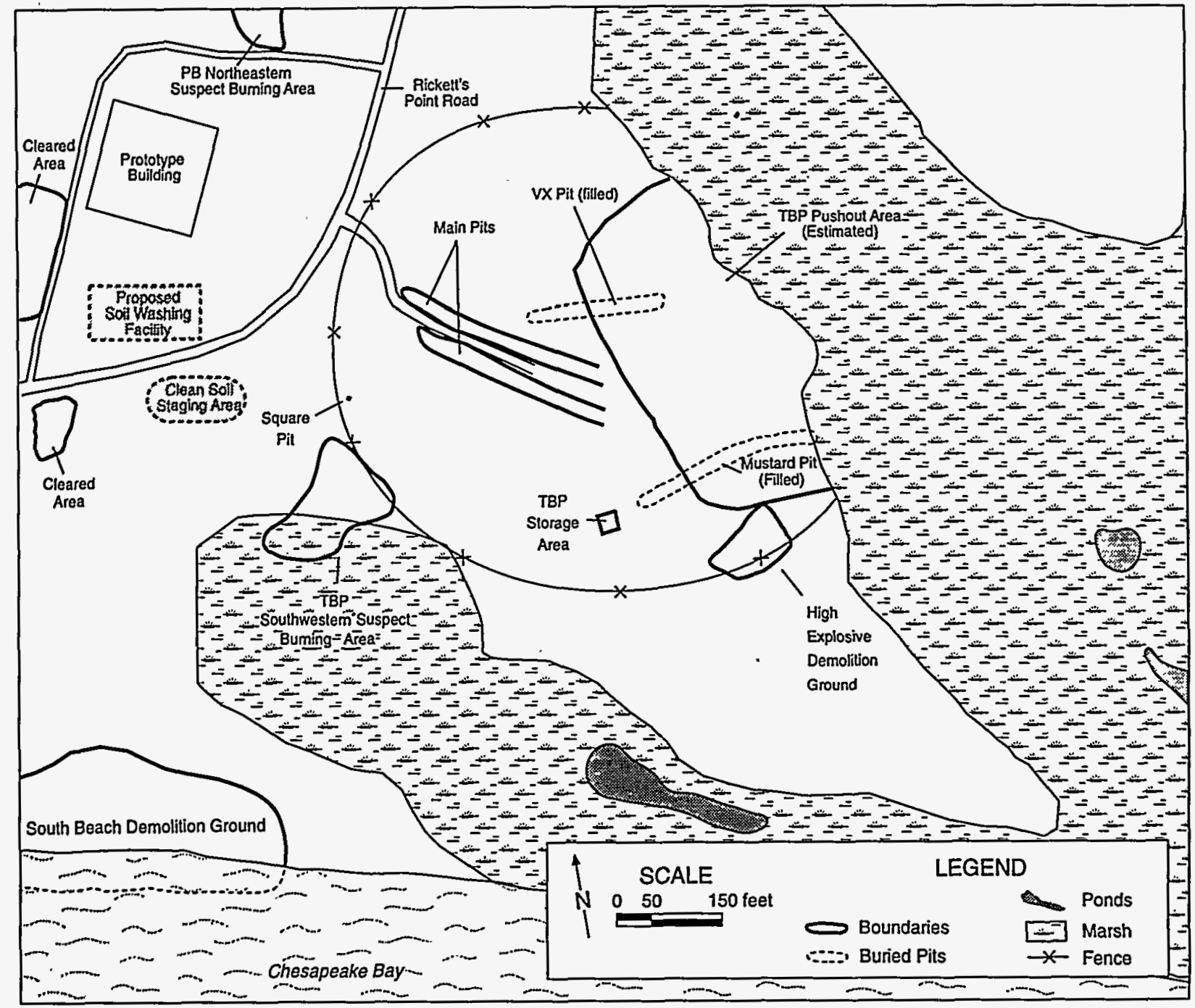

FIGURE 6.3 Location of Fenced Work Zone and Proposed Treatment Facility and Staging Area, Alternative 4

All processing equipment would be contained within the facility area (built on a concrete pad). Air emissions from the facility would be minimized through the use of emission control equipment, such as carbon absorption units. Because of these engineering controls, airborne emissions from the plant would be expected to be very low.

Support facilities would also be maintained on-site to provide potable water, portable sanitary facilities, and offices for the construction management staff. The soil washing/leaching plant would be dismantled at the end of the interim remedial action period and decontaminated for reuse. Process wash water would be sent to a sanitary wastewater treatment facility. 


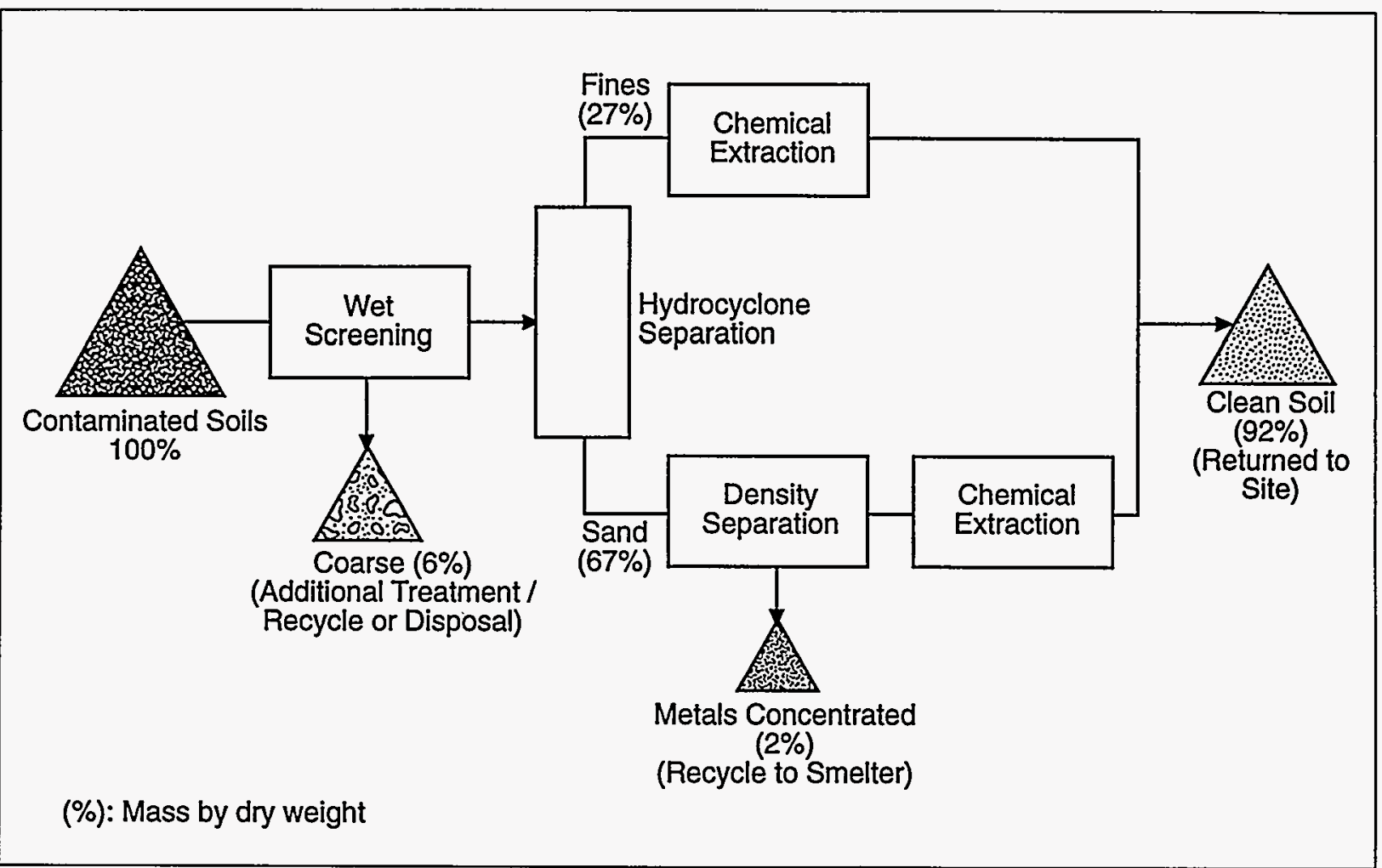

FIGURE 6.4 Process Flowchart for the Soil Washing/Leaching Facility (Source: Modified from ART 1995)

\subsubsection{PCB-Contaminated Soil}

PCB-contaminated soil, if present, would likely be containerized in 55-gal DOT- and TSCA-approved drums. If PCB-contaminated soil were required to be incinerated and containerized, a temporary staging area would be constructed in the work zone. Because the PCB-contaminated soil meets the definition of PCBs and PCB items that may be stored temporarily for up to 30 days [40 CFR 761.65(c)(I)(iii)], design specifications of PCB storage areas are not required [40 CFR 761.65(c)(I)].

\subsubsection{Limited Disposal}

All disposal activities would take place at an off-site facility. Under Alternative 4, PCBcontaminated soil would be sent off-site for treatment and disposal immediately following excavation and characterization. 
Other disposal activities would include shipping metal scrap and recovered metals (from the treatment process) to an off-site smelter to be recycled.

\subsection{ALTERNATIVE 5: REMOVAL, OFF-SITE TREATMENT, AND DISPOSAL}

\subsubsection{Removal}

Under Alternative 5, contaminated surface soil would be removed from the two main pits and pushout area in the same manner as described for Alternative 3 (Section 6.2.1). The area to be excavated is shown in Figures 3.1 and 3.2. A temporary staging area for excavated soil would be constructed in the work zone.

\subsubsection{Off-Site Treatment and Disposal}

Under Alternative 5, all excavated soil from the TBP area would be sent off-site for treatment and disposal. Following excavation, soil would be stockpiled at a temporary staging area to await loading. Hauling trucks would be decontaminated before leaving the work zone. Soils would be treated by stabilization, then disposed of in a Subtitle C landfill. PCB-contaminated soil would require stabilization or incineration, depending on the concentrations. 


\section{DETAILED EVALUATION OF ALTERNATIVES}

The EPA has identified nine criteria in the NCP that must be evaluated for each alternative retained through the screening stage [Section 300.430(e)(9)(iii)]. The criteria are explained as follows.

1. Overall protection of human health and the environment. Addresses protection from unacceptable risks in both the short term and the long term by minimizing exposures, in accordance with the purpose and objectives of the proposed action described in Section 3. Because of its broad scope, this criterion also reflects the focus of criteria 2 through 5 .

2. Compliance with ARARs. Addresses the attainment of federal and state environmental requirements determined to be either applicable or relevant and appropriate to the alternative on the basis of site-specific considerations. Potential ARARs are listed in Appendix B.

3. Long-term effectiveness and permanence. Addresses residual risks (i.e., those risks remaining after completion of a remedial action). EPA guidance states that it is usually sufficient to indicate whether an alternative has the potential to achieve the PRGs and not necessary to quantify the risk that would remain after the alternative was implemented (EPA 1991c).

4. Reduction of contaminant toxicity, mobility, and volume. Addresses the degree to which treatment is used to address the principal threat(s) at the TBP area; the amount of material treated; the magnitude, significance, and irreversibility of the given reduction; and the nature and quantity of treatment residuals.

5. Short-term effectiveness. Addresses the potential impacts of implementing the alternative to site workers, the general public, and the environment during the action period; the effectiveness and reliability of mitigative measures; and the time required to achieve protectiveness.

6. Implementability. Addresses technical feasibility, including the availability and reliability of required resources (such as specific technologies, materials and equipment, facility capacities, and skilled workers), the ease of implementation, and the ability to monitor effectiveness. This criterion also addresses administrative feasibility. 
7. Cost. Addresses both capital costs and annual operation and maintenance costs. Costs for the individual components of the alternatives are also considered. Costs presented for Alternative 1, 3, 4, and 5 were estimated by using the Remedial Action Cost Engineering and Requirements System (RACER). Costs for Alternative 2 were developed by ICF Kaiser Engineers, Inc. Details concerning the structure of the cost estimates and assumptions used are discussed in Appendix F.

8. State acceptance. Addresses the comments made by the State of Maryland on the alternatives being considered for site remediation. Because the state's comments will not be received until after this report has been issued for public review, the state acceptance criterion will be addressed in the ROD.

9. Community acceptance. Addresses the comments made by the community on the alternatives being considered. Because public comments will not be received until after this report has been issued for public review, the community acceptance criterion will be addressed in the ROD.

Five alternatives (Alternatives 1, 2,3,4, and 5) were retained through the screening process presented in Section 5. Section 6 describes these final alternatives. Each alternative is evaluated in detail in the following subsections on the basis of criteria 1 through 7 . In each subsection, the evaluation of an alternative against these seven criteria is organized to follow the order in which the criteria are listed in the NCP (EPA 1990a). A comparative analysis is presented in Section 8.

\subsection{ALTERNATIVE 1: NO ACTION}

\subsubsection{Overall Protection of Human Health and the Environment}

Alternative 1 would not be protective of human health and the environment over the long term. Under this alternative, the site would continue to be managed as it has been in the past. Current institutional controls, such as restricted access and monitoring, would continue to be implemented. Exposure of biota to surface soil contaminants would continue, as would the potential for exposure of site workers. Under the no-action alternative, contaminant source areas would not be removed or treated and exposures could increase over time, leading to potential adverse environmental impacts. Results of the J-Field ERA (Hlohowskyj et al. 1996) indicate that ecological resources at the TBP area are heavily impacted by past activities and current levels of contamination. The current levels of contamination also pose a risk to wildlife species at J-Field. These impacts and risks would continue under the no-action alternative. 


\subsubsection{Compliance with ARARs}

Potential regulatory requirements that might be applicable or relevant and appropriate to the interim remedial action alternatives are identified and evaluated in Appendix $B$. Under the no-action alternative, some ARARs would not be met. For example, although RCRA disposal site requirements and LDRs are not applicable under the no-action alternative (because no movement or placement of soil would occur and no waste was placed in J-Field after 1979) (Office of Solid Waste and Emergency Response [OSWER] Directive 9234.1-01, August 8, 1988), they may be relevant and appropriate if the problem to be addressed (i.e., migration of hazardous waste constituents into the environment) is sufficiently similar. In addition, because the remediation at J-Field is being performed under the joint authority of CERCLA and RCRA (EPA and U.S. Department of the Army 1990), under Alternative 1, TBP area soil contaminated with RCRA characteristic hazardous wastes (e.g., lead), and possibly RCRA-listed hazardous wastes, would not meet the corrective action requirement under RCRA. Also, the TSCA cleanup policy (a TBC for J-Field), which requires that PCB-contaminated soil in restricted access areas be cleaned to less than $25 \mathrm{ppm}$, would not be met.

The no-action alternative also fails to meet the CERCLA-mandated preference for remedies that reduce contaminant toxicity, mobility, or volume through treatment [CERCLA Section 121(b)(1)].

\subsubsection{Long-Term Effectiveness and Permanence}

Alternative 1 would not be protective of human health and the environment over the long term. Under this alternative, maintenance and monitoring activities would be carried out for an indefinite period. Existing institutional controls would continue to limit access to site workers and other authorized personnel, thus reducing risk to the general public. However, exposures to the general public could occur through unauthorized entry. Exposures to biota and risks associated with these exposures would continue at current levels; adverse ecological impacts would be expected with long-term exposure to surface soil contamination. In addition, contaminant levels in the marsh adjacent to the pushout area could increase because of transport of contaminated material via surface water runoff, resulting in increased risks to biota in the marsh over time.

\subsubsection{Protection of Human Health}

Workers would be on-site periodically to carry out monitoring (e.g., toxicity testing in the marsh) and maintenance activities (e.g., mowing); the risks to workers involved in these activities are considered to be low. Because the site is restricted, potential impacts to members of the general public over the long term are also considered to be low (ICF Kaiser Engineers 1994b, 1995a). 


\subsubsection{Environmental Protection}

Under Alternative 1, the level of contamination and risks to biota in terrestrial and aquatic habitats in the long term would be similar to current levels; however, these levels might increase over time as a result of contaminant transport via surface water runoff.

\subsubsection{Reduction of Toxicity, Mobility, or Volume}

Reduction of toxicity, mobility, or volume through treatment is not applicable to Alternative 1 because it does not involve treatment.

\subsubsection{Short-Term Effectiveness}

\subsubsection{Protection of Human Health}

Under Alternative 1, existing institutional controls would continue to limit access to site workers and other authorized personnel, thus reducing risks to the general public. However, exposures to the general public could occur through unauthorized entry. Short-term risks to workers involved in monitoring and maintenance activities are considered to be low (ICF Kaiser Engineers 1994b).

\subsubsection{Environmental Protection}

Under Alternative 1, protection of the environment would be minimal. The level of contamination and risks to biota in terrestrial and aquatic habitats in the short term are considered to be significant as indicated by the results of the J-Field ERA (Hlohowskyj et al. 1996). Short-term risks to the environment as a result of monitoring and maintenance activities are considered to be low.

\subsubsection{Implementability}

Minimum site operations would continue with use of readily available resources for monitoring and maintenance activities. 


\subsubsection{Cost}

Costs for Alternative 1 are associated with continuing the environmental monitoring program and maintenance activities (e.g., mowing). Estimated total annual costs for Alternative 1 would be about $\$ 300,000$.

\subsection{ALTERNATIVE 2: LIMITED REMOVAL AND DISPOSAL, AND IN-SITU CONTAINMENT}

\subsubsection{Overall Protection of Human Health and the Environment}

Alternative 2 would be protective of human health and the environment over the short term. Under this alternative, local "hot spots" of contamination (in particular, arsenic and PCBs) would be removed from the two main pits and the excavation areas would be backfilled. Following the limited removal and backfilling, surface soils in the main pits and pushout areas would be contained in place with a protective cover of soil (see Section 6.2). Exposures of biota to surface contaminants would be reduced, as would the potential for exposure of site workers and the general public.

\subsubsection{Compliance with ARARs}

Alternative 2 would comply with pertinent ARARs and TBCs, with waivers as appropriate. Location-specific ARARs and TBCs address the protection of historic sites, archeological and cultural resources, endangered species and habitats, floodplains, and wetlands. No impacts to archeological and cultural resources are expected because the area to be remediated has been subject to disturbances on a massive scale, including open burning/open detonation of high explosives and wastes, plowing, excavation of soil from large areas, and disposal of a variety of hazardous wastes. Because the pushout area, in effect, filled in existing wetlands, removal of soil from the pushout area as part of this alternative could be viewed as a wetland mitigative measure.

No critical habitats have been identified at the TBP area. Most of the area to be addressed by Alternative 2 is located within the 100-year floodplain (FEMA 1986) and borders wetlands. To address the contamination present at the site, wetlands and a portion of the 100-year floodplain would have to be disturbed, and adjacent wetlands could be affected. Mitigative measures may be required, such as wetland replacement.

Action-specific ARARs address the protection of water, sediment, soil, watersheds, and air during implementation of the remedial action. Alternative 2 would involve limited soil movement and covering; state regulations related to sediment and erosion control would apply (Water 
Management 4[1] and 4[2]). Installation of the soil protective cover may require the preparation of a sediment and erosion control plan (Water Management 25[09:1] and [09:2]).

Some of the soil excavated at the site may meet the regulatory definition of characteristic waste (e.g., toxic for lead) as determined by the TCLP test. In addition, Maryland lists the following as acute hazardous wastes: CWA, waste CWA, mixtures of any of these substances and any characteristic or listed hazardous waste, and residues from treatment of CWA listed wastes. Because the TBP area was used for the disposal of CWA and CWA treatment residues, soil excavated from the site may be considered a listed acute hazardous waste (i.e., if it contains CWAs listed by Maryland). However, no CWAs have been detected in the TBP area soils to date.

Soil excavated from the southern main pit would likely contain detectable concentrations of PCBs. Because a number of samples from the southern main pit contained soil with PCB concentrations greater than $50 \mathrm{mg} / \mathrm{kg}$ (the regulatory "trigger" requiring implementation of the TSCA PCB handling regulations), the soil generated during the excavation of the southern main pit may have to be handled according to TSCA regulations. Areas contaminated with PCBs may have to be remediated to satisfy the PCB spill cleanup policy for a contaminant-specific TBC. However, as stated in the policy, PCB contamination resulting from historical spills is to be decontaminated to levels established at the discretion of EPA regional offices. Because EPA Region III is involved in the regulatory review and public participation process for this FFS, this PCB TBC would be satisfied.

State regulations related to air releases would also be action-specific ARARs. Particulate matter and VOCs would have to be controlled during earthmoving activities in accordance with Maryland requirements (Air Quality 26[11:1], 26[11:3], and 26[11:6]).

Appropriate permits would have to be obtained from the U.S. Army Corps of Engineers before the riprap berm could be constructed along the southern shoreline of the Gunpowder Neck Peninsula.

\subsubsection{Long-Term Effectiveness and Permanence}

Alternative 2 would be protective of human health and the environment over the long term. Under this alternative, contaminated surface soil from the main pits and pushout area would be contained in place with a "risk-reduction cover," and maintenance activities would continue. Monitoring activities would be conducted to assess the effectiveness and potential impacts of the protective cover. In-situ containment would reduce contaminant mobility (especially via surface water runoff); therefore, potential exposures due to contaminant releases from these source areas into the marsh would be low. Although the potential for downward leaching of contaminants into the 
surficial aquifer would still exist, the flux rate of leaching contaminants is estimated to be fairly slow (see Appendix A).

Shoreline stabilization would be part of this alternative as an erosion control for the southern shoreline of the Gunpowder Neck Peninsula. However, long-term effectiveness may be affected by the potential for flooding because the TBP area is located within the 100-year floodplain (FEMA 1986).

\subsubsection{Protection of Human Health}

Workers would be on-site periodically to carry out monitoring and maintenance activities. Residual risks would be reduced because contaminated soil exceeding cleanup criteria would be contained in place. Long-term exposures of workers and the general public to contaminants would be negligible because contaminated soil would be covered.

\subsubsection{Environmental Protection}

Alternative 2 would result in a significant reduction in contaminant levels and exposures to biota. The in-situ containment of contaminated soil would reduce the potential for transport of contaminants to the nearby marsh and pond via surface water runoff, thereby producing a positive benefit to surface water and wetland resources in the long term. In addition, direct exposures to terrestrial wildlife and threatened and endangered species would also be reduced.

\subsubsection{Reduction of Toxicity, Mobility, or Volume}

Under Alternative 2, about $400 \mathrm{yd}^{3}$ of soil would be removed from the main pits and treated, thereby reducing contaminant toxicity, mobility, and volume in these areas. The in-situ containment component would reduce contaminant mobility via leaching and surface runoff but would not reduce contaminant toxicity or volume.

\subsubsection{Short-Term Effectiveness}

\subsubsection{Duration of Remedial Activities}

Remedial action activities (including limited soil removal and installation of a 2-ft soil cover) under Alternative 2 would be expected to be completed in about 30 days. Monitoring 
activities would take place during and after implementation of the action; maintenance activities would begin after the action was implemented.

\subsubsection{Protection of Human Health}

Short-term risks to site workers and the general public would be significant for Alternative 2, and mitigative measures would need to be employed (see Section 7.6). Excavation of contaminated soil at the TBP area, though not as extensive as that proposed under Alternatives 3 through 5 , is complicated by the possible presence of buried UXO, some of which may contain chemical agents. The health and safety implications of encountering UXOs and CWAs or other chemical contaminants would be addressed in the health and safety plan for the selected alternative. Soil would be excavated using conventional equipment following U.S. Army standard operating procedures.

The release of particulate emissions during excavation would need to be minimized. Although workers could wear respiratory protection, off-site dispersion of contaminated dust could present a health risk to other APG personnel and the general public. Engineering controls would be needed to reduce the air concentrations of CWAs and toxic chemicals released during excavation. The use of enclosures to contain airborne emissions may be required.

Monitoring for chemical agents and hazardous chemicals would also be required during excavation. Continuous personal and work-site monitoring for airborne vapors and particulates is a standard industrial hygiene practice. Even if the highest levels of protective clothing and equipment were used, chemical monitoring would be necessary in the event that personal protective gear malfunctioned or was improperly operated. Personal protective clothing and equipment would also be required to prevent dermal exposure through direct contact with contaminated soil.

Alternative 2 also involves the placement of a 2-ft protective layer of soil over geotextile fabric. Because no ground disturbance would occur as part of this component, a UXO survey would not be required for the in-situ containment component. However, respiratory protection would still be needed to protect workers against particulate inhalation.

\subsubsection{Environmental Protection}

Limited excavation and in-situ containment would disturb approximately 5 acres of soil, vegetation, and wildlife habitat. Soil excavation would disturb less than 0.3 acres, in-situ containment would disturb about 5 acres, and construction and improvement of access roads would disturb an additional 0.3 acres of the TBP area. Adverse impacts associated with these activities include increases in fugitive dust emissions and ambient noise levels and loss of vegetation and wildlife 
habitat at the main pits and pushout areas. The construction of a berm along the pushout-marsh boundary would reduce surface water drainage from the pushout area into the marsh. However, the pushout area accounts for only a small portion of the area draining into the marsh, and impacts from the resulting changes in surface water runoff would be localized and minor. Although the reduction of surface water input into the marsh could result in localized adverse impacts to marsh habitat, the berm would benefit the surrounding marsh ecosystem by reducing the erosion and transport of contaminated soils into the marsh. Air quality and noise impacts could disturb ecological resources near the construction areas, but these impacts would be minor and temporary. Although some loss of vegetation and wildlife habitat is expected, the amount of vegetation and habitat that would be affected is small, none of the areas that would be disturbed contained high-quality habitats or support listed biota, and most of the disturbed areas (77\%) are contaminated and have been identified to pose risk to ecological receptors at the TBP area and at J-Field as a whole.

Placement of riprap along the southern shoreline of J-Field also has potential impacts to ecological resources, although the degree of impacts would depend upon the final design of the riprap structure. Marsh vegetation that is inundated during high tides often serves as refuge and foraging habitat for many fish species, especially smaller species and juveniles of larger species. Construction of a riprap barrier can curtail or prevent access to such areas. Fishery surveys conducted by the U.S. Fish and Wildlife Service off the southern end of J-Field (Robins Point) determined that nursery habitat for striped bass and marginal nursery habitat for Atlantic croaker and white perch exist in this area (Swihart et al. 1994). The impact to fish populations due to loss of access to this area of marsh habitat is unknown, although it would probably be minor. The presence of riprap could benefit some fish species by providing artificial habitat for a number of invertebrate species that could serve as food. There is also a potential benefit from reduction of erosion along the southern shoreline of J-Field because future erosion of contaminated soils in the TBP area could pose an ecological risk to aquatic organisms.

Potential impacts to air quality and noise levels during implementation of Alternative 2 would be temporary and would cease upon completion of all excavation, construction, and restoration activities. In addition, the magnitude of the potential impacts could be mitigated during all phases of Alternative 2 through the use of good engineering practices. For example, siltation fences, berms, and a runoff collection system could be used to control runoff from excavation and construction areas, mufflers could be used to limit noise levels, and water spraying could be employed to minimize fugitive dust emissions (see Section 7.6). No state or federally listed species would be expected to be disturbed during the implementation of Alternative 2.

\subsubsection{Implementability}

Construction and operation of the components of Alternative 2 would be straightforward. Resources are readily available for UXO screening (and safety measures), soil removal, in-situ 
containment, and shoreline stabilization. Standard hand excavation tools and UXO screening methods would be used to remove contaminated soil. Soil would be sampled during excavation activities to verify that all contaminated surface soil within the excavation area was removed. The sampling procedures for soil at APG are well established. Standard earthmoving equipment would be used to install the soil cover.

Installation of the riprap berm along the southern shoreline of the Gunpowder Neck Peninsula would be relatively straightforward. Because of the shallow depths offshore, riprap would most likely have to be trucked in via Rickett's Point Road and the unnamed road that runs south toward the South Beach Demolition Ground. The berm would be built across the shoreline from west to east so that trucks could drive over the top of it.

The implementation of Alternative 2 would not adversely affect the performance of additional remedial actions that might be required at the TBP area. The ability to implement future groundwater remediation at the site (if needed) would not be affected by the excavation operations or construction of the soil cover (e.g., the soil cover would be built around the trees currently in place as part of the groundwater phytoremediation pilot study). Any additional wells (e.g., for pumping) or excavation could still be implemented, if needed.

\subsubsection{Cost}

The components that make up Alternative 2 are shown in Table 7.1. The costs provided are for limited excavation to $2 \mathrm{ft}$, with some localized excavation to $4 \mathrm{ft}$ if needed (for a total of about $\left.400 \mathrm{yd}^{3}\right)$. Because this alternative would involve only limited excavation, estimates for excavation are not broken down for two depths ( $6 \mathrm{in}$. and $2 \mathrm{ft}$ ) as they are for Alternatives 3 through 5 . Cost components of Alternative 2 include obtaining all necessary federal, state, and local permits; repairing and resurfacing the existing access road (final course will be applied when remediation work is complete); UXO screening; clearing and grubbing; constructing a staging area; excavating pits; disposing of materials off-site; and landscaping all excavated areas. Excavations to depths greater than $2 \mathrm{ft}$ may occur if localized contamination is detected at deeper levels. This alternative also would include emplacing a 2 -ft protective soil cover with a dike along the pushout-marsh boundary to minimize the impacts of flooding. Shoreline stabilization would also be included. All excavated material would be disposed of in an off-site hazardous waste landfill and TSCA-approved incinerator, as required.

The estimated cost for the UXO screening effort is $\$ 25,000$, which would consist of providing UXO supervision of the remediation effort at the main pit area and surveying up to $24,000 \mathrm{ft}^{2}$ along the shoreline. The existing access road would be repaired and resurfaced in conjunction with the construction of the staging area. The final surface course would be applied when remediation is complete and all equipment is demobilized. The estimated cost for this work is $\$ 40,000$. 
TABLE 7.1 Cost Estimate for Alternative 2 (April $1996 \$$ )

\begin{tabular}{|c|c|c|}
\hline \multirow[b]{2}{*}{ Activity } & \multicolumn{2}{|c|}{ Cost $(\$ 1,000)$} \\
\hline & $\begin{array}{l}\text { Subcontract and } \\
\text { Other Direct Costs }\end{array}$ & $\begin{array}{c}\text { Contractor } \\
\text { Unloaded } \\
\end{array}$ \\
\hline \multicolumn{3}{|l|}{ Direct costs } \\
\hline Repair/resurface existing road & & 40 \\
\hline UXO screening & 25 & \\
\hline Clear and grub & & 5 \\
\hline Excavate/drum/stage soil (PCB) & 1.4 & 12.6 \\
\hline Excavate/drum/stage soil (metals) & 5.5 & 49.5 \\
\hline Off-site disposal, soil (PCB) & 30 & \\
\hline Off-site disposal, soil (metals) & 195 & \\
\hline Off-site disposal, remediation-derived waste & 8.5 & \\
\hline Sampling and analysis & 9 & \\
\hline Landscape excavated area & & 12 \\
\hline Install 2-ft earth cover & 194.5 & 17.5 \\
\hline Site stakeout and control & & 16 \\
\hline Sediment control plans and specs & & 5 \\
\hline Perimeter dike with flood protection & 46 & 17 \\
\hline Remedial action professional labor & & 17 \\
\hline Remedial design & & 45 \\
\hline Shoreline stabilization & 73.4 & 45.6 \\
\hline Contractor general conditions ${ }^{\mathrm{b}}$ & & 125 \\
\hline 30-year operation and maintenance & 50 & \\
\hline Contractor unloaded cost ${ }^{\mathrm{a}}$ & & 407.2 \\
\hline Contractor loaded cost ${ }^{\mathrm{a}}$ & 638.3 & \\
\hline \multicolumn{3}{|l|}{ Indirect costs } \\
\hline Contractor unloaded and overhead & & 736 \\
\hline Contractor subtotal cost & & 1,375 \\
\hline Fee $(8 \%)$ & & 110 \\
\hline Total contractor cost & & 1,485 \\
\hline \multicolumn{3}{|l|}{ Other } \\
\hline Contingencies (10\%) & & 148 \\
\hline Project management (8\%) & & 119 \\
\hline Total project cost & & 1,752 \\
\hline
\end{tabular}

a Loaded costs $=$ subcontract and other direct costs; unloaded = contractor costs, less overhead.

b For this estimate, ICF Kaiser Engineers, Inc., included contractor general conditions under direct costs. 
The cost of metals-contaminated soil disposal in a hazardous waste disposal facility would be about $\$ 286 /$ ton. The cost includes transportation in roll-offs to the facility, stabilization of the material, and all taxes and fees for proper disposal. The cost for PCB-contaminated soil in 55-gal drums at a TSCA-approved incinerator is approximately $\$ 425$ per drum, which includes transportation and incineration. The cost of remediation-derived wastes such as personal protective equipment, if it requires incineration, is approximately $\$ 425$ per drum, which includes transportation.

The sampling and analysis effort would consist of performing analysis to fully characterize the excavated soil for acceptance into disposal facilities and to confirm that the excavations removed arsenic and PCB to levels at or below the noncarcinogenic industrial risk-based concentration and ARAR, respectively. The estimated cost for sampling and analysis is $\$ 9,000$.

The final component of this alternative would be placing erosion control measures along $3,000 \mathrm{ft}$ of beachfront to the south of the TBP area. This component would involve clearing debris, lining the area with geotextile fabric, and then overlaying the fabric with riprap (at a cost of about $\$ 16$ per linear foot) over an area of about $8 \mathrm{ft}$ by $3,000 \mathrm{ft}$. An alternative to riprap is geotube (at a cost of about $\$ 135$ per linear foot). To minimize costs, the estimate assumes that riprap would be used. The estimated beachfront stabilization cost is $\$ 119,000$.

The final two direct-cost items for this alternative are professional labor and remedial design. Professional labor amounts to $\$ 17,000$. Remedial design costs for the 2 -ft excavation, soil cover, and shoreline erosion control are estimated at $\$ 45,000$ on the basis of a low level of complexity for this alternative.

The total direct and contractor overhead costs for this alternative are estimated to be $\$ 736,000$. Loaded costs, which include subcontractor and other direct costs (ODCs), added $\$ 638,300$. An $8 \%$ fee of the sum of the loaded cost, total direct cost, and overhead cost is included in this project. The sum of the fee, loaded cost, contractor direct cost, and overhead cost is the total contractor cost, which is estimated to be $\$ 1,485,000$. A contingency factor of $10 \%$ of the total contractor cost adds $\$ 148,000$ to the cost of the project. Project management adds an additional $8 \%$ of the total contractor cost $(\$ 119,000)$ to the cost of the alternative. The total project cost of this alternative, which is the sum of the total contractor cost, contingency factor, and project management, is estimated to be $\$ 1,752,000$. 


\subsection{ALTERNATIVE 3: REMOVAL AND SHORT-TERM STORAGE}

\subsubsection{Overall Protection of Human Health and the Environment}

Alternative 3 would be protective of human health and the environment over the short term. Under this alternative, contaminated surface soil in the main pits and pushout area would be removed and stored in a containment building located north of the TBP area for an estimated five years (see Section 6.3). Exposures of biota to surface contaminants would be reduced, as would the potential for exposure of site workers and the general public.

\subsubsection{Compliance with ARARs}

Compliance with location-specific ARARs under Alternative 3 would be the same as for Alternative 2.

Action-specific ARARs address the protection of water, sediment, soil, watersheds, and air during implementation of the remedial action. Alternative 3 would involve moving, grading, transporting, or otherwise disturbing soil; state regulations related to sediment and erosion control would apply (Water Management 4[1] and 4[2]). Implementing the soil excavation component of Alternative 3 would require the preparation of a sediment and erosion control plan (Water Management 25[09:1] and [09:2]).

Some of the soil excavated at the site might meet the regulatory definition of characteristic waste (e.g., toxic for lead) as determined by the TCLP test. In addition, Maryland lists the following as acute hazardous wastes: CWAs, waste CWAs, mixtures of any of these substances and any characteristic or listed hazardous waste, and residues from treatment of CWA wastes listed as acute hazardous waste. Because the TBP area was used for the disposal of CWAs and CWA treatment residues, soil excavated from the site might be considered a listed acute hazardous waste (i.e., if it contains CWAs listed by Maryland). However, no CWAs have been detected in the TBP area soils to date.

If hazardous waste is present, RCRA siting requirements for new treatment, storage, and disposal (TSD) facilities would apply for certain storage unit operations constructed to store waste under Alternative 3, that is, the temporary storage facility. The RCRA requirements and similar state requirements specify that any facility located in a 100-year floodplain should be constructed, operated, and maintained to prevent washout of any waste by a 100-year flood. These requirements might apply to locating and operating the short-term storage facility. 
General TSD facility standards, including waste analysis, security, inspections, training, preparedness and prevention, and contingency planning/emergency procedures, would be applicable to such waste management activities. Alternatively, site managers could rely on 40 CFR 264.553 (Temporary Units) to satisfy RCRA ARARs for the storage of wastes. Under this regulation, the EPA regional administrator can determine that temporary tanks and container storage areas used for the treatment or storage of hazardous remediation wastes may meet an alternate design, operating, or closure standard.

Soil excavated from the southern main pit would likely contain detectable concentrations of PCBs. Because a number of samples from the southern main pit contained soil with PCB concentrations greater than $50 \mathrm{mg} / \mathrm{kg}$ (the regulatory "trigger" requiring implementation of the TSCA PCB handling regulations), the soil generated during the excavation of the southern main pit might have to be handled according to TSCA regulations. Areas contaminated with PCBs might have to be remediated to satisfy the PCB spill cleanup policy for a contaminant-specific TBC. However, as stated in the policy, PCB contamination resulting from historical spills is to be decontaminated to levels established at the discretion of EPA regional offices. Because EPA Region III is involved in the regulatory review and public participation process for this FFS, this PCB TBC would be satisfied.

State regulations related to air releases would also be action-specific ARARs. Particulate matter and VOCs would have to be controlled during earthmoving activities in accordance with Maryland requirements (Air Quality 26[11:1], 26[11:3], and 26[11:6]).

Appropriate permits would have to be obtained from the U.S. Army Corps of Engineers before the riprap berm could be constructed along the southern shoreline of the Gunpowder Neck Peninsula.

\subsubsection{Long-Term Effectiveness and Permanence}

\subsubsection{Protection of Human Health}

Under Alternative 3, workers would be on-site periodically to carry out monitoring and maintenance activities. Residual risks would be reduced because contaminated soil exceeding cleanup criteria would be removed and contained. Long-term exposures of workers and the general public to contaminants would be negligible because contaminated soil would be removed and transported to a storage building and the excavated areas backfilled. Alternative 3 is not considered a long-term or permanent remedy; therefore, another component to this alternative would also involve (at some future date) off-site transport, treatment, and disposal of contaminated soil. Because this component would involve the off-site transport of contaminated materials, the eventual overall 
risk of exposure to the general public would be comparable to that expected for Alternative 5. Site workers and off-site contractors responsible for the transport of soil would be equipped with and trained in the use of personal protective equipment. Mitigative measures are further addressed in Section 7.6.

\subsubsection{Environmental Protection}

Alternative 3 would result in a significant reduction in environmental contaminant concentrations in site soils and thus reduce direct exposure of vegetation and wildlife to surface soil contaminants as well as reduce or eliminate food chain transport of contaminants to ecological receptors in higher trophic levels. Excavation and storage of contaminated surface soils would largely eliminate the transport of soil-bound contaminants by surface runoff to the nearby marsh and pond, thereby producing a long-term benefit to surface water and wetland resources at the site. Restoration of the excavation areas would also establish better-quality wildlife habitat than is currently present at the site.

\subsubsection{Reduction of Toxicity, Mobility, or Volume}

Under Alternative 3, about $16,000 \mathrm{yd}^{3}$ (27,200 tons) of soil would be removed from the main pits and pushout areas and stored temporarily on-site. Storage would take place over a period of 5 years until soil was sent off-site for permanent treatment and disposal; therefore, the reduction of contaminant toxicity, mobility, and volume through treatment would be deferred.

\subsubsection{Short-Term Effectiveness}

\subsubsection{Duration of Remedial Activities}

Remedial action activities (including construction of storage facility and removal of soil) under Alternative 3 should be completed in about 4 months; the storage facility would operate for about 5 years. Monitoring activities would take place during and after implementation of the action.

\subsubsection{Protection of Human Health}

The short-term risks to site workers and the general public would be significant for Alternative 3, and mitigative measures would need to be employed (see Section 7.6). Excavation of contaminated soil at the TBP area is complicated by the possible presence of buried UXO, some of 
which may contain chemical agents. The health and safety implications of encountering UXO and CWAs or other chemical contaminants would be addressed in the health and safety plan for the selected alternative. Soil would be excavated by using conventional equipment following U.S. Army standard operating procedures.

The release of particulate emissions during excavation would need to be minimized. Although workers could wear respiratory protection, off-site dispersion of contaminated dust could present a health risk to other APG personnel and the general public. Engineering controls would be needed to reduce the air concentrations of CWAs and toxic chemicals released during excavation. The use of enclosures to contain airborne emissions might be required.

Monitoring for chemical agents and hazardous chemicals would also be required during excavation. Continuous personal and work-site monitoring for airborne vapors and particulates is a standard industrial hygiene practice. Even if the highest levels of protective clothing and equipment were used, chemical monitoring would be necessary in the event that personal protective gear malfunctioned or was improperly operated. Personal protective clothing and equipment would also be required to prevent dermal exposure through direct contact with contaminated soil.

Alternative 3 would also involve short-term, on-site storage of excavated soil from the TBP area. Construction of a storage facility would need to incorporate a vapor-phase emission control system to reduce risks to site workers and the general public associated with the inhalation of VOCs. Site workers at the storage facility might need to be equipped with and trained in the use of personal protective equipment, which would reduce the potential for exposure during the storage period. Mitigative measures are further addressed in Section 7.6.

\subsubsection{Environmental Protection}

Excavation of contaminated soil and construction of the interim storage facility would disturb approximately 6.5 acres of soil, vegetation, and wildlife habitat. Soil excavation would disturb about 5 acres, construction of the storage facility would disturb up to 1.1 acres, and construction and improvement of access roads would disturb an additional 0.3 acres of the TBP area. Adverse impacts associated with these activities include increases in fugitive dust emissions and ambient noise levels; potential increased surface soil runoff to the marsh and pond; and loss of vegetation and wildlife habitat at the main pits, pushout area, and interim storage facility areas. Air quality and noise impacts could disturb ecological resources near the construction areas, but these impacts would be minor and temporary. Although some loss of vegetation and wildlife habitat would be expected, the amount of vegetation and habitat that would be affected is small, none of the areas that would be disturbed contain high-quality habitats or support listed biota, and most of the disturbed areas (77\%) are contaminated and have been identified to pose a risk to ecological receptors at the TBP 
area and at J-Field as a whole. When all excavation activities were completed, the excavated areas would be backfilled with clean fill and revegetated to restore wildlife habitat.

Placement of riprap along the southern shoreline of J-Field also has potential impacts to ecological resources, although the degree of impacts would depend upon the final design of the riprap structure. Marsh vegetation that is inundated during high tides often serves as refuge and foraging habitat for many fish species, especially smaller species and juveniles of larger species. Construction of a riprap barrier can curtail or prevent access to such areas. Fishery surveys conducted by the U.S. Fish and Wildlife Service off the southern end of J-Field (Robins Point) determined that nursery habitat for striped bass and marginal nursery habitat for Atlantic croaker and white perch exist in this area (Swihart et al. 1994). The impact to fish populations due to loss of access to this area of marsh habitat is unknown, although it would probably be minor. The presence of riprap could benefit some fish species by providing artificial habitat for a number of invertebrate species that could serve as food. There is also a potential benefit from reduction of erosion along the southern shoreline of J-Field because future erosion of contaminated soils in the TBP area could pose an ecological risk to aquatic organisms.

Potential impacts to surface water, air quality, and noise levels during implementation of Alternative 3 would be temporary and would cease upon completion of all excavation, construction, and restoration activities. In addition, the magnitude of the potential impacts could be mitigated during all phases of Alternative 3 through the use of good engineering practices. For example, siltation fences, berms, and a runoff collection system could control runoff from excavation and construction areas; mufflers could limit noise levels; and water spraying could minimize fugitive dust emissions (see Section 7.6). No state or federally listed species would be expected to be disturbed during the implementation of Alternative 3.

\subsubsection{Implementability}

Construction and operation of most components of Alternative 3 would be straightforward. Resources are readily available for UXO screening (and safety measures), soil removal, and off-site treatment and disposal. Standard excavation and construction equipment would be used to remove contaminated soil. Soil would be sampled during excavation activities to verify that all contaminated surface soil within the excavation area was removed. The sampling procedures for soil at APG are well established.

A recent HFA survey of 10- by 10-ft areas in the pushout area showed a range of 1 to 28 contacts per $100-\mathrm{ft}^{2}$ area. Twenty-five contacts were found in a burning pit (an area of 100 by $6 \mathrm{ft}$ ). It is estimated that about 100 contacts per day would be identified and excavated per two-man team, provided none of the contacts were UXO. If UXO were encountered, work would cease until the UXO was located and destroyed. Downtime for this operation would be from one to four hours. 
Once all contacts were excavated or destroyed, conventional earthmoving equipment could be used to excavate the cleared area to a depth of $2 \mathrm{ft}$.

The storage facility would be relatively straightforward to construct and operate. All necessary equipment is readily available; temporary structures are available through a number of companies and can be purchased as kits, which can be customized to fit project specifications. The facility would require a supervisor and a small inspection/maintenance crew.

Installation of the riprap berm along the southern shoreline of the Gunpowder Neck Peninsula would be relatively straightforward. Because of the shallow depths offshore, riprap would most likely have to be trucked in via Rickett's Point Road and the unnamed road that runs south toward the South Beach Demolition Ground. The berm would be built across the shoreline from west to east such that trucks could drive over the top of it.

Implementation of Alternative 3 would not adversely affect the performance of additional remedial actions that might be required at the TBP area. The ability to implement future groundwater remediation at the site (if needed) would not be affected by the excavation and backfilling operations; however, in the case of phytoremediation, some coordination would be needed in the timing of excavation and planting of vegetation.

\subsubsection{Cost}

The components that make up the treatment train for Alternative 3 are shown in Table 7.2. Costs are given for both the 6 -in. and 2 -ft excavations. Before the interim remedial action could be performed, several site improvements must be made. The first site improvement is improvement/ construction of an access road, which was deemed necessary to hándle the heavy equipment that would be required to excavate and haul the soil to the temporary storage building. Construction/ improvement of a one-lane gravel road was estimated to cost $\$ 26,000$. The second site improvement is extension of electric service to the storage site to provide power to the storage building for the lighting, ventilation system, and air scrubber system. The cost of this site improvement was estimated at $\$ 82,000$.

Before the site is excavated, it must be screened for UXO and then cleared of vegetation (clear and grub). Because excavation would not be greater than $2 \mathrm{ft}$, only one UXO screening is required for either excavation depth. The area screened is about 5 acres $\left(218,000 \mathrm{ft}^{2}\right)$. Because of the potential for CWA, it is assumed that the UXO screening teams would use a MINICAMS to detect the presence of CWA. The total cost of UXO screening is $\$ 156,000$, for both the 6 -in. and the $2-\mathrm{ft}$ excavations. The cost to clear and grub the site was estimated at $\$ 20,000$. 
TABLE 7.2 Cost Estimate for Alternative 3 (April $1996 \$)^{\mathrm{a}}$

\begin{tabular}{|c|c|c|}
\hline \multirow[b]{2}{*}{ Activity } & \multicolumn{2}{|c|}{ Cost $(\$ 1,000)$} \\
\hline & 6-in. Excavation & 2-ft Excavation \\
\hline \multicolumn{3}{|l|}{ Direct costs } \\
\hline Construct/improve access road & 26 & 26 \\
\hline Extend electric service & 82 & 82 \\
\hline UXO screening & 156 & 156 \\
\hline Clear and grub & 20 & 20 \\
\hline Excavate pushout and pits & 81 & 197 \\
\hline Construct storage building & 1,024 & 1,966 \\
\hline Transport to storage building & 7 & 23 \\
\hline Landscape excavated area & 4 & 4 \\
\hline Remedial action professional labor & 15 & 16 \\
\hline Remedial design & 47 & 87 \\
\hline Beach erosion control & 119 & 119 \\
\hline 5-year operation and maintenance $(O \& M)^{b}$ & 66 & 145 \\
\hline Total direct costs & 1,647 & 2,841 \\
\hline \multicolumn{3}{|l|}{ Indirect costs } \\
\hline Contractor general conditions & 501 & 797 \\
\hline Contractor overhead and profit & 410 & 639 \\
\hline Total contract indirect costs & 911 & 1,436 \\
\hline Total contract cost (direct and indirect) & 2,558 & 4,277 \\
\hline \multicolumn{3}{|l|}{ Other } \\
\hline Contingencies (10\%) & 256 & 428 \\
\hline Project management (8\%) & 205 & 342 \\
\hline Total project cost & 3,019 & 5,047 \\
\hline Unit cost $\left(\$ / y^{3}\right)$ & 749 & 313 \\
\hline
\end{tabular}

a Costs for the 6-in. excavation are included for comparative purposes only.

b Annual O\&M cost would be about $\$ 13,000$ for the 6-in. excavation and $\$ 29,000$ for the 2-ft excavation. 
Construction of the storage building would begin before excavation of the contaminated area so that the building would be ready once the excavation took place. To accommodate the different layers used in the special foundation, which include the impermeable clay layer, the leachate collection system, and the concrete pad, the area where the building will be constructed would need to be excavated to a depth of about $5 \mathrm{ft}$. However, the soil excavated could be stockpiled and used as backfill in the contaminated area. In addition to the foundation excavation and the special foundation, other cost components associated with the storage building are the building fabric, support trusses, and building erection; protective concrete barriers around the inside perimeter; inside ventilation system; air scrubber system; and site work needed for proper drainage around the buildings. The total estimated cost for these activities is about $\$ 1,024,000$ for the 6-in. excavation and $\$ 1,966,000$ for the 2 -ft excavation. These costs were estimated from cost data obtained from the Army Corps of Engineers for a similar soil storage building that was constructed in Winfield, West Virginia. The storage building accounts for $67 \%$ of the total direct cost for the 6 -in. excavation and $72 \%$ of that for the 2 -ft excavation.

Also, while the soil is stored, annual costs would be associated with operation and maintenance (O\&M) of the scrubber system. These costs were estimated to be about $\$ 13,000 / \mathrm{yr}$ for the 6-in. excavation and $\$ 29,000 / y r$ for the 2-ft excavation. The O\&M cost shown in Table 7.2 assumes that the soil is stored for 5 years. Consequently, the estimated 5-year O\&M cost is $\$ 66,000$ for the 6-in. excavation and $\$ 145,000$ for the 2 -ft excavation.

Excavation is the next component of the treatment train. This cost estimate is for conventional, and not remote, excavation. Because part of the excavation area is adjacent to the marsh, precautions must be taken to prevent infiltration of marsh water into the excavated area. Sheet piling would be used as a mitigative measure. In addition, the area near the marsh would be excavated and backfilled before the rest of the area was excavated. It is also assumed that all areas would be backfilled with clean soil so that potentially contaminated soil would not be exposed. The estimated cost to excavate the area to a depth of 6 in. is $\$ 81,000$, while the cost to excavate to a depth of $2 \mathrm{ft}$ is $\$ 197,000$. Excavated soil would also need to be transported to the storage building by truck and piled with earthmoving equipment, such as dozers. The cost to transport and pile soil from the 6-in. and 2-ft excavations would be $\$ 7,000$ and $\$ 23,000$, respectively. After the excavation was complete, the site would be landscaped by grading and seeding, for a cost of $\$ 4,000$.

The final component of this alternative is the placement of erosion control measures along $3,000 \mathrm{ft}$ of beachfront to the south of the TBP area. This component would involve clearing debris, lining the area with geotextile fabric, and then overlaying the fabric with riprap (at a cost of about $\$ 16$ per linear foot) over an area of about $8 \mathrm{ft}$ by $5,300 \mathrm{ft}$. An alternative to riprap is geotube (at a cost of about $\$ 135$ per linear foot). To minimize costs, the estimate assumes that riprap would be used. The estimated beachfront stabilization cost is $\$ 119,000$. 
The final two direct-cost items for this alternative are professional labor and remedial design. Professional labor accounts for the professional labor tasks required in all components of the treatment train. This cost was estimated to be $\$ 15,000$ and $\$ 16,000$ for the 6-in. and 2-ft excavations, respectively. The estimated cost of the remedial design for the 6 -in. excavation is $\$ 47,000$, and the cost for the 2-ft excavation is $\$ 87,000$, assuming a moderate level of complexity for this alternative.

The total direct cost of this alternative is estimated to be $\$ 1,647,000$ for the 6 -in. excavation and $\$ 2,841,000$ for the 2 -ft excavation. Indirect costs, such as contractor general conditions and contractor overhead and profit, added $\$ 501,000$ and $\$ 410,000$, respectively, to the total cost for the 6-in. excavation and $\$ 797,000$ and $\$ 639,000$, respectively, for the 2 - $\mathrm{ft}$ excavation. A contingency factor of $10 \%$ was assumed for this remedial action to account for unforeseen conditions at the site or changes in the project scope based on more detailed site information. This added $\$ 256,000$ to the 6 -in. excavation and $\$ 428,000$ to the 2-ft excavation. The contingency factor used here is less than in previous draft reports because the site is now better characterized. Because more data have been obtained and analyzed, fewer unknowns and changes are expected. Finally, it is assumed that project management adds an additional $8 \%$ or $\$ 205,000$ for the 6-in. excavation and $\$ 342,000$ for the $2-\mathrm{ft}$ excavation. Consequently, the total estimated cost of this alternative is $\$ 3,019,000$ for the 6-in. excavation and $\$ 5,047,000$ for the 2 -ft excavation. This translates into a unit cost of $\$ 749 / \mathrm{yd}^{3}$ for the 6-in. excavation and $\$ 313 / \mathrm{yd}^{3}$ for the 2-ft excavation.

\subsection{ALTERNATIVE 4: REMOVAL, ON-SITE TREATMENT, AND LIMITED DISPOSAL}

\subsubsection{Overall Protection of Human Health and the Environment}

Alternative 4 would be protective of human health and the environment over the long term. Under this alternative, contaminated surface soil in the main pits and pushout area would be removed and treated. Exposures of biota to surface contaminants would be reduced, as would the potential for exposure of site workers and the general public.

\subsubsection{Compliance with ARARs}

Compliance with location-specific and contaminant-specific ARARs under Alternative 4 would be the same as for Alternatives 2 and 3. General TSD facility standards, including waste analysis, security, inspections, training, preparedness and prevention, and contingency planning/ emergency procedures, would be applicable to such waste management activities. Alternatively, site managers could rely on 40 CFR 264.553 (Temporary Units) to satisfy RCRA ARARs for the treatment of wastes. Under this regulation, the EPA regional administrator can determine that 
temporary tanks and container storage areas used for the treatment or storage of hazardous remediation wastes may meet an alternate design, operating, or closure standard. In addition, should soil be excavated, treated, and replaced, the RCRA LDR would apply.

Action-specific ARARs address the protection of water, sediment, soil, watersheds, and air during implementation of the remedial action. Alternative 4 would involve moving, grading, transporting, or otherwise disturbing soil; state regulations related to sediment and erosion control would apply (Water Management 4[1] and 4[2]). Implementing the soil excavation component of Alternative 4 would require the preparation of a sediment and erosion control plan (Water Management 25[09:1] and [09:2]).

State regulations related to air releases would also be action-specific ARARs. Particulate matter and VOCs would have to be controlled during earthmoving activities in accordance with Maryland requirements (Air Quality 26[11:1], 26[11:3], and 26[11:6]). Emissions resulting from remedial actions, such as soil washing/leaching, would also have to be controlled in accordance with Maryland requirements (Air Quality 26[11:15]).

\subsubsection{Long-Term Effectiveness and Permanence}

Alternative 4 would be protective of human health and the environment over the long term. Under this alternative, contaminated soil from the main pits and pushout area would be removed and treated, and maintenance activities would continue. Monitoring activities would be conducted to assess the effectiveness and potential impacts of the remedial action. Excavation and treatment by soil washing/leaching would greatly reduce contaminant mobility and volume; therefore, potential for exposures due to contaminant releases from these source areas would be low.

\subsubsection{Protection of Human Health}

Workers would be on-site periodically to carry out monitoring and maintenance activities (e.g., mowing). Residual risks would be reduced because contaminated soil exceeding cleanup criteria would be removed and treated. Long-term exposures of workers and the general public to contaminants would be negligible because contaminated soil would be removed from the site and the excavated areas backfilled.

\subsubsection{Environmental Protection}

Alternative 4 would result in a significant reduction in contaminant levels and exposures to biota. The removal and treatment of contaminated soil would reduce the potential for transport 
of contaminants to the nearby marsh and pond via surface water runoff, thereby producing a positive benefit to surface water and wetland resources in the long term. In addition, direct exposures to terrestrial wildlife and threatened and endangered species would also be reduced. Restoration of the excavation areas would create wildlife habitat of better quality than is currently present at these locations.

\subsubsection{Reduction of Toxicity, Mobility, or Volume}

The treatment technology implemented as part of Alternative 4 would be soil washing/ leaching. The physical and chemical treatment of TBP area soils with soil washing/leaching technologies would significantly reduce contaminant mobility and volume.

It is estimated that about $16,000 \mathrm{yd}^{3}$ (27,200 tons) of soil would be treated on-site by soil washing/leaching. The soil washing process would separate and treat the oversize and sand fractions from the soil, while concentrating the contaminants in the fines. Treating TBP area soils by soil washing/leaching could reduce the original contaminated soil volume by $94 \%$; the remaining $6 \%$ would be sent off-site for disposal. Cleaned soil would be returned to the site, and recovered metals would be recycled. A treatability study would be needed to confirm the effectiveness of the process in achieving PRGs. Toxicity of lead would not be reduced; however, the metal would be removed and recycled.

\subsubsection{Short-Term Effectiveness}

\subsubsection{Duration of Remedial Activities}

Remedial action activities (including construction of the treatment facility and soil removal, treatment, and disposal) under Alternative 4 should be completed in about 8 months; monitoring activities would take place during and after implementation of the action.

\subsubsection{Protection of Human Health}

The short-term risks to site workers and the general public would be significant for Alternative 4, and mitigative measures would need to be employed (see Section 7.5). Excavation of contaminated soil at the TBP area is complicated by the possible presence of buried UXO, some of which may contain chemical agents. The health and safety implications of encountering UXO and

CWAs or other chemical contaminants would be addressed in the health and safety plan for the 
selected alternative. Soil would be excavated with conventional equipment following U.S. Army standard operating procedures.

The release of particulate emissions during excavation would need to be minimized. Although workers could wear respiratory protection, off-site dispersion of contaminated dust could present a health risk to other APG personnel and the general public. Engineering controls would be needed to reduce the air concentrations of CWAs and toxic chemicals released during excavation. The use of enclosures to contain airborne emissions might be required.

Monitoring for chemical agents and hazardous chemicals would also be required during excavation. Continuous personal and work-site monitoring for airborne vapors and particulates is a standard industrial hygiene practice. Even if the highest levels of protective clothing and equipment were used, chemical monitoring would be necessary in the event that personal protective gear malfunctioned or was improperly operated. Personal protective clothing and equipment would also be required to prevent dermal exposure through direct contact with contaminated soil.

Another component of Alternative 4 would involve the on-site treatment of excavated soil via soil washing/leaching. The soil washing/leaching facility might need to incorporate a vaporphase emission control system to reduce risks to site workers and the general public associated with the inhalation of VOCs. Site workers operating the treatment facility would be equipped with and trained in the use of personal protective equipment, which would reduce the potential for exposure during the pretreatment and washing activities. Mitigative measures are further addressed in Section 7.6.

\subsubsection{Environmental Protection}

Soil, vegetation, and wildlife habitat disturbance would occur as a result of the soil excavation activities, which would cover an area of about 5 acres. An estimated 1.5 acres of land would be disturbed to provide areas for staging soil and operating the soil washing/leaching facility. Adverse impacts associated with these activities include increases in fugitive dust emissions and ambient noise levels; potential increased soil transport via surface runoff to the marsh and pond; and loss of vegetation and wildlife habitat at the main pits, pushout area, and soil staging areas. Air quality and noise impacts could disturb ecological resources near construction areas, but these impacts would be minor and temporary. Although some permanent loss of vegetation and wildlife habitats would be expected, the amount of vegetation and habitat eliminated would be small; moreover, because of the existing contaminant levels and past activities, none of the areas to be excavated represent high-quality habitat or support listed biota. These potential risks are considered acceptable when weighed against the current adverse risk associated with contaminated surface soil (Sections 2.7.3 and 3.3). Upon completion of all treatment activities, the soil washing/leaching facility would be removed and the disturbed land would be backfilled and revegetated to restore 
wildlife habitat of better quality than is currently present. Potential impacts to surface water, air quality, and noise levels during implementation of Alternative 4 could be mitigated through the use of good engineering practices. For example, siltation fences could control runoff from the excavation and construction sites, berms and a runoff collection system could control runoff from the staging areas, mufflers could limit noise levels, and water spraying could minimize dust emissions (Section 7.6). No state or federally listed species would be expected to be disturbed during the implementation of Alternative 4.

\subsubsection{Implementability}

Construction and operation of most components of Alternative 4 would be straightforward. Resources are readily available for UXO screening (and safety measures), soil removal, and on-site treatment by soil washing/leaching. Standard excavation and construction equipment would be used to remove contaminated soil. Soil would be sampled during excavation activities to verify that all contaminated surface soil within the excavation area was removed. The sampling procedures for soil at APG are well established.

The soil washing/leaching facility would be relatively straightforward to construct and operate. All necessary equipment is readily available because the process has been used frequently in the mining industry and hazardous waste treatment applications. The treatment system would consist of a relatively standard configuration of industrial equipment. The facility would require a supervisor and general laborers with industrial work experience, as well as maintenance personnel and laboratory and administrative employees. Further bench-scale testing is required to define and optimize the design of the system.

The soil washing/leaching process would require delivery of contaminated soil by truck to the facility each day. Most likely, contaminated soil would be stockpiled at a temporary staging area until being transported to the facility for treatment. Clean soil would be stockpiled in a clean zone south of the treatment facility until all excavation activities had been completed; once excavation was complete, the cleaned soil would be used to fill the excavated area. Alternative 4 would use established technologies. The technology for soil washing/leaching has been used at several hazardous waste sites (currently, it is being demonstrated at TCAAP, New Brighton, Minnesota) and probably would not require further development before implementation at the TBP area. From 1986 to 1989 , soil washing was one of the selected source control remedies at eight Superfund sites (EPA 1994). Several vendors would be available to submit competitive bids.

Disposal of the waste generated from the soil washing/treatment process is considered to be minimal. Contaminated fines and process residuals generated from soil washing would be further treated through soil leaching. The leachate solution would be cleaned and recycled continuously throughout the process. At the end of treatment, process fluids would be cleaned and put through the 
sanitary wastewater system. Metal scrap and recovered metals would be shipped to an off-site smelter.

Implementation of Alternative 4 would not adversely affect the performance of additional remedial actions that might be required at the TBP area. The ability to implement future groundwater remediation at the site (if needed) would not be affected by the excavation and backfilling operations; however, in the case of phytoremediation, some coordination would be needed in the timing of excavation and planting of vegetation.

\subsubsection{Cost}

The components that make up the treatment train for Alternative 4 are shown in Table 7.3. As for the previous alternative, costs are given for both the 6-in. and 2-ft excavations. Many of the components that make up the soil remediation treatment train for Alternative 4 are identical to those in Alternative 3: UXO and CWA screening, constructing an access road, extending electric service (to provide electric power to the soil washing/leaching facility), clearing and grubbing, excavating all areas, transporting soil to a treatment/storage area, and landscaping all excavated areas. The new components in the treatment train of this alternative are construction of a soil washing/leaching facility and staging area instead of temporary storage.

As soil was excavated, it would be transported by truck to a staging area. A staging area would be necessary because the soil would be excavated faster than it could be washed. With a soil washing facility throughput of 15 tons/h and a 10-hour daily shift working six days a week, 8 weeks would be required to wash the soil from the 6-in. excavation and 31 weeks for the 2 -ft excavation. It is assumed that the soil would be stored in a bermed and drained concrete pad and covered with plastic laminate. A pad of about $25,000 \mathrm{ft}^{2}$ would be needed to store soil from the 6-in. excavation and a pad of about $48,000 \mathrm{ft}^{2}$ for the 2 -ft excavation. The pads would cost $\$ 126,000$ and $\$ 268,000$, respectively. It is assumed that excavated soil would be loaded directly onto a truck and hauled to the staging area. A fleet of about three trucks with a capacity of $32 \mathrm{yd}^{3}$ each would be needed to continuously haul the excavated soil to the staging area. The estimated cost to haul the soil is about $\$ 7,000$ for the 6-in. excavation and $\$ 23,000$ for the $2-\mathrm{ft}$ excavation.

The cost of the soil washing/leaching component was based on a treatability study on the TBP area soil performed by ART (1995). The cost includes both treatment of residual water from the process and disposal of the $6 \%$ solid waste fraction resulting from the process. This waste would be disposed of in an off-site hazardous waste landfill and would cost about $\$ 312$ ton (Whorton 1996). This cost includes loading onto trucks, transporting to the landfill, stabilizing the waste, and all taxes and fees for landfill disposal. Consequently, the total estimated direct cost of the soil washing/leaching component is $\$ 2,361,000$ for the 6 -in. excavation and $\$ 6,723,000$ for the 2 - $\mathrm{ft}$ excavation. This accounts for about $79 \%$ of the direct cost for the 6 -in. excavation and $86 \%$ for the 2-ft excavation. 


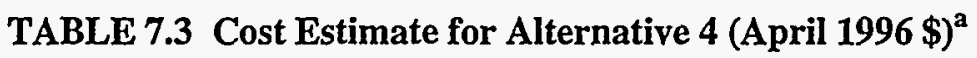

\begin{tabular}{|c|c|c|}
\hline \multirow[b]{2}{*}{ Activity } & \multicolumn{2}{|c|}{ Cost $(\$ 1,000)$} \\
\hline & $\begin{array}{c}\text { 6-in. } \\
\text { Excavation }\end{array}$ & $\begin{array}{c}2-\mathrm{ft} \\
\text { Excavation }\end{array}$ \\
\hline \multicolumn{3}{|l|}{ Direct costs } \\
\hline Construct/improve access road & 26 & 26 \\
\hline Extend electric service & 82 & 82 \\
\hline UXO screening & 156 & 156 \\
\hline Clear and grub & 20 & 20 \\
\hline Excavate pushout and pits & 81 & 197 \\
\hline Construct and operate soil wash/leach facility & 2,361 & 6,723 \\
\hline Construct staging area & 126 & 268 \\
\hline Transport to staging area & 7 & 23 \\
\hline Sampling and analysis & 6 & 11 \\
\hline Landscape excavated area & 4 & 4 \\
\hline Remedial action professional labor & 23 & 23 \\
\hline Remedial design & 101 & 275 \\
\hline Total direct costs & 2,994 & 7,810 \\
\hline \multicolumn{3}{|l|}{ Indirect costs } \\
\hline Contractor general conditions & 752 & 1,562 \\
\hline Contractor overhead and profit & 728 & 1,717 \\
\hline Total contract indirect costs & 1,480 & 3,279 \\
\hline Total contract cost (direct and indirect) & 4,473 & 11,089 \\
\hline \multicolumn{3}{|l|}{ Other } \\
\hline Contingencies $(10 \%)$ & 447 & 1,109 \\
\hline Project management (8\%) & 358 & 887 \\
\hline Total project cost & 5,279 & 13,085 \\
\hline Unit cost $\left(\$ / y d^{3}\right)$ & 1,309 & 811 \\
\hline
\end{tabular}

a Costs for the 6-in. excavation are included for comparative purposes only. 
Before the solid waste fraction from the soil washing process was shipped to the off-site hazardous waste landfill, sampling and analysis would be required. Random samples of waste would be taken and TCLP analyses performed to characterize the waste, as required by the landfill operator. Sampling and analysis costs $\$ 6,000$ for the 6-in. excavation and $\$ 11,000$ for the 2 -ft excavation.

The final two direct-cost items for this alternative are professional labor and remedial design. Professional labor amounts to $\$ 23,000$ for both excavations. Remedial design costs $\$ 101,000$ for the 6-in. excavation and $\$ 275,000$ for the 2-ft excavation, assuming a moderate level of complexity for this alternative.

The total direct cost of this alternative is estimated to be $\$ 2,994,000$ for the 6 -in. excavation and $\$ 7,810,000$ for the 2-ft excavation. Indirect costs, such as contractor general conditions and contractor overhead and profit, add $\$ 752,000$ and $\$ 728,000$, respectively, to the total cost for the 6 -in. excavation and $\$ 1,562,000$ and $\$ 1,717,000$, respectively, for the 2-ft excavation. A contingency factor of $10 \%$ adds $\$ 447,000$ to the cost of the 6-in. excavation and $\$ 1,109,000$ to the 2 - $\mathrm{ft}$ excavation. Finally, it is assumed that project management adds an additional $8 \%$, or $\$ 358,000$ for the 6-in. excavation and $\$ 887,000$ for the 2 -ft excavation. Consequently, the total estimated cost of this alternative is $\$ 5,279,000$ for the 6 -in. excavation and $\$ 13,085,000$ for the 2 - $\mathrm{ft}$ excavation. This translates into a unit cost of $\$ 1,309 / \mathrm{yd}^{3}$ for the 6-in. excavation and $\$ 811 / \mathrm{yd}^{3}$ for the 2 -ft excavation.

\subsection{ALTERNATIVE 5: REMOVAL, OFF-SITE TREATMENT, AND DISPOSAL}

\subsubsection{Overall Protection of Human Health and the Environment}

Alternative 5 would be protective of human health and the environment over the long term. Under this alternative, contaminated surface soil in the main pits and pushout area would be removed and treated. Exposures of biota to surface contaminants would be reduced, as would the potential for exposure of site workers and the general public.

\subsubsection{Compliance with ARARs}

Compliance with location-specific and contaminant-specific ARARs under Alternative 5 would be the same as for Alternatives 2, 3, and 4. Alternative 5 would comply with the same actionspecific ARARs and TBCs as Alternative 4, except for on-site disposal requirements. The key ARARs related to the off-site disposal component of this alternative would be the RCRA hazardous waste generator and record-keeping regulations and the TSCA PCB generator and record-keeping regulations. In general, the site operator.would be required to ensure proper characterization of excavated soil (as soil containing listed hazardous waste, characteristic hazardous waste, and/or 
PCBs), proper completion of hazardous waste and PCB manifests, receipt of "come-back" copies of manifests from destination disposal sites, and proper retention of waste characterization and manifest records for at least five years. In addition, under the CERCLA procedures for planning and implementing off-site response action (40 CFR 300.440), any facility chosen to receive CERCLA wastes for treatment, storage, or ultimate disposal must be deemed in compliance with applicable RCRA regulations and have no unpermitted releases of hazardous waste, constituents, or substances into the groundwater, surface water, soil, or air.

\subsubsection{Long-Term Effectiveness and Permanence}

Alternative 5 would be protective of human health and the environment over the long term. Under this alternative, (1) contaminated soil from the main pits and pushout area would be removed and treated and (2) maintenance activities would continue. Monitoring activities might be conducted to assess the effectiveness and potential impacts of the remedial action. Excavation and off-site treatment by chemical stabilization/solidification would greatly reduce contaminant mobility; therefore, risk of potential exposures due to contaminant releases from these source areas would be low. Restoration of the excavated areas would also create wildlife habitat of better quality than is currently present in these areas.

\subsubsection{Protection of Human Health}

Workers would be on-site periodically to carry out monitoring and maintenance activities (e.g., mowing). Residual risks would be reduced because contaminated soil exceeding cleanup criteria would be removed and treated. Exposures of workers and the general public to contaminants would be negligible because contaminated soil would be removed from the site and the excavated areas backfilled.

\subsubsection{Environmental Protection}

Alternative 5 would significantly reduce contaminant levels and exposures to biota. The removal and treatment of contaminated soil would reduce the potential for transport of contaminants to the nearby marsh and pond via surface water runoff, thereby benefiting surface water and wetland resources in the long term. In addition, direct exposures to terrestrial wildlife and threatened or endangered species would be greatly reduced, and restoration activities would create higher-quality habitat at the site. 


\subsubsection{Reduction of Toxicity, Mobility, or Volume}

The treatment technology implemented as part of Alternative 5 would be chemical stabilization/solidification, and any soils regulated under TSCA (i.e., PCB concentrations that exceed $50 \mathrm{ppm}$ ) would require incineration prior to stabilization. The chemical treatment of TBP area soils with stabilization technology would significantly reduce contaminant mobility. Incineration, if needed, would significantly reduce the toxicity of PCB contamination.

It is estimated that about $16,000 \mathrm{yd}^{3}$ (27,200 tons) of soil would be excavated and shipped. off-site for treatment by chemical stabilization/solidification. The chemical stabilization/solidification process could increase the original soil volume and weight by as much as $30 \%$ and $60 \%$, respectively, with the addition of cement and fly ash. This would result in a total treated volume of about $20,800 \mathrm{yd}^{3}$ and a total weight of about 35,360 tons, which would be placed in a landfill. Contaminant toxicity would not be reduced.

Limited information is available to quantify the durability of chemically stabilized/ solidified waste upon exposure to the environment, that is, if the disposal facility failed and no corrective actions were taken. The durability of the product after failure would depend on the degree of failure and the quantity and quality of infiltrating water. Contaminants could leach from the cement slowly over time, and the leach rate would increase with an increase in dissolution or fracturing of the treated waste. Because the chemically treated product could eventually be leached and degraded if the waste were continuously exposed to the environment over a long period, the chemical stabilization/solidification process could be considered not entirely irreversible. However, appropriate design and good engineering practices (e.g., monitoring and maintenance activities) over the long term would reduce the likelihood of waste exposure and degradation.

\subsubsection{Short-Term Effectiveness}

\subsubsection{Duration of Remedial Activities}

Remedial action activities (including removal of soil, treatment, and disposal) under Alternative 5 should be completed in about 4 months; monitoring activities would take place during and after implementation of the action.

\subsubsection{Protection of Human Health}

The short-term risks to site workers and the general public would be significant for Alternative 5, and mitigative measures would need to be employed (Section 7.6). Excavation of 
contaminated soil at the TBP area is complicated by the possible presence of buried UXO, some of which may contain chemical agents. The health and safety implications of possibly encountering UXO and CWAs or other chemical contaminants would be addressed in the health and safety plan for the selected alternative. Soil would be excavated with conventional equipment following U.S. Army standard operating procedures.

The release of particulate emissions during excavation would need to be minimized. Although workers could wear respiratory protection, off-site dispersion of contaminated dust could present a health risk to other APG personnel and the general public. Engineering controls would be needed to reduce the air concentrations of CWAs and toxic chemicals released during excavation. The use of enclosures to contain airborne emissions might be required.

Monitoring for chemical agents and hazardous chemicals would also be required during excavation. Continuous personal and work-site monitoring for airborne vapors and particulates is a standard industrial hygiene practice. Even if the highest levels of protective clothing and equipment were used, chemical monitoring would be necessary in the event that personal protective gear malfunctioned or was improperly operated. Personal protective clothing and equipment would also be required to prevent dermal exposure through direct contact with contaminated soil.

Another component of Alternative 5 would involve the off-site transport, treatment, and disposal of contaminated soil. Because this component would involve the off-site transport of contaminated materials, the overall risk of exposure to the general public is higher than for Alternative 4. Site workers and off-site contractors responsible for transporting soil would be equipped with and trained in the use of personal protective equipment. Mitigative measures are further addressed in Section 7.6.

\subsubsection{Environmental Protection}

Soil, vegetation, and wildlife habitat disturbance would occur as a result of the soil excavation activities that would cover an area of about 5 acres. An estimated 0.5 acre of land would be disturbed to provide staging areas for soil awaiting transport to an off-site facility. Adverse impacts associated with these activities would include increases in fugitive dust emissions and ambient noise levels; potential increased sediment transport to the marsh and pond; and loss of vegetation and wildlife habitat at the main pits, pushout area, and soil staging areas. Air quality and noise impacts could disturb ecological resources near construction areas, but these impacts would . be minor and temporary. Although some permanent loss of vegetation and wildlife habitat would be expected, the amount of vegetation and habitat eliminated would be small; moreover, none of the areas to be excavated represent a quality habitat, contain important or critical plant species, or support listed biota. These potential risks are considered acceptable when weighed against the current adverse risk associated with contaminated surface soil (Sections 2.7.3 and 3.3). When all 
excavation activities were complete, the disturbed land would be backfilled and revegetated to create wildlife habitat of better quality than is currently present at the site.

Potential impacts to surface water, air quality, and noise levels during implementation of Alternative 5 could be mitigated through the use of good engineering practices. For example, siltation fences could control sediment runoff from the excavation and construction sites, berms and a runoff collection system could control runoff from the staging areas, mufflers could limit noise levels, and water spraying could minimize dust emissions (Section 7.6). No state or federally listed species would be expected to be disturbed during the implementation of Alternative 5.

\subsubsection{Implementability}

Construction and operation of most components of Alternative 5 would be straightforward. Resources are readily available for UXO screening (and safety measures), soil removal, and off-site treatment and disposal. Standard excavation and construction equipment would be used to remove contaminated soil. Soil would be sampled during excavation activities to verify that all contaminated surface soil within the excavation area was removed. The sampling procedures for soil at APG are well established.

Alternative 5 would use established treatment technologies. The stabilization/solidification technology is considered to be a reliable process and would not require further development before implementation. Several off-site treatment/disposal vendors would be available to submit competitive bids.

The implementation of Alternative 5 would not adversely affect the performance of additional remedial actions that might be required at the TBP area. The ability to implement future groundwater remediation at the site (if needed) would not be affected by the excavation and backfilling operations; however, in the case of phytoremediation, some coordination would be needed in the timing of excavation and planting of vegetation.

\subsubsection{Cost}

The components that make up the treatment train for Alternative 5 are shown in Table 7.4. As for Alternatives 3 and 4, costs are given for both the 6-in. and 2-ft excavations. Many of the components that make up the soil remediation treatment train for Alternative 5 are identical to those in Alternatives 2 through 4: UXO and CWA screening, constructing an access road, clearing and grubbing, excavating all areas, constructing a staging area, transporting soil to the staging area, and landscaping all excavated areas. Extension of electric service is not needed in this alternative. The 
TABLE 7.4 Cost Estimate for Alternative 5 (April 1996\$)

\begin{tabular}{|c|c|c|}
\hline \multirow[b]{2}{*}{ Activity } & \multicolumn{2}{|c|}{ Cost $(\$ 1,000)$} \\
\hline & $\begin{array}{c}\text { 6-in. } \\
\text { Excavation }\end{array}$ & $\begin{array}{c}2-\mathrm{ft} \\
\text { Excavation }\end{array}$ \\
\hline \multicolumn{3}{|l|}{ Direct costs } \\
\hline Construct/improve access road & 26 & 26 \\
\hline UXO screening & 156 & 156 \\
\hline Clear and grub & 20 & 20 \\
\hline Excavate pushout and pits & 81 & 197 \\
\hline Construct staging area & 126 & 268 \\
\hline Transport to staging area & 7 & 23 \\
\hline Off-site land disposal & 2,119 & 5,660 \\
\hline Sampling and analysis & 23 & 82 \\
\hline Landscape excavated area & 4 & 4 \\
\hline Remedial action professional labor & 16 & 19 \\
\hline Remedial design & 93 & 238 \\
\hline Total direct costs & 2,672 & 6,695 \\
\hline \multicolumn{3}{|l|}{ Indirect costs } \\
\hline Contractor general conditions & 444 & 824 \\
\hline Contractor overhead and profit & 618 & 1,415 \\
\hline Total contract indirect costs & 1,062 & 2,239 \\
\hline Total contract cost (direct and indirect) & 3734 & 8934 \\
\hline \multicolumn{3}{|l|}{ Other } \\
\hline Contingencies (10\%) & 373 & 893 \\
\hline Project management (8\%) & 299 & 715 \\
\hline Total project cost & 4,406 & 10,542 \\
\hline Unit cost $\left(\$ / y d^{3}\right)$ & 1,093 & 653 \\
\hline
\end{tabular}

a Costs for the 6-in. excavation are included for comparative purposes only. 
new component in the treatment train of this alternative is disposal of all excavated material in an off-site hazardous waste landfill.

As for Alternative 4, a staging area would be needed to stockpile the soil because it would probably be excavated faster than it could be transported to the off-site landfill. The staging area in this alternative was assumed to be the same size and construction as in Alternative 4. Soil would be trucked from the excavation site to the staging area and covered with plastic laminate.

As noted for Alternative 4, the contract cost of soil disposal in a hazardous waste landfill would be about $\$ 208 /$ ton ( $\$ 312 /$ ton for the 6-in. excavation, because of the smaller quantities). The cost includes loading onto trucks, transporting to the landfill, stabilizing the waste, and all taxes and fees for landfill disposal. The cost of disposal for the 6-in. excavation would be $\$ 2,119,000$, whereas the cost of disposal for the 2 -ft excavation would be $\$ 5,660,000$. This would amount to nearly $79 \%$ of the direct cost for the 6-in. excavation and nearly $85 \%$ for the 2 -ft excavation.

To characterize the excavated soil before off-site shipment, screening for CWAs and TCLP analyses would be performed. If CWAs were present, additional processing (on-site) would be required. Additional processing costs are not included in this estimate. The estimated cost for sampling and analysis is $\$ 23,000$ for the 6-in. excavation and $\$ 82,000$ for the 2 -ft excavation.

The final two direct-cost items for this alternative are professional labor and remedial design. Professional labor amounts to $\$ 16,000$ for the 6-in. excavation and $\$ 19,000$ for the 2 -ft excavation. Remedial design costs $\$ 93,000$ for the 6-in. excavation and $\$ 238,000$ for the 2 -ft excavation, assuming a low level of complexity for this alternative.

The total direct cost of this alternative is estimated to be $\$ 2,672,000$ for the 6 -in. excavation and $\$ 6,695,000$ for the 2 -ft excavation. Indirect costs, such as contractor general conditions and contractor overhead and profit, add $\$ 444,000$ and $\$ 618,000$, respectively, to the total cost for the 6 -in. excavation and $\$ 824,000$ and $\$ 1,415,000$, respectively, to the total cost for the 2-ft excavation. A contingency factor of $10 \%$ adds $\$ 373,000$ to the cost of the 6-in. excavation and $\$ 893,000$ to the 2 -ft excavation. Finally, it is assumed that project management adds an additional $8 \%$, or $\$ 299,000$ for the 6-in. excavation and $\$ 715,000$ for the 2 -ft excavation. Consequently, the total estimated cost of this alternative is $\$ 4,406,000$ for the 6-in. excavation and $\$ 10,542,000$ for the 2 - $\mathrm{ft}$ excavation. This translates into a unit cost of about $\$ 1,093 / \mathrm{yd}^{3}$ for the 6 -in. excavation and $\$ 653 / \mathrm{yd}^{3}$ for the $2-\mathrm{ft}$ excavation.

\subsection{MONITORING AND MITIGATIVE MEASURES}

The primary monitoring and mitigative measures that would be used at the TBP area during remediation are summarized in Table 7.5. These measures would provide a high degree of effectiveness in minimizing the potential for adverse effects associated with remediation activities. 
TABLE 7.5 Major Monitoring and Mitigative Measures for Action Alternatives

\begin{tabular}{ccc}
\hline Factor & Potential Impact & Mitigative Measure \\
\hline
\end{tabular}

Construction and excavation activities
Transport of contaminated and uncontaminated soil to adjacent marsh by surface water runoff

\section{Loss of terrestrial habitats}

Disturbance of local biota and site workers by noise

Disturbance of local biota, site workers, and general public and impacts to local air quality as a result of fugitive dust emissions

Transport of contaminated soil from TBP area to on-site storage or treatment facility
Accidental spill (release) of contaminated material as a result of equipment failure or vehicular accident

Inadvertent transport of contaminated material on haul vehicle surfaces or tires leaving work zone
Good engineering practices would be implemented, including sediment barriers, dikes, siltation ponds, and drainage channels to direct runoff away from marsh; surface would be backfilled upon completion of excavation.

In addition, surface water and sediment would continue to be monitored for related contaminants so contaminated media could be addressed appropriately (through removal or treatment), as needed.

Habitats would be restored, as appropriate. The final form of mitigation would be determined in consultation with appropriate state and federal agencies.

Vehicle and equipment mufflers would be checked periodically and maintained in good condition.

Dust would be controlled by using wet methods and covers at the excavation site, along access roads, and at staging areas. Work areas would be covered, as needed (e.g., at night and during high winds).

Soil would be transported in covered trucks traveling at low speeds. Soil would be dewatered before transport.

Contingency plans would be in place to address any spills that might occur during transport.

Haul vehicles would be decontaminated and inspected before leaving the work zone. 
TABLE 7.5 (Cont.)

\begin{tabular}{ccc}
\hline Factor & Potential Impact & Mitigative Measure \\
\hline
\end{tabular}

Transport of contaminated soil to an off-site treatment and disposal facility

All phases of remedial activities
Accidental spill (release) of contaminated material as a result of equipment failure or vehicular accident

Inadvertent transport of contaminated material on haul vehicle surfaces or tires leaving work zone

Protection of site workers

Protection of the general public
Soil would be transported in closed containers. Contingency plans would be in place to address any spills that might occur during transport.

Haul vehicles and containers would be decontaminated and inspected before leaving the work zone.

All activities would be conducted in accordance with project health and safety plans and would include continuous monitoring of the work environment, UXO screening, and the use of protective equipment, as needed.

Air and water would be monitored at the site and vicinity, and appropriate responses would be implemented if measured contaminant levels increased significantly above background.

Access to construction and excavation areas would be limited; public vehicle access would also be limited along some of the off-site haul routes. Engineering controls would be applied to minimize dust and erosion during remedial action activities Decontamination methods would be employed to minimize vehicle tracking of contaminants to surrounding uncontaminated areas. All traffic associated with the remedial action would be coordinated to minimize impacts on nearby facilities. 
TABLE 7.5 (Cont.)

\begin{tabular}{lll}
\hline \multicolumn{1}{c|}{ Factor } & Potential Impact & \multicolumn{1}{c}{ Mitigative Measure } \\
\hline $\begin{array}{l}\text { All phases of remedial activities } \\
\text { (cont.) }\end{array}$ & $\begin{array}{l}\text { Environmental monitoring } \\
\text { Environmental restoration }\end{array}$ & $\begin{array}{l}\text { Air quality would be monitored for contaminated particulates } \\
\text { at the site perimeter. Surface water downgradient of exca- } \\
\text { vation and construction areas would be monitored for } \\
\text { contaminants. Appropriate responses would be implemented } \\
\text { as indicated by monitoring results. }\end{array}$ \\
& $\begin{array}{l}\text { Disturbed areas would be restored by backfilling with clean } \\
\text { fill, regrading, and revegetating with native and/or forage } \\
\text { species. If necessary, wetlands would be constructed, as } \\
\text { indicated, on the basis of consultation with the appropriate } \\
\text { state and federal agencies. }\end{array}$ \\
\hline
\end{tabular}

state and federal agencies. 


\section{COMPARATIVE ANALYSIS OF ALTERNATIVES}

The comparative analysis of final interim remedial action alternatives for the J-Field TBP area compares the alternatives according to the nine evaluation criteria described in Section 7. This analysis is the second stage of the detailed evaluation process and provides information for making a balanced decision for site cleanup. For this analysis, the nine criteria are grouped into three general categories that make up the tiered evaluation system identified in the NCP (EPA 1990a): threshold criteria, primary balancing criteria, and modifying criteria.

The alternatives are compared in Sections 8.1 and 8.2 according to the threshold and primary balancing criteria, and Table 8.1 presents the results of this analysis. Section 8.3 introduces the modifying criteria. The comparative analysis is summarized in Section 8.4.

\subsection{THRESHOLD CRITERIA}

The threshold criteria category contains the two criteria that must be satisfied by the selected alternative:

- Overall protection of human health and the environment and

- Compliance with ARARs, unless a waiver condition applies.

These criteria are of greatest importance in the comparative analysis because they reflect the key statutory mandates of CERCLA. If an alternative does not satisfy both criteria, it cannot be selected as the cleanup remedy.

\subsubsection{Overall Protection of Human Health and the Environment}

Alternatives 2, 4, and 5 would provide long-term protection of human health and the environment. This protection could not be ensured by the no-action alternative (Alternative 1) because only general baseline maintenance and monitoring activities would continue, and contaminants could migrate over time (e.g., from surface runoff into the marsh) and result in possible future adverse impacts. Alternative 3 , intended to be an interim measure only, would also not provide longterm protection of human health and the environment, although it would meet project objectives by reducing exposures and minimizing contaminant migration by removing the sources of contamination. Alternative 2 would limit exposures to contaminants by removing "hot spots" in the main pits and covering remaining contaminated surface soil. Arsenic- and PCB-contaminated soil would be sent off-site for treatment and disposal. Shoreline stabilization would be an adjunct to this 
TABLE 8.1 Comparative Analysis of Alternatives

\begin{tabular}{|c|c|c|c|c|}
\hline $\begin{array}{l}\text { Altemative 1: } \\
\text { No Action }\end{array}$ & $\begin{array}{l}\text { Altemative 2: } \\
\text { Limited Removal and Disposal, and In- } \\
\text { Situ Containment } \\
\end{array}$ & $\begin{array}{c}\text { Alternative 3: } \\
\text { Removal and Short-Term Storage } \\
\end{array}$ & $\begin{array}{c}\text { Altemative 4: } \\
\begin{array}{c}\text { Removal, On-Site Treatment, } \\
\text { and Limited Disposal }\end{array} \\
\end{array}$ & $\begin{array}{c}\text { Altemative 5: } \\
\text { Removal, Off-Site Treatment, } \\
\text { and Disposal } \\
\end{array}$ \\
\hline \multicolumn{5}{|c|}{ Overall Protection of Human Health and the Environment } \\
\hline $\begin{array}{l}\text { Would not ensure protection of } \\
\text { human health and the environ- } \\
\text { ment in the long term. Source } \\
\text { areas would not be removed or } \\
\text { treated, and exposures could } \\
\text { increase over time. }\end{array}$ & $\begin{array}{l}\text { Engineering and mitigative measures } \\
\text { would be employed during the remedial } \\
\text { action period so that no significant } \\
\text { adverse impacts would occur to the } \\
\text { general public or environment. Worker } \\
\text { exposures would be similarly } \\
\text { controlled to levels within health- } \\
\text { protective limits. Long-term exposures } \\
\text { would be minimized by removing "hot } \\
\text { spots" (arsenic and PCBs) from the } \\
\text { main pits and by covering remaining } \\
\text { contaminated soil with a protective soil } \\
\text { cover. }\end{array}$ & $\begin{array}{l}\text { Somewhat greater than Alternative } 2 \text {. } \\
\text { Long-term exposures would be } \\
\text { minimized by removing and storing } \\
\text { contaminated soil from the main pits } \\
\text { and pushout area for about } 5 \text { years. At } \\
\text { the end of that time, an additional } \\
\text { component (e.g., off-site treatment and } \\
\text { disposal) would be needed to ensure } \\
\text { long-term protection. }\end{array}$ & $\begin{array}{l}\text { Generally similar to Altemative } 3 \text {. } \\
\text { Long-term exposures would be } \\
\text { minimized by removing and treating } \\
\text { contaminated soil from the main pits } \\
\text { and pushout area. }\end{array}$ & $\begin{array}{l}\text { Generally similar to Alternatives } 3 \text { and } \\
\text { 4. Treatment and disposal of a large } \\
\text { volume of contaminated soil would be } \\
\text { conducted off-site; therefore, the } \\
\text { overall risk of exposure to the general } \\
\text { public would be higher than that for } \\
\text { Alternatives } 2,3 \text {, and } 4 \text {. }\end{array}$ \\
\hline \multicolumn{5}{|l|}{ Compliance with ARARs } \\
\hline $\begin{array}{l}\text { Would not meet all ARARs, } \\
\text { including the corrective action } \\
\text { requirements of RCRA and } \\
\text { TSCA. In addition, would not } \\
\text { satisfy the CERCLA-mandated } \\
\text { preference for remedies that } \\
\text { reduce contaminant toxicity, } \\
\text { mobility, or volume } \\
\text { through treatment. }\end{array}$ & $\begin{array}{l}\text { Would meet all pertinent ARARs (with } \\
\text { waivers as appropriate), including } \\
\text { those that address protection of } \\
\text { endangered species and habitats, } \\
\text { floodplains, and wetlands. } \\
\text { Implementing Alternative } 2 \text { might } \\
\text { require preparation of a sediment and } \\
\text { erosion control plan. }\end{array}$ & $\begin{array}{l}\text { Same as Alternative } 2 \text {. The on-site } \\
\text { storage facility would be operated to } \\
\text { ensure compliance with RCRA. }\end{array}$ & $\begin{array}{l}\text { Same as Alternatives } 2 \text { and } 3 \text {. The } \\
\text { on-site treatment facility would be } \\
\text { operated to ensure compliance } \\
\text { with RCRA. }\end{array}$ & $\begin{array}{l}\text { Same as Altematives } 2,3 \text {, and } 4 \text {, with } \\
\text { additional disposal requirements that } \\
\text { would be met, including RCRA } \\
\text { hazardous waste generator. }\end{array}$ \\
\hline
\end{tabular}




\section{TABLE 8.1 (Cont.)}

\begin{tabular}{|c|c|c|c|c|}
\hline $\begin{array}{l}\text { Altemative 1: } \\
\text { No Action }\end{array}$ & $\begin{array}{l}\text { Altemative 2: } \\
\text { Limited Removal and Disposal, and In- } \\
\text { Situ Containment } \\
\end{array}$ & $\begin{array}{l}\text { Altemative 3: } \\
\text { Removal and Short-Term Storage }\end{array}$ & $\begin{array}{c}\text { Alternative 4: } \\
\text { Removal, On-Site Treatment, } \\
\text { and Limited Disposal } \\
\end{array}$ & $\begin{array}{c}\text { Alternative 5: } \\
\text { Removal, Off-Site Treatment, } \\
\text { and Disposal } \\
\end{array}$ \\
\hline \multicolumn{5}{|c|}{ Long-Term Effectiveness and Permanence } \\
\hline $\begin{array}{l}\text { Current exposures and impacts } \\
\text { would continue and could } \\
\text { increase over time because of } \\
\text { continued contaminant migra- } \\
\text { tion. Existing institutional } \\
\text { controls would continue to limit } \\
\text { access to site workers and other } \\
\text { authorized personnel, thereby } \\
\text { reducing risk to the general } \\
\text { public. }\end{array}$ & $\begin{array}{l}\text { More protective than Alternative } 1 \\
\text { because contaminated soil would be } \\
\text { partially removed; the remaining soil } \\
\text { then would be covered to reduce } \\
\text { exposure of human and environmental } \\
\text { receptors to surface contamination. Soil } \\
\text { cleanup criteria would be applied to the } \\
\text { removal of soils and to the delineation } \\
\text { of the area to be covered. }\end{array}$ & $\begin{array}{l}\text { More protective than Alternative I } \\
\text { because contaminated soil would be } \\
\text { removed and stored in an enclosed } \\
\text { facility to provide an interim solution } \\
\text { for risk posed by contaminated surface } \\
\text { soil. Soil cleanup criteria would be } \\
\text { applied as appropriate to the removal } \\
\text { of soils, so the action would reduce } \\
\text { contaminant concentrations remaining } \\
\text { in soil to the most protective } \\
\text { levels practicable. }\end{array}$ & $\begin{array}{l}\text { More protective than Alternatives } 1 \text {, } \\
2 \text {, and } 3 \text { because contaminated } \\
\text { surface soil would be removed and } \\
\text { treated (soil washing/leaching) to } \\
\text { provide a permanent solution for } \\
\text { risk posed by contaminated surface } \\
\text { soil. Soil cleanup criteria would be } \\
\text { applied as appropriate to the } \\
\text { removal of soils, so the action } \\
\text { would reduce contaminant } \\
\text { concentrations remaining in soil to } \\
\text { the most protective } \\
\text { levels practicable. }\end{array}$ & $\begin{array}{l}\text { Similar to Altemative 4, except that } \\
\text { exposure of stabilized/solidified waste } \\
\text { to the environment could result in } \\
\text { contaminants leaching from the waste } \\
\text { over time. }\end{array}$ \\
\hline \multicolumn{5}{|c|}{ Reduction of Toxicity, Mobility, or Volume } \\
\hline $\begin{array}{l}\text { Toxicity, mobility, and volume } \\
\text { of contaminated soil would } \\
\text { not change. }\end{array}$ & $\begin{array}{l}\text { The in-situ containment component } \\
\text { would significantly reduce contaminant } \\
\text { mobility. Contaminant volume would } \\
\text { be somewhat reduced by the limited } \\
\text { removal and disposal component. } \\
\text { Contaminant toxicity would not be } \\
\text { reduced. }\end{array}$ & $\begin{array}{l}\text { Short-term storage of soil in an on-site } \\
\text { facility would significantly reduce } \\
\text { contaminant mobility. An estimated } \\
16,000 \mathrm{yd}^{3}(27,200 \text { tons) of soil would } \\
\text { be stored on-site for about } 5 \text { years. } \\
\text { Contaminant toxicity and volume } \\
\text { would not be reduced. }\end{array}$ & $\begin{array}{l}\text { Chemical treatment of soil by soil } \\
\text { washing/leaching would signif- } \\
\text { icantly reduce contaminant mobility } \\
\text { and volume. An estimated } \\
16,000 \text { yd }^{3}(27,200 \text { tons) of soil } \\
\text { would be treated on-site by soil } \\
\text { washing/leaching. This process } \\
\text { could reduce original soil volume by } \\
\text { about } 94 \% \text {; the remaining } 6 \% \text { could } \\
\text { then be sent off-site for disposal. } \\
\text { Toxicity of PCBs would be reduced. } \\
\text { Lead toxicity would not be reduced; } \\
\text { however, the metal would be } \\
\text { removed and recycled. }\end{array}$ & $\begin{array}{l}\text { Chemical treatment of soil with the } \\
\text { stabilization/solidification technology } \\
\text { would significantly reduce contaminant } \\
\text { mobility. An estimated } 16,000 \mathrm{yd}^{3} \\
(27,200 \text { tons) of soil would be treated } \\
\text { off-site by chemical stabilizations } \\
\text { solidification. This process could } \\
\text { increase the original soil volume and } \\
\text { weight by as much as } 30 \% \text { and } 60 \% \text {, } \\
\text { respectively. This would result in a } \\
\text { total treated volume of about } \\
20,800 \mathrm{yd}^{3} \text { and total weight of about } \\
35,360 \text { tons to be placed in a landfill. } \\
\text { Contaminant toxicity would } \\
\text { not be reduced. }\end{array}$ \\
\hline
\end{tabular}


TABLE 8.1 (Cont.)

\begin{tabular}{|c|c|c|c|c|}
\hline $\begin{array}{l}\text { Altemative 1: } \\
\text { No Action } \\
\end{array}$ & $\begin{array}{c}\text { Altemative 2: } \\
\text { Limited Removal and Disposal, and In- } \\
\text { Situ Containment } \\
\end{array}$ & $\begin{array}{l}\text { Alternative 3: } \\
\text { Removal and Short-Term Storage }\end{array}$ & $\begin{array}{l}\text { Alternative 4: } \\
\text { Removal, On-Site Treatment, } \\
\text { and Limited Disposal }\end{array}$ & $\begin{array}{c}\text { Alternative 5: } \\
\text { Removal, Off-Site Treatment, } \\
\text { and Disposal } \\
\end{array}$ \\
\hline \multicolumn{5}{|l|}{ Short-Term Effectiveness } \\
\hline $\begin{array}{l}\text { Current exposures and adverse } \\
\text { impacts would continue. Existing } \\
\text { institutional controls would } \\
\text { continue to limit access to site } \\
\text { workers and other authorized } \\
\text { personnel, thus reducing risks to } \\
\text { the general public. Short-term } \\
\text { risks to site workers and the } \\
\text { environment as a result of } \\
\text { monitoring and maintenance } \\
\text { activities are considered low. }\end{array}$ & $\begin{array}{l}\text { Exposures would be lower than for } \\
\text { Ailternatives } 3,4 \text {, and } 5 \text {, which involve } \\
\text { large-scale excavation. Mitigative } \\
\text { measures would still be required in the } \\
\text { short term because of particulate and } \\
\text { VOC emissions associated with } \\
\text { removal and transportation activities. } \\
\text { No adverse impacts to the general } \\
\text { public are expected from contaminant } \\
\text { releases during implementation of this } \\
\text { altemative. Soil, vegetation, and } \\
\text { wildlife disturbances would be } \\
\text { significant during soil excavation } \\
\text { activities. An estimated } 5 \text { acres would } \\
\text { be affected. Most impacts to biota } \\
\text { would be temporary. Surface water } \\
\text { impacts associated with the } \\
\text { construction of a berm along the } \\
\text { pushout-marsh boundary would be } \\
\text { minimal (and localized). Surface water } \\
\text { input would be reduced, but reduction } \\
\text { in erosion and transport of soils into the } \\
\text { marsh would be a benefit to the marsh } \\
\text { ecosystem. Mitigative measures would } \\
\text { be implemented to minimize impacts to } \\
\text { air quality and those associated with } \\
\text { noise levels. }\end{array}$ & $\begin{array}{l}\text { Exposures could be higher than } \\
\text { Alternatives I and } 2 \text { in the short term } \\
\text { because of particulate and VOC } \\
\text { emissions associated with removal, } \\
\text { transportation, and storage activities. } \\
\text { Mitigative measures would be } \\
\text { implemented to minimize potential } \\
\text { human health and environmental } \\
\text { impacts. Risks to a site worker would } \\
\text { increase compared to Alternative } 1 \text {; } \\
\text { however, worker health and safety } \\
\text { precautions would be used to control } \\
\text { exposures. No adverse impacts to the } \\
\text { general public are expected from } \\
\text { contaminant releases during imple- } \\
\text { mentation of this alternative. Soil, } \\
\text { vegetation, and wildlife disturbances } \\
\text { would be significant during soil } \\
\text { excavation activities. An estimated } \\
5 \text { acres would be affected. Most } \\
\text { impacts to biota would be temporary. } \\
\text { Activities are not expected to affect } \\
\text { threatened or endangered species. } \\
\text { Mitigative measures would be } \\
\text { employed to minimize impacts to } \\
\text { surface water resources (including the } \\
\text { adjacent marsh), air quality, and those } \\
\text { associated with noise levels. }\end{array}$ & Similar to Alternative 3. & $\begin{array}{l}\text { Similar to Alternatives } 3 \text { and } 4 \text {, except } \\
\text { that overall risk to the general public } \\
\text { would be higher because this alter- } \\
\text { native would involve the off-site } \\
\text { transport of a large volume of } \\
\text { contaminated soil. Additional } \\
\text { mitigative measures would be } \\
\text { implemented to reduce related impacts. }\end{array}$ \\
\hline
\end{tabular}


TABLE 8.1 (Cont.)

\begin{tabular}{|c|c|c|c|c|}
\hline $\begin{array}{l}\text { Altemative 1: } \\
\text { No Action }\end{array}$ & $\begin{array}{c}\text { Altemative 2: } \\
\text { Limited Removal and Disposal, and In- } \\
\text { Situ Containment }\end{array}$ & $\begin{array}{c}\text { Alternative 3: } \\
\text { Removal and Short-Term Storage }\end{array}$ & $\begin{array}{l}\text { Alternative 4: } \\
\text { Removal, On-Site Treatment, } \\
\text { and Limited Disposal } \\
\end{array}$ & $\begin{array}{c}\text { Alternative 5: } \\
\text { Removal, Off-Site Treatment, } \\
\text { and Disposal } \\
\end{array}$ \\
\hline \multicolumn{5}{|l|}{ Implementability } \\
\hline $\begin{array}{l}\text { Minimum site operations } \\
\text { (monitoring and maintenance) } \\
\text { would continue with the use of } \\
\text { readily available resources. }\end{array}$ & $\begin{array}{l}\text { Fairly straightforward to implement. } \\
\text { Resources are readily available for } \\
\text { UXO screening, soil removal, in-situ } \\
\text { containment, and shoreline } \\
\text { stabilization. }\end{array}$ & $\begin{array}{l}\text { Fairly straightforward to implement. } \\
\text { Resources are readily available for } \\
\text { UXO screening, soil removal, and } \\
\text { on-site storage. Short-term storage } \\
\text { facilities are available as kits and } \\
\text { can be customized to meet } \\
\text { project specifications. }\end{array}$ & $\begin{array}{l}\text { Similar to Alternative } 3 \text {. Soil } \\
\text { washing/leaching has been used at } \\
\text { several hazardous waste sites and } \\
\text { probably would not require further } \\
\text { development before it could be } \\
\text { implemented at the TBP area. } \\
\text { Further bench-scale testing would } \\
\text { be required to refine and optimize } \\
\text { the design of the treatment system. }\end{array}$ & $\begin{array}{l}\text { Similar to Alternatives } 3 \text { and } 4 \text {. } \\
\text { Chemical stabilization/solidification is } \\
\text { an established technology and would } \\
\text { not require further development before } \\
\text { it could be implemented. }\end{array}$ \\
\hline \multicolumn{5}{|l|}{ Cost } \\
\hline $\begin{array}{l}\text { The total cost would be the } \\
\text { lowest in the short term (about } \\
\$ 3 \text { million over a 10-year } \\
\text { period), but the comparative } \\
\text { level of effectiveness would be } \\
\text { low. In addition, the cost could } \\
\text { be potentially higher than the } \\
\text { action alternatives over the long } \\
\text { term because conditions could } \\
\text { worsen over time, necessitating } \\
\text { an expensive expanded response } \\
\text { in the future. }\end{array}$ & $\begin{array}{l}\text { The total cost would be about } \\
\$ 1.8 \text { million, the lowest cost of all the } \\
\text { action altematives. This cost, however, } \\
\text { reflects only O\&M costs for the next } \\
30 \text { years. Because contaminated soil } \\
\text { will remain in place, O\&M costs will } \\
\text { likely extend indefinitely into the } \\
\text { future. Repairs associated with the } \\
\text { catastrophic effects of a } 100 \text {-year flood } \\
\text { are also not reflected in this estimate. }\end{array}$ & $\begin{array}{l}\text { The total cost would be about } \\
\$ 5.0 \text { million (for } 16,000 \text { yd }{ }^{3} \text { of soil), } \\
\text { the second lowest of all the action } \\
\text { alternatives. This cost, however, does } \\
\text { not include the cost of an additional } \\
\text { component (off-site treatment and } \\
\text { disposal) that would be needed to } \\
\text { ensure long-term protectiveness and } \\
\text { permanence. Therefore, while this } \\
\text { altemative would achieve project } \\
\text { objectives of reducing exposures and } \\
\text { minimizing contaminant migration at a } \\
\text { low cost, it is considered the least cost- } \\
\text { effective because additional } \\
\text { components would be required when } \\
\text { the } 5 \text {-year storage period ended. }\end{array}$ & $\begin{array}{l}\text { The total cost would be about } \\
\$ 13.0 \text { million (for } 16,000 \mathrm{yd}^{3} \\
\text { of soil), which is the highest of } \\
\text { the action altematives. The soil } \\
\text { washing/leaching component would } \\
\text { account for } 86 \% \text { of the total direct } \\
\text { cost of this altemative. }\end{array}$ & $\begin{array}{l}\text { The total cost would be about } \\
\$ 10.5 \text { million (for } 16,000 \mathrm{yd}^{3} \text { of soil), } \\
\text { which is lower than Alternative } 4 \text { for } \\
\text { the same overall level of effectiveness. } \\
\text { Off-site treatment and disposal would } \\
\text { account for } 85 \% \text { of the total direct cost } \\
\text { of this alternative. }\end{array}$ \\
\hline
\end{tabular}


activity to prevent erosion of the shoreline to the south of the TBP area. Alternative 4 would limit exposures to contaminants by removing the sources of contamination, treating the contaminated soil on-site (via soil washing/leaching), then returning the cleaned soil to the site to be used as fill. In addition, PCB-contaminated soil would be sent off-site for treatment (incineration or stabilization) and disposal. Alternative 5 is similar to Alternative 4, except that the soil would be sent off-site for treatment (via stabilization/solidification) and disposal. Clean soil would be brought in to fill the excavated areas.

The two main differences between Alternatives 4 and 5 are the treatment method and disposal location, which includes a transportation component for off-site disposal. Under both Alternatives 4 and 5, PCB-contaminated soil would be sent off-site for treatment and disposal. Under Alternative 4, contaminated soil (an estimated $16,000 \mathrm{yd}^{3}$ for an excavation to a depth of $2 \mathrm{ft}$ ) would be treated on-site with a small volume of material sent off-site for disposal. Under Alternative 5, all of the $16,000 \mathrm{yd}^{3}$ of contaminated soil would be sent off-site for treatment and disposal.

Although potential health impacts during cleanup activities could be significant for all the alternatives, mitigative measures would be employed to control exposures to levels within healthprotective limits. Impacts to the general public would be relatively higher for Alternative 5 than for Alternatives 2, 3, and 4 because of the increased likelihood of exposures and accidents during the waste handling and transportation activities associated with off-site disposal. Impacts to site workers would be highest for Alternatives 3, 4, and 5 because these alternatives involve large-scale excavation components.

Environmental impacts for all the alternatives could be significant. Each alternative involves excavating soil from source areas and constructing temporary staging areas, although excavation for Alternative 2 is fairly limited. Potential environmental impacts include increased fugitive dust and VOC emissions, increased ambient noise levels, increased sediment transport to the marsh and pond, and loss of vegetation and wildlife habitat. Most of these impacts are considered short term, although some loss of habitat may result. This impact would be offset by backfilling and revegetating the site, creating a wildlife habitat of better quality than is currently present at the site. Mitigative measures, such as those described in Section 7.6, would be employed to minimize these impacts.

\subsubsection{Compliance with ARARs}

Except for Alternative 1, the attainment of ARARs under each final alternative would be comparable; applicable requirements would be met both during and following cleanup unless a waiver condition is applied. A comprehensive list of potential ARARs for this remedial action is presented in Appendix B; key requirements are discussed in Section 7 within the evaluation of each alternative against this criterion. 
Alternative 1 would not attain certain applicable requirements, including RCRA corrective action requirements and TSCA. Alternatives $2,3,4$, and 5 would meet applicable standards.

\subsection{PRIMARY BALANCING CRITERIA}

The primary balancing criteria category contains the five criteria used to assess the relative advantages and disadvantages of the alternatives to determine the most appropriate solution for a given site:

- Long-term effectiveness and permanence;

- Reduction of toxicity, mobility, or volume through treatment;

- Short-term effectiveness;

- Implementability; and

- Cost.

The first and second criteria address the statutory preference for treatment as a principal element of the remedy and the bias against off-site disposal of untreated waste. Together with the third and fourth criteria, they form the basis for determining the general feasibility of the remedy and whether costs are proportional to the overall effectiveness, considering both the cleanup period and the time following cleanup. By this means, it can be determined whether the remedy is cost-effective.

\subsubsection{Long-Term Effectiveness and Permanence}

Alternative 1 would not ensure long-term protection of human health or the environment because contaminants would be left in place, resulting in continued exposures to site workers and biota. In addition, contaminant levels in the marsh adjacent to the pushout area could increase due to contaminant migration from the source areas. Alternative 3 , an interim measure, also would not ensure long-term protection, although it would accomplish project objectives. A long-term and more permanent component (such as off-site disposal) would be required to ensure long-term effectiveness. In contrast, Alternative 2 would provide long-term protection by limited removal and treatment and in-situ containment; however, long-term effectiveness could be affected by the potential for flooding. Alternatives 4 and 5 also would provide a permanent solution and long-term protection because they both involve removing and treating contaminated soil. The cleanup activities under all alternatives would reduce risks to levels considered protective of both human health and the environment. 


\subsubsection{Reduction of Toxicity, Mobility, or Volume}

The toxicity, mobility, or volume of contaminated material at the TBP area would not change under Alternative 1. In contrast, Alternative 2 would reduce contaminant mobility; however, because Alternative 2 involves only limited removal and treatment, contaminant toxicity and volume would be only somewhat reduced. Alternatives 3,4 , and 5 would remove contaminated soil, and the overall reduction in contaminant mobility would be higher than Alternative 2 and generally similar for each alternative. The toxicity and volume of contaminated soils would not be affected by Alternative 3. The volume of contaminated soils would be reduced by about $94 \%$ under Alternative 4; cleaned soil would be returned to the site, and recovered metals would be recycled. Under Alternative 5, soil volume would increase because of the addition of cement and fly ash to the soil matrix to stabilize it before disposal. Soil volume could increase by as much as $30 \%$ under this alternative. The toxicity of PCB-contaminated soil would be reduced by incineration under Alternatives 2, 4, and 5. Toxicity of lead would not be reduced under any alternative; however, the metal would be removed and recycled under Alternative 4.

\subsubsection{Short-Term Effectiveness}

For Alternative 1, conditions would remain essentially the same in the short term, and no significant changes in potential exposures would be expected. Estimated risks associated with these exposures have been reported in the BRA (ICF Kaiser Engineers 1995b) and ERA (Hlohowskyj et al. 1996). For Alternatives 2, 3, 4, and 5, the various removal, treatment, and disposal activities would result in increased short-term exposures compared with Alternative 1. The short-term impacts associated with excavating and constructing temporary staging areas would be similar for all alternatives because the same procedures would be used. Potential impacts to the public would be minimized through the use of protective mitigative measures (Section 7.5). The risk of transportation accidents and related exposures would be highest for Alternative 5 because the greatest volume of soil would be sent off-site for disposal (resulting in a larger number of truck trips to the treatment and disposal facilities). The berm to be built as part of the in-situ containment component under Alternative 2 would result in a reduction of surface water input into the adjacent marsh but would produce the overall benefit of reducing erosion transport of contaminated soils into the marsh.

Potential short-term environmental impacts for all alternatives include increased fugitive dust and VOC emissions, increased ambient noise levels, increased sediment transport to the marsh and pond, and temporary loss of vegetation and wildlife habitat. Mitigative measures, such as those described in Section 7.6, would be employed to minimize these impacts. 


\subsubsection{Implementability}

All the action alternatives would be fairly straightforward to implement. The UXO screening, removal, treatment, disposal, and in-situ containment activities could be carried out with standard equipment and procedures and readily available resources. The storage facility under Alternative 3 can be purchased as a kit and customized according to project specifications. The soil washing/leaching technology under Alternative 4 has been used at several hazardous waste sites and probably would not require further development for implementation at the TBP area, although further pilot-scale testing would be required. The stabilization/solidification treatment technology under Alternative 5 is well established and reliable.

The implementation of Alternative 2, 3, 4, or 5 would not adversely affect the performance of any future remedial actions that might be required at the TBP area. For example, the ability to implement future groundwater remediation (if needed) at the site would not be affected by excavation and backfilling operations or by emplacement of the "risk-reduction cover."

\subsubsection{Cost}

Alternative 1 would include monitoring and maintenance costs and would be the least expensive of all the alternatives in the short term. However, total costs are expected to be highest in the long term because site conditions could worsen over time in the absence of cleanup, such that the potential impacts and the magnitude of the cleanup effort could increase in the future. Therefore, the cost-effectiveness of the no-action alternative is low.

Preliminary costs estimated for Alternatives 2, 3, 4, and 5 allow a balanced comparison for considering overall effectiveness. Final costs will be developed during the detailed design stage after the remedy for site cleanup is selected. The costs presented in this report were estimated by using the RACER model (Appendix F) and information supplied by vendors. Table 8.2 lists comparative costs for the removal, storage, treatment, and disposal components of Alternatives 2, 3, 4, and 5 . Alternative 2 has the lowest total costs. Alternative 4 costs more than Alternative 5 because higher costs are associated with on-site treatment (soil washing/leaching) and disposal. Although Alternative 4 offers no increased benefit for overall protectiveness, it does satisfy EPA's preference for on-site treatment. Of concern for Alternative 5 is the continued, long-term monitoring and maintenance of the off-site disposal facility. Because it would be a commercial facility, the maintenance of institutional controls at the site would be the responsibility of a private company instead of the federal government. Breakdowns in institutional controls resulting in contaminant releases from U.S. Army waste could lead to future liability issues. This concern does not exist for the on-site treatment of contaminated soil under Alternative 4 because soil would be cleaned and returned to the site (pending a treatability variance), and metals would be recovered and recycled. 
TABLE 8.2 Comparative Costs for Cleanup Activities under Alternatives 2, 3, 4, and 5

\begin{tabular}{|c|c|c|c|c|}
\hline \multirow[b]{2}{*}{ Activity } & \multicolumn{4}{|c|}{ Estimated Cost ( $\$$ million) } \\
\hline & Alternative 2 & Alternative 3 & Alternative 4 & Alternative 5 \\
\hline Removal & 0.1 & $0.4(0.3)^{\mathrm{a}}$ & $0.4(0.3)$ & $0.4(0.3)$ \\
\hline In-situ containment & 0.4 & $N A^{b}$ & $N A^{b}$ & $N A^{b}$ \\
\hline Storage & $N A^{c}$ & $2.2(1.2)$ & $N A^{c}$ & $N A^{c}$ \\
\hline Treatment & $-d$ & $\mathrm{NA}^{\mathrm{e}}$ & $6.4(2.5)$ & $-{ }^{d}$ \\
\hline Disposal & 0.3 & $\mathrm{NA}^{\mathrm{e}}$ & $0.3(0.1)$ & $6.1(2.3)$ \\
\hline Other $^{f}$ & 1.0 & $2.4(1.5)$ & $6.0(2.4)$ & $4.0(1.8)$ \\
\hline Total & 1.8 & $5.0(3.0)$ & $13.1(5.3)$ & $10.5(4.4)$ \\
\hline
\end{tabular}

a Cleanup costs listed are for excavation to $2 \mathrm{ft}$ (total soil volume of $16,000 \mathrm{yd}^{3}$ ); numbers in parentheses represent cleanup costs for excavation to 6 in. (total soil volume of $4,000 \mathrm{yd}^{3}$ ) for Alternatives 3,4 , and 5 .

b Not applicable; in-situ containment is not a component of Alternative 3, 4, or 5 .

c Not applicable; storage facility is not a component of Alternative 4 or 5 .

d Treatment and disposal costs are estimated together for Alternatives 3 and 5.

e Not applicable; treatment and disposal is not a component of Alternative 3.

f Other costs include indirect costs, such as contractor overhead and profit, remedial design, labor and project management, and contingencies:

Cost estimates for Alternative 4 were based on the assumption that soil volume would be reduced by $94 \%$, resulting in $6 \%$ of the soil being sent off-site for further treatment and disposal.

Alternative 2 is considered the most cost-effective alternative because it provides overall protection for human health and the environment and has the lowest total cost as compared to Alternatives 3, 4, and 5. However, because this alternative has only been costed to 30 years, it is not directly comparable to the costs for Alternatives 3,4 , and 5 . 


\subsection{MODIFYING CRITERIA}

The modifying criteria include:

- State acceptance and

- Community acceptance.

As discussed in Section 7, this category can be fully considered only after this FFS has been issued to the state and the public for formal comment. Therefore, these modifying criteria are not addressed in this comparative analysis. They will be addressed in detail in the Responsiveness Summary for the ROD for this remedial action.

\subsection{SUMMARY}

In summary, all of the final remedial action alternatives for the TBP area, except for the no-action alternative (Alternative 1), satisfy the threshold criteria for protecting human health and the environment and complying with regulatory requirements, with waivers as appropriate. Under each alternative, exposures and risks would be minimized by removing the sources of contamination and treating the contaminated soil. Alternative 2 would also involve covering contaminated soil in place to reduce surface exposures. Overall protectiveness under Alternatives 4 and 5 would be comparable to and somewhat greater than that under Alternative 2 because contaminant removal and treatment would be the major components of these alternatives. Alternative 3 , while protective in the short term, would require an additional component (e.g., off-site treatment and disposal) to be as protective as Alternatives 4 and 5 .

With regard to the primary balancing criteria, only Alternatives 2, 4, and 5 are expected to provide a permanent solution that would ensure protection for a very long time, although long-term effectiveness under Alternative 2 could be affected by the potential for flooding. It is possible that the soil washing/leaching treatment under Alternative 4 would be more protective than Alternative 5 if, at some future date, the stabilized/solidified waste were to be exposed to the environment and contaminants leached. However, appropriate design and good engineering practices would minimize the likelihood of such an occurrence.

Each action alternative would reduce contaminant mobility. Waste toxicity and volume would be only somewhat reduced under Alternative 2 . Waste volume would not be affected by Alternative 3. Waste volume would decrease under Alternative 4. Waste volume would increase under Alternative 5 because of the addition of cement and fly ash to stabilize the waste. Treatment methods (under Alternatives 4 and 5) would reduce contaminant toxicity; under Alternative 4, metals would be recovered and recycled. 
The short-term effectiveness of Alternatives 2,3,4, and 5 is comparable, except that the overall risk to the general public would be higher for Alternative 5 because it would involve off-site transport of contaminated soil. Environmental impacts at the TBP area from excavation and construction activities would be common for all action alternatives, and comparable impacts would be expected. Mitigative measures would be used to minimize potential short-term impacts.

Emplacement of the "risk-reduction cover" would be fairly straightforward. Construction of the storage facility under Alternative 3 also would be fairly straightforward. The implementation of Alternative 4 would be fairly straightforward, although additional studies would be required to refine the soil washing/leaching treatment system design and cost estimates. The chemical stabilization/solidification treatment that would be performed off-site under Alternative 5 is fairly well established and would not require further development before implementation.

Alternative 2 has the lowest overall cost ( $\$ 1.8$ million) of the action alternatives; however, this cost is not directly comparable to Alternatives 3,4 , and 5 . Alternative 5 is considered more cost-effective than Alternative 4 for site cleanup. The estimated total cost of Alternative 5 is $\$ 10.5$ million (for excavation to $2 \mathrm{ft}$ ), and it would provide a similar level of overall effectiveness as Alternative 4, with an estimated cost of $\$ 13.1$ million. 


\section{REFERENCES}

Alternative Remedial Technologies, Inc., 1995, Soil Washing Technology Screening Study at the Aberdeen Proving Ground Pushout Area at J-Field, prepared by Alternative Remedial Technologies, Inc., Tampa, Fla., for Argonne National Laboratory, Argonne, Ill., July 21.

ART — See Alternative Remedial Technologies, Inc.

Bradbury, K.R., and M.A. Muldoon, 1990, "Hydraulic Conductivity Determinations in Unlithified Glacial and Fluvial Materials," in Ground Water and Vadose Zone Monitoring, D.M. Nielsen and A.I. Johnson (editors), ASTM STP 1053, American Society for Testing and Materials, Philadelphia, Pa., pp. 138-151.

Daudt, C.R., et al., 1994, Environmental Geophysics at J-Field, Aberdeen Proving Ground, Maryland, ANL/ESD/TM-77, Argonne National Laboratory, Argonne, Ill.

Davies, B.E., et al., 1995, Phase II Environmental Geophysics at J-Field, Aberdeen Proving Ground, Maryland, ANL/ESD/TM-97, Argonne National Laboratory, Argonne, Ill.

Davis, R.S., 1994, Region III Interim Ecological Risk Assessment Guidelines, Draft, U.S. Environmental Protection Agency, Region III, Philadelphia, Pa., July.

DOE - See U.S. Department of Energy.

EPA - See U.S. Environmental Protection Agency.

Federal Emergency Management Agency, 1986, Flood Insurance Study, Harford County, Maryland, June 17.

FEMA — See Federal Emergency Management Agency.

Freeze, R.A., and J.A. Cherry, 1979, Groundwater, Prentice-Hall, Inc., Englewood Cliffs, N.J.

Hlohowskyj, I., et al., 1995, Work Plan for Conducting an Ecological Risk Assessment at J-Field, Aberdeen Proving Ground, Maryland, ANL/EAD/TM-45, prepared by Argonne National Laboratory, Argonne, Ill., for U.S. Army, Directorate of Safety, Health, and Environment, Aberdeen Proving Ground, Md., March.

Hlohowskyj, I., et al., 1996, Remedial Investigation Report for J-Field, Aberdeen Proving Ground, Maryland, Volume 2: Ecological Risk Assessment, draft prepared by Argonne National Laboratory, Argonne, Ill., for U.S. Army, Directorate of Safety, Health, and Environment, Aberdeen Proving Ground, Md.

Huang, S., 1994, Microbiological Characterization and Nutrient Interaction Tests on Impacted Soils at the Toxic Burning Pits, draft report, Chester Environmental, Pittsburgh, Pa., May 27. 
Hughes, W.B., 1991, “Application of Marine Seismic Profiling to a Ground Water Contamination Study, Aberdeen Proving Ground, Maryland," Ground Water Monitoring Review 11(1):97-102.

Hughes, W.B., 1992, "Use of Marine-Seismic Profiling to Study Ground-Water Contamination at Aberdeen Proving Ground, Maryland," in Proceedings of the Symposium on the Application of Geophysics to Engineering and Environmental Problems, R.S. Bell (editor), pp. 163-172.

Hughes, W.B., 1993a, Hydrogeology and Soil Gas at J-Field, Aberdeen Proving Ground, Maryland, Water Resources Investigations Report 92-4087, U.S. Geological Survey, Towson, Md.

Hughes, W.B., 1993b, personal communication from Hughes (U.S. Geological Survey, Towson, Md.) to J.J. Quinn (Argonne National Laboratory, Argonne, Ill.), Nov. 9.

Hughes, W.B., 1993c, personal communication from Hughes (U.S. Geological Survey, Towson, Md.) to J.J. Quinn (Argonne National Laboratory, Argonne, Ill.), Oct. 5.

ICF Kaiser Engineers, 1994a, Comparison of Chemical Concentrations at Selected Sites at J-Field with Risk-Based Concentrations, draft report, submitted to U.S. Army Environmental Center, Aberdeen Proving Ground Installation Restoration Risk Assessment Support, Aberdeen Proving Ground, Md., Feb.

ICF Kaiser Engineers, 1994b, Workplan for Conducting a Human Health Risk Assessment at the J-Field Study Area, final draft, submitted to U.S. Army Environmental Center, Aberdeen Proving Ground Installation Restoration Risk Assessment Support, Aberdeen Proving Ground, Md., May.

ICF Kaiser Engineers, 1995a, Reference Sampling and Analysis Program at the U.S. Army Aberdeen Proving Ground, Soil, Sediment, and Surface Water Reference Data Report, prepared for U.S. Army Environmental Center, Aberdeen Proving Ground, Md., July.

ICF Kaiser Engineers, 1995b, J-Field Toxic Burning Pits Area Baseline Human Health Risk Assessment, draft, prepared for U.S. Army Environmental Center, Aberdeen Proving Ground, Md., Aug.

ICF Kaiser Engineers, 1996, Volume II: Human Health Risk Assessment for J-Field Edgewood Area, Aberdeen Proving Ground, prepared by ICF Kaiser Engineers, Abingdon, Md., for U.S. Army Environmental Center, Aberdeen Proving Ground, Md., Jan.

Kerhin, R.T., et al., 1988, The Surficial Sediments of the Chesapeake Bay, Maryland: Physical Characteristics and Sediment Budget, Report of Investigations No. 48, Maryland Geological Survey, Towson, Md.

Lemaster, K., 1995, personal communication from Lemaster (Maryland Department of the Environment, Baltimore) to J. Wrobel (U.S. Army Directorate of Safety, Health, and Environment, Aberdeen Proving Ground, Md.), June 15. 
Lorah, M.M., and J.S. Clark, 1992, Contamination of Groundwater, Surface Water, and Soil, and Evaluation of Selected Pumpage Scenarios in the Canal Creek Area of Aberdeen Proving Ground, Maryland, draft open-file report, U.S. Geological Survey, Towson, Md.

Maryland Department of Natural Resources, 1992, Rare, Threatened, and Endangered Animals of Maryland, Annapolis, Md., May.

McKegg, J., 1992, letter with attachments from McKegg (Director of Maryland Natural Heritage Program) to C. Dunn (Argonne National Laboratory, Argonne, Ill.), Oct. 8.

MDNR - See Maryland Department of Natural Resources.

National Oceanic and Atmospheric Administration, 1993, "Chesapeake Bay Approaches to Baltimore Harbor," map 12278, 1:40,000, Washington, D.C.

National Oceanic and Atmospheric Administration/HAZMAT, undated, NOA Screening Guidelines for Organics and Inorganics, NOAA Quick Screening Reference Cards, NOAA/HAZMAT, Seattle, Wash.

Nemeth, G., 1989, RCRA Facility Assessment Report, Edgewood Area, Aberdeen Proving Ground, Maryland, 39-26-0490-90, U.S. Army Environmental Hygiene Agency, Waste Disposal Engineering Division, Aberdeen Proving Ground, Md.

NOAA - See National Oceanic and Atmospheric Administration.

Oliveros, J.P., and D.A. Vroblesky, 1989, Hydrogeology of Canal Creek Area, Aberdeen Proving Ground, Maryland, Water-Resources Investigation Report 89-4021, U.S. Geological Survey, Towson, Md.

Opresko, D.M., et al., 1994, Toxicological Benchmarks for Wildlife: 1994 Revision, ES/ER/TM86/R1, prepared by Oak Ridge National Laboratory, Oak Ridge, Tenn., for the U.S. Department of Energy, Sept.

Patton, T.L., 1994, Installation of Well 173 at J-Field, Aberdeen Proving Ground, Maryland, TU-2/ANL/APG/J-F/RI, Argonne National Laboratory, Argonne, Ill., Jan.

Perkins, S.O., and H.B. Winant, 1927, Soil Survey of Harford County, Maryland, U.S. Department of Agriculture, Beltsville, Md.

Peters, R., 1995, Feasibility/Treatability Studies for Soil Washing and Solidification/Stabilization at J-Field, Aberdeen Proving Ground, Maryland, TU-18/ANL/APG/J-F/RI-FFS, draft, Argonne National Laboratory, Argonne, Ill., May.

Princeton Aqua Science, 1984, Munitions Disposal Study, prepared for U.S. Department of the Army, Directorate of Engineering and Housing, Environmental Management Office, Aberdeen Proving Ground, Md., Nov. 
Quinn, J., 1995, Pump Test of Well 183 at J-Field, Aberdeen Proving Ground, Maryland, TU-17/ANL/APG/J-F/RI, Argonne National Laboratory, Argonne, Ill., April.

Smith, H., and E.D. Matthews, 1975, Soil Survey of Harford County Area, Maryland, U.S. Department of Agriculture Soil Conservation Service, in cooperation with Maryland Agricultural Experiment Station, Beltsville, Md.

Sonntag, W., 1991, Sampling and Analysis Plan for the Investigation of Ground-Water Contamination at J-Field, Aberdeen Proving Ground, Maryland, draft report, U.S. Geological Survey, Reston, Va.

Swihart, G.L., et al., 1994, Fishery Inventory and Baseline Water Quality of the Aberdeen Proving Ground, Aberdeen, Maryland, U.S. Fish and Wildlife Service, White Marsh, Va.

U.S. Army, 1965, aerial photographs of Edgewood Area, roll no. G\&O 85047, frames no. 8-1, 8-2, and 9-1 to 9-4, Environmental Hygiene Agency, Aberdeen Proving Ground, Md.

U.S. Army Toxic and Hazardous Materials Agency, 1993, Risk and Biological Impact Assessment at U.S. Army Aberdeen Proving Ground, Maryland, Technical Plan, Vol. I, prepared by ICF Kaiser Engineers, Abingdon, Md., March.

USATHAMA — See U.S. Army Toxic and Hazardous Materials Agency.

U.S. Department of Energy, 1993/1994, Technology Profiles, Technology Search Program, Office of Environmental Restoration, Washington, D.C.

U.S. Environmental Protection Agency, 1988, Guidance for Conducting Remedial Investigations and Feasibility Studies under CERCLA, Interim Final, EPA/540/G-89/004 (OSWER Directive 9355.3-01), Office of Emergency and Remedial Response, Washington, D.C., Oct.

U.S. Environmental Protection Agency, 1989a, Risk Assessment Guidance for Superfund, Vol. I, Human Health Evaluation Manual, Part A, EPA/540/1-89/002, Office of Emergency and Remedial Response, Washington, D.C., Dec.

U.S. Environmental Protection Agency, 1989b, Risk Assessment Guidance for Superfund, Vol. II, Environmental Evaluation Manual, EPA/540/1-89/001; Office of Emergency and Remedial Response, Washington, D.C., March.

U.S. Environmental Protection Agency, 1990a, "National Oil and Hazardous Substances Pollution Contingency Plan; Final Rule (40 CFR Part 300)," Federal Register, 55(35):6154-6176, Feb. 21.

U.S. Environmental Protection Agency, 1990b, Obtaining a Soil and Debris Treatability Variance for Removal Actions, Superfund LDR Guide \#6B, Office of Emergency and Remedial Response, Sept. 
U.S. Environmental Protection Agency, 1991a, Human Health Evaluation Manual, Supplemental Guidance: Standard Default Exposure Factors, OSWER Directive 9285.6-03, Office of Emergency and Remedial Response, Washington, D.C., March 25.

U.S. Environmental Protection Agency, 1991b, Risk Assessment Guidance for Superfund, Vol. 1, Human Health Evaluation Manual, Part B, Development of Risk-Based Preliminary Remediation Goals, EPA/540/R-92/003, Office of Emergency and Remedial Response, Washington, D.C., Dec.

U.S. Environmental Protection Agency, 1991c, Risk Assessment Guidance for Superfund, Vol. 1, Human Health Evaluation Manual, Part C, Risk Evaluation of Remedial Alternatives, EPA/540/R-92/004, Office of Emergency and Remedial Response, Washington, D.C., Dec.

U.S. Environmental Protection Agency, 1993a, Selecting Exposure Routes and Contaminants of Concern by Risk-Based Screening, EPA/903/R-93-001, EPA Region III, Hazardous Waste Management Division, Office of Superfund Programs, Philadelphia, Pa., Jan.

U.S. Environmental Protection Agency, 1993b, Superfund Innovative Technology Evaluation Program, Technology Profiles, 6th edition, EPA/540/R-93/526, Office of Research and Development, Washington, D.C., Nov.

U.S. Environmental Protection Agency, 1993c, Remediation Technologies Screening Matrix and Reference Guide, EPA 542-B-93-005, Office of Solid Waste and Emergency Response, Washington, D.C., July.

U.S. Environmental Protection Agency, 1993d, VISITT Vendor Information System for Innovative Treatment Technologies, Version 2.0, User Manual Report No. EPA 512-R-93-001, Office of Solid Waste and Emergency Response, Washington, D.C., April.

U.S. Environmental Protection Agency, 1993e, Wildlife Exposure Factors Handbook, Vols. I and II, EPA/600/R-93/187a and b, Office of Research and Development, Washington, D.C., Dec.

U.S. Environmental Protection Agency, 1994, Revised Interim Soil Lead Guidance for CERCLA Sites and RCRA Corrective Action Sites, OSWER Directive 9355.4-12, Office of Emergency and Remedial Response, Washington, D.C., Aug.

U.S. Environmental Protection Agency, 1995, Risk-Based Concentration Table, January-June 1995, EPA Region III, Hazardous Waste Management Division, Office of Superfund Programs, Philadelphia, Pa., Jan.

U.S. Environmental Protection Agency and U.S. Department of the Army, 1990, "Federal Facility Agreement, Aberdeen Proving Ground," Administrative Docket Number III-FCA-CERC-004.

Van Lonkhuyzen, R., 1994, Wetland Delineation at the Toxic Burn Pits, J-Field, TU-12/ANL/APG/J-F/RI-ERA, Argonne National Laboratory, Argonne, Ill., July. 
Vroblesky, D.A., et al., 1989, Ground-Water, Surface-Water, and Bottom-Sediment Contamination in the O-Field Area, Aberdeen Proving Ground, Maryland, and the Possible Effects of Selected Remedial Actions on Ground Water, Open-File Report 89-399, U.S. Geological Survey, Towson, Md.

Whorton, R., 1996, personal communication from Whorton (Advanced Environmental Technical Services) to K. Bankerd (Directorate of Contracting, U.S. Army Aberdeen Proving Ground, Md.), April 24.

Will, M.E., and G.W. Suter, 1994, Toxicological Benchmarks for Screening Potential Contaminants of Concern for Effects on Terrestrial Plants: 1994 Revision, ES/ER/TM-85/R1, prepared by Oak Ridge National Laboratory, Oak Ridge, Tenn., for the U.S. Department of Energy, Sept.

Wolflin, J.P., 1992, letter from Wolflin (Supervisor, Chesapeake Bay Field Office, U.S. Fish and Wildlife Service) to C.P. Dunn (Argonne National Laboratory, Argonne, Ill.), Oct. 7.

Wrobel, J., 1994, personal communication from Wrobel (Directorate of Safety, Health, and Environment, U.S. Army Aberdeen Proving Ground, Md.) to J. Quinn (Argonne National Laboratory, Argonne, Ill.), Aug. 23.

Wrobel, J., 1995, personal communication from Wrobel (Directorate of Safety, Health, and Environment, U.S. Army Aberdeen Proving Ground, Md.) to L. Martino (Argonne National Laboratory, Argonne, Ill.), July 15.

Yuen, R., et al., 1996, Remedial Investigation Report for J-Field, Aberdeen Proving Ground, Maryland, Volume 1: Remedial Investigation Results, draft prepared by Argonne National Laboratory, Argonne, Ill., for U.S. Army, Aberdeen Proving Ground, Md., Directorate of Safety, Health, and Environment.

Zar, J.H., 1984, Biostatistical Analysis, second edition, Prentice Hall, Inc., Englewood Cliffs, N.J. 


\section{LIST OF PREPARERS}

This FFS report was prepared for the U.S. Army Directorate of Safety, Health, and Environment by ANL's Environmental Assessment Division. Larry Thebeau and Prakash Ramaswamy of ICF Kaiser Engineers, Inc., developed Alternative 2 (Limited Removal and Disposal, and In-Situ Containment). The following ANL staff contributed to the preparation of this report.

\begin{tabular}{|c|c|}
\hline Name & Education/Experience \\
\hline Louis Martino & $\begin{array}{l}\text { M.S., environmental toxicology; } 16 \text { years } \\
\text { experience in environmental } \\
\text { assessment. }\end{array}$ \\
\hline Terri Patton & $\begin{array}{l}\text { M.S., geology; } 13 \text { years experience in } \\
\text { environmental research and assessment. }\end{array}$ \\
\hline Paul Benioff & $\begin{array}{l}\text { Ph.D., nuclear chemistry; } 17 \text { years experience in } \\
\text { theoretical chemistry; } 16 \text { years experience in } \\
\text { environmental assessment. }\end{array}$ \\
\hline Carole Biang & $\begin{array}{l}\text { B.S., chemical engineering; } 16 \text { years experience } \\
\text { in management and remediation of hazardous } \\
\text { waste sites, environmental assessment. }\end{array}$ \\
\hline James Butler & $\begin{array}{l}\text { Ph.D., environmental health sciences; } 15 \text { years } \\
\text { experience in health risk assessment. }\end{array}$ \\
\hline William Davies & $\begin{array}{l}\text { M.S., hydrogeology; } 11 \text { years experience } \\
\text { conducting environmental investigations. }\end{array}$ \\
\hline Rebecca Haffenden & $\begin{array}{l}\text { J.D., } 6 \text { years experience in environmental law, } \\
\text { specializing in RCRA and CERCLA; } 11 \text { years } \\
\text { experience in energy law. }\end{array}$ \\
\hline
\end{tabular}

J-Field project manager; description of site characterization; contamination source identification and characterization; data analysis.

FFS task leader; development of remedial action objectives; description of alternatives; engineering evaluation; comparative summary.

Technology screening; assessment of soil impacts.

Description of alternatives; engineering evaluation; comparative summary.

Assessment of human health impacts; identification of COCs; development of human health risk-based interim PRGs.

Description of alternatives; contamination source identification and characterization; data analysis; engineering evaluation.

Assessment of ARARs. 


\begin{tabular}{|c|c|c|}
\hline Name & Education/Experience & Contribution \\
\hline John Hayse & $\begin{array}{l}\text { Ph.D., zoology; } 13 \text { years experience in ecology; } \\
5 \text { years experience in environmental assessment. }\end{array}$ & $\begin{array}{l}\text { Assessment of ecological } \\
\text { impacts; identification of } \\
\text { COECs; modeling of } \\
\text { contaminant uptake by } \\
\text { ecological receptors. }\end{array}$ \\
\hline Ihor Hlohowskyj & $\begin{array}{l}\text { Ph.D., zoology; } 20 \text { years experience in } \\
\text { ecological research; } 16 \text { years experience in } \\
\text { environmental and ecological risk assessment. }\end{array}$ & $\begin{array}{l}\text { Assessment of ecological } \\
\text { impacts; identification of COCs; } \\
\text { development of ecological } \\
\text { risk-based interim PRGs. }\end{array}$ \\
\hline Margy Ortigara & $\begin{array}{l}\text { M.A., English; } 6 \text { years experience in technical } \\
\text { editing. }\end{array}$ & Overall editorial responsibility. \\
\hline Leslie Poch & $\begin{array}{l}\text { M.S., nuclear engineering; } 11 \text { years experience } \\
\text { in technology assessment and cost engineering. }\end{array}$ & $\begin{array}{l}\text { Evaluation of costs for } \\
\text { alternatives. }\end{array}$ \\
\hline Edgar Portante & $\begin{array}{l}\text { M.S., electrical engineering; M.S., business } \\
\text { management; } 16 \text { years experience in power } \\
\text { system and energy planning. }\end{array}$ & $\begin{array}{l}\text { Evaluation of costs for } \\
\text { alternatives. }\end{array}$ \\
\hline John Quinn & $\begin{array}{l}\text { M.S., hydrogeology; } 7 \text { years experience in } \\
\text { hydrogeologic analysis. }\end{array}$ & $\begin{array}{l}\text { Description of site geological } \\
\text { conditions. }\end{array}$ \\
\hline Cheong-Yip Yuen & $\begin{array}{l}\text { Ph.D., geology (hydrogeology and } \\
\text { environmental geology); } 7 \text { years experience in } \\
\text { hydrological analysis; } 13 \text { years experience in } \\
\text { process geomorphology. }\end{array}$ & $\begin{array}{l}\text { Technology screening; } \\
\text { contamination source identifi- } \\
\text { cation and characterization; } \\
\text { estimates of soil volumes to be } \\
\text { calculated. }\end{array}$ \\
\hline Yug-Yea Wang & $\begin{array}{l}\text { Ph.D., civil engineering/environmental } \\
\text { engineering; } 11 \text { years experience in } \\
\text { environmental research; } 3 \text { years experience in } \\
\text { environmental assessment. }\end{array}$ & Data analysis. \\
\hline Gus Williams & $\begin{array}{l}\text { Ph.D., environmental geotechnology; } 8 \text { years } \\
\text { experience in numerical modeling development } \\
\text { and application. }\end{array}$ & Vadose zone modeling. \\
\hline
\end{tabular}


APPENDIX A:

VADOSE ZONE MODEL OF METAL TRANSPORT FOR THE TOXIC BURNING PITS AREA OF J-FIELD 
A-2 


\section{APPENDIX A:}

\section{VADOSE ZONE MODEL OF METAL TRANSPORT FOR THE TOXIC BURNING PITS AREA OF J-FIELD}

\section{A.1 INTRODUCTION}

A model of the vadose zone of the Toxic Burning Pits (TBP) area of J-Field was developed to evaluate transport of metal contamination from the surface to the water table (i.e., vadose zone) by using the TRACR3D code (Travis and Birdsell 1991). The vadose zone model assumed a depth to water table of $2 \mathrm{~m}$. Simulations were performed for a 50 -year period. The model calculates saturation and concentration values at $2-\mathrm{cm}$ vertical intervals through the vadose zone.

The objective of this modeling study was to evaluate the various processes that may affect the transport of metals from the near-surface to the water table and estimate approximate travel times for selected contaminants of concern (e.g., arsenic, cadmium, lead, zinc).

Surface contamination can reach groundwater via pathways other than those modeled by vadose zone transport models. In the vadose zone, numerous preferential pathways exist for contaminant and fluid transport, especially in the near-surface; these include such common features as desiccation cracks, holes that result from the decay of a former plant root, and animal burrows. These features can provide a means for surface contamination to reach the groundwater much faster than predicted by using vadose zone matrix flow and the transport mechanisms. In general, these types of features are difficult to model because it is difficult to characterize their location and properties in the field.

\section{A.2 CONCEPTUAL MODEL}

A conceptual model of the vadose zone was developed on the basis of the results of field investigations performed at the TBP area (Yuen et al. 1996). Metal transport within the vadose zone to the water table was assumed to occur because of near-surface metal contamination in the top $10 \mathrm{~cm}$ of the soil. The metal was assumed to undergo linear, instantaneous, equilibrium sorptiondesorption between the aqueous and solid phases as it was transported through the vadose zone. The area contaminated with metals was assumed to be large, so that transport within the vadose zone could be assumed to be vertically downward with no lateral dispersion (i.e., one-dimensional). This assumption is conservative, because lateral dispersion and diffusion would tend to lower the concentration and delay the arrival time of a contaminant at the water table given a finite duration source, such as that assumed for this model. 
The vadose zone comprised a homogeneous silty loam material $2 \mathrm{~m}$ thick (Perkins and Winant 1927), with a hydraulic conductivity of 2.0 Darcies $^{1}$ (Quinn 1995), a porosity of 0.45 (Guymon 1994), and an irreducible water saturation of 0.067 (Guymon 1994).

This model assumed a monthly rainfall of $10.0 \mathrm{~cm}$ (Smith and Matthews 1975), which occurred in a single event at the start of each month. This assumption is conservative because a single wetting event will transport material faster and further than constant infiltration, given the same total volume over the entire month.

\section{A.3 MODEL DESIGN AND INPUT PARAMETERS}

A finite-difference grid was designed to model a depth to groundwater of $2 \mathrm{~m}$, which is representative of the TBP area. The grid developed for this model contains 10 divisions in the horizontal direction and 100 in the vertical. The cell size is $2.0 \mathrm{~cm}$ square. The results from these simulations can be used to evaluate the transport of metals in areas where the depth to groundwater is less than $2 \mathrm{~m}$ by using the results for the 1-m depth. These estimates will not be conservative because of faster transport times in more saturated soils. As the depth to water table decreases, the saturation of the model increases due to capillary effects. However, these estimates should be relatively accurate. When depth to the water table becomes shallower (less than $1 \mathrm{~m}$ ), these assumptions become worse and the model simulations reported here cannot be used to estimate contaminant transport. At shallow depths, a conservative estimate would be to assume that concentrations in the vadose zone water at the groundwater table are equal to the initial vadose zone concentrations. Dilution would occur as the vadose zone fluids mix with the saturated zone fluids, and concentrations would be lowered further as contaminants are transported within the saturated zone because of dilution, sorption onto the solid phases, and other geochemical and physical processes.

The model grid is two-dimensional; however, initial and boundary conditions are such that the flow regime modeled is one-dimensional. The left and right sides of the model are no-flow boundaries, creating a one-dimensional flow regime. No lateral dispersion is modeled. The bottom boundary represents the water table and is modeled by using a constant-pressure/constant-saturation condition for fluid flux and a zero-gradient condition for contaminant transport. This boundary condition allows continuous contaminant outflow when a contaminant plume reaches it. The surface boundary (top of the model) models the total monthly precipitation event as a single ponded water condition. This boundary condition applies a fluid saturation and pressure equal to a given depth of water. The ponded water depth automatically decreases as fluid leaves the surface by infiltration and enters the subsurface. When all of the water has infiltrated the subsurface, air pressure at the upper

12.0 Darcies is equivalent to a saturated hydraulic conductivity of $1.9 \times 10^{-3} \mathrm{~cm} / \mathrm{s}$. 
boundary is set to 0 gage pressure, and air saturation is set to 1.0 (completely air-saturated). Surface infiltration occurred once per month for the entire 50-year run.

The material distribution in the vadose zone is assumed to be homogeneous, with a permeability of 2.0 Darcies in the horizontal and vertical directions. This aspect of the model setup adds a degree of conservatism, because vertical saturated permeability is generally less than horizontal saturated permeability (typically 1/10) (Domenico and Schwartz 1990).

Determining the saturation-permeability relationship for soils is a difficult task that requires special laboratories and considerable time and effort. In addition, the results of these tests can have large uncertainty (Guymon 1994). For this study, the relationship between saturation and permeability developed by van Genuchten (1980) was used. Values for porosity, irreducible soil moisture, and the van Genuchten parameters from Guymon (1994) were used because no sitespecific data were available. The porosity is 0.45 , and the irreducible water content is 0.067 . The van Genuchten parameters are 0.2908 and $50 \mathrm{~cm}$ for $(1-1 / \beta)$ and $1 / \alpha$, respectively. These parameters match those of a silty loam (Guymon 1994).

Initial water saturations approximate equilibrium values, with the soils near the water table more water-saturated than soils near the surface. The values used for initial water saturations approximate a drained condition for the soil.

\section{A.4 TRANSPORT STUDIES}

For all computations, the fluid in the top $10 \mathrm{~cm}$ of the vadose zone was assumed to be a tracer at a concentration ratio, $\mathrm{C} / \mathrm{C}_{0}$ equal to 1 , in equilibrium with sorbed tracer on the solid matrix. ${ }^{2}$ In one-dimensional studies, the $C / C_{0}$ parameter is a way to nondimensionalize concentration measurements, providing general information that is invariant with respect to the initial concentration. Model-computed values of $\mathrm{C} / \mathrm{C}_{0}$ can be multiplied by a chosen initial concentration to arrive at model-predicted concentrations. As a conservative estimate, the solubility limit of a compound is typically used as an initial concentration. Multiplying the computed $\mathrm{C} / \mathrm{C}_{0}$ value by a compound's solubility gives a conservative estimate of subsurface contamination values.

A set of simulations was completed by using a range of $\mathrm{K}_{\mathrm{d}}$ values: $0,5,15$, and $150 \mathrm{~mL} / \mathrm{g}$ (Table A.1). This range covers the estimated $K_{d}$ values for the metal contaminants present at the TBP area. In the following sections, these simulations are discussed. The metal that could be modeled by a given $\mathrm{K}_{\mathrm{d}}$ is identified in each section along with reported $\mathrm{K}_{\mathrm{d}}$ ranges from the literature. No site-specific values exist for $\mathrm{K}_{\mathrm{d}}$ at the TBP area.

$2 \mathrm{C}$ is the current concentration of a tracer, and $\mathrm{C}_{0}$ is the initial concentration. 
TABLE A.1 $\mathrm{K}_{\mathrm{d}}$ Values and Results

\begin{tabular}{lcll}
\hline \multicolumn{1}{c}{ Description } & $\begin{array}{c}\mathrm{K}_{\mathrm{d}} \\
(\mathrm{mL} / \mathrm{g})\end{array}$ & $\begin{array}{c}\text { Depth after } \\
50 \text { years } \\
(\mathrm{cm})\end{array}$ & \multicolumn{1}{c}{ Notes } \\
\hline Conservative tracer & 0.0 & - & $\begin{array}{l}\text { Tracer was flushed from the vadose zone after } \\
\text { approximately } 4 \text { months }\end{array}$ \\
Lead & 150.0 & $\sim 45$ & $\begin{array}{l}\text { Very immobile } \\
\text { Relatively immobile, after } 50 \text { years the } \\
\text { Cadmium }\end{array}$ \\
Zinc & 15.0 & $\sim 85$ & $\begin{array}{l}\text { Tramination has moved less than } 1 \mathrm{~m} \\
\text { approximately } 30 \text { years }\end{array}$ \\
\hline
\end{tabular}

\section{A.4.1 Nonreactive Tracers}

An initial set of simulations was run as a base-case assuming a conservative tracer (i.e., nondegrading, nonreactive, and nonsorbing $\left[\mathrm{K}_{\mathrm{d}}=0\right]$ ). Nonreactive tracer transport was rapid. The tracer reached the groundwater table in approximately two months. After four months, all the tracer had been flushed from the vadose zone. The model was configured to produce output at the end of each 30-day period. At the end of the third period, tracer concentrations were still measurable in the vadose zone. By the end of the fourth period, no tracers were present in the model - they had all been transported across the lower boundary.

\section{A.4.2 Lead}

$\mathrm{K}_{\mathrm{d}}$ values for lead range from $1.8 \times 10^{2}$ to $6.3 \times 10^{4} \mathrm{~mL} / \mathrm{g}$ (Sheppard et al. 1984), with the higher values generally occurring in soils rich in organic matter. In sand, the highest reported value is $3.5 \times 10^{3} \mathrm{~mL} / \mathrm{g}$. For this study, a conservative value ${ }^{3}$ of $150 \mathrm{~mL} / \mathrm{g}$ was used to model lead transport in the vadose zone. Under these conditions, the lead was not mobile.

Pure lead is insoluble (Chemical Rubber Company [CRC] 1968); however, various lead compounds are soluble to varying degrees. The solubility of lead-oxide $(\mathrm{PbO})$ is $0.0017 \mathrm{~g} / 100 \mathrm{cc}$, while red lead-oxide $\left(\mathrm{Pb}_{3} \mathrm{O}_{4}\right)$ is insoluble (CRC 1968). Lead is mostly present in the lead-oxide form (Peters 1995).

3 Lower values of $\mathrm{K}_{\mathrm{d}}$ allow the contaminant to be more mobile in the subsurface. 
Figure A.1 shows the results of a calculation spanning 50 years. The initial depth of contamination was $10 \mathrm{~cm}$ with a concentration ratio, $\mathrm{C} / \mathrm{C}_{0}$, of 1 . After 50 years, the center of mass of the lead plume is at a depth of approximately $20 \mathrm{~cm}$, while the leading edge is at a depth of less than $40 \mathrm{~cm}$.

\section{A.4.3 Cadmium}

Reported $\mathrm{K}_{\mathrm{d}}$ values for cadmium range from 47.6 to $500 \mathrm{~mL} / \mathrm{g}$ in sands, 9.8 to $76 \mathrm{~mL} / \mathrm{g}$ in silty soils, and 23 to $1.7 \times 10^{4} \mathrm{~mL} / \mathrm{g}$ in soils rich in organic matter (Sheppard et al. 1984; Thibault et al. 1990). For this study, a value of $15 \mathrm{~mL} / \mathrm{g}$ was used to model cadmium transport, which is near the low end of the range for silty soils. Cadmium is slightly soluble, and the compound cadmiumsulfide has a solubility of $0.00013 \mathrm{~g} / 100 \mathrm{cc}$ (CRC 1968).

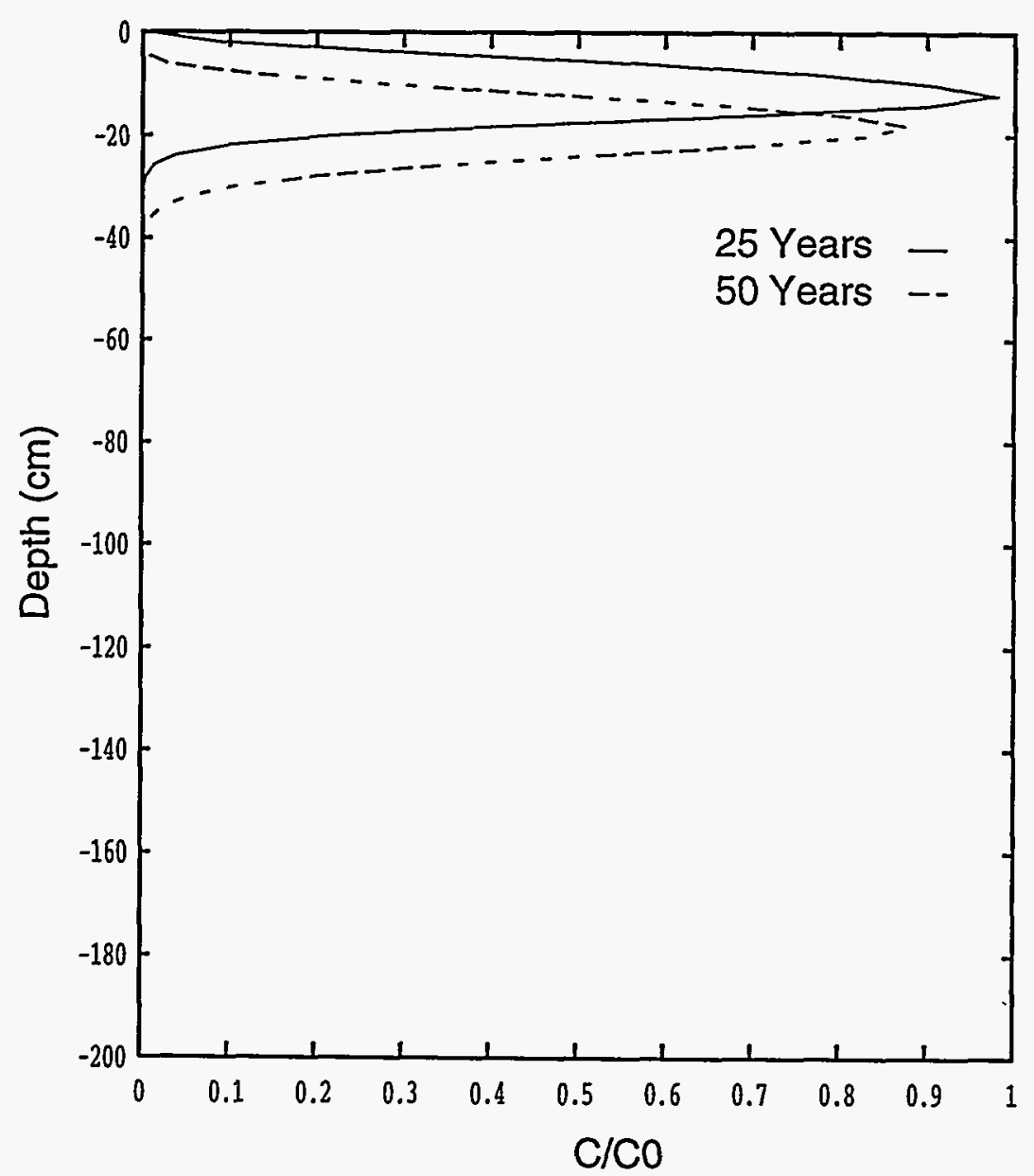

FIGURE A.1 Concentration Profiles for Lead Using a $\mathrm{K}_{d}$ Value of $150 \mathrm{~mL} / \mathrm{g}$ for a $50-$ Year Period 
Figure A.2 shows the results of a calculation spanning 50 years. The initial depth of contamination was $10 \mathrm{~cm}$ with a concentration ratio, $\mathrm{C} / \mathrm{C}_{0}$, of 1 . After 50 years, the center of mass of the cadmium plume is at a depth of approximately $85 \mathrm{~cm}$, while the leading edge is at a depth of less than $130 \mathrm{~cm}$.

\section{A.4.4 Zinc}

Reported $\mathrm{K}_{\mathrm{d}}$ values for zinc range from 0.1 to $2,120 \mathrm{~mL} / \mathrm{g}$ in sands, 3.6 to $100 \mathrm{~mL} / \mathrm{g}$ in silty soils, and 70 to $1.3 \times 10^{4} \mathrm{~mL} / \mathrm{g}$ in soils rich in organic matter (Sheppard et al. 1984; Thibault et al. 1990). For this study, a value of $5 \mathrm{~mL} / \mathrm{g}$ was used, which is near the low end of the range for silty soils. The results of the calculations for lead and cadmium, which used $K_{d}$ values of 150 and $15 \mathrm{~mL} / \mathrm{g}$, respectively, can be used to estimate the effects of a higher $\mathrm{K}_{\mathrm{d}}$ on zinc transport.

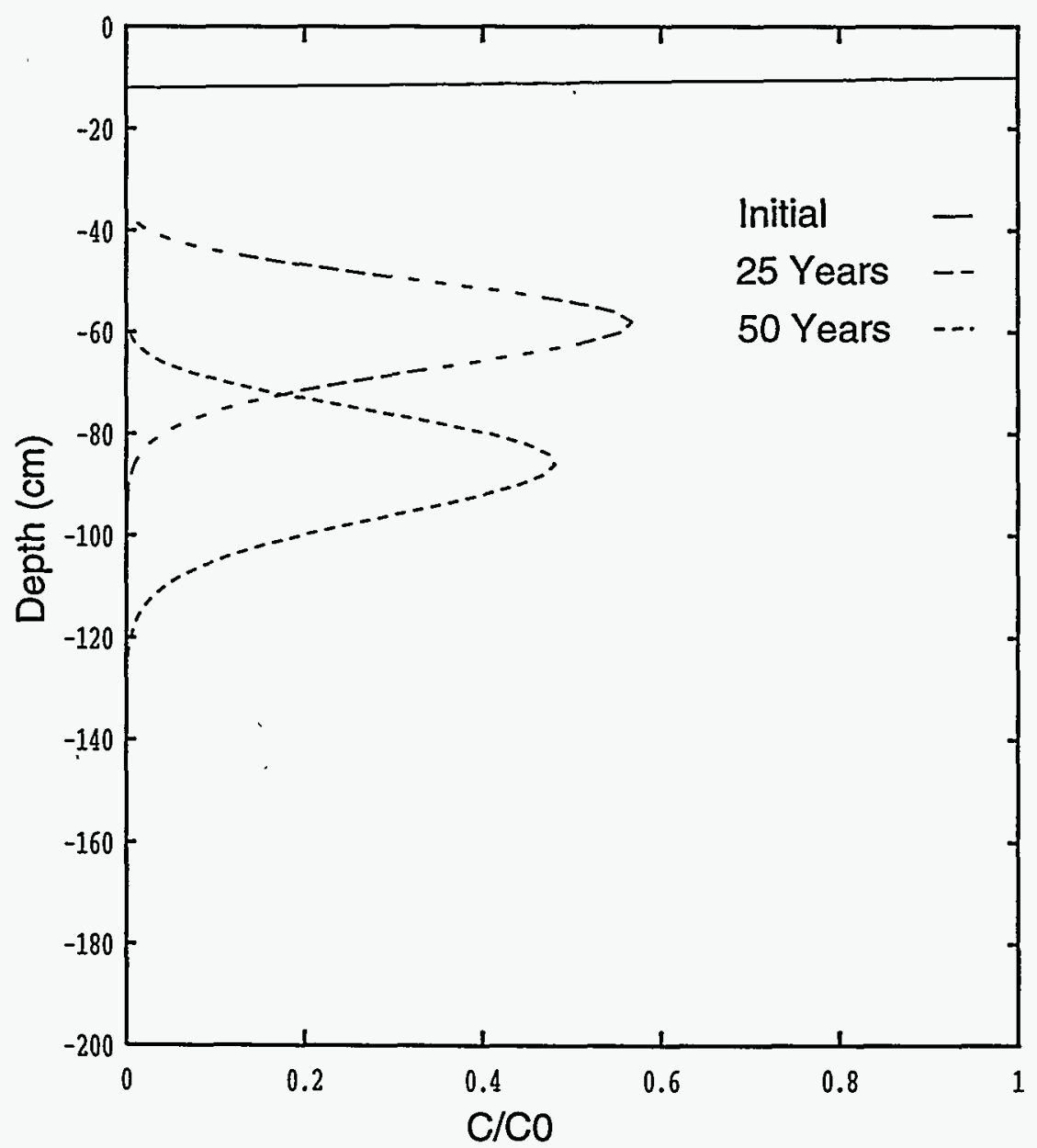

FIGURE A.2 Concentration Profiles for Cadmium Using a $\mathrm{K}_{\mathrm{d}}$ Value of $15 \mathrm{~mL} / \mathrm{g}$ (Shown are $\mathrm{C} / \mathrm{C}_{0}$ values versus depth for 0,25 , and 50 years) 
Figure A.3 shows the results of a calculation spanning 20 years. The initial depth of contamination was $10 \mathrm{~cm}$ with a concentration ratio, $C / C_{0}$, of 1 . After 30 years, the zinc plume has been flushed from the vadose zone; no zinc occurs in solution in any of the vadose zone water. During this 30 -year period, the maximum $\mathrm{C} / \mathrm{C}_{0}$ ratio at the water table was approximately 0.38 .

Assuming the zinc is present as zinc-oxide, with a maximum solubility of $0.00016 \mathrm{~g} / 100 \mathrm{cc}$ (CRC 1968), the maximum concentration at the water table would be below $6.0 \times 10^{-7} \mathrm{~g} / \mathrm{mL}$. This is calculated by assuming that the initial concentration of zinc in the vadose zone fluid was equal to the maximum solubility limit of zinc-oxide and multiplying this value by the computed ratio of the current concentration to the initial concentration, $\mathrm{C}_{\mathrm{C}_{0}}$, which in this case was 0.38 .

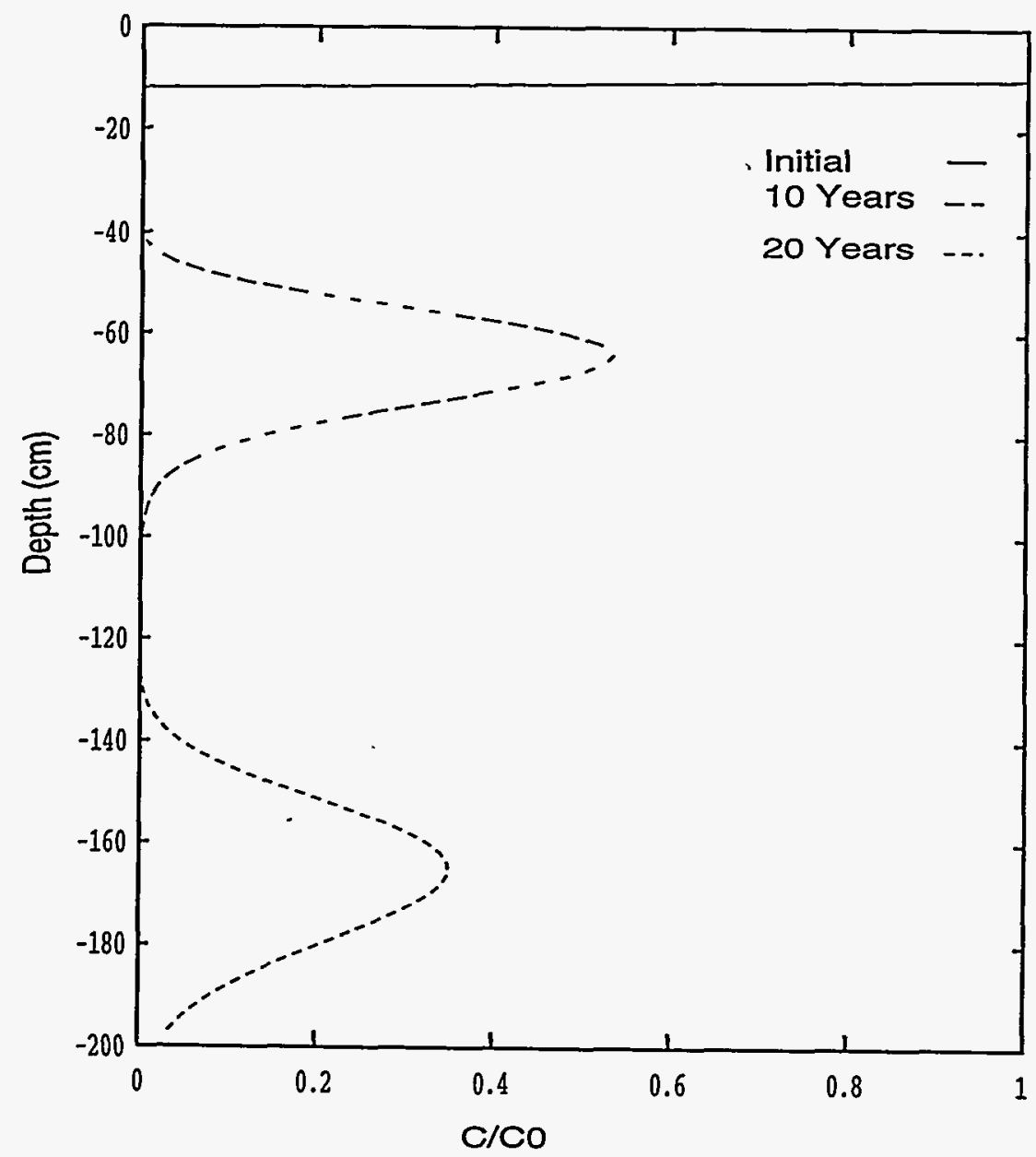

FIGURE A.3 Concentration Profiles for Zinc Using a $K_{d}$ Value of $5.0 \mathrm{~mL} / \mathrm{g}$ (Shown are $\mathrm{C} / \mathrm{C}_{0}$ versus depth profiles for 0,10 , and 20 years) 


\section{A.5 OTHER CONTAMINANTS}

Table A.2 lists some inorganic materials of concern at J-Field. Estimates of how these materials would behave during vadose zone transport can be made by determining which of the modeled $\mathrm{K}_{\mathrm{d}}$ values most closely approximates that of the material of interest. The reported values of $K_{d}$ span a large range because of the sensitivity of $K_{d}$ values to soil types and other factors. Generally, the lowest reported values are for clean sands (no organics, clays, or silts) or clean gravels. The highest values reported are generally for clay and organic-rich soils.

\section{A.6 CONCLUSIONS}

The model assumptions made in this study were conservative (i.e., tended to encourage transport at higher rates); however, even using these assumptions, lead contamination of the groundwater due to vadose zone transport from surface soil contamination was unlikely to be above levels of concern. Because of the high affinity of lead to sorb onto solids (especially clays and organic particles), lead is only slightly mobile in the subsurface. If lead is transported through the vadose zone to the water table, it would take several hundreds of years and be at low concentrations because of dispersion and dilution. Because of the estimated time required for lead to reach the groundwater, simulations were not performed to predict concentrations at the groundwater table.

TABLE A.2 Inorganic Materials of Concern $K_{d}$ Values $^{2}$

\begin{tabular}{lrcr}
\hline Material & $\begin{array}{c}\mathrm{K}_{\mathrm{d}} \text { Range } \\
(\mathrm{mL} / \mathrm{g})\end{array}$ & Material & \multicolumn{1}{c}{$\begin{array}{c}\mathrm{K}_{\mathrm{d}} \text { Range } \\
(\mathrm{mL} / \mathrm{g})\end{array}$} \\
\hline Antimony & $180-4,000$ & Copper & $76-266$ \\
Arsenic & $1.0-18$ & Lead & $180-63,000$ \\
Barium & $0.4-6.0$ & Selenium & $36-310$ \\
Cadmium & $9.0-17,000$ & Silver & $75-1,000$ \\
Chromium & $50-1,000$ & Zinc & $0.1-13,000$ \\
Cobalt & $10-2,500$ & & \\
\hline
\end{tabular}

a $K_{d}$ values cover a large range. Generally, the lowest values reported here are for either a laboratory clean sand or gravel, while the highest values are for a clay or organic-rich soil. Typical field values are generally toward the higher portion of the range.

Source: Thibault et al. (1990). 
These low concentrations would be further reduced by dilution that would occur as the vadose zone fluids mixed with the fluids below the water table. This dilution would be significant during any lateral transport, such as moving from the TBP area to the nearby marsh. Given the results of these calculations and the low concentrations of lead in groundwater samples from the TBP area, ${ }^{4}$ the transport of lead through the vadose zone to the groundwater table presents a low risk of contamination at levels of concern $(50 \mu \mathrm{g} / \mathrm{L})$.

Cadmium, or other metals with a $\mathrm{K}_{\mathrm{d}}$ of $15 \mathrm{~mL} / \mathrm{g}$, is only slightly mobile, with the center of the contamination plume moving less than $1.5 \mathrm{~m}$ during the 50 -year period modeled.

Zinc, or metals with small $\mathrm{K}_{\mathrm{d}}$ values $(5 \mathrm{~mL} / \mathrm{g}$ ), reached the groundwater in approximately 20 years. Under the conditions modeled, the maximum concentration was estimated to be $6.0 \times 10^{-7} \mathrm{~g} / \mathrm{mL}$.

This model simulates only transport of metals via matrix flow in the vadose zone. If preferential pathways for flow exist, highly retarded metals, such as lead, could reach the groundwater in a much shorter time. This will, however, be a local event, and the groundwater should dilute the contaminant to below levels of concern. This is the most likely pathway for the lead contamination measured in the groundwater at the TBP area.

This study does not look at the effects of saturated zone transport of metal contaminants. Metals undergoing transport in the saturated zone would undergo a number of processes that would lower the initial concentrations at the source, if the source existed for a finite time (was not continuous). Thus, concentrations in the groundwater at points of concern may be lower than those estimated at the groundwater table by this model.

\section{A.7 REFERENCES FOR APPENDIX A}

Chemical Rubber Company, 1968, CRC Handbook of Chemistry and Physics 1968-69, R.C. Weast, editor, Cleveland, Ohio.

CRC: See Chemical Rubber Company.

Domenico, P.A., and F.W. Schwartz, 1990, Physical and Chemical Hydrogeology, John Wiley and Sons, New York, N.Y.

Guymon, G.L., 1994, Unsaturated Zone Hydrology, Prentice Hall, Englewood Cliffs, N.J.

4 The maximum concentration found was $92 \mu \mathrm{g} / \mathrm{L}$ (in only one sample); most samples have lead values below the $\mathrm{MCL}$ of $50 \mu \mathrm{g} / \mathrm{L}\left(5 \times 10^{-3} \mathrm{mg} / \mathrm{L}\right)$. 
Hughes, W.B., 1993, Hydrogeology and Soil Gas at J-Field, Aberdeen Proving Ground, Maryland, Water Resources Investigations Report 92-4087, U.S. Geological Survey, Towson, Md.

Hughes, W.B., 1995, Ground-Water Flow and the Possible Effects of Remedial Actions at J-Field, Aberdeen Proving Ground, Maryland, Water Resources Investigations Report 95-4075, U.S. Geological Survey, Towson, Md.

Perkins, S.O., and H.B. Winant, 1927, Soil Survey of Harford County, Maryland, U.S. Department of Agriculture, Washington, D.C.

Peters, R., 1995, Feasibility/Treatability Studies for Soil Washing and Solidification/Stabilization at J-Field, Aberdeen Proving Ground, Maryland, TU-18/ANL/APG/J-F/RI-FFS, Argonne National Laboratory, Argonne, Ill.

Quinn, J.J., 1995, Pump Test of Well 183 at J-Field, Aberdeen Proving Ground, Maryland: J-Field Remedial Investigation Technical Update, TU-17/ANL/APG/J-F/RI, Argonne National Laboratory, Argonne, Ill.

Sheppard, M.L., et al., 1984, Soil Nuclide Distribution Coefficients and Their Statistical Distributions, Whiteshell Nuclear Research Establishment, Atomic Energy of Canada Limited, Pinawa, Manitoba, Canada.

Smith, H., and E.D. Matthews, 1975, Soil Survey of Harford County Area, Maryland, U.S. Department of Agriculture and Soil Conservation Service, Washington, D.C., in cooperation with the Maryland Agricultural Experiment Station.

Thibault, D.H., et al., 1990, A Critical Compilation and Review of Default Soil Solid/Liquid Partition Coefficients, $K_{d}$, for Use in Environmental Assessments, Whiteshell Nuclear Research Establishment, Atomic Energy of Canada Limited, Pinawa, Manitoba, Canada.

Travis, B.J., and K.H. Birdsell, 1991, TRACR3D: A Model of Flow and Transport in Porous Media, Model Description and User's Manual, LA-11798-M UC-814, Los Alamos National Laboratory, Los Alamos, N.M.

van Genuchten, M.Th., 1980, "A Closed-Form Equation for Predicting the Hydraulic Conductivity of Unsaturated Soils,”. Soil Science of America Journal 44:892-898.

Yuen, R., et al., 1996, Remedial Investigation Report for J-Field, Aberdeen Proving Ground, Maryland, Volume 1: Remedial Investigation Results, draft prepared by Argonne National Laboratory, Argonne, Ill., for U.S. Army, Aberdeen Proving Ground, Md., Directorate of Safety, Health, and Environment. 
$B-1$

APPENDIX B:

APPLICABLE OR RELEVANT AND APPROPRIATE REQUIREMENTS 
B-2 
TABLE B.1 State Regulations and To-Be-Considered Requirements for J-Field

\begin{tabular}{|c|c|c|c|c|}
\hline Potential ARAR & Medium & Requirements & $\begin{array}{l}\text { Preliminary } \\
\text { Determination }\end{array}$ & Remarks \\
\hline $\begin{array}{l}\text { Chesapeake Bay Critical Area } \\
\text { Protection Program, Annotated Code } \\
\text { of Maryland, NR } \$ 8-1801 \text { et seq.; } \\
\text { COMAR } 27\end{array}$ & $\begin{array}{l}\text { Water, } \\
\text { sediment, } \\
\text { and soil }\end{array}$ & $\begin{array}{l}\text { Protection of the bay, and criteria for any } \\
\text { development in the bay area. Hazardous waste } \\
\text { collection or disposal facilities are not } \\
\text { permitted in the Critical Area unless no } \\
\text { environmentally acceptable alternative exists. }\end{array}$ & $\begin{array}{l}\text { Potentially } \\
\text { applicable }\end{array}$ & $\begin{array}{l}\text { Applies to Chesapeake Bay only. The bay } \\
\text { borders the site to the south and may } \\
\text { receive discharge from groundwater } \\
\text { aquifers. Potential impacts will depend on } \\
\text { the remedial actions. }\end{array}$ \\
\hline $\begin{array}{l}\text { Maryland Nonpoint Source Pollution } \\
\text { Control Laws, Annotated Code of } \\
\text { Maryland EN § 4-101 et seq. }\end{array}$ & $\begin{array}{l}\text { Soil and } \\
\text { sediment }\end{array}$ & $\begin{array}{l}\text { Construction, including soil movement, } \\
\text { grading, transporting, or otherwise disturbing } \\
\text { land, requires a grading and building permit, } \\
\text { issued after review and approval of the } \\
\text { Department of the Environment. }\end{array}$ & $\begin{array}{l}\text { Potentially } \\
\text { applicable }\end{array}$ & $\begin{array}{l}\text { Any excavation of soils may require } \\
\text { compliance with this law. }\end{array}$ \\
\hline $\begin{array}{l}\text { Maryland Nonpoint Source Pollution } \\
\text { Control Laws, Stormwater } \\
\text { Management, Annotated Code of } \\
\text { Maryland, EN \& 4-201 et seq.; } \\
\text { COMAR 26.09.05 }\end{array}$ & Stormwater & $\begin{array}{l}\text { A federal agency may not clear land, move } \\
\text { soil, or engage in construction without } \\
\text { submitting a stormwater management plan for } \\
\text { approval to the Department of the } \\
\text { Environment. }\end{array}$ & $\begin{array}{l}\text { Potentially } \\
\text { applicable }\end{array}$ & $\begin{array}{l}\text { Any soil movement may require compliance } \\
\text { with these requirements, including } \\
\text { mitigation. }\end{array}$ \\
\hline $\begin{array}{l}\text { Maryland Wetland Law, Annotated } \\
\text { Code of Maryland, EN } \S 9-301 \\
\text { et seq.; COMAR } 08.07\end{array}$ & Wetlands & $\begin{array}{l}\text { Any person proposing to conduct any activity } \\
\text { not authorized in the wetland regulations must } \\
\text { apply for a permit from the Department of } \\
\text { Natural Resources. }\end{array}$ & $\begin{array}{l}\text { Potentially } \\
\text { applicable }\end{array}$ & $\begin{array}{l}\text { Because the definition of "person" does not } \\
\text { include the federal government, these } \\
\text { regulations would not be applicable; } \\
\text { however, any clearing, filling, excavation, } \\
\text { or dredging within wetland areas may } \\
\text { require consultation with the Department. }\end{array}$ \\
\hline
\end{tabular}


TABLE B.1 (Cont.)

\begin{tabular}{|c|c|c|c|c|}
\hline Potential ARAR & Medium & Requirements & $\begin{array}{c}\text { Preliminary } \\
\text { Determination }\end{array}$ & Remarks \\
\hline $\begin{array}{l}\text { Nontidal Wetlands Protection Act, } \\
\text { Annotated Code of Maryland, NR } \\
\S 8-1201 \text { et seq.; COMAR 08.05.04 }\end{array}$ & $\begin{array}{l}\text { Nontidal } \\
\text { wetlands }\end{array}$ & $\begin{array}{l}\text { No person may conduct a regulated activity, } \\
\text { including removal, excavation, or dredging of } \\
\text { soil; grading; or destroying or removing plant } \\
\text { life, without first obtaining a permit from the } \\
\text { Department of Natural Resources. No activity } \\
\text { may (1) degrade the aquatic ecosystem, } \\
\text { diversity, productivity and stability, wildlife, } \\
\text { recreational and economic value, and public } \\
\text { welfaré; (2) violate any applicable State water } \\
\text { quality standard or the Clean Water Act; or } \\
\text { (3) degrade surface or groundwater quality. } \\
\text { An activity must be consistent with any } \\
\text { applicable comprehensive watershed } \\
\text { management plan. }\end{array}$ & $\begin{array}{l}\text { Potentially } \\
\text { applicable }\end{array}$ & $\begin{array}{l}\text { Any excavation, dredging, or dumping of } \\
\text { soil in a nontidal wetland area must comply } \\
\text { with these regulations. }\end{array}$ \\
\hline COMAR 26.08.04 & Water & $\begin{array}{l}\text { No person may construct a wastewater } \\
\text { treatment plant that discharges to the waters of } \\
\text { the State without first obtaining an NPDES } \\
\text { permit from the Department of the } \\
\text { Environment. }\end{array}$ & $\begin{array}{l}\text { Potentially } \\
\text { applicable }\end{array}$ & $\begin{array}{l}\text { If construction of a new wastewater } \\
\text { treatment plant at J-Field is part of the } \\
\text { proposed action, permit discharge limits } \\
\text { would be applicable. If wastewater from a } \\
\mathrm{J} \text {-Field soil washing/leaching facility is to } \\
\text { be treated at the O-Field treatment plant or } \\
\text { discharged through the POTW, a permit } \\
\text { modification may be necessary. }\end{array}$ \\
\hline
\end{tabular}


TABLE B.1 (Cont.)

\begin{tabular}{|c|c|c|c|c|}
\hline Potential ARAR & Medium & Requirements & $\begin{array}{l}\text { Preliminary } \\
\text { Determination }\end{array}$ & Remarks \\
\hline $\begin{array}{l}\text { Maryland Air Quality Control Act, } \\
\text { Annotated Code of Maryland, EN } \\
\text { \& 2-101 et seq.; COMAR 26.11.01, } \\
26.11 .03 \text {, and } 26.11 .06\end{array}$ & Air & $\begin{array}{l}\text { State-adopted national ambient air quality } \\
\text { standards and guidelines must be met for the } \\
\text { following: PM } 10-50 \mu \mathrm{g} / \mathrm{m}^{3} \text { annual mean, } \\
150 \mu \mathrm{g} / \mathrm{m}^{3} 24 \text {-hour average; sulfur } \\
\text { dioxide }-80 \mu \mathrm{g} / \mathrm{m}^{3} \text { annual arithmetic mean, } \\
365 \mu \mathrm{g} / \mathrm{m}^{3} \text { maximum } 24-\text { hour concentration; } \\
\text { nitrogen dioxide }-100 \mu \mathrm{g} / \mathrm{m}^{3} \text { annual } \\
\text { arithmetic mean; lead }-1.5 \mu \mathrm{g} / \mathrm{m}^{3} \text { maximum } \\
\text { mean over calendar quarter; carbon } \\
\text { monoxide - } 10 \mu \mathrm{g} / \mathrm{m}^{3} \text { maximum } 8 \text {-hour } \\
\text { concentration, } 40 \mu \mathrm{g} / \mathrm{m}^{3} \text { maximum 1-hour } \\
\text { concentration; ozone - } 235 \mu \mathrm{g} / \mathrm{m}^{3} \text {. For } \\
\text { particulate matter from materials handling and } \\
\text { construction, reasonable precautions must be } \\
\text { taken to prevent matter from becoming } \\
\text { airborne; i.c., use of water or chemicals for } \\
\text { dust control and covering open-bodied } \\
\text { vehicles transporting soils. }\end{array}$ & $\begin{array}{l}\text { Potentially } \\
\text { relevant and } \\
\text { appropriate }\end{array}$ & $\begin{array}{l}\text { These requirements do not apply directly to } \\
\text { sources of emissions; rather, they are } \\
\text { limitations on ambient concentrations. The } \\
\text { site is an unconfined source in what is } \\
\text { termed an Area III (per } 26.11 .01 \text { ). } \\
\text { Particulate matter must be controlled during } \\
\text { demolition or other earth-moving activities. }\end{array}$ \\
\hline COMAR 26.11.15 & Air & $\begin{array}{l}\text { Any installation or source that discharges } \\
\text { Class I or II toxic air pollutants into the } \\
\text { ambient air and must obtain a permit under } \\
\text { this subtitle must meet the requirements of } \\
\text { these regulations. Even if the installation need } \\
\text { not obtain a permit, the Department of the } \\
\text { Environment may require any source that is } \\
\text { not subject to permit or approval to meet these } \\
\text { requirements if the Department determines } \\
\text { that the installation has the potential to } \\
\text { discharge toxic air pollutants in quantities that } \\
\text { may unreasonably endanger the public health } \\
\text { (COMAR 26.11.15.03(A)(4)). }\end{array}$ & $\begin{array}{l}\text { Potentially } \\
\text { applicable }\end{array}$ & $\begin{array}{l}\text { Potentially applicable to any emissions } \\
\text { resulting from remedial actions, such as } \\
\text { in-situ treatment and pump-and-treat } \\
\text { actions. In addition, VX, GB, and mustard } \\
\text { gas are Class I toxic air pollutants (COMAR } \\
26.11 .15 .11 \text { ). Potential emissions may occur } \\
\text { in the marshes where chemical agents and } \\
\text { UXO may exist and during emergency use } \\
\text { of the TBP and WPP. }\end{array}$ \\
\hline
\end{tabular}


TABLE B.1 (Cont.)

\begin{tabular}{|c|c|c|c|c|}
\hline Potential ARAR & Medium & Requirements & $\begin{array}{l}\text { Preliminary } \\
\text { Determination }\end{array}$ & Remarks \\
\hline $\begin{array}{l}\text { Maryland Air Quality Control Act, } \\
\text { Annotated Code of Maryland, EN } \\
\S 2-101 \text { et seq.; COMAR 26.11.01, } \\
26.11 .03\end{array}$ & Air & $\begin{array}{l}\text { No person may construct a new source } \\
\text { protection source, including a sewage } \\
\text { treatment plant, without a permit to construct } \\
\text { from the Department of Environment. }\end{array}$ & $\begin{array}{l}\text { Potentially } \\
\text { applicable }\end{array}$ & $\begin{array}{l}\text { If construction of a new wastewater } \\
\text { treatment plant at J-Field is part of the } \\
\text { proposed action, permit discharge limits } \\
\text { would be applicable. }\end{array}$ \\
\hline COMAR 26.11.04(A)(44) & Air & $\begin{array}{l}\text { A person may not operate any petroleum- } \\
\text { contaminated soil treatment facility without } \\
\text { first obtaining a permit to operate from the } \\
\text { Department of the Environment. }\end{array}$ & $\begin{array}{l}\text { Potentially } \\
\text { applicable }\end{array}$ & $\begin{array}{l}\text { If treatment of petroleum-contaminated soil } \\
\text { will be part of the proposed action at } \\
\mathrm{J} \text {-Field, permit requirements would be } \\
\text { applicable. }\end{array}$ \\
\hline COMAR 26.11.06.06 & Air & $\begin{array}{l}\text { A person may not treat or dispose of waste } \\
\text { containing VOCs in a manner that results in } \\
\text { evaporation of greater than } 20 \mathrm{lb} / \text { day into the } \\
\text { atmosphere. }\end{array}$ & $\begin{array}{l}\text { Potentially } \\
\text { applicable }\end{array}$ & $\begin{array}{l}\text { If treatment of contaminated soil will be } \\
\text { part of the proposed action at J-Field, VOC } \\
\text { emissions must meet these requirements. }\end{array}$ \\
\hline $\begin{array}{l}\text { Maryland Landfill Siting Law, } \\
\text { Annotated Code of Maryland, EN } \\
\text { §9-209 et seq.; COMAR 26.04.07 }\end{array}$ & Solid waste & $\begin{array}{l}\text { General regulations for disposing of solid } \\
\text { waste in a land-based unit, including } \\
\text { procedures for closure and postclosure. Also, } \\
\text { sites that act as a transfer station or processing } \\
\text { facility for on-site disposal must follow these }\end{array}$ & $\begin{array}{l}\text { Potentially } \\
\text { applicable }\end{array}$ & $\begin{array}{l}\text { Should the remedial action involve } \\
\text { landfilling, transferring, and/or processing } \\
\text { the waste (as defined by COMAR } \\
26.04 .07 .02 \text { ), these regulations must be } \\
\text { followed. }\end{array}$ \\
\hline
\end{tabular}


TABLE B.1 (Cont.)

\begin{tabular}{|c|c|c|c|c|}
\hline Potential ARAR & Medium & Requirements & $\begin{array}{c}\text { Preliminary } \\
\text { Determination }\end{array}$ & Remarks \\
\hline \multirow[t]{4}{*}{ COMAR 26.13.02 } & $\begin{array}{c}\text { Hazardous } \\
\text { waste }\end{array}$ & $\begin{array}{l}\text { These regulations identify and list hazardous } \\
\text { waste and define hazardous waste. } \\
\text { Maryland-listed acute hazardous wastes } \\
\text { include the chemicals GA (tabun), GB (sarin), } \\
\text { GD (soman), VX, L (lewisite), DM (adamsite), } \\
\text { HD (sulfur mustard), and T, waste military } \\
\text { chemical warfare agents (Hazardous waste } \\
\text { codes K991 through K999) having any of } \\
\text { these substances as their active or principal } \\
\text { ingredient, or mixtures of any of these } \\
\text { substances and any characteristic or listed } \\
\text { hazardous waste or residues from the treatment } \\
\text { of wastes K991 through K999. Maryland- } \\
\text { listed hazardous waste from specific sources } \\
\text { includes residues from the treatment of the } \\
\text { above-listed wastes, except when treated at the } \\
\text { following: }\end{array}$ & $\begin{array}{l}\text { Potentially } \\
\text { applicable }\end{array}$ & $\begin{array}{l}\text { These requirements are applicable to any } \\
\text { removal actions if the waste at the site } \\
\text { meets the prerequisites for definition as } \\
\text { characteristic or listed hazardous waste. } \\
\text { These requirements would apply to any } \\
\text { interim waste storage or treatment facilities } \\
\text { or to groundwater monitoring for such } \\
\text { storage or treatment facilities, such as a } \\
\text { contaminated soil waste pile. }\end{array}$ \\
\hline & & $\begin{array}{l}\text { U.S. Army Aberdeen Proving } \\
\text { Ground/U.S. Army Chemical Research } \\
\text { Development and Engineering Center; }\end{array}$ & & \\
\hline & $\checkmark$ & $\begin{array}{l}\text { U.S. Army Product Assurance } \\
\text { Directorate, Aberdeen Proving Ground; } \\
\text { or }\end{array}$ & & \\
\hline & & $\begin{array}{l}\text { U.S. Army Aberdeen Proving } \\
\text { Ground/Medical Research Institute of } \\
\text { Chemical Defense }\end{array}$ & & \\
\hline
\end{tabular}


TABLE B.1 (Cont.)

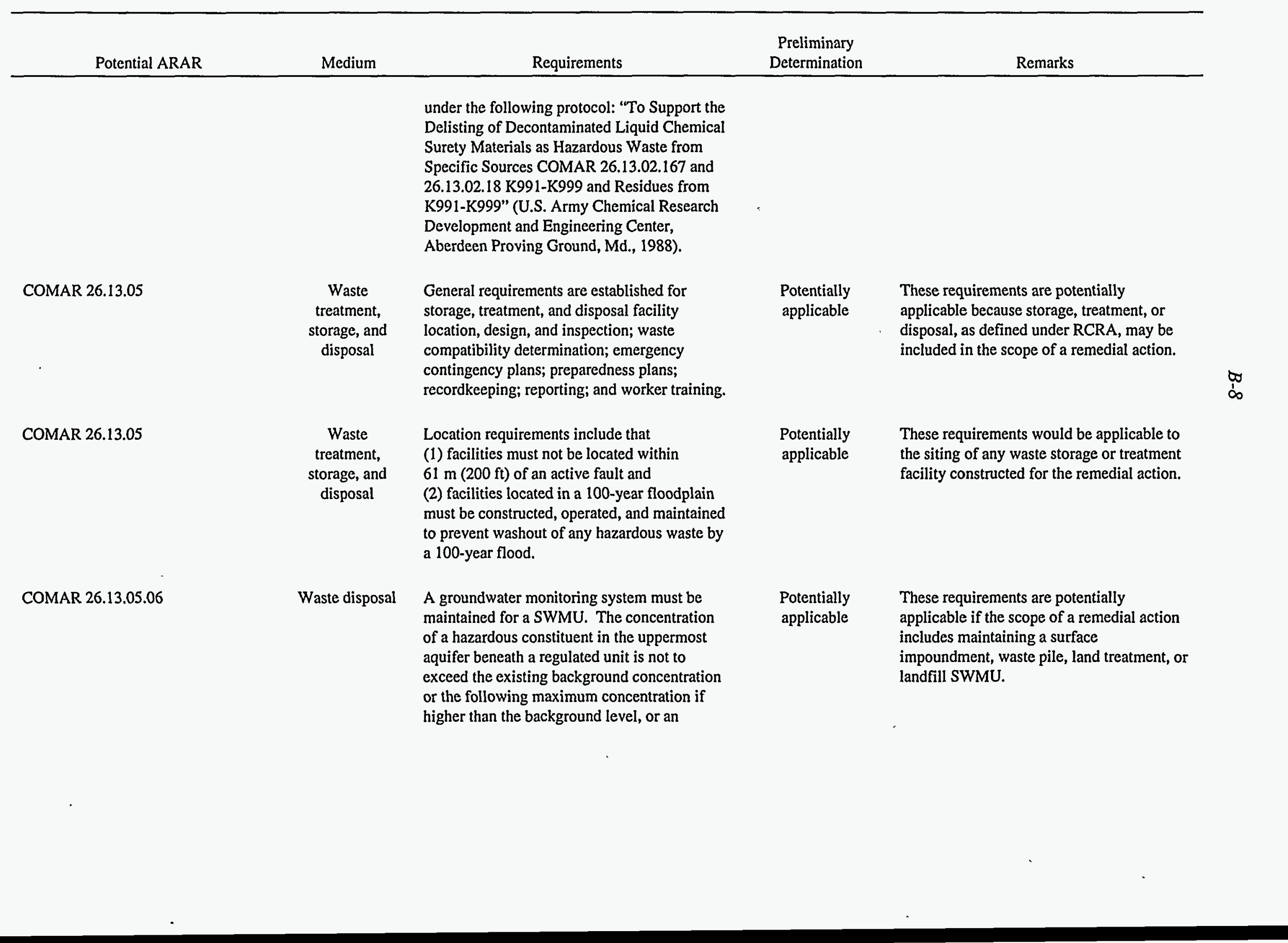


TABLE B.1 (Cont.)

\begin{tabular}{|c|c|c|c|}
\hline Potential ARAR & Medium & \multirow{2}{*}{\multicolumn{2}{|c|}{$\begin{array}{l}\text { alternative concentration limit, unless an } \\
\text { exemption is granted: }\end{array}$}} \\
\hline & & & \\
\hline & & Constituent & $\begin{array}{c}\text { Maximum Concentration } \\
\text { for Groundwater Protection } \\
(\mu \mathrm{g} / \mathrm{L})\end{array}$ \\
\hline & & $\begin{array}{l}\text { Arsenic } \\
\text { Lead }\end{array}$ & $\begin{array}{l}0.05 \\
0.05\end{array}$ \\
\hline
\end{tabular}

COMAR 26.13.05.09

COMAR 26.13.05.12

COMAR 26.13.05.10

COMAR 26.13.03
Waste storage

tanks must meet specific integrity and design requirements such that leaks can be detected and spills responded to.

Waste storage

Waste storage that provides protection from precipitation so that neither runoff nor leachate is generated need not meet the design and operating requirements of this Subpart if certain controls are established.

\section{Waste} management

Standards for accumulating labeling, marking, and shipping hazardous waste. Also, requirements for record keeping and reporting hazardous waste activities.
Preliminary

Determination

Remarks
Potentially applicable

Potentially applicable

Potentially applicable

These requirements may be applicable to the remedial action, container storage, and transportation of site waste that meets the prerequisites for definition as characteristic hazardous waste.

If contaminated soils are to be excavated and stored in a waste pile, these regulation would apply.

If contaminated wastewaters meet the definition of hazardous waste and are to be stored in tanks before transfer to the O-Field treatment plant, these regulations would apply.

Potentially applicable
If hazardous wastes are generated due to remedial actions, these wastes must be managed pursuant to these requirements. 
TABLE B.1 (Cont.)

\begin{tabular}{|c|c|c|c|c|}
\hline Potential ARAR & Medium & Requirements & $\begin{array}{c}\text { Preliminary } \\
\text { Determination }\end{array}$ & Remarks \\
\hline $\begin{array}{c}\text { COMAR 26.13.05.07 } \\
\text {. }\end{array}$ & $\begin{array}{c}\text { Waste } \\
\text { management }\end{array}$ & $\begin{array}{l}\text { All treatment, storage, and disposal facilities } \\
\text { must have a closure plan; all waste must be } \\
\text { removed and equipment decontaminated. For } \\
\text { certain facilities, postclosure requirements for } \\
\text { monitoring and notification are necessary. }\end{array}$ & $\begin{array}{l}\text { Potentially } \\
\text { applicable }\end{array}$ & $\begin{array}{l}\text { If storage or treatment facilities are a part of } \\
\text { the remedial action, closure requirements } \\
\text { must be met. }\end{array}$ \\
\hline $\begin{array}{l}\text { Maryland Hazardous Waste Facilities } \\
\text { Siting Law, Annotated Code of } \\
\text { Maryland, NR § 3-701 et seq. }\end{array}$ & $\begin{array}{c}\text { Waste } \\
\text { management }\end{array}$ & $\begin{array}{l}\text { The Hazardous Waste Facilities Siting Board } \\
\text { must issue a certificate of public necessity for } \\
\text { siting HW facilities. }\end{array}$ & $\begin{array}{l}\text { Potentially } \\
\text { applicable }\end{array}$ & $\begin{array}{l}\text { If an HW storage or treatment facility is to } \\
\text { be constructed at J-Field, the requirements } \\
\text { for these would be applicable. }\end{array}$ \\
\hline
\end{tabular}


TABLE B.2 Federal Regulations and To-Be-Considered Requirements for J-Field — Potential Contaminant-Specific Requirements

\begin{tabular}{|c|c|c|c|c|c|}
\hline Potential ARARs & Contaminant & Medium & Requirements & $\begin{array}{c}\text { Preliminary } \\
\text { Determination } \\
\end{array}$ & Remarks \\
\hline \multirow[t]{2}{*}{$\begin{array}{l}\text { Clean Air Act, as amended } \\
\text { ( } 42 \text { USC } 7401-7642) ; \text { National } \\
\text { Primary and Secondary } \\
\text { Ambient Air Quality Standards } \\
\text { ( } 40 \text { CFR Part 50) }\end{array}$} & $\begin{array}{l}\text { Particulate } \\
\text { matter }\end{array}$ & Air & $\begin{array}{l}\text { Federal standards for ambient air } \\
\text { quality include the following: sulfur } \\
\text { dioxide }-80 \mu \mathrm{g} / \mathrm{m}^{3} \text { annual arithmetic } \\
\text { mean, } 365 \mu \mathrm{g} / \mathrm{m}^{3} \text { maximum } 24 \text {-hour } \\
\text { concentration; particulate matter - } \\
150 \mu \mathrm{g} / \mathrm{m}^{3} 24 \text {-hour average concentra- } \\
\text { tion, } 50 \mu \mathrm{g} / \mathrm{m}^{3} \text { annual arithmetic } \\
\text { mean; carbon monoxide }-10 \mathrm{mg} / \mathrm{m}^{3} \\
8 \text {-hour average concentration, } \\
35 \mathrm{mg} / \mathrm{m}^{3} 1 \text {-hour average concentra- } \\
\text { tion; ozone - } 235 \mu \mathrm{g} / \mathrm{m}^{3} \text { maximum } \\
\text { hourly average concentration; nitrogen } \\
\text { dioxide - } 100 \mu \mathrm{g} / \mathrm{m}^{3} \text { annual arithmetic } \\
\text { mean; lead - } 1.5 \mu \mathrm{g} / \mathrm{m}^{3} \text { maximum } \\
\text { arithmetic mean averaged over } \\
\text { calendar quarter. }\end{array}$ & $\begin{array}{l}\text { Potentially relevant } \\
\text { and appropriate }\end{array}$ & $\begin{array}{l}\text { These requirements do not apply directly } \\
\text { to source-specific emissions; rather, they } \\
\text { are national limitations on ambient con- } \\
\text { centrations. However, they will be } \\
\text { addressed in controlling particulate } \\
\text { emissions and ozone (VOC) emissions } \\
\text { that could result from implementing a } \\
\text { remedial action. }\end{array}$ \\
\hline & Lead & Air & $\begin{array}{l}\text { As for the above conditions, the } \\
\text { standard for lead and its compounds, } \\
\text { as elemental lead, is } 1.5 \mu \mathrm{g} / \mathrm{m}^{3} \\
\text { maximum arithmetic mean averaged } \\
\text { over one calendar quarter. }\end{array}$ & $\begin{array}{l}\text { Potentially relevant } \\
\text { and appropriate }\end{array}$ & $\begin{array}{l}\text { These requirements do not apply directly } \\
\text { to source-specific emissions; rather, they } \\
\text { are national limitations on ambient con- } \\
\text { centrations. However, they will be } \\
\text { addressed in controlling lead emissions } \\
\text { that could result from implementing a } \\
\text { remedial action. }\end{array}$ \\
\hline
\end{tabular}


TABLE B.2 (Cont.)

\begin{tabular}{|c|c|c|c|c|c|}
\hline Potential ARARs & Contaminant & Medium & Requirements & $\begin{array}{c}\text { Preliminary } \\
\text { Determination }\end{array}$ & Remarks \\
\hline $\begin{array}{l}\text { TSCA, as amended } \\
\text { (15 USC 2607-2629, } \\
\text { PL } 94-469 \text { et seq.); Poly- } \\
\text { chlorinated Biphenyls } \\
\text { Manufacturing, Processing, } \\
\text { Distribution in Commerce, and } \\
\text { Use Prohibitions [ } 40 \text { CFR } \\
\text { Part } 761 \text { (Subpart G)] }\end{array}$ & PCBs & Soil & $\begin{array}{l}\text { For spills of materials contaminated } \\
\text { with }>50 \text { ppm PCBs in unrestricted } \\
\text { access areas (e.g., residential areas), } \\
\text { soil within the spill area must be } \\
\text { excavated and backfilled with soil } \\
\text { containing < } 1 \text { ppm PCBs. Contami- } \\
\text { nated soil may be decontaminated to } \\
10 \text { ppm by weight by excavating a } \\
\text { minimum of } 10 \text { in. and backfilling } \\
\text { with soil containing <1 ppm PCBs. } \\
\text { For spills at outdoor electrical sub- } \\
\text { stations, the soil must be cleaned to } \\
25 \text { ppm by weight (as for other } \\
\text { restricted access areas) or to } 50 \text { ppm } \\
\text { by weight with posting of a visible } \\
\text { notice. }\end{array}$ & To be considered & $\begin{array}{l}\text { Any such spills at the site would have } \\
\text { preceded the effective date of this } \\
\text { requirement; hence, it is not applicable. } \\
\text { Because the EPA policy on PCBs is not } \\
\text { an enforceable requirement, it is not } \\
\text { considered relevant and appropriate. } \\
\text { However, these regulations are the } \\
\text { guidelines used by the EPA for setting } \\
\text { preliminary remediation goals for PCBs } \\
\text { in soil at a remediation site. }\end{array}$ \\
\hline
\end{tabular}


TABLE B.3 Federal Regulations and To-Be-Considered Requirements for J-Field — Potential Location-Specific Requirements

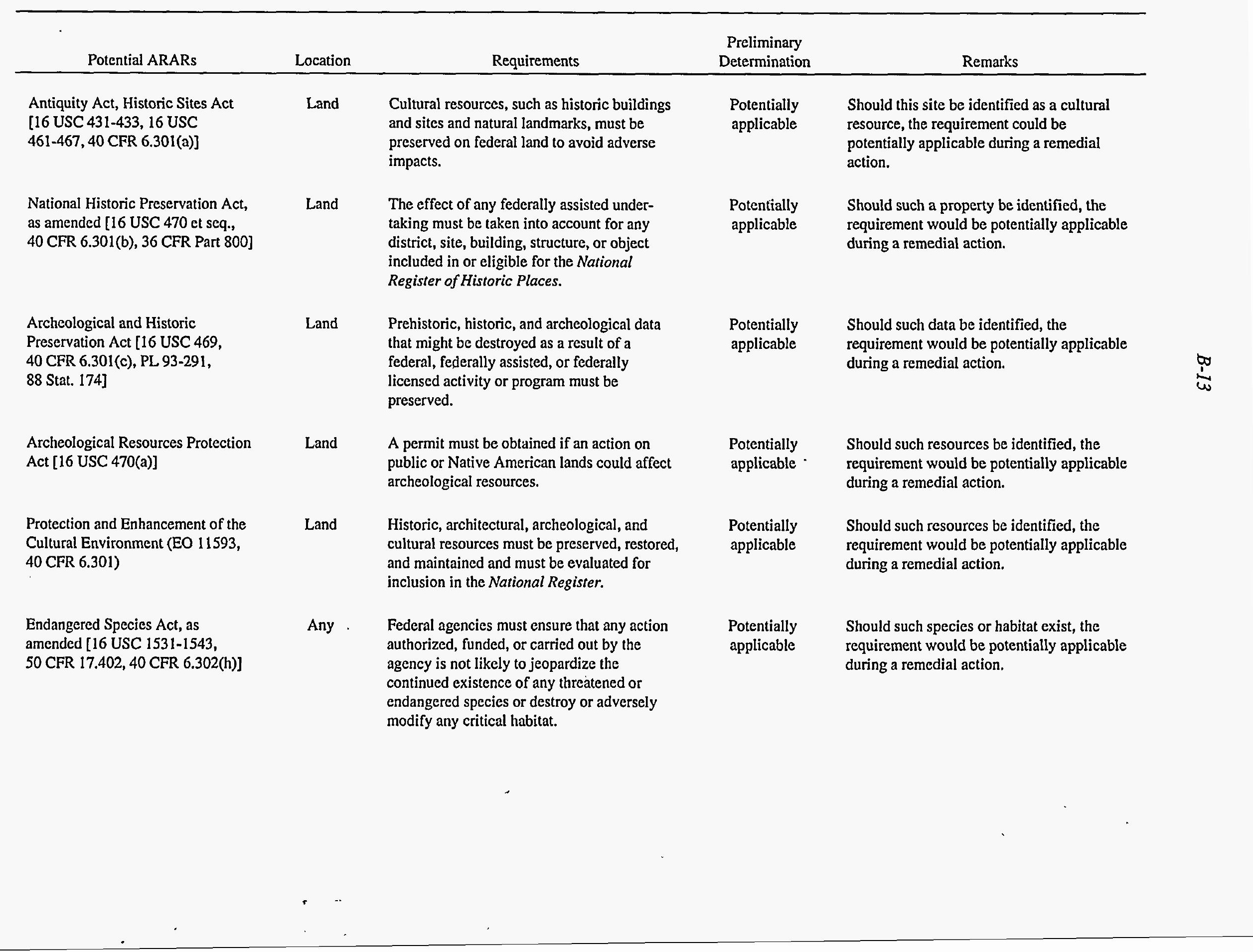


TABLE B.3 (Cont.)

\begin{tabular}{|c|c|c|c|c|}
\hline Potential ARARs & Location & Requirements & $\begin{array}{c}\text { Preliminary } \\
\text { Determination }\end{array}$ & Remarks \\
\hline $\begin{array}{l}\text { Fish and Wildlife Coordination Act } \\
\text { [14 USC 441-444, } \\
40 \text { CFR 4.302(a)] }\end{array}$ & Any & $\begin{array}{l}\text { Adequate protection of fish and wildlife } \\
\text { resources is required when any federal } \\
\text { department or agency proposes or authorizes } \\
\text { any modification (e.g., diversion or } \\
\text { channeling) of any stream or other water body } \\
\text { or any modification of areas affecting any } \\
\text { stream or other water body. }\end{array}$ & $\begin{array}{l}\text { Potentially } \\
\text { applicable }\end{array}$ & $\begin{array}{l}\text { Should modification of any stream or any } \\
\text { other water bodies or areas affecting water } \\
\text { bodies be required during a remedial action, } \\
\text { the requirement would be potentially } \\
\text { applicable. }\end{array}$ \\
\hline $\begin{array}{l}\text { Bald and Golden Eagle Protection } \\
\text { Act (16 USC 668-668d) }\end{array}$ & Any & $\begin{array}{l}\text { It is unlawful to take, pursue, molest, or } \\
\text { disturb bald eagles, their nests, or eggs. }\end{array}$ & $\begin{array}{l}\text { Potentially } \\
\text { applicable }\end{array}$ & $\begin{array}{l}\text { If any remedial activities would disturb the } \\
\text { habitat of the bald eagle, consultation with } \\
\text { the U.S. Department of the Interior would be } \\
\text { necessary. }\end{array}$ \\
\hline $\begin{array}{l}\text { Floodplain Management } \\
\text { (EO 11988, 40 CFR Part 6) }\end{array}$ & Floodplain & $\begin{array}{l}\text { Federal agencies must avoid, to the maximum } \\
\text { extent possible, any adverse impacts } \\
\text { associated with direct and indirect develop- } \\
\text { ment of a floodplain. }\end{array}$ & $\begin{array}{l}\text { Potentially } \\
\text { applicable }\end{array}$ & The site is within the 100 -year floodplain. \\
\hline $\begin{array}{l}\text { Protection of Wetlands } \\
\text { (EO } 11990,40 \text { CFR Part 6) }\end{array}$ & Wetlands & $\begin{array}{l}\text { Federal agencies must avoid, to the extent } \\
\text { possible, any adverse impacts associated with } \\
\text { the destruction or loss of wetlands and the } \\
\text { support of new construction in wetlands if a } \\
\text { practicable alternative exists. }\end{array}$ & $\begin{array}{l}\text { Potentially } \\
\text { applicable }\end{array}$ & Wetlands exist in the affected area. \\
\hline
\end{tabular}


TABLE B.4 Federal Regulations and To-Be-Considered Requirements for J-Field — Potential Action-Specific Requirements

\begin{tabular}{|c|c|c|c|c|}
\hline Potential ARARs & Action & Requirements & $\begin{array}{c}\text { Preliminary } \\
\text { Determination }\end{array}$ & Remarks \\
\hline $\begin{array}{l}\text { Hazardous Material } \\
\text { Transportation Act, as amended } \\
\text { (49 USC 1801-1812); DOT } \\
\text { HAZMAT Transportation } \\
\text { Regulations } \\
\text { (49 CFR Parts 172-179) }\end{array}$ & Transportation & $\begin{array}{l}\text { Generic requirements are established for } \\
\text { minimizing the environmental impacts of spills } \\
\text { or releases of hazardous materials, as are } \\
\text { procedures for transporting hazardous waste. }\end{array}$ & $\begin{array}{l}\text { Potentially } \\
\text { applicable }\end{array}$ & $\begin{array}{l}\text { These requirements are not part of an } \\
\text { environmental law and hence are not } \\
\text { subject to evaluation for attainment or } \\
\text { waiver as part of the ARAR process. } \\
\text { However, they could be pertinent to any } \\
\text { remedial action in which hazardous waste } \\
\text { is transported off-site. In this case, the } \\
\text { pertinent requirements (e.g., for spill } \\
\text { response) would be addressed during } \\
\text { implementation. }\end{array}$ \\
\hline $\begin{array}{l}\text { Noise Control Act, as amended; } \\
\text { Noise Pollution and Abatement } \\
\text { Act (42 USC } 4901 \text { et seq.) }\end{array}$ & $\begin{array}{l}\text { Detonation, } \\
\text { heavy } \\
\text { equipment } \\
\text { usage }\end{array}$ & $\begin{array}{l}\text { The public must be protected from noises (e.g., } \\
\text { that could result from remedial action activities) } \\
\text { that jeopardize health or welfare. }\end{array}$ & $\begin{array}{l}\text { Potentially } \\
\text { applicable }\end{array}$ & $\begin{array}{l}\text { This requirement is potentially applicable } \\
\text { if, during a remedial action, any heavy } \\
\text { equipment is used. }\end{array}$ \\
\hline $\begin{array}{l}\text { OSHA Standards, Occupational } \\
\text { Health and Environmental } \\
\text { Control [29 CFR 1910.95(g)] }\end{array}$ & Noise, air & $\begin{array}{l}\text { The permissible occupational exposure level for } \\
\text { noise is } 90 \mathrm{dBA} \text { (slow response) for an } 8 \text {-hour } \\
\text { day; with decreasing times of exposure, the } \\
\text { levels increase to } 115 \mathrm{dBA} \text { per } 15 \text {-minute day. }\end{array}$ & $\begin{array}{l}\text { Potentially } \\
\text { applicable }\end{array}$ & $\begin{array}{l}\text { These requirements are part of an employee } \\
\text { protection law (rather than an } \\
\text { environmental law) with which all } \\
\text { CERCLA response actions should comply. } \\
\text { Because this compliance is directly } \\
\text { required, as promulgated in the NCP, these } \\
\text { requirements are not subject to evaluation } \\
\text { for attainment or waiver as part of the } \\
\text { ARAR process. However, they constitute } \\
\text { requirements for worker protection with } \\
\text { which any remedial action will comply. }\end{array}$ \\
\hline
\end{tabular}


TABLE B.4 (Cont.)

\begin{tabular}{|c|c|c|c|c|}
\hline Potential ARARs & Action & Requirements & $\begin{array}{l}\text { Preliminary } \\
\text { Determination }\end{array}$ & Remarks \\
\hline $\begin{array}{l}\text { OSHA Standards for Hazardous } \\
\text { Waste Operations and } \\
\text { Emergency Response } \\
\text { (29 CFR Part 1910) }\end{array}$ & $\begin{array}{c}\text { Waste } \\
\text { management }\end{array}$ & $\begin{array}{l}\text { General worker protection requirements are } \\
\text { established, as are requirements for worker } \\
\text { training and the development of an emergency } \\
\text { response plan and a safety and health program } \\
\text { for employees. In addition, procedures are } \\
\text { established for hazardous waste operations - } \\
\text { including decontamination and drum/container } \\
\text { handling. }\end{array}$ & $\begin{array}{l}\text { Potentially } \\
\text { applicable }\end{array}$ & $\begin{array}{l}\text { These requirements are parts of an } \\
\text { employee protection law (rather than an } \\
\text { environmental law) with which all } \\
\text { CERCLA response actions should comply. } \\
\text { Because this compliance is directly } \\
\text { required, as promulgated in the NCP, these } \\
\text { requirements are not subject to evaluation } \\
\text { for attainment or waiver as part of the } \\
\text { ARAR process. However, they constitute } \\
\text { requirements for worker protection with } \\
\text { which a remedial action will comply. }\end{array}$ \\
\hline
\end{tabular}

TSCA, as amended (15 USC

2607-2629, PL 94-469 et seq.);

PCB testing

Inspection and testing are required for material contaminated with PCBs.

Potentially

applicable

This requirement may be applicable to

Polychlorinated Biphenyls

Manufacturing, Processing,

Distribution in Commerce, and

Use Prohibitions

[40 CFR Part 761 (Subpart A)]

TSCA, as amended (15 USC

2607-2629, PL 94-499 et seq.)

Polychlorinated Biphenyls

Manufacturing, Processing,

Distribution in Commerce, and

Use Prohibitions

[40 CFR Part 761 (Subpart D)]

PCB storage and disposal

\section{When material contaminated with PCBs}

$>50 \mathrm{ppm}$ is stored, the facility used for storage must be marked as such and must not be located in a 100-year floodplain. Disposal of material contaminated with PCBs $>50$ ppm requires

either incineration or chemical waste landfilling at EPA-approved facilities.
Potentially applicable

These requirements are potentially applicable because disposal of material from the site that may be contaminated with PCBs may be included in the scope of the remedial action. 
TABLE B.4 (Cont.)

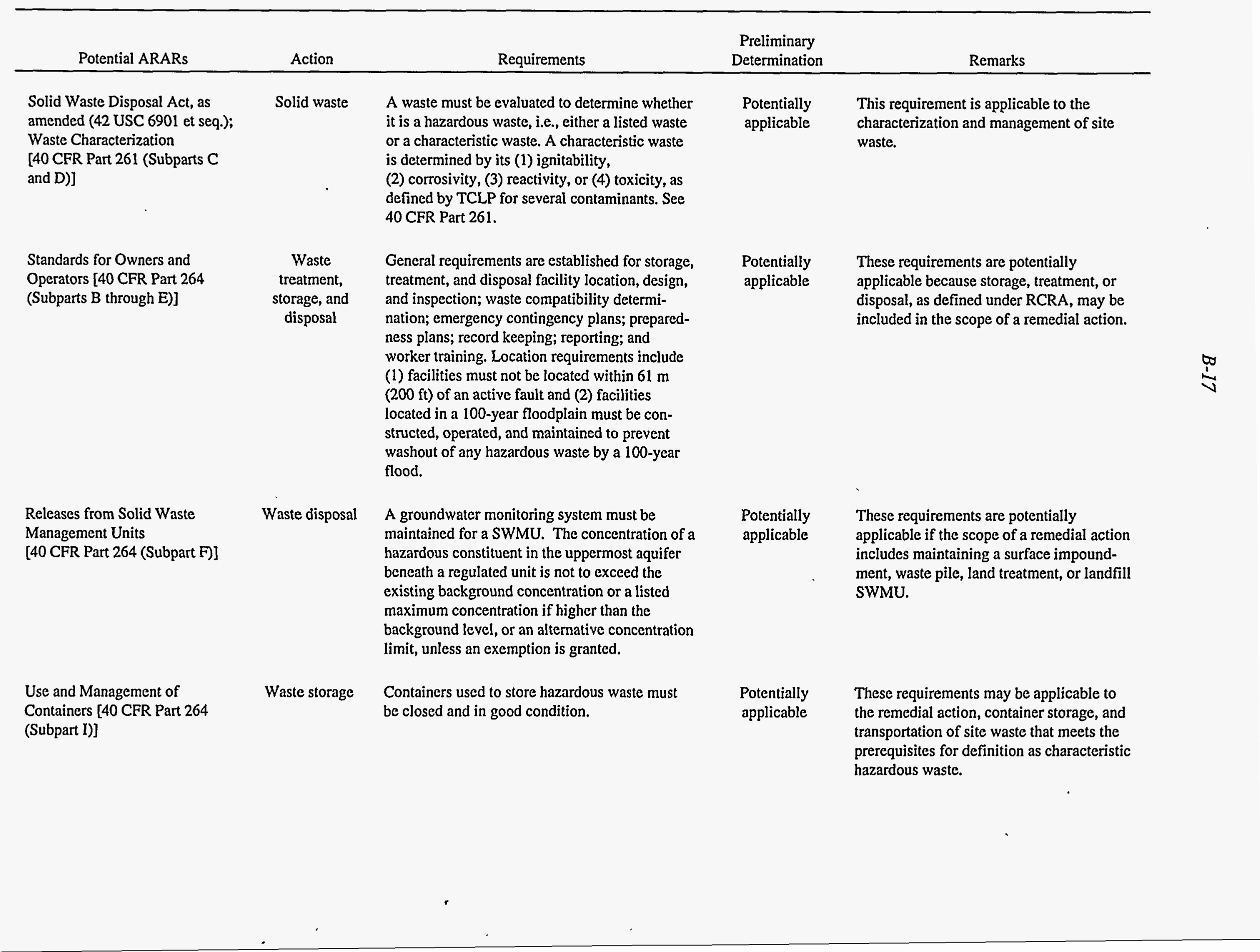


TABLE B.4 (Cont.)

\begin{tabular}{|c|c|c|c|c|}
\hline Potential ARARs & Action & Requirements & $\begin{array}{c}\text { Preliminary } \\
\text { Determination }\end{array}$ & Remarks \\
\hline $\begin{array}{l}\text { Prohibitions on Land Disposal } \\
\text { [ } 40 \text { CFR Part } 268 \text { (Subpart C)] }\end{array}$ & Waste disposal & $\begin{array}{l}\text { The land disposal of certain hazardous waste } \\
\text { (e.g., contaminated soil and debris) without } \\
\text { proper treatment is restricted, unless a } \\
\text { treatability variance is appropriate. Such } \\
\text { treatment must attain levels achievable by the } \\
\text { "best demonstrated available technologies" for } \\
\text { each hazardous constituent in the listed waste. }\end{array}$ & $\begin{array}{l}\text { Potentially } \\
\text { applicable }\end{array}$ & $\begin{array}{l}\text { These requirements are potentially } \\
\text { applicable for any remedial action at } \\
\text { J-Field that includes disposal or any } \\
\text { consolidation of site waste into a new } \\
\text { disposal or storage area. }\end{array}$ \\
\hline $\begin{array}{l}\text { Waste Piles [ } 40 \text { CFR Part } 264 \\
\text { (Subpart L)] }\end{array}$ & Waste storage & $\begin{array}{l}\text { A waste pile that is inside or under a structure } \\
\text { that provides protection from precipitation so } \\
\text { that neither runoff nor leachate is generated need } \\
\text { not meet the design and operating requirements } \\
\text { of this Subpart if certain controls are established. }\end{array}$ & $\begin{array}{l}\text { Potentially } \\
\text { applicable }\end{array}$ & $\begin{array}{l}\text { If contaminated soils are to be excavated } \\
\text { and stored in a waste pile, these regulations } \\
\text { would apply. }\end{array}$ \\
\hline $\begin{array}{l}\text { Containment Buildings } \\
\text { [40 CFR Part } 264 \text { (Subpart DD)] }\end{array}$ & Waste storage & $\begin{array}{l}\text { Wastes stored within a completely enclosed, } \\
\text { self-supporting structure that has a primary } \\
\text { barrier to contain all wastes must conform to } \\
\text { these regulations. }\end{array}$ & $\begin{array}{l}\text { Potentially } \\
\text { applicable }\end{array}$ & $\begin{array}{l}\text { If contaminated soils are to be excavated } \\
\text { and stored in a containment building, these } \\
\text { regulations would apply. }\end{array}$ \\
\hline $\begin{array}{l}\text { Tanks [40 CFR Part } 264 \\
\text { (Subpart J)] }\end{array}$ & Waste storage & $\begin{array}{l}\text { Wastes stored in tanks must meet specific } \\
\text { integrity and design requirements such that leaks } \\
\text { can be detected and spills responded to. }\end{array}$ & $\begin{array}{l}\text { Potentially } \\
\text { applicable }\end{array}$ & $\begin{array}{l}\text { If contaminated wastewaters meet the } \\
\text { definition of hazardous waste and are to be } \\
\text { stored in tanks before transfer to the } \\
\text { O-Field treatment plant, these regulations } \\
\text { would apply. }\end{array}$ \\
\hline $\begin{array}{l}\text { Corrective Action for Solid } \\
\text { Waste Management Units } \\
\text { [40 CFR Part } 264 \text { (Subpart S)] }\end{array}$ & Waste storage & $\begin{array}{l}\text { Temporary tanks and container storage areas for } \\
\text { treatment or storage of hazardous remediation } \\
\text { wastes generated during RCRA corrective } \\
\text { actions may meet alternative requirements } \\
\text { contained in this Subpart. }\end{array}$ & $\begin{array}{l}\text { Potentially } \\
\text { applicable }\end{array}$ & $\begin{array}{l}\text { These regulations would apply if tank or } \\
\text { container storage is a part of the proposed } \\
\text { action at J-Field. }\end{array}$ \\
\hline $\begin{array}{l}\text { Closure and } \\
\text { Post-Closure [ } 40 \text { CFR Part } 264 \\
\text { (Subpart G)] }\end{array}$ & $\begin{array}{l}\text { Waste } \\
\text { management }\end{array}$ & $\begin{array}{l}\text { All treatment, storage, and disposal facilities } \\
\text { must have a closure plan; all waste must be } \\
\text { removed and equipment decontaminated. For } \\
\text { certain facilities, postclosure requirements for } \\
\text { monitoring and notification are necessary. }\end{array}$ & $\begin{array}{l}\text { Potentially } \\
\text { applicable }\end{array}$ & $\begin{array}{l}\text { If storage or treatment facilities are a part } \\
\text { of the remedial action, closure requirements } \\
\text { must be met. }\end{array}$ \\
\hline
\end{tabular}


$C-1$

APPENDIX C:

SAMPLING DATA FOR THE TOXIC BURNING PITS AREA JANUARY 1993-JUNE 1995 


\section{C-3}

\section{APPENDIX C:}

\section{SAMPLING DATA FOR THE TOXIC BURNING PITS AREA}

JANUARY 1993-JUNE 1995

This appendix presents the sampling data for surface water, sediment, soil, and groundwater collected at the J-Field Toxic Burning Pits (TBP) area between January 1993 and June 1995. Soilgas measurements are not presented here. A complete data set for all J-Field areas of concern, including the TBP area, is summarized and discussed in the Remedial Investigation Report for J-Field, Aberdeen Proving Ground, Maryland, Volume 1: Remedial Investigation Results (Yuen, R., et al., 1996, prepared by Argonne National Laboratory, Argonne, Ill., for U.S. Army, Aberdeen Proving Ground, Md., Directorate of Safety, Health, and Environment), which is currently in draft form.

Table C.1 provides an index to the data tables. 
TABLE C.1 Index to Data Tables for the J-Field TBP Area

\begin{tabular}{|c|c|c|c|c|}
\hline $\begin{array}{l}\text { Table } \\
\text { No. }\end{array}$ & Sample Medium & Analyses & Date & $\begin{array}{c}\text { Page } \\
\text { Number }\end{array}$ \\
\hline C. $2 \mathrm{a}$ & Surface water & Volatile organics & Apr 1993 & C-6 \\
\hline C. $2 b$ & Surface water & Volatile organics & Sept 1993 & C-8 \\
\hline C.2c & Surface water & Volatile organics & Feb 1994 & C-10 \\
\hline C.2d & Surface water & Volatile organics & May 1994 & $\mathrm{C}-13$ \\
\hline C. $3 a$ & Surface water & Semivolatile organics & Apr 1993 & C-14 \\
\hline C.3b & Surface water & Semivolatile organics & Sept 1993 & $\mathrm{C}-17$ \\
\hline C.3c & Surface water & Semivolatile organics & May 1994 & C-19 \\
\hline C. $4 \mathrm{a}$ & Surface water & Inorganics & Sept 1993 & $\mathrm{C}-21$ \\
\hline C. $4 b$ & Surface water & Inorganics & May 1994 & C-23 \\
\hline C.5a & Surface water & Pesticides and PCBs & Apr 1993 & $\mathrm{C}-24$ \\
\hline C. $5 \mathrm{~b}$ & Surface water & Pesticides and PCBs & Sept 1993 & C-26 \\
\hline C.5c & Surface water & Pesticides and PCBs & May 1994 & C-28 \\
\hline C.6a & Surface water & General chemistry & May 1994 & C-29 \\
\hline C. $6 b$ & Surface water & Explosive compounds & May 1994 & $C-30$ \\
\hline C.6c & Surface water & $\begin{array}{l}\text { CWA degradation products } \\
\text { Organosulfur compounds }\end{array}$ & Apr 1993 & $C-31$ \\
\hline C.7a & Sediment & Volatile organics & Apr 1994 & $\mathrm{C}-32$ \\
\hline C.7b & Sediment & Volatile organics & June 1995 & $\mathrm{C}-38$ \\
\hline C.8a & Sediment & Semivolatile organics & Apr 1994 & C-40 \\
\hline C. $8 \mathrm{~b}$ & Sediment & Semivolatile organics & June 1995 & $\mathrm{C}-53$ \\
\hline C.9a & Sediment & Inorganics & Apr 1994 & C-55 \\
\hline C. $9 b$ & Sediment & Inorganics & June 1995 & C- 60 \\
\hline C. 10 & Sediment & Pesticides and PCBs & June 1995 & C-62 \\
\hline C.11 & Sediment & Explosive compounds & June 1995 & C-63 \\
\hline C. 12 & Sediment & $\begin{array}{l}\text { CWA degradation products } \\
\text { Organosulfur compounds }\end{array}$ & June 1995 & C-64 \\
\hline C.13a & Soil & Volatile organics & Jan 1993 & C-65 \\
\hline C. $13 b$ & Soil & Volatile organics & Jan 1994 & C-71 \\
\hline C. $13 c$ & Soil & Volatile organics & May 1994 & C-77 \\
\hline C. $13 \mathrm{~d}$ & Soil & Volatile organics & May 1995 & C-91 \\
\hline C. $14 \mathrm{a}$ & Soil & Semivolatile organics & Jan 1993 & C-102 \\
\hline C. $14 b$ & Soil & Semivolatile organics & Jan 1994 & C-116 \\
\hline C. $14 \mathrm{c}$ & Soil & Semivolatile organics & May 1994 & $C-126$ \\
\hline C. $14 d$ & Soil & Semivolatile organics & May 1995 & C-142 \\
\hline C.15a & Soil & Inorganics & Jan 1993 & $C-160$ \\
\hline C. $15 b$ & Soil & Inorganics & Jan 1994 & $C-165$ \\
\hline C.15c & Soil & Inorganics & May 1994 & C-169 \\
\hline C.15d & Soil & Inorganics & May 1995 & C-176 \\
\hline
\end{tabular}




\section{C-5}

TABLE C.1 (Cont.)

\begin{tabular}{|c|c|c|c|c|}
\hline $\begin{array}{l}\text { Table } \\
\text { No. }\end{array}$ & Sample Medium & Analytes & Date & $\begin{array}{c}\text { Page } \\
\text { Number }\end{array}$ \\
\hline C.16a & Soil & Pesticides and PCBs & Jan 1993 & C-188 \\
\hline C. $16 \mathrm{~b}$ & Soil & Pesticides and PCBs & May 1995 & C-193 \\
\hline C. 17 & Soil & On-site analytical suite & $\begin{array}{l}\text { Dec } 1993- \\
\text { May } 1994\end{array}$ & C-195 \\
\hline C. 18 & Soil & Explosives & May'1995 & C-198 \\
\hline C. 19 & Soil & $\begin{array}{l}\text { CWA degradation products } \\
\text { Organosulfur compounds }\end{array}$ & May 1995 & $C-200$ \\
\hline C. 20 & Soil & $\begin{array}{l}\text { Dioxins } \\
\text { Total petroleum } \\
\text { hydrocarbons }\end{array}$ & May 1995 & $\mathrm{C}-202$ \\
\hline C.21a & Groundwater & Volatile organics & May 1994 & C-203 \\
\hline C. $21 \mathrm{~b}$ & Groundwater & Volatile organics & Sept 1994 & $\mathrm{C}-208$ \\
\hline C.22 & Groundwater & Semivolatile organics & May 1994 & $\mathrm{C}-211$ \\
\hline C. 23 & Groundwater & Inorganics & May 1994 & $C-215$ \\
\hline C. 24 & Groundwater & General chemistry & May 1994 & $\mathrm{C}-220$ \\
\hline C.25 & Groundwater & Pesticides and PCBs & May 1994 & $\mathrm{C}-223$ \\
\hline C. 26 & Groundwater & Explosive compounds & June 1994 & $\mathrm{C}-224$ \\
\hline C. 27 & Groundwater & Radiochemistry & June 1994 & $\mathrm{C}-225$ \\
\hline
\end{tabular}


TABLE C.2a Volatile Organics Analyses for Surface Water, April $1993^{\mathrm{a}}$

\begin{tabular}{|c|c|c|c|c|c|c|c|c|c|c|c|c|c|c|c|c|}
\hline \multirow{3}{*}{$\begin{array}{l}\text { Compound } \\
\text { Acetone }\end{array}$} & \multicolumn{16}{|c|}{ Surface Water Concentrations $(\mu \mathrm{g} / \mathrm{L})$} \\
\hline & \multicolumn{2}{|c|}{ SW-6 } & \multicolumn{2}{|c|}{ SW-7 } & \multicolumn{2}{|c|}{ SW-8 } & \multicolumn{2}{|c|}{ SW-10 } & \multicolumn{2}{|c|}{ SW-10-Dup } & \multicolumn{2}{|c|}{ SW-11 } & \multicolumn{2}{|c|}{ SW-12 } & \multicolumn{2}{|c|}{ SW-13 } \\
\hline & 9 & $J$ & 10 & & 6 & $\mathrm{~J}$ & 32 & $\mathbf{J}$ & 110 & DJ & 8 & $\mathrm{~J}$ & 8 & $\mathrm{~J}$ & 11 & \\
\hline Benzene & 10 & $\mathrm{U}$ & 10 & $\mathrm{U}$ & 10 & $\mathbf{U}$ & 62 & $\mathbf{U}$ & 250 & $\mathbf{U}$ & 10 & $\mathrm{U}$ & 10 & $\mathrm{U}$ & 10 & $\mathbf{U}$ \\
\hline Bromodichloromethane & 10 & $\mathbf{U}$ & 10 & $\mathrm{U}$ & 10 & $\mathbf{U}$ & 62 & $\mathrm{U}$ & 250 & $\mathbf{U}$ & 10 & $\mathrm{U}$ & 10 & $\mathrm{U}$ & 10 & $\mathbf{U}$ \\
\hline Bromoform & 10 & $U$ & 10 & $\mathbf{U}$ & 10 & $\mathbf{U}$ & 62 & U & 250 & $\mathrm{U}$ & 10 & $U$ & 10 & $\mathrm{U}$ & 10 & $\mathbf{U}$ \\
\hline Bromomethane & 10 & $U$ & 10 & $\mathbf{U}$ & 10 & $\mathbf{U}$ & 62 & $\mathrm{U}$ & 250 & $\mathrm{U}$ & 10 & $\mathbf{U}$ & 10 & $\mathbf{U}$ & 10 & $\mathrm{U}$ \\
\hline 2-Butanone & 2 & $\mathbf{J}$ & 2 & $\mathrm{~J}$ & 10 & $\mathbf{U}$ & 62 & $\mathrm{U}$ & 250 & U & 10 & $\mathrm{U}$ & 10 & $\mathrm{U}$ & 5 & $\mathbf{J}$ \\
\hline Carbon disulfide & 10 & $\mathbf{U}$ & 10 & $\mathrm{U}$ & 10 & $\mathrm{U}$ & 62 & $\mathbf{U}$ & 250 & $U$ & 10 & $\mathrm{U}$ & 10 & $\mathbf{U}$ & 10 & $\mathrm{U}$ \\
\hline Carbon tetrachloride & 10 & $\mathrm{U}$ & 10 & $\mathbf{U}$ & 10 & $\mathbf{U}$ & 62 & $\mathbf{U}$ & 250 & $U$ & 10 & $U$ & 10 & $\mathrm{U}$ & 10 & $\mathbf{U}$ \\
\hline Chlorobenzene & 10 & $\mathbf{U}$ & 10 & $\mathrm{U}$ & 10 & $\mathbf{U}$ & 62 & $\mathrm{U}$ & 250 & $\mathbf{U}$ & 10 & $\mathrm{U}$ & 10 & $\mathbf{U}$ & 10 & $\mathbf{U}$ \\
\hline Chioroethane & 10 & $\mathrm{U}$ & 10 & $\mathrm{U}$ & 10 & $\mathbf{U}$ & 62 & $\mathbf{U}$ & 250 & 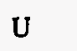 & 10 & $\mathrm{U}$ & 10 & $\mathbf{U}$ & 10 & U \\
\hline Chloroform & 10 & $\mathbf{U}$ & 10 & $\mathrm{U}$ & 10 & $\mathbf{U}$ & 62 & $\mathrm{U}$ & 250 & $U$ & 10 & $\mathrm{U}$ & 10 & $\mathrm{U}$ & 10 & $\mathbf{U}$ \\
\hline Chloromethane & 10 & U & 10 & $\mathrm{u}$ & 10 & $\mathrm{U}$ & 62 & $\mathrm{U}$ & 250 & $\mathrm{U}$ & 10 & $\mathrm{U}$ & 10 & $\mathrm{U}$ & 10 & $\mathbf{U}$ \\
\hline Dibromochloromethane & 10 & $\mathrm{U}$ & 10 & $\mathrm{U}$ & 10 & $\mathrm{U}$ & 62 & $\mathrm{U}$ & 250 & U & 10 & $\mathbf{U}$ & 10 & $\mathbf{U}$ & 10 & $\mathrm{U}$ \\
\hline 1,1-Dichloroethane & 10 & $\mathbf{U}$ & 10 & $\mathrm{U}$ & 10 & $\mathbf{U}$ & 62 & $\mathrm{U}$. & 250 & $\mathrm{U}$ & 10 & $\mathrm{U}$ & 10 & $\mathrm{U}$ & 10 & $\mathbf{U}$ \\
\hline 1,2-Dichloroethane & 10 & $\mathbf{U}$ & 10 & U & 10 & $\mathrm{U}$ & 62 & $U$ & 250 & $\mathrm{U}$ & 10 & 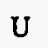 & 10 & $\mathrm{U}$ & 10 & $\mathrm{U}$ \\
\hline 1,1-Dichloroethene & 10 & U & 10 & $U$ & 10 & $U$ & 62 & $\mathrm{U}$ & 250 & $U$ & 10 & $\mathbf{U}$ & 10 & $\mathbf{U}$ & 10 & $\mathrm{U}$ \\
\hline 1,2-Dichloroethene (total) & 10 & $\mathrm{U}$ & 19 & & 10 & $\mathrm{U}$ & 1,400 & & 1,400 & $D$ & 16 & & 10 & $\mathrm{U}$. & 10 & $\mathbf{U}$ \\
\hline 1,2-Dichloropropane & 10 & $\mathrm{U}$ & 10 & U & 10 & $\mathrm{U}$ & 62 & $\mathrm{U}$ & 250 & $\mathrm{U}$ & 10 & $\mathbf{U}$ & 10 & $\mathbf{U}$ & 10 & $\mathrm{U}$ \\
\hline cis-1,3-Dichloropropene & 10 & $\mathrm{U}$ & 10 & U & 10 & $U$ & 62 & $\mathbf{U}$ & 250 & $\mathrm{U}$ & 10 & $\mathbf{U}$ & 10 & $\mathbf{u}$ & 10 & $\mathbf{U}$ \\
\hline trans-1,3-Dichloropropene & 10 & $\mathrm{U}$ & 10 & U & 10 & $\mathrm{U}$ & 62 & $\mathrm{U}$ & 250 & $U$ & 10 & $\mathrm{U}$ & 10 & $\mathrm{U}$ & 10 & U \\
\hline Ethylbenzene & 10 & $\mathbf{U}$ & 10 & $U$ & 10 & U & 62 & $\mathbf{U}$ & 250 & $\mathrm{U}$ & 10 & $\mathbf{U}$ & 10 & $\mathbf{U}$ & 10 & $\mathrm{U}$ \\
\hline 2-Hexanone & 10 & $U$ & 10 & $U$ & 10 & $\mathrm{U}$ & 62 & U & 250 & $\mathrm{U}$ & 10 & $\mathbf{U}$ & 10 & $\mathrm{U}$ & 10 & $U$ \\
\hline 4-Methyl-2-pentanone & 10 & $\mathrm{U}$ & 10 & $\mathrm{U}$ & 10 & $\mathrm{U}$ & 62 & $\mathrm{U}$ & 250 & $\mathrm{U}$ & 10 & $\mathrm{U}$ & 10 & $\mathrm{U}$ & 10 & $\mathrm{U}$ \\
\hline Methylene chloride & 10 & $\mathbf{U}$ & 1 & $\mathrm{BJ}$ & 10 & $\mathrm{U}$ & 62 & $\mathbf{U}$ & 27 & BDJ & 10 & $\mathrm{U}$ & 10 & $\mathrm{U}$ & 10 & $\mathrm{U}$ \\
\hline Styrene & 10 & $\mathrm{U}$ & 10 & $U$ & 10 & $\mathrm{U}$ & 62 & $\mathrm{U}$ & 250 & $\mathrm{U}$ & 10 & $\mathbf{U}$ & 10 & $\mathrm{U}$ & 10 & $\mathrm{U}$ \\
\hline 1,1,2,2-Tetrachloroethane & 10 & $\mathbf{U}$ & 190 & & 2 & J & 2,200 & & 2,300 & $\mathrm{D}$ & 8 & $\mathbf{J}$ & 10 & $\mathrm{U}$ & 10 & $\mathrm{U}$ \\
\hline Tetrachloroethene & 10 & $\mathbf{U}$ & 1 & $\mathrm{~J}$ & 10 & $\mathrm{U}$ & 44 & $\mathrm{~J}$ & 40 & DJ & 10 & $\mathbf{U}$ & 10 & $\mathbf{U}$ & 10 & $\mathrm{U}$ \\
\hline Toluene & 10 & $U$ & 10 & $U$ & 10 & $\mathrm{U}$ & 62 & $\mathbf{U}$ & 250 & U & 10 & $\mathbf{U}$ & 10 & $\mathrm{U}$ & 10 & $\mathrm{U}$ \\
\hline 1,1,1-Trichloroethane & 10 & $\mathbf{U}$ & 10 & $U$ & 10 & $U$ & 62 & $\mathbf{U}$ & .250 & U & 10 & $\mathbf{U}$ & 10 & $\mathrm{U}$ & 10 & U \\
\hline 1,1,2-Trichloroethane & 10 & U & 13 & & 10 & U & 93 & & 250 & $\mathbf{U}$ & 1 & $\mathrm{~J}$ & 10 & $U$ & 10 & U \\
\hline
\end{tabular}


TABLE C.2a (Cont.)

\begin{tabular}{|c|c|c|c|c|c|c|c|c|c|c|c|c|c|c|c|c|}
\hline \multirow{3}{*}{$\begin{array}{l}\text { Compound } \\
\text { Trichlorosthene }\end{array}$} & \multicolumn{16}{|c|}{ Surface Water Concentrations $(\mu g / L)$} \\
\hline & \multicolumn{2}{|c|}{ SW-6 } & \multicolumn{2}{|c|}{ SW-7 } & \multicolumn{2}{|c|}{ SW-8 } & \multicolumn{2}{|c|}{ SW-10 } & \multicolumn{2}{|c|}{ Sw-10-Dup } & \multicolumn{2}{|c|}{ SW-11 } & \multicolumn{2}{|c|}{ sw-12 } & \multicolumn{2}{|c|}{ SW-13 } \\
\hline & 10 & $\mathbf{U}$ & 59 & & 10 & $\mathrm{U}$ & 2,100 & & 250 & $\mathbf{U}$ & 6 & $\mathbf{J}$ & 10 & $\mathbf{U}$ & 10 & $\mathrm{U}$ \\
\hline Vinyl chloride & 10 & $\mathbf{U}$ & 10 & $\mathbf{U}$ & 10 & $\mathrm{U}$ & 62 & $\mathbf{U}$ & 250 & $U$ & 2 & J & 10 & U & 10 & $\mathrm{u}$ \\
\hline Xylenes (total) & 10 & $\mathbf{U}$ & 10 & $\mathbf{U}$ & 10 & $\mathrm{U}$ & 62 & $\mathbf{U}$ & 250 & $\mathrm{U}$ & 10 & $\mathbf{U}$ & 10 & $\mathbf{U}$ & 10 & $\mathbf{u}$ \\
\hline
\end{tabular}

a Sampled by ANL and USGS, analyzed by Enesco, CLP/HSL volatile organics. Provisional data, validation in progress. Data qualifiers:

$\mathrm{U}=$ analyte was analyzed for but not detected; detection limit given.

$\mathrm{J}=$ estimated value.

B = analyte was found in the associated blank.

$\mathrm{D}=$ sample was diluted for analysis. 
TABLE C.2b Volatile Organics Analyses for Surface Water, September $1993^{\mathrm{a}}$

\begin{tabular}{|c|c|c|}
\hline \multirow[b]{2}{*}{ Compound } & \multicolumn{2}{|c|}{$\begin{array}{c}\text { Surface Water } \\
\text { Concentrations } \\
(\mu \mathrm{g} / \mathrm{L})\end{array}$} \\
\hline & \multicolumn{2}{|c|}{ SW-7 } \\
\hline Acetone & 17 & \\
\hline Benzene & 10 & $\mathrm{U}$ \\
\hline Bromodichloromethane & 10 & $U$ \\
\hline Bromoform & 10 & $\mathrm{U}$ \\
\hline Bromomethane & 10 & $\mathrm{U}$ \\
\hline 2-Butanone & 10 & $\mathrm{U}$ \\
\hline Carbon disulfide & 10 & $\mathrm{U}$ \\
\hline Carbon tetrachloride & 10 & $U$ \\
\hline Chlorobenzene & 10 & $U$ \\
\hline Chloroethane & 10 & $\mathrm{U}$ \\
\hline Chloroform & 10 & $\mathrm{U}$ \\
\hline Chloromethane & 10 & $\mathrm{U}$ \\
\hline Dibromochloromethane & 10 & $U$ \\
\hline 1,1-Dichloroethane & 10 & $\mathrm{U}$ \\
\hline 1,2-Dichloroethảne & 10 & $U$ \\
\hline 1,1-Dichloroethene & 10 & $U$ \\
\hline 1,2-Dichloroethene (total) & 10 & $\mathrm{U}$ \\
\hline 1,2-Dichloropropane & 10 & $\mathrm{U}$ \\
\hline cis-1,3-Dichloropropene & 10 & $U$ \\
\hline trans-1,3,-Dichloropropene & 10 & $\mathrm{U}$ \\
\hline Ethylbenzene & 10 & $\mathrm{U}$ \\
\hline 2-Hexanone & 10 & $\mathrm{U}$ \\
\hline 4-Methyl-2-pentanone & 10 & $\mathrm{U}$ \\
\hline Methylene chloride & 1 & $\mathrm{BJ}$ \\
\hline Styrene & 10 & $\mathrm{U}$ \\
\hline 1,1,2,2-Tetrachloroethane & 10 & $\mathrm{U}$ \\
\hline Tetrachloroethene & 10 & $\mathrm{U}$ \\
\hline Toluene & 1 & $\mathbf{J}$ \\
\hline 1,1,1-Trichloroethane & 10 & $\mathrm{U}$ \\
\hline 1,1,2-Trichloroethane & 10 & $U$ \\
\hline
\end{tabular}




\section{C-9}

TABLE C.2b (Cont.)

\begin{tabular}{|c|c|c|}
\hline \multirow[b]{2}{*}{ Compound } & \multicolumn{2}{|c|}{$\begin{array}{c}\text { Surface Water } \\
\text { Concentrations } \\
(\mu \mathrm{g} / \mathrm{L})\end{array}$} \\
\hline & \multicolumn{2}{|c|}{ SW-7 } \\
\hline Trichloroethene & 10 & $U$ \\
\hline Vinyl chloride & 10 & $U$ \\
\hline Xylenes (total) & 10 & $\mathrm{U}$ \\
\hline
\end{tabular}

a Sampled by USGS, analyzed by Enseco, CLP/HSL volatile organics. Provisional data, validation in progress.

Data qualifiers:

$\mathrm{U}=$ analyte was analyzed for but not detected; detection limit given.

$\mathrm{B}=$ analyte was found in the associated blank.

$\mathrm{J}=$ estimated value. 
TABLE C.2c Volatile Organics Analyses for Surface Water, February $1994^{\mathrm{a}}$

\begin{tabular}{|c|c|c|c|c|c|c|c|c|c|c|c|c|c|c|c|c|c|c|}
\hline \multirow{3}{*}{$\begin{array}{l}\text { Compound } \\
\text { Acetone }\end{array}$} & \multicolumn{18}{|c|}{ Surface Water Concentrations $(\mu \mathrm{g} / \mathrm{L})$} \\
\hline & \multicolumn{2}{|c|}{ Q55SW } & \multicolumn{2}{|c|}{ Q55SW-Dup } & \multicolumn{2}{|c|}{ Q56SW } & \multicolumn{2}{|c|}{ Q58SW } & \multicolumn{2}{|c|}{ Q59SW } & \multicolumn{2}{|c|}{ Q60sW } & \multicolumn{2}{|c|}{ Q62SW } & \multicolumn{2}{|c|}{ Q65SW } & \multicolumn{2}{|c|}{ Q93SW } \\
\hline & 17 & B & 18 & B & 14 & B & 15 & $\mathbf{J}$ & 12 & B & 10 & $\mathrm{U}$ & 14 & & 21 & B & 8 & BJ \\
\hline Benzene & 10 & $\mathbf{U}$ & 10 & $\mathbf{U}$ & 10 & $\mathbf{U}$ & 10 & $\mathrm{U}$ & 10 & U & 10 & U & 10 & $\mathbf{U}$ & 10 & $\mathbf{U}$ & 10 & $\mathrm{U}$ \\
\hline Bromodichloromethane & 10 & $\mathrm{U}$ & 10 & $\mathrm{U}$ & 10 & $\mathbf{U}$ & 10 & $\mathbf{U}$ & 10 & $\mathbf{U}$ & 10 & $\mathbf{U}$ & 10 & $\mathrm{U}$ & 10 & $\mathbf{U}$ & 10 & $\mathrm{U}$ \\
\hline Bromoform & 10 & $\mathbf{U}$ & 10 & $\mathrm{U}$ & 10 & $\mathbf{U}$ & 10 & $\mathrm{U}$ & 10 & $\mathbf{U}$ & 10 & $U$ & 10 & $\mathbf{U}$ & 10 & $\mathbf{U}$ & 10 & $\mathrm{U}$ \\
\hline Bromomethane & 10 & $\mathbf{U}$ & 10 & U & 10 & $\mathbf{U}$ & 10 & $\mathbf{U}$ & 10 & U & 10 & $\mathrm{U}$ & 10 & $U$ & 10 & $\mathbf{U}$ & 10 & $\mathrm{U}$ \\
\hline 2-Butanone & 10 & $\mathbf{U}$ & 10 & $\mathrm{U}$ & 10 & $\mathrm{U}$ & 10 & $\mathbf{U}$ & 10 & $\mathbf{U}$ & 10 & U & 10 & $\mathbf{U}$ & 10 & $\mathbf{U}$ & 10 & $\mathrm{U}$ \\
\hline Carbon disulfide & 10 & U & 10 & $\mathrm{U}$ & 2 & $J$ & 10 & $\mathbf{U}$ & 10 & $\mathbf{U}$ & 10 & $\mathrm{U}$ & 10 & $\mathrm{U}$ & 10 & $\mathbf{U}$ & 10 & $\mathbf{U}$ \\
\hline Carbon tetrachloride & 10 & $U$ & 10 & $U$ & 10 & $\mathbf{U}$ & 10 & $\mathbf{U}$ & 10 & $\mathbf{U}$ & 10 & $\mathrm{U}$ & 10 & $\mathrm{U}$ & 10 & $\mathrm{U}$ & 10 & $\mathrm{U}$ \\
\hline Chlorobenzene & 10 & $\mathbf{U}$ & 10 & $\mathrm{U}$ & 10 & $\mathbf{U}$ & 10 & $\mathrm{U}$ & 10 & $\mathrm{U}$ & 10 & $\mathrm{U}$ & 10 & $\mathrm{U}$ & 10 & $\mathrm{U}$ & 10 & $\mathrm{U}$ \\
\hline Chloroethane & 10 & $\mathbf{U}$ & 10 & $\mathrm{U}$ & 10 & $\mathbf{U}$ & 10 & U & 10 & $\mathrm{U}$ & 10 & $\mathrm{U}$ & 10 & $\mathrm{U}$ & 10 & $\mathrm{U}$ & 10 & $\mathrm{U}$ \\
\hline Chloroform & 10 & $\mathrm{U}$ & 10 & $\mathrm{U}$ & 10 & $\mathbf{U}$ & 10 & $\mathbf{U}$ & 10 & U & 10 & $\mathrm{U}$ & 10 & U & 10 & $\mathrm{U}$ & 10 & $\mathbf{U}$ \\
\hline Chloromethane & 10 & U & $10^{\circ}$ & $\mathrm{U}$ & 10 & $\mathrm{U}$ & 10 & $\mathrm{U}$ & 10 & $\mathrm{U}$ & 10 & $\mathrm{U}$ & 10 & $\mathrm{U}$ & 10 & $\mathrm{U}$ & 10 & $U$ \\
\hline Dibromochloromethane & 10 & U & 10 & $\mathrm{U}$ & 10 & $\mathbf{U}$ & 10 & $\mathbf{U}$ & 10 & $U$ & 10 & $\mathbf{U}$ & 10 & U & 10 & $\mathbf{U}$ & 10 & $\mathbf{U}$ \\
\hline 1,1-Dichloroethane & 10 & $\mathrm{U}$ & 10 & $\mathbf{U}$ & 10 & $\mathrm{U}$ & 10 & $U$ & 10 & $\mathrm{U}$ & 10 & $\mathrm{U}$ & 10 & $\mathrm{U}$ & 10 & $\mathrm{U}$ & 10 & $\mathbf{U}$ \\
\hline 1,2-Dichloroethane & 10 & $\mathrm{U}$ & 10 & $\mathrm{U}$ & 10 & $\mathrm{U}$ & 10 & $\mathbf{U}$ & 10 & $\mathrm{U}$ & 10 & $\mathbf{U}$ & 10 & $\mathrm{U}$ & 10 & $\mathbf{U}$ & 10 & $\mathbf{U}$ \\
\hline 1,1-Dichloroethene & 10 & $\mathrm{U}$ & 10 & $\mathbf{U}$ & 10 & $\mathrm{U}$ & 10 & $\mathbf{U}$ & 10 & $\mathrm{U}$ & 10 & $\mathbf{U}$ & 10 & $\mathbf{U}$ & 10 & $U$ & 10 & $\mathbf{U}$ \\
\hline cis-1,2-Dichloroethene & 10 & $\mathrm{U}$ & 10 & $\mathrm{U}$ & 10 & $\mathrm{U}$ & 10 & $\mathrm{U}$ & 10 & $U$ & 6 & j & 5 & $\mathbf{J}$ & 10 & $\mathbf{U}$ & 6 & $\mathrm{~J}$ \\
\hline trans-1,2-Dichloroethene & 10 & $\mathrm{U}$ & 10 & $\mathrm{U}$ & 10 & $\mathrm{U}$ & 10 & U & 10 & $\mathrm{U}$ & 10 & $\mathbf{U}$ & 10 & $\mathbf{U}$ & 10 & $\mathrm{U}$ & 10 & $\mathbf{U}$ \\
\hline 1,2-Dichloropropane & 10 & $\mathrm{U}$ & 10 & $\mathrm{U}$ & 10 & $\mathrm{U}$ & 10 & $\mathrm{U}$ & 10 & $U$ & 10 & U & 10 & $\mathbf{U}$ & 10 & $\mathrm{U}$ & 10 & $\mathbf{U}$ \\
\hline cis-1,3-Dichloropropene & 10 & $\mathrm{U}$ & 10 & $\mathbf{U}$ & 10 & $\mathrm{U}$ & 10 & $U$ & 10 & $\mathrm{U}$ & 10 & $\mathbf{U}$ & 10 & $\mathbf{U}$ & 10 & $\mathrm{U}$ & 10 & $\mathbf{U}$ \\
\hline trans-1,3-Dichloropropene & 10 & $\mathbf{U}$ & 10 & $\mathrm{U}$ & 10 & $\mathrm{U}$ & 10 & $\mathbf{U}$ & 10 & $\mathrm{U}$ & 10 & $\mathbf{U}$ & 10 & $\mathbf{U}$ & 10 & $\mathrm{U}$ & 10 & $\mathrm{U}$ \\
\hline Ethyl benzene & 10 & $\mathbf{U}$ & 10 & $\mathbf{U}$ & 10 & U & 10 & $\mathrm{U}$ & 10 & U & 10 & $\mathbf{U}$ & 10 & $\mathbf{U}$ & 10 & $\mathrm{U}$ & 10 & $\mathrm{U}$ \\
\hline 2-Hexanone & 10 & $\mathbf{U}$ & 10 & $\mathrm{U}$ & 10 & $\mathrm{U}$ & 10 & $\mathrm{U}$ & 10 & $\mathrm{U}$ & 10 & $\mathbf{U}$ & 10 & $\mathbf{U}$ & 10 & $\mathrm{U}$ & 10 & $\mathbf{U}$ \\
\hline 4-Methyl-2-pentanone & 10 & $\mathbf{U}$ & 10 & $\mathbf{U}$ & 10 & $\mathrm{U}$ & 10 & $\mathrm{U}$ & 10 & $\mathrm{U}$ & 10 & $\mathbf{U}$ & 10 & $\mathrm{U}$ & 10 & $\mathrm{U}$ & 10 & $\mathrm{U}$ \\
\hline Methylene chloride & 10 & $\mathbf{U}$ & 10 & $\mathrm{U}$ & 10 & $\mathrm{U}$ & 10 & $\mathrm{U}$ & 10 & U & 10 & $\mathrm{U}$ & 10 & $\mathbf{U}$ & 10 & $\mathrm{U}$ & 10 & $U$ \\
\hline Styrene & 10 & $\mathbf{U}$ & 10 & $\mathbf{U}$ & 10 & $\mathrm{U}$ & 10 & $\mathrm{U}$ & 10 . & $\mathrm{U}$ & 10 & $\mathbf{U}$ & 10 & $\mathbf{U}$ & 10 & $\mathrm{U}$ & 10 & $\mathrm{U}$ \\
\hline 1,1,2,2-Tetrachloroethane & 10 & $\mathbf{U}$ & 5 & $\mathbf{J}$ & $10^{\prime}$ & $\mathbf{U}$ & 10 & $\mathrm{U}$ & 10 & $\mathbf{U}$ & 10 & $U$ & 10 & $\mathbf{U}$ & 5 & $\mathbf{J}$ & 6 & $\mathbf{J}$ \\
\hline Toluene & 10 & U & 10 & $\mathrm{U}$ & 10 & $\mathrm{U}$ & 10 & $\mathrm{U}$ & 10 & $\mathbf{U}$ & 10 & $\mathrm{U}$ & 10 & $\mathbf{U}$ & 10 & $\mathbf{U}$ & 10 & $\mathrm{U}$ \\
\hline 1,1,1-Trichloroethane & 10 & $\mathbf{U}$ & 10 & U & 10 & $\mathrm{U}$ & 10 & $\mathrm{U}$ & 10 & $\mathbf{U}$ & 10 & $\mathrm{U}$ & 10 & U & 10 & $\mathrm{U}$ & 10 & $-U$ \\
\hline 1,1,2-Trichloroethane & 10 & $\mathbf{U}$ & 10 & $\mathrm{U}$ & 10 & $\mathrm{U}$ & 10 & $U$ & 10 & $U$ & 10 & $\mathrm{U}$ & 10 & $\mathrm{U}$ & 10 & $\mathrm{U}$ & 10 & $\mathrm{U}$ \\
\hline
\end{tabular}


TABLE C.2c (Cont.)

\begin{tabular}{|c|c|c|c|c|c|c|c|c|c|c|c|c|c|c|c|c|c|c|}
\hline \multirow{3}{*}{ Compound } & \multicolumn{18}{|c|}{ Surface Water Concentrations $(\mu \mathrm{g} / \mathrm{L})$} \\
\hline & \multicolumn{2}{|c|}{ Q55sW } & \multicolumn{2}{|c|}{ Q55sW-Dup } & \multicolumn{2}{|c|}{ Q56SW } & \multicolumn{2}{|c|}{ Q58SW } & \multicolumn{2}{|c|}{ Q59SW } & \multicolumn{2}{|c|}{ Q60sW } & \multicolumn{2}{|c|}{ Q62SW } & \multicolumn{2}{|c|}{ Q65SW } & \multicolumn{2}{|c|}{ Q93sW } \\
\hline & 10 & $\mathbf{U}$ & 10 & $\mathrm{U}$ & 10 & U & 10 & $\mathbf{U}$ & 10 & $\mathbf{U}$ & 10 & & 7 & J & 10 & $\mathbf{U}$ & 6 & J \\
\hline Vinyl acetate & 10 & $\mathbf{U}$ & 10 & $\mathrm{U}$ & 10 & $\mathrm{U}$ & 10 & $\mathrm{U}$ & 10 & U & 10 & $\mathrm{U}$ & 10 & $\mathbf{U}$ & 10 & $\mathbf{U}$ & 10 & U \\
\hline Vinyl chloride & 10 & $\mathbf{U}$ & 10 & $\mathrm{U}$ & 10 & $\mathrm{U}$ & 10 & U & 10 & $\mathrm{U}$ & 10 & $\mathrm{U}$ & 10 & $\mathbf{U}$ & 10 & $\mathbf{U}$ & 10 & U \\
\hline $\mathrm{m}$ - and $\mathrm{p}$-Xylene & 10 & $\mathbf{U}$ & 10 & $\mathbf{U}$ & 10. & $\mathrm{U}$ & 10 & $\mathrm{U}$ & 10 & $\mathrm{U}$ & 10 & $\mathrm{U}$ & 10 & $\mathbf{U}$ & 10 & $\mathrm{U}$ & 10 & $\mathbf{U}$ \\
\hline o-Xylene & 10 & $\mathbf{U}$ & 10 & $\mathbf{U}$ & 10 & U & 10 & $\mathrm{U}$ & 10 & $\mathbf{U}$ & 10 & $U$ & 10 & $\mathbf{U}$ & 10 & U & 10 & $\mathbf{U}$ \\
\hline
\end{tabular}

Surface Water Concentrations $(\mu \mathrm{g} / \mathrm{L})$

\begin{tabular}{lrrrrrrrrrr}
\multicolumn{1}{c}{ Compound } & Q95SW & SW-7 & SW-10 & SW-10-Dup & SW-11 \\
\hline Acetone & 22 & $\mathrm{~B}$ & 10 & $\mathrm{U}$ & 10 & $\mathrm{U}$ & 30 & & 10 & $\mathrm{U}$ \\
Benzene & 10 & $\mathrm{U}$ & 10 & $\mathrm{U}$ & 10 & $\mathrm{U}$ & 10 & $\mathrm{U}$ & 10 & $\mathrm{U}$ \\
Bromodichloromethane & 10 & $\mathrm{U}$ & 10 & $\mathrm{U}$ & 10 & $\mathrm{U}$ & 10 & $\mathrm{U}$ & 10 & $\mathrm{U}$ \\
Bromoform & 10 & $\mathrm{U}$ & 10 & $\mathrm{U}$ & 10 & $\mathrm{U}$ & 10 & $\mathrm{U}$ & 10 & $\mathrm{U}$ \\
Bromomethane & 10 & $\mathrm{U}$ & 10 & $\mathrm{U}$ & 10 & $\mathrm{U}$ & 10 & $\mathrm{U}$ & 10 & $\mathrm{U}$ \\
2-Butanone & 10 & $\mathrm{U}$ & 10 & $\mathrm{U}$ & 10 & $\mathrm{U}$ & 10 & $\mathrm{U}$ & 10 & $\mathrm{U}$ \\
Carbon disulfide & 10 & $\mathrm{U}$ & 10 & $\mathrm{U}$ & 10 & $\mathrm{U}$ & 10 & $\mathrm{U}$ & 10 & $\mathrm{U}$ \\
Carbon tetrachloride & 10 & $\mathrm{U}$ & 10 & $\mathrm{U}$ & 10 & $\mathrm{U}$ & 10 & $\mathrm{U}$ & 10 & $\mathrm{U}$ \\
Chlorobenzene & 10 & $\mathrm{U}$ & 10 & $\mathrm{U}$ & 10 & $\mathrm{U}$ & 10 & $\mathrm{U}$ & 10 & $\mathrm{U}$ \\
Chlorocthane & 10 & $\mathrm{U}$ & 10 & $\mathrm{U}$ & 10 & $\mathrm{U}$ & 10 & $\mathrm{U}$ & 10 & $\mathrm{U}$ \\
Chloroform & 10 & $\mathrm{U}$ & 10 & $\mathrm{U}$ & 3 & $\mathrm{~J}$ & 3 & $\mathrm{~J}$ & 10 & $\mathrm{U}$ \\
Chloromethane & 10 & $\mathrm{U}$ & 10 & $\mathrm{U}$ & 10 & $\mathrm{U}$ & 10 & $\mathrm{U}$ & 10 & $\mathrm{U}$ \\
Dibromochloromethane & 10 & $\mathrm{U}$ & 10 & $\mathrm{U}$ & 10 & $\mathrm{U}$ & 10 & $\mathrm{U}$ & 10 & $\mathrm{U}$ \\
1,1-Dichloroethane & 10 & $\mathrm{U}$ & 10 & $\mathrm{U}$ & 10 & $\mathrm{U}$ & 10 & $\mathrm{U}$ & 10 & $\mathrm{U}$ \\
1,2-Dichlorocthane & 10 & $\mathrm{U}$ & 10 & $\mathrm{U}$ & 10 & $\mathrm{U}$ & 10 & $\mathrm{U}$ & 10 & $\mathrm{U}$ \\
1,1-Dichlorocthene & 10 & $\mathrm{U}$ & 10 & $\mathrm{U}$ & 5 & $\mathrm{~J}$ & 4 & $\mathrm{~J}$ & 10 & $\mathrm{U}$ \\
cis-1,2-Dichloroethene & 11 & & 7 & $\mathrm{~J}$ & 1,724 & 1,809 & 239 & 2 & $\mathrm{~J}$ \\
trans-1,2-Dichloroethene & 10 & $\mathrm{U}$ & 2 & $\mathrm{~J}$ & 173 & & 239 & $\mathrm{U}$ \\
1,2-Dichloropropane & 10 & $\mathrm{U}$ & 10 & $\mathrm{U}$ & 10 & $\mathrm{U}$ & 10 & $\mathrm{U}$ & 10 & $\mathrm{U}$
\end{tabular}


TABLE C.2c (Cont.)

\begin{tabular}{|c|c|c|c|c|c|c|c|c|c|c|}
\hline \multirow{3}{*}{$\frac{\text { Compound }}{\text { cis-1,3-Dichloropropene }}$} & \multicolumn{10}{|c|}{ Surface Water Concentrations ( $\mu \mathrm{g} / \mathrm{L}$ ) } \\
\hline & \multicolumn{2}{|c|}{ Q95SW } & \multicolumn{2}{|c|}{ SW-7 } & \multicolumn{2}{|c|}{ SW-10 } & \multicolumn{2}{|c|}{ SW-10-Dup } & \multicolumn{2}{|c|}{ SW-11 } \\
\hline & 10 & $\mathrm{U}$ & 10 & $\mathrm{U}$ & 10 & $\mathrm{U}$ & 10 & $\mathrm{U}$ & 10 & $\mathbf{U}$ \\
\hline trans-1,3-Dichloropropene & 10 & $\mathbf{U}$ & 10 & $\mathbf{U}$ & 10 & $U$ & 10 & $\mathrm{U}$ & 10 & $\mathrm{U}$ \\
\hline Ethyl benzene & 10 & $\mathbf{U}$ & 10 & $\mathrm{U}$ & 10 & $\mathbf{U}$ & 10 & $\mathbf{U}$ & 10 & $\mathrm{U}$ \\
\hline 2-Hexanone & 10 & $\mathbf{U}$ & 10 & $\mathbf{U}$ & 56 & & 59 & & 10 & $\mathbf{U}$ \\
\hline 4-Methyl-2-pentanone & 10 & $\mathbf{U}$ & 10 & $\mathbf{U}$ & 10 & $\mathrm{U}$ & 10 & $\mathbf{U}$ & 10 & $\mathrm{U}$ \\
\hline Methylene chloride & 10 & $\mathbf{U}$ & 10 & $\mathrm{U}$ & 10 & $\mathbf{U}$ & 10 & $\mathbf{U}$ & 10 & $\mathbf{U}$ \\
\hline Styrene & 10 & $\mathbf{U}$ & 10 & $\mathbf{U}$ & 10 & $\mathrm{U}$ & 10 & $\mathbf{U}$ & 10 & $\mathbf{U}$ \\
\hline 1,1,2,2-Tetrachloroethane & 15 & & 211 & & 3,220 & & 4,348 & & 10 & $\mathbf{U}$ \\
\hline Toluene & 10 & $\mathrm{U}$ & 10 & $\mathrm{U}$ & 10 & $\mathbf{U}$ & 10 & $\mathbf{U}$ & 10 & $\mathbf{U}$ \\
\hline 1,1,1-Trichloroethane & 10 & $\mathbf{U}$ & 10 & $\mathbf{U}$ & 10 & $\mathbf{U}^{-}$ & 10 & $\mathbf{U}$ & 10 & $U$ \\
\hline 1,1,2-Trichloroethane & 1 & $\mathbf{J}$ & 10 & $\mathbf{U}$ & 124 & & 138 & & 10 & $\mathbf{U}$ \\
\hline Trichloroethene & 15 & & 37 & & 3,214 & & 3,615 & & 2 & $\mathbf{J}$ \\
\hline Vinyl acetate & 10 & $\mathbf{U}$ & 10 & U & 10 & $\mathrm{U}$ & 10 & $\mathrm{U}$ & 10 & $\mathrm{U}$ \\
\hline Vinyl chloride & 10 & $U$ & 10 & U & 26 & & 29 & & 10 & U \\
\hline $\mathrm{m}$ - and $\mathrm{p}$-Xylene & 10 & $\mathrm{U}$ & 10 & $U$ & 10 & U & 10 & $\mathrm{U}$ & 10 & $U$ \\
\hline O-Xylene & 10 & U & 10 & $\mathrm{U}$ & 10 & $\mathrm{U}$ & 10 & $\mathbf{U}$ & 10 & $\mathrm{U}$ \\
\hline
\end{tabular}

a Sampled by ANL, analyzed by ANL-ACL, CLP/HSL volatile organics.

Data qualifiers:

$\mathrm{U}=$ analyte was analyzed for but not detected.

$\mathrm{B}=$ analyte was found in the associated blank.

$\mathrm{J}=$ estimated value. 
TABLE C.2d Volatile Organics Analyses for Surface Water, May $1994^{\mathrm{a}}$

\begin{tabular}{|c|c|c|c|c|c|c|c|c|c|c|}
\hline \multirow{3}{*}{ Compound } & \multicolumn{10}{|c|}{ Surface Water Concentrations $(\mu g / L)$} \\
\hline & \multicolumn{2}{|c|}{ SW-7 } & \multicolumn{2}{|c|}{ SW-10 } & \multicolumn{2}{|c|}{ SW-11 } & \multicolumn{2}{|c|}{ SW-11 Dup } & \multicolumn{2}{|c|}{ SW-12 } \\
\hline & 10 & $\mathbf{U}$ & 10 & $\mathbf{U}$ & 10 & U & 10 & $\mathbf{U}$ & 10 & $\mathbf{U}$ \\
\hline Benzene & 10 & $\mathbf{U}$ & 10 & $\mathbf{U}$ & 10 & $\mathbf{U}$ & 10 & $\mathrm{U}$ & 10 & $\mathrm{U}$ \\
\hline Bromodichloromethane & 10 & $\mathbf{U}$ & 10 & $U$ & 10 & $\mathbf{U}$ & 10 & $\mathbf{U}$ & 10 & $\mathbf{U}$ \\
\hline Bromoform & 10 & $\mathbf{U}$ & 10 & $\mathbf{U}$ & 10 & $\mathbf{U}$ & 10 & $\mathrm{U}$ & 10 & $\mathbf{U}$ \\
\hline Bromomethane & 10 & $\mathbf{U}$ & 10 & $\mathbf{U}$ & 10 & $\mathbf{U}$ & 10 & $\mathrm{U}$ & 10 & $\mathbf{U}$ \\
\hline 2-Butanone & 10 & $\mathbf{U}$ & 10 & $\mathbf{U}$ & 10 & $\mathbf{U}$ & 10 & $U$ & 10 & $\mathrm{U}$ \\
\hline Carbon disulfide & 10 & $\mathbf{U}$ & 10 & $\mathrm{U}$ & 10 & $\mathbf{U}$ & 10 & $\mathrm{U}$ & 10 & $\mathbf{U}$ \\
\hline Carbon tetrachloride & 10 & $\mathbf{U}$ & 10 & $\mathbf{U}$ & 10 & $\mathbf{U}$ & 10 & $\mathrm{U}$ & 10 & $\mathbf{U}$ \\
\hline Chlorobenzene & 10 & $\mathbf{U}$ & 10 & $\mathbf{U}$ & 10 & $\mathbf{U}$ & 10 & $\mathrm{U}$ & 10 & $\mathbf{U}$ \\
\hline Chloroethane & 10 & $\mathrm{U}$ & 10 & $\mathbf{U}$ & 18 & & 12 & & 10 & $\mathbf{U}$ \\
\hline Chloroform & 10 & $\mathbf{U}$ & 10 & $\mathbf{U}$ & 10 & $\mathbf{U}$ & 10 & $U$ & 10 & U \\
\hline Chloromethane & 10 & $\mathbf{U}$ & 10 & $\mathbf{U}$ & 10 & $\mathbf{U}$ & 10 & $\mathbf{U}$ & 10 & $\mathbf{U}$ \\
\hline Dibromochloromethane & 10 & $\mathbf{U}$ & 10 & $\mathbf{U}$ & 10 & $\mathbf{U}$ & 10 & U & 10 & $\mathbf{U}$ \\
\hline 1,1-Dichloroethane & 10 & $\mathbf{U}$ & 10 & $\mathbf{U}$ & 10 & $\mathbf{U}$ & 10 & $\mathrm{U}$ & 10 & $\mathbf{U}$ \\
\hline 1,2-Dichloroethane & 10 & $\mathbf{U}$ & 10 & $\mathbf{U}$ & 10 & $\mathbf{U}$ & 10 & $\mathrm{U}$ & 10 & $\mathbf{U}$ \\
\hline 1,1-Dichloroethene & 10 & $\mathbf{U}$ & 3 & $\mathrm{~J}$ & 10 & $\mathbf{U}$ & 10 & U & 10 & $\mathbf{U}$ \\
\hline 1,2-Dichloroethene (total) & 10 & $\mathrm{U}$ & 1,700 & $E$ & 86 & & 56 & & 10 & $\mathrm{U}$ \\
\hline 1,2-Dichloropropane & 10 & $\mathbf{U}$ & 10 & $\mathbf{U}$ & 10 & $\mathbf{U}$ & 10 & $\mathrm{U}$ & 10 & $\mathbf{U}$ \\
\hline cis-1,3-Dichloropropene & 10 & $\mathbf{U}$ & 10 & $\mathrm{U}$ & $\cdot 10$ & $\mathbf{U}$ & 10 & $\mathrm{U}$ & 10 & $\mathbf{U}$ \\
\hline trans-1,3-Dichloropropene & 10 & $\mathbf{U}$ & 10 & $\mathbf{U}$ & 10 & $\mathbf{U}$ & 10 & $\mathbf{U}$ & 10 & $\mathbf{U}$ \\
\hline Ethylbenzene & 10 & $\mathbf{U}$ & 10 & $\mathbf{U}$ & 10 & $\mathbf{U}$ & 10 & $\mathrm{U}$ & 10 & $\mathrm{U}$ \\
\hline 2-Hexanone & 10 & $\mathbf{U}$ & 10 & 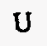 & 10 & $\mathbf{U}$ & 10 & $\mathrm{U}$ & 10 & $\mathbf{U}$ \\
\hline 4-Methyl-2-pentanone & 10 & $\mathbf{U}$ & 10 & $\mathbf{U}$ & 10 & $\mathbf{U}$ & 10 & $\mathrm{U}$ & 10 & $\mathbf{U}$ \\
\hline Methylene chloride & 10 & $\mathbf{U}$ & 10 & U & 10 & $\mathbf{U}$ & 10 & $\mathrm{U}$ & 10 & $\mathbf{U}$ \\
\hline Styrene & 10 & $\mathbf{U}$ & 10 & $\mathbf{U}$ & 10 & $\mathbf{U}$ & 10 & $\mathrm{U}$ & 10 & $\mathrm{U}$ \\
\hline 1,1,2,2-Tetrachloroethane & 10 & $\mathbf{U}$ & 910 & $\mathrm{E}$ & 3 & $\mathbf{J}$ & 10 & $\mathrm{U}$ & 10 & $\mathbf{U}$ \\
\hline Tetrachloroethene & 10 & $\mathbf{U}$ & 10 & $\mathbf{U}$ & 10 & $\mathbf{U}$ & 10 & $\mathrm{U}$ & 10 & $\mathbf{U}$ \\
\hline Toluene & 10 & $\mathbf{U}$ & 10 & $\mathbf{U}$ & 10 & $\mathbf{U}$ & 10 & $\mathrm{U}$ & 10 & $\mathbf{U}$ \\
\hline 1,1,1-Trichloroethane & 10 & $\mathbf{U}$ & 10 & $\mathbf{U}$ & 10 & $\mathbf{U}$ & 10 & $\mathrm{U}$ & 10 & $\mathbf{u}$ \\
\hline 1,1,2-Trichloroethane & 10 & $\mathbf{U}$ & 95 & & 3 & $\mathrm{~J}$ & 10 & $U$ & 10 & $\mathbf{U}$ \\
\hline Trichloroethene & 3 & J & 94 & & 13 & & 9 & $\mathbf{J}$ & 10 & $\mathbf{U}$ \\
\hline Vinyl chloride & 10 & $\mathbf{U}$ & 26 & & 22 & & 14 & & 10 & $\mathbf{u}$ \\
\hline Xylenes (total) & 10 & $\mathbf{U}$ & 10 & $\mathrm{U}$ & 10 & $\mathbf{U}$ & 10 & $U$ & 10 & $\mathrm{U}$ \\
\hline
\end{tabular}

a Sampled by ANL, analyzed by EA Laboratories, CLP/HSL volatile organics.

Data qualifiers:

$\mathrm{U}=$ analyte was analyzed for but not detected; detection limit given.

$\mathbf{J}=$ estimated value.

$\mathrm{E}=$ analyte concentration exceeded calibration range of instrument; concentration is greater than value given. 
TABLE C.3a Semivolatile Organics Analyses for Surface Water, April 1993ª

\begin{tabular}{|c|c|c|c|c|c|c|c|c|c|c|c|c|c|c|c|c|}
\hline \multirow{3}{*}{$\begin{array}{l}\text { Compound } \\
\text { Acenaphthene }\end{array}$} & \multicolumn{16}{|c|}{ Surface Water Concentrations ( $\mu \mathrm{g} / \mathrm{L}$ ) } \\
\hline & \multicolumn{2}{|c|}{ SW-6 } & \multicolumn{2}{|c|}{ SW-7 } & \multicolumn{2}{|c|}{ SW-8 } & \multicolumn{2}{|c|}{ SW-9 } & \multicolumn{2}{|c|}{ SW-10 } & \multicolumn{2}{|c|}{ SW-11 } & \multicolumn{2}{|c|}{$s W-12$} & \multicolumn{2}{|c|}{$s w-13$} \\
\hline & 10 & $\mathrm{U}$ & 10 & $U$ & 10 & $\mathrm{U}$ & 10 & $\mathrm{U}$ & 10 & $\mathrm{U}$ & 10 & $\mathbf{U}$ & 10 & $\mathrm{U}$ & 10 & $\mathbf{U}$ \\
\hline Acenaphthylene & 10 & $\mathrm{U}$ & 10 & $U$ & 10 & $U$ & 10 & $\mathrm{U}$ & 10 & $U$ & 10 & $\mathbf{U}$ & 10 & $\mathbf{U}$ & 10 & $\mathbf{U}$ \\
\hline Anthracene & 10 & $U$ & 10 & $\mathrm{U}$ & 10 & $\mathrm{U}$ & 10 & $\mathrm{U}$ & 10 & $\mathrm{U}$ & 10 & $\mathbf{U}$ & 10 & $\mathrm{U}$ & 10 & $U$ \\
\hline Benz(a)anthracene & 10 & $\mathrm{U}$ & 10 & $\mathrm{U}$ & 10 & $\mathrm{U}$ & 10 & $\mathrm{U}$ & 10 & U & 10 & $\mathbf{U}$ & 10 & $\mathrm{U}$ & 10 & $\mathbf{U}$ \\
\hline Benzo[a]pyrene & 10 & $\mathrm{U}$ & 10 & $\mathrm{U}$ & 10 & $\mathbf{U}$ & 10 & $\mathrm{U}$ & 10 & $\mathrm{U}$ & 10 & $\mathrm{U}$ & 10 & $\mathrm{U}$ & 10 & $\mathrm{U}$ \\
\hline Benzo[b]fluoranthene & 10 & $\mathrm{U}$ & 10 & $\mathrm{U}$ & 10 & U & 10 & $\mathrm{U}$ & 10 & U & 10 & $\mathbf{U}$ & 10 & $\mathrm{U}$ & 10 & $\mathbf{U}$ \\
\hline Benzo[g,h,i]perylene & 10 & $\mathrm{U}$ & 10 & $\mathrm{U}$ & 10 & $\mathbf{U}$ & 10 & $\mathbf{U}$ & 10 & $\mathbf{U}$ & 10 & $\mathrm{U}$ & 10 & U & 10 & $\mathbf{U}$ \\
\hline Benzo[k]fluoranthene & 10 & $\mathbf{U}$ & 10 & $\mathrm{U}$ & 10 & $\mathbf{U}$ & 10 & $\mathbf{U}$ & 10 & $\mathbf{U}$ & 10 & $\mathbf{U}$ & 10 & $\mathrm{U}$ & 10 & U \\
\hline Bis(2-chloroethyl)ether & 10 & $\mathrm{U}$ & 10 & $\mathbf{U}$ & 10 & $\mathbf{U}$ & 10 & $\mathbf{U}$ & 10 & $\mathbf{U}$ & 10 & U & 10 & $\mathbf{U}$ & 10 & $\mathbf{U}$ \\
\hline Bis(2-chloroisopropyl)ether & 10 & $\mathrm{U}$ & 10 & $\mathrm{U}$ & 10 & $\mathbf{U}$ & 10 & $\mathbf{u}$ & 10 & $\mathrm{U}$ & 10 & $\mathbf{U}$ & 10 & $\mathbf{U}$ & 10 & $U$ \\
\hline Bis(2-ethylhexyl)phthalate & 2 & $\mathrm{~J}$ & 2 & J & 10 & $\mathrm{U}$ & 10 & $\mathbf{U}$ & 10 & $\mathrm{U}$ & 10 & $\mathbf{U}$ & 10 & $\mathbf{U}$ & 1 & $\mathbf{J}$ \\
\hline 4-Bromophenyl phenyl ether & 10 & $\mathrm{U}$ & 10 & $\mathrm{U}$ & 10 & $\mathbf{U}$ & 10 & $\mathbf{U}$ & 10 & $\mathbf{U}$ & 10 & $\mathrm{U}$ & 10 & $\mathrm{U}$ & 10 & $\mathrm{U}$ \\
\hline Butylbenzylphthalate & 10 & $\mathbf{U}$ & 10 & $\mathbf{U}$ & 10 & $\mathrm{U}$ & 10 & $\mathrm{U}$ & 10 & 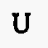 & 10 & $\mathrm{U}$ & 10 & $\mathbf{U}$ & 10 & $\mathbf{U}$ \\
\hline Carbazole & 10 & $\mathrm{U}$ & 10 & $\mathbf{U}$ & 10 & $\mathbf{U}$ & 10 & $\mathbf{U}$ & 10 & $\mathbf{U}$ & 10 & $\mathrm{U}$ & 10 & $\mathrm{U}$ & 10 & U \\
\hline 4-Chloro-3-methylphenol & 10 & $\mathbf{u}$ & 10 & $\mathrm{U}$ & 10 & $\mathbf{U}$ & 10 & $\mathrm{U}$ & 10 & U & 10 & U & 10 & U & 10 & $\mathrm{U}$ \\
\hline 4-Chloroaniline & 10 & $\mathrm{U}$ & 10 & $\mathbf{U}$ & 10 & U & 10 & $\mathbf{U}$ & 10 & $\mathbf{U}$ & 10 & $\mathrm{U}$ & 10 & $U$ & 10 & $\mathrm{U}$ \\
\hline cis(2-Chloroethoxy) methane & 10 & $U$ & 10 & U & 10 & U & 10 & U & 10 & $\mathbf{U}$ & 10 & $\mathrm{U}$ & 10 & $U$ & 10 & $\mathrm{U}$ \\
\hline 2-Chloronaphthalene & 10 & $\mathrm{U}$ & 10 & $\mathbf{U}$ & 10 & $U$ & 10 & $\mathbf{U}$ & 10 & $U$ & 10 & $\mathbf{U}$ & 10 & $\mathrm{U}$ & 10 & $\mathrm{U}$ \\
\hline 2-Chlorophenol & 10 & $\mathrm{U}$ & 10 & $\mathrm{U}$ & 10 & U & 10 & $\mathrm{U}$ & 10 & $\mathbf{U}$ & 10 & $\mathrm{U}$ & 10 & $\mathrm{U}$ & 10 & U 、 \\
\hline 4-Chlorophenyl phenyl ether & 10 & $\mathrm{U}$ & 10 & $\mathrm{U}$ & 10 & $\mathrm{U}$ & 10 & $\mathrm{U}$ & 10 & $\mathrm{U}$ & 10 & $\mathrm{U}$ & 10 & $\mathrm{U}$ & 10 & $\mathrm{U}$ \\
\hline Chrysene & 10 & $\mathrm{U}$ & 10 & U & 10 & $\mathbf{U}$ & 10 & $\mathrm{U}$ & 10 & $\mathrm{U}$ & 10 & $\mathrm{U}$ & 10 & $\mathrm{U}$ & 10 & $\mathrm{U}$ \\
\hline Di-n-butylphthalate & 10 & $\mathbf{U}$ & 10 & $\mathrm{U}$ & 10 & $\mathrm{U}$ & 10 & $\mathrm{U}$ & 10 & $\mathrm{U}$ & 10 & $\mathrm{U}$ & 10 & $\mathrm{U}$ & 10 & $\mathrm{U}$ \\
\hline Di-n-octyl phthalate & 10 & U & 10 & $\mathbf{U}$ & 10 & $\mathbf{U}$ & 10 & $\mathrm{U}$ & 10 & U & 10 & $\mathrm{U}$ & 10 & $\mathrm{U}$ & 10 & $\mathrm{U}$ \\
\hline Dibenz $[a, h]$ anthracene & 10 & $\mathbf{U}$ & 10 & U & 10 & $\mathrm{U}$ & 10 & $U$ & 10 & $U$ & 10 & $\mathrm{U}$ & 10 & $\mathbf{U}$ & 10 & $\mathbf{U}$ \\
\hline Dibenzofuran & 10 & $U$ & 10 & U & 10 & $\mathrm{U}$ & 10 & $\mathrm{U}$ & 10 & $\mathrm{U}$ & 10 & $\mathrm{U}$ & 10 & $\mathrm{U}$ & 10 & $\mathrm{U}$ \\
\hline 1,2-Dichlorobenzene & 10 & $\mathrm{U}$ & 10 & $\mathrm{U}$ & 10 & $\mathrm{U}$ & 10 & $\mathrm{U}$ & 10 & $\mathbf{U}$ & 10 & $\mathrm{U}$ & 10 & $\mathbf{U}$ & 10 & $\mathbf{U}$ \\
\hline 1,3-Dichlorobenzene & 10 & U & 10 & $U$ & 10 & $\mathrm{U}$ & 10 & U & 10 & $\mathrm{U}$ & 10 & $\mathbf{U}$ & 10 & $\mathbf{U}$ & 10 & $\mathbf{U}$ \\
\hline 1,4-Dichlorobenzene & 10 & $\mathrm{U}$ & 10 & $\mathrm{U}$ & 10 & $\mathrm{U}$ & 10 & $\mathrm{U}$ & 10 & $\mathbf{U}$ & 10 & $\mathrm{U}$ & 10 & $\mathbf{U}$ & 10 & $\mathbf{U}$ \\
\hline 3,3'-Dichlorobenzidine & 10 & $U$ & 10 & $\mathrm{U}$ & 10 & $\mathrm{U}$ & 10 & $U$ & 10 & U & 10 & $\mathbf{U}$ & 10 & $\mathbf{U}$ & 10 & $\mathbf{U}$ \\
\hline 2,4-Dichlorophenol & 10 & $U$ & 10 & $U$ & 10 & $\mathrm{U}$ & 10 & $\mathrm{U}$ & 10 & $\mathrm{U}$ & 10 & $\mathrm{U}$ & 10 & U & 10 & $\mathrm{U}$ \\
\hline
\end{tabular}




\begin{tabular}{|c|c|c|c|c|c|c|c|c|c|c|c|c|c|c|c|c|}
\hline$\Omega$ & OI & $\Omega$ & OI & $\mathbf{n}$ & ol & $\mathrm{n}$ & or & $\Omega$ & OI & $\Omega$ & OI & $\Omega$ & oI & $\Omega$ & oI & jousyd \\
\hline $\mathbf{n}$ & OI & $\Omega$ & ol & $\Omega$ & OI & $\Omega$ & OI & $\Omega$ & OI & $n$ & OI & $\Omega$ & or & $\mathrm{n}$ & ot & 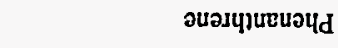 \\
\hline $\mathbf{n}$ & $\$ 2$ & $\Omega$ & $\$ 2$ & $\Omega$ & $\$ Z$ & $\Omega$ & $s 2$ & $\Omega$ & $s \tau$ & $\Omega$ & $s \tau$ & $\Omega$ & $\varsigma Z$ & $\Omega$ & $\varsigma Z$ & 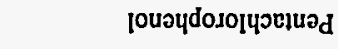 \\
\hline$\Omega$ & $0 I$ & $\Omega$ & OI & $\Omega$ & OI & $\Omega$ & ol & $\Omega$ & OI & $\Omega$ & 0I & $\Omega$ & OI & $\Omega$ & OI & ou!lue $\mid$ Kdosd-u-!p-oson! $! N-N$ \\
\hline I & 1 & r & $\tau$ & $\mathcal{S}$ & $\tau$ & 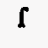 & $\tau$ & f & $\tau$ & I & I & I & I & r & $z$ & (1) ou!ur|রusud!poson! $N$ - $N$ \\
\hline$\Omega$ & $\$ \tau$ & $\Omega$ & $\$ Z$ & $\Omega$ & $s \tau$ & $\Omega$ & $\$ 2$ & $\Omega$ & $s \tau$ & $\Omega$ & $s \tau$ & $\Omega$ & $s z$ & $\Omega$ & $s \tau$ & 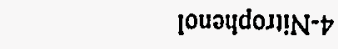 \\
\hline$\Omega$ & ol & $\Omega$ & OI & $\Omega$ & OI & $\Omega$ & or & $\mathrm{n}$ & 01 & $\Omega$ & OI & $\mathrm{n}$ & OI & $\Omega$ & OI & ןouəభdoג!!N-Z \\
\hline$\Omega$ & ol & $\Omega$ & OI & $\Omega$ & OI & $\Omega$ & OI & ก & OI & $\Omega$ & OI & $\mathrm{n}$ & OI & $\Omega$ & OI & วuəzuəqon!!N \\
\hline$\Omega$ & $S Z$ & $n$ & $\boldsymbol{S Z}$ & $\Omega$ & $\$ \tau$ & $\Omega$ & $\varsigma 乙$ & $\Omega$ & sZ & $\Omega$ & $S Z$ & $\Omega$ & $\mathfrak{S Z}$ & $\mathrm{n}$ & $S \tau$ & จu!!!ucod!) \\
\hline$\Omega$ & $\$ Z$ & $\Omega$ & $S Z$ & $\Omega$ & $\varsigma \tau$ & $\Omega$ & $\varsigma \tau$ & $\Omega$ & $s \tau$ & $\Omega$ & $\$ Z$ & $\Omega$ & $S Z$ & $\Omega$ & $s Z$ & จu!!!ucon!) $N-\varepsilon$ \\
\hline$\Omega$ & $\$ 乙$ & $\mathrm{n}$ & $\mathbf{s Z}$ & $\Omega$ & $s \tau$ & $\mathrm{n}$ & $s Z$ & $\Omega$ & $\varsigma \tau$ & $\Omega$ & $\$ 2$ & $\Omega$ & $s z$ & $\Omega$ & $\$ 2$ & au!!!ucon!! $N-\tau$ \\
\hline$\Omega$ & OI & $\Omega$ & OI & $\Omega$ & OI & $\Omega$ & 01 & $\Omega$ & $0 I$ & $\Omega$ & 01 & $\Omega$ & OI & $\Omega$ & 01 & จuəpuludeN \\
\hline$\Omega$ & OI & $\Omega$ & OI & $\Omega$ & OI & $\Omega$ & 01 & $\Omega$ & 01 & $\Omega$ & $0 \mathrm{I}$ & $\mathrm{n}$ & $0 I$ & $\Omega$ & $0 I$ & 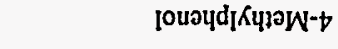 \\
\hline$\Omega$ & OI & $\Omega$ & OI & $\Omega$ & OI & $\Omega$ & 01 & $\Omega$ & $0 I$ & $\mathbf{n}$ & OI & $\Omega$ & or & $\Omega$ & 01 & 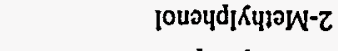 \\
\hline$\Omega$ & OI & $\Omega$ & OI & $\Omega$ & $0 \mathrm{I}$ & $\Omega$ & ol & $\Omega$ & ol & $\Omega$ & 01 & $\Omega$ & 01 & $\Omega$ & $0 I$ & 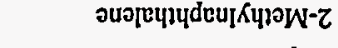 \\
\hline$\Omega$ & OI & $\Omega$ & OI & $\mathrm{n}$ & 01 & $\Omega$ & 01 & $\Omega$ & 01 & $\Omega$ & OI & $\Omega$ & 01 & $\Omega$ & OI & auojoydosI \\
\hline$\Omega$ & OI & $\Omega$ & OI & $\Omega$ & ol & $\Omega$ & ol & $\Omega$ & 01 & $\Omega$ & 0l & $\Omega$ & OI & $\Omega$ & 01 & 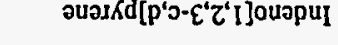 \\
\hline$\Omega$ & OI & $\Omega$ & OI & $\Omega$ & OI & $\Omega$ & OI & $\Omega$ & $0 \mathrm{I}$ & $\Omega$ & 01 & $\Omega$ & $0 I$ & $\Omega$ & $0 \mathbf{I}$ & 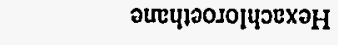 \\
\hline$\Omega$ & OI & $\mathbf{n}$ & ol & $\Omega$ & ol & $\Omega$ & $0 I$ & ก & $0 \mathrm{I}$ & 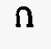 & 01 & ก & 01 & $\Omega$ & 01 & 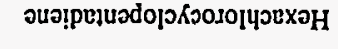 \\
\hline$\Omega$ & OI & $\Omega$ & OI & $\mathbf{n}$ & $\mathbf{0 I}$ & $\Omega$ & OI & $\Omega$ & ol & $\Omega$ & OI & $\Omega$ & oI & $\Omega$ & OI & 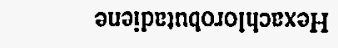 \\
\hline $\mathrm{n}$ & ol & $\Omega$ & ol & $\Omega$ & OI & $\Omega$ & $0 I$ & $\Omega$ & $0 \mathrm{I}$ & $\Omega$ & 0I & $\Omega$ & OI & $\Omega$ & OI & 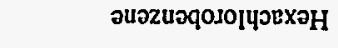 \\
\hline$\Omega$ & OI & $\Omega$ & OI & $\Omega$ & OI & $\Omega$ & OI & $\Omega$ & OI & $\Omega$ & ol & $\Omega$ & OI & $\Omega$ & OI & จแลวоกษ \\
\hline$\Omega$ & OI & $\Omega$ & $0 I$ & $\Omega$ & OI & $\mathbf{\Omega}$ & OI & $\Omega$ & OI & $\Omega$ & 01 & $\Omega$ & OI & $\Omega$ & OI & 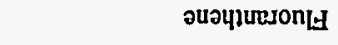 \\
\hline$\Omega$ & 01 & $\Omega$ & OI & $\Omega$ & OI & $\Omega$ & OI & $\Omega$ & 01 & $\Omega$ & OI & $\Omega$ & ol & $\Omega$ & 01 & 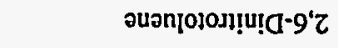 \\
\hline$\Omega$ & ol & $\Omega$ & OI & $\Omega$ & OI & $\mathbf{\Omega}$ & OI & $\Omega$ & OI & $\Omega$ & OI & $\Omega$ & OI & $\Omega$ & OI & 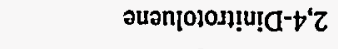 \\
\hline$n$ & $\$ Z$ & $\Omega$ & $\$ 乙$ & $\Omega$ & $s \tau$ & $\Omega$ & $s Z$ & $\Omega$ & $\$ Z$ & $\Omega$ & $S Z$ & $\Omega$ & $\mathfrak{S Z}$ & $\Omega$ & $\$ Z$ & 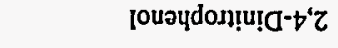 \\
\hline $\mathrm{n}$ & $\$ Z$ & $\Omega$ & $s Z$ & $\Omega$ & $s \tau$ & $\Omega$ & $s Z$ & $\Omega$ & $S Z$ & $\mathrm{n}$ & $S Z$ & $\mathbf{n}$ & $\$ Z$ & $\Omega$ & $S Z$ & 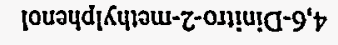 \\
\hline $\mathbf{n}$ & OI & $\Omega$ & 01 & ก & OI & $\Omega$ & 01 & $\Omega$ & OI & $\mathbf{n}$ & OI & $\Omega$ & OI & $\Omega$ & OI & 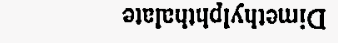 \\
\hline$\Omega$ & ol & $\Omega$ & OI & $\Omega$ & OI & $\Omega$ & $0 \mathrm{I}$ & $\Omega$ & OI & $\mathrm{n}$ & $0 \mathrm{I}$ & $\mathrm{n}$ & OI & $\mathrm{n}$ & OI & 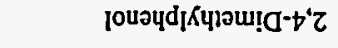 \\
\hline $\mathbf{n}$ & 0I & $\Omega$ & ol & $\Omega$ & OI & $\mathbf{\Omega}$ & OI & $\Omega$ & OI & $n$ & OI & $\mathrm{n}$ & OI & $\Omega$ & OI & 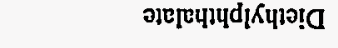 \\
\hline \multicolumn{2}{|c|}{$\varepsilon[-M S$} & \multicolumn{2}{|c|}{$Z I-M S$} & \multicolumn{2}{|c|}{ II-MS } & \multicolumn{2}{|c|}{ OI-MS } & \multicolumn{2}{|c|}{ 6-MS } & \multicolumn{2}{|c|}{$8-M S$} & \multicolumn{2}{|c|}{$L-M S$} & \multicolumn{2}{|c|}{$9-M S$} & punodwos \\
\hline
\end{tabular}

(วนоว) вย:ว สTดนL 
TABLE C.3a (Cont.)

\begin{tabular}{|c|c|c|c|c|c|c|c|c|c|c|c|c|c|c|c|c|}
\hline \multirow[b]{2}{*}{ Compound } & \multicolumn{16}{|c|}{ Surface Water Concentrations $(\mu \mathrm{g} / \mathrm{L})$} \\
\hline & \multicolumn{2}{|c|}{ SW-6 } & \multicolumn{2}{|c|}{ SW-7 } & \multicolumn{2}{|c|}{ SW-8 } & \multicolumn{2}{|c|}{ SW-9 } & \multicolumn{2}{|c|}{ SW-10 } & \multicolumn{2}{|c|}{ SW-11 } & \multicolumn{2}{|c|}{ SW-12 } & \multicolumn{2}{|c|}{ SW-13 } \\
\hline Pyrene & 10 & $\mathrm{U}$ & 10 & $\mathbf{U}$ & 10 & $\mathrm{U}$ & 10 & $\mathbf{U}$ & 10 & $\mathrm{U}$ & 10 & $\mathrm{U}$ & 10 & $\mathrm{U}$ & 10 & $\mathrm{U}$ \\
\hline 1,2,4-Trichlorobenzene & 10 & U & 10 & U & 10 & $\mathbf{u}$ & 10 & $\mathrm{U}$ & 10 & $\mathrm{U}$ & 10 & $\mathrm{U}$ & 10 & $\mathrm{U}$ & 10 & $\mathrm{U}$ \\
\hline 2,4,5-Trichlorophenol & 25 & $\mathrm{U}$ & 25 & U & 25 & $\mathbf{U}$ & 25 & $\mathbf{U}$ & 25 & $\mathrm{U}$ & 25 & $\mathbf{U}$ & 25 & U & 25 & U \\
\hline 2,4,6-Trichlorophenol & 10 & $U$ & 10 & $U$ & 10 & $\mathrm{U}$ & 10 & $\mathrm{U}$ & 10 & $\mathbf{U}$ & 10 & $\mathrm{U}$ & 10 & $\mathbf{U}$ & 10 & $\mathrm{U}$ \\
\hline
\end{tabular}

a Sampled by ANL and USGS, analyzed by Enseco, CLP/HSL semivolatile organics. Provisional data, validation in progress. Data qualifiers:

$\mathrm{U}=$ analyte was analyzed for but not detected; detection limit given.

$\mathbf{J}=$ estimated value. 
TABLE C.3b Semivolatile Organics Analyses for Surface Water, September $1993^{\mathrm{a}}$

\begin{tabular}{|c|c|c|}
\hline \multirow[b]{2}{*}{ Compound } & \multicolumn{2}{|c|}{$\begin{array}{c}\text { Surface Water } \\
\text { Concentrations } \\
(\mu \mathrm{g} / \mathrm{L})\end{array}$} \\
\hline & \multicolumn{2}{|c|}{ SW-7 } \\
\hline Acenaphthene & 10 & $\mathrm{U}$ \\
\hline Acenaphthylene & 10 & $U$ \\
\hline Anthracene & 10 & $\mathrm{U}$ \\
\hline Bis(2-chloroethoxy)methane & 10 & $\mathrm{U}$ \\
\hline Bis(2-chloroisopropyl)ether & 10 & $\mathrm{U}$ \\
\hline Bis(2-chloroethyl)ether & 10 & $\mathrm{U}$ \\
\hline 4-Bromophenyl phenyl ether & 10 & $\mathrm{U}$ \\
\hline 4-Chloro-3-methylphenol & 10 & $\mathrm{U}$ \\
\hline 4-Chloroaniline & 10 & $U$ \\
\hline 2-Chloronaphthalene & 10 & $\mathrm{U}$ \\
\hline 2-Chlorophenol & 10 & $\mathrm{U}$ \\
\hline 4-Chlorophenyl phenyl ether & 10 & $U$ \\
\hline Dibenzofuran & 10 & $U$ \\
\hline 1,2-Dichlorobenzene & 10 & $U$ \\
\hline 1,3-Dichlorobenzene & 10 & $\mathrm{U}$ \\
\hline 1,4-Dichlorobenzene & 10 & $\mathrm{U}$ \\
\hline 2,4-Dichlorophenol & 10 & $U$ \\
\hline Diethylphthalate & 10 & $\mathrm{U}$ \\
\hline Dimethyl phthalate & 10 & $\mathrm{U}$ \\
\hline 2,4-Dimethylphenol & 10 & $\mathrm{U}$ \\
\hline 4,6-Dinitro-2-methylphenol & 5 & $\mathrm{~J}$ \\
\hline 2,4-Dinitrophenol & 10 & $U$ \\
\hline 2,4-Dinitrotoluene & 10 & $\mathrm{U}$ \\
\hline 2,6-Dinitrotoluene & 10 & $\mathrm{U}$ \\
\hline Fluorene & 10 & $\mathrm{U}$ \\
\hline Hexachlorobenzene & 10 & $\mathrm{U}$ \\
\hline Hexachlorobutadiene & 10 & $\mathrm{U}$ \\
\hline Hexachlorocyclopentadiene & 10 & $\mathrm{U}$ \\
\hline Hexachloroethane & 10 & $\mathrm{U}$ \\
\hline Isophorone & -10 & $\mathrm{U}$ \\
\hline 2-Methylnaphthalene & 10 & $\mathrm{U}$ \\
\hline 2-Methylphenol & 3 & $\mathrm{~J}$ \\
\hline
\end{tabular}




\begin{tabular}{lrl}
\hline & $\begin{array}{c}\text { Surface Water } \\
\text { Concentrations } \\
(\mu \mathrm{g} / \mathrm{L})\end{array}$ \\
\cline { 2 - 3 } \multicolumn{1}{c}{ Compound } & SW-7 \\
\hline 4-Methylphenol & 9 & $\mathrm{~J}$ \\
Naphthalene & 10 & $\mathrm{U}$ \\
2-Nitroaniline & 10 & $\mathrm{U}$ \\
3-Nitroaniline & 10 & $\mathrm{U}$ \\
4-Nitroaniline & 10 & $\mathrm{U}$ \\
Nitrobenzene & 10 & $\mathrm{U}$ \\
2-Nitrophenol & 10 & $\mathrm{U}$ \\
4-Nitrophenol & 10 & $\mathrm{U}$ \\
N-Nitroso-di-n-propylamine & 10 & $\mathrm{U}$ \\
N-Nitrosodiphenylamine & 10 & $\mathrm{U}$ \\
Pentachlorophenol & 10 & $\mathrm{U}$ \\
Phenanthrene & 10 & $\mathrm{U}$ \\
Phenol & 6 & $\mathrm{~J}$ \\
1,2,4-Trichlorobenzene & 10 & $\mathrm{U}$ \\
2,4,5-Trichlorophenol & 10 & $\mathrm{U}$ \\
2,4,6-Trichlorophenol & 10 & $\mathrm{U}$ \\
\hline
\end{tabular}

a Sampled by ANL and USGS, analyzed by Enseco, CLP/HSL volatile organics. Provisional data, validation in progress.

Data qualifiers:

$\mathrm{J}$ = estimated value.

$\mathrm{U}=$ analyte was analyzed for but not detected; detection limit given. 
TABLE C.3c Semivolatile Organics Analyses for Surface Water, May $1994^{\mathrm{a}}$

\begin{tabular}{|c|c|c|c|c|c|c|c|c|c|c|}
\hline \multirow{3}{*}{$\begin{array}{r}\text { Compound } \\
\text { Acenaphthene }\end{array}$} & \multicolumn{10}{|c|}{ Surface Water Concentrations $(\mu \mathrm{g} / \mathrm{L})$} \\
\hline & \multicolumn{2}{|c|}{ SW-7 } & \multicolumn{2}{|c|}{ SW-10 } & \multicolumn{2}{|c|}{ SW-11 } & \multicolumn{2}{|c|}{ SW-11-Dup } & \multicolumn{2}{|c|}{ SW-12 } \\
\hline & 10 & $\mathrm{U}$ & 10 & $\mathrm{U}$ & 10 & $\mathrm{U}$ & 10 & $U_{+}$ & 10 & $\mathrm{U}$ \\
\hline Acenaphthylene & 10 & $\mathrm{U}$ & 10 & $\mathrm{U}$ & 10 & U & 10 & $U_{+}$ & 10 & $\mathrm{U}$ \\
\hline Anthracene & 10 & $\mathrm{U}$ & 10 & $\mathrm{U}$ & 10 & $\mathrm{U}$ & 10 & $\mathrm{U}_{+}$ & 10 & U \\
\hline Benz[a]anthracene & 10 & U & 10 & $\mathrm{U}$ & 10 & $\mathrm{U}$ & 10 & $U_{+}$ & 10 & $\mathrm{U}$ \\
\hline Benzo[a]pyrene & 10 & $\mathrm{U}$ & 10 & $U$ & 10 & $\mathrm{U}$ & 10 & $U_{+}$ & 10 & $\mathrm{U}$ \\
\hline Benzo[b]fluoranthene & 10 & $\mathrm{U}$ & 10 & $\mathrm{U}$ & 10 & $\mathrm{U}$ & 10 & $\mathrm{U}_{+}$ & 10 & $\mathrm{U}$ \\
\hline Benzo[g,h,i]perylene & 10 & $\mathrm{U}$ & 10 & $U$ & 10 & $\mathrm{U}$ & 10 & $\mathrm{U}_{+}$ & 10 & $\mathrm{U}$ \\
\hline Benzo[k]fluoranthene & 10 & $U$ & 10 & $\mathrm{U}$ & 10 & $\mathrm{U}$ & 10 & $U_{+}$ & 10 & $\mathrm{U}$ \\
\hline Bis(2-chloroethoxy)methane & 10 & $U$ & 10 & $\mathrm{U}$ & 10 & $\mathrm{U}$ & 10 & $U_{t}$ & 10 & $\mathrm{U}$ \\
\hline Bis(2-chloroethyl)ether & 10 & $U$ & 10 & U & 10 & $U$ & 10 & $U_{+}$ & 10 & $U$ \\
\hline Bis(2-ethylhexyl)phthalate & 10 & $U$ & 10 & $U$ & 10 & $\mathrm{U}$ & 10 & $U_{+}$ & 10 & $\mathrm{U}$ \\
\hline 4-Bromophenyl phenyl ether. & 10 & $\mathrm{U}$ & 10 & $U$ & 10 & $\mathrm{U}$ & 10 & $U_{+}$ & 10 & $U$ \\
\hline Butylbenzylphthalate & 10 & $U$ & 10 & $\mathrm{U}$ & 10 & $U$ & 10 & $\mathrm{U}_{+}$ & 10 & $\mathrm{U}$ \\
\hline Carbazole & 10 & $\mathrm{U}$ & 10 & $U$ & 10 & $\mathrm{U}$ & 10 & $U_{+}$ & 10 & $\mathrm{U}$ \\
\hline 4-Chloro-3-methylphenol & 10 & $U$ & 10 & U & 10 & $\mathrm{U}$ & 10 & $U_{+}$ & 10 & $\mathrm{U}$ \\
\hline 4-Chloroaniline & 10 & $\mathrm{U}$ & 10 & $\mathrm{U}$ & 10 & $\mathrm{U}$ & 10 & $U_{+}$ & 10 & $\mathrm{U}$ \\
\hline 2-Chloronaphthalene & 10 & $\mathrm{U}$ & 10 & $U$ & 10 & $\mathrm{U}$ & 10 & $U_{+}$ & 10 & $\mathrm{U}$ \\
\hline 2-Chlorophenol & 10 & $\mathrm{U}$ & 10 & $\mathrm{U}$ & 10 & $\mathrm{U}$ & 10 & $U_{+}$ & 10 & $\mathrm{U}$ \\
\hline 4-Chlorophenyl phenyl ether & 10 & $U$ & 10 & $U$ & 10 & $U$ & 10 & U+ & 10 & $\mathbf{U}$ \\
\hline Chrysene & 10 & $\mathrm{U}$ & 10 & $\mathrm{U}$ & 10 & $\mathrm{U}$ & 10 & $\mathrm{U}_{+}$ & 10 & U \\
\hline Di-n-butylphthalate & 10 & $U$ & 10 & $U$ & 10 & $\mathrm{U}$ & 10 & $U_{+}$ & 10 & $\mathrm{U}$ \\
\hline Di-n-octyl phthalate & 10 & $\mathrm{U}$ & 10 & $U$ & 10 & $\mathrm{U}$ & 10 & $\mathrm{U}_{+}$ & 10 & $U$ \\
\hline Dibenz $[a, h]$ anthracene & 10 & $\mathrm{U}$ & 10 & $\mathrm{U}$ & 10 & $\mathrm{U}$ & 10 & $U_{+}$ & 10 & $\mathrm{U}$ \\
\hline Dibenzofuran & 10 & $\mathrm{U}$ & 10 & $\mathrm{U}$ & 10 & $\mathrm{U}$ & 10 & $U_{+}$ & 10 & $\mathrm{U}$ \\
\hline 1,2-Dichlorobenzene & 10 & $U$ & 10 & $\mathrm{U}$ & 10 & $\mathrm{U}$ & 10 & $U_{+}$ & 10 & $\mathrm{U}$ \\
\hline 1,3-Dichlorobenzene & 10 & U & 10 & $\mathrm{U}$ & 10 & $\mathrm{U}$ & 10 & $U_{+}$ & 10 & U \\
\hline 1,4-Dichlorobenzene & 10 & $\mathrm{U}$ & 10 & $\mathrm{U}$ & 10 & $\mathrm{U}$ & 10 & U+ & 10 & $\mathrm{U}$ \\
\hline 3,3'-Dichlorobenzidine & 10 & $\mathrm{U}$ & 10 & $\mathbf{U}$ & 10 & $U$ & 10 & $\mathrm{U}_{+}$ & 10 & $\mathrm{U}$ \\
\hline 2,4-Dichlorophenol & 10 & $\mathrm{U}$ & 10 & $\mathrm{U}$ & 10 & $U$ & 10 & $U_{+}$ & 10 & $U$ \\
\hline Diethylphthalate & 10 & U & 10 & $\mathrm{U}$ & 10 & $\mathrm{U}$ & 10 & $\mathrm{U}_{+}$ & 10 & U \\
\hline 2,4-Dimethylphenol & 10 & $\mathrm{U}$ & 10 & $\mathrm{U}$ & 10 & $\mathrm{U}$ & 10 & $U_{+}$ & 10 & U \\
\hline Dimethylphthalate & 10 & $\mathrm{U}$ & 10 & $\mathrm{U}$ & 10 & $\mathrm{U}$ & 10 & $U_{+}$ & 10 & $\mathbf{U}$ \\
\hline 2,4-Dinitrophenol & 25 & $\mathrm{U}$ & 25 & $\mathrm{U}$ & 25 & $U$ & 25 & $\mathrm{U}_{+}$ & 25 & U \\
\hline
\end{tabular}


TABLE C.3c (Cont.)

\begin{tabular}{|c|c|c|c|c|c|c|c|c|c|c|}
\hline \multirow{3}{*}{$\frac{\text { Compound }}{\text { 2,4-Dinitrotoluene }}$} & \multicolumn{10}{|c|}{ Surface Water Concentrations $(\mu \mathrm{g} / \mathrm{L})$} \\
\hline & \multicolumn{2}{|c|}{ SW-7 } & \multicolumn{2}{|c|}{ SW-10 } & \multicolumn{2}{|c|}{ SW-11 } & \multicolumn{2}{|c|}{ SW-11-Dup } & \multicolumn{2}{|c|}{ SW-12 } \\
\hline & 10 & $U$ & 10 & $U$ & 10 & U & 10 & $U_{+}$ & 10 & $\mathrm{U}$ \\
\hline 2,6-Dinitrotoluene & 10 & $\mathrm{U}$ & 10 & $\mathrm{U}$ & 10 & $\mathrm{U}$ & 10 & $U_{+}$ & 10 & $\mathrm{U}$ \\
\hline Fluoranthene & 10 & $\mathrm{U}$ & 10 & $\mathrm{U}$ & 10 & U & 10 & $\mathrm{U}_{+}$ & 10 & $\mathrm{U}$ \\
\hline Fluorene & 10 & $\mathrm{U}$ & 10 & $\mathrm{U}$ & 10 & $\mathrm{U}$ & 10 & $U_{+}$ & 10 & $\mathrm{U}$ \\
\hline Hexachlorobenzene & 10 & $U$ & 10 & $\mathrm{U}$ & 10 & $\mathrm{U}$ & 10 & $U_{+}$ & 10 & U \\
\hline Hexachlorobutadiene & 10 & $\mathrm{U}$ & 10 & U & 10 & $U$ & 10 & $U_{+}$ & 10 & $U$ \\
\hline Hexachlorocyclopentadiene & 10 & $U$ & 10 & $\mathrm{U}$ & 10 & $\mathrm{U}$ & 10 & $U_{+}$ & 10 & $\mathrm{U}$ \\
\hline Hexachloroethane & 10 & $\mathrm{U}$ & 10 & $\mathbf{U}$ & 10 & $\mathrm{U}$ & 10 & $U_{+}$ & 10 & $\mathrm{U}$ \\
\hline Indeno[1,2,3-c,d]pyrene & 10 & $\mathrm{U}$ & 10 & $\mathrm{U}$ & 10 & $U$ & 10 & $U_{+}$ & 10 & $\mathrm{U}$ \\
\hline Isophorone & 10 & $U$ & 10 & $\mathrm{U}$ & 10 & $\mathrm{U}$ & 10 & $\mathrm{U}_{+}$ & 10 & U \\
\hline 2,Methyl-4,6-Dinitrophenol & 25 & $\mathrm{U}$ & 25 & $\mathrm{U}$ & 25 & $\mathrm{U}$ & 25 & $\mathrm{U}_{+}$ & 25 & $\mathrm{U}$ \\
\hline 2-Methylnaphthalene & 10 & $\mathrm{U}$ & 10 & $\mathrm{U}$ & 10 & $\mathrm{U}$ & 10 & $U_{+}$ & 10 & $\mathrm{U}$ \\
\hline 2-Methylphenol & 10 & $\mathrm{U}$ & 10 & $\mathrm{U}$ & 10 & $\mathrm{U}$ & 10 & $U_{+}$ & 10 & $U$ \\
\hline 4-Methylphenol & 10 & $\mathrm{U}$ & 10 & $\mathrm{U}$ & 10 & $\mathrm{U}$ & 10 & $U_{+}$ & 10 & $\mathrm{U}$ \\
\hline Naphthalene & 10 & $\mathrm{U}$ & 10 & $\mathrm{U}$ & 10 & $\mathrm{U}$ & 10 & $U_{+}$ & 10 & $U$ \\
\hline 2-Nitroaniline & 25 & $\mathrm{U}$ & 25 & $\mathrm{U}$ & 25 & $\mathrm{U}$ & 25 & $U_{+}$ & 25 & $\mathrm{U}$ \\
\hline 3-Nitroaniline & 25 & $U$ & 25 & $\mathrm{U}$ & 25 & $\mathrm{U}$ & 25 & $\mathrm{U}_{+}$ & 25 & $\mathrm{U}$ \\
\hline 4-Nitroaniline & 25 & $\mathrm{U}$ & 25 & $\mathrm{U}$ & 25 & $\mathrm{U}$ & 25 & $U_{+}$ & 25 & U \\
\hline Nitrobenzene & 10 & $\mathrm{U}$ & 10 & $\mathrm{U}$ & 10 & $\mathrm{U}$ & 10 & U+ & 10 & $\mathrm{U}$ \\
\hline 2-Nitrophenol & 10 & $\mathrm{U}$ & 10 & $U$ & 10 & $\mathrm{U}$ & 10 & Ut & 10 & $\mathrm{U}$ \\
\hline 4-Nitrophenol & 25 & $\mathrm{U}$ & 25 & $\mathrm{U}$ & 25 & $U$ & 25 & $U_{+}$ & 25 & U \\
\hline N-Nitroso-di-n-propylamine & 10 & $\mathrm{U}$ & 10 & $\mathrm{U}$ & 10 & U & 10 & Ut & 10 & U \\
\hline N-Nitrosodiphenylamine & 10 & $\mathrm{U}$ & 10 & $U$ & 10 & $\mathrm{U}$ & 10 & $U_{+}$ & 10 & $\mathrm{U}$ \\
\hline 2,2'-Oxybis(1-Chloropropane) & 10 & $\mathrm{U}$ & 10 & $\mathrm{U}$ & 10 & $\mathrm{U}$ & 10 & $U_{+}$ & 10 & $\mathrm{U}$ \\
\hline Pentachlorophenol & 25 & $\mathrm{U}$ & 25 & U & 25 & $U$ & 25 & $\mathrm{U}+$ & 25 & $\mathrm{U}$ \\
\hline Phenanthrene & 10 & $U$ & 10 & $\mathrm{U}$ & 10 & $U^{\circ}$ & 10 & $U_{+}$ & 10 & U \\
\hline Phenol & 10 & $\mathrm{U}$ & 10 & $U$ & 10 & $\mathrm{U}$ & 10 & $\mathrm{U}_{+}$ & 10 & U \\
\hline Pyrene & 10 & $\mathrm{U}$ & 10 & $\mathrm{U}$ & 10 & $\mathrm{U}$ & 10 & $U_{+}$ & 10 & U \\
\hline 1,2,4-Trichlorobenzene & 10 & $\mathrm{U}$ & 10 & $\mathrm{U}$ & 10 & $U$ & 10 & $\mathrm{U}_{+}$ & 10 & $\mathrm{U}$ \\
\hline 2,4,5-Trichlorophenol & 25 & $\mathrm{U}$ & 25 & $\mathrm{U}$ & 25 & $\mathrm{U}$ & 25 & $\mathrm{U}_{+}$ & 25 & $\mathrm{U}$ \\
\hline 2,4,6-Trichlorophenol & 10 & $\mathrm{U}$ & 10 & $\mathrm{U}$ & 10 & $\mathrm{U}$ & 10 & $\mathrm{U}_{+}$ & 10 & U \\
\hline
\end{tabular}

a Sampled by ANL, analyzed by EA Laboratories, CLP/HSL semivolatile organics.

Data qualifiers:

$\mathrm{U}=$ analyte was analyzed for but not detected; detection limit given.

$+=$ surrogate recoveries were outside $\mathrm{QC}$ limit(s). 
TABLE C.4a Inorganic Analyses for Surface Water, September $1993^{\mathrm{a}}$

\begin{tabular}{|c|c|c|c|c|c|c|c|c|c|c|c|c|c|c|c|c|}
\hline \multirow[b]{2}{*}{ Parameter } & \multicolumn{16}{|c|}{ Surface Water Concentrations $(\mu \mathrm{g} / \mathrm{L})$} \\
\hline & \multicolumn{2}{|c|}{ SW-6 } & \multicolumn{2}{|c|}{ SW-7 } & \multicolumn{2}{|c|}{ SW-8 } & \multicolumn{2}{|c|}{ SW-9 } & \multicolumn{2}{|c|}{ sw-10 } & \multicolumn{2}{|c|}{ SW-11 } & \multicolumn{2}{|c|}{ SW-12 } & \multicolumn{2}{|c|}{ SW-13 } \\
\hline Aluminum & 869 & & 261 & & 230 & & 64.9 & B & 47 & $\mathrm{U}$ & 58.2 & B & 47 & $\mathbf{U}$ & 108 & B \\
\hline Antimony & 49 & $\mathrm{U}$ & 49 & $\mathrm{U}$ & 49 & $\mathrm{U}$ & 49 & $\mathrm{U}$ & 49 & $\mathrm{U}$ & 49 & $\mathbf{U}$ & 49 & $\mathbf{u}$ & 49 & $\mathrm{U}$ \\
\hline Arsenic & 2.3 & $\mathrm{~B}$ & 2 & $\mathrm{U}$ & 2 & $\mathrm{U}$ & 2 & $\mathrm{U}$ & 3.8 & B & 2.2 & $\mathbf{B}$ & 2 & U & 2 & $\mathrm{U}$ \\
\hline Barium & 149 & B & 61.2 & B & 79.1 & B & 49.3 & B & 50.8 & B & 86 & B & 133 & B & 58.8 & B \\
\hline Beryllium & 1 & $\mathrm{U}$ & 1 & $\mathrm{U}$ & 1 & $\mathrm{U}$ & 1 & $\mathrm{U}$ & 1 & $U$ & 1 & $\mathbf{U}$ & 1 & $\mathrm{U}$ & 1 & $\mathrm{U}$ \\
\hline Cadmium & 4 & $\mathbf{U}$ & 4 & U & 4 & U & 4 & $\mathrm{U}$ & 4 & $\mathrm{U}$ & 4 & $\mathbf{U}$ & 4 & $\mathbf{U}$ & 4 & $\mathrm{U}$ \\
\hline Calcium & 27,700 & & 33,500 & & 123,000 & & 63,500 & & 78,500 & & 43,800 & & 23,600 & & 19,400 & \\
\hline Chromium & 6 & $\mathrm{U}$ & 6 & $\mathbf{U}$ & 6 & $\mathrm{U}$ & 6 & U & 6 & $\mathrm{U}$ & 6 & $\mathbf{U}$ & 6 & $\mathbf{U}$ & 6 & $\mathrm{U}$ \\
\hline Cobalt & 6 & $\mathbf{U}$ & 9.1 & B & 6 & $\mathrm{U}$ & 6 & $\mathbf{U}$ & 6 & $\mathrm{U}$ & 6 & $\mathbf{U}$ & 6 & $U$ & 6 & U \\
\hline Copper & 15.3 & B & 11.1 & B & 6.9 & B & 7.5 & B & 5 & $\mathbf{U}$ & 17.7 & B & 14.4 & B & 11.6 & B \\
\hline Iron & 181,100 & & 3,740 & & 2,980 & & 458 & & 1,170 & & 1,050 & & 3,190 & & 1,890 & \\
\hline Lead & 6.1 & & 1 & $\mathbf{U}$ & 1 & $\mathrm{U}$ & 1 & $\mathbf{U}$ & 1 & U & 7.8 & & 20.3 & & 2.4 & B \\
\hline Magnesium & 19,500 & & 25,100 & & 52,000 & & 24,900 & & 15,800 & & 58,000 & & 49,900 & & 15,600 & \\
\hline Manganese & 352 & & 385 & & 295 & & 70.4 & & 93.5 & & 106 & & 132 & . & 97.6 & \\
\hline Mercury & 0.1 & $\mathbf{U}$ & 0.1 & $U$ & 0.1 & $\mathbf{U}$ & 0.1 & $\mathbf{U}$ & 0.1 & $U$ & 0.1 & U & 0.1 & $\mathrm{U}$ & 0.1 & $\mathrm{U}$ \\
\hline Nickel & 13 & U & 13 & $\mathbf{U}$ & 13 & $\mathbf{U}$ & 13 & $\mathbf{U}$ & 13 & $\mathbf{U}$ & 13 & $\mathbf{U}$ & 13 & $\mathrm{U}$ & 13 & U \\
\hline Potassium & 3,410 & B & 4,970 & B & 7,430 & & 4,020 & B & 3,500 & B & 8,290 & & 5,870 & & 4,040 & B \\
\hline Selenium & 2.9 & & 2 & $\mathrm{U}$ & 3.4 & & 2 & $\mathbf{U}$ & 2 & $\mathbf{U}$ & 2 & $\mathrm{U}$ & 2 & $\mathrm{U}$ & 2 & $\mathbf{U}$ \\
\hline Silver & 7 & U & 7.6 & $\mathrm{~B}$ & 7 & $\mathrm{U}$ & 7 & $\mathbf{U}$ & 7 & $\mathrm{U}$ & 7 & U & 7 & $\mathrm{U}$ & 7 & $\mathbf{U}$ \\
\hline Sodium & 99,200 & & 156,000 & & 416,000 & & 110,000 & & 97,500 & & 58,600 & & 55,500 & & 74,800 & \\
\hline Thallium & 20 & $U$ & 20 & $\mathbf{U}$ & 20 & $\mathbf{U}$ & 2 & $\mathrm{U}$ & 2 & $\mathbf{U}$ & 20 & $U$ & 2 & $\mathrm{U}$ & 2 & U \\
\hline Vanadium & 6.1 & B & 6.7 & B & 5 & U & 5 & $\mathbf{U}$ & 5 & $\mathrm{U}$ & 5 & $\mathrm{U}$ & 5 & $\mathbf{U}$ & 5 & U \\
\hline Zinc & 73.4 & & 43 & & 18 & B & 32.8 & & 21.5 & & 262 & & 782 & & 36 & \\
\hline \multicolumn{17}{|l|}{ Other parameter } \\
\hline Cyanide & 10 & U & 10 & U & 10 & U & 10 & U & 10 & U & 10 & U & 10. & U & 10 & U \\
\hline
\end{tabular}


TABLE C.4a (Cont.)

\begin{tabular}{|c|c|c|c|c|}
\hline \multirow[b]{2}{*}{ Parameter } & \multicolumn{4}{|c|}{ Surface Water Concentrations $(\mu \mathrm{g} / \mathrm{L})$} \\
\hline & \multicolumn{2}{|c|}{ SW-14 } & \multicolumn{2}{|c|}{ SW-15 } \\
\hline \multicolumn{5}{|l|}{ Metals } \\
\hline Aluminum & 1,090 & & 237 & \\
\hline Antimony & 54 & $\mathrm{U}$ & 54 & $\mathrm{U}$ \\
\hline Arsenic & 3.4 & B & 2.9 & B \\
\hline Barium & 173 & B & 173 & B \\
\hline Beryllium & 3.4 & U & 3.4 & U \\
\hline Cadmium & 2.5 & $\mathbf{U}$ & 2.5 & $\mathbf{U}$ \\
\hline Calcium & 101,000 & & 99,500 & \\
\hline Chromium & 5.2 & $\mathrm{U}$ & 5.2 & $\mathrm{U}$ \\
\hline Cobalt & 3.6 & $\mathrm{U}$ & 3.6 & $\mathrm{U}$ \\
\hline Copper & 4.0 & $\mathrm{U}$ & 4.7 & B \\
\hline Iron & 2,900 & & 1,310 & \\
\hline Lead & 2.4 & B & 1.0 & $\mathrm{U}$ \\
\hline Magnesium & 218,000 & & 224,000 & \\
\hline Manganese & 2,530 & & 2,620 & \\
\hline Mercury & 0.05 & $\mathrm{U}$ & 0.05 & $\mathrm{U}$ \\
\hline Nickel & 8.0 & $\mathbf{U}$ & 8.0 & $\mathbf{U}$ \\
\hline Potassium & 53,900 & & 61,300 & \\
\hline Selenium & 1.0 & $U$ & 1.0 & U \\
\hline Silver & 5.6 & $\mathbf{U}$ & 5.6 & $\mathbf{U}$ \\
\hline Sodium & $1,530,000$ & & $1,620,000$ & \\
\hline Thallium & 5.0 & $\mathrm{U}$ & 5.0 & $\mathrm{U}$ \\
\hline Vanadium & 9.1 & B & 6.9 & B \\
\hline Zinc & 57.1 & & 30 & \\
\hline \multicolumn{5}{|l|}{ Other parameter } \\
\hline Cyanide & 10 & $\mathbf{U}$ & 10 & $\mathrm{U}$ \\
\hline
\end{tabular}

a Sampled by USGS, analyzed by Enseco, CLP/TAL metals and cyanide. Provisional data, validation in progress.

Data qualifiers:

$\mathrm{U}=$ analyte was analyzed for but not detected; detection limit given.

$B=$ reported value is less than the contract-required detection limit but greater than the instrument detection limit. 
TABLE C.4b Inorganic Analyses for Surface Water, May $1994^{a}$

\begin{tabular}{|c|c|c|c|c|c|c|c|c|c|c|}
\hline \multirow[b]{2}{*}{ Metal } & \multicolumn{10}{|c|}{ Surface Water Concentrations $(\mu \mathrm{g} / \mathrm{L})$} \\
\hline & \multicolumn{2}{|c|}{ SW-7 } & \multicolumn{2}{|c|}{ SW-10 } & \multicolumn{2}{|c|}{ SW-11 } & \multicolumn{2}{|c|}{ SW-11 Dup } & \multicolumn{2}{|c|}{ SW-12 } \\
\hline Aluminum & 429 & & 226 & & 18,000 & & 2,000 & & 731 & \\
\hline Antimony & 20 & $\mathrm{U}$ & 20 & $\mathrm{U}$ & 32.9 & B & 20 & $\mathrm{U}$ & 20 & U \\
\hline Arsenic & 2.4 & B & 6.4 & B & 36.3 & & 9.4 & B & 18.2 & \\
\hline Barium & 69.5 & $\mathrm{~B}$ & 43.4 & $\mathrm{~B}$ & 559 & & 167 & B & 234 & \\
\hline Beryllium & 1 & $U$ & 1 & $U$ & 1 & $\mathrm{U}$ & 1 & $\mathrm{U}$ & 1 & $U$ \\
\hline Cadmium & 3 & $\mathrm{U}$ & 3 & $\mathrm{U}$ & 4 & U & 4 & $\mathrm{U}$ & 4 & $U$ \\
\hline Calcium & 35,800 & & 106,000 & & 98,700 & & 90,700 & & 33,800 & \\
\hline Chromium & 5 & $U$ & 5.6 & B & 64.8 & & 7.6 & B & 8 & B \\
\hline Cobalt & 8.4 & B & 9.7 & B & 7 & U & 7.0 & $\mathrm{U}$ & 7 & $\mathrm{U}$ \\
\hline Copper & 3 & $\mathrm{U}$ & 3 & $\mathrm{U}$ & 525 & & 57.6 & & 105 & \\
\hline Iron & 21,100 & & 3,470 & & 128,000 & & 27,800 & & 13,000 & \\
\hline Lead & 2.1 & B & 6.5 & & 1,590 & & 210 & $S$ & 169 & \\
\hline Magnesium & 44,500 & & 28,500 & & 110,000 & & 97,300 & & 68,900 & \\
\hline Manganese & 664 & & 239 & & 1,080 & & 759 & & 496 & \\
\hline Mercury & 0.2 & $\mathrm{U}$ & 0.2 & $\mathrm{U}$ & 1.7 & & 0.31 & & 0.2 & $\mathrm{U}$ \\
\hline Nickel & 12 & $\mathrm{U}$ & 12 & $\mathrm{U}$ & 22.4 & B & 12 & $\mathrm{U}$ & 12.1 & B \\
\hline Potassium & 12,800 & & 4,430 & B & 17,000 & & 15,300 & & 9,000 & \\
\hline Selenium & 1 & UW & 1 & UW & 1 & U & 1 & UW & 1 & $U$ \\
\hline Silver & 4 & $\mathrm{U}$ & 5.3 & B & 4 & $\mathrm{U}$ & 4 & $U$ & 4 & U \\
\hline Sodium & 347,000 & & 127,000 & & 228,000 & & 197,000 & & 129,000 & \\
\hline Thallium & 2.00 & UNW & 2 & UNW & 2 & $\mathrm{U}$ & 2 & UW & 2 & U \\
\hline Vanadium & 6.3 & B & 5 & $\mathrm{U}$ & 42.7 & B & 5 & $\mathrm{U}$ & 6.8 & B \\
\hline Zinc & 11.8 & B*@ & 18.4 & B*@ & 4,040 & & 1,670 & $\mathrm{E}$ & 968 & \\
\hline
\end{tabular}

a Sampled by ANL, analyzed by EA Laboratories, CLP/TAL metals.

Data qualifiers:

$\mathrm{U}=$ analyte was analyzed for but not detected; detection limit given.

$\mathrm{B}=$ reported value is less than contract-required detection limit but greater than the instrument detection limit.

$\mathrm{W}=$ postdigestion spike out of control limits.

$\mathrm{N}=$ spiked sample recovery is not within control limits.

* = duplicate analyses are not within control limits.

@ = percent RPD of sample duplicate was outside of control limits.

$S=$ reported value is determined by method of standard additions.

$\mathrm{E}=$ reported value is estimated because of the presence of interference. 
TABLE C.5a Pesticide and Polychlorinated Biphenyl (PCB) Analyses for Surface Water, April 1993 ${ }^{\mathrm{a}}$

\begin{tabular}{|c|c|c|c|c|c|c|c|c|c|c|c|c|c|c|}
\hline \multirow{3}{*}{$\begin{array}{l}\text { Compound } \\
\text { Aldrin }\end{array}$} & \multicolumn{14}{|c|}{ Surface Water Concentrations $(\mu \mathrm{g} / \mathrm{L})$} \\
\hline & \multicolumn{2}{|c|}{ SW-6 } & \multicolumn{2}{|c|}{ SW-7 } & \multicolumn{2}{|c|}{ SW-9 } & \multicolumn{2}{|c|}{$S W-10$} & \multicolumn{2}{|c|}{ SW-11 } & \multicolumn{2}{|c|}{ SW-12 } & \multicolumn{2}{|c|}{ SW-13 } \\
\hline & 0.05 & $\mathrm{U}$ & 0.05 & $\mathrm{U}$ & 0.05 & $\mathrm{U}$ & 0.05 & $\mathrm{U}$ & 0.05 & $U$ & 0.05 & $\mathrm{U}$ & 0.05 & $\mathrm{U}$ \\
\hline Aroclor 1016 & 1.00 & $\mathrm{U}$ & 1.00 & $\mathrm{U}$ & 1.00 & $\mathrm{U}$ & 1.00 & $\mathrm{U}$ & 1.00 & $U$ & 1.00 & $\mathrm{U}$ & 1.00 & $\mathrm{U}$ \\
\hline Aroclor 1221 & 2.00 & $\mathrm{U}$ & 2.00 & $\mathrm{U}$ & 2.00 & $\mathrm{U}$ & 2.00 & $\mathrm{U}$ & 2.00 & $U$ & 2.00 & $\mathrm{U}$ & 2.00 & $\mathrm{U}$ \\
\hline Aroclor 1232 & 1.00 & $\mathrm{U}$ & 1.00 & $\mathrm{U}$ & 1.00 & $U$ & 1.00 & $\mathrm{U}$ & 1.00 & $\mathrm{U}$ & 1.00 & $\mathrm{U}$ & 1.00 & $\mathrm{U}$ \\
\hline Aroclor 1242 & 1.00 & $\mathrm{U}$ & 1.00 & $U$ & 1.00 & $\mathrm{U}$ & 1.00 & $U$ & 1.00 & $\mathrm{U}$ & 1.00 & $\mathrm{U}$ & 1.00 & $\mathrm{U}$ \\
\hline Aroclor 1248 & 1.00 & $\mathrm{U}$ & 1.00 & $U$ & 1.00 & $\mathrm{U}$ & 1.00 & $U$ & 1.00 & $\mathrm{U}$ & 1.00 & $\mathrm{U}$ & 1.00 & $\mathrm{U}$ \\
\hline Aroclor 1254 & 1.00 & $\mathrm{U}$ & 1.00 & $U$ & 1.00 & $\mathrm{U}$ & 1.00 & $U$ & 1.00 & $U$ & 1.00 & $\mathrm{U}$ & 1.00 & U \\
\hline Aroclor 1260 & 1.00 & $U$ & 1.00 & $U$ & 1.00 & $\mathrm{U}$ & 1.00 & $\mathrm{U}$ & 1.00 & $\mathrm{U}$ & 1.00 & $\mathrm{U}$ & 1.00 & $\mathrm{U}$ \\
\hline$\alpha-\mathrm{BHC}$ & 0.05 & $\mathrm{U}$ & 0.05 & $U$ & 0.05 & $\mathrm{U}$ & 0.05 & $U$ & 0.05 & $U$ & 0.05 & $\mathrm{U}$ & 0.05 & $U$ \\
\hline$\beta$-BHC & 0.05 & $\mathrm{U}$ & 0.05 & $\mathrm{U}$ & 0.05 & $\mathrm{U}$ & 0.05 & $U$ & 0.05 & $\mathrm{U}$ & 0.05 & $\mathrm{U}$ & 0.05 & $\mathrm{U}$ \\
\hline$\delta$-BHC & 0.05 & $\mathrm{U}$ & 0.05 & $\mathrm{U}$ & 0.05 & $U$ & 0.05 & $U$ & 0.05 & $\mathrm{U}$ & 0.05 & $\mathrm{U}$ & 0.05 & $\mathrm{U}$ \\
\hline$\gamma-\mathrm{BHC}$ (Lindane) & 0.05 & $U$ & 0.05 & $U$ & 0.05 & $\mathrm{U}$ & 0.05 & $\mathrm{U}$ & 0.05 & $U$ & 0.05 & $\mathrm{U}$ & 0.05 & $\mathrm{U}$ \\
\hline$\alpha$-Chlordane & 0.05 & $\mathrm{U}$ & 0.05 & $\mathrm{U}$ & 0.05 & $U$ & 0.05 & $\mathrm{U}$ & 0.05 & $U$ & 0.05 & $\mathrm{U}$ & 0.05 & $U$ \\
\hline$\gamma$-Chlordane & 0.05 & $U$ & 0.05 & $U$ & 0.05 & $U$ & 0.05 & $\mathrm{U}$ & 0.05 & $\mathrm{U}$ & 0.05 & $\mathrm{U}$ & 0.05 & $\mathrm{U}$ \\
\hline 4,4'-DDD & 0.10 & $\mathrm{U}$ & 0.10 & $U$ & 0.10 & $\mathrm{U}$ & 0.10 & $U$ & 0.10 & $U$ & 0.10 & $\mathrm{U}$ & 0.10 & $\mathrm{U}$ \\
\hline 4,4'-DDE & 0.10 & $\mathrm{U}$ & 0.10 & $U$ & 0.10 & $\mathrm{U}$ & 0.10 & $\mathrm{U}$ & 0.10 & $U$ & 0.10 & $\mathrm{U}$ & 0.10 & $\mathrm{U}$ \\
\hline 4,4'-DDT & 0.10 & $\mathrm{U}$ & 0.10 & $U$ & 0.10 & $\mathrm{U}$ & 0.10 & $\mathrm{U}$ & 0.10 & $\mathrm{U}$ & 0.10 & $\mathrm{U}$ & 0.10 & $\mathrm{U}$ \\
\hline Dieldrin & 0.10 & $\mathrm{U}$ & 0.10 & $\mathrm{U}$ & 0.10 & $\mathrm{U}$ & 0.10 & $U$ & 0.10 & $\mathrm{U}$ & 0.10 & $\mathrm{U}$ & 0.10 & $\mathrm{U}$ \\
\hline Endosulfan I & 0.05 & $\mathrm{U}$ & 0.05 & $\mathrm{U}$ & 0.05 & $\mathrm{U}$ & 0.05 & $\mathrm{U}$ & 0.05 & $\mathrm{U}$ & 0.05 & $\mathrm{U}$ & 0.05 & $\mathrm{U}$ \\
\hline Endosulfan sulfate & 0.10 & $\mathrm{U}$ & 0.10 & $\mathrm{U}$ & 0.10 & $U$ & 0.10 & $\mathrm{U}$ & 0.10 & $U$ & 0.10 & $\mathrm{U}$ & 0.10 & $\mathrm{U}$ \\
\hline Endosulfan II & 0.10 & $\mathrm{U}$ & 0.10 & $\mathrm{U}$ & 0.10 & U & 0.10 & $U$ & 0.10 & $\mathrm{U}$ & 0.10 & $\mathrm{U}$ & 0.10 & $\mathrm{U}$ \\
\hline
\end{tabular}


TABLE C.5a (Cont.)

\begin{tabular}{|c|c|c|c|c|c|c|c|c|c|c|c|c|c|c|}
\hline \multirow{3}{*}{$\begin{array}{l}\text { Compound } \\
\text { Endrin }\end{array}$} & \multicolumn{14}{|c|}{ Surface Water Concentrations ( $\mu \mathrm{g} / \mathrm{L}$ ) } \\
\hline & \multicolumn{2}{|c|}{ SW-6 } & \multicolumn{2}{|c|}{ SW-7 } & \multicolumn{2}{|c|}{ SW-9 } & \multicolumn{2}{|c|}{ SW-10 } & \multicolumn{2}{|c|}{ SW-11 } & \multicolumn{2}{|c|}{ SW-12 } & \multicolumn{2}{|c|}{ SW-13 } \\
\hline & 0.10 & $\mathrm{U}$ & 0.10 & $\mathrm{U}$ & 0.10 & $U$ & 0.10 & $\mathrm{U}$ & 0.10 & $\mathrm{U}$ & 0.10 & $\mathrm{U}$ & 0.10 & $U$ \\
\hline Endrin aldehyde & 0.10 & $\mathrm{U}$ & 0.10 & $\mathrm{U}$ & 0.10 & $\mathrm{U}$ & 0.10 & $\mathrm{U}$ & 0.10 & $\mathrm{U}$ & 0.10 & $\mathrm{U}$ & 0.10 & U \\
\hline Endrin ketone & 0.10 & $\mathrm{U}$ & 0.10 & $\mathrm{U}$ & 0.10 & $\mathrm{U}$ & 0.10 & $\mathrm{U}$ & 0.10 & $\mathrm{U}$ & 0.10 & $\mathrm{U}$ & 0.10 & $\mathrm{U}$ \\
\hline Heptachlor & 0.05 & $\mathrm{U}$ & 0.05 & $U$ & 0.05 & $\mathrm{U}$ & 0.05 & $\mathrm{U}$ & 0.05 & $\mathrm{U}$ & 0.05 & $\mathrm{U}$ & 0.05 & U \\
\hline Heptachlor epoxide & 0.05 & $\mathrm{U}$ & 0.05 & $U$ & 0.05 & $\mathrm{U}$ & 0.05 & $U$ & 0.05 & $\mathrm{U}$ & 0.05 & $\mathrm{U}$ & 0.05 & $\mathrm{U}$ \\
\hline Methoxychlor & 0.50 & $\mathrm{U}$ & 0.50 & $\mathrm{U}$ & 5.00 & $U$ & 0.50 & $U$ & 0.50 & $U$ & 0.50 & $\mathrm{U}$ & 0.50 & $\mathrm{U}$ \\
\hline Toxaphene & 5.00 & $\mathrm{U}$ & 5.00 & $\mathrm{U}$ & 5.00 & $\mathrm{U}$ & 5.00 & $\mathrm{U}$ & 5.00 & $\mathrm{U}$ & 5.00 & $\mathrm{U}$ & 5.00 & $U$ \\
\hline
\end{tabular}

a Sampled by ANL and USGS, analyzed by Enseco, CLP/HSL organochloride pesticides and PCBs. Provisional data, validation in progress.

Data qualifier:

$U=$ analyte was analyzed for but not detected. 
TABLE C.5b Pesticide and PCB

Analyses for Surface Water,

September $1993^{\mathrm{a}}$

\begin{tabular}{|c|c|c|}
\hline \multirow[b]{2}{*}{ Compound } & \multicolumn{2}{|c|}{$\begin{array}{c}\text { Surface Water } \\
\text { Concentrations } \\
(\mu \mathrm{g} / \mathrm{L})\end{array}$} \\
\hline & \multicolumn{2}{|c|}{ SW-7 } \\
\hline Aldrin & 0.05 & $\mathrm{U}$ \\
\hline Aroclor 1016 & 1.00 & $\mathrm{U}$ \\
\hline Aroclor 1221 & 2.00 & $\mathrm{U}$ \\
\hline Aroclor 1232 & 1.00 & $U$ \\
\hline Aroclor 1242 & 1.00 & $\mathrm{U}$ \\
\hline Aroclor 1248 & 1.00 & U \\
\hline Aroclor 1254 & 1.00 & $\mathrm{U}$ \\
\hline Aroclor 1260 & 1.00 & $\mathrm{U}$ \\
\hline$\alpha-\mathrm{BHC}$ & 0.05 & $U$ \\
\hline$\beta-\mathrm{BHC}$ & 0.05 & $U$ \\
\hline$\delta-B H C$ & 0.05 & $\mathrm{U}$ \\
\hline$\gamma$-BHC (Lindane) & 0.05 & $\mathrm{U}$ \\
\hline$\alpha$-Chlordane & 0.05 & $\mathrm{U}$ \\
\hline$\gamma$-Chlordane & 0.05 & $\mathrm{U}$ \\
\hline 4,4'-DDD. & 0.10 & $\mathrm{U}$ \\
\hline 4,4'-DDE & 0.10 & U \\
\hline 4,4'-DDT & 0.10 & $\mathrm{U}$ \\
\hline Dieldrin & 0.10 & $\mathrm{U}$ \\
\hline Endosulfan I & 0.05 & $\mathrm{U}$ \\
\hline Endosulfan sulfate & 0.10 & $\mathrm{U}$ \\
\hline Endosulfan II & 0.10 & $U$ \\
\hline Endrin & 0.10 & $\mathrm{U}$ \\
\hline Endrin aldehyde & 0.10 & $\mathrm{U}$ \\
\hline Endrin ketone & 0.10 & $U$ \\
\hline
\end{tabular}


TABLE C.5b (Cont.)

\begin{tabular}{|c|c|c|}
\hline & \multicolumn{2}{|c|}{$\begin{array}{c}\text { Surface Water } \\
\text { Concentrations } \\
(\mu \mathrm{g} / \mathrm{L})\end{array}$} \\
\hline Compound & \multicolumn{2}{|c|}{ SW-7 } \\
\hline Heptachlor & 0.05 & $U$ \\
\hline Heptachlor epoxide & 0.05 & $\mathrm{U}$ \\
\hline Methoxychlor & 0.50 & $U$ \\
\hline Toxaphene & 5.00 & $U$ \\
\hline
\end{tabular}

a Sampled by USGS, analyzed by Enseco, CLP/HSL organochloride pesticides and PCBs. Provisional data, validation in progress.

Data qualifier:

$\mathrm{U}=$ analyte was analyzed for but not detected; detection limit given. 
TABLE C.5c Pesticide and PCB Analyses for Surface Water, May $1994^{\mathrm{a}}$

\begin{tabular}{|c|c|c|c|c|c|c|c|c|c|c|}
\hline \multirow{3}{*}{$\begin{array}{l}\text { Compound } \\
\text { Aldrin }\end{array}$} & \multicolumn{10}{|c|}{ Surface Water Concentrations $(\mu \mathrm{g} / \mathrm{L})$} \\
\hline & \multicolumn{2}{|c|}{ SW-7 } & \multicolumn{2}{|c|}{ SW-10 } & \multicolumn{2}{|c|}{ SW-11 } & \multicolumn{2}{|c|}{ SW-11 Dup } & \multicolumn{2}{|c|}{ SW-12 } \\
\hline & 0.05 & $\mathrm{U}_{+}$ & 0.05 & $U_{+}$ & 0.05 & $\mathrm{U}_{+}$ & 0.05 & $\mathrm{U}_{+}$ & 0.05 & $U_{+}$ \\
\hline Aroclor 1016 & 1 & $U_{+}$ & 1 & U+ & 1 & $\mathrm{U}_{+}$ & 1 & $U_{+}$ & 1 & $\mathrm{U}_{+}$ \\
\hline Aroclor 1221 & 2 & U+ & 2 & $U_{+}$ & 2 & $U_{+}$ & 2 & $\mathrm{U}_{+}$ & 2 & $U_{+}$ \\
\hline Aroclor 1232 & 1 & $U_{+}$ & 1 & $\mathrm{U}_{+}$ & 1 & $U_{+}$ & 1 & $\mathrm{U}_{+}$ & 1 & U+ \\
\hline Aroclor 1242 & 1 & $U_{+}$ & 1 & Ut & 1 & $\mathrm{U}_{+}$ & 1 & $\mathrm{U}_{+}$ & 1 & $U_{+}$ \\
\hline Aroclor 1248 & 1 & $\mathrm{U}_{+}$ & 1 & $U_{+}$ & 1 & $\mathrm{U}_{+}$ & 1 & $\mathrm{U}_{+}$ & 1 & $U_{+}$ \\
\hline Aroclor 1254 & 1 & $\mathrm{U}_{+}$ & 1 & $\mathrm{Ut}_{+}$ & 1 & $\mathrm{U}_{+}$ & 1 & $\mathrm{U}_{+}$ & 1 & $U_{+}$ \\
\hline Aroclor 1260 & 1 & $\mathrm{U}_{+}$ & 1 & $U_{t}$ & 1 & $\mathrm{U}_{+}$ & 1 & $\mathrm{U}_{+}$ & 1 & $U_{t}$ \\
\hline$\alpha-\mathrm{BHC}$ & 0.05 & $\mathrm{U}_{+}$ & 0.05 & $\mathrm{U}_{+}$ & 0.05 & $U_{+}$ & 0.05 & $\mathrm{U}_{+}$ & 0.05 & $U_{+}$ \\
\hline$\beta$-BHC & 0.05 & Ut & 0.05 & $U_{+}$ & 0.05 & $\mathrm{U}+$ & 0.05 & $\mathrm{U}_{+}$ & 0.05 & $\mathrm{U}_{+}$ \\
\hline$\delta-B H C$ & 0.05 & $U_{+}$ & 0.05 & $U_{+}$ & 0.05 & $\mathrm{U}_{+}$ & 0.05 & $U_{+}$ & 0.05 & $\mathrm{U}_{+}$ \\
\hline$\gamma$-BHC & 0.05 & $\mathrm{U}_{+}$ & 0.05 & $U_{+}$ & 0.05 & $\mathrm{U}_{+}$ & 0.05 & $\mathrm{U}_{+}$ & 0.05 & $\mathrm{U}_{+}$ \\
\hline$\alpha$-Chlordane & 0.05 & $U_{+}$ & 0.05 & $\mathrm{U}_{+}$ & 0.05 & $U_{+}$ & 0.05 & $\mathrm{U}_{+}$ & 0.05 & Ut \\
\hline$\gamma$-Chlordane & 0.05 & $\mathrm{U}_{+}$ & 0.05 & $U_{+}$ & 0.05 & $\mathrm{U}_{+}$ & 0.05 & $U_{+}$ & 0.05 & $U_{t}$ \\
\hline 4,4'-DDD & 0.10 & $\mathrm{U}_{+}$ & 0.10 & $U_{+}$ & 0.10 & $U_{+}$ & 0.10 & $\mathrm{U}_{+}$ & 0.10 & $U_{+}$ \\
\hline $4,4^{\prime}-\mathrm{DDE}$ & 0.10 & $\mathrm{U}+$ & 0.10 & $U_{+}$ & 0.10 & $U_{+}$ & 0.10 & $\mathrm{U}_{+}$ & 0.10 & $U_{+}$ \\
\hline 4,4'-DDT & 0.10 & $U_{+}$ & 0.10 & $\mathrm{U}_{+}$ & 0.10 & $U_{+}$ & 0.10 & $\mathrm{U}_{+}$ & 0.10 & $\mathrm{U}_{+}$ \\
\hline Dieldrin & 0.10 & $U_{+}$ & 0.10 & $U_{+}$ & 0.10 & $U_{+}$ & 0.10 & $\mathrm{U}_{+}$ & 0.10 & $U_{+}$ \\
\hline Endosulfan I & 0.05 & $U_{+}$ & 0.05 & $U_{+}$ & 0.05 & $U_{+}$ & 0.05 & $\mathrm{U}_{+}$ & 0.05 & $U_{+}$ \\
\hline Endosulfan sulfate & 0.10 & $U_{+}$ & 0.10 & $U_{+}$ & 0.10 & $\mathrm{U}_{+}$ & $0.10^{\circ}$ & $\mathrm{U}_{+}$ & 0.10 & $U_{+}$ \\
\hline Endosulfan II & 0.10 & $\mathrm{U}_{+}$ & 0.10 & $U_{+}$ & 0.10 & $U_{+}$ & 0.10 & $U_{+}$ & 0.10 & $\mathrm{U}_{+}$ \\
\hline Endrin & 0.10 & $\mathrm{U}_{+}$ & 0.10 & $U_{+}$ & 0.10 & $\mathrm{U}_{+}$ & 0.10 & $U_{+}$ & 0.10 & $\mathrm{U}_{+}$ \\
\hline Endrin aldehyde & 0.10 & $\mathrm{U}_{+}$ & 0.10 & $\mathrm{U}_{+}$ & 0.10 & $U_{+}$ & 0.10 & $\mathrm{U}_{+}$ & 0.10 & $\mathrm{U}_{+}$ \\
\hline Endrin ketone & 0.10 & $\mathrm{U}_{+}$ & 0.10 & $U_{+}$ & 0.10 & $U_{+}$ & 0.10 & $\mathrm{U}_{+}$ & 0.10 & $U_{+}$ \\
\hline Heptachlor & 0.05 & U+ & 0.05 & $U_{+}$ & 0.05 & $U_{+}$ & 0.05 & $\mathrm{U}_{+}$ & 0.05 & $U_{+}$ \\
\hline Heptachlor epoxide & 0.05 & $\mathrm{U}_{+}$ & 0.05 & $U_{+}$ & 0.05 & $\mathrm{U}_{+}$ & 0.05 & $\mathrm{U}_{+}$ & 0.05 & $\mathrm{U}_{+}$ \\
\hline Methoxychlor & 0.50 & $\mathrm{U}_{+}$ & 0.50 & $U_{+}$ & 0.50 & $U_{+}$ & 0.50 & $U_{+}$ & 0.50 & $U_{+}$ \\
\hline Toxaphene & 5 & $\mathrm{U}_{+}$ & 5 & $U_{+}$ & 5 & $U_{+}$ & 5 & $U_{+}$ & 5 & $\mathrm{U}_{+}$ \\
\hline
\end{tabular}

a Sampled by ANL, analyzed by EA Laboratories, CLP/HSL organochloride pesticides and PCBs.

Data qualifiers:

$\mathrm{U}=$ analyte was analyzed for but not detected; detection limit given.

+ = surrogate recoveries were outside QC limit(s). 
TABLE C.6a General Chemistry Analyses for Surface Water, May $1994^{\mathrm{a}}$

\begin{tabular}{|c|c|c|c|c|c|c|c|c|c|c|}
\hline \multirow[b]{2}{*}{ Analyte } & \multicolumn{10}{|c|}{ Surface Water Concentrations (mg/L) ${ }^{b}$} \\
\hline & \multicolumn{2}{|c|}{ SW-7 } & \multicolumn{2}{|c|}{ SW-10 } & \multicolumn{2}{|c|}{ SW-11 } & \multicolumn{2}{|c|}{ SW-11 Dup } & \multicolumn{2}{|c|}{ SW-12 } \\
\hline Alkalinity & 60.8 & & 222 & & 207 & & 210 & & 248 & \\
\hline Bicarbonate & 60.8 & & 222 & & 206 & & 210 & & 247 & \\
\hline Bromide & 3.0 & & 1.3 & & 1.3 & & 1.3 & & 1.0 & \\
\hline Carbonate & 1.0 & $U$ & 1.0 & $U$ & 1.0 & $\mathrm{U}$ & 1.0 & $\mathrm{U}$ & 1.0 & $\mathrm{U}$ \\
\hline Chloride & 810 & & 270 & & 720 & & 630 & & 330 & \\
\hline Cyanide & 0.01 & $\mathrm{U}$ & 0.01 & $U$ & 0.01 & $\mathrm{U}$ & 0.01 & $U^{*}$ & 0.01 & U \\
\hline Fluoride & 0.1 & $U$ & 0.1 & $U$ & 0.1 & $\mathrm{U}$ & 0.1 & $\mathrm{U}$ & 0.1 & U \\
\hline Nitrate & 0.1 & $\mathrm{U}$ & 0.1 & $U$ & 0.1 & U & 3.6 & & 2.2 & \\
\hline Nitrite & 5.0 & $\mathrm{U}$ & 2.5 & $\mathrm{U}$ & 2.5 & $U$ & 2.5 & $\mathrm{U}$ & 0.5 & $\mathrm{U}$ \\
\hline Orthophosphate & 0.1 & $U$ & 0.1 & $\mathrm{U}$ & 0.1 & $U$ & 0.1 & $\mathrm{U}$ & 0.1 & $\mathrm{U}$ \\
\hline $\mathrm{pH}(\mathrm{SI})$ & 6.2 & & 7.0 & & 6.6 & + & 6.8 & + & 7.1 & + \\
\hline Phosphate, total & 1.9 & & 0.13 & & 2.7 & & 0.57 & & 0.75 & \\
\hline Sulfate & 64 & & 100 & & 190 & & 190 & & 37 & \\
\hline TDS & 1,400 & & 775 & & 1,510 & & 1,460 & & 790 & \\
\hline Turbidity (NTU) & 7.5 & & 2.6 & & 69 & & 28 & & 13.8 & \\
\hline Total organic halogens $(\mu \mathrm{g} / \mathrm{L})$ & 120 & & 2,600 & & NT & & NT & & NT & \\
\hline
\end{tabular}

a Sampled by ANL, analyzed by EA Laboratories, CLP/TAL metals.

b Units are $\mathrm{mg} / \mathrm{L}$, except where indicated.

Data qualifiers:

$U$ = analyte was analyzed for but not detected; detection limit given.

$+\quad=$ holding time was not met.

* = cyanide sample was not preserved in field with $\mathrm{NaOH}$.

$\mathrm{NT}=$ not tested. 
TABLE C.6b Explosive Compounds Analyses for Surface Water, May $1994^{\mathrm{a}}$

\begin{tabular}{|c|c|c|c|c|c|c|c|c|c|c|}
\hline \multirow{3}{*}{$\begin{array}{l}\text { Compound } \\
1,3-\mathrm{DNB}\end{array}$} & \multicolumn{10}{|c|}{ Surface Water Concentrations $(\mu \mathrm{g} / \mathrm{L})$} \\
\hline & \multicolumn{2}{|c|}{ SW-7 } & \multicolumn{2}{|c|}{ SW-10 } & \multicolumn{2}{|c|}{ SW-11 } & \multicolumn{2}{|c|}{ SW-11 Dup } & \multicolumn{2}{|c|}{ SW-12 } \\
\hline & 0.62 & $\mathrm{U}$ & 0.62 & $\mathrm{U}$ & 0.62 & $\mathrm{U}$ & 0.62 & $\mathrm{U}$ & 0.62 & $U$ \\
\hline 2,4-DNT & 0.43 & $\mathrm{U}$ & 0.43 & $\mathrm{U}$ & 0.43 & $\mathrm{U}$ & 0.43 & $\mathrm{U}$ & 0.43 & $\mathrm{U}$ \\
\hline 2,6-DNT & 1.2 & U & 1.2 & $\mathrm{U}$ & 1.2 & $\mathrm{U}$ & 1.2 & $\mathrm{U}$ & 1.2 & $\mathrm{U}$ \\
\hline HMX & 1.1 & $\mathrm{U}$ & 1.1 & $\mathrm{U}$ & 1.1 & $\mathrm{U}$ & 1.1 & $U$ & 1.1 & $\mathrm{U}$ \\
\hline NB & 0.45 & $\mathrm{U}$ & 0.45 & $\mathrm{U}$ & 0.45 & $U$ & 0.45 & $\mathrm{U}$ & 0.45 & U \\
\hline $\mathrm{RDX}$ & 1.7 & $\mathrm{U}$ & 1.7 & $\mathrm{U}$ & 0.48 & J I & 0.98 & J I & 1.0 & J I \\
\hline TETRYL & 1.9 & $\mathrm{U}$ & 1.9 & $U$ & 1.9 & $\mathrm{U}$ & 1.9 & $U$ & 1.9 & $\mathrm{U}$ \\
\hline $1,3,5-\mathrm{TNB}$ & 0.86 & $U$ & 0.86 & $U$ & 0.86 & $\mathrm{U}$ & 0.86 & $\mathrm{U}$ & 0.86 & U \\
\hline 2,4,6-TNT & 1.3 & $U$ & 1.3 & $\mathrm{U}$ & 1.3 & $\mathrm{U}$ & 1.3 & $\mathrm{U}$ & 1.3 & $\mathrm{U}$ \\
\hline
\end{tabular}

a Sampled by ANL, analyzed by EA Laboratories.

Data qualifiers:

$\mathrm{U}=$ analyte was analyzed for but not detected; detection limit given.

$\mathrm{J}=$ estimated value.

I = interferences in sample cause the quantitation and/or identification to be suspect. 


\section{C-31}

TABLE C.6c Chemical Warfare Agent (CWA) Degradation Products and Organosulfur Compounds Analyses for Surface Water, April $1993^{\mathrm{a}}$

\begin{tabular}{|c|c|c|c|c|c|c|c|c|}
\hline \multirow[b]{2}{*}{ Compound } & \multicolumn{8}{|c|}{ Surface Water Concentrations $(\mu \mathrm{g} / \mathrm{L})$} \\
\hline & \multicolumn{2}{|c|}{ SW-7 } & \multicolumn{2}{|c|}{ SW-10 } & \multicolumn{2}{|c|}{ SW-12 } & \multicolumn{2}{|c|}{ SW-13 } \\
\hline \multicolumn{9}{|l|}{ CWA degradation products } \\
\hline Diisopropyl methylphosphonate (DIMP) & 0.43 & $\mathbf{U}$ & 0.45 & & 0.43 & $\mathrm{U}$ & 0.43 & $\mathrm{U}$. \\
\hline Dimethyl methylphosphate (DMMP) & 0.2 & $\mathrm{U}$ & 0.2 & $\mathbf{U}$ & 0.2 & $\mathbf{U}$ & 0.2 & $\mathrm{U}$ \\
\hline Thiodiglycol & 10 & $\mathrm{U}$ & 10 & $\mathrm{U}$ & 10 & $\mathrm{U}$ & 10 & $\mathrm{U}$ \\
\hline \multicolumn{9}{|l|}{ Organosulfur compounds } \\
\hline Benzothiozole (BTZ) & 5.22 & $\mathrm{U}$ & 5.22 & $\mathrm{U}$ & 5.22 & $\mathrm{U}$ & 5.22 & $\mathrm{U}$ \\
\hline p-Chlorophenylmethyl sulfide (CPMS) & 6.04 & $U$ & 6.04 & $\mathrm{U}$ & 6.04 & $\mathrm{U}$ & 6.04 & $\mathrm{U}$ \\
\hline p-Chlorophenylmethyl sulfone (CPMSO2) & 6.43 & $\mathrm{U}$ & 6.43 & $\mathrm{U}$ & 6.43 & $\mathrm{U}$ & 6.43 & $\mathrm{U}$ \\
\hline p-Chlorophenylmethyl sulfoxide (CPMSO) & 11.9 & $\mathrm{U}$ & 11.9 & $\mathrm{U}$ & 11.9 & $\mathrm{U}$ & 11.9 & $\mathrm{U}$ \\
\hline Dimethyl disulfide (DMDS) & 0.55 & $\mathbf{U}$ & 0.55 & $\mathrm{U}$ & 0.55 & $\mathrm{U}$ & 0.55 & $\mathrm{U}$ \\
\hline Dithiane (DITH) & 1.57 & $\mathrm{U}$ & 2.49 & & 1.57 & $\mathrm{U}$ & 1.57 & $\mathrm{U}$ \\
\hline 1,1 Oxathiane (OXAT) & 2.55 & $\mathrm{U}$ & 12.2 & & 2.55 & $\mathrm{U}$ & 2.55 & $\mathrm{U}$ \\
\hline
\end{tabular}

a Sampled by ANL and USGS, analyzed by EA Laboratories.

Data qualifier:

$U$ = analyte was analyzed for but not detected; detection limit given. 
TABLE C.7a Volatile Organics Analyses for Sediment Borings, April 1994 ${ }^{\mathrm{a}}$

\begin{tabular}{|c|c|c|c|c|c|c|c|c|c|c|c|c|c|c|}
\hline \multirow{3}{*}{$\begin{array}{l}\text { Compound } \\
\text { Acetone }\end{array}$} & \multicolumn{14}{|c|}{ Sediment Concentrations $(\mu \mathrm{g} / \mathrm{kg})$ at Various Depth Intervals } \\
\hline & \multicolumn{2}{|c|}{$\begin{array}{c}\text { BOR1-1 } \\
(6-8 \mathrm{ft})\end{array}$} & \multicolumn{2}{|c|}{$\begin{array}{l}\text { BOR1-2 } \\
(8-10 \mathrm{ft})\end{array}$} & \multicolumn{2}{|c|}{$\begin{array}{c}\text { BORI-3 } \\
(10-12 \mathrm{ft})\end{array}$} & \multicolumn{2}{|c|}{$\begin{array}{l}\text { BOR2-1 } \\
(3-5 \mathrm{ft})\end{array}$} & \multicolumn{2}{|c|}{$\begin{array}{l}\text { BOR2-2 } \\
(5-8 \mathrm{ft})\end{array}$} & \multicolumn{2}{|c|}{$\begin{array}{l}\text { BOR2-3 } \\
(8-10 \mathrm{ft})\end{array}$} & \multicolumn{2}{|c|}{$\begin{array}{l}\text { BOR3-1 } \\
(6-8 \mathrm{ft})\end{array}$} \\
\hline & 15 & $\mathrm{U}$ & 43 & B & 14 & $\mathbf{U}$ & 1,100 & * & 40 & B & 12 & $\mathbf{U}$ & 17 & B \\
\hline Benzene & 15 & $\mathbf{U}$ & 13 & $\mathbf{U}$ & 12 & $\mathbf{U}$ & 26 & $\mathrm{U}^{*}$ & 14 & $\mathrm{U}$ & 12 & $\mathbf{U}$ & 13 & $\mathrm{U}$ \\
\hline Bromodichloromethane & 15 & $\mathrm{U}$ & 13 & $\mathrm{U}$ & 12 & $\mathbf{U}$ & 26 & $\mathrm{U}^{*}$ & 14 & $\mathbf{U}$ & 12 & $\mathbf{U}$ & 13 & $\mathrm{U}$ \\
\hline Bromoform & 15 & $U$ & 13 & $\mathrm{U}$ & 12 & $\mathbf{U}$ & 26 & $\mathbf{U}^{*}$ & 14 & $\mathrm{U}$ & 12 & $\mathbf{U}$ & 13 & $\mathbf{U}$ \\
\hline Bromomethane & 15 & $\mathbf{U}$ & 13 & $\mathrm{U}$ & 12 & $\mathbf{U}$ & 26 & $\mathrm{U}^{*}$ & 14 & $\mathbf{U}$ & 12 & $\mathbf{U}$ & 13 & $\mathrm{U}$ \\
\hline 2-Butanone & 15 & $\mathrm{U}$ & 13 & $\mathrm{U}$ & 12 & $\mathbf{U}$ & 150 & $*$ & 14 & $\mathbf{U}$ & 12 & $\mathbf{U}$ & 13 & U \\
\hline Carbon disulfide & 15 & $\mathbf{U}$ & 13 & $\mathbf{U}$ & 12 & $\mathbf{U}$ & 26 & $\mathbf{U}^{*}$ & 14 & $\mathbf{U}$ & 12 & $\mathbf{U}$ & 7 & $\mathbf{J}$ \\
\hline Carbon tetrachloride & 15 & $\mathbf{U}$ & 13 & $\mathrm{U}$ & 12 & $\mathbf{U}$ & 26 & $\mathbf{U}^{*}$ & 14 & $\mathbf{U}$ & 12 & $\mathrm{U}$ & 13 & $\mathrm{U}$ \\
\hline Chlorobenzene & 15 & $U$ & 13 & $\mathrm{U}$ & 12 & $\mathbf{U}$ & 26 & $\mathrm{U}^{*}$ & 14 & $\mathrm{U}$ & 12 & $\mathbf{U}$ & 13 & $\mathrm{U}$ \\
\hline Chlorocthane & 15 & U & 13 & $\mathrm{U}$ & 12 & $\mathbf{U}$ & 26 & $\mathrm{U}^{*}$ & 14 & $\mathbf{U}$ & 12 & $U$ & 13 & $\mathrm{U}$ \\
\hline Chloroform & 15 & $\mathrm{U}$ & 13 & $\mathrm{U}$ & 12 & $\mathbf{U}$ & 26 & $\mathbf{U}^{*}$ & 14 & $\mathrm{U}$ & 12 & $\mathbf{U}$ & 13 & $\mathrm{U}$ \\
\hline Chloromethane & 15 & $\mathrm{U}$ & 13 & $\mathbf{U}$ & 12 & $\mathbf{U}$ & 26 & $\mathrm{U}^{*}$ & 14 & U & 12 & U & 13 & $\mathrm{U}$ \\
\hline Dibromochloromethane & 15 & $\mathbf{U}$ & 13 & $\mathrm{U}$ & 12 & $\mathbf{U}$ & 26 & $\mathbf{U}^{*}$ & 14 & $\mathrm{U}$ & 12 & $\mathbf{U}$ & 13 & $\mathrm{U}$ \\
\hline 1,1-Dichloroethane & 15 & $\mathrm{U}$ & 13 & $\mathbf{U}$ & 12 & $\mathbf{U}$ & 26 & $\mathrm{U}^{*}$ & 14 & $\mathbf{U}$ & 12 & U & 13 & $\mathrm{U}$ \\
\hline 1,2-Dichloroethane & 15 & $\mathrm{U}$ & 13 & $\mathrm{U}$ & 12 & U & 26 & $\mathrm{U}^{*}$ & 14 & $U$ & 12 & $\mathrm{U}$ & 18 & \\
\hline 1,1-Dichloroethene & 15 & $\mathbf{U}$ & 13 & $\mathbf{U}$ & 12 & $\mathbf{U}$ & 26 & $\mathrm{U}^{*}$ & 14 & U & 12 & $U$ & 13 & $\mathrm{U}$ \\
\hline 1,2-Dichloroethene (total) & 15 & $\mathrm{U}$ & 13 & $\mathbf{U}$ & 12 & $U$ & 26 & $U^{*}$ & 14 & $\mathbf{U}$ & 12 & $\mathbf{U}$ & 89 & \\
\hline 1,2-Dichloropropane & 15 & $\mathrm{U}^{\cdot}$ & 13 & $\mathrm{U}$ & 12 & $\mathrm{U}$ & 26 & $\mathrm{U}^{*}$ & 14 & $\mathrm{U}$ & 12 & $U$ & 13 & $\mathrm{U}$ \\
\hline cis-1,3-Dichloropropene & 15 & $\mathrm{U}$ & 13 & $\mathbf{U}$ & 12 & $\mathrm{U}$ & 26 & $U^{*}$ & 14 & $\mathbf{U}$ & 12 & $\mathbf{U}$ & 13 & $\mathrm{U}$ \\
\hline trans-1,3-Dichloropropene & 15 & $\mathrm{U}$ & 13 & $\mathrm{U}$ & 12 & $\mathrm{U}$ & 26 & $\mathrm{U}^{*}$ & 14 & $U$ & 12 & U & 13 & $\mathrm{U}$ \\
\hline Ethylbenzene & 15 & $\mathbf{U}$ & 13 & $\mathbf{U}$ & 12 & $\mathrm{U}$ & 26 & $\mathrm{U}^{*}$ & 14 & $\mathrm{U}$ & 12 & $\mathrm{U}$ & 13 & $\mathrm{U}$ \\
\hline 2-Hexanone & 15 & $\mathrm{U}$ & 13 & $\mathbf{U}$ & 12 & $\mathrm{U}$ & 26 & $\mathrm{U}^{*}$ & 14 & $\mathrm{U}$ & 12 & $\mathrm{U}$ & 13 & $\mathrm{U}$ \\
\hline 4-Methyl-2-pentanone & 15 & $\mathbf{U}$ & 13 & $\mathbf{U}$ & 12 & U & 26 & $\mathrm{U}^{*}$ & 14 & $\mathrm{U}$ & 12 & $\mathrm{U}$ & 13 & $\mathrm{U}$ \\
\hline Methylene chloride & 15 & $\mathbf{U}$ & 13 & $\mathbf{U}$ & 12 & $U$ & 26 & $\mathrm{U}^{*}$ & 14 & $\mathrm{U}$ & 12 & $\mathbf{U}$ & 13 & $\mathrm{U}$ \\
\hline Styrene & 15 & $\mathbf{U}$ & 13 & $\mathbf{U}$ & 12 & $\mathrm{U}$ & 26 & $\mathrm{U}^{*}$ & 14 & $\mathrm{U}$ & 12 & $\mathrm{U}$ & 13 & $\mathrm{U}$ \\
\hline 1,1,2,2-Tetrachloroethane & 15 & $\mathbf{U}$ & 13 & U & 12 & $\mathrm{U}$ & 26 & $\mathrm{U}^{*}$ & 14 & $\mathrm{U}$ & 12 & $\mathbf{U}$ & 13 & U \\
\hline Tetrachloroethene & 15 & $\mathbf{U}$ & 13 & $\mathbf{U}$ & 12 & $\mathbf{U}$ & 26 & $\mathrm{U}^{*}$ & 14 & $\mathrm{U}$ & 12 & $\mathbf{U}$ & 13 & $\mathbf{U}$ \\
\hline Toluene & 15 & $\mathbf{U}$ & 13 & $\mathbf{U}$ & 12 & $\mathrm{U}$ & 150 & * & 20 & & 12 & $\mathbf{U}$ & 13 & $\mathbf{U}$ \\
\hline 1,1,1-Trichloroethane & 15 & $\mathbf{U}$ & 13 & $\mathbf{U}$ & 12 & $\mathbf{U}$ & 26 & $\mathrm{U}^{*}$ & 14 & $U$ & 12 & $\mathbf{U}$ & 13 & U \\
\hline
\end{tabular}


TABLE C.7a (Cont.)

\begin{tabular}{|c|c|c|c|c|c|c|c|c|c|c|c|c|c|c|}
\hline \multirow{3}{*}{$\frac{\text { Compound }}{1,1,2-\text { Trichloroethane }}$} & \multicolumn{14}{|c|}{ Sediment Concentrations $(\mu \mathrm{g} / \mathrm{kg}$ ) at Various Depth Intervals } \\
\hline & \multicolumn{2}{|c|}{$\begin{array}{c}\text { BOR1-1 } \\
(6-8 \mathrm{ft})\end{array}$} & \multicolumn{2}{|c|}{$\begin{array}{l}\text { BORI-2 } \\
(8-10 \mathrm{ft}) \\
\end{array}$} & \multicolumn{2}{|c|}{$\begin{array}{l}\text { BOR1-3 } \\
(10-12 \mathrm{ft})\end{array}$} & \multicolumn{2}{|c|}{$\begin{array}{c}\text { BOR2-1 } \\
(3-5 \mathrm{ft})\end{array}$} & \multicolumn{2}{|c|}{$\begin{array}{c}\text { BOR2-2 } \\
(5-8 \mathrm{ft})\end{array}$} & \multicolumn{2}{|c|}{$\begin{array}{l}\text { BOR2-3 } \\
(8-10 \mathrm{ft})\end{array}$} & \multicolumn{2}{|c|}{$\begin{array}{c}\text { BOR3-1 } \\
(6-8 \mathrm{ft})\end{array}$} \\
\hline & 15 & $\mathbf{U}$ & 13 & $\mathbf{U}$ & 12 & $\mathbf{U}$ & 26 & $\mathrm{U}^{*}$ & 14 & $\mathbf{U}$ & 12 & $\mathrm{U}$ & 13 & $\mathrm{U}$ \\
\hline Trichloroethene & 15 & $\mathbf{U}$ & 13 & U & 12 & $U$ & 26 & $\mathrm{U}^{*}$ & 14 & $\mathbf{U}$ & 12 & $\mathrm{U}$ & 170 & \\
\hline Vinyl chloride & 15 & $\mathbf{U}$ & 13 & $\mathrm{U}$ & 12 & U & 26 & $\mathrm{U}^{*}$ & 14 & $U$ & 12 & $\mathrm{U}$ & 13 & $\mathrm{U}$ \\
\hline \multirow[t]{3}{*}{ Xylenes (total) } & 15 & U & 13 & $\mathbf{U}$ & 12 & $\mathrm{U}$ & 26 & U* & 14 & $\mathrm{U}$ & 12 & U & 13 & $\mathrm{U}$ \\
\hline & \multicolumn{12}{|c|}{ Sediment Concentrations $(\mu \mathrm{g} / \mathrm{kg})$ at Various Depth Intervals } & & \\
\hline & \multicolumn{2}{|c|}{$\begin{array}{l}\text { BOR3-2 } \\
(8-10 \mathrm{ft})\end{array}$} & \multicolumn{2}{|c|}{$\begin{array}{l}\text { BOR4-1 } \\
(5-8 \mathrm{ft})\end{array}$} & \multicolumn{2}{|c|}{$\begin{array}{l}\text { BOR4-2 } \\
(8-10 \mathrm{ft})\end{array}$} & \multicolumn{2}{|c|}{$\begin{array}{c}\text { BOR5-1 } \\
(2-4 \mathrm{ft})\end{array}$} & \multicolumn{2}{|c|}{$\begin{array}{c}\text { BOR5-2 } \\
(4-6 \mathrm{ft}) \\
\end{array}$} & \multicolumn{2}{|c|}{$\begin{array}{c}\text { BOR5-3 } \\
(6-8 \mathrm{ft})\end{array}$} & & \\
\hline Acetone & 12 & $U$ & 20 & U & 19 & $\mathrm{~B}^{*}$ & 12 & $\mathbf{U}$ & 16 & B & $\cdot 12$ & U & & \\
\hline Benzene & 12 & $\mathrm{U}$ & 20 & $U$ & 13 & $\mathrm{U}^{*}$ & 12 & $\mathbf{U}$ & 12 & U & 12 & $\mathrm{U}$ & & \\
\hline Bromodichloromethane & 12 & $U$ & 20 & $\mathrm{U}$ & 13 & $\mathrm{U}^{*}$ & 12 & $\mathbf{U}$ & 12 & $\mathrm{U}$ & 12 & U & & \\
\hline Bromoform & 12 & $\mathbf{U}$ & 20 & $\mathbf{U}$ & 13 & $\mathrm{U}^{*}$ & 12 & $\mathbf{U}$ & 12 & $\mathbf{U}$ & 12 & $\mathrm{U}$ & & \\
\hline Bromomethane & 12 & $\mathbf{U}$ & 20 & $\mathrm{U}$ & 13 & $\mathbf{U}^{*}$ & 12 & $\mathrm{U}$ & 12 & $\mathbf{U}$ & 12 & U & & \\
\hline 2-Butanone & 12 & $\mathbf{U}$ & 20 & $\mathrm{U}$ & 13 & $\mathrm{U}^{*}$ & 12 & $\mathrm{U}$ & 12 & $\mathbf{U}$ & 12 & $\mathrm{U}$ & & \\
\hline Carbon disulfide & 12 & $\mathrm{U}$ & 20 & $\mathbf{U}$ & 13 & $\mathrm{U}^{*}$ & 12 & U & 12 & $\mathbf{U}$ & 12 & $\mathrm{U}$ & & \\
\hline Carbon tetrachloride & 12 & $\mathbf{U}$ & 20 & $\mathbf{U}$ & 13 & $\mathrm{U}^{*}$ & 12 & U & 12 & U & 12 & $\mathbf{U}$ & & \\
\hline Chlorobenzene & 12 & $\mathbf{U}$ & 20 & $\mathbf{U}^{*}$ & 13 & $\mathrm{U}^{*}$ & 12 & U & 12 & $\mathbf{U}$ & 12 & $\mathbf{U}$ & & \\
\hline Chloroethane & 12 & $\mathbf{U}$ & 20 & $\mathbf{U}$ & 13 & $\mathrm{U}^{*}$ & 12 & $\mathrm{U}$ & 12 & $\mathbf{U}$ & 12 & $\mathbf{U}$ & & \\
\hline Chloroform & 12 & $U$ & 20 & $\mathrm{U}$ & 13 & $U^{*}$ & 12 & $U$ & 12 & $\mathrm{U}$ & 12 & $\mathbf{U}$ & & \\
\hline Chloromethane & 12 & $\mathrm{U}$ & 20 & $\mathrm{U}$ & 13 & $\mathrm{U}^{*}$ & 12 & $\mathrm{U}$ & 12 & $\mathrm{U}$ & 12 & $\mathrm{U}$ & & \\
\hline Dibromochloromethane & 12 & $\mathrm{U}$ & 20 & $\mathbf{U}$ & 13 & $\mathrm{U}^{*}$ & 12 & $\mathrm{U}$ & 12 & $\mathrm{U}$ & 12 & $\mathbf{U}$ & & \\
\hline 1,1-Dichlorocthane & 12 & $\mathrm{U}$ & 20 & $\mathrm{U}$ & 13 & $\mathrm{U}^{*}$ & 12 & $\mathrm{U}$ & 12 & $\mathrm{U}$ & 12 & $\mathrm{U}$ & & \\
\hline 1,2-Dichloroethane & 12 & $\mathrm{U}$ & 20 & $\mathrm{U}$ & 13 & $\mathrm{U}^{*}$ & 12 & $\mathbf{U}$ & 12 & $\mathrm{U}$ & 12 & U & & \\
\hline 1, I-Dichloroethene & 12 & $\mathrm{U}$ & 20 & $\mathrm{U}$ & 13 & $\mathrm{U}^{*}$ & 12 & $\mathbf{U}$ & 12 & $\mathrm{U}$ & 12 & $U$ & & \\
\hline 1,2-Dichloroethene (total) & 12 & $\mathrm{U}$ & 2,200 & & 360 & $*$ & 12 & $\mathbf{U}$ & 12 & $\mathbf{U}$ & 12 & $\mathrm{U}$ & & \\
\hline 1,2-Dichloropropane & 12 & $\mathbf{U}$ & 20 & $\mathrm{U}$ & 13 & $\mathrm{U}^{*}$ & 12 & $\mathbf{U}$ & 12 & $\mathbf{U}$ & 12 & $\mathbf{U}$ & & \\
\hline cis-1,3-Dichloropropene & 12 & $\mathbf{U}$ & 20 & $\mathrm{U}$ & 13 & $\mathrm{U}^{*}$ & 12 & $\mathbf{U}$ & 12 & $\mathrm{U}$ & 12 & $\mathrm{U}$ & & \\
\hline trans-1,3-Dichloropropene & 12 & $\mathbf{U}$ & 20 & $\mathbf{U}$ & 13 & $\mathrm{U}^{*}$ & 12 & $U$ & 12 & $\mathbf{U}$ & 12 & $\mathrm{U}$ & & \\
\hline
\end{tabular}


TABLE C.7a (Cont.)

\begin{tabular}{|c|c|c|c|c|c|c|c|c|c|c|c|c|c|c|}
\hline \multirow{3}{*}{$\begin{array}{l}\text { Compound } \\
\text { Ethylbenzene }\end{array}$} & \multicolumn{12}{|c|}{ Sediment Concentrations $(\mu \mathrm{g} / \mathrm{kg})$ at Various Depth Intervals } & & \\
\hline & \multicolumn{2}{|c|}{$\begin{array}{l}\text { BOR3-2 } \\
(8-10 \mathrm{ft}) \\
\end{array}$} & \multicolumn{2}{|c|}{$\begin{array}{c}\text { BOR4-1 } \\
(5-8 \mathrm{ft}) \\
\end{array}$} & \multicolumn{2}{|c|}{$\begin{array}{l}\text { BOR4-2 } \\
(8-10 \mathrm{ft})\end{array}$} & \multicolumn{2}{|c|}{$\begin{array}{c}\text { BOR5-1 } \\
(2-4 \mathrm{ft})\end{array}$} & \multicolumn{2}{|c|}{$\begin{array}{l}\text { BOR5-2 } \\
(4-6 \mathrm{ft})\end{array}$} & \multicolumn{2}{|c|}{$\begin{array}{c}\text { BOR5-3 } \\
(6-8 \mathrm{ft})\end{array}$} & & \\
\hline & 12 & $\mathbf{U}$ & 20 & $\mathrm{U}^{*}$ & 13 & $\mathbf{U}^{*}$ & 12 & $\mathbf{U}$ & 12 & $\mathbf{U}$ & 12 & $\mathbf{U}$ & & \\
\hline 2-Hexanone & 12 & $\mathrm{U}$ & 20 & $\mathrm{U}^{*}$ & 13 & $\mathrm{U}^{*}$ & 12 & $\mathrm{U}$ & 12 & $\mathrm{U}$ & 12 & $\mathrm{U}$ & & \\
\hline 4-Methyl-2-pentanone & 12 & $\mathrm{U}$ & 20 & $\mathrm{U}^{*}$ & 13 & $\mathrm{U}^{*}$ & 12 & $\mathrm{U}$ & 12 & $\mathrm{U}$ & 12 & $\mathrm{U}$ & & \\
\hline Methylene chloride & 12 & $\mathrm{U}$ & 20 & $\mathrm{U}$ & 13 & $\mathrm{U}^{*}$ & 12 & $\mathbf{U}$ & 12 & $\mathbf{U}$ & 12 & $\mathrm{U}$ & & \\
\hline Styrene & 12 & $\mathbf{U}$ & 20 & $\mathrm{U}^{*}$ & 13 & $\mathrm{U}^{*}$ & 12 & $\mathbf{U}$ & 12 & $U$ & 12 & $\mathrm{U}$ & & \\
\hline 1,1,2,2-Tetrachloroethane & 31 & & 99 & $*$ & 13 & $\mathrm{U}^{*}$ & 12 & $\mathrm{U}$ & 12 & $\mathbf{U}$ & 12 & $\mathbf{U}$ & & \\
\hline Tetrachloroethene & 12 & $\mathbf{U}$ & 20 & $\mathrm{U}^{*}$ & 13 & $\mathrm{U}^{*}$ & 12 & $\mathbf{U}$ & 12 & $\mathrm{U}$ & 12 & $\mathrm{U}$ & & \\
\hline Toluene & 12 & $\mathbf{U}$ & 20 & $\mathrm{U}^{*}$ & 13 & $\mathrm{U}^{*}$ & 12 & $\mathbf{U}$ & 12 & $\mathrm{U}$ & 12 & $\mathbf{U}$ & & \\
\hline 1,1,1-Trichloroethane & 12 & $\mathrm{U}$ & 20 & $\mathbf{U}$ & 13 & $\mathrm{U}^{*}$ & 12 & $\mathrm{U}$ & 12 & $\mathrm{U}$ & 12 & $\mathbf{U}$ & & \\
\hline 1,1,2-Trichloroethane & 10 & $\mathbf{J}$ & 76 & & 13 & $\mathrm{U}^{*}$ & 12 & $\mathrm{U}$ & 12 & $\mathrm{U}$ & 12 & $\mathbf{U}$ & & \\
\hline Trichloroethene & 91 & & 12 & J & 13 & $\mathrm{U}^{*}$ & 12 & $\mathrm{U}$ & 12 & $U$ & 12 & $\mathbf{U}$ & & \\
\hline Vinyl chloride & 12 & $U$ & 54 & & 13 & $\mathrm{U}^{*}$ & 12 & $U$ & 12 & $\mathbf{U}$ & 12 & $\mathrm{U}$ & & \\
\hline \multirow[t]{3}{*}{ Xylenes (total) } & 12 & U & 20 & $\underline{U^{*}}$ & 13 & $U^{*}$ & 12 & U & 12 & $\mathrm{U}$ & 12 & $\mathbf{U}$ & & \\
\hline & \multicolumn{14}{|c|}{ Sediment Concentrations $(\mu \mathrm{g} / \mathrm{kg})$ at Various Depth Intervals } \\
\hline & \multicolumn{2}{|c|}{$\begin{array}{l}\text { BOR5-4 } \\
(8-10 \mathrm{ft}) \\
\end{array}$} & \multicolumn{2}{|c|}{$\begin{array}{c}\text { BOR5-4Dup } \\
(8-10 \mathrm{ft})\end{array}$} & \multicolumn{2}{|c|}{$\begin{array}{c}\text { BOR6-1 } \\
(2-4 \mathrm{ft})\end{array}$} & \multicolumn{2}{|c|}{$\begin{array}{c}\text { BOR6-2 } \\
(4-6 \mathrm{ft})\end{array}$} & \multicolumn{2}{|c|}{$\begin{array}{c}\text { BOR6-3 } \\
(6-8 \mathrm{ft}) \\
\end{array}$} & \multicolumn{2}{|c|}{$\begin{array}{l}\text { BOR6-4 } \\
(8-10 \mathrm{ft})\end{array}$} & \multicolumn{2}{|c|}{$\begin{array}{l}\text { BOR7-1 } \\
(2-4 \mathrm{ft}) \\
\end{array}$} \\
\hline Acetone & 12 & $\mathrm{U}$ & 12 & U+ & 12 & $\mathbf{U}$ & 12 & $\mathrm{U}$ & 12 & $\mathbf{U}$ & 12 & $\mathrm{U}$ & 14 & U \\
\hline Benzene & 12 & $\mathbf{U}$ & 12 & Ut & 3 & $\mathbf{J}$ & 12 & $\mathrm{U}$ & 4 & $\mathbf{J}$ & 12 & $\mathrm{U}$ & 14 & $\mathrm{U}$ \\
\hline Bromodichloromethane & 12 & $\mathbf{U}$ & 12 & Ut & 12 & U & 12 & $\mathbf{U}$ & 12 & $\mathrm{U}$ & 12 & $\mathrm{U}$ & 14 & $\mathrm{U}$ \\
\hline Bromoform & 12 & $\mathbf{U}$ & 12 & $\mathrm{U}+$ & 12 & $\mathrm{U}$ & 12 & $\mathrm{U}$ & 12 & $\mathbf{U}$ & 12 & $\mathrm{U}$ & 14 & $\mathrm{U}$ \\
\hline Bromomethane & 12 & $\mathbf{U}$ & 12 & $\mathrm{U}_{+}$ & 12 & $\mathbf{U}$ & 12 & $\mathbf{U}$ & 12 & $U$ & 12 & $\mathrm{U}$ & 14 & $\mathrm{U}$ \\
\hline 2-Butanone & 12 & $\mathrm{U}$ & 12 & $\mathrm{U}_{+}$ & 12 & $\mathrm{U}^{*}$ & 12 & U & 12 & $\mathrm{U}$ & 12 & $\mathrm{U}$ & 14 & $\mathrm{U}$ \\
\hline Carbon disulfide & 12 & $\mathrm{U}$ & 12 & $U_{+}$ & 12 & $\mathbf{U}$ & 12 & $\mathrm{U}$ & 12 & $\mathrm{U}$ & 12 & $\mathrm{U}$ & 14 & U \\
\hline Carbon tetrachloride & 12 & $\mathbf{U}$ & 12 & $\mathrm{U}_{+}$ & 12 & $\mathrm{U}$ & 12 & U & 12 & $U$ & 12 & $\mathbf{U}$ & 14 & U \\
\hline Chlorobenzene & 12 & $\mathbf{U}$ & 12 & U+ & 12 & $U$ & 12 & $\mathrm{U}$ & 12 & $\mathrm{U}$ & 12 & $\mathbf{U}$ & 14 & $\mathrm{U}$ \\
\hline Chloroethane & 12 & $\mathbf{U}$ & 12 & $\mathrm{U}_{+}$ & 12 & U & 12 & $\mathrm{U}$ & 12 & $\mathrm{U}$ & 12 & $\mathbf{U}$ & 14 & U \\
\hline Chloroform & 12 & $\mathbf{U}$ & 12 & $u_{+}$ & 12 & $\mathrm{U}$ & 12 & $\mathrm{U}$ & 12 & $\mathrm{U}$ & 12 & $\mathrm{U}$ & 14 & U \\
\hline
\end{tabular}


TABLE C.7a (Cont.)

\begin{tabular}{|c|c|c|c|c|c|c|c|c|c|c|c|c|c|c|}
\hline \multirow{3}{*}{$\begin{array}{l}\text { Compound } \\
\text { Chloromethane }\end{array}$} & \multicolumn{14}{|c|}{ Sediment Concentrations $(\mu \mathrm{g} / \mathrm{kg})$ at Various Depth Intervals } \\
\hline & \multicolumn{2}{|c|}{$\begin{array}{l}\text { BOR5-4 } \\
(8-10 \mathrm{ft}) \\
\end{array}$} & \multicolumn{2}{|c|}{$\begin{array}{c}\text { BOR5-4Dup } \\
(8-10 \mathrm{ft}) \\
\end{array}$} & \multicolumn{2}{|c|}{$\begin{array}{l}\text { BOR6-1 } \\
(2-4 \mathrm{ft})\end{array}$} & \multicolumn{2}{|c|}{$\begin{array}{c}\text { BOR6-2 } \\
(4-6 \mathrm{ft})\end{array}$} & \multicolumn{2}{|c|}{$\begin{array}{l}\text { BOR6-3 } \\
(6-8 \mathrm{ft})\end{array}$} & \multicolumn{2}{|c|}{$\begin{array}{l}\text { BOR6-4 } \\
(8-10 \mathrm{ft})\end{array}$} & \multicolumn{2}{|c|}{$\begin{array}{l}\text { BOR7-1 } \\
(2-4 \mathrm{ft})\end{array}$} \\
\hline & 12 & $\mathrm{U}$ & 12 & $U_{+}$ & 12 & $\mathrm{U}$ & 12 & $\mathrm{U}$ & 12 & $\mathbf{U}$ & 12 & $\mathbf{U}$ & 14 & $\mathbf{U}$ \\
\hline Dibromochloromethane & 12 & $\mathrm{U}$ & 12 & $\mathrm{U}+$ & 12 & $\mathrm{U}$ & 12 & $\mathrm{U}$ & 12 & $\mathbf{U}$ & 12 & $\mathbf{U}$ & 14 & U \\
\hline 1,1-Dichloroethane & 12 & $\mathrm{U}$ & 12 & $\mathrm{U}_{+}$ & 12 & $\mathrm{U}$ & 12 & $\mathrm{U}$ & 12 & $\mathbf{U}$ & 12 & $\mathbf{U}$ & 14 & $\mathrm{U}$ \\
\hline 1,2-Dichloroethane & 12 & $\mathrm{U}$ & 12 & $U_{+}$ & 12 & $\mathbf{U}$ & 12 & $\mathbf{U}$ & 12 & $\mathrm{U}$ & 12 & $\mathrm{U}$ & 14 & $\mathrm{U}$ \\
\hline 1,1-Dichloroethene & 12 & $\mathrm{U}$ & 12 & $U_{+}$ & 12 & $\mathbf{U}$ & 12 & $\mathrm{U}$ & 12 & $\mathrm{U}$ & 12 & $U$ & 14 & $\mathrm{U}$ \\
\hline 1,2-Dichloroethene (total) & 12 & $\mathbf{U}$ & 12 & $U_{+}$ & 12 & $\mathbf{U}$ & 12 & $\mathbf{U}$ & 12 & $\mathrm{U}$ & 12 & $\mathrm{U}$ & 14 & U \\
\hline 1,2-Dichloropropane & 12 & $\mathrm{U}$ & 12 & U+ & 12 & $\mathbf{U}$ & 12 & $\mathbf{U}$ & 12 & $\mathrm{U}$ & 12 & $\mathrm{U}$ & 14 & U \\
\hline cis-1,3-Dichloropropene & 12 & $\mathbf{U}$ & 12 & $\mathrm{U}+$ & 12 & $\mathbf{U}$ & 12 & $\mathbf{U}$ & 12 & $\mathrm{U}$ & 12 & $U$ & 14 & U \\
\hline trans-1,3-Dichloropropene & 12 & $\mathbf{U}$ & 12 & $\mathrm{U}+$ & 12 & $\mathbf{U}$ & 12 & $\mathbf{U}$ & 12 & $\mathrm{U}$ & 12 & $U$ & 14 & U \\
\hline Ethylbenzene & 12 & $\mathbf{U}$ & 12 & $U_{+}$ & 12 & $\mathbf{U}$ & 12 & $\mathbf{U}$ & 12 & $\mathrm{U}$ & 12 & U & 14 & U \\
\hline 2-Hexanone & 12 & $\mathbf{U}$ & 12 & $\mathrm{U}_{+}$ & 12 & $\mathbf{U}$ & 12 & $\mathbf{U}$ & 12 & $\mathbf{U}$ & 12 & $U$ & 14 & U \\
\hline 4-Methyl-2-pentanone & 12 & $\mathrm{U}$ & 12 & $U_{+}$ & 12 & $U$ & 12 & $\mathbf{U}$ & 12 & $U$ & 12 & $\mathrm{U}$ & 14 & $\mathrm{U}$ \\
\hline Methylene chloride & 12 & $\mathrm{U}$ & 12 & Ut & 12 & $\mathrm{U}$ & 12 & $U$ & 12 & $\mathbf{U}$ & 12 & $\mathbf{U}$ & 14 & $\mathrm{U}$ \\
\hline Styrene & 12 & $\mathrm{U}$ & 12 & $\mathrm{U}+$ & 12 & $\mathrm{U}$ & 12 & $\mathbf{U}$ & 12 & $\mathrm{U}$ & 12 & $\mathbf{U}$ & 14 & $\mathrm{U}$ \\
\hline 1,1,2,2-Tetrachloroethane & 12 & $\mathbf{U}$ & 12 & $\mathrm{U}+$ & 12 & $\mathrm{U}$ & 12 & $\mathbf{U}$ & 12 & $\mathbf{U}$ & 12 & $\mathbf{U}$ & 14 & U \\
\hline Tetrachloroethene & 12 & $\mathrm{U}$ & 12 & $\mathrm{U}_{+}$ & 12 & $\mathrm{U}$ & 12 & $\mathrm{U}$ & 12 & $\mathbf{U}$ & 12 & $\mathbf{U}$ & 14 & U \\
\hline Toluene & 12 & $\mathrm{U}$ & 12 & $U_{+}$ & 12 & $\mathrm{U}$ & 12 & $\mathrm{U}$ & 12 & $\mathbf{U}$ & 12 & $\mathrm{U}$ & 14 & $U$ \\
\hline 1,1,1-Trichlorocthane & 12 & $U$ & 12 & $\mathrm{U}_{+}$ & 12 & $\mathbf{U}$ & 12 & $U$ & 12 & $U$ & 12 & $\mathbf{U}$ & 14 & $\mathrm{U}$ \\
\hline 1,1,2-Trichloroethane & 12 & $\mathrm{U}$ & 12 & $\mathrm{U}_{+}$ & 12 & $\mathrm{U}$ & 12 & $\mathrm{U}$ & 12 & $\mathrm{U}$ & 12 & U & 14 & $\mathrm{U}$ \\
\hline Trichloroethene & 12 & $\mathrm{U}$ & 12 & U+ & 12 & $\mathrm{U}$ & 12 & $\mathrm{U}$ & 12 & $\mathrm{U}$ & 12 & U & 14 & U \\
\hline Vinyl chloride & 12 & $\mathbf{U}$ & 12 & $U_{+}$ & 12 & $\mathrm{U}$ & 12 & $\mathbf{U}$ & 12 & $\mathrm{U}$ & 12 & $U$ & 14 & $\mathrm{U}$ \\
\hline Xylenes (total) & 12 & U & 12 & Ut & 12 & U & 12 & U & 12 & $\mathrm{U}$ & 12 & U & 14 & $\mathrm{U}$ \\
\hline
\end{tabular}


TABLE C.7a (Cont.)

\begin{tabular}{|c|c|c|c|c|c|c|c|c|c|c|c|c|c|c|c|c|c|c|}
\hline \multirow{3}{*}{$\begin{array}{l}\text { Compound } \\
\text { Acetone }\end{array}$} & \multicolumn{18}{|c|}{ Sediment Concentrations ( $\mu \mathrm{g} / \mathrm{kg}$ ) at Various Depth Intervals } \\
\hline & \multicolumn{2}{|c|}{$\begin{array}{c}\text { BOR7-2 } \\
(4-6 \mathrm{ft})\end{array}$} & \multicolumn{2}{|c|}{$\begin{array}{l}\text { BOR7-3 } \\
(6-8 \mathrm{ft})\end{array}$} & \multicolumn{2}{|c|}{$\begin{array}{l}\text { BOR7-4 } \\
(8-10 \mathrm{ft})\end{array}$} & \multicolumn{2}{|c|}{$\begin{array}{l}\text { BOR8-1 } \\
(0-2 \mathrm{ft})\end{array}$} & \multicolumn{2}{|c|}{$\begin{array}{l}\text { BOR8-2 } \\
(2-4 \mathrm{ft})\end{array}$} & \multicolumn{2}{|c|}{$\begin{array}{l}\text { BOR8-3 } \\
(4-6 \mathrm{ft})\end{array}$} & \multicolumn{2}{|c|}{$\begin{array}{l}\text { BOR8-3Dup } \\
(4-6 \mathrm{ft})\end{array}$} & \multicolumn{2}{|c|}{$\begin{array}{l}\text { BOR8-4 } \\
(6-8 \mathrm{ft})\end{array}$} & \multicolumn{2}{|c|}{$\begin{array}{l}\text { BOR8-5 } \\
(8-10 \mathrm{ft})\end{array}$} \\
\hline & 12 & $\mathrm{U}$ & 12 & $\mathbf{U}$ & 1,100 & B & 20 & B & 12 & $U$ & 17 & B & 23 & B & 20 & $\mathrm{~B}$ & 88 & B \\
\hline Benzene & 12 & $\mathrm{U}$ & 12 & U & 12 & $\mathbf{U}$ & 13 & $\mathbf{U}$ & 12 & $\mathrm{U}$ & 12 & $U$ & 12 & $\mathbf{U}$ & 12 & $U$ & 12 & $\mathrm{U}$ \\
\hline Bromodichloromethane & 12 & $\mathrm{U}$ & 12 & $\mathrm{U}$ & 12 & $\mathrm{U}$ & 13 & $\mathbf{U}$ & 12 & $U$ & 12 & $\mathrm{U}$ & 12 & $U$ & 12 & $\mathrm{U}$ & 12 & U \\
\hline Bromoform & 12 & $\mathrm{U}$ & 12 & $\mathbf{U}$ & 12 & $\mathbf{U}$ & 13 & $\mathbf{U}$ & 12 & 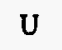 & 12 & $\mathrm{U}$ & 12 & U & 12 & $U$ & 12 & U \\
\hline Bromomethane & 12 & $\mathbf{U}$ & $' 12$ & $\mathrm{U}$ & 12 & $\mathrm{U}$ & 13 & $\mathbf{U}$ & 12 & $U$ & 12 & $\mathrm{U}$ & 12 & $\mathrm{U}$ & 12 & $U$ & 12 & $\mathbf{U}$ \\
\hline 2-Butanone & 12 & $\mathbf{U}$ & 12 & $\mathbf{U}$ & 180 & & 13 & $\mathbf{U}$ & 12 & $\mathrm{U}$ & 12 & $U$ & 12 & $\mathrm{U}$ & 12 & $\mathrm{U}$ & 12 & $\mathbf{U}$ \\
\hline Carbon disulfide & 12 & $\mathrm{U}$ & 12 & U & 12 & $\mathrm{U}$ & 13 & $\mathrm{U}$ & 12 & $\mathrm{U}$ & 12 & $\mathrm{U}$ & 12 & $\mathrm{U}$ & 12 & $\mathbf{U}$ & 12 & $\mathbf{U}$ \\
\hline Carbon tetrachloride & 12 & $\mathbf{U}$ & 12 & $\mathrm{U}$ & 12 & $\mathbf{U}$ & 13 & $\mathbf{U}$ & 12 & $\mathbf{U}$ & 12 & $\mathbf{U}$ & 12 & U & 12 & $\mathbf{U}$ & 12 & $\mathrm{U}$ \\
\hline Chlorobenzene & 12 & $\mathrm{U}$ & 12 & $U$ & 12 & $\mathrm{U}$ & 13 & $\mathrm{U}$ & 12 & U & 12 & $\mathbf{U}$ & 12 & $\mathrm{U}$ & 12 & $\mathbf{U}$ & 12 & $\mathbf{u}$ \\
\hline Chloroethane & 12 & $U$ & 12 & $\mathrm{U}$ & 12 & $\mathrm{U}$ & 13 & $\mathrm{U}$ & 12 & $\mathbf{U}$ & 12 & $\mathbf{U}$ & 12 & $\mathrm{U}$ & 12 & $\mathbf{U}$ & 12 & $\mathrm{U}$ \\
\hline Chloroform & 12 & $\mathrm{U}$ & 12 & U & 12 & $\mathbf{U}$ & 13 & $\mathrm{U}$ & 12 & $\mathbf{U}$ & 12 & $\mathbf{U}$ & 12 & $\mathbf{U}$ & 12 & $\mathbf{U}$ & 12 & U \\
\hline Chloromethane & 12 & $\mathrm{U}$ & 12 & $\mathrm{U}$ & 12 & $U$ & 13 & $\mathbf{U}$ & 12 & $\mathbf{U}$ & 12 & $\mathrm{U}$ & 12 & $\mathbf{U}$ & 12 & $\mathbf{U}$ & 12 & $\mathrm{U}$ \\
\hline Dibromochloromethane & 12 & $\mathrm{U}$ & 12 & $\mathbf{U}$ & 12 & $\mathbf{U}$ & 13 & $\mathbf{U}$ & 12 & $\mathbf{U}$ & 12 & $\mathrm{U}$ & 12 & $\mathbf{U}$ & 12 & $\mathbf{U}$ & 12 & U \\
\hline 1,1-Dichloroethane & 12 & $\mathbf{U}$ & 12 & $\mathbf{U}$ & 12 & $\mathbf{U}$ & 13 & $\mathbf{U}$ & 12 & $\mathrm{U}$ & 12 & $\mathrm{U}$ & 12 & $\mathbf{U}$ & 12 & $U$ & 12 & $\mathrm{U}$ \\
\hline 1,2-Dichloroethane & 12 & $\mathbf{U}$ & 12 & $\mathbf{U}$ & 12 & $\mathbf{U}$ & 13 & $\mathrm{U}$ & 12 & $\mathrm{U}$ & 12 & $\mathrm{U}$ & 12 & $\mathbf{U}$ & 12 & $\mathrm{U}$ & 12 & $\mathrm{U}$ \\
\hline 1,1-Dichloroethene & 12 & $\mathbf{U}$ & 12 & $\mathrm{U}$ & 12 & $\mathbf{U}$ & 13 & $\mathbf{U}$ & 12 & $\mathrm{U}$ & 12 & $\mathrm{U}$ & 12 & $\mathbf{U}$ & 12 & $U$ & 12 & $\mathbf{U}$ \\
\hline 1,2-Dichloroethene (total) & 12 & U & 12 & $\mathrm{U}$ & 12 & $\mathrm{U}$ & 13 & $\mathbf{U}$ & 12 & $\mathrm{U}$ & 12 & $\mathrm{U}$ & 12 & $\mathrm{U}$ & 12 & $\mathrm{U}$ & 12 & $\mathrm{U}$ \\
\hline 1,2-Dichloropropane & 12 & $\mathrm{U}$ & 12 & $\mathbf{U}$ & 12 & $\mathrm{U}$ & 13 & $\mathbf{U}$ & 12 & $\mathrm{U}$ & 12 & $\mathbf{U}$ & 12 & $\mathrm{U}$ & 12 & $\mathrm{U}$ & 12 & $\mathbf{U}$ \\
\hline cis-1,3-Dichloropropene & 12 & $\mathbf{U}$ & 12 & $\mathrm{U}$ & 12 & $\mathrm{U}$ & 12 & $U$ & 12 & $\mathrm{U}$ & 12 & $\mathbf{U}$ & 12 & U & 12 & $\mathbf{U}$ & 12 & U \\
\hline trans-1,3-Dichloropropene & 12 & $\mathrm{U}$ & 12 & $\mathrm{U}$ & 12 & $\mathbf{U}$ & 13 & $\mathrm{U}$ & 12 & $\mathbf{U}$ & 12 & $\mathbf{U}$ & 12 & $\mathrm{U}$ & 12 & $\mathbf{U}$ & 12 & $\mathbf{U}$ \\
\hline Ethylbenzene & 12 & U & 12 & $\mathrm{U}$ & 12 & U & 13 & $\mathrm{U}$ & 12 & $\mathbf{U}$ & 12 & $\mathbf{U}$ & 12 & $U$ & 12 & $\mathbf{U}$ & 12 & $\mathbf{U}$ \\
\hline 2-Hexanone & 12 & $\mathrm{U}$ & 12 & $\mathrm{U}$ & 12 & $\mathrm{U}$ & 13 & $\mathrm{U}$ & 12 & $\mathbf{U}$ & 12 & $\mathrm{U}$ & 12 & $\mathbf{U}$ & 12 & $\mathbf{U}$ & 12 & $\mathbf{U}$ \\
\hline 4-Methyl-2-pentanone & 12 & $\mathrm{U}$ & 12 & $\mathrm{U}$ & 12 & $\mathrm{U}$ & 13 & $U$ & 12 & $\mathrm{U}$ & 12 & $\mathrm{U}$ & 12 & $\mathbf{U}$ & 12 & $\mathbf{U}$ & 12 & $\mathbf{U}$ \\
\hline Methylene chloride & 12 & $\mathrm{U}$ & 12 & $\mathbf{U}$ & 12 & $\mathrm{U}$ & 13 & $\mathrm{U}$ & 12 & $\mathbf{U}$ & 12 & $\mathbf{U}$ & 12 & $\mathbf{U}$ & 12 & $\mathbf{U}$ & 12 & U \\
\hline Styrene & 12 & $\mathrm{U}$ & 12 & $\mathrm{U}$ & 12 & $\mathbf{U}$ & 13 & $U$ & 12 & $\mathrm{U}$ & 12 & $U$ & 12 & $\mathbf{U}$ & 12 & $\mathrm{U}$ & 12 & $\mathrm{U}$ \\
\hline 1,1,2,2-Tetrachloroethane & 12 & $\mathbf{U}$ & 12 & $\mathbf{U}$ & 12 & $\mathbf{U}$ & 13 & $\mathbf{U}$ & 12 & $\mathrm{U}$ & 12 & $\mathrm{U}$ & 12 & $\mathbf{U}$ & 12 & $\mathrm{U}$ & 12 & U \\
\hline Tetrachloroethene & 12 & $\mathbf{U}$ & 12 & $\mathbf{U}$ & 12 & $\mathbf{U}$ & 13 & $\mathbf{U}$ & 12 & U & 12 & $\mathrm{U}$ & 12 & $\mathbf{U}$ & 12 & $\mathrm{U}$ & 12 & $\mathrm{U}$ \\
\hline Toluene & 12 & $\mathbf{U}$ & 12 & $\mathbf{U}$ & 12 & $\mathrm{U}$ & 13 & $\mathbf{U}$ & 12 & $\mathrm{U}$ & 12 & $\mathrm{U}$ & 12 & $\mathrm{U}$ & 12 & U & 12 & $\mathbf{U}$ \\
\hline
\end{tabular}


TABLE C.7a (Cont.)

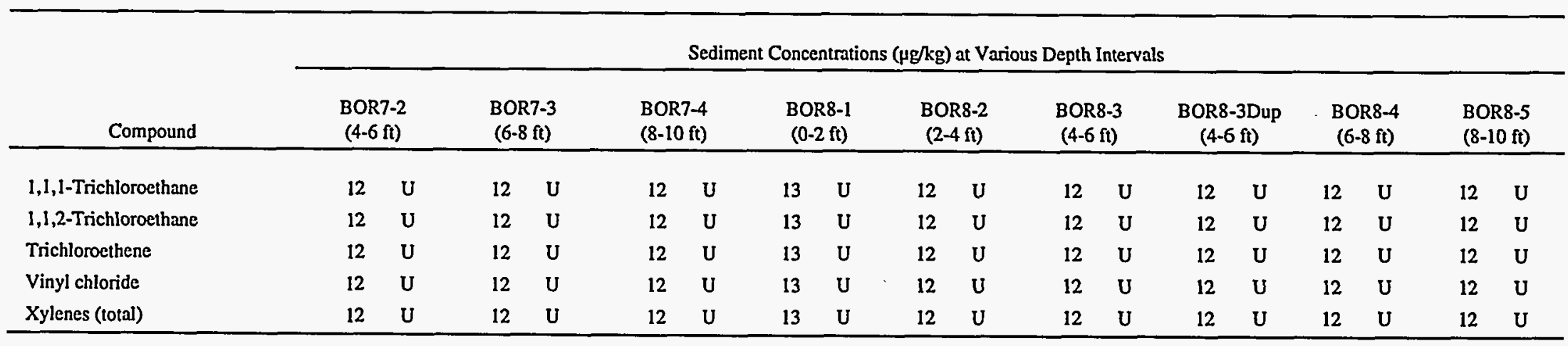

a Sampled by ANL, analyzed by Weston Gulf Coast, CLP/HSL volatile organics. Data qualifiers:

$\mathrm{U}=$ analyte was analyzed for but not detected; detection limit given.

$B=$ analyte found in associated blank.

* = internal standard area counts are outside QC limits.

$\mathrm{J}=$ estimated value.

+ = surrogate recoveries were outside QC limit(s). 
TABLE C.7b Volatile Organics Analyses for Sediment Borings, June $1995^{\mathfrak{a}}$

\begin{tabular}{|c|c|c|c|c|c|c|c|c|c|c|c|c|c|c|c|c|}
\hline \multirow{3}{*}{$\begin{array}{l}\text { Compound } \\
\text { Acetone }\end{array}$} & \multicolumn{16}{|c|}{ Sediment Concentrations $(\mu \mathrm{g} / \mathrm{kg})$ at $0-6 \mathrm{in}$. } \\
\hline & \multicolumn{2}{|c|}{ TPSED 1} & \multicolumn{2}{|c|}{ TPSED 2} & \multicolumn{2}{|c|}{ TPSED 3} & \multicolumn{2}{|c|}{ TPSED 4} & \multicolumn{2}{|c|}{ TPSED 5} & \multicolumn{2}{|c|}{ TPSED 6} & \multicolumn{2}{|c|}{ TPSED 7} & \multicolumn{2}{|c|}{ TPSED 8} \\
\hline & 61 & & 170 & & 200 & & 120 & & 20 & $U$ & 22 & $\mathrm{U}$ & 2 & & 14 & $\mathrm{U}$ \\
\hline Benzene & 32 & $\mathrm{U}$ & 17 & $\mathrm{U}$ & 24 & $\mathrm{U}$ & 24 & $\mathbf{U}$ & 20 & $U$ & 22 & $U$ & 15 & $\mathrm{U}$ & 14 & $\mathrm{U}$ \\
\hline Bromodichloromethane & 32 & $\mathrm{U}$ & 17 & $\mathrm{U}$ & 24 & $U$ & 24 & $\mathrm{U}$ & 20 & $U$ & 22 & $\mathrm{U}$ & 15 & $U$ & 14 & $\mathrm{U}$ \\
\hline Bromoform & 32 & $\mathrm{U}$ & 17 & $\mathrm{U}$ & 24 & $\mathrm{U}$ & 24 & $\mathrm{U}$ & 20 & $U$ & 22 & $U$ & 15 & $U$ & 14 & $\mathrm{U}$ \\
\hline Bromomethane & 32 & $\mathrm{U}$ & 17 & $\mathrm{U}$ & 24 & $\mathrm{U}$ & 24 & $\mathrm{U}$ & 20 & $U$ & 22 & $U$ & 15 & $U$ & 14 & $U$ \\
\hline 2-Butanone & 32 & $\mathrm{U}$ & 17 & $\mathrm{U}$ & 24 & $\mathrm{U}$ & 200 & & 20 & $U$ & 22 & $U$ & 15 & $\mathrm{U}$ & 14 & $U$ \\
\hline Carbon disulfide & 32 & $\mathrm{U}$ & 17 & $\mathrm{U}$ & 24 & $U$ & 24 & $\mathrm{U}$ & 20 & $\mathrm{U}$ & 22 & $\mathrm{U}$ & 15 & $U$ & 14 & $U$ \\
\hline Carbon tetrachloride & 32 & $U$ & 17 & $\mathrm{U}$ & 24 & $U$ & 24 & $\mathrm{U}$ & 20 & $\mathrm{U}$ & 22 & $\mathrm{U}$ & 15 & $\mathrm{U}$ & 14 & $U$ \\
\hline Chlorobenzene & 32 & $\mathbf{U}$ & 17 & $\mathrm{U}$ & 24 & $U$ & 24 & $\mathrm{U}$ & 20 & $\mathrm{U}$ & 22 & $\mathrm{U}$ & 15 & $\mathrm{U}$ & 14 & $\mathrm{U}$ \\
\hline Chloroethane & 32 & $U$ & 17 & $\mathrm{U}$ & 24 & $U$ & 24 & $\mathrm{U}$ & 20 & $U$ & 22 & $\mathrm{U}$ & 15 & $\mathrm{U}$ & 14 & $U$ \\
\hline Chloroform & 32 & $\mathrm{U}$ & 17 & $U$ & 24 & $\mathrm{U}$ & 24 & $\mathrm{U}$ & 20 & $\mathrm{U}$ & 22 & $\mathrm{U}$ & 15 & $U$ & 14 & $\mathrm{U}$ \\
\hline Chloromethane & 32 & $\mathrm{U}$ & 17 & $U$ & 24 & $U$ & 24 & $\mathrm{U}$ & 20 & $\mathrm{U}$ & 22 & $\mathrm{U}$ & 15 & $U$ & 14 & $\mathrm{U}$ \\
\hline Dibromochloromethane & 32 & $U$ & 17 & $\mathrm{U}$ & 24 & $U$ & 24 & $\mathrm{U}$ & 20 & $\mathrm{U}$ & 22 & $\mathrm{U}$ & 15 & $U$ & 14 & $U$ \\
\hline 1,1-Dichloroethane & 32 & $\mathrm{U}$ & 17 & $\mathrm{U}$ & 24 & $\mathrm{U}$ & 24 & $\mathrm{U}$ & 20 & $U$ & 22 & $\mathrm{U}$ & 15 & $U$ & 14 & $\mathrm{U}$ \\
\hline 1,2-Dichloroethane & 32 & $\mathrm{U}$ & 17 & $U$ & 24 & $U$ & 24 & $U$ & 20 & $\mathrm{U}$ & 22 & $\mathrm{U}$ & 3 & & 14 & $U$ \\
\hline 1,1-Dichloroethene & 32 & $\mathrm{U}$ & 17 & $U$ & 24 & $\mathrm{U}$ & 24 & $U$ & 20 & $\mathrm{U}$ & 22 & $\mathrm{U}$ & 15 & $\mathrm{U}$ & 14 & $\mathrm{U}$ \\
\hline 1,2-Dichloroethene (total) & 32 & $\mathrm{U}$ & 72 & & 45 & & 24 & $U$ & 20 & U & 22 & $U$ & 4 & & 14 & $\mathrm{U}$ \\
\hline 1,2-Dichloropropane & 32 & $\mathrm{U}$ & 17 & $\mathrm{U}$ & 24 & $\mathrm{U}$ & 24 & $U$ & 20 & $U$ & 22 & $U$ & 15 & $\mathrm{U}$ & 14 & $\mathrm{U}$ \\
\hline cis-1,3-Dichloropropene & 32 & $\mathrm{U}$ & 17 & $\mathrm{U}$ & 24 & $\mathrm{U}$ & 24 & $\mathrm{U}$ & 20 & $\mathrm{U}$ & 22 & $U$ & 15 & $\mathrm{U}$ & 14 & $\mathrm{U}$ \\
\hline trans-1,3-Dichloropropene & 32 & $U$ & 17 & $\mathrm{U}$ & 24 & $\mathrm{U}$ & 24 & $\mathrm{U}$ & 20 & $\mathrm{U}$ & 22 & $\mathrm{U}$ & 15 & $\mathrm{U}$ & 14 & $\mathrm{U}$ \\
\hline Ethyl benzene & 32 & U & 17 & $\mathrm{U}$ & 24 & $U$ & 24 & $\mathrm{U}$ & 20 & $U$ & 22 & $\mathrm{U}$ & 15 & $\mathrm{U}$ & 14 & $\mathrm{U}$ \\
\hline 2-Hexanone & 32 & $\mathrm{U}$ & 17 & $\mathrm{U}$ & 24 & $\mathrm{U}$ & 24 & $\mathrm{U}$ & 20 & $\mathrm{U}$ & 22 & $\mathrm{U}$ & 3 & & 14 & $U$ \\
\hline 4-Methyl-2-pentanone & 32 & $U$ & 17 & $\mathrm{U}$ & 24 & $\mathrm{U}$ & 24 & $\mathrm{U}$ & 20 & $\mathrm{U}$ & 22 & $\mathrm{U}$ & 2 & & 14 & $\mathrm{U}$ \\
\hline Methylene chloride & 32 & $U$ & 5 & $\mathrm{BJ}$ & 24 & $\mathrm{U}$ & 13 & & 6 & $\mathrm{BJ}$ & 13 & & 9 & & 7 & \\
\hline
\end{tabular}


TABLE C.7b (Cont.)

Sediment Concentrations $(\mu \mathrm{g} / \mathrm{kg})$ at $0-6$ in.

\begin{tabular}{|c|c|c|c|c|c|c|c|c|c|c|c|c|c|c|c|c|}
\hline \multirow[t]{2}{*}{ Compound } & \multicolumn{2}{|c|}{ TPSED 1} & \multicolumn{2}{|c|}{ TPSED 2} & \multicolumn{2}{|c|}{ TPSED 3} & \multicolumn{2}{|c|}{ TPSED 4} & \multicolumn{2}{|c|}{ TPSED 5} & \multicolumn{2}{|c|}{ TPSED 6} & \multicolumn{2}{|c|}{ TPSED 7} & \multicolumn{2}{|c|}{ TPSED 8} \\
\hline & 32 & $\mathrm{U}$ & 17 & $\mathrm{U}$ & 24 & $U$ & 24 & $U$ & 20 & $\mathrm{U}$ & 22 & $U$ & 15 & $\mathrm{U}$ & 14 & $\mathrm{U}$ \\
\hline 1,1,2,2-Tetrachloroethane & 32 & $\mathrm{U}$ & 17 & U & 23 & $\mathbf{J}$ & 24 & $\mathrm{U}$ & 20 & $\mathrm{U}$ & 22 & $\mathrm{U}$ & 6 & & 14 & $\mathrm{U}$ \\
\hline Tetrachloroethene & 32 & $\mathrm{U}$ & 17 & $\mathrm{U}$ & 24 & $U$ & 24 & $\mathrm{U}$ & 20 & $\mathrm{U}$ & 22 & $\mathrm{U}$ & 15 & $\mathrm{U}$ & 14 & $\mathrm{U}$ \\
\hline Toluene & 32 & $\mathrm{U}$ & 2 & $\mathrm{~J}$ & 24 & $U$ & 7 & & 20 & $\mathrm{U}$ & 22 & $\mathrm{U}$ & 15 & $\mathrm{U}$ & 14 & $\mathrm{U}$ \\
\hline 1,1,1-Trichloroethane & 32 & $\mathrm{U}$ & 17 & $\mathrm{U}$ & 24 & $U$ & 24 & $\mathrm{U}$ & 20 & $\mathrm{U}$ & 22 & $\mathbf{U}$ & 15 & $\mathrm{U}$ & 14 & $\mathrm{U}$ \\
\hline 1,1,2-Trichloroethane & 32 & $\mathrm{U}$ & 17 & $\mathrm{U}$ & 4 & $J$ & 24 & $\mathrm{U}$ & 20 & $U$ & 22 & $\mathrm{U}$ & 9 & & 14 & U \\
\hline Trichloroethene & 32 & $\mathrm{U}$ & 11 & $\mathbf{J}$ & 29 & & 24 & $\mathrm{U}$ & 20 & $U$ & 22 & $\mathrm{U}$ & 15 & & 14 & $\mathrm{U}$ \\
\hline Vinyl chloride & 32 & $U$ & 54 & & 18 & $\mathrm{~J}$ & 24 & $\mathrm{U}$ & 20 & $\mathrm{U}$ & 22 & $\mathbf{U}$ & 15 & $\mathrm{U}$ & 14 & $\mathrm{U}$ \\
\hline Xylenes (total) & 32 & $U$ & 17 & $U$ & 24 & U & 24 & $\mathrm{U}$ & 20 & $\mathrm{U}$ & 22 & $\mathrm{U}$ & 15 & $U$ & 14 & $\mathrm{U}$ \\
\hline
\end{tabular}

a Sampled by ANL and analyzed by GP Environmental Services.

Data qualifiers:

$\mathrm{U}$ = analyte was analyzed for but not detected; detection limit given.

$\mathrm{B}=$ analyte was found in the associated blank.

$\mathrm{J}=$ estimated value. 
TABLE C.8a Semivolatile Organics Analyses for Sediment Borings, April 1994a

\begin{tabular}{|c|c|c|c|c|c|c|c|c|c|c|c|c|}
\hline \multirow{3}{*}{$\begin{array}{l}\text { Compound } \\
\text { Acenaphthene }\end{array}$} & \multicolumn{12}{|c|}{ Sediment Concentrations $(\mu \mathrm{g} / \mathrm{kg}$ ) at Various Depth Intervals } \\
\hline & \multicolumn{2}{|c|}{$\begin{array}{l}\text { BOR1-1 } \\
(6-8 \mathrm{ft})\end{array}$} & \multicolumn{2}{|c|}{$\begin{array}{l}\text { BOR1-2 } \\
(8-10 \mathrm{ft})\end{array}$} & \multicolumn{2}{|c|}{$\begin{array}{c}\text { BOR1-3 } \\
(10-12 \mathrm{ft})\end{array}$} & \multicolumn{2}{|c|}{$\begin{array}{c}\text { BOR2-1 } \\
(3-5 \mathrm{ft})\end{array}$} & \multicolumn{2}{|c|}{$\begin{array}{l}\text { BOR2-2 } \\
(5-8 \mathrm{ft})\end{array}$} & \multicolumn{2}{|c|}{$\begin{array}{l}\text { BOR2-3 } \\
\text { (8-10 ft) }\end{array}$} \\
\hline & 480 & $\mathrm{U}$ & 440 & $\mathrm{U}$ & 410 & $\mathbf{U}$ & 850 & $\mathbf{U}$ & 460 & $\mathrm{U}$ & 400 & $\mathrm{U}$ \\
\hline Acenaphthylene & 480 & $\mathrm{U}$ & 440 & U & 410 & $\mathrm{U}$ & 850 & $\mathbf{U}$ & 460 & $\mathbf{U}$ & 400 & $\mathrm{U}$ \\
\hline Anthracene & 480 & $\mathrm{U}$ & 440 & $\mathrm{U}$ & 410 & $\mathbf{U}$ & 850 & $U$ & 460 & U & 400 & $\mathrm{U}$ \\
\hline Benz[a]anthracene & 480 & $\mathrm{U}$ & 440 & U & 410 . & $\mathrm{U}$ & 850 & $\mathrm{U}$ & 460 & $\mathrm{U}$ & 400 & $\mathrm{U}$ \\
\hline Benzo[a]pyrene & 480 & $\mathrm{U}$ & 440 & $\mathrm{U}$ & 410 & $\mathrm{U}$ & 850 & $\mathrm{U}$ & 460 & $\mathrm{U}$ & 400 & $\mathrm{U}$ \\
\hline Benzo[b]fluoranthene & 480 & $\mathrm{U}$ & 440 & U & 410 & $\mathrm{U}$ & 850 & $\mathrm{U}$ & 460 & $U$ & 400 & U \\
\hline Benzo[g,h,i]perylene & 480 & U & 440 & $\mathrm{U}$ & 410 & $\mathrm{U}$ & 850 & $\mathbf{U}$ & 460 & $U$ & 400 & $\mathrm{U}$ \\
\hline Benzo[k]fluoranthene & 480 & $\mathrm{U}$ & 440 & $\mathrm{U}$ & 410 & $U$ & 850 & $U$ & 460 & $\mathbf{U}$ & 400 & $\mathrm{U}$ \\
\hline Bis(2-chloroethoxy)methane & 480 & $\mathrm{U}$ & 440 & $\mathrm{U}$ & 410 & $\mathrm{U}$ & 850 & $\mathbf{U}$ & 460 & $U$ & 400 & $\mathrm{U}$ \\
\hline Bis(2-chloroethyl)ether & 480 & $U$ & 440 & $U$ & 410 & $\mathrm{U}$ & 850 & $\mathbf{U}$ & 460 & $\mathrm{U}$ & 400 & $\mathrm{U}$ \\
\hline Bis(2-chloroisopropyl)ether & 480 & $\mathrm{U}$ & 440 & $\mathrm{U}$ & 410 & $\mathrm{U}$ & 850 & U & 460 & U & 400 & $\mathrm{U}$ \\
\hline Bis(2-ethylhexyl)phthalate & 180 & J & 78 & $\mathbf{J}$ & 140 & $\mathbf{J}$ & 46 & J & 140 & $\mathbf{J}$ & 43 & $\mathbf{J}$ \\
\hline 4-Bromophenyl phenyl ether & 480 & $\mathrm{U}$ & 440 & $\mathbf{U}$ & 410 & $\mathrm{U}$ & 850 & $\mathrm{U}$ & 460 & $U$ & 400 & $\mathrm{U}$ \\
\hline Butylbenzylphthalate & 480 & $\mathrm{U}$ & 440 & $\mathrm{U}$ & 410 & $\mathbf{U}$ & 850 & $\mathrm{U}$ & 460 & $\mathrm{U}$ & 400 & $\mathrm{U}$ \\
\hline Carbazole & 480 & $\mathbf{U}$ & 440 & $\mathbf{U}$ & 410 & $\mathrm{U}$ & 850 & $\mathbf{U}$ & 460 & $\mathrm{U}$ & 400 & $\mathbf{U}$ \\
\hline 4-Chloro-3-methylphenol & 480 & $\mathrm{U}$ & 440 & $\mathbf{U}$ & 410 & $\mathbf{U}$ & 850 & $\mathrm{U}$ & 460 & $\mathbf{U}$ & 400 & $U$ \\
\hline 4-Chloroaniline & 480 & U & 440 & $\mathrm{U}$ & 410 & $\mathrm{U}$ & 850 & $\mathbf{U}$ & 460 & U & 400 & $\mathbf{U}$ \\
\hline 2-Chloronaphthalene & 480 & $\mathrm{U}$ & 440 & U & 410 & $\mathrm{U}$ & 850 & $\mathbf{U}$ & 460 & U & 400 & $\mathrm{U}$ \\
\hline 2-Chlorophenol & 480 & $\mathbf{U}$ & 440 & $\mathrm{U}$ & 410 & $\mathrm{U}$ & 850 & U & 460 & $\mathbf{U}$ & 400 & $\mathbf{U}$ \\
\hline 4-Chlorophenyl phenyl ether & 480 & $\mathbf{U}$ & 440 & $\mathbf{U}$ & 410 & $\mathbf{U}$ & 850 & $\mathbf{U}$ & 460 & $U$ & 400 & $\mathbf{U}$ \\
\hline Chrysene & 480 & $\mathrm{U}$ & 440 & $\mathbf{U}$ & 410 & $\mathrm{U}$ & 850 & $\mathbf{U}$ & 460 & $\mathbf{U}$ & 400 & $\mathrm{U}$ \\
\hline Di-n-butylphthalate & 150 & $\mathbf{J}$ & 130 & J & 120 & $\mathrm{~J}$ & 260 & J & 140 & $\mathbf{J}$ & 130 & $\mathbf{J}$ \\
\hline Di-n-octyl phthalate & 480 & $\mathbf{U}$ & 440 & $\mathrm{U}$ & 410 & $\mathbf{U}$ & 850 & $\mathrm{U}$ & 460 & $\mathrm{U}$ & 400 & $\mathrm{U}$ \\
\hline Dibenz[a,h]anthracene & 480 & $\mathrm{U}$ & 440 & $\mathbf{U}$ & 410 & $\mathrm{U}$ & 850 & $U$ & 460 & $\mathbf{U}$ & 400 & $U$ \\
\hline Dibenzofuran & 480 & $\mathrm{U}$ & 440 & $\mathbf{U}$ & 410 & U & 850 & $U$ & 460 & $U$ & 400 & $\mathbf{U}$ \\
\hline 1,2-Dichlorobenzene & 480 & $\mathbf{U}$ & 440 & $\mathrm{U}$ & 410 & $\mathbf{U}$ & 850 & $\mathrm{U}$ & 460 & U & 400 & $\mathrm{U}$ \\
\hline 1,3-Dichlorobenzene & 480 & $\mathbf{U}$ & 440 & $\mathbf{U}$ & 410 & $\mathrm{U}$ & 850 & $U$ & 460 & $\mathrm{U}$ & 400 & $\mathrm{U}$ \\
\hline 1,4-Dichlorobenzene & 480 & $\mathrm{U}$ & 440 & $\mathbf{U}$ & 410 & $\mathbf{U}$ & 850 & $\mathbf{U}$ & 460 & U & 400 & U \\
\hline
\end{tabular}


TABLE C.8a (Cont.)

\begin{tabular}{|c|c|c|c|c|c|c|c|c|c|c|c|c|}
\hline \multirow{3}{*}{$\begin{array}{l}\text { Compound } \\
\text { lorobenzidine }\end{array}$} & \multicolumn{12}{|c|}{ Sediment Concentrations $(\mu \mathrm{g} / \mathrm{kg}$ ) at Various Depth Intervals } \\
\hline & \multicolumn{2}{|c|}{$\begin{array}{c}\text { BOR1-1 } \\
(6-8 \mathrm{ft})\end{array}$} & \multicolumn{2}{|c|}{$\begin{array}{l}\text { BORl-2 } \\
(8-10 \mathrm{ft}) \\
\end{array}$} & \multicolumn{2}{|c|}{$\begin{array}{c}\text { BOR1-3 } \\
(10-12 \mathrm{ft})\end{array}$} & \multicolumn{2}{|c|}{$\begin{array}{c}\text { BOR2-1 } \\
(3-5 \mathrm{ft})\end{array}$} & \multicolumn{2}{|c|}{$\begin{array}{c}\text { BOR2-2 } \\
(5-8 \mathrm{ft})\end{array}$} & \multicolumn{2}{|c|}{$\begin{array}{l}\text { BOR2-3 } \\
(8-10 \mathrm{ft})\end{array}$} \\
\hline & 480 & $\mathrm{U}$ & 440 & $\mathrm{U}$ & 410 & $\mathbf{U}$ & 850 & $\mathrm{U}$ & 460 & $\mathrm{U}$ & 400 & $\mathrm{U}$ \\
\hline 2,4-Dichlorophenol & 480 & $\mathrm{U}$ & 440 & $U$ & 410 & $\mathbf{U}$ & 850 & $\mathbf{U}$ & 460 & $\mathbf{U}$ & 400 & $\mathrm{U}$ \\
\hline Diethylphthalate & 480 & $U$ & 440 & U & 410 & $\mathbf{U}$ & 850 & $\mathrm{U}$ & 460 & $\mathrm{U}$ & 400 & $\mathrm{U}$ \\
\hline Dimethylphthalate & 480 & $\mathbf{U}$ & 440 & $\mathrm{U}$ & 410 & $\mathrm{U}$ & 850 & $\mathrm{U}$ & 460 & $\mathrm{U}$ & 400 & $\mathrm{U}$ \\
\hline 2,4-Dimethylphenol & 480 & $\mathbf{U}$ & 440 & $\mathrm{U}$ & 410 & $\mathrm{U}$ & 850 & $U$ & 460 & $\mathrm{U}$ & 400 & $\mathrm{U}$ \\
\hline 4,6-Dinitro-2-methylphenol & 1,200 & $\mathrm{U}$ & 1,100 & $\mathrm{U}$ & 1,000 & $\mathrm{U}$ & 2,100 & U & 1,200 & $\mathrm{U}$ & 1,000 & $\mathrm{U}$ \\
\hline 2,4-Dinitrophenol & 1,200 & $U$ & 1,100 & $\mathrm{U}$ & 1,000 & $\mathrm{U}$ & 2,100 & $\mathrm{U}$ & 1,200 & U & 1,000 & $\mathrm{U}$ \\
\hline 2,4-Dinitrotoluene & 480 & $\mathrm{U}$ & 440 & $\mathrm{U}$ & 410 & $\mathrm{U}$ & 850 & $\mathrm{U}$ & 460 & $\mathrm{U}$ & 400 & $\mathrm{U}$ \\
\hline 2,6-Dinitrotoluene & 480 & $\mathrm{U}$ & 440 & $\mathrm{U}$ & 410 & $\mathrm{U}$ & 850 & $\mathbf{U}$ & 460 & $U$ & 400 & $U$ \\
\hline Fluoranthene & 480 & $U$ & 440 & $\mathrm{U}$ & 410 & $\mathrm{U}$ & 850 & $\mathbf{U}$ & 460 & $\mathrm{U}$ & 400 & $\mathrm{U}$ \\
\hline Fluorene & 480 & $U$ & 440 & U & 410 & $\mathbf{U}$ & 850 & $\mathbf{U}$ & 460 & $\mathrm{U}$ & 400 & $\mathrm{U}$ \\
\hline Hexachlorobenzene & 480 & $\mathrm{U}$ & 440 & $\mathrm{U}$ & 410 & $\mathrm{U}$ & 850 & $U$ & 460 & $U$ & 400 & $\mathrm{U}$ \\
\hline Hexachlorobutadiene & 480 & $\mathrm{U}$ & 440 & $\mathrm{U}$ & 410 & $\mathrm{U}$ & 850 & $\mathrm{U}$ & 460 & $\mathrm{U}$ & 400 & $\mathbf{U}$ \\
\hline Hexachlorocyclopentadiene & 480 & $\mathrm{U}$ & 440 & $U$ & 410 & $\mathrm{U}$ & 850 & $\mathbf{U}$ & 460 & $\mathrm{U}$ & 400 & U \\
\hline Hexachloroethane & 480 & $\mathrm{U}$ & 440 & $\mathrm{U}$ & 410 & $\mathbf{U}$ & 850 & $\mathbf{U}$ & 460 & $\mathbf{U}$ & 400 & $\mathbf{U}$ \\
\hline Indeno $[1,2,3-c, d]$ pyrene & 480 & U & 440 & $\mathrm{U}$ & 410 & $\mathbf{U}$ & 850 & $\mathrm{U}$ & 460 & $\mathrm{U}$ & 400 & $\mathrm{U}$ \\
\hline Isophorone & 480 & $\mathrm{U}$ & 440 & $\mathrm{U}$ & 410 & $\mathrm{U}$ & 850 & $U$ & 460 & $\mathbf{U}$ & 400 & $\mathrm{U}$ \\
\hline 2-Methylnaphthalene & 480 & $\mathbf{U}$ & 440 & $\mathbf{U}$ & 410 & $\mathrm{U}$ & 850 & $\mathbf{U}$ & 460 & $\mathbf{U}$ & 400 & $\mathbf{U}$ \\
\hline 2-Mcthylphenol & 480 & $\mathbf{U}$ & 440 & $\mathbf{U}$ & 410 & $\mathrm{U}$ & 850 & $\mathbf{U}$ & 460 & $\mathrm{U}$ & 400 & $\mathbf{U}$ \\
\hline 4-Methylphenol & 480 & $\mathbf{U}$ & 440 & $\mathbf{U}$ & 410 & $\mathrm{U}$ & 850 & $\mathbf{U}$ & 460 & $U$ & 400 & $\mathbf{U}$ \\
\hline Naphthalene & 480 & $\mathrm{U}$ & 440 & $\mathrm{U}$ & 410 & $\mathbf{U}$ & 850 & $\mathrm{U}$ & 460 & $U$ & 400 & $\mathrm{U}$ \\
\hline 2-Nitroaniline & 1,200 & $\mathrm{U}$ & 1,100 & $\mathrm{U}$ & 1,000 & $U$ & 2,100 & $\mathrm{U}$ & 1,200 & $\mathbf{U}$ & 1,000 & $\mathbf{U}$ \\
\hline 3-Nitroaniline & 1,200 & $\mathrm{U}$ & 1,100 & $\mathrm{U}$ & 1,000 & $U$ & 2,100 & $\mathrm{U}$ & 1,200 & $U$ & 1,000 & $\mathbf{U}$ \\
\hline 4-Nitroaniline & 1,200 & $\mathrm{U}$ & 1,100 & $\mathrm{U}$ & 1,000 & $U$ & 2,100 & $\mathrm{U}$ & 1,200 & $\mathbf{U}$ & 1,000 & $\mathrm{U}$ \\
\hline Nitrobenzene & 480 & $\mathrm{U}$ & 440 & $\mathrm{U}$ & 410 & $U$ & 850 & $U$ & 460 & U & 400 & $\mathrm{U}$ \\
\hline 2-Nitrophenol & 480 & $\mathrm{U}$ & 440 & $\mathrm{U}$ & 410 & $\mathrm{U}$ & 850 & $\mathrm{U}$ & 460 & U & 400 & $\mathrm{U}$ \\
\hline 4-Nitrophenol & 1,200 & $\mathrm{U}$ & 1,100 & $\mathrm{U}$ & 1,000 & $\mathrm{U}$ & 2,100 & U & 1,200 & $U$ & 1,000 & $\mathbf{U}$ \\
\hline N-Nitroso-di-n-propylamine & 480 & $\mathrm{U}$ & 440 & $\mathrm{U}$ & 410 & $U$ & 850 & $\mathbf{U}$ & 460 & $U$ & 400 & $\mathbf{U}$ \\
\hline
\end{tabular}




\section{TABLE C.8a (Cont.)}

\begin{tabular}{|c|c|c|c|c|c|c|c|c|c|c|c|c|}
\hline \multirow{3}{*}{$\frac{\text { Compound }}{\text { N-Nitrosodiphenylamine }}$} & \multicolumn{12}{|c|}{ Sediment Concentrations $(\mu \mathrm{g} / \mathrm{kg})$ at Various Depth Intervals } \\
\hline & \multicolumn{2}{|c|}{$\begin{array}{l}\text { BOR } 1-1 \\
(6-8 \mathrm{ft})\end{array}$} & \multicolumn{2}{|c|}{$\begin{array}{l}\text { BOR1-2 } \\
(8-10 \mathrm{ft})\end{array}$} & \multicolumn{2}{|c|}{$\begin{array}{c}\text { BOR1-3 } \\
(10-12 \mathrm{ft})\end{array}$} & \multicolumn{2}{|c|}{$\begin{array}{l}\text { BOR2-1 } \\
(3-5 \mathrm{ft})\end{array}$} & \multicolumn{2}{|c|}{$\begin{array}{l}\text { BOR2-2 } \\
(5-8 \mathrm{ft})\end{array}$} & \multicolumn{2}{|c|}{$\begin{array}{l}\text { BOR2-3 } \\
\text { (8-10 ft) }\end{array}$} \\
\hline & 480 & $\mathrm{U}$ & 440 & $\mathbf{U}$ & 410 & $\mathbf{U}$ & 850 & $\mathbf{U}$ & 460 & U & 400 & U \\
\hline Pentachlorophenol & 1,200 & $\mathbf{U}$ & 1,100 & $\mathrm{U}$ & 1,000 & $\mathrm{U}$ & 2,100 & $\mathrm{U}$ & 1,200 & $\mathrm{U}$ & 1,000 & $\mathrm{U}$ \\
\hline Phenanthrene & 480 & $\mathrm{U}$ & 440 & $\mathrm{U}$ & 410 & $\mathrm{U}$ & 850 & $\mathbf{U}$ & 460 & $\mathrm{U}$ & 400 & U \\
\hline Phenol & 480 & $\mathbf{U}$ & 440 & $\mathrm{U}$ & 410 & $\mathrm{U}$ & 850 & $\mathrm{U}$ & 460 & $\mathbf{U}$ & 53 & $\mathrm{~J}$ \\
\hline Pyrene & 480 & $\mathbf{U}$ & 440 & $\mathrm{U}$ & 410 & $\mathbf{U}$ & 850 & $\mathrm{U}$ & 460 & $\mathrm{U}$ & 400 & $\mathrm{U}$ \\
\hline 1,2,4-Trichlorobenzene & 480 & $\mathrm{U}$ & 440 & $\mathbf{U}$ & 410 & $\mathrm{U}$ & 850 & $\mathrm{U}$ & 460 & $\mathbf{U}$ & 400 & U \\
\hline 2,4,5-Trichlorophenol & 1,200 & $\mathrm{U}$ & 1,100 & $\mathrm{U}$ & 1,000 & $\mathbf{U}$ & 2,100 & $\mathrm{U}$ & 1,200 & $\mathrm{U}$ & 1,000 & $\mathrm{U}$ \\
\hline \multirow[t]{3}{*}{ 2,4,6-Trichlorophenol } & 480 & $\mathrm{U}$ & 440 & $\mathrm{U}$ & 410 & $\mathrm{U}$ & 850 & $\mathrm{U}$ & 460 & U & 400 & $\mathrm{U}$ \\
\hline & \multicolumn{12}{|c|}{ Sediment Concentrations $(\mu \mathrm{g} / \mathrm{kg})$ at Various Depth Intervals } \\
\hline & \multicolumn{2}{|c|}{$\begin{array}{c}\text { BOR3-1 } \\
(6-8 \mathrm{ft})\end{array}$} & \multicolumn{2}{|c|}{$\begin{array}{l}\text { BOR3-2 } \\
(8-10 \mathrm{ft})\end{array}$} & \multicolumn{2}{|c|}{$\begin{array}{c}\text { BOR4-1 } \\
(5-8 \mathrm{ft})\end{array}$} & \multicolumn{2}{|c|}{$\begin{array}{l}\text { BOR4-2 } \\
(8-10 \mathrm{ft})\end{array}$} & \multicolumn{2}{|c|}{$\begin{array}{c}\text { BOR5-1 } \\
(2-4 \mathrm{ft})\end{array}$} & \multicolumn{2}{|c|}{$\begin{array}{c}\text { BOR 5-2 } \\
(4-6 \mathrm{ft})\end{array}$} \\
\hline Acenaphthene & 420 & $\mathrm{U}$ & 390 & $\mathrm{U}$ & 660 & $\mathbf{U}$ & 440 & $\mathrm{U}$ & 400 & $\mathbf{U}$ & 400 & $\mathrm{U}$ \\
\hline Acenaphthylene & 420 & $\mathrm{U}$ & 390 & $\mathbf{U}$ & 660 & $U$ & 440 & $\mathrm{U}$ & 400 & $\mathrm{U}$ & 400 & U \\
\hline Anthracene & 420 & U & 390 & $\mathrm{U}$ & 660 & $\mathbf{U}$ & 440 & U & 400 & U & 400 & U \\
\hline Benz[a]anthracene & 420 & $\mathrm{U}$ & 390 & $\mathbf{U}$ & 660 & $U$ & 440 & $U$ & 400 & $\mathrm{U}$ & 400 & $\mathrm{U}$ \\
\hline Benzo[a]pyrene & 420 & $\mathbf{U}$ & 390 & $\mathrm{U}$ & 660 & $\mathrm{U}$ & 440 & $\mathbf{U}$ & 400 & $\mathrm{U}$ & 400 & $\mathbf{U}$ \\
\hline Benzo[b]fluoranthene & 420 & $\mathbf{U}$ & 390 & $\mathbf{U}$ & 660 & $\mathbf{U}$ & 440 & $\mathrm{U}$ & 400 & $\mathrm{U}$ & 400 & $\mathrm{U}$ \\
\hline Benzo[g,h,i]perylene & 420 & $U$ & 390 & $\mathbf{U}$ & 660 & $\mathrm{U}$ & 440 & U & 400 & $\mathrm{U}$ & 400 & $\mathbf{U}$ \\
\hline Benzo[k]fluoranthene & 420 & $\mathbf{U}$ & 390 & $\mathbf{U}$ & 660 & $\mathrm{U}$ & 440 & U & 400 & $\dot{U}$ & 400 & U \\
\hline Bis(2-chloroethoxy)methane & 420 & $\mathrm{U}$ & 390 & $\mathrm{U}$ & 660 & $\mathrm{U}$ & 440 & $U$ & 400 & $\mathrm{U}$ & 400 & $\mathbf{U}$ \\
\hline Bis(2-chlorocthyl)ether & 420 & $\mathrm{U}$ & 390 & $\mathrm{U}$ & 660 & $\mathbf{U}$ & 440 & U & 400 & $\mathbf{U}$ & 400 & U \\
\hline Bis(2-chloroisopropyl)ether & 420 & $\mathrm{U}$ & 390 & $\mathrm{U}$ & 660 & $\mathrm{U}$ & 440 & $U$ & 400 & $\mathrm{U}$ & 400 & $U$ \\
\hline Bis(2-ethylhexyl)phthalate & 420 & $\mathrm{U}$ & 44 & $\mathrm{U}$ & 660 & $\mathrm{U}$ & 72 & $\mathbf{J}$ & 400 & $\mathrm{U}$ & 400 & $\mathrm{U}$ \\
\hline 4-Bromophenyl-phenylether & 420 & $\mathrm{U}$ & 390 & U & 660 & $\mathbf{U}$ & 440 & $\mathrm{U}$ & 400 & $\mathbf{U}$ & 400 & $\mathbf{U}$ \\
\hline Butylbenzylphthalate & 420 & $U$ & 390 & $\mathbf{U}$ & 660 & $\mathbf{U}$ & 440 & $\mathrm{U}$ & 400 & $\mathbf{U}$ & 400 & $\mathbf{U}$ \\
\hline
\end{tabular}


TABLE C.8a (Cont.)

\begin{tabular}{|c|c|c|c|c|c|c|c|c|c|c|c|c|}
\hline \multirow{3}{*}{$\begin{array}{l}\text { Compound } \\
\text { Carbazole }\end{array}$} & \multicolumn{12}{|c|}{ Sediment Concentrations $(\mu \mathrm{g} / \mathrm{kg}$ ) at Various Depth Intervals } \\
\hline & \multicolumn{2}{|c|}{$\begin{array}{l}\text { BOR3-1 } \\
(6-8 \mathrm{ft})\end{array}$} & \multicolumn{2}{|c|}{$\begin{array}{l}\text { BOR3-2 } \\
(8-10 \mathrm{ft})\end{array}$} & \multicolumn{2}{|c|}{$\begin{array}{c}\text { BOR4-1 } \\
(5-8 \mathrm{ft})\end{array}$} & \multicolumn{2}{|c|}{$\begin{array}{l}\text { BOR4-2 } \\
(8-10 \mathrm{ft}) \\
\end{array}$} & \multicolumn{2}{|c|}{$\begin{array}{c}\text { BOR5-1 } \\
(2-4 \mathrm{ft})\end{array}$} & \multicolumn{2}{|c|}{$\begin{array}{l}\text { BOR5-2 } \\
(4-6 \mathrm{ft})\end{array}$} \\
\hline & 420 & $\mathbf{U}$ & 390 & $\mathrm{U}$ & 660 & $\mathbf{U}$ & 440 & $\mathbf{U}$ & 400 & $\mathbf{U}$ & 400 & $U$ \\
\hline 4-Chloro-3-methylphenol & 420 & $\mathbf{U}$ & 390 & $\mathrm{U}$ & 660 & $\mathbf{U}$ & 440 & $\mathbf{U}$ & 400 & $\mathbf{U}$ & 400 & $\mathrm{U}$ \\
\hline 4-Chloroaniline & 420 & $\mathrm{U}$ & 390 & $\mathrm{U}$ & 660 & $\mathrm{U}$ & 440 & $\mathbf{U}$ & 400 & $\mathbf{U}$ & 400 & $U$ \\
\hline 2-Chloronaphthalene & 420 & $\mathbf{U}$ & 390 & $\mathbf{U}$ & 660 & $\mathbf{U}$ & 440 & $\mathbf{U}$ & 400 & $\mathbf{U}$ & 400 & $\mathrm{U}$ \\
\hline 2-Chlorophenol & 420 & $\mathrm{U}$ & 390 & $\mathbf{U}$ & 660 & $\mathbf{U}$ & 440 & $\mathbf{U}$ & 400 & $\mathrm{U}$ & 400 & $\mathbf{U}$ \\
\hline 4-Chlorophenyl phenyl ether & 420 & $\mathrm{U}$ & 390 & $\mathrm{U}$ & 660 & $U$ & 440 & $\mathrm{U}$ & 400 & $\mathbf{U}$ & 400 & $U$ \\
\hline Chrysene & 420 & $\mathbf{U}$ & 390 & J & 660 & $\mathrm{U}$ & 440 & $U$ & 400 & U & 400 & $\mathbf{U}$ \\
\hline Di-n-butylphthalate & 140 & $\mathbf{J}$ & 130 & $\mathrm{~J}$ & 230 & $\mathbf{J}$ & 440 & $\mathrm{U}$ & 170 & $\mathbf{J}$ & 190 & $\mathrm{~J}$ \\
\hline Di-n-octylphthalate & 420 & $\mathbf{U}$ & 390 & $\mathbf{U}$ & 660 & $\mathrm{U}$ & 440 & $\mathrm{U}$ & 400 & $\mathrm{U}$ & 400 & $\mathbf{U}$ \\
\hline Dibenz $[a, h] a n t h r a c e n e$ & 420 & $\mathbf{U}$ & 390 & $U$ & 660 & $\mathrm{U}$ & 440 & $U$ & 400 & $\mathrm{U}$ & 400 & $\mathbf{U}$ \\
\hline Dibenzofuran & 420 & $\mathbf{U}$ & 390 & $\mathrm{U}$ & 660 & $U$ & 440 & $\mathbf{U}$ & 400 & $\mathbf{U}$ & 400 & $\mathbf{U}$ \\
\hline 1,2-Dichlorobenzene & 420 & $\mathrm{U}$ & 390 & $U$ & 660 & U & 440 & $U$ & 400 & $\mathrm{U}$ & 400 & $\mathbf{U}$ \\
\hline 1,3-Dichlorobenzene & 420 & $U$ & 390 & $\mathrm{U}$ & 660 & $\mathbf{U}$ & 440 & $\mathrm{U}$ & 400 & $U$ & 400 & $\mathbf{U}$ \\
\hline 1,4-Dichlorobenzene & 420 & $\mathbf{U}$ & 390 & $\mathbf{U}$ & 660 & $\mathbf{U}$ & 440 & $U$ & 400 & $\mathrm{U}$ & 400 & $U$ \\
\hline 3,3'-Dichlorobenzidine & 420 & $\mathrm{U}$ & 390 & $\mathrm{U}$ & 660 & $U$ & 440 & $\mathrm{U}$ & 400 & $\mathrm{U}$ & 400 & $U$ \\
\hline 2,4-Dichlorophenol & 420 & $U$ & 390 & $\mathrm{U}$ & 660 & $\mathbf{U}$ & 440 & U & 400 & $\mathrm{U}$ & 400 & $\mathbf{U}$ \\
\hline Diethylphthalate & 420 & $\mathbf{U}$ & 390 & $\mathrm{U}$ & 660 & U & 440 & $\mathrm{U}$ & 400 & $\mathrm{U}$ & 400 & $\mathbf{U}$ \\
\hline Dimethyl phthalate & 420 & $\mathbf{U}$ & 390 & $\mathbf{U}$ & 660 & U & 440 & $\mathrm{U}$ & 400 & $\mathrm{U}$ & 400 & $U$ \\
\hline 2,4-Dimethylphenol & 420 & $\mathrm{U}$ & 390 & U & 660 & $\mathrm{U}$ & 440 & $U$ & 400 & $U$ & 400 & $U$ \\
\hline 4,6-Dinitro-2-methylphenol & 1,000 & $U$ & 980 & $\mathrm{U}$ & 1,700 & $\mathrm{U}$ & 1,100 & U & 1,000 & U & 1,000 & U \\
\hline 2,4-Dinitrophenol & 1,000 & $\mathbf{U}$ & 980 & $\mathrm{U}$ & 1,700 & $\mathrm{U}$ & 1,100 & $\mathbf{U}$ & 1,000 & U & 1,000 & U \\
\hline 2,4-Dinitrotoluene & 420 & $U$ & 390 & $\mathrm{U}$ & 660 & $\mathbf{U}$ & 440 & $U$ & 400 & $\mathrm{U}$ & 400 & $\mathrm{U}$ \\
\hline 2,6-Dinitrotoluene & 420 & $\mathbf{U}$ & 390 & $U$ & 660 & $\mathbf{U}$ & 440 & $\mathrm{U}$ & 400 & $U$ & 400 & $U$ \\
\hline Fluoranthene & 420 & $\mathrm{U}$ & 390 & $U$ & 660 & $\mathrm{U}$ & 440 & $\mathbf{U}$ & 400 & $\mathrm{U}$ & 400 & $U$ \\
\hline Fluorene & 420 & $U$ & 390 & $U$ & 660 & $\mathbf{U}$ & 440 & $\mathbf{U}$ & 400 & $\mathbf{U}$ & 400 & $\mathrm{U}$ \\
\hline Hexachlorobenzene & 420 & $U$ & 390 & $\mathrm{U}$ & 660 & $\mathbf{U}$ & 440 & $U$ & 400 & $U$ & 400 & $\mathbf{U}$ \\
\hline Hexachlorobutadiene & 420 & $\mathbf{U}$ & 390 & $U$ & 660 & $\mathbf{U}$ & 440 & $\mathrm{U}$ & 400 & $U$ & 400 & $\mathbf{U}$ \\
\hline Hexachlorocyclopentadiene & 420 & U & 390 & $\mathbf{U}$ & 660 & $U$ & 440 & U & 400 & $U$ & 400 & $U$ \\
\hline
\end{tabular}


TABLE C.8a (Cont.)

\begin{tabular}{|c|c|c|c|c|c|c|c|c|c|c|c|c|}
\hline \multirow{3}{*}{$\begin{array}{l}\text { Compound } \\
\text { Hexachloroethane }\end{array}$} & \multicolumn{12}{|c|}{ Sediment Concentrations $(\mu \mathrm{g} / \mathrm{kg})$ at Various Depth Intervals } \\
\hline & \multicolumn{2}{|c|}{$\begin{array}{c}\text { BOR3-1 } \\
(6-8 \mathrm{ft}) \\
\end{array}$} & \multicolumn{2}{|c|}{$\begin{array}{l}\text { BOR3-2 } \\
(8-10 \mathrm{ft}) \\
\end{array}$} & \multicolumn{2}{|c|}{$\begin{array}{c}\text { BOR4-1 } \\
(5-8 \mathrm{ft}) \\
\end{array}$} & \multicolumn{2}{|c|}{$\begin{array}{l}\text { BOR4-2 } \\
(8-10 \mathrm{ft}) \\
\end{array}$} & \multicolumn{2}{|c|}{$\begin{array}{c}\text { BOR5-1 } \\
(2-4 \mathrm{ft}) \\
\end{array}$} & \multicolumn{2}{|c|}{$\begin{array}{l}\text { BOR5-2 } \\
(4-6 \mathrm{ft})\end{array}$} \\
\hline & 420 & $\mathrm{U}$ & 390 & $\mathbf{U}$ & 660 & $\mathrm{U}$ & 440 & $\mathrm{U}$ & 400 & $\mathbf{U}$ & 400 & $\mathrm{U}$ \\
\hline Indeno[1,2,3-c,d]pyrene & 420 & $\mathbf{U}$ & 390 & $\mathbf{U}$ & 660 & $\mathrm{U}$ & 440 & $\mathbf{U}$ & 400 & $U$ & 400 & $\mathrm{U}$ \\
\hline Isophorone & 420 & $U$ & 390 & $\mathbf{U}$ & 660 & $\mathrm{U}$ & 440 & $\mathbf{U}$ & 400 & $\mathrm{U}$ & 400 & $U$ \\
\hline 2-Methylnaphthalene & 420 & $\mathrm{U}$ & 390 & $\mathrm{U}$ & 660 & $\mathrm{U}$ & 440 & $U$ & 400 & $\mathrm{U}$ & 400 & $\mathrm{U}$ \\
\hline 2-Methylphenol & 420 & $\mathrm{U}$ & 390 & $\mathbf{U}$ & 660 & $\mathrm{U}$ & 440 & $\mathrm{U}$ & 400 & $\mathrm{U}$ & 400 & $\mathrm{U}$ \\
\hline 4-Methylphenol & 420 & $\dot{\mathrm{U}}$ & 390 & $\mathrm{U}$ & 660 & $\mathrm{U}$ & 440 & U & 400 & $\mathbf{U}$ & 400 & $\mathbf{U}$ \\
\hline N-Nitrosodiphenylamine & 420 & $\mathrm{U}$ & 390 & $\mathrm{U}$ & 660 & $\mathrm{U}$ & 440 & $\mathrm{U}$ & 400 & $U$ & 400 & $U$ \\
\hline N-Nitroso-di-n-propylamine & 420 & $\mathrm{U}$ & 390 & $\mathrm{U}$ & 660 & $\mathrm{U}$ & 440 & $\mathrm{U}$ & 400 & $\mathbf{U}$ & 400 & $\mathrm{U}$ \\
\hline Naphthalene & 420 & $\mathrm{U}$ & 390 & $\mathrm{U}$ & 660 & $U$ & 440 & $U$ & 400 & $U$ & 400 & $\mathbf{U}$ \\
\hline 2-Nitroaniline & 1,000 & $\mathrm{U}$ & 980 & $\mathrm{U}$ & 1,700 & $\mathrm{U}$ & 1,100 & $U$ & 1,000 & $\mathrm{U}$ & 1,000 & $\mathrm{U}$ \\
\hline 3-Nitroaniline & 1,000 & U & 980 & $\mathrm{U}$ & 1,700 & $\mathrm{U}$ & 1,100 & $\mathrm{U}$ & 1,000 & $\mathbf{U}$ & 1,000 & $\mathbf{U}$ \\
\hline 4-Nitroaniline & 1,000 & $\mathbf{U}$ & 980 & $\mathrm{U}$ & 1,700 & $\mathbf{U}$ & 1,100 & $U$ & 1,000 & $\mathbf{U}$ & 1,000 & $\mathrm{U}$ \\
\hline Nitrobenzene & 420 & $U$ & 390 & $\mathrm{U}$ & 660 & $\mathrm{U}$ & 440 & $\mathrm{U}$ & 400 & $\mathbf{U}$ & 400 & $\mathbf{U}$ \\
\hline 2-Nitrophenol & 420 & $\mathrm{U}$ & 390 & $\mathrm{U}$ & 660 & $\mathrm{U}$ & 440 & $\mathrm{U}$ & 400 & $\mathbf{U}$ & 400 & $\mathbf{U}$ \\
\hline 4-Nitrophenol & 1,000 & $\mathrm{U}$ & 980 & $\mathrm{U}$ & 1,700 & $\mathrm{U}$ & 1,100 & $U$ & 1,000 & $\mathbf{U}$ & 1,000 & $\mathrm{U}$ \\
\hline Pentachlorophenol & 1,000 & $U$ & 980 & $\mathrm{U}$ & 1,700 & $\mathbf{U}$ & 1,100 & $U$ & 1,000 & $\mathrm{U}$ & 1,000 & $\mathrm{U}$ \\
\hline Phenanthrene & 420 & $\mathrm{U}$ & 390 & U & 660 & $U$ & 440 & $\mathbf{U}$ & 400 & $\mathrm{U}$ & 400 & $\mathrm{U}$ \\
\hline Phenol & 420 & $\mathrm{U}$ & 390 & $\mathrm{U}$ & 660 & $\mathrm{U}$ & 440 & $U$ & 400 & $\mathrm{U}$ & 400 & $\mathrm{U}$ \\
\hline Pyrene & 420 & $\mathrm{U}$ & 390 & $\mathrm{U}$ & 660 & $\mathrm{U}$ & 440 & $\mathrm{U}$ & 400 & $\mathrm{U}$ & 400 & $\mathrm{U}$ \\
\hline 1,2,4-Trichlorobenzene & 420 & $\mathbf{U}$ & 390 & $\mathrm{U}$ & 660 & $\mathrm{U}$ & 440 & $\mathbf{U}$ & 400 & $\mathrm{U}$ & 400 & $\mathbf{U}$ \\
\hline 2,4,5-Trichlorophenol & 1,000 & $\mathbf{U}$ & 980 & $\mathbf{U}$ & 1,700 & $\mathrm{U}$ & 1,100 & $\mathrm{U}$ & 1,000 & $\mathbf{U}$ & 1,000 & $\mathrm{U}$ \\
\hline 2,4,6-Trichlorophenol & 420 & $\underline{U}$ & 390 & U & 660 & $\underline{U}$ & 440 & U & 400 & U & 400 & $\mathrm{U}$ \\
\hline
\end{tabular}


TABLE C.8a (Cont.)

\begin{tabular}{|c|c|c|c|c|c|c|c|c|c|c|c|c|}
\hline \multirow{3}{*}{$\begin{array}{l}\text { Compound } \\
\text { Acenaphthene }\end{array}$} & \multicolumn{12}{|c|}{ Sediment Concentrations $(\mu \mathrm{g} / \mathrm{kg}$ ) at Various Depth Intervals } \\
\hline & \multicolumn{2}{|c|}{$\begin{array}{l}\text { BOR5-3 } \\
(6-8 \mathrm{ft})\end{array}$} & \multicolumn{2}{|c|}{$\begin{array}{l}\text { BOR5-4 } \\
(8-10 \mathrm{ft})\end{array}$} & \multicolumn{2}{|c|}{$\begin{array}{l}\text { BOR5-4Dup } \\
(8-10 \mathrm{ft})\end{array}$} & \multicolumn{2}{|c|}{$\begin{array}{c}\text { BOR6-1 } \\
(2-4 \mathrm{ft}) \\
\end{array}$} & \multicolumn{2}{|c|}{$\begin{array}{l}\text { BOR6-2 } \\
(4-6 \mathrm{ft})\end{array}$} & \multicolumn{2}{|c|}{$\begin{array}{l}\text { BOR6-3 } \\
(6-8 \mathrm{ft})\end{array}$} \\
\hline & 400 & $\mathbf{U}$ & 390 & $\mathrm{U}$ & 400 & U & 410 & $\mathbf{U}$ & 400 & $\mathrm{U}$ & 400 & $\mathrm{U}$ \\
\hline Acenaphthylene & 400 & $\mathrm{U}$ & 390 & $\mathrm{U}$ & 400 & $\mathrm{U}$ & 410 & $\mathrm{U}$ & 400 & U & 400 & $\mathrm{U}$ \\
\hline Anthracene & 400 & $\mathbf{U}$ & 390 & $\mathrm{U}$ & 400 & $\mathrm{U}$ & 410 & $\mathrm{U}$ & $400^{\circ}$ & $\mathbf{U}$ & 400 & $\mathrm{U}$ \\
\hline Benz[a]anthracene & 400 & $\mathbf{U}$ & 390 & $\mathrm{U}$ & 400 & U & 410 & $U$ & 400 & $\mathrm{U}$ & 400 & $\mathrm{U}$ \\
\hline Benzo[a]pyrene & 400 & $\mathrm{U}$ & 390 & $\mathrm{U}$ & 400 & $U$ & 410 & $\mathrm{U}$ & 400 & $\mathbf{U}$ & 400 & $U$ \\
\hline Benzo[b]fluoranthene & 400 & $\mathrm{U}$ & 390 & $\mathrm{U}$ & 400 & $\mathrm{U}$ & 410 & $U$ & 400 & $U$ & 400 & U \\
\hline Benzo[g,h,i]perylene & 400 & $\mathrm{U}$ & 390 & $\mathrm{U}$ & 400 & $\mathrm{U}$ & 410 & $\mathrm{U}$ & 400 & $\mathrm{U}$ & 400 & $\mathbf{U}$ \\
\hline Benzo[k]fluoranthene & 400 & U & 390 & $\mathrm{U}$ & 400 & $U$ & 410 & U & 400 & $\mathbf{U}$ & 400 & $\mathbf{U}$ \\
\hline Bis(2-chloroethoxy)methane & 400 & $\mathbf{U}$ & 390 & $\mathrm{U}$ & 400 & $\mathrm{U}$ & 410 & U & 400 & $\mathbf{U}$ & 400 & $\mathbf{U}$ \\
\hline Bis(2-chloroethyl)ether & 400 & $\mathrm{U}$ & 390 & $\mathbf{U}$ & 400 & $\mathbf{U}$ & 410 & $\mathrm{U}$ & 400 & U & 400 & $\mathbf{U}$ \\
\hline Bis(2-chloroisopropyl)ether & 400 & $\mathbf{U}$ & 390 & $\mathrm{U}$ & 400 & $\mathrm{U}$ & 410 & U & 400 & $\mathbf{U}$ & 400 & $\mathbf{U}$ \\
\hline Bis(2-ethylhexyl)phthalate & 400 & U & 65 & $\mathbf{J}$ & 41 & $\mathbf{J}$ & 410 & U & 400 & $\mathbf{U}$ & 400 & $\mathbf{U}$ \\
\hline 4-Bromophenyl phenyl ether & 400 & U & 390 & $\mathrm{U}$ & 400 & $\mathbf{U}$ & 410 & $\mathbf{U}$ & 400 & $\mathrm{U}$ & 400 & $\mathbf{U}$ \\
\hline Butylbenzylphthalate & 400 & $U$ & 390 & U & 400 & $\mathbf{U}$ & 410 & U & 400 & $U$ & 400 & $\mathrm{U}$ \\
\hline Carbazole & 400 & $U$ & 390 & $\mathbf{U}$ & 400 & $\mathrm{U}$ & 410 & $\mathbf{U}$ & 400 & $U$ & 400 & $U$ \\
\hline 4-Chloro-3-methylphenol & 400 & U & 390 & $U$ & 400 & $\mathrm{U}$ & 410 & $\mathbf{U}$ & 400 & $\mathbf{U}$ & 400 & $\mathrm{U}$ \\
\hline 4-Chloroaniline & 400 & U & 390 & $\mathrm{U}$ & 400 & $\mathrm{U}$ & 410 & $\mathbf{U}$ & 400 & U & 400 & U \\
\hline 2-Chloronaphthalene & 400 & $\mathrm{U}$ & 390 & $\mathbf{U}$ & 400 & $\mathrm{U}$ & 410 & $\mathbf{U}$ & 400 & U & 400 & $\mathrm{U}$ \\
\hline 2-Chlorophenol & 400 & $\mathrm{U}$ & 390 & $\mathbf{U}$ & 400 & $\mathrm{U}$ & 410 & $\mathbf{U}$ & 400 & U & 400 & $\mathrm{U}$ \\
\hline 4-Chlorophenyl phenyl ether & 400 & $\mathrm{U}$ & 390 & $\mathrm{U}$ & 400 & U & 410 & U & 400 & $U$ & 400 & $\mathrm{U}$ \\
\hline Chrysene & 400 & U & 390 & $\mathbf{U}$ & 400 & $\mathbf{U}$ & 410 & $U$ & 400 & $\mathbf{U}$ & 400 & U \\
\hline Di-n-butylphthalate & 170 & J & 160 & $\mathrm{~J}$ & 140 & J & 170 & $\mathbf{J}$ & 140 & J & 98 & $\mathbf{J}$ \\
\hline Di-n-octylphthalate & 400 & $U$ & 390 & $\mathbf{U}$ & 400 & U & 410 & $\mathrm{U}$ & 400 & U & 400 & $\mathrm{U}$ \\
\hline Dibenz[a,h]anthracene & 400 & $\mathrm{U}$ & 390 & $\mathrm{U}$ & 400 & $\mathrm{U}$ & 410 & $U$ & 400 & $U$ & 400 & $\mathbf{U}$ \\
\hline Dibenzofuran & 400 & $\mathrm{U}$ & 390 & $\mathrm{U}$ & 400 & $\mathrm{U}$ & 410 & $\mathrm{U}$ & 400 & $\mathbf{U}$ & 400 & U \\
\hline
\end{tabular}


TABLE C.8a (Cont.)

\begin{tabular}{|c|c|c|c|c|c|c|c|c|c|c|c|c|}
\hline \multirow{3}{*}{$\frac{\text { Compound }}{\text { 1,2-Dichlorobenzene }}$} & \multicolumn{12}{|c|}{ Sediment Concentrations $(\mu \mathrm{g} / \mathrm{kg})$ at Various Depth Intervals } \\
\hline & \multicolumn{2}{|c|}{$\begin{array}{c}\text { BOR5-3 } \\
(6-8 \mathrm{ft}) \\
\end{array}$} & \multicolumn{2}{|c|}{$\begin{array}{l}\text { BOR5-4 } \\
(8-10 \mathrm{ft}) \\
\end{array}$} & \multicolumn{2}{|c|}{$\begin{array}{c}\text { BOR5-4Dup } \\
(8-10 \mathrm{ft})\end{array}$} & \multicolumn{2}{|c|}{$\begin{array}{c}\text { BOR6-1 } \\
(2-4 \mathrm{ft})\end{array}$} & \multicolumn{2}{|c|}{$\begin{array}{l}\text { BOR6-2 } \\
(4-6 \mathrm{ft})\end{array}$} & \multicolumn{2}{|c|}{$\begin{array}{l}\text { BOR6-3 } \\
(6-8 \mathrm{ft})\end{array}$} \\
\hline & 400 & $\mathbf{U}$ & 390 & $U$ & 400 & $\mathbf{U}$ & 410 & $\mathrm{U}$ & 400 & $\mathrm{U}$ & 400 & $\mathbf{U}$ \\
\hline 1,3-Dichlorobenzene & 400 & $\mathrm{U}$ & 390 & $\mathrm{U}$ & 400 & $\mathrm{U}$ & 410 & $\mathrm{U}$ & 400 & $\mathbf{U}$ & 400 & $\mathrm{U}$ \\
\hline 1,4-Dichlorobenzene & 400 & $\mathrm{U}$ & 390 & $\mathrm{U}$ & 400 & $\mathbf{U}$ & 410 & $\mathbf{U}$ & 400 & $\mathrm{U}$ & 400 & $U$ \\
\hline 3,3'-Dichlorobenzidine & 400 & $U$ & 390 & $\mathbf{U}$ & 400 & $\mathrm{U}$ & 410 & $\mathrm{U}$ & 400 & $\mathbf{U}$ & 400 & $\mathrm{U}$ \\
\hline 2,4-Dichlorophenol & 400 & $\mathrm{U}$ & 390 & $\mathrm{U}$ & 400 & $\mathrm{U}$ & 410 & $\mathrm{U}$ & 400 & $\mathbf{U}$ & 400 & $\mathrm{U}$ \\
\hline Diethylphthalate & 400 & $U$ & 390 & $\mathrm{U}$ & 400 & $U$ & 410 & $\mathrm{U}$ & 400 & $\mathbf{U}$ & 400 & $\mathbf{U}$ \\
\hline Dimethylphthalate & .400 & U & 390 & $U$ & 400 & $\mathrm{U}$ & 410 & U & 400 & $\mathbf{U}$ & 400 & $\mathbf{U}$ \\
\hline 2,4-Dimethylphenol & 400 & $\mathbf{U}$ & 390 & $\mathbf{U}$ & 400 & $\mathrm{U}$ & 410 & $\mathrm{U}$ & 400 & $\mathrm{U}$ & 400 & U \\
\hline 4,6-Dinitro-2-methylphenol & 1,000 & $\mathrm{U}$ & 980 & $\mathrm{U}$ & 990 & $\mathrm{U}$ & 1,000 & $\mathrm{U}$ & 1,000 & $\mathrm{U}$ & 1,000 & $\mathrm{U}$ \\
\hline 2,4-Dinitrophenol & 1,000 & $\mathbf{U}$ & 980 & $\mathrm{U}$ & 990 & $\mathrm{U}$ & 1,000 & $\mathrm{U}$ & 1,000 & $\mathrm{U}$ & 1,000 & U \\
\hline 2,4-Dinitrotoluene & 400 & $\mathrm{U}$ & 390 & $U$ & 400 & $\mathbf{U}$ & 410 & U & 400 & U & 400 & $\mathbf{U}$ \\
\hline 2,6-Dinitrotoluene & 400 & $\mathbf{U}$ & 390 & $\mathbf{U}$ & 400 & $\mathrm{U}$ & 410 & $\mathrm{U}$ & 400 & $\mathrm{U}$ & 400 & $\mathbf{U}$ \\
\hline Fluoranthene & 400 & U & 390 & $\mathrm{U}$ & 400 & $\mathrm{U}$ & 410 & U & 400 & U & 400 & $\mathbf{U}$ \\
\hline Fluorene & 400 & $\mathbf{U}$ & 390 & $\mathbf{U}$ & 400 & $\mathrm{U}$ & 410 & $U$ & 400 & $\mathbf{U}$ & 400 & $\mathrm{U}$ \\
\hline Hexachlorobenzene & 400 & $\mathrm{U}$ & 390 & $\mathbf{U}$ & 400 & $\mathbf{U}$ & 410 & $\mathbf{U}$ & 400 & U & 400 & $\mathbf{U}$ \\
\hline Hexachlorobutadiene & 400 & $\mathrm{U}$ & 390 & $\mathbf{U}$ & 400 & $\mathrm{U}$ & 410 & $U$ & 400 & $\mathbf{U}$ & 400 & $\mathbf{U}$ \\
\hline Hexachlorocyclopentadiene & 400 & $U$ & 390 & $U$ & 400 & $\mathbf{U}$ & 410 & $\mathrm{U}$ & 400 & $\mathbf{U}$ & 400 & $\mathbf{U}$ \\
\hline Hexachloroethane & 400 & $\mathrm{U}$ & 390 & $\mathbf{U}$ & 400 & $\mathrm{U}$ & 410 & $U$ & 400 & $\mathrm{U}$ & 400 & $\mathrm{U}$ \\
\hline Indeno $[1,2,3-c, d]$ pyrene & 400 & $\mathrm{U}$ & 390 & $\mathrm{U}$ & 400 & $\mathrm{U}$ & 410 & $\mathrm{U}$ & 400 & $\mathbf{U}$ & 400 & $\mathbf{U}$ \\
\hline Isophorone & 400 & $U$ & 390 & $\mathbf{U}$ & 400 & $\mathrm{U}$ & 410 & $U$ & 400 & $U$ & 400 & $\mathbf{U}$ \\
\hline 2-Methylnaphthalene & 400 & $\mathrm{U}$ & 390 & $\mathbf{U}$ & 400 & U & 410 & $\mathrm{U}$ & 400 & $\mathbf{U}$ & 400 & $\mathbf{U}$ \\
\hline 2-Methylphenol & 400 & $\mathrm{U}$ & 390 & $\mathrm{U}$ & 400 & $\mathrm{U}$ & 410 & $\mathrm{U}$ & 400 & $\mathbf{U}$ & 400 & $\mathbf{U}$ \\
\hline 4-Methylphenol & 400 & $\mathrm{U}$ & 390 & $\mathrm{U}$ & 400 & $\mathrm{U}$ & 410 & $\mathbf{U}$ & 400 & $\mathrm{U}$ & 400 & $\mathrm{U}$ \\
\hline Naphthalene & 400 & $\mathbf{U}$ & 390 & $\mathrm{U}$ & 400 & $U$ & 410 & $\mathrm{U}$ & 400 & $\mathbf{U}$ & 400 & $\mathbf{U}$ \\
\hline 2-Nitroaniline & 1,000 & $\mathrm{U}$ & 980 & $\mathrm{U}$ & 990 & U & 1,000 & $\mathbf{U}$ & 1,000 & $\mathbf{U}$ & 1,000 & $U$ \\
\hline 3-Nitroaniline & 1,000 & $\mathrm{U}$ & 980 & $\mathbf{U}$ & 990 & $\mathrm{U}$ & 1,000 & $\mathbf{U}$ & 1,000 & $\mathrm{U}$ & 1,000 & $\mathrm{U}$ \\
\hline 4-Nitroaniline & 1,000 & $\mathrm{U}$ & 980 & $\mathrm{U}$ & 990 & U & 1,000 & $\mathbf{U}$ & 1,000 & $U$ & 1,000 & U \\
\hline Nitrobenzene & 400 & $\mathrm{U}$ & 390 & $\mathbf{U}$ & 400 & $\mathbf{U}$ & 410 & $\mathbf{U}$ & 400 & $\mathbf{U}$ & 400 & $\mathrm{U}$ \\
\hline
\end{tabular}


TABLE C.8a (Cont.)

\begin{tabular}{|c|c|c|c|c|c|c|c|c|c|c|c|c|}
\hline \multirow{3}{*}{$\begin{array}{l}\text { Compound } \\
\text { 2-Nitrophenol }\end{array}$} & \multicolumn{12}{|c|}{ Sediment Concentrations $(\mu \mathrm{g} / \mathrm{kg})$ at Various Depth Intervals } \\
\hline & \multicolumn{2}{|c|}{$\begin{array}{c}\text { BOR5-3 } \\
(6-8 \mathrm{ft}) \\
\end{array}$} & \multicolumn{2}{|c|}{$\begin{array}{l}\text { BOR5-4 } \\
(8-10 \mathrm{ft}) \\
\end{array}$} & \multicolumn{2}{|c|}{$\begin{array}{c}\text { BOR5-4Dup } \\
(8-10 \mathrm{ft})\end{array}$} & \multicolumn{2}{|c|}{$\begin{array}{c}\text { BOR6-1 } \\
(2-4 \mathrm{ft}) \\
\end{array}$} & \multicolumn{2}{|c|}{$\begin{array}{l}\text { BOR6-2 } \\
(4-6 \mathrm{ft})\end{array}$} & \multicolumn{2}{|c|}{$\begin{array}{c}\text { BOR6-3 } \\
(6-8 \mathrm{ft}) \\
\end{array}$} \\
\hline & 400 & $U$ & 390 & $\mathrm{U}$ & 400 & $\mathbf{U}$ & 410 & $\mathbf{U}$ & 400 & $\mathbf{U}$ & 400 & $\mathbf{U}$ \\
\hline 4-Nitrophenol & 1,000 & U & 980 & $\mathbf{U}$ & 990 & $U$ & 1,000 . & $\mathbf{U}$ & 1,000 & U & 1,000 & U \\
\hline N-Nitroso-di-n-propylamine & 400 & $\mathbf{U}$ & 390 & $\mathbf{U}$ & 400 & $\mathbf{U}$ & 410 & $\mathbf{U}$ & 400 & $\mathbf{U}$ & 400 & $\mathbf{U}$ \\
\hline N-Nitrosodiphenylamine & 400 & $\mathrm{U}$ & 390 & $\mathrm{U}$ & 400 & $\mathbf{U}$ & 410 & $\mathbf{U}$ & 400 & U & 400 & $U$ \\
\hline Pentachlorophenol & 1,000 & $\mathrm{U}$ & 980 & U & 990 & $U$ & 1,000 & $\mathbf{U}$ & 1,000 & $\mathbf{U}$ & 1,000 & $\mathrm{U}$ \\
\hline Phenanthrene & 400 & $\mathrm{U}$ & 390 & $\mathrm{U}$ & 400 & $U$ & 410 & $\mathrm{U}$ & 400 & $\mathbf{U}$ & 400 & $\mathrm{U}$ \\
\hline Phenol & 400 & $U$ & 390 & $\mathrm{U}$ & 400 & $\mathbf{U}$ & 70 & $\mathrm{~J}$ & 400 & $\mathbf{U}$ & 400 & U \\
\hline Pyrene & 400 & $\mathrm{U}$ & 390 & $\mathrm{U}$ & 400 & $\mathrm{U}$ & 410 & $\mathbf{U}$ & 400 & $\mathbf{U}$ & 400 & $U$ \\
\hline 1,2,4-Trichlorobenzene & 400 & $\mathrm{U}$ & 390 & $\mathrm{U}$ & 400 & $\mathbf{U}$ & 410 & $\mathbf{U}$ & 400 & $\mathrm{U}$ & 400 & $\mathrm{U}$ \\
\hline 2,4,5-Trichlorophenol & 1,000 & $\mathbf{U}$ & 980 & $U$ & 990 & $\mathrm{U}$ & 1,000 & $\mathrm{U}$ & 1,000 & $\mathbf{U}$ & 1,000 & $\mathrm{U}$ \\
\hline \multirow[t]{3}{*}{ 2,4,6-Trichlorophenol } & 400 & U & 390 & $\mathrm{U}$ & 400 & $\mathrm{U}$ & 410 & $\mathrm{U}$ & 400 & $\mathbf{U}$ & 400 & $\mathrm{U}$ \\
\hline & \multicolumn{12}{|c|}{ Sediment Concentrations $(\mu \mathrm{g} / \mathrm{kg})$ at Various Depth Intervals } \\
\hline & \multicolumn{2}{|c|}{$\begin{array}{l}\text { BOR6-4 } \\
(8-10 \mathrm{ft}) \\
\end{array}$} & \multicolumn{2}{|c|}{$\begin{array}{c}\text { BOR7-1 } \\
(2-4 \mathrm{ft}) \\
\end{array}$} & \multicolumn{2}{|c|}{$\begin{array}{c}\text { BOR7-2 } \\
(4-6 \mathrm{ft})\end{array}$} & \multicolumn{2}{|c|}{$\begin{array}{c}\text { BOR7-3 } \\
(6-8 \mathrm{ft}) \\
\end{array}$} & \multicolumn{2}{|c|}{$\begin{array}{l}\text { BOR7-4 } \\
(8-10 \mathrm{ft}) \\
\end{array}$} & \multicolumn{2}{|c|}{$\begin{array}{c}\text { BOR8-1 } \\
(0-2 \mathrm{ft}) \\
\end{array}$} \\
\hline Acenaphthenc & 390 & $\mathbf{U}$ & 380 & $\mathrm{~J}$ & 390 & $\mathbf{U}$ & 400 & $\mathbf{U}$ & 400 & $\mathrm{U}$ & 420 & $\mathbf{U}$ \\
\hline Accnaphthylene & 390 & $\mathrm{U}$ & 130 & J & 390 & $\mathrm{U}$ & 400 & $U$ & 400 & $U$ & 420 & $\mathbf{U}$ \\
\hline Anthracene & 390 & $\mathbf{U}$ & 280 & J & 390 & $\mathrm{U}$ & 400 & $\mathbf{U}$ & 400 & U & 420 & $\mathrm{U}$ \\
\hline Benz[a]anthracene & 390 & $\mathbf{U}$ & 1,200 & & 390 & $\mathbf{U}$ & 110 & $\mathbf{J}$ & 400 & $\mathrm{U}$ & 420 & $\mathbf{U}$ \\
\hline Benzo[a]pyrene & 390 & $U$ & 900 & & 390 & $\mathbf{U}$ & 76 & $\mathrm{~J}$ & 400 & $U$ & 420 & $\mathbf{U}$ \\
\hline Benzo[b]fluoranthene & 390 & $\mathrm{U}$ & 1,700 & & 390 & $U$ & 150 & $J$ & 400 & $U$ & 420 & $\mathbf{U}$ \\
\hline Benzo[g,h,i]perylene & 390 & $\mathrm{U}$ & 490 & & $390^{\circ}$ & $U$ & 46 & $\mathbf{J}$ & 400 & $\mathrm{U}$ & 420 & $\mathbf{U}$ \\
\hline Benzo[k]fluoranthene & 390 & U & 700 & & 390 & U & 56 & J & 400 & U & 420 & U \\
\hline Bis(2-chloroethoxy)methane & 390 & U & 460 & $\mathrm{U}$ & 390 & U & 400 & $U$ & 400 & $U$ & 420 & $\mathrm{U}$ \\
\hline Bis(2-chlorocthyl)ether & 390 & $\mathbf{U}$ & 460 & $U$ & 390 & $U$ & 400 & $\mathrm{U}$ & 400 & $\mathrm{U}$ & 420 & $\mathbf{U}$ \\
\hline Bis(2-chloroisopropyl)ether & 390 & $U$ & 460 & $\mathrm{U}$ & 390 & $\mathrm{U}$ & 400 & $\mathbf{U}$ & 400 & $\mathrm{U}$ & 420 & $\mathrm{U}$ \\
\hline Bis(2-ethylhexyl)phthalate & 390 & U & 1,100 & & 230 & J & 400 & $\mathbf{U}$ & 400 & U & 420 & $U$ \\
\hline
\end{tabular}


TABLE C.8a (Cont.)

\begin{tabular}{|c|c|c|c|c|c|c|c|c|c|c|c|c|}
\hline \multirow{3}{*}{ Compound } & \multicolumn{12}{|c|}{ Sediment Concentrations $(\mu \mathrm{g} / \mathrm{kg})$ at Various Depth Intervals } \\
\hline & \multicolumn{2}{|c|}{$\begin{array}{l}\text { BOR6-4 } \\
(8-10 \mathrm{ft}) \\
\end{array}$} & \multicolumn{2}{|c|}{$\begin{array}{l}\text { BOR7-1 } \\
(2-4 \mathrm{ft})\end{array}$} & \multicolumn{2}{|c|}{$\begin{array}{c}\text { BOR7-2 } \\
(4-6 \mathrm{ft})\end{array}$} & \multicolumn{2}{|c|}{$\begin{array}{c}\text { BOR7-3 } \\
(6-8 \mathrm{ft}) \\
\end{array}$} & \multicolumn{2}{|c|}{$\begin{array}{l}\text { BOR7-4 } \\
(8-10 \mathrm{ft})\end{array}$} & \multicolumn{2}{|c|}{$\begin{array}{l}\text { BOR8-1 } \\
(0-2 \mathrm{ft})\end{array}$} \\
\hline & 390 & $\mathrm{U}$ & 460 & $\mathbf{U}$ & 390 & $\mathrm{U}$ & 400 & $\mathrm{U}$ & 400 & U & 420 & $U$ \\
\hline Butylbenzylphthalate & 390 & $\mathrm{U}$ & 460 & U & 390 & $\mathrm{U}$ & 400 & $\mathrm{U}$ & 400 & $\mathbf{U}$ & 420 & $\mathrm{U}$ \\
\hline Carbazole & 390 & $\mathrm{U}$ & 120 & $\mathrm{~J}$ & 390 & $\mathrm{U}$ & 400 & $\mathbf{U}$ & 400 & $\mathrm{U}$ & 420 & $\mathrm{U}$ \\
\hline 4-Chloro-3-methylphenol & 390 & $\mathrm{U}$ & 460 & $\mathrm{U}$ & 390 & U & 400 & $\mathrm{U}$ & 400 & $U$ & 420 & U \\
\hline 4-Chloroaniline & 390 & $\mathrm{U}$ & 460 & $\mathrm{U}$ & 390 & $\mathrm{U}$ & 400 & $U$ & 400 & $\mathrm{U}$ & 420 & U \\
\hline 2-Chloronaphthalene & 390 & $\mathrm{U}$ & 460 & $\mathrm{U}$ & 390 & U & 400 & U & 400 & $U$ & 420 & $\mathrm{U}$ \\
\hline 2-Chlorophenol & 390 & $\mathrm{U}$ & 460 & $\mathrm{U}$ & 390 & $\mathrm{U}$ & 400 & $\mathrm{U}$ & 400 & $\mathrm{U}$ & 420 & $\mathrm{U}$ \\
\hline 4-Chlorophenyl phenyl ether & 390 & $\mathrm{U}$ & 460 & $\mathrm{U}$ & 390 & $\mathrm{U}$ & 400 & $\mathrm{U}$ & 400 & $\mathrm{U}$ & 420 & U \\
\hline Chrysene & 390 & $\mathbf{U}$ & 1,200 & & 390 & U & 120 & $\mathrm{~J}$ & 400 & $\mathbf{U}$ & 420 & $\mathbf{U}$ \\
\hline Di-n-butylphthalate & 100 & $\mathrm{~J}$ & 120 & $\mathbf{J}$ & 110 & $\mathbf{J}$ & 110 & $\mathrm{~J}$ & 98 & $\mathrm{~J}$ & 110 & $\mathrm{~J}$ \\
\hline Di-n-octylphthalate & 390 & $\mathrm{U}$ & 460 & U & 390 & $\mathrm{U}$ & 400 & U & 400 & $\mathbf{U}$ & 420 & $\mathrm{U}$ \\
\hline Dibenz[a,h]anthracene & 390 & $U$ & 150 & $\mathbf{J}$ & 390 & $\mathrm{U}$ & 400 & $\mathrm{U}$ & 400 & $\mathrm{U}$ & 420 & $\mathrm{U}$ \\
\hline Dibenzofuran & 390 & $\mathrm{U}$ & 310 & $\mathbf{J}$ & 390 & $\mathrm{U}$ & 400 & $\mathbf{U}$ & 400 & $U$ & 420 & $\mathrm{U}$ \\
\hline 1,2-Dichlorobenzene & 390 & $\mathrm{U}$ & 460 & $\mathrm{U}$ & 390 & $\mathrm{U}$ & 400 & $\mathbf{U}$ & 400 & $\mathrm{U}$ & 420 & $\mathrm{U}$ \\
\hline 1,3-Dichlorobenzene & 390 & $\mathrm{U}$ & 460 & $\mathrm{U}$ & 390 & $\mathrm{U}$ & 400 & $U$ & 400 & $U$ & 420 & $\mathrm{U}$ \\
\hline 1,4-Dichlorobenzene & 390 & $\mathbf{U}$ & 460 & $\mathrm{U}$ & 390 & $\mathrm{U}$ & 400 & $\mathrm{U}$ & 400 & $\mathrm{U}$ & 420 & $\mathrm{U}$ \\
\hline 3,3'-Dichlorobenzidine & 390 & $\mathrm{U}$ & 460 & $\mathrm{U}$ & 390 & $\mathbf{U}$ & 400 & $\mathrm{U}$ & 400 & $\mathrm{U}$ & 420 & $\mathrm{U}$ \\
\hline 2,4-Dichlorophenol & 390 & $\mathrm{U}$ & 460 & $\mathrm{U}$ & 390 & $\mathrm{U}$ & 400 & $\mathrm{U}$ & 400 & U & 420 & $U$ \\
\hline Diethylphthalate & 390 & $\mathrm{U}$ & 460 & $U$ & 390 & $\mathrm{U}$ & 400 & $\mathrm{U}$ & 400 & $\mathbf{U}$ & 420 & $\mathrm{U}$ \\
\hline Dimethylphthalate & 390 & $\mathbf{U}$ & 460 & $\mathbf{U}$ & 390 & $\mathbf{U}$ & 400 & $\mathrm{U}$ & 400 & $\mathbf{U}$ & 420 & $\mathrm{U}$ \\
\hline 2,4-Dimethylphenol & 390 & $\mathrm{U}$ & 460 & $\mathbf{U}$ & 390 & $\mathrm{U}$ & 400 & $\mathbf{U}$ & 400 & $\mathrm{U}$ & 420 & $\mathbf{U}$ \\
\hline 4,6-Dinitro-2-methylphenol & 960 & $\mathrm{U}$ & 1,200 & $\mathrm{U}$ & 960 & $\mathrm{U}$ & 1,000 & $\mathbf{U}$ & 1,000 & $\mathrm{U}$ & 1,000 & $\mathbf{U}$ \\
\hline 2,4-Dinitrophenol & 960 & $\mathrm{U}$ & 1,200 & $U$ & 960 & $\mathrm{U}$ & 1,000 & $U$ & 1,000 & $\mathrm{U}$ & 1,000 & $\mathbf{U}$ \\
\hline 2,4-Dinitrotoluene & 390 & $\mathbf{U}$ & 460 & $\mathbf{U}$ & 390 & $\mathrm{U}$ & 400 & $U$ & 400 & $\mathrm{U}$ & 420 & $\mathbf{U}$ \\
\hline 2,6-Dinitrotoluene & 390 & $\mathrm{U}$ & 460 & $\mathrm{U}$ & 390 & $\mathrm{U}$ & 400 & $\mathrm{U}$ & 400 & $\mathbf{U}$ & 420 & $\mathrm{U}$ \\
\hline Fluoranthene & 390 & $U$ & 2,300 & & 390 & $\mathrm{U}$ & 180 & $\mathrm{~J}$ & 400 & $\mathrm{U}$ & 420 & $\mathbf{U}$ \\
\hline Fluorene & 390 & $\mathrm{U}$ & 410 & $\mathbf{J}$ & 390 & $\mathrm{U}$ & 400 & $\mathbf{U}$ & 400 & $\mathbf{U}$ & 420 & $\mathrm{U}$ \\
\hline Hexachlorobenzene & 390 & $\mathrm{U}$ & 460 & $\mathbf{U}$ & 390 & $\mathrm{U}$ & 400 & $\mathrm{U}$ & 400 & $\mathrm{U}$ & 420 & $\mathrm{U}$ \\
\hline
\end{tabular}


TABLE C.8a (Cont.)

\begin{tabular}{|c|c|c|c|c|c|c|c|c|c|c|c|c|}
\hline \multirow{3}{*}{ Compound } & \multicolumn{12}{|c|}{ Sediment Concentrations $(\mu \mathrm{g} / \mathrm{kg})$ at Various Depth Intervals } \\
\hline & \multicolumn{2}{|c|}{$\begin{array}{l}\text { BOR6-4 } \\
(8-10 \mathrm{ft}) \\
\end{array}$} & \multicolumn{2}{|c|}{$\begin{array}{l}\text { BOR7-1 } \\
(2-4 \mathrm{ft})\end{array}$} & \multicolumn{2}{|c|}{$\begin{array}{c}\text { BOR7-2 } \\
(4-6 \mathrm{ft}) \\
\end{array}$} & \multicolumn{2}{|c|}{$\begin{array}{l}\text { BOR7-3 } \\
(6-8 \mathrm{ft})\end{array}$} & \multicolumn{2}{|c|}{$\begin{array}{l}\text { BOR7-4 } \\
(8-10 \mathrm{ft})\end{array}$} & \multicolumn{2}{|c|}{$\begin{array}{c}\text { BOR8-1 } \\
(0-2 \mathrm{ft})\end{array}$} \\
\hline & 390 & $\mathbf{U}$ & 460 & $\mathbf{U}$ & 390 & $\mathrm{U}$ & 400 & $\mathbf{U}$ & 400 & $\mathbf{U}$ & 420 & $\mathbf{U}$ \\
\hline Hexachlorocyclopentadiene & 390 & $\mathbf{U}$ & 460 & $U$ & 390 & $\mathrm{U}$ & 400 & $\mathbf{U}$ & 400 & $\mathbf{U}$ & 420 & $\mathrm{U}$ \\
\hline Hexachloroethane & 390 & $\mathbf{U}$ & 460 & $\mathrm{U}$ & 390 & $\mathrm{U}$ & 400 & $\mathbf{U}$ & 400 & $\mathbf{U}$ & 420 & U \\
\hline Indeno[1,2,3-c,d]pyrene & 390 & $\mathrm{U}$ & 610 & & 390 & $\mathrm{U}$ & 58 & $\mathrm{~J}$ & 400 & $\mathrm{U}$ & 420 & $\mathrm{U}$ \\
\hline Isophorone & 390 & $\mathbf{U}$ & 460 & $\mathrm{U}$ & 390 & $\mathrm{U}$ & 400 & $\mathrm{U}$ & 400 & $\mathbf{U}$ & 420 & $\mathrm{U}$ \\
\hline 2-Methylnaphthalene & 390 & U & 210 & $\mathbf{J}$ & 390 & $U$ & 400 & $U$ & 400 & U & 420 & $\mathbf{U}$ \\
\hline 2-Methylphenol & 390 & $\mathrm{U}$ & 460 & $\mathrm{U}$ & 390 & U & 400 & $\mathrm{U}$ & 400 & U & 420 & $\mathrm{U}$ \\
\hline 4-Methylphenol & 390 & $U$ & 460 & $\mathbf{U}$ & 390 & U & 400 & $\mathrm{U}$ & 400 & $\mathbf{U}$ & 420 & $\mathbf{U}$ \\
\hline Naphthalene & 390 & $U$ & 460 & $\mathbf{U}$ & 390 & $\mathrm{U}$ & 400 & $\mathrm{U}$ & 400 & $\mathbf{U}$ & 420 & $\mathrm{U}$ \\
\hline 2-Nitroaniline & 960 & $\mathbf{U}$ & 1,200 & $\mathrm{U}$ & 960 & $\mathrm{U}$ & 1,000 & $U$ & 1,000 & U & 1,000 & $\mathrm{U}$ \\
\hline 3-Nitroaniline & 960 & U & 1,200 & $\mathrm{U}$ & 960 & $\mathrm{U}$ & 1,000 & $U$ & 1,000 & $\mathrm{U}$ & 1,000 & $\mathrm{U}$ \\
\hline 4-Nitroaniline & 960 & $\mathbf{U}$ & 1,200 & $\mathrm{U}$ & 960 & $\mathrm{U}$ & 1,000 & $\mathbf{U}$ & 1,000 & $\mathbf{U}$ & 1,000 & $\mathbf{U}$ \\
\hline Nitrobenzene & 390 & $U$ & 460 & $\mathrm{U}$ & 390 & $\mathbf{U}$ & 400 & $\mathbf{U}$ & 400 & $\mathrm{U}$ & 420 & $\mathbf{U}$ \\
\hline 2-Nitrophenol & 390 & $\mathrm{U}$ & 460 & $\mathrm{U}$ & 390 & $U$ & 400 & $\mathbf{U}$ & 400 & U & 420 & $\mathbf{U}$ \\
\hline 4-Nitrophenol & 960 & $\mathrm{U}$ & 1,200 & $U$ & 960 & $U$ & 1,000 & $U$ & 1,000 & $U$ & 1,000 & $U$ \\
\hline N-Nitroso-di-n-propylamine & 390 & $\mathbf{U}$ & 460 & $\mathrm{U}$ & 390 & $U$ & 400 & $\mathbf{U}$ & 400 & $U$ & 420 & $\mathbf{U}$ \\
\hline N-Nitrosodiphenylamine & 390 & $\mathrm{U}$ & 460 & $U$ & 390 & $U$ & 400 & $\mathrm{U}$ & 400 & U & 420 & $U$ \\
\hline Pentachlorophenol & 960 & $\mathrm{U}$ & 1,200 & $\mathbf{U}$ & 960 & U & 1,000 & $U$ & 1,000 & $\mathbf{U}$ & 1,000 & $U$ \\
\hline Phenanthrene & 390 & $\mathrm{U}$ & 1,400 & & 390 & U & 400 & $U$ & 400 & $\mathbf{U}$ & 420 & $U$ \\
\hline Phenol & 390 & $\mathbf{U}$ & 460 & $\mathrm{U}$ & 390 & U & 400 & $U$ & 400 & $\mathbf{U}$ & 420 & U \\
\hline Pyrene & 390 & $\mathrm{U}$ & 1,800 & & 390 & $U$ & 160 & J & 400 & $\mathbf{U}$ & 420 & $\mathbf{U}$ \\
\hline 1,2,4-Trichlorobenzene & 390 & 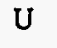 & 460 & U & 390 & U & 400 & $\mathbf{U}$ & 400 & $\mathbf{U}$ & 420 & U \\
\hline 2,4,5-Trichlorophenol & 960 & U & 1,200 & $U$ & 960 & $\mathrm{U}$ & 1,000 & $\mathrm{U}$ & 1,000 & $\mathbf{U}$ & 1,000 & $\mathrm{U}$ \\
\hline 2,4,6-Trichlorophenol & 390 & $\mathrm{U}$ & 460 & U & 390 & $\mathrm{U}$ & 400 & $\mathrm{U}$ & 400 & $\mathbf{U}$ & 420 & $\mathrm{U}$ \\
\hline
\end{tabular}


TABLE C.8a (Cont.)

\begin{tabular}{|c|c|c|c|c|c|c|c|c|c|c|}
\hline \multirow{3}{*}{$\begin{array}{l}\text { Compound } \\
\text { Acenaphthene }\end{array}$} & \multicolumn{10}{|c|}{ Sediment Concentrations $(\mu \mathrm{g} / \mathrm{kg}$ ) at Various Depth Intervals } \\
\hline & \multicolumn{2}{|c|}{$\begin{array}{c}\text { BOR8-2 } \\
(2-4 \mathrm{ft}) \\
\end{array}$} & \multicolumn{2}{|c|}{$\begin{array}{c}\text { BOR8-3 } \\
(4-6 \mathrm{ft}) \\
\end{array}$} & \multicolumn{2}{|c|}{$\begin{array}{l}\text { BOR8-3Dup } \\
(4-6 \mathrm{ft})\end{array}$} & \multicolumn{2}{|c|}{$\begin{array}{c}\text { BOR8-4 } \\
(6-8 \mathrm{ft}) \\
\end{array}$} & \multicolumn{2}{|c|}{$\begin{array}{l}\text { BOR8-5 } \\
(8-10 \mathrm{ft}) \\
\end{array}$} \\
\hline & 410 & $\mathbf{U}$ & 400 & $\mathbf{U}$ & 400 & $\mathbf{U}$ & 390 & $\mathbf{U}$ & 410 & $\mathrm{U}$ \\
\hline Acenaphthylene & 410 & $\mathrm{U}$ & 400 & $\mathrm{U}$ & 400 & $\mathbf{U}$ & 390 & $\mathrm{U}$ & 410 & $\mathrm{U}$ \\
\hline Anthracene & 410 & $\mathrm{U}$ & 400 & $\mathrm{U}$ & 400 & $\mathrm{U}$ & 390 & U & 410 & $\mathrm{U}$ \\
\hline Benz[a]anthracene & 410 & $\mathrm{U}$ & 400 & $\mathrm{U}$ & 400 & $\mathbf{U}$ & 390 & $\mathbf{U}$ & 410 & $\mathbf{U}$ \\
\hline Benzo[a]pyrene & 410 & $\mathrm{U}$ & 400 & $\mathrm{U}$ & 400 & $\mathrm{U}$ & 390 & $\mathbf{U}$ & 410 & $\mathrm{U}$ \\
\hline Benzo[b]fluoranthene & 410 & $\mathrm{U}$ & 400 & $\mathrm{U}$ & 400 & $\mathrm{U}$ & 390 & $\mathrm{U}$ & 410 & $\mathrm{U}$ \\
\hline Benzo[g,h,i]perylene & 410 & U & 400 & $\mathrm{U}$ & 400 & $\mathrm{U}$ & 390 & $\mathbf{U}$ & 410 & $\mathrm{U}$ \\
\hline Benzo[k]fluoranthene & 410 & $\mathbf{U}$ & 400 & $U$ & 400 & $\mathrm{U}$ & 390 & $U$ & 410 & $\mathrm{U}$ \\
\hline Bis(2-chloroethoxy)methane & 410 & $\mathrm{U}$ & 400 & $\mathrm{U}$ & 400 & $\mathrm{U}$ & 390 & $\mathrm{U}$ & 410 & $\mathrm{U}$ \\
\hline Bis(2-chloroethyl)ether & 410 & $U$ & 400 & $\mathbf{U}$ & 400 & $\mathbf{U}$ & 390 & $\mathbf{U}$ & 410 & $\mathrm{U}$ \\
\hline Bis(2-chloroisopropyl)ether & 410 & $\mathrm{U}$ & 400 & $\mathrm{U}$ & 400 & $\mathbf{U}$ & 390 & $\mathrm{U}$ & 410 & $\mathrm{U}$ \\
\hline Bis(2-ethylhexyl)phthalate & 410 & $\mathrm{U}$ & 400 & $U$ & 400 & $\mathrm{U}$ & 50 & J & 410 & $\mathrm{U}$ \\
\hline 4-Bromophenyl phenylether & 410 & $U$ & 400 & $\mathrm{U}$ & 400 & $\mathbf{U}$ & 390 & $\mathbf{U}$ & 410 & U \\
\hline Butylbenzylphthalate & 410 & $\mathrm{U}$ & 400 & $\mathrm{U}$ & 400 & $\mathrm{U}$ & 390 & $\mathrm{U}$ & 410 & $\mathrm{U}$ \\
\hline Carbazole & 410 & $\mathbf{U}$ & 400 & $\mathrm{U}$ & 400 & $\mathbf{U}$ & 390 & $\mathrm{U}$ & 410 & U \\
\hline 4-Chloro-3-methylphenol & 410 & $\mathrm{U}$ & 400 & $\mathrm{U}$ & 400 & $\mathbf{U}$ & 390 & $\mathrm{U}$ & 410 & $\mathrm{U}$ \\
\hline 4-Chloroaniline & 410 & $\mathrm{U}$ & 400 & $\mathrm{U}$ & 400 & $\mathbf{U}$ & 390 & $\mathrm{U}$ & 410 & $\mathrm{U}$ \\
\hline 2-Chloronaphthalene & 410 & $\mathbf{U}$ & 400 & $\mathrm{U}$ & 400 & $\mathrm{U}$ & 390 & $\mathbf{U}$ & 410 & $\mathrm{U}$ \\
\hline 2-Chlorophenol & 410 & $\mathrm{U}$ & 400 & $\mathrm{U}$ & 400 & $\mathbf{U}$ & 390 & $\mathrm{U}$ & 410 & $\mathrm{U}$ \\
\hline 4-Chlorophenyl phenyl ether & 410 & $\mathrm{U}$ & 400 & $\mathbf{U}$ & 400 & $\mathrm{U}$ & 390 & $\mathrm{U}$ & 410 & $U$ \\
\hline Chrysene & 410 & $\mathbf{U}$ & 400 & $\mathrm{U}$ & 400 & $\mathbf{U}$ & 390 & $\mathrm{U}$ & 410 & $\mathrm{U}$ \\
\hline Di-n-butylphthalate & 110 & $\mathbf{J}$ & 150 & J & 200 & $\mathrm{~J}$ & 390 & $\mathrm{U}$ & 67 & $\mathbf{J}$ \\
\hline Di-n-octylphthalate & 410 & $\mathbf{U}$ & 400 & $U$ & 400 & $\mathrm{U}$ & 390 & $\mathrm{U}$ & 410 & $\mathrm{U}$ \\
\hline Dibenz$[a, h] a n t h r a c e n e$ & 410 & $\mathrm{U}$ & 400 & $\mathrm{U}$ & 400 & $\mathrm{U}$ & 390 & $\mathrm{U}$ & 410 & $\mathrm{U}$ \\
\hline Dibenzofuran & 410 & $\mathrm{U}$ & 400 & $\mathbf{U}$ & 400 & $\mathrm{U}$ & 390 & $\mathrm{U}$ & 410 & U \\
\hline 1,2-Dichlorobenzene & 410 & $\mathrm{U}$ & 400 & $\mathbf{U}$ & 400 & $\mathrm{U}$ & 390 & $\mathrm{U}$ & 410 & $\mathbf{U}$ \\
\hline 1,3-Dichlorobenzene & 410 & $\mathrm{U}$ & 400 & $\mathbf{U}$ & 400 & $\mathrm{U}$ & 390 & $U$ & 410 & U \\
\hline 1,4-Dichlorobenzene & 410 & $\mathrm{U}$ & 400 & $\mathbf{U}$ & 400 & $\mathbf{U}$ & 390 & $\mathbf{U}$ & 410 & $\mathbf{U}$ \\
\hline
\end{tabular}


TABLE C.8a (Cont.)

\begin{tabular}{|c|c|c|c|c|c|c|c|c|c|c|}
\hline \multirow[b]{2}{*}{ Compound } & \multicolumn{10}{|c|}{ Sediment Concentrations $(\mu \mathrm{g} / \mathrm{kg})$ at Various Depth Intervals } \\
\hline & \multicolumn{2}{|c|}{$\begin{array}{l}\text { BOR8-2 } \\
(2-4 \mathrm{ft})\end{array}$} & \multicolumn{2}{|c|}{$\begin{array}{l}\text { BOR8-3 } \\
(4-6 \mathrm{ft})\end{array}$} & \multicolumn{2}{|c|}{$\begin{array}{c}\text { BOR8-3Dup } \\
\text { (4-6ft) }\end{array}$} & \multicolumn{2}{|c|}{$\begin{array}{c}\text { BOR8-4 } \\
(6-8 \mathrm{ft})\end{array}$} & \multicolumn{2}{|c|}{$\begin{array}{l}\text { BOR8-5 } \\
(8-10 \mathrm{ft})\end{array}$} \\
\hline 3,3'-Dichlorobenzidine & 410 & $\mathrm{U}$ & 400 & $\mathrm{U}$ & 400 & $\mathrm{U}$ & 390 & U & 410 & $\mathrm{U}$ \\
\hline 2,4-Dichlorophenol & 410 & $\mathrm{U}$ & 400 & $\mathrm{U}$ & 400 & $\mathbf{U}$ & 390 & U & 410 & U- \\
\hline Diethylphthalate & 410 & $\mathrm{U}$ & 400 & $\mathbf{U}$ & 400 & $\mathbf{U}$ & 390 & U & 410 & $\mathrm{U}$ \\
\hline Dimethylphthalate & 410 & $\mathrm{U}$ & 400 & $\mathbf{U}$ & 400 & $U$ & 390 & $U$ & 410 & $\mathrm{U}$ \\
\hline 2,4-Dimethylphenol & 410 & $U$ & 400 & $\mathbf{U}$ & 400 & $\mathbf{U}$ & 390 & $\mathrm{U}$ & 410 & $\mathrm{U}$ \\
\hline 4,6-Dinitro-2-methylphenol & 1,000 & $\mathrm{U}$ & 1,000 & $\mathrm{U}$ & 1,000 & $\mathbf{U}$ & 980 & $\mathbf{U}$ & 1,000 & $U$ \\
\hline 2,4-Dinitrophenol & 1,000 & $\mathrm{U}$ & 1,000 & $\mathrm{U}$ & 1,000 & $\mathbf{U}$ & 980 & $\mathbf{U}$ & 1,000 & U \\
\hline 2,4-Dinitrotoluene & 410 & $\mathbf{U}$ & 400 & $U$ & 400 & 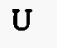 & 390 & $U$ & 410 & $\mathrm{U}$ \\
\hline 2,6-Dinitrotoluene & 410 & $\mathbf{U}$ & 400 & $\mathrm{U}$ & 400 & U & 390 & $U$ & 410 & $\mathrm{U}$ \\
\hline Fluoranthene & 410 & U & 400 & $\mathrm{U}$ & 400 & $\mathrm{U}$ & 390 & U & 410 & $\mathrm{U}$ \\
\hline Fluorene & 410 & $\mathbf{U}$ & 400 & $\mathrm{U}$ & 400 & $U$ & 390 & $\mathrm{U}$ & 410 & $\mathbf{U}$ \\
\hline Hexachlorobenzene & 410 & U & 400 & $\mathrm{U}$ & 400 & $\mathbf{U}$ & 390 & $\mathbf{U}$ & 410 & $\mathrm{U}$ \\
\hline Hexachlorobutadiene & 410 & $\mathrm{U}$ & 400 & $\mathbf{U}$ & 400 & $\mathbf{U}$ & 390 & $\mathrm{U}$ & 410 & $\mathrm{U}$ \\
\hline Hexachlorocyclopentadiene & 410 & $\mathrm{U}$ & 400 & $\mathbf{U}$ & 400 & $\mathrm{U}$ & 390 & $\mathbf{U}$ & 410 & $\mathrm{U}$ \\
\hline Hexachloroethane & 410 & $\mathrm{U}$ & 400 & U & 400 & $\mathrm{U}$ & 390 & $\mathbf{U}$ & 410 & $\mathbf{U}$ \\
\hline Indeno $[1,2,3-c, d] p y r e n e$ & 410 & $\mathrm{U}$ & 400 & $\mathrm{U}$ & 400 & $\mathrm{U}$ & 390 & $\mathbf{U}$ & 410 & $\mathbf{U}$ \\
\hline Isophorone & 410 & $\mathrm{U}$ & 400 & $\mathrm{U}$ & 400 & $\mathrm{U}$ & 390 & $U$ & 410 & $\mathbf{U}$ \\
\hline 2-Methylnaphthalene & 410 & $\mathrm{U}$ & 400 & $\mathbf{U}$ & 400 & $\mathrm{U}$ & 390 & $U$ & 410 & $\mathbf{U}$ \\
\hline 2-Methylphenol & 410 & $U$ & 400 & $\mathbf{U}$ & 400 & $\mathbf{U}$ & 390 & U & 410 & $\mathbf{U}$ \\
\hline 4-Methylphenol & 410 & $\mathrm{U}$ & 400 & $\mathbf{U}$ & 400 & $\mathbf{U}$ & 390 & $\mathrm{U}$ & 410 & $\mathbf{U}$ \\
\hline Naphthalene & 410 & U & 400 & $\mathbf{U}$ & 400 & $\mathbf{U}$ & 390 & $\mathrm{U}$ & 410 & $\mathbf{U}$ \\
\hline 2-Nitroaniline & 1,000 & $\mathbf{U}$ & 1,000 & $\mathbf{U}$ & 1,000 & $\mathbf{U}$ & 980 & $\mathrm{U}$ & 1,000 & U \\
\hline 3-Nitroaniline & 1,000 & $\mathrm{U}$ & 1,000 & $\mathbf{U}$ & 1,000 & $\mathrm{U}$ & 980 & $\mathrm{U}$ & 1,000 & $U$ \\
\hline 4-Nitroaniline & 1,000 & $U$ & 1,000 & $\mathbf{U}$ & 1,000 & $\mathrm{U}$ & 980 & $\mathbf{U}$ & 1,000 & U \\
\hline Nitrobenzene & $\cdot 410$ & $U$ & 400 & $\mathbf{U}$ & 400 & U & 390 & $\mathrm{U}$ & 410 & $\mathrm{U}$ \\
\hline 2-Nitrophenol & 410 & $U$ & 400 & $\mathbf{U}$ & 400 & $\mathrm{U}$ & 390 & $\mathrm{U}$ & 410 & U \\
\hline 4-Nitrophenol & 1,000 & $U$ & 1,000 & U & 1,000 & $\mathrm{U}$ & 980 & $\mathrm{U}$ & 1,000 & $U$ \\
\hline
\end{tabular}




\section{TABLE C.8a (Cont.)}

\begin{tabular}{|c|c|c|c|c|c|c|c|c|c|c|}
\hline \multirow{3}{*}{$\frac{\text { Compound }}{\text { oso-di-n-propylamine }}$} & \multicolumn{10}{|c|}{ Sediment Concentrations $(\mu \mathrm{g} / \mathrm{kg})$ at Various Depth Intervals } \\
\hline & \multicolumn{2}{|c|}{$\begin{array}{l}\text { BOR8-2 } \\
(2-4 \mathrm{ft})\end{array}$} & \multicolumn{2}{|c|}{$\begin{array}{c}\text { BOR8-3 } \\
(4-6 \mathrm{ft})\end{array}$} & \multicolumn{2}{|c|}{$\begin{array}{c}\text { BOR8-3Dup } \\
(4-6 \mathrm{ft})\end{array}$} & \multicolumn{2}{|c|}{$\begin{array}{c}\text { BOR8-4 } \\
(6-8 \mathrm{ft})\end{array}$} & \multicolumn{2}{|c|}{$\begin{array}{l}\text { BOR8-5 } \\
(8-10 \mathrm{ft}) \\
\end{array}$} \\
\hline & 410 & $\mathrm{U}$ & 400 & $\mathbf{U}$ & 400 & $\mathrm{U}$ & 390 & U & 410 & $\mathrm{U}$ \\
\hline N-Nitrosodiphenylamine & 410 & $\mathrm{U}$ & 400 & $\mathrm{U}$ & 400 & $\mathrm{U}$ & 390 & $\mathrm{U}$ & 410 & $\mathrm{U}$ \\
\hline Pentachlorophenol & 1,000 & $\mathrm{U}$ & 1,000 & $\mathrm{U}$ & 1,000 & $\mathrm{U}$ & 980 & $\mathrm{U}$ & 1,000 & $\mathrm{U}$ \\
\hline Phenanthrene & 410 & $\mathrm{U}$ & 400 & U & 400 & $\mathrm{U}$ & 390 & $\mathrm{U}$ & 410 & $\mathrm{U}$ \\
\hline Phenol & 410 & U & 400 & $\mathrm{U}$ & 400 & $\mathrm{U}$ & 390 & $\mathbf{U}$ & 410 & $\mathrm{U}$ \\
\hline Pyrene & 410 & $\mathrm{U}$ & 400 & $\mathrm{U}$ & 400 & $\mathrm{U}$ & 390 & $\mathbf{U}$ & 410 & $\mathrm{U}$ \\
\hline 1,2,4-Trichlorobenzene & 410 & $\mathrm{U}$ & 400 & U & 400 & $\mathrm{U}$ & 390 & $\mathrm{U}$ & 410 & $\mathrm{U}$ \\
\hline 2,4,5-Trichlorophenol & 1,000 & $\mathrm{U}$ & 1,000 & U & 1,000 & $\mathrm{U}$ & 980 & $\mathbf{U}$ & 1,000 & $\mathrm{U}$ \\
\hline 2,4,6-Trichlorophenol & 410 & U & 400 & U & 400 & $\mathrm{U}$ & 390 & $\mathbf{U}$ & 410 & $\mathrm{U}$ \\
\hline
\end{tabular}

a Samples by ANL, analyzed by Weston Gulf Coast, CLP/HSL semivolatile organics. Data qualifiers:

$\mathrm{U}=$ analyte was analyzed for but not detected; detection limit given.

$\mathrm{J}=$ indicates an estimated value. 


\begin{tabular}{|c|c|c|c|c|c|c|c|c|c|c|}
\hline \multirow{3}{*}{$\begin{array}{l}\text { Compound } \\
\text { Acenaphthene }\end{array}$} & \multicolumn{10}{|c|}{ Sediment Concentrations $(\mu \mathrm{g} / \mathrm{kg})$ at $0-6 \mathrm{in}$. } \\
\hline & \multicolumn{2}{|c|}{ TPSED 2} & \multicolumn{2}{|c|}{ TPSED 3} & \multicolumn{2}{|c|}{ TPSED 4} & \multicolumn{2}{|c|}{ TPSED 5} & \multicolumn{2}{|c|}{ TPSED 7} \\
\hline & 558 & $U$ & 805 & $U$ & 805 & $\mathrm{U}$ & 674 & $\mathrm{U}$ & 485 & U \\
\hline Acenaphthylene & 558 & $\mathrm{U}$ & 805 & $U$ & 805 & $U$ & 674 & $\mathrm{U}$ & 485 & $\mathrm{U}$ \\
\hline Anthracene & 558 & $\mathrm{U}$ & 805 & $U$ & 805 & $\mathrm{U}$ & 674 & $\mathrm{U}$ & 485 & $\mathrm{U}$ \\
\hline Benz(a)anthracene & 558 & $\mathrm{U}$ & 805 & $U$ & 805 & $U$ & 674 & $U$ & 485 & $\mathrm{U}$ \\
\hline Benzo(a)pyrene & 558 & $\mathrm{U}$ & 805 & $\mathrm{U}$ & 805 & $\mathrm{U}$ & 674 & $U$ & 485 & U \\
\hline Benzo(b)fluoranthene & 558 & $U$ & 805 & $\mathrm{U}$ & 805 & $\mathrm{U}$ & 674 & $U$ & 485 & $\mathrm{U}$ \\
\hline $\operatorname{Benzo}(\mathrm{g}, \mathrm{h}, \mathrm{i})$ perylene & 558 & $U$ & 805 & $U$ & 805 & $U$ & 674 & $U$ & 485 & $\mathrm{U}$ \\
\hline Benzo(k)fluoranthene & 558 & $\mathrm{U}$ & 805 & $\mathrm{U}$ & 805 & $U$ & 674 & $\mathrm{U}$ & 485 & $\mathrm{U}$ \\
\hline Bis(2-chloroethoxy)methane & 558 & $\mathrm{U}$ & 805 & $\mathrm{U}$ & 805 & $\mathrm{U}$ & 674 & $\mathrm{U}$ & 485 & $\mathrm{U}$ \\
\hline Bis(2-chloroethyl)ether & 558 & $\mathrm{U}$ & 805 & $\mathrm{U}$ & 805 & $U$ & 674 & $\mathrm{U}$ & 485 & $\mathrm{U}$ \\
\hline Bis(2-ethylhexyl)phthalate & 558 & $\mathrm{U}$ & 805 & $U$ & 805 & $U$ & 674 & $\mathrm{U}$ & 485 & $\mathrm{U}$ \\
\hline 4-Bromophenyl phenyl ether & 558 & $\mathrm{U}$ & 805 & $U$ & 805 & $U$ & 674 & $\mathrm{U}$ & 485 & $\mathrm{U}$ \\
\hline Butylbenzylphthalate & 558 & $\mathrm{U}$ & 805 & $U$ & 805 & $U$ & 674 & $\mathrm{U}$ & 485 & $\mathrm{U}$ \\
\hline Carbazole & 558 & $\mathrm{U}$ & 805 & $\mathrm{U}$ & 805 & $\mathrm{U}$ & 674 & $\mathrm{U}$ & 485 & $\mathrm{U}$ \\
\hline 4-Chloro-3-methylphenol & 558 & $U$ & 805 & $\mathrm{U}$ & 805 & $\mathrm{U}$ & 674 & $\mathrm{U}$ & 485 & $\mathrm{U}$ \\
\hline 4-Chloroaniline & 558 & $U$ & 805 & $U$ & 805 & $\mathrm{U}$ & 674 & $\mathrm{U}$ & 485 & $\mathrm{U}$ \\
\hline 2-Chloronaphthalene & 558 & $U$ & 805 & $U$ & 805 & $U$ & 674 & $\mathrm{U}$ & 485 & $\mathrm{U}$ \\
\hline 2-Chlorophenol & 558 & $\mathrm{U}$ & 805 & $U$ & 805 & $U$ & 674 & $U$ & 485 & $\mathrm{U}$ \\
\hline 4-Chlorophenyl phenyl ether & 558 & $U$ & 805 & $\mathrm{U}$ & 805 & $\mathrm{U}$ & 674 & $\mathrm{U}$ & 485 & $\mathrm{U}$ \\
\hline Chrysene & 558 & $U$ & 805 & $\mathrm{U}$ & 805 & $\mathrm{U}$ & 674 & $\mathrm{U}$ & 485 & $U$ \\
\hline Di-n-butylphthalate & 558 & $\mathrm{U}$ & 805 & $U$ & 805 & $\mathrm{U}$ & 674 & $\mathrm{U}$ & 485 & $U$ \\
\hline Di-n-octylphthalate & 558 & $U$ & 805 & $U$ & 805 & $\mathrm{U}$ & 674 & $\mathrm{U}$ & 485 & $\mathrm{U}$ \\
\hline Dibenz $(a, h)$ anthracene & 558 & $\mathrm{U}$ & 805 & $\mathrm{U}$ & 805 & $U$ & 674 & $\mathrm{U}$ & 485 & $\mathrm{U}$ \\
\hline Dibenzofuran & 558 & $\mathrm{U}$ & 805 & $U$ & 805 & $\mathrm{U}$ & 674 & $\mathrm{U}$ & 485 & $U$ \\
\hline 1,2-Dichlorobenzene & 558 & $\mathrm{U}$ & 805 & $U$ & 805 & $\mathrm{U}$ & 674 & $U$ & 485 & $U$ \\
\hline 1,3-Dichlorobenzene & 558 & $U$ & 805 & $\mathrm{U}$ & 805 & $U$ & 674 & $U$ & 485 & $\mathrm{U}$ \\
\hline 1,4-Dichlorobenzene & 558 & $U$ & 89 & $\mathbf{J}$ & 805 & $\mathrm{U}$ & 674 & $\mathrm{U}$ & 485 & $\mathrm{U}$ \\
\hline 3,3'-Dichlorobenzidine & 558 & $U$ & 805 & $\mathrm{U}$ & 805 & $\mathrm{U}$ & 674 & $\mathrm{U}$ & 485 & $U$ \\
\hline 2,4-Dichlorophenol & 558 & $U$ & 805 & $U$ & 805 & $\mathrm{U}$ & 674 & $\mathrm{U}$ & 485 & $U$ \\
\hline Diethyl phthalate & 558 & $\mathrm{U}$ & 805 & $U$ & 805 & $\mathrm{U}$ & 674 & $\mathrm{U}$ & 485 & U \\
\hline Dimethyl phthalate & 558 & $U$ & 805 & $\mathrm{U}$ & 805 & $U$ & 674 & U & 485 & $U$ \\
\hline 2,4-Dimethylphenol & 558 & $\mathrm{U}$ & 805 & $U$ & 805 & $U$ & 674 & $U$ & 485 & $\mathrm{U}$ \\
\hline 4,6-Dinitro-2-methylphenol & 1,400 & $U$ & 2,020 & $U$ & 2,020 & $\mathrm{U}$ & 1,690 & $\mathrm{U}$ & 1,220 & $\mathrm{U}$ \\
\hline 2,4-Dinitrophenol & 1,400 & $U$ & 2,020 & $\mathrm{U}$ & 2,020 & $\mathrm{U}$ & 1,690 & $\mathrm{U}$ & 1,220 & $\mathrm{U}$ \\
\hline 2,4-Dinitrotoluene & 558 & $\mathrm{U}$ & 805 & $\mathrm{U}$ & 805 & $U$ & 674 & $\mathrm{U}$ & 485 & $\mathrm{U}$ \\
\hline 2,6-Dinitrotoluene & 558 & $U$ & 805 & $\mathrm{U}$ & 805 & $U$ & 674 & $\mathrm{U}$ & 485 & $\mathrm{U}$ \\
\hline
\end{tabular}


TABLE C.8b (Cont.)

\begin{tabular}{|c|c|c|c|c|c|c|c|c|c|c|}
\hline \multirow{3}{*}{$\begin{array}{l}\text { Compound } \\
\text { Fluoranthene }\end{array}$} & \multicolumn{10}{|c|}{ Sediment Concentrations $(\mu \mathrm{g} / \mathrm{kg})$ at $0-6$ in. } \\
\hline & \multicolumn{2}{|c|}{ TPSED 2} & \multicolumn{2}{|c|}{ TPSED 3} & \multicolumn{2}{|c|}{ TPSED 4} & \multicolumn{2}{|c|}{ TPSED 5} & \multicolumn{2}{|c|}{ TPSED 7} \\
\hline & 61 & $\mathrm{~J}$ & 805 & $\mathrm{U}$ & 805 & $\mathrm{U}$ & 674 & $U$ & 485 & $U$ \\
\hline Fluorene & 558 & $\mathrm{U}$ & 805 & $\mathrm{U}$ & 805 & $\mathrm{U}$ & 674 & $\mathrm{U}$ & 485 & $\mathrm{U}$ \\
\hline Hexachlorobenzene & 84 & $\mathrm{~J}$ & 805 & $U$ & 805 & $\mathrm{U}$ & 674 & $\mathrm{U}$ & 485 & $\mathrm{U}$ \\
\hline Hexachlorobutadiene & 558 & $\mathrm{U}$ & 805 & $\mathrm{U}$ & 805 & $\mathrm{U}$ & 674 & $\mathrm{U}$ & 485 & $\mathrm{U}$ \\
\hline Hexachlorocyclopentadiene & 558 & $\mathrm{U}$ & 805 & $\mathrm{U}$ & .805 & $U$ & 674 & $U$ & 485 & $U$ \\
\hline Hexachloroethane & 558 & $\mathrm{U}$ & 805 & $\mathrm{U}$ & 805 & $\mathrm{U}$ & 674 & $\mathrm{U}$ & 485 & $\mathrm{U}$ \\
\hline Indeno(1,2,3-cd)pyrene & 558 & $\mathrm{U}$ & 805 & $\mathrm{U}$ & 805 & $U$ & 674 & $U$ & 485 & $U$ \\
\hline Isophorone & 558 & $\mathrm{U}$ & 805 & $\mathrm{U}$ & 805 & $U$ & 674 & U & 485 & U \\
\hline 2-Methylnaphthalene & 558 & $\mathrm{U}$ & 805 & U & 805 & $\mathrm{U}$ & 674 & $\mathrm{U}$ & 485 & $\mathrm{U}$ \\
\hline 2-Methylphenol & 558 & $\mathrm{U}$ & 805 & $\mathrm{U}$ & 805 & $U$ & 674 & $U$ & 485 & $U$ \\
\hline 4-Methylphenol & 558 & $\mathrm{U}$ & 805 & $\mathrm{U}$ & 805 & $\mathrm{U}$ & 674 & $\mathrm{U}$ & 485 & $U$ \\
\hline Naphthalene & 558 & $\mathrm{U}$ & 805 & $\mathrm{U}$ & 805 & $\mathrm{U}$ & 674 & $U$ & 485 & $\mathrm{U}$ \\
\hline 2-Nitroaniline & 1,400 & $\mathrm{U}$ & 2,020 & $\mathrm{U}$ & 2,020 & $U$ & 1,690 & $U$ & 1,220 & $U$ \\
\hline 3-Nitroaniline & 1,400 & $\mathrm{U}$ & 2,020 & $\mathrm{U}$ & 2,020 & $U$ & 1,690 & $U$ & 1,220 & $U$ \\
\hline 4-Nitroaniline & 1,400 & $\mathrm{U}$ & 2,020 & $\mathrm{U}$ & 2,020 & $\mathrm{U}$ & 1,690 & $U$ & 1,220 & $\mathrm{U}$ \\
\hline Nitrobenzene & 558 & $\mathrm{U}$ & 805 & $\mathrm{U}$ & 805 & $U$ & 674 & $\mathrm{U}$ & 485 & $\mathrm{U}$ \\
\hline 2-Nitrophenol & 558 & $\mathrm{U}$ & 805 & $\mathrm{U}$ & 805 & $\mathrm{U}$ & 674 & $\mathrm{U}$ & 485 & $U$ \\
\hline 4-Nitrophenol & 1,400 & $\mathrm{U}$ & 2,020 & $\mathrm{U}$ & 2,020 & $\mathrm{U}$ & 1,690 & $\mathrm{U}$ & 1,220 & $\mathrm{U}$ \\
\hline N-Nitroso-di-n-propylamine & 558 & $\mathrm{U}$ & 805 & $\mathrm{U}$ & 805 & $U$ & 674 & $U$ & 485 & $\mathrm{U}$ \\
\hline N-Nitrosodiphenylamine & 558 & $U$ & 805 & $\mathrm{U}$ & 805 & $\mathrm{U}$ & 674 & $\mathrm{U}$ & 485 & $\mathrm{U}$ \\
\hline 2,2'-Oxybis-(1-chloropropane) & 558 & $\mathrm{U}$ & 805 & $\mathrm{U}$ & 805 & $\mathrm{U}$ & 674 & $\mathrm{U}$ & 485 & U \\
\hline Pentachlorophenol & 1,400 & $\mathrm{U}$ & 2,020 & $\mathrm{U}$ & 2,020 & $U$ & 1,690 & $U$ & 1,220 & $\mathrm{U}$ \\
\hline Phenanthrene & 558 & $\mathrm{U}$ & 805 & $\mathrm{U}$ & 805 & $\mathrm{U}$ & 674 & $U$ & 485 & $\mathrm{U}$ \\
\hline Phenol & 558 & $\mathrm{U}$ & 805 & $\mathrm{U}$ & 805 & $U$ & 674 & $U$ & 485 & $U$ \\
\hline Pyrene & 64 & $\mathrm{~J}$ & 805 & $\mathrm{U}$ & 805 & $\mathrm{U}$ & 674 & $U$ & 485 & $\mathrm{U}$ \\
\hline 1,2,4-Trichlorobenzene & 558 & $\mathrm{U}$ & 805 & $\mathrm{U}$ & 805 & $\mathrm{U}$ & 674 & $U$ & 485 & $\mathrm{U}$ \\
\hline 2,4,5-Trichlorophenol & 1,400 & $\mathrm{U}$ & 2,020 & $U$ & 2,020 & $\mathrm{U}$ & 1,690 & $U$ & 1,220 & $\mathrm{U}$ \\
\hline 2,4,6-Trichlorophenol & 558 & $\mathrm{U}$ & 805 & $\mathrm{U}$ & 805 & $\mathrm{U}$ & 674 & $\mathrm{U}$ & 485 & $\mathrm{U}$ \\
\hline
\end{tabular}

a Sampled by ANL and analyzed by GP Environmental Services.

Data Qualifiers:

$\mathrm{U}=$ analyte was analyzed for but not detected; detection limit given.

$\mathrm{J}=$ indicates an estimated value. 
TABLE C.9a Inorganic Analyses for Sediment Borings, April 1994

\begin{tabular}{|c|c|c|c|c|c|c|c|c|c|c|c|c|c|c|c|c|}
\hline \multirow[b]{2}{*}{ Parameter } & \multicolumn{16}{|c|}{ Sediment Concentrations (mg/kg) at Various Depth Intervals } \\
\hline & \multicolumn{2}{|c|}{$\begin{array}{c}\text { BOR1-1 } \\
(6-8 \mathrm{ft})\end{array}$} & \multicolumn{2}{|c|}{$\begin{array}{l}\text { BORI-2 } \\
(8-10 \mathrm{ft}) \\
\end{array}$} & \multicolumn{2}{|c|}{$\begin{array}{c}\text { BORl-3 } \\
(10-12 \mathrm{ft}) \\
\end{array}$} & \multicolumn{2}{|c|}{$\begin{array}{c}\text { BOR2-1 } \\
(3-5 \mathrm{ft}) \\
\end{array}$} & \multicolumn{2}{|c|}{$\begin{array}{c}\text { BOR2-2 } \\
(5-8 \mathrm{ft})\end{array}$} & \multicolumn{2}{|c|}{$\begin{array}{l}\text { BOR2-3 } \\
(8-10 \mathrm{ft}) \\
\end{array}$} & \multicolumn{2}{|c|}{$\begin{array}{c}\text { BOR3-1 } \\
(6-8 \mathrm{ft}) \\
\end{array}$} & \multicolumn{2}{|c|}{$\begin{array}{l}\text { BOR3-2 } \\
(8-10 \mathrm{ft}) \\
\end{array}$} \\
\hline Aluminum & 11,800 & $\mathrm{~N}$ & 10,100 & & 8,110 & $\mathrm{~N}$ & 9,820 & $\mathrm{~N}$ & 10,000 & $N$ & 6,990 & $\mathrm{~N}$ & 5,330 & $\mathbf{N}$ & 4,400 & $\mathbf{N}$ \\
\hline Antimony & 6 & UN & 6.2 & UN & 5.4 & UN & 10.5 & UN & 6.1 & UN & 5.0 & UN & 4.8 & UN & 5.0 & UN \\
\hline Arsenic & 4.4 & & 10.5 & & 1.2 & & 14.4 & & 5.6 & & 1.4 & & 0.96 & & 0.31 & \\
\hline Barium & 77.6 & & 64.6 & & 55.5 & & 202 & & 78.2 & & 51 & & 26.7 & & 30.6 & \\
\hline Beryllium & 0.62 & & 0.97 & & 0.36 & & 0.35 & & 0.36 & & 0.68 & & 0.28 & & 0.28 & \\
\hline Cadmium & 0.57 & U & 0.59 & $\mathrm{U}$ & 0.51 & $\mathbf{U}$ & 2.6 & & 0.58 & $\mathbf{U}$ & 0.48 & $\mathrm{U}$ & 0.46 & $\mathrm{U}$ & 0.48 & $\mathrm{U}$ \\
\hline Calcium & 596 & & 421 & & 351 & & 1,300 & & 691 & & 471 & & 413 & & 275 & \\
\hline Chromium & 18.4 & & 20 & & 13.5 & & 36.3 & & 14.1 & & 11.9 & & 7.0 & & 7.1 & \\
\hline Cobait & 5.8 & & 5.1 & & 3.5 & & 4.1 & & 3.2 & & 4.9 & & 1.5 & & 2.2 & \\
\hline Copper & 17.8 & & 18.2 & & 10.8 & & 319 & & 11.4 & & 11.3 & & 1.5 & & 3.5 & \\
\hline Iron & 14,100 & & 16,500 & & 9,350 & & 14,200 & & 9,750 & & 14,000 & & 6,710 & & 4,530 & \\
\hline Lead & 13.1 & $@ N$ & 20.6 & & 12.3 & $@ N$ & 318 & $@ N$ & 13 & $@ N$ & 7.9 & $@ N$ & 5.6 & $@ N$ & 8.3 & $@ N$ \\
\hline Magnesium & 2,200 & & 2,370 & & 1,360 & & 2,030 & & 1,630 & & 1,650 & & 552 & & 973 & \\
\hline Manganese & 55.5 & & 62.1 & $@$ & 35.8 & & 51.6 & & 43.3 & & 53 & & 13.9 & & 34.3 & \\
\hline Mercury & 0.11 & $\mathrm{U}$ & 0.11 & U@ & 0.09 & $U$ & 0.38 & & 0.14 & U & 0.09 & $\mathbf{U}$ & 0.09 & $\mathrm{U}$ & 0.11 & $\mathrm{U}$ \\
\hline Nickel & 12.7 & & 11.3 & & 9.5 & & 15.2 & & 7.2 & & 10.6 & & 3.3 & & 8.1 & \\
\hline Potassium & 969 & & 978 & & 699 & & 796 & & 732 & & 602 & & 447 & & 473 & \\
\hline Sclenium & 0.36 & & 0.28 & & 0.16 & U & 1.0 & & 0.36 & & 0.15 & $\mathrm{U}$ & 0.18 & $\mathbf{U}$ & 0.17 & $\mathbf{U}$ \\
\hline Silver & 0.58 & & 0.59 & U & 0.51 & & 2.8 & & 0.58 & U & 0.48 & $\mathbf{U}$ & 0.46 & $U$ & 0.48 & $\mathbf{U}$ \\
\hline Sodium & 1,020 & & 801 & $\mathrm{E}$ & 636 & & 2,280 & & 1,270 & & 738 & & 190 & & 78 & \\
\hline Thallium & 0.32 & U & 0.33 & $\mathrm{U}$ & 0.26 & $\mathbf{U}$ & 0.59 & $\mathbf{U}$ & 0.31 & U & 0.25 & $\mathbf{U}$ & 0.29 & $U$ & 0.27 & $\mathbf{U}$ \\
\hline Vanadium & 19.4 & & 22.3 & & 11.4 & & 21 & & 21.4 & & 14.3 & & 11 & & 6.5 & \\
\hline Zinc & 56.9 & E & 45.7 & & 60.1 & E & 445 & E & 31.7 & E & 64.4 & $\mathrm{E}$ & 11.9 & $\mathrm{E}$ & 38.6 & $\mathrm{E}$ \\
\hline Other Parameters & & & & . & & & & & & & & & & & & \\
\hline Cyanide (mg/kg) & 0.69 & U & 0.57 & U & 0.55 & $\mathbf{U}$ & 1.2 & $\mathrm{U}$ & 0.69 & $\mathrm{U}$ & 0.56 & $U$ & 0.57 & $\mathrm{U}$ & 0.54 & $\mathbf{U}$ \\
\hline Solids (\%) & 68.6 & & $\underline{75.9}$ & & 80.8 & & 39 & & 70.4 & & 82.7 & & 78.7 & & 84.1 & \\
\hline
\end{tabular}


TABLE C.9a (Cont.)

\begin{tabular}{|c|c|c|c|c|c|c|c|c|c|c|c|c|c|c|}
\hline \multirow[b]{2}{*}{ Parameter } & \multicolumn{14}{|c|}{ Sediment Concentrations (mg/kg) at Various Depth Intervals } \\
\hline & \multicolumn{2}{|c|}{$\begin{array}{l}\text { BOR4-1 } \\
(5-8 \mathrm{ft})\end{array}$} & \multicolumn{2}{|c|}{$\begin{array}{l}\text { BOR4-2 } \\
(8-10 \mathrm{ft})\end{array}$} & \multicolumn{2}{|c|}{$\begin{array}{l}\text { BOR5-1 } \\
(2-4 \mathrm{ft})\end{array}$} & \multicolumn{2}{|c|}{$\begin{array}{c}\text { BOR5-2 } \\
\text { (4-6 ft) }\end{array}$} & \multicolumn{2}{|c|}{$\begin{array}{c}\text { BOR5-3 } \\
\text { (6-8 ft) }\end{array}$} & \multicolumn{2}{|c|}{$\begin{array}{l}\text { BOR5-4 } \\
(8-10 \mathrm{ft})\end{array}$} & \multicolumn{2}{|c|}{$\begin{array}{l}\text { BOR5-4Dup } \\
(8-10 \mathrm{ft})\end{array}$} \\
\hline & & & & & & & & & \multicolumn{6}{|c|}{ Metals } \\
\hline Aluminum & 3,480 & $\mathrm{~N}$ & 1,850 & $\mathrm{~N}$ & 9,830 & & 12,400 & & 6,780 & & 7,520 & & 6,080 & \\
\hline Antimony & 9.0 & UN & 5.7 & UN & 5.5 & UN & 4.9 & UN & 5.5 & UN & 5.6 & UN & 5.2 & UN \\
\hline Arsenic & 6.7 & & 1.9 & & 3.4 & & 3.4 & & 3.2 & & 3.9 & & 2.1 & \\
\hline Barium & 34.1 & & 11 & & 50.3 & & 51.8 & & 15.8 & & 36.9 & $\cdot$ & 38.5 & \\
\hline Beryllium & 0.54 & & 0.42 & & 0.51 & & 0.46 & & 0.17 & & 0.62 & & 0.54 & \\
\hline Cadmium & 0.85 & $\mathrm{U}$ & 0.54 & $\mathrm{U}$ & 0.52 & $\mathbf{U}$ & 0.46 & $\mathrm{U}$ & 0.52 & $\mathrm{U}$ & 0.53 & $\mathrm{U}$ & 0.49 & $\mathbf{U}$ \\
\hline Calcium & 1,150 & & 346 & & 503 & & 506 & & 284 & & 258 & & 225 & \\
\hline Chromium & 10.3 & & 5.4 & & 12.2 & & 17.6 & & 10.9 & & 12 & & 9.6 & \\
\hline Cobalt & 14.4 & & 2.7 & & 7.4 & & 9.9 & & 6.2 & & 5.9 & & 5.4 & \\
\hline Copper & 16.2 & & 4.5 & & 5.4 & & 8.9 & & 5.0 & & 7.4 & & 6.8 & \\
\hline Iron & 10,600 & & 4,800 & & 10,900 & & 17,400 & & 12,000 & & 12,000 & & 9,480 & \\
\hline Lead & 61.6 & $@ N$ & 7.4 & $@ N$ & 11.2 & & 8.7 & & 5.7 & & 10.7 & & 6.2 & \\
\hline Magnesium & 907 & & 350 & & 1,620 & & 1,980 & & 1,180 & & 1,360 & & 1,230 & \\
\hline Manganese & 40.4 & & 16.8 & & 431 & $@$ & 152 & @ & 61.8 & $@$ & 49.6 & @ & 47.4 & $@$ \\
\hline Mercury. & 0.15 & $\mathrm{U}$ & 0.12 & $\mathrm{U}$ & 0.08 & U@ & 0.08 & U@ & 0.16 & @ & 0.1 & U@ & 0.1 & U@ \\
\hline Nickel & 8.5 & & 3.1 & & 9.4 & & 10.8 & & 10.4 & & 11.7 & & 10.7 & \\
\hline Potassium & 402 & & 218 & & 624 & & 925 & & 604 & & 533 & & 556 & \\
\hline Selenium & 0.73 & & 0.25 & & 0.28 & & 0.16 & & 0.22 & & 0.19 & & 0.18 & $\mathrm{U}$ \\
\hline Silver & 0.85 & $U$ & 0.54 & U & 0.52 & $\mathrm{U}$ & 0.46 & $U$ & 0.52 & $\mathrm{U}$ & 0.49 & $\mathrm{U}$ & 1.0 & $\mathbf{U}$ \\
\hline Sodium & 1130 & & 226 & & 592 & $\mathrm{E}$ & 636 & $\mathbf{E}$ & 588 & $\mathbf{E}$ & 648 & E. & 549 & $\mathrm{E}$ \\
\hline Thallium & 0.45 & $\mathrm{U}$ & 0.3 & $U$ & 0.31 & $\mathbf{U}$ & 0.26 & $\mathbf{U}$ & 0.29 & $\mathbf{U}$ & 0.3 & $\mathrm{U}$ & 0.3 & $\mathbf{U}$ \\
\hline Vanadium & 6.3 & & 3.9 & & 17.9 & & 24.4 & & 14.9 & & 15 & & 8.1 & \\
\hline Zinc & 193 & E & 42.9 & $\mathrm{E}$ & 26.5 & & 32.7 & & 24.8 & & 46 & & 36.6 & \\
\hline \multicolumn{15}{|l|}{ Other Parameters } \\
\hline Cyanide $(\mathrm{mg} / \mathrm{kg})$ & 0.92 & $\mathrm{U}$ & 0.62 & $\mathrm{U}$ & 0.58 & U & 0.58 & $\mathbf{U}$ & 0.6 & $\mathbf{U}$ & 0.59 & $\mathrm{U}$ & 0.59 & $\mathrm{U}$ \\
\hline Solids (\%) & 49.1 & & 75.4 & & 81.9 & & 81.7 & & 82.2 & & 83.7 & & 83.5 & \\
\hline
\end{tabular}


TABLE C.9a (Cont.)

\begin{tabular}{|c|c|c|c|c|c|c|c|c|c|c|c|c|c|c|}
\hline \multirow[b]{2}{*}{ Parameter } & \multicolumn{14}{|c|}{ Sediment Concentrations ( $\mathrm{mg} / \mathrm{kg}$ ) at Various Depth Intervals } \\
\hline & \multicolumn{2}{|c|}{$\begin{array}{c}\text { BOR6-1 } \\
(2-4 \mathrm{ft}) \\
\end{array}$} & \multicolumn{2}{|c|}{$\begin{array}{c}\text { BOR6-2 } \\
(4-6 \mathrm{ft}) \\
\end{array}$} & \multicolumn{2}{|c|}{$\begin{array}{c}\text { BOR6-3 } \\
(6-8 \mathrm{ft}) \\
\end{array}$} & \multicolumn{2}{|c|}{$\begin{array}{l}\text { BOR6-4 } \\
(8-10 \mathrm{ft}) \\
\end{array}$} & \multicolumn{2}{|c|}{$\begin{array}{c}\text { BOR7-1 } \\
(2-4 \mathrm{ft}) \\
\end{array}$} & \multicolumn{2}{|c|}{$\begin{array}{c}\text { BOR7-2 } \\
(4-6 \mathrm{ft})\end{array}$} & \multicolumn{2}{|c|}{$\begin{array}{c}\text { BOR7-3 } \\
(6-8 \mathrm{ft}) \\
\end{array}$} \\
\hline Aluminum & 9,180 & & 7,680 & & 5,990 & & 10,100 & & 6,430 & & 7,530 & & 6,960 & \\
\hline Antimony & 5.9 & UN & 5.6 & UN & 5.3 & UN & 5.1 & UN & 6.3 & UN & 5.0 & UN & 5.9 & UN \\
\hline Arsenic & 3.1 & & 3.8 & & 2.1 & & 2.6 & & 1.9 & & 1.2 & & 3.1 & \\
\hline Barium & 34.1 & & 46.2 & & 22.7 & & 34.9 & & 36.6 & & 35 & & 57.6 & \\
\hline Beryllium & 0.37 & & 0.51 & & 0.32 & & 0.62 & & 0.49 & & 0.44 & & 0.73 & \\
\hline Cadmium & 0.56 & $\mathrm{U}$ & 0.52 & $\mathrm{U}$ & 0.5 & $\mathrm{U}$ & 0.48 & $\mathbf{U}$ & 0.6 & $\mathbf{U}$ & 0.47 & $\mathbf{U}$ & 0.55 & $\mathbf{U}$ \\
\hline Calcium & 427 & & 493 & & 369 & & 614 & & 754 & & 504 & & 428 & \\
\hline Chromium & 11.7 & & 14.6 & & 8.8 & & 17.1 & & 9.5 & & 12.4 & & 14.2 & \\
\hline Cobalt & 4.6 & & 5.6 & & 3.5 & & 5.8 & & 3.5 & & 4.9 & & 8.2 & \\
\hline Copper & 4.3 & & 8.3 & & 5.0 & & 9.0 & & 5.8 & & 5.8 & & 8.7 & \\
\hline Iron & 12,300 & & 14,600 & & 8,430 & & 12,000 & & 8,570 & & 8,070 . & & 11,600 & \\
\hline Lead & 6.7 & & 10.3 & & 4.4 & & 7.4 & & 7.7 & & 5.6 & & 10.4 & \\
\hline Magnesium & 1,390 & & 1,560 & & 1,200 & & 2,050 & & 1,260 & & 1,160 & & 1,400 & \\
\hline Manganese & 113 & @ & 88.4 & @ & 71.9 & @ & 80.3 & @ & 37.6 & @ & 20.2 & @ & 33.7 & @ \\
\hline Mercury & 0.11 & U@ & 0.09 & U@ & 0.1 & u@ & 0.1 & U@ & 0.11 & U@ & 0.1 & U@ & 0.12 & U@ \\
\hline Nickel & 8.8 & & 8.6 & & 6.6 & & 11.9 & & 7.6 & & 7.4 & & 12.6 & \\
\hline Potassium - & 563 & & 682 & & 457 & & 636 & & 467 & & 462 & & 537 & \\
\hline Selenium & 0.2 & $\mathrm{U}$ & 0.18 & $\mathrm{U}$ & 0.19 & $\mathrm{U}$ & 0.19 & & 0.34 & & 0.18 & U & 0.26 & \\
\hline Silver & 0.56 & $\mathrm{U}$ & 0.52 & $\mathbf{U}$ & 0.5 & $\mathrm{U}$ & 0.52 & & 0.6 & U & 0.47 & $\mathrm{U}$ & 0.57 & \\
\hline Sodium & 825 & $\mathrm{E}$ & 762 & $\mathrm{E}$ & 571 & $\mathbf{E}$ & 803 & $E$ & 1,290 & $\mathrm{E}$ & 990 & $E$ & 878 & $\mathrm{E}$ \\
\hline Thallium & 0.32 & $\mathbf{U}$ & 0.29 & $\mathrm{U}$ & 0.3 & $\mathbf{U}$ & 0.27 & $\mathbf{U}$ & 0.33 & $\mathrm{U}$ & 0.3 & $\mathrm{U}$ & 0.31 & U \\
\hline Vanadium & 16.4 & & 16.4 & & 12.1 & & 17.7 & & 12.6 & & 9.3 & & 19.9 & \\
\hline Zinc & 21.2 & & 23.9 & & 24 & & 43.1 & & 32.5 & & 26.4 & & 46.6 & \\
\hline \multicolumn{15}{|l|}{ Other Parameters } \\
\hline Cyanide (mg/kg) & 0.58 & $\mathrm{U}$ & 0.56 & $\mathbf{U}$ & 0.54 & $\mathbf{U}$ & 0.58 & & 0.68 & $\mathrm{U}$ & 0.57 & $\mathbf{U}$ & 0.61 & $\mathrm{U}$ \\
\hline Solids (\%) & 80 & & 82.9 & & 83.1 & & 85.3 & U & 70.6 & & 84 & & 81.6 & \\
\hline
\end{tabular}


TABLE C.9a (Cont.)

\begin{tabular}{|c|c|c|c|c|c|c|c|c|c|c|c|c|c|c|}
\hline \multirow[b]{2}{*}{ Parameter } & \multicolumn{14}{|c|}{ Sediment Concentrations (mg/kg) at Various Depth Intervals } \\
\hline & \multicolumn{2}{|c|}{$\begin{array}{l}\text { BOR7-4 } \\
(8-10 \mathrm{ft})\end{array}$} & \multicolumn{2}{|c|}{$\begin{array}{l}\text { BOR8-1 } \\
(0-2 \mathrm{ft})\end{array}$} & \multicolumn{2}{|c|}{$\begin{array}{l}\text { BOR8-2 } \\
(2-4 \mathrm{ft})\end{array}$} & \multicolumn{2}{|c|}{$\begin{array}{l}\text { BOR8-3 } \\
(4-6 \mathrm{ft})\end{array}$} & \multicolumn{2}{|c|}{$\begin{array}{l}\text { BOR8-3Dup } \\
(4-6 \mathrm{ft})\end{array}$} & \multicolumn{2}{|c|}{$\begin{array}{l}\text { BOR8-4 } \\
(6-8 \mathrm{ft})\end{array}$} & \multicolumn{2}{|c|}{$\begin{array}{l}\text { BOR8-5 } \\
(8-10 \mathrm{ft})\end{array}$} \\
\hline Aluminum & 8,670 & & 9,090 & & 3,690 & & 2,230 & & 2,640 & & 2,530 & & 1,900 & \\
\hline Antimony & 5.5 & UN & 6.1 & UN & 5.2 & UN & 5.2 & UN & 5.6 & UN & 5.8 & UN & 6.0 & UN \\
\hline Arsenic & 3.1 & & 3.4 & & 3.5 & & 1.7 & & 1.7 & & 3.5 & & 2.7 & \\
\hline Barium & 35.5 & & 88.3 & & 15.5 & & 9.4 & & 11.5 & & 11.9 & & 9.9 & \\
\hline Beryllium & 0.46 & & 0.67 & & 0.49 & & 0.24 & & 0.25 & & 0.31 & & 0.31 & \\
\hline Cadmium & 0.52 & $\mathrm{U}$ & 0.58 & $\mathbf{U}$ & 0.49 & U & 0.49 & $\mathbf{U}$ & 0.53 & U & 0.54 & $U$ & 0.56 & $\mathrm{U}$ \\
\hline Calcium & 393 & & 606 & & 253 & & 115 & & 141 & & 131 & & 94.4 & \\
\hline Chromium & 16.3 & & 13.3 & & 7.1 & & 4.9 & & 5.2 & & 4.9 & & 4.0 & \\
\hline Cobalt & 5.9 & & 3.0 & & 1.9 & & 1.3 & & 1.2 & & 1.6 & & 0.99 & \\
\hline Copper & 7.7 & & 21.9 & & 3.9 & & 2.3 & & 3.2 & & 2.6 & & 2.2 & \\
\hline Iron & 11,500 & & 6,600 & & 6,020 & & 2,930 & & 3,740 & & 4,110 & - & 3,250 & \\
\hline Lead & 9.6 & & 19.9 & & 3.5 & & 2.9 & & 4.2 & & 3.6 & & 2.4 & \\
\hline Magnesium & 1,570 & & 1,050 & & 642 & & 472 & & 515 & & 519 & & 436 & \\
\hline Manganese & 40.1 & @ & 38.8 & @ & 23 & @ & 18.3 & @ & 20.5 & @ & 23.3 & $@$ & 19.1 & $@$ \\
\hline Mercury & 0.08 & U@ & 0.11 & U@ & 0.11 & U@ & 0.62 & $@$ & 0.1 & U@ & 0.12 & U@ & 0.09 & U@ \\
\hline Nickel & 12.6 & & 6.2 & & 3.5 & & 2.6 & & 2.7 & & 4.1 & & 2.8 & $\mathrm{U}$ \\
\hline Potassium & 626 & & 477 & & 335 & & 293 & & 288 & & 322 & & 168 & \\
\hline Selenium & 0.17 & $\mathrm{U}$ & 0.32 & & 0.19 & U & 0.19 & $\mathrm{U}$ & 0.19 & $\mathrm{U}$ & 0.18 & $\mathbf{U}$ & 0.16 & $\mathrm{U}$ \\
\hline Silver & 0.52 & $\mathbf{U}$ & 0.58 & U & 0.49 & $\mathrm{U}$ & 0.49 & $U$ & 0.53 & $\mathbf{U}$ & 0.54 & $\mathbf{U}$ & 0.56 & $\mathrm{U}$ \\
\hline Sodium & 861 & $\mathbf{E}$ & 441 & $E$ & 124 & $\mathbf{E}$ & 49 & $\mathbf{E}$ & 55.3 & $E$ & 38.4 & $\mathrm{E}$ & 30.9 & $\mathrm{E}$ \\
\hline Thallium & 0.27 & $\mathbf{U}$ & 0.32 & $U$ & 0.3 & $\mathrm{U}$ & 0.31 & U & 0.31 & $\mathrm{U}$ & 0.3 & $\mathbf{U}$ & 0.27 & U \\
\hline Vanadium & 16.9 & & 14.5 & & 8.7 & & 4.8 & & 5.6 & & 6.4 & & 4.9 & \\
\hline Zinc & 32.5 & & 63.7 & & 27.2 & & 15.4 & & 16.9 & & 13.7 & & 16.5 & \\
\hline
\end{tabular}




\section{TABLE C.9a (Cont.)}

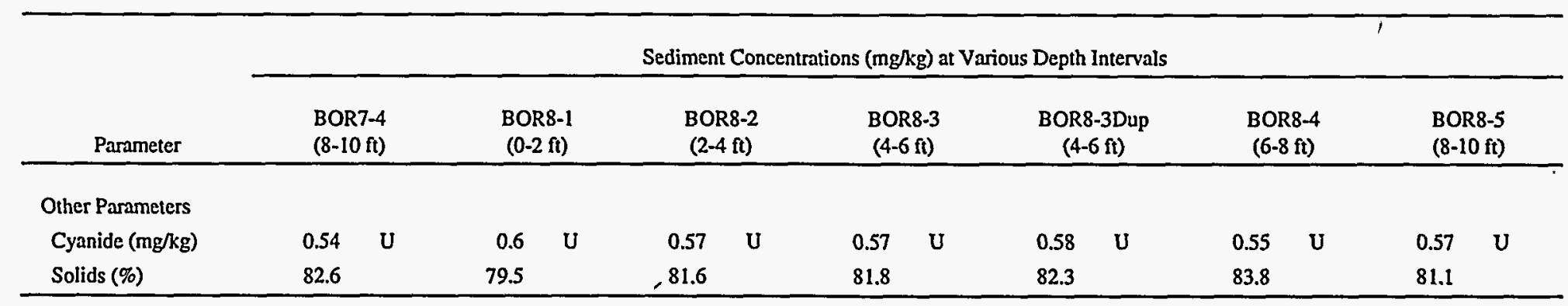

a Sampled by ANL, analyzed by Weston Gulf Coast, CLP/TAL metals and cyanide. Data qualifiers:

$\mathrm{N}=$ spike and spike duplicate recovery of percent RPD were outside the control limits.

$\mathrm{U}=$ analyte was analyzed for but not detected; detection limit given.

@ = percent RPD of sample duplicate was outside of control limits.

$E$ = serial dilution percent difference was outside $Q C$ limit. 
TABLE C.9b Inorganic Analyses for Sediment Borings, June $1995^{2}$

\begin{tabular}{|c|c|c|c|c|c|c|c|c|}
\hline \multirow[b]{2}{*}{ Parameter } & \multicolumn{8}{|c|}{ Sediment Concentrations $(\mathrm{mg} / \mathrm{kg})$ at $0-6$ in. } \\
\hline & \multicolumn{2}{|c|}{ TPSED 1} & \multicolumn{2}{|c|}{ TPSED 2} & \multicolumn{2}{|c|}{ TPSED 3} & \multicolumn{2}{|c|}{ TPSED 4} \\
\hline \multicolumn{2}{|l|}{ Metals } & & & & & & & \\
\hline Aluminum & 26,900 & $*$ & 20,800 & * & 5,260 & $*$ & & \\
\hline Antimony & 15.9 & $\mathrm{BJN}$ & 10.9 & $\mathrm{JN}$ & 0.412 & UJN & 6,120 & \\
\hline Arsenic & 12.3 & & 14.1 & & 6.98 & & 0.599 & \\
\hline Barium & 927 & $\mathrm{~N}$ & 267 & $\mathrm{~N}$ & 104 & $N$ & 1.48 & \\
\hline Beryllium & 1.05 & BJ & 0.89 & $\mathbf{J}$ & 0.379 & $\mathrm{BJ}$ & 50.4 & \\
\hline Cadmium & $7.04^{\circ}$ & $\mathbf{J}$ & 1.32 & $\mathbf{J}$ & 1.55 & $\mathrm{~J}$ & 0.291 & \\
\hline Calcium & 2,470 & & 1,530 & & 3,300 & & 1.06 & \\
\hline Chromium & 80.2 & $\mathrm{~N}$ & 45.9 & $\mathrm{~N}$ & 8.74 & $\mathrm{~N}$ & 5,720 & \\
\hline Cobalt & 9 & $\mathrm{BJ}$ & 8.08 & BJ & 3.15 & UJ & 7.19 & \\
\hline Copper & 515 & & 209 & & 54.7 & & 3.17 & $\mathrm{U}$ \\
\hline Iron & 33,400 & & 25,700 & & 9,870 & & 15.3 & \\
\hline Lead & 1,780 & $*$ & 1,260 & $*$ & 34.9 & * & 5,740 & \\
\hline Magnesium & 5,110 & & 3,080 & & 994 & & 24.2 & \\
\hline Manganese & 160 & & 91.2 & & 84.7 & B & 1,760 & \\
\hline Mercury & 1.71 & & 0.748 & & 0.159 & B & 66.4 & \\
\hline Nickel & 35.2 & & 16.2 & & 5.08 & $\mathrm{U}$ & 0.247 & \\
\hline Potassium & 1,640 & & 1,080 & & 246 & B & 9.04 & \\
\hline Selenium & 1.76 & $\mathrm{JN}$ & 0.614 & BJN & 0.972 & BJN & 429 & \\
\hline Silver & 3.74 & $\mathrm{JN}$ & 1.3 & BJN & 0.169 & UJN & 0.482 & \\
\hline Sodium & 430 & B & 162 & $\mathrm{~B}$ & 716 & $\mathrm{~B}$ & 0.171 & $\mathrm{U}$ \\
\hline Solids (\%) & 30.6 & & 58.5 & & 41.3 & & 1,020 & \\
\hline Thallium & 0.915 & $\mathrm{U}$ & 0.479 & $\mathrm{U}$ & 0.678 & $\mathbf{U}$ & 0.683 & $\mathrm{U}$ \\
\hline Vanadium & 50.2 & $\mathbf{J}$ & 31.5 & $\mathbf{J}$. & 15.4 & $\mathbf{J}$ & 14.1 & \\
\hline Zinc & 3,410 & & 1,410 & & 240 & & 107 & \\
\hline \multicolumn{9}{|l|}{ Other Parameters } \\
\hline Cyanide (total) & 3.27 & & NT & & 2.42 & & NT & \\
\hline $\mathrm{pH}(\mathrm{SI})$ & 7.22 & & 6.47 & & 6.32 & & 6.23 & \\
\hline Solids (\%) & NT & & NT & & NT & & 41 & \\
\hline & \multicolumn{8}{|c|}{ Sediment Concentrations $(\mathrm{mg} / \mathrm{kg})$ at $0-6 \mathrm{in}$. } \\
\hline Parameter & TPS & D 5 . & TPS & D 6 & TPS & D 7 & TPS & D 8 \\
\hline \multicolumn{9}{|l|}{ Metals } \\
\hline Aluminum & 5600 & @J & 6,380 & & 9,750 & & 5,450 & \\
\hline Antimony & 0.344 & UNJ & 0.372 & $\mathrm{U}$ & 0.248 & $\mathbf{U}$ & 0.232 & $\mathbf{U}$ \\
\hline Arsenic & 1.65 & B & 2.91 & & 3.02 & & 1.11 & \\
\hline
\end{tabular}




\begin{tabular}{|c|c|c|c|c|c|c|c|c|}
\hline \multirow[b]{2}{*}{ Parameter } & \multicolumn{8}{|c|}{ Sediment Concentrations $(\mathrm{mg} / \mathrm{kg})$ at $0-6$ in. } \\
\hline & \multicolumn{2}{|c|}{ TPSED 5} & \multicolumn{2}{|c|}{ TPSED 6} & \multicolumn{2}{|c|}{ TPSED 7} & \multicolumn{2}{|c|}{ TPSED 8} \\
\hline \multicolumn{9}{|l|}{ Metals (Cont.) } \\
\hline Barium & 35.4 & B & 49.1 & & 42.6 & & 146 & \\
\hline Beryllium & 0.323 & B & 0.414 & & 0.491 & & 0.464 & \\
\hline Cadmium & 0.886 & B & 0.656 & $\mathrm{U}$ & 0.565 & & 0.654 & \\
\hline Calcium & 2,720 & & 3,870 & & 3,520 & & 1,020 & \\
\hline Chromium & 8.67 & & 10.3 & & 46.2 & & 9.02 & \\
\hline Cobalt & 2.63 & $\mathrm{U}$ & 4.88 & & 3.76 & & 2.23 & \\
\hline Copper & 12.6 & & 16 & & 13.4 & & 34 & \\
\hline Iron & 4,920 & & 9,620 & & 35,600 & & 5,780 & \\
\hline Lead & 18 & & 21 & & 8.26 & & 20.9 & \\
\hline Magnesium & 1,700 & $\mathrm{E}$ & 1,840 & & 1,080 & & 793 & \\
\hline Manganese & 41.9 & $\mathbf{E}$ & 80.9 & & 40.9 & & 31.4 & \\
\hline Mercury & 0.101 & $\mathrm{U}$ & 0.112 & & 0.072 & $\mathrm{U}$ & 0.056 & $\mathbf{U}$ \\
\hline Nickel & 10.9 & & 10.2 & & 9.02 & & 6.54 & \\
\hline Potassium & 410 & B & 473 & & 394 & & 277 & \\
\hline Selenium & 0.46 & B & 1.08 & & 0.289 & & 0.271 & \\
\hline Silver & 0.142 & $\mathbf{U}$ & 0.153 & $\mathrm{U}$ & 0.102 & $\mathrm{U}$ & 0.096 & $\mathrm{U}$ \\
\hline Sodium & 1,130 & & 1,780 & & 328 & & 180 & \\
\hline Thallium & 0.567 & $\mathrm{U}$ & 0.613 & $\mathrm{U}$ & 0.409 & $\mathrm{U}$ & 0.383 & $\mathrm{U}$ \\
\hline Vanadium & 17.1 & & 13.7 & & 13.3 & & 11.8 & \\
\hline Zinc & 69 & & 66.7 & & 51.8 & & 28.7 & \\
\hline \multicolumn{9}{|l|}{ Other Parameters } \\
\hline Cyanide (total) & 2.02 & & NT & & 1.46 & & NT & \\
\hline $\mathrm{pH}(\mathrm{SI})$ & 6.15 & & NT & & 4.79 & & NT & \\
\hline Solids (\%) & 49.4 & & 45.7 & & 68.4 & & 73.1 & \\
\hline
\end{tabular}

a Sampled by ANL and analyzed by GP Environmental Services.

Data qualifiers:

$\mathrm{U}=$ analyte was analyzed for but not detected; detection limit given.

* = internal standard area counts were outside $\mathrm{QC}$ limits.

$\mathrm{B} \quad=$ analyte was found in the associated blank.

$\mathrm{J}=$ estimated value.

$\mathrm{N}=$ spike and spike duplicate recovery of percent RPD were outside the control limits.

$\mathrm{NT}=$ not tested.

@ = percent RPD of sample duplicate was outside of the control limits.

$\mathrm{E}=$ serial dilution percent difference was outside $\mathrm{QC}$ limit. 
TABLE C.10 Pesticide and PCB Analyses for Sediment, June $1995^{\mathrm{a}}$

\begin{tabular}{|c|c|c|c|c|c|c|c|c|c|c|}
\hline \multirow{3}{*}{$\begin{array}{l}\text { Compound } \\
\text { Aldrin }\end{array}$} & \multicolumn{10}{|c|}{ Sediment Concentrations $(\mu \mathrm{g} / \mathrm{kg})$ at $0-6$ in. } \\
\hline & \multicolumn{2}{|c|}{ TPSED 2} & \multicolumn{2}{|c|}{ TPSED 3} & \multicolumn{2}{|c|}{ TPSED 4} & \multicolumn{2}{|c|}{ TPSED 5} & \multicolumn{2}{|c|}{ TPSED 7} \\
\hline & 2.91 & $U$ & 4.08 & $\mathrm{U}$ & 4.05 & $\mathrm{U}$ & 3.43 & $U$ & 2.48 & $U$ \\
\hline alpha-BHC & 2.91 & $\mathrm{U}$ & 4.08 & $\mathrm{U}$ & 4.05 & $U$ & 3.43 & $\mathrm{U}$ & 2.48 & $U$ \\
\hline alpha-Chlordane & 2.91 & $U$ & 4.08 & U & 4.05 & $\mathrm{U}$ & 3.43 & $\mathrm{U}$ & 2.48 & U \\
\hline Aroclor 1016 & 56.4 & $U$ & 79.2 & $\mathrm{U}$ & 78.5 & $\mathrm{U}$ & 66.7 & $U$ & 48.2 & $\mathrm{U}$ \\
\hline Aroclor 1221 & 114 & $\mathrm{U}$ & 161 & $\mathrm{U}$ & 159 & $U$ & 135 & $\mathrm{U}$ & 97.8 & $\mathrm{U}$ \\
\hline Aroclor 1232 & 56.4 & $\mathrm{U}$ & 79.2 & $U$ & 78.5 & $\mathrm{U}$ & 66.7 & $\mathrm{U}$ & 48.2 & $\mathrm{U}$ \\
\hline Aroclor 1242 & 56.4 & $U$ & 79.2 & $U$ & 78.5 & $U$ & 66.7 & $\mathrm{U}$ & 48.2 & $\mathrm{U}$ \\
\hline Aroclor 1248 & 56.4 & $\mathrm{U}$ & 79.2 & $\mathrm{U}$ & 78.5 & $\mathrm{U}$ & 66.7 & $\mathrm{U}$ & 48.2 & $\mathrm{U}$ \\
\hline Aroclor 1254 & 56.4 & $\mathrm{U}$ & 79.2 & $\mathrm{U}$ & 78.5 & $\mathrm{U}$ & 66.7 & $U$ & 48.2 & $\mathrm{U}$ \\
\hline Aroclor 1260 & 56.4 & $U$ & 79.2 & $\mathrm{U}$ & 78.5 & $\mathrm{U}$ & 66.7 & $U$ & 48.2 & $\mathrm{U}$ \\
\hline beta-BHC & 2.91 & $\mathrm{U}$ & 4.08 & $U$ & 4.05 & $\mathrm{U}$ & 3.43 & $\mathrm{U}$ & 2.48 & $\mathrm{U}$ \\
\hline 4,4'-DDD & 11 & & 22 & & 3.1 & & 6.5 & & 3 & \\
\hline 4,4'-DDE & 7.3 & & 16 & & 8.2 & & 9.3 & & 4.2 & \\
\hline 4,4'-DDT & 1.6 & $\mathrm{~J}$ & 7.92 & $\mathrm{U}$ & 7.85 & $\mathrm{U}$ & 6.67 & $U$ & 4.82 & $\mathrm{U}$ \\
\hline delta-BHC & 2.91 & $\mathrm{U}$ & 4.08 & $\mathrm{U}$ & 4.05 & $\mathrm{U}$ & 3.43 & $\mathrm{U}$ & 2.48 & $\mathrm{U}$ \\
\hline Dieldrin & 5.64 & $\mathrm{U}$ & 7.92 & $\mathrm{U}$ & 7.85 & $\mathrm{U}$ & 6.67 & $\mathrm{U}$ & 4.82 & $\mathrm{U}$ \\
\hline Endosulfan I & 2.91 & $U$ & 4.08 & $\mathrm{U}$ & 4.05 & $U$ & 3.43 & $U$ & 2.48 & $U$ \\
\hline Endosulfan II & 5.64 & $U$ & 7.92 & $\mathrm{U}$ & 7.85 & $\mathrm{U}$ & 6.67 & $U$ & 4.82 & $\mathrm{U}$ \\
\hline Endosulfan sulfate & 5.64 & $\mathrm{U}$ & 7.92 & $U$ & 7.85 & $\mathrm{U}$ & 6.67 & $\mathrm{U}$ & 4.82 & $\mathrm{U}$ \\
\hline Endrin & 5.64 & $\mathrm{U}$ & 7.92 & $U$ & 7.85 & $\mathrm{U}$ & 6.67 & $\mathrm{U}$ & 4.82 & $\mathrm{U}$ \\
\hline Endrin aldehyde & 5.64 & $\mathrm{U}$ & 7.92 & $\mathrm{U}$ & 7.85 & $\mathrm{U}$ & 6.67 & $U$ & 4.82 & $\mathrm{U}$ \\
\hline Endrin ketone & 5.64 & $U$ & 7.92 & $\mathrm{U}$ & 7.85 & $\mathrm{U}$ & 6.67 & $\mathrm{U}$ & 4.82 & $\mathrm{U}$ \\
\hline gamma-Chlordane & 2.91 & $\mathrm{U}$ & 4.08 & $\mathrm{U}$ & 4.05 & $\mathrm{U}$ & 3.43 & $\mathrm{U}$ & 2.48 & U \\
\hline Heptachlor & 2.91 & $\mathrm{U}$ & 4.08 & $\mathrm{U}$ & 4.05 & $\mathrm{U}$ & 3.43 & $U$ & 2.48 & $U$ \\
\hline Heptachlor epoxide & 2.91 & $\mathrm{U}$ & 4.08 & $\mathrm{U}$ & 4.05 & $\mathrm{U}$ & 3.43 & $\mathrm{U}$ & 2.48 & $U$ \\
\hline Lindane (gamma-BHC) & 2.91 & $\mathrm{U}$ & 4.08 & $\mathrm{U}$ & 4.05 & $\mathrm{U}$ & 3.43 & $\mathrm{U}$ & 2.48 & $U$ \\
\hline Methoxychlor & 29.1 & $\mathrm{U}$ & 40.8 & $\mathrm{U}$ & 40.5 & $\mathrm{U}$ & 34.3 & $\mathrm{U}$ & 24.8 & $\mathrm{U}$ \\
\hline Toxaphene & 291 & U & 408 & $\mathrm{U}$ & 405 & $\mathrm{U}$ & 343 & U & 248 & $\mathrm{U}$ \\
\hline
\end{tabular}

a Sampled by ANL and analyzed by GP Environmental Services.

Data qualifiers:

$\mathrm{U}=$ analyte was analyzed for but not detected; detection limit given.

$J$ = estimated value. 
TABLE C.11 Explosive Compounds Analyses for Sediment, June 1995

\begin{tabular}{|c|c|c|c|c|c|c|c|c|c|c|c|c|c|c|c|c|}
\hline \multirow{3}{*}{$\frac{\text { Compound }}{\text { 4-Amino-2,6-dinitrotoluene }}$} & \multicolumn{16}{|c|}{ Sediment Concentrations $(\mu \mathrm{g} / \mathrm{kg})$ at $0-6 \mathrm{in}$. } \\
\hline & \multicolumn{2}{|c|}{ TPSED 1} & \multicolumn{2}{|c|}{ TPSED 2} & \multicolumn{2}{|c|}{ TPSED 3} & \multicolumn{2}{|c|}{ TPSED 4} & \multicolumn{2}{|c|}{ TPSED 5} & \multicolumn{2}{|c|}{ TPSED 6} & \multicolumn{2}{|c|}{ TPSED 7} & \multicolumn{2}{|c|}{ TPSED 8} \\
\hline & 40.8 & $\mathbf{U}$ & 40.8 & $\mathrm{U}$ & 40.8 & $\mathrm{U}$ & 40.8 & $\mathrm{U}$ & 40.8 & $\mathbf{U}$ & 40.8 & $\mathbf{U}$ & 40.8 & $\mathrm{U}$ & 40.8 & $\mathbf{U}$ \\
\hline 2-Amino-4,6-dinitrotoluene & 46.7 & $\mathbf{U}$ & 46.7 & $\mathrm{U}$ & 46.7 & $\mathrm{U}$ & 46.7 & $\mathrm{U}$ & 46.7 & $\mathbf{U}$ & 46.7 & U & 46.7 & $\mathrm{U}$ & 46.7 & $\mathrm{U}$ \\
\hline 1,3-Dinitrobenzene & 37.2 & $\mathbf{U}$ & 37.2 & $\mathrm{U}$ & 37.2 & $\mathrm{U}$ & 37.2 & $\mathrm{U}$ & 37.2 & $\mathbf{U}$ & 37.2 & $\mathbf{U}$ & 37.2 & U & 37.2 & U \\
\hline 2,4-Dinitrotoluene & 2110 & & 51.6 & $\mathrm{U}$ & 51.6 & $\mathrm{U}$ & 51.6 & $\mathrm{U}$ & 51.6 & U & 51.6 & U & 51.6 & $U$ & 51.6 & $\mathrm{U}$ \\
\hline 2,6-Dinitrotoluene & 47.6 & $\mathbf{U}$ & 47.6 & $\mathrm{U}$ & 47.6 & $\mathrm{U}$ & 47.6 & $\mathrm{U}$ & 47.6 & $\mathrm{U}$ & 47.6 & $\mathrm{U}$ & 47.6 & $\mathrm{U}$ & 47.6 & $\mathrm{U}$ \\
\hline HMX & 70.5 & $\mathrm{U}$ & 70.5 & $\mathrm{U}$ & 70.5 & $\mathrm{U}$ & 70.5 & $\mathrm{U}$ & 70.5 & $U$ & 70.5 & $\mathbf{U}$ & 70.5 & $\mathbf{U}$ & 70.5 & $\mathrm{U}$ \\
\hline Nitrobenzene & 35.2 & U & 35.2 & $\mathrm{U}$ & 35.2 & $\mathbf{U}$ & 35.2 & $\mathrm{U}$ & 35.2 & $\mathrm{U}$ & 35.2 & $\mathrm{U}$ & 35.2 & $\mathrm{U}$ & 35.2 & $\mathrm{U}$ \\
\hline Nitroglycerin & 10,000 & $U$ & 10,000 & U & 10,000 & $\mathrm{U}$ & 10,000 & $\mathrm{U}$ & 10,000 & $\mathrm{U}$ & 10,000 & $\mathrm{U}$ & 10,000 & $\mathrm{U}$ & 10,000 & $\mathrm{U}$ \\
\hline 2-Nitrotoluene & 81.4 & $U$ & 81.4 & $\mathrm{U}$ & 81.4 & $\mathrm{U}$ & 81.4 & $\mathrm{U}$ & 81.4 & $\mathrm{U}$ & 81.4 & $\mathbf{U}$ & 81.4 & $\mathrm{U}$ & 81.4 & $\mathrm{U}$ \\
\hline 3-Nitrotoluene & 81.7 & $\mathrm{U}$ & 81.7 & $\mathbf{U}$ & 81.7 & $\mathrm{U}$ & 81.7 & $\mathrm{U}$ & 81.7 & $U$ & 81.7 & $\mathrm{U}$ & 81.7 & $\mathrm{U}$ & 81.7 & $\mathrm{U}$ \\
\hline 4-Nitrotoluene & 87.2 & U & 87.2 & $\mathrm{U}$ & 87.2 & $\mathrm{U}$ & 87.2 & $\mathrm{U}$ & 87.2 & $\mathrm{U}$ & 87.2 & $\mathrm{U}$ & 87.2 & $\mathbf{U}$ & 87.2 & $\mathrm{U}$ \\
\hline Pentaerythritol tetranitrate & 250 & $\mathbf{U}$ & 250 & $\mathrm{U}$ & 250 & $\mathrm{U}$ & 250 & $\mathrm{U}$ & 250 & $U$ & 500 & U & 250 & $\mathrm{U}$ & 250 & $\mathrm{U}$ \\
\hline RDX & 50.9 & $\mathbf{U}$ & 50.9 & $U$ & 50.9 & $\mathrm{U}$ & 50.9 & $\mathrm{U}$ & 50.9 & $\mathrm{U}$ & 50.9 & $U$ & 50.9 & $\mathrm{U}$ & 50.9 & $\mathrm{U}$ \\
\hline Tetryl & 163 & $\mathbf{U}$ & 163 & $\mathrm{U}$ & 163 & $\mathrm{U}$ & 163 & $\mathrm{U}$ & 163 & $\mathrm{U}$ & 163 & $\mathrm{U}$ & 163 & $U$ & 163 & $\mathrm{U}$ \\
\hline Thiodiglycol (TDGCL) & NT & & NT & & NT & & 9.62 & $\mathrm{U}$ & 7.98 & $\mathrm{U}$ & 8.62 & $\mathrm{U}$ & 5.76 & $\mathrm{U}$ & 5.39 & $\mathrm{U}$ \\
\hline 1,3,5-Trinitrobenzene & 40.2 & $\mathrm{U}$ & 40.2 & $\mathrm{U}$ & 40.2 & $\mathrm{U}$ & 40.2 & $\mathrm{U}$ & 40.2 & $\mathrm{U}$ & 40.2 & $\mathrm{U}$ & 40.2 & $\mathrm{U}$ & 40.2 & $\mathrm{U}$ \\
\hline 2,4,6-Trinitrotoluene & 35.6 & $\mathrm{U}$ & 35.6 & $\mathrm{U}$ & 35.6 & $\mathrm{U}$ & 35.6 . & $\mathrm{U}$ & 35.6 & $\mathrm{U}$ & 35.6 & $U$ & 35.6 & $\mathrm{U}$ & 35.6 & $\mathrm{U}$ \\
\hline
\end{tabular}

a Sampled by ANL and analyzed by GP Environmental Services.

Data qualifiers:

$\mathrm{U}=$ analyte was analyzed for but not detected; detection limit given.

NT $=$ not tested. 


\section{TABLE C.12 CWA Degradation Products and Organosulfur Compounds Analyses for Sediment, June $1995^{\mathrm{a}}$}

\begin{tabular}{|c|c|c|c|c|c|c|c|c|c|c|c|c|c|c|c|c|}
\hline \multirow[b]{2}{*}{ Compound } & \multicolumn{16}{|c|}{ Sediment Concentrations $(\mu \mathrm{g} / \mathrm{kg}$ ) at 0-6 in. } \\
\hline & \multicolumn{2}{|c|}{ TPSED 1} & \multicolumn{2}{|c|}{ TPSED 2} & \multicolumn{2}{|c|}{ TPSED 3} & \multicolumn{2}{|c|}{ TPSED 4} & \multicolumn{2}{|c|}{ TPSED 5} & \multicolumn{2}{|c|}{ TPSED 6} & \multicolumn{2}{|c|}{ TPSED 7} & \multicolumn{2}{|c|}{ TPSED 8} \\
\hline Diisopropyl methylphosphonate (DIMP) & 0.373 & $\mathbf{U}$ & 1.85 & U & 2.61 & $\mathrm{U}$ & 2.64 & $\mathrm{U}$ & 2.18 & U & 2.36 & $\mathrm{U}$ & 1.58 & $\mathbf{U}$ & 1.48 & $\mathrm{U}$ \\
\hline Dimethyl methylphosphate (DMMP) & 0.435 & $\mathbf{U}$ & 3.51 & U & 5.15 & $\mathrm{U}$ & 2.79 & $\grave{\mathbf{U}}$ & 2.64 & $\mathbf{U}$ & 2.29 & $\mathrm{U}$ & 1.54 & $\mathrm{U}$ & 1.66 & U \\
\hline Isopropyl methylphosphonic acid (IMPA) & 8.15 & $\mathbf{U}$ & 6.73 & $\mathbf{U}$ & 9.54 & $\mathbf{U}$ & NT & & NT & & NT & & NT & & NT & \\
\hline Methyl phosphonic acid & 8.15 & $\mathbf{U}$ & 1.18 & U & 1.67 & $\mathrm{U}$ & 1.69 & $\mathrm{u}$ & 1.4 & U & 1.52 & $\mathrm{u}$ & 1.01 & $\mathrm{U}$ & 0.948 & U \\
\hline Thiodiglycol (TDGCL) & 12.9 & $\mathrm{U}$ & 0.195 & U & 0.276 & $\mathrm{U}$ & 0.278 & $\mathbf{U}$ & 0.23 & $\mathbf{U}$ & 0.25 & $\mathrm{U}$ & 0.166 & $\mathrm{U}$ & 0.156 & $\mathrm{U}$ \\
\hline \multicolumn{17}{|l|}{ Organosulfur compounds } \\
\hline Benzothiozole (BTZ) & 3.53 & $\mathrm{U}$ & 2.51 & $\mathrm{U}$ & 3.56 & $\mathbf{U}$ & 3.59 & $\mathbf{U}$ & 2.97 & U & 3.22 & $\mathbf{U}$ & 2.15 & $\mathbf{U}$ & 2.01 & U \\
\hline p-Chlorophenylmethyl sulfide (CPMS) & 3.53 & $\mathrm{U}$ & 1.46 & u & 2.07 & $\mathbf{U}$ & 2.09 & $\mathrm{U}$ & 1.73 & U & 1.87 & U & 1.25 & $\mathrm{U}$ & 1.17 & $\mathrm{U}$ \\
\hline p-Chlorophenylmethyl sulfone (CPMSO2) & 7.75 & $\mathbf{U}$ & 3.85 & $\mathrm{U}$ & 5.44 & U & 5.49 & $\mathbf{U}$ & 4.54 & $\mathrm{U}$ & 4.93 & $\mathbf{U}$ & 3.28 & $\mathbf{U}$ & 3.08 & $\mathrm{U}$ \\
\hline p-Chlorophenylmethyl sulfoxide (CPMSO) & 7.36 & $\mathrm{U}$ & 4.05 & $\mathrm{U}$ & 5.74 & $\mathrm{U}$ & 5.78 & $\mathbf{U}$ & 4.79 & $u$ & 5.19 & U & 3.46 & U & 3.25 & $\mathrm{U}$ \\
\hline Dimethyl disulfide (DMDS) & 2.26 & U & 3.51 & $\mathbf{U}$ & 5.15 & $\mathbf{U}$ & 2.79 & $\mathbf{U}$ & 2.64 & $\mathrm{U}$ & 2.29 & $\mathbf{U}$ & 1.54 & $\mathbf{U}$ & 1.66 & U \\
\hline 1,4-Dithiane & 4.81 & $\mathrm{U}$ & 0.227 & $U$ & 0.322 & $\mathbf{U}$ & 0.324 & $\mathbf{U}$ & 0.269 & $U$ & 0.291 & $\mathbf{U}$ & 0.194 & $\mathbf{U}$ & 0.182 & $\mathrm{U}$ \\
\hline 1,4-Oxathiane & 2.8 & $\mathrm{U}$ & 1.85 & $\mathrm{U}$ & 2.61 & $\mathbf{U}$ & 2.64 & $\mathbf{U}$ & 2.18 & $\mathrm{U}$ & 2.36 & $\mathrm{U}$ & 1.58 & $\mathbf{U}$ & 1.48 & $\mathrm{U}$ \\
\hline
\end{tabular}

a Sampled by ANL and analyzed by GP Environmental Services. Data qualifiers:

$\mathrm{U}$ = analyte was analyzed for but not detected; detection limit given.

$\mathrm{NT}=$ not tested. 
TABLE C.13a Volatile Organics Analyses for Soil Borings, January $1993^{2}$

\begin{tabular}{|c|c|c|c|c|c|c|c|c|c|c|c|c|c|c|c|c|}
\hline \multirow{3}{*}{$\begin{array}{l}\text { Compound } \\
\text { Acetone }\end{array}$} & \multicolumn{16}{|c|}{ Borehole Concentrations $(\mu \mathrm{g} / \mathrm{kg})$ at Various Depths } \\
\hline & \multicolumn{2}{|c|}{$\begin{array}{c}\text { JBP1-E-2' } \\
(2 \mathrm{ft})\end{array}$} & \multicolumn{2}{|c|}{$\begin{array}{c}\text { JBP1-E-2'Dup } \\
(2 \mathrm{ft})\end{array}$} & \multicolumn{2}{|c|}{$\begin{array}{c}\text { JBP 1-E-4' } \\
(4 \mathrm{ft})\end{array}$} & \multicolumn{2}{|c|}{$\begin{array}{l}\text { JBPI-W-2' } \\
(2 \mathrm{ft})\end{array}$} & \multicolumn{2}{|c|}{$\begin{array}{c}\text { JBP } 1-W-4^{\prime} \\
(4 \mathrm{ft})\end{array}$} & \multicolumn{2}{|c|}{$\begin{array}{c}\text { JBP2-E-2' } \\
(2 \mathrm{ft}) \\
\end{array}$} & \multicolumn{2}{|c|}{$\begin{array}{c}\text { JBP2-E-4' } \\
(4 \mathrm{ft})\end{array}$} & \multicolumn{2}{|c|}{$\begin{array}{c}\text { JBP2-E-4'Dup } \\
\text { (4 ft) }\end{array}$} \\
\hline & 16 & & 14 & B & 33 & B & 22 & B & 11 & BJ & 45 & $\mathrm{~B}$ & 116 & B & 18 & B \\
\hline Benzene & 6 & $\mathrm{u}$ & 6 & $U$ & 6 & $\mathbf{U}$ & 6 & $\mathbf{U}$ & 6 & $\mathbf{U}$ & 6 & $\mathbf{U}$ & 6 & $\mathbf{U}$ & 6 & $\mathbf{U}$ \\
\hline Bromodichloromethane & 6 & $\mathbf{U}$ & 6 & $\mathbf{U}$ & 6 & $\mathrm{U}$ & 6 & $\mathbf{U}$ & 6 & $\mathbf{U}$ & 6 & $\mathbf{U}$ & 6 & $\mathbf{U}$ & 6 & $\mathbf{U}$ \\
\hline Bromoform & 6 & $\mathbf{U}$ & 6 & $\mathbf{U}$ & 6 & $\mathrm{U}$ & 6 & $\mathrm{U}$ & 6 & $\mathbf{U}$ & 6 & $\mathbf{U}$ & 6 & $\mathrm{U}$ & 6 & $\mathbf{U}$ \\
\hline Bromomethane & 12 & $\mathbf{U}$ & 12 & $\mathbf{U}$ & 12 & $\mathrm{U}$ & 12 & $\mathbf{U}$ & 12 & $\mathbf{U}$ & 12 & $\mathbf{U}$ & 12 & $\mathbf{U}$ & 12 & $\mathbf{U}$ \\
\hline 2-Butanone & 12 & $\mathbf{U}$ & 12 & $\mathrm{U}$ & 12 & $\mathrm{U}$ & 12 & $\mathbf{U}$ & 12 & $\mathbf{U}$ & 12 & $\mathrm{U}$ & 12 & $\mathbf{U}$ & 12 & $\mathbf{U}$ \\
\hline Carbon disulfide & 6 & U & 6 & $\mathbf{U}$ & 6 & $\mathrm{U}$ & 6 & $\mathrm{U}$ & 6 & $\mathrm{U}$ & 6 & $\mathbf{U}$ & 6 & $\mathbf{U}$ & 6 & $\mathrm{U}$ \\
\hline Carbon tetrachloride & 6 & U & 6 & $\mathbf{U}$ & 6 & $\mathrm{U}$ & 6 & $\mathbf{U}$ & 6 & $\mathbf{U}$ & 6 & $\mathbf{U}$ & 6 & $\mathbf{U}$ & 6 & $\mathbf{U}$ \\
\hline Chlorobenzene & 6 & $U$ & 6 & U & 6 & $\mathrm{U}$ & 6 & $\mathbf{U}$ & 6 & U & 6 & $U$ & 6 & $\mathrm{U}$ & 6 & $\mathbf{U}$ \\
\hline Chloroethane & 12 & U & 12 & $U$ & 12 & $\mathrm{U}$ & 12 & $\mathrm{U}$ & 12 & $\mathrm{U}$ & 12 & $\mathbf{U}$ & 12 & $\mathbf{U}$ & 12 & $\mathbf{U}$ \\
\hline 2-Chloroethylvinyl ether & 12 & $\mathrm{U}$ & 12 & $\mathrm{U}$ & 12 & $\mathbf{U}$ & 12 & $\mathrm{U}$ & 12 & $\mathbf{U}$ & 12 & $\mathbf{U}$ & 12 & $\mathrm{U}$ & 12 & $\mathbf{U}$ \\
\hline Chloroform & 6 & $\mathrm{U}$ & 6 & $\mathrm{U}$ & 6 & $U$ & 6 & $\mathbf{U}$ & 6 & $\mathbf{U}$ & 6 & $\mathbf{U}$ & 6 & $\mathbf{U}$ & 6 & $\mathbf{U}$ \\
\hline Chloromethane & 12 & $\mathrm{U}$ & 12 & $\mathrm{U}$ & 12 & $\mathrm{U}$ & 12 & $\mathbf{U}$ & 12 & $\mathrm{U}$ & 12 & $\mathrm{U}$ & 12 & $\mathbf{U}$ & 12 & $\mathbf{U}$ \\
\hline Dibromochloromethane & 6 & $u$ & 6 & $\mathrm{U}$ & 6 & $\mathrm{U}$ & 6 & $\mathrm{U}$ & 6 & $\mathrm{U}$ & 6 & $\mathbf{U}$ & 6 & $\mathbf{U}$ & 6 & $\mathbf{U}$ \\
\hline 1,1-Dichloroethane & 6 & $\mathbf{U}$ & 6 & $\mathbf{U}$ & 6 & $U$ & 6 & $\mathrm{U}$ & 6 & $\mathbf{U}$ & 6 & $\mathrm{U}$ & 6 & $\mathbf{U}$ & 6 & $\mathbf{U}$ \\
\hline 1,2-Dichloroethane & 6 & $\mathbf{U}$ & 6 & $\mathrm{U}$ & 6 & $\mathrm{U}$ & 6 & $\mathrm{U}$ & 6 & $\mathrm{U}$ & 6 & $\mathbf{U}$ & 6 & $\mathbf{U}$ & 6 & $\mathbf{U}$ \\
\hline 1,1-Dichloroethene & 6 & $\mathbf{U}$ & 6 & $U$ & 6 & $\mathbf{U}$ & 6 & $\mathbf{U}$ & 6 & $\mathbf{U}$ & 6 & $\mathbf{U}$ & 6 & $\mathbf{U}$ & 6 & $U$ \\
\hline trans-1,2-Dichloroethene & 2 & J & 6 & $\mathrm{U}$ & 6 & $\mathbf{U}$ & 6 & $\mathrm{u}$ & 6 & $\mathrm{U}$ & 6 & $U$ & 6 & $\mathrm{U}$ & 6 & $\mathrm{U}$ \\
\hline 1,2-Dichloropropane & 6 & $\mathbf{U}$ & 6 & U & 6 & $\mathbf{U}$ & 6 & $\mathbf{U}$ & 6 & $U$ & 6 & $\mathrm{U}$ & 6 & $\mathrm{U}$ & 6 & $\mathrm{U}$ \\
\hline cis-1,3-Dichloropropene & 6 & $\mathbf{U}$ & 6 & $\mathbf{U}$ & 6 & $\mathrm{U}$ & 6 & $\mathbf{U}$ & 6 & $\mathrm{U}$ & 6 & $\mathrm{U}$ & 6 & $\mathbf{U}$ & 6 & $\mathrm{U}$ \\
\hline trans-1,3-Dichloropropene & 6 & $\mathbf{U}$ & 6 & $U$ & 6 & $\mathbf{U}$ & 6 & $U$ & 6 & $\mathrm{U}$ & 6 & $U$ & 6 & $\mathrm{U}$ & 6 & U \\
\hline Ethylbenzene & 6 & $\mathbf{U}$ & 6 & $\mathrm{u}$ & 6 & $\mathbf{U}$ & 6 & $\mathrm{U}$ & 6 & $\mathrm{U}$ & 6 & $\mathbf{U}$ & 6 & $\mathrm{U}$ & 6 & $U$ \\
\hline 2-Hexanone & 12 & $\mathrm{U}$ & 12 & $\mathrm{U}$ & 12 & $\mathrm{U}$ & 12 & $\mathbf{U}$ & 12 & $U$ & 12 & $\mathbf{U}$ & 12 & $\mathrm{U}$ & 12 & $\mathrm{U}$ \\
\hline 4-Methyl-2-pentanone & 12 & $\mathrm{U}$ & 12 & U & 12 & $U$ & 12 & $U$ & 12 & $\mathrm{U}$ & 12 & $\mathbf{U}$ & 12 & $\mathrm{U}$ & 12 & $\mathrm{U}$ \\
\hline Methylene chloride & 4 & J & 6 & BJ & 6 & B & 7 & B & 5 & BJ & 6 & BJ & 6 & B & 3 & BJ \\
\hline Styrene & 6 & U & 6 & $\mathbf{U}$ & 6 & U & 6 & U & 6 & $U$ & 6 & $\mathbf{U}$ & 6 & $U$ & 6 & $\mathrm{U}$ \\
\hline
\end{tabular}


TABLE C.13a (Cont.)

\begin{tabular}{|c|c|c|c|c|c|c|c|c|c|c|c|c|c|c|c|c|}
\hline \multirow{3}{*}{$\frac{\text { Compound }}{1,1,2,2 \text {-Tetrachloroethane }}$} & \multicolumn{16}{|c|}{ Borehole Concentrations $(\mu \mathrm{g} / \mathrm{kg})$ at Various Depths } \\
\hline & \multicolumn{2}{|c|}{$\begin{array}{l}\text { JBPI-E-2' } \\
(2 \mathrm{ft})\end{array}$} & \multicolumn{2}{|c|}{$\begin{array}{c}\text { JBP 1-E-2'Dup } \\
(2 \mathrm{ft})\end{array}$} & \multicolumn{2}{|c|}{$\begin{array}{c}\text { JBP1-E-4' } \\
(4 \mathrm{ft}) \\
\end{array}$} & \multicolumn{2}{|c|}{$\begin{array}{c}\text { JBPI-W-2' } \\
(2 \mathrm{ft})\end{array}$} & \multicolumn{2}{|c|}{$\begin{array}{c}\text { JBPI-W-4' } \\
(4 \mathrm{ft})\end{array}$} & \multicolumn{2}{|c|}{$\begin{array}{l}\text { JBP2-E-2' } \\
(2 \mathrm{ft})\end{array}$} & \multicolumn{2}{|c|}{$\begin{array}{c}\text { JBP2-E-4' } \\
(4 \mathrm{ft})\end{array}$} & \multicolumn{2}{|c|}{$\begin{array}{c}\text { JBP2-E-4'Dup } \\
(4 \mathrm{ft})\end{array}$} \\
\hline & 7 & & 3 & J & 4 & $\mathrm{~J}$ & 3 & $\mathrm{BJ}$ & 6 & $\mathrm{U}$ & 3 & $\mathbf{J}$ & 6 & $\mathbf{J}$ & 6 & $\mathbf{U}$ \\
\hline Tetrachloroethene & 6 & $\mathbf{U}$ & 6 & $\mathrm{U}$ & 6 & $\mathbf{U}$ & 6 & $\mathrm{U}$ & 6 & $\mathrm{U}$ & 6 & U & 6 & $\mathrm{U}$ & 6 & $\mathrm{U}$ \\
\hline Toluene & 2 & $\mathbf{J}$ & 3 & $\mathbf{J}$ & 6 & $\mathbf{u}$ & 6 & $\mathrm{U}$ & 6 & $\mathrm{U}$ & 6 & $\mathbf{U}$ & 6 & $\mathrm{U}$ & 6 & $\mathbf{U}$ \\
\hline 1,1,1-Trichloroethane & 6 & $U$ & 6 & $U$ & 6 & $\mathrm{U}$ & 6 & $U$ & 6 & $\mathrm{U}$ & 6 & U & 6 & $\mathrm{U}$ & 6 & $U$ \\
\hline 1,1,2-Trichloroethane & 6 & $\mathbf{U}$ & 6 & $U$ & 6 & $\mathbf{U}$ & 6 & $\mathrm{U}$ & 6 & $\mathrm{U}$ & 6 & $\mathrm{U}$ & 6 & U & 6 & $\mathbf{u}$ \\
\hline Trichloroethene & 28 & & 5 & $\mathbf{J}$ & 6 & $\mathrm{U}$ & 6 & $U$ & 6 & $\mathbf{U}$ & 6 & U & 6 & U & 6 & $\mathbf{U}$ \\
\hline Vinyl acetate & 12 & $\mathrm{U}$ & 12 & $\mathrm{U}$ & 12 & $\mathbf{U}$ & 12 & $\mathrm{U}$ & 12 & $\mathbf{U}$ & 12 & $\mathbf{U}$ & 12 & U & 12 & $\mathrm{U}$ \\
\hline Vinyl chloride & 12 & $\mathrm{U}$ & 12 & $\mathrm{U}$ & 12 & $\mathrm{U}$ & 12 & $\mathrm{U}$ & 12 & $\mathrm{U}$ & 12 & $\mathbf{U}$ & 12 & $\mathrm{U}$ & 12 & $\mathbf{U}$ \\
\hline \multirow[t]{2}{*}{ Xylenes (total) } & 6 & U & 12 & & 6 & U & 6 & $\mathrm{U}$ & 6 & U & 6 & U & 6 & U & 6 & U \\
\hline & \multicolumn{14}{|c|}{ Borehole Concentrations $(\mu \mathrm{g} / \mathrm{kg}$ ) at Various Depths } & & \\
\hline Compound & \multicolumn{2}{|c|}{$\begin{array}{c}\text { JBP2-C-2' } \\
(2 \mathrm{ft})\end{array}$} & \multicolumn{2}{|c|}{$\begin{array}{l}\text { JBP2-C-4' } \\
(4 \mathrm{ft})\end{array}$} & \multicolumn{2}{|c|}{$\begin{array}{l}\text { JBP2-W-2' } \\
(2 \mathrm{ft})\end{array}$} & \multicolumn{2}{|c|}{$\begin{array}{l}\text { JBP2-W-4' } \\
(4 \mathrm{ft})\end{array}$} & \multicolumn{2}{|c|}{$\begin{array}{c}\text { JHDP-C-4' } \\
(4 \mathrm{ft})\end{array}$} & \multicolumn{2}{|c|}{$\begin{array}{l}\text { JHDP-C-6' } \\
(6 \mathrm{ft})\end{array}$} & \multicolumn{2}{|c|}{$\begin{array}{c}\text { JHDP-C-6'Dup } \\
(6 \mathrm{ft})\end{array}$} & & \\
\hline Acetone & 19 & B & 30 & B & 18 & $\mathbf{B}$ & 17 & B & 177 & & 76 & & 113 & & & \\
\hline Benzene & 7 & $\mathbf{U}$ & 6 & $\mathbf{U}$ & 6 & $\mathrm{U}$ & 6 & $\mathbf{U}$ & 19 & & 83 & & 58 & & & \\
\hline Bromodichloromethane & 7 & $\mathbf{U}$ & 6 & $\mathbf{U}$ & 6 & $\mathrm{U}$ & 6 & $\mathbf{U}$ & 2 & J & 6 & $\mathbf{J}$ & 5 & $\mathbf{J}$ & & \\
\hline Bromoform & 7 & $\mathrm{U}$ & 6 & $\mathrm{U}$ & 6. & $\mathrm{U}$ & 6 & $\mathbf{U}$ & 6 & $\mathbf{U}$ & 6 & $\mathrm{U}$ & 6 & $\mathrm{U}$ & & \\
\hline Bromomethane & 14 & $\mathbf{U}$ & 12 & $\mathbf{U}$ & 12 & $\mathrm{U}$ & 12 & $\mathrm{U}$ & 12 & $\mathrm{U}$ & 12 & $U$ & 11 & U & & \\
\hline 2-Butanone & 14 & $\mathrm{U}$ & 12 & $\mathbf{U}$ & 12 & $\mathrm{U}$ & 12 & $\mathbf{U}$ & 12 & $\mathbf{U}$ & 12 & $\mathrm{U}$ & 11 & $\mathbf{U}$ & & \\
\hline Carbon disulfide & 7 & $\mathbf{U}$ & 6 & $\mathbf{U}$ & 6 & $\mathrm{U}$ & 6 & $\mathrm{U}$ & 6 & $\mathrm{U}$ & 1 & $\mathrm{~J}$ & 1 & $\mathbf{J}$ & & \\
\hline Carbon tetrachloride & 7 & $\mathrm{U}$ & 6 & $\mathbf{U}$ & 6 & $U$ & 6 & $\mathbf{u}$ & 17 & & 172 & & 107 & & & . \\
\hline Chlorobenzene & 7 & $\mathbf{U}$ & 6 & $\mathbf{U}$ & 6 & $\mathrm{U}$ & 6 & $\mathbf{U}$ & 6 & $\mathrm{U}$ & 6 & $\mathrm{U}$ & 6 & $U$ & & \\
\hline Chloroethane & 14 & U & 12 & $\mathrm{U}$ & 12 & $\mathrm{U}$ & 12 & $\mathbf{U}$ & 12 & $\mathrm{U}$ & 12 & $\mathbf{U}$ & 11 & $\mathrm{U}$ & & \\
\hline 2-Chloroethylvinyl ether & 14 & $\mathbf{U}$ & 12 & $\mathbf{U}$ & 12 & $\mathrm{U}$ & 12 & $\mathbf{U}$ & 12 & $\mathrm{U}$ & 12 & $\mathbf{U}$ & 11 & $\mathbf{U}$ & & \\
\hline Chloroform & 17 & & 6 & $\mathrm{U}$ & 6 & $\mathrm{U}$ & 1 & $\mathbf{J}$ & 142 & & 445 & & 444 & & & \\
\hline Chloromethane & 14 & $\mathbf{U}$ & 12 & $\mathrm{U}$ & 12 & $\mathbf{U}$ & 12 & $\mathbf{U}$ & 12 & $\mathrm{U}$ & 12 & $\mathbf{U}$ & 11 & $\mathbf{U}$ & & \\
\hline Dibromochloromethane & 7 & $\mathbf{U}$ & 6 & $\mathrm{U}$ & 6 & $\mathrm{U}$ & 6 & $\mathbf{U}$ & 6 & $\mathbf{U}$ & 6 & $\mathbf{U}$ & 6 & $\mathrm{U}$ & & \\
\hline
\end{tabular}


TABLE C.13a (Cont.)

\begin{tabular}{|c|c|c|c|c|c|c|c|c|c|c|c|c|c|c|c|c|c|}
\hline \multirow{3}{*}{$\frac{\text { Compound }}{\text { 1,1-Dichloroethane }}$} & & \multicolumn{14}{|c|}{ Borehole Concentrations $(\mu \mathrm{g} / \mathrm{kg}$ ) at Various Depths } & & \\
\hline & & \multicolumn{2}{|c|}{$\begin{array}{c}\text { JBP2-C-2' } \\
(2 \mathrm{ft}) \\
\end{array}$} & \multicolumn{2}{|c|}{$\begin{array}{c}\text { JBP2-C-4' } \\
(4 \mathrm{ft}) \\
\end{array}$} & \multicolumn{2}{|c|}{$\begin{array}{c}\text { JBP2-W-2' } \\
(2 \mathrm{ft})\end{array}$} & \multicolumn{2}{|c|}{$\begin{array}{c}\text { JBP2-W-4' } \\
(4 \mathrm{ft})\end{array}$} & \multicolumn{2}{|c|}{$\begin{array}{l}\text { JHDP-C-4' } \\
(4 \mathrm{ft})\end{array}$} & \multicolumn{2}{|c|}{$\begin{array}{l}\text { JHDP-C-6' } \\
(6 \mathrm{ft})\end{array}$} & \multicolumn{2}{|c|}{$\begin{array}{c}\text { JHDP-C-6'Dup } \\
(6 \mathrm{ft})\end{array}$} & & \\
\hline & · & 7 & $\mathrm{U}$ & 6 & $\mathrm{U}$ & 6 & $\mathbf{U}$ & 6 & $\mathbf{U}$ & 6 & $\mathbf{U}$ & 7 & & 9 & & & \\
\hline 1,2-Dichloroethane & & 2 & $\mathbf{J}$ & 6 & $\mathrm{U}$ & 6 & $\mathbf{U}$ & 6 & U & 40 & & 53 & & 62 & & & \\
\hline 1,1-Dichloroethene & & 14 & & 6 & $\mathrm{U}$ & 6 & $U$ & 6 & $\mathrm{U}$ & 31 & & 78 & & 77 & & & \\
\hline trans-1,2-Dichloroethene & & 92 & & 5 & $\mathbf{J}$ & 16 & & 62 & & 3,860 & $\mathrm{D}$ & 1,710 & $D$ & 3,220 & $\mathrm{D}$ & & \\
\hline 1,2-Dichloropropane & & 7 & U & 6 & $\mathrm{U}$ & 6 & $\mathbf{U}$ & 6 & $\mathrm{U}$ & 6 & $\mathbf{U}$ & 6 & $\mathrm{U}$ & 6 & $\mathrm{U}$ & & \\
\hline cis-1,3-Dichloropropene & & 7 & $\mathbf{U}$ & 6 & $\mathrm{U}$ & 6 & $\mathrm{U}$ & 6 & $\mathrm{U}$ & 6 & $\mathrm{U}$ & 6 & $\mathrm{U}$ & 6 & $U$ & & \\
\hline trans-1,3-Dichloropropene & & 7 & $\mathrm{U}$ & 6 & $\mathrm{U}$ & 6 & $\mathrm{U}$ & 6 & $U$ & 6 & $\mathrm{U}$ & 6 & $\mathrm{U}$ & 6 & $U$ & & \\
\hline Ethylbenzene & & 7 & $\mathrm{U}$ & 6 & $\mathbf{U}$ & 6 & $\mathbf{U}$ & 6 & $\mathbf{U}$ & 6 & $\mathrm{U}$ & 6 & $\mathrm{U}$ & 6 & $\mathbf{U}$ & & \\
\hline 2-Hexanone & & 14 & $\mathrm{U}$ & 12 & $\mathrm{U}$ & 12 & $\mathbf{U}$ & 12 & $U$ & 12 & $\mathrm{U}$ & 12 & $\mathrm{U}$ & 11 & $U$ & & \\
\hline 4-Methyl-2-pentanone & & 14 & $U$ & 12 & $\mathrm{U}$ & 12 & $\mathrm{U}$ & 12 & $U$ & 12 & $U$ & 12 & $U$ & 11 & U & & \\
\hline Methylene chloride & & 7 & B & 5 & BJ & 6 & $\mathbf{B}$ & 6 & $\mathrm{BJ}$ & 45 & B & 40 & B & 41 & B & & \\
\hline Styrene & & 7 & $\mathbf{U}$ & 6 & $\mathbf{U}$ & 6 & $U$ & 6 & U & 6 & $\mathrm{U}$ & 6 & $\mathrm{U}$ & 6 & $U$ & & \\
\hline 1,1,2,2-Tetrachlorocthane & & 7 & $\mathbf{U}$ & 6 & $\mathbf{U}$ & 26 & $U$ & 16 & & 289,000 & D & $1,890,000$ & $\mathrm{D}$ & $3,270,000$ & $\mathrm{D}$ & & \\
\hline Tetrachloroethene & & 582 & D & 40 & & 26 & & 9 & & 682 & & 5,730 & $\mathrm{D}$ & 25,700 & $\mathrm{D}$ & & \\
\hline Toluene & & 7 & $\mathbf{U}$ & 6 & $\mathbf{U}$ & 6 & $\mathbf{U}$ & 6 & $\mathbf{U}$ & 2 & $\mathbf{J}$ & 6 & $\mathbf{U}$ & 6 & $\mathrm{U}$ & & \\
\hline 1,1,1-Trichloroethane & & 7 & $\mathbf{U}$ & 6 & $U$ & 6 & $U$ & 6 & $\mathrm{U}$ & 6 & $\mathbf{U}$ & 6 & $\mathrm{U}$ & 6 & $\mathbf{U}$ & & \\
\hline 1,1,2-Trichloroethane & & 7 & $\mathbf{U}$ & 6 & $\mathbf{U}$ & 6 & $\mathrm{U}$ & 6 & $\mathrm{U}$ & 2,100 & $\mathrm{D}$ & 7,860 & D & 8,540 & $\mathrm{D}$ & & \\
\hline Trichlorocthene & & 499 & D & 39 & & 176 & D & 168 & $\mathrm{D}$ & 6,780 & D & 33,100 & D & 263,000 & $D$ & & \\
\hline Vinyl acetate & & 14 & $\mathbf{U}$ & 12 & U & 12 & $\mathbf{U}$ & 12 & $\mathbf{U}$ & 12 & $\mathbf{U}$ & 12 & $\mathbf{U}$ & 11 & $\mathbf{U}$ & & \\
\hline Vinyl chloride & & 14 & $\mathbf{U}$ & 12 & $\mathbf{U}$ & 12 & $\mathrm{U}$ & 12 & $\mathbf{U}$ & 315 & & 170 & & 302 & & & \\
\hline \multirow[t]{2}{*}{ Xylenes (total) } & & 7 & $\mathbf{U}$ & 6 & U & 6 & 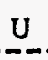 & 6 & U & 6 & U & -6 & 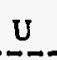 & -6 & $\underline{U}$ & & \\
\hline & & \multicolumn{16}{|c|}{ Borehole Concentrations $(\mu \mathrm{g} / \mathrm{kg})$ at Various Depths } \\
\hline Compound & & \multicolumn{2}{|c|}{$\begin{array}{c}\text { JVXP-C-4' } \\
(4 \mathrm{ft}) \\
\end{array}$} & \multicolumn{2}{|c|}{$\begin{array}{c}\text { JVXP-C-6 } \\
(6 \mathrm{ft}) \\
\end{array}$} & \multicolumn{2}{|c|}{$\begin{array}{c}\text { JSDP-C-4' } \\
(4 \mathrm{ft})\end{array}$} & \multicolumn{2}{|c|}{$\begin{array}{c}\text { JSDP-C-6' } \\
(6 \mathrm{ft})\end{array}$} & \multicolumn{2}{|c|}{$\begin{array}{c}\text { JBPM-A-3" } \\
(3 \text { in. }) \\
\end{array}$} & \multicolumn{2}{|c|}{$\begin{array}{c}\text { JBPM-A-3"Dup } \\
\text { (3 in.) }\end{array}$} & \multicolumn{2}{|c|}{$\begin{array}{c}\text { JBPM-A-1' } \\
(1 \mathrm{ft}) \\
\end{array}$} & \multicolumn{2}{|c|}{$\begin{array}{c}\text { JBPM-B-3" } \\
(3 \text { in.) } \\
\end{array}$} \\
\hline Acetone & & 13 & $\mathbf{U}$ & 14 & $U$ & 344 & & 13 & $\mathbf{U}$ & 67 & & 275 & & 1,460 & BJ & 324 & \\
\hline Benzene & & 7 & $U$ & 7 & $U$ & 33 & $\mathbf{U}$ & 7 & $\mathbf{U}$ & 27 & $\mathbf{U}$ & 30 & $\mathbf{U}$ & 743 & $\mathbf{U}$ & 29 & $\mathbf{U}$ \\
\hline Bromodichloromethane & & 7 & $\mathrm{U}$ & 7 & $\mathbf{U}$ & 33 & $\mathbf{U}$ & 7 & $\mathbf{U}$ & 27 & $\mathbf{U}$ & 30 & $\mathbf{U}$ & 743 & $\mathbf{U}$ & 29 & $U$ \\
\hline
\end{tabular}


TABLE C.13a (Cont.)

\begin{tabular}{|c|c|c|c|c|c|c|c|c|c|c|c|c|c|c|c|c|}
\hline \multirow{3}{*}{$\frac{\text { Compound }}{\text { Bromoform }}$} & \multicolumn{16}{|c|}{ Borehole Concentrations ( $\mu \mathrm{g} / \mathrm{kg}$ ) at Various Depths } \\
\hline & \multicolumn{2}{|c|}{$\begin{array}{c}\text { JVXP-C-4 } \\
(4 \mathrm{ft}) \\
\end{array}$} & \multicolumn{2}{|c|}{$\begin{array}{c}\text { JVXP-C-6' } \\
(6 \mathrm{ft})\end{array}$} & \multicolumn{2}{|c|}{$\begin{array}{c}\text { JSDP-C-4' } \\
(4 \mathrm{ft})\end{array}$} & \multicolumn{2}{|c|}{$\begin{array}{c}\text { JSDP-C-6' } \\
(6 \mathrm{ft})\end{array}$} & \multicolumn{2}{|c|}{$\begin{array}{l}\text { JBPM-A-3" } \\
(3 \text { in.) }\end{array}$} & \multicolumn{2}{|c|}{$\begin{array}{c}\text { JBPM-A-3"Dup } \\
\text { (3 in.) }\end{array}$} & \multicolumn{2}{|c|}{$\begin{array}{c}\text { JBPM-A-1' } \\
(1 \mathrm{ft})\end{array}$} & \multicolumn{2}{|c|}{$\begin{array}{c}\text { JBPM-B-3" } \\
(3 \text { in.) }\end{array}$} \\
\hline & 7 & $\mathrm{U}$ & 7 & $\mathbf{U}$ & 33 & $U$ & 7 & $\mathbf{U}$ & 27 & U & 30 & U & 743 & $\mathrm{U}$ & 29 & $\mathrm{U}$ \\
\hline Bromomethane & 13 & $\mathrm{U}$ & 14 & $\mathbf{U}$ & 67 & $\mathbf{U}$ & 13 & $\mathbf{U}$ & 54 & $\mathrm{U}$ & 59 & $\mathrm{U}$ & 1,490 & $\mathbf{U}$ & 57 & $\mathrm{U}$ \\
\hline 2-Butanone & 13 & $\mathrm{U}$ & 14 & U & 67 & U & 13 & $\mathbf{U}$ & 54 & U & 59 & $\mathrm{U}$ & 1,490 & $\mathrm{U}$ & 57 & $\mathrm{U}$ \\
\hline Carbon disulfide & 7 & $\mathrm{U}$ & 7 & $\mathbf{U}$ & 33 & U & 7 & $\mathbf{U}$ & 27 & $\mathbf{U}$ & 30 & $\mathrm{U}$ & 743 & U & 29 & $\mathrm{U}$ \\
\hline Carbon tetrachloride & 7 & $\mathbf{U}$ & 7 & $\mathbf{U}$ & 33 & U & 7 & $\mathbf{U}$ & 27 & $U$ & 30 & $\mathrm{U}$ & 743 & $\mathbf{U}$ & 29 & $\mathrm{U}$ \\
\hline Chlorobenzene & 7 & $\mathbf{U}$ & 7 & U & 33 & $\mathrm{U}$ & 7 & $\mathrm{U}$ & 27 & $\mathbf{U}$ & 30 & $\mathrm{U}$ & 743 & $\mathbf{U}$ & 29 & $U$ \\
\hline Chloroethane & 13 & $\mathrm{U}$ & 14 & $\mathbf{U}$ & 67 & U & 13 & $\mathbf{U}$ & 54 & $\mathbf{U}$ & 59 & $\mathrm{U}$ & 1,490 & $\mathbf{U}$ & 57 & $\mathrm{U}$ \\
\hline 2-Chloroethylvinyl ether & 13 & $\mathrm{U}$ & 14 & $\mathrm{U}$ & 67 & $\mathbf{U}$ & 13 & $\mathrm{U}$ & 54 & $\mathbf{U}$ & 59 & $U$ & 1,490 & $\mathbf{U}$ & 57 & U \\
\hline Chloroform & 7 & $\mathrm{U}$ & 6 & $\mathbf{J}$ & 33 & U & 7 & $\mathbf{U}$ & 27 & $\mathrm{U}$ & 30 & $\mathbf{U}$ & 743 & $\mathbf{U}$ & 29 & $\mathrm{U}$ \\
\hline Chloromethane & 13 & $\mathbf{U}$ & 14 & U & 67 & $\mathbf{U}$ & 13 & $\mathbf{U}$ & 54 & $\mathrm{U}$ & 59 & $\mathrm{U}$ & 1,490 & $U$ & 57 & $\mathrm{U}$ \\
\hline Dibromochloromethane & 7 & $\mathbf{U}$ & 7 & $\mathrm{U}$ & 33 & $\mathrm{u}$ & 7 & $\mathrm{U}$ & 27 & $\mathbf{U}$ & 30 & $\mathbf{U}$ & 743 & $\mathbf{U}$ & 29 & $\mathrm{U}$ \\
\hline 1,1-Dichloroethane & 7 & $U$ & 7 & $\mathrm{U}$ & 33 & $\mathbf{U}$ & 7 & $\mathbf{U}$ & 27 & $\mathrm{U}$ & 30 & $\mathbf{U}$ & 743 & $U$ & 29 & $\mathbf{U}$ \\
\hline 1,2-Dichloroethane & 7 & $\mathbf{U}$ & 7 & $\mathrm{U}$ & 33 & $\mathrm{U}$ & 7 & $\mathbf{U}$ & 27 & $\mathrm{U}$ & 30 & $\mathbf{U}$ & 743 & $\mathrm{U}$ & 29 & $\mathrm{U}$ \\
\hline 1,1-Dichloroethene & 7 & $\mathbf{U}$ & 7 & $\mathbf{U}$ & 33 & $\mathbf{U}$ & 7 & $\mathrm{U}$ & 27 & $\mathrm{U}$ & 30 & $\mathbf{U}$ & 743 & $\mathrm{U}$ & 29 & $\mathbf{U}$ \\
\hline trans-1,2-Dichloroethene & 7 & $U$ & 7 & $\mathbf{U}$ & 78 & & 7 & $\mathbf{U}$ & 27 & $\mathrm{U}$ & 30 & $\mathbf{U}$ & 743 & $\mathrm{U}$ & 50 & \\
\hline 1,2-Dichloropropane & 7 & $\mathrm{U}$ & 7 & $\mathrm{U}$ & 33 & $\mathrm{U}$ & 7 & $U$ & 27 & $\mathrm{U}$ & 30 & $\mathbf{U}$ & 743 & U & 29 & $\mathbf{U}$ \\
\hline cis-1,3-Dichloropropene & 7 & $\mathrm{U}$ & 7 & $U$ & 33 & $\mathbf{U}$ & 7 & $\mathrm{U}$ & 27 & $\mathrm{U}$ & 30 & $\mathbf{U}$ & 743 & $\mathrm{U}$ & 29 & $\mathbf{U}$ \\
\hline trans-1,3-Dichloropropene & 7 & $\mathrm{U}$ & 7 & $\mathrm{U}$ & 33 & $\mathrm{U}$ & 7 & $\mathbf{U}$ & 27 & $\mathrm{U}$ & 30 & $\mathbf{U}$ & 743 & $U$ & 29 & U \\
\hline Ethylbenzene & 7 & $\mathrm{U}$ & 7 & $\mathrm{U}$ & 33 & $U$ & 7 & $\mathrm{U}$ & 27 & $\mathrm{U}$ & 30 & $\mathbf{U}$ & 743 & $\mathbf{U}$ & 29 & $\mathbf{U}$ \\
\hline 2-Hexanone & 13 & $U$ & 14 & $\mathrm{U}$ & 67 & $\mathbf{U}$ & 13 & $\mathbf{U}$ & 54 & $\mathrm{U}$ & 59 & $\mathbf{U}$ & 1,490 & $U$ & 57 & $\mathbf{U}$ \\
\hline 4-Methyl-2-pentanone & 13 & $\mathrm{U}$ & 14 & $\mathrm{U}$ & 67 & $\mathrm{U}$ & 13 & $\mathrm{U}$ & 54 & $\mathrm{U}$ & 59 & $\mathbf{U}$ & 1,490 & $\mathbf{u}$ & 57 & $\mathbf{U}$ \\
\hline Methylene chloride & 7 & B & 8 & B & 44 & B & 12 & B & 21 & BJ & 36 & B & 467 & $\mathbf{B J}^{-}$ & 36 & B \\
\hline Styrene & 7 & $\mathrm{U}$ & 7 & $\mathrm{U}$ & 33 & $\mathrm{U}$ & 7 & $\mathbf{U}$ & 27 & $\mathbf{U}$ & 30 & $\mathbf{U}$ & 743 & $U$ & 29 & $\mathrm{U}$ \\
\hline 1,1,2,2-Tetrachloroethane & 16 & & 39 & & 15,200 & & 26 & & 123 & & 118 & & 1,460 & $\mathrm{D}$ & 13,200 & D \\
\hline Tetrachloroethene & 7 & $U$ & 7 & $\mathbf{U}$ & 27 & $\mathbf{J}$ & 7 & $\mathbf{U}$ & 27 & $\mathbf{U}$ & 13 & J & 530 & $\mathbf{J}$ & 17 & $\mathbf{J}$ \\
\hline Toluene & 3 & J & 4 & J & 33 & $\mathbf{U}$ & 4 & $\mathrm{~J}$ & 11 & $\mathbf{J}$ & 30 & $\mathbf{U}$ & 743 & $\mathrm{U}$ & 29 & U \\
\hline 1,1,1-Trichloroethane & 7 & $\mathbf{U}$ & 7 & $\mathbf{U}$ & 33 & $\mathrm{U}$ & 7 & $\mathrm{U}$ & 27 & $\mathbf{U}$ & 30 & U & 743 & $\mathrm{U}$ & 29 & U \\
\hline 1,1,2-Trichloroethane & 7 & $\mathrm{U}$ & 7 & U & 81 & & 7 & $\mathrm{U}$ & 33 & & 61 & & 367 & $\mathrm{~J}$ & 80 & \\
\hline Trichloroethene & 3 & $J$ & 16 & & 345 & D & 3 & $\mathbf{J}$ & 245 & & 843 & & 26,000 & $\mathrm{D}$ & 517 & \\
\hline
\end{tabular}


TABLE C.13a (Cont.)

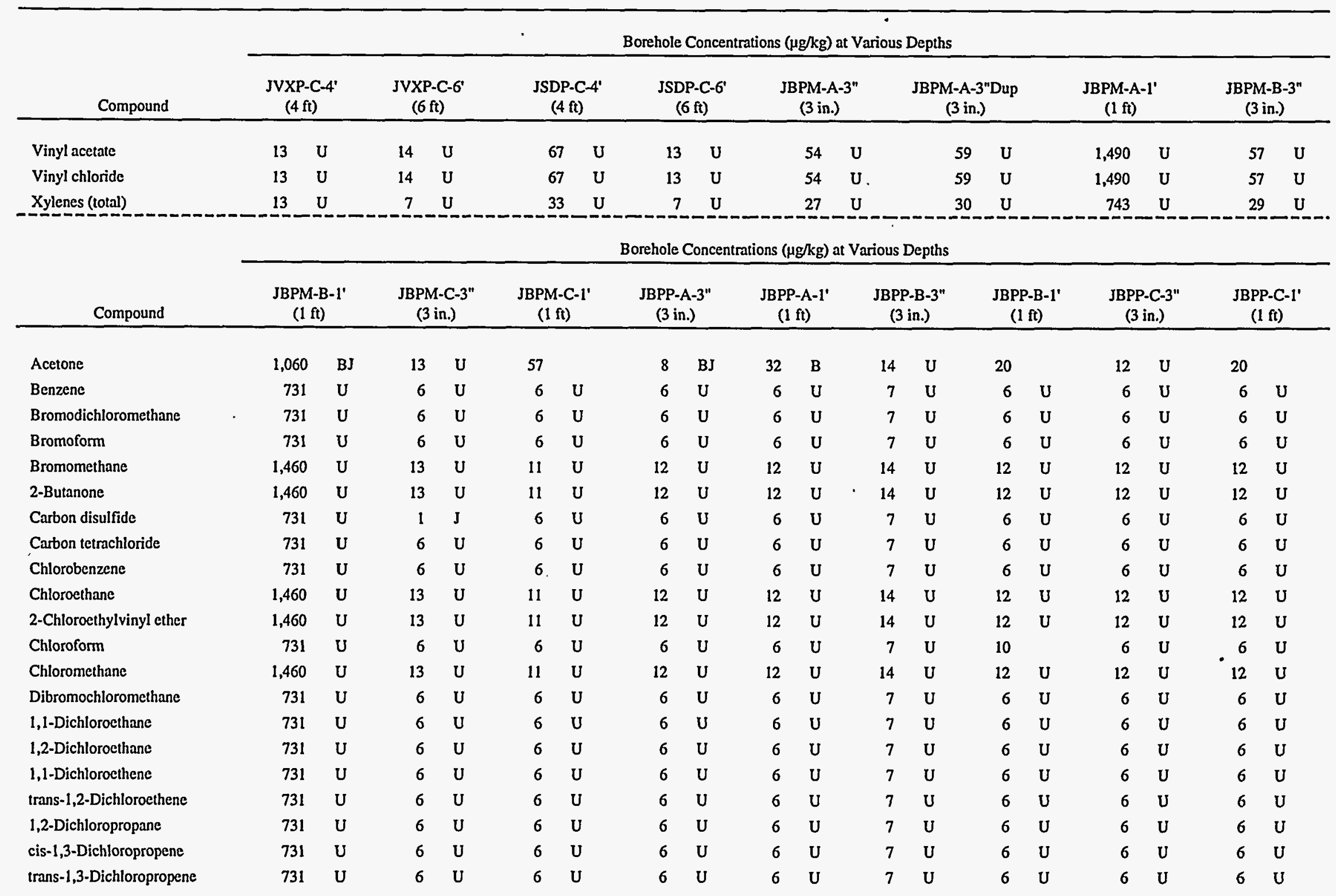


TABLE C.13a (Cont.)

\begin{tabular}{|c|c|c|c|c|c|c|c|c|c|c|c|c|c|c|c|c|c|c|}
\hline \multirow{3}{*}{$\begin{array}{l}\text { Compound } \\
\text { Ethylbenzene }\end{array}$} & \multicolumn{18}{|c|}{ Borehole Concentrations $(\mu \mathrm{g} / \mathrm{kg}$ ) at Various Depths } \\
\hline & \multicolumn{2}{|c|}{$\begin{array}{c}\text { JBPM-B-1' } \\
(1 \mathrm{ft}) \\
\end{array}$} & \multicolumn{2}{|c|}{$\begin{array}{c}\text { JBPM-C-3" } \\
(3 \text { in. }) \\
\end{array}$} & \multicolumn{2}{|c|}{$\begin{array}{c}\text { JBPM-C-1' } \\
(1 \mathrm{ft}) \\
\end{array}$} & \multicolumn{2}{|c|}{$\begin{array}{c}\text { JBPP-A-3" } \\
(3 \text { in. }) \\
\end{array}$} & \multicolumn{2}{|c|}{$\begin{array}{c}\text { JBPP-A-1' } \\
(1 \mathrm{ft})\end{array}$} & \multicolumn{2}{|c|}{$\begin{array}{c}\text { JBPP-B-3" } \\
(3 \text { in. }) \\
\end{array}$} & \multicolumn{2}{|c|}{$\begin{array}{c}\text { JBPP-B-1' } \\
(1 \mathrm{ft}) \\
\end{array}$} & \multicolumn{2}{|c|}{$\begin{array}{c}\text { JBPP-C-3" } \\
(3 \text { in. })\end{array}$} & \multicolumn{2}{|c|}{$\begin{array}{c}\text { JBPP-C- } 1 \\
(1 \mathrm{ft})\end{array}$} \\
\hline & 731 & $\mathbf{U}$ & 2 & $\mathbf{J}$ & 6 & $\mathbf{U}$ & 6 & $\mathrm{U}$ & 6 & $\mathbf{U}$ & 7 & $\mathbf{U}$ & 6 & $\mathbf{U}$ & 6 & $\mathrm{U}$ & 6 & $\mathrm{U}$ \\
\hline 2-Hexanone & 1,460 & $\mathbf{U}$ & 13 & $\mathbf{U}$ & 11 & $\mathrm{U}$ & 12 & $\mathbf{U}$ & 12 & $\mathbf{U}$ & 14 & U & 12 & $\mathrm{U}$ & 12 & $\mathbf{U}$ & 12 & $\mathbf{U}$ \\
\hline 4-Methyl-2-pentanone & 1,460 & $\mathbf{U}$ & 13 & $\mathrm{U}$ & 11 & $\mathbf{U}$ & 12 & $\mathrm{U}$ & 12 & $\mathrm{U}$ & 14 & $\mathrm{U}$ & 12 & $\mathbf{U}$ & 12 & $\mathrm{U}$ & 12 & $\mathrm{U}$ \\
\hline Methylene chloride & 451 & $\mathrm{BJ}$ & 9 & B & 6 & B & 7 & B & 8 & B & 8 & B & 8 & & 5 & $\mathbf{J}$ & 6 & \\
\hline Styrene & 731 & $\mathbf{U}$ & 6 & $\mathbf{U}$ & 6 & $\mathrm{U}$ & 6 & $\mathbf{U}$ & 6 & $\mathrm{U}$ & 7 & U & 6 & $\mathrm{U}$ & 6 & $\mathrm{U}$ & 6 & $\mathrm{U}$ \\
\hline 1,1,2,2-Tetrachloroethane & 15,200 & & 71 & & 41 & & 7 & & 5 & $\mathrm{~J}$ & 4 & $\mathbf{J}$ & 2 & $\mathbf{J}$ & 6 & $\mathrm{U}$ & 9 & \\
\hline Tetrachlorocthene & 731 & $\mathbf{U}$ & 6 & $U$ & 6 & $\mathbf{U}$ & 6 & $\mathbf{u}$ & 6 & $\mathbf{U}$ & 24 & & 99 & & 6 & $\mathbf{U}$ & 6 & $\mathbf{U}$ \\
\hline Toluene & 731 & $\mathbf{U}$ & 7 & & 6 & $\mathbf{U}$ & 6 & $\mathbf{U}$ & 2 & $\mathbf{J}$ & 7 & $\mathrm{U}$ & 3 & J & 6 & $\mathbf{U}$ & 6 & U \\
\hline 1,1,1-Trichloroethane & 731 & $\mathbf{U}$ & 6 & $\mathbf{U}$ & 6 & $U$ & 6 & $\mathbf{U}$ & 6 & $\mathbf{U}$ & 7 & $U$ & 6 & $\mathrm{U}$ & 6 & $\mathbf{U}$ & 6 & $\mathrm{U}$ \\
\hline 1,1,2-Trichloroethane & 731 & $\mathrm{U}$ & 6 & $\mathrm{U}$ & 6 & $\mathrm{U}$ & 6 & $\mathrm{U}$ & 6 & $\mathbf{U}$ & 7 & $\mathrm{U}$ & 6 & $\mathrm{U}$ & 6 & $\mathrm{U}$ & 6 & U \\
\hline Trichloroethene & 251 & $\mathbf{J}$ & 10 & & 3 & $\mathbf{J}$ & 6 & $\mathrm{~J}$ & 6 & $\mathbf{U}$ & 9 & & 31 & & 6 & $\mathbf{U}$ & 6 & $\mathrm{U}$ \\
\hline Vinyl acetate & 1,460 & $\mathrm{U}$ & 13 & $\mathrm{U}$ & 11 & $U$ & 12 & $\mathbf{U}$ & 12 & $\mathrm{U}$ & 14 & $\mathrm{U}$ & 12 & U & 12 & $\mathrm{U}$ & 12 & $\mathbf{U}$ \\
\hline Vinyl chloride & 1,460 & $\mathrm{U}$ & 13 & $\mathrm{U}$ & 11 & $\mathrm{U}$ & 12 & $\mathrm{U}$ & 12 & $\mathbf{U}$ & 14 & U & 12 & $\mathbf{U}$ & 12 & $\mathbf{U}$ & 12 & $\mathbf{U}$ \\
\hline Xylenes (total) & 731 & $\mathrm{U}$ & 9 & & 6 & U & 6 & $\mathbf{U}$ & 6 & $\mathbf{U}$ & 7 & $\mathrm{U}$ & 6 & $\mathrm{U}$ & 6 & $\mathrm{U}$ & 6 & $\mathrm{U}$ \\
\hline
\end{tabular}

a Sampled by Weston, analyzed by GP Environmental Services, TCL volatile organics-SW846 8240s; provisional data. Data qualifiers:

$\mathrm{U}=$ analyte was analyzed for but not detected.

$\mathrm{J}=$ estimated value.

$B=$ analyte was found in the associated blank.

$\mathrm{D}=$ sample was diluted for analysis. 
TABLE C.13b Volatile Organics Analyses for Soil Borings, January $1994^{\mathrm{a}}$

\begin{tabular}{|c|c|c|c|c|c|c|c|c|c|c|c|c|c|c|c|}
\hline \multirow[b]{2}{*}{ Compound } & \multicolumn{14}{|c|}{ Soil Concentrations $(\mu \mathrm{g} / \mathrm{kg})$ at Various Depth Intervals } & \\
\hline & \multicolumn{2}{|c|}{$\begin{array}{c}\text { CLP1 } \\
(0-6 \text { in. }) \\
\end{array}$} & \multicolumn{2}{|c|}{$\begin{array}{c}\text { CLP1 } \\
\text { (6-24 in.) }\end{array}$} & \multicolumn{2}{|c|}{$\begin{array}{l}\text { CLP1-RE } \\
\text { (6-24 in.) }\end{array}$} & \multicolumn{2}{|c|}{$\begin{array}{c}\text { CLP1 } \\
(24-40 \text { in.) }\end{array}$} & \multicolumn{2}{|c|}{$\begin{array}{c}\text { CLP2 } \\
(0.6 \text { in.) }\end{array}$} & \multicolumn{2}{|c|}{$\begin{array}{c}\text { CLP2 } \\
(6-24 \text { in. })\end{array}$} & \multicolumn{2}{|c|}{$\begin{array}{l}\text { CLP2-RE } \\
(6-24 \text { in.) }\end{array}$} & \\
\hline Acetone & 21 & B & 9 & JB & 24 & B & 13 & $\mathbf{U}$ & 13 & $\mathrm{U}$ & 28 & $\mathbf{B}$ & 54 & B & \\
\hline Benzene & 15 & $\mathrm{U}$ & 13 & $\mathrm{U}$ & 13 & $\mathbf{U}$ & 13 & $\mathbf{U}$ & 13 & $\mathrm{U}$ & 13 & $\mathrm{U}$ & 13 & $\mathrm{U}$ & \\
\hline Bromodichloromethane & 15 & $\mathbf{U}$ & 13 & $\mathbf{U}$ & 13 & $\mathrm{U}$ & 13 & $\mathrm{U}$ & 13 & $\mathrm{U}$ & 13 & U & 13 & $\mathbf{U}$ & \\
\hline Bromoform & 15 & $\mathbf{U}$ & 13 & $\mathrm{U}$ & 13 & $\mathrm{U}$ & 13 & $\mathrm{U}$ & 13 & $\mathbf{U}$ & 13 & U & 13 & $\mathbf{U}$ & \\
\hline Bromomethane & 15 & $U$ & 13 & $\mathrm{U}$ & 13 & $U$ & 13 & $\mathbf{U}$ & 13 & $\mathrm{U}$ & 13 & $U$ & 13 & $\mathbf{U}$ & \\
\hline 2-Butanone & 15 & $U$ & 13 & $\mathrm{U}$ & 13 & $\mathrm{U}$ & 13 & $\mathbf{U}$ & 13 & $\mathbf{U}$ & 13 & $U$ & 13 & $\mathrm{U}$ & \\
\hline Carbon disulfide & 15 & $\mathrm{U}$ & 13 & $\mathbf{U}$ & 13 & $\mathrm{U}$ & 13 & $U$ & 13 & $\mathrm{U}$ & 13 & U & 13 & $\mathrm{U}$ & \\
\hline Carbon tetrachloride & 15 & $\mathrm{U}$ & 13 & $\mathbf{U}$ & 13 & $\mathrm{U}$ & 13 & $\mathrm{U}$ & 13 & $\mathrm{U}$ & 13 & $\mathrm{U}$ & 13 & $\mathrm{U}$ & \\
\hline Chlorobenzene & 15 & $\mathrm{U}$ & 8 & J & 5 & $\mathrm{~J}$ & 7 & $\mathbf{J}$ & 13 & $\mathbf{U}$ & 13 & $\mathrm{U}$ & 13 & $\mathrm{U}$ & \\
\hline Chloroethane & 15 & $\mathbf{U}$ & 13 & $U$ & 13 & $\mathrm{U}$ & 13 & $\mathbf{U}$ & 13 & $\mathbf{U}$ & 13 & $\mathbf{U}$ & 13 & $\mathrm{U}$ & \\
\hline Chloroform & 15 & $\mathbf{U}$ & 13 & $\mathbf{U}$ & 13 & $\mathrm{U}$ & 13 & $\mathrm{U}$ & 13 & $\mathbf{U}$ & 13 & $\mathbf{U}$ & 13 & $\mathrm{U}$ & \\
\hline Chloromethane & 15 & $\mathrm{U}$ & 13 & $\mathbf{U}$ & 13 & $\mathrm{U}$ & 13 & $U$ & 13 & $U$ & 13 & $\mathrm{U}$ & 13 & $\mathrm{U}$ & \\
\hline Dibromochloromethane & 15 & U & 13 & $\mathrm{U}$ & 13 & $\mathbf{U}$ & 13 & $\mathrm{U}$ & 13 & $\mathbf{U}$ & 13 & $\mathbf{U}$ & 13 & $\mathrm{U}$ & \\
\hline 1,1-Dichloroethane & 15 & $\mathrm{U}$ & 13 & $\mathrm{U}$ & 13 & $\mathbf{U}$ & 13 & $\mathrm{U}$ & 13 & $\mathbf{U}$ & 13 & $\mathbf{U}$ & 13 & $\mathbf{U}$ & \\
\hline 1,2-Dichloroethane & 15 & $\mathrm{U}$ & 13 & $\mathrm{U}$ & 13 & $\mathrm{U}$ & 13 & $\mathrm{U}$ & 13 & $\mathrm{U}$ & 13 & $\mathbf{U}$ & 13 & $\mathrm{U}$ & \\
\hline 1,1-Dichloroethene & 15 & $\mathbf{U}$ & 13 & $\mathrm{U}$ & 13 & $\mathrm{U}$ & 13. & $\mathrm{U}$ & 13 & $\mathrm{U}$ & 13 & $\mathrm{U}$ & 13 & $\mathbf{U}$ & \\
\hline 1,2-Dichloroethene (total) & 15 & $\mathbf{U}$ & 13 & $\mathrm{U}$ & 13 & $\mathbf{U}$ & 13 & $\mathrm{U}$ & 13 & $\mathrm{U}$ & 13 & $\mathrm{U}$ & 13 & $\mathrm{U}$ & $\cdot$ \\
\hline cis-1,3-Dichloropropane & 15 & $\mathbf{U}$ & 13 & $\mathbf{U}$ & 13 & $\mathbf{U}$ & 13 & $\mathrm{U}$ & 13 & $\mathrm{U}$ & 13 & U & 13 & $\mathrm{U}$ & \\
\hline 1,2-Dichloropropane & 15 & $U$ & 13 & U & 13 & $\mathrm{U}$ & 13 & $\mathrm{U}$ & 13 & $\mathrm{U}$ & 13 & $U$ & 13 & $\mathrm{U}$ & \\
\hline trans-1,3-Dichloropropene & 15 & $\mathrm{U}$ & 13 & $U$ & 13 & $\mathrm{U}$ & 13 & $\mathbf{U}$ & 13 & $\mathrm{U}$ & 13 & $\mathrm{U}$ & 13 & $\mathrm{U}$ & \\
\hline Ethylbenzene & 15 & $\mathbf{U}$ & 13 & $U$ & 13 & $\mathrm{U}$ & 13 & $\mathrm{U}$ & 13 & $\mathrm{U}$ & 13 & $\mathbf{U}$ & 13 & $\mathrm{U}$ & \\
\hline 2-Hexanone & 15 & $\mathbf{U}$ & 13 & $\mathrm{U}$ & 13 & $U$ & 13 & $\mathrm{U}$ & 13 & $\mathrm{U}$ & 13 & $\mathrm{U}$ & 13 & $\mathbf{U}$ & \\
\hline 4-Methyl-2-pentanone & 15 & $U$ & 13 & $\mathrm{U}$ & 13 & $\mathrm{U}$ & 13 & $\mathrm{U}$ & 13 & $\mathbf{U}$ & 13 & $\mathrm{U}$ & 13 & $\mathbf{U}$ & \\
\hline Methylene chloride & 15 & $U$ & 13 & $\mathrm{U}$ & 13 & U & 13 & $\mathbf{U}$ & 13 & $\mathbf{U}$ & 13 & $\mathbf{U}$ & 13 & $\mathrm{U}$ & \\
\hline Styrene & 15 & U & 13 & U & 13 & $\mathbf{U}$ & 13 & $\mathbf{U}$ & 13 & $U$ & 13 & $\mathbf{U}$ & 13 & $\mathrm{U}$ & \\
\hline 1,1,2,2- Tetrachloroethane & 15 & $U$ & 13 & $\mathrm{U}$ & 13 & $\mathrm{U}$ & 13 & $\mathrm{U}$ & 13 & $\mathrm{U}$ & 13 & U & 13 & $\mathrm{U}$ & \\
\hline Tetrachloroethene & 15 & $U$ & 3 & J & 3 & J & 13 & $\mathbf{U}$ & 13 & $\mathrm{U}$ & 13 & $\mathbf{U}$ & 13 & $\mathbf{U}$ & \\
\hline
\end{tabular}


TABLE C.13b (Cont.)

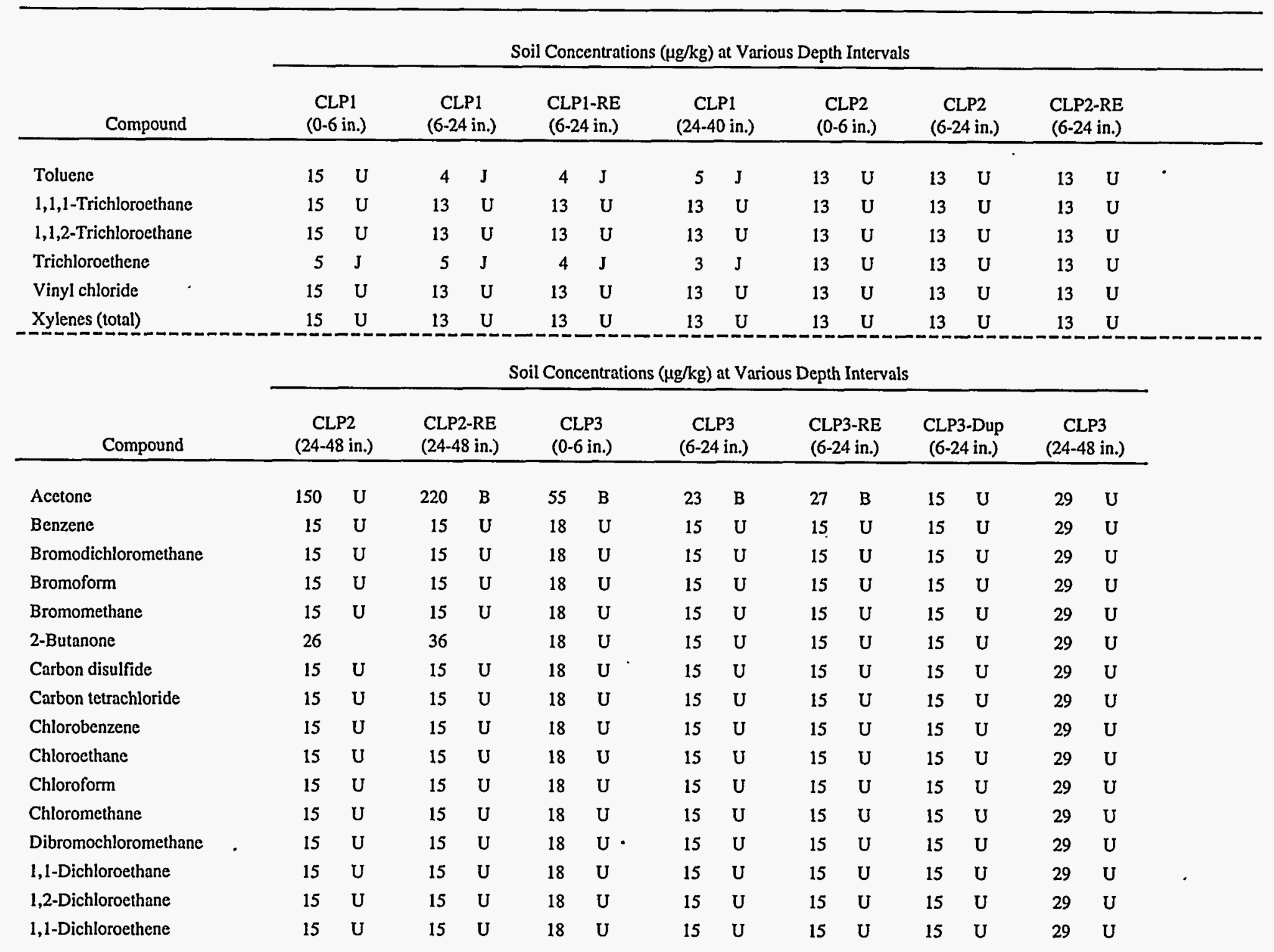


TABLE C.13b (Cont.)

\begin{tabular}{|c|c|c|c|c|c|c|c|c|c|c|c|c|c|c|c|c|}
\hline \multirow{3}{*}{$\frac{\text { Compound }}{\text { 1,2-Dichloroethene (total) }}$} & \multicolumn{14}{|c|}{ Soil Concentrations $(\mu \mathrm{g} / \mathrm{kg})$ at Various Depth Intervals } & & \\
\hline & \multicolumn{2}{|c|}{$\begin{array}{c}\text { CLP2 } \\
\text { (24-48 in.) }\end{array}$} & \multicolumn{2}{|c|}{$\begin{array}{l}\text { CLP2-RE } \\
(24-48 \text { in.) }\end{array}$} & \multicolumn{2}{|c|}{$\begin{array}{c}\text { CLP3 } \\
\text { (0.6 in.) } \\
\end{array}$} & \multicolumn{2}{|c|}{$\begin{array}{c}\text { CLP3 } \\
(6-24 \text { in. })\end{array}$} & \multicolumn{2}{|c|}{$\begin{array}{l}\text { CLP3-RE } \\
\text { (6-24 in.) }\end{array}$} & \multicolumn{2}{|c|}{$\begin{array}{l}\text { CLP3-Dup } \\
\text { (6-24 in.) }\end{array}$} & \multicolumn{2}{|c|}{$\begin{array}{c}\text { CLP3 } \\
\text { (24-48 in.) }\end{array}$} & & \\
\hline & 15 & $\mathrm{U}$ & 15 & $\mathbf{U}$ & 18 & $\mathrm{U}$ & 15 & $\mathrm{U}$ & 15 & $\mathrm{U}$ & 15 & $\mathbf{U}$ & 29 & $\mathbf{U}$ & & \\
\hline 1,2-Dichloropropane & 15 & $\mathrm{U}$ & 15 & U & 18 & $\mathrm{U}$ & 15 & $\mathbf{U}$ & 15 & $\mathrm{U}$ & 15 & $\mathrm{U}$ & 29 & $\mathbf{U}$ & & \\
\hline cis-1,3-Dichloropropane & 15 & $\mathrm{U}$ & 15 & $\mathbf{U}$ & 18 & $\mathbf{U}$ & 15 & $\mathbf{U}$ & 15 & $\mathrm{U}$ & 15 & U & 29 & $\mathrm{U}$ & & \\
\hline trans-1,3-Dichloropropene & 15 & $\mathrm{U}$ & 15 & $\mathbf{U}$ & 18 & $\mathrm{U}$ & 15 & U & 15 & $\mathrm{U}$ & 15 & $\mathrm{U}$ & 29 & $\mathbf{U}$ & & \\
\hline Ethylbenzene & 15 & $\mathrm{U}$ & 15 & $\mathbf{U}$ & 18 & $\mathrm{U}$ & 15 & $U$ & 15 & $\mathrm{U}$ & 15 & $\mathbf{U}$ & 29 & U & & \\
\hline 2-Hexanone & 15 & $\mathrm{U}$ & 15 & $U$ & 18 & $\mathrm{U}$ & 15 & U & 15 & $\mathbf{U}$ & 15 & $\mathbf{U}$ & 29 & $\mathbf{U}$ & & \\
\hline 4-Methyl-2-pentanone & 15 & $\mathrm{U}$ & 15 & $\mathbf{U}$ & 18 & $\mathbf{U}$ & 15 & $\mathrm{U}$ & 15 & $\mathrm{U}$ & 15 & $\mathrm{U}$ & 29 & $\mathrm{U}$ & & \\
\hline Methylene chloride & 15 & U & 15 & $\mathbf{U}$ & 18 & $\mathbf{U}$ & 15 & $U$ & 15 & $\mathrm{U}$ & 15 & $U$ & 29 & $\mathrm{U}$ & & \\
\hline Styrene & 15 & $\mathrm{U}$ & 15 & $\mathrm{U}$ & 18 & $\mathbf{U}$ & 15 & $\mathrm{U}$ & 15 & $\mathrm{U}$ & 15 & $\mathrm{U}$ & 29 & $\mathbf{U}$ & & \\
\hline 1,1,2,2-Tetrachloroethane & 15 & $\mathrm{U}$ & 15 & $\mathbf{U}$ & 18 & $\mathrm{U}$ & 15 & $\mathrm{U}$ & 15 & $\mathrm{U}$ & 15 & $\mathrm{U}$ & 29 & $\mathbf{U}$ & & \\
\hline Tetrachloroethene & 15 & $\mathbf{U}$ & 15 & $\mathrm{U}$ & 18 & $\mathbf{U}$ & 15 & $\mathrm{U}$ & 15 & $\mathrm{U}$ & 15 & $\mathrm{U}$ & 29 & $\mathbf{U}$ & & \\
\hline Toluene & 8 & $\mathbf{J}$ & 6 & $\mathrm{~J}$ & 18 & $\mathbf{U}$ & 15 & $\mathbf{U}$ & 15 & $\mathbf{U}$ & 15 & $U$ & 60 & & & \\
\hline 1,1,1-Trichloroethane & 15 & U & 15 & $\mathrm{U}$ & 18 & $\mathbf{U}$ & 15 & $\mathrm{U}$ & 15 & $\mathrm{U}$ & 15 & $\mathrm{U}$ & 29 & $\mathrm{U}$ & & \\
\hline 1,1,2-Trichloroethane & 15 & $\mathrm{U}$ & 15 & $U$ & 18 & $\mathbf{U}$ & 15 & $U$ & 15 & $\mathrm{U}$ & 15 & $\mathrm{U}$ & 29 & $\mathrm{U}$ & & \\
\hline Trichlorocthene & 15 & $U$ & 15 & $\mathrm{U}$ & 18 & $\mathbf{U}$ & 15 & $\mathrm{U}$ & 15 & $\mathbf{U}$ & 15 & $\mathbf{U}$ & 29 & $\mathrm{U}$ & & * \\
\hline Vinyl chloride & 15 & $\mathbf{U}$ & 15 & $\mathrm{U}$ & 18 & $\mathrm{U}$ & 15 & $\mathbf{U}$ & 15 & $\mathrm{U}$ & 15 & $\mathbf{U}$ & 29 & $\mathrm{U}$ & & \\
\hline \multirow[t]{3}{*}{ Xylenes (total) } & 15 & U & 15 & U & 18 & U & 15 & $\mathrm{U}$ & 15 & $\mathbf{U}$ & 15 & U & 29 & U & & \\
\hline & \multicolumn{16}{|c|}{ Soil Concentrations $(\mu \mathrm{g} / \mathrm{kg})$ at Various Depth Intervals } \\
\hline & \multicolumn{2}{|c|}{$\begin{array}{l}\text { CLP3-RE } \\
(24-48 \text { in.) } \\
\end{array}$} & \multicolumn{2}{|c|}{$\begin{array}{c}\text { CLP4 } \\
(0-6 \text { in. }) \\
\end{array}$} & \multicolumn{2}{|c|}{$\begin{array}{c}\text { CLP4 } \\
(6-24 \text { in. }) \\
\end{array}$} & \multicolumn{2}{|c|}{$\begin{array}{c}\text { CLP4 } \\
\text { (24-48 in.) } \\
\end{array}$} & \multicolumn{2}{|c|}{$\begin{array}{c}\text { CLP5 } \\
\text { (0-6 in.) } \\
\end{array}$} & \multicolumn{2}{|c|}{$\begin{array}{c}\text { CLP5 } \\
\text { (6-24 in.) } \\
\end{array}$} & \multicolumn{2}{|c|}{$\begin{array}{c}\text { CLPS } \\
\text { (24-48 in.) } \\
\end{array}$} & \multicolumn{2}{|c|}{$\begin{array}{l}\text { CLP5-Dup } \\
\text { (24-48 in.) } \\
\end{array}$} \\
\hline Acetone & 29 & $\mathrm{U}$ & 14 & $\mathrm{U}$ & 16 & B & 62 & B & 13 & $\mathbf{U}$ & 12 & $\mathrm{U}$ & 110 & B & 13 & $\mathrm{U}$ \\
\hline Benzene & 29 & U & 14 & $\mathrm{U}$ & 13 & U & 26 & $\mathbf{U}$ & 13 & U & 12 & $\mathrm{U}$ & 14 & $\mathrm{U}$ & 13 & U \\
\hline Bromodichloromethane & 29 & U & 14 & U & 13 & $\mathrm{U}$ & 26 & $\mathrm{U}$ & 13 & $\mathrm{U}$ & 12 & U & 14 & $U$ & 13 & 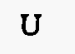 \\
\hline Bromoform & 29 & $\mathrm{U}$ & 14 & $\mathbf{U}$ & 13 & $\mathbf{U}$ & 26 & $U$ & 13 & $\mathbf{U}$ & 12 & $\mathrm{U}$ & 14 & $\mathrm{U}$ & 13 & $U$ \\
\hline Bromomethane & 29 & $\mathrm{U}$ & 14 & U & 13 & $\mathrm{U}$ & 26 & U & 13 & $\mathbf{U}$ & 12 & $\mathrm{U}$ & 14 & $\mathrm{U}$ & 13 & $\mathrm{U}$ \\
\hline
\end{tabular}




\begin{tabular}{|c|c|c|c|c|c|c|c|c|c|c|c|c|c|c|c|c|}
\hline \multirow{3}{*}{$\frac{\text { Compound }}{\text { 2-Butanone }}$} & \multicolumn{16}{|c|}{ Soil Concentrations $(\mu \mathrm{g} / \mathrm{kg})$ at Various Depth Intervals } \\
\hline & \multicolumn{2}{|c|}{$\begin{array}{l}\text { CLP3-RE } \\
\text { (24-48 in.) } \\
\end{array}$} & \multicolumn{2}{|c|}{$\begin{array}{c}\text { CLP4 } \\
\text { (0-6 in.) } \\
\end{array}$} & \multicolumn{2}{|c|}{$\begin{array}{c}\text { CLP4 } \\
\text { (6-24 in.) } \\
\end{array}$} & \multicolumn{2}{|c|}{$\begin{array}{c}\text { CLP4 } \\
(24-48 \text { in.) }\end{array}$} & \multicolumn{2}{|c|}{$\begin{array}{c}\text { CLP5 } \\
(0-6 \text { in.) }\end{array}$} & \multicolumn{2}{|c|}{$\begin{array}{c}\text { CLP5 } \\
\text { (6-24 in.) }\end{array}$} & \multicolumn{2}{|c|}{$\begin{array}{c}\text { CLP5 } \\
\text { (24-48 in.) }\end{array}$} & \multicolumn{2}{|c|}{$\begin{array}{l}\text { CLP5-Dup } \\
\text { (24-48 in.) }\end{array}$} \\
\hline & 29 & $\mathrm{U}$ & 14 & $\mathrm{U}$ & 13 & $\mathrm{U}$ & 26 & $U$ & 13 & $\mathbf{U}$ & 12 & $\mathrm{U}$ & 20 & & 13 & U \\
\hline Carbon disulfide & 29 & U & 14 & $U$ & 13 & $\mathrm{U}$ & 29 & & 13 & $\mathrm{U}$ & 12 & $\mathrm{U}$ & 14 & $U$ & 13 & $\mathrm{U}$ \\
\hline Carbon tetrachloride & 29 & $U$ & 14 & $U$ & 13 & $\mathrm{U}$ & 26 & $\mathrm{U}$ & 13 & U & 12 & $\mathrm{U}$ & 14 & $\mathrm{U}$ & 13 & $U$ \\
\hline Chlorobenzene & 29 & $\mathrm{U}$ & 14 & $\mathrm{U}$ & 13 & $\mathrm{U}$ & 26 & $\mathrm{U}$ & 13 & U & 12 & $\mathrm{U}$ & 14 & $\mathrm{U}$ & 13 & $\mathrm{U}$ \\
\hline Chloroethane & 29 & $\mathrm{U}$ & 14 & U & 13 & $\mathrm{U}$ & 26 & $\mathrm{U}$ & 13 & $\mathbf{U}$ & 12 & $\mathrm{U}$ & 14 & $\mathrm{U}$ & 13 & $\mathrm{U}$ \\
\hline Chloroform & 29 & $\mathbf{U}$ & 14 & $U$ & 13 & $\mathrm{U}$ & 26 & $\mathrm{U}$ & 13 & $\mathrm{U}$ & 12 & U & 14 & $\mathrm{U}$ & 13 & $\mathbf{U}$ \\
\hline Chloromethane & 29 & $\mathrm{U}$ & 14 & $\mathrm{U}$ & 13 & $\mathrm{U}$ & 26 & $\mathrm{U}$ & 13 & $\mathbf{U}$ & 12 & $\mathrm{U}$ & 14 & $\mathrm{U}$ & 13 & $\mathrm{U}$ \\
\hline Dibromochloromethane & 29 & $U$ & 14 & $\mathrm{U}$ & 13 & $\mathrm{U}$ & 26 & $\mathrm{U}$ & 13 & $\mathrm{U}$ & 12 & $U$ & 14 & $\mathrm{U}$ & 13 & $\mathbf{U}$ \\
\hline 1,1-Dichloroethane & 29 & $\mathrm{U}$ & 14 & $\mathrm{U}$ & 13 & $\mathrm{U}$ & 26 & $U$ & 13 & $\mathrm{U}$ & 12 & $\mathrm{U}$ & 14 & $U$ & 13 & $\mathbf{U}$ \\
\hline 1,2-Dichloroethane & 29 & $\mathrm{U}$ & 14 & U & 13 & $\mathbf{U}$ & 26 & $\mathrm{U}$ & 13 & $\mathrm{U}$ & 12 & $U$ & 14 & U & 13 & $\mathrm{U}$ \\
\hline 1,1-Dichloroethene & 29 & $U$ & 14 & $\mathrm{U}$ & 13 & $\mathrm{U}$ & 26 & $\mathrm{U}$ & 13 & $\mathrm{U}$ & 12 & $\mathrm{U}$ & 14 & $\mathrm{U}$ & 13 & $\mathbf{U}$ \\
\hline 1,2-Dichloroethene (total) & 29 & $\mathrm{U}$ & 14. & $U$ & 13 & $\mathrm{U}$ & 600 & & 16 & & 13 & & 180 & & 83 & \\
\hline 1,2-Dichloropropane & 29 & $\mathrm{U}$ & 14 & $\mathrm{U}$ & 13 & $\mathrm{U}$ & 26 & $\mathbf{U}$ & 13 & $\mathbf{U}$ & 12 & $\mathbf{U}$ & 14 & $\mathrm{U}$ & 13 & $U$ \\
\hline cis-1,3-Dichloropropane & 29 & $\mathrm{U}$ & 14 & $\mathrm{U}$ & 13 & $\mathrm{U}$ & 26 & $U$ & 13 & $\mathrm{U}$ & 12 & $U$ & 14 & $\mathrm{U}$ & 13 & $\mathrm{U}$ \\
\hline trans-1,3-Dichloropropene & 29 & $\mathrm{U}$ & 14 & $\mathbf{U}$ & 13 & $\mathrm{U}$ & 26 & $\mathrm{U}$ & 13 & $U$ & 12 & $\mathrm{U}$ & 14 & $U$ & 13 & $U$ \\
\hline Ethylbenzene & 29 & $\mathrm{U}$ & 14 & $\mathrm{U}$ & 13 & $\mathrm{U}$ & 26 & $\mathrm{U}$ & 13 & $\mathbf{U}$ & 12 & $\mathbf{U}$ & 14 & $\mathrm{U}$ & 13 & U \\
\hline 2-Hexanone & 29 & $U$ & 14 & $\mathbf{U}$ & 13 & $\mathrm{U}$ & 26 & $\mathbf{U}$ & 13 & $\mathrm{U}$ & 12 & $\mathrm{U}$ & 14 & $\mathrm{U}$ & 13 & $\mathrm{U}$ \\
\hline 4-Methyl-2-pentanone & 29 & $\mathrm{U}$ & 14 & $U$ & 13 & $\mathrm{U}$ & 26 & $\mathrm{U}$ & 13 & $U$ & 12 & $U$ & 14 & $\mathrm{U}$ & 13 & $\mathrm{U}$ \\
\hline Methylene chloride & 29 & $\mathrm{U}$ & 14 & $\mathrm{U}$ & 13 & $\mathbf{U}$ & 26 & $\mathrm{U}$ & 13 & $\mathrm{U}$ & 12 & $\mathrm{U}$ & 14 & $\mathbf{U}$ & 13 & $\mathrm{U}$ \\
\hline Styrene & 29 & $U$ & 14 & $\mathrm{U}$ & 13 & $\mathrm{U}$ & 26 & $\mathrm{U}$ & 13 & $\mathrm{U}$ & 12 & $\mathrm{U}$ & 14 & $\mathrm{U}$ & 13 & U \\
\hline 1,1,2,2-Tetrachloroethane & 29 & $\mathrm{U}$ & 14 & $\mathrm{U}$ & 13 & $U$ & 5,600 & $\mathrm{E}$ & 13 & $\mathrm{U}$ & 12 & $\mathrm{U}$ & 14 & $U$ & 13 & $U$ \\
\hline Tetrachloroethene & 29 & $\mathbf{U}$ & 14 & $\mathrm{U}$ & 13 & $\mathbf{U}$ & 1,500 & $\mathrm{E}$ & 13 & $\mathrm{U}$ & 12 & $\mathrm{U}$ & 14 & $\mathbf{U}$ & 13 & $\mathrm{U}$ \\
\hline Toluene & 29 & $\mathbf{U}$ & 14 & $\mathrm{U}$ & 13 & $\mathrm{U}$ & 99 & & 12 & $\mathbf{J}$ & 27 & & 33 & & 6 & $\mathbf{J}$ \\
\hline 1,1,1-Trichloroethane & 29 & $\mathrm{U}$ & 14 & $\mathrm{U}$ & 13 & U & 26 & $\mathrm{U}$ & 13 & $\mathrm{U}$ & 12 & $\mathrm{U}$ & 14 & $\mathrm{U}$ & 13 & $\mathrm{U}$ \\
\hline 1,1,2-Trichloroethane & 29 & $U$ & 14 & $\mathrm{U}$ & 13 & $\mathrm{U}$ & 500 & & 13 & $\mathbf{U}$ & 12 & $\mathrm{U}$ & 14 & $\mathrm{U}$ & 13 & $U$ \\
\hline Trichloroethene & 29 & $\mathrm{U}$ & 14 & $\mathrm{U}$ & 13 & $\mathrm{U}$ & 3,100 & & 22 & & 17 & & 9 & $\mathbf{J}$ & 3 & $\mathbf{J}$ \\
\hline Vinyl chloride & 29 & $\mathrm{U}$ & 14 & $\mathrm{U}$ & 13 & $\mathrm{U}$ & 26 & $U$ & 13 & $U$ & 12 & $\mathrm{U}$ & 14 & $\mathrm{U}$ & 13 & U \\
\hline Xylenes (total) & 29 & $\underline{-}$ & 14 & U & 13 & $\mathrm{U}$ & 26 & U & 13 & U & 12 & U & 14 & $U$ & 13 & U \\
\hline
\end{tabular}




\section{TABLE C.13b (Cont.)}

\begin{tabular}{|c|c|c|c|c|c|c|c|c|c|c|c|c|c|c|c|c|}
\hline \multirow{3}{*}{$\begin{array}{l}\text { Compound } \\
\text { Acetone }\end{array}$} & \multicolumn{16}{|c|}{ Soil Concentrations $(\mu \mathrm{g} / \mathrm{kg})$ at Various Depth Intervals } \\
\hline & \multicolumn{2}{|c|}{$\begin{array}{c}\text { CLP6 } \\
\text { (0-6 in.) }\end{array}$} & \multicolumn{2}{|c|}{$\begin{array}{c}\text { CLP6 } \\
\text { (6-24 in.) }\end{array}$} & \multicolumn{2}{|c|}{$\begin{array}{c}\text { CLP7 } \\
\text { (0-6 in.) }\end{array}$} & \multicolumn{2}{|c|}{$\begin{array}{c}\text { CLP7 } \\
(6-24 \text { in.) }\end{array}$} & \multicolumn{2}{|c|}{$\begin{array}{c}\text { CLP7 } \\
\text { (24-48 in.) }\end{array}$} & \multicolumn{2}{|c|}{$\begin{array}{c}\text { CLP8 } \\
\text { (0-6 in.) }\end{array}$} & \multicolumn{2}{|c|}{$\begin{array}{l}\text { CLP8-RE } \\
\text { (0-6 in.) }\end{array}$} & \multicolumn{2}{|c|}{$\begin{array}{c}\text { CLP9 } \\
\text { (0-6 in.) }\end{array}$} \\
\hline & 13 & $\mathrm{U}$ & 20 & & 16 & $\mathbf{U}$ & 13 & $\mathrm{U}$ & 13 & $\mathrm{U}$ & 31 & $\mathrm{U}$ & 31 & $\mathbf{U}$ & 12 & $\mathbf{U}$ \\
\hline Benzene & 13 & $\mathrm{U}$ & 13 & $\mathbf{U}$ & 16 & $\mathbf{U}$ & 13 & $\mathbf{U}$ & 13 & $\mathrm{U}$ & 31 & $\mathbf{U}$ & 31 & $\mathbf{U}$ & 12 & $\mathrm{U}$ \\
\hline Bromodichloromethane & 13 & $\mathrm{U}$ & 13 & $\mathrm{U}$ & 16 & $\mathbf{U}$ & 13 & $\mathrm{U}$ & 13 & $\mathrm{U}$ & 31 & $\mathrm{U}$ & 31 & $\mathbf{U}$ & 12 & $\mathrm{U}$ \\
\hline Bromoform & 13 & $U$ & 13 & U & 16 & $\mathbf{U}$ & 13 & $\mathrm{U}$ & 13 & $\mathrm{U}$ & 31 & $\mathrm{U}$ & 31 & $\mathbf{U}$ & 12 & $\mathrm{U}$ \\
\hline Bromomethane & 13 & $\mathbf{U}$ & 13 & $\mathrm{U}$ & 16 & $\mathbf{U}$ & 13 & $\mathrm{U}$ & 13 & $\mathrm{U}$ & 31 & $\mathbf{U}$ & 31 & $\mathrm{U}$ & 12 & $\mathbf{U}$ \\
\hline 2-Butanone & 13 & $\mathrm{U}$ & 13 & $\mathbf{U}$ & 16 & $\mathrm{U}$ & 13 & $\mathbf{U}$ & 13 & $U$ & 31 & U & 31 & $\mathbf{U}$ & $12^{\circ}$ & $\mathbf{U}$ \\
\hline Carbon disulfide & 13 & $\mathrm{U}$ & 4 & $\mathbf{J}$ & 16 & $U$ & 13 & $\mathbf{U}$ & 13 & $\mathbf{U}$ & 31 & $\mathbf{U}$ & 31 & $\mathbf{U}$ & 12 & $U$ \\
\hline Carbon tetrachloride & 13 & $\mathrm{U}$ & 13 & $\mathbf{U}$ & 16 & $\mathbf{U}$ & 13 & $U$ & 13 & U & 31 & $\mathbf{U}$ & 31 & $\mathrm{U}$ & 12 & $\mathrm{U}$ \\
\hline Chlorobenzene & 13 & $U$ & 13 & $U$ & 16 & $\mathbf{U}$ & 13 & $\mathbf{U}$ & 13 & $U$ & 31 & $U$ & 31 & $\mathrm{U}$ & 12 & $\mathrm{U}$ \\
\hline Chloroethane & 13 & $\mathbf{U}$ & 13 & $\mathbf{U}$ & 16 & $\mathrm{U}$ & 13 & $\mathrm{U}$ & 13 & $\mathrm{U}$ & 31 & $\mathrm{U}$ & 31 & $\mathbf{U}$ & 12 & $U$ \\
\hline Chloroform & 13 & $\mathrm{U}$ & 13 & $\mathbf{U}$ & 16 & $\mathrm{U}$ & 13 & $U$ & 13 & $\mathbf{U}$ & 31 & $\mathbf{U}$ & 31 & $\mathbf{U}$ & 12 & $\mathbf{U}$ \\
\hline Chloromethane & 13 & $U$ & 13 & $\mathbf{U}$ & 16 & $\mathrm{U}$ & 13 & $U$ & 13 & $\mathrm{U}$ & 31 & $\mathrm{U}$ & 31 & $\mathbf{U}$ & 12 & $\mathbf{U}$ \\
\hline Dibromochloromethane & 13 & $\mathrm{U}$ & 13 & $U$ & 16 & $\mathrm{U}$ & 13 & $\mathrm{U}$ & 13 & $U$ & 31 & $\mathrm{U}$ & 31 & $\mathbf{U}$ & 12 & $\mathrm{U}$ \\
\hline 1,1-Dichloroethane & 13 & $\mathrm{U}$ & 13 & $\mathrm{U}$ & 16 & $\mathrm{U}$ & 13 & $U$ & 13 & $\mathrm{U}$ & 31 & $\mathrm{U}$ & 31 & $\mathbf{U}$ & 12 & $\mathrm{U}$ \\
\hline 1,2-Dichloroethane & 13 & $\mathrm{U}$ & 13 & $\mathrm{U}$ & 16 & $\mathrm{U}$ & 13 & $\mathrm{U}$ & 13 & $\mathrm{U}$ & 31 & $\mathbf{U}$ & 31 & $U$ & 12 & $\mathbf{U}$ \\
\hline 1,1-Dichloroethene & 13 & $U$ & 13 & U & 16 & $\mathbf{U}$ & 13 & $\mathrm{U}$ & 13 & $\mathbf{U}$ & 31 & $\mathbf{U}$ & 31 & $U$ & 12 & $\mathbf{U}$ \\
\hline 1,2-Dichloroethene (total) & 11 & $\mathbf{J}$ & 48 & & 16 & $\mathbf{U}$ & 13 & $\mathrm{U}$ & 13 & $\mathbf{U}$ & 28 & $\mathbf{J}$ & 8 & $\mathbf{J}$ & 20 & J \\
\hline 1,2-Dichloropropane & 13 & $U$ & 13 & $\mathrm{U}$ & 16 & $\mathbf{U}$ & 13 & $\mathbf{U}$ & 13 & $\mathrm{U}$ & 31 & $\mathrm{U}$ & 31 & $\mathrm{U}$ & 12 & $U$ \\
\hline cis-1,3-Dichloropropane & 13 & $\mathrm{U}$ & 13 & $U$ & 16 & $U$ & 13 & $\mathbf{U}$ & 13 & $\mathrm{U}$ & 31 & $\mathbf{U}$ & 31 & $\mathrm{U}$ & 12 & $U$ \\
\hline trans-1,3-Dichloropropene & 13 & $\mathbf{U}$ & 13 & $\mathbf{U}$ & 16 & $\mathbf{U}$ & 13 & $\mathrm{U}$ & 13 & $\mathbf{U}$ & 31 & $\mathbf{U}$ & 31 & $\mathrm{U}$ & 12 & $\mathbf{U}$ \\
\hline Ethylbenzene & 13 & $\mathbf{U}$ & 13 & $\mathbf{U}$ & 16 & $\mathbf{U}$ & 13 & 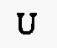 & 13 & $\mathbf{U}$ & 31 & $\mathbf{U}$ & 31 & $U$ & 12 & $\mathrm{U}$ \\
\hline 2-Hexanone & 13 & $\mathbf{U}$ & 13 & $\mathbf{U}$ & 16 & $\mathbf{U}$ & 13 & $\mathbf{U}$ & 13 & $\mathbf{U}$ & 31 & $\mathrm{U}$ & 31 & $U$ & 12 & $\mathrm{U}$ \\
\hline 4-Methyl-2-pentanone & 13 & $\mathbf{U}$ & 13 & $\mathrm{U}$ & 16 & $\mathrm{U}$ & 13 & $\mathrm{U}$ & 13 & $U$ & 31 & $\mathrm{U}$ & 31 & $U$ & 12 & $\mathrm{U}$ \\
\hline Methylene chloride & 13 & U & 13 & $\mathbf{U}$ & .16 & $\mathrm{U}$ & 13 & $\mathbf{U}$ & 13 & $\mathbf{U}$ & 31 & $\mathbf{U}$ & 31 & $\mathrm{U}$ & 12 & $\mathbf{U}$ \\
\hline Styrene & 13 & $U$ & 13 & $\mathrm{U}$ & 16 & $\mathbf{U}$ & 13 & $U$ & 13 & $\mathbf{U}$ & 31 & $\mathbf{U}$ & 31 & $\mathrm{U}$ & 12 & $\mathbf{U}$ \\
\hline 1,1,2,2-Tetrachloroethane & 13 & $\mathrm{U}$ & 13 & $U$ & 16 & $\mathbf{U}$ & 13 & $U$ & 13 & $\mathrm{U}$ & 31 & $\mathbf{U}$ & 31 & U & 12 & $\mathbf{U}$ \\
\hline Tetrachloroethene & 13 & $\mathbf{U}$ & 13 & $\mathrm{U}$ & 16 & $\mathbf{U}$ & 13 & $\mathbf{U}$ & 13 & $U$ & 31 & $\mathbf{U}$ & 31 & $\mathbf{U}$ & 12 & $\mathbf{U}$ \\
\hline Toluene & 17 & & 24 & & 16 & $\mathrm{U}$ & 13 & $\mathbf{U}$ & 13 & $\mathrm{U}$ & 31 & $\mathrm{U}$ & 31 & $\mathbf{U}$ & 12 & $\mathbf{U}$ \\
\hline
\end{tabular}


TABLE C.13b (Cont.)

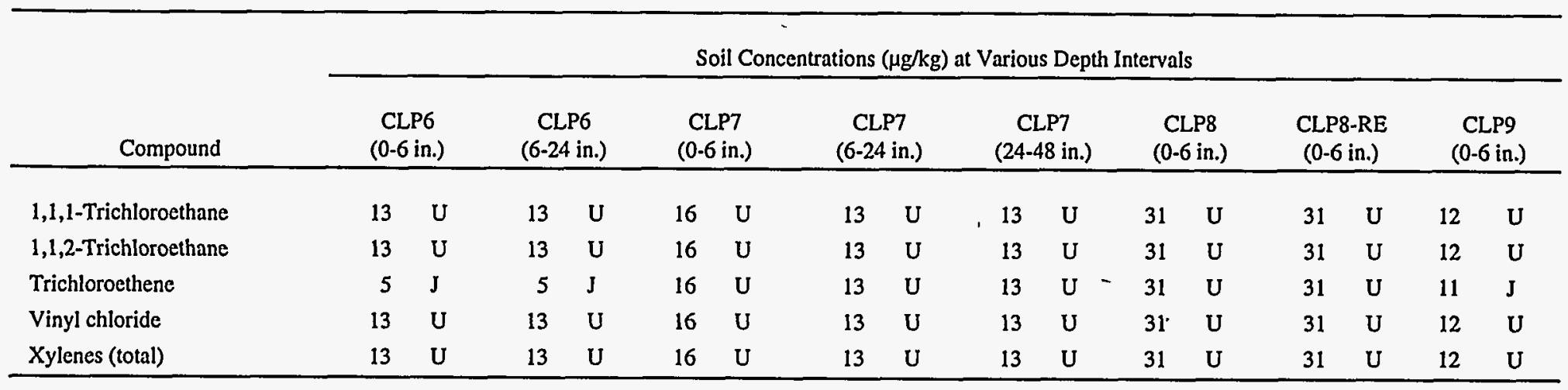

a Sampled by ANL, analyzed by Westion Gulf Coast, TCL volatile organics-SW846 8240s. Data qualifiers:

$U=$ analyte was analyzed for but not detected.

$\mathrm{B}=$ analyte was found in the associated blank.

$\mathrm{J}=$ estimated value.

$\mathbf{E}=$ analyte concentration exceeded calibration range of instrument; concentration estimated. 
TABLE C.13c Volatile Organics Analyses for Soil Borings, May $1994^{\mathrm{a}}$

\begin{tabular}{|c|c|c|c|c|c|c|c|c|c|c|c|c|}
\hline \multirow{3}{*}{$\begin{array}{l}\text { Compound } \\
\text { Acetone }\end{array}$} & \multicolumn{10}{|c|}{ Soil Concentrations $(\mu \mathrm{g} / \mathrm{kg})$ at Various Depth Intervals } & & \\
\hline & \multicolumn{2}{|c|}{$\begin{array}{c}\text { TBSPBORI } \\
(0-2 \mathrm{ft}) \\
\end{array}$} & \multicolumn{2}{|c|}{$\begin{array}{c}\text { TSBPBOR1-RE } \\
(0-2 \mathrm{ft})\end{array}$} & \multicolumn{2}{|c|}{$\begin{array}{c}\text { TBSPBOR1-Dup } \\
(0-2 \mathrm{ft})\end{array}$} & \multicolumn{2}{|c|}{$\begin{array}{c}\text { TSBPBOR1-Dup-RE } \\
(0-2 \mathrm{ft}) \\
\end{array}$} & \multicolumn{2}{|c|}{$\begin{array}{c}\text { TBSPBOR1 } \\
(2-4 \mathrm{ft}) \\
\end{array}$} & \multicolumn{2}{|c|}{$\begin{array}{c}\text { TSBPBOR1- } \\
\text { RE } \\
(2-4 \mathrm{ft}) \\
\end{array}$} \\
\hline & 350 & B* & 120 & B & 12 & $\mathrm{U}^{*+}$ & 18 & $\mathbf{B}$ & 73 & $\mathbf{B}$ & 12 & $\mathrm{U}$ \\
\hline Benzene & 12 & $\mathrm{U}^{*}$ & 12 & $\mathrm{U}$ & 12 & $U^{*}+$ & 12 & $U$ & 2 & $\mathbf{J}$ & 12 & $\mathrm{U}$ \\
\hline Bromodichloromethane & 12 & $\mathrm{U}^{*}$ & 12 & $\mathrm{U}$ & 12 & $U^{*}+$ & 12 & $\mathrm{U}$ & 12 & $\mathrm{U}$ & 12 & $\mathrm{U}$ \\
\hline Bromoform & 12 & $\mathrm{U}^{*}$ & 12 & $\mathbf{U}$ & 12 & $\mathrm{U}^{*}+$ & 12 & $\mathrm{U}$ & 12 & $\mathrm{U}$ & 12 & U \\
\hline Bromomethane & 12 & $\mathrm{U}^{*}$ & 12 & $\mathbf{U}$ & 12 & $\mathrm{U}^{*}+$ & 12 & $\mathrm{U}$ & 12 & $\mathrm{U}$ & 12 & $\mathrm{U}$ \\
\hline 2-Butanone & 37 & $*$ & 12 & $\mathbf{U}$ & 12 & $\mathrm{U}^{*}+$ & 12 & $\mathrm{U}$ & 12 & $\mathrm{U}$ & 7 & $\mathbf{J}$ \\
\hline Carbon disulfide & 12 & $U^{*}$ & 12 & U & 12 & $U^{*}+$ & 12 & $\mathbf{U}$ & 12 & $\mathrm{U}$ & 12 & $\mathrm{U}$ \\
\hline Carbon tetrachloride & 12 & $\mathrm{U}^{*}$ & 12 & $U$ & 12 & $\mathrm{U}^{*+}$ & 12 & $U$ & 12 & $\mathrm{U}$ & 12 & $\mathrm{U}$ \\
\hline Chlorobenzene & 12 & $\mathrm{U}^{*}$ & 12 & $U$ & 12 & $\mathrm{U}^{*}+$ & 12 & $U$ & 12 & $\mathrm{U}$ & 12 & $\mathrm{U}$ \\
\hline Chloroethane & 12 & $\mathrm{U}^{*}$ & 12 & $U$ & 12 & $\mathrm{U}^{*}+$ & 12 & $\mathrm{U}$ & 12 & $\mathrm{U}$ & 12 & $\mathrm{U}$ \\
\hline Chloroform & 12 & $\mathrm{U}^{*}$ & 12 & $\mathbf{U}$ & 12 & $\mathbf{U}^{*+}$ & 12 & $\mathrm{U}$ & 12 & $\mathrm{U}$ & 12 & $\mathrm{U}$ \\
\hline Chloromethane & 12 & $\mathrm{U}^{*}$ & 12 & $\mathrm{U}$ & 12 & $\mathbf{U}^{*+}$ & 12 & $\mathrm{U}$ & 12 & $\mathrm{U}$ & 12 & $U$ \\
\hline Dibromochloromethane & 12 & $\mathrm{U}^{*}$ & 12 & $\mathbf{U}$ & 12 & $U^{*+}$ & 12 & $\mathbf{U}$ & 12 & $\mathbf{U}$ & 12 & $\mathrm{U}$ \\
\hline 1,1-Dichloroethane & 12 & $\mathrm{U}^{*}$ & 12 & $\mathbf{U}$ & 12 & $\mathrm{U}^{*+}$ & 12 & $\mathrm{U}$ & 12 & $\mathbf{U}$ & 12 & $\mathrm{U}$ \\
\hline 1,2-Dichloroethane & 12 & $U^{*}$ & 12 & $\mathrm{U}$ & 12 & $\mathrm{U}^{*+}$ & 12 & $\mathbf{U}$ & 12 & $\mathrm{U}$ & 12 & $\mathrm{U}$ \\
\hline 1,1-Dichloroethene & 12 & $\mathrm{U}^{*}$ & 12 & $\mathrm{U}$ & 12 & $\mathrm{U}^{*+}$ & 12 & $\mathrm{U}$ & 12 & $\mathrm{U}$ & 12 & $\mathrm{U}$ \\
\hline 1,2-Dichloroethene (total) & 86 & $*$ & 10 & $\mathbf{J}$ & 170 & $*+$ & 14 & & 7 & $\mathrm{~J}$ & 8 & $\mathbf{J}$ \\
\hline 1,2-Dichloropropane & 12 & $\mathrm{U}^{*}$ & 12 & $\mathrm{U}$ & 12 & $\mathrm{U}^{*}+$ & 12 & $\mathrm{U}$ & 12 & $\mathbf{U}$ & 12 & $\mathbf{U}$ \\
\hline cis-1,3-Dichloropropene & 12 & $\mathrm{U}^{*}$ & 12 & $\mathrm{U}$ & 12 & $\mathrm{U}^{*}+$ & 12 & $U$ & 12 & $\mathrm{U}$ & 12 & $\mathbf{U}$ \\
\hline trans-1,3-Dichloropropene & 12 & $\mathrm{U}^{*}$ & 12 & $\mathrm{U}$ & 12 & $\mathrm{U}^{*}+$ & 12 & $U$ & 12 & $\mathrm{U}$ & 12 & U \\
\hline Ethylbenzene & 12 & $\mathrm{U}^{*}$ & 12 & $\mathrm{U}$ & 12 & $U^{*}+$ & 12 & $\mathrm{U}$ & 12 & $\mathrm{U}$ & 12 & $\mathbf{U}$ \\
\hline 2-Hexanone & 12 & $\mathrm{U}^{*}$ & 12 & $\mathrm{U}$ & 12 & $U^{*}+$ & 12 & $U$ & 12 & $\mathrm{U}$ & 12 & $\mathbf{U}$ \\
\hline 4-Methyl-2-pentanone & 12 & $\mathrm{U}^{*}$ & 12 & $\mathrm{U}$ & 12 & $\mathrm{U}^{*+}$ & 12 & $\mathrm{U}$ & 12 & $U$ & 12 & $\mathbf{U}$ \\
\hline Methylene chloride & 4 & $\mathrm{~J}^{*}$ & 83 & & 12 & $U^{*}+$ & 12 & $\mathrm{U}$ & 12 & $\mathrm{U}$ & 63 & \\
\hline
\end{tabular}




\begin{tabular}{|c|c|c|c|c|c|c|c|c|c|c|c|c|}
\hline \multirow[b]{2}{*}{ Compound } & \multicolumn{12}{|c|}{ Soil Concentrations $(\mu \mathrm{g} / \mathrm{kg})$ at Various Depth Intervals } \\
\hline & \multicolumn{2}{|c|}{$\begin{array}{c}\text { TBSPBORI } \\
(0-2 \mathrm{ft})\end{array}$} & \multicolumn{2}{|c|}{$\begin{array}{c}\text { TSBPBOR1-RE } \\
(0-2 \mathrm{ft})\end{array}$} & \multicolumn{2}{|c|}{$\begin{array}{c}\text { TBSPBOR1-Dup } \\
(0-2 \mathrm{ft})\end{array}$} & \multicolumn{2}{|c|}{$\begin{array}{c}\text { TSBPBOR1-Dup-RE } \\
(0-2 \mathrm{ft})\end{array}$} & \multicolumn{2}{|c|}{$\begin{array}{c}\text { TBSPBOR } 1 \\
(2-4 \mathrm{ft})\end{array}$} & \multicolumn{2}{|c|}{$\begin{array}{c}\text { TSBPBOR } 1 \\
\text { RE } \\
(2-4 \mathrm{ft})\end{array}$} \\
\hline Styrene & 12 & $\mathrm{U}^{*}$ & 12 & $\mathrm{U}$ & 12 & $\mathrm{U}^{*}+$ & 12 & $\mathbf{U}$ & 12 & $\mathrm{U}$ & 12 & $\mathrm{U}$ \\
\hline 1,1,2,2-Tetrachloroethane & 49 & * & 9 & $J$ & 100 & $*_{+}$ & 19 & & 8 & $\mathbf{J}$ & 14 & \\
\hline Tetrachloroethene & 12 & $\mathrm{U}^{*}$ & 12 & $\mathrm{U}$ & 12 & $\mathrm{U}^{*}+$ & 12 & $\mathrm{U}$ & 12 & $U$ & 12 & $\mathrm{U}$ \\
\hline Toluene & 12 & $\mathbf{U}^{*}$ & 12 & $\mathbf{U}$ & 12 & $\mathrm{U}^{*}+$ & 12 & $\mathbf{U}$ & 12 & $\mathrm{U}$ & 12 & $\mathrm{U}$ \\
\hline 1,1,1-Trichloroethane & 12 & $\mathrm{U}^{*}$ & 12 & $\mathrm{U}$ & 12 & $\mathrm{U}^{*+}$ & 12 & $\mathrm{U}$ & 12 & $\mathrm{U}$ & 12 & $\mathrm{U}$ \\
\hline 1,1,2-Trichloroethane & 12 & $U^{*}$ & 12 & $\mathrm{U}$ & 12 & $\mathrm{U}^{*}+$ & 12 & $\mathrm{U}$ & 12 & $\mathrm{U}$ & 12 & $\mathrm{U}$ \\
\hline Trichloroethene & 50 & $*$ & 4 & $\mathbf{J}$ & 37 & $*_{+}$ & 10 & $\mathbf{J}$ & $12^{\circ}$ & $\mathrm{U}$ & 12 & $\mathrm{U}$ \\
\hline Vinyl chloride & 12 & $\mathrm{U}^{*}$ & 12 & $\mathrm{U}$ & 12 & $\mathrm{U}^{*}+$ & 12 & $U$ & 12 & $\mathrm{U}$ & 12 & $\mathrm{U}$ \\
\hline Xylenes (total) & 12 & $\mathrm{U}^{*}$ & 12 & U & 12 & $\mathbf{U}^{*+}+$ & 12 & $\mathrm{U}$ & 12 & $\mathrm{U}$ & 12 & U \\
\hline \multicolumn{13}{|c|}{ Soil Concentrations $(\mu \mathrm{g} / \mathrm{kg})$ at Various Depth Intervals } \\
\hline Compound & \multicolumn{2}{|c|}{$\begin{array}{l}\text { TBSPBOR } 1 \\
(4-6 \mathrm{ft})\end{array}$} & \multicolumn{2}{|c|}{$\begin{array}{c}\text { TBSPBOR } 1 \\
(6-8 \mathrm{ft})\end{array}$} & \multicolumn{2}{|c|}{$\begin{array}{l}\text { TBSPBOR1 } \\
(8-10 \mathrm{ft}) \\
\end{array}$} & \multicolumn{2}{|c|}{$\begin{array}{c}\text { TBSPBOR1 } \\
(10-12 \mathrm{ft}) \\
\end{array}$} & \multicolumn{2}{|c|}{$\begin{array}{c}\text { TBSPBOR2 } \\
(0-2 \mathrm{ft}) \\
\end{array}$} & \multicolumn{2}{|c|}{$\begin{array}{c}\text { TBSPBOR2- } \\
\text { Dup } \\
(0-2 \mathrm{ft}) \\
\end{array}$} \\
\hline Acetone & 280 & B & 42 & & 42 & & 30 & & 12 & $\mathrm{U}$ & 12 & $\mathbf{U}$ \\
\hline Benzene & 12 & $\mathbf{U}$ & 5 & $\mathbf{J}$ & 12 & $\mathbf{U}$ & 12 & $\mathrm{U}$ & 12 & $\mathrm{U}$ & 12 & U* \\
\hline Bromodichloromethane & 12 & $\mathbf{U}$ & 12 & $\mathrm{U}$ & 12 & $\mathbf{U}$ & 12 & $\mathrm{U}$ & 12 & $\mathrm{U}$ & 12 & $\mathrm{U}^{*}$ \\
\hline Bromoform & 12 & U & 12 & $U$ & 12 & $\mathbf{U}$ & 12 & $U$ & 12 & $\mathrm{U}$ & 12 & $\mathrm{U}^{*}$ \\
\hline Bromomethane & 12 & $\mathrm{U}$ & 12 & $\mathrm{U}$ & 12 & $\mathbf{U}$ & 12 & $U$ & 12 & $\mathrm{U}$ & 12 & $U$ \\
\hline 2-Butanone & 12 & $\mathrm{U}$ & 12 & $U$ & 12 & $\mathrm{U}$ & 12 & $\mathrm{U}$ & 12 & U & 12 & $\mathrm{U}$ \\
\hline Carbon disulfide & 6 & J & 4 & $\mathbf{J}$ & 12 & $\mathrm{U}$ & 12 & $\mathrm{U}$ & 12 & $U$ & 12 & $U$ \\
\hline Carbon tetrachloride & 12 & $\mathrm{U}$ & 12 & $\mathrm{U}$ & 12 & $\mathrm{U}$ & 12 & $\mathrm{U}$ & 12 & $\mathbf{U}$ & 12 & $\mathrm{U}^{*}$ \\
\hline Chlorobenzene & 12 & $\mathrm{U}$ & 12 & $\mathrm{U}$ & 12 & $\mathrm{U}$ & 12 & $\mathrm{U}$ & 12 & $\mathrm{U}$ & 12 & $\mathrm{U}^{*}$ \\
\hline
\end{tabular}


TABLE C.13c (Cont.)

Soil Concentrations $(\mu \mathrm{g} / \mathrm{kg})$ at Various Depth Intervals

\begin{tabular}{|c|c|c|c|c|c|c|c|c|c|c|c|c|}
\hline \multirow[b]{2}{*}{ Chloroethane } & \multicolumn{2}{|c|}{$\begin{array}{c}\text { TBSPBOR1 } \\
(4-6 \mathrm{ft})\end{array}$} & \multicolumn{2}{|c|}{$\begin{array}{c}\text { TBSPBORI } \\
(6-8 \mathrm{ft})\end{array}$} & \multicolumn{2}{|c|}{$\begin{array}{c}\text { TBSPBOR1 } \\
(8-10 \mathrm{ft})\end{array}$} & \multicolumn{2}{|c|}{$\begin{array}{c}\text { TBSPBOR1 } \\
(10-12 \mathrm{ft}) \\
\end{array}$} & \multicolumn{2}{|c|}{$\begin{array}{c}\text { TBSPBOR2 } \\
(0-2 \mathrm{ft})\end{array}$} & \multicolumn{2}{|c|}{$\begin{array}{c}\text { TBSPBOR2- } \\
\text { Dup } \\
(0-2 \mathrm{ft})\end{array}$} \\
\hline & 12 & $\mathrm{U}$ & 12 & $\mathrm{U}$ & 12 & $\mathrm{U}$ & 12 & $\mathbf{U}$ & 12 & U & 12 & $\mathbf{U}$ \\
\hline & 12 & $\mathrm{U}$ & 12 & $\mathrm{U}$ & 12 & $\mathrm{U}$ & 12 & $U$ & 12 & $\mathrm{U}$ & 12 & $\mathrm{U}$ \\
\hline Chloromethane & 12 & $\mathrm{U}$ & 12 & $\mathrm{U}$ & 12 & $\mathrm{U}$ & 12 & $U$ & 12 & $\mathbf{U}$ & 12 & U \\
\hline Dibromochloromethane & 12 & $\mathrm{U}$ & 12 & $\mathbf{U}$ & 12 & $U$ & 12 & $\mathrm{U}$ & 12 & $\mathrm{U}$ & 12 & $\mathrm{U}^{*}$ \\
\hline 1,1-Dichloroethane & 12 & $\mathbf{U}$ & 12 & $\mathbf{U}$ & 12 & $\mathrm{U}$ & 12 & $\mathrm{U}$ & 12 & $\mathrm{U}$ & 12 & $\mathrm{U}$ \\
\hline 1,2-Dichloroethane & 12 & $\mathrm{U}$ & 4 & $\mathrm{~J}$ & 12 & $\mathrm{U}$ & 12 & $\mathrm{U}$ & 12 & $U$ & 12 & $\mathrm{U}$ \\
\hline 1,1-Dichloroethene & 12 & $\mathbf{U}$ & 15 & & 12 & $\mathrm{U}$ & 12 & $\mathrm{U}$ & 12 & $U$ & 12 & $\mathrm{U}$ \\
\hline 1,2-Dichloroethene (total) & 68 & & 4,400 & & 1,500 & & 11 & $\mathrm{~J}$ & 12 & $\mathrm{U}$ & 12 & $\mathbf{U}$ \\
\hline 1,2-Dichloropropane & 12 & $\mathrm{U}$ & 12 & $\mathrm{U}$ & 12 & $\mathbf{U}$ & 12 & $U$ & 12 & $\mathrm{U}$ & 12 & $\mathrm{U}^{*}$ \\
\hline cis-1,3-Dichloropropene & 12 & $U$ & 12 & $U$ & 12 & $\mathrm{U}$ & 12 & $U$ & 12 & $\mathrm{U}$ & 12 & $\mathrm{U}^{*}$ \\
\hline trans-1,Dichloropropene & 12 & $\mathrm{U}$ & 12 & U & 12 & U & 12 & $U$ & 12 & $\mathbf{U}$ & 12 & $U^{*}$ \\
\hline Ethylbenzene & 12 & $U$ & 19 & & 12 & $U$ & 12 & $\mathrm{U}$ & 12 & U & 12 & $\mathrm{U}^{*}$ \\
\hline 2-Hexanone & 12 & $U$ & 12 & $\mathrm{U}$ & 12 & $\mathrm{U}$ & 12 & $\mathrm{U}$ & 12 & $\mathrm{U}$ & 12 & $\mathrm{U}^{*}$ \\
\hline 4-Methyl-2-pentanone & 12 & $\mathrm{U}$ & 12 & $\mathbf{U}$ & 12 & $\mathrm{U}$ & 12 & $\mathrm{U}$ & 12 & $\mathrm{U}$ & 12 & $\mathrm{U}^{*}$ \\
\hline Methylene chloride & 12 & $U$ & 12 & $\mathrm{U}$ & 12 & $\mathrm{U}$ & 12 & $\mathrm{U}$ & 12 & $U$ & 12 & $\mathrm{U}$ \\
\hline Styrene & 12 & $\mathrm{U}$ & 12 & U & 12 & $\mathrm{U}$ & 12 & $\mathrm{U}$ & 12 & $\mathrm{U}$ & 12 & $\mathrm{U}^{*}$ \\
\hline 1,1,2,2-Tetrachloroethane & 9 & J & 7 & $\mathrm{~J}$ & 600 & & 280 & & 12 & & 2 & $\mathrm{~J}^{*}$ \\
\hline Tetrachloroethene & 12 & $\mathrm{U}$ & 12 & $\mathbf{U}$ & 41 & & 12 & $\mathrm{U}$ & 12 & $U$ & 12 & $\mathrm{U}^{*}$ \\
\hline Toluene & 12 & $\mathbf{U}$ & 8 & $\mathrm{~J}$ & 12 & $\mathbf{U}$ & 12 & $\mathrm{U}$ & 12 & $\mathrm{U}$ & 12 & $\mathrm{U}^{*}$ \\
\hline 1,1,1-Trichloroethane & 12 & U & 12 & $\mathrm{U}$ & 12 & $\mathrm{U}$ & 12 & U & 12 & $\mathrm{U}$ & 12 & $\mathrm{U}^{*}$ \\
\hline 1,1,2-Trichloroethane & 12 & $\mathrm{U}$ & 3 & $\mathbf{J}$ & 140 & & 15 & & 12 & $U$ & 12 & $\mathrm{U}^{*}$ \\
\hline Trichlorocthene & 4 & $\mathbf{J}$ & 370 & & 550 & & 12 & & 12 & $\mathrm{U}$ & 12 & $\mathrm{U}^{*}$ \\
\hline Vinyl chloride & 19 & & 180 & & 16 & & 12 & U & 12 & $\mathrm{U}$ & 12 & $\mathrm{U}$ \\
\hline Xylenes (total) & 16 & & 12 & $\mathrm{~J}$ & 12 & $U$ & 12 & $U$ & 12 & U & 12 & $U$ \\
\hline
\end{tabular}


TABLE C.13c (Cont.)

\begin{tabular}{|c|c|c|c|c|c|c|c|c|c|c|}
\hline \multirow{3}{*}{$\begin{array}{l}\text { Compound } \\
\text { Acetone }\end{array}$} & \multicolumn{10}{|c|}{ Soil Concentrations $(\mu \mathrm{g} / \mathrm{kg})$ at Various Depth Intervals } \\
\hline & \multicolumn{2}{|c|}{$\begin{array}{l}\text { TSBPBOR2-REDup } \\
(0-2 \mathrm{ft})\end{array}$} & \multicolumn{2}{|c|}{$\begin{array}{c}\text { TBSPBOR2 } \\
(2-4 \mathrm{ft}) \\
\end{array}$} & \multicolumn{2}{|c|}{$\begin{array}{c}\text { TBSPBOR2 } \\
(4-6 \mathrm{ft}) \\
\end{array}$} & \multicolumn{2}{|c|}{$\begin{array}{c}\text { TBSPBOR2 } \\
(6-8 \mathrm{ft}) \\
\end{array}$} & \multicolumn{2}{|c|}{$\begin{array}{c}\text { TBSPBOR2 } \\
(8-10 \mathrm{ft})\end{array}$} \\
\hline & 12 & $\mathrm{U}$ & 12 & $\mathrm{U}$ & 97 & $\mathrm{JB}$ & 120 & $U$ & 130 & B \\
\hline Benzene & 12 & $\mathrm{U}$ & 12 & $\mathrm{U}$ & 120 & $U$ & 120 & $\mathrm{U}$ & 120 & U \\
\hline Bromodichloromethane & 12 & $\mathrm{U}$ & 12 & $\mathrm{U}$ & 120 & $\mathrm{U}$ & 120 & $\mathrm{U}$ & 120 & $\mathbf{U}$ \\
\hline Bromoform & 12 & $\mathrm{U}$ & 12 & $\mathrm{U}$ & 120 & $\mathbf{U}$ & 120 & $\mathrm{U}$ & 120 & U \\
\hline Bromomethane & 12 & $\mathrm{U}$ & 12 & $\mathrm{U}$ & 120 & $\mathrm{U}$ & 120 & $\mathrm{U}$ & 120 & $U$ \\
\hline 2-Butanone & 12 & $\mathrm{U}$ & 12 & $\mathrm{U}$ & 120 & $\mathrm{U}$ & 120 & $\mathrm{U}$ & 120 & $\mathbf{U}$ \\
\hline Carbon disulfide & 12 & $\mathrm{U}$ & 12 & $\mathrm{U}$ & 120 & $\mathrm{U}$ & 120 & $U$ & 120 & $\mathrm{U}$ \\
\hline Carbon tetrachloride & 12 & $\mathrm{U}$ & 12 & U & 120 & $\mathbf{U}$ & 120 & U & 120 & $\mathbf{U}$ \\
\hline Chlorobenzene & 12 & $\mathrm{U}$ & 12 & $U$ & 120 & $\mathrm{U}$ & 120 & $\mathbf{U}$ & 120 & $\mathbf{U}$ \\
\hline Chloroethane & 12 & $\mathrm{U}$ & 12 & $\mathrm{U}$ & 120 & $\mathrm{U}$ & 120 & $U$ & 120 & $U$ \\
\hline Chloroform & 12 & $\mathbf{U}$ & 12 & $\mathrm{U}$ & 120 & $\mathrm{U}$ & 120 & $\mathbf{U}$ & 120 & $\mathbf{U}$ \\
\hline Chloromethane & 12 & $\mathrm{U}$ & 12 & $\mathrm{U}$ & 120 & $\mathrm{U}$ & 120 & U & 120 & $\mathbf{U}$ \\
\hline Dibromochloromethane & 12 & $\mathrm{U}$ & 12 & $\mathrm{U}$ & 120 & $\mathrm{U}$ & 120 & $U$ & 120 & $U$ \\
\hline 1,1-Dichloroethane & 12 & $\mathbf{U}$ & 12 & $\mathrm{U}$ & 120 & $\mathrm{U}$ & 120 & $\mathbf{U}$ & 120 & $\mathrm{U}$ \\
\hline 1,2-Dichloroethane & 12 & $\mathbf{U}$ & 12 & $U$ & 120 & $\mathrm{U}$ & 120 & $\mathbf{U}$ & 120 & $\mathrm{U}$ \\
\hline 1,1-Dichloroethene & 12 & $\mathbf{U}$ & 12 & $\mathbf{U}$ & 120 & $\mathrm{U}$ & 120 & $U$ & 120 & $\mathbf{U}$ \\
\hline 1,2-Dichloroethene (total) & 12 & U & 12 & U & 120 & $\mathbf{J}$ & 460 & & 8,400 & \\
\hline 1,2-Dichloropropane & 12 & $\mathbf{U}$ & 12 & $\mathrm{U}$ & 120 & $\mathrm{U}$ & 120 & $\mathrm{U}$ & 120 & $\mathrm{U}$ \\
\hline cis-1,3-Dichloropropene & 12 & $U$ & 12 & $\mathrm{U}$ & 120 & U & 120 & $U$ & 120 & $\mathrm{U}$ \\
\hline trans-1,3-Dichloropropene & 12 & $\mathbf{U}$ & 12 & $\mathrm{U}$ & 120 & $\mathrm{U}$ & 120 & $\mathrm{U}$ & 120 & $\mathrm{U}$ \\
\hline Ethylbenzene & 12 & $\mathrm{U}$ & 12 & $\mathrm{U}$ & 120 & U & 120 & $\mathrm{U}$ & 120 & U \\
\hline 2-Hexanone & 12 & $U$ & 12 & $\mathrm{U}$ & 120 & $\mathrm{U}$ & 120 & $U$ & 120 & U \\
\hline 4-Methyl-2-pentanone & 12 & $\mathrm{U}$ & 12 & $\mathrm{U}$ & 120 & $\mathrm{U}$ & 120 & $\mathrm{U}$ & 120 & $\mathrm{U}$ \\
\hline
\end{tabular}


TABLE C.13c (Cont.)

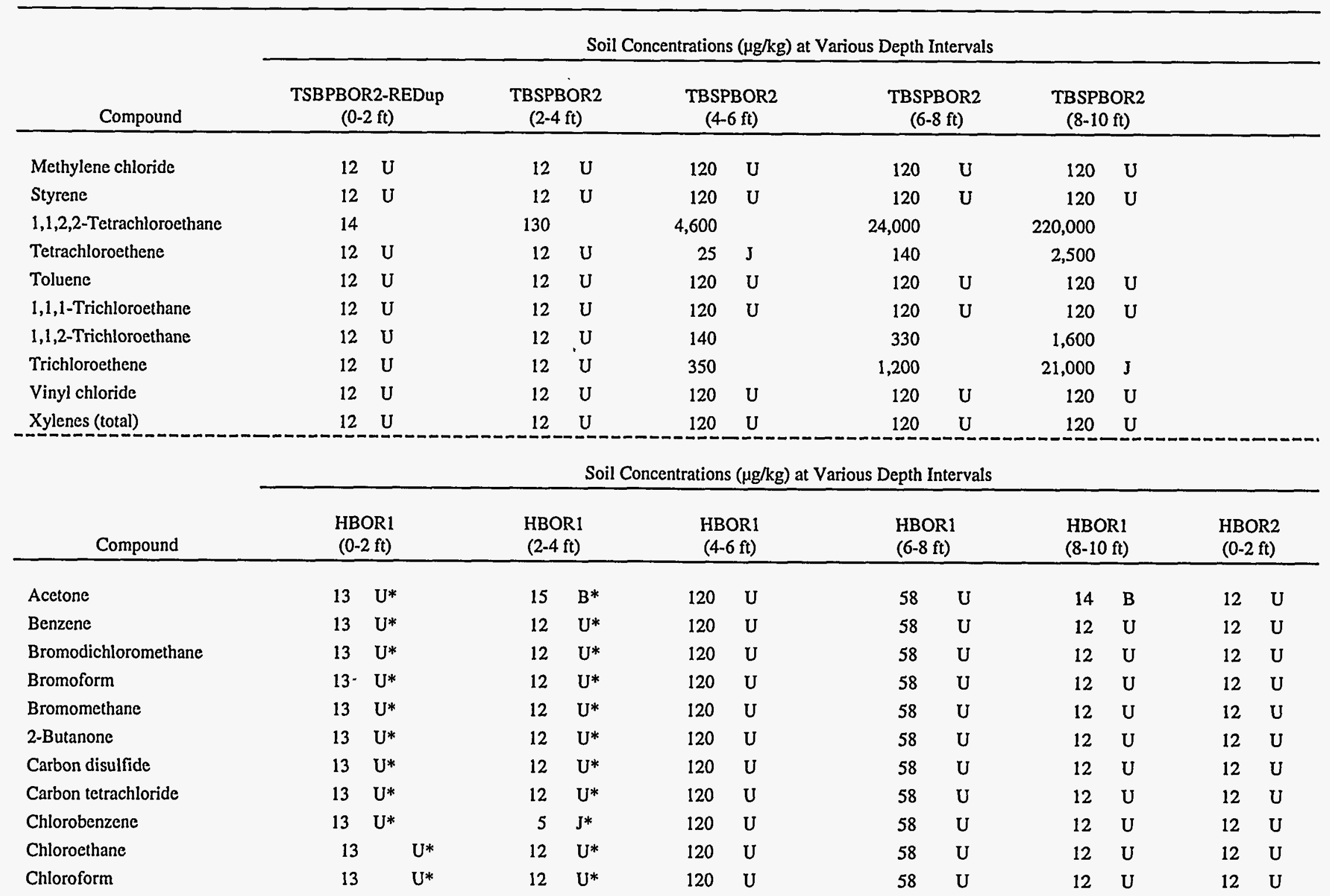


TABLE C.13c (Cont.)

\begin{tabular}{|c|c|c|c|c|c|c|c|c|c|c|c|c|}
\hline \multirow{3}{*}{$\frac{\text { Compound }}{\text { Chloromethane }}$} & \multicolumn{10}{|c|}{ Soil Concentrations $(\mu \mathrm{g} / \mathrm{kg})$ at Various Depth Intervals } & & \\
\hline & \multicolumn{2}{|c|}{$\begin{array}{l}\text { HBOR } 1 \\
(0-2 \mathrm{ft})\end{array}$} & \multicolumn{2}{|c|}{$\begin{array}{l}\text { HBOR1 } \\
(2-4 \mathrm{ft}) \\
\end{array}$} & \multicolumn{2}{|c|}{$\begin{array}{l}\text { HBOR1 } \\
(4-6 \mathrm{ft}) \\
\end{array}$} & \multicolumn{2}{|c|}{$\begin{array}{l}\text { HBORI } \\
(6-8 \mathrm{ft}) \\
\end{array}$} & \multicolumn{2}{|c|}{$\begin{array}{l}\text { HBORI } \\
(8-10 \mathrm{ft}) \\
\end{array}$} & \multicolumn{2}{|c|}{$\begin{array}{l}\text { HBOR2 } \\
(0-2 \mathrm{ft})\end{array}$} \\
\hline & 13 & $\mathrm{U}^{*}$ & 12 & $\mathrm{U}^{*}$ & 120 & $\mathrm{U}$ & 58 & $\mathrm{U}$ & 12 & $\mathrm{U}$ & 12 & U \\
\hline Dibromochloromethane & 13 & $\mathrm{U}^{*}$ & 12 & $\mathrm{U}^{*}$ & 120 & $U$ & 58 & $\mathrm{U}$ & 12 & $\mathbf{U}$ & 12 & $\mathrm{U}$ \\
\hline 1,1-Dichloroethane & 13 & $U^{*}$ & 12 & $\mathrm{U}^{*}$ & 120 & $\mathrm{U}$ & 58 & U & 12 & $\mathbf{U}$ & 12 & U \\
\hline 1,2-Dichloroethane & 13 & $U^{*}$ & 12 & $\mathrm{U}^{*}$ & 120 & $\mathrm{U}$ & 58 & $\mathrm{U}$ & 12 & $\mathbf{U}$ & 12 & $U$ \\
\hline 1,1-Dichlorocthene & 13 & $\mathrm{U}^{*}$ & 12 & $\mathrm{U}^{*}$ & 120 & $\mathrm{U}$ & 58 & $\mathrm{U}$ & 12 & $\mathbf{U}$ & 12 & U \\
\hline 1,2-Dichloroethene (total) & 120 & $\mathrm{U}^{*}$ & 17 & $*$ & 120 & $U$ & 58 & U & 12 & U & 12 & U \\
\hline 1,2-Dichloropropane & 13 & $U^{*}$ & 12 & $\mathrm{U}^{*}$ & 120 & $\mathrm{U}$ & 58 & $\mathrm{U}$ & 12 & $\mathrm{U}$ & 12 & U \\
\hline cis-1,3-Dichloropropene & 13 & $U^{*}$ & 12 & $\mathrm{U}^{*}$ & 120 & $\mathrm{U}$ & 58 & $\mathrm{U}$ & 12 & $\mathrm{U}$ & 12 & U \\
\hline trans-1,3-Dichloropropene & 13 & $\mathrm{U}^{*}$ & 12 & $\mathrm{U}^{*}$ & 120 & $U$ & 58 & $U$ & 12 & $\mathrm{U}$ & 12 & U \\
\hline Ethylbenzene & 13 & $\mathrm{U}^{*}$ & 12 & $\mathrm{U}^{*}$ & 120 & U & 58 & U & 12 & $\mathbf{U}$ & 12 & U \\
\hline 2-Hexanone & 13 & $\mathrm{U}^{*}$ & 12 & $\mathrm{U}^{*}$ & 120 & $\mathrm{U}$ & 58 & $\mathrm{U}$. & 12 & $\mathbf{U}$ & 12 & U \\
\hline 4-Methyl-2-pentanone & 13 & $\mathrm{U}^{*}$ & 12 & $\mathrm{U}^{*}$ & 120 & $\mathbf{U}$ & 58 & $U$ & 12 & $\mathrm{U}$ & 12 & U \\
\hline Methylene chloride & 13 & $\mathrm{U}^{*}$ & 12 & $\mathrm{U}^{*}$ & 120 & $\mathrm{U}$ & 58 & U & 12 & $\mathbf{U}$ & 12 & $\mathrm{U}$ \\
\hline Styrene & 13 & $\mathrm{U}^{*}$ & 12 & $\mathrm{U}^{*}$ & 120 & $\mathrm{U}$ & 58 & $U$ & 12 & $U$ & 12 & $\mathbf{U}$ \\
\hline 1,1,2,2-Tetrachloroethane & 18 & $\mathrm{U}^{*}$ & 44 & $*$ & 120 & $\mathbf{U}$ & 17 & $\mathbf{J}$ & 96 & & 12 & $U$ \\
\hline Tetrachloroethene & 13 & $\mathrm{U}^{*}$ & 12 & $\mathrm{U}^{*}$ & 120 & $\mathbf{U}$ & 58 & $U$ & 12 & $\mathrm{U}$ & 12 & $\mathbf{U}$ \\
\hline Toluene & 13 & $U^{*}$ & 12 & $\mathrm{U}^{*}$ & 120 & $U$ & 58 & U & 12 & $\mathrm{U}$ & 12 & $\mathrm{U}$ \\
\hline 1,1,2-Trichloroethane & 13 & $\mathrm{U}^{*}$ & 12 & $\mathrm{U}^{*}$ & 120 & $U$ & 58 & $\mathrm{U}$ & 12 & $U$ & 12 & U \\
\hline 1,1,1-Trichloroethane & 13 & $\mathrm{U}^{*}$ & 12 & $\mathrm{U}^{*}$ & 120 & $\mathbf{U}$ & 60 & & 22 & & 12 & $U$ \\
\hline Trichloroethene & 130 & $\mathrm{U}^{*}$ & 9 & $\mathrm{~J}^{*}$ & 120 & $\mathrm{U}$ & 58 & $U$ & 30 & & 3 & $\mathrm{~J}$ \\
\hline Vinyl chloride & 13 & $\mathrm{U}^{*}$ & 12 & $U^{*}$ & 120 & $\mathrm{U}$ & 58 & $\mathbf{U}$ & 12 & $U$ & 12 & $\mathrm{U}$ \\
\hline Xylenes (total) & 13 & $\mathrm{U}^{*}$ & 12 & $U^{*}$ & 120 & $\mathrm{U}$ & 58 & $\mathrm{U}$ & 12. & $\mathbf{U}$ & 12 & $\mathrm{U}$ \\
\hline
\end{tabular}


TABLE C.13c (Cont.)

\begin{tabular}{|c|c|c|c|c|c|c|c|c|c|c|c|c|c|}
\hline \multirow{3}{*}{$\begin{array}{l}\text { Compound } \\
\text { Acetone }\end{array}$} & \multicolumn{11}{|c|}{ Soil Concentrations $(\mu \mathrm{g} / \mathrm{kg})$ at Various Depth Intervals } & & \\
\hline & \multicolumn{2}{|c|}{$\begin{array}{r}\text { HBOR2 } \\
(2-4 \mathrm{ft}) \\
\end{array}$} & \multicolumn{2}{|c|}{$\begin{array}{l}\text { HBOR2 } \\
(4-6 \mathrm{ft})\end{array}$} & \multicolumn{2}{|c|}{$\begin{array}{l}\text { HBOR2 } \\
(6-8 \mathrm{ft})\end{array}$} & & \multicolumn{2}{|c|}{$\begin{array}{l}\text { HBOR2 } \\
(8-10 \mathrm{ft})\end{array}$} & \multicolumn{2}{|c|}{$\begin{array}{c}\text { TBNPBOR1 } \\
(0-2 \mathrm{ft}) \\
\end{array}$} & \multicolumn{2}{|c|}{$\begin{array}{c}\text { TBNPBORI } \\
(2-4 \mathrm{ft})\end{array}$} \\
\hline & 12 & $\mathrm{U}$ & 12 & $U$ & 16 & B & & 26 & B & 12 & B & 13 & B \\
\hline Benzene & 12 & $\mathbf{U}$ & 12 & $\mathrm{U}$ & 12 & $\mathrm{U}$ & & 12 & $\mathbf{U}$ & 12 & $\mathbf{U}^{*}$ & 12 & $\mathbf{U}$ \\
\hline Bromodichloromethane & 12 & $\mathbf{U}$ & 12 & $\mathrm{U}$ & 12 & $U$ & & 12 & $\mathbf{U}$ & 12 & $\mathrm{U}^{*}$ & 12 & $\mathrm{U}$ \\
\hline Bromoform & 12 & $U$ & 12 & $\mathrm{U}$ & 12 & U & & 12 & $\mathbf{U}$ & 12 & $\mathrm{U}^{*}$ & 12 & $\mathrm{U}$ \\
\hline Bromomethane & 12 & $U$ & 12 & $\mathrm{U}$ & 12 & U & & 12 & $\mathbf{U}$ & 12 & $\mathrm{U}$ & 12 & $\mathrm{U}$ \\
\hline 2-Butanone & 12 & $U$ & 12 & $\mathrm{U}$ & 12 & $\mathrm{U}$ & & 12 & $\mathbf{U}$ & 12 & $\mathrm{U}$ & 12 & $\mathbf{U}$ \\
\hline Carbon disulfide & 12 & $U$ & 12 & $U$ & 12 & $\mathrm{U}$ & - & 12 & $\mathbf{U}$ & 12 & $\mathrm{U}$ & 12 & $\mathrm{U}$ \\
\hline Carbon tetrachloride & 12 & $\mathbf{U}$ & 12 & $U$ & 12 & $\mathbf{U}$ & & 12 & $\mathbf{U}$ & 12 & $\mathrm{U}^{*}$ & 12 & $\mathbf{U}$ \\
\hline Chlorobenzene & 12 & $\mathbf{U}$ & 12 & $\mathrm{U}$ & 12 & $\mathbf{U}$ & & 12 & $\mathrm{U}$ & 12 & $\mathrm{U}^{*}$ & 12 & $\mathbf{U}$ \\
\hline Chloroethane & 12 & $\mathrm{U}$ & 12 & $\mathrm{U}$ & 12 & $\mathrm{U}$ & & 12 & U & 12 & $\mathrm{U}$ & 12 & $\mathbf{U}$ \\
\hline Chloroform & 12 & $\mathbf{U}$ & 12 & $\mathbf{U}$ & 12 & $\mathrm{U}$ & & 12 & $\mathrm{U}$ & 12 & $\mathrm{U}$ & 10 & $\mathbf{J}$ \\
\hline Chloromethane & 12 & $\mathbf{U}$ & 12 & $\mathbf{U}$ & 12 & $\mathrm{U}$ & & 12 & $U$ & 12 & $\mathrm{U}$ & 12 & $\mathrm{U}$ \\
\hline Dibromochloromethane & 12 & $\mathrm{U}$ & 12 & $\mathbf{U}$ & 12 & $\mathrm{U}$ & & 12 & $\mathrm{U}$ & 12 & $\mathrm{U}^{*}$ & 12 & $\mathbf{U}$ \\
\hline 1,1-Dichloroethane & 12 & $\mathrm{U}$ & 12 & $\mathbf{U}$ & 12 & $\mathbf{U}$ & & 12 & $\mathrm{U}$ & 12 & $\mathrm{U}$ & 12 & $\mathbf{U}$ \\
\hline 1,2-Dichloroethane & 12 & $\mathrm{U}$ & 12 & $\mathbf{U}$ & 12 & $\mathbf{U}$ & & 12 & $U$ & 12 & $\mathrm{U}$ & 12 & $\mathrm{U}$ \\
\hline 1,1-Dichloroethene & 12 & $\mathrm{U}$ & 12 & $\mathbf{U}$ & 12 & U & & 12 & $\mathrm{U}$ & 12 & $\mathbf{U}$ & 12 & $\mathrm{U}$ \\
\hline 1,2-Dichloroethene (total) & 12 & $\mathrm{U}$ & 12 & $U$ & 12 & $\mathrm{U}$ & & 12 & $\mathrm{U}$ & 9 & J & 100 & \\
\hline 1,2-Dichloropropane & 12 & U & 12 & $\mathrm{U}$ & 12 & $\mathrm{U}$ & & 12 & $\mathbf{U}$ & 12 & $\mathrm{U}^{*}$ & 12 & $\mathrm{U}$ \\
\hline cis-1,3-Dichloropropene & 12 & $\mathrm{U}$ & 12 & $U$ & 12 & $\mathrm{U}$ & & 12 & $\mathrm{U}$ & 12 & $\mathrm{U}^{*}$ & 12 & $\mathrm{U}$ \\
\hline trans-1,3-Dichloropropene & 12 & $U$ & 12 & $\mathrm{U}$ & 12 & $\mathrm{U}$ & & 12 & $\mathrm{U}$ & 12 & $\mathrm{U}^{*}$ & 12 & $\mathrm{U}$ \\
\hline Ethylbenzene & 12 & $\mathrm{U}$ & 12 & $\mathbf{U}$ & 12 & $\mathrm{U}$ & & 12 & $\mathrm{U}$ & 12 & $\mathrm{U}^{*}$ & 12 & $\mathrm{U}$ \\
\hline 2-Hexanone & 12 & U & 12 & $\mathrm{U}$ & 12 & $\mathrm{U}$ & & 12 & $\mathbf{U}$ & 12 & $\mathrm{U}^{*}$ & 12 & $\mathrm{U}$ \\
\hline 4-Methyl-2-pentanone & 12 & $U$ & 12 & $\mathrm{U}$ & 12 & $\mathrm{U}$ & & 12 & U & 12 & $\mathrm{U}^{*}$ & 12 & $\mathbf{U}$ \\
\hline Methylene chloride & 12 & $\mathrm{U}$ & 12 & $\mathrm{U}$ & 12 & $\mathrm{U}$ & & 12 & $U$ & 12 & $\mathrm{U}$ & 12 & $\mathrm{U}$ \\
\hline Styrene & 12 & $U$ & 12 & $\mathrm{U}$ & 12 & $\mathrm{U}$ & & 12 & $\mathrm{U}$ & 12 & $\mathrm{U}^{*}$ & 12 & $U$ \\
\hline 1,1,2,2-Tetrachloroethane & 12 & $\mathrm{U}$ & 12 & $\mathrm{U}$ & 12 & $\mathrm{U}$ & & 5 & J & 53 & $*$ & 93 & \\
\hline
\end{tabular}


TABLE C.13c (Cont.)

\begin{tabular}{|c|c|c|c|c|c|c|c|c|c|c|c|c|}
\hline \multirow{3}{*}{$\begin{array}{l}\text { Compound } \\
\text { Tetrachloroethene }\end{array}$} & \multicolumn{10}{|c|}{ Soil Concentrations $(\mu \mathrm{g} / \mathrm{kg})$ at Various Depth Intervals } & \multirow{2}{*}{\multicolumn{2}{|c|}{$\begin{array}{c}\text { TBNPBOR } \\
(2-4 \mathrm{ft})\end{array}$}} \\
\hline & \multicolumn{2}{|c|}{$\begin{array}{r}\text { HBOR2 } \\
(2-4 \mathrm{ft}) \\
\end{array}$} & \multicolumn{2}{|c|}{$\begin{array}{r}\text { HBOR2 } \\
(4-6 \mathrm{ft})\end{array}$} & \multicolumn{2}{|c|}{$\begin{array}{c}\text { HBOR2 } \\
(6-8 \mathrm{ft}) \\
\end{array}$} & \multicolumn{2}{|c|}{$\begin{array}{l}\text { HBOR2 } \\
(8-10 \mathrm{ft}) \\
\end{array}$} & \multicolumn{2}{|c|}{$\begin{array}{c}\text { TBNPBOR1 } \\
(0-2 \mathrm{ft})\end{array}$} & & \\
\hline & 12 & U & 12 & $\mathbf{U}$ & 12 & $\mathbf{U}$ & 12 & $\mathbf{U}$ & 9 & $\mathbf{J}^{*}$ & 19 & \\
\hline Toluene & 12 & $U$ & 12 & $\mathbf{U}$ & 12 & $\mathbf{U}$ & 12 & $\mathrm{U}$ & 12 & $\mathrm{U}^{*}$ & 12 & $\mathrm{U}$ \\
\hline 1,1,1-Trichloroethane & 12 & $\mathrm{U}$ & 12 & $\mathrm{U}$ & 12 & $\mathbf{U}$ & 12 & U & 12 & $\mathrm{U}^{*}$ & 12 & $\mathrm{U}$ \\
\hline 1,1,2-Trichloroethane & 12 & $\mathrm{U}$ & 12 & $\mathrm{U}$ & 12 & $U$ & 12 & $\mathrm{U}$ & 12 & $\mathrm{U}^{*}$ & 12 & $\mathrm{U}$ \\
\hline Trichloroethene & 12 & $U$ & 12 & $\mathbf{U}$ & 12 & $\mathrm{U}$ & 5 & $\mathbf{J}$ & 83 & $*$ & 230 & \\
\hline Vinyl chloride & 12 & $\mathrm{U}$ & 12 & $U$ & 12 & $\mathrm{U}$ & 12 & $\mathrm{U}$ & 12 & U & 12 & $\mathrm{U}$ \\
\hline Xylenes (total) & 12 & U & 12 & $\mathrm{U}$ & 12 & U & 12 & $\mathbf{U}$ & 12 & $\mathrm{U}^{*}$ & 12 & $\mathrm{U}$ \\
\hline
\end{tabular}

Soil Concentrations $(\mu \mathrm{g} / \mathrm{kg})$ at Various Depth Intervals

\begin{tabular}{lccccccc} 
& \multicolumn{7}{c}{ Soil Concentrations $(\mu \mathrm{g} / \mathrm{kg})$ at Various Depth Intervals } \\
\cline { 2 - 7 } \multicolumn{1}{c}{ Compound } & TBNPBORI & TBNPBOR1 & TBNPBOR1 \\
& $(4-6 \mathrm{ft})$ & $(6-8 \mathrm{ft})$ & $(8-10 \mathrm{ft})$ \\
\hline Acetone & 22 & $\mathrm{~B}$ & 12 & $\mathrm{U}$ & 12 & $\mathrm{U}$ \\
Benzene & 12 & $\mathrm{U}$ & 12 & $\mathrm{U}$ & 12 & $\mathrm{U}$ \\
Bromodichloromethane & 12 & $\mathrm{U}$ & 12 & $\mathrm{U}$ & 12 & $\mathrm{U}$ \\
Bromoform & 12 & $\mathrm{U}$ & 12 & $\mathrm{U}$ & 12 & $\mathrm{U}$ \\
Bromomethane & 12 & $\mathrm{U}$ & 12 & $\mathrm{U}$ & 12 & $\mathrm{U}$ \\
2-Butanone & 12 & $\mathrm{U}$ & 12 & $\mathrm{U}$ & 12 & $\mathrm{U}$ \\
Carbon disulfide & 12 & $\mathrm{U}$ & 12 & $\mathrm{U}$ & 12 & $\mathrm{U}$ \\
Carbon tetrachloride & 12 & $\mathrm{U}$ & 12 & $\mathrm{U}$ & 12 & $\mathrm{U}$ \\
Chlorobenzene & 12 & $\mathrm{U}$ & 12 & $\mathrm{U}$ & 12 & $\mathrm{U}$ \\
Chloroethane & 12 & $\mathrm{U}$ & 12 & $\mathrm{U}$ & 12 & $\mathrm{U}$ \\
Chloroform & 9 & $\mathrm{~J}$ & 12 & $\mathrm{U}$ & 12 & $\mathrm{U}$ \\
Chloromethane & 12 & $\mathrm{U}$ & 12 & $\mathrm{U}$ & 12 & $\mathrm{U}$ \\
Dibromochloromethane & 12 & $\mathrm{U}$ & 12 & $\mathrm{U}$ & 12 & $\mathrm{U}$
\end{tabular}


TABLE C.13c (Cont.)

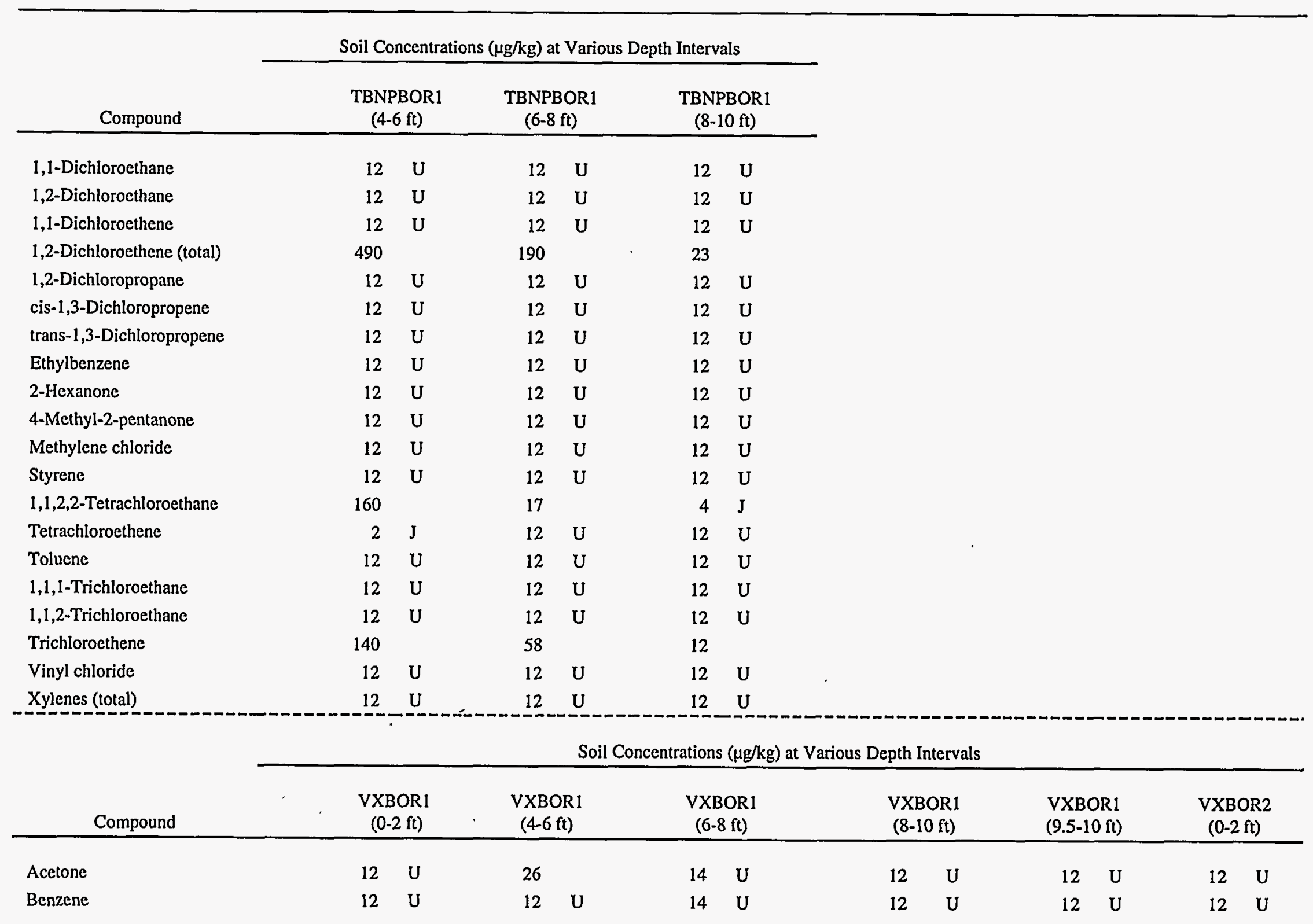


TABLE C.13c (Cont.)

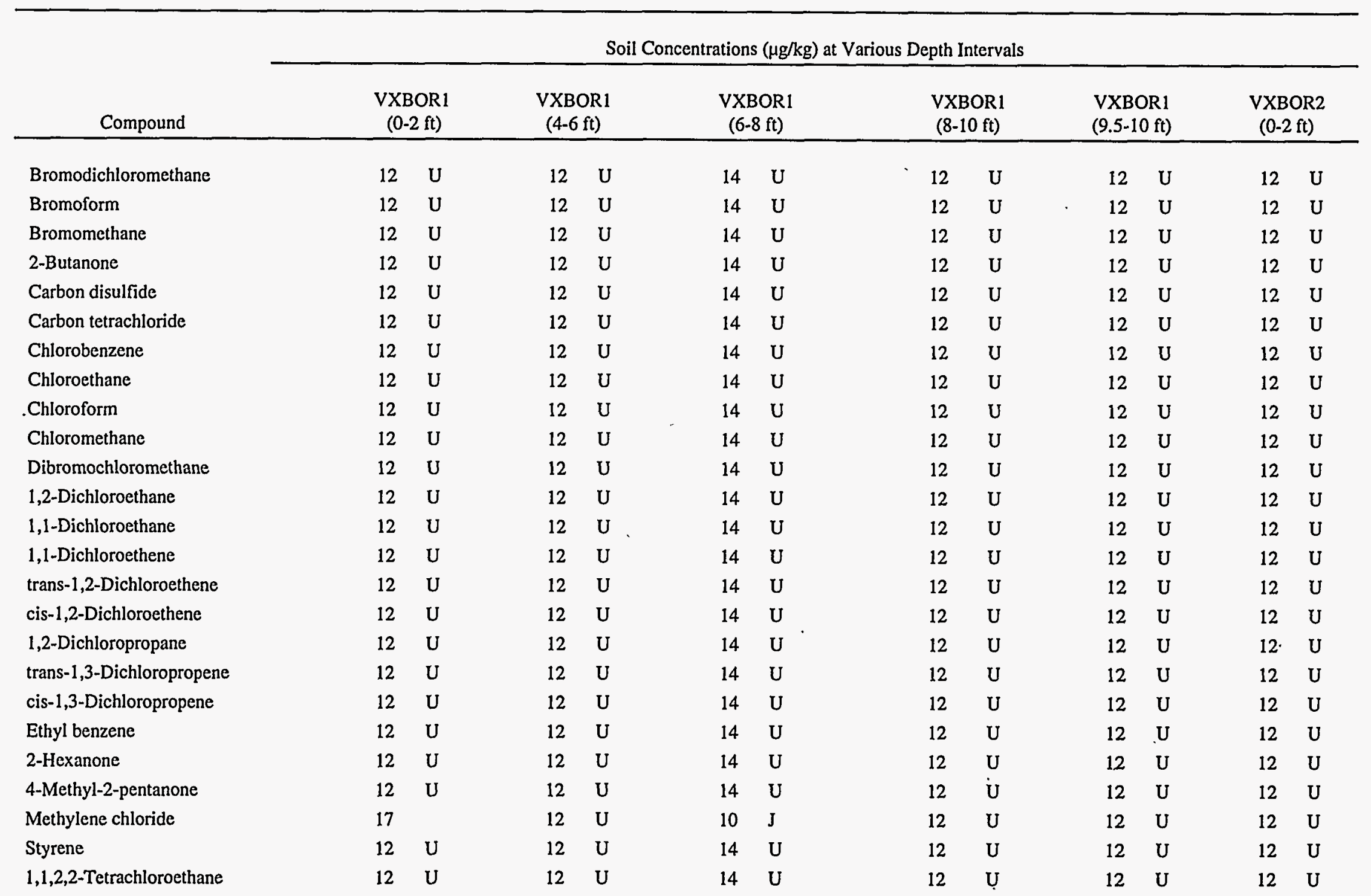


TABLE C.13c (Cont.)

\begin{tabular}{|c|c|c|c|c|c|c|c|c|c|c|c|c|}
\hline \multirow[b]{2}{*}{ Compound } & \multicolumn{12}{|c|}{ Soil Concentrations $(\mu \mathrm{g} / \mathrm{kg})$ at Various Depth Intervals } \\
\hline & \multicolumn{2}{|c|}{$\begin{array}{l}\text { VXBOR1 } \\
(0-2 \mathrm{ft}) \\
\end{array}$} & \multicolumn{2}{|c|}{$\begin{array}{c}\text { VXBOR1 } \\
(4-6 \mathrm{ft})\end{array}$} & \multicolumn{2}{|c|}{$\begin{array}{c}\text { VXBOR1 } \\
(6-8 \mathrm{ft})\end{array}$} & \multicolumn{2}{|c|}{$\begin{array}{l}\text { VXBOR } 1 \\
(8-10 \mathrm{ft})\end{array}$} & \multicolumn{2}{|c|}{$\begin{array}{l}\text { VXBOR1 } \\
(9.5-10 \mathrm{ft})\end{array}$} & \multicolumn{2}{|c|}{$\begin{array}{l}\text { VXBOR2 } \\
(0-2 \mathrm{ft})\end{array}$} \\
\hline Tetrachloroethene & 12 & $\mathrm{U}$ & 12 & $\mathrm{U}$ & 14 & $\mathrm{U}$ & 12 & $\mathbf{U}$ & 12 & $\mathrm{U}$ & 12 & $\mathrm{U}$ \\
\hline Toluene & 12 & $\mathrm{U}$ & 12 & $\mathbf{U}$ & 14 & $\mathrm{U}$ & 12 & $\mathbf{U}$ & 12 & $\mathrm{U}$ & 12 & U \\
\hline 1,1,2-Trichloroethane & 12 & $\mathrm{U}$ & 12 & $\mathrm{U}$ & 14 & $\mathrm{U}$ & 12 & $\mathbf{U}$ & 12 & $\mathrm{U}$ & 12 & $\mathrm{U}$ \\
\hline 1,1,1-Trichloroethane & 12 & $\mathrm{U}$ & 12 & $\mathrm{U}$ & 14 & $\mathrm{U}$ & 12 & $\mathrm{U}$ & 12 & $\mathbf{U}$ & 12 & $\mathrm{U}$ \\
\hline Trichloroethene & 12 & $\mathrm{U}$ & 12 & $\mathrm{U}$ & 14 & $U$ & 12 & $\mathbf{U}$ & 12 & U & 12 & U \\
\hline Vinyl acetate & 12 & $\mathbf{U}$ & 12 & $\mathrm{U}$ & 14 & $\mathrm{U}$ & 12 & $\mathbf{U}$ & 12 & $\mathrm{U}$ & 12 & $\mathrm{U}$ \\
\hline Vinyl chloride & 12 & $\mathbf{U}$ & 12 & $\mathrm{U}$ & 14 & $\mathrm{U}$ & 12 & $\mathbf{U}$ & 12 & $\mathrm{U}$ & 12 & $\mathbf{U}$ \\
\hline $\mathrm{m}$ - and $\mathrm{p}$-Xylene & 12 & $\mathrm{U}$ & 12 & $\mathbf{U}$ & 14 & $\mathbf{U}$ & 12 & $\mathbf{U}$ & 12 & $\mathbf{U}$ & 12 & $\mathrm{U}$ \\
\hline o-Xylene & 12 & U & 12 & U & 14 & $U$ & 12 & $\mathrm{U}$ & 12 & U & 12 & $\mathrm{U}$ \\
\hline \multicolumn{13}{|c|}{ Soil Concentrations $(\mu \mathrm{g} / \mathrm{kg})$ at Various Depth Intervals } \\
\hline Compound & \multicolumn{2}{|c|}{$\begin{array}{c}\text { VXBOR2 } \\
(2-4 \mathrm{ft})\end{array}$} & \multicolumn{2}{|c|}{$\begin{array}{c}\text { VXBOR2 } \\
(4-6 \mathrm{ft}) \\
\end{array}$} & \multicolumn{2}{|c|}{$\begin{array}{l}\text { FTBOR1 } \\
(0-2 \mathrm{ft})\end{array}$} & \multicolumn{2}{|c|}{$\begin{array}{c}\text { FTBOR1-Dup } \\
(0-2 \mathrm{ft})\end{array}$} & \multicolumn{2}{|c|}{$\begin{array}{c}\text { FTBOR1 } \\
(2-4 \mathrm{ft}) \\
\end{array}$} & \multicolumn{2}{|c|}{$\begin{array}{c}\text { FTBOR1-Dup } \\
(2-4 \mathrm{ft})\end{array}$} \\
\hline Acetone & 12 & $\mathrm{U}$ & 12 & $\mathrm{U}$ & 12 & U & 12 & $\mathrm{U}$ & 12 & $\mathrm{U}$ & 11 & $\mathrm{U}$ \\
\hline Benzene & 12 & U & 12 & $\mathrm{U}$ & 12 & U & 12 & $\mathrm{U}$ & 12 & $\mathbf{U}$ & 11 & U \\
\hline Bromodichloromethane & 12 & $U$ & 12 & $\mathbf{U}$ & 12 & U & 12 & $\mathrm{U}$ & 12 & $\mathrm{U}$ & 11 & $\mathrm{U}$ \\
\hline Bromoform & 12 & $\mathrm{U}$ & 12 & $\mathrm{U}$ & 12 & U & 12 & $\mathrm{U}$ & 12 & $\mathrm{U}$ & 11 & $\mathrm{U}$ \\
\hline Bromomethane & 12 & $\mathrm{U}$ & 12 & $\mathbf{U}$ & 12 & $\mathbf{U}$ & 12 & $\mathrm{U}$ & 12 & $\mathbf{U}$ & 11 & $\mathrm{U}$ \\
\hline 2-Butanone & 12 & $\mathrm{U}$ & 12 & $\mathrm{U}$ & 12 & $\mathbf{U}$ & 12 & $\mathrm{U}$ & 12 & $\mathrm{U}$ & 11 & $\mathrm{U}$ \\
\hline Carbon disulfide & 12 & $\mathrm{U}$ & 12 & $\mathrm{U}$ & 12 & $\mathbf{U}$ & 12 & $\mathrm{U}$ & 12 & $\mathbf{U}$ & 11 & $\mathrm{U}$ \\
\hline Carbon tetrachloride & 12 & $\mathrm{U}$ & 12 & $\mathrm{U}$ & 12 & $\mathrm{U}$ & 12 & $\mathrm{U}$ & 12 & $U$ & 11 & $\mathrm{U}$ \\
\hline Chlorobenzene & 12 & $\mathrm{U}$ & 12 & $\mathrm{U}$ & 12 & $\mathrm{U}$ & 12 & $\mathrm{U}$ & 12 & $\mathbf{U}$ & 11 & $\mathrm{U}$ \\
\hline Chloroethane & 12 & $\mathrm{U}$ & 12 & $U$ & 12 & $\mathrm{U}$ & 12 & $U$ & 12 & $\mathrm{U}$ & 11 & $U$ \\
\hline Chloroform & 12 & $\mathrm{U}$ & 12 & $\mathrm{U}$ & 12 & $\mathrm{U}$ & 12 & $\mathrm{U}$ & 12 & 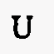 & 11 & $\mathrm{U}$ \\
\hline Chloromethane & 12 & $\dot{U}$ & 12 & $\mathbf{U}$ & 12 & $\mathrm{U}$ & 12 & U & 12 & $\mathrm{U}$ & 11 & $\mathrm{U}$ \\
\hline
\end{tabular}




\begin{tabular}{|c|c|c|c|c|c|c|c|c|c|c|c|c|}
\hline \multirow{3}{*}{$\begin{array}{c}\text { Compound } \\
\text { Dibromochloromethane }\end{array}$} & \multicolumn{12}{|c|}{ Soil Concentrations $(\mu \mathrm{g} / \mathrm{kg}$ ) at Various Depth Intervals } \\
\hline & \multicolumn{2}{|c|}{$\begin{array}{c}\text { VXBOR2 } \\
(2-4 \mathrm{ft}) \\
\end{array}$} & \multicolumn{2}{|c|}{$\begin{array}{c}\text { VXBOR2 } \\
(4-6 \mathrm{ft})\end{array}$} & \multicolumn{2}{|c|}{$\begin{array}{c}\text { FTBOR1 } \\
(0-2 \mathrm{ft}) \\
\end{array}$} & \multicolumn{2}{|c|}{$\begin{array}{l}\text { FTBOR1-Dup } \\
(0.2 \mathrm{ft})\end{array}$} & \multicolumn{2}{|c|}{$\begin{array}{c}\text { FTBOR1 } \\
(2-4 \mathrm{ft})\end{array}$} & \multicolumn{2}{|c|}{$\begin{array}{c}\text { FTBOR1-Dup } \\
(2-4 \mathrm{ft})\end{array}$} \\
\hline & 12 & $\mathrm{U}$ & 12 & $\mathrm{U}$ & 12 & $\mathrm{U}$ & 12 & $\mathrm{U}$ & 12 & $\mathrm{U}$ & 11 & $\mathbf{U}$ \\
\hline 1,1-Dichloroethane & 12 & $\mathrm{U}$ & 12 & $\mathrm{U}$ & 12 & $\mathbf{U}$ & 12 & $\mathrm{U}$ & 12 & $\mathrm{U}$ & 11 & U \\
\hline 1,2-Dichloroethane & 12 & $\mathrm{U}$ & 12 & $\mathbf{U}$ & 12 & $\mathbf{U}$ & 12 & $\mathbf{U}$ & 12 & $\mathrm{U}$ & 11 & U \\
\hline 1,1-Dichloroethene & 12 & $U$ & 12 & $\mathrm{U}$ & 12 & $\mathbf{U}$ & 12 & $\mathrm{U}$ & 12 & $\mathbf{U}$ & 11 & $\mathbf{U}$ \\
\hline cis-1,2-Dichloroethene & 12 & U & 12 & $U$ & 12 & $\mathbf{U}$ & 12 & $\mathrm{U}$ & 12 & $\mathrm{U}$ & 11 & $\mathrm{U}$ \\
\hline trans-1,2-Dichloroethene & 12 & $\mathrm{U}$ & 12 & $\mathrm{U}$ & 12 & $\mathbf{U}$ & 12 & $\mathrm{U}$ & 12 & $\mathrm{U}$ & 11 & $\mathrm{U}$ \\
\hline 1,2-Dichloropropane & 12 & $\mathrm{U}$ & 12 & $\mathrm{U}$ & 12 & $\mathbf{U}$ & 12 & $\mathrm{U}$ & 12 & $\mathrm{U}$ & 11 & $\mathbf{U}$ \\
\hline cis-1,3-Dichloropropene & 12 & $\mathrm{U}$ & 12 & $\mathrm{U}$ & 12 & $\mathrm{U}$ & 12 & $\mathrm{U}$ & 12 & $\mathrm{U}$ & 11 & $\mathrm{U}$ \\
\hline trans-1,3-Dichloropropene & 12 & $\mathrm{U}$ & 12 & $\mathbf{U}$ & 12 & $\mathrm{U}$ & 12 & U & 12 & $\mathrm{U}$ & 11 & $\mathrm{U}$ \\
\hline Ethyl benzene & 12 & $\mathrm{U}$ & 12 & $\mathbf{U}$ & 12 & $\mathrm{U}$ & 12 & $\mathrm{U}$ & 12 & $\mathrm{U}$ & 11 & $\mathrm{U}$ \\
\hline 2-Hexanone & 12 & $\mathrm{U}$ & 12 & $\mathrm{U}$ & 12 & $\mathrm{U}$ & 12 & $\mathrm{U}$ & 12 & $\mathrm{U}$ & 11 & $\mathrm{U}$ \\
\hline 4-Methyl-2-pentanone & 12 & $U$ & 12 & $\mathrm{U}$ & 12 & $\mathrm{U}$ & 12 & $\mathrm{U}$ & 12 & $\mathrm{U}$ & 11 & $\mathrm{U}$ \\
\hline Methylene chloride & 12 & $U$ & 12 & $\mathrm{U}$ & 12 & $\mathrm{U}$ & 12 & $\mathrm{U}$ & 10 & $\mathbf{J}$ & 11 & $\mathrm{U}$ \\
\hline Styrene & 12 & $\mathrm{U}$ & 12 & $\mathrm{U}$ & 12 & $\mathrm{U}$ & 12 & $\mathrm{U}$ & 12 & $\mathrm{U}$ & 11 & $U$ \\
\hline 1,1,2,2-Tetrachloroethane & 12 & $\mathrm{U}$ & 12 & $\mathrm{U}$ & 12 & $\mathrm{U}$ & 12 & $\mathrm{U}$ & 12 & $\mathrm{U}$ & 11 & $\mathrm{U}$ \\
\hline Tetrachloroethene & 12 & $U$ & 12 & $\mathrm{U}$ & 12 & $\mathrm{U}$ & 12 & $\mathrm{U}$ & 12 & $\mathrm{U}$ & 11 & $\mathrm{U}$ \\
\hline Toluene & 12 & $\mathrm{U}$ & 12 & $\mathrm{U}$ & 12 & $U$ & 12 & $U$ & 12 & $\mathrm{U}$ & 11 & $\mathrm{U}$ \\
\hline 1,1,2-Trichloroethane & 12 & $\mathrm{U}$ & 12 & $\mathrm{U}$ & 12 & $\mathrm{U}$ & 12 & $\mathrm{U}$ & 12 & $\mathrm{U}$ & 11 & $U$ \\
\hline 1,1,1-Trichloroethane & 12 & $\mathrm{U}$ & 12 & $U$ & 12 & $\mathrm{U}$ & 12 & $U$ & 12 & $\mathrm{U}$ & 11 & $\mathrm{U}$ \\
\hline Trichloroethene & 12 & $\mathrm{U}$ & 12 & $\mathrm{U}$ & 12 & $\mathrm{U}$ & 12 & $\mathrm{U}$ & 12 & $\mathrm{U}$ & 11 & $U$ \\
\hline Vinyl acetate & 12 & $\mathrm{U}$ & 12 & $\mathrm{U}$ & 12 & $U$ & 12 & $\mathrm{U}$ & 12 & $\mathrm{U}$ & 11 & $\mathrm{U}$ \\
\hline Vinyl chloride & 12 & $\mathrm{U}$ & 12 & $\mathrm{U}$ & 12 & $\mathrm{U}$ & 12 & $\mathrm{U}$ & 12 & $\mathbf{U}$ & 11 & $U$ \\
\hline $\mathrm{m}$ - and $\mathrm{p}$-Xylene & 12 & $U$ & 12 & U & 12 & $\mathrm{U}$ & 12 & $U$ & 12 & $\mathrm{U}$ & 11 & $\mathrm{U}$ \\
\hline o-Xylene & 12 & U & 12 & U & 12 & U & 12 & U & 12 & U & 11 & $\mathrm{U}$ \\
\hline
\end{tabular}


TABLE C.13c (Cont.)

\begin{tabular}{|c|c|c|c|c|c|c|c|c|}
\hline \multirow[b]{2}{*}{ Compound } & \multicolumn{8}{|c|}{ Soil Concentrations $(\mu \mathrm{g} / \mathrm{kg})$ at Various Depth Intervals } \\
\hline & \multicolumn{2}{|c|}{$\begin{array}{c}\text { FTBOR1 } \\
(4-6 \mathrm{ft})\end{array}$} & \multicolumn{2}{|c|}{$\begin{array}{c}\text { FTBORI } \\
(6-8 \mathrm{ft})\end{array}$} & \multicolumn{2}{|c|}{$\begin{array}{l}\text { FTBORI } \\
(8-10 \mathrm{ft})\end{array}$} & \multicolumn{2}{|c|}{$\begin{array}{l}\text { FTBOR1 } \\
(10-12 \mathrm{ft})\end{array}$} \\
\hline Acetone & 12 & $\mathbf{U}$ & 12 & $\mathbf{U}$ & 17 & B & 12 & $\mathrm{U}$ \\
\hline Benzene & 12 & $\mathrm{U}$ & 12 & $\mathbf{U}$ & 14 & $\mathbf{U}$ & 12 & $\mathrm{U}$ \\
\hline Bromodichloromethane & 12 & $\mathrm{U}$ & 12 & $\mathrm{U}$ & 14 & $\mathrm{U}$ & 12 & $\mathrm{U}$ \\
\hline Bromoform & 12 & $\mathrm{U}$ & 12 & $\mathrm{U}$ & 14 & $\mathrm{U}$ & 12 & $\mathbf{U}$ \\
\hline Bromomethane & 12 & $\mathrm{U}$ & 12 & $\mathrm{U}$ & 14 & $\mathrm{U}$ & 12 & $\mathbf{U}$ \\
\hline 2-Butanone & 12 & $\mathrm{U}$ & 12 & $\mathrm{U}$ & 14 & $\mathrm{U}$ & 12 & $\mathrm{U}$ \\
\hline Carbon disulfide & 12 & $\mathbf{U}$ & 12 & $\mathrm{U}$ & 14 & $\mathbf{U}$ & 12 & $\mathbf{U}$ \\
\hline Carbon tetrachloride & 12 & $\mathbf{U}$ & 12 & $\mathrm{U}$ & 14 & $\mathbf{U}$ & 12 & $\mathrm{U}$ \\
\hline Chlorobenzene & 12 & $\mathrm{U}$ & 12 & $U$ & 14 & $\mathrm{U}$ & 12 & $\mathrm{U}$ \\
\hline Chloroethane & 12 & $\mathrm{U}$ & 12 & $\mathrm{U}$ & 14 & $\mathrm{U}$ & 12 & $\mathrm{U}$ \\
\hline Chloroform & 12 & $\mathrm{U}$ & 12 & $\mathrm{U}$ & 14 & $\mathbf{U}$ & 12 & $\mathrm{U}$ \\
\hline Chloromethane & 12 & $\mathrm{U}$ & 12 & $\mathrm{U}$ & 14 & $\mathrm{U}$ & 12 & $\mathrm{U}$ \\
\hline Dibromochloromethane & 12 & $\mathrm{U}$ & 12 & $\mathrm{U}$ & 14 & $\mathrm{U}$ & 12 & $\mathrm{U}$ \\
\hline 1,1-Dichloroethane & 12 & $\mathrm{U}$ & 12 & $\mathrm{U}$ & 14 & $\mathrm{U}$ & 12 & $\mathbf{U}$ \\
\hline 1,2-Dichloroethane & 12 & $U$ & 12 & $\mathrm{U}$ & 14 & $\mathrm{U}$ & 12 & $\mathbf{U}$ \\
\hline 1,1-Dichloroethene & 12 & $\mathrm{U}$ & 12 & $\mathrm{U}$ & 14 & U & 12 & $\mathrm{U}$ \\
\hline cis-1,2-Dichloroethene & 12 & U & 12 & $\mathrm{U}$ & 14 & U & 12 & $\mathbf{U}$ \\
\hline trans-1,2-Dichloroethene & 12 & $\mathrm{U}$ & 12 & $\mathbf{U}$ & 14 & U & 12 & $\mathrm{U}$ \\
\hline 1,2-Dichloropropane & 12 & $\mathbf{U}$ & 12 & $\mathbf{U}$ & 14 & $\mathbf{U}$ & 12 & $\mathrm{U}$ \\
\hline cis-1,3-Dichloropropene & 12 & $\mathrm{U}$ & 12 & $U$ & 14 & U & 12 & $\mathrm{U}$ \\
\hline trans-1,3-Dichloropropene & 12 & $\mathrm{U}$ & 12 & $\mathbf{U}$ & 14 & $U$ & 12 & $\mathrm{U}$ \\
\hline Ethyl benzene & 12 & $\mathrm{U}$ & 12 & $\mathrm{U}$ & 14 & $\mathbf{U}$ & 12 & $\mathrm{U}$ \\
\hline 2-Hexanone & 12 & U & 12 & $U$ & 14 & $\mathbf{U}$ & 12 & U \\
\hline 4-Methyl-2-pentanone & 12 & $\mathrm{U}$ & 12 & $U$ & 14 & $U$ & 12 & $\mathbf{U}$ \\
\hline Methylene chloride & 12 & $\mathrm{U}$ & 12 & $U$ & 14 & $\mathrm{U}$ & 12 & $\mathbf{U}$ \\
\hline Styrene & 12 & $\mathrm{U}$ & 12 & $\mathrm{U}$ & 14 & $\mathrm{U}$ & 12 & $\mathbf{U}$ \\
\hline
\end{tabular}


TABLE C.13c (Cont.)

\begin{tabular}{|c|c|c|c|c|c|c|c|c|}
\hline \multirow{3}{*}{$\frac{\text { Compound }}{1,1,2,2-\text { Tetrachloroethane }}$} & \multicolumn{8}{|c|}{ Soil Concentrations $(\mu \mathrm{g} / \mathrm{kg})$ at Various Depth Intervals } \\
\hline & \multicolumn{2}{|c|}{$\begin{array}{c}\text { FTBORI } \\
(4-6 \mathrm{ft})\end{array}$} & \multicolumn{2}{|c|}{$\begin{array}{c}\text { FTBOR1 } \\
(6-8 \mathrm{ft})\end{array}$} & \multicolumn{2}{|c|}{$\begin{array}{l}\text { FTBOR1 } \\
(8-10 \mathrm{ft})\end{array}$} & \multicolumn{2}{|c|}{$\begin{array}{l}\text { FTBOR1 } \\
(10-12 \mathrm{ft})\end{array}$} \\
\hline & 12 & $\mathrm{U}$ & 12 & $\mathrm{U}$ & 5 & $\mathrm{~J}$ & 12 & U \\
\hline Tetrachloroethene & 12 & $\mathrm{U}$ & 12 & $\mathrm{U}$ & 14 & $\mathbf{U}$ & 12 & $\mathbf{U}$ \\
\hline Toluene & 12 & $\mathrm{U}$ & 12 & $U$ & 14 & $\mathrm{U}$ & 12 & $\mathrm{U}$ \\
\hline 1,1,1-Trichloroethane & 12 & $U$ & 12 & $\mathbf{U}$ & 14 & $\mathrm{U}$ & 12 & U \\
\hline 1,1,2-Trichloroethane & 12 & $\mathrm{U}$ & 12 & U & 14 & $\mathbf{U}$ & 12 & $\mathrm{U}$ \\
\hline Trichloroethene & 12 & U & 12 & $\mathrm{U}$ & 14 & $\mathrm{U}$ & 12 & $\mathrm{U}$ \\
\hline Vinyl acetate & 12 & $\mathrm{U}$ & 12 & $\mathrm{U}$ & NT & & 12 & $\mathrm{U}$ \\
\hline Vinyl chloride & 12 & $\mathrm{U}$ & 12 & U & 14 & $\mathrm{U}$ & 12 & $\mathrm{U}$ \\
\hline $\mathrm{m}$ - and $\mathrm{p}$-Xylene & 12 & $\mathbf{U}$ & 12 & $\mathrm{U}$ & 14 & $\mathrm{U}$ & 12 & $\mathrm{U}$ \\
\hline o-Xylene & 12 & $\mathrm{U}$ & 12 & $\mathrm{U}$ & 14 & $\mathrm{U}$ & 12 & $\mathrm{U}$ \\
\hline
\end{tabular}

a Sampled by ANL, analyzed by Weston Gulf Coast or ANL/ACL, CLP/HSL volatile organics. Data qualifiers:

$\mathrm{U}=$ analyte was analyzed for but not detected; detection limits given.

* = internal standard area counts were outside QC limits.

$\mathbf{J}=$ estimated value.

$\mathrm{B}=$ analyte was found in the associated blank.

$+\quad=$ surrogate recoveries were outside $\mathrm{QC}$ limits.

$\mathrm{NT}=$ not tested. 
TABLE C.13d Volatile Organics Analyses for Soil Borings, May $1995^{\mathrm{a}}$

\begin{tabular}{|c|c|c|c|c|c|c|c|c|}
\hline \multirow{3}{*}{$\begin{array}{l}\text { Compound } \\
\text { Acetone }\end{array}$} & \multicolumn{8}{|c|}{ Soil Concentrations $(\mu \mathrm{g} / \mathrm{kg})$ at Various Depth Intervals } \\
\hline & \multicolumn{2}{|c|}{$\begin{array}{c}\text { HBOR4 } \\
(4-6 \mathrm{ft})\end{array}$} & \multicolumn{2}{|c|}{$\begin{array}{c}\text { HBOR4 } \\
(6-8 \mathrm{ft}) \\
\end{array}$} & \multicolumn{2}{|c|}{$\begin{array}{l}\text { HBOR4 } \\
(8-10 \mathrm{ft}) \\
\end{array}$} & \multicolumn{2}{|c|}{$\begin{array}{c}\text { HBOR4 } \\
(14-16 \mathrm{ft})\end{array}$} \\
\hline & 67 & & 27 & & 2,100 & & 780 & $* \mathrm{E}$ \\
\hline Benzene & 12.1 & $\mathrm{U}$ & 11.8 & $U$ & 56.8 & $\mathrm{U}$ & 12.3 & UJ \\
\hline Bromodichloromethane & 12.1 & $\mathrm{U}$ & 11.8 & U & 56.8 & $\mathrm{U}$ & 12.3 & UJ \\
\hline Bromoform & 12.1 & $\mathrm{U}$ & 11.8 & $U$ & 56.8 & $\mathrm{U}$ & 12.3 & UJ \\
\hline Bromomethane & 12.1 & $\mathrm{U}$ & 11.8 & $U$ & 56.8 & $\mathrm{U}$ & 12.3 & UJ \\
\hline 2-Butanone & 12.1 & $U$ & 11.8 & $\mathrm{U}$ & 56.8 & $\mathrm{U}$ & 12.3 & UJ \\
\hline Carbon disulfide & 12.1 & $U$ & 11.8 & $\mathrm{U}$ & 56.8 & $\mathrm{U}$ & 2.8 & $\mathbf{J}$ \\
\hline Carbon tetrachloride & 12.1 & $\mathrm{U}$ & 11.8 & $U$ & 56.8 & $\mathrm{U}$ & 12.3 & UJ \\
\hline Chlorobenzene & 12.1 & $U$ & 11.8 & $U$ & 56.8 & $\mathrm{U}$ & 12.3 & UJ \\
\hline Chloroethane & 12.1 & $\mathrm{U}$ & 11.8 & $U$ & 56.8 & $U$ & 12.3 & UJ \\
\hline Chloroform & 12.1 & $\mathrm{U}$ & 11.8 & $U$ & 56.8 & $\mathrm{U}$ & 12.3 & UJ \\
\hline Chloromethane & 12.1 & $\mathrm{U}$ & 11.8 & $U$ & 56.8 & $U$ & 12.3 & UJ \\
\hline Dibromochloromethane & 12.1 & $\mathrm{U}$ & 11.8 & $\mathrm{U}$ & 56.8 & $\mathrm{U}$ & 12.3 & UJ \\
\hline 1,1-Dichloroethane & 12.1 & $\mathrm{U}$ & 11.8 & $\mathrm{U}$ & 56.8 & $\mathrm{U}$ & 12.3 & UJ \\
\hline 1,2-Dichloroethane & 12.1 & $U$ & 11.8 & $\mathrm{U}$ & 56.8 & $\mathrm{U}$ & 1 & $\mathrm{~J}$ \\
\hline 1,1-Dichloroethene & 12.1 & $\mathrm{U}$ & 11.8 & $\mathrm{U}$ & 56.8 & $\mathrm{U}$ & 12.3 & UJ \\
\hline 1,2-Dichloroethene (total) & 12.1 & $U$ & 11.8 & $\mathrm{U}$ & 56.8 & $\mathrm{U}$ & 450 & $* E$ \\
\hline 1,2-Dichloropropane & 12.1 & $U$ & 11.8 & $\mathrm{U}$ & 56.8 & $\mathrm{U}$ & 12.3 & UJ \\
\hline cis-1,3-Dichloropropene & 12.1 & U & 11.8 & $\mathrm{U}$ & 56.8 & $U$ & 12.3 & UJ \\
\hline trans-1,3-Dichloropropene & 12.1 & $\mathrm{U}$ & 11.8 & $U$ & 56.8 & $\mathrm{U}$ & 12.3 & UJ \\
\hline Ethyl benzene & 12.1 & $\mathrm{U}$ & 11.8 & $U$ & 56.8 & $\mathrm{U}$ & 12.3 & UJ \\
\hline 2-Hexanone & 12.1 & $\mathrm{U}$ & 11.8 & $\mathrm{U}$ & 56.8 & $\mathrm{U}$ & 12.3 & UJ \\
\hline
\end{tabular}




\begin{tabular}{|c|c|c|c|c|c|c|c|c|c|c|c|}
\hline \multirow{3}{*}{ Compound } & \multicolumn{9}{|c|}{ Soil Concentrations $(\mu \mathrm{g} / \mathrm{kg})$ at Various Depth Intervals } & & \\
\hline & \multicolumn{2}{|c|}{$\begin{array}{c}\text { HBOR4 } \\
(4-6 \mathrm{ft})\end{array}$} & \multicolumn{2}{|c|}{$\begin{array}{c}\text { HBOR4 } \\
(6-8 \mathrm{ft}) \\
\end{array}$} & \multicolumn{2}{|c|}{$\begin{array}{l}\text { HBOR4 } \\
(8-10 \mathrm{ft})\end{array}$} & \multicolumn{3}{|c|}{$\begin{array}{c}\text { HBOR4 } \\
(14-16 \mathrm{ft})\end{array}$} & & \\
\hline & 12.1 & $U$ & 11.8 & $\mathrm{U}$ & 56.8 & $U$ & & 12.3 & UJ & & \\
\hline Methylene chloride & 6 & $\mathrm{BJ}$ & 4 & $\mathrm{BJ}$ & 38 & $\mathrm{~J}$ & & 8 & $\mathbf{J}$ & & \\
\hline Styrene & 12.1 & $U$ & 11.8 & $\mathrm{U}$ & 56.8 & $\mathrm{U}$ & & 12.3 & UJ & & \\
\hline 1,1,2,2-Tetrachloroethane & 12.1 & $\mathrm{U}$ & 11.8 & $\mathrm{U}$ & 56.8 & $U$ & & 480 & @JE & & \\
\hline Tetrachloroethene & 12.1 & $\mathrm{U}$ & 11.8 & $\mathrm{U}$ & 56.8 & $U$ & & 32 & $\mathrm{~J}$ & & \\
\hline Toluene & 12.1 & $U$ & 11.8 & $\mathrm{U}$ & 56.8 & $U$ & & 12.3 & UJ & & \\
\hline 1,1,1-Trichloroethane & 12.1 & $\mathrm{U}$ & 11.8 & $\mathrm{U}$ & 56.8 & $\mathrm{U}$ & & 12.3 & UJ & & \\
\hline 1,1,2-Trichloroethane & 12.1 & U & 11.8 & $\mathrm{U}$ & 56.8 & $U$ & & 57 & $\mathbf{J}$ & & \\
\hline Trichloroethene & 12.1 & $\mathrm{U}$ & 11.8 & $\mathrm{U}$ & 56.8 & $U$ & & 450 & $* \mathrm{E}$ & & \\
\hline Vinyl chloride & 12.1 & $\mathrm{U}$ & 11.8 & $\mathrm{U}$ & 56.8 & $\mathrm{U}$ & & 12.3 & UJ & & \\
\hline \multirow[t]{2}{*}{ Xylenes (total) } & 12.1 & U & 11.8 & $U$ & 56.8 & 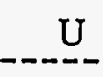 & & 12.3 & UJ & & \\
\hline & \multicolumn{9}{|c|}{ Soil Concentrations $(\mu \mathrm{g} / \mathrm{kg})$ at Various Depth Intervals } & & \\
\hline Compound & \multicolumn{2}{|c|}{$\begin{array}{c}\text { TBNPBOR2 } \\
(0-2 \mathrm{ft})\end{array}$} & \multicolumn{2}{|c|}{$\begin{array}{c}\text { TBNPBOR2 } \\
(2-6 \mathrm{ft})\end{array}$} & \multicolumn{2}{|c|}{$\begin{array}{c}\text { TBNPBOR2 } \\
(10-12 \mathrm{ft}) \\
\end{array}$} & \multicolumn{2}{|c|}{$\begin{array}{c}\text { TBNPBOR3 } \\
(0-2 \mathrm{ft})\end{array}$} & & \multicolumn{2}{|c|}{$\begin{array}{c}\text { TBNPBOR3 } \\
(2-4 \mathrm{ft})\end{array}$} \\
\hline Acetone & 10 & $\mathrm{~J}$ & 6 & $\mathbf{J}$ & 1020 & B & .67 & B & & 210 & $\mathrm{~J}^{*}$ \\
\hline Benzene & 12 & $U$ & 11.6 & $\mathrm{U}$ & 61.7 & $\mathrm{U}$ & 12 & $\mathrm{U}$ & & 67.6 & UJ* \\
\hline Bromodichloromethane & 12 & $\mathrm{U}$ & 11.6 & $\mathrm{U}$ & 61.7 & $\mathrm{U}$ & 12 & $\mathrm{U}$ & & 67.6 & UJ* \\
\hline Bromoform & 12 & $\mathrm{U}$ & 11.6 & $\mathrm{U}$ & 61.7 & $\mathrm{U}$ & 12 & $\mathrm{U}$ & & 67.6 & UJ* \\
\hline Bromomethane & 12 & $U$ & 11.6 & $\mathrm{U}$ & 61.7 & $\mathrm{U}$ & 12 & $\mathrm{U}$ & & 67.6 & UJ* \\
\hline 2-Butanone & 12 & $U$ & 11.6 & $\mathrm{U}$ & 61.7 & $\mathrm{U}$ & 12 & $\mathrm{U}$ & & 67.6 & UJ* \\
\hline
\end{tabular}




\begin{tabular}{|c|c|c|c|c|c|c|c|c|c|c|}
\hline \multirow[b]{2}{*}{ Compound } & \multicolumn{10}{|c|}{ Soil Concentrations $(\mu \mathrm{g} / \mathrm{kg})$ at Various Depth Intervals } \\
\hline & \multicolumn{2}{|c|}{$\begin{array}{c}\text { TBNPBOR2 } \\
(0-2 \mathrm{ft})\end{array}$} & \multicolumn{2}{|c|}{$\begin{array}{c}\text { TBNPBOR2 } \\
(2-6 \mathrm{ft}) \\
\end{array}$} & \multicolumn{2}{|c|}{$\begin{array}{c}\text { TBNPBOR2 } \\
(10-12 \mathrm{ft})\end{array}$} & \multicolumn{2}{|c|}{$\begin{array}{c}\text { TBNPBOR3 } \\
(0-2 \mathrm{ft})\end{array}$} & \multicolumn{2}{|c|}{$\begin{array}{c}\text { TBNPBOR3 } \\
(2-4 \mathrm{ft})\end{array}$} \\
\hline Carbon disulfide & 2 & $\mathbf{J}$ & 11.6 & $\mathrm{U}$ & $61.7^{\circ}$ & $\mathrm{U}$ & 4 & $\mathrm{~J}$ & 8 & $\mathrm{~J}^{*}$ \\
\hline Carbon tetrachloride & 12 & $\mathrm{U}$ & 11.6 & $\mathrm{U}$ & 61.7 & $\mathrm{U}$ & 12 & $\mathrm{U}$ & 67.6 & UJ* \\
\hline Chlorobenzene & 12 & $\mathrm{U}$ & 11.6 & $\mathrm{U}$ & 61.7 & $\mathrm{U}$ & 12 & $U$ & 980 & $\mathrm{~J}^{*}$ \\
\hline Chloroethane & 12 & $\mathrm{U}$ & 11.6 & $\mathrm{U}$ & 61.7 & $\mathrm{U}$ & 12 & $\mathrm{U}$ & 67.6 & UJ* \\
\hline Chloroform & 12 & $U$ & 11.6 & $\mathrm{U}$ & 61.7 & $\mathrm{U}$ & 12 & $\mathrm{U}$ & 20 & $\mathrm{~J}^{*}$ \\
\hline Chloromethane & 12 & $U$ & 11.6 & $U$ & 61.7 & $\mathrm{U}$ & 12 & $\mathrm{U}$ & 67.6 & UJ* \\
\hline Dibromochloromethane & 12 & $U$ & 11.6 & $U$ & 61.7 & $\mathrm{U}$ & 12 & $\mathrm{U}$ & 67.6 & UJ* \\
\hline 1,1-Dichloroethane & 12 & $U$ & 11.6 & $U$ & 61.7 & $U$ & 12 & $\mathrm{U}$ & 67.6 & UJ* \\
\hline 1,2-Dichloroethane & 12 & $U$ & 11.6 & $\mathrm{U}$ & 61.7 & $\mathrm{U}$ & 12 & $\mathrm{U}$ & 67.6 & UJ* \\
\hline 1,1-Dichloroethene & 12 & $\mathrm{U}$ & 11.6 & $\mathrm{U}$ & 61.7 & $U$ & 12 & $U$ & 67.6 & UJ* \\
\hline 1,2-Dichloroethene (total) & 4 & $\mathbf{J}$ & 11.6 & $\mathrm{U}$ & 61.7 & $\mathrm{U}$ & 22 & & 280 & $\mathrm{~J} *$ \\
\hline 1,2-Dichloropropane & 12 & $\mathrm{U}$ & 11.6 & $\mathrm{U}$ & 61.7 & $\mathrm{U}$ & 12 & $U$ & 67.6 & UJ* \\
\hline cis-1,3-Dichloropropene & 12 & $\mathrm{U}$ & 11.6 & $\mathrm{U}$ & 61.7 & $\mathrm{U}$ & 12 & $U$ & 67.6 & UJ* \\
\hline trans-1,3-Dichloropropene & 12 & $\mathrm{U}$ & 11.6 & $U$ & 61.7 & $\mathrm{U}$ & 12 & $U$ & 67.6 & UJ* \\
\hline Ethyl benzene & 12 & $\mathrm{U}$ & 11.6 & $U$ & 61.7 & $\mathrm{U}$ & 12 & $U$ & 67.6 & UJ* \\
\hline 2-Hexanone & 12 & $\mathrm{U}$ & 11.6 & $U$ & 61.7 & $\mathrm{U}$ & 12 & $\mathbf{U}$ & 67.6 & UJ* \\
\hline 4-Methyl-2-pentanone & 12 & $\mathrm{U}$ & 11.6 & $U$ & 61.7 & $\mathrm{U}$ & 12 & $U$ & 67.6 & UJ* \\
\hline Methylene chloride & 10 & $\mathrm{BJ}$ & 8 & $\mathrm{BJ}$ & 31 & $\mathrm{BJ}$ & 11.9 & $\mathrm{BJ}$ & 41 & $\mathrm{BJ} *$ \\
\hline Styrene & 12 & $\mathrm{U}$ & 11.6 & $\mathrm{U}$ & 61.7 & $\mathrm{U}$ & 12 & $U$ & 67.6 & UJ* \\
\hline 1,1,2,2-Tetrachloroethane & 12 & $\mathrm{U}$ & 11.6 & $\mathrm{U}$ & 61.7 & $\mathrm{U}$ & 12 & $U$ & 67.6 & UJ* \\
\hline Tetrachloroethene & 6 & $\mathrm{~J}$ & 11.6 & $\mathrm{U}$ & 61.7 & $U$ & 2 & $\mathbf{J}$ & 43 & $\mathrm{~J} *$ \\
\hline Toluene & 12 & $U$ & 11.6 & $\mathrm{U}$ & 61.7 & $U$ & 12 & $\mathrm{U}$ & 7 & $\mathrm{~J}^{*}$ \\
\hline
\end{tabular}


TABLE C.13d (Cont.)

\begin{tabular}{|c|c|c|c|c|c|c|c|c|c|c|}
\hline \multirow[b]{2}{*}{ Compound } & \multicolumn{10}{|c|}{ Soil Concentrations $(\mu \mathrm{g} / \mathrm{kg})$ at Various Depth Intervals } \\
\hline & \multicolumn{2}{|c|}{$\begin{array}{c}\text { TBNPBOR2 } \\
(0-2 \mathrm{ft})\end{array}$} & \multicolumn{2}{|c|}{$\begin{array}{c}\text { TBNPBOR2 } \\
(2-6 \mathrm{ft})\end{array}$} & \multicolumn{2}{|c|}{$\begin{array}{c}\text { TBNPBOR2 } \\
(10-12 \mathrm{ft})\end{array}$} & \multicolumn{2}{|c|}{$\begin{array}{c}\text { TBNPBOR3 } \\
(0-2 \mathrm{ft})\end{array}$} & \multicolumn{2}{|c|}{$\begin{array}{c}\text { TBNPBOR? } \\
(2-4 \mathrm{ft})\end{array}$} \\
\hline 1,1,1-Trichloroethane & 12 & $\mathrm{U}$ & 11.6 & $\mathrm{U}$ & 61.7 & $\mathrm{U}$ & 12 & U & 67.6 & UJ* \\
\hline 1,1,2-Trichloroethane & 12 & $U$ & 11.6 & $\mathrm{U}$ & 61.7 & $\mathrm{U}$ & 12 & $\mathrm{U}$ & 67.6 & UJ* \\
\hline Trichloroethene & 8 & $\mathbf{J}$ & 11.6 & $\mathrm{U}$ & 61.7 & $\mathrm{U}$ & 13 & & 105 & $\mathrm{~J}^{*}$ \\
\hline Vinyl chloride & 12 & $\mathrm{U}$ & 11.6 & $\mathrm{U}$ & 61.7 & $\mathrm{U}$ & 12 & $\mathrm{U}$ & $37^{\prime}$ & $\mathrm{J}^{*}$ \\
\hline Xylenes (total) & 12 & $\mathrm{U}$ & 11.6 & $\mathrm{U}$ & 61.7 & $\mathrm{U}$ & 12 & $\mathrm{U}$ & 67.6 & UJ* \\
\hline
\end{tabular}

Soil Concentrations $(\mu \mathrm{g} / \mathrm{kg})$ at Various Depth Intervals

\begin{tabular}{|c|c|c|c|c|c|c|c|c|}
\hline \multirow{2}{*}{ Compound } & \multicolumn{2}{|c|}{$\begin{array}{c}\text { TBNPBOR3 } \\
(4-6 \mathrm{ft})\end{array}$} & \multicolumn{2}{|c|}{$\begin{array}{c}\text { TBNPBOR3 } \\
(6-8 \mathrm{ft})\end{array}$} & \multicolumn{2}{|c|}{$\begin{array}{c}\text { TBNPBOR3 } \\
(8-10 \mathrm{ft})\end{array}$} & \multicolumn{2}{|c|}{$\begin{array}{c}\text { TBNPBOR3 } \\
(10-12 \mathrm{ft}) \\
\end{array}$} \\
\hline & 70.5 & UJ & 1,500 & & 6,000 & @ & 140 & $\mathrm{~B}$ \\
\hline Benzene & 51 & $\mathbf{J}$ & 67 & & 63.3 & $\mathrm{U}$ & 61.5 & UJ \\
\hline Bromodichloromethane & 70.5 & UJ & 59.5 & $\mathrm{U}$ & 63.3 & $\mathrm{U}$ & 61.5 & UJ \\
\hline Bromoform & 70.5 & UJ & 59.5 & $\mathrm{U}$ & 63.3 & $\mathrm{U}$ & 61.5 & UJ \\
\hline Bromomethane & 70.5 & UJ & 59.5 & $\mathrm{U}$ & 63.3 & $\mathrm{U}$ & 61.5 & UJ \\
\hline 2-Butanone & 70.5 & UJ & 59.5 & $\mathrm{U}$ & 63.3 & $U$ & 61.5 & UJ \\
\hline Carbon disulfide & 70.5 & UJ & 59.5 & $\mathrm{U}$ & 63.3 & $\mathrm{U}$ & 61.5 & UJ \\
\hline Carbon tetrachloride & 70.5 & UJ & 59.5 & $\mathrm{U}$ & 63.3 & $\mathrm{U}$ & 61.5 & UJ \\
\hline Chlorobenzene & 23,000 & $\sim J, E$ & 9,600 & @ & 140 & & 1,000 & J \\
\hline Chloroethane & 70.5 & UJ & 59.5 & $U$ & 63.3 & $\mathrm{U}$ & 61.5 & UJ \\
\hline Chloroform & 19 & $\mathrm{~J}$ & 59.5 & $U$ & 63.3 & $\mathrm{U}$ & 61.5 & UJ \\
\hline Chloromethane & 70.5 & UJ & 59.5 & $\mathrm{U}$ & 63.3 & $\mathrm{U}$ & 61.5 & UJ \\
\hline
\end{tabular}




\begin{tabular}{|c|c|c|c|c|c|c|c|c|}
\hline \multirow[b]{2}{*}{ Compound } & \multicolumn{8}{|c|}{ Soil Concentrations $(\mu \mathrm{g} / \mathrm{kg})$ at Various Depth Intervals } \\
\hline & \multicolumn{2}{|c|}{$\begin{array}{c}\text { TBNPBOR3 } \\
(4-6 \mathrm{ft}) \\
\end{array}$} & \multicolumn{2}{|c|}{$\begin{array}{c}\text { TBNPBOR3 } \\
(6-8 \mathrm{ft})\end{array}$} & \multicolumn{2}{|c|}{$\begin{array}{c}\text { TBNPBOR3 } \\
(8-10 \mathrm{ft})\end{array}$} & \multicolumn{2}{|c|}{$\begin{array}{c}\text { TBNPBOR3 } \\
(10-12 \mathrm{ft})\end{array}$} \\
\hline Dibromochloromethane & 70.5 & UJ & 59.5 & $\mathrm{U}$ & 63.3 & $\mathrm{U}$ & 61.5 & UJ \\
\hline 1,1-Dichloroethane & 70.5 & UJ & 59.5 & $\mathrm{U}$ & 63.3 & $\mathrm{U}$ & 61.5 & UJ \\
\hline 1,2-Dichloroethane & 70.5 & UJ & 59.5 & $\mathrm{U}$ & 63.3 & $\mathrm{U}$ & 61.5 & UJ \\
\hline 1,1-Dichloroethene & 70.5 & UJ & 59.5 & $\mathrm{U}$ & 63.3 & $\mathrm{U}$ & 61.5 & UJ \\
\hline 1,2-Dichloroethene (total) & 980 & $\mathbf{J}$ & 2,000 & & 230 & & 350 & $\mathbf{J}$ \\
\hline 1,2-Dichloropropane & 70.5 & UJ & 59.5 & $U$ & 63.3 & $U$ & 61.5 & UJ \\
\hline trans-1,3-Dichloropropene & 70.5 & UJ & 59.5 & $\mathrm{U}$ & 63.3 & $\mathrm{U}$ & 61.5 & UJ \\
\hline cis-1,3-Dichloropropene & 70.5 & UJ & 59.5 & $\mathrm{U}$ & 63.3 & $\mathrm{U}$ & 61.5 & UJ \\
\hline Ethyl benzene & 250 & $\mathrm{~J}$ & 6,600 & @ & 90 & & 1,100 & \\
\hline 2-Hexanone & 70.5 & UJ & 59.5 & $\mathrm{U}$ & 63.3 & $\mathrm{U}$ & 61.5 & UJ \\
\hline 4-Methyl-2-pentanone & 70.5 & UJ & 59.5 & U & 63.3 & $\mathrm{U}$ & 61.5 & UJ \\
\hline Methylene chloride & 23 & $\mathrm{BJ}$ & 59.5 & $\mathrm{U}$ & 27 & $\mathrm{BJ}$ & 35 & $\mathrm{BJ}$ \\
\hline Styrene & 70.5 & UJ & 59.5 & $\mathrm{U}$ & 63.3 & $\mathrm{U}$ & 61.5 & $\mathrm{U}$ \\
\hline 1,1,2,2-Tetrachloroethane & 70.5 & UJ & 59.5 & $\mathrm{U}$ & 63.3 & $\mathrm{U}$ & 61.5 & UJ \\
\hline Tetrachloroethene & 70.5 & UJ & 750 & & 10 & $\mathbf{J}$ & 160 & $\mathrm{~J}$ \\
\hline Toluene & 320 & $\mathrm{~J}$ & 4,200 & @ & 55 & $\mathbf{J}$ & 660 & \\
\hline 1,1,1-Trichloroethane & 70.5 & UJ & 59.5 & $\mathrm{U}$ & 63.3 & $\mathrm{U}$ & 61.5 & UJ \\
\hline 1,1,2-Trichloroethane & 70.5 & UJ & 59.5 & $U$ & 63.3 & $\mathrm{U}$ & 61.5 & UJ \\
\hline Trichloroethene & 58 & $\mathrm{~J}$ & 59.5 & $\mathrm{U}$ & 63.3 & $U$ & 61.5 & UJ \\
\hline Vinyl chloride & 750 & $\mathrm{~J}$ & 59.5 & $U$ & 63.3 & $U$ & 61.5 & UJ \\
\hline Xylenes (total) & 680 & $\mathrm{~J}$ & 46,000 & $@$ & 540 & & 2,400 & \\
\hline
\end{tabular}




\begin{tabular}{|c|c|c|c|c|c|c|c|c|c|c|}
\hline \multirow[b]{2}{*}{ Compound } & \multicolumn{10}{|c|}{ Soil Concentrations $(\mu \mathrm{g} / \mathrm{kg})$ at Various Depth Intervals } \\
\hline & \multicolumn{2}{|c|}{$\begin{array}{c}\text { VXBOR3 } \\
(2-4 \mathrm{ft}) \\
\end{array}$} & \multicolumn{2}{|c|}{$\begin{array}{c}\text { VXBOR4 } \\
(2-4 \mathrm{ft}) \\
\end{array}$} & \multicolumn{2}{|c|}{$\begin{array}{c}\text { VXBOR4 } \\
(4-6 \mathrm{ft})\end{array}$} & \multicolumn{2}{|c|}{$\begin{array}{l}\text { VXBOR5 } \\
(0-2 \mathrm{ft})\end{array}$} & \multicolumn{2}{|c|}{$\begin{array}{c}\text { VXBOR5 } \\
(4-6 \mathrm{ft}) \\
\end{array}$} \\
\hline Acetone & 18 & & 130 & $\mathbf{J}$ & 260 & & 12 & $\mathrm{U}$ & 160 & \\
\hline Benzene & 42 & & 63.6 & UJ & 61.2 & $\mathrm{U}$ & 12 & $\mathrm{U}$ & 65.1 & $U$ \\
\hline Bromodichloromethane & 12 & $U$ & 63.6 & UJ & 61.2 & $\mathrm{U}$ & 12 & $\mathrm{U}$ & 65.1 & $U$ \\
\hline Bromoform & 12 & $\mathrm{U}$ & 63.6 & UJ & 61.2 & $\mathrm{U}$ & 12 & $\mathrm{U}$ & 65.1 & $U$ \\
\hline Bromomethane & 12 & $\mathrm{U}$ & 63.6 & UJ & 61.2 & $\mathrm{U}$ & 12 & $U$ & 65.1 & $U$ \\
\hline 2-Butanone & 12 & $\mathrm{U}$ & 63.6 & UJ & 61.2 & $\mathrm{U}$ & 12 & $\mathrm{U}$ & 65.1 & $\mathrm{U}$ \\
\hline Carbon disulfide & 11 & $\mathbf{J}$ & 63.6 & UJ & 61.2 & $\mathrm{U}$ & 2 & $\mathrm{~J}$ & 65.1 & $U$ \\
\hline Carbon tetrachloride & 12 & $\mathrm{U}$ & 63.6 & UJ & 61.2 & $\mathrm{U}$ & 12 & $U$ & 65.1 & $U$ \\
\hline Chlorobenzene & 12 & $U$ & 63.6 & UJ & 61.2 & $\mathrm{U}$ & 12 & $\mathrm{U}$ & 65.1 & $\mathrm{U}$ \\
\hline Chloroethane & 12 & $\mathrm{U}$ & 63.6 & UJ & 61.2 & $U$ & 12 & $\mathrm{U}$ & 65.1 & $U$ \\
\hline Chloroform & 12 & $\mathrm{U}$ & 63.6 & UJ & 61.2 & $\mathrm{U}$ & 12 & $\mathrm{U}$ & 65.1 & $U$ \\
\hline Chloromethane & 12 & $\mathrm{U}$ & 63.6 & UJ & 61.2 & $\mathrm{U}$ & 12 & $U$ & 65.1 & $\mathrm{U}$ \\
\hline Dibromochloromethane & 12 & $\mathrm{U}$ & 63.6 & UJ & 61.2 & U & 12 & $U$ & 65.1 & $\mathrm{U}$ \\
\hline 1,1-Dichloroethane & 12 & $U$ & 63.6 & UJ & 61.2 & $U$ & 12 & $U$ & 65.1 & $\mathrm{U}$ \\
\hline 1,2-Dichloroethane & 12 & $\mathrm{U}$ & 63.6 & UJ & 61.2 & $U$ & 12 & $U$ & 65.1 & $\mathrm{U}$ \\
\hline 1,1-Dichloroethene & 12 & $\mathrm{U}$ & 63.6 & UJ & 61.2 & $U$ & 12 & $U$ & 65.1 & $\mathrm{U}$ \\
\hline 1,2-Dichloroethene (total) & 5 & $\mathrm{~J}$ & 63.6 & UJ & 61.2 & $\mathrm{U}$ & 12 & $\mathrm{U}$ & 65.1 & U \\
\hline 1,2-Dichloropropane & 12 & $\mathrm{U}$ & 63.6 & UJ & 61.2 & $\mathrm{U}$ & 12 & $\mathrm{U}$ & 65.1 & $U$ \\
\hline cis-1,3-Dichloropropene & 12 & $\mathrm{U}$ & 63.6 & UJ & 61.2 & $\mathrm{U}$ & 12 & $\mathrm{U}$ & 65.1 & $\mathrm{U}$ \\
\hline trans-1,3-Dichloropropene & 12 & $\mathrm{U}$ & 63.6 & UJ & 61.2 & $U$ & 12 & $U$ & 65.1 & $U$ \\
\hline Ethyl benzene & 58 & & 1,300 & $\mathrm{~J} @ \mathrm{E}$ & 2,900 & $@$ & 12 & $\mathrm{U}$ & 65.1 & $U$ \\
\hline 2-Hexanone & 12 & $\mathrm{U}$ & 63.6 & UJ & 61.2 & $U$ & 12 & $\mathrm{U}$ & 65.1 & $U$ \\
\hline
\end{tabular}




\begin{tabular}{|c|c|c|c|c|c|c|c|c|c|c|}
\hline \multirow{3}{*}{$\frac{\text { Compound }}{\text { 4-Methyl-2-pentanone }}$} & \multicolumn{10}{|c|}{ Soil Concentrations $(\mu \mathrm{g} / \mathrm{kg})$ at Various Depth Intervals } \\
\hline & \multicolumn{2}{|c|}{$\begin{array}{c}\text { VXBOR3 } \\
(2-4 \mathrm{ft})\end{array}$} & \multicolumn{2}{|c|}{$\begin{array}{c}\text { VXBOR4 } \\
(2-4 \mathrm{ft}) \\
\end{array}$} & \multicolumn{2}{|c|}{$\begin{array}{c}\text { VXBOR4 } \\
(4-6 \mathrm{ft})\end{array}$} & \multicolumn{2}{|c|}{$\begin{array}{l}\text { VXBOR5 } \\
(0-2 \mathrm{ft})\end{array}$} & \multicolumn{2}{|c|}{$\begin{array}{c}\text { VXBOR5 } \\
(4-6 \mathrm{ft})\end{array}$} \\
\hline & 12 & $\mathrm{U}$ & 63.6 & UJ & 61.2 & $\mathrm{U}$ & 12 & $\mathrm{U}$ & 65.1 & $\mathrm{U}$ \\
\hline Methylene chloride & 12 & $\mathrm{U}$ & 53 & $\mathrm{~J}$ & 52 & $\mathbf{J}$ & 7 & $\mathbf{J}$ & 39 & $\mathrm{~J}$ \\
\hline Styrene & 12 & $\mathrm{U}$ & 63.6 & UJ & 61.2 & U & 12 & $U$ & 65.1 & $\mathrm{U}$ \\
\hline 1,1,2,2-Tetrachloroethane & 12 & $\mathrm{U}$ & 63.6 & UJ & 61.2 & $\mathrm{U}$ & 12 & $\mathrm{U}$ & 65.1 & $\mathrm{U}$ \\
\hline Tetrachloroethene & 12 & $\mathrm{U}$ & 63.6 & UJ & 61.2 & $U$ & 12 & $\mathrm{U}$ & 17 & $\mathrm{~J}$ \\
\hline Toluene & 12 & $\mathrm{U}$ & 63.6 & UJ & 61.2 & $\mathrm{U}$ & 12 & $\mathrm{U}$ & 65.1 & $\mathrm{U}$ \\
\hline 1,1,1-Trichloroethane & 12 & $\mathrm{U}$ & 63.6 & UJ & 61.2 & $\mathrm{U}$ & 12 & $\mathrm{U}$ & 65.1 & $U$ \\
\hline 1,1,2-Trichloroethane & 12 & $\mathrm{U}$ & 63.6 & UJ & 61.2 & $\mathrm{U}$ & 12 & $\mathrm{U}$ & 65.1 & $U$ \\
\hline Trichloroethene & 15 & & 63.6 & UJ & 61.2 & $U$ & 12 & $U$ & 8 & $\mathbf{J}$ \\
\hline Vinyl chloride & 12 & $\mathrm{U}$ & 63.6 & UJ & 61.2 & $U$ & 12 & $U$ & 65.1 & $\mathrm{U}$ \\
\hline Xylenes (total) & 27 & & 1,200 & $\mathbf{J}$ & 2,300 & & 12 & $U$ & 65.1 & $\mathrm{U}$ \\
\hline
\end{tabular}

Soil Concentrations $(\mu \mathrm{g} / \mathrm{kg})$ at Various Depth Intervals

\begin{tabular}{|c|c|c|c|c|c|c|c|c|c|c|}
\hline \multirow{2}{*}{$\begin{array}{l}\text { Compound } \\
\text { Acetone }\end{array}$} & \multicolumn{2}{|c|}{$\begin{array}{l}\text { VXBOR5 } \\
(6-8 \mathrm{ft})\end{array}$} & \multicolumn{2}{|c|}{$\begin{array}{l}\text { VXBOR5 } \\
(8-10 \mathrm{ft})\end{array}$} & \multicolumn{2}{|c|}{$\begin{array}{l}\text { VXBOR5 } \\
(10-12 \mathrm{ft}) \\
\end{array}$} & \multicolumn{2}{|c|}{$\begin{array}{l}\text { VXBOR5 } \\
(12-14 \mathrm{ft}) \\
\end{array}$} & \multicolumn{2}{|c|}{$\begin{array}{l}\text { VXBOR5 } \\
(14-16 \mathrm{ft}) \\
\end{array}$} \\
\hline & 20 & 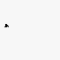 & 210 & & 14 & & 550 & $*$ & 1,100 & \\
\hline Benzene & 12.4 & $\mathrm{U}$ & 12.4 & $\mathrm{U}$ & 12.5 & $\mathrm{U}$ & 12.5 & $U$ & 61.8 & $U$ \\
\hline Bromodichloromethane & 12.4 & $\mathrm{U}$ & 12.4 & $\mathrm{U}$ & 12.5 & $\mathrm{U}$ & 12.5 & $U$ & 61.8 & $\mathrm{U}$ \\
\hline Bromoform & 12.4 & $\mathrm{U}$ & 12.4 & $U$ & 12.5 & $\mathrm{U}$ & 12.5 & $\mathrm{U}$ & 61.8 & $U$ \\
\hline Bromomethane & 12.4 & $\mathrm{U}$ & 12.4 & $\mathrm{U}$ & 12.5 & $\mathrm{U}$ & 12.5 & $\mathrm{U}$ & 61.8 & U \\
\hline 2-Butanone & 12.4 & $\mathrm{U}$ & 12.4 & $U$ & 12.5 & $\mathrm{U}$ & 12.5 & $U$ & 61.8 & $\mathrm{U}$ \\
\hline
\end{tabular}




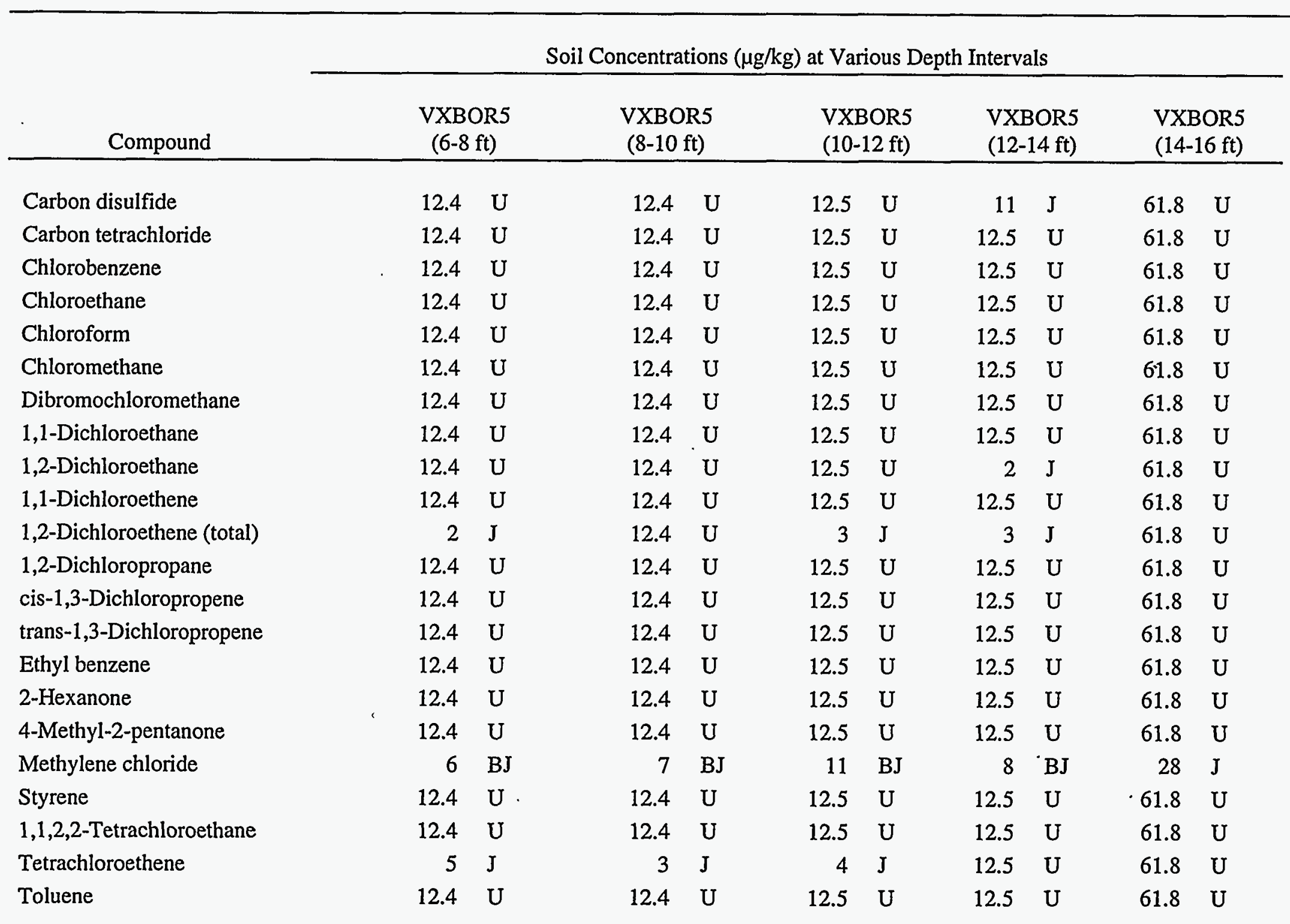




\section{TABLE C.13d (Cont.)}

\begin{tabular}{|c|c|c|c|c|c|c|c|c|c|c|}
\hline \multirow[b]{2}{*}{ Compound } & \multicolumn{10}{|c|}{ Soil Concentrations $(\mu \mathrm{g} / \mathrm{kg})$ at Various Depth Intervals } \\
\hline & \multicolumn{2}{|c|}{$\begin{array}{c}\text { VXBOR5 } \\
(6-8 \mathrm{ft})\end{array}$} & \multicolumn{2}{|c|}{$\begin{array}{l}\text { VXBOR5 } \\
(8-10 \mathrm{ft})\end{array}$} & \multicolumn{2}{|c|}{$\begin{array}{l}\text { VXBOR5 } \\
(10-12 \mathrm{ft}) \\
\end{array}$} & \multicolumn{2}{|c|}{$\begin{array}{l}\text { VXBOR5 } \\
(12-14 \mathrm{ft})\end{array}$} & \multicolumn{2}{|c|}{$\begin{array}{l}\text { VXBOR5 } \\
(14-16 \mathrm{ft})\end{array}$} \\
\hline 1,1,1-Trichloroethane & 12.4 & $\mathrm{U}$ & 12.4 & $\mathrm{U}$ & 12.5 & $\mathrm{U}$ & 12.5 & $\mathrm{U}$ & 61.8 & $\mathrm{U}$ \\
\hline 1,1,2-Trichloroethane & 12.4 & $\mathrm{U}$ & 12.4 & $\mathrm{U}$ & 12.5 & $\mathrm{U}$ & 12.5 & $\mathrm{U}$ & 61.8 & U \\
\hline Trichloroethene & 12.4 & U & 12.4 & $\mathrm{U}$ & 12.5 & $\mathrm{U}$ & 12.5 & $\mathrm{U}$ & 61.8 & U \\
\hline Vinyl chloride & 12.4 & $\mathrm{U}$ & 12.4 & $\mathrm{U}$ & 12.5 & $\mathrm{U}$ & 3 & $\mathrm{~J}$ & 61.8 & $U$ \\
\hline Xylenes (total) & 12.4 & U & 12.4 & $\mathrm{U}$ & 12.5 & $\mathrm{U}$ & 12.5 & $\mathrm{U}$ & 61.8 & U \\
\hline
\end{tabular}

Soil Concentrations $(\mu \mathrm{g} / \mathrm{kg})$ at $0-6 \mathrm{in}$.

\begin{tabular}{lrrrrr}
\multicolumn{1}{c}{ Compound } & \multicolumn{2}{c}{ SQPS 5 } & \multicolumn{2}{c}{ SQPS-8 } \\
\hline Acetone & 3 & & 13 & BJ* \\
Benzene & 12 & $\mathrm{U}$ & 24 & $\mathrm{U}$ \\
Bromodichloromethane & 12 & $\mathrm{U}$ & 24 & $\mathrm{U}$ \\
Bromoform & 12 & $\mathrm{U}$ & 24 & $\mathrm{U}$ \\
Bromomethane & 12 & $\mathrm{U}$ & 24 & $\mathrm{U}$ \\
2-Butanone & 12 & $\mathrm{U}$ & 24 & $\mathrm{U}$ \\
Carbon disulfide & 12 & $\mathrm{U}$ & 38 & $*$ \\
Carbon tetrachloride & 12 & $\mathrm{U}$ & 24 & $\mathrm{U}$ \\
Chlorobenzene & 12 & $\mathrm{U}$ & 24 & $\mathrm{U}$ \\
Chloroethane & 12 & $\mathrm{U}$ & 24 & $\mathrm{U}$ \\
Chloroform & 12 & $\mathrm{U}$ & 24 & $\mathrm{U}$ \\
Chloromethane & 12 & $\mathrm{U}$ & 24 & $\mathrm{U}$
\end{tabular}


TABLE C.13d (Cont.)

\begin{tabular}{|c|c|c|c|c|}
\hline \multirow{3}{*}{$\frac{\text { Compound }}{\text { Dibromochloromethane }}$} & \multicolumn{4}{|c|}{ Soil Concentrations $(\mu \mathrm{g} / \mathrm{kg})$ at $0-6 \mathrm{in}$. } \\
\hline & \multicolumn{2}{|c|}{ SQPS 5} & \multicolumn{2}{|c|}{ SQPS-8 } \\
\hline & 12 & $\mathrm{U}$ & 24 & $\mathrm{U}$ \\
\hline 1,1-Dichloroethane & 12 & $\mathrm{U}$ & 24 & $\mathrm{U}$ \\
\hline 1,2-Dichloroethane & 12 & $\mathrm{U}$ & 24 & $\mathrm{U}$ \\
\hline 1,1-Dichloroethene & 12 & $\mathrm{U}$ & 24 & $U$ \\
\hline 1,2-Dichloroethene (total) & 12 & $\mathrm{U}$ & 24 & $\mathrm{U}$ \\
\hline 1,2-Dichloropropane & 12 & $\mathrm{U}$ & 24 & $\mathrm{U}$ \\
\hline cis-1,3-Dichloropropene & 12 & $U$ & 24 & $\mathrm{U}$ \\
\hline trans-1,3-Dichloropropene & 12 & $U$ & 24 & $U$ \\
\hline Ethyl benzene & 12 & $\mathrm{U}$ & 24 & $\mathrm{U}$ \\
\hline 2-Hexanone & 12 & $\mathrm{U}$ & 24 & $\mathrm{U}$ \\
\hline 4-Methyl-2-pentanone & 12 & $\mathrm{U}$ & 24 & $U$ \\
\hline Methylene chloride & 6 & & 11 & $\mathrm{BJ} *$ \\
\hline Styrene & 12 & $\mathrm{U}$ & 24 & $U$ \\
\hline 1,1,2,2-Tetrachloroethane & 12 & $\mathrm{U}$ & 24 & $U$ \\
\hline Tetrachloroethene & 12 & $\mathrm{U}$ & 24 & $U$ \\
\hline Toluene & 12 & $U$ & 24 & $\mathrm{U}$ \\
\hline 1,1,1-Trichloroethane & 12 & $\mathrm{U}$ & 24 & $\mathrm{U}$ \\
\hline 1,1,2-Trichloroethane & 12 & $\mathrm{U}$ & 24 & $\mathrm{U}$ \\
\hline Trichloroethene & 12 & $\mathrm{U}$ & 24 & $\mathrm{U}$ \\
\hline Vinyl chloride & 12 & $U$ & 24 & $U$ \\
\hline Xylenes (total) & 12 & $\mathrm{U}$ & 24 & $\mathrm{U}$ \\
\hline
\end{tabular}

See next page for footnotes. 


\section{TABLE C.13d (Cont.)}

a Sampled by ANL and analyzed by GP Environmental Services. Data qualifiers:

$\mathrm{U}=$ analyte was analyzed for but not detected; detection limits given.

$\mathrm{B}=$ analyte was found in the associated blank.

$\mathrm{J}=$ estimated value.

$@$ = value obtained from a 1:125 dilution.

$E=$ concentration exceeded the calibration range of the instrument.

$*$ = QC result outside the laboratory control limits.

$\sim$ = value obtained from a 1:100 dilution. 
TABLE C.14a Semivolatile Organics Analyses for Soil Borings, January 1993 $^{\text {a }}$

\begin{tabular}{|c|c|c|c|c|c|c|c|c|c|c|c|c|c|c|}
\hline \multirow{3}{*}{$\begin{array}{l}\text { Compound } \\
\text { Acenaphthene }\end{array}$} & \multicolumn{14}{|c|}{ Borehole Concentrations $(\mu \mathrm{g} / \mathrm{kg})$ at Various Depths } \\
\hline & \multicolumn{2}{|c|}{$\begin{array}{l}\text { JBPI-E-2' } \\
(2 \mathrm{ft})\end{array}$} & \multicolumn{2}{|c|}{$\begin{array}{c}\text { JBP1-E-2'Dup } \\
(2 \mathrm{ft})\end{array}$} & \multicolumn{2}{|c|}{$\begin{array}{l}\text { JBP1-E-4' } \\
(4 \mathrm{ft})\end{array}$} & \multicolumn{2}{|c|}{$\begin{array}{c}\text { JBP1-W-2' } \\
(2 \mathrm{ft})\end{array}$} & \multicolumn{2}{|c|}{$\begin{array}{c}\text { JBP1-W-4' } \\
(4 \mathrm{ft})\end{array}$} & \multicolumn{2}{|c|}{$\begin{array}{l}\text { JBP2-E-2' } \\
(2 \mathrm{ft})\end{array}$} & \multicolumn{2}{|c|}{$\begin{array}{c}\text { JBP2-E-4' } \\
(4 \mathrm{ft})\end{array}$} \\
\hline & 402 & $\mathbf{U}$ & 392 & $\mathrm{U}$ & 402 & $\mathrm{U}$ & 402 & $\mathrm{U}$ & 409 & $\mathrm{U}$ & 396 & $U$ & 396 & U \\
\hline Acenaphthylene & 402 & $\mathbf{U}$ & 392 & $\mathrm{U}$ & 402 & $\mathrm{U}$ & 402 & $\mathbf{U}$ & 409 & $\mathbf{U}$ & 396 & 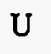 & 396 & $U$ \\
\hline Anthracene & 402 & $\mathbf{U}$ & 392 & $\mathbf{U}$ & 402 & $\mathrm{U}$ & 402 & $\mathbf{U}$ & 409 & $\mathrm{U}$ & 396 & $\mathrm{U}$ & 396 & U \\
\hline Benz[a]anthracene & 234 & $\mathbf{J}$ & 392 & $\mathbf{U}$ & 402 & $\mathrm{U}$ & 402 & $\mathrm{U}$ & 409 & $\mathbf{U}$ & 396 & $\mathrm{U}$ & 396 & $U$ \\
\hline Benzoic acid & 2,010 & $\mathbf{U}$ & 1,960 & $U$ & 2,010 & $\mathrm{U}$ & 2,010 & $\mathrm{U}$ & 2,050 & $\mathrm{U}$ & 1,980 & $U$ & 1,980 & U \\
\hline Benzo[a]pyrene & 137 & $\mathrm{~J}$ & 392 & $\mathrm{U}$ & $402^{\circ}$ & $\mathrm{U}$ & 402 & $\mathbf{U}$ & 409 & $\mathbf{U}$ & 396 & $\mathbf{U}$ & 396 & $\mathrm{U}$ \\
\hline Benzo[b]fluoranthene & 221 & $\mathbf{J}$ & 392 & $\mathbf{U}$ & 402 & $\mathrm{U}$ & 402 & $\mathbf{U}$ & 409 & $\mathbf{U}$ & 396 & $\mathbf{U}$ & 396 & $\mathrm{U}$ \\
\hline Benzo[g,h,i]perylene & 402 & $\mathrm{U}$ & 392 & 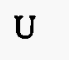 & 402 & $\mathrm{U}$ & 402 & $\mathbf{U}$ & 409 & $\mathbf{U}$ & 396 & $\mathrm{U}$ & 396 & $\mathrm{U}$ \\
\hline Benzo[k]fluoranthene & 92 & $\mathbf{J}$ & 392 & $\mathbf{U}$ & 402 & $\mathrm{U}$ & 402 & $\mathrm{U}$ & 409 & $\mathrm{U}$ & 396 & $\mathbf{U}$ & 396 & $\mathrm{U}$ \\
\hline Benzyl alcohol & 805 & $\mathrm{U}$ & 785 & $\mathrm{U}$ & 805 & $\mathrm{U}$ & 805 & $\mathbf{U}$ & 818 & $\mathrm{U}$ & 792 & $\mathrm{U}$ & 792 & $\mathrm{U}$ \\
\hline Bis(2-chloroethoxy)methane & 402 & $\mathrm{U}$ & 392 & $\mathbf{U}$ & 402 & $\mathrm{U}$ & 402 & $\mathrm{U}$ & 409 & $\mathrm{U}$ & 396 & $\mathrm{U}$ & 396 & $\mathrm{U}$ \\
\hline Bis(2-chloroethyl)ether & 402 & $\mathrm{U}$ & 392 & $U$ & 402 & $\mathrm{U}$ & 402 & $U$ & 409 & $\mathrm{U}$ & 396 & $\mathrm{U}$ & 396 & $U$ \\
\hline Bis(2-chloroisopropyl)ether & 402 & $\mathrm{U}$ & 392 & $\mathrm{U}$ & 402 & $\mathrm{U}$ & 402 & $\mathrm{U}$ & 409 & $\mathrm{U}$ & 396 & $\mathrm{U}$ & 396 & $\mathrm{U}$ \\
\hline Bis(2-ethylhexyl)phthalate & 402 & $\mathrm{U}$ & 392 & $\mathbf{U}$ & 402 & $U$ & 402 & $\mathrm{U}$ & 409 & $\mathrm{U}$ & 396 & $\mathrm{U}$ & 396 & U \\
\hline 4-Bromophenyl phenyl ether & 402 & $\mathrm{U}$ & 392 & $\mathrm{U}$ & 402 & $\mathrm{U}$ & 402 & $U$ & 409 & $\mathrm{U}$ & 396 & $\mathrm{U}$ & 396 & $U$ \\
\hline Butyl benzyl phthalate & 402 & $\mathrm{U}$ & 392 & $\mathbf{U}$ & 402 & $\mathbf{U}$ & 402 & $\mathrm{U}$ & 409 & $\mathrm{U}$ & 396 & $\mathrm{U}$ & 396 & $\mathbf{U}$ \\
\hline 4-Chloro-3-methylphenol & 805 & $\mathrm{U}$ & 785 & $\mathrm{U}$ & 805 & $\mathrm{U}$ & 805 & $\mathrm{U}$ & 818 & $\mathrm{U}$ & 792 & $\mathrm{U}$ & 792 & $\mathrm{U}$ \\
\hline 4-Chloroaniline & 805 & $\mathrm{U}$ & 785 & $\mathrm{U}$ & 805 & $\mathrm{U}$ & 805 & $\mathbf{U}$ & 818 & $\mathrm{U}$ & 792 & $\mathrm{U}$ & 792 & $\mathbf{U}$ \\
\hline 2-Chloronaphthalene & 402 & $\mathbf{U}$ & 392 & $\mathrm{U}$ & 402 & $\mathbf{U}$ & 402 & $\mathrm{U}$ & 409 & $\mathrm{U}$ & 396 & $U$ & 396 & $\mathbf{U}$ \\
\hline 2-Chlorophenol & 402 & Ù & 392 & $\mathrm{U}$ & 402 & $\mathbf{U}$ & 402 & $\mathrm{U}$ & 409 & $\mathrm{U}$ & 396 & $\mathrm{U}$ & 396 & $\mathrm{U}$ \\
\hline 4-Chlorophenyl phenyl ether & 402 & $U$ & 392 & $\mathrm{U}$ & 402 & $\mathrm{U}$ & 402 & $\mathrm{U}$ & 409 & $\mathrm{U}$ & 396 & U & 396 & $U$ \\
\hline Chrysene & 335 & J & 392 & $\mathrm{U}$ & 402 & $\mathrm{U}$ & 402 & $\mathrm{U}$ & 409 & $\mathrm{U}$ & 396 & $U$ & 396 & $U$ \\
\hline Di-n-butylphthalate & 402 & $\mathrm{U}$ & 392 & $\mathrm{U}$ & 402 & $\mathbf{U}$ & 402 & $\mathrm{U}$ & 409 & $\mathrm{U}$ & 77 & J & 396 & $U$ \\
\hline Di-n-octylphthalate & 402 & $\mathrm{U}$ & 392 & $U$ & 402 & $\mathrm{U}$ & 402 & $\mathrm{U}$ & 409 & $\mathrm{U}$ & 396 & $\mathrm{U}$ & 396 & $\mathrm{U}$ \\
\hline Dibenz[a,h]anthracene & 402 & $\mathrm{U}$ & 392 & $\mathrm{U}$ & 402 & $\mathrm{U}$ & 402 & $\mathrm{U}$ & 409 & $\mathrm{U}$ & 396 & $\mathrm{U}$ & 396 & $U$ \\
\hline Dibenzofuran & 402 & $\mathrm{U}$ & 392 & U & 402 & $\mathbf{U}$ & 402 & $\mathbf{U}$ & 409 & $\mathrm{U}$ & 396 & $\mathrm{U}$ & 396 & $U$ \\
\hline
\end{tabular}


TABLE C.14a (Cont.)

\begin{tabular}{|c|c|c|c|c|c|c|c|c|c|c|c|c|c|c|}
\hline \multirow{3}{*}{ Compound } & \multicolumn{14}{|c|}{ Borehole Concentrations $(\mu \mathrm{g} / \mathrm{kg})$ at Various Depths } \\
\hline & \multicolumn{2}{|c|}{$\begin{array}{c}\text { JBP1-E-2' } \\
(2 \mathrm{ft}) \\
\end{array}$} & \multicolumn{2}{|c|}{$\begin{array}{c}\text { JBP1-E-2'Dup } \\
(2 \mathrm{ft}) \\
\end{array}$} & \multicolumn{2}{|c|}{$\begin{array}{c}\text { JBP1-E-4' } \\
(4 \mathrm{ft})\end{array}$} & \multicolumn{2}{|c|}{$\begin{array}{c}\text { JBP1-W-2' } \\
(2 \mathrm{ft}) \\
\end{array}$} & \multicolumn{2}{|c|}{$\begin{array}{l}\text { JBPl-W-4' } \\
(4 \mathrm{ft})\end{array}$} & \multicolumn{2}{|c|}{$\begin{array}{c}\text { JBP2-E-2' } \\
(2 \mathrm{ft})\end{array}$} & \multicolumn{2}{|c|}{$\begin{array}{c}\text { JBP2-E-4' } \\
(4 \mathrm{ft})\end{array}$} \\
\hline & 402 & $\mathrm{U}$ & 392 & $\mathrm{U}$ & 402 & $\mathrm{U}$ & 402 & $\mathbf{U}$ & 409 & $\mathrm{U}$ & 396 & $\mathrm{U}$ & 396 & $\mathbf{U}$ \\
\hline 1,3-Dichlorobenzene & 402 & $\mathrm{U}$ & 392 & $\mathrm{U}$ & 402 & $\mathrm{U}$ & 402 & $\mathbf{U}$ & 409 & $\mathrm{U}$ & 396 & $\mathrm{U}$ & 396 & U \\
\hline 1,4-Dichlorobenzene & 402 & $\mathrm{U}$ & 392 & $U$ & 402 & $\mathrm{U}$ & 402 & $\mathrm{U}$ & 409 & $\mathrm{U}$ & 396 & $\mathbf{U}$ & 396 & $\mathrm{U}$ \\
\hline 3,3'-Dichlorobenzidine & 805 & $\mathbf{U}$ & 785 & $\mathrm{U}$ & 805 & $U$ & 805 & $\mathrm{U}$ & 818 & $\mathrm{U}$ & 792 & $\mathrm{U}$ & 792 & $\mathbf{U}$ \\
\hline 2,4-Dichlorophenol & 402 & $\mathrm{U}$ & 392 & $\mathrm{U}$ & 402 & $\mathrm{U}$ & 402 & $\mathrm{U}$ & 409 & $\mathrm{U}$ & 396 & $\mathrm{U}$ & 396 & U \\
\hline Diethylphthalate & 402 & $\mathrm{U}$ & 392 & $\mathrm{U}$ & 402 & $\mathrm{U}$ & 402 & $\mathrm{U}$ & 409 & $\mathrm{U}$ & 396 & $\mathbf{U}$ & 396 & $\mathrm{U}$ \\
\hline 2,4-Dimethylphenol & 402 & $\mathrm{U}$ & 392 & $\mathbf{U}$ & 402 & $\mathrm{U}$ & 402 & $\mathrm{U}$ & 409 & U & 396 & $\mathrm{U}$ & 396 & $\mathbf{U}$ \\
\hline Dimethylphthalate & 402 & $\mathrm{U}$ & 392 & $U$ & 402 & $\mathrm{U}$ & 402 & $\mathbf{U}$ & 409 & $\mathrm{U}$ & 396 & $\mathrm{U}$ & 396 & U \\
\hline 4,6-Dinitro-2-methylphenol & 2,010 & $\mathbf{U}$ & 1,960 & $\mathrm{U}$ & 2,010 & $\mathrm{U}$ & 2,010 & $\mathrm{U}$ & 2,050 & $\mathrm{U}$ & 1,980 & $\mathrm{U}$ & 1,980 & $\mathrm{U}$ \\
\hline 2,4-Dinitrophenol & 2,010 & $\mathrm{U}$ & 1,960 & $\mathrm{U}$ & 2,010 & $\mathrm{U}$ & 2,010 & $\mathrm{U}$ & 2,050 & $\mathrm{U}$ & 1,980 & $\mathrm{U}$ & 1,980 & U \\
\hline 2,4-Dinitrotoluene & 402 & $\mathrm{U}$ & 392 & $\mathrm{U}$ & 402 & $\mathrm{U}$ & 402 & $U$ & 409 & $\mathbf{U}$ & 396 & $\mathrm{U}$ & 396 & $U$ \\
\hline 2,6-Dinitrotoluene & 402 & $\mathrm{U}$ & 392 & $\mathbf{U}$ & 402 & U & 402 & $U$ & 409 & $U$ & 396 & $\mathrm{U}$ & 396 & $\mathrm{U}$ \\
\hline Fluoranthene & 306 & J & 392 & $U$ & 402 & $\mathrm{U}$ & 402 & $\mathrm{U}$ & 409 & $\mathrm{U}$ & 396 & $\mathrm{U}$ & 396 & $U$ \\
\hline Fluorene & 402 & $\mathrm{U}$ & 392 & $\mathrm{U}$ & 402 & $\mathrm{U}$ & 402 & $\mathrm{U}$ & 409 & $\mathbf{U}$ & 396 & $\mathbf{U}$ & 396 & $\mathrm{U}$ \\
\hline Hexachlorobenzene & 402 & $U$ & 392 & $\mathbf{U}$ & 402 & $\mathrm{U}$ & 402 & $\mathrm{U}$ & 409 & $\mathbf{U}$ & 396 & $\mathbf{U}$ & 396 & $\mathrm{U}$ \\
\hline Hexachlorobutadiene & 402 & $\mathrm{U}$ & 392 & $\mathrm{U}$ & 402 & $\mathbf{U}$ & 402 & $\mathrm{U}$ & 409 & $\mathbf{U}$ & 396 & $U$ & 396 & $U$ \\
\hline Hexachlorocyclopentadiene & 402 & $\mathrm{U}$ & 392 & $\mathrm{U}$ & 402 & $\mathbf{U}$ & 402 & $\mathrm{U}$ & 409 & $\mathbf{U}$ & 396 & $\mathbf{U}$ & 396 & $\mathrm{U}$ \\
\hline Hexachloroethane & 402 & U & 392 & $\mathbf{U}$ & 402 & $\mathbf{U}$ & 402 & $\mathrm{U}$ & 490 & $\mathbf{U}$ & 396 & $\mathbf{U}$ & 396 & $\mathrm{U}$ \\
\hline Indeno[1,2,3-c,d]pyrene & 402 & $\mathrm{U}$ & 392 & $\mathrm{U}$ & 402 & U & 402 & $\mathbf{U}$ & 409 & U & 396 & $\mathbf{U}$ & 396 & $\mathrm{U}$ \\
\hline Isophorone & 402 & $\mathrm{U}$ & 392 & $\mathrm{U}$ & 402 & $U$ & 402 & $\mathrm{U}$ & 409 & $U$ & 396 & $\mathrm{U}$ & 396 & U \\
\hline 2-Methylnaphthalene & 471 & & 392 & $\mathrm{U}$ & 402 & $\mathrm{U}$ & 402 & $\mathrm{U}$ & 409 & $U$ & 396 & $\mathrm{U}$ & 396 & U \\
\hline 2-Methylphenol & 402 & $\mathrm{U}$ & 392 & $U$ & 402 & $\mathrm{U}$ & 402 & $U$ & 409 & $\mathrm{U}$ & 396 & $\mathbf{U}$ & 396 & U \\
\hline 4-Methylphenol & 402 & $\mathrm{U}$ & 392 & $\mathrm{U}$ & 402 & $\mathrm{U}$ & 402 & $\mathbf{U}$ & 409 & $\mathrm{U}$ & 396 & $\mathrm{U}$ & 396 & U \\
\hline Naphthalene & 107 & $\mathbf{J}$ & 392 & $\mathrm{U}$ & 402 & $\mathrm{U}$ & 402 & $\mathrm{U}$ & 409 & $\mathrm{U}$ & 396 & $\mathrm{U}$ & 396 & $\mathrm{U}$ \\
\hline 2-Nitroaniline & 2,010 & $\mathbf{U}$ & 1,960 & U & 2,010 & $U$ & 2,010 & $\mathrm{U}$ & 2,050 & $\mathrm{U}$ & 1,980 & $\mathrm{U}$ & 1,980 & $\mathrm{U}$ \\
\hline 3-Nitroaniline & 2,010 & $\mathrm{U}$ & 1,960 & $\mathrm{U}$ & 2,010 & $\mathbf{U}$ & 2,010 & $U$ & 2,050 & $\mathrm{U}$ & 1,980 & $\mathrm{U}$ & 1,980 & $\mathrm{U}$ \\
\hline
\end{tabular}


TABLE C.14a (Cont.)

\begin{tabular}{|c|c|c|c|c|c|c|c|c|c|c|c|c|c|c|}
\hline \multirow{3}{*}{$\begin{array}{l}\text { Compound } \\
\text { 4-Nitroaniline }\end{array}$} & \multicolumn{14}{|c|}{ Borehole Concentrations $(\mu \mathrm{g} / \mathrm{kg}$ ) at Various Depths } \\
\hline & \multicolumn{2}{|c|}{$\begin{array}{l}\text { JBP1-E-2' } \\
(2 \mathrm{ft})\end{array}$} & \multicolumn{2}{|c|}{$\begin{array}{c}\text { JBPI-E-2'Dup } \\
(2 \mathrm{ft})\end{array}$} & \multicolumn{2}{|c|}{$\begin{array}{c}\text { JBP1-E-4' } \\
(4 \mathrm{ft})\end{array}$} & \multicolumn{2}{|c|}{$\begin{array}{c}\text { JBP1-W-2' } \\
(2 \mathrm{ft})\end{array}$} & \multicolumn{2}{|c|}{$\begin{array}{c}\text { JBP1-W-4' } \\
(4 \mathrm{ft})\end{array}$} & \multicolumn{2}{|c|}{$\begin{array}{l}\text { JBP2-E-2' } \\
(2 \mathrm{ft})\end{array}$} & \multicolumn{2}{|c|}{$\begin{array}{c}\text { JBP2-E-4' } \\
(4 \mathrm{ft})\end{array}$} \\
\hline & 2,010 & $\mathrm{U}$ & 1,960 & $\mathrm{U}$ & 2,010 & $\mathrm{U}$ & 2,010 & $\mathrm{U}$ & 2,050 & $\mathrm{U}$ & 1,980 & $\mathrm{U}$ & 1,980 & $\mathrm{U}$ \\
\hline Nitrobenzene & 402 & $\mathrm{U}$ & 392 & $\mathrm{U}$ & 402 & U & 402 & $\mathrm{U}$ & 409 & $\mathrm{U}$ & 396 & $\mathrm{U}$ & 396 & $\mathrm{U}$ \\
\hline 2-Nitrophenol & 402 & $\mathrm{U}$ & 392 & $U$ & 402 & $\mathrm{U}$ & 402 & $\mathrm{U}$ & 409 & $\mathrm{U}$ & 396 & $\mathrm{U}$ & 396 & $\mathrm{U}$ \\
\hline 4-Nitrophenol & 2,010 & $\mathrm{U}$ & 1,960 & $U$ & 2,010 & $\mathrm{U}$ & 2,010 & $\mathrm{U}$ & 2,050 & $\mathrm{U}$ & 1,980 & $\mathrm{U}$ & 1,980 & U \\
\hline N-Nitroso-di-n-propylamine & 402 & $U$ & 392 & $U$ & 402 & $U$ & 402 & $U$ & 409 & $\mathrm{U}$ & 396 & $\mathrm{U}$ & 396 & $\mathbf{U}$ \\
\hline N-Nitrosodiphenylamine & 402 & $\mathrm{U}$ & 392 & $\mathrm{U}$ & 402 & $\mathrm{U}$ & 402 & $\mathrm{U}$ & 409 & $\mathrm{U}$ & 396 & $\mathrm{U}$ & 396 & $\mathrm{U}$ \\
\hline Pentachlorophenol & 2,010 & $U$ & 1,960 & $\mathrm{U}$ & 2,010 & $\mathrm{U}$ & 2,010 & $U$ & 2,050 & $u$ & 1,980 & $\mathrm{U}$ & 1,980 & $\mathrm{U}$ \\
\hline Phenanthrene & 376 & $\mathrm{~J}$ & 392 & $U$ & 402 & $\mathbf{U}$ & 402 & $U$ & 409 & $\mathrm{U}$ & 396 & $\mathrm{U}$ & 396 & $\mathrm{U}$ \\
\hline Phenol & 402 & $\mathrm{U}$ & 392 & $\mathrm{U}$ & 402 & $U$ & 402 & U & 409 & U & 396 & $\mathrm{U}$ & 396 & $\mathrm{U}$ \\
\hline Pyrene & 580 & & 392 & $U$ & 402 & U & 402 & $\mathrm{U}$ & 409 & $U$ & 396 & $U$ & 396 & U \\
\hline 1,2,4-Trichlorobenzene & 402 & $\mathrm{U}$ & 392 & $\mathrm{U}$ & 402 & $\mathrm{U}$ & 402 & $U$ & 409 & U & 396 & $\mathrm{U}$ & 396 & $\mathrm{U}$ \\
\hline 2,4,5-Trichlorophenol & 402 & $\mathbf{U}$ & 392 & $\mathbf{U}$ & 402 & $\mathbf{U}$ & 402 & $u$ & 409 & $\mathrm{U}$ & 396 & $\mathrm{U}$ & 396 & $\mathrm{U}$ \\
\hline 2,4,6-Trichlorophenol & 402. & $U$ & 392 & $\mathrm{U}$ & 402 & U & 402 & $u$ & 409 & $\mathrm{U}$ & 396 & $\mathrm{U}$ & 396 & $\mathrm{U}$ \\
\hline & \multicolumn{14}{|c|}{ Borehole Concentrations $(\mu \mathrm{g} / \mathrm{kg}$ ) at Various Depths } \\
\hline Compound & \multicolumn{2}{|c|}{$\begin{array}{l}\text { JBP2-E-4'Dup } \\
(4 \mathrm{ft})\end{array}$} & \multicolumn{2}{|c|}{$\begin{array}{c}\text { JBP2-C-2' } \\
(2 \mathrm{ft}) \\
\end{array}$} & \multicolumn{2}{|c|}{$\begin{array}{c}\text { JBP2-C-4' } \\
(4 \mathrm{ft}) \\
\end{array}$} & \multicolumn{2}{|c|}{$\begin{array}{c}\text { JBP2-W-2' } \\
(2 \mathrm{ft})\end{array}$} & \multicolumn{2}{|c|}{$\begin{array}{c}\text { JBP2-W-4' } \\
(4 \mathrm{ft})\end{array}$} & \multicolumn{2}{|c|}{$\begin{array}{c}\text { JHDP-C-4' } \\
(4 \mathrm{ft})\end{array}$} & \multicolumn{2}{|c|}{$\begin{array}{l}\text { JHDP-C-6' } \\
(6 \mathrm{ft})\end{array}$} \\
\hline Acenaphthene & 392 & $\mathrm{U}$ & 455 & $\mathrm{U}$ & 392 & $\mathrm{U}$ & 396 & $\mathrm{U}$ & 392 & $\mathrm{U}$ & 396 & $\mathbf{U}$ & 402 & $U$ \\
\hline Acenaphthylene & 392 & $\mathrm{U}$ & 455 & $\mathrm{U}$ & 392 & $\mathrm{U}$ & 396 & $\mathrm{U}$ & 392 & $\mathrm{U}$ & 396 & $\mathrm{U}$ & 402 & U \\
\hline Anthracene & 392 & $U$ & 455 & $U$ & 392 & $\mathrm{U}$ & 396 & $\mathrm{U}$ & 392 & $\mathrm{U}$ & 396 & $\mathrm{U}$ & 402 & $\mathrm{U}$ \\
\hline Benz[a]anthracene & 392 & $\mathrm{U}$ & 455 & $\mathrm{U}$ & 392 & $U$ & 396 & $\mathrm{U}$ & 392 & $\mathrm{U}$ & 396 & $\mathrm{U}$ & 402 & $\mathrm{U}$ \\
\hline Benzo[a]pyrene & 392 & $\mathrm{U}$ & 455 & $\mathrm{U}$ & 392 & U & 396 & $U$ & 392 & $U$ & 396 & $U$ & 402 & U \\
\hline Benzo[b]fluoranthene & 392 & $\mathrm{U}$ & 455 & $\mathrm{U}$ & 392 & $\mathrm{U}$ & 396 & $\mathrm{U}$ & 392 & $\mathrm{U}$ & 396 & $\mathrm{U}$ & 402 & $\mathrm{U}$ \\
\hline Benzo[g,h,i]perylene & 392 & $\mathrm{U}$ & 455 & $\mathrm{U}$ & 392 & $\mathrm{U}$ & 396 & $\mathbf{U}$ & 392 & $\mathrm{U}$ & 396 & $\mathrm{U}$ & 402 & U \\
\hline Benzoic acid & 1,960 & $\mathrm{U}$ & 2,280 & $\mathrm{U}$ & 1,960 & $\mathrm{U}$ & 118 & $\mathrm{~J}$ & $1 ; 960$ & $U$ & 175 & $\mathbf{J}$ & 74 & $\mathrm{~J}$ \\
\hline
\end{tabular}




\begin{tabular}{|c|c|c|c|c|c|c|c|c|c|c|c|c|c|c|}
\hline \multirow{3}{*}{ Compound } & \multicolumn{14}{|c|}{ Borehole Concentrations $(\mu \mathrm{g} / \mathrm{kg})$ at Various Depths } \\
\hline & \multicolumn{2}{|c|}{$\begin{array}{c}\text { JBP2-E-4'Dup } \\
(4 \mathrm{ft}) \\
\end{array}$} & \multicolumn{2}{|c|}{$\begin{array}{c}\text { JBP2-C-2' } \\
(2 \mathrm{ft}) \\
\end{array}$} & \multicolumn{2}{|c|}{$\begin{array}{c}\text { JBP2 }-\mathrm{C}-4^{\prime} \\
(4 \mathrm{ft}) \\
\end{array}$} & \multicolumn{2}{|c|}{$\begin{array}{c}\text { JBP2-W-2' } \\
(2 \mathrm{ft}) \\
\end{array}$} & \multicolumn{2}{|c|}{$\begin{array}{c}\text { JBP2-W-4' } \\
(4 \mathrm{ft})\end{array}$} & \multicolumn{2}{|c|}{$\begin{array}{c}\text { JHDP-C-4' } \\
(4 \mathrm{ft}) \\
\end{array}$} & \multicolumn{2}{|c|}{$\begin{array}{l}\text { JHDP-C-6' } \\
(6 \mathrm{ft}) \\
\end{array}$} \\
\hline & 392 & $\mathrm{U}$ & 455 & $\mathrm{U}$ & 392 & $\mathrm{U}$ & 396 & $\mathbf{U}$ & 392 & $\mathrm{U}$ & 396 & $\mathbf{U}$ & 402 & $\mathbf{U}$ \\
\hline Benzyl alcohol & 785 & $\mathrm{U}$ & 910 & $\mathrm{U}$ & 785 & $\mathrm{U}$ & 792 & $\mathrm{U}$ & 785 & $\mathrm{U}$ & 792 & $\mathrm{U}$ & 805 & $\mathbf{U}$ \\
\hline Bis(2-chloroethoxy)methane & 392 & $\mathrm{U}$ & 455 & $\mathrm{U}$ & 392 & $\mathrm{U}$ & 396 & $\mathbf{U}$ & 392 & $\mathrm{U}$ & 396 & $\mathrm{U}$ & 402 & $\mathbf{U}$ \\
\hline Bis(2-chloroethyl)ether & 392 & $\mathbf{U}$ & 455 & U & 392 & $\mathrm{U}$ & 396 & $\mathrm{U}$ & 392 & $\mathrm{U}$ & 396 & $\mathrm{U}$ & 402 & $\mathbf{U}$ \\
\hline Bis(2-chloroisopropyl)ether & 392 & $\mathbf{U}$ & 455 & $\mathrm{U}$ & 392 & $\mathrm{U}$ & 396 & $\mathrm{U}$ & 392 & $\mathrm{U}$ & 396 & $\mathrm{U}$ & 402 & $\mathrm{U}$ \\
\hline Bis(2-ethylhexyl)phthalate & 392 & U & 455 & $\mathrm{U}$ & 392 & $\mathrm{U}$ & 396 & $U$ & 392 & $U$ & 396 & $U$ & 402 & $\mathbf{U}$ \\
\hline 4-Bromophenyl phenyl ether & 392 & $U$ & 455 & $\mathrm{U}$ & 392 & $U$ & 396 & $\mathrm{U}$ & 392 & $\mathrm{U}$ & 396 & $\mathrm{U}$ & 402 & $\mathbf{U}$ \\
\hline Butyl benzyl phthalate & 392 & $\mathrm{U}$ & 455 & $\mathrm{U}$ & 392. & $\mathrm{U}$ & 396 & $\mathrm{U}$ & 392 & $\mathrm{U}$ & 396 & $\mathrm{U}$ & 402 & $\mathrm{U}$ \\
\hline 4-Chloro-3-methylphenol & 785 & $\mathrm{U}$ & 910 & $\mathrm{U}$ & 785 & $\mathrm{U}$ & 792 & $\mathbf{U}$ & 785 & $\mathrm{U}$ & 792 & $\mathrm{U}$ & 805 & $\mathbf{U}$ \\
\hline 4-Chloroaniline & 785 & $\mathbf{U}$ & 910 & $\mathbf{U}$ & 785 & $\mathrm{U}$ & 792 & $U$ & 785 & $\mathrm{U}$ & 792 & $\mathrm{U}$ & 805 & $\mathbf{U}$ \\
\hline 2-Chloronaphthalene & 392 & U & 455 & $\mathrm{U}$ & 392 & $\mathbf{U}$ & 396 & $\mathbf{U}$ & 392 & $\mathrm{U}$ & 396 & $\mathrm{U}$ & 402 & $\mathbf{U}$ \\
\hline 2-Chlorophenol & 392 & $U$ & 455 & $\mathrm{U}$ & 392 & $\mathrm{U}$ & 396 & $\mathbf{U}$ & 392 & $\mathrm{U}$ & 396 & $\mathbf{U}$ & 402 & $\mathrm{U}$ \\
\hline 4-Chlorophenyl phenyl ether & 392 & $\mathbf{U}$ & 455 & $\mathrm{U}$ & 392 & $\mathrm{U}$ & 396 & $\mathrm{U}$ & 392 & U & 396 & $\mathrm{U}$ & 402 & $\mathbf{U}$ \\
\hline Chrysene & 392 & $\mathbf{U}$ & 455 & $\mathbf{U}$ & 392 & $\mathbf{U}$ & 396 & $U$ & 392 & $\mathrm{U}$ & 396 & $\mathrm{U}$ & 402 & $\mathrm{U}$ \\
\hline Di-n-butylphthalate & 392 & $\mathbf{U}$ & 455 & $U$ & 392 & $\mathbf{U}$ & 396 & $\mathrm{U}$ & 392 & $\mathbf{U}$ & 396 & $\mathrm{U}$ & 402 & $\mathbf{U}$ \\
\hline Di-n-octylphthalate & 392 & $\mathbf{U}$ & 455 & $U$ & 392 & $\mathrm{U}$ & 396 & $\mathrm{U}$ & 392 & U & 396 & $U$ & 402 & $\mathbf{U}$ \\
\hline Dibenz[a,h]anthracene & 392 & $U$ & 455 & $\mathbf{U}$ & 392 & $\mathrm{U}$ & 396 & $\mathrm{U}$ & 392 & $U$ & 396 & $\mathbf{U}$ & 402 & $U$ \\
\hline Dibenzofuran & 392 & $\mathbf{U}$ & 455 & U & 392 & $\mathrm{U}$ & 396 & $\mathrm{U}$ & 392 & U & 396 & $\mathrm{U}$ & 402 & $U$ \\
\hline 1,2-Dichlorobenzene & 392 & $\mathrm{U}$ & 455 & $\mathbf{U}$ & 392 & $\mathrm{U}$ & 396 & $\mathrm{U}$ & 392 & $U$ & 396 & $U$ & 402 & $U$ \\
\hline 1,3-Dichlorobenzene & 392 & $\mathrm{U}$ & 455 & $U$ & 392 & $U$ & 396 & $\mathrm{U}$ & 392 & U & 396 & $\mathrm{U}$ & 402 & $U$ \\
\hline 1,4-Dichlorobenzene & 392 & $U$ & 455 & $\mathrm{U}$ & 392 & $\mathrm{U}$ & 396 & $\mathrm{U}$ & 392 & U & 396 & $U$ & 402 & $\mathrm{U}$ \\
\hline 3,3'-Dichlorobenzidine & 785 & $\mathrm{U}$ & 910 & $\mathbf{U}$ & 785 & $\mathbf{U}$ & 792 & $\mathrm{U}$ & 785 & U & 792 & $\mathrm{U}$ & 805 & $\mathbf{U}$ \\
\hline 2,4-Dichlorophenol & 392 & $\mathrm{U}$ & 455 & $\mathbf{U}$ & 392 & $\mathbf{U}$ & 396 & $U$ & 392 & U & 396 & $\mathrm{U}$ & 402 & $\mathrm{U}$ \\
\hline Diethylphthalate & 392 & $\mathrm{U}$ & 455 & $\mathrm{U}$ & 392 & $\mathrm{U}$ & 396 & $\mathrm{U}$ & 392 & $\mathrm{U}$ & 396 & $\mathbf{U}$ & 402 & $\mathrm{U}$ \\
\hline 2,4-Dimethylphenol & 392 & $U$ & 455 & $\mathbf{U}$ & 392 & $\mathrm{U}$ & 396 & $\mathrm{U}$ & 392 & $\mathrm{U}$ & 396 & $\mathrm{U}$ & 402 & U \\
\hline Dimethylphthalate & 392 & $\mathrm{U}$ & 455 & $\mathrm{U}$ & 392 & $\mathbf{U}$ & 396 & $\mathrm{U}$ & 392 & $\mathrm{U}$ & 396 & $\mathrm{U}$ & 402 & U \\
\hline
\end{tabular}




\begin{tabular}{|c|c|c|c|c|c|c|c|c|c|c|c|c|c|c|}
\hline \multirow{3}{*}{$\frac{\text { Compound }}{\text { 4,6-Dinitro-2-methylphenol }}$} & \multicolumn{14}{|c|}{ Borehole Concentrations $(\mu \mathrm{g} / \mathrm{kg})$ at Various Depths } \\
\hline & \multicolumn{2}{|c|}{$\begin{array}{c}\text { JBP2-E-4'Dup } \\
(4 \mathrm{ft})\end{array}$} & \multicolumn{2}{|c|}{$\begin{array}{c}\text { JBP2-C-2' } \\
(2 \mathrm{ft}) \\
\end{array}$} & \multicolumn{2}{|c|}{$\begin{array}{c}\text { JBP2-C-4' } \\
(4 \mathrm{ft}) \\
\end{array}$} & \multicolumn{2}{|c|}{$\begin{array}{c}\text { JBP2-W-2' } \\
(2 \mathrm{ft}) \\
\end{array}$} & \multicolumn{2}{|c|}{$\begin{array}{c}\text { JBP2-W-4' } \\
(4 \mathrm{ft})\end{array}$} & \multicolumn{2}{|c|}{$\begin{array}{c}\text { JHDP-C-4' } \\
(4 \mathrm{ft})\end{array}$} & \multicolumn{2}{|c|}{$\begin{array}{c}\text { JHDP-C-6' } \\
(6 \mathrm{ft})\end{array}$} \\
\hline & 1,960 & $\mathrm{U}$ & 2,280 & $\mathrm{U}$ & 1,960 & $\mathrm{U}$ & 1,980 & U & 1,960 & $\mathrm{U}$ & 1,980 & $\mathrm{U}$ & 2,010 & $\mathbf{U}$ \\
\hline 2,4-Dinitrophenol & 1,960 & $\mathrm{U}$ & 2,280 & $\mathrm{U}$ & 1,960 & $\mathrm{U}$ & 1,980 & U & 1,960 & $\mathrm{U}$ & 1,980 & $\mathrm{U}$ & 2,010 & $\mathrm{U}$ \\
\hline 2,4-Dinitrotoluene & 392 & $\mathrm{U}$ & 455 & $\mathrm{U}$ & 392 & $\mathrm{U}$ & 396 & $\mathrm{U}$ & 392 & $\mathrm{U}$ & 396 & $U$ & 402 & $\mathrm{U}$ \\
\hline 2,6-Dinitrotoluene & 392 & $\mathrm{U}$ & 455 & $\mathrm{U}$ & 392 & $U$ & 396 & $\mathrm{U}$ & 392 & $\mathrm{U}$ & 396 & $U$ & 402 & $\mathrm{U}$ \\
\hline Fluoranthene & 392 & $\mathrm{U}$ & 455 & $\mathrm{U}$ & 392 & $\mathrm{U}$ & 396 & $\mathrm{U}$ & 392 & $\mathrm{U}$ & 396 & $\mathrm{U}$ & 402 & $\mathrm{U}$ \\
\hline Fluorene & 392 & $\mathbf{U}$ & 531 & & 392 & U & 396 & $\mathbf{U}$ & 392 & $\mathrm{U}$ & 396 & $\mathbf{U}$ & 402 & $\mathrm{U}$ \\
\hline Hexachlorobenzene & 392 & U & 455 & U & 380 & J & 845 & & 392 & $\mathrm{U}$ & 396 & U & 402 & $\mathrm{U}$ \\
\hline Hexachlorobutadiene & 392 & $\mathrm{U}$ & 455 & $\mathbf{U}$ & 392 & U & 396 & $\mathrm{U}$ & 392 & $\mathrm{U}$ & 396 & U & 402 & $\mathrm{U}$ \\
\hline Hexachlorocyclopentadiene & 392 & U & 455 & $\mathrm{U}$ & 392 & $\mathrm{U}$ & 396 & $\mathrm{U}$ & 392 & $\mathrm{U}$ & 396 & $\mathbf{U}$ & 402 & $U$ \\
\hline Hexachloroethane & 392 & $\mathbf{U}$ & 455 & $\mathbf{U}$ & 392 & U & 396 & $\mathrm{U}$ & 392 & $\mathrm{U}$ & 396 & U & 628 & \\
\hline Indeno $[1,2,3-c, d]$ pyrene & 392 & $\mathrm{U}$ & 455 & $\mathrm{U}$ & 392 & $U$ & 396 & $\mathrm{U}$ & 392 & $\mathrm{U}$ & 396 & $U$ & 402 & U \\
\hline Isophorone & 392 & $\mathrm{U}$ & 455 & $U$ & 392 & $U$ & 396 & $\mathrm{U}$ & 392 & $\mathrm{U}$ & 396 & U & 402 & $\mathrm{U}$ \\
\hline 2-Methylnaphthalene & 392 & U & 455 & $\mathrm{U}$ & 392 & $\mathbf{U}$ & 396 & $\mathrm{U}$ & 392 & $\mathrm{U}$ & 396 & U & 402 & $\mathrm{U}$ \\
\hline 2-Methylphenol & 392 & $\mathrm{U}$ & 455 & $\mathrm{U}$ & 392 & $\mathbf{U}$ & 396 & $\mathrm{U}$ & 392 & $\mathrm{U}$ & 396 & $\mathbf{U}$ & 402 & $\mathrm{U}$ \\
\hline 4-Methylphenol & 392 & $\mathrm{U}$ & 455 & U & 392 & $\mathbf{U}$ & 396 & $\mathrm{U}$ & 392 & $\mathbf{U}$ & 396 & $\mathbf{U}$ & 402 & $\mathrm{U}$ \\
\hline Naphthalene & 392 & $\mathbf{U}$ & 50 & $\mathbf{J}$ & 392 & $\mathbf{U}$ & 396 & $U$ & 392 & $\mathrm{U}$ & 396 & $\mathrm{U}$ & 402 & $\mathrm{U}$ \\
\hline 2-Nitroaniline & 1,960 & $\mathrm{U}$ & 2,280 & $\mathrm{U}$ & 1,960 & $\mathbf{U}$ & 1,980 & $\mathrm{U}$ & 1,960 & $\mathrm{U}$ & 1,980 & $\mathrm{U}$ & 2,010 & $\mathrm{U}$ \\
\hline 3-Nitroaniline & 1,960 & $\mathrm{U}$ & 2,280 & $\mathrm{U}$ & 1,960 & $\mathbf{U}$ & 1,980 & $\mathrm{U}$ & 1,960 & $\mathrm{U}$ & 1,980 & $\mathbf{U}$ & 2,010 & $\mathrm{U}$ \\
\hline 4-Nitroaniline & 1,960 & $\mathrm{U}$ & 2,280 & $\mathrm{U}$ & 1,960 & $\mathbf{U}$ & 1,980 & $\mathrm{U}$ & 1,960 & $\mathrm{U}$ & 1,980 & $\mathrm{U}$ & 2,010 & $\mathrm{U}$ \\
\hline Nitrobenzene & 57 & $\mathbf{J}$ & 455 & $\mathrm{U}$ & 57 & $\mathbf{J}$ & 396 & $\mathbf{U}$ & 392 & $U$ & 396 & $\mathbf{U}$ & 402 & $\mathrm{U}$ \\
\hline 2-Nitrophenol & 392 & $\mathrm{U}$ & 455 & $\mathrm{U}$ & 392 & $\mathrm{U}$ & 396 & $\mathrm{U}$ & 392 & $\mathrm{U}$ & 396 & $U$ & 402 & $\mathrm{U}$ \\
\hline 4-Nitrophenol & 1,960 & $\mathrm{U}$ & 2,280 & $\mathrm{U}$ & 1,960 & $\mathrm{U}$ & 1,980 & $\mathrm{U}$ & 1,960 & $\mathrm{U}$ & 1,980 & $U$ & 2,010 & $\mathrm{U}$ \\
\hline N-Nitroso-di-n-propylamine & 392 & $U$ & 455 & $\mathrm{U}$ & 392 & $\mathrm{U}$ & 396 & $\mathrm{U}$ & 392 & $\mathrm{U}$ & 396 & $\mathrm{U}$ & 402 & U \\
\hline N-Nitrosodiphenylamine & 392 & $\mathrm{U}$ & 455 & $\mathrm{U}$ & 392 & $\mathrm{U}$ & 396 & $\mathrm{U}$ & 392 & $\mathbf{U}$ & 396 & $\mathrm{U}$ & 402 & $\mathrm{U}$ \\
\hline Pentachlorophenol & 1,960 & $\mathrm{U}$ & 2,280 & $\mathrm{U}$ & 1,960 & $\mathrm{U}$ & 1,980 & U & 1,960 & $\mathrm{U}$ & 1,980 & $\mathrm{U}$ & 2,010 & $\mathrm{U}$ \\
\hline Phenanthrene & 392 & $\mathrm{U}$ & 52 & $\mathrm{~J}$ & 43 & $\mathbf{J}$ & 396 & $U$ & 392 & $\mathbf{U}$ & 396 & $\mathrm{U}$ & 402 & $\mathrm{U}$ \\
\hline
\end{tabular}




\section{TABLE C.14a (Cont.)}

\begin{tabular}{|c|c|c|c|c|c|c|c|c|c|c|c|c|c|c|}
\hline \multirow[b]{2}{*}{ Compound } & \multicolumn{14}{|c|}{ Borehole Concentrations $(\mu \mathrm{g} / \mathrm{kg})$ at Various Depths } \\
\hline & \multicolumn{2}{|c|}{$\begin{array}{c}\text { JBP2-E-4'Dup } \\
(4 \mathrm{ft}) \\
\end{array}$} & \multicolumn{2}{|c|}{$\begin{array}{c}\text { JBP2-C-2' } \\
(2 \mathrm{ft}) \\
\end{array}$} & \multicolumn{2}{|c|}{$\begin{array}{c}\text { JBP2-C-4' } \\
(4 \mathrm{ft}) \\
\end{array}$} & \multicolumn{2}{|c|}{$\begin{array}{c}\text { JBP2-W-2' } \\
(2 \mathrm{ft})\end{array}$} & \multicolumn{2}{|c|}{$\begin{array}{c}\text { JBP2-W-4 } \\
(4 \mathrm{ft}) \\
\end{array}$} & \multicolumn{2}{|c|}{$\begin{array}{c}\text { JHDP-C-4' } \\
(4 \mathrm{ft}) \\
\end{array}$} & \multicolumn{2}{|c|}{$\begin{array}{c}\text { JHDP-C-6' } \\
(6 \mathrm{ft}) \\
\end{array}$} \\
\hline Phenol & 392 & $U$ & 455 & $\mathbf{U}$ & 392 & $\mathbf{U}$ & 396 & $\mathbf{U}$ & 392 & $\mathrm{U}$ & 396 & $\mathbf{U}$ & 402 & $\mathrm{U}$ \\
\hline Pyrene & 392 & $\mathrm{U}$ & 455 & $\mathbf{U}$ & 392 & U & 396 & $\mathbf{U}$ & 392 & $\mathbf{U}$ & 396 & $\mathrm{U}$ & 402 & $\mathbf{U}$ \\
\hline 1,2,4-Trichlorobenzene & 392 & $\mathrm{U}$ & 455 & $\mathbf{U}$ & 392 & U & 396 & $\mathbf{U}$ & 392 & $\mathbf{U}$ & 396 & $\mathrm{U}$ & 402 & $\mathbf{U}$ \\
\hline 2,4,5-Trichlorophenol & 392 & $\mathrm{U}$ & 455 & $\mathrm{U}$ & 392 & $\mathrm{U}$ & 396 & $\mathbf{U}$ & 392 & $\mathrm{U}$ & 396 & $\mathrm{U}$ & 402 & $\mathbf{U}$ \\
\hline 2,4,6-Trichlorophenol & 392 & U & 455 & U & 392 & $\underline{U}$ & 396 & $\underline{U}$ & 392 & $\underline{-U}$ & 396 & $\underline{U}$ & 402 & $\underline{-}$ \\
\hline & \multicolumn{14}{|c|}{ Borehole Concentrations $(\mu \mathrm{g} / \mathrm{kg}$ ) at Various Depths } \\
\hline Compound & \multicolumn{2}{|c|}{$\begin{array}{c}\text { JHDP-C-6'Dup } \\
(6 \mathrm{ft}) \\
\end{array}$} & \multicolumn{2}{|c|}{$\begin{array}{c}\text { JVXP-C-4' } \\
(4 \mathrm{ft}) \\
\end{array}$} & \multicolumn{2}{|c|}{$\begin{array}{c}\text { JVXP-C-6' } \\
(6 \mathrm{ft}) \\
\end{array}$} & \multicolumn{2}{|c|}{$\begin{array}{l}\text { JSDP-C }-4 \\
(4 \mathrm{ft})\end{array}$} & \multicolumn{2}{|c|}{$\begin{array}{c}\text { JSDP-C-6' } \\
(6 \mathrm{ft})\end{array}$} & \multicolumn{2}{|c|}{$\begin{array}{c}\text { JBPM-A } 3 " \text { " } \\
(3 \text { in. }) \\
\end{array}$} & \multicolumn{2}{|c|}{$\begin{array}{c}\text { JBPM-A-3"Dup } \\
(3 \text { in.) } \\
\end{array}$} \\
\hline Acenaphthene & 369 & $\mathrm{U}$ & 435 & $\mathbf{U}$ & 465 & $\mathbf{U}$ & 442 & $U$ & 432 & $\mathbf{U}$ & 392 & $\mathrm{U}$ & 392 & $U$ \\
\hline Acenaphthylene & 369 & U & 435 & $\mathrm{U}$ & 465 & $\mathrm{U}$ & 442 & $\mathrm{U}$ & 432 & $\mathbf{U}$ & 392 & $\mathbf{U}$ & 392 . & $\mathbf{U}$ \\
\hline Anthracene & 369 & $\mathrm{U}$ & 435 & $\mathrm{U}$ & 465 & $\mathbf{U}$ & 442 & $\mathrm{U}$ & 432 & $\mathrm{U}$ & 392 & $U$ & 392 & $U$ \\
\hline Benz[a]anthracene & 369 & $U$ & 435 & $\mathrm{U}$ & 465 & $\mathrm{U}$ & 442 & $\mathrm{U}$ & 432 & $\mathbf{U}$ & 392 & $\mathbf{U}$ & 392 & $\mathrm{U}$ \\
\hline Benzo[a]pyrene & 369 & $U$ & 435 & $U$ & 465 & $\mathrm{U}$ & 442 & $\mathrm{U}$ & 432 & $\mathbf{U}$ & 392 & U & 392 & $U$ \\
\hline Benzo[b]fluoranthene & 369 & $\mathrm{U}$ & 435 & $\mathrm{U}$ & 465 & $\mathrm{U}$ & 442 & $\mathrm{U}$ & 432 & $\mathrm{U}$ & 392 & $U$ & 392 & $\mathrm{U}$ \\
\hline Benzo[g,h,i]perylene & 369 & $U$ & 435 & $U$ & 465 & U & 442 & $\mathrm{U}$ & 432 & $U$ & 392 & $\mathbf{U}$ & 392 & $\mathrm{U}$ \\
\hline Benzoic acid & 78 & J & 91 & $\mathbf{J}$ & 2,330 & U & 2,210 & $\mathrm{U}$ & 2,160 & $U$ & 1,960 & $U$ & 1,960 & $\mathrm{U}$ \\
\hline Benzo[k]fluoranthene & 369 & $\mathrm{U}$ & 435 & U & 465 & $\mathrm{U}$ & 442 & $\mathrm{U}$ & 432 & $U$ & 392 & $\mathrm{U}$ & 392 & $\mathrm{U}$ \\
\hline Benzyl alcohol & 739 & $\mathrm{U}$ & 871 & $\mathrm{U}$ & 930 & $\mathrm{U}$ & 884 & $\mathrm{U}$ & 864 & $U$ & 785 & $\mathrm{U}$ & 785 & $\mathrm{U}$ \\
\hline Bis(2-chloroethoxy)methane & 369 & $\mathbf{U}$ & 435 & $\mathbf{U}$ & 465 & $\mathbf{U}$ & 442 & $U$ & 432 & U & 392 & $\mathrm{U}$ & 392 & $U$ \\
\hline Bis(2-chloroethyl)ether & 369 & U & 435 & $\mathbf{U}$ & 465 & $\mathrm{U}$ & 442 & $\mathbf{U}$ & 432 & $\mathrm{U}$ & 392 & $\mathrm{U}$ & 392 & U \\
\hline Bis(2-chloroisopropyl)ether & 369 & $\mathrm{U}$ & 435 & $\mathbf{U}$ & 465 & U & 442 & $\mathbf{U}$ & 432 & $\mathrm{U}$ & 392 & $U$ & 392 & $U$ \\
\hline Bis(2-ethylhexyl)phthalate & 369 & U & 435 & $\mathbf{U}$ & 465 & U & 442 & $\mathbf{U}$ & 432 & $\mathbf{U}$ & 208 & $\mathbf{J}$ & 392 & U \\
\hline 4-Bromophenyl phenyl ether & 369 & $\mathrm{U}$ & 435 & $\mathbf{U}$ & 465 & U & 442 & $\mathbf{U}$ & 432 & $\mathbf{U}$ & 392 & $\mathrm{U}$ & 392 & $\mathbf{U}$ \\
\hline Butyl benzyl phthalate & 369 & $\mathrm{U}$ & 435 & $\mathbf{U}$ & 465 & $U$ & 442 & $\mathbf{U}$ & 432 & $\mathbf{U}$ & 392 & $U$ & 392 & $\mathbf{U}$ \\
\hline
\end{tabular}


TABLE C.14a (Cont.)

\begin{tabular}{|c|c|c|c|c|c|c|c|c|c|c|c|c|c|c|}
\hline \multirow{3}{*}{$\frac{\text { Compound }}{\text { 4-Chloro-3-methylphenol }}$} & \multicolumn{14}{|c|}{ Borehole Concentrations $(\mu \mathrm{g} / \mathrm{kg}$ ) at Various Depths } \\
\hline & \multicolumn{2}{|c|}{$\begin{array}{c}\text { JHDP-C-6'Dup } \\
(6 \mathrm{ft})\end{array}$} & \multicolumn{2}{|c|}{$\begin{array}{c}\text { JVXP-C-4' } \\
(4 \mathrm{ft})\end{array}$} & \multicolumn{2}{|c|}{$\begin{array}{c}\text { JVXP-C-6' } \\
(6 \mathrm{ft})\end{array}$} & \multicolumn{2}{|c|}{$\begin{array}{l}\text { JSDP-C-4' } \\
(4 \mathrm{ft})\end{array}$} & \multicolumn{2}{|c|}{$\begin{array}{l}\text { JSDP-C-6' } \\
(6 \mathrm{ft})\end{array}$} & \multicolumn{2}{|c|}{$\begin{array}{l}\text { JBPM-A-3" } \\
\text { (3 in.) }\end{array}$} & \multicolumn{2}{|c|}{$\begin{array}{c}\text { JBPM-A-3"Dup } \\
\text { (3 in.) }\end{array}$} \\
\hline & 739 & $\mathrm{U}$ & 871 & $\mathrm{U}$ & 930 & $\mathrm{U}$ & 884 & $\mathrm{U}$ & 864 & U & 785 & $\mathrm{U}$ & 785 & $U$ \\
\hline 4-Chloroaniline & 739 & $\mathrm{U}$ & 871 & $\mathrm{U}$ & 930 & $\mathrm{U}$ & 884 & $\mathrm{U}$ & 864 & $\mathrm{U}$ & 785 & $\mathbf{U}$ & 785 & $\mathbf{u}$ \\
\hline 2-Chloronaphthalene & 369 & $\mathrm{U}$ & 435 & $\mathrm{U}$ & 465 & $\mathrm{U}$ & 442 & $U$ & 432 & $U$ & 392 & $\mathrm{U}$ & 392 & $\mathrm{U}$ \\
\hline 2-Chlorophenol & 369 & $U$ & 435 & $U$ & 465 & $\mathrm{U}$ & 442 & $\mathrm{U}$ & 432 & $\mathrm{U}$ & 392 & $\mathrm{U}$ & 392 & $\mathrm{U}$ \\
\hline 4-Chlorophenyl phenyl ether & 369 & $\mathrm{U}$ & 435 & $\mathrm{U}$ & 465 & $\mathrm{U}$ & 442 & $\mathrm{U}$ & 432 & $U$ & 392 & $\mathrm{U}$ & 392 & $U$ \\
\hline Chrysene & 369 & $\mathrm{U}$ & 435 & $\mathbf{U}$ & 465 & $\mathbf{U}$ & 442 & $\mathrm{U}$ & 432 & $\mathrm{U}$ & 392 & $\mathrm{U}$ & 392 & $\mathrm{U}$ \\
\hline Di-n-butylphthalate & 369 & $\mathrm{U}$ & 435 & $\mathbf{U}$ & 70 & $\mathrm{~J}$ & 442 & $U$ & 432 & $\mathrm{U}$ & 392 & $\mathrm{U}$ & 392 & $\mathrm{U}$ \\
\hline Di-n-octylphthalate & 369 & $\mathrm{U}$ & 435 & $\mathrm{U}$ & 465 & $\mathrm{U}$ & 442 & $\mathrm{U}$ & 432 & $\mathrm{U}$ & 392 & $\mathrm{U}$ & 392 & $\mathrm{U}$ \\
\hline Dibenz $[a, h] a n t h r a c e n e$ & 369 & $\mathrm{U}$ & 435 & $\mathbf{U}$ & 465 & $\mathrm{U}$ & 442 & $\mathrm{U}$ & 432 & $U$ & 392 & $\mathrm{U}$ & 392. & $\mathrm{U}$ \\
\hline Dibenzofuran & 369 & $\mathrm{U}$ & 435 & $U$ & 465 & $\mathrm{U}$ & 442 & $\mathrm{U}$ & 432 & $\mathrm{U}$ & 392 & $\mathrm{U}$ & 392 & $\mathrm{U}$ \\
\hline 1,2-Dichlorobenzene & 369 & $\mathrm{U}$ & 435 & $\mathbf{U}$ & 465 & $\mathrm{U}$ & 442 & $\mathrm{U}$ & 432 & $\mathrm{U}$ & 392 & $\mathrm{U}$ & 392 & $\mathrm{U}$ \\
\hline 1,3-Dichlorobenzene & 369 & $\mathrm{U}$ & 435 & $\mathrm{U}$ & 465 & $\mathrm{U}$ & 442 & $U$ & 432 & $\mathrm{U}$ & 392 & $\mathbf{U}$ & 392 & $\mathrm{U}$ \\
\hline 1,4-Dichlorobenzene & 369 & $\mathrm{U}$ & 435 & $\mathrm{U}$ & 465 & $\mathrm{U}$ & 442 & $\mathrm{U}$ & 432 & U & 392 & $\mathbf{U}$ & 392 & $\mathbf{U}$ \\
\hline 3,3'-Dichlorobenzidine & 739 & $\mathbf{U}$ & 871 & $U$ & 930 & $\mathrm{U}$ & 884 & $\mathrm{U}$ & 864 & $U$ & 785 & $\mathrm{U}$ & 785 & $\mathrm{U}$ \\
\hline 2,4-Dichlorophenol & 369 & $\mathrm{U}$ & 435 & $\mathrm{U}$ & 465 & $\mathrm{U}$ & 442 & $\mathrm{U}$ & 432 & $\mathrm{U}$ & 392 & $\mathrm{U}$ & 392 & $\mathrm{U}$ \\
\hline Diethylphthalate & 369 & $\mathrm{U}$ & 435 & $\mathrm{U}$ & 465 & $\mathrm{U}$ & 442 & U & 432 & $U$ & 392 & $\mathbf{U}$ & 392 & $\mathrm{U}$ \\
\hline 2,4-Dimethylphenol & 369 & $\mathrm{U}$ & 435 & $\mathrm{U}$ & 465 & $\mathrm{U}$ & 442 & $\mathrm{U}$ & 432 & $\mathrm{U}$ & 392 & $\mathrm{U}$ & 392 & $\mathrm{U}$ \\
\hline Dimethylphthalate & 369 & $\mathrm{U}$ & 435 & $\mathrm{U}$ & 465 & $\mathrm{U}$ & 442 & $\mathrm{U}$ & 432 & $\mathrm{U}$ & 392 & $\mathrm{U}$ & 392 & $U$ \\
\hline 4,6-Dinitro-2-methylphenol & 1,850 & $\mathrm{U}$ & 2,180 & $U$ & 2,330 & $U$ & 2,210 & $\mathrm{U}$ & 2,160 & $\mathrm{U}$ & 1,960 & $\mathrm{U}$ & 1,960 & $\mathrm{U}$ \\
\hline 2,4-Dinitrophenol & 1,850 & $\mathrm{U}$ & 2,180 & $\mathrm{U}$ & 2,330 & $\mathrm{U}$ & 2,210 & $\mathrm{U}$ & 2,160 & $\mathrm{U}$ & 1,960 & $\mathbf{U}$ & 1,960 & $\mathrm{U}$ \\
\hline 2,4-Dinitrotoluene & 369 & $\mathrm{U}$ & 435 & $\mathrm{U}$ & 465 & $\mathrm{U}$ & 442 & U & 432 & $\mathrm{U}$ & 392 & $\mathrm{U}$ & 392 & $\mathrm{U}$ \\
\hline 2,6-Dinitrotoluene & 369 & $U$ & 435 & $\mathrm{U}$ & 465 & $\mathrm{U}$ & 442 & $\mathrm{U}$ & 432 & $\mathrm{U}$ & 392 & $\mathrm{U}$ & 392 & $\mathrm{U}$ \\
\hline Fluoranthene & 369 & $\mathrm{U}$ & 435 & $\mathrm{U}$ & 465 & $\mathrm{U}$ & 442 & $\mathrm{U}$ & 432 & $\mathrm{U}$ & 77 & $\mathbf{J}$ & 392 & $U$ \\
\hline Fluorene & 369 & $\mathrm{U}$ & 435 & $\mathrm{U}$ & 465 & $\mathrm{U}$ & 442 & $\mathrm{U}$ & 432 & $\mathrm{U}$ & 392 & $\mathrm{U}$ & 392 & $\mathrm{U}$ \\
\hline Hexachlorobenzene & 369 & $\mathrm{U}$ & 435 & $\mathrm{U}$ & 465 & $U$ & 442 & $\mathrm{U}$ & 432 & $\mathrm{U}$ & 392 & $U$ & 392 & $\mathrm{U}$ \\
\hline Hexachlorobutadiene & 369 & $U$ & 435 & $U$ & 465 & $\mathrm{U}$ & 442 & $\mathrm{U}$ & 432 & $\mathrm{U}$ & 392 & $\mathrm{U}$ & 392 & $\mathrm{U}$ \\
\hline
\end{tabular}


TABLE C.14a (Cont.)

\begin{tabular}{|c|c|c|c|c|c|c|c|c|c|c|c|c|c|c|}
\hline \multirow{3}{*}{$\frac{\text { Compound }}{\text { Hexachlorocyclopentadiene }}$} & \multicolumn{14}{|c|}{ Borehole Concentrations $(\mu \mathrm{g} / \mathrm{kg}$ ) at Various Depths } \\
\hline & \multicolumn{2}{|c|}{$\begin{array}{c}\text { JHDP-C-6'Dup } \\
(6 \mathrm{ft})\end{array}$} & \multicolumn{2}{|c|}{$\begin{array}{c}\text { JVXP-C-4' } \\
(4 \mathrm{ft}) \\
\end{array}$} & \multicolumn{2}{|c|}{$\begin{array}{c}\text { JVXP-C-6' } \\
(6 \mathrm{ft})\end{array}$} & \multicolumn{2}{|c|}{$\begin{array}{c}\text { JSDP-C-4 } \\
(4 \mathrm{ft})\end{array}$} & \multicolumn{2}{|c|}{$\begin{array}{c}\text { JSDP-C-6' } \\
(6 \mathrm{ft})\end{array}$} & \multicolumn{2}{|c|}{$\begin{array}{c}\text { JBPM-A-3" } \\
\text { (3 in.) }\end{array}$} & \multicolumn{2}{|c|}{$\begin{array}{c}\text { JBPM-A-3"Dup } \\
\text { (3 in.) }\end{array}$} \\
\hline & 369 & U & 435 & $U$ & 465 & $\mathrm{U}$ & 442 & $U$ & 432 & $\mathrm{U}$ & 392 & $\mathbf{U}$ & 392 & $\mathbf{U}$ \\
\hline Hexachloroethane & 282 & $J$ & 435 & $\mathrm{U}$ & 465 & $\mathrm{U}$ & 442 & $\mathrm{U}$ & 432 & $\mathrm{U}$ & 392 & $\mathbf{U}$ & 392 & $\mathrm{U}$ \\
\hline Indeno[1,2,3-c,d]pyrene & 369 & $\mathrm{U}$ & 435 & $\mathrm{U}$ & 465 & $\mathrm{U}$ & 442 & $\mathrm{U}$ & 432 & $\mathrm{U}$ & 392 & $\mathbf{U}$ & 392 & $\mathbf{U}$ \\
\hline Isophorone & 369 & $\mathrm{U}$ & 435 & $\mathrm{U}$ & 465 & $\mathrm{U}$ & 442 & $\mathbf{U}$ & 432 & $\mathbf{U}$ & 392 & $\mathbf{U}$ & 392 & $\mathrm{U}$ \\
\hline 2-Methylnaphthalene & 369 & $\mathrm{U}$ & 435 & $\mathrm{U}$ & 465 & $\mathrm{U}$ & 442 & $\mathrm{U}$ & 432 & $\mathrm{U}$ & 139 & $\mathrm{~J}$ & 392 & $\mathbf{U}$ \\
\hline 2-Methylphenol & 369 & $\mathrm{U}$ & 435 & $U$ & 465 & $\mathrm{U}$ & 442 & $\mathrm{U}$ & 432 & $\mathrm{U}$ & 392 & $\mathbf{U}$ & 392 & $\mathbf{U}$ \\
\hline 4-Methylphenol & 369 & $\mathrm{U}$ & 435 & $\mathrm{U}$ & 465 & $\mathrm{U}$ & 442 & $\mathbf{U}$ & 432 & $\mathrm{U}$ & 392 & $\mathbf{U}$ & 392 & $U$ \\
\hline Naphthalene & 369 & $\mathrm{U}$ & 435 & $\mathbf{U}$ & 465 & $\mathrm{U}$ & 442 & $\mathrm{U}$ & 432 & $\mathrm{U}$ & 48 & $\mathrm{~J}$ & 392 & U \\
\hline 2-Nitroaniline & 1,850 & $\mathrm{U}$ & 2,180 & $\mathrm{U}$ & 2,330 & $U$ & 2,210 & $\mathrm{U}$ & 2,160 & $U$ & 1,960 & $\mathbf{U}$ & 1,960 & $\mathbf{U}$ \\
\hline 3-Nitroaniline & 1,850 & $\mathrm{U}$ & 2,180 & $\mathrm{U}$ & 2,330 & $\mathrm{U}$ & 2,210 & $\mathbf{U}$ & 2,160 & $\mathrm{U}$ & 1,960 & $\mathrm{U}$ & 1,960 & $\mathbf{U}$ \\
\hline 4-Nitroaniline & 1,850 & $\mathbf{U}$ & 2,180 & $\mathrm{U}$ & 2,330 & $\mathrm{U}$ & 2,210 & $\mathbf{U}$ & 2,160 & $\mathrm{U}$ & 1,960 & $\mathrm{U}$ & 1,960 & $\mathbf{U}$ \\
\hline Nitrobenzene & 369 & $\mathrm{U}$ & 435 & U & 465 & $U$ & 442 & $\mathbf{U}$ & 432 & $\mathrm{U}$ & 392 & $\mathbf{U}$ & 392 & $\mathrm{U}$ \\
\hline 2-Nitrophenol & 369 & $\mathrm{U}$ & 435 & $\mathrm{U}$ & 465 & $U$ & 442 & $\mathbf{U}$ & 432 & $\mathrm{U}$ & 392 & $\mathbf{U}$ & 392 & $\mathbf{U}$ \\
\hline 4-Nitrophenol & 1,850 & $\mathrm{U}$ & 2,180 & $U$ & 2,330 & $\mathrm{U}$ & 2,210 & $\mathrm{U}$ & 2,160 & $U$ & 1,960 & $\mathrm{U}$ & 1,960 & $\mathbf{U}$ \\
\hline N-Nitroso-di-n-propylamine & 369 & U & 435 & $\mathrm{U}$ & 465 & $\mathrm{U}$ & 442 & $\mathbf{U}$ & 432 & $\mathrm{U}$ & 392 & $\mathrm{U}$ & 392 & $\mathbf{U}$ \\
\hline N-Nitrosodiphenylamine & 369 & $\mathbf{U}$ & 435 & $\mathrm{U}$ & 465 & $\mathrm{U}$ & 442 & $\mathrm{U}$ & 432 & $\mathrm{U}$ & 392 & $\mathrm{U}$ & 392 & $\mathbf{U}$ \\
\hline Pentachlorophenol & 1,850 & $\mathbf{U}$ & 2,180 & $\mathbf{U}$ & 2,230 & $\mathrm{U}$ & 2,210 & $\mathrm{U}$ & 2,160 & $\mathrm{U}$ & 1,960 & $\mathrm{U}$ & 1960 & $\mathrm{U}$ \\
\hline Phenanthrene & 369 & $\mathbf{U}$ & 435 & $\mathrm{U}$ & 465 & $\mathrm{U}$ & 442 & $\mathbf{U}$ & 432 & $\mathrm{U}$ & 311 & $\mathbf{J}$ & 392 & $\mathrm{U}$ \\
\hline Phenol & 369 & $\mathbf{U}$ & 435 & $\mathbf{U}$ & 465 & $\mathbf{U}$ & 442 & $\mathrm{U}$ & 432 & $\mathrm{U}$ & 392 & $\mathrm{U}$ & 392 & $\mathrm{U}$ \\
\hline Pyrene & 369 & $\mathbf{U}$ & 435 & $\mathrm{U}$ & 465 & $\mathbf{U}$ & 442 & $\mathrm{U}$ & 432 & $\mathbf{U}$ & 215 & J & 392 & $\mathbf{U}$ \\
\hline 1,2,4-Trichlorobenzene & 369 & $U$ & 435 & $\mathrm{U}$ & 465 & $\mathrm{U}$ & 442 & $\mathbf{U}$ & 432 & $\mathbf{U}$ & 392 & 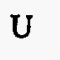 & 392 & $\mathrm{U}$ \\
\hline 2,4,5-Trichlorophenol & 369 & $\mathrm{U}$ & 435 & $\mathbf{U}$ & 465 & $\mathrm{U}$ & 442 & $U$ & 432 & $\mathbf{U}$ & 392 & $\mathbf{U}$ & 392 & $\mathbf{U}$ \\
\hline 2,4,6-Trichlorophenol & 369 & $\underline{U}$ & 435 & $\mathrm{U}$ & 465 & $\mathbf{U}$ & 442 & $U$ & 432 & U & 392 & $\underline{-}$ & 392 & $U$ \\
\hline
\end{tabular}




\begin{tabular}{|c|c|c|c|c|c|c|c|c|c|c|c|c|c|c|}
\hline \multirow{3}{*}{$\begin{array}{l}\text { Compound } \\
\text { Acenaphthene }\end{array}$} & \multicolumn{14}{|c|}{ Borehole Concentrations $(\mu \mathrm{g} / \mathrm{kg})$ at Various Depths } \\
\hline & \multicolumn{2}{|c|}{$\begin{array}{c}\text { JBPM-A-1' } \\
(1 \mathrm{ft}) \\
\end{array}$} & \multicolumn{2}{|c|}{$\begin{array}{c}\text { JBPM-B-3" } \\
(3 \text { in. })\end{array}$} & \multicolumn{2}{|c|}{$\begin{array}{l}\text { JBPM-B-1' } \\
(1 \mathrm{ft}) \\
\end{array}$} & \multicolumn{2}{|c|}{$\begin{array}{c}\text { JBPM-C-3" } \\
(3 \text { in. }) \\
\end{array}$} & \multicolumn{2}{|c|}{$\begin{array}{c}\text { JBPM-C-1' } \\
(1 \mathrm{ft})\end{array}$} & \multicolumn{2}{|c|}{$\begin{array}{c}\text { JBPP-A-3" } \\
\text { (3 in.) }\end{array}$} & \multicolumn{2}{|c|}{$\begin{array}{c}\text { JBPP-A-1' } \\
(1 \mathrm{ft})\end{array}$} \\
\hline & 392 & $\mathrm{U}$ & 376 & $\mathbf{U}$ & 386 & $\mathbf{U}$ & 419 & $\mathrm{U}$ & 379 & $U$ & 386 & $\mathrm{U}$ & 392 & $\mathrm{U}$ \\
\hline Acenaphthylene & 392 & $\mathrm{U}$ & 376 & $\mathrm{U}$ & 386 & $\mathrm{U}$ & 419 & $U$ & 379 & U & 386 & $\mathbf{U}$ & 392 & $\mathbf{U}$ \\
\hline Anthracene & 392 & U & 376 & U & 386 & $\mathrm{U}$ & 419 & U & 379 & $U$ & 386 & $\mathrm{U}$ & 392 & $U$ \\
\hline Benz[a]anthracene & 392 & $\mathrm{U}$ & 376 & $\mathrm{U}$ & 386 & $\mathbf{U}$ & 419 & $U$ & 379 & $\mathrm{U}$ & 386 & $\mathrm{U}$ & 392 & $\mathrm{U}$ \\
\hline Benzo[a]pyrene & 392 & $\mathrm{U}$ & 376 & $\mathrm{U}$ & 386 & $\mathrm{U}$ & 419 & U & 379 & U & 386 & $U$ & 392 & $\mathrm{U}$ \\
\hline Benzo[b]fluoranthene & 392 & $\mathbf{U}$ & 376 & $\mathrm{U}$ & 386 & $U$ & 419 & $U$ & 379 & $U$ & 386 & $\mathrm{U}$ & 392 & $U$ \\
\hline Benzo[g,h,i]perylene & 392 & $\mathrm{U}$ & 376 & $\mathrm{U}$ & 386 & $\mathrm{U}$ & 419 & $U$ & 379 & $\mathrm{U}$ & 386 & $\mathrm{U}$ & 392 & U \\
\hline Benzoic acid & 1,960 & $\mathrm{U}$ & 1,880 & $\mathrm{U}$ & 1,930 & $\mathrm{U}$ & 2,100 & $\mathrm{U}$ & 1,900 & U & 1,930 & $\mathrm{U}$ & 1,960 & $\mathrm{U}$ \\
\hline Benzo[k]fluoranthene & 392 & $\mathbf{U}$ & 376 & $U$ & 386 & $U$ & 419 & $\mathrm{U}$ & 379 & $\mathrm{U}$ & 386 & $\mathrm{U}$ & 392 & $U$ \\
\hline Benzyl alcohol & 785 & $\mathrm{U}$ & 752 & $\mathrm{U}$ & 772 & $\mathrm{U}$ & 838 & $\mathbf{U}$ & 759 & $U$ & 772 & $\mathrm{U}$ & 785 & $\mathrm{U}$ \\
\hline $\mathrm{Bis}$ (2-chloroethoxy)methane & 392 & $\mathrm{U}$ & 376 & U & 386 & $\mathrm{U}$ & 419 & $U$ & 379 & U & 386 & $\mathbf{U}$ & 392 & $\mathrm{U}$ \\
\hline Bis(2-chloroethyl)ether & 392 & $\mathbf{U}$ & 376 & $\mathrm{U}$ & 386 & $\mathrm{U}$ & 419 & $\mathrm{U}$ & 379 & $U$ & 386 & $\mathrm{U}$ & 392 & $\dot{U}$ \\
\hline Bis(2-chloroisopropyl)ether & 392 & $\mathbf{U}$ & 376 & $U$ & 386 & $\mathrm{U}$ & 419 & $\mathbf{U}$ & 379 & $U$ & 386 & $\mathrm{U}$ & 392 & $\mathrm{U}$ \\
\hline Bis(2-ethylhexyl)phthalate & 392 & $\mathrm{U}$ & 190 & $\mathbf{J}$ & 386 & $U$ & 419 & $\mathrm{U}$ & 379 & $\mathbf{U}$ & 386 & $\mathrm{U}$ & 392 & U \\
\hline 4-Bromophenyl phenyl ether & 392 & $\mathrm{U}$ & 376 & U & 386 & $U$ & 419 & $\mathrm{U}$ & 379 & $\mathrm{U}$ & 386 & $U$ & 392 & $U$ \\
\hline Butyl benzyl phthalate & 392 & $\mathbf{U}$ & 376 & $\mathrm{U}$ & 386 & $\mathrm{U}$ & 419 & $\mathbf{U}$ & 379 & $\mathbf{U}$ & 386 & $\mathrm{U}$ & 392 & $\mathrm{U}$ \\
\hline 4-Chloro-3-methylphenol & 785 & $\mathrm{U}$ & 752 & U & 772 & $U$ & 838 & $\mathbf{U}$ & 759 & $\mathbf{U}$ & 772 & $\mathbf{U}$ & 785 & $\mathrm{U}$ \\
\hline 4-Chloroaniline & 785 & $\mathbf{U}$ & 752 & $\mathrm{U}$ & 772 & $\mathrm{U}$ & 838 & $\mathrm{U}$ & 759 & $\mathrm{U}$ & 772 & $U$ & 785 & U \\
\hline 2-Chloronaphthalene & 392 & $\mathbf{U}$ & 376 & $\mathrm{U}$ & 386 & 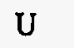 & 419 & $\mathbf{U}$ & 379 & $\mathrm{U}$ & 386 & $\mathrm{U}$ & 392 & U \\
\hline 2-Chlorophenol & 392 & $\mathrm{U}$ & 376 & $\mathrm{U}$ & 386 & $U$ & 419 & $\mathrm{U}$ & 379 & $\mathrm{U}$ & 386 & $U$ & 392 & $\mathrm{U}$ \\
\hline 4-Chlorophenyl phenyl ether & 392 & $\mathbf{U}$ & 376 & $\mathrm{U}$ & 386 & $\mathrm{U}$ & 419 & $U$ & 379 & $\mathrm{U}$ & 386 & $U$ & 392 & $\mathrm{U}$ \\
\hline Chrysene & 392 & $\mathrm{U}$ & 376 & $\mathrm{U}$ & 386 & $\mathrm{U}$ & 419 & $\mathrm{U}$ & 379 & $\mathrm{U}$ & 386 & $\mathrm{U}$ & 392 & $\mathrm{U}$ \\
\hline Di-n-butylphthalate & 77 & $\mathrm{~J}$ & 376 & $U$ & 386 & $\mathrm{U}$ & 419 & $\mathrm{U}$ & 379 & $U$ & 386 & $\mathrm{U}$ & 392 & $\mathrm{U}$ \\
\hline Di-n-octylphthalate & 392 & $\mathbf{U}$ & 376 & $\mathbf{U}$ & 386 & $\mathrm{U}$ & 419 & $\mathrm{U}$ & 379 & $\mathrm{U}$ & 386 & $U$ & 392 & $\mathrm{U}$ \\
\hline Dibenz[a,h]anthracene & 392 & $\mathrm{U}$ & 376 & $\mathrm{U}$ & 386 & $\mathrm{U}$ & 419 & $\mathrm{U}$ & 379 & $\mathrm{U}$ & 386 & $\mathrm{U}$ & 392 & $\mathrm{U}$ \\
\hline Dibenzofuran & 392 & $\mathrm{U}$ & 376 & $\mathrm{U}$ & 386 & $\mathrm{U}$ & 419 & $U$ & 379 & $\mathrm{U}$ & 386 & $\mathrm{U}$ & 392 & $\mathbf{U}$ \\
\hline
\end{tabular}




\begin{tabular}{|c|c|c|c|c|c|c|c|c|c|c|c|c|c|c|}
\hline \multirow{3}{*}{$\frac{\text { Compound }}{\text { 1,2-Dichlorobenzene }}$} & \multicolumn{14}{|c|}{ Borehole Concentrations $(\mu \mathrm{g} / \mathrm{kg})$ at Various Depths } \\
\hline & \multicolumn{2}{|c|}{$\begin{array}{c}\text { JBPM-A-1' } \\
(1 \mathrm{ft}) \\
\end{array}$} & \multicolumn{2}{|c|}{$\begin{array}{c}\text { JBPM-B-3" } \\
(3 \text { in. }) \\
\end{array}$} & \multicolumn{2}{|c|}{$\begin{array}{c}\text { JBPM-B-1' } \\
(1 \mathrm{ft}) \\
\end{array}$} & \multicolumn{2}{|c|}{$\begin{array}{c}\text { JBPM-C-3" } \\
\text { (3 in.) }\end{array}$} & \multicolumn{2}{|c|}{$\begin{array}{c}\text { JBPM-C-1' } \\
(1 \mathrm{ft}) \\
\end{array}$} & \multicolumn{2}{|c|}{$\begin{array}{c}\text { JBPP-A-3" } \\
(3 \text { in. }) \\
\end{array}$} & \multicolumn{2}{|c|}{$\begin{array}{c}\text { JBPP-A-1' } \\
(1 \mathrm{ft}) \\
\end{array}$} \\
\hline & 392 & $\mathbf{U}$ & 376 & $\mathbf{U}$ & 386 & $\mathbf{U}$ & 419 & $\mathbf{U}$ & 379 & $\mathbf{U}$ & 386 & $\mathrm{U}$ & 392 & $\mathbf{U}$ \\
\hline 1,3-Dichlorobenzene & 392 & $\mathbf{U}$ & 376 & $\mathrm{U}$ & 386 & $\mathrm{U}$ & 419 & $U$ & 379 & $U$ & 386 & $\mathrm{U}$ & 392 & $\mathrm{U}$ \\
\hline 1,4-Dichlorobenzene & 392 & $\mathrm{U}$ & 376 & $\mathrm{U}$ & 386 & $\mathrm{U}$ & 419 & $\mathrm{U}$ & 379 & $\mathbf{U}$ & 386 & $\mathrm{U}$ & 392 & $\mathrm{U}$ \\
\hline 3,3'-Dichlorobenzidine & 785 & $\mathrm{U}$ & 752 & $\mathrm{U}$ & 772 & $\mathbf{U}$ & 838 & $\mathrm{U}$ & 759 & $\mathbf{U}$ & 772 & $\mathrm{U}$ & 785 & $\mathrm{U}$ \\
\hline 2,4-Dichlorophenol & 392 & $\mathrm{U}$ & 376 & $U$ & 386 & $\mathrm{U}$ & 419 & $\mathrm{U}$ & 379 & $\mathrm{U}$ & 386 & $\mathrm{U}$ & 392 & $\mathrm{U}$ \\
\hline Diethylphthalate & 49 & $\mathbf{J}$ & 376 & $\mathrm{U}$ & 386 & $\mathbf{U}$ & 419 & $\mathrm{U}$ & 379 & $\mathbf{U}$ & 386 & $\mathbf{U}$ & 392 & $\mathrm{U}$ \\
\hline 2,4-Dimethylphenol & 392 & $\mathrm{U}$ & 376 & $\mathbf{U}$ & 386 & $\mathrm{U}$ & 419 & $\mathrm{U}$ & 379 & $\mathrm{U}$ & 386 & $\mathbf{U}$ & 392 & $U$ \\
\hline Dimethylphthalate & 392 & $\mathrm{U}$ & 376 & $\mathrm{U}$ & 386 & $\mathbf{U}$ & 419 & $U$ & 379 & $\mathbf{U}$ & 386 & $\mathrm{U}$ & 392 & $\mathrm{U}$ \\
\hline 4,6-Dinitro-2-methylphenol & 1,960 & $\mathrm{U}$ & 1,880 & $\mathrm{U}$ & 1,930 & $\mathrm{U}$ & 2,100 & $\mathbf{U}$ & 1,900 & U & 1,930 & $\mathbf{U}$ & 1,960 & $\mathrm{U}$ \\
\hline 2,4-Dinitrophenol & 1,960 & $\mathrm{U}$ & 1,880 & $\mathbf{U}$ & 1,930 & $\mathrm{U}$ & 2,100 & $\mathrm{U}$ & 1,900 & U & 1,930 & $\mathbf{U}$ & 1,960 & $U$ \\
\hline 2,4-Dinitrotoluene & 392 & $\mathrm{U}$ & 376 & $U$ & 386 & $\mathbf{U}$ & 419 & $\mathbf{U}$ & 379 & $\mathbf{U}$ & 386 & $\mathbf{U}$ & 392 & $\mathrm{U}$ \\
\hline 2,6-Dinitrotoluene & 392 & $\mathrm{U}$ & 376 & $\mathrm{U}$ & 386 & $\mathrm{U}$ & 419 & U & 379 & $U$ & 386 & $\mathbf{U}$ & 392 & $\mathrm{U}$ \\
\hline Fluoranthene & 392 & $\mathrm{U}$ & 376 & $\mathbf{U}$ & 386 & $\mathrm{U}$ & 419 & U & 379 & U & 386 & $\mathbf{U}$ & 392 & U \\
\hline Fluorene & 392 & $\mathrm{U}$ & 376 & $\mathrm{U}$ & 386 & $\mathrm{U}$ & 419 & $\mathrm{U}$ & 379 & $\mathbf{U}$ & 386 & $\mathbf{U}$ & 392 & $\mathrm{U}$ \\
\hline Hexachlorobenzene & 392 & $\mathrm{U}$ & 376 & $\mathrm{U}$ & 386 & U & 419 & $\mathrm{U}$ & 379 & $\mathbf{U}$ & 386 & $\mathbf{U}$ & 392 & $\mathrm{U}$ \\
\hline Hexachlorobutadiene & 392 & $\mathrm{U}$ & 376 & $\mathrm{U}$ & 386 & $\mathrm{U}$ & 419 & U & 379 & U & 386 & $\mathbf{U}$ & 392 & U \\
\hline Hexachlorocyclopentadiene & 392 & $\mathbf{U}$ & 376 & $\mathrm{U}$ & 386 & $U$ & 419 & U & 379 & $U$ & 386 & $\mathbf{U}$ & 392 & U \\
\hline Hexachloroethane & 498 & & 376 & $\mathrm{U}$ & 386 & $\mathrm{U}$ & 419 & U & 379 & $\mathrm{U}$ & 386 & $\mathbf{U}$ & 392 & $U$ \\
\hline Indeno $[1,2,3-c, d]$ pyrene & 392 & $\mathbf{U}$ & 376 & $\mathrm{U}$ & 386 & $\mathrm{U}$ & $\dot{4} 19$ & $\mathrm{U}$ & 379 & $\mathrm{U}$ & 386 & U & 392 & $\mathrm{U}$ \\
\hline Isophorone & 392 & $\mathrm{U}$ & 376 & $U$ & 386 & $\mathrm{U}$ & 419 & U & 379 & $\mathrm{U}$ & 386 & $\mathrm{U}$ & 392 & U \\
\hline 2-Methylnaphthalene & 392 & $\mathrm{U}$ & 376 & $\mathrm{U}$ & 386 & $\mathrm{U}$ & 419 & U & 379 & $\mathrm{U}$ & 386 & $U$ & 392 & U \\
\hline 2-Methylphenol & 392 & $U$ & 376 & $\mathrm{U}$ & 386 & $U$ & 419 & $\mathbf{U}$ & 379 & $\mathrm{U}$ & 386 & U & 392 & $\mathrm{U}$ \\
\hline 4-Methylphenol & 392 & $\mathbf{U}$ & 376 & $\mathrm{U}$ & 386 & $\mathrm{U}$ & 419 & U & 379 & $\mathbf{U}$ & 386 & U & 392 & U \\
\hline Naphthalene & 392 & $U$ & 376 & $\mathrm{U}$ & 386 & $\mathrm{U}$ & 419 & $\mathrm{U}$ & 379 & $\mathrm{U}$ & 386 & $\mathrm{U}$ & 392 & $\mathrm{U}$ \\
\hline 2-Nitroaniline & 1,960 & $\mathrm{U}$ & 1,880 & $\mathrm{U}$ & 1,930 & $\mathrm{U}$ & 2,100 & $\mathbf{U}$ & 1,900 & $U$ & 1,930 & $\mathrm{U}$ & 1,960 & $\mathrm{U}$ \\
\hline 3-Nitroaniline & 1,960 & $U$ & 1,880 & $U$ & 1,930 & $\mathrm{U}$ & 2,100 & $\mathbf{U}$ & 1,900 & $\mathrm{U}$ & 1,930 & $\mathbf{U}$ & 1,960 & $\mathbf{U}$ \\
\hline
\end{tabular}


TABLE C.14a (Cont.)

\begin{tabular}{|c|c|c|c|c|c|c|c|c|c|c|c|c|c|c|}
\hline \multirow{3}{*}{$\frac{\text { Compound }}{\text { 4-Nitroaniline }}$} & \multicolumn{14}{|c|}{ Borehole Concentrations $(\mu \mathrm{g} / \mathrm{kg})$ at Various Depths } \\
\hline & \multicolumn{2}{|c|}{$\begin{array}{c}\text { JBPM-A-1' } \\
(1 \mathrm{ft})\end{array}$} & \multicolumn{2}{|c|}{$\begin{array}{c}\text { JBPM-B-3" } \\
(3 \text { in.) }\end{array}$} & \multicolumn{2}{|c|}{$\begin{array}{c}\text { JBPM-B-1' } \\
(1 \mathrm{ft})\end{array}$} & \multicolumn{2}{|c|}{$\begin{array}{c}\text { JBPM-C-3" } \\
(3 \text { in.) }\end{array}$} & \multicolumn{2}{|c|}{$\begin{array}{c}\text { JBPM-C-1' } \\
(1 \mathrm{ft})\end{array}$} & \multicolumn{2}{|c|}{$\begin{array}{c}\text { JBPP-A-3" } \\
(3 \text { in.) } \\
\end{array}$} & \multicolumn{2}{|c|}{$\begin{array}{c}\text { JBPP-A-1' } \\
(1 \mathrm{ft})\end{array}$} \\
\hline & 1,960 & $\mathrm{U}$ & 1,880 & $\mathrm{U}$ & 1,930 & $\mathrm{U}$ & 2,100 & U & 1,900 & $\mathrm{U}$ & 1,930 & $U$ & 1,960 & $\mathrm{U}$ \\
\hline Nitrobenzene & 392 & $\mathbf{U}$ & 376 & $\mathrm{U}$ & 386 & $\mathrm{U}$ & 419 & $\mathrm{U}$ & 379 & $\mathrm{U}$ & 386 & $\mathrm{U}$ & 392 & $\mathrm{U}$ \\
\hline 2-Nitrophenol & 392 & $\mathbf{U}$ & 376 & $\mathrm{U}$ & 386 & $U$ & 419 & $\mathrm{U}$ & 379 & $\mathrm{U}$ & 386 & $\mathrm{U}$ & 392 & $\mathrm{U}$ \\
\hline 4-Nitrophenol & 1,960 & $\mathbf{U}$ & 1,880 & u & 1,930 & $\mathrm{U}$ & 2,100 & $\mathrm{U}$ & 1,900 & $\mathrm{U}$ & 1,930 & $U$ & 1,960 & $\mathrm{U}$ \\
\hline N-Nitroso-di-n-propylamine & 392 & $\mathrm{U}$ & 376 & $U$ & 386 & $\mathrm{U}$ & 419 & $\mathrm{U}$ & 379 & $\mathrm{U}$ & 386 & $\mathrm{U}$ & 392 & $\mathrm{U}$ \\
\hline N-Nitrosodiphenylamine & 392 & $\mathrm{U}$ & 376 & $\mathrm{U}$ & 386 & $\mathrm{U}$ & 419 & U & 379 & $\mathrm{U}$ & 386 & U & 392 & $\mathrm{U}$ \\
\hline Pentachlorophenol & 1,960 & $U$ & 1,880 & $\mathrm{U}$ & 1,930 & $\mathrm{U}$ & 2,100 & U & 1,900 & $\mathrm{U}$ & 1,930 & $\mathrm{U}$ & 1,960 & $\mathrm{U}$ \\
\hline Phenanthrene & 392 & $U$ & 376 & $\mathrm{U}$ & 386 & $\mathrm{U}$ & 419 & U & 379 & $U$ & 386 & $\mathrm{U}$ & 392 & U \\
\hline Phenol & 392 & $\mathrm{U}$ & 376 & $\mathrm{U}$ & 386 & U & 419 & $\mathrm{U}$ & 379 & $U$ & 386 & $\mathrm{U}$ & 392 & U \\
\hline Pyrene & 392 & $\mathrm{U}$ & 376 & $\mathrm{U}$ & 386 & U & 419 & U & 379 & $\mathrm{U}$ & 386 & $\mathrm{U}$ & 392 & $\mathrm{U}$ \\
\hline 1,2,4-Trichlorobenzene & 392 & $\mathrm{U}$ & 376 & U & 386 & U & 419 & $\mathrm{U}$ & 379 & $\mathrm{U}$ & 386 & $\mathrm{U}$ & 392 & $\mathrm{U}$ \\
\hline 2,4,5-Trichlorophenol & 392 & $\mathrm{U}$ & 376 & $\mathrm{U}$ & 386 & U & 419 & $\mathrm{U}$ & 379 & $\mathrm{U}$ & 386 & $\mathrm{U}$ & 392 & $\mathrm{U}$ \\
\hline 2,4,6-Trichlorophenol & 392 & $\mathrm{U}$ & 376 & $\mathrm{U}$ & 386 & $u$ & 419 & U & 379 & $\mathrm{U}$ & 386 & $\mathrm{U}$ & 392 & $\mathrm{U}$ \\
\hline
\end{tabular}

\begin{tabular}{lrlcccccc} 
& \multicolumn{6}{c}{ Borehole Concentrations $(\mu \mathrm{g} / \mathrm{kg})$ at Various Depths } \\
\cline { 2 - 8 } \multicolumn{1}{c}{ Compound } & $\begin{array}{c}\text { JBPP-B-3" } \\
(3 \mathrm{in} \text {. })\end{array}$ & $\begin{array}{c}\text { JBPP-B-1' } \\
(1 \mathrm{ft})\end{array}$ & $\begin{array}{c}\text { JBPP-C-3" } \\
(3 \mathrm{in} .)\end{array}$ & $\begin{array}{c}\text { JBPP-C-1' } \\
(1 \mathrm{ft})\end{array}$ \\
\hline Acenaphthene & 455 & $\mathrm{U}$ & 389 & $\mathrm{U}$ & 392 & $\mathrm{U}$ & 392 & $\mathrm{U}$ \\
Acenaphthylene & 455 & $\mathrm{U}$ & 389 & $\mathrm{U}$ & 392 & $\mathrm{U}$ & 392 & $\mathrm{U}$ \\
Anthracene & 455 & $\mathrm{U}$ & 389 & $\mathrm{U}$ & 392 & $\mathrm{U}$ & 392 & $\mathrm{U}$ \\
Benz[a]anthracene & 455 & $\mathrm{U}$ & 389 & $\mathrm{U}$ & 392 & $\mathrm{U}$ & 392 & $\mathrm{U}$ \\
Benzo[a]pyrene & 455 & $\mathrm{U}$ & 389 & $\mathrm{U}$ & 392 & $\mathrm{U}$ & 392 & $\mathrm{U}$ \\
Benzo[b]fluoranthene & 455 & $\mathrm{U}$ & 389 & $\mathrm{U}$ & 392 & $\mathrm{U}$ & 392 & $\mathrm{U}$ \\
Benzo[g,h,i]perylene & 455 & $\mathrm{U}$ & 389 & $\mathrm{U}$ & 392 & $\mathrm{U}$ & 392 & $\mathrm{U}$ \\
Benzoic acid & 2,280 & $\mathrm{U}$ & 1,950 & $\mathrm{U}$ & 1,960 & $\mathrm{U}$ & 1,960 & $\mathrm{U}$
\end{tabular}


TABLE C.14a (Cont.)

\begin{tabular}{|c|c|c|c|c|c|c|c|c|}
\hline \multirow{3}{*}{$\begin{array}{r}\text { Compound } \\
\text { Benzo[k]fluoranthene }\end{array}$} & \multicolumn{8}{|c|}{ Borehole Concentrations $(\mu \mathrm{g} / \mathrm{kg})$ at Various Depths } \\
\hline & \multicolumn{2}{|c|}{$\begin{array}{c}\text { JBPP-B-3" } \\
(3 \text { in. }) \\
\end{array}$} & \multicolumn{2}{|c|}{$\begin{array}{c}\text { JBPP-B-1' } \\
(1 \mathrm{ft})\end{array}$} & \multicolumn{2}{|c|}{$\begin{array}{c}\text { JBPP-C-3" } \\
(3 \text { in. }) \\
\end{array}$} & \multicolumn{2}{|c|}{$\begin{array}{c}\text { JBPP-C-1 } \\
(1 \mathrm{ft})\end{array}$} \\
\hline & 455 & $\mathrm{U}$ & 389 & $\mathbf{U}$ & 392 & U & 392 & $\mathrm{U}$ \\
\hline Benzyl alcohol & 910 & $\mathrm{U}$ & 778 & $\mathrm{U}$ & 785 & $\mathrm{U}$ & 785 & $\mathrm{U}$ \\
\hline Bis(2-chloroethoxy)methane & 455 & $\mathrm{U}$ & 389 & $\mathrm{U}$ & 392 & $\mathrm{U}$ & 392 & $\mathbf{U}$ \\
\hline Bis(2-chloroethyl)ether & 455 & $U$ & 389 & $\mathrm{U}$ & 392 & $\mathrm{U}$ & 392 & $\mathrm{U}$ \\
\hline Bis(2-chloroisopropyl)ether & 455 & $\mathrm{U}$ & 389 & $\mathrm{U}$ & 392 & $\mathrm{U}$ & 392 & $\mathrm{U}$ \\
\hline Bis(2-ethylhexyl)phthalate & 455 & $\mathrm{U}$ & 389 & $U$ & 392 & $\mathrm{U}$ & 392 & $\mathbf{U}$ \\
\hline 4-Bromophenyl phenyl ether & 455 & $\mathrm{U}$ & 389 & $\mathrm{U}$ & 392 & $\mathrm{U}$ & 392 & $U$ \\
\hline Butyl benzyl phthalate & 455 & $\mathrm{U}$ & 389 & $U$ & 392 & $\mathrm{U}$ & 392 & $\mathbf{U}$ \\
\hline 4-Chloro-3-methylphenol & 910 & $\mathbf{U}$ & 778 & $U$ & 785 & $\mathrm{U}$ & 785 & $\mathbf{U}$ \\
\hline 4-Chloroaniline & 910 & $U$ & 778 & $\mathbf{U}$ & 785 & $\mathrm{U}$ & 785 & $\mathrm{U}$ \\
\hline 2-Chloronaphthalene & 455 & $\mathrm{U}$ & 389 & $\mathbf{U}$ & 392 & $\mathbf{U}$ & 392 & $\mathbf{U}$ \\
\hline 2-Chlorophenol & 455 & $\mathrm{U}$ & 389 & $U$ & 392 & $\mathrm{U}$ & 392 & $\mathrm{U}$ \\
\hline 4-Chlorophenyl phenyl ether & 455 & $\mathbf{U}$ & 389 & $\mathbf{U}$ & 392 & $\mathbf{U}$ & 392 & $\mathbf{U}$ \\
\hline Chrysene & 455 & $\mathbf{U}$ & 389 & $\mathrm{U}$ & 392 & $\mathbf{U}$ & 392 & $\mathrm{U}$ \\
\hline Di-n-butylphthalate & 56 & $\mathrm{~J}$ & 389 & $\mathrm{U}$ & 392 & U & 392 & $\mathrm{U}$ \\
\hline Di-n-octylphthalate & 455 & U & 389 & $\mathrm{U}$ & 392 & $\mathbf{U}$ & 392 & $\mathrm{U}$ \\
\hline Dibenz $[\mathrm{a}, \mathrm{h}]$ anthracene & 455 & U & 389 & $\mathrm{U}$ & 392 & $\mathrm{U}$ & 392 & $\mathrm{U}$ \\
\hline Dibenzofuran & 455 & U & 389 & $\mathrm{U}$ & 392 & $\mathrm{U}$ & 392 & $\mathrm{U}$ \\
\hline 1,2-Dichlorobenzene & 455 & $U$ & 389 & $\mathrm{U}$ & 392 & $\mathrm{U}$ & 392 & $\mathrm{U}$ \\
\hline 1,3-Dichlorobenzene & 455 & $\mathrm{U}$ & 389 & $\mathrm{U}$ & 392 & $\mathrm{U}$ & 392 & $\mathrm{U}$ \\
\hline 1,4-Dichlorobenzene & 455 & $\mathrm{U}$ & 389 & $\mathrm{U}$ & 392 & $\mathrm{U}$ & 392 & $\mathbf{U}$ \\
\hline 3,3'-Dichlorobenzidine & 910 & $\mathrm{U}$ & 778 & $\mathbf{U}$ & 785 & $\mathrm{U}$ & 785 & $\mathbf{U}$ \\
\hline 2,4-Dichlorophenol & 455 & $\mathrm{U}$ & 389 & U & 392 & $\mathrm{U}$ & 392 & $\mathrm{U}$ \\
\hline Diethylphthalate & 455 & $\mathrm{U}$ & 389. & $\mathrm{U}$ & 392 & $\mathrm{U}$ & 392 & $\mathrm{U}$ \\
\hline 2,4-Dimethylphenol & 455 & $\mathrm{U}$ & 389 & $\mathbf{U}$ & 392 & $\mathrm{U}$ & 392 & U \\
\hline Dimethylphthalate & 455 & U & 389 & $\mathbf{U}$ & 392 & $\mathrm{U}$ & 392 & $\mathrm{U}$ \\
\hline
\end{tabular}


TABLE C.14a (Cont.)

\begin{tabular}{|c|c|c|c|c|c|c|c|c|}
\hline \multirow{3}{*}{$\frac{\text { Compound }}{\text { 4,6-Dinitro-2-methylphenol }}$} & \multicolumn{8}{|c|}{ Borehole Concentrations $(\mu \mathrm{g} / \mathrm{kg})$ at Various Depths } \\
\hline & \multicolumn{2}{|c|}{$\begin{array}{c}\text { JBPP-B-3" } \\
\text { (3 in.) }\end{array}$} & \multicolumn{2}{|c|}{$\begin{array}{c}\text { JBPP-B-1' } \\
(1 \mathrm{ft}) \\
\end{array}$} & \multicolumn{2}{|c|}{$\begin{array}{c}\text { JBPP-C-3" } \\
(3 \text { in. }) \\
\end{array}$} & \multicolumn{2}{|c|}{$\begin{array}{c}\text { JBPP-C-1' } \\
(1 \mathrm{ft})\end{array}$} \\
\hline & 2,280 & U & 1,950 & $\mathrm{U}$ & 1,960 & $\mathbf{U}$ & 1,960 & $\mathrm{U}$ \\
\hline 2,4-Dinitrophenol & 2,280 & $\mathrm{U}$ & 1,950 & $\mathrm{U}$ & 1,960 & $\mathrm{U}$ & 1,960 & U \\
\hline 2,4-Dinitrotoluene & 455 & U & 389 & $\mathrm{U}$ & 392 & $\mathrm{U}$ & 392 & U \\
\hline 2,6-Dinitrotoluene & 455 & U & 389 & $\mathrm{U}$ & 392 & $\mathrm{U}$ & 392 & U \\
\hline Fluoranthene & 455 & $\mathrm{U}$ & 389 & $\mathbf{U}$ & 392 & $\mathrm{U}$ & 392 & $\mathbf{U}$ \\
\hline Fluorene & 455 & $\mathrm{U}$ & 389 & $\mathbf{U}$ & 392 & $U$ & 392 & $\mathrm{U}$ \\
\hline Hexachlorobenzene & 455 & $\mathbf{U}$ & 389 & U & 392 & $\mathrm{U}$ & 392 & $\mathbf{U}$ \\
\hline Hexachlorobutadiene & 455 & $\mathbf{U}$ & 389 & $\mathrm{U}$ & 392 & $U$ & 392 & $\mathrm{U}$ \\
\hline Hexachlorocyclopentadiene & 455 & $\mathbf{U}$ & 389 & $\mathrm{U}$ & 392 & $\mathrm{U}$ & 392 & $\mathbf{U}$ \\
\hline Hexachloroethane & 455 & $\mathrm{U}$ & 389 & $\mathrm{U}$ & 392 & $\mathrm{U}$ & 392 & $\mathrm{U}$ \\
\hline Indeno $[1,2,3-c, d]$ pyrene & 455 & $\mathrm{U}$ & 389 & $\mathrm{U}$ & 392 & U & 392 & $\mathrm{U}$ \\
\hline Isophorone & 455 & $U$ & 389 & $\mathrm{U}$ & 392 & $\mathbf{U}$ & 392 & U \\
\hline 2-Methylnaphthalene & 161 & J & 389 & $\mathrm{U}$ & 392 & $\mathrm{U}$ & 392 & U \\
\hline 2-Methylphenol & 455 & U & 389 & $\mathrm{U}$ & 392 & $\mathrm{U}$ & 392 & $U$ \\
\hline 4-Methylphenol & 455 & $\mathrm{U}$ & 389 & $\mathrm{U}$ & 392 & $\mathbf{U}$ & 392 & $\mathrm{U}$ \\
\hline Naphthalene & 309 & $\mathbf{J}$ & 389 & $\mathrm{U}$ & 392 & $\mathbf{U}$ & 392 & $\mathbf{U}$ \\
\hline 2-Nitroaniline & 2,280 & $\mathrm{U}$ & 1,950 & $\mathbf{U}$ & 1,960 & $\mathbf{U}$ & 1,960 & $\mathrm{U}$ \\
\hline 3-Nitroaniline & 2,280 & $\mathbf{U}$ & 1,950 & $U$ & 1,960 & $\mathbf{U}$ & 1,960 & $\mathrm{U}$ \\
\hline 4-Nitroaniline & 2,280 & $\mathrm{U}$ & 1,950 & $\mathrm{U}$ & 1,960 & $\mathrm{U}$ & 1,960 & $\mathrm{U}$ \\
\hline Nitrobenzene & 455 & U & 389 & $U$ & 392 & U & 392 & $U$ \\
\hline 2-Nitrophenol & 455 & $\mathrm{U}$ & 389 & $\mathrm{U}$ & 392 & $\mathrm{U}$ & 392 & U \\
\hline 4-Nitrophenol & 2,280 & $U$ & 1,950 & $\mathrm{U}$ & 1,960 & U & 1,960 & $\mathbf{U}$ \\
\hline N-Nitroso-di-n-propylamine & 455 & $\mathbf{U}$ & 389 & $\mathrm{U}$ & 392 & $\mathrm{U}$ & 392 & $\mathrm{U}$ \\
\hline N-Nitrosodiphenylamine & 455 & $\mathrm{U}$ & 389 & $\mathrm{U}$ & 392 & $\mathrm{U}$ & 392 & $\mathbf{U}$ \\
\hline Pentachlorophenol & 2,280 & $\mathrm{U}$ & 1,950 & U & 1,960 & $\mathrm{U}$ & 1,960 & $\mathbf{U}$ \\
\hline Phenanthrene & 73 & $\mathbf{J}$ & 389 & U & 392 & $\mathrm{U}$ & 392 & $U$ \\
\hline
\end{tabular}


TABLE C.14a (Cont.)

\begin{tabular}{|c|c|c|c|c|c|c|c|c|}
\hline \multirow[b]{2}{*}{ Compound } & \multicolumn{8}{|c|}{ Borehole Concentrations $(\mu \mathrm{g} / \mathrm{kg})$ at Various Depths } \\
\hline & \multicolumn{2}{|c|}{$\begin{array}{c}\text { JBPP-B-3" } \\
(3 \text { in. })\end{array}$} & \multicolumn{2}{|c|}{$\begin{array}{c}\text { JBPP-B-1' } \\
(1 \mathrm{ft})\end{array}$} & \multicolumn{2}{|c|}{$\begin{array}{c}\text { JBPP-C-3" } \\
(3 \text { in.) }\end{array}$} & \multicolumn{2}{|c|}{$\begin{array}{c}\text { JBPP-C-1' } \\
(1 \mathrm{ft})\end{array}$} \\
\hline Phenol & 455 & $\mathrm{U}$ & 389 & $\mathrm{U}$ & 392 & $\mathbf{U}$ & 392 & $\mathrm{U}$ \\
\hline Pyrene & 455 & $\mathrm{U}$ & 389 & $\mathrm{U}$ & 392 & $\mathrm{U}$ & 392 & $\mathbf{U}$ \\
\hline 1,2,4-Trichlorobenzene & 455 & U & 389 & $\mathrm{U}$ & 392 & $\mathrm{U}$ & 392 & $U$ \\
\hline 2,4,5-Trichlorophenol & 455 & $\mathrm{U}$ & 389 & $\mathrm{U}$ & 392 & $\mathrm{U}$ & 392 & $\mathbf{U}$ \\
\hline 2,4,6-Trichlorophenol & 455 & $\mathrm{U}$ & 389 & $\mathrm{U}$ & 392 & $\mathrm{U}$ & 392 & $\mathbf{U}$ \\
\hline
\end{tabular}

a Sampled by Weston, analyzed by GP Environmental Services, CLP/HSL volatile organics; provisional data.

Data qualifiers:

$\mathrm{U}=$ analyte was analyzed for but not detected.

$\mathrm{J}=$ estimated value. 
TABLE C.14b Semivolatile Organics Analyses for Soil Borings, January $1994^{a}$

\begin{tabular}{|c|c|c|c|c|c|c|c|c|c|c|}
\hline \multirow{3}{*}{ Compound } & \multicolumn{10}{|c|}{ Soil Concentrations $(\mu \mathrm{g} / \mathrm{kg}$ ) at Various Depth Intervals } \\
\hline & \multicolumn{2}{|c|}{$\begin{array}{c}\text { CLPI } \\
(0.6 \text { in. })\end{array}$} & \multicolumn{2}{|c|}{$\begin{array}{c}\text { CLP1 } \\
(6-24 \text { in. })\end{array}$} & \multicolumn{2}{|c|}{$\begin{array}{c}\text { CLP1 } \\
\text { (24-40 in.) }\end{array}$} & \multicolumn{2}{|c|}{$\begin{array}{c}\text { CLP2 } \\
(0-6 \text { in. })\end{array}$} & \multicolumn{2}{|c|}{$\begin{array}{c}\text { CLP2 } \\
(6-24 \text { in. })\end{array}$} \\
\hline & 500 & U & 420 & $U$ & 420 & $\mathbf{U}$ & 420 & $\mathrm{U}$ & 430 & $\mathrm{U}$ \\
\hline Acenaphthylene & 500 & $\mathrm{U}$ & 420 & $\mathrm{U}$ & 420 & $\mathbf{U}$ & 420 & $\mathrm{U}$ & 430 & $\mathbf{U}$ \\
\hline Anthracene & 500 & $\mathbf{U}$ & 420 & $\mathrm{U}$ & 420 & $\mathrm{U}$ & 420 & $\mathrm{U}$ & 430 & $\mathbf{U}$ \\
\hline Benz[a]anthracene & 500 & U & 420 & $\mathrm{U}$ & 420 & $U$ & 420 & $\mathrm{U}$ & 430 & $\mathbf{U}$ \\
\hline Benzo[a]pyrene & 500 & $U$ & 420 & $\mathrm{U}$ & 420 & $\mathbf{U}$ & 420 & $\mathbf{U}$ & 430 & $\mathrm{U}$ \\
\hline Benzo[b]fluoranthene & 500 & U & 420 & $\mathrm{U}$ & 420 & $\mathrm{U}$ & 420 & $\mathbf{U}$ & 430 & $\mathbf{U}$ \\
\hline Benzo[g,h,i]perylene & 500 & $U$ & 420 & $\mathbf{U}$ & 420 & $\mathbf{U}$ & 420 & $\mathrm{U}$ & 430 & $\mathbf{U}$ \\
\hline Benzo[k]fluoranthene & 500 & $\mathbf{U}$ & 420 & $\mathrm{U}$ & 420 & $\mathbf{U}$ & 420 & $\mathbf{U}$ & 430 & $\mathrm{U}$ \\
\hline Bis(2-chloroethoxy)methane & 500 & $\mathrm{U}$ & 420 & $\mathbf{U}$ & 420 & $\mathrm{U}$ & 420 & $\mathbf{U}$ & 430 & $\mathrm{U}$ \\
\hline Bis(2-chloroethyl)ether & 500 & $\mathrm{U}$ & 420 & $\mathbf{u}$ & 420 & $\mathbf{U}$ & 420 & $\mathbf{U}$ & 430 & $\mathrm{U}$ \\
\hline Bis(2-chloroisopropyl)ether & 500 & $\mathrm{U}$ & 420 & $\mathrm{U}$ & 420 & $\mathbf{U}$ & 420 & U & 430 & $\mathbf{U}$ \\
\hline Bis(2-ethylhexyl)phthalate & 500 & JB & 420 & $\mathrm{JB}$ & 420 & JB & 420 & JB & 430 & JB \\
\hline 4-Bromophenyl phenyl ether & 500 & $\mathbf{U}$ & 420 & $\mathbf{U}$ & 420 & $\mathbf{U}$ & 420 & $\mathbf{U}$ & 430 & $\mathrm{U}$ \\
\hline Butylbenzylphthalate & 500 & $\mathbf{U}$ & 420 & $\mathrm{U}$ & 420 & $\mathrm{U}$ & 420 & $\mathbf{U}$ & 430 & $\mathrm{U}$ \\
\hline Carbazole & 500 & $\mathbf{U}$ & 420 & $\mathrm{U}$ & 420 & $\mathrm{U}$ & 420 & $\mathrm{U}$ & 430 & $\mathbf{U}$ \\
\hline 4-Chloro-3-methylphenol & 500 & $\mathbf{U}$ & 420 & $\mathrm{U}$ & 420 & $\mathbf{U}$ & 420 & $U$ & 430 & $U$ \\
\hline 4-Chloroaniline & 500 & $\mathrm{U}$ & 420 & $U$ & 420 & $\mathrm{U}$ & 420 & $\mathrm{U}$ & 430 & U \\
\hline 2-Chloronaphthalene & 500 & $\mathbf{U}$ & 420 & $\mathrm{U}$ & 420 & $\mathrm{U}$ & 420 & $\mathrm{U}$ & 430 & $\mathrm{U}$ \\
\hline 2-Chlorophenol & 500 & $\mathbf{U}$ & 420 & $U$ & 420 & $\mathrm{U}$ & 420 & $\mathrm{U}$ & 430 & $\mathrm{U}$ \\
\hline 4-Chlorophenyl phenyl ether & 500 & $\mathbf{U}$ & 420 & $\mathrm{U}$ & 420 & $U$ & 420 & $U$ & 430 & $\mathbf{U}$ \\
\hline Chrysene & 500 & $\mathrm{U}$ & 420 & $\mathrm{U}$ & 420 & $\mathrm{U}$ & 420 & $U$ & 430 & $\mathrm{U}$ \\
\hline Di-n-butylphthalate & 500 & $\mathrm{JB}$ & 420 & $\mathrm{JB}$ & 420 & $\mathrm{JB}$ & 420 & $\mathrm{JB}$ & 430 & JB \\
\hline Di-n-octyl phthalate & 500 & $\mathrm{U}$ & 420 & $\mathrm{U}$ & 420 & $\mathrm{U}$ & 420 & $\mathrm{U}$ & 430 & $\mathbf{U}$ \\
\hline Dibenz $[a, h] a n t h r a c e n e$ & 500 & $U$ & 420 & $u$ & 420 & $\mathrm{U}$ & 420 & $U$ & 430 & $\mathbf{U}$ \\
\hline Dibenzofuran & 500 & $\mathrm{U}$ & 420 & $\mathrm{U}$ & 420 & $\mathbf{U}$ & 420 & $\mathrm{U}$ & 430 & $\mathbf{U}$ \\
\hline 1,2-Dichlorobenzene & 500 & $\mathrm{U}$ & 420 & $\mathbf{U}$ & 420 & U & 420 & $\mathrm{U}$ & 430 & $U$ \\
\hline 1,3-Dichlorobenzene & 500 & $\mathrm{U}$ & 420 & $\mathbf{U}$ & 420 & & 420 & U & 430 & $\mathrm{U}$ \\
\hline 1,4-Dichlorobenzene & 500 & $\mathrm{U}$ & 420 & $\mathrm{U}$ & 420 & $\mathrm{U}$ & 420 & $\mathbf{U}$ & 430 & $\mathbf{U}$ \\
\hline
\end{tabular}


TABLE C.14b (Cont.)

\begin{tabular}{|c|c|c|c|c|c|c|c|c|c|c|}
\hline \multirow{3}{*}{$\frac{\text { Compound }}{\text { 3,3'-Dichlorobenzidine }}$} & \multicolumn{10}{|c|}{ Soil Concentrations $(\mu \mathrm{g} / \mathrm{kg})$ at Various Depth Intervals } \\
\hline & \multicolumn{2}{|c|}{$\begin{array}{c}\text { CLP1 } \\
(0-6 \text { in.) }\end{array}$} & \multicolumn{2}{|c|}{$\begin{array}{c}\text { CLP1 } \\
\text { (6-24 in.) }\end{array}$} & \multicolumn{2}{|c|}{$\begin{array}{c}\text { CLPI } \\
(24-40 \text { in.) }\end{array}$} & \multicolumn{2}{|c|}{$\begin{array}{c}\text { CLP2 } \\
(0.6 \text { in. })\end{array}$} & \multicolumn{2}{|c|}{$\begin{array}{c}\text { CLP2 } \\
\text { (6-24 in.) } \\
\end{array}$} \\
\hline & 500 & U & 420 & $\mathrm{U}$ & 420 & $\mathrm{U}$ & 420 & $\mathbf{U}$ & 430 & $\mathrm{U}$ \\
\hline 2,4-Dichlorophenol & 500 & U & 420 & $\mathrm{U}$ & 420 & $\mathbf{U}$ & 420 & $\mathrm{U}$ & 430 & $\mathbf{U}$ \\
\hline Diethylphthalate & 500 & $\mathrm{U}$ & 420 & $\mathrm{U}$ & 420 & J & 420 & $\mathbf{U}$ & 430 & \\
\hline 2,4-Dimethylphenol & 500 & $\mathrm{U}$ & 420 & U & 420 & $\mathrm{U}$ & 420 & $\mathbf{J}$ & 430 & $\mathrm{~J}$ \\
\hline Dimethylphthalate & 500 & $\mathrm{U}$ & 420 & $\mathrm{U}$ & 420 & $\mathrm{U}$ & 420 & $\mathrm{U}$ & 430 & $\mathrm{U}$ \\
\hline 4,6-Dinitro-2-methylphenol & 1,200 & $U$ & 1,000 & $\mathbf{U}$ & 1,000 & $\mathrm{U}$ & 1,000 & $\mathrm{U}$ & 1,100 & $\mathbf{U}$ \\
\hline 2,4-Dinitrophenol & 1,200 & $\mathrm{U}$ & 1,000 & $\mathrm{U}$ & 1,000 & $\mathbf{U}$ & 1,000 & $\mathrm{U}$ & 1,100 & $\mathrm{U}$ \\
\hline 2,4-Dinitrotoluene & 500 & $U$ & 420 & $\mathrm{U}$ & 420 & $\mathbf{U}$ & 420 & $U$ & 430 & u \\
\hline 2,6-Dinitrotoluene & 500 & U & 420 & $\mathrm{U}$ & 420 & $\mathbf{U}$ & 420 & $\mathbf{U}$ & 430 & $\mathbf{U}$ \\
\hline Fluoranthene & 500 & $\mathbf{U}$ & 420 & $\mathrm{U}$ & 420 & U & 420 & U & 430 & $\mathbf{U}$ \\
\hline Fluorene & 500 & $\mathrm{U}$ & 420 & $\mathrm{U}$ & 420 & U & 420 & U & 430 & $\mathrm{U}$ \\
\hline Hexachlorobenzene & 500 & $\mathbf{J}$ & 420 & $\mathrm{U}$ & 420 & $\mathbf{J}$ & 420 & $\mathbf{J}$ & 430 & $\mathbf{J}$ \\
\hline Hexachlorobutadiene & 500 & $\mathrm{U}$ & 420 & $\mathrm{U}$ & 420 & $\mathbf{U}$ & 420 & $\mathbf{U}$ & 430 & $\mathbf{U}$ \\
\hline Hexachlorocyclopentadiene & 500 & $\mathrm{U}$ & 420 & U & 420 & $\mathbf{U}$ & 420 & $\mathrm{U}$ & 430 & $\mathrm{U}$ \\
\hline Hexachloroethane & 500 & $U$ & 420 & $\mathbf{U}$ & 420 & $\mathrm{U}$ & 420 & $\mathrm{U}$ & 430 & $\mathrm{U}$ \\
\hline Indeno[1,2,3-c,d]pyrene & 500 & $\mathbf{U}$ & 420 & $\mathbf{U}$ & 420 & $\mathbf{U}$ & 420 & $U$ & 430 & $\mathrm{U}$ \\
\hline Isophorone & 500 & $\mathbf{U}$ & 420 & $\mathbf{U}$ & 420 & $\mathbf{U}$ & 420 & $U$ & 430 & $\mathrm{U}$ \\
\hline 2-Methylnaphthalene & 500 & $\mathbf{U}$ & 420 & $\mathrm{U}$ & 420 & $\mathbf{U}$ & 420 & $\mathrm{U}$ & 430 & $\mathbf{J}$ \\
\hline 2-Methylphenol & 500 & $\mathbf{U}$ & 420 & $\mathbf{U}$ & 420 & $\mathbf{U}$ & 420 & $\mathbf{J}$ & 430 & \\
\hline 4-Methylphenol & 500 & $\mathbf{U}$ & 420 & $\mathbf{U}$ & 420 & $\mathbf{U}$ & 420 & & 430 & \\
\hline Naphthalene & 500 & $\mathrm{U}$ & 420 & $\mathbf{U}$ & 420 & $U$ & 420 & $\mathbf{U}$ & 430 & J \\
\hline 2-Nitroaniline & 1,200 & $\mathbf{U}$ & 1,000 & $\mathrm{U}$ & 1,000 & $\mathbf{U}$ & 1,000 & $\mathbf{U}$ & 1,100 & $\mathrm{U}$ \\
\hline 3-Nitroaniline & 1,200 & $\mathbf{U}$ & 1,000 & $\mathrm{U}$ & 1,000 & $\mathbf{U}$ & 1,000 & U & 1,100 & $\mathrm{U}$ \\
\hline 4-Nitroaniline & 1,200 & $\mathbf{U}$ & 1,000 & $\mathbf{U}$ & 1,000 & $\mathrm{U}$ & 1,000 & $\mathbf{U}$ & 1,100 & $\mathrm{U}$ \\
\hline Nitrobenzene & 500 & $\mathrm{U}$ & 420 & $\mathbf{U}$ & 420 & $\mathrm{U}$ & 420 & $\mathbf{U}$ & 430 & $\mathrm{U}$ \\
\hline 2-Nitrophenol & 500 & $\mathbf{U}$ & 420 & $\mathbf{U}$ & 420 & $\mathbf{U}$ & 420 & $\mathbf{U}$ & 430 & $\mathrm{U}$ \\
\hline 4-Nitrophenol & 1,200 & $\mathbf{U}$ & 1,000 & $\mathbf{U}$ & 1,000 & $\mathbf{U}$ & 1,000 & $\mathbf{U}$ & 1,100 & $\mathrm{U}$ \\
\hline N-Nitroso-di-n-propylamine & 500 & $\mathbf{U}$ & 420 & $\mathrm{U}$ & 420 & U & 420 & $\mathbf{U}$ & 430 & U \\
\hline N-Nitrosodiphenylamine & 500 & $\mathbf{U}$ & 420 & U & 420 & $U$ & 420 & $\mathbf{U}$ & 430 & J \\
\hline
\end{tabular}




\section{TABLE C.14b (Cont.)}

\begin{tabular}{|c|c|c|c|c|c|c|c|c|c|c|}
\hline \multirow{3}{*}{$\begin{array}{c}\text { Compound } \\
\text { Pentachlorophenol }\end{array}$} & \multicolumn{10}{|c|}{ Soil Concentrations $(\mu \mathrm{g} / \mathrm{kg})$ at Various Depth Intervals } \\
\hline & \multicolumn{2}{|c|}{$\begin{array}{l}\text { CLPI } \\
(0-6 \text { in. }) \\
\end{array}$} & \multicolumn{2}{|c|}{$\begin{array}{c}\text { CLP1 } \\
(6-24 \text { in. })\end{array}$} & \multicolumn{2}{|c|}{$\begin{array}{c}\text { CLP1 } \\
\text { (24-40 in.) }\end{array}$} & \multicolumn{2}{|c|}{$\begin{array}{c}\text { CLP2 } \\
(0.6 \text { in. }) \\
\end{array}$} & \multicolumn{2}{|c|}{$\begin{array}{c}\text { CLP2 } \\
(6-24 \text { in.) }\end{array}$} \\
\hline & 1,200 & $\mathbf{U}$ & 1,000 & $\mathbf{U}$ & 1,000 & $\mathbf{U}$ & 1,000 & $\mathbf{U}$ & 1,100 & $\mathrm{U}$ \\
\hline Phenanthrene & 500 & $\mathrm{U}$ & 420 & $\mathbf{U}$ & 420 & U & 420 & $\mathrm{U}$ & 430 & $\mathbf{U}$ \\
\hline Phenol & 500 & $\mathbf{U}$ & 420 & $\mathbf{U}$ & 420 & $\mathbf{U}$ & 420 & J & 430 & J \\
\hline Pyrene & 500 & $\mathbf{U}$ & 420 & $\mathbf{U}$ & 420 & $\mathrm{U}$ & 420 & $\mathrm{U}$ & 430 & $\mathrm{U}$ \\
\hline 1,2,4-Trichlorobenzene & 500 & $\mathbf{u}$ & 420 & $\mathbf{U}$ & 420 & $\mathbf{U}$ & 420 & $\mathbf{U}$ & 430 & $\mathrm{U}$ \\
\hline 2,4,5-Trichlorophenol & 1,200 & $\mathbf{U}$ & 1,000 & $\mathbf{U}$ & 1,000 & $\mathbf{U}$ & 1,000 & $\mathrm{U}$ & 1,100 & $\mathrm{U}$ \\
\hline 2,4,6-Trichlorophenol & 500 & U & 420 & $\mathrm{U}$ & 420 & U & 420 & $\mathrm{U}$ & 430 & $\mathrm{U}$ \\
\hline \multirow[b]{2}{*}{ Compound } & \multicolumn{10}{|c|}{ Soil Concentrations $(\mu \mathrm{g} / \mathrm{kg})$ at Various Depth Intervals } \\
\hline & \multicolumn{2}{|c|}{$\begin{array}{c}\text { CLP2 } \\
\text { (24-48 in.) }\end{array}$} & \multicolumn{2}{|c|}{$\begin{array}{c}\text { CLP3 } \\
\text { (0.6 in.) } \\
\end{array}$} & \multicolumn{2}{|c|}{$\begin{array}{c}\text { CLP3 } \\
(6-24 \text { in. }) \\
\end{array}$} & \multicolumn{2}{|c|}{$\begin{array}{l}\text { CLP3-Dup } \\
\text { (6-24 in.) }\end{array}$} & \multicolumn{2}{|c|}{$\begin{array}{c}\text { CLP3 } \\
\text { (24-48 in.) }\end{array}$} \\
\hline Acenaphthene & 500 & $\mathrm{U}$ & 590 & U & 490 & $\mathrm{U}$ & 2,500 & $\mathrm{U}$ & 970 & $\mathrm{U}$ \\
\hline Acenaphthylene & 500 & $U$ & 590 & $\mathbf{U}$ & 490 & $\mathrm{U}$ & 2,500 & $\mathrm{U}$ & 970 & $\mathrm{U}$ \\
\hline Anthracene & 500 & $\mathbf{U}$ & 590 & U & 490 & $\mathbf{U}$ & 2,500 & $\mathrm{U}$ & 970 & $\mathrm{U}$ \\
\hline Benz[a]anthracene & 500 & $\mathbf{U}$ & 590 & $\mathrm{U}$ & 490 & $\mathrm{U}$ & 2,500 & $\mathrm{U}$ & 970 & $\mathrm{U}$ \\
\hline Benzo[a]pyrene & 500 & $\mathrm{U}$ & 590 & $\mathrm{U}$ & 490 & $\mathbf{U}$ & 2,500 & $\mathrm{U}$ & 970 & U \\
\hline Benzo[b]fluoranthene & 500 & $\mathrm{U}$ & 590 & $\mathrm{U}$ & 490 & $\mathbf{U}$ & 2,500 & $\mathrm{U}$ & 970 & $\mathrm{U}$ \\
\hline Benzo[g,h,i]perylene & 500 & $\mathbf{U}$ & 590 & $\mathbf{U}$ & 490 & $\mathrm{U}$ & 2,500 & $\mathrm{U}$ & 970 & $\mathbf{U}$ \\
\hline Benzo[k]fluoranthene & 500 & $\mathbf{U}$ & 590 & $\mathrm{U}$ & 490 & $\mathbf{U}$ & 2,500 & $\mathrm{U}$ & 970 & $\mathrm{U}$ \\
\hline Bis(2-chloroethoxy)methane & 500 & $\mathrm{U}$ & 590 & $\mathrm{U}$ & 490 & $U$ & 2,500 & $\mathrm{U}$ & 970 & $\mathbf{U}$ \\
\hline Bis(2-chloroethyl)ether & 500 & $\mathrm{U}$ & 590 & $\mathrm{U}$ & 490 & $\mathrm{U}$ & 2,500 & $\mathrm{U}$ & 970 & $\mathrm{U}$ \\
\hline Bis(2-chloroisopropyl)ether & 500 & $U$ & 590 & $U$ & 490 & $\mathrm{U}$ & 2,500 & $\mathrm{U}$ & 970 & $\mathbf{U}$ \\
\hline Bis(2-ethylhexyl)phthalate & 500 & $\mathrm{U}$ & .590 & $\mathrm{JB}$ & 260 & JB & 2,500 & $\mathrm{U}$ & 460 & JB \\
\hline 4-Bromophenyl phenyl ether & 500 & $U$ & 590 & $\mathrm{U}$ & 490 & $\mathrm{U}$ & 2,500 & $\mathrm{U}$ & 970 & $\mathbf{U}$ \\
\hline Butylbenzylphthalate & 500 & $\mathbf{U}$ & 590 & $\mathrm{U}$ & 490 & $\mathbf{U}$ & 2,500 & $\mathrm{U}$ & 970 & $\mathbf{U}$ \\
\hline Carbazole & 500 & $\mathrm{U}$ & 590 & $\mathrm{U}$ & 490 & $\mathbf{U}$ & 2,500 & $\mathrm{U}$ & 970 & $\mathbf{U}$ \\
\hline 4-Chloro-3-methylphenol & 500 & $\mathrm{U}$ & 590 & $\mathrm{U}$ & 490 & $\mathrm{U}$ & 2,500 & $\mathrm{U}$ & 970 & $\mathbf{U}$ \\
\hline 4-Chloroaniline & 500 & $\mathrm{U}$ & 590 & $\mathrm{U}$ & 490 & $\mathbf{U}$ & 2,500 & U & 970 & $\mathbf{U}$ \\
\hline
\end{tabular}


TABLE C.14b (Cont.)

\begin{tabular}{|c|c|c|c|c|c|c|c|c|c|c|}
\hline \multirow{3}{*}{$\frac{\text { Compound }}{\text { 2-Chloronaphthalene }}$} & \multicolumn{10}{|c|}{ Soil Concentrations $(\mu \mathrm{g} / \mathrm{kg})$ at Various Depth Intervals } \\
\hline & \multicolumn{2}{|c|}{$\begin{array}{c}\text { CLP2 } \\
\text { (24-48 in.) } \\
\end{array}$} & \multicolumn{2}{|c|}{$\begin{array}{c}\text { CLP3 } \\
(0-6 \text { in. }) \\
\end{array}$} & \multicolumn{2}{|c|}{$\begin{array}{c}\text { CLP3 } \\
\text { (6-24 in.) } \\
\end{array}$} & \multicolumn{2}{|c|}{$\begin{array}{c}\text { CLP3-Dup } \\
\text { (6-24 in.) }\end{array}$} & \multicolumn{2}{|c|}{$\begin{array}{c}\text { CLP3 } \\
\text { (24-48 in.) }\end{array}$} \\
\hline & 500 & $\mathbf{U}$ & 590 & $\mathrm{U}$ & 490 & $\mathrm{U}$ & 2,500 & $\mathbf{U}$ & 970 & $\mathbf{U}$ \\
\hline 2-Chlorophenol & 500 & $\mathbf{U}$ & 590 & $\mathrm{U}$ & 490 & $\mathrm{U}$ & 2,500 & $\mathrm{U}$ & 970 & $\mathbf{U}$ \\
\hline 4-Chlorophenyl phenyl ether & 500 & $\mathbf{U}$ & 590 & $\mathrm{U}$ & 490 & $\mathrm{U}$ & 2,500 & $\mathbf{U}$ & 970 & $\mathbf{U}$ \\
\hline Chrysene & 500 & $U$ & 590 & $\mathbf{J}$ & 490 & $\mathrm{U}$ & 2,500 & $\mathbf{U}$ & 970 & U \\
\hline Di-n-butylphthalate & 500 & $\mathrm{U}$ & 590 & JB & 220 & JB & 2,500 & $\mathbf{U}$ & 380 & JB \\
\hline Di-n-octyl phthalate & 500 & $\mathbf{U}$ & 590 & $\mathrm{U}$ & 490 & $\mathbf{U}$ & 2,500 & $\mathrm{U}$ & 970 & $\mathbf{U}$ \\
\hline Dibenz $[\mathrm{a}, \mathrm{h}] \mathrm{anthracene}$ & 500 & $\mathbf{U}$ & 590 & $\mathrm{U}$ & 490 & $U$ & 2,500 & $\mathbf{U}$ & 970 & $\mathbf{U}$ \\
\hline Dibenzofuran & 500 & $\mathbf{U}$ & 590 & $\mathbf{U}$ & 490 & U & 2,500 & $\mathbf{U}$ & 970 & U \\
\hline 1,2-Dichlorobenzene & 500 & $\mathbf{U}$ & 590 & $\mathrm{U}$ & 490 & $\mathbf{U}$ & 2,500 & $\mathbf{U}$ & 420 & $\mathrm{~J}$ \\
\hline 1,3-Dichlorobenzene & 500 & $\mathrm{U}$ & 590 & $\mathbf{U}$ & 490 & $\mathbf{U}$ & 2,500 & $U$ & 210 & $\mathbf{J}$ \\
\hline 1,4-Dichlorobenzene & 500 & $\mathrm{U}$ & 590 & $\mathrm{U}$ & 490 & $\mathbf{U}$ & 2,500 & $\mathbf{U}$ & 970 & $\mathrm{U}$ \\
\hline 3,3'-Dichlorobenzidine & 500 & $\mathbf{U}$ & 590 & $\mathbf{U}$ & 490 & U & 2,500 & $\mathrm{U}$ & 970 & $\mathbf{U}$ \\
\hline 2,4-Dichlorophenol & 500 & $\mathbf{U}$ & 590 & $\mathbf{U}$ & 490 & $\mathbf{U}$ & 2,500 & $U$ & 970 & U \\
\hline Diethylphthalate & 500 & $\mathbf{U}$ & 590 & $\mathbf{U}$ & 2,000 & & 2,500 & $U$ & 970. & $\mathbf{U}$ \\
\hline 2,4-Dimethylphenol & 500 & $U$ & 590 & $\mathbf{U}$ & 490 & $\mathbf{U}$ & 2,500 & $\mathrm{U}$ & 970 & U \\
\hline Dimethylphthalate & 500 & $U$ & 590 & $\mathbf{U}$ & 490 & $\mathbf{U}$ & 2,500 & U & 970 & $\mathbf{U}$ \\
\hline 4,6-Dinitro-2-methylphenol & 1,200 & $\mathrm{U}$ & 1,500 & $\mathbf{U}$ & 1,200 & $\mathrm{U}$ & 6,200 & $\mathbf{U}$ & 2,400 & $\mathbf{U}$ \\
\hline 2,4-Dinitrophenol & 1,200 & $\mathbf{U}$ & 1,500 & $\mathbf{U}$ & 1,200 & $\mathbf{U}$ & 6,200 & $U$ & 2,400 & $\mathbf{U}$ \\
\hline 2,4-Dinitrotoluene & 500 & U & 590 & $\mathrm{U}$ & 490 & $\mathrm{U}$ & 2,500 & $\mathrm{U}$ & 970 & U \\
\hline 2,6-Dinitrotoluene & 500 & $U$ & 590 & $\mathbf{U}$ & 490 & $\mathbf{U}$ & 2,500 & $U$ & 970 & $\mathrm{U}$ \\
\hline Fluoranthene & 500 & U & 590 & $\mathbf{J}$ & 490 & U & 2,500 & $\mathbf{U}$ & 970 & $\mathrm{U}$ \\
\hline Fluorene & 500 & $\mathrm{U}$ & 590 & $\mathbf{U}$ & 490 & $\mathrm{U}$ & 2,500 & $\mathbf{U}$ & 970 & $\mathbf{U}$ \\
\hline Hexachlorobenzene & 500 & $\mathrm{U}$ & 590 & & 3,100 & & 2,500 & $\mathbf{U}$ & 710 & $\mathbf{J}$ \\
\hline Hexachlorobutadiene & 500 & $\mathrm{U}$ & 590 & $U$ & 490 & $U$ & 2,500 & $\mathrm{U}$ & 970 & $\mathbf{U}$ \\
\hline Hexachlorocyclopentadiene & 500 & $\mathrm{U}$ & 590 & $U$ & 490 & U & 2,500 & $\mathrm{U}$ & 970 & $\mathbf{U}$ \\
\hline Hexachloroethane & 500 & $\mathrm{U}$ & 590 & $\mathbf{J}$ & 490 & $\mathbf{U}$ & 2,500 & $\mathbf{U}$ & 970 & $\mathbf{U}$ \\
\hline Indeno $[1,2,3-c, d]$ pyrene & 500 & $\mathbf{U}$ & 590 & $\mathrm{U}$ & 490 & $\mathbf{U}$ & 2,500 & $\mathbf{U}$ & 970 & $\mathbf{U}$ \\
\hline Isophorone & 500 & $\mathbf{U}$ & 590 & $\mathrm{U}$ & 490 & $\mathbf{U}$ & 2,500 & $\mathbf{U}$ & 970 & $\mathbf{U}$ \\
\hline 2-Methylnaphthalene & 500 & $\mathbf{U}$ & 590 & $\mathrm{U}$ & 200 & $J$ & 2,500 & U & 97 & $\mathbf{J}$ \\
\hline
\end{tabular}


TABLE C.14b (Cont.)

\begin{tabular}{|c|c|c|c|c|c|c|c|c|c|c|}
\hline \multirow{3}{*}{$\frac{\text { Compound }}{\text { 2-Methylphenol }}$} & \multicolumn{10}{|c|}{ Soil Concentrations $(\mu g / \mathrm{kg})$ at Various Depth Intervals } \\
\hline & \multicolumn{2}{|c|}{$\begin{array}{c}\text { CLP2 } \\
\text { (24-48 in.) }\end{array}$} & \multicolumn{2}{|c|}{$\begin{array}{c}\text { CLP3 } \\
(0-6 \text { in. }) \\
\end{array}$} & \multicolumn{2}{|c|}{$\begin{array}{c}\text { CLP3 } \\
(6-24 \text { in. }) \\
\end{array}$} & \multicolumn{2}{|c|}{$\begin{array}{l}\text { CLP3-Dup } \\
\text { (6-24 in.) }\end{array}$} & \multicolumn{2}{|c|}{$\begin{array}{c}\text { CLP3 } \\
(24-48 \text { in.) }\end{array}$} \\
\hline & 500 & $\mathrm{U}$ & 590 & $\mathbf{U}$ & 130 & J & 2,500 & $\mathrm{U}$ & 140 & J \\
\hline 4-Methylphenol & 500 & $U$ & 590 & $\mathbf{U}$ & 180 & J & 2,500 & $\mathbf{U}$ & 190 & J \\
\hline Naphthalene & 500 & $\mathrm{U}$ & 590 & $\mathbf{U}$ & 90 & $\mathrm{~J}$ & 2,500 & $\mathbf{U}$ & 970 & $\mathrm{U}$ \\
\hline 2-Nitroaniline & 1,200 & $\mathrm{U}$ & 1,500 & $\mathrm{U}$ & 1,200 & $\mathbf{U}$ & 6,200 & U & 2,400 & $\mathrm{U}$ \\
\hline 3-Nitroaniline & 1,200 & $\mathrm{U}$ & 1,500 & $\mathbf{U}$ & 1,200 & $\mathbf{U}$ & 6,200 & $\mathbf{U}$ & 2,400 & $\mathrm{U}$ \\
\hline 4-Nitroaniline & 1,200 & U & 1,500 & $\mathbf{U}$ & 1,200 & $\mathbf{U}$ & 6,200 & $\mathbf{U}$ & 2,400 & $\mathrm{U}$ \\
\hline Nitrobenzene & 500 & $U$ & 590 & $\mathrm{U}$ & 490 & $\mathrm{U}$ & 2,500 & $\mathrm{U}$ & 970 & U \\
\hline 2-Nitrophenol & 500 & $\mathbf{U}$ & 590 & $\mathbf{U}$ & 490 & $\mathbf{U}$ & 2,500 & $\mathrm{U}$ & 1,400 & \\
\hline 4-Nitrophenol & 1,200 & U & 1,500 & $\mathbf{U}$ & 1,200 & $\mathbf{U}$ & 6,200 & $\mathbf{U}$ & 2,400 & $\mathrm{U}$ \\
\hline N-Nitroso-di-n-propylamine & 500 & $\mathbf{U}$ & 590 & $\mathbf{U}$ & 490 & $\mathrm{U}$ & 2,500 & $\mathrm{U}$ & 970 & $\mathrm{U}$ \\
\hline N-Nitrosodiphenylamine & 500 & U & 590 & $\mathbf{U}$ & 240 & J & 2,500 & $\mathrm{U}$ & 970 & U \\
\hline Pentachlorophenol & 1,200 & $\mathbf{U}$ & 1,500 & U & 1,200 & $\mathrm{U}$ & 6,200 & $\mathrm{U}$ & 2,400 & $\mathrm{U}$ \\
\hline Phenanthrene & 500 & $\mathbf{U}$ & 590 & $\mathrm{U}$ & 490 & $\mathrm{U}$ & 2,500 & U & 970 & $\mathrm{U}$ \\
\hline Phenol & 500 & U & 590 & U & 490 & $U$ & 2,500 & $\mathrm{U}$ & 970 & $\mathrm{U}$ \\
\hline Pyrene & 500 & $\mathbf{U}$ & 590 & $\mathrm{~J}$ & 53 & J & 2,500 & $U$ & 970 & $\mathrm{U}$ \\
\hline 1,2,4-Trichlorobenzene & 500 & U & 590 & $\mathrm{U}$ & 490 & $\mathrm{U}$ & 2,500 & $\mathrm{U}$ & 970 & $\mathbf{U}$ \\
\hline 2,4,5-Trichlorophenol & 1,200 & $\mathbf{U}$ & 1,500 & $U$ & 1,200 & $\mathrm{U}$ & 6,200 & U & 2,400 & $\mathbf{U}$ \\
\hline 2,4,6-Trichlorophenol & 500 & $\underline{U}$ & 590 & U & 490 & U & 2,500 & U & 970 & $\mathrm{U}$ \\
\hline
\end{tabular}


TABLE C.14b (Cont.)

\begin{tabular}{|c|c|c|c|c|c|c|c|c|c|c|c|c|c|c|c|c|c|c|}
\hline \multirow{3}{*}{$\begin{array}{l}\text { Compound } \\
\text { Accnaphthene }\end{array}$} & \multicolumn{18}{|c|}{ Soil Concentrations ( $\mu \mathrm{g} / \mathrm{kg}$ ) at Various Depth Intervals } \\
\hline & \multicolumn{2}{|c|}{$\begin{array}{c}\text { CLP4 } \\
(0-6 \mathrm{in.}) \\
\end{array}$} & \multicolumn{2}{|c|}{$\begin{array}{c}\text { CLP4 } \\
(6-24 \text { in.) } \\
\end{array}$} & \multicolumn{2}{|c|}{$\begin{array}{c}\text { CLP4 } \\
\text { (24-48 in.) }\end{array}$} & \multicolumn{2}{|c|}{$\begin{array}{l}\text { CLP4-RE } \\
\text { (24-48 in.) }\end{array}$} & \multicolumn{2}{|c|}{$\begin{array}{c}\text { CLP5 } \\
(0.6 \mathrm{in} .) \\
\end{array}$} & \multicolumn{2}{|c|}{$\begin{array}{l}\text { CLP5-RE } \\
(0-6 \text { in.) } \\
\end{array}$} & \multicolumn{2}{|c|}{$\begin{array}{c}\text { CLP5 } \\
\text { (6-24 in.) } \\
\end{array}$} & \multicolumn{2}{|c|}{$\begin{array}{c}\text { CLP5 } \\
\text { (24-48 in.) } \\
\end{array}$} & \multicolumn{2}{|c|}{$\begin{array}{l}\text { CLPS-Dup } \\
\text { (24-48 in.) }\end{array}$} \\
\hline & 470 & $\mathbf{U}$ & 440 & $\mathbf{U}$ & 4,300 & $\mathrm{U}$ & 4,300 & $\mathbf{u}$ & 420 & $\mathbf{U}$ & 420 & $\mathrm{U}$ & 400 & $\mathbf{U}$ & 440 & $\mathrm{U}$ & 440 & $\mathbf{U}$ \\
\hline Acenaphthylene & 470 & $\mathbf{U}$ & 440 & $\mathrm{U}$ & 4,300 & $\mathrm{U}$ & 4,300 & $\mathbf{u}$ & 420 & $\mathbf{U}$ & 420 & $\mathbf{U}$ & 400 & $\mathbf{U}$ & 440 & $U$ & 440 & $\mathrm{U}$ \\
\hline Anthracene & 470 & $\mathrm{U}$ & 440 & $\mathrm{U}$ & 4,300 & $\mathbf{U}$ & 4,300 & $\mathbf{u}$ & 420 & $\mathbf{U}$ & 420 & $\mathbf{U}$ & 400 & $\mathbf{U}$ & 440 & $U$ & 440 & $\mathbf{U}$ \\
\hline Benz[a]anthracene & 69 & J & 440 & $\mathrm{U}$ & 4,300 & $\mathbf{U}$ & 4,300 & $\mathbf{U}$ & 420 & $\mathbf{U}$ & 420 & $\mathrm{U}$ & 400 & $\mathbf{U}$ & 440 & $\mathrm{U}$ & 440 & $\mathrm{U}$ \\
\hline Benzo[a]pyrene & 470 & $\mathrm{U}$ & 440 & $\mathrm{U}$ & 4,300 & $\mathbf{U}$ & 4,300 & $\mathbf{u}$ & 420 & $\mathbf{U}$ & 420 & $\mathbf{U}$ & 400 & $\mathbf{U}$ & 440 & $\mathbf{U}$ & 440 & $\mathbf{U}$ \\
\hline Benzo[b]fluoranthene & 200 & J & 440 & $\mathrm{U}$ & 4,300 & $\mathbf{U}$ & 4,300 & $\mathbf{U}$ & 420 & $\mathbf{u}$ & 420 & $\mathrm{U}$ & 400 & $\mathbf{U}$ & 440 & $\mathrm{U}$ & 440 & $\mathrm{U}$ \\
\hline Benzo[g,h,i]perylene & 470 & $\mathrm{U}$ & 440 & $\mathrm{U}$ & 4,300 & $\mathbf{U}$ & 4,300 & $\mathbf{U}$ & 420 & $\mathbf{U}$ & 420 & $\mathrm{U}$ & 400 & $\mathbf{U}$ & 440 & $\mathbf{U}$ & 440 & $\mathrm{U}$ \\
\hline Benzo[k]fluoranthene & 470 & $\mathrm{U}$ & 440 & $\mathrm{U}$ & 4,300 & $\mathbf{U}$ & 4,300 & $\mathbf{U}$ & 420 & $\mathrm{U}$ & 420 & $\mathrm{U}$ & 400 & $\mathbf{U}$ & 440 & $\mathrm{U}$ & 440 & $\mathrm{U}$ \\
\hline Bis(2-chloroethoxy)methane & 470 & $\mathrm{U}$ & 440 & $\mathrm{U}$ & 4,300 & $\mathbf{U}$ & 4,300 & $\mathbf{U}$ & 420 & $\mathbf{U}$ & 420 & $\mathbf{U}$ & 400 & $\mathbf{U}$ & 440 & $U$ & 440 & $\mathrm{U}$ \\
\hline Bis(2-chloroethyl)ether & 470 & $\mathrm{U}$ & 440 & $\mathrm{U}$ & 4,300 & $\mathbf{u}$ & 4,300 & $\mathbf{u}$ & 420 & $\mathbf{U}$ & 420 & $U$ & 400 & $\mathbf{U}$ & 440 & $\mathrm{U}$ & 440 & $\mathrm{U}$ \\
\hline Bis(2-chloroisopropyl)ether & 470 & $\mathrm{U}$ & 440 & $\mathrm{U}$ & 4,300 & $\mathrm{U}$ & 4,300 & $\mathbf{U}$ & 420 & $\mathbf{U}$ & 420 & $\mathrm{U}$ & 400 & $\mathbf{U}$ & 440 & $\mathrm{U}$ & 440 & $\mathrm{U}$ \\
\hline Bis(2-ethylhexyl)phthalate & 170 & JB & 140 & JB & 4,300 & U & 440 & $\mathrm{JB}$ & 870 & B & 790 & B & 400 & $\mathbf{U}$ & 130 & JB & 140 & "JB \\
\hline 4-Bromophenyl phenyl ether & $470^{\circ}$ & $\mathbf{U}$ & 440 & $\mathrm{U}$ & 4,300 & $\mathbf{U}$ & 4,300 & $\mathbf{u}$ & 420 & $\mathbf{U}$ & 420 & $\mathbf{U}$ & 400 & $\mathbf{U}$ & 440 & $\mathrm{U}$ & 440 & U \\
\hline Butylbenzylphthalate & 470 & $\mathbf{U}$ & 440 & $\mathrm{U}$ & 4,300 & $\mathbf{U}$ & 4,300 & $U$ & 420 & $\mathbf{U}$ & 420 & U & 400 & $\mathbf{U}$ & 440 & $U$ & 440 & $\mathrm{U}$ \\
\hline Carbazole & 470 & $\mathrm{U}$ & 440 & $\mathrm{U}$ & 4,300 & $\mathbf{U}$ & 4,300 & $\mathbf{U}$ & 420 & $\mathbf{U}$ & 420 & $\mathrm{U}$ & 400 & $\mathbf{U}$ & 440 & $\mathrm{U}$ & 440 & $\mathrm{U}$ \\
\hline 4-Chloro-3-methylphenol & 470 & $\mathbf{U}$ & 440 & $\mathrm{U}$ & 4,300 & U & 4,300 & $\mathbf{U}$ & 420 & $\mathbf{U}$ & 420 & $\mathbf{U}$ & 400 & $\mathbf{U}$ & 440 & $U$ & 440 & $\mathrm{U}$ \\
\hline 4-Chloroaniline & 470 & $\mathbf{U}$ & 440 & $\mathrm{U}$ & 4,300 & $\mathbf{U}$ & 4,300 & $\mathbf{U}$ & 420 & $\mathbf{U}$ & 420 & $\mathbf{U}$ & 400 & $\mathbf{U}$ & 440 & $U$ & 440 & $\mathrm{U}$ \\
\hline 2-Chloronaphthalene & 470 & $\mathbf{U}$ & 440 & $\mathrm{U}$ & 4,300 & $\mathbf{U}$ & 4,300 & $\mathbf{U}$ & 420 & $\mathbf{U}$ & 420 & $U$ & 400 & $\mathbf{U}$ & 440 & U & 440 & $U$ \\
\hline 2-Chlorophenol & 470 & $\mathbf{U}$ & 440 & $\mathbf{U}$ & 4,300 & $\mathbf{U}$ & 4,300 & $\mathrm{U}$ & 420 & $\mathrm{U}$ & 420 & $\mathrm{U}$ & 400 & $\mathbf{U}$ & 440 & $\mathrm{U}$ & 440 & $\mathbf{U}$ \\
\hline 4-Chlorophenyl phenyl ether & 470 & $\mathbf{U}$ & 440 & $\mathrm{U}$ & 4,300 & $\mathbf{U}$ & 4,300 & $\mathbf{U}$ & 420 & $U$ & 420 & $\mathrm{U}$ & 400 & $\mathbf{U}$ & 440 & $\mathrm{U}$ & 440 & $\mathrm{U}$ \\
\hline Chrysene & 110 & $\mathrm{~J}$ & 440 & $\mathrm{u}$ & 4,300 & $\mathbf{U}$ & 4,300 & U , & 420 & $U$ & 420 & $\mathbf{U}$ & 400 & $U$ & 440 & $\mathrm{U}$ & 440 & $\mathrm{U}$ \\
\hline Di-n-butylphthalate & 230 & $\mathrm{JB}$ & 120 & JB & 4,300 & $\mathbf{U}$ & 4,300 & $\mathrm{U}$ & 180 & JB & 200 & JB & 85 & JB & 100 & JB & 120 & JB \\
\hline Di-n-octylphthalate & 470 & $\mathbf{U}$ & 440 & $\mathbf{U}$ & 4,300 & $\mathrm{U}$ & 4,300 & $\mathrm{U}$ & 420 & $\mathrm{U}$ & 420 & $\mathbf{U}$ & 400 & $U$ & 440 & $\mathbf{U}$ & 440 & $\mathbf{U}$ \\
\hline Dibenz $[a, h]$ anthracene & 470 & $\mathbf{U}$ & 440 & $\mathbf{u}$ & 4,300 & $\mathrm{U}$ & 4,300 & $\mathrm{U}$ & 420 & $\mathrm{U}$ & 420 & $\mathrm{U}$ & 400 & $\mathrm{U}$ & 440 & $\mathbf{U}$ & 440 & $\mathrm{U}$ \\
\hline Dibenzofuran & 470 & $\mathbf{U}$ & 440 & $\mathbf{U}$ & 4,300 & $\mathrm{U}$ & 4,300 & $\mathrm{U}$ & 420 & $U$ & 420 & $\mathbf{U}$ & 400 & $U$ & 440 & $\mathbf{U}$ & 440 & 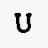 \\
\hline 1,2-Dichlorobenzene & 470 & $\mathrm{U}$ & 440 & u & 4,300 & $\mathrm{U}$ & 4,300 & $\mathrm{U}$ & 420 & $\mathrm{U}$ & 420 & $\mathbf{U}$ & 400 & $\mathrm{U}$ & 440 & $\mathbf{U}$ & 440 & $\mathbf{U}$ \\
\hline 1,3-Dichlorobenzene & 470 & $U$ & 440 & $U$ & 4,300 & $\mathrm{U}$ & 4,300 & $u$ & 420 & $\mathrm{U}$ & 420 & $\mathbf{U}$ & 400 & $U$ & 440 & $\mathbf{U}$ & 440 & $\mathbf{U}$ \\
\hline 1,4-Dichlorobenzene & 470 & $\mathrm{U}$ & 440 & $\mathbf{u}$ & 4,300 & $\mathrm{U}$ & 4,300 & $U$ & 420 & $\mathrm{U}$ & 420 & $\mathbf{U}$ & 400 & $\mathrm{U}$ & 440 & $\mathbf{U}$ & 440 & $\mathbf{U}$ \\
\hline 3,3'-Dichlorobenzidine & 470 & $U$ & 440 & $\mathbf{U}$ & 4,300 & U & 4,300 & $\mathbf{U}$ & 420 & $\mathrm{U}$ & 420 & $\mathrm{U}$ & 400 & $\mathrm{U}$ & 440 & $\mathbf{u}$ & 440 & $\mathbf{U}$ \\
\hline 2,4-Dichlorophenol . & 470 & $\mathrm{U}$ & 440 & $\mathrm{U}$ & 4,300 & $\mathrm{U}$ & 4,300 & $U$ & 420 & $\mathrm{u}$ & 420 & $\mathrm{U}$ & 400 & $U$ & 440 & $\mathbf{u}$ & 440 & $\mathbf{U}$ \\
\hline
\end{tabular}


TABLE C.14b (Cont.)

\begin{tabular}{|c|c|c|c|c|c|c|c|c|c|c|c|c|c|c|c|c|c|c|c|}
\hline \multirow{2}{*}{\multicolumn{2}{|c|}{ Compound }} & \multicolumn{18}{|c|}{ Soil Concentrations $(\mu \mathrm{g} / \mathrm{kg})$ at Various Depth Intervals } \\
\hline & & \multicolumn{2}{|c|}{$\begin{array}{c}\text { CLP4 } \\
(0-6 \text { in. }) \\
\end{array}$} & \multicolumn{2}{|c|}{$\begin{array}{c}\text { CLP4 } \\
\text { (6-24 in.) }\end{array}$} & \multicolumn{2}{|c|}{$\begin{array}{c}\text { CLP4 } \\
(24-48 \text { in.) }\end{array}$} & \multicolumn{2}{|c|}{$\begin{array}{l}\text { CLP4-RE } \\
\text { (24-48 in.) }\end{array}$} & \multicolumn{2}{|c|}{$\begin{array}{l}\text { CLP5 } \\
(0.6 \text { in.) }\end{array}$} & \multicolumn{2}{|c|}{$\begin{array}{l}\text { CLP5-RE } \\
\text { (0.6 in.) }\end{array}$} & \multicolumn{2}{|c|}{$\begin{array}{c}\text { CLP5 } \\
\text { (6-24 in.) }\end{array}$} & \multicolumn{2}{|c|}{$\begin{array}{c}\text { CLP5 } \\
\text { (24-48 in.) }\end{array}$} & \multicolumn{2}{|c|}{$\begin{array}{l}\text { CLP5-Dup } \\
\text { (24-48 in.) }\end{array}$} \\
\hline Diethylphthalate & & 470 & $\mathbf{U}$ & 440 & $\mathrm{U}$ & 4,300 & $\mathrm{U}$ & 4,300 & $\mathbf{U}$ & 420 & $\mathbf{U}$ & 420 & $\mathrm{U}$ & 400 & $\mathbf{U}$ & 49 & $\mathrm{~J}$ & 440 & U \\
\hline 2,4-Dimethylphenol & & 470 & $\mathrm{U}$ & 440 & $\mathrm{U}$ & 4,300 & $\mathrm{U}$ & 4,300 & $\mathbf{U}$ & 420 & $\mathrm{U}$ & 420 & $\mathrm{U}$ & 400 & $\mathrm{U}$ & 440 & $\mathbf{U}$ & 440 & $\mathrm{U}$ \\
\hline Dimethylphthalate & & 470 & $\mathrm{U}$ & 440 & $\mathrm{U}$ & 4,300 & $\mathbf{U}$ & 4,300 & $\mathbf{U}$ & 420 & $\mathbf{U}$ & 420 & $\mathrm{U}$ & 400 & $\mathbf{U}$ & 440 & $\mathrm{U}$ & 440 & $\mathrm{U}$ \\
\hline 4,6-Dinitro-2-methylphenol & & 1,200 & $\mathrm{U}$ & 1,100 & $\mathrm{U}$ & 11,000 & $\mathbf{U}$ & 11,000 & $\mathbf{U}$ & 1,100 & 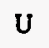 & 1,100 & $\mathrm{U}$ & 990 & $\mathrm{U}$ & 1,100 & $\mathbf{U}$ & 1,100 & U \\
\hline 2,4-Dinitrophenol & & 1,200 & $\mathbf{U}$ & 1,100 & $\mathrm{U}$ & 11,000 & $\mathbf{u}$ & 11,000 & $\mathbf{U}$ & 1,100 & $\mathbf{U}$ & 1,100 & $\mathbf{U}$ & 990 & U & 1,100 & $\mathrm{U}$ & 1,100 & $\mathrm{U}$ \\
\hline 2,4-Dinitrotoluene & & 470 & $\mathbf{U}$ & 440 & $U$ & 4,300 & $\mathbf{U}$ & 4,300 & U & 420 & $\mathrm{U}$ & 420 & $\mathrm{U}$ & 400 & $\mathrm{U}$ & 440 & $\mathbf{U}$ & 440 & U \\
\hline 2,6-Dinitrotoluene & & 470 & $\mathbf{U}$ & 440 & $\mathrm{U}$ & 4,300 & $\mathrm{u}$ & 4,300 & $\mathbf{U}$ & 420 & $\mathrm{U}$ & 420 & $\mathbf{U}$ & 400 & $\mathrm{U}$ & 440 & $\mathrm{U}$ & 440 & $\mathrm{U}$ \\
\hline Fluoranthene & & 150 & $\mathrm{~J}$ & 62 & J & 4,300 & $\mathbf{U}$ & 4,300 & $\mathbf{U}$ & 420 & $\mathbf{U}$ & 420 & $\mathrm{U}$ & 400 & $\mathbf{U}$ & 440 & $\mathbf{U}$ & 440 & $\mathrm{U}$ \\
\hline Fluorene & & 470 & $\mathrm{U}$ & 440 & $\mathrm{U}$ & 4,300 & $\mathrm{U}$ & 4,300 & U & 420 & $\mathbf{U}$ & 420 & $\mathbf{U}$ & 400 & U & 440 & $\mathrm{U}$ & 440 & U \\
\hline Hexachlorobenzene & & 430 & $\mathbf{J}$ & 440 & $\mathrm{U}$ & 4,300 & $\mathbf{U}$ & 4,300 & U & 420 & $\mathbf{U}$ & 420 & $\mathbf{U}$ & 400 & $\mathbf{U}$ & 440 & $\mathrm{U}$ & 440 & U \\
\hline Hexachlorobutadiene & & 470 & $\mathbf{u}$ & 440 & $\mathbf{U}$ & 4,300 & $\mathbf{U}$ & 4,300 & U & 420 & $\mathrm{U}$ & 420 & $\mathbf{U}$ & 400 & U & 440 & $\mathrm{U}$ & 440 & $\mathrm{U}$ \\
\hline Hexachlorocyclopentadiene & & 470 & $\mathbf{u}$ & 440 & $\mathrm{U}$ & 4,300 & $\mathbf{U}$ & 4,300 & U & 420 & $\mathbf{U}$ & 420 & $\mathbf{U}$ & 400 & $\mathbf{U}$ & 440 & $\mathrm{U}$ & 440 & U \\
\hline Hexachloroethane & & 470 & $U$ & 440 & $\mathrm{U}$ & 4,300 & $U$ & 4,300 & $\mathbf{U}$ & 120 & $\mathbf{U}$ & 100 & $\mathrm{~J}$ & 400 & $\mathbf{U}$ & 440 & $\mathbf{U}$ & 440 & U \\
\hline Indeno[1,2,3-c,d]pyrene & & 470 & $\mathrm{U}$ & 440 & $\mathbf{U}$ & 4,300 & $\mathbf{U}$ & 4,300 & $\mathrm{U}$ & 420 & $\mathbf{U}$ & 420 & $\mathbf{U}$ & 400 & $\mathrm{U}$ & 440 & $\mathrm{U}$ & 440 & $\mathrm{U}$ \\
\hline Isophorone & & 470 & $\mathbf{U}$ & 440 & $\mathbf{U}$ & 4,300 & $U$ & 4,300 & $\mathrm{U}$ & 420 & $\mathbf{U}$ & 420 & $\mathbf{U}$ & 400 & $\mathbf{U}$ & 440 & $\mathrm{U}$ & 440 & $\mathrm{U}$ \\
\hline 2-Methylnaphthalene & & 470 & $\mathrm{U}$ & 200 & $\mathbf{U}$ & 4,300 & $\mathrm{U}$ & 4,300 & $\mathrm{U}$ & 420 & $\mathbf{U}$ & 420 & $\mathbf{U}$ & 400 & $\mathbf{U}$ & 440 & $\mathbf{U}$ & 440 & U \\
\hline 2-Methylphenol & & 470 & $\mathrm{U}$ & 110 & $\mathbf{U}$ & 4,300 & $\mathrm{U}$ & 4,300 & $\mathrm{U}$ & 420 & $\mathbf{U}$ & 420 & $\mathbf{U}$ & 400 & $\mathrm{U}$ & 440 & $\mathrm{U}$ & 440 & U \\
\hline 4-Methylphenol & & 470 & $U$ & 440 & $\mathbf{U}$ & 4,300 & $\mathrm{U}$ & 4,300 & $\mathbf{U}$ & 420 & $\mathbf{U}$ & 420 & $\mathrm{U}$ & 400 & $\mathbf{U}$ & 440 & $\mathbf{U}$ & 440 & U \\
\hline Naphthalene & & 470 & $\mathrm{U}$ & 120 & $\mathrm{U}$ & 4,300 & $\mathrm{U}$ & 4,300 & $\mathrm{U}$ & 420 & $\mathbf{U}$ & 420 & $\mathbf{U}$ & 400 & $U$ & 440 & $\mathrm{U}$ & 440 & $\mathrm{U}$ \\
\hline 2-Nitroaniline & & 1,200 & $\mathrm{U}$ & 1,100 & $\mathrm{U}$ & 11,000 & $\mathrm{U}$ & 11,000 & $\mathrm{U}$ & 1,100 & $\mathrm{U}$ & 1,100 & $\mathbf{U}$ & 990 & U & 1,100 & U & 1,100 & $\mathrm{U}$ \\
\hline 3-Nitroaniline & & 1,200 & $\mathrm{U}$ & 1,100 & $\mathrm{U}$ & 11,000 & $\mathrm{U}$ & 11,000 & U & 1,100 & $U$ & 1,100 & $\mathrm{U}$ & 990 & $\mathrm{U}$ & 1,100 & $\mathbf{U}$ & 1,100 & $\mathbf{U}$ \\
\hline 4-Nitroaniline & & 1,200 & $\mathrm{U}$ & 1,100 & $U$ & 11,000 & $\mathrm{U}$ & 11,000 & $U$ & 1,100 & $\mathbf{U}$ & 1,100 & $\mathbf{U}$ & 990 & U & 1,100 & $\mathrm{U}$ & 1,100 & $\mathrm{U}$ \\
\hline Nitrobenzene & & 470 & $\mathrm{U}$ & 440 & $\mathbf{U}$ & 4,300 & $\mathrm{U}$ & 4,300 & $\mathrm{U}$ & 420 & $\mathrm{U}$ & 420 & $U$ & 400 & U & 440 & $\mathrm{U}$ & 440 & $\mathbf{U}$ \\
\hline 2-Nitrophenol & & 470 & $U$ & 440 & $\mathrm{U}$ & 4,300 & $\mathrm{U}$ & 4,300 & $U$ & 420 & $\mathbf{U}$ & 420 & $\mathbf{U}$ & 400 & $\mathrm{U}$ & 440 & $\mathbf{U}$ & 440 & $\mathrm{U}$ \\
\hline 4-Nitrophenol & & 1,200 & $\mathrm{U}$ & 1,100 & $\mathrm{U}$ & 11,000 & $\mathrm{U}$ & 11,000 & $\mathrm{U}$ & 1,100 & $\mathrm{U}$ & 1,100 & $U$ & 990 & $U$ & 1,100 & $U$ & 1,100 & U \\
\hline N-Nitroso-di-n-propylamine & & 470 & $U$ & 440 & $\mathrm{U}$ & 4,300 & $\mathrm{U}$ & 4,300 & $\mathrm{U}$ & 420 & $\mathrm{U}$ & 420 & $\mathrm{U}$ & 400 & $\mathrm{U}$ & 440 & $\mathrm{U}$ & 440 & U \\
\hline N-Nitrosodiphenylamine & & 470 & $\mathrm{U}$ & 440 & $\mathrm{U}$ & 4,300 & $\mathrm{U}$ & 4,300 & $\mathrm{U}$ & 420 & $U$ & 420 & $\mathbf{U}$ & 400 & U & 440 & $U$ & 440 & $\mathbf{u}$ \\
\hline Pentachlorophenol & & 1,200 & $\mathrm{U}$ & 1,100 & $\mathrm{U}$ & 11,000 & $\mathrm{U}$ & 11,000 & $\mathbf{U}$ & 1,100 & $\mathrm{U}$ & 1,100 & $\mathrm{U}$ & 990 & $\mathrm{U}$ & 1,100 & $\mathrm{U}$ & 1,100 & $\mathrm{U}$ \\
\hline Phenanthrene & & 59 & $\mathrm{~J}$ & 120 & J & 4,300 & $\mathrm{U}$ & 4,300 & $\mathrm{U}$ & 420 & $U$ & 420 & $U$ & 400 & $U$ & 440 & $\mathrm{U}$ & 440 & $\mathrm{U}$ \\
\hline Phenol & & 470 & $\mathrm{U}$ & 440 & $\mathrm{U}$ & 4,300 & $\mathrm{U}$ & 4,300 & $\mathrm{U}$ & 420 & $U$ & 420 & $U$ & 400 & $\mathrm{U}$ & 440 & $\mathbf{U}$ & 440 & $\mathbf{U}$ \\
\hline
\end{tabular}


TABLE C.14b (Cont.)

\begin{tabular}{|c|c|c|c|c|c|c|c|c|c|c|c|c|c|c|c|c|c|c|}
\hline \multirow[b]{2}{*}{ Compound } & \multicolumn{18}{|c|}{ Soil Concentrations $(\mu \mathrm{g} / \mathrm{kg})$ at Various Depth Intervals } \\
\hline & \multicolumn{2}{|c|}{$\begin{array}{c}\text { CLP4 } \\
(0.6 \text { in. })\end{array}$} & \multicolumn{2}{|c|}{$\begin{array}{c}\text { CLP4 } \\
\text { (6-24 in.) }\end{array}$} & \multicolumn{2}{|c|}{$\begin{array}{c}\text { CLP4 } \\
\text { (24-48 in.) } \\
\end{array}$} & \multicolumn{2}{|c|}{$\begin{array}{l}\text { CLP4-RE } \\
\text { (24-48 in.) } \\
\end{array}$} & \multicolumn{2}{|c|}{$\begin{array}{c}\text { CLP5 } \\
(0-6 \text { in. }) \\
\end{array}$} & \multicolumn{2}{|c|}{$\begin{array}{c}\text { CLP5-RE } \\
(0-6 \text { in.) } \\
\end{array}$} & \multicolumn{2}{|c|}{$\begin{array}{c}\text { CLP5 } \\
\text { (6-24 in.) }\end{array}$} & \multicolumn{2}{|c|}{$\begin{array}{c}\text { CLPS } \\
\text { (24-48 in.) }\end{array}$} & \multicolumn{2}{|c|}{$\begin{array}{l}\text { CLP5-Dup } \\
\text { (24-48 in.) }\end{array}$} \\
\hline Pyrene & 130 & J & 86 & J & 4,300 & $\mathrm{U}$ & 4,300 & $\mathrm{U}$ & 420 & $\mathbf{U}$ & 420 & U & 400 & $\mathrm{U}$ & 440 & $\mathbf{U}$ & 440 & $\mathrm{U}$ \\
\hline 1,2,4-Trichlorobenzene & 470 & $\mathbf{U}$ & 440 & $\mathbf{U}$ & 4,300 & $\mathrm{U}$ & 4,300 & U & 420 & $\mathbf{U}$ & 420 & $\mathbf{u}$ & 400 & $\mathrm{U}$ & 440 & $\mathbf{U}$ & 440 & $\mathbf{U}$ \\
\hline 2,4,5-Trichlorophenol & 1,200 & $\mathbf{U}$ & 1,100 & $\mathbf{U}$ & 11,000 & $\mathrm{U}$ & 11,000 & $\mathrm{U}$ & 1,100 & $\mathrm{U}$ & 1,100 & $\mathrm{U}$ & 990 & $\mathrm{U}$ & 1,100 & $\mathbf{U}$ & 1,100 & $\mathrm{U}$ \\
\hline 2,4,6-Trichlorophenol & 470 & U & 440 & U & 4,300 & $\mathrm{U}$ & 4,300 & $\mathrm{U}$ & 420 & U & 420 & U & 400 & U & 440 & U & 440 & $\mathbf{U}$ \\
\hline & \multicolumn{18}{|c|}{ Soil Concentrations $(\mu \mathrm{g} / \mathrm{kg})$ at Various Depth Intervals } \\
\hline Compound & \multicolumn{2}{|c|}{$\begin{array}{c}\text { CLP6 } \\
(0-6 \text { in.) }\end{array}$} & \multicolumn{2}{|c|}{$\begin{array}{c}\text { CLP6 } \\
(6-24 \text { in. }) \\
\end{array}$} & \multicolumn{2}{|c|}{$\begin{array}{l}\text { CLP6-RE } \\
\text { (6-24 in.) } \\
\end{array}$} & \multicolumn{2}{|c|}{$\begin{array}{c}\text { CLP7 } \\
\text { (0-6 in.) } \\
\end{array}$} & \multicolumn{2}{|c|}{$\begin{array}{c}\text { CLP7 } \\
(6-24 \text { in. }) \\
\end{array}$} & \multicolumn{2}{|c|}{$\begin{array}{l}\text { CLP7-RE } \\
\text { (6-24 in.) }\end{array}$} & \multicolumn{2}{|c|}{$\begin{array}{c}\text { CLP7 } \\
(24-48 \text { in. }) \\
\end{array}$} & \multicolumn{2}{|c|}{$\begin{array}{c}\text { CLP8 } \\
\text { (0.6 in.) }\end{array}$} & \multicolumn{2}{|c|}{$\begin{array}{c}\text { CLP9 } \\
\text { (0-6 in.) } \\
\end{array}$} \\
\hline Accnaphthene & 880 & $\mathrm{U}$ & 420 & $\mathrm{U}$ & 420 & $\mathrm{U}$ & 510 & $\mathrm{U}$ & 420 & $\mathbf{U}$ & 420 & $\mathbf{U}$ & 420 & $\mathrm{U}$ & 2,000 & $\mathbf{U}$ & 820 & $U$ \\
\hline Acenaphthylene & 880 & $U$ & 420 & $\mathrm{U}$ & 420 & $u$ & 510 & $\mathrm{u}$ & 420 & $\mathbf{U}$ & 420 & $\mathrm{U}$ & 420 & $\mathrm{U}$ & 2,000 & $\mathbf{U}$ & 820 & U \\
\hline Anthracene & 880 & $\mathrm{U}$ & 420 & $\mathrm{U}$ & 420 & $\mathbf{U}$ & 510 & $\mathbf{U}$ & 420 & $\mathbf{U}$ & 420 & $\mathrm{U}$ & 420 & $\mathbf{U}$ & 2,000 & $U$ & 820 & $\mathrm{U}$ \\
\hline Benz[a]anthracene & 880 & $\mathrm{U}$ & 86 & J & 58 & $\mathrm{~J}$ & 510 & $\mathrm{U}$ & 420 & $\mathbf{U}$ & 420 & $\mathbf{U}$ & 420 & $\mathbf{U}$ & 2,000 & $\mathbf{U}$ & 820 & U \\
\hline Benzo[a]pyrene & 880 & $\mathrm{U}$ & 420 & $\mathrm{U}$ & 420 & $\mathrm{U}$ & 510 & $\mathbf{U}$ & 420 & $\mathbf{U}$ & 420 & $U$ & 420 & $\mathbf{U}$ & 2,000 & $U$ & 820 & $\mathbf{U}$ \\
\hline Benzo[b]fluoranthene & 880 & $\mathrm{U}$ & 420 & $\mathrm{U}$ & 420 & $\mathbf{U}$ & 510 & $\mathbf{u}$ & 420 & $\mathbf{U}$ & 420 & $\mathrm{U}$ & 420 & $\mathbf{U}$ & 2,000 & $\mathbf{U}$ & 820 & $\mathbf{U}$ \\
\hline Benzo[g,h,i]perylene & 880 & $\mathrm{U}$ & 420 & $U$ & 420 & $\mathbf{U}$ & 510 & $\mathrm{U}$ & 420 & $\mathbf{U}$ & 420 & $\mathrm{U}$ & 420 & $\mathbf{U}$ & 2,000 & $\mathrm{U}$ & 820 & $\mathbf{U}$ \\
\hline Benzo[k]fluoranthene & 880 & $\mathrm{U}$ & 420 & $\mathrm{U}$ & 420 & $\mathrm{U}$ & 510 & $\mathbf{U}$ & 420 & $\mathbf{U}$ & 420 & $\mathrm{U}$ & 420 & $\mathbf{U}$ & 2,000 & U & 820 & $\mathbf{U}$ \\
\hline Bis(2-chlorocthoxy)methane & 880 & $\mathrm{U}$ & 420 & $\mathrm{U}$ & 420 & $\mathrm{U}$ & 510 & $\mathbf{U}$ & 420 & $\mathbf{U}$ & 420 & $\mathrm{u}$ & 420 & $\mathbf{U}$ & 2,000 & $\mathbf{U}$ & 820 & $\mathbf{U}$ \\
\hline Bis(2-chlorocthyl)ether & 880 & $\mathrm{U}$ & 420 & $\mathrm{U}$ & 420 & $\mathbf{U}$ & 510 & $\mathrm{U}$ & 420 & $\mathrm{U}$ & 420 & $\mathrm{U}$ & 420 & $\mathbf{U}$ & 2,000 & U & 820 & U \\
\hline Bis(2-chloroisopropyl)ether & 880 & $u$ & 420 & $\mathrm{U}$ & 420 & $\mathbf{U}$ & 510 & $\mathrm{U}$ & 420 & $\mathrm{U}$ & 420 & $\mathrm{U}$ & 420 & $\mathrm{U}$ & 2,000 & $U$ & 820 & U \\
\hline Bis(2-ethylhexyl)phthalate & 180 & JB & 160 & JB & 130 & JB & 170 & JB & 140 & $\mathrm{JB}$ & 49 & JB & 85 & $\mathrm{JB}$ & 480 & JB & 120 & $\mathrm{JB}$ \\
\hline 4-Bromophenyl phenyl ether & 880 & $\mathrm{U}$ & 420 & $\mathrm{U}$ & 420 & $\mathbf{U}$ & 510 & $\mathbf{U}$ & 420 & $\mathrm{U}$ & 420 & $\mathrm{U}$ & 420 & $\mathbf{U}$ & 2,000 & $\mathrm{U}$ & 820 & $\mathrm{U}$ \\
\hline Butylbenzylphthalate & 880 & $\mathrm{U}$ & 420 & $U$ & 420 & U & 510 & $U$ & 420 & $U$ & 420 & $\mathbf{U}$ & 420 & $\mathrm{U}$ & 2,000 & $U$ & 820 & $\mathrm{U}$ \\
\hline Carbazole & 880 & $\mathrm{U}$ & 420 & $\mathrm{U}$ & 420 & $\mathrm{U}$ & 510 & $\mathbf{U}$ & 420 & $\mathbf{U}$ & 420 & $U$ & 420 & $U$ & 2,000 & $U$ & 820 & $\mathrm{U}$ \\
\hline 4-Chloro-3-methylphenol & 880 & $\mathbf{U}$ & 420 & $\mathbf{U}$ & 420 & $\mathrm{U}$ & 510 & $\mathrm{U}$ & 420 & $\mathrm{U}$ & 420 & $\mathrm{u}$ & 420 & $\mathrm{U}$ & 2,000 & $\mathbf{U}$ & 820 & $\mathrm{U}$ \\
\hline 4-Chloroaniline & 880 & $\mathbf{U}$ & 420 & $\mathbf{u}$ & 420 & $U$ & 510 & $\mathrm{U}$ & 420 & $\mathrm{U}$ & 420 & $\mathbf{U}$ & 420 & $U$ & 2,000 & $U$ & 820 & $U$ \\
\hline 2-Chloronaphthalene & 880 & $\mathbf{U}$ & 420 & $\mathbf{u}$ & 420 & $\mathrm{U}$ & 510 & $\mathrm{u}$ & 420 & $U$ & 420 & $\mathrm{U}$ & 420 & $\mathbf{U}$ & 2,000 & $\mathrm{U}$ & 820 & $\mathbf{U}$ \\
\hline 2-Chlorophenol & 880 & $\mathbf{U}$ & 420 & $\mathbf{U}$ & 420 & $U$ & 510 & $\mathbf{U}$ & 420 & $\mathbf{U}$ & 420 & $\mathrm{U}$ & 420 & $U$ & 2,000 & $\mathbf{U}$ & 820 & $\mathbf{U}$ \\
\hline 4-Chlorophenyl phenyl ether & 880 & $\mathbf{U}$ & 420 & $\mathbf{U}$ & 420 & $\mathbf{U}$ & 510 & $\mathrm{U}$ & 420 & $\mathrm{U}$ & 420 & $\mathbf{U}$ & 420 & $U$ & 2,000 & $\mathrm{U}$ & 820 & $\mathbf{U}$ \\
\hline Chrysene & 880 & $U$ & 97 & $\mathbf{J}$ & 64 & J & 510 & $\mathrm{U}$ & 420 & $U$ & 420 & $\mathbf{U}$ & 420 & $\mathrm{U}$ & 2,000 & U & 820 & U \\
\hline
\end{tabular}


TABLE C.14b (Cont.)

\begin{tabular}{|c|c|c|c|c|c|c|c|c|c|c|c|c|c|c|c|c|c|c|}
\hline \multirow{3}{*}{$\frac{\text { Compound }}{\text { Di-n-butyiphthalate }}$} & \multicolumn{18}{|c|}{ Soil Concentrations $(\mu \mathrm{g} / \mathrm{kg})$ at Various Depth Intervals } \\
\hline & \multicolumn{2}{|c|}{$\begin{array}{c}\text { CLP6 } \\
(0-6 \text { in.) }\end{array}$} & \multicolumn{2}{|c|}{$\begin{array}{c}\text { CLP6 } \\
(6-24 \text { in.) } \\
\end{array}$} & \multicolumn{2}{|c|}{$\begin{array}{l}\text { CLPG-RE } \\
\text { (6-24 in.) } \\
\end{array}$} & \multicolumn{2}{|c|}{$\begin{array}{c}\text { CLP7 } \\
(0-6 \text { in. }) \\
\end{array}$} & \multicolumn{2}{|c|}{$\begin{array}{c}\text { CLP7 } \\
\text { (6-24 in.) } \\
\end{array}$} & \multicolumn{2}{|c|}{$\begin{array}{l}\text { CLP7-RE } \\
\text { (6-24 in.) } \\
\end{array}$} & \multicolumn{2}{|c|}{$\begin{array}{c}\text { CLP7 } \\
\text { (24-48 in.) } \\
\end{array}$} & \multicolumn{2}{|c|}{$\begin{array}{c}\text { CLP8 } \\
\text { (0.6 in.) } \\
\end{array}$} & \multicolumn{2}{|c|}{$\begin{array}{c}\text { CLP9 } \\
(0-6 \text { in.) } \\
\end{array}$} \\
\hline & 880 & $\mathbf{U}$ & 160 & JB & 170 & JB & 190 & JB & 94 & $\mathrm{JB}$ & 420 & U & 100 & JB & 2,000 & $\mathrm{U}$ & 120 & JB \\
\hline Di-n-octylphthalate & 880 & $\mathbf{U}$ & 420 & $\mathbf{U}$ & 420 & $\mathrm{U}$ & 510 & $\mathrm{U}$ & 420 & $\mathrm{U}$ & 420 & $\mathrm{U}$ & 420 & $\mathrm{U}$ & 2,000 & $\mathrm{U}$ & 820 & $\mathrm{U}$ \\
\hline Dibenz[a,h]anthracene & 880 & $\mathbf{U}$ & 420 & $\mathbf{U}$ & 420 & $\mathrm{U}$ & 510 & $\mathbf{U}$ & 420 & $\mathbf{U}$ & 420 & $\mathrm{U}$ & 420 & $\mathbf{U}$ & 2,000 & $U$ & 820 & $\mathbf{U}$ \\
\hline Dibenzofuran & 880 & $\mathbf{U}$ & 420 & $\mathbf{U}$ & 420 & $\mathrm{U}$ & 510 & $\mathbf{U}$ & 420 & $\mathbf{U}$ & 420 & $\mathbf{U}$ & 420 & $U$ & 2,000 & $U$ & 820 & $U$ \\
\hline 1,2-Dichlorobenzene & 880 & $\mathrm{U}$ & 420 & $\mathbf{U}$ & 420 & $\mathrm{U}$ & 510 & $\mathbf{U}$ & 420 & $\mathbf{U}$ & 420 & $\mathrm{U}$ & 420 & $\mathrm{U}$ & 2,000 & $\mathrm{U}$ & 820 & $\mathrm{U}$ \\
\hline 1,3-Dichlorobenzene & 880 & $\mathrm{U}$ & 420 & $\mathrm{U}$ & 420 & $\mathrm{U}$ & 510 & $\mathbf{U}$ & 420 & U & 420 & $\mathrm{U}$ & 420 & $\mathbf{U}$ & 2,000 & $U$ & 820 & $\mathbf{U}$ \\
\hline 1,4-Dichlorobenzene & 880 & $\mathrm{U}$ & 420 & $\mathbf{U}$ & 420 & $\mathrm{U}$ & 510 & $\mathbf{U}$ & 420 & $\mathbf{U}$ & 420 & $\mathbf{U}$ & 420 & $\mathbf{U}$ & 2,000 & $\mathrm{U}$ & 820 & $\mathrm{U}$ \\
\hline 3,3'-Dichlorobenzidine & 880 & $U$ & 420 & $\mathbf{U}$ & 420 & $\mathrm{U}$ & 510 & $\mathbf{U}$ & 420 & $\mathbf{U}$ & 420 & $\mathrm{U}$ & 420 & $\mathbf{U}$ & 2,000 & $\mathbf{U}$ & 820 & $\mathrm{U}$ \\
\hline 2,4-Dichlorophenol & 880 & $\mathrm{U}$ & 420 & $\mathrm{U}$ & 420 & $\mathbf{U}$ & 510 & $\mathbf{U}$ & 420 & $\mathbf{U}$ & 420 & $\mathbf{U}$ & 420 & $\mathbf{U}$ & 2,000 & $U$ & 820 & $\mathrm{U}$ \\
\hline Diethylphthalate & 880 & $U$ & 420 & U & 420 & $\mathbf{U}$ & 510 & U & 420 & $\mathbf{U}$ & 420 & $\mathbf{U}$ & 420 & $\mathbf{U}$ & 2,000 & $\mathrm{U}$ & 820 & $\mathrm{U}$ \\
\hline 2,4-Dimethylphenol & 880 & $\mathrm{U}$ & 420 & $\mathrm{U}$ & 420 & $\mathbf{u}$ & 510 & $\mathbf{U}$ & 420 & $\mathbf{U}$ & 420 & $\mathbf{U}$ & 420 & U & 2,000 & $\mathbf{U}$ & 820 & $\mathrm{U}$ \\
\hline Dimethylphthalate & 880 & $\mathrm{U}$ & 420 & $U$ & 420 & $\mathbf{U}$ & 510 & $\mathbf{U}$ & 420 & $\mathbf{U}$ & 420 & $\mathbf{U}$ & 420 & $\mathbf{U}$ & 2,000 & $\mathrm{U}$ & 820 & $\mathrm{U}$ \\
\hline 4,6-Dinitro-2-methyiphenol & 2,200 & $U$ & 1,000 & $\mathrm{U}$ & 1,000 & $\mathrm{U}$ & 1,300 & $\mathrm{U}$ & 1,000 & $\mathbf{U}$ & 1,100 & $\mathbf{U}$ & 1,000 & U & 5,100 & $\mathrm{U}$ & 2,000 & $U$ \\
\hline 2,4-Dinitrophenol & 2,200 & $\mathrm{U}$ & 1,000 & $\mathrm{U}$ & 1,000 & $\mathbf{u}$ & 1,300 & $\mathbf{U}$ & 1,000 & $\mathrm{U}$ & 1,100 & $\mathbf{U}$ & 1,000 & $\mathbf{U}$ & 5,100 & $\mathbf{U}$ & 2,000 & $\mathrm{U}$ \\
\hline 2,4-Dinitrotoluene & 880 & $\mathrm{U}$ & 420 & $U$ & 420 & U & 510 & $\mathbf{U}$ & 420 & $\mathbf{U}$ & 420 & $\mathbf{U}$ & 420 & $\mathbf{U}$ & 2,000 & $\mathrm{U}$ & 820 & $\mathrm{U}$ \\
\hline 2,6-Dinitrotoluene & 880 & $\mathrm{U}$ & 420 & $\mathrm{U}$ & 420 & $\mathrm{u}$ & 510 & $\mathrm{U}$ & 420 & $\mathbf{U}$ & 420 & $\mathbf{U}$ & 420 & $\mathrm{U}$ & 2,000 & $\mathbf{U}$ & 820 & $U$ \\
\hline Fluoranthene & 880 & $\mathrm{U}$ & 140 & $\mathbf{J}$ & 140 & J & 510 & $\mathrm{U}$ & 420 & U & 420 & $\mathbf{U}$ & 420 & $\mathbf{U}$ & 2,000 & $\mathbf{U}$ & 820 & $\mathrm{U}$ \\
\hline Fluorene & 880 & $\mathrm{U}$ & 420 & $\mathrm{U}$ & 420 & $\mathbf{U}$ & 510 & $\mathbf{U}$ & 420 & $\mathbf{U}$ & 420 & $\mathbf{U}$ & 420 & $\mathbf{U}$ & 2,000 & $\mathbf{U}$ & 820 & $\mathrm{U}$ \\
\hline Hexachlorobenzene & 880 & U & 65 & $\mathrm{~J}$ & 75 & J & 510 & $\mathrm{U}$ & 420 & $\mathbf{U}$ & 420 & $\mathbf{U}$ & 420 & $\mathrm{U}$ & 490 & $\mathrm{~J}$ & 500 & $\mathrm{U}$ \\
\hline Hexachlorobutadiene & 880 & $\mathbf{U}$ & 420 & $\mathrm{U}$ & 420 & $U$ & 510 & $\mathrm{U}$ & 420 & U & 420 & $\mathbf{U}$ & 420 & $\mathbf{U}$ & 2,000 & $\mathbf{U}$ & 820 & $\mathrm{U}$ \\
\hline Hexachlorocyclopentadiene & 880 & $\mathrm{U}$ & 420 & $U$ & 420 & $\mathrm{U}$ & 510 & $\mathbf{U}$ & 420 & $\mathrm{U}$ & 420 & $\mathrm{U}$ & 420 & U & 2,000 & $\mathbf{U}$ & 820 & $\mathrm{U}$ \\
\hline Hexachlorocthane & 880 & U & 420 & $\mathrm{U}$ & 420 & $\mathrm{U}$ & 510 & $\mathrm{U}$ & 420 & U & 420 & U & 420 & U & 2,000 & U & 820 & $\mathrm{U}$ \\
\hline Indeno $[1,2,3-c, d] p y r e n e$ & 880 & $\mathbf{U}$ & 420 & $\mathbf{U}$ & 420 & $U$ & 510 & $\mathrm{U}$ & 420 & $\mathrm{U}$ & 420 & U & 420 & $\mathrm{U}$ & 2,000 & $\mathrm{U}$ & 820 & $\mathbf{U}$ \\
\hline Isophorone & 880 & U & 420 & $\mathrm{U}$ & 420 & U & 510 & $\mathbf{U}$ & 420 & $\mathbf{U}$ & 420 & $\mathrm{U}$ & 420 & U & 2,000 & $\mathbf{U}$ & 820 & $\mathrm{U}$ \\
\hline 2-Methylnaphthalene & 880 & $\mathrm{U}$ & 120 & J & 420 & $U$ & 510 & $\mathrm{U}$ & 420 & $\mathrm{U}$ & 420 & $\mathrm{U}$ & 420 & $\mathrm{U}$ & 2,000 & $\mathbf{U}$ & 820 & $\mathbf{U}$ \\
\hline 2-Methylphenol & 880 & $\mathbf{U}$ & 80 & J & 75 & $\mathrm{~J}$ & 510 & $\mathrm{U}$ & 420 & $\mathrm{U}$ & 420 & $\mathbf{U}$ & 420 & $\mathrm{U}$ & 2,000 & $U$ & 820 & $\mathbf{U}$ \\
\hline 4-Methylphenol & 880 & $\mathbf{U}$ & 92 & J & 91 & $\mathrm{U}$ & 510 & $\mathrm{U}$ & 420 & $\mathrm{U}$ & 420 & $U$ & 420 & $\mathrm{U}$ & 2,000 & $U$ & 820 & $U$ \\
\hline Naphthalene & 880 & $\mathbf{U}$ & 67 & $\mathrm{~J}$ & 63 & $\mathrm{~J}$ & 510 & $\mathrm{U}$ & 420 & $\mathrm{U}$ & 420 & $\mathrm{U}$ & 420 & $\mathrm{U}$ & 2,000 & $U$ & 820 & $\mathbf{U}$ \\
\hline 2-Nitroaniline & 2,200 & $\mathbf{U}$ & 1,000 & $\mathbf{U}$ & 1,000 & $\mathrm{U}$ & 1,300 & $\mathrm{U}$ & 1,000 & $\mathrm{U}$ & 1,100 & $\mathbf{U}$ & 1,000 & $\mathrm{U}$ & 5,100 & U & 2,000 & $\mathbf{U}$ \\
\hline 3-Nitroaniline & 2,200 & $\mathrm{U}$ & 1,000 & $\mathbf{U}$ & 1,000 & $\mathrm{U}$ & 1,300 & $\mathbf{U}$ & 1,000 & $U$ & 1,100 & $\mathbf{U}$ & 1,000 & $\mathrm{U}$ & 5,100 & $\mathrm{U}$ & 2,000 & u \\
\hline
\end{tabular}


TABLE C.14b (Cont.)

\begin{tabular}{|c|c|c|c|c|c|c|c|c|c|c|c|c|c|c|c|c|c|c|}
\hline \multirow[b]{2}{*}{ Compound } & \multicolumn{18}{|c|}{ Soil Concentrations ( $\mu \mathrm{g} / \mathrm{kg}$ ) at Various Depth Intervals } \\
\hline & \multicolumn{2}{|c|}{$\begin{array}{c}\text { CLP6 } \\
\text { (0-6 in.) }\end{array}$} & \multicolumn{2}{|c|}{$\begin{array}{c}\text { CLP6 } \\
\text { (6-24 in.) }\end{array}$} & \multicolumn{2}{|c|}{$\begin{array}{l}\text { CLPG-RE } \\
\text { (6-24 in.) }\end{array}$} & \multicolumn{2}{|c|}{$\begin{array}{l}\text { CLP7 } \\
\text { (0-6 in.) }\end{array}$} & \multicolumn{2}{|c|}{$\begin{array}{c}\text { CLP7 } \\
\text { (6-24 in.) }\end{array}$} & \multicolumn{2}{|c|}{$\begin{array}{l}\text { CLP7-RE } \\
\text { (6-24 in.) }\end{array}$} & \multicolumn{2}{|c|}{$\begin{array}{c}\text { CLP7 } \\
\text { (24-48 in.) }\end{array}$} & \multicolumn{2}{|c|}{$\begin{array}{c}\text { CLP8 } \\
\text { (0-6 in.) }\end{array}$} & \multicolumn{2}{|c|}{$\begin{array}{c}\text { CLP9 } \\
\text { (0-6 in.) }\end{array}$} \\
\hline 4-Nitroaniline & 2,200 & $\mathrm{U}$ & 1,000 & $\mathbf{u}^{-}$ & 1,000 & $\mathbf{U}$ & 1,300 & $\mathbf{U}$ & 1,000 & U & 1,100 & $\mathrm{U}$ & 1,000 & $\mathbf{U}$ & 5,100 & $\mathbf{U}$ & 2,000 & $U$ \\
\hline Nitrobenzene & 880 & $\mathrm{U}$ & 420 & $\mathbf{U}$ & 420 & $\mathrm{U}$ & 510 & $\mathrm{U}$ & 420 & $U$ & 420 & $U$ & 420 & $\mathbf{U}$ & 2,000 & $\mathbf{U}$ & 820 & $\mathrm{U}$ \\
\hline 2-Nitrophenol & 880 & $\mathrm{U}$ & 420 & $\mathrm{U}$ & 420 & $\mathrm{U}$ & 510 & $\mathrm{U}$ & 420 & $U$ & 420 & U & 420 & U & 2,000 & U & 820 & $\mathrm{U}$ \\
\hline 4-Nitrophenol & 2,200 & $\mathbf{U}$ & 1,000 & $\mathbf{U}$ & 1,000 & $\mathrm{U}$ & 1,300 & $\mathrm{U}$ & 1,000 & $\mathrm{U}$ & 1,100 & $\mathrm{U}$ & 1,000 & $\mathbf{U}$ & 5,100 & $\mathbf{U}$ & 2,000 & $\mathrm{u}$ \\
\hline N-Nitroso-di-n-propylamine & 880 & $\mathbf{U}$ & 420 & $\mathbf{U}$ & 420 & U & 510 & $\mathbf{U}$ & 420 & U & 420 & $\mathbf{U}$ & 420 & $\mathbf{U}$ & 2,000 & U & 820 & U \\
\hline N-Nitrosodiphenylamine & 880 & $\mathbf{U}$ & 420 & $\mathbf{u}$ & 420 & $\mathrm{U}$ & 510 & $U$ & 420 & $U$ & 420 & $\mathrm{U}$ & 420 & $\mathbf{U}$ & 2,000 & $\mathbf{U}$ & 820 & $\mathrm{U}$ \\
\hline Pentachlorophenol & 2,200 & $\mathbf{U}$ & 1,000 & $\mathbf{U}$ & 1,000 & U & 1,300 & $\mathrm{U}$ & 1,000 & $\mathrm{U}$ & 1,100 & $\mathrm{U}$ & 1,000 & $\mathbf{U}$ & 5,100 & U & 2,000 & $\mathrm{U}$ \\
\hline Phenanthrene & 880 & $\mathrm{U}$ & 74 & $\mathrm{~J}$ & 71 & J & 510 & $\mathrm{U}$ & 420 & $\mathrm{U}$ & 420 & $\mathrm{U}$ & 420 & $\mathbf{U}$ & 2,000 & $U$ & 820 & $\mathrm{U}$ \\
\hline Phenol & 880 & $\mathbf{u}$ & 420 & $\mathrm{U}$ & 420 & $\mathrm{U}$ & 510 & $\mathrm{U}$ & 420 & $\mathrm{U}$ & 420 & $\mathbf{U}$ & 420 & $\mathbf{U}$ & 2,000 & U & 820 & $\mathrm{U}$ \\
\hline Pyrene & 880 & $\mathbf{U}$ & 180 & J & 140 & $\mathbf{J}$ & 510 & U & 420 & $\mathbf{U}$ & 420 & $U$ & 420 & $\mathrm{U}$ & 2,000 & $\mathbf{U}$ & 44 & $\mathbf{J}$ \\
\hline 1,2,4-Trichlorobenzene & 880 & $\mathbf{U}$ & 46 & J & 45 & $\mathbf{J}$ & 510 & $\mathrm{U}$ & 420 & $U$ & 420 & U & 420 & $\mathbf{U}$ & 2,000 & U & 820 & U \\
\hline 2,4,5-Trichlorophenol & 2,200 & $\mathbf{U}$ & 1,000 & $\mathbf{U}$ & 1,000 & $\mathrm{U}$ & 1,300 & $\mathrm{U}$ & 1,000 & $\mathrm{U}$ & 1,100 & $U$ & 1,000 & $\mathbf{U}$ & 5,100 & U & 2,000 & $\mathrm{U}$ \\
\hline 2,4,6-Trichlorophenol & 880 & $\mathbf{U}$ & 420 & $\mathrm{U}$ & 420 & $\mathrm{U}$ & 510 & $\mathrm{U}$ & 420 & $\mathrm{U}$ & 420 & $\mathrm{U}$ & 420 & $\mathrm{U}$ & 2,000 & U & 820 & U \\
\hline
\end{tabular}

2 Sampled by ANL, analyzed by Weston Gulf Coast, CLP/HSL semivolatile organics.

Data qualifiers:

$U=$ analyte was analyzed for but not detected; detection limit given.

$\mathrm{J}=$ estimated value.

$B=$ analyte was found in the associated blank. 
TABLE C.14c Semivolatile Organics Analyses for Soil Borings, May 1994a

\begin{tabular}{|c|c|c|c|c|c|c|c|c|c|c|c|c|}
\hline \multirow{3}{*}{$\begin{array}{l}\text { Compound } \\
\text { Acenaphthene }\end{array}$} & \multicolumn{12}{|c|}{ Soil Concentrations $(\mu \mathrm{g} / \mathrm{kg})$ at Various Depth Intervals } \\
\hline & \multicolumn{2}{|c|}{$\begin{array}{l}\text { TBSPBOR1 } \\
(0-2 \mathrm{ft})\end{array}$} & \multicolumn{2}{|c|}{$\begin{array}{l}\text { TBSPBOR1 Dup } \\
(0-2 \mathrm{ft}) \\
\end{array}$} & \multicolumn{2}{|c|}{$\begin{array}{l}\text { TBSPBOR1 } \\
(2-4 \mathrm{ft}) \\
\end{array}$} & \multicolumn{2}{|c|}{$\begin{array}{l}\text { TBSPBOR1 } \\
(4-6 \mathrm{ft})\end{array}$} & \multicolumn{2}{|c|}{$\begin{array}{c}\text { TBSPBOR1 } \\
(6-8 \mathrm{ft})\end{array}$} & \multicolumn{2}{|c|}{$\begin{array}{c}\text { TBSPBOR1 } \\
(8-10 \mathrm{ft})\end{array}$} \\
\hline & 380 & $\mathrm{U}$ & 380 & $U$ & 410 & $\mathrm{U}$ & 400 & $\mathrm{U}$ & 410 & $\mathrm{U}$ & 410 & $\mathrm{U}$ \\
\hline Acenaphthylene & 380 & $\mathrm{U}$ & 380 & $U$ & 410 & $\mathrm{U}$ & 400 & $\mathrm{U}$ & 410 & $\mathrm{U}$ & 410 & $\mathrm{U}$ \\
\hline Anthracene & 380 & $\mathrm{U}$ & 380 & $U$ & 410 & $\mathrm{U}$ & 61 & $\mathrm{~J}$ & 410 & $\mathrm{U}$ & 410 & $\mathrm{U}$ \\
\hline Benz[a]anthracene & 42 & $\mathrm{~J}$ & 380 & $U$ & 410 & $\mathrm{U}$ & 400 & $\mathrm{U}$ & 410 & $\mathrm{U}$ & 410 & $\mathrm{U}$ \\
\hline Benzo[a]pyrene & 380 & $U$ & 380 & $\mathrm{U}$ & 410 & $\mathrm{U}$ & 400 & $\mathrm{U}$ & 410 & $U$ & 410 & $U$ \\
\hline Benzo[b]fluoranthene & 380 & $U$ & 380 & $\mathrm{U}$ & 410 & $\mathrm{U}$ & 400 & $\mathrm{U}$ & 410 & $U$ & 410 & $\mathrm{U}$ \\
\hline Benzo[g,h,i]perylene & 380 & $\mathrm{U}$ & 380 & $\mathrm{U}$ & 410 & $\mathrm{U}$ & 400 & $\mathrm{U}$ & 410 & $\mathrm{U}$ & 410 & $U$ \\
\hline Benzo[k]fluoranthene & 380 & $\mathrm{U}$ & 380 & $\mathrm{U}$ & 410 & $U$ & 400 & $U$ & 410 & U & 410 & $U$ \\
\hline Bis(2-chloroethoxy)methane & 380 & $U$ & 380 & $\mathbf{U}$ & 410 & $\mathrm{U}$ & 400 & $\mathrm{U}$ & 410 & $U$ & 410 & $\mathrm{U}$ \\
\hline Bis(2-chloroethyl)ether & 380 & $U$ & 380 & $\mathrm{U}$ & 410 & $\mathrm{U}$ & 400 & $\mathrm{U}$ & 410 & $U$ & 410 & $\mathrm{U}$ \\
\hline Bis(2-chloroisopropyl)ether & 380 & $\mathrm{U}$ & 380 & $\mathrm{U}$ & 410 & $\mathrm{U}$ & 400 & $\mathrm{U}$ & 410 & $\mathrm{U}$ & 410 & $U$ \\
\hline Bis(2-ethylhexyl)phthalate & 240 & J & 380 & $\mathrm{U}$ & 410 & $\mathrm{U}$ & 400 & $\mathrm{U}$ & 54 & $\mathrm{~J}$ & 410 & $\mathrm{U}$ \\
\hline 4-Bromophenyl phenyl ether & 380 & $\mathrm{U}$ & 380 & $\mathrm{U}$ & 410 & $\mathrm{U}$ & 400 & $\mathrm{U}$ & 410 & $U$ & 410 & $\mathrm{U}$ \\
\hline Butylbenzylphthalate & 380 & $\mathrm{U}$ & 380 & $\mathrm{U}$ & 410 & $\mathrm{U}$ & 400 & $\mathrm{U}$ & 410 & $U$ & 410 & U \\
\hline Carbazole & 380 & $\mathrm{U}$ & 380 & $\mathrm{U}$ & 47 & $\mathrm{~J}$ & 88 & $\mathbf{J}$ & 410 & $U$ & 410 & $\mathrm{U}$ \\
\hline 4-Chloro-3-methylphenol & 380 & $\mathrm{U}$ & 380 & $U$ & 410 & $\mathrm{U}$ & 400 & $\mathrm{U}$ & 410 & $U$ & 410 & U \\
\hline 4-Chloroaniline & 380 & $U$ & 380 & $U$ & 410 & $\mathrm{U}$ & 400 & $\mathrm{U}$ & 410 & $\mathrm{U}$ & 410 & $U$ \\
\hline 2-Chloronaphthalene & 380 & $U$ & 380 & $\mathrm{U}$ & 410 & $U$ & 400 & $U$ & 410 & $\mathrm{U}$ & 410 & $\mathrm{U}$ \\
\hline 2-Chlorophenol & 380 & $\mathrm{U}$ & 380 & $U$ & 410 & $U$ & 400 & $U$ & 410 & $\mathrm{U}$ & 410 & $\mathrm{U}$ \\
\hline 4-Chlorophenyl phenyl ether & 380 & $\mathrm{U}$ & 380 & $\mathrm{U}$ & 410 & $\mathrm{U}$ & 400 & $U$ & 410 & $\mathrm{U}$ & 410 & $\mathrm{U}$ \\
\hline Chrysene & 43 & $\mathbf{J}$ & 380 & $U$ & 410 & $\mathrm{U}$ & 400 & $\mathrm{U}$ & 410 & $\mathrm{U}$ & 410 & $U$ \\
\hline Di-n-butylphthalate & 390 & B & 290 & JB & 310 & JB & 290 & $\mathrm{JB}$ & 320 & JB & 110 & JB \\
\hline Di-n-octyl phthalate & 380 & $U$ & 380 & $\mathrm{U}$ & 410 & $U$ & 400 & $U$ & 410 & $\mathrm{U}$ & 410 & $\mathrm{U}$ \\
\hline Dibenz[a,h]anthracene & 380 & $U$ & 380 & $\mathrm{U}$ & 410 & $\mathrm{U}$ & 400 & $U$ & 410 & $\mathrm{U}$ & 410 & $\mathrm{U}$ \\
\hline
\end{tabular}


TABLE C.14c (Cont.)

Soil Concentrations $(\mu \mathrm{g} / \mathrm{kg})$ at Various Depth Intervals

\begin{tabular}{|c|c|c|c|c|c|c|c|c|c|c|c|c|c|}
\hline \multirow{2}{*}{$\frac{\text { Compound }}{\text { Dibenzofuran }}$} & \multicolumn{2}{|c|}{$\begin{array}{l}\text { TBSPBOR1 } \\
(0-2 \mathrm{ft})\end{array}$} & \multicolumn{3}{|c|}{$\begin{array}{l}\text { TBSPBOR1 Dup } \\
(0-2 \mathrm{ft})\end{array}$} & \multicolumn{2}{|c|}{$\begin{array}{c}\text { TBSPBOR1 } \\
(2-4 \mathrm{ft})\end{array}$} & \multicolumn{2}{|c|}{$\begin{array}{c}\text { TBSPBOR I } \\
(4-6 \mathrm{ft})\end{array}$} & \multicolumn{2}{|c|}{$\begin{array}{c}\text { TBSPBOR1 } \\
(6-8 \mathrm{ft}) \\
\end{array}$} & \multicolumn{2}{|c|}{$\begin{array}{l}\text { TBSPBOR } 1 \\
(8-10 \mathrm{ft})\end{array}$} \\
\hline & 380 & $\mathrm{U}$ & & 38 & $\mathrm{~J}$ & 410 & $\mathrm{U}$ & 400 & $\mathrm{U}$ & 410 & $U$ & 410 & $U$ \\
\hline 1,2-Dichlorobenzene & 380 & $U$ & & 380 & $\mathrm{U}$ & 410 & $U$ & 400 & $\mathrm{U}$ & 410 & $\mathrm{U}$ & 410 & $\mathrm{U}$ \\
\hline 1,3-Dichlorobenzene & 380 & $U$ & & 380 & $\mathrm{U}$ & 410 & $\mathrm{U}$ & 400 & $\mathrm{U}$ & 410 & $U$ & 410 & $\mathrm{U}$ \\
\hline 1,4-Dichlorobenzene & 380 & $\mathrm{U}$ & & 380 & $\mathrm{U}$ & 410 & $\mathrm{U}$ & 400 & $\mathrm{U}$ & 410 & $\mathrm{U}$ & 410 & $\mathrm{U}$ \\
\hline 3,3'-Dichlorobenzidine & 380 & $\mathrm{U}$ & & 380 & $\mathrm{U}$ & 410 & $U$ & 400 & $\mathrm{U}$ & 410 & $\mathrm{U}$ & 410 & $\mathrm{U}$ \\
\hline 2,4-Dichlorophenol & 380 & $\mathrm{U}$ & & 380 & $\mathrm{U}$ & 410 & $\mathrm{U}$ & 400 & $\mathrm{U}$ & 410 & $\mathrm{U}$ & 410 & $\mathrm{U}$ \\
\hline Diethylphthalate & 190 & $\mathrm{~J}$ & & 99 & $\mathrm{~J}$ & 410 & $\mathrm{U}$ & 79 & $\mathrm{~J}$ & 410 & $\mathrm{U}$ & 410 & $\mathrm{U}$ \\
\hline 2,4-Dimethylphenol & 380 & $\mathrm{U}$ & & 380 & $\mathrm{U}$ & 410 & $U$ & 400 & $\mathrm{U}$ & 410 & $\mathrm{U}$ & 410 & $\mathrm{U}$ \\
\hline Dimethylphthalate & 380 & $\mathrm{U}$ & & 380 & $\mathrm{U}$ & 410 & $\mathrm{U}$ & 400 & $\mathrm{U}$ & 410 & $U$ & 410 & $\mathrm{U}$ \\
\hline 4,6-Dinitro-2-methylphenol & 960 & $\mathrm{U}$ & & 940 & $\mathrm{U}$ & 1,000 & $U$ & 1,000 & $\mathrm{U}$ & 1,000 & $U$ & 1,000 & $\mathrm{U}$ \\
\hline 2,4-Dinitrophenol & 960 & $\mathrm{U}$ & ‘ & 940 & $U$ & 1,000 & $\mathrm{U}$ & 1,000 & $\mathrm{U}$ & 1,000 & $\mathrm{U}$ & 1,000 & $\mathrm{U}$ \\
\hline 2,4-Dinitrotoluene & 380 & $U$ & & 380 & $U$ & 410 & $\mathrm{U}$ & 400 & $\mathrm{U}$ & 410 & $U$ & 410 & $\mathrm{U}$ \\
\hline 2,6-Dinitrotoluene & 380 & $U$ & & 380 & $\mathrm{U}$ & 410 & $\mathrm{U}$ & 400 & $\mathrm{U}$ & 410 & $U$ & 410 & $\mathrm{U}$ \\
\hline Fluoranthene & 73 & $\mathbf{J}$ & & 63 & $\mathbf{J}$ & 410 & $\mathrm{U}$ & 400 & $\mathrm{U}$ & 410 & $\mathrm{U}$ & 410 & $U$ \\
\hline Fluorene & 380 & $U$ & & 380 & $\mathrm{U}$ & 410 & $\mathrm{U}$ & 88 & $\mathrm{~J}$ & 410 & $U$ & 410 & $\mathrm{U}$ \\
\hline Hexachlorobenzene & 200 & $\mathbf{J}$ & & 210 & $\mathbf{J}$ & 410 & $\mathrm{U}$ & 400 & $U$ & 410 & $\mathrm{U}$ & 410 & $U$ \\
\hline Hexachlorobutadiene & 380 & $U$ & & 380 & $\mathrm{U}$ & 410 & $\mathrm{U}$ & 400 & $U$ & 410 & $\mathrm{U}$ & 410 & $\mathrm{U}$ \\
\hline Hexachlorocyclopentadiene & 380 & $\mathrm{U}$ & & 380 & $U$ & 410 & $\mathrm{U}$ & 400 & $\mathrm{U}$ & 410 & $\mathrm{U}$ & 410 & $U$ \\
\hline Hexachloroethane & 580 & & & 350 & $\mathbf{J}$ & 410 & $\mathrm{U}$ & 400 & $U$ & 410 & $U$ & 410 & $\mathrm{U}$ \\
\hline Indeno[1,2,3-c,d]pyrene & 380 & $\mathrm{U}$ & & 380 & $U$ & 410 & $U$ & 400 & $\mathrm{U}$ & 410 & $\dot{U}$ & 410 & $U$ \\
\hline Isophorone & 380 & $U$ & & 380 & $U$ & 410 & U & 400 & $U$ & 410 & $\mathrm{U}$ & 410 & $\mathrm{U}$ \\
\hline 2-Methylnaphthalene & 110 & $\mathrm{~J}$ & & 230 & J & 410 & $\mathrm{U}$ & 400 & $\mathrm{U}$ & 410 & $\mathrm{U}$ & 410 & $\mathrm{U}$ \\
\hline 2-Methylphenol & 380 & $U$ & & 380 & $\mathrm{U}$ & 410 & $\mathrm{U}$ & 400 & $\mathrm{U}$ & 410 & $\mathrm{U}$ & 410 & $\mathrm{U}$ \\
\hline
\end{tabular}


TABLE C.14c (Cont.)

\begin{tabular}{|c|c|c|c|c|c|c|c|c|c|c|c|c|}
\hline \multirow{3}{*}{$\begin{array}{l}\text { Compound } \\
\text { 4-Methylphenol }\end{array}$} & \multicolumn{12}{|c|}{ Soil Concentrations $(\mu \mathrm{g} / \mathrm{kg})$ at Various Depth Intervals } \\
\hline & \multicolumn{2}{|c|}{$\begin{array}{l}\text { TBSPBOR } 1 \\
(0-2 \mathrm{ft})\end{array}$} & \multicolumn{2}{|c|}{$\begin{array}{l}\text { TBSPBOR1 Dup } \\
(0-2 \mathrm{ft}) \\
\end{array}$} & \multicolumn{2}{|c|}{$\begin{array}{c}\text { TBSPBOR1 } \\
(2-4 \mathrm{ft}) \\
\end{array}$} & \multicolumn{2}{|c|}{$\begin{array}{c}\text { TBSPBOR1 } \\
(4-6 \mathrm{ft})\end{array}$} & \multicolumn{2}{|c|}{$\begin{array}{c}\text { TBSPBOR1 } \\
(6-8 \mathrm{ft})\end{array}$} & \multicolumn{2}{|c|}{$\begin{array}{c}\text { TBSPBOR } \\
(8-10 \mathrm{ft}) \\
\end{array}$} \\
\hline & 380 & $\mathrm{U}$ & 380 & $\mathrm{U}$ & 410 & $\mathrm{U}$ & 400 & $\mathrm{U}$ & 410 & $\mathrm{U}$ & 410 & U \\
\hline Naphthalene & 380 & $\mathrm{U}$ & 61 & $\mathrm{~J}$ & 410 & $\mathrm{U}$ & 400 & $U$ & 410 & $U$ & 410 & $\mathrm{U}$ \\
\hline 2-Nitroaniline & 960 & $\mathrm{U}$ & 940 & $\mathrm{U}$ & 1,000 & $\mathrm{U}$ & 1,000 & $\mathrm{U}$ & 1,000 & $\mathrm{U}$ & 1,000 & $\mathbf{U}$ \\
\hline 3-Nitroaniline & 960 & $\mathrm{U}$ & 940 & $\mathrm{U}$ & 1,000 & $\mathrm{U}$ & 1,000 & $\mathrm{U}$ & 1,000 & $U$ & 1,000 & $U$ \\
\hline 4-Nitroaniline & 960 & $U$ & 940 & $\mathrm{U}$ & 1,000 & $\mathrm{U}$ & 1,000 & $\mathrm{U}$ & 1,000 & $\mathrm{U}$ & 1,000 & $\mathrm{U}$ \\
\hline Nitrobenzene & 380 & $\mathrm{U}$ & 380 & $\mathrm{U}$ & 410 & $\mathrm{U}$ & 400 & $\mathrm{U}$ & 410 & $\mathrm{U}$ & 410 & $\mathrm{U}$ \\
\hline 2-Nitrophenol & 380 & $\mathrm{U}$ & 380 & $U$ & 410 & $\mathrm{U}$ & 400 & $\mathrm{U}$ & 410 & $\mathrm{U}$ & 410 & $\mathrm{U}$ \\
\hline 4-Nitrophenol & 960 & $\mathrm{U}$ & 940 & $\mathrm{U}$ & 1,000 & $\mathrm{U}$ & 1,000 & $\mathrm{U}$ & 1,000 & $\mathrm{U}$ & 1,000 & $\mathrm{U}$ \\
\hline N-Nitroso-di-n-propylamine & 380 & $\mathrm{U}$ & 380 & $\mathrm{U}$ & 410 & $U$ & 400 & $\mathrm{U}$ & 410 & $\mathrm{U}$ & 410 & $\mathrm{U}$ \\
\hline N-Nitrosodiphenylamine & 650 & & 950 & & 64 & $\mathrm{~J}$ & 120 & $J$ & 44 & $\mathbf{J}$ & 410 & $\mathrm{U}$ \\
\hline Pentachlorophenol & 960 & $\mathrm{U}$ & 940 & $\mathrm{U}$ & 1,000 & $\mathrm{U}$ & 1,000 & $\mathrm{U}$ & 1,000 & $\mathrm{U}$ & 1,000 & $\mathrm{U}$ \\
\hline Phenanthrene & 99 & $\mathrm{~J}$ & 130 & $J$ & 53 & $\mathrm{~J}$ & 62 & $\mathrm{~J}$ & 410 & $U$ & 410 & $\mathrm{U}$ \\
\hline Phenol & 380 & $\mathrm{U}$ & 380 & $\mathrm{U}$ & 410 & $\mathrm{U}$ & 400 & $\mathbf{U}$ & 410 & $\mathrm{U}$ & 410 & $\mathrm{U}$ \\
\hline Pyrene & 63 & $\mathbf{J}$ & 74 & $\mathrm{~J}$ & 42 & $\mathrm{~J}$ & 400 & $\mathrm{U}$ & 410 & $\mathrm{U}$ & 410 & $\mathrm{U}$ \\
\hline 1,2,4-Trichlorobenzene & 130 & $\mathrm{~J}$ & 340 & $\mathbf{J}$ & 410 & $\mathrm{U}$ & 400 & $\mathrm{U}$ & 410 & $\mathrm{U}$ & 410 & $\mathrm{U}$ \\
\hline 2,4,5-Trichlorophenol & 960 & $\mathrm{U}$ & 940 & $\mathrm{U}$ & 1,000 & $\mathrm{U}$ & 1,000 & $\mathrm{U}$ & 1,000 & $U$ & 1,000 & U \\
\hline 2,4,6-Trichlorophenol & 380 & $\mathrm{U}$ & 380 & $U$ & 410 & $\mathrm{U}$ & 400 & U & 410 & $\mathrm{U}$ & 410 & U \\
\hline
\end{tabular}


TABLE C.14c (Cont.)

\begin{tabular}{|c|c|c|c|c|c|c|c|c|c|c|c|c|c|c|}
\hline \multirow{3}{*}{$\begin{array}{l}\text { Compound } \\
\text { Acenaphthene }\end{array}$} & \multicolumn{14}{|c|}{ Soil Concentrations $(\mu \mathrm{g} / \mathrm{kg})$ at Various Depth Intervals } \\
\hline & \multicolumn{2}{|c|}{$\begin{array}{l}\text { TBSPBOR1 } \\
(10-12 \mathrm{ft})\end{array}$} & \multicolumn{2}{|c|}{$\begin{array}{c}\text { TBSPBOR2 } \\
(0-2 \mathrm{ft})\end{array}$} & \multicolumn{2}{|c|}{$\begin{array}{l}\text { TBSPBOR2 Dup } \\
(0-2 \mathrm{ft}) \\
\end{array}$} & \multicolumn{2}{|c|}{$\begin{array}{c}\text { TBSPBOR2 } \\
(2-4 \mathrm{ft})\end{array}$} & \multicolumn{2}{|c|}{$\begin{array}{c}\text { TBSPBOR2 } \\
(4-6 \mathrm{ft})\end{array}$} & \multicolumn{2}{|c|}{$\begin{array}{c}\text { TBSPBOR2 } \\
(6-8 \mathrm{ft})\end{array}$} & \multicolumn{2}{|c|}{$\begin{array}{c}\text { TBSPBOR2 } \\
(8-10 \mathrm{ft})\end{array}$} \\
\hline & 390 & $\mathrm{U}$ & 390 & $\mathrm{U}$ & 390 & $\mathrm{U}$ & 390 & $U$ & 390 & $\mathrm{U}$ & 400 & $U$ & 400 & $\mathrm{U}$ \\
\hline Acenaphthylene & 390 & $\mathrm{UN}$ & 390 & $\mathrm{U}$ & 390 & $\mathrm{U}$ & 390 & $\mathrm{U}$ & 390 & $\mathrm{U}$ & 400 & $\mathrm{U}$ & 400 & $U$ \\
\hline Anthracene & 390 & $\mathrm{U}$ & 390 & $\mathrm{U}$ & 390 & $U$ & 390 & $\mathrm{U}$ & 390 & $\mathrm{U}$ & 400 & $\mathrm{U}$ & 400 & $U$ \\
\hline Benz[a]anthracene & 390 & $\mathrm{U}$ & 390 & $\mathrm{U}$ & 390 & $\mathrm{U}$ & 390 & $\mathrm{U}$ & 390 & $\mathrm{U}$ & 400 & $\mathrm{U}$ & 400 & $U$ \\
\hline Benzo[a]pyrene & 390 & $\mathrm{U}$ & 390 & $U$ & 390 & $\mathrm{U}$ & 390 & $U$ & 390 & $U$ & 400 & $\mathrm{U}$ & 400 & $U$ \\
\hline Benzo[b]fluoranthene & 390 & $\mathrm{U}$ & 390 & $\mathrm{U}$ & 390 & $U$ & 390 & $\mathrm{U}$ & 390 & $\mathrm{U}$ & 400 & $U$ & 400 & $\mathrm{U}$ \\
\hline Benzo[g,h,i]perylene & 390 & $\mathrm{U}$ & 390 & $U$ & 390 & $\mathrm{U}$ & 390 & $\mathrm{U}$ & 390 & $\mathrm{U}$ & 400 & $\mathrm{U}$ & 400 & $U$ \\
\hline Benzo[k]fluoranthene & 390 & $\mathrm{U}$ & 390 & $\mathrm{U}$ & 390 & $\mathrm{U}$ & 390 & $U$ & 390 & $\mathrm{U}$ & 400 & $\mathrm{U}$ & 400 & $U$ \\
\hline Bis(2-chloroethoxy)methane & 390 & $\mathrm{U}$ & 390 & $\mathrm{U}$ & 390 & $\mathrm{U}$ & 390 & $U$ & 390 & $\mathrm{U}$ & 400 & $U$ & 400 & U \\
\hline Bis(2-chloroethyl)ether & 390 & $\mathrm{U}$ & 390 & $\mathrm{~J}$ & 390 & $\mathrm{U}$ & 390 & $U$ & 390 & $U$ & 400 & $U$ & 400 & $\mathbf{U}$ \\
\hline Bis(2-chloroisopropyl)ether & 390 & $\mathrm{U}$ & 390 & $U$ & 390 & $\mathrm{U}$ & 390 & $\mathrm{U}$ & 390 & $\mathrm{U}$ & 400 & $\mathrm{U}$ & 400 & $\mathrm{U}$ \\
\hline Bis(2-ethylhexyl)phthalate & 390 & $\mathrm{U}$ & 390 & $U$ & 390 & $U$ & 390 & $\mathrm{U}$ & 390 & $\mathrm{U}$ & 400 & $\mathrm{U}$ & 400 & $\mathbf{U}$ \\
\hline 4-Bromophenyl phenyl ether & 390 & $\mathrm{U}$ & 390 & $\mathrm{U}$ & 390 & $\mathrm{U}$ & 390 & $\mathrm{U}$ & 390 & $\mathrm{U}$ & 400 & $U$ & 400 & $U$ \\
\hline Butylbenzylphthalate & 390 & $U$ & 390 & $\mathrm{U}$ & 390 & $\mathrm{U}$ & 390 & $U$ & 390 & $U$ & 400 & $\mathrm{U}$ & 400 & $\mathrm{U}$ \\
\hline Carbazole & 390 & $\mathrm{U}$ & 390 & $\mathrm{U}$ & 390 & $U$ & 390 & $U$ & 390 & $\mathrm{U}$ & 400 & $\mathrm{U}$ & 400 & $\mathrm{U}$ \\
\hline 4-Chloro-3-methylphenol & 390 & $\mathrm{U}$ & 390 & $\mathrm{U}$ & 390 & $U$ & 390 & $\mathrm{U}$ & 390 & $\mathrm{U}$ & 400 & $U$ & 400 & $U$ \\
\hline 4-Chloroaniline & 390 & $\mathrm{U}$ & 390 & $U$ & 390 & $\mathrm{U}$ & 390 & $U$ & 390 & $U$ & 400 & $\mathrm{U}$ & 400 & $\mathrm{U}$ \\
\hline 2-Chloronaphthalene & 390 & $\mathrm{U}$ & 390 & $U$ & 390 & $\mathrm{U}$ & 390 & $U$ & 390 & $\mathrm{U}$ & 400 & $\mathrm{U}$ & 400 & $U$ \\
\hline 2-Chlorophenol & 390 & $\mathrm{U}$ & 390 & $U$ & 390 & $\mathrm{U}$ & 390 & $U$ & 390 & $\mathrm{U}$ & 400 & U & 400 & U \\
\hline 4-Chlorophenyl phenyl ether & 390 & $\mathrm{U}$ & 390 & $U$ & 390 & $\mathrm{U}$ & 390 & $U$ & 390 & $\mathrm{U}$ & 400 & $\mathrm{U}$ & 400 & $\mathrm{U}$ \\
\hline Chrysene & 390 & $\mathrm{U}$ & 390 & $\mathrm{U}$ & 390 & $U$ & 390 & $\mathrm{U}$ & 390 & $\mathrm{U}$ & 400 & $\mathrm{U}$ & 400 & $\mathrm{U}$ \\
\hline Di-n-butylphthalate & 150 & JB & 230 & JB & 190 & $\mathrm{JB}$ & 230 & $\mathrm{JB}$ & 260 & JB & 240 & JB & 190 & $\mathrm{JB}$ \\
\hline Di-n-octylphthalate & 390 & $U$ & 390 & $U$ & 390 & $U$ & 390 & $U$ & 390 & $\mathrm{U}$ & 400 & $U$ & 400 & $U$ \\
\hline
\end{tabular}




\begin{tabular}{|c|c|c|c|c|c|c|c|c|c|c|c|c|c|c|}
\hline \multirow{3}{*}{$\frac{\text { Compound }}{\text { Dibenz }[\mathrm{a}, \mathrm{h}] \text { anthracene }}$} & \multicolumn{14}{|c|}{ Soil Concentrations $(\mu \mathrm{g} / \mathrm{kg})$ at Various Depth Intervals } \\
\hline & \multicolumn{2}{|c|}{$\begin{array}{l}\text { TBSPBOR } 1 \\
(10-12 \mathrm{ft})\end{array}$} & \multicolumn{2}{|c|}{$\begin{array}{c}\text { TBSPBOR2 } \\
(0-2 \mathrm{ft})\end{array}$} & \multicolumn{2}{|c|}{$\begin{array}{l}\text { TBSPBOR2 Dup } \\
(0-2 \mathrm{ft})\end{array}$} & \multicolumn{2}{|c|}{$\begin{array}{l}\text { TBSPBOR2 } \\
(2-4 \mathrm{ft})\end{array}$} & \multicolumn{2}{|c|}{$\begin{array}{c}\text { TBSPBOR2 } \\
(4-6 \mathrm{ft})\end{array}$} & \multicolumn{2}{|c|}{$\begin{array}{c}\text { TBSPBOR2 } \\
(6-8 \mathrm{ft})\end{array}$} & \multicolumn{2}{|c|}{$\begin{array}{c}\text { TBSPBOR2 } \\
(8-10 \mathrm{ft})\end{array}$} \\
\hline & 390 & $\mathrm{U}$ & 390 & $\mathrm{U}$ & 390 & U & 390 & $\mathrm{U}$ & 390 & $\mathrm{U}$ & 400 & $\mathrm{U}$ & 400 & $\mathrm{U}$ \\
\hline Dibenzofuran & 390 & $U$ & 390 & $\mathrm{U}$ & 390 & U & 390 & $\mathrm{U}$ & 390 & $\mathrm{U}$ & 400 & $\mathrm{U}$ & 400 & $\mathrm{U}$ \\
\hline 1,2-Dichlorobenzene & 390 & $\mathrm{U}$ & 170 & $\mathrm{~J}$ & 390 & $\mathrm{U}$ & 390 & $\mathrm{U}$ & 390 & $\mathrm{U}$ & 400 & $\mathrm{U}$ & 400 & $\mathrm{U}$ \\
\hline 1,3-Dichlorobenzene & 390 & $\mathrm{U}$ & 390 & $U$ & 390 & $\mathrm{U}$ & 390 & $\mathrm{U}$ & 390 & $\mathrm{U}$ & 400 & $\mathrm{U}$ & 400 & $\mathrm{U}$ \\
\hline 1,4-Dichlorobenzene & 390 & UN & 390 & $\mathrm{U}$ & 390 & $\mathrm{U}$ & 390 & $\mathrm{U}$ & 390 & $\mathrm{U}$ & 400 & $\mathrm{U}$ & 400 & $\mathrm{U}$ \\
\hline 3,3'-Dichlorobenzidine & 390 & $\mathrm{U}$ & 390 & $\mathrm{U}$ & 390 & $U$ & 390 & $\mathrm{U}$ & 390 & $\mathrm{U}$ & 400 & $\mathrm{U}$ & 400 & $\mathrm{U}$ \\
\hline 2,4- Dichlorophenol & 390 & $\mathrm{U}$ & 390 & $\mathrm{U}$ & 390 & $U$ & 390 & $\mathrm{U}$ & 390 & $\mathrm{U}$ & 400 & $\mathrm{U}$ & 400 & $\mathrm{U}$ \\
\hline Diethylphthalate & 390 & $U$ & 390 & $\mathrm{U}$ & 390 & $\mathrm{U}$ & 390 & $\mathrm{U}$ & 390 & $\mathrm{U}$ & 400 & U & 400 & U \\
\hline 2,4-Dimethylphenol & 390 & $\mathrm{U}$ & 390 & $U$ & 390 & $\mathrm{U}$ & 390 & $U$ & 390 & $\mathrm{U}$ & 400 & $\mathrm{U}$ & 400 & $\mathrm{U}$ \\
\hline Dimethylphthalate & 390 & $\mathrm{U}$ & 390 & $\mathrm{U}$ & 390 & $\mathrm{U}$ & 390 & $\mathrm{U}$ & 390 & $\mathrm{U}$ & 400 & $\mathrm{U}$ & 400 & $\mathrm{U}$ \\
\hline 4,6-Dinitro-2-methylphenol & 980 & $U$ & 970 & U & 960 & $\mathrm{U}$ & 980 & $\mathrm{U}$ & 980 & $\mathrm{U}$ & 990 & $\mathrm{U}$ & 1,000 & $\mathrm{U}$ \\
\hline 2,4-Dinitrophenol & 980 & $\mathrm{U}$ & 970 & $\mathrm{U}$ & 960 & $U$ & 980 & $\mathrm{U}$ & 980 & $\mathrm{U}$ & 990 & $\mathrm{U}$ & 1,000 & $\mathrm{U}$ \\
\hline 2,4-Dinitrotoluene & 390 & $\mathrm{U}$ & 390 & $\mathrm{U}$ & 390 & $\mathrm{U}$ & 390 & $\mathrm{U}$ & 390 & $\mathrm{U}$ & 400 & $U$ & 400 & $U$ \\
\hline 2,6-Dinitrotoluene & 390 & $U$ & 390 & $\mathrm{U}$ & 390 & $\mathrm{U}$ & 390 & $\mathrm{U}$ & 390 & $\mathrm{U}$ & 400 & $\mathrm{U}$ & 400 & $\mathrm{U}$ \\
\hline Fluoranthene & 390 & $\mathrm{U}$ & 390 & $\mathrm{U}$ & 390 & $U$ & 390 & $\mathrm{U}$ & 390 & $\mathrm{U}$ & 400 & $\mathrm{U}$ & 400 & $\mathrm{U}$ \\
\hline Fluorene & 390 & $\mathrm{U}$ & 390 & $U$ & 390 & $\mathrm{U}$ & 390 & $U$ & 390 & $\mathrm{U}$ & 400 & $\mathrm{U}$ & 400 & $\mathrm{U}$ \\
\hline Hexachlorobenzene & 390 & $\mathrm{U}$ & 390 & $\mathrm{U}$ & 390 & U & 390 & $\mathrm{U}$ & 390 & $\mathrm{U}$ & 400 & $\mathrm{U}$ & 400 & $\mathrm{U}$ \\
\hline Hexachlorobutadiene & 390 & $\mathrm{U}$ & 390 & $\mathrm{U}$ & 390 & $U$ & 390 & $U$ & 390 & $U$ & 400 & $\mathrm{U}$ & 400 & $\mathrm{U}$ \\
\hline Hexachlorocyclopentadiene & 390 & $U$ & 390 & $U$ & 390 & $\mathrm{U}$ & 390 & $\mathrm{U}$ & 390 & $\mathrm{U}$ & 400 & $\mathrm{U}$ & 400 & U \\
\hline Hexachloroethane & 390 & $U$ & 390 & $U$ & 390 & $\mathrm{U}$ & 390 & $\mathrm{U}$ & 390 & $\mathrm{U}$ & 400 & $\mathrm{U}$ & 58 & $\mathrm{~J}$ \\
\hline Indeno[1,2,3-c,d]pyrene & 390 & $\mathrm{U}$ & 390 & $\mathrm{U}$ & 390 & $\mathrm{U}$ & 390 & $\mathrm{U}$ & 390 & $\mathrm{U}$ & 400 & $\mathrm{U}$ & 400 & $\mathrm{U}$ \\
\hline Isophorone & 390 & $\mathrm{U}$ & 390 & $\mathrm{U}$ & 390 & $\mathrm{U}$ & 390 & $U$ & 390 & $\mathrm{U}$ & 400 & $\mathrm{U}$ & 400 & $\mathrm{U}$ \\
\hline 2-Methylnaphthalene & 390 & $U$ & 390 & $U$ & 71 & J & 390 & $U$ & 390 & $U$ & 400 & $\mathrm{U}$ & 400 & $\mathrm{U}$ \\
\hline
\end{tabular}


TABLE C.14c (Cont.)

\begin{tabular}{|c|c|c|c|c|c|c|c|c|c|c|c|c|c|c|}
\hline \multirow{3}{*}{ Compound } & \multicolumn{14}{|c|}{ Soil Concentrations $(\mu \mathrm{g} / \mathrm{kg})$ at Various Depth Intervals } \\
\hline & \multicolumn{2}{|c|}{$\begin{array}{c}\text { TBSPBOR1 } \\
(10-12 \mathrm{ft})\end{array}$} & \multicolumn{2}{|c|}{$\begin{array}{c}\text { TBSPBOR2 } \\
(0-2 \mathrm{ft})\end{array}$} & \multicolumn{2}{|c|}{$\begin{array}{l}\text { TBSPBOR2 Dup } \\
(0-2 \mathrm{ft})\end{array}$} & \multicolumn{2}{|c|}{$\begin{array}{c}\text { TBSPBOR2 } \\
(2-4 \mathrm{ft})\end{array}$} & \multicolumn{2}{|c|}{$\begin{array}{c}\text { TBSPBOR2 } \\
(4-6 \mathrm{ft})\end{array}$} & \multicolumn{2}{|c|}{$\begin{array}{c}\text { TBSPBOR2 } \\
(6-8 \mathrm{ft})\end{array}$} & \multicolumn{2}{|c|}{$\begin{array}{c}\text { TBSPBOR2 } \\
(8-10 \mathrm{ft})\end{array}$} \\
\hline & 390 & $\mathrm{U}$ & 390 & $\mathrm{U}$ & 390 & $U$ & 390 & $\mathrm{U}$ & 390 & $\mathrm{U}$ & 400 & $\mathrm{U}$ & 400 & $\mathrm{U}$ \\
\hline 4-Methylphenol & 390 & $\mathrm{U}$ & 390 & $\mathrm{U}$ & 390 & $\mathrm{U}$ & 390 & $U$ & 390 & $U$ & 400 & $\mathrm{U}$ & 400 & $\mathrm{U}$ \\
\hline Naphthalene & 390 & $\mathrm{U}$ & 390 & $\mathrm{U}$ & 390 & $\mathrm{U}$ & 390 & $\mathrm{U}$ & 390 & $\mathrm{U}$ & 400 & $\mathrm{U}$ & 400 & $\mathrm{U}$ \\
\hline 2-Nitroaniline & 980 & $\mathrm{U}$ & 970 & $\mathrm{U}$ & 960 & $\mathrm{U}$ & 980 & $\mathrm{U}$ & 980 & $\mathrm{U}$ & 990 & $U$ & 1,000 & $\mathrm{U}$ \\
\hline 3-Nitroaniline & 980 & $\mathrm{U}$ & 970 & $\mathrm{U}$ & 960 & $\mathrm{U}$ & 980 & $\mathrm{U}$ & 980 & $\mathrm{U}$ & 990 & $U$ & 1,000 & $\mathrm{U}$ \\
\hline 4-Nitroaniline & 980 & $\mathrm{U}$ & 970 & $\mathrm{U}$ & 960 & $\mathrm{U}$ & 980 & $U$ & 980 & $\mathrm{U}$ & 990 & $\mathrm{U}$ & 1,000 & $U$ \\
\hline Nitrobenzene & 390 & $\mathrm{U}$ & 390 & $U$ & 390 & $\mathrm{U}$ & 390 & $U$ & 390 & $U$ & 400 & $\mathrm{U}$ & 400 & $\mathrm{U}$ \\
\hline 2-Nitrophenol & 390 & $\mathrm{U}$ & 390 & $\mathrm{U}$ & 390 & $\mathrm{U}$ & 390 & $U$ & 390 & $\mathrm{U}$ & 400 & $\mathrm{U}$ & 400 & $\mathrm{U}$ \\
\hline 4-Nitrophenol & 980 & UN & 970 & $\mathrm{U}$ & 960 & $\mathrm{U}$ & 980 & $\mathrm{U}$ & 980 & $U$ & 990 & $\mathrm{U}$ & 1,000 & $U$ \\
\hline N-Nitroso-di-n-propylamine & 390 & $\mathrm{U}$ & 390 & $U$ & 390 & $\mathrm{U}$ & 390 & $\mathrm{U}$ & 390 & $\mathrm{U}$ & 400 & $\mathrm{U}$ & 400 & $\mathrm{U}$ \\
\hline N-Nitrosodiphenylamine & 390 & $\mathrm{U}$ & 390 & $\mathrm{U}$ & 390 & $\mathrm{U}$ & 390 & $\mathrm{U}$ & 390 & $\mathrm{U}$ & 400 & $\mathrm{U}$ & 400 & $\mathrm{U}$ \\
\hline Pentachlorophenol & 980 & UN & 970 & $\mathrm{U}$ & 960 & $\mathrm{U}$ & 980 & $\mathrm{U}$ & 980 & $U$ & 990 & $U$ & 1,000 & $U$ \\
\hline Phenanthrene & 390 & $\mathrm{U}$ & 390 & $\mathrm{U}$ & 390 & $U$ & 390 & $\mathrm{U}$ & 390 & $U$ & 400 & $\mathrm{U}$ & 400 & $U$ \\
\hline Phenol & 390 & $\mathrm{U}$ & 390 & $\mathrm{U}$ & 390 & $\mathrm{U}$ & 390 & $\mathbf{U}$ & 390 & $\mathbf{U}$ & 400 & $\mathrm{U}$ & 400 & $\mathrm{U}$ \\
\hline Pyrene & 390 & $\mathrm{U}$ & 390 & $\mathrm{U}$ & 390 & $U$ & 390 & U & 390 & $\mathrm{U}$ & 400 & $\mathrm{U}$ & 400 & $\mathrm{U}$ \\
\hline 1,2,4-Trichlorobenzene & 390 & UN & 390 & $\mathrm{U}$ & 390 & $\mathrm{U}$ & 390 & $U$ & 390 & $\mathrm{U}$ & 400 & $\mathrm{U}$ & 400 & $\mathrm{U}$ \\
\hline 2,4,5-Trichlorophenol & 980 & $U$ & 970 & $\mathrm{U}$ & 960 & $\mathrm{U}$ & 980 & $\mathrm{U}$ & 980 & $U$ & 990 & $U$ & 1,000 & $\mathrm{U}$ \\
\hline 2,4,6-Trichlorophenol & 390 & $U$ & 390 & $U$ & 390 & $\mathrm{U}$ & 390 & $\mathrm{U}$ & 390 & $\mathrm{U}$ & 400 & $\mathrm{U}$ & 400 & U \\
\hline
\end{tabular}


TABLE C.14c (Cont.)

\begin{tabular}{|c|c|c|c|c|c|c|c|c|c|c|c|c|}
\hline \multirow{3}{*}{$\begin{array}{l}\text { Compound } \\
\text { Acenaphthene }\end{array}$} & \multicolumn{12}{|c|}{ Soil Concentrations $(\mu \mathrm{g} / \mathrm{kg})$ at Various Depth Intervals } \\
\hline & \multicolumn{2}{|c|}{$\begin{array}{l}\text { HBOR1 } \\
(0-2 \mathrm{ft})\end{array}$} & \multicolumn{2}{|c|}{$\begin{array}{c}\text { HBOR1 } \\
(2-4 \mathrm{ft}) \\
\end{array}$} & \multicolumn{2}{|c|}{$\begin{array}{l}\text { HBOR1 } \\
(4-6 \mathrm{ft})\end{array}$} & \multicolumn{2}{|c|}{$\begin{array}{r}\text { HBOR1 } \\
(6-8 \mathrm{ft}) \\
\end{array}$} & \multicolumn{2}{|c|}{$\begin{array}{l}\text { HBOR1 } \\
(8-10 \mathrm{ft}) \\
\end{array}$} & \multicolumn{2}{|c|}{$\begin{array}{l}\text { HBOR2 } \\
(0-2 \mathrm{ft})\end{array}$} \\
\hline & 430 & $\mathrm{U}$ & 400 & $\mathrm{U}$ & 400 & $U$ & 390 & $U$ & 380 & $\mathrm{U}$ & 390 & $\mathrm{U}$ \\
\hline Acenaphthylene & 430 & $\mathrm{U}$ & 400 & $\mathrm{U}$ & 400 & $\mathrm{U}$ & 390 & $\mathrm{U}$ & 380 & $\mathrm{U}$ & 390 & $\mathrm{U}$ \\
\hline Anthracene & 430 & $\mathrm{U}$ & 400 & $\mathrm{U}$ & 400 & $\mathrm{U}$ & 390 & $\mathrm{U}$ & 380 & $\mathbf{U}$ & 390 & $\mathrm{U}$ \\
\hline Benz[a]anthracene & 310 & $\mathrm{~J}$ & 400 & $U$ & 400 & $\mathrm{U}$ & 390 & $\mathrm{U}$ & 380 & $\mathrm{U}$ & 390 & $\mathrm{U}$ \\
\hline Benzo[a]pyrene & 400 & $\mathrm{~J}$ & 400 & $U$ & 400 & $U$ & 390 & $\mathrm{U}$ & 380 & $\mathrm{U}$ & 390 & $\mathrm{U}$ \\
\hline Benzo[b]fluoranthene & 660 & & 400 & $U$ & 400 & $\mathrm{U}$ & 390 & $\mathrm{U}$ & 380 & $\mathrm{U}$ & 50 & $\mathrm{~J}$ \\
\hline Benzo[g,h,i]perylene & 110 & $\mathrm{~J}$ & 400 & $\mathrm{U}$ & 400 & $U$ & 390 & $\mathrm{U}$ & 380 & $\mathrm{U}$ & 390 & $\mathrm{U}$ \\
\hline Benzo[k]fluoranthene & 120 & $\mathrm{~J}$ & 400 & $\mathrm{U}$ & 400 & $\mathrm{U}$ & 390 & $\mathrm{U}$ & 380 & $\mathrm{U}$ & 390 & $U$ \\
\hline Bis(2-chloroethoxy)methane & 430 & $\mathrm{U}$ & 400 & $U$ & 400 & $U$ & 390 & $\mathrm{U}$ & 380 & $\mathrm{U}$ & 390 & $U$ \\
\hline Bis(2-chloroethyl)ether & 430 & $\mathrm{U}$ & 400 & $\mathrm{U}$ & 400 & $U$ & 390 & $\mathrm{U}$ & 380 & $\mathrm{U}$ & 390 & $U$ \\
\hline Bis(2-chloroisopropyl)ether & 430 & $\mathrm{U}$ & 400 & $\mathrm{U}$ & 400 & $\mathrm{U}$ & 390 & $\mathrm{U}$ & 380 & $\mathrm{U}$ & 390 & $\mathrm{U}$ \\
\hline Bis(2-ethylhexyl)phthalate & 430 & $\mathrm{U}$ & 400 & $\mathrm{U}$ & 42 & $\mathrm{~J}$ & 950 & & 42 & $\mathbf{J}$ & 39 & $\mathbf{J}$ \\
\hline 4-Bromophenyl phenyl ether & 430 & $\mathrm{U}$ & 400 & $\mathrm{U}$ & 400 & $\mathrm{U}$ & 390 & $\mathrm{U}$ & 380 & $\mathrm{U}$ & 390 & $U$ \\
\hline Butylbenzylphthalate & 430 & $\mathrm{U}$ & 49 & $\mathrm{~J}$ & 46 & $\mathrm{~J}$ & 54 & $\mathrm{~J}$ & 46 & $\mathbf{J}$ & 390 & $\mathrm{U}$ \\
\hline Carbazole & 430 & $\mathrm{U}$ & 400 & $\mathrm{U}$ & 400 & $\mathrm{U}$ & 390 & $\mathrm{U}$ & 380 & $U$ & 390 & $\mathrm{U}$ \\
\hline 4-Chloro-3-methylphenol & 430 & $U$ & 400 & $\mathrm{U}$ & 400 & $U$ & 390 & U & 380 & $U$ & 390 & $U$ \\
\hline 4-Chloroaniline. & 430 & $U$ & 400 & $\mathrm{U}$ & 400 & $\mathrm{U}$ & 390 & $\mathrm{U}$ & 380 & $\mathrm{U}$ & 390 & $\mathrm{U}$ \\
\hline 2-Chloronaphthalene & 430 & $\mathrm{U}$ & 400 & $\mathrm{U}$ & 400 & $\mathrm{U}$ & 390 & $U$ & 380 & $\mathrm{U}$ & 390 & $U$ \\
\hline 2-Chlorophenol & 430 & $\mathrm{U}$ & 400 & $U$ & 400 & $U$ & 390 & $\mathrm{U}$ & 380 & $U$ & 390 & U \\
\hline 4-Chlorophenyl phenyl ether & 430 & $\mathrm{U}$ & 400 & $\mathrm{U}$ & 400 & $\mathrm{U}$ & 390 & $\mathrm{U}$ & 380 & $\mathrm{U}$ & 390 & $U$ \\
\hline Chrysene & 390 & $\mathrm{~J}$ & 400 & $\mathrm{U}$ & 400 & $\mathrm{U}$ & 390 & $U$ & 380 & $\mathrm{U}$ & 390 & $U$ \\
\hline Di-n-butylphthalate & 290 & JB & 260 & JB & 270 & JB & 210 & JB & 210 & JB & 210 & $\mathrm{JB}$ \\
\hline Di-n-octylphthalate & 430 & $\mathrm{U}$ & 400 & $U$ & 400 & U & 190 & $\mathbf{J}$ & 380 & U & 390 & $\mathrm{U}$ \\
\hline Dibenz[a,h]anthracene & 55 & $\mathrm{~J}$ & 400 & $\mathrm{U}$ & 400 & $\mathrm{U}$ & 390 & $U$ & 380 & $\mathrm{U}$ & 390 & $\mathrm{U}$ \\
\hline
\end{tabular}


TABLE C.14c (Cont.)

\begin{tabular}{|c|c|c|c|c|c|c|c|c|c|c|c|c|}
\hline \multirow{3}{*}{$\begin{array}{l}\text { Compound } \\
\text { Dibenzofuran }\end{array}$} & \multicolumn{12}{|c|}{ Soil Concentrations $(\mu \mathrm{g} / \mathrm{kg})$ at Various Depth Intervals } \\
\hline & \multicolumn{2}{|c|}{$\begin{array}{l}\text { HBOR1 } \\
(0-2 \mathrm{ft})\end{array}$} & \multicolumn{2}{|c|}{$\begin{array}{l}\text { HBOR1 } \\
(2-4 \mathrm{ft}) \\
\end{array}$} & \multicolumn{2}{|c|}{$\begin{array}{l}\text { HBOR1 } \\
(4-6 \mathrm{ft})\end{array}$} & \multicolumn{2}{|c|}{$\begin{array}{l}\text { HBORI } \\
(6-8 \mathrm{ft})\end{array}$} & \multicolumn{2}{|c|}{$\begin{array}{l}\text { HBOR1 } \\
(8-10 \mathrm{ft}) \\
\end{array}$} & \multicolumn{2}{|c|}{$\begin{array}{l}\text { HBOR2 } \\
(0-2 \mathrm{ft}) \\
\end{array}$} \\
\hline & 430 & $\mathrm{U}$ & 400 & $\mathrm{U}$ & 400 & $\mathrm{U}$ & 390 & $\mathrm{U}$ & 380 & $\mathrm{U}$ & 390 & $\mathrm{U}$ \\
\hline 1,2-Dichlorobenzene & 430 & $\mathrm{U}$ & 400 & $\mathrm{U}$ & 400 & $\mathrm{U}$ & 390 & $\mathrm{U}$ & 380 & $\mathrm{U}$ & 390 & $\mathrm{U}$ \\
\hline 1,3-Dichlorobenzene & 430 & $U$ & 400 & $\mathrm{U}$ & 400 & $\mathrm{U}$ & 390 & $\mathrm{U}$ & 380 & $\mathrm{U}$ & 390 & $\mathrm{U}$ \\
\hline 1,4-Dichlorobenzene & 430 & $U$ & 400 & $\mathrm{U}$ & 400 & $\mathrm{U}$ & 390 & $\mathrm{U}$ & 380 & $\mathrm{U}$ & 390 & $\mathrm{U}$ \\
\hline 3,3'-Dichlorobenzidine & 430 & $U$ & 400 & $\mathrm{U}$ & 400 & $U$ & 390 & $\mathrm{U}$ & 380 & $\mathrm{U}$ & 390 & $\mathrm{U}$ \\
\hline 2,4-Dichlorophenol & 430 & $U$ & 400 & $\mathrm{U}$ & 400 & $\mathrm{U}$ & 390 & $\mathrm{U}$ & 380 & $\mathrm{U}$ & 390 & $\mathrm{U}$ \\
\hline Diethylphthalate & 430 & $\mathrm{U}$ & 400 & $U$ & 400 & $U$ & 390 & $\mathrm{U}$ & 380 & $\mathrm{U}$ & 390 & $\mathrm{U}$ \\
\hline 2,4-Dimethylphenol & 430 & $\mathrm{U}$ & 400 & $\mathrm{U}$ & 400 & $\mathrm{U}$ & 390 & $\mathrm{U}$ & 380 & $\mathrm{U}$ & 390 & $\mathrm{U}$ \\
\hline Dimethylphthalate & 430 & $\mathrm{U}$ & 400 & $\mathrm{U}$ & 400 & $\mathrm{U}$ & 390 & $\mathrm{U}$ & 380 & $U$ & 390 & $\mathrm{U}$ \\
\hline 4,6-Dinitro-2-methylphenol & 1,100 & $\mathrm{U}$ & 990 & $\mathrm{U}$ & 1,000 & $\mathrm{U}$ & 960 & $U$ & 950 & $U$ & 980 & $\mathrm{U}$ \\
\hline 2,4-Dinitrophenol & 1,100 & $U$ & 990 & $\mathrm{U}$ & 1,000 & $U$ & 960 & U & 950 & $U$ & 980 & $\mathrm{U}$ \\
\hline 2,4-Dinitrotoluene & 430 & $\mathrm{U}$ & 400 & $\mathrm{U}$ & 400 & $\mathrm{U}$ & 390 & $\mathrm{U}$ & 380 & $\mathrm{U}$ & 390 & $\mathrm{U}$ \\
\hline 2,6-Dinitrotoluene & 430 & $\mathrm{U}$ & 400 & $\mathrm{U}$ & 400 & $\mathrm{U}$ & 390 & $U$ & 380 & $\mathrm{U}$ & 390 & $\mathrm{U}$ \\
\hline Fluoranthene & 260 & $\mathrm{~J}$ & 400 & $\mathrm{U}$ & 400 & $\mathrm{U}$ & 390 & $\mathrm{U}$ & 380 & $\mathrm{U}$ & 62 & $\mathrm{~J}$ \\
\hline Fluorene & 430 & $\mathrm{U}$ & 400 & $U$ & 400 & $\mathrm{U}$ & 390 & $U$ & 380 & $\mathrm{U}$ & 390 & $\mathrm{U}$ \\
\hline Hexachlorobenzene & 430 & $\mathrm{U}$ & 400 & $\mathrm{U}$ & 400 & $\mathrm{U}$ & 390 & $U$ & 380 & $\mathrm{U}$ & 390 & $U$ \\
\hline Hexachlorobutadiene & 430 & $U$ & 58 & $\mathrm{~J}$ & 400 & $U$ & 390 & $\mathrm{U}$ & 380 & $U$ & 390 & U \\
\hline Hexachlorocyclopentadiene & 430 & $\mathrm{U}$ & 400 & $U$ & 400 & $\mathrm{U}$ & 390 & $\mathrm{U}$ & 380 & $\mathrm{U}$ & 390 & $\mathrm{U}$ \\
\hline Hexachloroethane & 430 & $\mathrm{U}$ & 400 & $U$ & 400 & $U$ & 390 & $U$ & 380 & $U$ & 390 & $\mathrm{U}$ \\
\hline Indeno $[1,2,3-c, d] p y r e n e$ & 120 & $\mathrm{~J}$ & 400 & $U$ & 400 & $\mathrm{U}$ & 390 & $\mathrm{U}$ & 380 & $\mathrm{U}$ & 390 & $U$ \\
\hline Isophorone & 430 & $\mathrm{U}$ & 400 & $\mathrm{U}$ & 400 & $U$ & 390 & $U$ & 380 & $\mathrm{U}$ & 390 & $U$ \\
\hline 2-Methylnaphthalene & 430 & $U$ & 400 & $\mathrm{U}$ & 400 & $U$ & 390 & $U$ & 380 & $\mathrm{U}$ & 390 & $\mathrm{U}$ \\
\hline 2-Methylphenol & 430 & $U$ & 400 & $\mathrm{U}$ & 400 & $U$ & 390 & $\mathrm{U}$ & 380 & $\mathrm{U}$ & 390 & $\mathrm{U}$ \\
\hline 4-Methylphenol & 430 & $U$ & 400 & $\mathrm{U}$ & 400 & $U$ & 390 & $\mathrm{U}$ & 380 & $\mathrm{U}$ & 390 & $\mathrm{U}$ \\
\hline
\end{tabular}


TABLE C.14c (Cont.)

\begin{tabular}{|c|c|c|c|c|c|c|c|c|c|c|c|c|}
\hline \multirow{3}{*}{$\frac{\text { Compound }}{\text { Naphthalene }}$} & \multicolumn{12}{|c|}{ Soil Concentrations $(\mu \mathrm{g} / \mathrm{kg})$ at Various Depth Intervals } \\
\hline & \multicolumn{2}{|c|}{$\begin{array}{l}\text { HBOR1 } \\
(0-2 \mathrm{ft})\end{array}$} & \multicolumn{2}{|c|}{$\begin{array}{c}\text { HBOR1 } \\
(2-4 \mathrm{ft}) \\
\end{array}$} & \multicolumn{2}{|c|}{$\begin{array}{l}\text { HBOR1 } \\
(4-6 \mathrm{ft}) \\
\end{array}$} & \multicolumn{2}{|c|}{$\begin{array}{c}\text { HBOR1 } \\
(6-8 \mathrm{ft}) \\
\end{array}$} & \multicolumn{2}{|c|}{$\begin{array}{l}\text { HBOR1 } \\
(8-10 \mathrm{ft}) \\
\end{array}$} & \multicolumn{2}{|c|}{$\begin{array}{l}\text { HBOR2 } \\
(0-2 \mathrm{ft})\end{array}$} \\
\hline & 430 & $U$ & 400 & $U$ & 400 & $\mathrm{U}$ & 390 & $U$ & 380 & U & 390 & $U$ \\
\hline 2-Nitroaniline & 1,100 & $\mathrm{U}$ & 990 & $\mathrm{U}$ & 1,000 & $\mathrm{U}$ & 960 & $\mathrm{U}$ & 950 & $\mathrm{U}$ & 980 & $U$ \\
\hline 3-Nitroaniline & 1,100 & $U$ & 990 & $U$ & 1,000 & $\mathrm{U}$ & 960 & $U$ & 950 & $U$ & 980 & $\mathrm{U}$ \\
\hline 4-Nitroaniline & 1,100 & $U$ & 990 & $\mathrm{U}$ & 1,000 & $U$ & 960 & $U$ & 950 & $U$ & 980 & $\mathrm{U}$ \\
\hline Nitrobenzene & 430 & $U$ & 400 & $\mathrm{U}$ & 400 & $U$ & 390 & $U$ & 380 & $U$ & 390 & $\mathrm{U}$ \\
\hline 2-Nitrophenol & 430 & $U$ & 400 & $\mathrm{U}$ & 400 & $U$ & 390 & $U$ & 380 & $U$ & 390 & $\mathrm{U}$ \\
\hline 4-Nitrophenol & 1,100 & $U$ & 990 & $\mathrm{U}$ & 1,000 & $U$ & 960 & $\mathrm{U}$ & 950 & $U$ & 980 & $U$ \\
\hline N-Nitroso-di-n-propylamine & 430 & U & 400 & $\mathrm{U}$ & 400 & $U$ & 390 & $U$ & 380 & $U$ & 390 & $\mathrm{U}$ \\
\hline N-Nitrosodiphenylamine & 430 & $\mathrm{U}$ & 400 & $\mathrm{U}$ & 400 & $\mathrm{U}$ & 390 & $\mathrm{U}$ & 380 & $U$ & 390 & $\mathrm{U}$ \\
\hline Pentachlorophenol & 1,100 & $U$ & 990 & $U$ & 1,000 & U & 960 & $\mathrm{U}$ & 950 & $U$ & 980 & $U$ \\
\hline Phenanthrene & 73 & $\mathrm{~J}$ & 400 & $\mathrm{U}$ & 400 & $U$ & 390 & $\mathrm{U}$ & 380 & $\mathrm{U}$ & 390 & $\mathrm{U}$ \\
\hline Phenol & 430 & $\mathrm{U}$ & 400 & $\mathrm{U}$ & 400 & $\mathrm{U}$ & 390 & $U$ & 380 & $U$ & 390 & $\mathrm{U}$ \\
\hline Pyrene & 200 & $\mathrm{~J}$ & 400 & $\mathrm{U}$ & 400 & $U$ & 390 & $U$ & 380 & $U$ & 55 & $\mathrm{~J}$ \\
\hline 1,2,4-Trichlorobenzene & 430 & $U$ & 400 & $U$ & 400 & $U$ & 390 & $U$ & 380 & $U$ & 390 & $\mathrm{U}$ \\
\hline 2,4,5-Trichlorophenol & 1,100 & $U$ & 990 & $\mathrm{U}$ & 1,000 & $U$ & 960 & $\mathrm{U}$ & 950 & $U$ & 980 & $\mathrm{U}$ \\
\hline 2,4,6-Trichlorophenol & 430 & $\mathrm{U}$ & 400 & $\mathrm{U}$ & 400 & $U$ & 390 & $\mathrm{U}$ & 380 & U & 390 & $\mathrm{U}$ \\
\hline
\end{tabular}


TABLE C.14c (Cont.)

\begin{tabular}{|c|c|c|c|c|c|c|c|c|}
\hline \multirow{3}{*}{$\begin{array}{l}\text { Compound } \\
\text { Acenaphthene }\end{array}$} & \multicolumn{8}{|c|}{ Soil Concentrations $(\mu \mathrm{g} / \mathrm{kg})$ at Various Depth Intervals } \\
\hline & \multicolumn{2}{|c|}{$\begin{array}{l}\text { HBOR2 } \\
(2-4 \mathrm{ft})\end{array}$} & \multicolumn{2}{|c|}{$\begin{array}{l}\text { HBOR2 } \\
(4-6 \mathrm{ft})\end{array}$} & \multicolumn{2}{|c|}{$\begin{array}{l}\text { HBOR2 } \\
(6-8 \mathrm{ft})\end{array}$} & \multicolumn{2}{|c|}{$\begin{array}{l}\text { HBOR2 } \\
(8-10 \mathrm{ft})\end{array}$} \\
\hline & 390 & $U$ & 390 & $\mathrm{U}$ & 400 & $\mathrm{U}$ & 420 & $\mathrm{U}$ \\
\hline Acenaphthylene & 390 & $\mathrm{U}$ & 390 & $\mathrm{U}$ & 400 & $\mathrm{U}$ & 420 & $\mathrm{U}$ \\
\hline Anthracene & 390 & $\mathrm{U}$ & 390 & $\mathrm{U}$ & 400 & $\mathrm{U}$ & 420 & $\mathrm{U}$ \\
\hline Benz[a]anthracene & 390 & $\mathrm{U}$ & 390 & $\mathrm{U}$ & 400 & $U$ & 420 & $\mathrm{U}$ \\
\hline Benzo[a]pyrene & 390 & $U^{*}$ & 390 & $\mathrm{U}$ & 400 & U & 420 & $\mathrm{U}$ \\
\hline Benzo[b]fluoranthene & 390 & $\mathrm{U}^{*}$ & 390 & $\mathrm{U}$ & 400 & $\mathrm{U}$ & 420 & $\mathrm{U}$ \\
\hline Benzo[g,h,i]perylene & 390 & $\mathrm{U}^{*}$ & 390 & $U$ & 400 & $U$ & 420 & $\mathrm{U}$ \\
\hline Benzo[k]fluoranthene & 390 & $\mathrm{U}^{*}$ & 390 & $\mathrm{U}$ & 400 & $U$ & 420 & $U$ \\
\hline Bis(2-chloroethoxy)methane & 390 & $\mathrm{U}$ & 390 & $\mathrm{U}$ & 400 & $\mathrm{U}$ & 420 & $\mathrm{U}$ \\
\hline Bis(2-chloroethyl)ether & 390 & $U$ & 390 & $\mathrm{U}$ & 400 & $\mathrm{U}$ & 420 & $\mathrm{U}$ \\
\hline Bis(2-chloroisopropyl)ether & 390 & $\mathrm{U}$ & 390 & $\mathrm{U}$ & 400 & $\mathrm{U}$ & 420 & $U$ \\
\hline Bis(2-ethylhexyl)phthalate & 200 & $\mathrm{~J}$ & 41 & $\mathrm{~J}$ & 400 & $U$ & 420 & U \\
\hline 4-Bromophenyl phenyl ether & 390 & $\mathrm{U}$ & 390 & $\mathrm{U}$ & 400 & $\mathbf{U}$ & 420 & U \\
\hline Butylbenzylphthalate & 390 & $U$ & 390 & U & 400 & $\mathrm{U}$ & 420 & $\mathrm{U}$ \\
\hline Carbazole & 390 & $U$ & 390 & $\mathrm{U}$ & 400 & $\mathrm{U}$ & 420 & $\mathrm{U}$ \\
\hline 4-Chloro-3-methylphenol & 390 & $\mathrm{U}$ & 390 & $\mathrm{U}$ & 400 & $\cdot \mathrm{U}$ & 420 & U \\
\hline 4-Chloroaniline & 390 & $\mathrm{U}$ & 390 & $\mathrm{U}$ & 400 & $\mathrm{U}$ & 420 & $\mathrm{U}$ \\
\hline 2-Chloronaphthalene & 390 & $U$ & 390 & $\mathrm{U}$ & 400 & $U$ & 420 & U \\
\hline 2-Chlorophenol & 390 & $U$ & 390 & $\mathrm{U}$ & 400 & $U$ & 420 & $\mathrm{U}$ \\
\hline 4-Chlorophenyl phenyl ether & 390 & $\mathrm{U}$ & 390 & $\mathrm{U}$ & 400 & $\cdot \mathrm{U}$ & 420 & $\mathrm{U}$ \\
\hline Chrysene & 390 & $\mathrm{U}$ & 390 & $\mathbf{U}$ & 400 & $\mathrm{U}$ & 420 & $\mathrm{U}$ \\
\hline Di-n-butylphthalate & 270 & $\mathrm{JB}$ & 190 & JB & 180 & JB & 190 & $\mathrm{~J}$ \\
\hline Di-n-octylphthalate & 390 & $U^{*}$ & 390 & $\mathrm{U}$ & 400 & $U$ & 420 & $\mathrm{U}$ \\
\hline Dibenz $[a, h]$ anthracene & 390 & $U^{*}$ & 390 & $\mathrm{U}$ & 400 & U & 420 & $\mathrm{U}$ \\
\hline
\end{tabular}


TABLE C.14c (Cont.)

\begin{tabular}{|c|c|c|c|c|c|c|c|c|}
\hline \multirow{3}{*}{$\begin{array}{l}\text { Compound } \\
\text { Dibenzofuran }\end{array}$} & \multicolumn{8}{|c|}{ Soil Concentrations $(\mu \mathrm{g} / \mathrm{kg})$ at Various Depth Intervals } \\
\hline & \multicolumn{2}{|c|}{$\begin{array}{l}\text { HBOR2 } \\
(2-4 \mathrm{ft})\end{array}$} & \multicolumn{2}{|c|}{$\begin{array}{l}\text { HBOR2 } \\
(4-6 \mathrm{ft})\end{array}$} & \multicolumn{2}{|c|}{$\begin{array}{l}\text { HBOR2 } \\
(6-8 \mathrm{ft}) \\
\end{array}$} & \multicolumn{2}{|c|}{$\begin{array}{l}\text { HBOR2 } \\
(8-10 \mathrm{ft}) \\
\end{array}$} \\
\hline & 390 & $\mathrm{U}$ & 390 & $U$ & 400 & $\mathrm{U}$ & 420 & $\mathrm{U}$ \\
\hline 1,2-Dichlorobenzene & 390 & $\mathrm{U}$ & 390 & $\mathrm{U}$ & 400 & $\mathrm{U}$ & 420 & $\mathrm{U}$ \\
\hline 1,3-Dichlorobenzene & 390 & $\mathrm{U}$ & 390 & $\mathrm{U}$ & 400 & $\mathrm{U}$ & 420 & $\mathrm{U}$ \\
\hline 1,4-Dichlorobenzene & 390 & $U$ & 390 & $\mathrm{U}$ & 400 & $\mathbf{U}$ & 420 & U \\
\hline 3,3'-Dichlorobenzidine & 390 & $\mathrm{U}$ & 390 & $\mathrm{U}$ & 400 & $\mathrm{U}$ & 420 & $\mathrm{U}$ \\
\hline 2,4-Dichlorophenol & 390 & $\mathrm{U}$ & 390 & $\mathrm{U}$ & 400 & $\mathrm{U}$ & 420 & $\mathrm{U}$ \\
\hline Diethylphthalate & 390 & $\mathbf{U}$ & 390 & $\mathrm{U}$ & 400 & $\mathrm{U}$ & 420 & $\mathrm{U}$ \\
\hline 2,4-Dimethylphenol & 390 & $\mathrm{U}$ & 390 & $\mathrm{U}$ & 400 & $\mathrm{U}$ & 420 & $\mathrm{U}$ \\
\hline Dimethylphthalate & 390 & $\mathrm{U}$ & 390 & $U$ & 400 & $U$ & 420 & $\mathrm{U}$ \\
\hline 4,6-Dinitro-2-methylphenol & 970 & $\mathrm{U}$ & 960 & $\mathrm{U}$ & 1,000 & $\mathrm{U}$ & 1,000 & $\mathrm{U}$ \\
\hline 2,4-Dinitrophenol & 970 & $\mathrm{U}$ & 960 & $\mathrm{U}$ & 1,000 & $U$ & 1,000 & $\mathrm{U}$ \\
\hline 2,4-Dinitrotoluene & 390 & $U$ & 390 & $\mathrm{U}$ & 400 & $U$ & 420 & $\mathrm{U}$ \\
\hline 2,6-Dinitrotoluene & 390 & $\mathrm{U}$ & 390 & $\mathrm{U}$ & 400 & U & 420 & $\mathrm{U}$ \\
\hline Fluoranthene & 390 & $\mathrm{U}$ & 390 & $\mathrm{U}$ & 400 & $U$ & 420 & $\mathrm{U}$ \\
\hline Fluorene & 390 & $U$ & 390 & $U$ & 400 & $U$ & 420 & $U$ \\
\hline Hexachlorobenzene & 390 & $\mathrm{U}$ & 390 & $\mathrm{U}$ & 400 & $U$ & 420 & $U$ \\
\hline Hexachlorobutadiene & 390 & $U$ & 390 & $U$ & 400 & $\mathrm{U}$ & 420 & $\mathrm{U}$ \\
\hline Hexachlorocyclopentadiene & 390 & $U$ & 390 & $U$ & 400 & $\mathrm{U}$ & 420 & $\mathrm{U}$ \\
\hline Hexachloroethane & 390 & $\mathrm{U}$ & 390 & $\mathrm{U}$ & 400 & $U$ & 420 & $U$ \\
\hline Indeno[1,2,3-c,d]pyrene & 390 & $\mathrm{U}^{*}$ & 390 & $\mathrm{U}$ & 400 & U & 420 & $\mathrm{U}$ \\
\hline Isophorone & 390 & $U$ & 390 & $U$ & 400 & $\mathrm{U}$ & 420 & $\mathrm{U}$ \\
\hline 2-Methylnaphthalene & 390 & U & 390 & $\mathrm{U}$ & 400 & $\mathrm{U}$ & 420 & $U$ \\
\hline 2-Methylphenol & 390 & $U$ & 390 & $\mathrm{U}$ & 400 & $\mathrm{U}$ & 420 & $\mathrm{U}$ \\
\hline 4-Methylphenol & 390 & $\mathrm{U}$ & 390 & $U$ & 400 & $\mathrm{U}$ & 420 & $\mathrm{U}$ \\
\hline
\end{tabular}


TABLE C.14c (Cont.)

\begin{tabular}{|c|c|c|c|c|c|c|c|c|}
\hline \multirow[b]{2}{*}{ Compound } & \multicolumn{8}{|c|}{ Soil Concentrations ( $\mu \mathrm{g} / \mathrm{kg}$ ) at Various Depth Intervals } \\
\hline & \multicolumn{2}{|c|}{$\begin{array}{l}\text { HBOR2 } \\
(2-4 \mathrm{ft})\end{array}$} & \multicolumn{2}{|c|}{$\begin{array}{l}\text { HBOR2 } \\
(4-6 \mathrm{ft})\end{array}$} & \multicolumn{2}{|c|}{$\begin{array}{l}\mathrm{HBOR} 2 \\
(6-8 \mathrm{ft})\end{array}$} & \multicolumn{2}{|c|}{$\begin{array}{l}\text { HBOR2 } \\
(8-10 \mathrm{ft})\end{array}$} \\
\hline Naphthalene & 390 & $U$ & 390 & $\mathrm{U}$ & 400 & $\mathrm{U}$ & 420 & $\mathrm{U}$ \\
\hline 2-Nitroaniline & 970 & $\mathrm{U}$ & 960 & $\mathrm{U}$ & 1,000 & $\mathrm{U}$ & 1,000 & $\mathrm{U}$ \\
\hline 3-Nitroaniline & 970 & $\mathrm{U}$ & 960 & $\mathrm{U}$ & 1,000 & $\mathrm{U}$ & 1,000 & $\mathrm{U}$ \\
\hline 4-Nitroaniline & 970 & $\mathrm{U}$ & 960 & $\mathrm{U}$ & 1,000 & $\mathrm{U}$ & 1,000 & $\mathrm{U}$ \\
\hline Nitrobenzene & 390 & $\mathrm{U}$ & 390 & $\mathrm{U}$ & 400 & $\mathrm{U}$ & 420 & $\mathrm{U}$ \\
\hline 2-Nitrophenol & 390 & $\mathrm{U}$ & 390 & $\mathrm{U}$ & 400 & $\mathrm{U}$ & 420 & $\mathrm{U}$ \\
\hline 4-Nitrophenol & 970 & $\mathrm{U}$ & 960 & $U$ & 1,000 & $\mathrm{U}$ & 1,000 & $U$ \\
\hline N-Nitroso-di-n-propylamine & 390 & $U$ & 390 & $\mathrm{U}$ & 400 & $U$ & 420 & U \\
\hline N-Nitrosodiphenylamine & 390 & $\mathrm{U}$ & 390 & $U$ & 400 & $\mathrm{U}$ & 420 & U \\
\hline Pentachlorophenol & 970 & U & 960 & $U$ & 1,000 & $\mathrm{U}$ & 1,000 & $U$ \\
\hline Phenanthrene & 390 & $U$ & 390 & $U$ & 400 & $U$ & 420 & $U$ \\
\hline Phenol & 390 & $U$ & 390 & $\mathrm{U}$ & 400 & 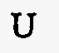 & 420 & $\mathrm{U}$ \\
\hline Pyrene & 75 & $\mathbf{J}$ & 390 & $U$ & 400 & $\mathrm{U}$ & 420 & U \\
\hline 1,2,4-Trichlorobenzene & 390 & $U$ & 390 & $\mathrm{U}$ & 400 & $\mathrm{U}$ & 420 & $U$ \\
\hline 2,4,5-Trichlorophenol & 970 & $U$ & 960 & $\mathrm{U}$ & 1,000 & $\mathrm{U}$ & 1,000 & $U$ \\
\hline 2,4,6-Trichlorophenol & 390 & $\mathrm{U}$ & 390 & U & 400 & $U$ & 420 & U \\
\hline
\end{tabular}


TABLE C.14c (Cont.)

\begin{tabular}{|c|c|c|c|c|c|c|c|c|c|c|}
\hline \multirow{3}{*}{$\begin{array}{l}\text { Compound } \\
\text { Acenaphthene }\end{array}$} & \multicolumn{10}{|c|}{ Soil Concentrations $(\mu \mathrm{g} / \mathrm{kg})$ at Various Depth Intervals } \\
\hline & \multicolumn{2}{|c|}{$\begin{array}{c}\text { TBNPBOR1 } \\
(0-2 \mathrm{ft})\end{array}$} & \multicolumn{2}{|c|}{$\begin{array}{c}\text { TBNPBOR1 } \\
(2-4 \mathrm{ft})\end{array}$} & \multicolumn{2}{|c|}{$\begin{array}{l}\text { TBNPBOR1 } \\
(4-6 \mathrm{ft})\end{array}$} & \multicolumn{2}{|c|}{$\begin{array}{c}\text { TBNPBOR1 } \\
(6-8 \mathrm{ft}) \\
\end{array}$} & \multicolumn{2}{|c|}{$\begin{array}{l}\text { TBNPBORI } \\
(8-10 \mathrm{ft})\end{array}$} \\
\hline & 410 & $\mathrm{U}$ & 410 & $\mathrm{U}$ & 410 & $\mathrm{U}$ & 410 & $\mathrm{U}$ & 400 & U \\
\hline Acenaphthylene & 410 & $U$ & 410 & $\mathrm{U}$ & 410 & U & 410 & $U$ & 400 & $\mathrm{U}$ \\
\hline Anthracene & 410 & $U$ & 410 & $\mathrm{U}$ & 410 & $\mathrm{U}$ & 410 & $U$ & 400 & U \\
\hline Benz[a]anthracene & 410 & $\mathrm{U}$ & 410 & $U$ & 410 & $U$ & 410 & $U$ & 400 & $\mathrm{U}$ \\
\hline Benzo[a]pyrene & 410 & $\mathrm{U}^{*}$ & 410 & $\mathrm{U}$ & 410 & $\mathrm{U}$ & 410 & $\mathrm{U}$ & 400 & $\mathrm{U}$ \\
\hline Benzo[b]fluoranthene & 410 & $\mathrm{U}^{*}$ & 410 & $\mathrm{U}$ & 410 & $\mathrm{U}$ & 410 & $\mathrm{U}$ & 400 & $\mathrm{U}$ \\
\hline Benzo[g,h,i]perylene & 410 & $\mathrm{U}^{*}$ & 410 & $\mathrm{U}$ & 410 & $\mathrm{U}$ & 410 & $\mathrm{U}$ & 400 & $\mathrm{U}$ \\
\hline Benzo[k]fluoranthene & 410 & $\mathrm{U}^{*}$ & 410 & U & 410 & $\mathrm{U}$ & 410 & $U$ & 400 & $\mathrm{U}$ \\
\hline Bis(2-chloroethoxy)methane & 410 & $U$ & 410 & $U$ & 410 & $U$ & 410 & $\mathrm{U}$ & 400 & $\mathrm{U}$ \\
\hline Bis(2-chloroethyl)ether & 410 & $\mathrm{U}$ & 410 & $U$ & 410 & $U$ & 410 & $\mathrm{U}$ & 400 & $\mathrm{U}$ \\
\hline Bis(2-chloroisopropyl)ether & 410 & $U$ & 410 & $\mathrm{U}$ & 410 & $\mathrm{U}$ & 410 & $\mathrm{U}$ & 400 & $\mathrm{U}$ \\
\hline Bis(2-ethylhexyl)phthalate & 210 & $\mathrm{~J}$ & 100 & $\mathrm{~J}$ & 93 & $\mathrm{~J}$ & 45 & $\mathrm{~J}$ & 160 & $\mathrm{~J}$ \\
\hline 4-Bromophenyl phenyl ether & 410 & $\mathrm{U}$ & 410 & $U$ & 410 & $U$ & 410 & $\mathrm{U}$ & 400 & $\mathrm{U}$ \\
\hline Butylbenzylphthalate & 410 & $U$ & 410 & $\mathrm{U}$ & 410 & U & 410 & $U$ & 400 & $\mathrm{U}$ \\
\hline Carbazole & 410 & $\mathrm{U}$ & 410 & $\mathrm{U}$ & 410 & $U$ & 410 & $\mathrm{U}$ & 400 & $U$ \\
\hline 4-Chloro-3-methylphenol & 410 & $\mathrm{U}$ & 410 & $U$ & 410 & $\mathrm{U}$ & 410 & $U$ & 400 & $\mathrm{U}$ \\
\hline 4-Chloroaniline & 410 & $\mathrm{U}$ & 410 & $\mathrm{U}$ & 410 & $\mathrm{U}$ & 410 & $\mathrm{U}$ & 400 & $\mathrm{U}$ \\
\hline 2-Chloronaphthalene & 410 & $U$ & 410 & $\mathrm{U}$ & 410 & $\mathrm{U}$ & 410 & $\mathrm{U}$ & 400 & $\mathrm{U}$ \\
\hline 2-Chlorophenol & 410 & $U$ & 410 & $\mathrm{U}$ & 410 & $\mathrm{U}$ & 410 & $\mathrm{U}$ & 400 & $\mathrm{U}$ \\
\hline 4-Chlorophenyl phenyl ether & 410 & $\mathrm{U}$ & 410 & $U$ & 410 & $\mathrm{U}$ & 410 & $U$ & 400 & $\mathrm{U}$ \\
\hline Chrysene & 410 & $\mathrm{U}$ & 410 & $\mathrm{U}$ & 410 & $\mathrm{U}$ & 410 & $\mathrm{U}$ & 400 & $\mathrm{U}$ \\
\hline Di-n-butylphthalate & 310 & $\mathrm{JB}$ & 290 & $\mathrm{JB}$ & 190 & $\mathrm{JB}$ & 200 & $\mathrm{JB}$ & 210 & JB \\
\hline Di-n-octylphthalate & 410 & $U^{*}$ & 410 & $\mathrm{U}$ & 410 & $\mathrm{U}$ & 410 & $\mathrm{U}$ & 400 & $\mathrm{U}$ \\
\hline Dibenz $[a, h]$ anthracene & 410 & $U^{*}$ & 410 & $\mathrm{U}$ & 410 & $\mathrm{U}$ & 410 & $\mathrm{U}$ & 400 & $\mathrm{U}$ \\
\hline
\end{tabular}


TABLE C.14c (Cont.)

\begin{tabular}{|c|c|c|c|c|c|c|c|c|c|c|}
\hline \multirow{3}{*}{$\begin{array}{l}\text { Compound } \\
\text { Dibenzofuran }\end{array}$} & \multicolumn{10}{|c|}{ Soil Concentrations $(\mu \mathrm{g} / \mathrm{kg})$ at Various Depth Intervals } \\
\hline & \multicolumn{2}{|c|}{$\begin{array}{c}\text { TBNPBOR1 } \\
(0-2 \mathrm{ft})\end{array}$} & \multicolumn{2}{|c|}{$\begin{array}{c}\text { TBNPBORI } \\
(2-4 \mathrm{ft})\end{array}$} & \multicolumn{2}{|c|}{$\begin{array}{c}\text { TBNPBORI } \\
(4-6 \mathrm{ft})\end{array}$} & \multicolumn{2}{|c|}{$\begin{array}{c}\text { TBNPBOR1 } \\
(6-8 \mathrm{ft})\end{array}$} & \multicolumn{2}{|c|}{$\begin{array}{c}\text { TBNPBOR1 } \\
(8-10 \mathrm{ft})\end{array}$} \\
\hline & 410 & $\mathrm{U}$ & 410 & $U$ & 410 & $\mathrm{U}$ & 410 & $\mathrm{U}$ & 400 & $\mathrm{U}$ \\
\hline 1,2-Dichlorobenzene & 410 & $\mathrm{U}$ & 410 & $\mathrm{U}$ & 410 & $U$ & 410 & $\mathrm{U}$ & 400 & $\mathrm{U}$ \\
\hline 1,3-Dichlorobenzene & 410 & $\mathrm{U}$ & 410 & $\mathrm{U}$ & 410 & 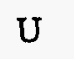 & 410 & $\mathrm{U}$ & 400 & $\mathrm{U}$ \\
\hline 1,4-Dichlorobenzene & 410 & $\mathrm{U}$ & 410 & $\mathrm{U}$ & 410 & $U$ & 410 & $\mathrm{U}$ & 400 & U \\
\hline 3,3'-Dichlorobenzidine & 410 & U & 410 & $\mathrm{U}$ & 410 & $U$ & 410 & $\mathrm{U}$ & 400 & $U$ \\
\hline 2,4-Dichlorophenol & 410 & $U$ & 410 & $U$ & 410 & $\mathrm{U}$ & 410 & $\mathrm{U}$ & 400 & $\mathrm{U}$ \\
\hline Diethylphthalate & 410 & $\mathrm{U}$ & 410 & $U$ & 410 & $\mathrm{U}$ & 410 & $U$ & 400 & $\mathrm{U}$ \\
\hline 2,4-Dimethylphenol & 410 & $\mathrm{U}$ & 410 & $U$ & 410 & $U$ & 410 & $\mathrm{U}$ & 400 & $U$ \\
\hline Dimethylphthalate & 410 & $\mathrm{U}$ & $410^{\circ}$ & $\mathrm{U}$ & 410 & $\mathrm{U}$ & 410 & $\mathrm{U}$ & 400 & $U$ \\
\hline 4,6-Dinitro-2-methylphenol & 1,000 & $\mathrm{U}$ & 1,000 & $\mathrm{U}$ & 1,000 & $\mathrm{U}$ & 1,000 & $U$ & 1,000 & $\mathrm{U}$ \\
\hline 2,4-Dinitrophenol & 1,000 & U & 1,000 & $\mathrm{U}$ & 1,000 & $\mathrm{U}$ & 1,000 & $U$ & 1,000 & $\mathrm{U}$ \\
\hline 2,4-Dinitrotoluene & 410 & $\mathrm{U}$ & 410 & $\mathrm{U}$ & 410 & $U$ & 410 & $\mathrm{U}$ & 400 & $U$ \\
\hline 2,6-Dinitrotoluene & 410 & $\mathrm{U}$ & 410 & $\mathrm{U}$ & 410 & $U$ & 410 & $U$ & 400 & $U$ \\
\hline Fluoranthene & 410 & U & 410 & $U$ & 410 & $U$ & 410 & $\mathrm{U}$ & 400 & $\mathrm{U}$ \\
\hline Fluorene & 410 & $U$ & 410 & $U$ & 410 & $U$ & 410 & $\mathrm{U}$ & 400 & $U$ \\
\hline Hexachlorobenzene & 410 & $U$ & 920 & & 180 & $\mathrm{~J}$ & 97 & $\mathrm{~J}$ & 400 & $U$ \\
\hline Hexachlorobutadiene & 410 & U & 410 & $U$ & 410 & $\mathrm{U}$ & 410 & $\mathrm{U}$ & 400 & $\mathrm{U}$ \\
\hline Hexachlorocyclopentadiene & 410 & $\mathrm{U}$ & 410 & $\mathrm{U}$ & 410 & $\mathrm{U}$ & 410 & $\mathrm{U}$ & 400 & $\mathrm{U}$ \\
\hline Hexachloroethane & 410 & $U$ & 410 & $\mathrm{U}$ & 410 & $\mathrm{U}$ & 410 & U & 400 & $\mathrm{U}$ \\
\hline Indeno $[1,2,3-c, d]$ pyrene & 410 & $\mathrm{U}^{*}$ & 410 & $\mathrm{U}$ & 410 & $U$ & 410 & $U$ & 400 & $\mathrm{U}$ \\
\hline Isophorone & 410 & $\mathrm{U}$ & 410 & $U$ & 410 & U & 410 & $\mathrm{U}$ & 400 & $\mathrm{U}$ \\
\hline 2-Methylnaphthalene & 230 & $\mathbf{J}$ & 42 & $\mathrm{~J}$ & 410 & $\mathrm{U}$ & 410 & $U$ & 400 & $\mathrm{U}$ \\
\hline
\end{tabular}




\begin{tabular}{|c|c|c|c|c|c|c|c|c|c|c|}
\hline \multirow{3}{*}{$\begin{aligned} \text { Compound } \\
\text { 2-Methylphenol }\end{aligned}$} & \multicolumn{10}{|c|}{ Soil Concentrations $(\mu \mathrm{g} / \mathrm{kg})$ at Various Depth Intervals } \\
\hline & \multicolumn{2}{|c|}{$\begin{array}{c}\text { TBNPBORI } \\
(0-2 \mathrm{ft})\end{array}$} & \multicolumn{2}{|c|}{$\begin{array}{c}\text { TBNPBOR1 } \\
(2-4 \mathrm{ft})\end{array}$} & \multicolumn{2}{|c|}{$\begin{array}{c}\text { TBNPBOR1 } \\
(4-6 \mathrm{ft}) \\
\end{array}$} & \multicolumn{2}{|c|}{$\begin{array}{c}\text { TBNPBOR1 } \\
(6-8 \mathrm{ft})\end{array}$} & \multicolumn{2}{|c|}{$\begin{array}{c}\text { TBNPBOR1 } \\
(8-10 \mathrm{ft}) \\
\end{array}$} \\
\hline & 410 & $\mathrm{U}$ & 410 & $U$ & 410 & $\mathrm{U}$ & 410 & $\mathrm{U}$ & 400 & $\mathrm{U}$ \\
\hline 4-Methylphenol & 410 & $\mathrm{U}$ & 410 & $U$ & 410 & $\mathrm{U}$ & 410 & $\mathrm{U}$ & 400 & $\mathrm{U}$ \\
\hline Naphthalene & 89 & $J$ & 42 & $\mathrm{~J}$ & 410 & $U$ & 410 & $\mathrm{U}$ & 400 & $\mathrm{U}$ \\
\hline 2-Nitroaniline & 1,000 & $\mathrm{U}$ & 1,000 & $\mathrm{U}$ & 1,000 & $U$ & 1,000 & $U$ & 1,000 & $U$ \\
\hline 3-Nitroaniline & 1,000 & $U$ & 1,000 & $\mathrm{U}$ & 1,000 & $\mathrm{U}$ & 1,000 & U & 1,000 & $U$ \\
\hline 4-Nitroaniline & 1,000 & $\mathrm{U}$ & 1,000 & $\mathrm{U}$ & 1,000 & $\mathrm{U}$ & 1,000 & $\mathrm{U}$ & 1,000 & $U$ \\
\hline Nitrobenzene & 55 & $\mathrm{~J}$ & 410 & $U$ & 410 & $\mathrm{U}$ & 410 & U & 400 & $U$ \\
\hline 2-Nitrophenol & 410 & $\mathrm{U}$ & 410 & U & 410 & $\mathrm{U}$ & 410 & $\mathrm{U}$ & 400 & $U$ \\
\hline 4-Nitrophenol & 1,000 & $U$ & 1,000 & $\mathrm{U}$ & 1,000 & $\mathrm{U}$ & 1,000 & U & 1,000 & $U$ \\
\hline N-Nitroso-di-n-propylamine & 410 & $\mathrm{U}$ & 410 & $U$ & 410 & $\mathrm{U}$ & 410 & $\mathrm{U}$ & 400 & U \\
\hline $\mathrm{N}$-Nitrosodiphenylamine & 410 & $\mathrm{U}$ & 160 & $\mathrm{~J}$ & 410 & $\mathrm{U}$ & 410 & $U$ & 400 & U \\
\hline Pentachlorophenol & 1,000 & $\mathrm{U}$ & 1,000 & $U$ & 1,000 & $\mathrm{U}$ & 1,000 & $\mathrm{U}$ & 1,000 & $\mathrm{U}$ \\
\hline Phenanthrene & 250 & $\mathrm{~J}$ & 410 & $U$ & 410 & $\mathrm{U}$ & 410 & $\mathrm{U}$ & 400 & $\mathrm{U}$ \\
\hline Phenol & 410 & $U$ & 410 & $U$ & 410 & $\mathrm{U}$ & 410 & $\mathrm{U}$ & 400 & $\mathrm{U}$ \\
\hline Pyrene & 79 & $\mathrm{~J}$ & 410 & $\mathrm{U}$ & 410 & $U$ & 410 & $\mathrm{U}$ & 400 & $\mathrm{U}$ \\
\hline 1,2,4-Trichlorobenzene & 410 & $\mathrm{U}$ & 410 & $\mathrm{U}$ & 410 & $U$ & 410 & $\mathrm{U}$ & 400 & $\mathrm{U}$ \\
\hline 2,4,5-Trichlorophenol & 1,000 & $\mathrm{U}$ & 1,000 & $\mathrm{U}$ & 1,000 & U & 1,000 & $\mathrm{U}$ & 1,000 & $\mathrm{U}$ \\
\hline 2,4,6-Trichlorophenol & 43 & $\mathrm{~J}$ & 410 & $\mathrm{U}$ & 410 & $\mathrm{U}$ & 410 & $\mathrm{U}$ & 400 & $\mathrm{U}$ \\
\hline
\end{tabular}

See next page for footnotes. 
a Sampled by ANL, analyzed by Weston Gulf Coast or ANL/ACL, CLP/HSL semivolatile organics. Data qualifiers:

$\mathrm{U}=$ analyte was analyzed for but not detected; detection limit given.

$\mathrm{J}=$ estimated value.

$\mathrm{B}=$ analyte was found in the associated blank.

$\mathrm{N}=$ spike and spike duplicate recovery or percent RPD were outside the control limits.

* = internal standard area counts were outside QC limits. 
TABLE C.14d Semivolatile Organics Analyses for Soil Borings, May 1995 ${ }^{\mathrm{a}}$

\begin{tabular}{|c|c|c|c|c|c|c|c|c|c|c|c|c|}
\hline \multirow{3}{*}{$\begin{array}{l}\text { Compound } \\
\text { Acenaphthene }\end{array}$} & \multicolumn{12}{|c|}{ Soil Concentrations $(\mu \mathrm{g} / \mathrm{kg})$ at Various Depth Intervals } \\
\hline & \multicolumn{2}{|c|}{$\begin{array}{c}\text { VXBOR1 } \\
(0-2 \mathrm{ft})\end{array}$} & \multicolumn{2}{|c|}{$\begin{array}{c}\text { VXBOR1 } \\
(2-4 \mathrm{ft}) \\
\end{array}$} & \multicolumn{2}{|c|}{$\begin{array}{c}\text { VXBOR1 } \\
(6-8 \mathrm{ft})\end{array}$} & \multicolumn{2}{|c|}{$\begin{array}{l}\text { VXBOR1 } \\
(8-10 \mathrm{ft}) \\
\end{array}$} & \multicolumn{2}{|c|}{$\begin{array}{c}\text { VXBOR2 } \\
(0-2 \mathrm{ft}) \\
\end{array}$} & \multicolumn{2}{|c|}{$\begin{array}{c}\text { VXBOR2 } \\
(2-4 \mathrm{ft}) \\
\end{array}$} \\
\hline & 380 & $\mathrm{U}$ & 410 & $\mathrm{U}$ & 460 & $U$ & 390 & $\mathrm{U}$ & 410 & $\mathrm{U}$ & 380 & $\mathrm{U}$ \\
\hline Acenaphthylene & 380 & $\mathrm{U}$ & 410 & $\mathrm{U}$ & 460 & $U$ & 390 & $\mathrm{U}$ & 410 & $\mathrm{U}$ & 380 & $\mathrm{U}$ \\
\hline Anthracene & 380 & $\mathrm{U}$ & 410 & $\mathrm{U}$ & 460 & $\mathrm{U}$ & 1,400 & & 410 & $U$ & 380 & $\mathrm{U}$ \\
\hline Benz[a]anthracene & 380 & $\mathrm{U}$ & 410 & $\mathrm{U}$ & 460 & $\mathrm{U}$ & 390 & $U$ & 410 & $\mathrm{U}$ & 380 & $\mathrm{U}$ \\
\hline Benzo[a]pyrene & 380 & $\mathrm{U}$ & 410 & $\mathrm{U}$ & 460 & $\mathrm{U}$ & 390 & $U$ & 410 & $\mathrm{U}$ & 380 & $\mathrm{U}$ \\
\hline Benzo[b]fluoranthene & 380 & $\mathrm{U}$ & 410 & $\mathbf{U}$ & 460 & $\mathrm{U}$ & 390 & $\mathrm{U}$ & 410 & $\mathrm{U}$ & 380 & $\mathrm{U}$ \\
\hline Benzo[g,h,i]perylene & 380 & $\mathrm{U}$ & 410 & $\mathrm{U}$ & 460 & $\mathrm{U}$ & 390 & U & 410 & $\mathrm{U}$ & 380 & $\mathrm{U}$ \\
\hline Benzo[k]fluoranthene & 380 & $\mathrm{U}$ & 410 & $\mathrm{U}$ & 460 & $\mathrm{U}$ & 390 & $U$ & 410 & $\mathrm{U}$ & 380 & $\mathrm{U}$ \\
\hline Bis(2-chloroethoxy)methane & 380 & $\mathrm{U}$ & 410 & $U$ & 460 & $\mathrm{U}$ & 390 & $\mathrm{U}$ & 410 & $\mathrm{U}$ & 380 & $\mathrm{U}$ \\
\hline Bis(2-chloroethyl)ether & 380 & $\mathrm{U}$ & 410 & $U$ & 460 & $\mathrm{U}$ & 390 & $U$ & 410 & $\mathrm{U}$ & 380 & $\mathrm{U}$ \\
\hline Bis(2-ethylhexyl)phthalate & 1,600 & $\mathrm{~B}$ & 1,400 & B & 2,500 & B & 1,100 & B & 1,300 & B & 960 & $\mathrm{~B}$ \\
\hline 4-Bromophenyl phenyl ether & 380 & $\mathrm{U}$ & 410 & $\mathrm{U}$ & 460 & $\mathrm{U}$ & 390 & $U$ & 410 & $\mathrm{U}$ & 380 & $\mathrm{U}$ \\
\hline Butylbenzylphthalate & 750 & B & 260 & $\mathrm{JB}$ & 460 & $\mathrm{U}$ & 390 & $\mathrm{U}$ & 410 & $\mathrm{U}$ & 380 & $U$ \\
\hline Carbazole & 380 & $\mathrm{U}$ & 410 & $\mathrm{U}$ & 460 & $\mathrm{U}$ & 390 & $\mathrm{U}$ & 410 & $U$ & 380 & $U$ \\
\hline 4-Chloro-3-methylphenol & 380 & $\mathrm{U}$ & 410 & $U$ & 460 & $U$ & 390 & $\mathrm{U}$ & 410 & $U$ & 380 & $U$ \\
\hline 4-Chloroaniline & 380 & $\mathrm{U}$ & 410 & $\mathrm{U}$ & 460 & $U$ & 390 & $U$ & 410 & $U$ & 380 & $\mathrm{U}$ \\
\hline 2-Chloronaphthalene & 380 & $\mathrm{U}$ & 410 & $U$ & 460 & $U$ & 390 & $\mathrm{U}$ & 410 & $\mathrm{U}$ & 380 & $\mathrm{U}$ \\
\hline 2-Chlorophenol & 380 & $U$ & 410 & $U$ & 460 & $U$ & 390 & $\mathrm{U}$ & 410 & $\mathrm{U}$ & 380 & $\mathrm{U}$ \\
\hline 4-Chlorophenyl phenyl ether & 380 & $U$ & 410 & $\mathrm{U}$ & 460 & $U$ & 390 & $\mathrm{U}$ & 410 & $\mathrm{U}$ & 380 & $\mathrm{U}$ \\
\hline Chrysene & 380 & $U$ & 410 & $\mathrm{U}$ & 460 & $\mathrm{U}$ & 390 & $\mathrm{U}$ & 410 & $\mathrm{U}$ & 380 & $\mathrm{U}$ \\
\hline Di-n-butylphthalate & 200 & $\mathrm{JB}$ & 1,200 & B & 350 & $\mathrm{JB}$ & 460 & $\mathrm{~B}$ & 160 & $\mathrm{JB}$ & 380 & $U$ \\
\hline Di-n-octylphthalate & 380 & $U$ & 410 & $\mathrm{U}$ & 460 & $\mathrm{U}$ & 390 & $\mathrm{U}$ & 410 & $\mathrm{U}$ & 380 & $\mathrm{U}$ \\
\hline Dibenz[a,h]anthracene & 380 & $\mathrm{U}$ & 410 & $U$ & 460 & $\mathrm{U}$ & 390 & $\mathrm{U}$ & 410 & $\mathrm{U}$ & 380 & $\mathrm{U}$ \\
\hline Dibenzofuran & 380 & $U$ & 410 & $U$ & 460 & $\mathrm{U}$ & 390 & $\mathrm{U}$ & 410 & $\mathrm{U}$ & 380 & $\mathrm{U}$ \\
\hline
\end{tabular}




\begin{tabular}{|c|c|c|c|c|c|c|c|c|c|c|c|c|}
\hline \multirow{3}{*}{$\begin{array}{r}\text { Compound } \\
1,2-\text { Dichlorobenzene }\end{array}$} & \multicolumn{12}{|c|}{ Soil Concentrations $(\mu \mathrm{g} / \mathrm{kg})$ at Various Depth Intervals } \\
\hline & \multicolumn{2}{|c|}{$\begin{array}{c}\text { VXBOR1 } \\
(0-2 \mathrm{ft})\end{array}$} & \multicolumn{2}{|c|}{$\begin{array}{l}\text { VXBOR1 } \\
(2-4 \mathrm{ft}) \\
\end{array}$} & \multicolumn{2}{|c|}{$\begin{array}{l}\text { VXBOR1 } \\
(6-8 \mathrm{ft}) \\
\end{array}$} & \multicolumn{2}{|c|}{$\begin{array}{l}\text { VXBOR1 } \\
(8-10 \mathrm{ft})\end{array}$} & \multicolumn{2}{|c|}{$\begin{array}{c}\text { VXBOR2 } \\
(0-2 \mathrm{ft})\end{array}$} & \multicolumn{2}{|c|}{$\begin{array}{c}\text { VXBOR2 } \\
(2-4 \mathrm{ft}) \\
\end{array}$} \\
\hline & 380 & $\mathrm{U}$ & 410 & $\mathrm{U}$ & 460 & $U$ & 390 & $\mathrm{U}$ & 410 & $U$ & 380 & $\mathrm{U}$ \\
\hline 1,3-Dichlorobenzene & 380 & $\mathrm{U}$ & 410 & $\mathrm{U}$ & 460 & $\mathrm{U}$ & 390 & $\mathrm{U}$ & 410 & $\mathrm{U}$ & 380 & $\mathrm{U}$ \\
\hline 1,4-Dichlorobenzene & 380 & $\mathrm{U}$ & 410 & $\mathrm{U}$ & 460 & $\mathrm{U}$ & 390 & $\mathrm{U}$ & 410 & $\mathrm{U}$ & 380 & $\mathrm{U}$ \\
\hline 3,3'-Dichlorobenzidine & 380 & $\mathrm{U}$ & 410 & $\mathrm{U}$ & 460 & $\mathbf{U}$ & 390 & $\mathrm{U}$ & 410 & $\mathrm{U}$ & 380 & $\mathrm{U}$ \\
\hline 2,4-Dichlorophenol & 380 & $\mathrm{U}$ & 410 & $\mathbf{U}$ & 460 & $\mathrm{U}$ & 390 & U & 410 & $\mathrm{U}$ & 380 & $U$ \\
\hline Diethylphthalate & 380 & $U$ & 410 & $\mathrm{U}$ & 460 & $\mathrm{U}$ & 390 & $\mathrm{U}$ & 410 & $\mathbf{U}$ & 380 & $\mathrm{U}$ \\
\hline 2,4-Dimethylphenol & 380 & $\mathrm{U}$ & 410 & $\mathrm{U}$ & 460 & $\mathrm{U}$ & 390 & $\mathrm{U}$ & 410 & $\mathbf{U}$ & 380 & $\mathrm{U}$ \\
\hline Dimethylphthalate & 380 & $\mathrm{U}$ & 410 & $\mathrm{U}$ & 460 & $\mathrm{U}$ & 390 & $\mathrm{U}$ & 410 & $\mathrm{U}$ & 380 & $\mathrm{U}$ \\
\hline 4,6-Dinitro-2-methylphenol & 950 & $\mathbf{U}$ & 1,000 & $\mathbf{U}$ & 1,200 & $\mathrm{U}$ & 990 & $\mathrm{U}$ & 1,000 & $\mathbf{U}$ & 950 & $\mathrm{U}$ \\
\hline 2,4-Dinitrophenol & 950 & $\mathrm{U}$ & 1,000 & $U$ & 1,200 & $\mathrm{U}$ & 990 & $\mathrm{U}$ & 1,000 & $\mathbf{U}$ & 950 & $\mathrm{U}$ \\
\hline 2,4-Dinitrotoluene & 380 & $U$ & 410 & $\mathrm{U}$ & 460 & $\mathrm{U}$ & 390 & $\mathbf{U}$ & 410 & $\mathbf{U}$ & 380 & $\mathrm{U}$ \\
\hline 2,6-Dinitrotoluene & 380 & $\mathrm{U}$ & 410 & $\mathrm{U}$ & 460 & $\mathrm{U}$ & 390 & $\mathrm{U}$ & 410 & $\mathrm{U}$ & 380 & $\mathrm{U}$ \\
\hline Fluoranthene & 380 & $\mathrm{U}$ & 410 & $\mathrm{U}$ & 460 & $\mathrm{U}$ & 390 & $\mathrm{U}$ & 410 & $\mathbf{U}$ & 380 & $\mathrm{U}$ \\
\hline Fluorene & 380 & $\mathrm{U}$ & 410 & $\mathrm{U}$ & 980 & & 390 & $\mathrm{U}$ & 410 & $\mathrm{U}$ & 380 & $\mathbf{U}$ \\
\hline Hexachlorobenzene & 380 & $\mathrm{U}$ & 410 & $\mathrm{U}$ & 460 & $\mathrm{U}$ & 390 & $\mathrm{U}$ & 410 & $\mathrm{U}$ & 380 & $\mathrm{U}$ \\
\hline Hexachlorobutadiene & 380 & $\mathrm{U}$ & 410 & $\mathrm{U}$ & 460 & $\mathrm{U}$ & 390 & $\mathrm{U}$ & 410 & $\mathrm{U}$ & 380 & $\mathrm{U}$ \\
\hline Hexachlorocyclopentadiene & 380 & $U$ & 410 & $\mathrm{U}$ & 460 & $\mathrm{U}$ & 390 & $\mathrm{U}$ & 410 & $\mathrm{U}$ & 380 & $\mathrm{U}$ \\
\hline Hexachloroethane & 380 & $\mathrm{U}$ & 410 & $\mathrm{U}$ & 460 & $\mathrm{U}$ & 390 & $\mathrm{U}$ & 410 & $\mathrm{U}$ & 380 & $\mathrm{U}$ \\
\hline Indeno[1,2,3-c,d]pyrene & 380 & $\mathrm{U}$ & 410 & $\mathbf{U}$ & 460 & $\mathrm{U}$ & 390 & $\mathrm{U}$ & 410 & $U$ & 380 & $\mathrm{U}$ \\
\hline Isophorone & 380 & $\mathrm{U}$ & 410 & $\mathrm{U}$ & 460 & $\mathbf{U}$ & 390 & $\mathrm{U}$ & 410 & $\mathbf{U}$ & 380 & $\mathrm{U}$ \\
\hline 2-Methylnaphthalene & 380 & $\mathrm{U}$ & 410 & $\mathrm{U}$ & 460 & $\mathrm{U}$ & 390 & $U$ & 410 & $U$ & 380 & $U$ \\
\hline 2-Methylphenol & 380 & $\mathrm{U}$ & 410 & $\mathrm{U}$ & 460 & $\mathrm{U}$ & 390 & $\mathrm{U}$ & 410 & $\mathbf{U}$ & 380 & $\mathrm{U}$ \\
\hline 4-Methylphenol & 380 & $\mathrm{U}$ & 410 & $\mathrm{U}$ & 460 & $\mathrm{U}$ & 390 & $\mathrm{U}$ & 410 & $\mathrm{U}$ & 380 & $\mathrm{U}$ \\
\hline
\end{tabular}


TABLE C.14d (Cont.)

\begin{tabular}{|c|c|c|c|c|c|c|c|c|c|c|c|c|}
\hline \multirow{3}{*}{$\begin{array}{l}\text { Compound } \\
\text { Naphthalene }\end{array}$} & \multicolumn{12}{|c|}{ Soil Concentrations $(\mu \mathrm{g} / \mathrm{kg})$ at Various Depth Intervals } \\
\hline & \multicolumn{2}{|c|}{$\begin{array}{c}\text { VXBOR1 } \\
(0-2 \mathrm{ft}) \\
\end{array}$} & \multicolumn{2}{|c|}{$\begin{array}{c}\text { VXBOR1 } \\
(2-4 \mathrm{ft})\end{array}$} & \multicolumn{2}{|c|}{$\begin{array}{c}\text { VXBOR1 } \\
(6-8 \mathrm{ft}) \\
\end{array}$} & \multicolumn{2}{|c|}{$\begin{array}{l}\text { VXBOR1 } \\
(8-10 \mathrm{ft})\end{array}$} & \multicolumn{2}{|c|}{$\begin{array}{l}\text { VXBOR2 } \\
(0-2 \mathrm{ft})\end{array}$} & \multicolumn{2}{|c|}{$\begin{array}{c}\text { VXBOR2 } \\
(2-4 \mathrm{ft})\end{array}$} \\
\hline & 380 & $\mathrm{U}$ & 410 & $\mathrm{U}$ & 460 & U & 390 & $\mathrm{U}$ & 410 & $U$ & 380 & $\mathrm{U}$ \\
\hline 2-Nitroaniline & 950 & $\mathrm{U}$ & 1,000 & $\mathrm{U}$ & 1,200 & $U$ & 990 & $U$ & 1,000 & $\mathrm{U}$ & 950 & $U$ \\
\hline 3-Nitroaniline & 950 & $\mathrm{U}$ & 1,000 & $\mathrm{U}$ & 1,200 & $\mathrm{U}$ & 990 & $\mathrm{U}$ & 1,000 & $\mathrm{U}$ & 950 & $\mathrm{U}$ \\
\hline 4-Nitroaniline & 950 & $U$ & 1,000 & $\mathrm{U}$ & 1,200 & $\mathrm{U}$ & 990 & $\mathrm{U}$ & 1,000 & $U$ & 950 & $\mathrm{U}$ \\
\hline Nitrobenzene & 380 & $\mathrm{U}$ & 410 & $\mathrm{U}$ & 460 & $\mathrm{U}$ & 390 & $\mathrm{U}$ & 410 & $\mathrm{U}$ & 380 & $\mathrm{U}$ \\
\hline 2-Nitrophenol & 380 & $\mathrm{U}$ & 410 & $\mathrm{U}$ & 460 & $\mathrm{U}$ & 390 & $\mathrm{U}$ & 410 & $U$ & 380 & $\mathrm{U}$ \\
\hline 4-Nitrophenol & 950 & $U$ & 1,000 & $\mathrm{U}$ & 1,200 & $\mathrm{U}$ & 990 & $\mathrm{U}$ & 1,000 & $\mathrm{U}$ & 950 & $U$ \\
\hline N-Nitroso-di-n-propylamine & 380 & $U$ & 410 & $\mathrm{U}$ & 460 & $\mathrm{U}$ & 390 & $\mathrm{U}$ & 410 & $U$ & 380 & $\mathrm{U}$ \\
\hline N-Nitrosodiphenylamine & 380 & $\mathrm{U}$ & 410 & $U$ & 460 & $\mathrm{U}$ & 390 & $\mathrm{U}$ & 410 & $\mathrm{U}$ & 380 & $\mathrm{U}$ \\
\hline 2,2'-Oxybis-(1-chloropropane) & 380 & $\mathrm{U}$ & 410 & $U$ & 460 & $\mathrm{U}$ & 390 & $\mathrm{U}$ & 410 & $\mathrm{U}$ & 380 & $\mathrm{U}$ \\
\hline Pentachlorophenol & 950 & $\mathrm{U}$ & 1,000 & $\mathrm{U}$ & 1,200 & $U$ & 990 & $\mathrm{U}$ & 1,000 & $\mathrm{U}$ & 950 & $\mathrm{U}$ \\
\hline Phenanthrene & 380 & $\mathrm{U}$ & 3,500 & & 2,000 & & 1,200 & & 410 & $U$ & 380 & $U$ \\
\hline Phenol & 380 & $\mathrm{U}$ & 410 & $\mathrm{U}$ & 460 & $\mathrm{U}$ & 390 & $\mathrm{U}$ & 410 & $\mathrm{U}$ & 380 & $U$ \\
\hline Pyrene & 380 & $\mathrm{U}$ & 280 & $\mathrm{~J}$ & 460 & $\mathrm{U}$ & 160 & $\mathrm{~J}$ & 410 & $U$ & 380 & $\mathrm{U}$ \\
\hline 1,2,4-Trichlorobenzene & 380 & $\mathrm{U}$ & 410 & $U$ & 460 & $U$ & 390 & $\mathrm{U}$ & 410 & $\mathrm{U}$ & 380 & $\mathrm{U}$ \\
\hline 2,4,5-Trichlorophenol & 950 & $\mathrm{U}$ & 1,000 & $U$ & 1,200 & $\mathrm{U}$ & 990 & $\mathrm{U}$ & 1,000 & $\mathrm{U}$ & 950 & $U$ \\
\hline 2,4,6-Trichlorophenol & 380 & $\mathrm{U}$ & 410 & $U$ & 460 & U & 390 & U & 410 & U & 380 & $\mathrm{U}$ \\
\hline
\end{tabular}


TABLE C.14d (Cont.)

\begin{tabular}{|c|c|c|c|c|c|c|c|c|c|c|c|c|}
\hline \multirow{3}{*}{$\begin{array}{l}\text { Compound } \\
\text { Acenaphthene }\end{array}$} & \multicolumn{12}{|c|}{ Soil Concentrations $(\mu \mathrm{g} / \mathrm{kg})$ at Various Depth Intervals } \\
\hline & \multicolumn{2}{|c|}{$\begin{array}{c}\text { VXBOR2 } \\
(4-6 \mathrm{ft})\end{array}$} & \multicolumn{2}{|c|}{$\begin{array}{c}\text { VXBOR2 } \\
(6-8 \mathrm{ft}) \\
\end{array}$} & \multicolumn{2}{|c|}{$\begin{array}{l}\text { VXBOR2 } \\
(8-10 \mathrm{ft})\end{array}$} & \multicolumn{2}{|c|}{$\begin{array}{l}\text { VXBOR2 } \\
(10-12 \mathrm{ft})\end{array}$} & \multicolumn{2}{|c|}{$\begin{array}{c}\text { FTBOR1 } \\
(0-2 \mathrm{ft})\end{array}$} & \multicolumn{2}{|c|}{$\begin{array}{l}\text { FTBOR1 Dup } \\
(0-2 \mathrm{ft})\end{array}$} \\
\hline & 390 & $\mathrm{U}$ & 410 & $\mathrm{U}$ & 420 & $U$ & 390 & $\mathrm{U}$ & 390 & $\mathrm{U}$ & 390 & $\mathrm{U}$ \\
\hline Acenaphthylene & 390 & $U$ & 410 & $\mathrm{U}$ & 420 & $\mathrm{U}$ & 390 & $\mathrm{U}$ & 390 & $\mathrm{U}$ & 390 & U \\
\hline Anthracene & 390 & $\mathrm{U}$ & 410 & $\mathrm{U}$ & 420 & $\mathrm{U}$ & 390 & $\mathrm{U}$ & 390 & $\mathrm{U}$ & 390 & $\mathrm{U}$ \\
\hline Benz[a]anthracene & 390 & $\mathrm{U}$ & 410 & $\mathrm{U}$ & 420 & $\mathrm{U}$ & 390 & $\mathrm{U}$ & 390 & $U$ & 390 & $U$ \\
\hline Benzo[a]pyrene & 390 & $\mathrm{U}$ & 410 & $\mathrm{U}$ & 420 & $\mathrm{U}$ & $390^{\circ}$ & $\mathrm{U}$ & 390 & $\mathrm{U}$ & 390 & $U$ \\
\hline Benzo[b]fluoranthene & 390 & $U$ & 410 & $U$ & 420 & $\mathrm{U}$ & 390 & $\mathbf{U}$ & 390 & U & 390 & $\mathrm{U}$ \\
\hline Benzo[g,h,i]perylene & 390 & $U$ & 410 & $\mathrm{U}$ & 420 & $\mathrm{U}$ & 390 & $U$ & 390 & $\mathrm{U}$ & 390 & $\mathrm{U}$ \\
\hline Benzo[k]fluoranthene & 390 & $U$ & 410 & $\mathrm{U}$ & 420 & $\mathrm{U}$ & 390 & $\mathrm{U}$ & 390 & $\mathrm{U}$ & 390 & $\mathrm{U}$ \\
\hline Bis(2-chloroethoxy)methane & 390 & $\mathrm{U}$ & 410 & $\mathrm{U}$ & 420 & $\mathrm{U}$ & 390 & $\mathrm{U}$ & 390 & $\mathrm{U}$ & 390 & $\mathrm{U}$ \\
\hline Bis(2-chloroethyl)ether & 390 & $\mathrm{U}$ & 410 & $U$ & 420 & $\mathrm{U}$ & 390 & $\mathrm{U}$ & 390 & $\mathrm{U}$ & 390 & $U$ \\
\hline Bis(2-ethylhexyl)phthalate & 1,500 & & 2,000 & & 4,300 & B & 4,100 & B & 1,700 & $\mathrm{~B}$ & 4,600 & B \\
\hline 4-Bromophenyl phenyl ether & 390 & $\mathrm{U}$ & 410 & $\mathrm{U}$ & 420 & $\mathrm{U}$ & 390 & $\mathrm{U}$ & 390 & $U$ & 390 & $\mathrm{U}$ \\
\hline Butylbenzylphthalate & 390 & $\mathrm{U}$ & 410 & $\mathrm{U}$ & 420 & $U$ & 390 & $\mathrm{U}$ & 390 & $\mathrm{U}$ & 390 & $U$ \\
\hline Carbazole & 390 & $\mathrm{U}$ & 410 & $\mathrm{U}$ & 420 & $\mathrm{U}$ & 390 & $\mathrm{U}$ & 390 & $U$ & 390 & U \\
\hline 4-Chloro-3-methylphenol & 390 & $U$ & 410 & $\mathrm{U}$ & 420 & $\mathrm{U}$ & 390 & $U$ & 390 & $U$ & 390 & $\mathrm{U}$ \\
\hline 4-Chloroaniline & 390 & $U$ & 410 & $\mathrm{U}$ & 420 & $\mathrm{U}$ & 390 & $U$ & 390 & $U$ & 390 & $U$ \\
\hline 2-Chloronaphthalene & 390 & $U$ & 410 & $\mathrm{U}$ & 420 & $U$ & 390 & $U$ & 390 & $U$ & 390 & $\mathrm{U}$ \\
\hline 2-Chlorophenol & 390 & $\mathbf{U}$ & 410 & $\mathrm{U}$ & 420 & $\mathrm{U}$ & 390 & $U$ & 390 & $U$ & 390 & $\mathrm{U}$ \\
\hline 4-Chlorophenyl phenyl ether & 390 & $\mathrm{U}$ & 410 & $\mathrm{U}$ & 420 & $\mathrm{U}$ & 390 & $\mathrm{U}$ & 390 & $U$ & 390 & $\mathrm{U}$ \\
\hline Chrysene & 390 & $\mathrm{U}$ & 410 & $U$ & 420 & $U$ & 390 & $U$ & 390 & $U$ & 390 & $\mathrm{U}$ \\
\hline Di-n-butylphthalate & 140 & JB & 410 & $\mathrm{U}$ & 100 & $\mathrm{~J}$ & 210 & $\mathrm{~J}$ & 110 & $\mathrm{~J}$ & 170 & $\mathrm{~J}$ \\
\hline Di-n-octylphthalate & 390 & $U$ & 410 & $U$ & 420 & $\mathrm{U}$ & 390 & $\mathrm{U}$ & 390 & $\mathbf{U}$ & 390 & $\mathrm{U}$ \\
\hline Dibenz[a,h]anthracene & 390 & $\mathrm{U}$ & 410 & $U$ & 420 & $\mathrm{U}$ & 390 & $\mathrm{U}$ & 390 & $\mathbf{U}$ & 390 & U \\
\hline Dibenzofuran & 390 & $\mathrm{U}$ & 410 & $\mathrm{U}$ & 420 & $\mathbf{U}$ & 390 & $\mathrm{U}$ & 390 & $\mathrm{U}$ & 390 & $\mathrm{U}$ \\
\hline
\end{tabular}




\begin{tabular}{|c|c|c|c|c|c|c|c|c|c|c|c|c|}
\hline \multirow{3}{*}{ Compound } & \multicolumn{12}{|c|}{ Soil Concentrations $(\mu \mathrm{g} / \mathrm{kg})$ at Various Depth Intervals } \\
\hline & \multicolumn{2}{|c|}{$\begin{array}{c}\text { VXBOR2 } \\
(4-6 \mathrm{ft})\end{array}$} & \multicolumn{2}{|c|}{$\begin{array}{l}\text { VXBOR2 } \\
(6-8 \mathrm{ft})\end{array}$} & \multicolumn{2}{|c|}{$\begin{array}{l}\text { VXBOR2 } \\
(8-10 \mathrm{ft})\end{array}$} & \multicolumn{2}{|c|}{$\begin{array}{l}\text { VXBOR2 } \\
(10-12 \mathrm{ft}) \\
\end{array}$} & \multicolumn{2}{|c|}{$\begin{array}{c}\text { FTBOR1 } \\
(0-2 \mathrm{ft}) \\
\end{array}$} & \multicolumn{2}{|c|}{$\begin{array}{c}\text { FTBOR1 Dup } \\
(0-2 \mathrm{ft})\end{array}$} \\
\hline & 390 & $U$ & 410 & $\mathrm{U}$ & 420 & $\mathrm{U}$ & 390 & $U$ & 390 & $\mathrm{U}$ & 390 & $U$ \\
\hline 1,3-Dichlorobenzene & 390 & $U$ & 410 & $U$ & 420 & $\mathrm{U}$ & 390 & $U$ & 390 & $\mathrm{U}$ & 390 & $\mathrm{U}$ \\
\hline 1,4-Dichlorobenzene & 390 & $\mathrm{U}$ & 410 & U & 420 & $\mathrm{U}$ & 390 & $\mathrm{U}$ & 390 & $\mathrm{U}$ & 390 & $\mathrm{U}$ \\
\hline 3,3'-Dichlorobenzidine & 390 & $U$ & 410 & $\mathrm{U}$ & 420 & $\mathrm{U}$ & 390 & $U$ & 390 & $\mathrm{U}$ & 390 & $U$ \\
\hline 2,4-Dichlorophenol & 390 & $U$ & 410 & $U$ & 420 & $U$ & 390 & $U$ & 390 & $\mathrm{U}$ & 390 & $U$ \\
\hline Diethylphthalate & 390 & $U$ & 410 & U & 420 & $\mathrm{U}$ & 390 & $U$ & 390 & $\mathrm{U}$ & 390 & $U$ \\
\hline 2,4-Dimethylphenol & 390 & $\mathrm{U}$ & 410 & $\mathrm{U}$ & 420 & $\mathrm{U}$ & 390 & $U$ & 390 & $\mathrm{U}$ & 390 & $U$ \\
\hline Dimethylphthalate & 390 & $\mathrm{U}$ & 410 & $U$ & 420 & $U$ & 390 & $\mathrm{U}$ & 390 & $\mathrm{U}$ & 390 & $U$ \\
\hline 4,6-Dinitro-2-methylphenol & 990 & $\mathrm{U}$ & 1,000 & $U$ & 1,100 & $\mathrm{U}$ & 980 & $U$ & 980 & $\mathrm{U}$ & 990 & $U$ \\
\hline 2,4-Dinitrophenol & 990 & $\mathrm{U}$ & 1,000 & $U$ & 1,100 & $\mathrm{U}$ & 980 & $U$ & 980 & $\mathrm{U}$ & 990 & $U$ \\
\hline 2,4-Dinitrotoluene & 390 & $U$ & 410 & $U$ & 420 & $U$ & 390 & $\mathrm{U}$ & 390 & $\mathrm{U}$ & 390 & $\mathrm{U}$ \\
\hline 2,6-Dinitrotoluene & 390 & $U$ & 410 & $U$ & 420 & $U$ & 390 & U & 390 & $\mathbf{U}$ & 390 & $\mathrm{U}$ \\
\hline Fluoranthene & 390 & $\mathrm{U}$ & 410 & $U$ & 420 & $\mathrm{U}$ & 390 & $\mathrm{U}$ & 390 & $\mathrm{U}$ & 390 & $\mathrm{U}$ \\
\hline Fluorene & 390 & $\mathrm{U}$ & 410 & $U$ & 420 & $U$ & 390 & $\mathrm{U}$ & 390 & $\mathrm{U}$ & 390 & $\mathrm{U}$ \\
\hline Hexachlorobenzene & 390 & $\mathrm{U}$ & 410 & $U$ & 420 & $\mathrm{U}$ & 390 & $\mathrm{U}$ & 390 & $\mathrm{U}$ & 390 & $\mathrm{U}$ \\
\hline Hexachlorobutadiene & 390 & $\mathrm{U}$ & 410 & $U$ & 420 & $\mathrm{U}$ & 390 & $\mathrm{U}$ & 390 & $\mathrm{U}$ & 390 & $U$ \\
\hline Hexachlorocyclopentadiene & 390 & $\mathrm{U}$ & 410 & $\mathrm{U}$ & 420 & $\mathrm{U}$ & 390 & $U$ & 390 & $\mathrm{U}$ & 390 & $U$ \\
\hline Hexachloroethane & 390 & $\mathrm{U}$ & 410 & $\mathrm{U}$ & 420 & $\mathrm{U}$ & 390 & $\mathrm{U}$ & 390 & $\mathrm{U}$ & 390 & $\mathrm{U}$ \\
\hline Indeno[ $[1,2,3-c, d]$ pyrene & 390 & $U$ & 410 & $\mathrm{U}$ & 420 & $U$ & 390 & $\mathrm{U}$ & 390 & $U$ & 390 & $U$ \\
\hline Isophorone & 390 & U & 410 & $\mathrm{U}$ & 420 & $\mathrm{U}$ & 390 & $\mathrm{U}$ & 390 & $\mathrm{U}$ & 390 & $\mathrm{U}$ \\
\hline 2-Methylnaphthalene & 390 & $\mathrm{U}$ & 410 & $\mathrm{U}$ & 420 & $U$ & 390 & $\mathrm{U}$ & 390 & $U$ & 390 & $U$ \\
\hline 4-Methylphenol & 390 & $U$ & 410 & $\mathrm{U}$ & 420 & $\mathrm{U}$ & 390 & $U^{\prime}$ & 390 & $\mathrm{U}$ & 390 & $U$ \\
\hline 2-Methylphenol & 390 & $U$ & 410 & $\mathrm{U}$ & 420 & $\mathrm{U}$ & 390 & U & 390 & $U$ & 390 & $U$ \\
\hline Naphthalene & 390 & $\mathrm{U}$ & 410 & U & 420 & $U$ & 390 & $U$ & 390 & $\mathrm{U}$ & 390 & $U$ \\
\hline
\end{tabular}


TABLE C.14d (Cont.)

\begin{tabular}{|c|c|c|c|c|c|c|c|c|c|c|c|c|}
\hline \multirow{3}{*}{$\frac{\text { Compound }}{\text { 2-Nitroaniline }}$} & \multicolumn{12}{|c|}{ Soil Concentrations $(\mu \mathrm{g} / \mathrm{kg})$ at Various Depth Intervals } \\
\hline & \multicolumn{2}{|c|}{$\begin{array}{c}\text { VXBOR2 } \\
(4-6 \mathrm{ft})\end{array}$} & \multicolumn{2}{|c|}{$\begin{array}{c}\text { VXBOR2 } \\
(6-8 \mathrm{ft})\end{array}$} & \multicolumn{2}{|c|}{$\begin{array}{l}\text { VXBOR2 } \\
(8-10 \mathrm{ft})\end{array}$} & \multicolumn{2}{|c|}{$\begin{array}{l}\text { VXBOR2 } \\
(10-12 \mathrm{ft})\end{array}$} & \multicolumn{2}{|c|}{$\begin{array}{c}\text { FTBOR1 } \\
(0-2 \mathrm{ft})\end{array}$} & \multicolumn{2}{|c|}{$\begin{array}{l}\text { FTBOR1 Dup } \\
(0-2 \mathrm{ft})\end{array}$} \\
\hline & 990 & $\mathrm{U}$ & 1,000 & $\mathrm{U}$ & 1,100 & $U$ & 980 & U & 980 & $\mathrm{U}$ & 990 & $\mathrm{U}$ \\
\hline 3-Nitroaniline & 990 & $\mathrm{U}$ & 1,000 & $\mathrm{U}$ & 1,100 & U & 980 & $\mathrm{U}$ & 980 & $\mathbf{U}$ & 990 & $\mathrm{U}$ \\
\hline 4-Nitroaniline & 990 & $\mathbf{U}$ & 1,000 & $\mathrm{U}$ & 1,100 & $\mathrm{U}$ & 980 & $\mathrm{U}$ & 980 & $\mathrm{U}$ & 990 & $\mathrm{U}$ \\
\hline Nitrobenzene & 390 & $\mathrm{U}$ & 410 & $\mathrm{U}$ & 420 & $U$ & 390 & $\mathrm{U}$ & 390 & $\mathrm{U}$ & 390 & $\mathrm{U}$ \\
\hline 2-Nitrophenol & 390 & $\mathrm{U}$ & 410 & $\mathrm{U}$ & 420 & $\mathrm{U}$ & 390 & $\mathrm{U}$ & 390 & $\mathrm{U}$ & 390 & $\mathrm{U}$ \\
\hline 4-Nitrophenol & 990 & $\mathrm{U}$ & 1,000 & $\mathrm{U}$ & 1,100 & $U$ & 980 & $\mathrm{U}$ & 980 & $\mathbf{U}$ & 990 & $\mathrm{U}$ \\
\hline N-Nitroso-di-n-propylamine & 390 & $\mathbf{U}$ & 410 & $U$ & 420 & $\mathrm{U}$ & 390 & $\mathrm{U}$ & 390 & $\mathrm{U}$ & 390 & $\mathrm{U}$ \\
\hline N-Nitrosodiphenylamine & 390 & $\mathrm{U}$ & 410 & $\mathrm{U}$ & 420 & $\mathrm{U}$ & 390 & $\mathrm{U}$ & 390 & $\mathbf{U}$ & 390 & $U$ \\
\hline 2,2'-Oxybis-(1-chloropropane) & 390 & $U$ & 410 & $\mathrm{U}$ & 420 & $U$ & 390 & $\mathrm{U}$ & 390 & $\mathbf{U}$ & 390 & $U$ \\
\hline Pentachlorophenol & 990 & $\mathrm{U}$ & 1,000 & $\mathrm{U}$ & 1,100 & $\mathrm{U}$ & 980 & $\mathrm{U}$ & 980 & U & 990 & $U$ \\
\hline Phenanthrene & 390 & $U$ & 410 & $\mathrm{U}$ & 420 & $\mathrm{U}$ & 390 & $\mathbf{U}$ & 390 & $\mathbf{U}$ & 390 & $\mathrm{U}$ \\
\hline Phenol & 390 & $\mathrm{U}$ & 410 & $\mathrm{U}$ & 420 & $\mathrm{U}$ & 390 & $\mathrm{U}$ & 390 & $U$ & 390 & $U$ \\
\hline Pyrene & 390 & $\mathrm{U}$ & 410 & $\mathrm{U}$ & 420 & $\mathrm{U}$ & 390 & $\mathrm{U}$ & 390 & U & 390 & $\mathrm{U}$ \\
\hline 1,2,4-Trichlorobenzene & 390 & $\mathrm{U}$ & 410 & $\mathrm{U}$ & 420 & $\mathrm{U}$ & 390 & $\mathrm{U}$ & 390 & $U$ & 390 & $\mathrm{U}$ \\
\hline 2,4,5-Trichlorophenol & 990 & $\mathrm{U}$ & 1,000 & $\mathrm{U}$ & 1,100 & $\mathbf{U}$ & 980 & $\mathrm{U}$ & 980 & $U$ & 990 & $\mathrm{U}$ \\
\hline 2,4,6-Trichlorophenol & 390 & U & 410 & $\underline{U}$ & 420 & U & 390 & $\mathrm{U}$ & 390 & $U$ & 390 & $U$ \\
\hline
\end{tabular}




\section{TABLE C.14d (Cont.)}

\begin{tabular}{|c|c|c|c|c|c|c|c|c|c|c|c|c|}
\hline \multirow{3}{*}{$\begin{array}{l}\text { Compound } \\
\text { Acenaphthene }\end{array}$} & \multicolumn{12}{|c|}{ Soil Concentrations $(\mu \mathrm{g} / \mathrm{kg})$ at Various Depth Intervals } \\
\hline & \multicolumn{2}{|c|}{$\begin{array}{c}\text { FTBOR1 } \\
(2-4 \mathrm{ft})\end{array}$} & \multicolumn{2}{|c|}{$\begin{array}{c}\text { FTBOR1 Dup } \\
(2-4 \mathrm{ft})\end{array}$} & \multicolumn{2}{|c|}{$\begin{array}{c}\text { FTBOR1 } \\
(4-6 \mathrm{ft}) \\
\end{array}$} & \multicolumn{2}{|c|}{$\begin{array}{c}\text { FTBOR1 } \\
(6-8 \mathrm{ft}) \\
\end{array}$} & \multicolumn{2}{|c|}{$\begin{array}{l}\text { FTBOR1 } \\
(8-10 \mathrm{ft})\end{array}$} & \multicolumn{2}{|c|}{$\begin{array}{l}\text { FTBOR1 } \\
(10-12 \mathrm{ft}) \\
\end{array}$} \\
\hline & 380 & $\mathrm{U}$ & 380 & $\mathrm{U}$ & 390 & $\mathrm{U}$ & 400 & $\mathrm{U}$ & 460 & $\mathrm{U}+$ & 410 & $\mathrm{U}$ \\
\hline Acenaphthylene & 380 & $\mathrm{U}$ & 380 & $\mathrm{U}$ & 390 & $U$ & 400 & $\mathrm{U}$ & 460 & $\mathrm{U}+$ & 410 & $U$ \\
\hline Anthracene & 380 & $U$ & 380 & $\mathrm{U}$ & 390 & $U$ & 400 & $\mathrm{U}$ & 460 & U+ & 410 & $U$ \\
\hline Benz[a]anthracene & 380 & $U$ & 380 & $\mathrm{U}$ & 390 & $U$ & 400 & $\mathrm{U}$ & 460 & $\mathrm{U}_{+}$ & 410 & $\mathrm{U}$ \\
\hline Benzo[a]pyrene & 380 & $\mathrm{U}$ & 380 & $\mathrm{U}$ & 390 & $\mathrm{U}$ & 400 & $\mathrm{U}$ & 460 & $U_{+}$ & 410 & $U$ \\
\hline Benzo[b]fluoranthene & 380 & $\mathrm{U}$ & 380 & $\mathrm{U}$ & 390 & $\mathrm{U}$ & 400 & $\mathrm{U}$ & 460 & $\mathrm{U}_{+}$ & 410 & $\mathrm{U}$ \\
\hline Benzo[g,h,i]perylene & 380 & $\mathrm{U}$ & 380 & $\mathrm{U}$ & 390 & $\mathrm{U}$ & 400 & $U$ & 460 & $U_{+}$ & 410 & $\mathrm{U}$ \\
\hline Benzo[k]fluoranthene & 380 & $\mathrm{U}$ & 380 & $\mathrm{U}$ & 390 & $\mathrm{U}$ & 400 & $\mathrm{U}$ & 460 & $\mathrm{U}_{+}$ & 410 & $\mathrm{U}$ \\
\hline Bis(2-chloroethoxy)methane & 380 & $\mathrm{U}$ & 380 & $\mathbf{U}$ & 390 & $\mathrm{U}$ & 400 & $\mathrm{U}$ & 460 & $\mathrm{U}_{+}$ & 410 & $\mathrm{U}$ \\
\hline Bis(2-chloroethyl)ether & 380 & $\mathrm{U}$ & 380 & $\mathrm{U}$ & 390 & $U$ & 400 & $\mathrm{U}$ & 460 & $\mathrm{U}_{+}$ & 410 & $\mathrm{U}$ \\
\hline Bis(2-ethylhexyl)phthalate & 4,300 & $\mathrm{~B}$ & 4,100 & B & 4,500 & $\mathrm{~B}$ & 3,200 & B & 460 & $\mathrm{U}_{+}$ & 3,200 & B \\
\hline 4-Bromophenyl phenyl ether & 380 & $\mathrm{U}$ & 380 & $\mathrm{U}$ & 390 & $U$ & 400 & $U$ & 460 & $\mathrm{U}_{+}$ & 410 & $\mathrm{U}$ \\
\hline Butylbenzylphthalate & 380 & $\mathrm{U}$ & 380 & $\mathrm{U}$ & 390 & $U$ & 400 & $\mathrm{U}$ & 460 & $\mathrm{U}_{+}$ & 410 & $\mathrm{U}$ \\
\hline Carbazole & 380 & $U$ & 380 & $\mathrm{U}$ & 390 & $\mathrm{U}$ & 400 & $\mathrm{U}$ & 460 & $\mathrm{U}_{+}$ & 410 & $\mathrm{U}$ \\
\hline 4-Chloro-3-methylphenol & 380 & $\mathrm{U}$ & 380 & $\mathrm{U}$ & 390 & $U$ & 400 & $\mathrm{U}$ & 460 & $\mathrm{U}_{+}$ & 410 & $\mathrm{U}$ \\
\hline 4-Chloroaniline & 380 & $\mathrm{U}$ & 380 & $U$ & 390 & $U$ & 400 & $\mathrm{U}$ & 460 & $U_{+}$ & 410 & $\mathrm{U}$ \\
\hline 2-Chloronaphthalene & 380 & $\mathrm{U}$ & 380 & $\mathrm{U}$ & 390 & $\mathrm{U}$ & 400 & $\mathrm{U}$ & 460 & $\mathrm{U}_{+}$ & 410 & $\mathrm{U}$ \\
\hline 2-Chlorophenol & 380 & $\mathrm{U}$ & 380 & U & 390 & $\mathrm{U}$ & 400 & $U$ & 460 & $U_{+}$ & 410 & $\mathrm{U}$ \\
\hline 4-Chlorophenyl phenyl ether & 380 & $U$ & 380 & $\mathrm{U}$ & 390 & $U$ & 400 & $U$ & 460 & $U_{+}$ & 410 & $U$ \\
\hline Chrysene & 380 & $\mathrm{U}$ & 380 & $\mathrm{U}$ & 390 & $U$ & 400 & $U$ & 460 & U+ & 410 & $U$ \\
\hline Di-n-butylphthalate & 380 & $\mathrm{U}$ & 140 & $\mathbf{J}$ & 130 & $\mathbf{J}$ & 120 & $\mathrm{~J}$ & 200 & $\mathrm{JB}+$ & 410 & $\mathrm{U}$ \\
\hline Di-n-octylphthalate & 380 & $U$ & 380 & $\mathrm{U}$ & 390 & $\mathrm{U}$ & 400 & $\mathrm{U}$ & 460 & $U_{+}$ & 410 & $\mathrm{U}$ \\
\hline Dibenz[a,h]anthracene & 380 & $\mathrm{U}$ & 380 & $\mathrm{U}$ & 390 & $\mathrm{U}$ & 400 & $\mathrm{U}$ & 460 & $U_{+}$ & 410 & $\mathrm{U}$ \\
\hline Dibenzofuran & 380 & $U$ & 380 & $\mathrm{U}$ & 390 & $\mathrm{U}$ & 400 & $\mathrm{U}$ & 460 & $U_{+}$ & 410 & $\mathrm{U}$ \\
\hline
\end{tabular}


TABLE C.14d (Cont.)

\begin{tabular}{|c|c|c|c|c|c|c|c|c|c|c|c|c|}
\hline \multirow{3}{*}{ Compound } & \multicolumn{12}{|c|}{ Soil Concentrations $(\mu \mathrm{g} / \mathrm{kg})$ at Various Depth Intervals } \\
\hline & \multicolumn{2}{|c|}{$\begin{array}{l}\text { FTBOR1 } \\
(2-4 \mathrm{ft})\end{array}$} & \multicolumn{2}{|c|}{$\begin{array}{l}\text { FTBOR1 Dup } \\
(2-4 \mathrm{ft})\end{array}$} & \multicolumn{2}{|c|}{$\begin{array}{l}\text { FTBOR1 } \\
(4-6 \mathrm{ft})\end{array}$} & \multicolumn{2}{|c|}{$\begin{array}{c}\text { FTBOR1 } \\
(6-8 \mathrm{ft})\end{array}$} & \multicolumn{2}{|c|}{$\begin{array}{l}\text { FTBOR1 } \\
(8-10 \mathrm{ft})\end{array}$} & \multicolumn{2}{|c|}{$\begin{array}{l}\text { FTBOR1 } \\
(10-12 \mathrm{ft})\end{array}$} \\
\hline & 380 & $\mathrm{U}$ & 380 & $U$ & 390 & $\mathrm{U}$ & 400 & $U$ & 460 & $\mathrm{U}_{+}$ & 410 & $\mathrm{U}$ \\
\hline 1,3-Dichlorobenzene & 380 & $\mathrm{U}$ & 380 & $\mathrm{U}$ & 390 & $\mathrm{U}$ & 400 & $\mathrm{U}$ & 460 & $\mathrm{U}+$ & 410 & $\mathrm{U}$ \\
\hline 1,4-Dichlorobenzene & 380 & $\mathrm{U}$ & 380 & $\mathrm{U}$ & 390 & $\mathrm{U}$ & 400 & $\mathrm{U}$ & 460 & $\mathrm{U}+$ & 410 & $\mathrm{U}$ \\
\hline $3,3^{\prime}$-Dichlorobenzidine & 380 & $\mathrm{U}$ & 380 & $\mathrm{U}$ & 390 & $\mathrm{U}$ & 400 & $\mathrm{U}$ & 460 & $U_{+}$ & 410 & $\mathrm{U}$ \\
\hline 2,4-Dichlorophenol & 380 & $\mathrm{U}$ & 380 & $\mathrm{U}$ & 390 & $U$ & 400 & $\mathrm{U}$ & 460 & $\mathrm{U}+$ & 410 & $\mathrm{U}$ \\
\hline Diethylphthalate & 380 & $\mathrm{U}$ & 380 & $\mathrm{U}$ & 390 & $U$ & 400 & $U$ & 460 & $\mathrm{U}+$ & 410 & $\mathrm{U}$ \\
\hline 2,4-Dimethylphenol & 380 & $U$ & 380 & $\mathrm{U}$ & 390 & $\mathrm{U}$ & 400 & $\mathrm{U}$ & 460 & $\mathrm{U}+$ & 410 & $\mathrm{U}$ \\
\hline Dimethylphthalate & 380 & $\mathrm{U}$ & 380 & $\mathrm{U}$ & 390 & $\mathrm{U}$ & 400 & $\mathrm{U}$ & 460 & $U_{+}$ & 410 & $U$ \\
\hline 4,6-Dinitro-2-methylphenol & 960 & $\mathrm{U}$ & 950 & $\mathrm{U}$ & 980 & $\mathrm{U}$ & 1,000 & $\mathrm{U}$ & 1,100 & $\mathrm{U}+$ & 1,000 & $U$ \\
\hline 2,4-Dinitrophenol & 960 & $\mathrm{U}$ & 950 & $\mathrm{U}$ & 980 & $\mathrm{U}$ & 1,000 & $\mathrm{U}$ & 1,100 & $U_{+}$ & 1,000 & $\mathrm{U}$ \\
\hline 2,4-Dinitrotoluene & 380 & $\mathrm{U}$ & 380 & $\mathrm{U}$ & 390 & $\mathrm{U}$ & 400 & $\mathrm{U}$ & 460 & $\mathrm{U}_{+}$ & 410 & $\mathrm{U}$ \\
\hline 2,6-Dinitrotoluene & 380 & $\mathrm{U}$ & 380 & $\mathrm{U}$ & 390 & $\mathrm{U}$ & 400 & $\mathrm{U}$ & 460 & $\mathrm{U}+$ & 410 & $\mathrm{U}$ \\
\hline Fluoranthene & 380 & $\mathrm{U}$ & 380 & $U$ & 390 & $\mathrm{U}$ & 400 & $U$ & 460 & $\mathrm{U}_{+}$ & 410 & $\mathrm{U}$ \\
\hline Fluorene & 380 & $\mathrm{U}$ & 380 & $U$ & 390 & $\mathrm{U}$ & 400 & $\mathrm{U}$ & 460 & $\mathrm{U}_{+}$ & 410 & $U$ \\
\hline Hexachlorobenzene & 380 & $\mathrm{U}$ & 380 & U & 390 & $\mathbf{U}$ & 400 & $\mathrm{U}$ & 460 & $\mathrm{U}_{+}$ & 410 & $U$ \\
\hline Hexachlorobutadiene & 380 & $\mathbf{U}$ & 380 & U & 390 & $\mathrm{U}$ & 400 & $\mathrm{U}$ & 460 & $\mathrm{U}_{+}$ & 410 & $U$ \\
\hline Hexachlorocyclopentadiene & 380 & $\mathbf{U}$ & 380 & $\mathrm{U}$ & 390 & $\mathrm{U}$ & 400 & $\mathrm{U}$ & 460 & $\mathrm{U}_{+}$ & 410 & $U$ \\
\hline Hexachloroethane & 380 & $\mathbf{U}$ & 380 & $\mathrm{U}$ & 390 & $\mathrm{U}$ & 400 & $\mathrm{U}$ & 460 & $\mathrm{U}+$ & 410 & $U$ \\
\hline Indeno[ $1,2,3-c, d] p y r e n e$ & 380 & $\mathrm{U}$ & 380 & $\mathrm{U}$ & 390 & $\mathrm{U}$ & 400 & $\mathrm{U}$ & 460 & $\mathrm{U}_{+}$ & 410 & $\mathrm{U}$ \\
\hline Isophorone & 380 & $\mathrm{U}$ & 380 & $\mathrm{U}$ & 390 & $\mathrm{U}$ & 400 & $\mathrm{U}$ & 460 & $U+$ & 410 & U \\
\hline 2-Methylnaphthalene & 380 & $\mathrm{U}$ & 380 & $U$ & 390 & U & 400 & $\mathrm{U}$ & 460 & $U_{+}$ & 410 & $\mathrm{U}$ \\
\hline 2-Methylphenol & 380 & $\mathrm{U}$ & 380 & $\mathrm{U}$ & 390 & $\mathrm{U}$ & 400 & $\mathrm{U}$ & 460 & $U_{+}$ & 410 & $\mathrm{U}$ \\
\hline 4-Methylphenol & 380 & $U$ & 380 & $\mathrm{U}$ & 390 & $\mathrm{U}$ & 400 & $\mathrm{U}$ & 460 & $U_{+}$ & 410 & $\mathrm{U}$ \\
\hline Naphthalene & 380 & $\mathrm{U}$ & 380 & $\mathrm{U}$ & 390 & $\mathrm{U}$ & 400 & $\mathrm{U}$ & 460 & $U_{+}$ & 410 & $\mathrm{U}$ \\
\hline
\end{tabular}


TABLE C.14d (Cont.)

\begin{tabular}{|c|c|c|c|c|c|c|c|c|c|c|c|c|}
\hline \multirow{3}{*}{$\frac{\text { Compound }}{\text { 2-Nitroaniline }}$} & \multicolumn{12}{|c|}{ Soil Concentrations $(\mu \mathrm{g} / \mathrm{kg})$ at Various Depth Intervals } \\
\hline & \multicolumn{2}{|c|}{$\begin{array}{c}\text { FTBOR1 } \\
(2-4 \mathrm{ft})\end{array}$} & \multicolumn{2}{|c|}{$\begin{array}{l}\text { FTBOR1 Dup } \\
(2-4 \mathrm{ft})\end{array}$} & \multicolumn{2}{|c|}{$\begin{array}{c}\text { FTBOR1 } \\
(4-6 \mathrm{ft})\end{array}$} & \multicolumn{2}{|c|}{$\begin{array}{l}\text { FTBOR1 } \\
(6-8 \mathrm{ft})\end{array}$} & \multicolumn{2}{|c|}{$\begin{array}{l}\text { FTBOR1 } \\
(8-10 \mathrm{ft})\end{array}$} & \multicolumn{2}{|c|}{$\begin{array}{l}\text { FTBOR1 } \\
(10-12 \mathrm{ft})\end{array}$} \\
\hline & 960 & $\mathrm{U}$ & 950 & $U$ & 980 & $\mathrm{U}$ & 1,000 & $\mathrm{U}$ & 1,100 & $U_{+}$ & 1,000 & $\mathrm{U}$ \\
\hline 3-Nitroaniline & 960 & $\mathrm{U}$ & 950 & $\mathrm{U}$ & 980 & $\mathrm{U}$ & 1,000 & $U$ & 1,100 & $U_{+}$ & 1,000 & $\mathrm{U}$ \\
\hline 4-Nitroaniline & 960 & $U$ & 950 & $U$ & 980 & $U$ & 1,000 & $\mathrm{U}$ & 1,100 & $U_{+}$ & 1,000 & $\mathrm{U}$ \\
\hline Nitrobenzene & 380 & $U$ & 380 & $U$ & 390 & $\mathrm{U}$ & 400 & $U$ & 460 & $U_{+}$ & 410 & $\mathrm{U}$ \\
\hline 2-Nitrophenol & 380 & $U$ & 380 & $U$ & 390 & $\mathrm{U}$ & 400 & $\mathrm{U}$ & 460 & $U_{+}$ & 410 & $\mathrm{U}$ \\
\hline 4-Nitrophenol & 960 & $U$ & 950 & $\mathrm{U}$ & 980 & $\mathrm{U}$ & 1,000 & $U$ & 1,100 & $U_{+}$ & 1,000 & U \\
\hline N-Nitroso-di-n-propylamine & 380 & $\mathrm{U}$ & 380 & $\mathrm{U}$ & 390 & $U$ & 400 & $\mathrm{U}$ & 460 & $\mathrm{U}_{+}$ & 410 & $U$ \\
\hline N-Nitrosodiphenylamine & 380 & $\mathrm{U}$ & 380 & $U$ & 390 & $U$ & 400 & $\mathrm{U}$ & 460 & $\mathrm{U}_{+}$ & 410 & $\mathrm{U}$ \\
\hline 2,2'-Oxybis-(1-chloropropane) & 380 & $\mathrm{U}$ & 380 & $\mathrm{U}$ & 390 & $U$ & 400 & $\mathrm{U}$ & 460 & $\mathrm{U}_{+}$ & 410 & $\mathrm{U}$ \\
\hline Pentachlorophenol & 960 & $\mathrm{U}$ & 950 & $\mathrm{U}$ & 980 & $U$ & 1,000 & $\mathrm{U}$ & 1,100 & $\mathrm{U}+$ & 1,000 & U \\
\hline Phenanthrene & 380 & $U$ & 380 & $\mathrm{U}$ & 390 & $\mathrm{U}$ & 400 & $\mathrm{U}$ & 460 & $U_{+}$ & 410 & U \\
\hline Phenol & 380 & $\mathrm{U}$ & 380 & $\mathrm{U}$ & 390 & $\mathrm{U}$ & 400 & $U$ & 460 & $U_{+}$ & 410 & $\mathrm{U}$ \\
\hline Pyrene & 380 & $U$ & 380 & U & 390 & $\mathrm{U}$ & 400 & $U$ & 460 & $\mathrm{U}_{+}$ & 410 & $\mathrm{U}$ \\
\hline 1,2,4-Trichlorobenzene & 380 & $\mathrm{U}$ & 380 & $U$ & 390 & $\mathrm{U}$ & 400 & $\mathrm{U}$ & 460 & $U_{+}$ & 410 & $\mathrm{U}$ \\
\hline 2,4,5-Trichlorophenol & 960 & $\mathrm{U}$ & 950 & $U$ & 980 & $\mathrm{U}$ & 1,000 & $U$ & 1,100 & $U_{+}$ & 1,000 & $\mathrm{U}$ \\
\hline 2,4,6-Trichlorophenol & 380 & $\mathrm{U}$ & 380 & $\mathrm{U}$ & 390 & $U$ & 400 & U & 460 & $\mathrm{U}_{+}$ & 410 & $U$ \\
\hline
\end{tabular}


Soil Concentrations $(\mu \mathrm{g} / \mathrm{kg})$ at Various Depth Intervals

\begin{tabular}{|c|c|c|c|c|c|c|c|c|c|c|c|c|}
\hline \multirow[b]{2}{*}{ Acenaphthene } & \multicolumn{2}{|c|}{$\begin{array}{c}\text { TBNPBOR3 } \\
(0-2 \mathrm{ft})\end{array}$} & \multicolumn{2}{|c|}{$\begin{array}{c}\text { TBNPBOR } \\
(2-4 \mathrm{ft})\end{array}$} & \multicolumn{2}{|c|}{$\begin{array}{c}\text { TBNPBOR3 } \\
(4-6 \mathrm{ft})\end{array}$} & \multicolumn{2}{|c|}{$\begin{array}{c}\text { TBNPBOR3 } \\
(6-8 \mathrm{ft})\end{array}$} & \multicolumn{2}{|c|}{$\begin{array}{c}\text { TBNPBOR } \\
(8-10 \mathrm{ft})\end{array}$} & \multicolumn{2}{|c|}{$\begin{array}{c}\text { TBNPBOR3 } \\
(10-12 \mathrm{ft})\end{array}$} \\
\hline & 393 & $U$ & 446 & UJ & 465 & U & 393 & $\mathbf{U}$ & 412 & $\mathrm{U}$ & 406 & $\mathrm{U} * \mathrm{~J}$ \\
\hline Acenaphthylene & 393 & $\mathbf{U}$ & 446 & UJ & 465 & $\mathrm{U}$ & 393 & $\mathbf{U}$ & 412 & $U$ & 406 & $\mathrm{U} * \mathrm{~J}$ \\
\hline Anthracene & 393 & U & 446 & UJ & 465 & $\mathrm{U}$ & 393 & $\mathbf{U}$ & 412 & $\mathrm{U}$ & 406 & $\mathrm{U} * \mathrm{~J}$ \\
\hline Benz[a]anthracene & 393 & $\mathrm{U}$ & 446 & UJ & 465 & $U$ & 393 & $\mathbf{U}$ & 412 & $\mathrm{U}$ & 406 & $U * J$ \\
\hline Benzo[a]pyrene & 393 & $\mathbf{U}$ & 446 & UJ & 465 & $\mathrm{U}$ & 393 & $\mathrm{U}$ & 412 & $U^{\bullet}$ & 406 & $\mathrm{U} * \mathrm{~J}$ \\
\hline Benzo[b]fluoranthene & 393 & $\mathbf{U}$ & 446 & UJ & 465 & $\mathrm{U}$ & 393 & $\mathrm{U}$ & 412 & $\mathrm{U}$ & 406 & $\mathrm{U} * \mathrm{~J}$ \\
\hline Benzo[g,h,i]perylene & 393 & $\mathrm{U}$ & 446 & UJ & 465 & $\mathrm{U}$ & 393 & $\mathrm{U}$ & 412 & $\mathrm{U}$ & 406 & $\mathrm{U} * \mathrm{~J}$ \\
\hline Benzo[k]fluoranthene & 51 & $\mathbf{J}$ & 446 & UJ & 465 & $\mathrm{U}$ & 393 & $\mathrm{U}$ & 412 & $U$ & 406 & $U * J$ \\
\hline Bis(2-chloroethoxy)methane & 393 & $\mathrm{U}$ & 446 & UJ & 465 & $\mathrm{U}$ & 393 & $\mathrm{U}$ & 412 & $U$ & 406 & $U * J$ \\
\hline Bis(2-chloroethyl)ether & 393 & $\mathrm{U}$ & 446 & UJ & 465 & $\mathrm{U}$ & 393 & $\mathbf{U}$ & 412 & $U$ & 406 & $\mathrm{U} * \mathrm{~J}$ \\
\hline Bis(2-ethylhexyl)phthalate & 65 & $\mathbf{J}$ & 446 & UJ & 1,300 & & 1,900 & & 210 & $\mathbf{J}$ & 1,800 & $* \mathrm{~J}$ \\
\hline 4-Bromophenyl phenyl ether & 393 & $U$ & 446 & UJ & 465 & $\mathrm{U}$ & 393 & $\mathrm{U}$ & 412 & $\mathrm{U}$ & 406 & $\mathrm{U}^{* J}$ \\
\hline Butylbenzylphthalate & 393 & $U$ & 446 & UJ & 465 & $\mathrm{U}$ & 393 & $\mathrm{U}$ & 412 & $\mathrm{U}$ & 406 & $\mathrm{U} * \mathrm{~J}$ \\
\hline Carbazole & 393 & $U$ & 446 & UJ & 465 & $\mathrm{U}$ & 393 & $\mathrm{U}$ & 412 & $\mathrm{U}$ & 406 & $\mathrm{U} * J$ \\
\hline 4-Chloro-3-methylphenol & 393 & $U$ & 446 & UJ & 465 & $U$ & 393 & $\mathrm{U}$ & 412 & $\mathrm{U}$ & 406 & $\mathrm{U} * J$ \\
\hline 4-Chloroaniline & 393 & $\mathrm{U}$ & 446 & UJ & 465 & $U$ & 393 & $\mathrm{U}$ & 412 & $\mathrm{U}$ & 406 & $\mathrm{U} * \mathrm{~J}$ \\
\hline 2-Chloronaphthalene & 393 & $U$ & 446 & UJ & 465 & $\mathrm{U}$ & 393 & $\mathrm{U}$ & 412 & $\mathrm{U}$ & 406 & $\mathrm{U} * \mathrm{~J}$ \\
\hline 2-Chlorophenol & 393 & $U$ & 446 & UJ & 465 & $\mathrm{U}$ & 393 & $\mathrm{U}$ & 412 & $U$ & 406 & $\mathrm{U} * \mathbf{J}$ \\
\hline 4-Chlorophenyl phenyl ether & 393 & $\mathrm{U}$ & $\cdot 446$ & UJ & 465 & $\mathrm{U}$ & 393 & $\mathrm{U}$ & 412 & $U$ & 406 & $\mathrm{U} * \mathrm{~J}$ \\
\hline Chrysene & 393 & $\mathrm{U}$ & 446 & UJ & 465 & $\mathrm{U}$ & 393 & $\mathrm{U}$ & 412 & $\mathrm{U}$ & 406 & $U * J$ \\
\hline di-n-Butylphthalate & 393 & $\mathrm{U}$ & 446 & UJ & 465 & $\mathrm{U}$ & 393 & $\mathrm{U}$ & 63 & $\mathrm{~J}$ & 406 & $U * J$ \\
\hline di-n-Octylphthalate & $\cdot 393$ & $\mathrm{U}$ & 446 & UJ & 465 & $\mathrm{U}$ & 393 & $\mathrm{U}$ & 412 & $\mathrm{U}$ & 406 & $\mathrm{U} * \mathrm{~J}$ \\
\hline Dibenz $[a, h]$ anthracene & 393 & $\mathrm{U}$ & 446 & UJ & 465 & $\mathrm{U}$ & 393 & $\mathrm{U}$ & 412 & U & 406 & $\mathrm{U} * \mathrm{~J}$ \\
\hline Dibenzofuran & 393 & $U$ & 446 & UJ & 465 & $\mathrm{U}$ & 393 & $\mathrm{U}$ & 412 & $U$ & 406 & $\mathrm{U} * \mathrm{~J}$ \\
\hline
\end{tabular}




\begin{tabular}{|c|c|c|c|c|c|c|c|c|c|c|c|c|}
\hline \multirow{3}{*}{$\frac{\text { Compound }}{1,2 \text {-Dichlorobenzene }}$} & \multicolumn{12}{|c|}{ Soil Concentrations $(\mu \mathrm{g} / \mathrm{kg})$ at Various Depth Intervals } \\
\hline & \multicolumn{2}{|c|}{$\begin{array}{c}\text { TBNPBOR3 } \\
(0-2 \mathrm{ft})\end{array}$} & \multicolumn{2}{|c|}{$\begin{array}{c}\text { TBNPBOR } \\
(2-4 \mathrm{ft})\end{array}$} & \multicolumn{2}{|c|}{$\begin{array}{c}\text { TBNPBOR3 } \\
(4-6 \mathrm{ft})\end{array}$} & \multicolumn{2}{|c|}{$\begin{array}{c}\text { TBNPBOR3 } \\
(6-8 \mathrm{ft})\end{array}$} & \multicolumn{2}{|c|}{$\begin{array}{c}\text { TBNPBOR } \\
(8-10 \mathrm{ft}) \\
\end{array}$} & \multicolumn{2}{|c|}{$\begin{array}{c}\text { TBNPBOR3 } \\
(10-12 \mathrm{ft}) \\
\end{array}$} \\
\hline & 393 & $\mathrm{U}$ & 446 & UJ & 465 & $\mathrm{U}$ & 393 & $\mathrm{U}$ & 412 & $\mathrm{U}$ & 406 & $\mathrm{U}^{* \mathrm{~J}}$ \\
\hline 1,3-Dichlorobenzene & 393 & $\mathrm{U}$ & 446 & UJ & 465 & $\mathrm{U}$ & 393 & $U$ & 412 & $\mathrm{U}$ & 406 & $\mathrm{U} * \mathrm{~J}$ \\
\hline 1,4-Dichlorobenzene & 393 & $\mathrm{U}$ & 446 & UJ & 465 & $\mathrm{U}$ & 393 & $\mathrm{U}$ & 412 & $\mathrm{U}$ & 406 & $\mathrm{U} * \mathrm{~J}$ \\
\hline 3,3'-Dichlorobenzidine & 393 & $\mathrm{U}$ & 446 & UJ & 465 & $U$ & 393 & $\mathrm{U}$ & 412 & $\mathrm{U}$ & 406 & $\mathrm{U} * \mathrm{~J}$ \\
\hline 2,4-Dichlorophenol & 393 & $\mathrm{U}$ & 446 & UJ & 465 & $\mathrm{U}$ & 393 & $\mathrm{U}$ & 412 & $\mathrm{U}$ & 406 & $\mathrm{U}^{* J}$ \\
\hline Diethylphthalate & 393 & $\mathrm{U}$ & 446 & $\mathrm{UJ}$ & 465 & $U$ & 393 & $U$ & 412 & $\mathrm{U}$ & 406 & $\mathrm{U} * \mathrm{~J}$ \\
\hline 2,4-Dimethylphenol & 393 & $\mathrm{U}$ & 446 & UJ & 465 & $U$ & 393 & $\mathrm{U}$ & 412 & $U$ & 406 & $\mathrm{U} * \mathrm{~J}$ \\
\hline Dimethylphthalate & 393 & $U$ & 446 & UJ & 465 & $\mathrm{U}$ & 393 & $\mathrm{U}$ & 412 & $U$ & 406 & U*J \\
\hline 4,6-Dinitro-2-methylphenol & 988 & $U$ & 1,120 & UJ & 1,170 & $\mathrm{U}$ & 988 & $\mathrm{U}$ & 1,040 & $\mathrm{U}$ & 1,020 & $\mathrm{U} * \mathrm{~J}$ \\
\hline 2,4-Dinitrophenol & 988 & $\mathrm{U}$ & 1,120 & UJ & 1,170 & $\mathrm{U}$ & 988 & $\mathrm{U}$ & 1,040 & $\mathrm{U}$ & 1,020 & $\mathrm{U} * \mathrm{~J}$ \\
\hline 2,4-Dinitrotoluene & 393 & $U$ & 446 & UJ & 465 & $U$ & 393 & $\mathrm{U}$ & 412 & $\mathrm{U}$ & 406 & $\mathrm{U} * \mathrm{~J}$ \\
\hline 2,6-Dinitrotoluene & 393 & $\mathrm{U}$ & 446 & UJ & 465 & $U$ & 393 & $\mathrm{U}$ & 412 & $U$ & 406 & $\mathrm{U}^{* \mathrm{~J}}$ \\
\hline Fluoranthene & 393 & $\mathbf{U}$ & 446 & UJ & 465 & $\mathrm{U}$ & 393 & $\mathrm{U}$ & 412 & $U$ & 406 & $\mathrm{U}^{*} \mathrm{~J}$ \\
\hline Fluorene & 393 & $\mathbf{U}$ & 446 & UJ & 465 & $\mathrm{U}$ & 393 & $\mathrm{U}$ & 412 & $\mathrm{U}$ & 406 & U*J \\
\hline Hexachlorobenzene & 170 & $\mathrm{~J}$ & 446 & UJ & 465 & $\mathbf{U}$ & 393 & $\mathrm{U}$ & 412 & $\mathbf{U}$ & 406 & $\mathrm{U} * \mathrm{~J}$ \\
\hline Hexachlorobutadiene & 393 & U & 446 & UJ & 465 & $\mathrm{U}$ & 393 & $U$ & 412 & $\mathrm{U}$ & 406 & $\mathrm{U}^{* \mathrm{~J}}$ \\
\hline Hexachlorocyclopentadiene & 393 & $U$ & 446 & UJ & 465 & $U$ & 393 & $\mathrm{U}$ & 412 & $\mathrm{U}$ & 406 & $\mathrm{U} * \mathrm{~J}$ \\
\hline Hexachloroethane & 393 & $\mathrm{U}$ & 446 & UJ & 465 & $\mathrm{U}$ & 393 & $U$ & 412 & $U$ & 406 & $\mathrm{U}^{*} \mathrm{~J}$ \\
\hline Indeno[1,2,3-cd]pyrene & 393 & $U$ & 446 & UJ & 465 & $\mathrm{U}$ & 393 & $\mathrm{U}$ & 412 & $U$ & 406 & $\mathrm{U}^{* \mathrm{~J}}$ \\
\hline Isophorone & 393 & $U$ & 446 & UJ & 465 & $\mathrm{U}$ & 393 & $U$ & 412 & $U$ & 406 & $\mathrm{U}^{* \mathrm{~J}}$ \\
\hline 2-Methylnaphthalene & 120 & $J$ & 446 & UJ & 580 & & 2,100 & & 412 & $U$ & 1,700 & $* J$ \\
\hline 2-Methylphenol & 393 & $\mathrm{U}$ & 446 & UJ & 465 & $\mathrm{U}$ & 393 & $\mathrm{U}$ & 412 & $\mathrm{U}$ & 406 & $U^{*} \mathrm{~J}$ \\
\hline 4-Methylphenol & 393 & $\mathrm{U}$ & 446 & UJ & 465 & $\mathrm{U}$ & 393 & $\mathrm{U}$ & 412 & $\mathrm{U}$ & 406 & $\mathrm{U}^{* \mathrm{~J}}$ \\
\hline Naphthalene & 393 & $\mathrm{U}$ & 446 & UJ & 710 & & 1,800 & & 412 & $\mathrm{U}$ & 1,600 & $* \mathrm{~J}$ \\
\hline
\end{tabular}


TABLE C.14d (Cont.)

Soil Concentrations $(\mu \mathrm{g} / \mathrm{kg})$ at Various Depth Intervals

\begin{tabular}{|c|c|c|c|c|c|c|c|c|c|c|c|c|}
\hline \multirow[b]{2}{*}{ 2-Nitroaniline } & \multicolumn{2}{|c|}{$\begin{array}{c}\text { TBNPBOR3 } \\
(0-2 \mathrm{ft})\end{array}$} & \multicolumn{2}{|c|}{$\begin{array}{c}\text { TBNPBOR } \\
(2-4 \mathrm{ft})\end{array}$} & \multicolumn{2}{|c|}{$\begin{array}{c}\text { TBNPBOR3 } \\
(4-6 \mathrm{ft})\end{array}$} & \multicolumn{2}{|c|}{$\begin{array}{c}\text { TBNPBOR3 } \\
(6-8 \mathrm{ft})\end{array}$} & \multicolumn{2}{|c|}{$\begin{array}{c}\text { TBNPBOR } \\
(8-10 \mathrm{ft})\end{array}$} & \multicolumn{2}{|c|}{$\begin{array}{c}\text { TBNPBOR3 } \\
(10-12 \mathrm{ft})\end{array}$} \\
\hline & 988 & $\mathrm{U}$ & 1,120 & UJ & 1,170 & $U$ & 988 & $\mathrm{U}$ & 1,040 & $\mathrm{U}$ & 1,020 & $\mathrm{U}^{* \mathrm{~J}}$ \\
\hline 3-Nitroaniline- & 988 & $\mathrm{U}$ & 1,120 & UJ & 1,170 & $U$ & 988 & $\mathrm{U}$ & 1,040 & $\mathrm{U}$ & 1,020 & $\mathrm{U}^{* J}$ \\
\hline 4-Nitroaniline & 988 & $\mathrm{U}$ & 1,120 & UJ & 1,170 & $\mathrm{U}$ & 988 & $\mathrm{U}$ & 1,040 & $\mathrm{U}$ & 1,020 & $\mathrm{U}^{* J}$ \\
\hline Nitrobenzene & 393 & $\mathrm{U}$ & 446 & UJ & 465 & $U$ & 393 & $\mathrm{U}$ & 412 & $\mathrm{U}$ & 406 & $\mathrm{U}^{*} \mathrm{~J}$ \\
\hline 2-Nitrophenol & 393 & $\mathrm{U}$ & 446 & UJ & 465 & $U$ & 393 & $U$ & 412 & $\mathrm{U}$ & 406 & $\mathrm{U}^{* J}$ \\
\hline 4-Nitrophenol & 988 & $\mathrm{U}$ & 1,120 & UJ & 1,170 & $\mathrm{U}$ & 988 & $\mathrm{U}$ & 1,040 & $\mathrm{U}$ & 1,020 & $\mathrm{U}^{*} \mathrm{~J}$ \\
\hline N-Nitroso-di-n-propylamine & 393 & $\mathrm{U}$ & 446 & UJ & 465 & $\mathrm{U}$ & 393 & $\mathrm{U}$ & 412 & $\mathrm{U}$ & 406 & $U^{* J}$ \\
\hline N-Nitrosodiphenylamine & 393 & $\mathrm{U}$ & 446 & UJ & 465 & $\mathrm{U}$ & 393 & $\mathrm{U}$ & 412 & $\mathrm{U}$ & 406 & $\mathrm{U} * \mathrm{~J}$ \\
\hline 2,2'-Oxybis-(1-chloropropane) & 393 & $\mathrm{U}$ & 446 & UJ & 465 & $U$ & 393 & $\mathrm{U}$ & 412 & $\mathrm{U}$ & 406 & $\mathrm{U} * \mathrm{~J}$ \\
\hline Pentachlorophenol & 988 & $U$ & 1,120 & UJ & 1,170 & $\mathrm{U}$ & 988 & $\mathrm{U}$ & 1,040 & $\mathrm{U}$ & 1,020 & $\mathrm{U}^{*} \mathrm{~J}$ \\
\hline Phenanthrene & 93 & $\mathbf{J}$ & 446 & UJ & 465 & U & 880 & & 412 & $\mathrm{U}$ & 406 & $U^{* J}$ \\
\hline Phenol & 393 & $U$ & 446 & UJ & 465 & $\mathrm{U}$ & 393 & $U$ & 412 & U & 406 & $\mathrm{U}^{* J}$ \\
\hline Pyrene & 62 & $\mathbf{J}$ & 446 & UJ & 465 & $\mathrm{U}$ & 393 & $U$ & 412 & $\mathrm{U}$ & 406 & $\mathrm{U}^{* J}$ \\
\hline 1,2,4-Trichlorobenzene & 393 • & $U$ & 446 & UJ & 465 & $\mathrm{U}$ & 393 & $\mathrm{U}$ & 412 & $\mathrm{U}$ & 406 & $\mathrm{U} * \mathrm{~J}$ \\
\hline 2,4,5-Trichlorophenol & 988 & $\mathrm{U}$ & 1,120 & UJ & 1,170 & $\mathbf{U}$ & 988 & $\mathbf{U}$ & 1,040 & $\mathrm{U}$ & 1,020 & $\mathrm{U}^{* \mathrm{~J}}$ \\
\hline 2,4,6-Trichlorophenol & 393 & $U$ & 446 & UJ & 465 & $\mathrm{U}$ & 393 & U & 412 & $\mathrm{U}$ & 406 & $\mathrm{U}^{* \mathrm{~J}}$ \\
\hline
\end{tabular}

Soil Concentrations $(\mu \mathrm{g} / \mathrm{kg})$ at Various Depth Intervals

\begin{tabular}{|c|c|c|c|c|c|c|c|c|c|c|c|}
\hline \multirow[b]{2}{*}{ Compound } & & \multicolumn{10}{|c|}{ Soil Concentrations $(\mu \mathrm{g} / \mathrm{kg})$ at Various Depth Intervals } \\
\hline & & \multicolumn{2}{|c|}{$\begin{array}{c}\text { VXBOR3 } \\
(2-4 \mathrm{ft})\end{array}$} & \multicolumn{2}{|c|}{$\begin{array}{c}\text { VXBOR4 } \\
(2-4 \mathrm{ft})\end{array}$} & \multicolumn{2}{|c|}{$\begin{array}{c}\text { VXBOR4 } \\
(4-6 \mathrm{ft})\end{array}$} & \multicolumn{2}{|c|}{$\begin{array}{c}\text { VXBOR5 } \\
(4-6 \mathrm{ft})\end{array}$} & \multicolumn{2}{|c|}{$\begin{array}{r}\text { VXBOR5 } \\
(8-10 \mathrm{ft}) \\
\end{array}$} \\
\hline Acenaphthene & $\sim$ & 7,920 & $\mathrm{U}$ & 8,350 & UJ & 8,050 & $\mathrm{U}$ & 428 & $\mathrm{U}$ & 407 & $\mathrm{U}$ \\
\hline Acenaphthylene & & 7,920 & $\mathrm{U}$ & 8,350 & UJ & 8,050 & $\mathrm{U}$ & 428 & $\mathrm{U}$ & 407 & $\mathrm{U}$ \\
\hline Anthracene & & 810 & $\mathrm{~J}$ & 8,350 & UJ & 8,050 & $\mathrm{U}$ & 428 & $U$ & 407 & $\mathrm{U}$ \\
\hline
\end{tabular}




\begin{tabular}{|c|c|c|c|c|c|c|c|c|c|c|}
\hline \multirow{3}{*}{$\frac{\text { Compound }}{\text { Benz[a]anthracene }}$} & \multicolumn{10}{|c|}{ Soil Concentrations $(\mu \mathrm{g} / \mathrm{kg})$ at Various Depth Intervals } \\
\hline & \multicolumn{2}{|c|}{$\begin{array}{c}\text { VXBOR3 } \\
(2-4 \mathrm{ft}) \\
\end{array}$} & \multicolumn{2}{|c|}{$\begin{array}{c}\text { VXBOR4 } \\
(2-4 \mathrm{ft}) \\
\end{array}$} & \multicolumn{2}{|c|}{$\begin{array}{c}\text { VXBOR4 } \\
(4-6 \mathrm{ft}) \\
\end{array}$} & \multicolumn{2}{|c|}{$\begin{array}{c}\text { VXBOR5 } \\
(4-6 \mathrm{ft}) \\
\end{array}$} & \multicolumn{2}{|c|}{$\begin{array}{r}\text { VXBOR5 } \\
(8-10 \mathrm{ft}) \\
\end{array}$} \\
\hline & 7,920 & $\mathrm{U}$ & 1,200 & UJ & 8,050 & $\mathrm{U}$. & 428 & $U$ & 407 & $\mathrm{U}$ \\
\hline Benzo[a]pyrene & 7,920 & $\mathrm{U}$ & 1,300 & $\mathrm{~J}$ & 8,050 & $\mathrm{U}$ & 428 & $\mathrm{U}$ & 407 & $\mathrm{U}$ \\
\hline Benzo[b]fluoranthene & 7,920 & U & 1,200 & $\mathbf{J}$ & 1,020 & $\mathrm{~J}$ & 428 & $U$ & 407 & $\mathrm{U}$ \\
\hline Benzo[g,h,i]perylene & 890 & $\mathrm{~J}$ & 2,400 & $J$ & 1,600 & $\mathrm{~J}$ & 428 & U & 407 & $\mathrm{U}$ \\
\hline Benzo[k]fluoranthene & 7,920 & $\mathrm{U}$ & 8,350 & UJ & 3,100 & $\mathbf{J}$ & 428 & $U$ & 407 & $\mathrm{U}$ \\
\hline Bis(2-chloroethoxy)methane & 7,920 & $\mathrm{U}$ & 8,350 & UJ & 8,050 & $\mathrm{U}$ & 428 & $\mathrm{U}$ & 407 & $\mathrm{U}$ \\
\hline Bis(2-chloroethyl)ether & 7,920 & $\mathrm{U}$ & 8,350 & UJ & 8,050 & $\mathrm{U}$ & 428 & $\mathrm{U}$ & 407 & $\mathrm{U}$ \\
\hline Bis(2-ethylhexyl)phthalate & 7,920 & $U$ & 8,350 & UJ & 8,050 & $\mathrm{U}$ & 428 & $\mathrm{U}$ & 407 & $\mathrm{U}$ \\
\hline 4-Bromophenyl phenyl ether & 7,920 & $\mathrm{U}$ & 8,350 & UJ & 8,050 & $\mathrm{U}$ & 428 & $U$ & 407 & $\mathrm{U}$ \\
\hline Butylbenzylphthalate & 7,920 & $U$ & 8,350 & UJ & 8,050 & $\mathrm{U}$ & 428 & $U$ & 407 & $\mathrm{U}$ \\
\hline Carbazole & 7,920 & U & 8,350 & UJ & 8,050 & $\mathrm{U}$ & 428 & $U$ & 407 & $\mathrm{U}$ \\
\hline 4-Chloro-3-methylphenol & 7,920 & $U$ & 8,350 & UJ & 8,050 & $\mathrm{U}$ & 428 & U & 407 & $\mathrm{U}$ \\
\hline 4-Chloroaniline & 7,920 & $\mathrm{U}$ & 8,350 & UJ & 8,050 & $\mathrm{U}$ & 428 & $\mathrm{U}$ & 407 & $\mathrm{U}$ \\
\hline 2-Chloronaphthalene & 7,920 & $\mathrm{U}$ & 8,350 & UJ & 8,050 & $U$ & 428 & $\mathrm{U}$ & 407 & $\mathrm{U}$ \\
\hline 2-Chlorophenol & 7,920 & $\mathrm{U}$ & 8,350 & UJ & 8,050 & $\mathrm{U}$ & 428 & $\mathrm{U}$ & 407 & $\mathrm{U}$ \\
\hline 4-Chlorophenyl phenyl ether & 7,920 & $\mathrm{U}$ & 8,350 & UJ & 8,050 & $\mathrm{U}$ & 428 & $\mathrm{U}$ & 407 & $\mathrm{U}$ \\
\hline Chrysene & 1,500 & $\mathbf{J}$ & 2,100 & $\mathbf{J}$ & 1,100 & $\mathbf{J}$ & 428 & $\mathrm{U}$ & 407 & $U$ \\
\hline di-n-Butylphthalate & 7,920 & $\mathrm{U}$ & 47,000 & $\mathrm{BJ}$ & 27,000 & $B$ & 428 & $U$ & 73 & JB \\
\hline di-n-Octylphthalate & 7,920 & $U$ & 8,350 & UJ & 8,050 & $\mathrm{U}$ & 428 & $U$ & 407 & U \\
\hline Dibenz[a,h]anthracene & 7,920 & $U$ & 1,700 & $J$ & 8,050 & $\mathrm{U}$ & 428 & U & 407 & $U$ \\
\hline Dibenzofuran & 7,920 & $\mathrm{U}$ & 8,350 & UJ & 8,050 & $U$ & 428 & $U$ & 407 & $U$ \\
\hline 1,2-Dichlorobenzene & 7,920 & $U$ & 8,350 & UJ & 8,050 & $\mathrm{U}$ & 428 & $U$ & 407 & $\mathrm{U}$ \\
\hline 1,3-Dichlorobenzene & 7,920 & $\mathrm{U}$ & 8,350 & UJ & 8,050 & $\mathrm{U}$ & 428 & $U$ & 407 & $U$ \\
\hline 1,4-Dichlorobenzene & 7,920 & $\mathrm{U}$ & 8,350 & UJ & 8,050 & $\mathrm{U}$ & 428 & $\mathrm{U}$ & 407 & $U$ \\
\hline
\end{tabular}




\begin{tabular}{|c|c|c|c|c|c|c|c|c|c|c|}
\hline \multirow[b]{2}{*}{ Compound } & \multicolumn{10}{|c|}{ Soil Concentrations $(\mu \mathrm{g} / \mathrm{kg})$ at Various Depth Intervals } \\
\hline & \multicolumn{2}{|c|}{$\begin{array}{c}\text { VXBOR3 } \\
(2-4 \mathrm{ft})\end{array}$} & \multicolumn{2}{|c|}{$\begin{array}{c}\text { VXBOR4 } \\
(2-4 \mathrm{ft})\end{array}$} & \multicolumn{2}{|c|}{$\begin{array}{c}\text { VXBOR4 } \\
(4-6 \mathrm{ft})\end{array}$} & \multicolumn{2}{|c|}{$\begin{array}{c}\text { VXBOR5 } \\
(4-6 \mathrm{ft})\end{array}$} & \multicolumn{2}{|c|}{$\begin{array}{r}\text { VXBOR5 } \\
(8-10 \mathrm{ft})\end{array}$} \\
\hline 3,3'-Dichlorobenzidine & 7,920 & $U$ & 8,350 & UJ & 8,050 & $\mathrm{U}$ & 428 & $\mathrm{U}$ & 407 & $U$ \\
\hline 2,4-Dichlorophenol & 7,920 & $\mathrm{U}$ & 8,350 & UJ & 8,050 & $\mathrm{U}$ & 428 & $\mathrm{U}$ & 407 & $\mathrm{U}$ \\
\hline Diethylphthalate & 7,920 & $\mathrm{U}$ & 8,350 & UJ & 8,050 & $\mathrm{U}$ & 428 & U & 407 & $\mathrm{U}$ \\
\hline 2,4-Dimethylphenol & 7,920 & $\mathrm{U}$ & 8,350 & UJ & 8,050 & $\mathrm{U}$ & 428 & $\mathrm{U}$ & 407 & $\mathrm{U}$ \\
\hline Dimethylphthalate & 7,920 & $\mathrm{U}$ & 8,350 & UJ & 8,050 & $\mathrm{U}$ & 428 & $\mathbf{U}$ & 407 & $\mathrm{U}$ \\
\hline 4,6-Dinitro-2-methylphenol & 19,900 & $\mathbf{U}$ & 21,000 & UJ & 20,200 & $U$ & 1080 & $\mathrm{U}$ & 1020 & $\mathrm{U}$ \\
\hline 2,4-Dinitrophenol & 19,900 & $\mathrm{U}$ & 21,000 & UJ & 20,200 & $\mathrm{U}$ & 1080 & $\mathrm{U}$ & 1020 & $\mathrm{U}$ \\
\hline 2,4-Dinitrotoluene & 7,920 & $\mathrm{U}$ & 8,350 & UJ & 8,050 & $\mathrm{U}$ & 428 & $\mathbf{U}$ & 407 & $\mathrm{U}$ \\
\hline 2,6-Dinitrotoluene & 7,920 & $\mathrm{U}$ & 8,350 & UJ & 8,050 & $\mathrm{U}$ & 428 & $\mathbf{U}$ & 407 & $\mathrm{U}$ \\
\hline Fluoranthene & 7,920 & $\mathrm{U}$ & 2,600 & $\mathrm{~J}$ & 1,900 & $\mathbf{J}$ & 150 & $\mathrm{~J}$ & 407 & $\mathrm{U}$ \\
\hline Fluorene & 7,920 & $\mathrm{U}$ & 8,350 & UJ & 8,050 & $\mathrm{U}$ & 428 & $\mathbf{U}$ & 407 & $\mathrm{U}$ \\
\hline Hexachlorobenzene & 7,920 & $\mathrm{U}$ & 8,350 & UJ & 8,050 & $\mathrm{U}$ & 428 & $\mathbf{U}$ & 407 & $\mathrm{U}$ \\
\hline Hexachlorobutadiene & 7,920 & $U$ & 8,350 & UJ & 8,050 & $\mathrm{U}$ & 428 & $\mathrm{U}$ & 407 & $\mathrm{U}$ \\
\hline Hexachlorocyclopentadiene & 7,920 & $U$ & 8,350 & UJ & 8,050 & $\mathrm{U}$ & 428 & $\mathbf{U}$ & 407 & $\mathrm{U}$ \\
\hline Hexachloroethane & 7,920 & $U$ & 8,350 & UJ & 8,050 & $U$ & 428 & $U$ & 407 & $\mathrm{U}$ \\
\hline Indeno[1,2,3-cd]pyrene & 7,920 & $\mathrm{U}$ & 2,000 & $\mathbf{J}$ & 8,050 & $\mathrm{U}$ & 428 & $\mathrm{U}$ & 407 & $\mathrm{U}$ \\
\hline Isophorone & 7,920 & U & 8,350 & UJ & 8,050 & $U$ & 428 & $U$ & 407 & $\mathrm{U}$ \\
\hline 2-Methylnaphthalene & 980 & $\mathbf{J}$ & 53,000 & $\mathbf{J}$ & 12,000 & & 8100 & $*$ & 407 & $\mathrm{U}$ \\
\hline 2-Methylphenol & 7,920 & $U$ & 8,350 & UJ & 8,050 & $\mathrm{U}$ & 428 & $U$ & 407 & $\mathrm{U}$ \\
\hline 4-Methylphenol & 7,920 & $\mathrm{U}$ & 8,350 & UJ & 8,050 & $\mathrm{U}$ & 428 & $U$ & 407 & $\mathrm{U}$ \\
\hline Naphthalene & 7,920 & $U$ & 8,350 & UJ & 8,050 & $\mathrm{U}$ & 420 & $\mathbf{J}$ & 407 & $\mathbf{U}$ \\
\hline 2-Nitroaniline & 19,900 & $U$ & 21,000 & UJ & 20,200 & $\mathrm{U}$ & 1080 & $\mathrm{U}$ & 1020 & $\mathrm{U}$ \\
\hline 3-Nitroaniline & 19,900 & $\mathrm{U}$ & 21,000 & UJ & 20,200 & $\mathrm{U}$ & 1080 & $\mathrm{U}$ & 1020 & $\mathbf{U}$ \\
\hline 4-Nitroaniline & 19,900 & $U$ & 21,000 & UJ & 20,200 & $\mathbf{U}$ & 1080 & $\mathrm{U}$ & 1020 & $\mathbf{U}$ \\
\hline
\end{tabular}


TABLE C.14d (Cont.)

\begin{tabular}{|c|c|c|c|c|c|c|c|c|c|c|}
\hline \multirow{3}{*}{$\begin{array}{l}\text { Compound } \\
\text { Nitrobenzene }\end{array}$} & \multicolumn{10}{|c|}{ Soil Concentrations $(\mu \mathrm{g} / \mathrm{kg})$ at Various Depth Intervals } \\
\hline & \multicolumn{2}{|c|}{$\begin{array}{c}\text { VXBOR3 } \\
(2-4 \mathrm{ft}) \\
\end{array}$} & \multicolumn{2}{|c|}{$\begin{array}{c}\text { VXBOR4 } \\
(2-4 \mathrm{ft}) \\
\end{array}$} & \multicolumn{2}{|c|}{$\begin{array}{c}\text { VXBOR4 } \\
(4-6 \mathrm{ft}) \\
\end{array}$} & \multicolumn{2}{|c|}{$\begin{array}{c}\text { VXBOR5 } \\
(4-6 \mathrm{ft}) \\
\end{array}$} & \multicolumn{2}{|c|}{$\begin{array}{r}\text { VXBOR5 } \\
(8-10 \mathrm{ft}) \\
\end{array}$} \\
\hline & 7,920 & $U$ & 8,350 & UJ & 8,050 & U & 428 & $U^{-}$ & 407 & $\mathrm{U}$ \\
\hline 2-Nitrophenol & 7,920 & $\mathrm{U}$ & 8,350 & UJ & 8,050 & $\mathrm{U}$ & 428 & $\mathrm{U}$ & 407 & $\mathrm{U}$ \\
\hline 4-Nitrophenol & 19,900 & $\mathrm{U}$ & 21,000 & UJ & 20,200 & U & 1080 & $\mathrm{U}$ & 1020 & $U$ \\
\hline N-Nitroso-di-n-propylamine & 7,920 & $\mathrm{U}$ & 8,350 & UJ & 8,050 & $\mathrm{U}$ & 428 & $U$ & 407 & $U$ \\
\hline N-Nitrosodiphenylamine & 7,920 & $\mathrm{U}$ & 8,350 & UJ & 8,050 & $U$ & 428 & $\mathrm{U}^{-}$ & 407 & $U$ \\
\hline 2,2'-Oxybis-(1-chloropropane) & 7,920 & $\mathrm{U}$ & 8,350 & UJ & 8,050 & $U$ & 428 & $\mathrm{U}$ & 407 & $U$ \\
\hline Pentachlorophenol & 19,900 & $\mathrm{U}$ & 21,000 & UJ & 20,200 & $\mathrm{U}$ & 1080 & $U$ & 1020 & $U$ \\
\hline Phenanthrene & 1,500 & $\mathrm{~J}$ & 32,000 & $\mathbf{J}$ & 27,000 & & 3100 & & 407 & $U$ \\
\hline Phenol & 7,920 & $\mathrm{U}$ & 8,350 & UJ & 8,050 & $\mathrm{U}$ & 428 & $\mathrm{U}$ & 407 & $\mathrm{U}$ \\
\hline Pyrene & 3,300 & $\mathrm{~J}$ & 8,350 & UJ & 8,050 & $\mathrm{U}$ & 170 & $\mathrm{~J}$ & 407 & $U$ \\
\hline 1,2,4-Trichlorobenzene & 7,920 & $\mathrm{U}$ & 8,350 & UJ & 8,050 & $\mathrm{U}$ & 428 & $U$ & 407 & $\mathrm{U}$ \\
\hline 2,4,5-Trichlorophenol & 19,900 & $\mathrm{U}$ & 21,000 & UJ & 20,200 & $\mathrm{U}$ & 1080 & $\mathrm{U}$ & 1020 & $\mathrm{U}$ \\
\hline \multirow[t]{2}{*}{ 2,4,6-Trichlorophenol } & 7,920 & $\mathrm{U}$ & 8,350 & UJ & 8,050 & U & 428 & $\mathrm{U}$ & 407 & $\mathrm{U}$ \\
\hline & \multicolumn{6}{|c|}{ Soil Concentrations $(\mu \mathrm{g} / \mathrm{kg})$ at $0-6 \mathrm{in}$. } & & & & \\
\hline Compound & \multicolumn{2}{|c|}{ SQPS-1 } & \multicolumn{2}{|c|}{ SQPS-5 } & \multicolumn{2}{|c|}{ SQPS-8 } & & & & \\
\hline Acenaphthene & 412 & $U$ & 407 & $U$ & 686 & $U$ & & & & \\
\hline Acenaphthylene & 412 & $U$ & 407 & $U$ & 686 & $U$ & & & & \\
\hline Anthracene & 412 & $\mathrm{U}$ & 407 & $U$ & 686 & $\mathrm{U}$ & & & & \\
\hline Benz[a]anthracene & 412 & $\mathrm{U}$ & 407 & $\mathrm{U}$ & 686 & $U$ & & & & \\
\hline Benzo[a]pyrene & 412 & $\mathrm{U}$ & 407 & $U$ & 686 & $U$ & & & & \\
\hline Benzo[b]fluoranthene & 412 & $\mathrm{U}$ & 407 & $\mathrm{U}$ & 686 & $\mathrm{U}$ & & & & \\
\hline Benzo[g,h,i]perylene & 412 & $U$ & 407 & $U$ & 686 & $U$ & & & & \\
\hline
\end{tabular}


TABLE C.14d (Cont.)

Soil Concentrations $(\mu \mathrm{g} / \mathrm{kg})$ at $0-6$ in.

\begin{tabular}{lccccccc}
\multicolumn{1}{c}{ Compound } & \multicolumn{2}{c}{ SQPS-1 } & SQPS-5 & \multicolumn{2}{c}{ SQPS-8 } \\
\hline Benzo[k]fluoranthene & 412 & $\mathrm{U}$ & 42 & & 686 & $\mathrm{U}$ \\
Bis(2-chloroethoxy)methane & 412 & $\mathrm{U}$ & 407 & $\mathrm{U}$ & 686 & $\mathrm{U}$ \\
Bis(2-chloroethyl)ether & 412 & $\mathrm{U}$ & 407 & $\mathrm{U}$ & 686 & $\mathrm{U}$ \\
Bis(2-ethylhexyl)phthalate & 412 & $\mathrm{U}$ & 407 & $\mathrm{U}$ & 686 & $\mathrm{U}$ \\
4-Bromophenyl phenyl ether & 412 & $\mathrm{U}$ & 407 & $\mathrm{U}$ & 686 & $\mathrm{U}$ \\
Butylbenzylphthalate & 412 & $\mathrm{U}$ & 407 & $\mathrm{U}$ & 686 & $\mathrm{U}$ \\
Carbazole & 412 & $\mathrm{U}$ & 407 & $\mathrm{U}$ & 686 & $\mathrm{U}$ \\
4-Chloro-3-methylphenol & 412 & $\mathrm{U}$ & 407 & $\mathrm{U}$ & 686 & $\mathrm{U}$ \\
4-Chloroaniline & 412 & $\mathrm{U}$ & 407 & $\mathrm{U}$ & 686 & $\mathrm{U}$ \\
2-Chloronaphthalene & 412 & $\mathrm{U}$ & 407 & $\mathrm{U}$ & 686 & $\mathrm{U}$ \\
2-Chlorophenol & 412 & $\mathrm{U}$ & 407 & $\mathrm{U}$ & 686 & $\mathrm{U}$ \\
4-Chlorophenyl phenyl ether & 412 & $\mathrm{U}$ & 407 & $\mathrm{U}$ & 686 & $\mathrm{U}$ \\
Chrysene & 412 & $\mathrm{U}$ & 407 & $\mathrm{U}$ & 686 & $\mathrm{U}$ \\
di-n-Butylphthalate & 412 & $\mathrm{U}$ & 407 & $\mathrm{U}$ & 686 & $\mathrm{U}$ \\
di-n-Octylphthalate & 412 & $\mathrm{U}$ & 407 & $\mathrm{U}$ & 686 & $\mathrm{U}$ \\
Dibenz[a,h]anthracene & 412 & $\mathrm{U}$ & 407 & $\mathrm{U}$ & 686 & $\mathrm{U}$ \\
Dibenzofuran & 412 & $\mathrm{U}$ & 407 & $\mathrm{U}$ & 686 & $\mathrm{U}$ \\
1,2-Dichlorobenzene & 412 & $\mathrm{U}$ & 407 & $\mathrm{U}$ & 686 & $\mathrm{U}$ \\
1,3-Dichlorobenzene & 412 & $\mathrm{U}$ & 407 & $\mathrm{U}$ & 686 & $\mathrm{U}$ \\
1,4-Dichlorobenzene & 412 & $\mathrm{U}$ & 407 & $\mathrm{U}$ & 686 & $\mathrm{U}$ \\
3,3'-Dichlorobenzidine & 412 & $\mathrm{U}$ & 407 & $\mathrm{U}$ & 686 & $\mathrm{U}$ \\
2,4-Dichlorophenol & 412 & $\mathrm{U}$ & 407 & $\mathrm{U}$ & 686 & $\mathrm{U}$ \\
Diethylphthalate & 412 & $\mathrm{U}$ & 407 & $\mathrm{U}$ & 686 & $\mathrm{U}$ \\
& & & & & &
\end{tabular}


TABLE C.14d (Cont.)

\begin{tabular}{|c|c|c|c|c|c|c|}
\hline \multirow{3}{*}{$\frac{\text { Compound }}{\text { 2,4-Dimethylphenol }}$} & \multicolumn{6}{|c|}{ Soil Concentrations $(\mu \mathrm{g} / \mathrm{kg})$ at $0-6$ in. } \\
\hline & \multicolumn{2}{|c|}{ SQPS-1 } & \multicolumn{2}{|c|}{ SQPS-5 } & \multicolumn{2}{|c|}{ SQPS-8 } \\
\hline & 412 & $U$ & 407 & $\mathrm{U}$ & 686 & $\mathrm{U}$ \\
\hline Dimethylphthalate & 412 & $U$ & 407 & $\mathrm{U}$ & 686 & $\mathrm{U}$ \\
\hline 4,6-Dinitro-2-methylphenol & 1,040 & $\mathrm{U}$ & 1,020 & $U$ & 1,730 & $\mathrm{U}$ \\
\hline 2,4-Dinitrophenol & 1,040 & $\mathrm{U}$ & 1,020 & $U$ & 1,730 & $\mathrm{U}$ \\
\hline 2,4-Dinitrotoluene & 412 & $\mathrm{U}$ & 407 & $\mathrm{U}$ & 686 & $U$ \\
\hline 2,6-Dinitrotoluene & 412 & $\mathrm{U}$ & 407 & $\mathrm{U}$ & 686 & $\mathrm{U}$ \\
\hline Fluoranthene & 412 & $\mathrm{U}$ & 407 & $U$ & 686 & $\mathrm{U}$ \\
\hline Fluorene & 412 & $\mathrm{U}$ & 407 & $U$ & 686 & $U$ \\
\hline Hexachlorobenzene & 412 & $\mathrm{U}$ & 407 & $U$ & 686 & $U$ \\
\hline Hexachlorobutadiene & 412 & $\mathrm{U}$ & 407 & $U$ & 686 & $U$ \\
\hline Hexachlorocyclopentadiene & 412 & $\mathrm{U}$ & 407 & $U$ & 686 & UJ \\
\hline Hexachloroethane & 412 & $\mathrm{U}$ & 407 & $U$ & 686 & $\mathrm{U}$ \\
\hline Indeno[1,2,3-cd]pyrene & 412 & $U$ & 407 & $U$ & 686 & $U$ \\
\hline Isophorone & 412 & $U$ & 407 & $U$ & 686 & $\mathrm{U}$ \\
\hline 2-Methylnaphthalene & 412 & $U$ & 407 & $U$ & 686 & $U$ \\
\hline -2-Methylphenol & 412 & $U$ & 407 & $U$ & 686 & $\mathrm{U}$ \\
\hline 4-Methy!phenol & 412 & $U$ & 407 & $\mathrm{U}$ & 686 & $\mathrm{U}$ \\
\hline Naphthalene & 412 & $\mathrm{U}$ & 407 & $\mathrm{U}$ & 686 & $\mathrm{U}$ \\
\hline 2-Nitroaniline & 1,040 & $\mathrm{U}$ & 1,020 & $\mathbf{U}$ & 1,730 & $\mathrm{U}$ \\
\hline 3-Nitroaniline & 1,040 & $\mathrm{U}$ & 1,020 & U & 1,730 & $U$ \\
\hline 4-Nitroaniline & 1,040 & $\mathrm{U}$ & 1,020 & $\mathrm{U}$ & 1,730 & $\mathrm{U}$ \\
\hline Nitrobenzene & 412 & $\mathrm{U}$ & 407 & $\mathrm{U}$ & 686 & $\mathrm{U}$ \\
\hline 2-Nitrophenol & 412 & $\mathrm{U}$ & 407 & $\mathrm{U}$ & 686 & $\mathrm{U}$ \\
\hline 4-Nitrophenol & 1,040 & $U$ & 1,020 & $\mathrm{U}$ & 1,730 & $\mathrm{U}$ \\
\hline
\end{tabular}




\section{TABLE C.14d (Cont.)}

\begin{tabular}{|c|c|c|c|c|c|c|}
\hline \multirow{3}{*}{$\frac{\text { Compound }}{\text { N-Nitroso-di-n-propylamine }}$} & \multicolumn{6}{|c|}{ Soil Concentrations $(\mu \mathrm{g} / \mathrm{kg})$ at $0-6$ in. } \\
\hline & \multicolumn{2}{|c|}{ SQPS-1 } & \multicolumn{2}{|c|}{ SQPS-5 } & \multicolumn{2}{|c|}{ SQPS-8 } \\
\hline & 412 & $\mathrm{U}$ & 407 & $\mathrm{U}$ & 686 & $\mathrm{U}$ \\
\hline N-Nitrosodiphenylamine & 412 & $\mathrm{U}$ & 407 & $\mathrm{U}$ & 686 & $\mathrm{U}$ \\
\hline 2,2'-Oxybis-(1-chloropropane) & 412 & $U$ & 407 & $\mathrm{U}$ & 686 & $\mathrm{U}$ \\
\hline Pentachlorophenol & 1,040 & $\mathrm{U}$ & 1,020 & $\mathrm{U}$ & 1,730 & U \\
\hline Phenanthrene & 412 & $\mathrm{U}$ & 407 & $\mathrm{U}$ & 686 & $\mathrm{U}$ \\
\hline Phenol & 412 & $U$ & 407 & $\mathrm{U}$ & 686 & $U$ \\
\hline Pyrene & 412 & U & 407 & $\mathrm{U}$ & 686 & $U$ \\
\hline 1,2,4-Trichlorobenzene & 412 & $\mathrm{U}$ & 407 & $\mathrm{U}$ & 686 & U \\
\hline 2,4,5-Trichlorophenol & 1,040 & $\mathrm{U}$ & 1,020 & $\mathrm{U}$ & 1,730 & $\mathrm{U}$ \\
\hline 2,4,6-Trichlorophenol & 412 & U & 407 & $\mathrm{U}$ & 686 & $\mathrm{U}$ \\
\hline
\end{tabular}

a Sampled by ANL and analyzed by GP Environmental Services.

Data qualifiers:

$\mathrm{U}=$ analyte was analyzed for but not detected; detection limit given.

$\mathrm{J}=$ estimated value.

* = internal standard area counts were outside QC limits.

$B=$ analyte was found in the associated blank. 
TABLE C.15a Inorganic Analysis for Soil Borings, January $1993^{\mathrm{a}}$

\begin{tabular}{|c|c|c|c|c|c|c|c|c|c|c|c|c|c|c|c|c|}
\hline \multirow{3}{*}{$\begin{array}{c}\text { Analyte } \\
\text { Aluminum }\end{array}$} & \multicolumn{16}{|c|}{ Soil Concentrations (mg/kg) at Various Depths } \\
\hline & \multicolumn{2}{|c|}{$\begin{array}{c}\text { JBP1-E-2' } \\
(2 \mathrm{ft}) \\
\end{array}$} & \multicolumn{2}{|c|}{$\begin{array}{c}\text { JBP1-E-2'Dup } \\
(2 \mathrm{ft})\end{array}$} & \multicolumn{2}{|c|}{$\begin{array}{c}\text { JBP1-E-4' } \\
(4 \mathrm{ft})\end{array}$} & \multicolumn{2}{|c|}{$\begin{array}{c}\mathrm{JBP} 1-\mathrm{W}-2 \\
(2 \mathrm{ft}) \\
\end{array}$} & \multicolumn{2}{|c|}{$\begin{array}{c}\text { JBP1-W-4' } \\
(4 \mathrm{ft})\end{array}$} & \multicolumn{2}{|c|}{$\begin{array}{c}\text { JBP2-E-2' } \\
(2 \mathrm{ft}) \\
\end{array}$} & \multicolumn{2}{|c|}{$\begin{array}{c}\text { JBP2-E-4' } \\
(4 \mathrm{ft}) \\
\end{array}$} & \multicolumn{2}{|c|}{$\begin{array}{c}\text { JBP2-E-4'Dup } \\
(4 \mathrm{ft})\end{array}$} \\
\hline & 11,300 & & 6,870 & & 12,600 & & 14,000 & & 12,800 & & 10,900 & & 3,810 & & 6,480 & \\
\hline Antimony & 5.08 & & 4.57 & $\mathrm{U}$ & 4.7 & $U$ & 4.68 & $\mathrm{U}$ & 5.63 & & 4.6 & $\mathbf{U}$ & 4.59 & $\mathrm{U}$ & 4.57 & $U$ \\
\hline Arsenic & 5.02 & & 3.22 & & 4.18 & & 3.58 & & 2.01 & & 3.5 & & 1.32 & & 2.33 & \\
\hline Barium & 125 & & 45.3 & & 34.1 & & 47.5 & & 22.4 & & 32.7 & & 21.5 & & 29.5 & \\
\hline Beryllium & 0.31 & & 0.19 & $U$ & 0.45 & & 0.33 & & 0.28 & & 0.23 & & 0.19 & $\mathrm{U}$ & 0.38 & \\
\hline Cadmium & 3.21 & & 0.57 & $\mathrm{U}$ & 0.59 & $\mathrm{U}$ & 0.59 & $\mathrm{U}$ & 0.75 & & 0.58 & $\mathrm{U}$ & 0.57 & $\mathrm{U}$ & 0.57 & $U$ \\
\hline Calcium & 1,530 & & 5,670 & & 787 & & 529 & & 828 & & 987 & & 618 & & 3,640 & \\
\hline Chromium & 36.6 & & 11.6 & & 18.2 & & 16.5 & & 16.5 & & 14.2 & & 6.51 & & 12.7 & \\
\hline Cobalt & 5.64 & & 5.43 & $\mathrm{U}$ & 5.58 & $\mathbf{U}$ & 5.56 & $\mathrm{U}$ & 5.66 & $\mathrm{U}$ & 5.47 & $U$ & 5.45 & $\mathrm{U}$ & 5.43 & $\mathrm{U}$ \\
\hline Copper & 248 & & 34.1 & & 10.1 & & 19.9 & & 10.9 & & 6.85 & & 9.73 & & 10.1 & \\
\hline Iron & 35,800 & & 11,400 & & 23,100 & & 13,300 & & 20,400 & & 14,100 & & 4,900 & & 21,100 & \\
\hline Lead & 340 & & 36.4 & & 10.5 & & 13.2 & & 9.31 & & 15.9 & & 23.6 & & 96.3 & \\
\hline Magnesium & 2,340 & & 1,200 & & 1,940 & & 2,490 & & 1,610 & & 1,560 & & 572 & & 704 & \\
\hline Manganese & 197 & & 118 & & 72.6 & & 98.6 & & 47 & & 64.6 & & 21.5 & & .108 & \\
\hline Mercury & 0.12 & $\mathrm{U}$ & 0.12 & $\mathrm{U}$ & 0.12 & $\mathrm{U}$ & 0.12 & $U$ & 0.12 & $\mathrm{U}$ & 0.12 & $\mathrm{U}$ & 0.12 & $\mathrm{U}$ & 0.12 & $\mathrm{U}$ \\
\hline Nickel & 20.4 & & 9.34 & & 13.8 & & 15.4 & & 10 & & 8.19 & & 6.91 & $\mathbf{U}$ & 6.88 & $\mathbf{U}$ \\
\hline Potassium & 916 & & 530 & & 1,220 & & 1,460 & & 1,460 & & 971 & & 338 & & 482 & \\
\hline Selenium & 1.05 & $U$ & 1.02 & $\mathrm{U}$ & 1.05 & $\mathrm{U}$ & 1.05 & $\mathrm{U}$ & 1.07 & $\mathrm{U}$ & 1.03 & $U$ & 1.03 & $\mathrm{U}$ & 1.02 & $\mathrm{U}$ \\
\hline Silver & 1.63 & & 0.17 & $\mathrm{U}$ & 0.17 & $\mathrm{U}$ & 0.56 & & 0.17 & $\mathrm{U}$ & 0.17 & $U$ & 0.17 & $\mathrm{U}$ & 0.17 & $\mathrm{U}$ \\
\hline Sodium & 46.5 & $\mathrm{U}$ & 45.2 & $U$ & 46.5 & $\mathrm{U}$ & 46.3 & $\mathrm{U}$ & 47.2 & $\mathbf{U}$ & 333 & & 45.4 & $U$ & 86.5 & \\
\hline Thallium & 0.56 & $\mathrm{U}$ & 0.54 & $U$ & 0.56 & $\mathrm{U}$ & 0.56 & $\mathrm{U}$ & 0.57 & $U$ & 0.55 & $\mathrm{U}$ & 0.55 & $\mathrm{U}$ & 0.55 & $\mathrm{U}$ \\
\hline Vanadium & 19.8 & & 12.8 & & 23.4 & & 22.1 & & 25.1 & & 19.2 & & 7.57 & & 18.9 & \\
\hline Zinc & 1,220 & & 182 & & 123 & & 303 & & 52.1 & & 94.4 & & 76.5 & & 72 & \\
\hline
\end{tabular}


TABLE C.15a (Cont.)

\begin{tabular}{|c|c|c|c|c|c|c|c|c|c|c|c|c|c|c|c|c|}
\hline \multirow{3}{*}{$\begin{array}{l}\text { Analyte } \\
\text { Aluminum }\end{array}$} & \multicolumn{16}{|c|}{ Soil Concentrations (mg/kg) at Various Depths } \\
\hline & \multicolumn{2}{|c|}{$\begin{array}{l}\mathrm{JBP} 2-\mathrm{C}-2^{\prime} \\
(2 \mathrm{ft}) \\
\end{array}$} & \multicolumn{2}{|c|}{$\begin{array}{c}\text { JBP2-C-4' } \\
(4 \mathrm{ft})\end{array}$} & \multicolumn{2}{|c|}{$\begin{array}{c}\text { JBP2-W-2 } \\
(2 \mathrm{ft}) \\
\end{array}$} & \multicolumn{2}{|c|}{$\begin{array}{c}\text { JBP2-W-4' } \\
(4 \mathrm{ft}) \\
\end{array}$} & \multicolumn{2}{|c|}{$\begin{array}{c}\text { JHDP-C-4' } \\
(4 \mathrm{ft})\end{array}$} & \multicolumn{2}{|c|}{$\begin{array}{c}\text { JHDP-C-6 } \\
(6 \mathrm{ft})\end{array}$} & \multicolumn{2}{|c|}{$\begin{array}{c}\text { JHDP-C-6'Dup } \\
(6 \mathrm{ft})\end{array}$} & \multicolumn{2}{|c|}{$\begin{array}{c}\text { JVXP-C-4' } \\
(4 \mathrm{ft})\end{array}$} \\
\hline & 4,980 & & 5,190 & & 6,000 & & 8,800 & & 8,020 & & 8,200 & & 5,620 & & 4,130 & \\
\hline Antimony & 5.29 & $\mathrm{U}$ & 4.57 & $\mathbf{U}$ & 4.62 & $\mathrm{U}$ & 4.58 & $\mathrm{U}$ & 4.6 & $\mathrm{U}$ & 4.67 & & 4.3 & U & 5.06 & $\mathbf{U}$ \\
\hline Arsenic & 7.91 & & 6.9 & & 26.6 & & 3.98 & & 3.94 & & 6.29 & & 3.6 & & 1.19 & \\
\hline Barium & 121 & & 91.8 & & 87.8 & & 28.8 & & 32.3 & & 504 & & 32.4 & & 22 & \\
\hline Beryllium & 0.24 & & 0.19 & $U$ & 0.19 & & 0.19 & $\mathrm{U}$ & 0.46 & & 0.29 & & 0.41 & & 0.21 & $\mathrm{U}$ \\
\hline Cadmium & 6.97 & & 0.57 & U & 0.58 & U & 0.57 & U & 0.57 & $\mathrm{U}$ & 7.23 & & 1 & & 0.63 & $\mathrm{U}$ \\
\hline Calcium & 2,660 & & 803 & & 535 & & 222 & & 1,540 & & 2,190 & & 1,310 & & 334 & \\
\hline Chromium & 7.35 & & 8.42 & & 11 & & 13.4 & & 11.9 & & 44.1 & & 13.8 & & 5.33 & \\
\hline Cobalt & 6.28 & $\mathrm{U}$ & 5.42 & $\mathrm{U}$ & 5.49 & $\mathrm{U}$ & 5.44 & $\mathrm{U}$ & 5.46 & $\mathrm{U}$ & 5.55 & $\mathrm{U}$ & 5.1 & U & 6.01 & \\
\hline Copper & 413 & & 42.7 & & 17.5 & & 17.9 & & 4.12 & $\mathrm{U}$ & 123 & & 18.9 & & 4.53 & $\mathrm{U}$ \\
\hline Iron & 10,700 & & 8,860 & & 10,400 & & 12,200 & & 10,400 & & 42,100 & & 17,400 & & 5,700 & \\
\hline Lead & 403 & & 37.8 & & 37.6 & & 8.54 & & 10.5 & & 121 & & 25.4 & & 10.5 & \\
\hline Magnesium & 805 & & 903 & & 1,150 & & 1,830 & & 913 & & 3,900 & & 696 & & 1,100 & \\
\hline Manganese & 70 & & 52.1 & & 46.5 & & 57.2 & & 31.4 & & 157 & & 23.7 & & 45.8 & \\
\hline Mercury & 0.14 & $\mathrm{U}$ & 0.12 & $\mathrm{U}$ & 0.12 & $U$ & 0.12 & $\mathrm{U}$ & 0.1 & $U$ & 0.11 & & 0.11 & & 0.1 & $U$ \\
\hline Nickel & 9.91 & & 6.87 & $\mathrm{U}$ & 8.04 & & 10.3 & & 6.92 & $\mathrm{U}$ & 31.8 & & 6.46 & $\mathrm{U}$ & $\cdot 7.62$ & $U$ \\
\hline Potassium & 501 & & 529 & & 730 & & 1,160 & & 432 & & 260 & & 568 & & 669 & \\
\hline Selenium & 1.18 & $\mathrm{U}$ & 1.02 & $\mathrm{U}$ & 1.03 & $\mathrm{U}$ & 1.02 & $\mathrm{U}$ & 1.03 & $U$ & 1.05 & $\mathrm{U}$ & 0.96 & $\mathrm{U}$ & 1.13 & $\mathrm{U}$ \\
\hline Silver & 0.19 & $\mathrm{U}$ & 0.17 & $U$ & 0.17 & $\mathrm{U}$ & 0.17 & $\mathrm{U}$ & 0.17 & $U$ & 0.17 & $\mathrm{U}$ & 0.16 & $\mathrm{U}$ & 0.18 & $\mathrm{U}$ \\
\hline Sodium & 52.3 & $U$ & 45.2 & U & 45.7 & $U$ & 45.3 & $\mathrm{U}$ & 51.2 & & 73 & & 42.5 & $\mathrm{U}$ & 50.1 & $\mathrm{U}$ \\
\hline Thallium & 0.63 & $\mathrm{U}$ & 0.55 & $\mathrm{U}$ & 0.55 & $U$ & 0.55 & $\mathbf{U}$ & 0.55 & $\mathrm{U}$ & 0.56 & $\mathrm{U}$ & 0.52 & $\mathrm{U}$ & 0.61 & $\mathrm{U}$ \\
\hline Vanadium & 7.72 & & 11.1 & & 12.5 & & 19.6 & & 16 & & 14.2 & & 15.2 & & 5.95 & \\
\hline Zinc & 17,800 & & 834 & & 516 & & 167 & & 25.1 & & 296 & & 49.1 & & 33.8 & \\
\hline
\end{tabular}


TABLE C.15a (Cont.)

\begin{tabular}{|c|c|c|c|c|c|c|c|c|c|c|c|c|c|c|c|c|}
\hline \multirow[b]{2}{*}{ Analyte } & \multicolumn{16}{|c|}{ Soil Concentrations (mg $/ \mathrm{kg}$ ) at Various Depths } \\
\hline & \multicolumn{2}{|c|}{$\begin{array}{l}\text { JVXP-C-6 } \\
(6 \mathrm{ft})\end{array}$} & \multicolumn{2}{|c|}{$\begin{array}{c}\text { JSDP-C-4' } \\
(4 \mathrm{ft})\end{array}$} & \multicolumn{2}{|c|}{$\begin{array}{c}\text { JSDP-C-6' } \\
(6 \mathrm{ft}) \\
\end{array}$} & \multicolumn{2}{|c|}{$\begin{array}{c}\text { JBPM-A-3" } \\
(3 \text { in. }) \\
\end{array}$} & \multicolumn{2}{|c|}{$\begin{array}{c}\text { JBPM-A-3"Dup } \\
\text { (3 in.) }\end{array}$} & \multicolumn{2}{|c|}{$\begin{array}{c}\text { JBPM-A-1' } \\
(1 \mathrm{ft})\end{array}$} & \multicolumn{2}{|c|}{$\begin{array}{c}\text { JBPM-B-3" } \\
(3 \text { in. })\end{array}$} & \multicolumn{2}{|c|}{$\begin{array}{c}\text { JBPM-B-1 } \\
(1 \mathrm{ft})\end{array}$} \\
\hline Aluminum & 2,230 & & 4,700 & & 4,120 & & 8,480 & & 7,860 & & 8,320 & & 8,680 & & 11,900 & \\
\hline Antimony & 5.41 & $\mathrm{U}$ & 5.12 & $\mathrm{U}$ & 5.03 & $\mathrm{U}$ & 4.58 & $\mathrm{U}$ & 4.55 & $\mathrm{U}$ & 4.57 & $\mathrm{U}$ & 13.7 & & 4.49 & $\mathrm{U}$ \\
\hline Arsenic & 1.04 & $\mathrm{U}$ & 1.38 & & 0.97 & $\mathrm{U}$ & 3.95 & & 4.8 & & 22.5 & & 7.49 & & 3.58 & \\
\hline Barium & 8.1 & & 15.5 & & 12.7 & & 403 & & 158 & & 216 & & 336 & & 42.8 & \\
\hline Beryllium & 0.23 & $\mathbf{U}$ & 2.14 & $\mathrm{U}$ & 0.21 & $U$ & 0.43 & & 0.30 & & 0.26 & & 0.34 & & 0.40 & \\
\hline Cadmium & 0.68 & $\mathbf{U}$ & 0.64 & $\mathrm{U}$ & 0.63 & $U$ & 2.95 & & 2.37 & & 6.05 & & 5.94 & & 0.56 & U \\
\hline Calcium & 178 & & 240 & & 269 & & 1,170 & & 1,150 & & 1,930 & & 1,710 & & 228 & \\
\hline Chromium & 3.15 & & 4.09 & & 5.54 & & 37.8 & & 34.9 & & 67.9 & & 53.4 & & 15.6 & \\
\hline Cobalt & 6.42 & & 6.09 & $\mathrm{U}$ & 5.98 & $\mathrm{U}$ & 5.44 & $\mathrm{U}$ & 5.41 & $\mathrm{U}$ & 5.42 & $U$ & 6.41 & & 5.33 & $U$ \\
\hline Copper & 4.84 & $\mathrm{U}$ & 4.59 & $U$ & 4.51 & $\mathrm{U}$ & 305 & 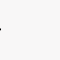 & 209 & & 392 & & 521 & & 4.77 & \\
\hline Iron & 3,170 & & 5,970 & & 5,090 & & 13,400 & & 12,600 & & 21,000 & & 28,300 & & 20,500 & \\
\hline Lead & 2.6 & & 3.37 & & 8.22 & & 145 & & 129 & & 542 & & 79,800 & & 11.2 & \\
\hline Magnesium & 551 & & 1,010 & & 944 & & 1,470 & & 1,170 & & 1,350 & & 4,460 & & 1,550 & \\
\hline Manganese & 25.6 & & 48.1 & & 38.4 & & 142 & & 138 & & 163 & & 209 & & 86.6 & \\
\hline Mercury & 0.1 & $\mathrm{U}$ & 0.1 & $U$ & 0.1 & $\mathrm{U}$ & 0.13 & & 0.22 & & 0.95 & & 0.22 & & 0.1 & U \\
\hline Nickel & 8.14 & $\mathrm{U}$ & 7.72 & $\mathrm{U}$ & 7.58 & $\dot{U}$ & 8.19 & & 6.86 & $\mathrm{U}$ & 12.5 & & 24.2 & & 7.26 & \\
\hline Potassium & 405 & & 383 & & 376 & & 431 & & 384 & & 429 & & 243 & & 508 & \\
\hline Selenium & 1.21 & $U$ & 1.15 & $\mathrm{U}$ & 1.13 & $\mathrm{U}$ & 1.03 & $U$ & 1.02 & $\mathrm{U}$ & 1.02 & U & 1.98 & & 1.01 & $\mathrm{U}$ \\
\hline Silver & 0.20 & $\mathrm{U}$ & 0.19 & $\mathrm{U}$ & 0.18 & $U$ & 2.91 & & 1.87 & & 1.81 & & 1.49 & & 0.16 & $\mathrm{U}$ \\
\hline Sodium & 53.5 & . & 50.7 & $\mathrm{U}$ & 49.8 & $\mathrm{U}$ & 51 & & 91.7 & & 91.9 & & 206 & & 50 & \\
\hline Thallium & 0.65 & $\mathrm{U}$ & 0.61 & U & 0.60 & $U$ & 0.55 & $\mathrm{U}$ & 0.55 & $\mathrm{U}$ & 0.55 & $\mathrm{U}$ & 0.52 & $U$ & 0.54 & U \\
\hline Vanadium & 6 & $U$ & 6.74 & & 5.58 & $\mathrm{U}$ & 15.1 & & 15.8 & & 13.8 & & 10.4 & & 26.3 & \\
\hline Zinc & 13.1 & & 13.5 & & 12.8 & & 237 & & 690 & & 678 & & 1,000 & & 46.9 & \\
\hline
\end{tabular}


TABLE C.15a (Cont.)

\begin{tabular}{|c|c|c|c|c|c|c|c|c|c|c|c|c|c|c|c|c|}
\hline \multirow[b]{2}{*}{ Analyte } & \multicolumn{16}{|c|}{ Soil Concentrations (mg/kg) at Various Depths } \\
\hline & \multicolumn{2}{|c|}{$\begin{array}{c}\text { JBPM-C-3" } \\
\text { (3 in.) }\end{array}$} & \multicolumn{2}{|c|}{$\begin{array}{c}\text { JBPM-C-1' } \\
(1 \mathrm{ft})\end{array}$} & \multicolumn{2}{|c|}{$\begin{array}{c}\text { JBPP-A-3" } \\
\text { (3 in.) }\end{array}$} & \multicolumn{2}{|c|}{$\begin{array}{c}\text { JBPP-A-1' } \\
(1 \mathrm{ft})\end{array}$} & \multicolumn{2}{|c|}{$\begin{array}{c}\text { JBPP-B-3" } \\
\text { (3 in.) }\end{array}$} & \multicolumn{2}{|c|}{$\begin{array}{c}\text { JBPP-B-1' } \\
(1 \mathrm{ft})\end{array}$} & \multicolumn{2}{|c|}{$\begin{array}{c}\text { JBPP-C-3" } \\
(3 \text { in. })\end{array}$} & \multicolumn{2}{|c|}{$\begin{array}{c}\text { JBPP-C-1' } \\
(1 \mathrm{ft})\end{array}$} \\
\hline Aluminum & 10,400 & & 5,100 & & 5,670 & & 7,320 & & 6,720 & & 5,860 & & 5,910 & & 10,500 & \\
\hline Antimony & 4.88 & $\mathrm{U}$ & 4.4 & $U$ & 4.5 & U & 4.55 & U & 67.3 & & 44.2 & & 4.57 & $U$ & 4.57 & $\mathbf{U}$ \\
\hline Arsenic & 12.3 & & 2.32 & & 1.76 & & 2.32 & & 16.7 & & 109 & & 2.56 & & 1.88 & \\
\hline Barium & 2,400 & & 150 & & 107 & & 31.5 & & 534 & & 300 & & 53.2 & & 32.4 & \\
\hline Beryllium & 0.20 & $\mathrm{U}$ & 0.30 & & 0.21 & & 0.19 & $\mathrm{U}$ & 0.22 & $\mathrm{U}$ & 0.19 & $\mathrm{U}$ & 0.21 & & 0.26 & \\
\hline Cadmium & 2.43 & & 0.55 & $\mathrm{U}$ & 0.56 & $U$ & 0.57 & $U$ & 11.4 & & 9.57 & & 0.99 & & 0.57 & U \\
\hline Calcium & 1,240 & & 155 & & 445 & & 526 & & 27,900 & & 1,390 & & 420 & & 701 & \\
\hline Chromium & 89.6 & & 7.47 & & 17 & & 10.3 & & 223 & & 103 & & 11.3 & & 14.3 & \\
\hline Cobalt & 5.79 & $\mathrm{U}$ & 5.22 & $\mathrm{U}$ & 5.34 & $U$ & 5.41 & $\mathrm{U}$ & 11.1 & & 108 & & 5.43 & $U$ & 5.43 & U \\
\hline Copper & 365 & & 21 & & 60.5 & & 4.08 & $\mathrm{U}$ & 908 & & 662 & & 33.2 & & 8.39 & \\
\hline Iron & 18,600 & & 7,470 & & 11,300 & & 11,900 & & 24,900 & & 47,100 & & 9,790 & & 17,400 & \\
\hline Lead & 290 & & 6.05 & & 105 & & 8.37 & & 1,180 & & 1,110 & & 28 & & 9 & \\
\hline Magnesium & 22,400 & & 3,020 & & 874 & & 999 & & 13,500 & & 2,220 & & 984 & & 1,380 & \\
\hline Manganese & 229 & & 73.3 & & 75.6 & & 61.7 & & 270 & & 240 & & 85.8 & & 83 & \\
\hline Mercury & 0.1 & $\mathbf{U}$ & 0.1 & $\mathrm{U}$ & 0.12 & $\mathrm{U}$ & 0.12 & $\mathrm{U}$ & 0.42 & & 3.6 & & 0.12 & $\mathrm{U}$ & 0.12 & $\mathbf{U}$ \\
\hline Nickel & 20.9 & & 6.62 & $\mathrm{U}$ & 6.77 & $\mathrm{U}$ & 6.86 & $U$ & 103 & & 43.3 & & 7 & & 7.53 & \\
\hline Potassium & 271 & & 329 & & 331 & & 384 & & 668 & & 381 & & 337 & & 554 & \\
\hline Selenium & 1.09 & $\mathrm{U}$ & 0.99 & $\mathrm{U}$ & 1.01 & $\mathrm{U}$ & 1.02 & $\mathrm{U}$ & 1.18 & $U$ & 7.12 & & 1.02 & $\mathrm{U}$ & 1.0 & U \\
\hline Silver & 0.45 & & 0.16 & $\mathrm{U}$ & 0.26 & & 0.17 & $\mathrm{U}$ & 8.53 & & 5.84 & & 0.19 & & 0.17 & U \\
\hline Sodium & 54.3 & & 43.5 & $\mathrm{U}$ & 44.5 & $U$ & 45 & $\mathbf{U}$ & 176 & & 44.8 & $\mathrm{U}$ & 45.2 & $U$ & 45.2 & $U$ \\
\hline Thallium & 0.58 & $\mathbf{U}$ & 0.53 & $\mathrm{U}$ & 0.54 & $\mathrm{U}$ & 0.55 & $\mathbf{U}$ & 0.63 & $\mathrm{U}$ & 0.54 & $\mathrm{U}$ & 0.55 & $\mathrm{U}$ & 0.55 & U \\
\hline
\end{tabular}


TABLE C.15a (Cont.)

\begin{tabular}{|c|c|c|c|c|c|c|c|c|}
\hline \multirow[b]{2}{*}{ Analyte } & \multicolumn{8}{|c|}{ Soil Concentrations $(\mathrm{mg} / \mathrm{kg})$ at Various Depths } \\
\hline & $\begin{array}{c}\text { JBPM-C-3" } \\
\text { (3 in.) }\end{array}$ & $\begin{array}{c}\text { JBPM-C-1' } \\
(1 \mathrm{ft})\end{array}$ & $\begin{array}{c}\text { JBPP-A-3" } \\
(3 \text { in.) }\end{array}$ & $\begin{array}{c}\text { JBPP-A-1' } \\
(1 \mathrm{ft})\end{array}$ & $\begin{array}{c}\text { JBPP-B-3" } \\
(3 \text { in.) }\end{array}$ & $\begin{array}{c}\text { JBPP-B-1' } \\
(1 \mathrm{ft})\end{array}$ & $\begin{array}{l}\text { JBPP-C-3" } \\
(3 \text { in.) }\end{array}$ & $\begin{array}{c}\text { JBPP-C-1 } \\
(1 \mathrm{ft})\end{array}$ \\
\hline Vanadium & 11.3 & 10.6 & 12.6 & 15 & 25.2 & 12.3 & 12 & 23.4 \\
\hline Zinc & 252 & 27 & 84.1 & 20.2 & 1,640 & 5,820 & 82.8 & 20.5 \\
\hline
\end{tabular}

a Sampled by Weston, analyzed by GP Environmental Services; provisional data.

Data qualifier:

$\mathbf{U}=$ analyte was analyzed for but not detected; detection limit given. 
TABLE C.15b Inorganic Analyses for Soil Borings, January $1994^{\mathrm{a}}$

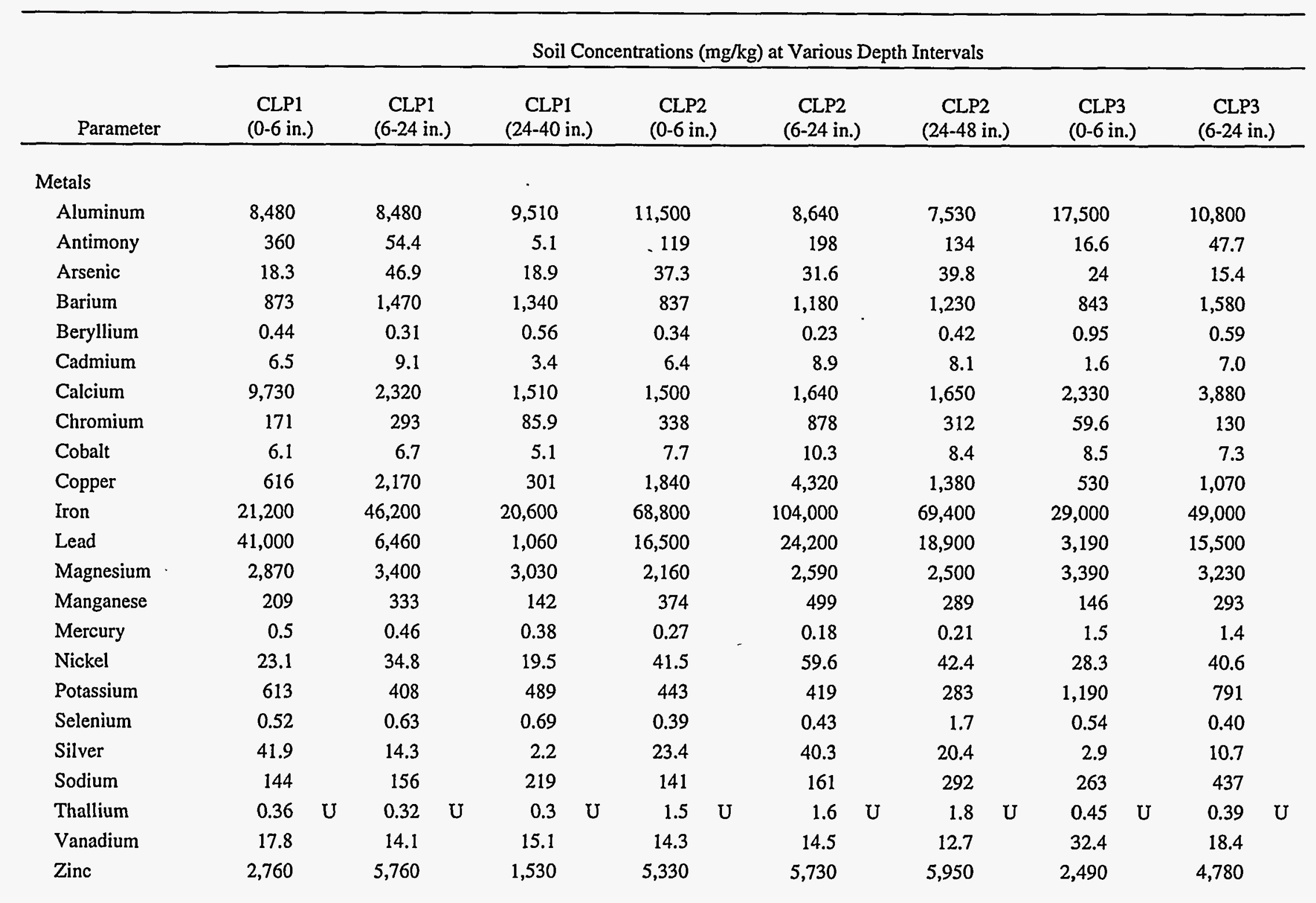


TABLE C.15b (Cont.)

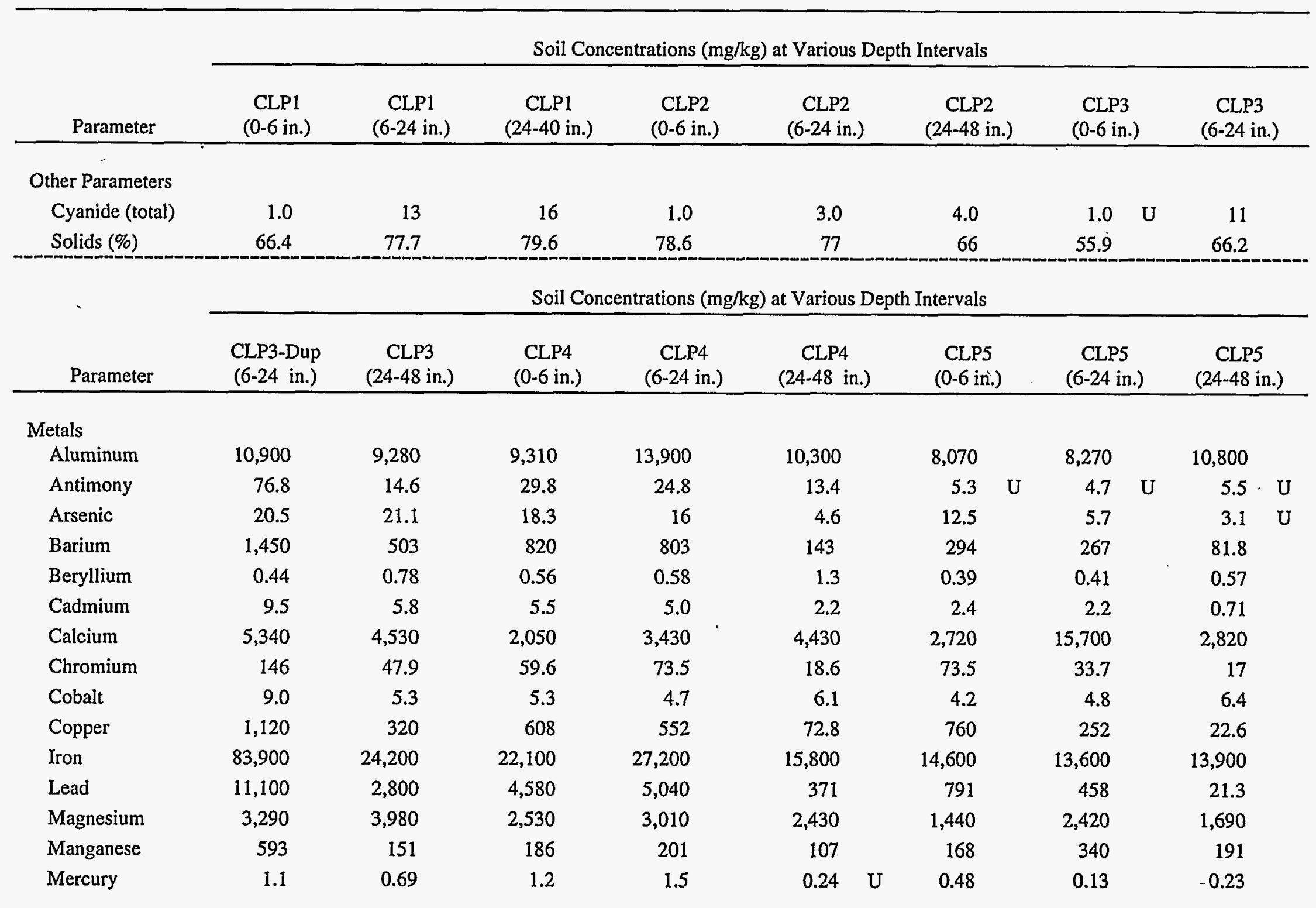




\begin{tabular}{|c|c|c|c|c|c|c|c|c|c|c|c|c|c|c|c|c|}
\hline \multirow{3}{*}{$\begin{array}{l}\text { Parameter } \\
\text { Nickel }\end{array}$} & \multicolumn{16}{|c|}{ Soil Concentrations $(\mathrm{mg} / \mathrm{kg})$ at Various Depth Intervals } \\
\hline & \multicolumn{2}{|c|}{$\begin{array}{l}\text { CLP3-Dup } \\
\text { (6-24 in.) }\end{array}$} & \multicolumn{2}{|c|}{$\begin{array}{c}\text { CLP3 } \\
\text { (24-48 in.) }\end{array}$} & \multicolumn{2}{|c|}{$\begin{array}{c}\text { CLP4 } \\
\text { (0-6 in.) }\end{array}$} & \multicolumn{2}{|c|}{$\begin{array}{c}\text { CLP4 } \\
(6-24 \text { in. })\end{array}$} & \multicolumn{2}{|c|}{$\begin{array}{c}\text { CLP4 } \\
\text { (24-48 in.) }\end{array}$} & \multicolumn{2}{|c|}{$\begin{array}{c}\text { CLP5 } \\
\text { (0-6 in.) }\end{array}$} & \multicolumn{2}{|c|}{$\begin{array}{c}\text { CLP5 } \\
\text { (6-24 in.) }\end{array}$} & \multicolumn{2}{|c|}{$\begin{array}{c}\text { CLP5 } \\
\text { (24-48 in.) }\end{array}$} \\
\hline & 45 & & 18.8 & & 23.8 & & 26.2 & & 13.3 & & 12.2 & & 13 & $\mathrm{U}$ & 10.2 & \\
\hline Potassium & 675 & & 1,190 & & 617 & & 662 & & 952 & & 506 & & 339 & & 557 & \\
\hline Selenium & 0.36 & & 0.73 & $\mathrm{U}$ & 0.35 & $\mathrm{U}$ & 0.33 & $\mathbf{U}$ & 0.66 & $\mathrm{U}$ & 0.42 & & 0.38 & & 0.5 & \\
\hline Silver & 12.5 & & 3.1 & & 4.6 & & 3.5 & & 3.1 & & 3.7 & & 1.3 & & 0.66 & \\
\hline Sodium & 521 & & 1,400 & & 189 & & 284 & & 537 & & 88.7 & & 158 & & 125 & \\
\hline Thallium & 1.9 & $\mathrm{U}$ & 0.85 & $\mathrm{U}$ & 2.0 & $\mathrm{U}$ & 1.9 & $U$ & 0.76 & $\mathrm{U}$ & 0.31 & $U$ & 0.29 & $\mathrm{U}$ & 0.33 & $U$ \\
\hline Vanadium & 15.7 & & 13.6 & & 14.8 & & 15 & & 15.2 & & 13.8 & & 13.6 & & 18.1 & \\
\hline Zinc & 6,690 & & 2,960 & & 2,880 & & 2,940 & & 1,400 & & 732 & & 845 & & 114 & \\
\hline \multicolumn{17}{|l|}{ Other Parameter } \\
\hline Cyanide (mg/kg) & 120 & & 16 & & 0.8 & $\mathrm{U}$ & 1.0 & & 2.0 & U & 0.8 & $\mathrm{U}$ & 0.7 & $\mathrm{U}$ & 0.8 & $\mathrm{U}$ \\
\hline Solids (\%) & 34.4 & & 67.3 & & 68.8 & & 74.8 & & 38.3 & & 78.6 & & 83.8 & & 74.3 & \\
\hline & \multicolumn{15}{|c|}{ Soil Concentrations (mg/kg) at Various Depth Intervals } & \\
\hline Parameter & $\begin{array}{l}\text { CLP5-Du } \\
\text { (24-48 in. }\end{array}$ & & $\begin{array}{r}\text { CLP6 } \\
\text { (0-6 in. } \\
\end{array}$ & & $\begin{array}{r}\text { CLP6 } \\
(6-24 \text { in } \\
\end{array}$ & & $\begin{array}{r}\text { CLP7 } \\
(0-6 \text { in. }\end{array}$ & & $\begin{array}{c}\text { CLP7 } \\
(6-24 \text { in. }) \\
\end{array}$ & & $\begin{array}{r}\text { CLP } \\
(24-48 \\
\end{array}$ & & $\begin{array}{r}\text { CLPE } \\
(0-6 \text { in } \\
\end{array}$ & & $\begin{array}{c}\text { CLP9 } \\
\text { (0-6 in.) }\end{array}$ & \\
\hline \multicolumn{17}{|l|}{ Metals } \\
\hline Aluminum & 8,820 & & 7,990 & & 8,640 & & 17,000 & & 7,030 & & 8,930 & & 5,080 & & 6,780 & \\
\hline Antimony & 5.0 & $\mathbf{U}$ & 20.2 & & 38.6 & & 6.3 & $U$ & 5.3 & $U$ & 5.2 & U & 501 & & 19.5 & \\
\hline Arsenic & 2.2 & & 39.8 & & 22.9 & & 12.3 & & 4.5 & & 6.2 & & 41 & & 17.1 & \\
\hline Barium & 62.1 & & 756 & & 828 & & 157 & & 87.7 & & 245 & & 1,560 & & 498 & \\
\hline Beryllium & 0.62 & & 0.54 & & 0.42 & & 0.98 & & 0.55 & & 0.52 & & 0.45 & & 0.31 & \\
\hline Cadmium & 0.78 & & 2.5 & & 6.2 & & 1.4 & & 0.9 & & 0.67 & $\mathrm{U}$ & 2.1 & & 4.5 & \\
\hline
\end{tabular}


TABLE C.15b (Cont.)

\begin{tabular}{|c|c|c|c|c|c|c|c|c|c|c|c|c|c|c|c|c|}
\hline \multirow[b]{2}{*}{ Parameter } & \multicolumn{16}{|c|}{ Soil Concentrations (mg/kg) at Various Depth Intervals } \\
\hline & \multicolumn{2}{|c|}{$\begin{array}{l}\text { CLP5-Dup } \\
\text { (24-48 in.) }\end{array}$} & \multicolumn{2}{|c|}{$\begin{array}{c}\text { CLP6 } \\
\text { (0-6 in.) }\end{array}$} & \multicolumn{2}{|c|}{$\begin{array}{c}\text { CLP6 } \\
\text { (6-24 in.) }\end{array}$} & \multicolumn{2}{|c|}{$\begin{array}{c}\text { CLP7 } \\
(0-6 \text { in.) }\end{array}$} & \multicolumn{2}{|c|}{$\begin{array}{c}\text { CLP7 } \\
(6-24 \text { in. })\end{array}$} & \multicolumn{2}{|c|}{$\begin{array}{c}\text { CLP7 } \\
(24-48 \text { in.) } \\
\end{array}$} & \multicolumn{2}{|c|}{$\begin{array}{c}\text { CLP8 } \\
(0-6 \text { in. })\end{array}$} & \multicolumn{2}{|l|}{$\begin{array}{c}\text { CLP9 } \\
(0-6 \text { in. })\end{array}$} \\
\hline Calcium & 2,140 & & 3,520 & & 2,800 & & 3,950 & & 4,080 & & 11,100 & & 386 & & 1,090 & \\
\hline Chromium & 10.8 & & 65.2 & & 79.3 & & 28.6 & & 11.8 & & 14.4 & & 118 & & 82.5 & \\
\hline Cobalt & 6.6 & & 6.1 & & 9.0 & & 9.1 & & 4.2 & & 4.8 & & 5.6 & & 3.8 & \\
\hline Copper & 15.3 & & 439 & & 559 & & 61.5 & & 28.6 & & 26.4 & & 1,040 & & 449 & \\
\hline Iron & 9,830 & & 28,600 & & 60,900 & & 22,700 & & 8,370 & & 11,100 & & 90,800 & & 16,500 & \\
\hline Lead & 23.1 & & 2,440 & & 5,340 & & 163 & & 135 & & 107 & & 94,200 & & 2,050 & \\
\hline Magnesium & 1,500 & & 2,170 & & 2,350 & & 2,560 & & 1,090 & & 1,400 & & 7.65 & & 3,880 & \\
\hline Manganese & 99.7 & & 316 & & 393 & & 340 & & 172 & & 216 & & 134 & & 156 & \\
\hline Mercury & 0.13 & & 0.79 & & 0.46 & & 0.2 & & 0.11 & $\mathbf{U}$ & 0.13 & $U$ & 0.6 & & 0.22 & \\
\hline Nickel & 9.4 & & 20.4 & & 38.2 & & 17.2 & & 8.4 & & 9.5 & & 24.8 & & 17.9 & \\
\hline Potassium & 417 & & 507 & & 606 & & 870 & & 384 & & 505 & & 1,130 & & 308 & \\
\hline Selenium & 0.44 & & 0.43 & & 0.62 & & 0.42 & & 0.43 & & 0.36 & & 2.8 & & 0.5 & \\
\hline Silver & 0.6 & $U$ & 5.1 & & 6.7 & & 0.75 & $\mathrm{U}$ & 0.63 & $U$ & 0.62 & $U$ & 12.7 & & 2.0 & \\
\hline Sodium & 102 & & 156 & & 250 & & 101 & & 81.9 & & 133 & & 504 & & 78.3 & \\
\hline Thallium & 0.33 & $U$ & 0.32 & $\mathrm{U}$ & 0.32 & $\mathrm{U}$ & 0.38 & $\mathrm{U}$ & 0.31 & $\mathrm{U}$ & 0.33 & $\mathrm{U}$ & 3.8 & $\mathrm{U}$ & 0.29 & $\mathrm{U}$ \\
\hline Vanadium & 13.3 & & 16.9 & & 20.1 & & 32.7 & & 12.2 & & 16.5 & & 20.2 & & 11.7 & \\
\hline Zinc & 87.9 & & 3,720 & & 4,450 & & 176 & & 92.2 & & 103 & & 1,420 & & 1,250 & \\
\hline \multicolumn{17}{|l|}{ Other Parameters } \\
\hline Cyanide (total) & 0.8 & $\mathrm{U}$ & 0.8 & $\mathrm{U}$ & 0.8 & U & 0.9 & $U$ & 0.8 & $U$ & 0.8 & $\mathrm{U}$ & 5.0 & & 0.7 & $\mathrm{U}$ \\
\hline Solids (\%) & 75.3 & & 75.3 & & 78.5 & & 64.2 & & 78.1 & & & & 32.5 & & 81.1 & \\
\hline
\end{tabular}

a Sampled by ANL, analyzed by Weston Gulf Coast, CLP TAL metals and other inorganic parameters.

Data qualifier:

$\mathrm{U}=$ analyte was analyzed for but not detected; detection limit given. 
TABLE C.15c Inorganic Analyses for Soil Borings, 1994-1995 ${ }^{2}$

\begin{tabular}{|c|c|c|c|c|c|c|c|c|c|c|c|c|}
\hline \multirow[b]{2}{*}{ Parameter } & \multicolumn{12}{|c|}{ Soil Concentrations (mg/kg) at Various Depth Intervals } \\
\hline & \multicolumn{2}{|c|}{$\begin{array}{c}\text { TBSPBOR1 } \\
(0-2 \mathrm{ft})\end{array}$} & $\begin{array}{c}\text { TBSPBOR1 Dup } \\
(0-2 \mathrm{ft})\end{array}$ & $\begin{array}{c}\text { TBSPBOR1 } \\
(2-4 \mathrm{ft})\end{array}$ & \multicolumn{2}{|c|}{$\begin{array}{c}\text { TBSPBOR1 } \\
(4-6 \mathrm{ft})\end{array}$} & \multicolumn{2}{|c|}{$\begin{array}{c}\text { TBSPBOR1 } \\
(6-8 \mathrm{ft})\end{array}$} & \multicolumn{2}{|c|}{$\begin{array}{c}\text { TBSPBOR1 } \\
(8-10 \mathrm{ft})\end{array}$} & \multicolumn{2}{|c|}{$\begin{array}{c}\text { TBSPBOR1 } \\
(10-12 \mathrm{ft})\end{array}$} \\
\hline Aluminum & 10,900 & & 9,940 & 13,300 & 13,300 & & 13,100 & & 11,400 & & 8,520 & \\
\hline Antimony & 6.2 & $\mathrm{~N}$ & 6.0 & $2.9 \cdot \mathrm{UN}$ & 4.6 & $\mathrm{~N}$ & 2.8 & UN & 2.9 & UN & 2.8 & UN \\
\hline Arsenic & 28.2 & & 20.2 & 9.7 & 8.9 & & 6.5 & & 6.8 & & 3.0 & \\
\hline Barium & 212 & & 283 & 124 & 147 & & 143 & & 53.5 & & 42.3 & \\
\hline Beryllium & 0.43 & & 0.38 & 0.54 & 0.5 & & 0.52 & & 0.4 & & 0.32 & \\
\hline Cadmium & 2.1 & & 3.0 & 3.2 & 1.0 & & 1.5 & & 0.79 & & 0.57 & \\
\hline Calcium & 2,130 & & 3,900 & 1,580 & 2,250 & & 1,790 & & 2,000 & & 1,650 & \\
\hline Chromium & 34.3 & & 53.8 & 24.2 & 25 & & 20.8 & & 19.2 & & 14.3 & \\
\hline Cobalt & 7.0 & & 5.6 & 6.3 & 6.0 & & 6.0 & & 5.8 & & 5.9 & \\
\hline Copper & 277 & & 366 & 151 & 71.1 & & 36.3 & & 24.8 & & 10.3 & \\
\hline Iron & 52,000 & & 26,500 & 20,300 & 20,400 & & 21,800 & & 17,200 & & 15,300 & \\
\hline Lead & 650 & @ & 831 & 204 & 116 & @ & 38.8 & @ & 58.8 & @ & 10 & @ \\
\hline Magnesium & 1,580 & & 1,720 & 1,700 & 2,010 & & 1,960 & & 1,550 & & 1,490 & \\
\hline Manganese & 219 & & 172 & 88.6 & 116 & & 91.3 & & 78.2 & & 64 & \\
\hline Mercury & 1.3 & & 1.8 & 0.38 & 0.1 & $\mathrm{U}$ & 0.13 & $\mathrm{U}$ & 0.1 & $\mathrm{U}$ & 0.1 & $\mathrm{U}$ \\
\hline Nickel & 24.4 & & 19 & 14.2 & 13 & & 12.1 & & 11.8 & & 12.3 & \\
\hline Potassium & 531 & & 473 & 530 & 603 & & 630 & & 716 & & 596 & \\
\hline Selenium & 1.7 & & 1.4 & 1.1 & 0.23 & W & 0.24 & W & 0.26 & W & 0.16 & UW \\
\hline Silver & 1.6 & & 2.5 & 1.0 & 0.42 & & 2.4 & & 0.65 & & 0.37 & $\mathbf{U}$ \\
\hline Sodium & 179 & & 186 & 136 & 91.9 & & 76 & & 55.4 & & 35.8 & \\
\hline Thallium & 0.26 & UW & 0.25 & 0.27 & 0.26 & UW & 0.27 & UW & 0.27 & UW & 0.25 & UW \\
\hline
\end{tabular}


TABLE C.15c (Cont.)

\begin{tabular}{|c|c|c|c|c|c|c|c|c|c|c|c|c|c|c|}
\hline \multirow[b]{2}{*}{ Parameter } & \multicolumn{14}{|c|}{ Soil Concentrations (mg/kg) at Various Depth Intervals } \\
\hline & \multicolumn{2}{|c|}{$\begin{array}{l}\text { TBSPBOR1 } \\
(0-2 \mathrm{ft})\end{array}$} & \multicolumn{2}{|c|}{$\begin{array}{c}\text { TBSPBOR1 Dup } \\
(0-2 \mathrm{ft})\end{array}$} & \multicolumn{2}{|c|}{$\begin{array}{l}\text { TBSPBOR1 } \\
(2-4 \mathrm{ft})\end{array}$} & \multicolumn{2}{|c|}{$\begin{array}{l}\text { TBSPBOR1 } \\
(4-6 \mathrm{ft})\end{array}$} & \multicolumn{2}{|c|}{$\begin{array}{l}\text { TBSPBOR1 } \\
(6-8 \mathrm{ft})\end{array}$} & \multicolumn{2}{|c|}{$\begin{array}{l}\text { TBSPBOR1 } \\
(8-10 \mathrm{ft})\end{array}$} & \multicolumn{2}{|c|}{$\begin{array}{c}\text { TBSPBOR1 } \\
(10-12 \mathrm{ft})\end{array}$} \\
\hline Vanadium & 17.8 & & 17.6 & & 20.6 & & 25.5 & & 26.2 & & 21.7 & & 14.5 & \\
\hline Zinc & 757 & $\mathrm{E}$ & 1,240 & & 450 & $\mathrm{E}$ & 192 & $\mathrm{E}$ & 79.6 & $\mathrm{E}$ & 61.3 & $\mathrm{E}$ & 38.1 & $E$ \\
\hline \multicolumn{15}{|l|}{ Other parameter } \\
\hline Cyanide (total) & 1.9 & $\mathrm{U}$ & 1.9 & $\mathrm{U}$ & 2.0 & $\mathrm{U}$ & 1.7 & U & 1.9 & $\mathrm{U}$ & 1.7 & $\mathrm{U}$ & 1.8 & $\mathrm{U}$ \\
\hline & \multicolumn{12}{|c|}{ Soil Concentrations (mg/kg) at Various Depth Intervals } & & \\
\hline Parameter & \multicolumn{2}{|c|}{$\begin{array}{c}\text { TBSPBOR2 } \\
(0-2 \mathrm{ft})\end{array}$} & \multicolumn{2}{|c|}{$\begin{array}{l}\text { TBSPBOR2 Dup } \\
(0-2 \mathrm{ft})\end{array}$} & \multicolumn{2}{|c|}{$\begin{array}{l}\text { TBSPBOR2 } \\
(2-4 \mathrm{ft})\end{array}$} & \multicolumn{2}{|c|}{$\begin{array}{l}\text { TBSPBOR2 } \\
(4-6 \mathrm{ft})\end{array}$} & \multicolumn{2}{|c|}{$\begin{array}{c}\text { TBSPBOR2 } \\
(6-8 \mathrm{ft})\end{array}$} & \multicolumn{2}{|c|}{$\begin{array}{c}\text { TBSPBOR2 } \\
(8-10 \mathrm{ft})\end{array}$} & & \\
\hline \multicolumn{15}{|l|}{ Metals } \\
\hline Aluminum & 11,300 & & 9,160 & & 9,900 & & 5,270 & & 6,380 & & 9,720 & & & \\
\hline Antimony & 2.8 & UN & 2.7 & $\mathrm{U}$ & 2.9 & UN & 2.8 & UN & 2.8 & UN & 2.8 & UN & & \\
\hline Arsenic & 5.4 & & 4.5 & & 4.9 & & 1.4 & & 1.9 & & 1.5 & $\mathrm{w}$ & & \\
\hline Barium & 53.1 & & 40.5 & & 39.3 & & 24.6 & & 36.5 & & 59.3 & & & \\
\hline Beryllium & 0.27 & & 0.28 & & 0.49 & & 0.23 & & 3.0 & & 0.37 & & & \\
\hline Cadmium & 0.95 & & 0.7 & & 0.51 & $\mathrm{U}$ & 0.49 & $\mathrm{U}$ & 0.5 & $\mathrm{U}$ & 0.5 & $U$ & & \\
\hline Calcium & 934 & & 937 & & 887 & & 716 & & 876 & & 1290 & & & \\
\hline Chromium & 19.4 & & 16.5 & & 16.4 & & 8.9 & & 11.2 & & 14.5 & & & \\
\hline Cobalt & 6.0 & & 5.2 & . & 5.2 & & 2.6 & & 4.6 & & 6.4 & & & \\
\hline Copper & 72.4 & & 55.7 & & 19.4 & & 6.8 & & 7.2 & & 11 & & & \\
\hline Iron & 16,200 & & 15,200 & & 19,700 & & 7,870 & & 13,400 & & 11,900 & & & \\
\hline Lead & 28.2 & $@$ & 22.5 & & 9.6 & @ & 11 & $@$ & 11.8 & @ & 16.2 & $@$ & & \\
\hline
\end{tabular}


TABLE C.15c (Cont.)

\begin{tabular}{|c|c|c|c|c|c|c|c|c|c|c|c|c|c|c|}
\hline \multirow{2}{*}{ Parameter } & \multicolumn{12}{|c|}{ Soil Concentrations (mg/kg) at Various Depth Intervals } & & \\
\hline & \multicolumn{2}{|c|}{$\begin{array}{c}\text { TBSPBOR2 } \\
(0-2 \mathrm{ft})\end{array}$} & \multicolumn{2}{|c|}{$\begin{array}{c}\text { TBSPBOR2 Dup } \\
(0-2 \mathrm{ft})\end{array}$} & \multicolumn{2}{|c|}{$\begin{array}{c}\text { TBSPBOR2 } \\
(2-4 \mathrm{ft})\end{array}$} & \multicolumn{2}{|c|}{$\begin{array}{l}\text { TBSPBOR2 } \\
(4-6 \mathrm{ft})\end{array}$} & \multicolumn{2}{|c|}{$\begin{array}{c}\text { TBSPBOR2 } \\
(6-8 \mathrm{ft})\end{array}$} & \multicolumn{2}{|c|}{$\begin{array}{c}\text { TBSPBOR2 } \\
(8-10 \mathrm{ft})\end{array}$} & & \\
\hline \multicolumn{15}{|l|}{ Metals (Cont.) } \\
\hline Magnesium & 2,130 & & 1,870 & & 1,660 & & 778 & & 1,100 & & 1,810 & & & \\
\hline Manganese & 99.3 & & 90.1 & & 66.9 & & 27 & & 57.2 & & 73.3 & & & \\
\hline Mercury & 0.09 & U & 0.1 & $\mathrm{U}$ & 0.1 & $\mathbf{U}$ & 0.11 & $\mathrm{U}$ & 0.1 & $\mathrm{U}$ & 0.11 & $\mathrm{U}$ & & \\
\hline Nickel & 13 & & 10.8 & & 10.6 & & 5.2 & & 7.9 & & 12.6 & & & \\
\hline Potassium & 748 & & 561 & & 606 & & 524 & & 550 & & 801 & & & \\
\hline Selenium & 0.22 & W & 0.24 & & 0.16 & UW & 0.16 & $\mathrm{U}$ & 0.2 & W & 0.33 & W & & \\
\hline Silver & 0.38 & $U$ & 0.36 & $\mathrm{U}$ & 0.39 & $\mathbf{U}$ & 0.38 & $\mathrm{U}$ & 0.38 & $\mathrm{U}$ & 0.38 & $\mathrm{U}$ & . & \\
\hline Sodium & 141 & & 123 & & 303 & & 174 & & 96.3 & & 69.1 & & & \\
\hline Thallium & 0.25 & UW & 0.26 & $U$ & 0.26 & UW & 0.26 & UW & 0.25 & UW & 0.27 & UW & & \\
\hline Vanadium & 21 & & 19.5 & & 20.8 & & 12.3 & & 10.8 & & 11.9 & & & \\
\hline Zinc & 97 & $\mathrm{E}$ & 77.4 & & 48.7 & $\mathrm{E}$ & 17.8 & $\mathrm{E}$ & 23 & $\mathrm{E}$ & 44.5 & $\mathrm{E}$ & & \\
\hline \multicolumn{15}{|l|}{ Other parameter } \\
\hline Cyanide (total) & 2.0 & $\mathrm{U}$ & 1.9 & $\underline{U}$ & 1.8 & $\mathrm{U}$ & 2.1 & U & 1.8 & $U$ & 2.1 & $U$ & & \\
\hline & \multicolumn{14}{|c|}{ Soil Concentrations $(\mathrm{mg} / \mathrm{kg}$ ) at Various Depth Intervals } \\
\hline Parameter & \multicolumn{2}{|c|}{$\begin{array}{c}\text { HBOR1 } \\
(0-2 \mathrm{ft})\end{array}$} & \multicolumn{2}{|c|}{$\begin{array}{c}\text { HBOR } 1 \\
(2-4 \mathrm{ft})\end{array}$} & \multicolumn{2}{|c|}{$\begin{array}{l}\text { HBOR1 } \\
(4-6 \mathrm{ft})\end{array}$} & \multicolumn{2}{|c|}{$\begin{array}{l}\text { HBOR1 } \\
(6-8 \mathrm{ft})\end{array}$} & \multicolumn{2}{|c|}{$\begin{array}{l}\text { HBOR1 } \\
(8-10 \mathrm{ft})\end{array}$} & \multicolumn{2}{|c|}{$\begin{array}{l}\text { HBOR2 } \\
(0-2 \mathrm{ft})\end{array}$} & \multicolumn{2}{|c|}{$\begin{array}{c}\text { HBOR2 } \\
(2-4 \mathrm{ft})\end{array}$} \\
\hline \multicolumn{15}{|l|}{ Metals } \\
\hline Aluminum & 11,600 & & 8,470 & & 6,920 & & 4,880 & & 3,530 & & 9,120 & & 8,440 & \\
\hline Antimony & 21.5 & $@ N$ & 5.7 & U@N & 5.7 & $U @ N$ & 4.5 & $\mathrm{U} @ N$ & 5.3 & $\mathrm{U} @ N$ & 5.5 & $\mathrm{U} @ N$ & 5.5 & U@N \\
\hline Arsenic & 15.7 & & 4.6 & & 2.7 & & 1.8 & & 1.7 & & 8.3 & & 12 & \\
\hline
\end{tabular}


TABLE C.15c (Cont.)

\begin{tabular}{|c|c|c|c|c|c|c|c|c|c|c|c|c|c|c|}
\hline \multirow{2}{*}{$\frac{\text { Parameter }}{\text { Metals (Cont.) }}$} & \multicolumn{14}{|c|}{ Soil Concentrations (mg/kg) at Various Depth Intervals } \\
\hline & \multicolumn{2}{|c|}{$\begin{array}{l}\text { HBOR1 } \\
(0-2 \mathrm{ft})\end{array}$} & \multicolumn{2}{|c|}{$\begin{array}{l}\text { HBOR1 } \\
(2-4 \mathrm{ft})\end{array}$} & \multicolumn{2}{|c|}{$\begin{array}{l}\text { HBOR1 } \\
(4-6 \mathrm{ft})\end{array}$} & \multicolumn{2}{|c|}{$\begin{array}{l}\text { HBOR1 } \\
(6-8 \mathrm{ft})\end{array}$} & \multicolumn{2}{|c|}{$\begin{array}{l}\text { HBOR1 } \\
(8-10 \mathrm{ft}) \\
\end{array}$} & \multicolumn{2}{|c|}{$\begin{array}{l}\text { HBOR2 } \\
(0-2 \mathrm{ft})\end{array}$} & \multicolumn{2}{|c|}{$\begin{array}{l}\text { HBOR2 } \\
(2-4 \mathrm{ft})\end{array}$} \\
\hline Barium & 380 & $@$ & 41.4 & @ & 40.5 & $@$ & 23 & @ & 16.1 & @ & 108 & $@$ & 156 & @ \\
\hline Beryllium & 0.75 & & 0.45 & & 0.45 & & 0.35 & & 0.33 & & 0.59 & & 0.57 & \\
\hline Cadmium & 1.7 & & 0.57 & & 0.53 & $\mathrm{U}$ & 0.42 & $\mathrm{U}$ & 0.5 & $\mathrm{U}$ & 0.64 & & 0.66 & \\
\hline Calcium & 5,320 & & 2,050 & & 1,690 & . & 917 & & 613 & & 2,590 & & 2,510 & \\
\hline Chromium & 33.5 & @E & 13 & @E & 12.7 & $@ E$ & 11.4 & $@ E$ & 8.6 & @E & 18.2 & @E & 24.3 & $@ \mathrm{E}$ \\
\hline Cobalt & 5.8 & & 1.9 & & 3.0 & & 2.1 & & 1.4 & & 4.9 & & 3.3 & \\
\hline Copper & 204 & & 16.3 & & 14.4 & & 6.1 & & 4.3 & & 55.2 & & 85.5 & \\
\hline Iron & 17,400 & & 10,600 & & 9,890 & & 6,690 & & 5,390 & & 13,800 & & 13,700 & \\
\hline Lead & 4,960 & @ & 165 & @ & 110 & @ & 21 & @ & 13.8 & @ & 859 & @ & 256 & @ \\
\hline Magnesium & 2,810 & & 941 & & 1,380 & & 867 & & 547 & & 1,620 & & 1,460 & \\
\hline Manganese & 213 & & 57.8 & & 61.1 & & 35.4 & & 28.9 & & 177 & & 108 & \\
\hline Mercury & 0.12 & & 0.11 & U & 0.12 & $\mathrm{U}$ & 0.1 & & 0.11 & U & 0.14 & & 0.22 & \\
\hline Nickel & 16.6 & & 4.2 & & 6.7 & & 3.6 & & 5.1 & & 10 & & 10.1 & \\
\hline Potassium & 703 & & 470 & & 453 & & 342 & & 369 & & 511 & & 588 & \\
\hline Selenium & 0.29 & & 0.19 & $U$ & 0.17 & $U$ & 0.16 & $\mathrm{U}$ & 0.16 & & 0.33 & & 0.34 & \\
\hline Silver & 0.77 & & 0.53 & $\mathrm{U}$ & 0.53 & $U$ & 0.42 & $\mathrm{U}$ & 0.5 & $\mathrm{U}$ & 0.86 & & 0.99 & \\
\hline Sodium & 127 & & 95.1 & & 65.8 & & 439 & & 40 & & 61.1 & & 65.7 & \\
\hline Thallium & 1.2 & $\mathrm{U}$ & 0.31 & $\mathrm{U}$ & 0.28 & $\mathrm{U}$ & 0.26 & $\mathrm{U}$ & 0.23 & $\mathrm{U}$ & 0.28 & $\mathrm{U}$ & 0.26 & $\mathrm{U}$ \\
\hline Vanadium & 20.3 & & 14 & & 12 & & 8.2 & & 7.9 & & 17.2 & & 15.7 & \\
\hline Zinc & 896 & @ & 82 & @ & 58.5 & @ & 23.6 & @ & 18.5 & @ & 287 & @ & 185 & @ \\
\hline \multicolumn{15}{|l|}{ Other parameter } \\
\hline Cyanide (total) & 1.7 & $@$ & 57 & $@$ & 1.6 & @ & 1.4 & U@ & 1.4 & U@ & 1.5 & U@ & 1.4 & U@ \\
\hline
\end{tabular}


TABLE C.15c (Cont.)

\begin{tabular}{|c|c|c|c|c|c|c|c|c|c|c|c|c|c|c|}
\hline \multirow[b]{2}{*}{ Parameter } & \multicolumn{12}{|c|}{ Soil Concentrations (mg/kg) at Various Depth Intervals } & \multicolumn{2}{|r|}{$\because$} \\
\hline & \multicolumn{2}{|c|}{$\begin{array}{l}\text { HBOR2 } \\
(4-6 \mathrm{ft})\end{array}$} & \multicolumn{2}{|c|}{$\begin{array}{l}\text { HBOR2 } \\
(6-8 \mathrm{ft})\end{array}$} & \multicolumn{2}{|c|}{$\begin{array}{l}\text { HBOR2 } \\
(8-10 \mathrm{ft})\end{array}$} & \multicolumn{2}{|c|}{$\begin{array}{c}\text { FTBOR1 } \\
(8-10 \mathrm{ft})\end{array}$} & \multicolumn{2}{|c|}{$\begin{array}{r}\text { HBOR3 } \\
(0-2 \mathrm{ft})\end{array}$} & \multicolumn{2}{|c|}{$\begin{array}{r}\text { HBOR3 } \\
(2-4 \mathrm{ft})\end{array}$} & \multicolumn{2}{|c|}{$\begin{array}{c}\text { HBOR4 } \\
(0-2 \mathrm{ft})\end{array}$} \\
\hline Aluminum & 8,220 & & 6,970 & & 2,980 & & 4,780 & & 8,440 & & 7,640 & & 9,210 & $\mathrm{E}$ \\
\hline Antimony & 5.5 & U@N & 5.2 & $\mathrm{U} @ N$ & 6.0 & U@N & 6.0 & $\mathrm{U} @ \mathrm{~N}$ & 8.1 & $@ N$ & 5.3 & U@N & 0.20 & UNWJ \\
\hline Arsenic & 5.4 & & 1.8 & & 2.0 & & 1.8 & & 8.1 & & 10.0 & & 3.48 & \\
\hline Barium & 41.3 & @ & 27.5 & @ & 13.7 & @ & 20 & $@$ & 116 & @ & 137 & @ & 55.1 & \\
\hline Beryllium & 0.52 & & 0.37 & & 0.45 & & 0.54 & & 0.76 & & 0.79 & & 0.30 & \\
\hline Cadmium & 0.52 & & 0.49 & $\mathrm{U}$ & 0.57 & U & 0.56 & $\mathrm{U}$ & 0.53 & $\mathrm{U}$ & 0.94 & & 0.46 & $\mathrm{U}$ \\
\hline Calcium & 3,000 & & 1,290 & & 532 & & 488 & & 3,400 & & 2,340 & & 3,540 & \\
\hline Chromium & 15 & @E & 12.8 & $@ \mathrm{E}$ & 6.4 & @E & 8.1 & $@ E$ & 20.2 & @E & 22.2 & @E & 12.7 & \\
\hline Cobalt & 3.5 & & 3.1 & & 1.5 & & 2.3 & & 4.2 & & 4.3 & & 50.4 & \\
\hline Copper & 17.2 & & 8.1 & & 3.7 & & 5.1 & & 69.2 & & 90 & U@ & 10.9 & \\
\hline Iron & 12,300 & & 9,280 & & 4,880 & & 7,080 & & 14,500 & & 14,000 & & 13,600 & \\
\hline Lead & 43 & @ & 12.4 & @ & 6.5 & $@$ & 5.4 & $@$ & 484 & & 419 & $@$ & 131 & $@ \mathrm{~J}$ \\
\hline Magnesium & 1,300 & & 1,380 & & 596 & & 917 & & 1,580 & & 1,460 & & 1,310 & \\
\hline Manganese & 106 & & 50.1 & & 28.9 & & 57.7 & & 152 & & 142 & & 93.2 & \\
\hline Mercury & 0.08 & $U$ & 0.1 & $\mathrm{U}$ & 0.1 & $U$ & 0.13 & $\mathrm{U}$ & 0.15 & & 0.21 & & 0.07 & \\
\hline Nickel & 8.4 & & 8.2 & & 2.8 & U & 4.3 & & 9.2 & & 8.7 & & 7.5 & \\
\hline Potassium & 629 & & 495 & & 295 & & 468 & & 503 & & 444 & & 392 & \\
\hline Selenium & 0.19 & & 0.16 & $\mathrm{U}$ & 0.19 & U & 0.2 & $\mathrm{U}$ & 0.28 & & 0.37 & & 0.18 & UNJ \\
\hline Silver & 0.57 & & 0.49 & U & 0.57 & U & 0.56 & $\mathrm{U}$ & 0.80 & & 1.3 & & 0.08 & $\mathrm{U}$ \\
\hline Sodium & 68.3 & & 50.9 & & 36.2 & & 42.6 & & 63.7 & & 65.1 & & 48.6 & \\
\hline Thallium & 0.24 & U & 0.25 & U & 0.32 & U & 0.33 & $\mathrm{U}$ & 0.29 & $\mathrm{U}$ & 0.26 & & 0.32 & $\mathrm{U}$ \\
\hline Vanadium & 16.2 & & 11.4 & & 5.1 & & 8.0 & & 19.0 & & 14.6 & & 17.4 & \\
\hline Zinc & 57.5 & @ & 29.2 & @ & 15.6 & @ & 25.3 & @ & 402 & @ & 224 & & 49.8 & \\
\hline
\end{tabular}


TABLE C.15c (Cont.)

\begin{tabular}{|c|c|c|c|c|c|c|c|c|c|c|c|c|c|c|}
\hline \multirow[b]{2}{*}{ Parameter } & \multicolumn{14}{|c|}{ Soil Concentrations (mg/kg) at Various Depth Intervals } \\
\hline & \multicolumn{2}{|c|}{$\begin{array}{l}\text { HBOR2 } \\
(4-6 \mathrm{ft})\end{array}$} & \multicolumn{2}{|c|}{$\begin{array}{c}\text { HBOR2 } \\
(6-8 \mathrm{ft})\end{array}$} & \multicolumn{2}{|c|}{$\begin{array}{l}\text { HBOR2 } \\
(8-10 \mathrm{ft}) \\
\end{array}$} & \multicolumn{2}{|c|}{$\begin{array}{l}\text { FTBOR1 } \\
(8-10 \mathrm{ft}) \\
\end{array}$} & \multicolumn{2}{|c|}{$\begin{array}{r}\text { HBOR3 } \\
(0-2 \mathrm{ft}) \\
\end{array}$} & \multicolumn{2}{|c|}{$\begin{array}{r}\text { HBOR3 } \\
(2-4 \mathrm{ft}) \\
\end{array}$} & \multicolumn{2}{|c|}{$\begin{array}{c}\text { HBOR4 } \\
(0-2 \mathrm{ft}) \\
\end{array}$} \\
\hline Cyanide (total) & 1.4 & U@ & 1.4 & U@ & 1.3 & U@ & 1.5 & U@ & 1.3 & U@ & 1.4 & U@ & 1.15 & $\underline{U}$ \\
\hline & \multicolumn{10}{|c|}{ Soil Concentrations (mg/kg) at Various Depth Intervals } & & & & \\
\hline Parameter & \multicolumn{2}{|c|}{$\begin{array}{l}\text { TBNPBOR1 } \\
(0-2 \mathrm{ft})\end{array}$} & \multicolumn{2}{|c|}{$\begin{array}{c}\text { TBNPBOR1 } \\
(2-4 \mathrm{ft})\end{array}$} & \multicolumn{2}{|c|}{$\begin{array}{c}\text { TBNPBOR1 } \\
(4-6 \mathrm{ft})\end{array}$} & \multicolumn{2}{|c|}{$\begin{array}{c}\text { TBNPBOR1 } \\
(6-8 \mathrm{ft})\end{array}$} & \multicolumn{2}{|c|}{$\begin{array}{c}\text { TBNPBOR1 } \\
(8-10 \mathrm{ft})\end{array}$} & & & & \\
\hline \multicolumn{15}{|l|}{ Metals } \\
\hline Aluminum & 22,600 & & 10,300 & & 5,990 & & 4,280 & & 4,710 & & & & & \\
\hline Antimony & 19.4 & $@ N$ & 15.2 & $@ N$ & 5.4 & $\mathrm{U} @ N$ & 4.9 & $\mathrm{U} @ \mathrm{~N}$ & 5.6 & $\mathrm{U} @ N$ & & & & \\
\hline Arsenic & 1,440 & & 2,290 & & 247 & & 199 & & 16.7 & & & & & \\
\hline Barium & 649 & @ & 1,140 & @ & 414 & @ & 305 & @ & 104 & @ & & & & \\
\hline Beryllium & 0.76 & & 0.78 & & 0.59 & & 0.39 & & 0.44 & & & & & \\
\hline Cadmium & 35.5 & & 12.9 & & 44.1 & & 77.4 & & 2.8 & & & & . & \\
\hline Calcium & 4,890 & & 1,550 & & 440 & & 293 & & 247 & & & & & \\
\hline Chromium & 240 & $@ \mathrm{E}$ & 81.7 & @E & 18.4 & $@ \mathrm{E}$ & 18.2 & $@ \mathrm{E}$ & 9.7 & $@ \mathrm{E}$ & & & & \\
\hline Cobalt & 10.8 & & 6.4 & & 2.6 & & 2.9 & & 1.8 & & & & & \\
\hline Copper & 2,240 & & 7,120 & & 1,120 & & 544 & & 90.7 & & & & & \\
\hline Iron & 61,900 & & 66,500 & & 26,500 & & 21,200 & & 8,940 & & & & & \\
\hline Lead & 1,910 & @ & 1,630 & @ & 117 & @ & 90.3 & @ & 48.4 & $@$ & & & & \\
\hline Magnesium & 2,890 & & 1,980 & & 759 & & 800 & & 952 & & & & & \\
\hline Manganese & 633 & & 253 & & 70.3 & & 81.9 & & 40.1 & & & & & \\
\hline Mercury & 2.2 & & 5.2 & & 0.85 & & 0.34 & & 0.09 & $U$ & & & & \\
\hline Nickel & 76.4 & & 51.6 & & 19.1 & & 17.8 & & 7.7 & & & & & \\
\hline
\end{tabular}


TABLE C.15c (Cont.)

\begin{tabular}{|c|c|c|c|c|c|c|c|c|c|}
\hline \multirow[b]{2}{*}{ Parameter } & \multicolumn{9}{|c|}{ Soil Concentrations $(\mathrm{mg} / \mathrm{kg}$ ) at Various Depth Intervals } \\
\hline & $\begin{array}{c}\text { TBNPBOR1 } \\
(0-2 \mathrm{ft})\end{array}$ & \multicolumn{2}{|c|}{$\begin{array}{c}\text { TBNPBOR1 } \\
(2-4 \mathrm{ft})\end{array}$} & \multicolumn{2}{|c|}{$\begin{array}{c}\text { TBNPBOR1 } \\
(4-6 \mathrm{ft})\end{array}$} & \multicolumn{2}{|c|}{$\begin{array}{c}\text { TBNPBOR1 } \\
(6-8 \mathrm{ft})\end{array}$} & \multicolumn{2}{|c|}{$\begin{array}{c}\text { TBNPBOR1 } \\
(8-10 \mathrm{ft})\end{array}$} \\
\hline \multicolumn{10}{|l|}{ Metals (Cont.) } \\
\hline Potassium & 802 & 1,050 & & 685 & & 478 & & 508 & \\
\hline Selenium & 0.61 & 0.17 & $\mathbf{U}$ & 0.31 & & 0.2 & $U$ & 0.18 & $\mathrm{U}$ \\
\hline Silver & 24.8 & 14.8 & & 4.4 & & 2.9 & & 0.53 & $\mathrm{U}$ \\
\hline Sodium & 254 & 153 & & 46.2 & & 41.3 & & 32.3 & \\
\hline Thallium & 7.9 & 3.4 & & 1.6 & $U$ & 0.32 & $\mathrm{U}$ & 0.3 & $\mathrm{U}$ \\
\hline Vanadium & 16.6 & 6.0 & & 6.9 & & 3.1 & & 5.8 & \\
\hline Zinc & 9,840 & 6,530 & @ & 4,360 & @ & 3,650 & @ & 1,150 & @ \\
\hline \multicolumn{10}{|l|}{ Other parameter } \\
\hline Cyanide (total) & 1.4 U@ & 1.4 & U@ & 1.5 & U@ & 1.4 & U@ & 1.3 & U@ \\
\hline
\end{tabular}

a Sampled by ANL, analyzed by Weston Gulf Coast or ANL/ACL, TCL TAL metals and other inorganic parameters.

Data qualifiers:

$\mathrm{N}=$ spike and spike duplicate recovery of percent RPD were outside the control limits.

$@$ = percent RPD of sample duplicate was outside the control limits.

$\mathrm{U}=$ analyte was analyzed for but not detected; detection limit given.

$\mathrm{W}=$ postdigestion spike for furnace AAS analysis was outside the control limits.

$\mathrm{E}=$ serial dilution percent difference was outside the $\mathrm{QC}$ limit. 
TABLE C.15d Inorganic Analysis for Soil Borings, May $1995^{\mathrm{a}}$

\begin{tabular}{|c|c|c|c|c|c|c|c|c|}
\hline \multirow[b]{2}{*}{ Parameter } & \multicolumn{8}{|c|}{ Soil Concentrations (mg/kg) at Various Depth Intervals } \\
\hline & \multicolumn{2}{|c|}{$\begin{array}{c}\text { TBNPBOR2 } \\
(0-2 \mathrm{ft})\end{array}$} & \multicolumn{2}{|c|}{$\begin{array}{c}\text { TBNPBOR2 } \\
(2-6 \mathrm{ft})\end{array}$} & \multicolumn{2}{|c|}{$\begin{array}{c}\text { TBNPBOR2 } \\
(6-8 \mathrm{ft})\end{array}$} & \multicolumn{2}{|c|}{$\begin{array}{c}\text { TBNPBOR } \\
(10-12 \mathrm{ft})\end{array}$} \\
\hline \multicolumn{9}{|l|}{ Metals } \\
\hline Aluminum & 12,100 & & 6,420 & & 6,340 & & 2630 & \\
\hline Antimony & 72.5 & $\mathrm{NJ}$ & 0.28 & & 0.208 & $U$ & 0.209 & $\mathrm{U}$ \\
\hline Arsenic & 14.4 & & 2.74 & & 2.11 & & 1.5 & \\
\hline Barium & 464 & $@$ & 22.8 & & 24.8 & & 10.9 & \\
\hline Beryllium & 0.272 & & 0.241 & & 0.181 & & 0.135 & $\mathrm{U}$ \\
\hline Cadmium & 15.8 & $@ J$ & 0.35 & $\mathrm{U}$ & 0.514 & & 0.385 & ' \\
\hline Calcium & 3,060 & E@ & 595 & & 580 & & 143 & \\
\hline Chromium & 106 & @J & 8.02 & & 9.11 & & 2.43 & \\
\hline Cobalt & 10 & & 3.96 & & 4.73 & & 3.07 & \\
\hline Copper & 1,030 & @J & 7.64 & & 7.41 & & 2.83 & U \\
\hline Iron & 29,200 & $E$ & 11,700 & & 12,700 & & 3760 & \\
\hline Lead & 4,790 & @J & 8.09 & & $8 . \dot{32}$ & & 3.71 & \\
\hline Magnesium & 2,950 & & 937 & & 1,290 & & 731 & \\
\hline Manganese & 232 & @J & 39.2 & & 43.6 & & 24.5 & \\
\hline Mercury & 1.53 & & 0.043 & U & 0.061 & $\mathrm{U}$ & 0.03 & \\
\hline Nickel & 49.2 & & 5.23 & & 8.44 & & 4.51 & \\
\hline Potassium & 653 & & 583 & & 454 & & 361 & \\
\hline Selenium & 0.792 & & 0.186 & $\mathrm{U}$ & 0.196 & $\mathrm{U}$ & 0.197 & $\mathrm{U}$ \\
\hline Silver & 9.84 & & 0.082 & $\mathrm{U}$ & 0.086 & $U$ & 0.086 & $U$ \\
\hline Sodium & 154 & & 67.2 & & 84.8 & & 20.9 & $U$ \\
\hline Thallium & 19.3 & & 0.326 & $\mathrm{U}$ & 0.343 & $U$ & 0.345 & $\mathrm{U}$ \\
\hline
\end{tabular}


TABLE C.15d (Cont.)

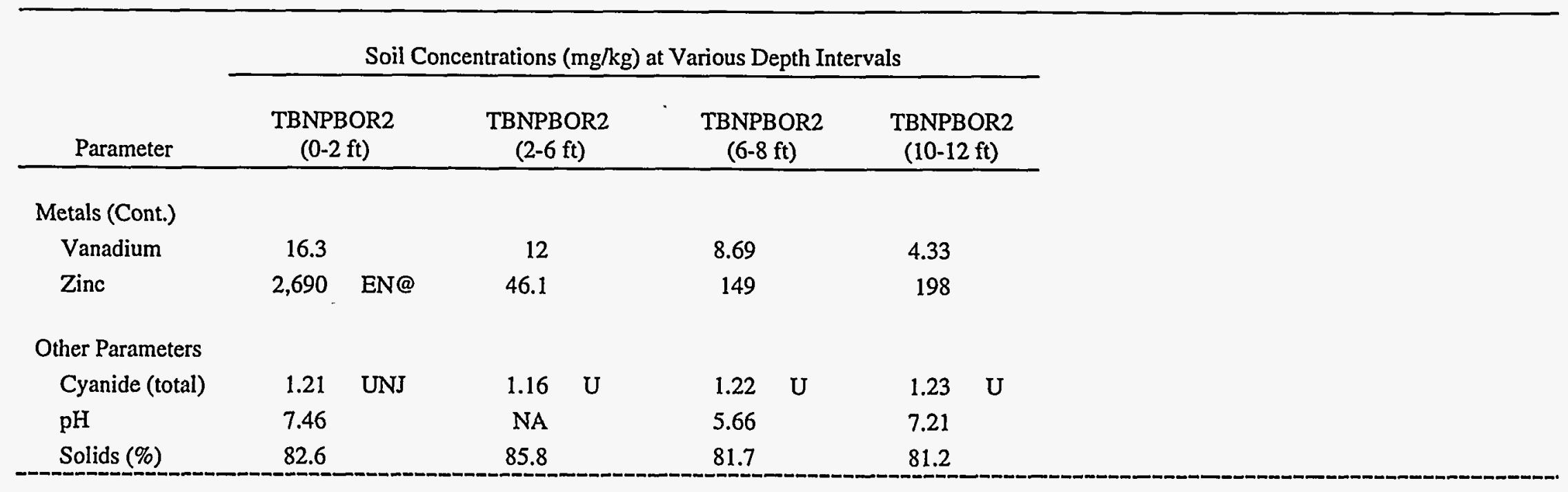

Soil Concentrations $(\mathrm{mg} / \mathrm{kg}$ ) at Various Depth Intervals

\begin{tabular}{|c|c|c|c|c|c|c|c|c|c|c|c|}
\hline Parameter & $\begin{array}{c}\text { TBNPBOR3 } \\
(0-2 \mathrm{ft})\end{array}$ & \multicolumn{2}{|c|}{$\begin{array}{c}\text { TBNPBOR3 } \\
(2-4 \mathrm{ft})\end{array}$} & \multicolumn{2}{|c|}{$\begin{array}{c}\text { TBNPBOR3 } \\
(4-6 \mathrm{ft})\end{array}$} & \multicolumn{2}{|c|}{$\begin{array}{c}\text { TBNPBOR3 } \\
(6-8 \mathrm{ft})\end{array}$} & \multicolumn{2}{|c|}{$\begin{array}{l}\text { TBNPBOR3 } \\
(8-10 \mathrm{ft})\end{array}$} & \multicolumn{2}{|c|}{$\begin{array}{c}\text { TBNPBOR3 } \\
(10-12 \mathrm{ft})\end{array}$} \\
\hline & & & & & & & & & & & \\
\hline Aluminum & 4,430 & 4,190 & $\mathbf{J}$ & 5,420 & & 6,710 & & 5,160 & & 2,570 & \\
\hline Antimony & 20.4 & 23.7 & $\mathrm{NJ}$ & 3.44 & NJ & 0.202 & $U$ & 0.212 & $U$ & 0.209 & UNJ \\
\hline Arsenic & 278 & 63.5 & & 316 & @J & 7.63 & & 6.44 & & 10.5 & @J \\
\hline Barium & 237 & 246 & @J & 1,240 & & 61.8 & & 30.6 & & 38.2 & \\
\hline Beryllium & 0.132 & 0.149 & $U$ & 0.204 & $\mathrm{~J}$ & 0.169 & & 0.253 & & 0.14 & $\mathbf{J}$ \\
\hline Cadmium & 5.13 & 3.55 & $@ \mathrm{~J}$ & 5.71 & N@J & 0.583 & & 0.698 & & 0.709 & N@J \\
\hline Calcium & 2,080 & 946 & $@ E$ & 811 & $\mathrm{E}$ & 193 & & 164 & & 168 & $\mathrm{E}$ \\
\hline
\end{tabular}


TABLE C.15d (Cont.)

\begin{tabular}{|c|c|c|c|c|c|c|c|c|c|c|c|c|}
\hline \multirow[b]{2}{*}{ Parameter } & \multicolumn{12}{|c|}{ Soil Concentrations $(\mathrm{mg} / \mathrm{kg})$ at Various Depth Intervals } \\
\hline & \multicolumn{2}{|c|}{$\begin{array}{c}\text { TBNPBOR3 } \\
(0-2 \mathrm{ft})\end{array}$} & \multicolumn{2}{|c|}{$\begin{array}{c}\text { TBNPBOR3 } \\
(2-4 \mathrm{ft}) \\
\end{array}$} & \multicolumn{2}{|c|}{$\begin{array}{c}\text { TBNPBOR3 } \\
(4-6 \mathrm{ft})\end{array}$} & \multicolumn{2}{|c|}{$\begin{array}{c}\text { TBNPBOR3 } \\
(6-8 \mathrm{ft})\end{array}$} & \multicolumn{2}{|c|}{$\begin{array}{c}\text { TBNPBOR3 } \\
(8-10 \mathrm{ft})\end{array}$} & \multicolumn{2}{|c|}{$\begin{array}{c}\text { TBNPBOR3 } \\
(10-12 \mathrm{ft})\end{array}$} \\
\hline Chromium & 72.1 & & 37.2 & $@ J$ & 23.6 & N@J & 9.23 & & 8.79 & & 5.24 & N@J \\
\hline Cobalt & 12.7 & & 9.48 & & 7.33 & & 3.98 & & 2.99 & & 2.75 & $\mathbf{J}$ \\
\hline Copper & 814 & & 916 & $@ \mathrm{~J}$ & 191 & & 15.3 & & 7.98 & & 11.9 & \\
\hline Iron & 154,000 & & 120,000 & $\mathrm{E}$ & 55,400 & @J & 9,840 & & 13,100 & & 4,660 & @J \\
\hline Lead & 3,230 & & 459 & @J & 92.7 & & 18.6 & & 6.69 & & 22.7 & \\
\hline Magnesium & 1,090 & & 720 & & 1,850 & $\mathrm{E}$ & 1,470 & & 1180 & & 636 & $\mathrm{E}$ \\
\hline Manganese & 470 & & 480 & @J & 186 & EN@ & 43.3 & & 51 & & 32.3 & EN”@ \\
\hline Mercury & 0.931 & & 0.074 & $\mathrm{~J}$ & 0.069 & $J$ & 0.044 & & 0.062 & $\mathrm{U}$ & 0.053 & $U$ \\
\hline Nickel & 84.5 & & 51.9 & & 68.8 & $\mathrm{~N} @ J$ & 8.03 & & 7.12 & & 6.13 & $\mathrm{~N} @ J$ \\
\hline Potassium & 366 & & 711 & & 667 & $\mathrm{~J}$ & 781 & & 650 & & 288 & $\mathrm{~J}$ \\
\hline Selenium & 1.64 & & 1.77 & & 0.424 & WJ & 0.19 & $\mathrm{U}$ & 0.2 & $\mathrm{U}$ & 0.197 & $\mathrm{U}$ \\
\hline Silver & 4.54 & & 0.147 & & 0.099 & $\mathrm{U}$ & 0.083 & $\mathrm{U}$ & 0.087 & $U$ & 0.086 & $\mathrm{U}$ \\
\hline Sodium & 83 & & 125 & & 113 & $\mathrm{~J}$ & 40.9 & & 48.6 & & 47.9 & $\mathrm{~J}$ \\
\hline Thallium & 0.335 & $\mathrm{U}$ & 0.378 & $\mathrm{U}$ & 0.395 & $\mathrm{U}$ & 0.333 & $\mathrm{U}$ & 0.35 & $\mathrm{U}$ & 0.344 & $U$ \\
\hline Vanadium & 4.29 & & 6.68 & & 8.09 & & 8.23 & & 10.2 & & 3.25 & $\mathrm{~J}$ \\
\hline Zinc & 13,900 & & 13,800 & $@ N E$ & 3,880 & & 283 & & 113 & & 205 & \\
\hline \multicolumn{13}{|l|}{ Other Parameters } \\
\hline Cyanide (total) & 1.2 & U & 40.8 & & 11.1 & & 1.19 & $U$ & 1.25 & $\mathrm{U}$ & 1.23 & $\mathrm{U}$ \\
\hline $\mathrm{pH}$ & 6.81 & & 6.22 & & 6.22 & & 7.05 & & 7.09 & & 6.5 & \\
\hline Solids (\%) & 83.5 & & 74 & & 70.9 & & 84 & & 79.9 & & 81.3 & \\
\hline
\end{tabular}


TABLE C.15d (Cont.)

\begin{tabular}{|c|c|c|c|c|c|c|c|c|c|c|c|c|c|c|}
\hline \multirow{3}{*}{$\begin{array}{l}\text { Parameter } \\
\text { Metals }\end{array}$} & \multicolumn{14}{|c|}{ Soil Concentrations (mg/kg) at Various Depth Intervals } \\
\hline & \multicolumn{2}{|c|}{$\begin{array}{c}\text { VXBOR1 } \\
(0-2 \mathrm{ft}) \\
\end{array}$} & \multicolumn{2}{|c|}{$\begin{array}{c}\text { VXBOR1 } \\
(4-6 \mathrm{ft}) \\
\end{array}$} & \multicolumn{2}{|c|}{$\begin{array}{c}\text { VXBOR1 } \\
(6-8 \mathrm{ft}) \\
\end{array}$} & \multicolumn{2}{|c|}{$\begin{array}{c}\text { VXBOR2 } \\
(0-2 \mathrm{ft})\end{array}$} & \multicolumn{2}{|c|}{$\begin{array}{c}\text { VXBOR2 } \\
(2-4 \mathrm{ft})\end{array}$} & \multicolumn{2}{|c|}{$\begin{array}{c}\text { VXBOR2 } \\
(4-6 \mathrm{ft})\end{array}$} & \multicolumn{2}{|c|}{$\begin{array}{c}\text { VXBOR2 } \\
(6-8 \mathrm{ft})\end{array}$} \\
\hline & & & & & & & & & & & & & & \\
\hline Aluminum & NA & & NA & & NA & & NA & & NA & & NA & & NA & \\
\hline Antimony & $\mathrm{NA}$ & & $\mathrm{NA}$ & & NA & & NA & & NA & & NA & & NA & \\
\hline Arsenic & 13 & $\mathrm{U}$ & 10 & $\mathrm{U}$ & 10 & $\mathrm{U}$ & 15 & & 10 & $U$ & 10 & U & 10 & $\mathrm{U}$ \\
\hline Barium & 224 & & 62 & & 30 & & 166 & & 51 & & 39 & & 37 & \\
\hline Beryllium & NA & & NA & & NA & & NA & & NA & & NA & & NA & \\
\hline Cadmium & 10 & $U$ & 10 & $U$ & 10 & $\mathrm{U}$ & 10 & $\mathrm{U}$ & 10 & $\mathrm{U}$ & 10 & $\mathrm{U}$ & 10 & $U$ \\
\hline Calcium & NA & & NA & & $\mathrm{NA}$ & & $\mathrm{NA}$ & & NA & & $\mathrm{NA}$ & & $\mathrm{NA}$ & \\
\hline Chromium & 37 & & 42 & & 13 & & 41 & & 25 & & 17 & & 13 & \\
\hline Cobalt & NA & & $\mathrm{NA}$ & & NA & & NA & & $\mathrm{NA}$ & & $\mathrm{NA}$ & & NA & \\
\hline Copper & 170 & & 192 & & 10 & $\mathrm{U}$ & 124 & & 10 & $\mathrm{U}$ & 40 & & 10 & $U$ \\
\hline Iron & $\mathrm{NA}$ & & $\mathrm{NA}$ & & $\mathrm{NA}$ & & $\mathrm{NA}$ & & $\mathrm{NA}$ & & $\mathrm{NA}$ & & $\mathrm{NA}$ & \\
\hline Lead & 210 & & 49 & & 10 & $\mathrm{U}$ & 161 & & 11 & & 10 & $U$ & 10 & $\mathrm{U}$ \\
\hline Magnesium & $\mathrm{NA}$ & & NA & & $\mathrm{NA}$ & & $\mathrm{NA}$ & & $\mathrm{NA}$ & & $\mathrm{NA}$ & & $\mathrm{NA}$ & \\
\hline Manganese & $\mathrm{NA}$ & & $\mathrm{NA}$ & & NA & & NA & & NA & & $\mathrm{NA}$ & & $\mathrm{NA}$ & \\
\hline Mercury & 10 & $U$ & 10 & $\mathrm{U}$ & 10 & $U$ & 10 & $U$ & 10 & $\mathrm{U}$ & 10 & $\mathrm{U}$ & 10 & $\mathrm{U}$ \\
\hline Nickel & 11 & & 11 & & 10 & $\mathrm{U}$ & 23 & & 13 & & 10 & $\mathrm{U}$ & 10 & $\mathrm{U}$ \\
\hline Potassium & NA & & NA & & NA & & $\mathrm{NA}$ & & NA & & $\mathrm{NA}$ & & $\mathrm{NA}$ & \\
\hline Selenium & 10 & $U$ & 10 & $\mathrm{U}$ & 10 & $\mathrm{U}$ & 10 & $\mathrm{U}$ & 10 & $\mathrm{U}$ & 10 & $\mathrm{U}$ & 10 & $U$ \\
\hline Silver & 10 & $U$ & 10 & $\mathrm{U}$ & 10 & $\mathrm{U}$ & 10 & $\mathrm{U}$ & 10 & $\mathrm{U}$ & 10 & $\mathrm{U}$ & 10 & $U$ \\
\hline Sodium & $\mathrm{NA}$ & & NA & & $\mathrm{NA}$ & & $\mathrm{NA}$ & & $\mathrm{NA}$ & & $\mathrm{NA}$ & & NA & \\
\hline Thallium & NA & & NA & & NA & & $\mathrm{NA}$ & & $\mathrm{NA}$ & & NA & & NA & \\
\hline Vanadium & 24 & & 27 & & 29 & & 39 & & 41 & & 26 & & 35 & \\
\hline Zinc & 432 & & 71 & & 19 & & 361 & & 17 & & 31 & & 32 & \\
\hline
\end{tabular}


TABLE C.15d (Cont.)

\begin{tabular}{|c|c|c|c|c|c|c|c|c|c|c|}
\hline \multirow[b]{2}{*}{ Parameter } & \multicolumn{10}{|c|}{ Soil Concentrations (mg/kg) at Various Depth Intervals } \\
\hline & \multicolumn{2}{|c|}{$\begin{array}{l}\text { VXBOR1 } \\
(0-2 \mathrm{ft}) \\
\end{array}$} & \multicolumn{2}{|c|}{$\begin{array}{c}\text { VXBOR1 } \\
(4-6 \mathrm{ft}) \\
\end{array}$} & \multicolumn{2}{|c|}{$\begin{array}{c}\text { VXBOR1 } \\
(6-8 \mathrm{ft}) \\
\end{array}$} & $\begin{array}{c}\text { VXBOR2 } \\
(0-2 \mathrm{ft})\end{array}$ & $\begin{array}{c}\text { VXBOR2 } \\
(2-4 \mathrm{ft})\end{array}$ & $\begin{array}{c}\text { VXBOR2 } \\
(4-6 \mathrm{ft})\end{array}$ & $\begin{array}{c}\text { VXBOR2 } \\
(6-8 \mathrm{ft})\end{array}$ \\
\hline \multicolumn{11}{|l|}{ Other Parameters } \\
\hline Cyanide (total) & \multicolumn{2}{|l|}{ NA } & \multicolumn{2}{|l|}{ NA } & \multicolumn{2}{|l|}{ NA } & NA & NA & NA & NA \\
\hline $\mathrm{pH}$ & \multicolumn{2}{|l|}{ NA } & \multicolumn{2}{|l|}{ NA } & \multicolumn{2}{|l|}{ NA } & NA & NA & NA & NA \\
\hline Solids (\%) & \multicolumn{2}{|l|}{ NA } & \multicolumn{2}{|l|}{ NA } & \multicolumn{2}{|l|}{ NA } & NA & NA & NA & NA \\
\hline & \multicolumn{6}{|c|}{ Soil Concentrations (mg/kg) at Various Depth Intervals } & & & & \\
\hline Parameter & \multicolumn{2}{|c|}{$\begin{array}{l}\text { VXBOR2 } \\
(8-10 \mathrm{ft}) \\
\end{array}$} & \multicolumn{2}{|c|}{$\begin{array}{l}\text { VXBOR2 } \\
(10-12 \mathrm{ft}) \\
\end{array}$} & \multicolumn{2}{|c|}{$\begin{array}{c}\text { VXBOR2-Dup } \\
(10-12 \mathrm{ft})\end{array}$} & & & & \\
\hline \multicolumn{11}{|l|}{ Metals } \\
\hline Aluminum & NA & & NA & & NA & & & & & \\
\hline Antimony & NA & & NA & & NA & & & & & \\
\hline Arsenic & 10 & $\mathrm{U}$ & 10 & $\mathrm{U}$ & 10 & $U$ & & & & \\
\hline Barium & 38 & & 45 & & 42 & & & & & \\
\hline Beryllium & $\mathrm{NA}$ & & $\mathrm{NA}$ & & NA & & & & & \\
\hline Cadmium & 10 & $\mathrm{U}$ & 10 & $\mathrm{U}$ & 10 & $\mathrm{U}$ & & & & \\
\hline Calcium & NA & & NA & & $\mathrm{NA}$ & & & & & \\
\hline Chromium & 10 & $\mathrm{U}$ & 17 & & 13 & & & & & \\
\hline Cobalt & $\mathrm{NA}$ & & $\mathrm{NA}$ & & $\mathrm{NA}$ & & & & & \\
\hline Copper & 10 & $\mathrm{U}$ & 10 & U & 10 & $U$ & & & & \\
\hline Iron & NA & & $\mathrm{NA}$ & & $\mathrm{NA}$ & & & & & \\
\hline Lead & 10 & $\mathrm{U}$ & 10 & $U$ & 10 & $U$ & & & & \\
\hline Magnesium: & $\mathrm{NA}$ & & NA & & $\mathrm{NA}$ & & & & & \\
\hline Manganese & $\mathrm{NA}$ & & $\mathrm{NA}$ & & $\mathrm{NA}$ & & & & & \\
\hline
\end{tabular}


TABLE C.15d (Cont.)

\begin{tabular}{|c|c|c|c|c|c|c|c|c|c|c|c|}
\hline \multirow[b]{2}{*}{ Parameter } & \multicolumn{6}{|c|}{ Soil Concentrations $(\mathrm{mg} / \mathrm{kg}$ ) at Various Depth Intervals } & & & & & \\
\hline & \multicolumn{2}{|c|}{$\begin{array}{l}\text { VXBOR2 } \\
(8-10 \mathrm{ft})\end{array}$} & \multicolumn{2}{|c|}{$\begin{array}{l}\text { VXBOR2 } \\
(10-12 \mathrm{ft}) \\
\end{array}$} & \multicolumn{2}{|c|}{$\begin{array}{c}\text { VXBOR2-Dup } \\
(10-12 \mathrm{ft})\end{array}$} & & & & & \\
\hline \multicolumn{12}{|l|}{ Metals (Cont.) } \\
\hline Mercury & 10 & $\mathrm{U}$ & 10 & $U$ & 10 & $\mathrm{U}$ & & & & & \\
\hline Nickel & 10 & $\mathrm{U}$ & 10 & $\mathrm{U}$ & 10 & $U$ & & & & & \\
\hline Potassium & NA & & NA & & NA & & & & & & \\
\hline Selenium & 10 & $\mathrm{U}$ & 10 & $\mathrm{U}$ & 10 & $\mathrm{U}$ & & & & & \\
\hline Silver & 10 & $\mathrm{U}$ & 10 & $\mathrm{U}$ & 10 & $U$ & & & & & \\
\hline Sodium & NA & & $\mathrm{NA}$ & & NA & & & & & & \\
\hline Thallium & NA & & NA & & NA & & & & & & \\
\hline Vanadium & 21 & & 25 & & 19 & & & & & & \\
\hline Zinc & 42 & & 63 & & 55 & & & & & & \\
\hline \multicolumn{12}{|l|}{ Other Parameters } \\
\hline Cyanide (total) & \multicolumn{2}{|l|}{ NA } & NA & & \multicolumn{2}{|l|}{ NA } & & & & & \\
\hline $\mathrm{pH}$ & \multicolumn{2}{|l|}{ NA } & NA & & \multicolumn{2}{|l|}{ NA } & & & & & \\
\hline Solids (\%) & \multicolumn{2}{|l|}{ NA } & NA & & \multicolumn{2}{|l|}{ NA } & & & & & \\
\hline & \multicolumn{11}{|c|}{ Soil Concentrations $(\mathrm{mg} / \mathrm{kg}$ ) at Various Depth Intervals } \\
\hline Parameter & \multicolumn{2}{|c|}{$\begin{array}{c}\text { VXBOR4 } \\
(2-4 \mathrm{ft})\end{array}$} & \multicolumn{2}{|c|}{$\begin{array}{c}\text { VXBOR4 } \\
(4-6 \mathrm{ft})\end{array}$} & \multicolumn{2}{|c|}{$\begin{array}{l}\text { VXBOR5 } \\
(0-2 \mathrm{ft})\end{array}$} & $\begin{array}{l}\text { VXBOR5 } \\
(4-6 \mathrm{ft})\end{array}$ & \multicolumn{2}{|c|}{$\begin{array}{c}\text { VXBOR5 } \\
(6-8 \mathrm{ft}) \\
\end{array}$} & $\begin{array}{l}\text { VXB } \\
(8-1\end{array}$ & $\begin{array}{l}\text { OR5 } \\
\mathrm{ft})\end{array}$ \\
\hline \multicolumn{12}{|l|}{ Metals } \\
\hline Aluminum & 22,200 & $\mathrm{E}$ & 3,360 & & 6,890 & & 6,950 & 1,810 & & 4,420 & \\
\hline Antimony & 112 & $\mathrm{NJ}$ & 0.691 & & 0.206 & UNJ & 0.485 & 0.209 & $\mathrm{U}$ & 0.211 & UNJ \\
\hline Arsenic & 18.9 & & 0.905 & & 6.09 & & 4.54 & 0.568 & & 1.94 & \\
\hline
\end{tabular}


TABLE C.15d (Cont.)

\begin{tabular}{|c|c|c|c|c|c|c|c|c|c|c|c|c|}
\hline \multirow{3}{*}{$\frac{\text { Parameter }}{\text { Metals (Cont.) }}$} & \multicolumn{12}{|c|}{ Soil Concentrations (mg/kg) at Various Depth Intervals } \\
\hline & \multicolumn{2}{|c|}{$\begin{array}{c}\text { VXBOR4 } \\
(2-4 \mathrm{ft}) \\
\end{array}$} & \multicolumn{2}{|c|}{$\begin{array}{c}\text { VXBOR4 } \\
(4-6 \mathrm{ft})\end{array}$} & \multicolumn{2}{|c|}{$\begin{array}{l}\text { VXBOR5 } \\
(0-2 \mathrm{ft})\end{array}$} & \multicolumn{2}{|c|}{$\begin{array}{l}\text { VXBOR5 } \\
(4-6 \mathrm{ft})\end{array}$} & \multicolumn{2}{|c|}{$\begin{array}{c}\text { VXBOR5 } \\
(6-8 \mathrm{ft})\end{array}$} & \multicolumn{2}{|c|}{$\begin{array}{l}\text { VXBOR5 } \\
(8-10 \mathrm{ft})\end{array}$} \\
\hline & & & & & & & & & & & & \\
\hline Barium & 2.93 & $\mathrm{U}$ & 17 & & 235 & $@ \mathrm{~J}$ & 1,410 & & 7.75 & & 17.6 & $@ \mathrm{~J}$ \\
\hline Beryllium & 0.14 & $\mathrm{U}$ & 0.135 & $U$ & 0.195 & & 0.143 & $U$ & 0.135 & $\mathrm{U}$ & 0.217 & \\
\hline Cadmium & 2.65 & & 0.49 & $U$ & 1.72 & @J & 3.33 & & 0.368 & $\mathrm{U}$ & 0.372 & U@J \\
\hline Calcium & 14,800 & & 377 & & 648 & E@ & 1,680 & & 175 & & 373 & E@ \\
\hline Chromium & 37.9 & & 6.28 & & 15.3 & @J & 43.3 & & 1.76 & & 9.22 & @J \\
\hline Cobalt & 3.99 & & 2.17 & & 5.2 & & 5.32 & & 3.01 & & 3.86 & \\
\hline Copper & 1,110 & & 33.7 & & 51.4 & $@ J$ & 218 & & 2.82 & $U$ & 3.78 & @J \\
\hline Iron & 16,900 & $\mathrm{E}$ & 4,930 & & 9,600 & $\mathrm{E}$ & 13,800 & & 3,040 & & 10,200 & $\mathrm{E}$ \\
\hline Lead & 1,690 & $@ \mathbf{J}$ & 13.7 & & 27.5 & @J & 26.3 & & 2.17 & & 2.77 & @J \\
\hline Magnesium & 2,460 & & 838 & & 2,480 & & 11,100 & & 504 & & 925 & \\
\hline Manganese & 223 & & 36.1 & & 61.4 & @J & 146 & & 21.5 & & 37.6 & @J \\
\hline Mercury & 0.426 & & 0.021 & $\mathrm{U}$ & 0.34 & & 0.263 & & 0.052 & $\mathrm{U}$ & 0.054 & $\mathrm{U}$ \\
\hline Nickel & 55.2 & & 3.89 & & 6.13 & & 16 & & 3.23 & & 4.3 & \\
\hline Potassium & 611 & & 332 & & 385 & & 372 & & 152 & & 476 & \\
\hline Selenium & 0.34 & $\mathrm{NJ}$ & 0.196 & $U$ & 0.29 & & 0.208 & $\mathrm{U}$ & 0.196 & $\mathrm{U}$ & 0.198 & U \\
\hline Silver & 2.51 & & 1.02 & & 0.085 & UWJ & 0.11 & & 0.086 & $\mathrm{U}$ & 0.087 & $U$ \\
\hline Sodium & 102 & & 20.8 & $U$ & 41.6 & & 55 & & 28 & & 42.7 & \\
\hline Thallium & 0.356 & $U$ & 0.343 & $\mathrm{U}$ & 0.338 & $\mathrm{U}$ & 0.364 & $\mathrm{U}$ & 0.344 & $U$ & 0.347 & $U$ \\
\hline Vanadium & 28.8 & & 5.02 & & 9.74 & & 8.83 & & 3.56 & $\mathrm{U}$ & 7.61 & \\
\hline Zinc & 2,320 & & 37.8 & & 223 & EN@ & 342 & & 11.9 & & 17.3 & EN@ \\
\hline
\end{tabular}


TABLE C.15d (Cont.)

\begin{tabular}{|c|c|c|c|c|c|c|c|}
\hline \multirow[b]{2}{*}{ Parameter } & \multicolumn{7}{|c|}{ Soil Concentrations (mg $/ \mathrm{kg}$ ) at Various Depth Intervals } \\
\hline & \multicolumn{2}{|c|}{$\begin{array}{c}\text { VXBOR4 } \\
(2-4 \mathrm{ft}) \\
\end{array}$} & $\begin{array}{c}\text { VXBOR4 } \\
(4-6 \mathrm{ft})\end{array}$ & $\begin{array}{l}\text { VXBOR5 } \\
(0-2 \mathrm{ft})\end{array}$ & $\begin{array}{l}\text { VXBOR5 } \\
(4-6 \mathrm{ft})\end{array}$ & $\begin{array}{c}\text { VXBOR5 } \\
(6-8 \mathrm{ft})\end{array}$ & $\begin{array}{l}\text { VXBOR5 } \\
(8-10 \mathrm{ft})\end{array}$ \\
\hline \multicolumn{8}{|l|}{ Other Parameters } \\
\hline Cyanide (total) & 2.63 & & $1.22 \mathrm{U}$ & $1.21 \mathrm{UNJ}$ & 1.3 & $1.23 \mathrm{U}$ & 1.24 UNJ \\
\hline $\mathrm{pH}$ & 7.35 & & 7.54 & 7.39 & 8.99 & 7.74 & 7.62 \\
\hline Solids (\%) & 78.6 & & 81.7 & 82.7 & 76.8 & 81.4 & 80.6 \\
\hline & \multicolumn{7}{|c|}{ Soil Concentrations $(\mathrm{mg} / \mathrm{kg})$ at $0-6 \mathrm{in}$. } \\
\hline Parameter & SQP & $S 1$ & SQPS 2 & SQPS 3 & SQPS 4 & SQPS 5 & SQPS 6 \\
\hline \multicolumn{8}{|l|}{ Metals } \\
\hline Aluminum & 4,240 & & 8,600 & 13,300 & 13,000 & 7,890 & 11,000 \\
\hline Antimony & 0.212 & $\mathrm{U}$ & 0.559 & 1.04 & 0.598 & 0.94 & 0.445 \\
\hline Arsenic & 0.224 & $\mathrm{U}$ & 2.96 & 4.96 & 3.59 & 2.71 & 3.02 \\
\hline Barium & 94.9 & & 183 & 323 & 148 & 124 & 166 \\
\hline Beryllium & 1.38 & & 0.419 & 0.539 & 0.411 & 0.298 & 0.517 \\
\hline Cadmium & 1.8 & & 1.43 & 1.99 & 2.06 & 1.23 & 1.41 \\
\hline Calcium & 6,320 & 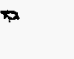 & 1,210 & 974 & 1,250 & 385 & 847 \\
\hline Chromium & 34.4 & & 67.4 & 85 & 70.5 & 92 & 38.9 \\
\hline Cobalt & 11.1 & & 4.45 & 4.78 & 4.86 & 2.19 & 4.9 \\
\hline Copper & 98.3 & & 216 & 267 & 215 & 355 & 120 \\
\hline Iron & 11,200 & & 13,600 & 21,400 & $17,000^{\circ}$ & 12,300 & 12,300 \\
\hline Lead & 229 & & 65.8 & 91.6 & 95.1 & 69.8 & 70.4 \\
\hline Magnesium & 2,740 & & 1,540 & 1,710 & 1,700 & 912 & 1,480 \\
\hline Manganese & 81.6 & & 170 & 262 & 158 & 99.9 & 234 \\
\hline
\end{tabular}


TABLE C.15d (Cont.)

\begin{tabular}{|c|c|c|c|c|c|c|c|c|c|c|c|c|}
\hline \multirow{3}{*}{$\frac{\text { Parameter }}{\text { Metals (Cont.) }}$} & \multicolumn{12}{|c|}{ Soil Concentrations $(\mathrm{mg} / \mathrm{kg})$ at $0-6$ in. } \\
\hline & \multicolumn{2}{|c|}{ SQPS 1} & \multicolumn{2}{|c|}{ SQPS 2} & \multicolumn{2}{|c|}{ SQPS 3} & \multicolumn{2}{|c|}{ SQPS 4} & \multicolumn{2}{|c|}{ SQPS 5} & \multicolumn{2}{|c|}{ SQPS 6} \\
\hline & & & & & & & & & & & & \\
\hline Mercury & 0.086 & & 0.123 & & 0.163 & & 0.166 & & 0.244 & & 0.104 & \\
\hline Nickel & 3.96 & & 8.77 & & 13.4 & & 8.3 & & 6.05 & & 8.87 & \\
\hline Potassium & 1,100 & & 396 & & 360 & & 393 & & 298 & & 432 & \\
\hline Selenium & 0.2 & $\mathrm{U}$ & 0.73 & & 0.438 & & 0.227 & $U$ & 0.263 & & 0.46 & \\
\hline Silver & 2.18 & & 3.97 & & 3.15 & & 3.32 & & 4.17 & & 1.92 & \\
\hline Sodium & 47 & & 71.8 & & 73.5 & & 84 & & 60.1 & & 59.5 & \\
\hline Thallium & 0.349 & $\mathrm{U}$ & 0.339 & $U$ & 0.347 & $\mathrm{U}$ & 0.397 & $U$ & 0.347 & $\mathrm{U}$ & 0.344 & $\mathrm{U}$ \\
\hline Vanadium & 4.98 & & 14 & & 18.5 & & $22: 1$ & & 14 & & 18.1 & \\
\hline Zinc & 78.6 & & 233 & & 603 & & 542 & & 148 & & 353 & \\
\hline \multicolumn{13}{|l|}{ Other Parameters } \\
\hline Cyanide (total) & 1.25 & $\mathrm{U}$ & NA & & NA & & NA & & NA & & NA & \\
\hline $\mathrm{pH}$ & 5.39 & & NA & & $\mathrm{NA}$ & & $\mathrm{NA}$ & & 5.12 & & $\mathrm{NA}$ & \\
\hline Solids (\%) & 80.2 & & 82.6 & & 80.6 & & 70.6 & & 81.6 & & 81.5 & \\
\hline
\end{tabular}

Soil Concentrations $(\mathrm{mg} / \mathrm{kg})$ at $0-6 \mathrm{in}$.

\begin{tabular}{lccc}
\cline { 2 - 4 } Parameter & SQPS 7 & SQPS-8 & SQPS 9 \\
\hline Metals & & & \\
Aluminum & 9,620 & 6,610 & 13100 \\
Antimony & 0.239 & 2.72 & 2.7 \\
Arsenic & 3.77 & 21.2 & 60.5 \\
Barium & 142 & 261 & 286
\end{tabular}


TABLE C.15d (Cont.)

\begin{tabular}{|c|c|c|c|c|}
\hline \multirow[b]{2}{*}{ Parameter } & \multicolumn{3}{|c|}{ Soil Concentrations ( $\mathrm{mg} / \mathrm{kg}$ ) at $0-6 \mathrm{in}$. } & \\
\hline & SQPS 7 & SQPS-8 & \multirow[t]{2}{*}{ SQPS 9} & \\
\hline \multicolumn{4}{|l|}{ Metals (Cont.) } & \\
\hline Beryllium & 0.527 & 0.298 & 0.309 & $\cdot$ \\
\hline Cadmium & 1.75 & 20.7 & 19.2 & \\
\hline Calcium & 1,330 & 4,610 & 1,360 & \\
\hline Chromium & 25.6 & 42.2 & 42.8 & \\
\hline Cobait & 4.69 & 3.82 & 4.12 & \\
\hline Copper & 65.2 & 561 & 758 & \\
\hline Iron & 14,700 & 31,800 & 32,700 & \\
\hline Lead & 63.5 & 165 & 289 & \\
\hline Magnesium & 1,140 & 1,580 & 2,120 & \\
\hline Manganese & 270 & 254 & 372 & \\
\hline Mercury & 0.09 & 0.242 & 0.25 & \\
\hline Nickel & 7.8 & 14 & 18.1 & \\
\hline Potassium & 361 & 547 & 316 & \\
\hline Selenium & 0.474 & 0.714 & 0.484 & 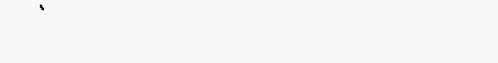 \\
\hline Silver & 1.84 & 5.56 & 15.1 & \\
\hline Sodium & 77.1 & 80.8 & 53 & \\
\hline Thallium & $0.364 \quad \mathrm{U}$ & 0.589 & 0.386 & \\
\hline Vanadium & 15.9 & 12.3 & 10.8 & \\
\hline Zinc & 420 & 7,970 & 5,340 & \\
\hline \multicolumn{5}{|l|}{ Other Parameters } \\
\hline Cyanide (total) & NA & $2.1 \mathrm{U}$ & $\mathrm{NA}$ & \\
\hline $\mathrm{pH}$ & NA & 4.69 & $\mathrm{NA}$ & \\
\hline Solids (\%) & 76.9 & 45.0 & 72.5 & \\
\hline
\end{tabular}


TABLE C.15d (Cont.)

\begin{tabular}{|c|c|c|c|c|c|c|c|c|c|c|c|c|}
\hline \multirow[b]{2}{*}{ Parameter } & \multicolumn{12}{|c|}{ Soil Concentrations $(\mathrm{mg} / \mathrm{kg})$ at $0-6 \mathrm{in}$. } \\
\hline & \multicolumn{2}{|c|}{ TPDGS 1} & \multicolumn{2}{|c|}{ TPDGS 2} & \multicolumn{2}{|c|}{ TPDGS 3} & \multicolumn{2}{|c|}{ TPDGS 4} & \multicolumn{2}{|c|}{ TPDGS 5} & \multicolumn{2}{|c|}{ TPDGS 6} \\
\hline \multicolumn{13}{|l|}{ Metals } \\
\hline Aluminum & 8,650 & & 11,600 & & 8,490 & & 13,900 & & 11,400 & & 15,700 & \\
\hline Antimony & 0.921 & & 0.512 & & 0.212 & $\mathrm{U}$ & 0.213 & $\mathrm{U}$ & 0.207 & $\mathrm{U}$ & 0.209 & $\mathrm{U}$ \\
\hline Arsenic & 3.36 & & 4.02 & & 3.17 & & 3.63 & & 3.34 & & 4.18 & \\
\hline Barium & 82.3 & & 120 & & 71.4 & & 90.9 & & 75.9 & & 77.4 & \\
\hline Beryllium & 0.524 & & 0.539 & & 0.61 & & 0.546 & & 0.51 & & 0.494 & \\
\hline Cadmium & 1.1 & & 0.918 & & 0.682 & & 0.926 & & 0.898 & & 1.07 & \\
\hline Calcium & 25,300 & & 22,200 & & 4,300 & & 2,410 & & 36,000 & & 2,590 & \\
\hline Chromium & 12 & & 17.5 & & 9.11 & & 13.5 & & 13.4 & & 15.1 & \\
\hline Cobalt & 3.2 & & 3.54 & & 3.78 & & 4.35 & & 5.05 & & 6.05 & \\
\hline Copper & 32.9 & & 128 & & 11.7 & & 18 & & 15 & & 10.7 & \\
\hline Iron & 11,600 & & 9,130 & & 10,400 & & 20,800 & & 17,300 & & 21,100 & \\
\hline Lead & 57.1 & & 53.3 & & 25.2 & & 23.5 & & 11.7 & & 17.6 & \\
\hline Magnesium & 1,080 & & 1150 & & 944 & & 1,220 & & 1,880 & & 1,600 & \\
\hline Manganese & 253 & & 202 & & 222 & & 201 & & 189 & & 209 & \\
\hline Mercury & 0.06 & $\mathrm{U}$ & 0.055 & $\mathrm{U}$ & 0.06 & $\mathrm{U}$ & 0.052 & & 0.06 & $\mathrm{U}$ & 0.06 & $\mathrm{U}$ \\
\hline Nickel & 7.2 & & 16.2 & & 6.46 & & 8.38 & & 7 & & 9.53 & \\
\hline Potassium & 367 & & 307 & & 300 & & 394 & & 459 & & 569 & \\
\hline Selenium & 0.244 & & 0.185 & $\mathbf{U}$ & 0.292 & & 0.293 & & 0.206 & & 0.341 & \\
\hline Silver & 0.085 & $U$ & 0.081 & $U$ & 0.118 & & 0.088 & $U$ & 0.085 & $\mathrm{U}$ & 0.086 & $\mathrm{U}$ \\
\hline Sodium & 151 & & 169 & & 101 & & 101 & & 204 & & 72.8 & \\
\hline Thallium & 0.34 & $\mathrm{U}$ & 0.324 & $\mathrm{U}$ & 0.35 & $\mathrm{U}$ & 0.35 & $\mathrm{U}$ & 0.341 & $\mathrm{U}$ & 0.344 & $\mathrm{U}$ \\
\hline Vanadium & 13.9 & & 12.2 & & 11.8 & & 18.5 & & 19.4 & & 21.9 & \\
\hline Zinc $\quad \cdot$ & 94.4 & & 79.3 & & 45.5 & & 68 & & 44.4 & & 49.8 & \\
\hline
\end{tabular}


TABLE C.15d (Cont.)

Soil Concentrations $(\mathrm{mg} / \mathrm{kg})$ at $0-6 \mathrm{in}$

\begin{tabular}{|c|c|c|c|c|c|c|}
\hline Parameter & TPDGS 1 & TPDGS 2 & TPDDGS 3 & TPDGS 4 & TPDGS 5 & TPDGS 6 \\
\hline Cyanide (total) & 1.21 & 1.16 & NA & NA & NA & NA \\
\hline $\mathrm{pH}$ & NA & NA & NA & NA & NA & NA \\
\hline Solids (\%) & 82.4 & 86.3 & 80 & 79.9 & 82 & 81.4 \\
\hline
\end{tabular}

a Sampled by ANL and analyzed by GP Environmental Services.

Data qualifiers:

$\mathrm{N}$ = spike and spike duplicate recovery of percent RPD were outside the control limits.

$\mathrm{J}=$ estimated value.

@ = percent RPD of sample duplicate was outside the control limits.

$\mathrm{E}=$ serial dilution percent difference was outside the $\mathrm{QC}$ limit.

$\mathrm{U}=$ analyte was analyzed for but not detected; detection limit given.

$\mathrm{NA}=$ not analyzed. 
TABLE C.16a Pesticide and PCB Analyses for Soil Borings, January $1993^{\mathrm{a}}$

\begin{tabular}{|c|c|c|c|c|c|c|c|c|c|c|c|c|c|c|c|c|}
\hline \multirow[b]{2}{*}{ Compound } & \multicolumn{16}{|c|}{ Borehole Concentrations $(\mu \mathrm{g} / \mathrm{kg})$ at Various Depth Intervals } \\
\hline & \multicolumn{2}{|c|}{ JBP1-E-2' } & \multicolumn{2}{|c|}{ JBP1-E-2'Dup } & \multicolumn{2}{|c|}{ JBP1-E-4' } & \multicolumn{2}{|c|}{ JBP1-W-2' } & \multicolumn{2}{|c|}{ JBP1-W-4' } & \multicolumn{2}{|c|}{ JBP2-E-2' } & \multicolumn{2}{|c|}{ JBP2-E-4' } & \multicolumn{2}{|c|}{ JBP2-E-4'Dup } \\
\hline Aldrin & 819 & $\mathrm{U}$ & 80 & $\mathrm{U}$ & 8 & $U$ & 2 & $\mathrm{U}$ & 2 & $\mathrm{U}$ & $2^{\circ}$ & $\mathrm{U}$ & 2 & $\mathrm{U}$ & 2 & $U$ \\
\hline alpha-BHC & 617 & $\mathrm{U}$ & 60 & $\mathrm{U}$ & 6 & $U$ & 1 & $\mathrm{U}$ & 1 & U & 1 & $U$ & 1 & $\mathrm{U}$ & 1 & $U$ \\
\hline Aroclor 1016 & 10,200 & $\mathrm{U}$ & 996 & $\mathrm{U}$ & 102 & $U$ & 20 & $\mathrm{U}$ & 21 & $\mathrm{U}$ & 20 & $\mathrm{U}$ & 20 & $\mathrm{U}$ & 20 & $U$ \\
\hline Aroclor 1221 & 10,200 & $\mathrm{U}$ & 996 & $\mathrm{U}$ & 102 & $U$ & 20 & $U$ & 21 & $U$ & 20 & $U$ & 20 & $\mathrm{U}$ & 20 & $U$ \\
\hline Aroclor 1232 & 10,200 & $\mathrm{U}$ & 996 & $\mathrm{U}$ & 102 & $\mathrm{U}$ & 20 & $\mathrm{U}$ & 21 & $U$ & 20 & $\mathrm{U}$ & 20 & $\mathrm{U}$ & 20 & $\mathrm{U}$ \\
\hline Aroclor 1242 & 13,300 & $\mathbf{U}$ & 1,300 & $\mathrm{U}$ & 133 & $\mathrm{U}$ & 27 & $U$ & 27 & $U$ & 26 & $\mathrm{U}$ & 26 & $\mathrm{U}$ & 26 & $U$ \\
\hline Aroclor 1248 & 143,000 & & 14,900 & & 1,180 & & 41 & $U$ & 42 & $\mathrm{U}$ & 40 & $\mathrm{U}$ & 40 & $\mathrm{U}$ & 40 & $U$ \\
\hline Aroclor 1254 & 20,500 & U & 1,990 & $\mathrm{U}$ & 204 & $\mathrm{U}$ & 41 & $\mathrm{U}$ & 42 & $\mathrm{U}$ & 224 & & 40 & $U$ & 40 & $\mathrm{U}$ \\
\hline Aroclor 1260 & 20,500 & $\mathrm{U}$ & 1,990 & $\mathrm{U}$ & 204 & $\mathrm{U}$ & 41 & $\mathrm{U}$ & 42 & $\mathrm{U}$ & 40 & $\mathrm{U}$ & 40 & U & 40 & $\mathrm{U}$ \\
\hline beta-BHC & 1,230 & $\mathrm{U}$ & 119 & $\mathrm{U}$ & 12 & $\mathrm{U}$ & 2 & $U$ & 2 & $\mathrm{U}$ & 2 & $\mathrm{U}$ & 2 & $\mathrm{U}$ & 2 & $\mathrm{U}$ \\
\hline Chlordane & 2,870 & $\mathrm{U}$ & 279 & $\mathrm{U}$ & 29 & $\mathrm{U}$ & 6 & $U$ & 6 & $\mathrm{U}$ & 6 & $\mathrm{U}$ & 6 & $\mathrm{U}$ & 6 & $\mathrm{U}$ \\
\hline 4,4'-DDD & 2,260 & $\mathrm{U}$ & 219 & $\mathrm{U}$ & 23 & $\mathrm{U}$ & 5 & $U$ & 5 & $\mathrm{U}$ & 4 & $\mathrm{U}$ & 4 & $U$ & 4 & $\mathrm{U}$ \\
\hline 4,4'-DDE & 819 & $\mathrm{U}$ & 80 & $U$ & 8 & $\mathrm{U}$ & 2 & $U$ & 2 & $\mathrm{U}$ & 2 & $\mathrm{U}$ & 2 & $\mathrm{U}$ & 2 & $\mathrm{U}$ \\
\hline 4,4'-DDT & 2,460 & $\mathrm{U}$ & 239 & $\mathrm{U}$ & 25 & $U$ & 5 & $\mathrm{U}$ & 5 & $U$ & 5 & $\mathrm{U}$ & 5 & $\mathrm{U}$ & 5 & $U$ \\
\hline delta-BHC & 1,840 & $U$ & 179 & $U$ & 18 & $\mathrm{U}$ & 4 & $\mathbf{U}$ & 4 & $U$ & 4 & $\mathrm{U}$ & 4 & $\mathrm{U}$ & 4 & $U$ \\
\hline Dieldrin & 409 & $U$ & 40 & $\mathrm{U}$ & 4 & $\mathrm{U}$ & 0.8 & $\mathrm{U}$ & 0.8 & $U$ & 0.8 & $\mathrm{U}$ & 0.8 & $\mathrm{U}$ & 0.8 & $\mathrm{U}$ \\
\hline Endosulfan I & 2,870 & $U$ & 279 & $\mathrm{U}$ & 29 & $U$ & 6 & $\mathrm{U}$ & 6 & $\mathrm{U}$ & 6 & $U$ & 6 & $U$ & 6 & $\mathrm{U}$ \\
\hline Endosulfan II & 819 & $U$ & 80 & $\mathrm{U}$ & 8 & $\mathrm{U}$ & 2 & $\mathrm{U}$ & 2 & $\mathrm{U}$ & 2 & $U$ & 2 & $U$ & 2 & $\mathrm{U}$ \\
\hline Endosulfan sulfate & 13,500 & $\mathrm{U}$ & 1,320 & $\mathrm{U}$ & 135 & $\mathrm{U}$ & 27 & $U$ & 27 & $\mathrm{U}$ & 26 & $U$ & 27 & $U$ & 26 & $\mathrm{U}$ \\
\hline Endrin & 1,230 & $\mathrm{U}$ & 119 & $\mathrm{U}$ & 12 & $\mathrm{U}$ & 2 & $\mathrm{U}$ & 2 & $\mathrm{U}$ & 2 & $\mathrm{U}$ & 2 & $\mathrm{U}$ & 2 & $\mathrm{U}$ \\
\hline Endrin aldehyde & 4,710 & $U$ & 458 & $U$ & 47 & $\mathrm{U}$ & 9 & $U$ & 10 & $\mathrm{U}$ & 9 & $\mathrm{U}$ & 9 & $U$ & 9 & $U$ \\
\hline gamma-BHC (Lindane) & 819 & $\mathrm{U}$ & 80 & $\mathrm{U}$ & 8 & $U$ & 2 & $\mathrm{U}$ & 2 & $U$ & 2 & $U$ & 2 & $U$ & 2 & $U$ \\
\hline Heptachlor & 617 & $U$ & 60 & $\mathrm{U}$ & 6 & $\mathrm{U}$ & 1 & $\mathrm{U}$ & 1 & $\mathrm{U}$ & 1 & $\mathrm{U}$ & 1 & $\mathrm{U}$ & 1 & $\mathrm{U}$ \\
\hline Heptachlor epoxide & 17,000 & $\mathrm{U}$ & 1,660 & $U$ & 169 & $U$ & 34 & $U$ & 35 & $\mathrm{U}$ & 33 & $U$ & 33 & $\mathrm{U}$ & 33 & $\mathrm{U}$ \\
\hline Methoxychlor & 36,000 & $\mathrm{U}$ & 3,510 & $\mathrm{U}$ & 360 & $U$ & 72 & $U$ & 73 & $U$ & 70 & $U$ & 71 & $\mathrm{U}$ & 70 & $\mathrm{U}^{\prime}$ \\
\hline Toxaphene & 49,100 & $\mathrm{U}$ & 4,780 & $\mathrm{U}$ & 491 & U & 98 & U & 100 & U & 96 & U & 97 & $\mathrm{U}$ & 96 & $\mathrm{U}$ \\
\hline
\end{tabular}


TABLE C.16a (Cont.)

Borehole Concentrations $(\mu \mathrm{g} / \mathrm{kg}$ ) at Various Depth Intervals

\begin{tabular}{|c|c|c|c|c|c|c|c|c|c|c|c|c|c|c|c|c|}
\hline Compound & \multicolumn{2}{|c|}{ JBP2-C-2' } & \multicolumn{2}{|c|}{ JBP2-C-4' } & \multicolumn{2}{|c|}{ JBP2-W-2' } & \multicolumn{2}{|c|}{ JBP2-W-4' } & \multicolumn{2}{|c|}{ JHDP-C-4' } & \multicolumn{2}{|c|}{ JHDP-C-6' } & \multicolumn{2}{|c|}{ JHDP-C-6'Dup } & \multicolumn{2}{|c|}{ JVXP-C-4' } \\
\hline Aldrin & 2 & $\mathrm{U}$ & 2 & $\mathrm{U}$ & 2 & $U$ & 2 & $\mathrm{U}$ & 2 & $\mathrm{U}$ & 2 & $\mathrm{U}$ & 2 & $\mathrm{U}$ & 2 & $\mathbf{U}$ \\
\hline alpha-BHC & 1 & $\mathrm{U}$ & 1 & $\mathrm{U}$ & 1 & $\mathrm{U}$ & 1 & $\mathrm{U}$ & 1 & $\mathrm{U}$ & 1 & $\mathbf{U}$ & 1 & $\mathrm{U}$ & 1 & $\mathrm{U}$ \\
\hline Aroclor 1016 & 23 & $\mathrm{U}$ & 20 & U & 20 & U & 20 & $\mathbf{U}$ & 20 & $U$ & 20 & U & 19 & U & 22 & $\mathrm{U}$ \\
\hline Aroclor 1221 & 23 & $\mathrm{U}$ & 20 & $\mathrm{U}$ & 20 & $U$ & 20 & $\mathrm{U}$ & 20 & $U$ & 20 & $\mathbf{U}$ & 19 & $U$ & 22 & $\mathrm{U}$ \\
\hline Aroclor 1232 & 23 & $\mathrm{U}$ & 20 & $\mathrm{U}$ & 20 & $\mathrm{U}$ & 20 & $\mathrm{U}$ & 20 & $\mathrm{U}$ & 20 & $\mathrm{U}$ & 19 & $U$ & 22 & $\mathrm{U}$ \\
\hline Aroclor 1242 & 30 & $\mathrm{U}$ & 26 & $U$ & 26 & U & 26 & $U$ & 26 & $\mathrm{U}$ & 27 & $\mathrm{U}$ & 24 & $\mathrm{U}$ & 29 & $U$ \\
\hline Aroclor 1248 & 46 & $\mathrm{U}$ & 40 & $\mathrm{U}$ & 40 & $\mathrm{U}$ & 40 & $\mathrm{U}$ & 40 & $\mathrm{U}$ & 77 & & 178 & & 44 & $\mathbf{U}$ \\
\hline Aroclor 1254 & 46 & $\mathrm{U}$ & 40 & $\mathrm{U}$ & 40 & $\mathrm{U}$ & 40 & $U$ & 40 & $\mathrm{U}$ & 41 & $\mathrm{U}$ & 38 & $\mathrm{U}$ & 44 & $\mathrm{U}$ \\
\hline Aroclor 1260 & 46 & $\mathrm{U}$ & 40 & $\mathbf{U}$ & 40 & $\mathrm{U}$ & 40 & $\mathrm{U}$ & 40 & $\mathrm{U}$ & 41 & U & 38 & $\mathrm{U}$ & 44 & $\mathbf{U}$ \\
\hline beta-BंHC & 3 & $\mathrm{U}$ & 2 & $\mathrm{U}$ & 2 & $\mathrm{U}$ & 2 & U & 2 & $U$ & 2 & $U$ & 2 & $\mathbf{U}$ & 3 & $\mathrm{U}$ \\
\hline Chlordane & 6 & $\mathrm{U}$ & 6 & $\mathrm{U}$ & 6 & $U$ & 6 & $\mathrm{U}$ & 6 & $\mathrm{U}$ & 6 & $\mathbf{U}$ & 5 & $\mathrm{U}$ & 6 & $\mathrm{U}$ \\
\hline 4,4'-DDD & 5 & $\mathrm{U}$ & 4 & $\mathrm{U}$ & 4 & $\mathrm{U}$ & 4 & $\mathrm{U}$ & 4 & $\mathrm{U}$ & 7 & & 4 & $\mathrm{U}$ & 5 & $\mathrm{U}$ \\
\hline $4,4^{\circ}-\mathrm{DDE}$ & 2 & $\mathrm{U}$ & 2 & $\mathrm{U}$ & 2 & $\mathrm{U}$ & 2 & $\mathrm{U}$ & 2 & U & 3 & & 3 & & 2 & $\mathrm{U}$ \\
\hline 4,4'-DDT & 6 & $\mathrm{U}$ & 5 & $U$ & 5 & $\mathrm{U}$ & 5 & $\mathrm{U}$ & 8 & & 179 & & 6 & & 5 & $U$ \\
\hline delta-BHC & 4 & $\mathrm{U}$ & 4 & $U$ & 4 & $U$ & 4 & $\mathrm{U}$ & 4 & $\mathrm{U}$ & 4 & $\mathrm{U}$ & 3 & U & 4 & U \\
\hline Dieldrin & 0.9 & $\mathrm{U}$ & 0.8 & $U$ & 0.8 & $\mathrm{U}$ & 0.8 & $\mathrm{U}$ & 0.8 & $\mathrm{U}$ & 0.8 & $\mathrm{U}$ & 0.8 & $\mathrm{U}$ & 0.9 & $U$ \\
\hline Endosulfan I & 6 & $\mathrm{U}$ & 6 & $\mathrm{U}$ & 6 & $\mathrm{U}$ & 6 & $\mathrm{U}$ & 6 & $\mathrm{U}$ & 6 & $\mathrm{U}$ & 5 & $\mathrm{U}$ & 6 & $U$ \\
\hline Endosulfan II & 2 & $\mathrm{U}$ & 2 & $U$ & 2 & $U$ & 2 & $\mathrm{U}$ & 2 & $\mathrm{U}$ & 2 & $\mathrm{U}$ & 2 & $U$ & 2 & $U$ \\
\hline Endosulfan sulfate & 31 & $\mathrm{U}$ & 26 & $\mathrm{U}$ & 27 & $U$ & 26 & $\mathrm{U}$ & 27 & $\mathrm{U}$ & 27 & $\mathrm{U}$ & 25 & $\mathrm{U}$ & 29 & $\mathrm{U}$ \\
\hline Endrin & 3 & $\mathrm{U}$ & 2 & $\mathrm{U}$ & 2 & $\mathrm{U}$ & 2 & $\mathrm{U}$ & 2 & $\mathrm{U}$ & 2 & $\mathrm{U}$ & 2 & $\mathrm{U}$ & 3 & $U$ \\
\hline Endrin aldehyde & 11 & $\mathrm{U}$ & 9 & $\mathrm{U}$ & 9 & $U$ & 9 & $\mathrm{U}$ & 9 & $\mathrm{U}$ & 9 & $\mathrm{U}$ & 9 & $\mathrm{U}$ & 10 & $U$ \\
\hline gamma-BHC (Lindane) & 2 & $U$ & 2 & $\mathrm{U}$ & 2 & $U$ & 2 & $\mathrm{U}$ & 2 & $\mathrm{U}$ & 2 & $\mathrm{U}$ & 2 & $\mathrm{U}$ & 2 & $\mathrm{U}$ \\
\hline Heptachlor & 1 & $U$ & 1 & $U$ & 1 & $\mathrm{U}$ & 1 & $\mathrm{U}$ & 1 & $\mathrm{U}$ & 1 & $U$ & 1 & $\mathrm{U}$ & 1 & $U$ \\
\hline Heptachlor epoxide & 38 & $U$ & 33 & $U$ & 33 & $\mathrm{U}$ & 33 & $\mathrm{U}$ & 33 & $\mathbf{U}$ & 34 & $\mathrm{U}$ & 31 & $U$ & 37 & $\mathrm{U}$ \\
\hline Methoxychlor & 81 & $U$ & .70 & $\mathrm{U}$ & 71 & $\mathrm{U}$ & 70 & $U$ & 71 & $\mathrm{U}$ & 72 & $\mathrm{U}$ & 66 & $\mathrm{U}$ & 78 & $\mathrm{U}$ \\
\hline Toxaphene & 110 & $U$ & 96 & $\underline{U}$ & 97 & $\mathrm{U}$ & 96 & $\mathrm{U}$ & 97 & $\mathrm{U}$ & 98 & $\mathrm{U}$ & 90 & $\mathrm{U}$ & 106 & U \\
\hline
\end{tabular}


TABLE C.16a (Cont.)

\begin{tabular}{|c|c|c|c|c|c|c|c|c|c|c|c|c|c|c|c|c|}
\hline \multirow{3}{*}{$\begin{array}{l}\text { Compound } \\
\text { Aldrin }\end{array}$} & \multicolumn{16}{|c|}{ Borehole Concentrations $(\mu \mathrm{g} / \mathrm{kg})$ at Various Depth Intervals } \\
\hline & \multicolumn{2}{|c|}{ JVXP-C-6' } & \multicolumn{2}{|c|}{ JSDP-C-4' } & \multicolumn{2}{|c|}{ JSDP-C-6' } & \multicolumn{2}{|c|}{ JBPM-A-3" } & \multicolumn{2}{|c|}{ JBPM-A-3"Dup } & \multicolumn{2}{|c|}{ JBPM-A-1' } & \multicolumn{2}{|c|}{ JBPM-B-3" } & \multicolumn{2}{|c|}{ JBPM-B-1' } \\
\hline & 2 & U & 2 & U & 2 & $\mathrm{U}$ & 2 & $U$ & 2 & $\mathrm{U}$ & 2 & $\mathrm{U}$ & 2 & $\mathrm{U}$ & 2 & $\mathrm{U}$ \\
\hline alpha-BHC & 1 & $\mathrm{U}$ & 1 & $U$ & 1 & $\mathrm{U}$ & 1 & $U$ & 1 & $\mathrm{U}$ & 1 & $\mathrm{U}$ & 1 & $U$ & 1 & $\mathrm{U}$ \\
\hline Aroclor 1016 & 24 & $U$ & 22 & $U$ & 22 & $\mathrm{U}$ & 20 & $\mathrm{U}$ & 20 & $\mathrm{U}$ & 20 & $U$ & 19 & $U$ & 20 & $\mathrm{U}$ \\
\hline Aroclor 1221 & 24 & $\mathrm{U}$ & 22 & $U$ & 22 & $\mathrm{U}$ & 20 & $\mathrm{U}$ & 20 & $\mathrm{U}$ & 20 & $\mathrm{U}$ & 19 & $U$ & 20 & $\mathrm{U}$ \\
\hline Aroclor 1232 & 24 & $\mathbf{U}$ & 22 & $\mathrm{U}$ & 22 & $\mathrm{U}$ & 20 & $U$ & 20 & $U$ & 20 & $\mathrm{U}$ & 19 & $U$ & 20 & $\mathrm{U}$ \\
\hline Aroclor 1242 & 31 & $U$ & 29 & $U$ & 29 & $U$ & 26 & $U$ & 26 & $\mathrm{U}$ & 26 & $\mathrm{U}$ & 25 & $\mathrm{U}$ & 26 & $\mathrm{U}$ \\
\hline Aroclor 1248 & 47 & $\mathrm{U}$ & 45 & $\mathrm{U}$ & 44 & $U$ & 40 & $\mathrm{U}$ & .40 & $\mathrm{U}$ & 40 & $\mathrm{U}$ & 38 & $\mathrm{U}$ & 39 & $\mathrm{U}$ \\
\hline Aroclor 1254 & 47 & $\mathbf{U}$ & 45 & $\mathrm{U}$ & 44 & $\mathrm{U}$ & 1,700 & & 1,230 & & 3,160 & & 38 & $\mathrm{U}$ & 39 & $\mathrm{U}$ \\
\hline Aroclor 1260 & 47 & $\mathrm{U}$ & 45 & $U$ & 44 & $U$ & 40 & $U$ & 40 & $U$ & 40 & $\mathrm{U}$ & 38 & $\mathrm{U}$ & 39 & $\mathrm{U}$ \\
\hline beta-BHC & 3 & $U$ & 3 & $U$ & 3 & $\mathrm{U}$ & 2 & $\mathrm{U}$ & 2 & $\mathrm{U}$ & 2 & $\mathrm{U}$ & 2 & $\mathrm{U}$ & 2 & $\mathrm{U}$ \\
\hline Chlordane & 7 & $U$ & 6 & $\mathrm{U}$ & 6 & $\mathrm{U}$ & 6 & $\mathrm{U}$ & 6 & $U$ & 6 & $\mathrm{U}$ & 5 & $\mathrm{U}$ & 5 & $\mathrm{U}$ \\
\hline 4,4'-DDD & 5 & U & 5 & $\mathrm{U}$ & 5 & $\mathrm{U}$ & 4 & $\mathrm{U}$ & 4 & $U$ & 4 & $\mathrm{U}$ & 4 & $\mathrm{U}$ & 4 & $\mathrm{U}$ \\
\hline 4,4'-DDE & 2 & $U$ & 2 & $U$ & 2 & $\mathrm{U}$ & 2 & $\mathrm{U}$ & 2 & $U$ & 56 & & 6 & & 2 & $\mathrm{U}$ \\
\hline 4,4'-DDT & 6 & $\mathrm{U}$ & 5 & $\mathrm{U}$ & 5 & $U$ & 5 & $\mathrm{U}$ & 5 & $\mathrm{U}$ & 144 & & 7 & & 5 & $\mathrm{U}$ \\
\hline delta-BHC & 4 & $\mathrm{U}$ & 4 & $\mathrm{U}$ & 4 & $U$ & 4 & $\mathrm{U}$ & 4 & $\mathrm{U}$ & 4 & $\mathrm{U}$ & 4 & & 4 & $\mathrm{U}$ \\
\hline Dieldrin & 0.9 & $\mathrm{U}$ & 0.9 & $U$ & 0.9 & $\mathrm{U}$ & 0.8 & $\mathrm{U}$ & 0.8 & $\mathrm{U}$ & 0.8 & $\mathrm{U}$ & 0.8 & $U$ & 0.8 & $\mathrm{U}$ \\
\hline Endosulfan I & 7 & $\mathrm{U}$ & 6 & $\mathbf{U}$ & 6 & $U$ & 6 & $\mathrm{U}$ & 6 & $U$ & 6 & $\mathrm{U}$ & 5 & $\mathrm{U}$ & 5 & $\mathrm{U}$ \\
\hline Endosulfan II - & 2 & $\mathrm{U}$ & 2 & $\mathrm{U}$ & 2 & $\mathrm{U}$ & 2 & $\mathrm{U}$ & 2 & $U$ & 2 & $\mathrm{U}$ & 2 & $\mathrm{U}$ & 2 & U \\
\hline Endosulfan sulfate & 31 & $\mathrm{U}$ & 30 & $U$ & 29 & $U$ & 26 & $\mathrm{U}$ & 26 & $\mathrm{U}$ & 26 & $\mathrm{U}$ & 25 & $\mathrm{U}$ & 26 & $\mathrm{U}$ \\
\hline Endrin & 3 & $\mathrm{U}$ & 3 & $\mathrm{U}$ & 3 & $\mathrm{U}$ & 2 & $U$ & 2 & $U$ & 2 & $U$ & 2 & $\mathrm{U}$ & 2 & $\mathrm{U}$ \\
\hline Endrin aldehyde & 11 & U & 10 & $U$ & 10 & $\mathrm{U}$ & 9 & $\mathrm{U}$ & 9 & $U$ & 9 & $U$ & 9 & $\mathrm{U}$ & 9 & $\mathrm{U}$ \\
\hline gamma-BHC (Lindane) & 2 & $U$ & 2 & $U$ & 2 & $\mathrm{U}$ & 2 & $U$ & 2 & $\mathrm{U}$ & 2 & $U$ & 2 & $U$ & 2 & $\mathrm{U}$ \\
\hline Heptachlor & 1 & $U$ & 1 & $\mathrm{U}$ & 1 & $U$ & 1 & $U$ & 1 & $U$ & 1 & $U$ & 1 & $U$ & 1 & $\mathrm{U}$ \\
\hline Heptachlor epoxide & 39 & $U$ & 37 & $\mathrm{U}$ & 36 & $\mathrm{U}$ & 33 & $\mathrm{U}$ & 33 & $\mathrm{U}$ & $33^{\prime \prime}$ & $\mathrm{U}$. & 32 & $\mathrm{U}$ & 32 & $U$ \\
\hline Methoxychlor & 83 & $U$ & 79 & $U$ & 77 & $U$ & 70 & $\mathrm{U}$ & 70 & $\mathrm{U}$ & 70 & $U$ & 67 & $\mathrm{U}$ & 69 & $\mathrm{U}$ \\
\hline Toxaphene & 113 & $U$ & 107 & $\mathrm{U}$ & 105 & $U$ & 96 & $U$ & 96 & $\mathrm{U}$ & 96 & $\mathrm{U}$ & 92 & $\mathrm{U}$ & 94 & $\mathrm{U}$ \\
\hline
\end{tabular}


TABLE C.16a (Cont.)

\begin{tabular}{|c|c|c|c|c|c|c|c|c|c|c|c|c|c|c|c|c|}
\hline \multirow{3}{*}{$\begin{array}{r}\text { Compound } \\
\text { Aldrin }\end{array}$} & \multicolumn{16}{|c|}{ Borehole Concentrations $(\mu \mathrm{g} / \mathrm{kg}$ ) at Various Depth Intervals } \\
\hline & \multicolumn{2}{|c|}{ JBPM-C-3" } & \multicolumn{2}{|c|}{ JBPM-C-1' } & \multicolumn{2}{|c|}{ JBPP-A-3" } & \multicolumn{2}{|c|}{ JBPP-A-1' } & \multicolumn{2}{|c|}{ JBPP-B-3" } & \multicolumn{2}{|c|}{ JBPP-B-1' } & \multicolumn{2}{|c|}{ JBPP-C-3" } & \multicolumn{2}{|c|}{ JBPP-C-1' } \\
\hline & 2 & $\mathrm{U}$ & 2 & $\mathrm{U}$ & 2 & $\mathrm{U}$ & 2 & $U$ & 19 & $\mathbf{U}$ & 2 & $\mathrm{U}$ & 2 & $\mathrm{U}$ & 2 & $\mathrm{U}$ \\
\hline alpha-BHC & 1 & $\mathrm{U}$ & 1 & $\mathrm{U}$ & 1 & $\mathrm{U}$ & 1 & $\mathrm{U}$ & 14 & $\mathrm{U}$ & 1 & $\mathrm{U}$ & 1 & $\mathrm{U}$ & 1 & $\mathrm{U}$ \\
\hline Aroclor 1016 & 21 & $\mathrm{U}$ & 19 & $\mathrm{U}$ & 20 & $\mathrm{U}$ & 20 & $\mathrm{U}$ & 231 & $\mathrm{U}$ & 20 & $\mathrm{U}$ & 20 & $U$ & 20 & $\mathrm{U}$ \\
\hline Aroclor 1221 & 21 & $\mathrm{U}$ & 19 & $\mathrm{U}$ & 20 & $\mathrm{U}$ & 20 & $\mathrm{U}$ & 231 & $U$ & 20 & $\mathrm{U}$ & 20 & $\mathrm{U}$ & 20 & $\mathrm{U}$ \\
\hline Aroclor 1232 & 21 & $\mathrm{U}$ & 19 & $\mathrm{U}$ & 20 & $\mathrm{U}$ & 20 & $\mathrm{U}$ & 231 & $U$ & 20 & $\mathrm{U}$ & 20 & $\mathrm{U}$ & 20 & $U$ \\
\hline Aroclor 1242 & 28 & $\mathrm{U}$ & 25 & $\mathrm{U}$ & 26 & $\mathrm{U}$ & 26 & $\mathrm{U}$ & 300 & $\mathrm{U}$ & 26 & $\mathrm{U}$ & 26 & $\mathrm{U}$ & 26 & $U$ \\
\hline Aroclor 1248 & 43 & $\mathrm{U}$ & 39 & $\mathrm{U}$ & 39 & $\mathrm{U}$ & 40 & $\mathrm{U}$ & 3,820 & & 40 & $\mathrm{U}$ & 40 & $\mathrm{U}$ & 40 & $\mathrm{U}$ \\
\hline Aroclor 1254 & 43 & $\mathrm{U}$ & 39 & $U$ & 39 & $\mathrm{U}$ & 40 & $\mathrm{U}$ & 462 & $\mathrm{U}$ & 40 & $\mathrm{U}$ & 40 & $U$ & 40 & $U$ \\
\hline Aroclor 1260 & 43 & $\mathrm{U}$ & 39 & $U$ & 39 & $U$ & 40 & $\mathrm{U}$ & 462 & $\mathrm{U}$ & 40 & U & 40 & $\mathrm{U}$ & 40 & $U$ \\
\hline beta-BHC & 3 & $\mathrm{U}$ & 2 & $\mathrm{U}$ & 2 & $\mathrm{U}$ & 2 & $\mathrm{U}$ & 28 & $\mathrm{U}$ & 2 & $\mathrm{U}$ & 2 & $U$ & 2 & $\mathrm{U}$ \\
\hline Chlordane & 6 & $\mathrm{U}$ & 5 & $U$ & 5 & $\mathrm{U}$ & 6 & $\mathrm{U}$ & 65 & $\mathrm{U}$ & 6 & $U$ & 6 & $U$ & 6 & $\mathrm{U}$ \\
\hline $4,4^{\prime}-\mathrm{DDD}$ & 5 & $\mathrm{U}$ & 4 & $\mathrm{U}$ & 4 & $U$ & 4 & $\mathrm{U}$ & 51 & $\mathrm{U}$ & 4 & $\mathrm{U}$ & 4 & $U$ & 4 & $\mathrm{U}$ \\
\hline 4,4'-DDE & 12 & & 2 & $\mathrm{U}$ & 2 & $U$ & 2 & $\mathrm{U}$ & 19 & $\mathrm{U}$ & 42 & & 2 & $U$ & 2 & $\mathrm{U}$ \\
\hline 4,4'-DDT & 5 & $\mathrm{U}$ & 5 & $U$ & 5 & $\mathrm{U}$ & 5 & $\mathrm{U}$ & 56 & $\mathrm{U}$ & 5 & $\mathrm{U}$ & 5 & $U$ & 5 & $\mathrm{U}$ \\
\hline delta-BHC & 28 & & 3 & $U$ & 4 & $U$ & 4 & $\mathrm{U}$ & 42 & $U$ & 4 & $\mathrm{U}$ & 4 & & 4 & $\mathrm{U}$ \\
\hline Dieldrin & 0.9 & $\mathrm{U}$ & 0.8 & $U$ & 0.8 & $\mathrm{U}$ & 0.8 & $U$ & 9 & $\mathrm{U}$ & 0.8 & $\mathrm{U}$ & 0.8 & $U$ & 0.8 & $U$ \\
\hline Endosulfan I & 6 & $U$ & 5 & $U$ & 5 & $\mathrm{U}$ & 6 & $\mathrm{U}$ & 65 & $\mathrm{U}$ & 6 & $\mathrm{U}$ & 6 & $U$ & 6 & $\mathrm{U}$ \\
\hline Endosulfan II & 2 & $U$ & 2 & $\mathrm{U}$ & 2 & $\mathrm{U}$ & 2 & $U$ & 19 & $\mathrm{U}$ & 2 & $\mathrm{U}$ & 2 & $\mathrm{U}$ & 2 & $\mathrm{U}$ \\
\hline Endosulfan sulfate & 28 & $\mathrm{U}$ & 25 & $U$ & 26 & $\mathrm{U}$ & 26 & $U$ & 305 & $\mathrm{U}$ & 26 & $\mathrm{U}$ & 26 & $\mathrm{U}$ & 26 & $\mathrm{U}$ \\
\hline Endrin & 3 & $\mathrm{U}$ & 2 & $U$ & 2 & $\mathrm{U}$ & 2 & $\mathrm{U}$ & 28 & $\mathrm{U}$ & 3 & & 2 & $\mathrm{U}$ & 2 & $\mathrm{U}$ \\
\hline Endrin aldehyde & 10 & $\mathrm{U}$ & 9 & $\mathrm{U}$ & 9 & $U$ & 9 & $\mathrm{U}$ & 106 & $\mathrm{U}$ & 9 & $U$ & 9 & $\mathrm{U}$ & 9 & $\mathrm{U}$ \\
\hline gamma-BHC (Lindane) & 2 & $\mathrm{U}$ & 2 & $\mathrm{U}$ & 2 & $U$ & 2 & $\mathrm{U}$ & 19 & $\mathrm{U}$ & 2 & $\mathrm{U}$ & 2 & $\mathrm{U}$ & 2 & $\mathrm{U}$ \\
\hline Heptachlor & 1 & U & 1 & $\mathrm{U}$ & 1 & $U$ & 1 & $\mathrm{U}$ & 14 & $U$ & 20 & & 4 & & 1 & $\mathrm{U}$ \\
\hline Heptachlor epoxide & 35 & $U$ & 32 & $U$ & 33 & $U$ & 33 & $U$ & 383 & $U$ & 33 & $U$ & 33 & $\mathrm{U}$ & 33 & $\mathrm{U}$ \\
\hline Methoxychlor & 75 & $U$ & 68 & $U$ & 69 & $U$ & 70 & $\mathrm{U}$ & 813 & $\mathrm{U}$ & 70 & $\mathrm{U}$ & 70 & $U$ & 70 & $U$ \\
\hline Toxaphene & 102 & $\mathrm{U}$ & 93 & $\mathrm{U}$ & 94 & $\mathrm{U}$ & 96 & $\mathrm{U}$ & 1,110 & $\mathrm{U}$ & 95 & $\mathrm{U}$ & 96 & $\mathrm{U}$ & 96 & $\mathrm{U}$ \\
\hline
\end{tabular}

See next page for footnotes. 
TABLE C.16a (Cont.)

a Sampled by Weston, analyzed by GP Environmental Services, TCL pesticides and PCBs-SW846 8080; provisional data. Data qualifier:

$U=$ analyte was analyzed for but not detected. 
TABLE C.16b Pesticide and PCB Analyses for Soil Borings, May $1995^{\mathrm{a}}$

\begin{tabular}{|c|c|c|c|c|c|c|c|c|c|c|c|c|}
\hline \multirow{3}{*}{$\frac{\text { Compound }}{\text { Aldrin }}$} & \multicolumn{12}{|c|}{ Borehole Concentrations $(\mu \mathrm{g} / \mathrm{kg}$ ) at Various Depth Intervals } \\
\hline & \multicolumn{2}{|c|}{$\begin{array}{c}\text { TBNPBOR2 } \\
(0-2 \mathrm{ft})\end{array}$} & \multicolumn{2}{|c|}{$\begin{array}{l}\text { TBNPBOR2 } \\
(2-6 \mathrm{ft})\end{array}$} & \multicolumn{2}{|c|}{$\begin{array}{c}\text { TBNPBOR3 } \\
(0-2 \mathrm{ft})\end{array}$} & \multicolumn{2}{|c|}{$\begin{array}{c}\text { TBNPBOR3 } \\
(2-4 \mathrm{ft})\end{array}$} & \multicolumn{2}{|c|}{$\begin{array}{c}\text { TBNPBOR3 } \\
(4-6 \mathrm{ft})\end{array}$} & \multicolumn{2}{|c|}{$\begin{array}{c}\text { VXBOR3 } \\
(2-4 \mathrm{ft}) \\
\end{array}$} \\
\hline & 2.06 & $\mathrm{U}$ & 1.99 & $\mathrm{U}$ & 2.04 & $\mathrm{U}$ & 2.3 & $U$ & 2.4 & $\mathrm{U}$ & 40.6 & $\mathrm{U}$ \\
\hline alpha-BHC & 2.06 & $\mathrm{UJ}(t)$ & 1.99 & $\mathrm{U}$ & 2.04 & $\mathrm{U}$ & 2.3 & $U$ & 2.4 & UJ & 40.6 & $\mathrm{U}$ \\
\hline alpha-Chlordane & 2.06 & $\mathrm{UJ}(+)$ & 1.99 & $\mathrm{U}$ & 2.04 & $\mathrm{U}$ & 2.3 & $U$ & 2.4 & UJ & 40.6 & $\mathbf{U}$ \\
\hline Aroclor 1016 & 39.9 & $\mathrm{UJ}(+)$ & 38.6 & $\mathrm{U}$ & 39.5 & $\mathrm{U}$ & 44.6 & $\mathrm{U}$ & 46.5 & UJ & 789 & $\mathrm{U}$ \\
\hline Aroclor 1221 & 81.1 & $\mathrm{UJ}(+)$ & 78.4 & $\mathrm{U}$ & 80.3 & $\mathrm{U}$ & 90.5 & $\mathrm{U}$ & 94.5 & UJ & 1,600 & $\mathrm{U}$ \\
\hline Aroclor 1232 & 39.9 & $\mathrm{UJ}(t)$ & 38.6 & $\mathrm{U}$ & 39.5 & $\mathrm{U}$ & 44.6 & $U$ & 46.5 & UJ & 789 & $\mathrm{U}$ \\
\hline Aroclor 1242 & 39.9 & $\mathrm{UJ}(t)$ & 38.6 & $\mathbf{U}$ & 39.5 & $\mathbf{U}$ & 44.6 & $\mathrm{U}$ & 46.5 & $\mathrm{UJ}$ & 789 & $\mathrm{U}$ \\
\hline Aroclor 1248 & 570 & $\mathrm{~J}(+)$ & 38.6 & $\mathbf{U}$ & 39.5 & $\mathbf{U}$ & 44.6 & $\mathrm{U}$ & 46.5 & UJ & 789 & $\mathrm{U}$ \\
\hline Aroclor 1254 & 39.9 & $\mathrm{UJ}(+)$ & 38.6 & $\mathrm{U}$ & 39.5 & $\mathrm{U}$ & 44.6 & $\mathrm{U}$ & 46.5 & UJ & 789 & $\mathrm{U}$ \\
\hline Aroclor 1260 & 39.9 & $U J(t)$ & 38.6 & $U$ & 39.5 & $\mathrm{U}$ & 44.6 & $\mathrm{U}$ & 46.5 & UJ & 789 & $\mathrm{U}$ \\
\hline beta-BHC & 2.06 & $\mathrm{UJ}(t)$ & 1.99 & $\mathrm{U}$ & 2.04 & $\mathbf{U}$ & 2.3 & $\mathrm{U}$ & 2.4 & UJ & 40.6 & $\mathrm{U}$ \\
\hline 4,4'-DDD & 3.99 & $\mathrm{UJ}(+)$ & 3.86 & $\mathrm{U}$ & 3.95 & $\mathrm{U}$ & 4.46 & $\mathrm{U}$ & 4.65 & UJ & 78.8 & $\mathrm{JB}$ \\
\hline $4,4^{\prime}-\mathrm{DDE}$ & 3.99 & $\mathrm{UJ}(+)$ & 3.86 & $\mathrm{U}$ & 1.9 & $\mathrm{JP}$ & 4.46 & $\mathrm{U}$ & 4.65 & UJ & 18.2 & $\mathrm{JB}$ \\
\hline $4,4^{\prime}-\mathrm{DDT}$ & 3.99 & $\mathrm{UJ}(t)$ & 3.86 & $\mathrm{U}$ & 3.95 & $\mathbf{U}$ & 4.46 & $\mathrm{U}$ & 4.65 & UJ & 78.9 & $\mathrm{U}$ \\
\hline delta-BHC & 2.06 & $\mathrm{UJ}(+)$ & 1.99 & $\mathrm{U}$ & 2.04 & $\mathrm{U}$ & 2.3 & $\mathbf{U}$ & 2.4 & UJ & 40.6 & $\mathrm{U}$ \\
\hline Dieldrin & 3.99 & $\mathrm{UJ}(+)$ & 3.86 & $\mathrm{U}$ & 3.95 & $\mathrm{U}$ & 4.46 & $\mathrm{U}$ & 4.65 & UJ & 78.9 & $\mathrm{U}$ \\
\hline Endosulfan I & 2.06 & $\mathrm{UJ}(+)$ & 1.99 & $\mathrm{U}$ & 2.04 & $\mathrm{U}$ & 2.3 & $\mathrm{U}$ & 2.4 & UJ & 40.6 & $\mathrm{U}$ \\
\hline Endosulfan II & 3.99 & $\mathrm{UJ}(+)$ & 3.86 & $\mathrm{U}$ & 3.95 & $\mathrm{U}$ & 4.46 & $\mathrm{U}$ & 4.65 & UJ & 78.9 & $\mathbf{U}$ \\
\hline Endosulfan sulfate & 3.99 & $U \mathrm{U}(t)$ & 3.86 & $\mathrm{U}$ & 3.95 & $\mathrm{U}$ & 19 & $P$ & 4.65 & UJ & 78.9 & $\mathrm{U}$ \\
\hline Endrin & 3.99 & $\mathrm{UJ}(t)$ & 3.86 & $\mathrm{U}$ & 3.95 & $\mathrm{U}$ & 4.46 & $U$ & 4.65 & UJ & 78.9 & $\mathbf{U}$ \\
\hline Endrin aldehyde & 3.99 & $\mathrm{UJ}(t)$ & 3.86 & $U$ & 3.95 & $U$ & 4.46 & $\mathrm{U}$ & 4.65 & UJ & 78.9 & $\mathrm{U}$ \\
\hline Endrin ketone & 3.99 & $\mathrm{UJ}(t)$ & 3.86 & $U$ & 3.95 & $U$ & 4.9 & $\mathrm{P}$ & 4.65 & UJ & 78.9 & $\mathrm{U}$ \\
\hline gamma-Chlordane & 2.06 & $\mathrm{UJ}(+)$ & 1.99 & $\mathrm{U}$ & 2.04 & $U$ & 2.3 & $\mathrm{U}$ & 2.4 & UJ & 40.6 & $\mathrm{U}$ \\
\hline Heptachlor & 2.06 & $\mathrm{UJ}(+)$ & 1.99 & $\mathrm{U}$ & 2.04 & $U$ & 2.3 & $\mathrm{U}$ & 2.4 & UJ & 40.6 & $\mathrm{U}$ \\
\hline Heptachlor epoxide & 2.06 & $\mathrm{UJ}(t)$ & 1.99 & $\mathrm{U}$ & 2.04 & $U$ & 12.2 & & 2.4 & UJ & 40.6 & $\mathrm{U}$ \\
\hline Lindane (gamma-BHC) & 2.06 & $\mathrm{UI}(+)$ & 1.99 & $\mathrm{U}$ & 2.04 & $\mathrm{U}$ & 2.3 & $\mathrm{U}$ & 2.4 & UJ & 40.6 & $\mathrm{U}$ \\
\hline Methoxychlor & 20.6 & $\mathrm{UJ}(+)$ & 19.9 & $\mathbf{U}$ & 20.4 & $\mathrm{U}$ & 23 & $\mathrm{U}$ & 24 & UJ & 406 & $\mathrm{U}$ \\
\hline Toxaphene & 206 & $U J(t)$ & 199 & $\mathrm{U}$ & 204 & $\underline{U}$ & 230 & $U$ & 240 & UJ & 4,060 & $\mathrm{U}$ \\
\hline
\end{tabular}




\begin{tabular}{|c|c|c|c|c|c|c|c|c|}
\hline \multirow{3}{*}{$\begin{array}{l}\text { Compound } \\
\text { Aldrin }\end{array}$} & \multicolumn{8}{|c|}{ Borehole Concentrations $(\mu \mathrm{g} / \mathrm{kg})$ at Various Depth Intervals } \\
\hline & \multicolumn{2}{|c|}{$\begin{array}{l}\text { VXBOR4 } \\
(2-4 \mathrm{ft})\end{array}$} & \multicolumn{2}{|c|}{$\begin{array}{c}\text { VXBOR4 } \\
(4-6 \mathrm{ft})\end{array}$} & \multicolumn{2}{|c|}{$\begin{array}{c}\text { VXBOR5 } \\
(4-6 \mathrm{ft})\end{array}$} & \multicolumn{2}{|c|}{$\begin{array}{l}\text { VXBOR5 } \\
(8-10 \mathrm{ft})\end{array}$} \\
\hline & 43.2 & $\mathrm{U}$ & 20.8 & $\mathrm{U}$ & 2.21 & $\mathbf{U}$ & 2.11 & $\mathrm{U}$ \\
\hline alpha-BHC & 43.2 & $\mathrm{U}$ & 20.8 & $\mathrm{U}$ & 1.3 & JP & 2.11 & $\mathrm{U}$ \\
\hline alpha-Chlordane & 43.2 & $\mathbf{U}$ & 20.8 & $\mathrm{U}$ & 2.21 & $\mathrm{U}$ & 2.11 & $\mathbf{U}$ \\
\hline Aroclor 1016 & 838 & $\mathrm{U}$ & 404 & $\mathbf{U}$ & 43 & $\mathrm{U}$ & 40.9 & $\mathrm{U}$ \\
\hline Aroclor 1221 & 1700 & $\mathrm{U}$ & 820 & $\mathrm{U}$ & 87.2 & $\mathrm{U}$ & 83.1 & $\mathrm{U}$ \\
\hline Aroclor 1232 & 838 & $\mathrm{U}$ & 404 & $U$ & 43 & $\mathrm{U}$ & 40.9 & $U$ \\
\hline Aroclor 1242 & 838 & $\mathrm{U}$ & 404 & $\mathrm{U}$ & 43 & $\mathrm{U}$ & 40.9 & $\mathrm{U}$ \\
\hline Aroclor 1248 & 838 & $\mathrm{U}$ & 404 & $\mathrm{U}$ & 43 & $U$ & 40.9 & $\mathrm{U}$ \\
\hline Aroclor 1254 & 838 & $\mathrm{U}$ & 404 & $\mathrm{U}$ & 43 & $\mathrm{U}$ & 40.9 & U \\
\hline Aroclor 1260 & 838 & $\mathrm{U}$ & 404 & $U$ & 43 & $\mathrm{U}$ & 40.9 & $\mathbf{U}$ \\
\hline beta-BHC & 43.2 & $\mathrm{U}$ & 20.8 & $\mathrm{U}$ & 2.21 & $\mathrm{U}$ & 2.11 & $\mathrm{U}$ \\
\hline 4,4'-DDD & 83.8 & $\mathrm{U}$ & 40.4 & $\mathrm{U}$ & 4.6 & & 1.5 & $\mathrm{JB}$ \\
\hline 4,4'-DDE & 83.8 & $\mathrm{U}$ & 40.4 & $\mathrm{U}$ & 4.3 & $\mathrm{U}$ & 0.97 & JB \\
\hline 4,4'-DDT & 83.8 & $\mathrm{U}$ & 40.4 & $\mathrm{U}$ & 4.3 & $\mathrm{U}$ & 4.09 & $\mathrm{U}$ \\
\hline delta-BHC & 43.2 & $\mathrm{U}$ & 20.8 & $\mathrm{U}$ & 2.21 & $\mathrm{U}$ & 2.11 & $\mathrm{U}$ \\
\hline Dieldrin & 83.8 & $\mathrm{U}$ & 40.4 & $\mathrm{U}$ & 4.3 & $\mathrm{U}$ & 4.09 & $\mathrm{U}$ \\
\hline Endosulfan I & 43.2 & $\mathrm{U}$ & 20.8 & $\mathrm{U}$ & 2.21 & $U$ & 2.11 & $\mathrm{U}$ \\
\hline Endosulfan II & 83.8 & $\mathrm{U}$ & 40.4 & $\mathrm{U}$ & 4.3 & $U$ & 4.09 & $\mathrm{U}$ \\
\hline Endosulfan sulfate & 83.8 & $\mathrm{U}$ & 40.4 & $\mathrm{U}$ & 4.3 & $\mathrm{U}$ & 4.09 & $\mathrm{U}$ \\
\hline Endrin & 83.8 & $\mathrm{U}$ & 40.4 & $U$ & 4.3 & $\mathrm{U}$ & 4.09 & $\mathrm{U}$ \\
\hline Endrin aldehyde & 83.8 & $\mathrm{U}$ & 40.4 & $\mathrm{U}$ & 4.3 & $\mathrm{U}$ & 4.09 & $\mathbf{U}$ \\
\hline Endrin ketone & 83.8 & $\mathrm{U}$ & 40.4 & $\mathrm{U}$ & 2.9 & $\mathrm{JP}$ & 4.09 & $\mathrm{U}$ \\
\hline gamma-Chlordane & 43.2 & $\mathrm{U}$ & 20.8 & $\mathrm{U}$ & 2.21 & $\mathrm{U}$ & 2.11 & $\mathrm{U}$ \\
\hline Heptachlor & 43.2 & $\mathrm{U}$ & 20.8 & $\mathrm{U}$ & 2.21 & $\mathrm{U}$ & 2.11 & $\mathrm{U}$ \\
\hline Heptachlor epoxide & 43.2 & $\mathrm{U}$ & 20.8 & $\mathrm{U}$ & 2.21 & $\mathrm{U}$ & 2.11 & $\mathrm{U}$ \\
\hline Lindane (gamma-BHC) & 43.2 & $\mathrm{U}$ & 20.8 & $\mathrm{U}$ & 2.21 & $\mathrm{U}$ & 2.11 & $U$ \\
\hline Methoxychlor & 432 & $\mathrm{U}$ & 208 & $U$ & 22.1 & $\mathrm{U}$ & 21.1 & $\mathrm{U}$ \\
\hline Toxaphene & 4,320 & $\mathrm{U}$ & 2,080 & $\mathrm{U}$ & 221 & $\mathrm{U}$ & 211 & $\mathrm{U}$ \\
\hline
\end{tabular}

a Sampled by ANL and analyzed by GP Environmental Services.

Data qualifiers:

$\mathrm{U}=$ analyte was analyzed for but not detected.

$\mathrm{J}=$ estimated value.

$(+)=$ value obtained from a 1:10 dilution.

$\mathrm{B}$ = compound was found in the associated blank.

$P$ = percent difference between the results from two GTC columns is greater than $25 \%$, and the lower of the two values is reported. 
TABLE C.17 On-Site Analytical Suite Results for Soil Borings, December 1993-May 1994a

\begin{tabular}{|c|c|c|c|c|c|c|}
\hline \multirow[b]{2}{*}{$\begin{array}{c}\text { Sample No. } \\
\text { (Depth Interval) }\end{array}$} & \multirow[b]{2}{*}{$\begin{array}{c}\text { Collection } \\
\text { Date }\end{array}$} & \multirow{2}{*}{$\begin{array}{c}\text { Average } \\
\text { Depth } \\
\text { (ft) }\end{array}$} & \multicolumn{4}{|c|}{ Borehole Concentrations (mg/kg) } \\
\hline & & & PAH & TPH & PCB & TNT \\
\hline \multicolumn{7}{|l|}{ Sediment } \\
\hline BOR1-1 (6-8 ft) & $04 / 18 / 94$ & 7 & $1 U$ & $10 \mathrm{U}$ & $1^{1} \mathrm{U}$ & $.0 .7 \mathrm{U}$ \\
\hline BOR2-1 (3-5 ft) & 04/19/94 & 4 & $1 U$ & 100 U10 & $1 \mathrm{U}$ & $0.7 \mathrm{U}$ \\
\hline BOR3-1 (6-8 ft) & 04/19/94 & 7 & $1 \mathrm{U}$ & $100 \mathrm{G}$ & $1 \mathrm{U}$ & $0.7 \mathrm{G}$ \\
\hline BOR4-1 (5-8 ft) & $04 / 19 / 94$ & 7 & $1 \mathrm{U}$ & $100 \mathrm{U} 10$ & $1 \mathrm{U}$ & $0.7 \mathrm{U}$ \\
\hline BOR5-1 (2-4 ft) & $04 / 20 / 94$ & 3 & $1 \mathrm{U}$ & $100 \mathrm{U} 10$ & $1 \mathrm{U}$ & $0.7 \mathrm{U}$ \\
\hline BOR6-1 (2-4 ft) & $04 / 20 / 94$ & 3 & $1 \mathrm{U}$ & & $1 \mathrm{U}$ & $0.7 \mathrm{G}$ \\
\hline BOR7-1 (2-4 ft) & $04 / 20 / 94$ & 3 & & $100 \mathrm{U} 10$ & $1 \mathrm{U}$ & $0.7 \mathrm{U}$ \\
\hline BOR8-1 (0-2 ft) & $04 / 21 / 94$ & 1 & $1 \mathrm{U}$ & $10 \mathrm{U}$ & $1 U$ & $0.7 \mathrm{U}$ \\
\hline \multicolumn{7}{|l|}{ Soil } \\
\hline TBSPBOR1 (0-2ft) & $05 / 23 / 94$ & 1 & $10 \mathrm{U} 1$ & 100 U10 & $10 \mathrm{Ul}$ & $0.7 \mathrm{U}$ \\
\hline TBSPBOR1 (2-4ft) & $05 / 23 / 94$ & 3 & $1 \mathrm{U}$ & $100 \mathrm{U} 10$ & $1 \mathrm{U}$ & $0.7 \mathrm{U}$ \\
\hline TBSPBOR1 (4-6ft) & $05 / 23 / 94$ & 5 & $10 \mathrm{U} 1$ & $100 \mathrm{U} 10$ & $1 \mathrm{U}$ & $0.7 \mathrm{U}$ \\
\hline TBSPBOR1 $(6-8 \mathrm{ft})$ & $05 / 23 / 94$ & 7 & $1 \mathrm{U}$ & $10 \mathrm{U}$ & $1 \mathrm{U}$ & $0.7 \mathrm{U}$ \\
\hline TBSPBOR1 $(8-10 \mathrm{ft})$ & $05 / 23 / 94$ & 9 & $1 \mathrm{U}$ & $100 \mathrm{U} 10$ & $1 \mathrm{U}$ & $0.7 \mathrm{U}$ \\
\hline TBSPBOR1 (10-12ft) & $05 / 23 / 94$ & 11 & $1 U$ & $100 \mathrm{U} 10$ & $1 \mathrm{U}$ & $0.7 \mathrm{U}$ \\
\hline TBSPBOR2 $(0-2 \mathrm{ft})$ & $05 / 23 / 94$ & 1 & $1 \mathrm{U}$ & $100 \mathrm{U} 10$ & $10 \mathrm{G}$ & $0.7 \mathrm{U}$ \\
\hline TBSPBOR2 (2-4ft) & $05 / 23 / 94$ & 3 & $1 \mathrm{U}$ & $100 \mathrm{U} 10$ & $10 \mathrm{U} 1$ & $0.7 \mathrm{U}$ \\
\hline TBSPBOR2 $(4-6 \mathrm{ft})$ & $05 / 23 / 94$ & 5 & $1 \mathrm{U}$ & $10 \mathrm{U}$ & $1 U$ & $0.7 \mathrm{U}$ \\
\hline TBSPBOR2 (6-8ft) & $05 / 23 / 94$ & 7 & $1 \mathrm{U}$ & $100 \mathrm{G}$ & $1 \mathrm{U}$ & $0.7 \mathrm{U}$ \\
\hline TBSPBOR2 (8-10 ft) & $05 / 23 / 94$ & 9 & $1 \mathrm{U}$ & $100 \mathrm{G}$ & $1 \mathrm{U}$ & $0.7 \mathrm{U}$ \\
\hline TBNPBOR1 $(0-2 \mathrm{ft})$ & $05 / 24 / 94$ & 1 & $1 \mathrm{U}$ & $100 \mathrm{U} 10$ & $10 \mathrm{U} 1$ & NA \\
\hline TBNPBOR1 (2-4ft) & $05 / 24 / 94$ & 3 & $1 \mathrm{U}$ & $100 \mathrm{G}$ & $10 \mathrm{U1}$ & NA \\
\hline TBNPBOR1 $(4-6 \mathrm{ft})$ & $05 / 24 / 94$ & 5 & $1 \mathrm{U}$ & $100 \mathrm{U} 10$ & $10 \mathrm{U1}$ & NA \\
\hline TBNPBOR1 (6-8 ft) & $05 / 24 / 94$ & 7 & $1 \mathrm{U}$ & $10 U$ & NA & NA \\
\hline HBOR1 (0-2ft) & $05 / 24 / 94$ & 1 & $1 \mathrm{U}$ & $100 \mathrm{U} 10^{\circ}$ & $10 \mathrm{U} 1$ & NA \\
\hline HBORI (2-4ft) & $05 / 24 / 94$ & 3 & $1 U$ & $10 \mathrm{U}$ & $1 \mathrm{U}$ & NA \\
\hline HBOR1 (4-6ft) & $05 / 24 / 94$ & 5 & $1 \mathrm{U}$ & $10 \mathrm{U}$ & $10 \mathrm{U1}$ & NA \\
\hline HBOR1 (6-8 ft) & $05 / 24 / 94$ & 7 & $1 \mathrm{U}$ & $10 \mathrm{U}$ & NA & $\mathrm{NA}$ \\
\hline HBOR1 ( $8-10 \mathrm{ft})$ & $05 / 24 / 94$ & 9 & NA & $100 \mathrm{U} 10$ & NA & $\mathrm{NA}$ \\
\hline HBOR2 (0-2ft) & $05 / 25 / 94$ & 1 & $1 \mathrm{U}$ & $10 U$ & $1 \mathrm{U}$ & NA \\
\hline HBOR2 (4-6ft) & $05 / 25 / 94$ & 3 & $1 \mathrm{U}$ & $10 \mathrm{U}$ & $1 \mathrm{U}$ & $\mathrm{NA}$ \\
\hline VXBOR1 $(0-2 \mathrm{ft})$ & $05 / 16 / 94$ & 1 & $1 \mathrm{U}$ & $100 \mathrm{G}$ & $1 \mathrm{U}$ & $0.7 \mathrm{U}$ \\
\hline VXBOR1 $(4-6 \mathrm{ft})$ & $05 / 16 / 94$ & 5 & $10 \mathrm{G}$ & $100 \mathrm{G}$ & $1 U$ & $0.7 \mathrm{U}$ \\
\hline VXBORI (6-8ft) & $05 / 16 / 94$ & 7 & $10 \mathrm{G}$ & $100 \mathrm{G}$ & $1 \mathrm{U}$ & $0.7 \mathrm{U}$ \\
\hline VXBORI (8-10 ft) & $05 / 16 / 94$ & 9 & $10 \mathrm{G}$ & $100 \mathrm{G}$ & $1 U$ & $0.7 \mathrm{U}$ \\
\hline VXBOR2 (0-2 ft) & $05 / 16 / 94$ & 1 & $1 \mathrm{U}$ & $100 \mathrm{G}$ & $1 U$ & $0.7 \mathrm{U}$ \\
\hline VXBOR2 (2-4 ft) & $05 / 16 / 94$ & 3 & $1 \mathrm{U}$ & $100 \mathrm{G}$ & $1 \mathrm{U}$ & $0.7 \mathrm{U}$ \\
\hline VXBOR2 (4-6 ft) & $05 / 16 / 94$ & 5 & $1 \mathrm{U}$ & $100 \mathrm{G}$ & $1 \mathrm{U}$ & $0.7 \mathrm{U}$ \\
\hline VXBOR2 (6-8 ft) & $05 / 16 / 94$ & 7 & $1 U$ & $100 \mathrm{G}$ & $1 \mathrm{U}$ & $0.7 \mathrm{U}$ \\
\hline
\end{tabular}


TABLE C.17 (Cont.)

\begin{tabular}{|c|c|c|c|c|c|c|}
\hline \multirow{2}{*}{$\begin{array}{c}\text { Sample No. } \\
\text { (Depth Interval) }\end{array}$} & \multirow{2}{*}{$\begin{array}{c}\text { Collection } \\
\text { Date }\end{array}$} & \multirow{2}{*}{$\begin{array}{c}\text { Average } \\
\text { Depth } \\
\text { (ft) }\end{array}$} & \multicolumn{4}{|c|}{ Borehole Concentrations (mg/kg) } \\
\hline & & & $\mathrm{PAH}$ & TPH & PCB & TNT \\
\hline \multicolumn{7}{|l|}{ Soil (Cont.) } \\
\hline VXBOR2 $(8-10 \mathrm{ft})$ & $05 / 16 / 94$ & 9 & $1 \mathrm{U}$ & $100 \mathrm{U} 10$ & $1 \mathrm{U}$ & $0.7 \mathrm{U}$ \\
\hline VXBOR2 (10-12 ft) & $05 / 16 / 94$ & 11 & $1 \mathrm{U}$ & $100 \mathrm{G}$ & $1 \mathrm{U}$ & $0.7 \mathrm{U}$ \\
\hline CLP1 (0-6 in.) & $01 / 24 / 94$ & 0.25 & $1 U$ & $10 \mathrm{U}$ & $10 \mathrm{U1}$ & $0.7 \mathrm{U}$ \\
\hline CLP1 (6-24 in.) & $01 / 24 / 94$ & 1.25 & $1 \mathrm{U}$ & $10 U$ & $1 \mathrm{U}$ & 0.96 \\
\hline CLP2 (0-6 in.) & $01 / 24 / 94$ & 0.25 & $1 \mathrm{U}$ & $10 \mathrm{U}$ & $1 U$ & $0.7 \mathrm{U}$ \\
\hline CLP2 (6-24 in.) & $01 / 24 / 94$ & 1.25 & $1 \mathrm{U}$ & $10 U$ & $1 \mathrm{U}$ & $0.7 \mathrm{U}$ \\
\hline CLP2 (24-48 in.) & $01 / 24 / 94$ & 3 & $10 \mathrm{U1}$ & $100 \mathrm{U} 10$ & $1 \mathrm{U}$ & $0.7 \mathrm{U}$ \\
\hline CLP3 (0-6 in.) & $01 / 25 / 94$ & 0.25 & $10 \mathrm{UI}$ & $100 \mathrm{U} 10$ & $10 U 1$ & $0.7 \mathrm{U}$ \\
\hline CLP3 (6-24 in.) & $01 / 25 / 94$ & 1.25 & $10 \mathrm{U} 1$ & $10 \mathrm{U}$ & $1 \mathrm{U}$ & $0.7 \mathrm{U}$ \\
\hline CLP3 (6-24 in.) Dup & $01 / 25 / 94$ & 1.25 & $1 U$ & $10 \mathrm{U}$ & $1 \mathrm{U}$ & $0.7 \mathrm{U}$ \\
\hline CLP3 (24-48 in.) & $01 / 25 / 94$ & 3 & $1 U$ & $10 \mathrm{U}$ & $1 \mathrm{U}$ & $0.7 \mathrm{U}$ \\
\hline CLP4 (0-6 in.) & $01 / 25 / 94$ & 0.25 & $1 U$ & $10 U$ & $1 \mathrm{U}$ & $0.7 \mathrm{U}$ \\
\hline CLP4 (6-24 in.) & $01 / 25 / 94$ & 1.25 & $1 U$ & $100 \mathrm{U} 10$ & $1 \mathrm{U}$ & $0.7 \mathrm{U}$ \\
\hline CLP4 (24-48 in.) & $01 / 25 / 94$ & 3 & $1 U$ & $100 \mathrm{U} 10$ & $1 \mathrm{U}$ & $0.7 \mathrm{U}$ \\
\hline CLP5 (0-6 in.) & $01 / 25 / 94$ & 0.25 & $1 \mathrm{U}$ & $10 U$ & $1 \mathrm{U}$ & $0.7 \mathrm{U}$ \\
\hline CLP5 (6-24 in.) & $01 / 25 / 94$ & 1.25 & $1 \mathrm{U}$ & $100 \mathrm{U} 10$ & $1 \mathrm{U}$ & 1.95 \\
\hline CLP5 (24-48 in.) & $01 / 25 / 94$ & 3 & $1 U$ & $100 \mathrm{G}$ & $1 \mathrm{U}$ & 1.67 \\
\hline CLP5 (24-48 in.) Dup & $01 / 25 / 94$ & 3 & $1 \mathrm{U}$ & $100 \mathrm{G}$ & $1 \mathrm{U}$ & 0.99 \\
\hline CLP6 (0-6 in.) & $01 / 25 / 94$ & 0.25 & $1 \mathrm{U}$ & $10 \mathrm{U}$ & $1 U$ & $0.7 \mathrm{U}$ \\
\hline CLP6 (6-24 in.) & $01 / 25 / 94$ & 1.25 & $10 \mathrm{U} 1$ & $100 \mathrm{U10}$ & $1 U$ & $0.7 \mathrm{U}$ \\
\hline CLP7 (0-6 in.) & $01 / 25 / 94$ & 0.25 & $1 \mathrm{U}$ & $10 \mathrm{U}$ & $1 \mathrm{U}$ & $0.7 \mathrm{U}$ \\
\hline CLP7 (6-24 in.) & $01 / 25 / 94$ & 1.25 & $1 \mathrm{U}$ & $10 \mathrm{U}$ & $1 \mathrm{U}$ & $0.7 \mathrm{U}$ \\
\hline CLP7 (24-48 in.) & $01 / 25 / 94$ & 3 & $1 \mathrm{U}$ & $10 \mathrm{U}$ & $1 U$ & $0.7 \mathrm{U}$ \\
\hline CLP8 (0-6 in.) & $01 / 26 / 94$ & 0.25 & $1 \mathrm{U}$ & $10 \mathrm{U}$ & $1 U$ & $0.7 \mathrm{U}$ \\
\hline CLP9 (0-6 in.) & $01 / 26 / 94$ & 0.25 & $1 U$ & $10 U$ & $1 U$ & $0.7 \mathrm{U}$ \\
\hline OT $4 A$ (0-6 in.) & $11 / 09 / 93$ & 0.25 & $10 \mathrm{U}$ & $10 \mathrm{U}$ & $1 \mathrm{U}$ & $0.7 \mathrm{U}$ \\
\hline OT6A (0-6 in.) & $11 / 09 / 93$ & 0.25 & $10 \mathrm{U}$ & $10 \mathrm{U}$ & $1 \mathrm{U}$ & $0.7 \mathrm{U}$ \\
\hline OT8A (0-6 in.) & $10 / 13 / 93$ & 0.25 & NA & $\mathrm{NA}$ & NA & $0.7 \mathrm{U}$ \\
\hline OT9A (0-6 in.) & $10 / 13 / 93$ & 0.25 & $\mathrm{NA}$ & NA & NA & $0.7 \mathrm{U}$ \\
\hline OT15B (6-12 in.) & $11 / 08 / 93$ & 0.75 & $100 \mathrm{U} 10$ & $100 \mathrm{U} 10$ & $1 U$ & $\mathrm{NA}$ \\
\hline OT16B (6-12 in.) & $11 / 08 / 93$ & 0.75 & $10 \mathrm{U}$ & $10 U$ & $1 \mathrm{U}$ & NA \\
\hline OT18A (0-6 in.) & $11 / 08 / 93$ & 0.25 & $\mathrm{NA}$ & $\mathrm{NA}$ & $1 \mathrm{U}$ & NA \\
\hline OT18B (6-12 in.) & $11 / 08 / 93$ & 0.75 & $1 \mathrm{U}$ & $10 \mathrm{U}$ & NA & NA \\
\hline OT19A (0-6 in.) & $11 / 08 / 93$ & 0.25 & $\mathrm{NA}$ & $\mathrm{NA}$ & $1 \mathrm{U}$ & $\mathrm{NA}$ \\
\hline OT19B (6-12 in.) & $11 / 08 / 93$ & 0.75 & $1 \mathrm{U}$ & $\mathrm{NA}$ & NA & NA \\
\hline OT29A (0-6 in.) & $10 / 27 / 93$ & 0.25 & $1 \mathrm{U}$ & $100 \mathrm{U} 10$ & $10 \mathrm{U1}$ & NA \\
\hline OT29B (6-12 in.) & $10 / 27 / 93$ & 0.75 & $\mathrm{NA}$ & $10 \mathrm{U}$ & $1 U$ & NA \\
\hline OT30A (0-6 in.) & $10 / 27 / 93$ & 0.25 & $\mathrm{NA}$ & $\mathrm{NA}$ & $10 \mathrm{U} 1$ & $\mathrm{NA}$ \\
\hline OT31A (0-6 in.) & $10 / 13 / 93$ & 0.25 & NA & $\mathrm{NA}$ & $1 U$ & NA \\
\hline OT32A (0-6 in.) & $10 / 13 / 93$ & 0.25 & NA & $\mathrm{NA}$ & $1 \mathrm{U}$ & NA \\
\hline
\end{tabular}

See next page for footnotes. 


\section{TABLE C.17 (Cont.)}

a Sampled and analyzed on-site by ANL.

Data qualifiers:

$\mathrm{U}=<$ value given.

$10 \mathrm{U} 1=<10 \mathrm{mg} / \mathrm{kg}$ but $>1 \mathrm{mg} / \mathrm{kg}$.

$100 \mathrm{U} 10=<100 \mathrm{mg} / \mathrm{kg}$ but $>10 \mathrm{mg} / \mathrm{kg}$.

$\mathrm{G}=>$ value given.

$\mathrm{NA}=$ not analyzed. 
TABLE C.18 Explosive Compounds Analyses for Soil Samples, May $1995^{\mathrm{a}}$

\begin{tabular}{|c|c|c|c|c|c|c|c|c|c|c|c|c|c|c|}
\hline \multirow{3}{*}{$\frac{\text { Compound }}{\text { 2-Amino-4,6-dinitrotoluene }}$} & \multicolumn{12}{|c|}{ Soil Concentrations $(\mu \mathrm{g} / \mathrm{kg})$ at Various Depth Intervals } & & \\
\hline & \multicolumn{2}{|c|}{$\begin{array}{c}\text { TBNPBOR2 } \\
(0-2 \mathrm{ft})\end{array}$} & \multicolumn{2}{|c|}{$\begin{array}{c}\text { VXBOR4 } \\
(2-4 \mathrm{ft})\end{array}$} & \multicolumn{2}{|c|}{$\begin{array}{c}\text { VXBOR4 } \\
(4-6 \mathrm{ft})\end{array}$} & \multicolumn{2}{|c|}{$\begin{array}{c}\text { VXBOR5 } \\
(0-2 \mathrm{ft})\end{array}$} & \multicolumn{2}{|c|}{$\begin{array}{c}\text { VXBOR5 } \\
(4-6 \mathrm{ft}) \\
\end{array}$} & \multicolumn{2}{|c|}{$\begin{array}{r}\text { VXBOR5 } \\
(8-10 \mathrm{ft}) \\
\end{array}$} & & \\
\hline & 46.7 & $U$ & 46.7 & $\mathrm{U}$ & 46.7 & $\mathrm{U}$ & 46.7 & $\mathrm{U}$ & 46.7 & $\mathrm{U}$ & 46.7 & $U$ & & \\
\hline 4-Amino-2,6-dinitrotoluene & 40.8 & $\mathrm{U}$ & 40.8 & $U$ & 40.8 & $\mathrm{U}$ & 40.8 & $\mathrm{U}$ & 40.8 & $U$ & 40.8 & $\mathrm{U}$ & & \\
\hline 1,3-Dinitrobenzene & 37.2 & $\mathrm{U}$ & 37.2 & $\mathrm{U}$ & 37.2 & $\mathbf{U}$ & 37.2 & $\mathrm{U}$ & 37.2 & $\mathrm{U}$ & 37.2 & $U$ & & \\
\hline 2,4-Dinitrotoluene & 51.6 & $\mathrm{U}$ & 51.6 & $\mathrm{U}$ & 51.6 & $\mathrm{U}$ & 51.6 & $\mathrm{U}$ & 51.6 & $\mathrm{U}$ & 51.6 & $\mathrm{U}$ & & \\
\hline 2,6-Dinitrotoluene & 47.6 & $\mathrm{U}$ & 47.6 & $U$ & 47.6 & $\mathrm{U}$ & 47.6 & $\mathrm{U}$ & 47.6 & $\mathrm{U}$ & 47.6 & $\mathrm{U}$ & & \\
\hline $\mathrm{HMX}$ & 70.5 & $\mathrm{U}$ & 70.5 & $\mathrm{U}$ & 70.5 & $U$ & 70.5 & $\mathrm{U}$ & 70.5 & $\mathrm{U}$ & 70.5 & $\mathrm{U}$ & & \\
\hline Nitrobenzene & 35.2 & $\mathrm{U}$ & 35.2 & $\mathrm{U}$ & 35.2 & $U$ & 35.2 & $\mathrm{U}$ & 35.2 & $\mathrm{U}$ & 35.2 & $\mathrm{U}$ & & \\
\hline Nitroglycerin & 10,000 & $\mathrm{U}$ & 50,000 & $* U$ & 50,000 & $* U$ & 10,000 & $\mathrm{U}$ & 50,000 & $* U$ & 10,000 & $\mathrm{U}$ & & \\
\hline 2-Nitrotoluene & 81.4 & $\mathrm{U}$ & 81.4 & $U$ & 81.4 & $\mathrm{U}$ & 81.4 & U & 81.4 & $\mathrm{U}$ & 81.4 & $U$ & & \\
\hline 3-Nitrotoluene & 81.7 & $U$ & 81.7 & $U$ & 81.7 & $U$ & 81.7 & $U$ & 81.7 & $\mathrm{U}$ & 81.7 & $U$ & & \\
\hline 4-Nitrotoluene & 87.2 & $\mathrm{U}$ & 87.2 & $\mathrm{U}$ & 87.2 & $U$ & 87.2 & U & 87.2 & $\mathrm{U}$ & 87.2 & $\mathrm{U}$ & & \\
\hline Pentaerythritol tetranitrate & 250 & $\mathrm{U}$ & 1,670 & & 1,250 & $* \mathrm{U}$ & 250 & $U$ & 250 & $\mathrm{U}$ & 250 & $U$ & & \\
\hline $\mathrm{RDX}$ & 50.9 & $\mathrm{U}$ & 50.9 & $\mathrm{U}$ & 50.9 & $U$ & 50.9 & $U$ & 50.9 & U & 50.9 & $\mathrm{U}$ & & \\
\hline Tetryl & 163 & $U$ & 163 & $\mathrm{U}$ & 163 & $\mathrm{U}$ & 163 & $U$ & 163 & U & 163 & $U$ & & \\
\hline $1,3,5$-Trinitrobenzene & 40.2 & $U$ & 40.2 & $U$ & 40.2 & $\mathrm{U}$ & 40.2 & U & 40.2 & $\mathrm{U}$ & 40.2 & $U$ & & \\
\hline \multirow[t]{2}{*}{ 2,4,6-Trinitrotoluene } & 35.6 & U & 35.6 & U & 35.6 & U & 35.6 & U & 35.6 & $\mathrm{U}$ & 35.6 & U & & \\
\hline & \multicolumn{13}{|c|}{ Soil Concentrations $(\mu \mathrm{g} / \mathrm{kg})$ at $0-6$ in. } & \\
\hline Compound & \multicolumn{2}{|c|}{ SQPS 4} & \multicolumn{2}{|c|}{ SQPS 5} & \multicolumn{2}{|c|}{ SQPS 8} & \multicolumn{2}{|c|}{ SQPS 9} & \multicolumn{2}{|c|}{ TPDGS 3} & \multicolumn{2}{|c|}{ TPDGS 4} & \multicolumn{2}{|c|}{ TPDGS 5} \\
\hline 2-Amino-4,6-dinitrotoluene & 46.7 & $\mathrm{U}$ & 46.7 & U & 46.7 & U & 46.7 & $U$ & 46.7 & $U$ & 46.7 & $U$ & 46.7 & U \\
\hline 4-Amino-2,6-dinitrotoluene & 40.8 & $\mathrm{U}$ & 40.8 & $\mathrm{U}$ & 40.8 & $\mathrm{U}$ & 40.8 & $\mathrm{U}$ & 40.8 & $U$ & 40.8 & $\mathrm{U}$ & 40.8 & U \\
\hline 1,3-Dinitrobenzene & 37.2 & $\mathrm{U}$ & 37.2 & $\mathrm{U}$ & 37.2 & $U$ & 37.2 & $U$ & 37.2 & U & 37.2 & $U$ & 37.2 & $U$ \\
\hline
\end{tabular}




\section{TABLE C.18 (Cont.)}

\begin{tabular}{|c|c|c|c|c|c|c|c|c|c|c|c|c|c|c|}
\hline \multirow{3}{*}{$\frac{\text { Compound }}{2,4-\text { Dinitrotoluene }}$} & \multicolumn{14}{|c|}{ Soil Concentrations $(\mu \mathrm{g} / \mathrm{kg})$ at $0-6 \mathrm{in}$. } \\
\hline & \multicolumn{2}{|c|}{ SQPS 4} & \multicolumn{2}{|c|}{ SQPS 5} & \multicolumn{2}{|c|}{ SQPS 8} & \multicolumn{2}{|c|}{ SQPS 9} & \multicolumn{2}{|c|}{ TPDGS 3} & \multicolumn{2}{|c|}{ TPDGS 4} & \multicolumn{2}{|c|}{ TPDGS 5} \\
\hline & 51.6 & $U$ & 51.6 & $\mathrm{U}$ & 51.6 & $\mathrm{U}$ & 51.6 & $\mathrm{U}$ & 51.6 & $\mathrm{U}$ & 51.6 & $\mathrm{U}$ & 51.6 & $\mathrm{U}$ \\
\hline 2,6-Dinitrotoluene & 47.6 & $\mathrm{U}$ & 47.6 & $\mathrm{U}$ & 47.6 & $U$ & 47.6 & $\mathrm{U}$ & 47.6 & $\mathrm{U}$ & 47.6 & $\mathrm{U}$ & 47.6 & $U$ \\
\hline $\mathrm{HMX}$ & 70.5 & $\mathrm{U}$ & 70.5 & $U$ & 70.5 & $U$ & 70.5 & $\mathrm{U}$ & 70.5 & $\mathrm{U}$ & 70.5 & $U$ & 70.5 & $U$ \\
\hline Nitrobenzene & 35.2 & $\mathrm{U}$ & 35.2 & $U$ & 35.2 & $U$ & 35.2 & $\mathrm{U}$ & 35.2 & $\mathrm{U}$ & 35.2 & $U$ & 35.2 & $\mathrm{U}$ \\
\hline Nitroglycerin & 10,000 & $\mathrm{U}$ & 10,000 & $\mathrm{U}$ & 20,000 & $U$ & 10,000 & $\mathrm{U}$ & 10,000 & $\mathrm{U}$ & 15,300 & & 10,000 & U \\
\hline 2-Nitrotoluene & 81.4 & $\mathrm{U}$ & 81.4 & $\mathrm{U}$ & 81.4 & $\mathrm{U}$ & 81.4 & $\mathrm{U}$ & 81.4 & $\mathrm{U}$ & 81.4 & $\mathrm{U}$ & 81.4 & $\mathrm{U}$ \\
\hline 3-Nitrotoluene & 81.7 & $U$ & 81.7 & $\mathrm{U}$ & 81.7 & $U$ & 81.7 & $U$ & 81.7 & $\mathrm{U}$ & 81.7 & $\mathrm{U}$ & 81.7 & $\mathrm{U}$ \\
\hline 4-Nitrotoluene & 87.2 & $\mathrm{U}$ & 87.2 & $U$ & 87.2 & $\mathrm{U}$ & 87.2 & $\mathrm{U}$ & 87.2 & $\mathrm{U}$ & 87.2 & $\mathrm{U}$ & 87.2 & $\mathrm{U}$ \\
\hline Pentaerythritol tetranitrate & 250 & $\mathrm{U}$ & 250 & $U$ & 500 & $\mathrm{U}$ & 500 & $\mathrm{U}$ & 250 & $\mathrm{U}$ & 250 & $\mathrm{U}$ & 250 & $\mathrm{U}$ \\
\hline $\mathrm{RDX}$ & 50.9 & $U$ & 50.9 & $\mathrm{U}$ & 50.9 & $\mathrm{U}$ & 50.9 & $\mathrm{U}$ & 50.9 & $\mathrm{U}$ & 50.9 & $\mathrm{U}$ & 50.9 & $\mathrm{U}$ \\
\hline Tetryl & 163 & $U$ & 163 & $U$ & 163 & $\mathrm{U}$ & 163 & $\mathrm{U}$ & 163 & $\mathrm{U}$ & 163 & $\mathrm{U}$ & 163 & $\mathrm{U}$ \\
\hline 1,3,5-Trinitrobenzene & 40.2 & $U$ & 40.2 & $\mathrm{U}$ & 40.2 & $\mathrm{U}$ & 40.2 & $\mathrm{U}$ & 40.2 & $\mathrm{U}$ & 40.2 & $\mathrm{U}$ & 40.2 & $U$ \\
\hline 2,4,6-Trinitrotoluene & 35.6 & $\mathrm{U}$ & 35.6 & $\mathrm{U}$ & 35.6 & $\mathrm{U}$ & 35.6 & $\mathrm{U}$ & 35.6 & $U$ & 35.6 & $U$ & 35.6 & $U$ \\
\hline
\end{tabular}

a Sampled by ANL and analyzed by GP Environmental Services.

Data qualifiers:

$\mathrm{U}=$ analyte was analyzed for but not detected; detection limit given.

* = internal standard area counts were outside the QC limits. 
TABLE C.19 CWA Degradation Products and Organosulfur Compound Analyses for Soil, May 1995

\begin{tabular}{|c|c|c|c|c|c|c|c|c|c|c|c|c|}
\hline \multirow[b]{2}{*}{ Compound } & \multicolumn{12}{|c|}{ Soil Concentrations (mg/kg) at Various Depth Intervals } \\
\hline & \multicolumn{2}{|c|}{$\begin{array}{c}\text { HBOR4 } \\
(6-8 \mathrm{ft}) \\
\end{array}$} & \multicolumn{2}{|c|}{$\begin{array}{l}\text { HBOR4 } \\
(8-10 \mathrm{ft}) \\
\end{array}$} & \multicolumn{2}{|c|}{$\begin{array}{l}\text { HBOR4 } \\
(10-12 \mathrm{ft})\end{array}$} & \multicolumn{2}{|c|}{$\begin{array}{c}\text { HBOR4 } \\
(14-16 f t)\end{array}$} & \multicolumn{2}{|c|}{$\begin{array}{c}\text { TBNPBOR2 } \\
(0-2 \mathrm{ft})\end{array}$} & \multicolumn{2}{|c|}{$\begin{array}{c}\text { TBNPBOR2 } \\
(2-6 \mathrm{ft})\end{array}$} \\
\hline Diisopropyl methylphosphonate (DIMP) & 0.09 & J & 0.01 & $\mathbf{J}$ & 0.03 & $\mathrm{U}$ & 0.141 & $\mathrm{U}$ & 0.138 & $\mathrm{U}$ & 0.133 & $\mathrm{U}$ \\
\hline Dimethyl methylphosphate (DMMP) & 0.157 & $\mathrm{U}$ & 0.152 & $U$ & 0.16 & $\mathrm{U}$ & 0.165 & $\mathrm{U}$ & 0.161 & $\mathrm{U}$ & 0.156 & $\mathrm{U}$ \\
\hline Isopropyl methylphosphonic acid (IMPA) & 0.978 & $\mathrm{U}$ & 1.14 & $\mathrm{U}$ & 1.18 & $\mathrm{U}$ & 1.28 & $\mathrm{U}$ & 1.02 & $\mathrm{U}$ & 1.35 & $\mathrm{U}$ \\
\hline Methyl phosphonic acid & 0.978 & $\mathrm{U}$ & 1.14 & $\mathrm{U}$ & 1.18 & $\mathrm{U}$ & 1.28 & $\mathrm{U}$ & 1.02 & $\mathrm{U}$ & 1.35 & $\mathrm{U}$ \\
\hline Thiodiglycol (TDGCL) & 4.65 & $U$ & 4.49 & $\mathrm{U}$ & 4.73 & $\mathrm{U}$ & 4.88 & $\mathrm{U}$ & 4.77 & $\mathrm{U}$ & 4.61 & $\mathrm{U}$ \\
\hline \multicolumn{13}{|l|}{ Organosulfur compounds } \\
\hline Benzothiozole (BTZ) & 6.35 & $\mathrm{U}$ & 2.45 & $\mathrm{U}$ & 2.59 & $\mathrm{U}$ & 1.34 & $\mathrm{U}$ & 1.31 & $\mathbf{U}$ & 1.26 & $\mathbf{U}$ \\
\hline p-Chlorophenylmethyl sulfide (CPMS) & 6.35 & $\mathrm{U}$ & 2.45 & $\mathrm{U}$ & 2.59 & $\mathrm{U}$ & 1.34 & $\mathrm{U}$ & 1.31 & $\mathrm{U}$ & 1.26 & $\mathrm{U}$ \\
\hline p-Chlorophenylmethyl sulfone (CPMSO2) & 13.9 & $\mathrm{U}$ & 5.38 & $\mathrm{U}$ & 5.69 & $\mathrm{U}$ & 2.94 & U & 2.87 & $\mathrm{U}$ & 2.77 & $\mathrm{U}$ \\
\hline p-Chlorophenylmethyl sulfoxide (CPMSO) & 13.2 & $\mathrm{U}$ & 5.11 & $\mathrm{U}$ & 5.4 & $\mathrm{U}$ & 2.79 & $\mathrm{U}$ & 2.72 & $\mathrm{U}$ & 2.63 & $\mathbf{U}$ \\
\hline Dimethyl disulfide (DMDS) & 4.07 & U & 1.57 & $\mathrm{U}$ & 1.66 & $\mathrm{U}$ & 0.858 & $\mathrm{U}$ & 0.837 & $U$ & 0.81 & $\mathrm{U}$ \\
\hline 1,4-Dithiane & 2.65 & J & 1.94 & $\mathrm{U}$ & 1.03 & J & 1.82 & $\mathrm{U}$ & 1.78 & $\mathrm{U}$ & 1.72 & $\mathbf{U}$ \\
\hline 1,4-Oxathiane & 5.03 & $\mathrm{U}$ & 0.59 & $\mathrm{~J}$ & 2.05 & U & 1.06 & $\underline{U}$ & 1.04 & $\underline{U}$ & 1 & $U$ \\
\hline & \multicolumn{12}{|c|}{ Soil Concentrations $(\mathrm{mg} / \mathrm{kg}$ ) at Various Depth Intervals } \\
\hline Compound & \multicolumn{2}{|c|}{$\begin{array}{c}\text { TBNPBOR2 } \\
(6-8 \mathrm{ft})\end{array}$} & \multicolumn{2}{|c|}{$\begin{array}{c}\text { TBNPBOR2 } \\
(10-12 \mathrm{ft})\end{array}$} & \multicolumn{2}{|c|}{$\begin{array}{l}\text { VXBOR4 } \\
(2-4 \mathrm{ft})\end{array}$} & \multicolumn{2}{|c|}{$\begin{array}{c}\text { VXBOR4 } \\
(4-6 \mathrm{ft})\end{array}$} & \multicolumn{2}{|c|}{$\begin{array}{c}\text { VXBOR5 } \\
(0-2 \mathrm{ft})\end{array}$} & \multicolumn{2}{|c|}{$\begin{array}{l}\text { VXBOR5 } \\
(4-6 \mathrm{ft})\end{array}$} \\
\hline \multicolumn{13}{|l|}{ CWA degradation products } \\
\hline Diisopropyl methylphosphonate (DIMP) & 1.39 & $\mathrm{U}$ & 0.137 & $\mathrm{U}$ & 0.725 & $\mathrm{U}$ & 0.279 & $\mathbf{U}$ & 0.138 & $\mathrm{U}$ & 0.148 & $\mathrm{U}$ \\
\hline Dimethyl methylphosphate (DMMP) & 0.162 & $\mathrm{U}$ & 0.16 & $\mathrm{U}$ & 0.846 & $\mathrm{U}$ & 0.326 & U & 0.161 & $\mathrm{U}$ & 0.173 & $\mathrm{U}$ \\
\hline Isopropyl methylphosphonic acid (IMPA) & 1.43 & $\mathrm{U}$ & 1.1 & $\mathbf{U}$ & 1.36 & $\mathrm{U}$ & 0.828 & U & 1.09 & $\mathbf{U}$ & 1.49 & $\mathbf{U}$ \\
\hline Methyl phosphonic acid & 1.43 & $\mathrm{U}$ & 1.1 & $\mathbf{U}$ & 1.36 & $\mathrm{U}$ & 0.828 & $\mathbf{U}$ & 1.09 & $\mathbf{U}$ & 1.49 & $\mathrm{U}$ \\
\hline Thiodiglycol (TDGCL) & 4.81 & $\mathrm{U}$ & 4.85 & $U$ & 5 & $\mathrm{U}$ & 4.81 & $\mathbf{U}$ & 4.77 & $\mathbf{U}$ & 5.12 & $\mathrm{U}$ \\
\hline
\end{tabular}


Soil Concentrations $(\mathrm{mg} / \mathrm{kg})$ at Various Depth Intervals

\begin{tabular}{|c|c|c|c|c|c|c|c|c|c|c|c|c|}
\hline \multirow{2}{*}{ Organosulfur compounds } & \multicolumn{2}{|c|}{$\begin{array}{c}\text { TBNPBOR2 } \\
(6.8 \mathrm{ft}) \\
\end{array}$} & \multicolumn{2}{|c|}{$\begin{array}{c}\text { TBNPBOR2 } \\
(10-12 \mathrm{ft}) \\
\end{array}$} & \multicolumn{2}{|c|}{$\begin{array}{c}\text { VXBOR4 } \\
(2-4 \mathrm{ft}) \\
\end{array}$} & \multicolumn{2}{|c|}{$\begin{array}{c}\text { VXBOR4 } \\
(4-6 \mathrm{ft})\end{array}$} & \multicolumn{2}{|c|}{$\begin{array}{c}\text { VXBOR5 } \\
(0-2 \mathrm{ft})\end{array}$} & \multicolumn{2}{|c|}{$\begin{array}{l}\text { VXBORS } \\
(4-6 \mathrm{ft})\end{array}$} \\
\hline & & & & & & & & & & & & \\
\hline Benzothiozole (BTZ) & 1.32 & $\mathrm{U}$ & 1.33 & $\mathrm{U}$ & 68.7 & UJ & 26.4 & $U$ & 1.31 & $\mathrm{U}$ & 1.4 & $\mathrm{U}$ \\
\hline p-Chlorophenylmethyl sulfide (CPMS) & 1.32 & $\mathrm{U}$ & 1.33 & $\mathrm{U}$ & 68.7 & UJ & 26.4 & $\mathrm{U}$ & 1.31 & $\mathrm{U}$ & 1.4 & $\mathrm{U}$ \\
\hline p-Chlorophenylmethyl sulfone (CPMSO2) & 2.89 & $\mathrm{U}$ & 2.92 & $U$ & 151 & U & 58 & $\mathrm{U}$ & 2.87 & $\mathrm{U}$ & 3.08 & $\mathrm{U}$ \\
\hline p-Chlorophenylmethyl sulfoxide (CPMSO) & 2.74 & $\mathrm{U}$ & 0.851 & $\mathrm{U}$ & 143 & U & 55.1 & $\mathrm{U}$ & 2.72 & $\mathrm{U}$ & 2.92 & $\mathrm{U}$ \\
\hline Dimethyl disulfide (DMDS) & 0.844 & $\mathrm{U}$ & & $U$ & 44 & UJ & 16.9 & $\mathrm{U}$ & 0.837 & $\mathbf{U}$ & 0.9 & $\mathrm{U}$ \\
\hline 1,4-Dithiane & 1.79 & $\mathrm{U}$ & 1.81 & $\mathrm{U}$ & 93.5 & UJ & 36 & $\mathrm{U}$ & 0.46 & $\mathbf{J}$ & 1.91 & $\mathrm{U}$ \\
\hline 1,4-Oxathiane & 1.04 & U & 1.05 & U & 54.4 & UJ & 21 & $\mathrm{U}$ & 1.04 & $\mathrm{U}$ & 1.11 & U \\
\hline
\end{tabular}

Soil Concentrations $(\mathrm{mg} / \mathrm{kg}$ ) at Various Depth Intervals

\begin{tabular}{|c|c|c|c|c|c|c|c|c|}
\hline \multirow[b]{2}{*}{ Compound } & \multicolumn{8}{|c|}{ Soil Concentrations $(\mathrm{mg} / \mathrm{kg})$ at Various Depth Intervals } \\
\hline & \multicolumn{2}{|c|}{$\begin{array}{l}\text { VXBOR5 } \\
(8-10 \mathrm{ft})\end{array}$} & \multicolumn{2}{|c|}{$\begin{array}{l}\text { VXBOR5 } \\
(10-12 \mathrm{ft})\end{array}$} & \multicolumn{2}{|c|}{$\begin{array}{l}\text { VXBOR5 } \\
(12-14 \mathrm{ft})\end{array}$} & \multicolumn{2}{|c|}{$\begin{array}{l}\text { VXBOR5 } \\
(14-16 \mathrm{ft}) \\
\end{array}$} \\
\hline \multicolumn{9}{|l|}{ CWA degradation products } \\
\hline Diisopropyl methylphosphonate (DIMP) & 0.141 & $\mathrm{U}$ & 0.14 & $\mathrm{U}$ & 0.142 & $\mathrm{U}$ & 0.141 & $\mathrm{U}$ \\
\hline Dimethyl methylphosphate (DMMP) & 0.165 & $\mathrm{U}$ & 0.17 & $\mathrm{U}$ & 0.166 & $\mathrm{U}$ & 0.165 & $\mathrm{U}$ \\
\hline Isopropyl methylphosphonic acid (IMPA) & 1.26 & $\mathrm{U}$ & 1.16 & $\mathrm{U}$ & 1.36 & $\mathrm{U}$ & 1.14 & $\mathrm{U}$ \\
\hline Methyl phosphonic acid & 1.26 & $\mathrm{U}$ & 1.16 & $\mathbf{U}$ & 1.36 & $\mathrm{U}$ & 1.14 & $\mathrm{U}$ \\
\hline Thiodiglycol (TDGCL) & 4.88 & $\mathrm{U}$ & 4.92 & $\mathbf{U}$ & 4.92 & $\mathrm{U}$ & 4.88 & $\mathrm{U}$ \\
\hline \multicolumn{9}{|l|}{ Organosulfur compounds } \\
\hline Benzothiozole (BTZ) & 1.34 & $\mathrm{U}$ & 1.35 & $\mathrm{U}$ & 1.35 & $\mathrm{U}$ & 1.34 & U \\
\hline p-Chlorophenylmethyl sulfide (CPMS) & 1.34 & $\mathrm{U}$ & 1.35 & $U$ & 1.35 & $\mathrm{U}$ & 1.34 & $\mathrm{U}$ \\
\hline p-Chlorophenylmethyl sulfone (CPMSO2) & 2.94 & $\mathrm{U}$ & 2.96 & $\mathrm{U}$ & 2.96 & $\mathrm{U}$ & 2.94 & $\mathrm{U}$ \\
\hline p-Chlorophenylmethyl sulfoxide (CPMSO) & 2.79 & $\mathrm{U}$ & 2.81 & $\mathrm{U}$ & 2.81 & $\mathrm{U}$ & 2.79 & $\mathrm{U}$ \\
\hline Dimethyl disulfide (DMDS) & 0.858 & $\mathrm{U}$ & 0.87 & $\mathrm{U}$ & 0.865 & $\mathbf{U}$ & 0.858 & $\mathrm{U}$ \\
\hline 1,4-Dithiane & 1.82 & $\mathrm{U}$ & 1.84 & U & 0.23 & $\mathbf{J}$ & 1.82 & U \\
\hline 1,4-Oxathiane & 1.06 & $\mathrm{U}$ & 1.07 & $\mathrm{U}$ & 1.07 & $\mathbf{U}$ & 1.06 & $\mathrm{U}$ \\
\hline
\end{tabular}

a Sampled by ANL, analyzed by GP Environmental Services.

Data qualifiers: $\mathrm{J}=$ estimated value. $\mathrm{U}=$ analyte was analyzed for but not detected; detection limit given. 
TABLE C.20 Dioxin and Total Petroleum Hydrocarbons Analyses for Soil Samples, May $1995^{\mathrm{a}}$

\begin{tabular}{|c|c|c|c|c|c|c|c|c|c|}
\hline \multirow{3}{*}{$\frac{\text { Analyte }}{\text { Heptachlorodibenzo-p-dioxins }}$} & \multicolumn{9}{|c|}{ Soil Concentrations $(\mu \mathrm{g} / \mathrm{kg}$ ) at Various Depth Intervals } \\
\hline & $\begin{array}{l}\text { TBNPBOR3 } \\
(4-6 \mathrm{ft})\end{array}$ & \multicolumn{2}{|c|}{$\begin{array}{l}\text { VXBOR4 } \\
(2-4 \mathrm{ft})\end{array}$} & \multicolumn{2}{|c|}{$\begin{array}{l}\text { VXBOR4 } \\
(4-6 \mathrm{ft})\end{array}$} & \multicolumn{2}{|c|}{$\begin{array}{l}\text { VXBOR5 } \\
(4-6 \mathrm{ft})\end{array}$} & \multicolumn{2}{|c|}{$\begin{array}{l}\text { VXBOR5 } \\
(8-10 \mathrm{ft})\end{array}$} \\
\hline & 2.9 & 0.16 & $U$ & 0.15 & $\mathrm{U}$ & 0.11 & $\mathrm{U}$ & 0.03 & $\mathrm{U}$ \\
\hline Heptachlorodibenzo-p-furans & 2.9 & 0.07 & & 0.02 & $\mathrm{U}$ & 0.02 & $\mathrm{U}$ & 0.01 & $\mathrm{U}$ \\
\hline Hexachlorodibenzo-p-dioxins & 1.6 & 0.06 & $\mathrm{U}$ & 0.06 & U & 0.05 & $U$ & 0.04 & U \\
\hline Hexachlorodibenzo-p-furans & 3.1 & 0.03 & & 0.03 & $\mathrm{U}$ & 0.01 & $\mathrm{U}$ & 0.01 & $\mathrm{U}$ \\
\hline Octachlorodibenzo-p-dioxin & 4.3 & 0.32 & & 0.28 & & 0.1 & & 0.03 & U \\
\hline Octachlorodibenzo-p-furan & 1.7 & 0.04 & $U$ & 0.04 & U & 0.04 & $\mathrm{U}$ & 0.02 & $\mathrm{U}$ \\
\hline Pentachlorodibenzo-p-dioxins & 0.26 & 0.03 & $U$ & 0.03 & U & 0.04 & $U$ & 0.03 & $U$ \\
\hline Pentachlorodibenzo-p-furans & 3.4 & 0.14 & $U$ & 0.09 & $\mathrm{U}$ & 0.05 & $U$ & 0.02 & $U$ \\
\hline $2,3,7,8-\mathrm{TCDD}$ & 0.18 & 0.01 & $\mathrm{U}$ & 0.02 & U & 0.04 & $\mathrm{U}$ & 0.02 & U \\
\hline $2,3,7,8-\mathrm{TCDF}$ & 0.49 & 0.04 & & 0.04 & & 0.02 & $\mathrm{U}$ & 0.01 & $U$ \\
\hline Tetrachlorodibenzo-p-dioxins & 0.07 & 0.01 & $U$ & 0.02 & $\mathrm{U}$ & 0.04 & $\mathrm{U}$ & 0.02 & $U$ \\
\hline Tetrachlorodibenzo-p-furans & 1.5 & 0.04 & & 0.04 & & 0.02 & $\mathrm{U}$ & 0.01 & $U$ \\
\hline $\begin{array}{l}\text { Total petroleum hydrocarbons } \\
(\mathrm{mg} / \mathrm{kg})\end{array}$ & 19,000 & 35,400 & $J(+)$ & 18,200 & . & 666 & & 31 & $\mathrm{UJ}(+)$ \\
\hline
\end{tabular}

a Sampled by ANL and analyzed by GP Environmental Services.

Data qualifiers:

$U=$ analyte was analyzed for but not detected; detection limit given.

$\mathrm{J}=$ estimated value.

$+=$ value obtained from a 1:10 dilution. 


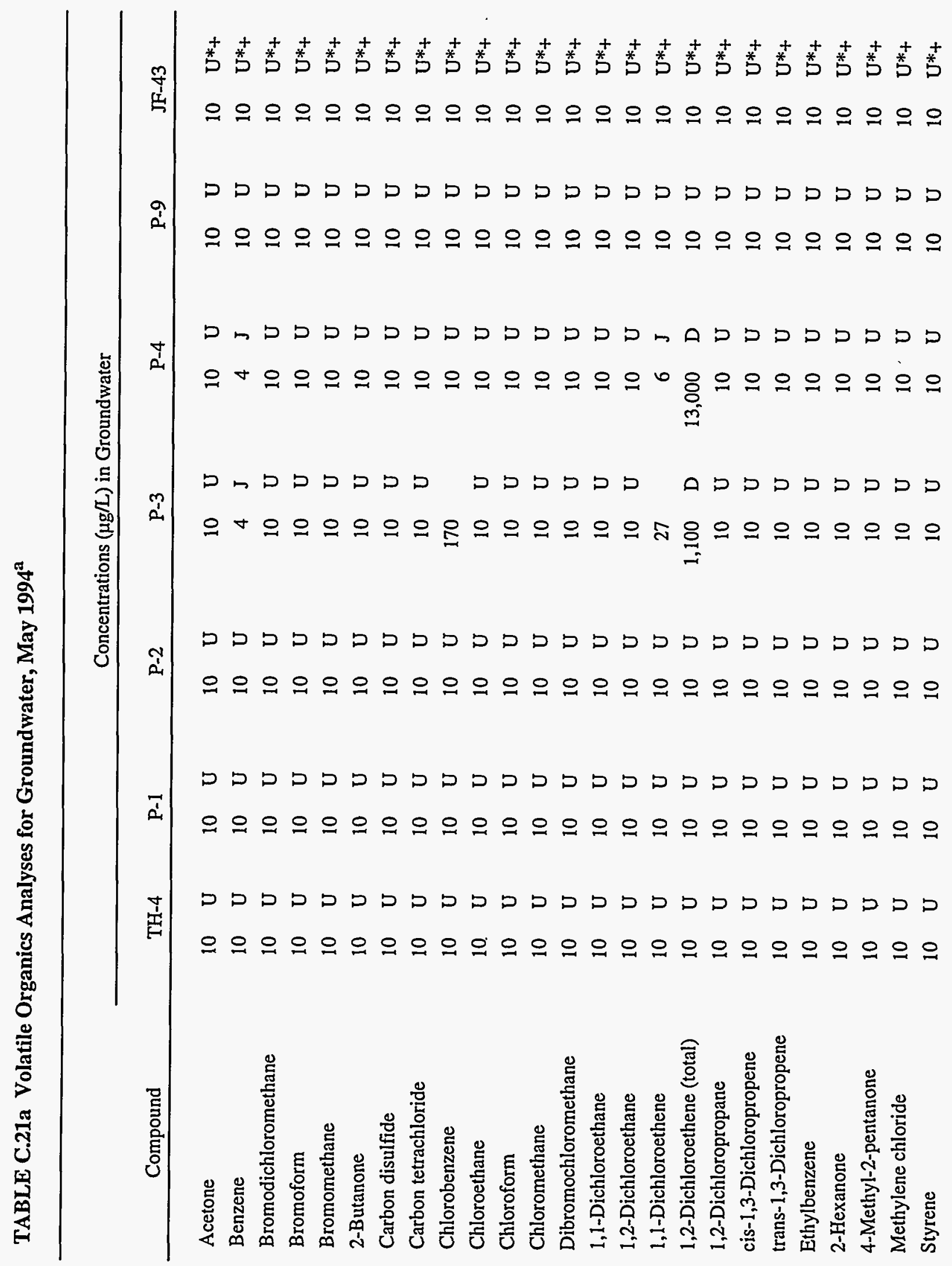


TABLE C.21a (Cont.)

\begin{tabular}{|c|c|c|c|c|c|c|c|c|c|c|c|c|c|c|}
\hline \multirow{3}{*}{$\frac{\text { Compound }}{1,1,2,2 \text {-Tetrachloroethane }}$} & \multicolumn{14}{|c|}{ Concentrations $(\mu \mathrm{g} / \mathrm{L})$ in Groundwater } \\
\hline & \multicolumn{2}{|c|}{ TH-4 } & \multicolumn{2}{|c|}{$\mathrm{P}-1$} & \multicolumn{2}{|c|}{$\mathrm{P}-2$} & \multicolumn{2}{|c|}{$\mathrm{P}-3$} & \multicolumn{2}{|c|}{ P-4 } & \multicolumn{2}{|c|}{ P-9 } & \multicolumn{2}{|c|}{$\mathrm{JF}-43$} \\
\hline & 10 & $\mathrm{U}$ & 10 & $\mathrm{U}$ & 10 & $U$ & 4 & $\mathbf{J}$ & 3,500 & $\mathrm{D}$ & 10 & $\mathrm{U}$ & 10 & $\mathrm{U}^{*}+$ \\
\hline Tetrachloroethene & 10 & $\mathrm{U}$ & 10 & $U$ & 10 & $U$ & 2,400 & $\mathrm{D}$ & 19 & & 10 & $\mathrm{U}$ & 10 & $U^{*}+$ \\
\hline Toluene & 10 & $\mathrm{U}$ & 10 & $\mathrm{U}$ & 10 & $\mathrm{U}$ & 6 & $\mathbf{J}$ & 10 & $\mathrm{U}$ & 10 & $\mathrm{U}$ & 10 & $\mathrm{U}^{*+}$ \\
\hline 1,1,1-Trichloroethane & 10 & $\mathrm{U}$ & 10 & $\mathrm{U}$ & 10 & $U$ & 10 & $U$ & 10 & $U$ & 10 & $\mathrm{U}$ & 10 & $\mathrm{U}^{*}+$ \\
\hline 1,1,2-Trichloroethane & 10 & $\mathrm{U}$ & 10 & U & 10 & $\mathrm{U}$ & 10 & $\mathrm{U}$ & 68 & & 10 & $\mathrm{U}$ & 10 & $\mathrm{U}^{*}+$ \\
\hline Trichloroethene & 10 & $\mathrm{U}$ & 10 & $\mathrm{U}$ & 10 & $U$ & 390 & $\mathrm{D}$ & 1,800 & $\mathrm{D}$ & 10 & $\mathrm{U}$ & 10 & $\mathrm{U}^{*+}$ \\
\hline Vinyl chloride & 10 & $U$ & 10 & $\mathrm{U}$ & 10 & $\mathrm{U}$ & 570 & $\mathrm{D}$ & 74 & & 10 & $U$ & 10 & $\mathrm{U}^{*}+$ \\
\hline \multirow[t]{2}{*}{ Xylenes (total) } & 10 & $\mathrm{U}$ & 10 & U & 10 & $\mathrm{U}$ & 3 & $\mathrm{~J}$ & 10 & $\mathrm{U}$ & 10 & U. & 10 & $\mathrm{U}^{*}+$ \\
\hline & \multicolumn{14}{|c|}{ Concentrations $(\mu \mathrm{g} / \mathrm{L})$ in Groundwater } \\
\hline Compound & \multicolumn{2}{|c|}{$\mathrm{JF}-53$} & \multicolumn{2}{|c|}{ JF-63 } & \multicolumn{2}{|c|}{ JF-73 } & \multicolumn{2}{|c|}{ JF-83 } & \multicolumn{2}{|c|}{ JF-173 } & \multicolumn{2}{|c|}{$\mathrm{JF}-183$} & \multicolumn{2}{|c|}{$\mathrm{JF}-52$} \\
\hline Acetone & 10 & $U$ & 10 & $\mathrm{U}$ & 10 & $U$ & 10 & $\mathrm{U}$ & 10 & $\mathrm{U}$ & 10 & $U$ & 10 & $\mathrm{U}$ \\
\hline Benzene & 10 & $U$ & 10 & $\mathrm{U}$ & 10 & $\mathrm{U}$ & 10 & $U$ & 10 & $\mathrm{U}$ & 3 & $\mathbf{J}$ & 10 & $U$ \\
\hline Bromodichloromethane & 10 & $U$ & 10 & $\mathrm{U}$ & 10 & $U$ & 10 & $\mathrm{U}$ & 10 & $\mathrm{U}$ & 10 & $\mathrm{U}$ & 10 & $U$ \\
\hline Bromoform & 10 & $\mathrm{U}$ & 10 & $U$ & 10 & $\mathrm{U}$ & 10 & U & 10 & $\mathrm{U}$ & 10 & $U$ & 10 & $U$ \\
\hline Bromomethane & 10 & $\mathrm{U}$ & 10 & $U$ & 10 & $\mathrm{U}$ & 10 & $U$ & 10 & U & 10 & $\mathrm{U}$ & 10 & $U$ \\
\hline 2-Butanone & 10 & $U$ & 10 & $U$ & 10 & $\mathrm{U}$ & 10 & $\mathrm{U}$ & 10 & U & 10 & $\mathrm{U}$ & 10 & $\mathrm{U}$ \\
\hline Carbon disulfide & 10 & $U$ & 10 & U & 10 & $\mathrm{U}$ & 10 & $\mathrm{U}$ & 10 & $U$ & 10 & $\mathrm{U}$ & 10 & $U$ \\
\hline Carbon tetrachloride & 10 & $U$ & 10 & $U$ & 10 & $\mathrm{U}$ & 10 & $\mathrm{U}$ & 10 & $\mathrm{U}$ & 3 & $\mathrm{~J}$ & 10 & $U$ \\
\hline Chlorobenzene & 10 & $\mathrm{U}$ & 10 & $U$ & 10 & $U$ & 10 & $\mathrm{U}$ & 10 & $\mathrm{U}$ & 10 & $\mathrm{U}$ & 10 & $U$ \\
\hline Chloroethane & 10 & $\mathrm{U}$ & 10 & U & 10 & $\mathrm{U}$ & 10 & $\mathrm{U}$ & 10 & $\mathrm{U}$ & 10 & $\mathrm{U}$ & 10 & $\mathrm{U}$ \\
\hline Chloroform & 10 & $\mathrm{U}$ & 9 & $\mathrm{~J}$ & 10 & $\mathrm{U}$ & 44 & & 10 & $U$ & 12 & & 10 & $\mathrm{U}$ \\
\hline Chloromethane & 10 & $\mathrm{U}$ & 10 & U & 10 & $\mathrm{U}$ & 10 & $\mathrm{U}$ & 10 & $U$ & 10 & $U$ & 10 & $\mathrm{U}$ \\
\hline
\end{tabular}




\begin{tabular}{|c|c|c|c|c|c|c|c|c|c|c|c|c|c|c|}
\hline \multirow{3}{*}{ Compound } & \multicolumn{14}{|c|}{ Concentrations $(\mu \mathrm{g} / \mathrm{L})$ in Groundwater } \\
\hline & \multicolumn{2}{|c|}{ JF-53 } & \multicolumn{2}{|c|}{$\mathrm{JF}-63$} & \multicolumn{2}{|c|}{ JF-73 } & \multicolumn{2}{|c|}{$\mathrm{JF}-83$} & \multicolumn{2}{|c|}{$\mathrm{JF}-173$} & \multicolumn{2}{|c|}{$\mathrm{JF}-183$} & \multicolumn{2}{|c|}{$\mathrm{JF}-52$} \\
\hline & 10 & $\mathrm{U}$ & 10 & $U$ & 10 & $\mathrm{U}$ & 10 & $\mathrm{U}$ & 10 & $\mathbf{U}$ & 10 & $\mathrm{U}$ & 10 & $U$ \\
\hline 1,1-Dichloroethane & 10 & $U$ & 10 & $U$ & 10 & $\mathrm{U}$ & 10 & $\mathrm{U}$ & 10 & $\mathrm{U}$ & 10 & $\mathrm{U}$ & 10 & $U$ \\
\hline 1,2-Dichloroethane & 10 & $\mathrm{U}$ & 10 & U & 10 & $\mathrm{~J}$ & 6 & $\mathrm{~J}$ & 10 & $\mathbf{U}$ & 5 & & 10 & $\mathrm{U}$ \\
\hline 1,1-Dichloroethene & 10 & $\mathrm{U}$ & 10 & $\mathrm{U}$ & 15 & & 12 & & 10 & $\mathrm{U}$ & 17 & & 10 & $U$ \\
\hline 1,2-Dichloroethene (total) & 2,200 & $\mathrm{D}$ & 44 & DJ & 8,900 & $\mathrm{D}$ & 5,800 & $\mathrm{E}$ & 1,400 & $\mathrm{D}$ & 10,000 & $\mathrm{D}$ & 62 & \\
\hline 1,2-Dichloropropane & 10 & $\mathrm{U}$ & 10 & $U$ & 10 & $\mathrm{U}$ & 10 & $\mathrm{U}$ & 10 & $\mathrm{U}$ & 10 & $\mathrm{U}$ & 10 & $\mathrm{U}$ \\
\hline cis-1,3-Dichloropropene & 10 & $U$ & 10 & $U$ & 10 & $\mathrm{U}$ & 10 & $\mathrm{U}$ & 10 & $\mathrm{U}$ & 10 & $\mathrm{U}$ & 10 & $\mathrm{U}$ \\
\hline trans-1,3-Dichloropropene & 10 & $\mathrm{U}$ & 10 & $\mathrm{U}$ & 10 & $\mathrm{U}$ & 10 & $\mathrm{U}$ & 10 & $\mathrm{U}$ & 10 & $\mathrm{U}$ & 10 & $\mathrm{U}$ \\
\hline Ethylbenzene & 10 & $\mathrm{U}$ & 10 & $U$ & 10 & $\mathrm{U}$ & 10 & $\mathrm{U}$ & 10 & $\mathrm{U}$ & 10 & $\mathrm{U}$ & 10 & $U$ \\
\hline 2-Hexanone & 10 & $\mathrm{U}$ & 10 & $U$ & 10 & $U$ & 10 & $U$ & 10 & $\mathrm{U}$ & 10 & $\mathrm{U}$ & 10 & $\mathrm{U}$ \\
\hline 4-Methyl-2-pentanone & 10 & $\mathrm{U}$ & 10 & $\mathrm{U}$ & 10 & $\mathrm{U}$ & 10 & $\mathrm{U}$ & 10 & $\mathrm{U}$ & 10 & $\mathrm{U}$ & 10 & $\mathrm{U}$ \\
\hline Methylene chloride & 10 & $\mathrm{U}$ & 10 & $U$ & 10 & $\mathrm{U}$ & 10 & $U$ & 10 & $U$ & 10 & $\mathrm{U}$ & 5 & $\mathrm{BJ}$ \\
\hline Styrene & 10 & $\mathrm{U}$ & 10 & $\mathrm{U}$ & 10 & $\mathrm{U}$ & 10 & $\mathrm{U}$ & 10 & $\mathrm{U}$ & 10 & $\mathrm{U}$ & 10 & $\mathrm{U}$ \\
\hline 1,1,2,2-Tetrachloroethane & 550 & $\mathrm{D}$ & 50 & & 13,000 & $\mathrm{D}$ & 160,000 & $\mathrm{D}$ & 12,000 & $\mathrm{D}$ & 39,000 & $\mathrm{D}$ & 10 & $\mathrm{U}$ \\
\hline Tetrachloroethene & 7 & $\mathbf{J}$ & 32 & & 250 & DJ & 1,100 & $\mathrm{E}$ & 170 & & 8,300 & & 10 & $\mathbf{U}$ \\
\hline Toluene & 10 & $\mathrm{U}$ & 10 & $\mathbf{U}$ & 10 & $\mathrm{U}$ & 10 & $\mathrm{U}$ & 10 & $\mathrm{U}$ & 10 & $\mathrm{U}$ & 10 & $\mathbf{U}$ \\
\hline 1,1,1-Trichloroethane & 10 & $\mathrm{U}$ & 10 & $\mathrm{U}$ & 10 & $\mathrm{U}$ & 10 & $\mathrm{U}$ & 10 & $\mathrm{U}$ & 10 & U & 10 & $\mathrm{U}$ \\
\hline 1,1,2-Trichloroethane & 58 & & 10 & $\mathrm{U}$ & 200 & $\mathrm{E}$ & 990 & $\mathrm{E}$ & 230 & $\mathrm{E}$ & 600 & $\mathrm{D}$ & 10 & $U$ \\
\hline Trichloroethene & 390 & $\mathrm{D}$ & 680 & $\mathrm{D}$ & 4,100 & $\mathrm{D}$ & 21,000 & D & 5,800 & $\mathrm{D}$ & 13,000 & $D$ & 9 & $\mathrm{~J}$ \\
\hline Vinyl chloride & 41 & & 12 & & 230 & $\mathrm{E}$ & 34 & & 13 & & 68 & & 30 & \\
\hline Xylenes (total) & 10 & $\mathrm{U}$ & 10 & $U$ & 10 & U & 10 & U & 10 & U & 10 & U & 10 & $\mathrm{U}$ \\
\hline
\end{tabular}


TABLE C.21a (Cont.)

\begin{tabular}{|c|c|c|c|c|c|c|c|c|c|c|c|c|c|c|}
\hline \multirow{3}{*}{$\begin{array}{l}\text { Compound } \\
\text { Acetone }\end{array}$} & \multicolumn{14}{|c|}{ Concentrations $(\mu \mathrm{g} / \mathrm{L})$ in Groundwater } \\
\hline & \multicolumn{2}{|c|}{$\mathrm{JF}-62$} & \multicolumn{2}{|c|}{$\mathrm{JF}-72$} & \multicolumn{2}{|c|}{$\mathrm{JF}-82$} & \multicolumn{2}{|c|}{$\mathrm{JF}-51$} & \multicolumn{2}{|c|}{$\mathrm{JF}-61$} & \multicolumn{2}{|c|}{$\mathrm{JF}-71$} & \multicolumn{2}{|c|}{$\mathrm{JF}-81$} \\
\hline & 10 & $\mathrm{U}$ & 52 & & 10 & $U$ & 10 & $\mathrm{U}$ & 10 & $\mathrm{U}$ & 10 & $\mathrm{U}$ & 10 & $\mathrm{U}$ \\
\hline Benzene & 10 & $\mathrm{U}$ & 10 & $\mathrm{U}$ & 10 & U & 10 & $\mathrm{U}$ & 10 & $\mathrm{U}$ & 10 & $\mathrm{U}$ & 10 & $\mathrm{U}$ \\
\hline Bromodichloromethane & 10 & $\mathrm{U}$ & 10 & $\mathrm{U}$ & 10 & $U$ & 10 & $\mathrm{U}$ & 10 & $U$ & 10 & $\mathrm{U}$ & 10 & $\mathrm{U}$ \\
\hline Bromoform & 10 & $\mathrm{U}$ & 10 & $\mathrm{U}$ & 10 & $\mathrm{U}$ & 10 & $U$ & 10 & $\mathrm{U}$ & 10 & $U$ & 10 & $U$ \\
\hline Bromomethane & 10 & $U$ & 10 & $\mathrm{U}$ & 10 & $\mathrm{U}$ & 10 & $\mathrm{U}$ & 10 & $U$ & 10 & $U$ & 10 & $U$ \\
\hline 2-Butanone & 10 & $U$ & 10 & $\mathrm{U}$ & 10 & $\mathrm{U}$ & 10 & $\mathrm{U}$ & 10 & $U$ & 10 & $U$ & 10 & $U$ \\
\hline Carbon disulfide & 10 & $U$ & 10 & $U$ & 10 & $\mathrm{U}$ & 10 & $\mathrm{U}$ & 10 & $U$ & 10 & $\mathrm{U}$ & 10 & $\mathrm{U}$ \\
\hline Carbon tetrachloride & 10 & $U$ & 10 & $U$ & 10 & $\mathrm{U}$ & 10 & $\mathrm{U}$ & 10 & $\mathrm{U}$ & 10 & $\mathrm{U}$ & 10 & $U$ \\
\hline Chlorobenzene & 10 & $\mathrm{U}$ & 10 & $U$ & 10 & $\mathrm{U}$ & 10 & $\mathrm{U}$ & 10 & $\mathrm{U}$ & 10 & $\mathrm{U}$ & 10 & $U$ \\
\hline Chloroethane & 10 & $\mathrm{U}$ & 10 & $U$ & 10 & $\mathrm{U}$ & 10 & $U$ & 10 & $\mathrm{U}$ & 10 & $\mathrm{U}$ & 10 & $\mathrm{U}$ \\
\hline Chloroform & 10 & $\mathrm{U}$ & 10 & $U$ & 10 & $\mathrm{U}$ & 10 & $U$ & 10 & $\mathrm{U}$ & 10 & $\mathrm{U}$ & 10 & $\mathrm{U}$ \\
\hline Chloromethane & 10 & $\mathrm{U}$ & 10 & $\mathrm{U}$ & 10 & $\mathrm{U}$ & 10 & $\mathrm{U}$ & 10 & $\mathrm{U}$ & 10 & $\mathrm{U}$ & 10 & $\mathrm{U}$ \\
\hline Dibromochloromethane & 10 & $\mathrm{U}$ & 10 & $\mathrm{U}$ & 10 & $U$ & 10 & $\mathrm{U}$ & 10 & $\mathrm{U}$ & 10 & $\mathrm{U}$ & 10 & $U$ \\
\hline 1,1-Dichloroethane & 10 & $\mathrm{U}$ & 10 & $\mathrm{U}$ & 10 & $U^{\cdot}$ & 10 & $\mathrm{U}$ & 10 & $\mathrm{U}$ & 10 & $\mathbf{U}$ & 10 & $U$ \\
\hline 1,2-Dichloroethane & 10 & $\mathrm{U}$ & 10 & $\mathrm{U}$ & 10 & $U$ & 10 & $\mathrm{U}$ & 10 & $U$ & 10 & $U$ & 10 & $U$ \\
\hline 1,1-Dichloroethene & 10 & $U$ & 10 & $U$ & 11 & & 6 & J & 10 & $\mathrm{U}$ & 10 & $\mathrm{U}$ & 28 & \\
\hline 1,2-Dichloroethene (total) & 10 & $\mathrm{U}$ & 3 & $\mathrm{~J}$ & 170 & $\mathrm{D}$ & 650 & $\mathrm{D}$ & 10 & $\mathrm{U}$ & 10 & $\mathrm{U}$ & 190 & \\
\hline 1,2-Dichloropropane & 10 & $\mathrm{U}$ & 10 & $U$ & 10 & $\mathrm{U}$ & 10 & $\mathrm{U}$ & 10 & $U$ & 10 & $\mathrm{U}$ & 10 & $\mathrm{U}$ \\
\hline cis-1,3-Dichloropropene & 10 & $\mathrm{U}$ & 10 & $\mathrm{U}$ & 10 & $\mathrm{U}$ & 10 & $\mathrm{U}$ & 10 & $\mathrm{U}$ & 10 & $\mathrm{U}$ & 10 & U \\
\hline trans-1,3-Dichloropropene & 10 & $U$ & 10 & $\mathrm{U}$ & 10 & $U$ & 10 & $\mathrm{U}$ & 10 & $\mathrm{U}$ & 10 & $U$ & $\cdot 10$ & $\mathrm{U}$ \\
\hline Ethylbenzene & 10 & $\mathrm{U}$ & 10 & $\mathrm{U}$ & 10 & $U$ & 10 & U & 10 & $\mathrm{U}$ & 10 & $U$ & 10 & $\mathrm{U}$ \\
\hline 2-Hexanone & 10 & $U$ & 10 & $U$ & 10 & $\mathrm{U}$ & 10 & U & 10 & $\mathrm{U}$ & 10 & $\mathrm{U}$ & 10 & U \\
\hline 4-Methyl-2-pentanone & 10 & $\mathrm{U}$ & 10 & $U$ & 10 & $\mathrm{U}$ & 10 & $\mathrm{U}$ & 10 & $U$ & 10 & $\mathrm{U}$ & 10 & $\mathrm{U}$ \\
\hline Methylene chloride & 6 & $\mathrm{BJ}$ & 10 & U & 10 & $\mathrm{U}$ & 10 & $U$ & 10 & $U$ & 10 & $U$ & 10 & U \\
\hline Styrene & 10 & $\mathrm{U}$ & 10 & $\mathbf{U}$ & 10 & $\mathrm{U}$ & 10 & $\mathrm{U}$ & 10 & $\mathrm{U}$ & 10 & $\mathrm{U}$ & 10 & $U$ \\
\hline
\end{tabular}


TABLE C.21a (Cont.)

\begin{tabular}{|c|c|c|c|c|c|c|c|c|c|c|c|c|c|c|}
\hline \multirow{3}{*}{$\frac{\text { Compound }}{1,1,2,2 \text {-Tetrachloroethane }}$} & \multicolumn{14}{|c|}{ Concentrations $(\mu \mathrm{g} / \mathrm{L})$ in Groundwater } \\
\hline & \multicolumn{2}{|c|}{ JF-62 } & \multicolumn{2}{|c|}{$\mathrm{JF}-72$} & \multicolumn{2}{|c|}{ JF-82 } & \multicolumn{2}{|c|}{$J F-51$} & \multicolumn{2}{|c|}{$\mathrm{JF}-61$} & \multicolumn{2}{|c|}{ JF-71 } & \multicolumn{2}{|c|}{$\mathrm{JF}-81$} \\
\hline & 10 & $\mathrm{U}$ & 10 & $U$ & 10 & $\mathrm{U}$ & 10 & $U$ & 10 & $\mathrm{U}$ & 10 & $\mathrm{U}$ & 10 & $\mathrm{U}$ \\
\hline Tetrachloroethene & 10 & $\mathrm{U}$ & 10 & $\mathrm{U}$ & 17 & & 10 & $U$ & 10 & $\mathbf{U}$ & 10 & $\mathrm{U}$ & 34 & \\
\hline Toluene & 10 & $\mathrm{U}$ & 10 & $\mathrm{U}$ & 10 & $U$ & 10 & U & 10 & $\mathbf{U}$ & 10 & $\mathrm{U}$ & 10 & $\mathrm{U}$ \\
\hline 1,1,1-Trichloroethane & 10 & $\mathrm{U}$ & 10 & $\mathrm{U}$ & 10 & $\mathrm{U}$ & 10 & $U$ & 10 & $\mathrm{U}$ & 10 & $\mathrm{U}$ & 10 & $\mathrm{U}$ \\
\hline 1,1,2-Trichloroethane & 10 & $\mathrm{U}$ & 10 & $\mathrm{U}$ & 10 & $U$ & 10 & $U$ & 10 & $\mathrm{U}$ & 10 & $U$ & 10 & $\mathrm{U}$ \\
\hline Trichloroethene & 10 & $\mathrm{U}$ & 10 & $U$ & 1,500 & $\mathrm{D}$ & 850 & $D$ & 6 & $\mathrm{~J}$ & 10 & U & 1,600 & $\mathrm{D}$ \\
\hline Vinyl chloride & 10 & $\mathrm{U}$ & 10 & $U$ & 23 & & 10 & $U$ & 10 & $\mathrm{U}$ & 10 & $\mathrm{U}$ & 10 & $U$ \\
\hline Xylenes (total) & 10 & $\mathrm{U}$ & 10 & U & 10 & $\mathrm{U}$ & 10 & U & 10 & $\mathrm{U}$ & 10 & $\mathrm{U}$ & 10 & $U$ \\
\hline
\end{tabular}

a Sampled by ANL, analyzed by EA Laboratories, CLP/HSL volatile organics. Wells JF-173 and JF-183 sampled in June and December 1994, respectively.

Data qualifiers:

$U=$ analyte was analyzed for but not detected; detection limit given.

$\mathrm{J}=$ estimated value.

$\mathrm{D}=$ analyte was identified at given concentration with a secondary dilution factor.

* = internal standard area counts were outside QC limits.

+ = surrogate recoveries were outside QC limits.

$E$ = analyte concentration exceeded calibration range of instrument; concentration estimated. 
TABLE C.21b Volatile Organics Analyses for Groundwater in Piezometer Located in Marsh, September $1994^{\mathrm{a}}$

\begin{tabular}{|c|c|c|c|c|c|c|c|c|c|c|}
\hline \multirow{3}{*}{$\begin{array}{l}\text { Compound } \\
\text { Acetone }\end{array}$} & \multicolumn{10}{|c|}{ Concentrations $(\mu \mathrm{g} / \mathrm{L})$ in Groundwater } \\
\hline & \multicolumn{2}{|c|}{$J B P M-1 A^{b}$} & \multicolumn{2}{|c|}{$J B P M-1 B^{c}$} & \multicolumn{2}{|c|}{ JBPM-2A } & \multicolumn{2}{|c|}{ JBPM-2B } & \multicolumn{2}{|c|}{ JBPM-3A } \\
\hline & 10 & $\mathrm{U}$ & 10 & $U$ & 10 & $\mathrm{U}$ & 10 & $\mathrm{U}$ & 10 & $\mathrm{U}$ \\
\hline Benzene & 2 & $\mathrm{~J}$ & 10 & $\mathrm{U}$ & 10 & $U$ & 10 & $U$ & 10 & $\mathrm{U}$ \\
\hline Bromodichloromethane & 10 & $\mathrm{U}$ & 10 & $\mathrm{U}$ & 10 & $\mathrm{U}$ & 10 & $\mathrm{U}$ & 10 & U \\
\hline Bromoform & 10 & $\mathrm{U}$ & 10 & $\mathbf{U}$ & 10 & $\mathrm{U}$ & 10 & $\mathrm{U}$ & 10 & $U$ \\
\hline Bromomethane & 10 & $\mathrm{U}$ & 10 & $\mathrm{U}$ & 10 & $\mathrm{U}$ & 10 & $\mathrm{U}$ & 10 & $\mathrm{U}$ \\
\hline 2-Butanone & 10 & $\mathrm{U}$ & 10 & $\mathrm{U}$ & 10 & $\mathrm{U}$ & 10 & $\mathrm{U}$ & 10 & $\mathrm{U}$ \\
\hline Carbon disulfide & 10 & U & 10 & $U$ & 10 & $U$ & 10 & $\mathrm{U}$ & 10 . & $U$ \\
\hline Carbon tetrachloride & 10 & $\mathrm{U}$ & 10 & $\mathrm{U}$ & 10 & $\mathrm{U}$ & 10 & $\mathrm{U}$ & 10 & $\mathrm{U}$ \\
\hline Chlorobenzene & 10 & $\mathrm{U}$ & 10 & $U$ & 10 & $U$ & 10 & $\mathrm{U}$ & 10 & $\mathrm{U}$ \\
\hline Chloroethane & 10 & $\mathrm{U}$ & 10 & $\mathrm{U}$ & 10 & $U$ & 10 & $\mathrm{U}$ & 10 & $U$ \\
\hline Chloroform & 13 & & 10 & $\mathrm{U}$ & 10 & $U$ & 10 & $\mathrm{U}$ & 10 & $U$ \\
\hline Chloromethane & 10 & $U$ & 10 & $\mathrm{U}$ & 10 & $\mathrm{U}$ & 10 & $\mathrm{U}$ & 10 & $U$ \\
\hline Dibromochloromethane & 10 & $U$ & 10 & $\mathrm{U}$ & 10 & $\mathrm{U}$ & 10 & $\mathrm{U}$ & 10 & $U$ \\
\hline 1,1-Dichloroethane & 10 & $\mathrm{U}$ & 10 & $U$ & 10 & $\mathrm{U}$ & 10 & $\mathrm{U}$ & 10 & $\mathrm{U}$ \\
\hline 1,2-Dichloroethane & 13 & & 4 & $\mathrm{~J}$ & 27 & & 10 & $\mathrm{U}$ & 12 & \\
\hline 1,1-Dichloroethene & 24 & & 2 & $\mathrm{~J}$ & 5 & $\mathrm{~J}$ & 10 & $U$ & 6 & $\mathrm{~J}$ \\
\hline 1,2-Dichloroethene (total) & 37,000 & $\mathrm{D}$ & 7,900 & $D$ & 1,900 & $\mathrm{D}$ & 6 & $\mathbf{J}$ & 1,400 & $\mathrm{D}$ \\
\hline 1,2-Dichloropropane & 10 & $\mathrm{U}$ & 10 & $\mathrm{U}$ & 10 & $\mathrm{U}$ & 10 & $U$ & 10 & $U$ \\
\hline cis-1,3-Dichloropropene & 10 & $U$ & 10 & $\mathrm{U}$ & 10 & $\mathrm{U}$ & 10 & $\mathrm{U}$ & 10 & $\mathrm{U}$ \\
\hline trans-1,3-Dichloropropene & 10 & $\mathrm{U}$ & 10 & $\mathrm{U}$ & 10 & $\mathrm{U}$ & 10 & $\mathrm{U}$ & 10 & $\mathrm{U}$ \\
\hline Ethylbenzene & 10 & $\mathrm{U}$ & 10 & $\mathrm{U}$ & 10 & $U$ & 10 & $U$ & 10 & $\mathrm{U}$ \\
\hline 2-Hexanone & 10 & U & 10 & $\mathrm{U}$ & 10 & $\mathrm{U}$ & 10 & $\mathrm{U}$ & 10 & $\mathrm{U}$ \\
\hline 4-Methyl-2-pentanone & 10 & $\mathrm{U}$ & 10 & $U$ & 10 & $\mathrm{U}$ & 10 & $U$ & 10 & U \\
\hline Methylene chloride & 10 & $\mathrm{U}$ & 10 & $\mathrm{U}$ & 10 & $\mathrm{U}$ & 10 & $\mathrm{U}$ & 10 & $\mathrm{U}$ \\
\hline Styrene & 10 & $\mathrm{U}$ & 10 & $\mathrm{U}$ & 10 & $\mathrm{U}$ & 10 & $U$ & 10 & $\mathbf{U}$ \\
\hline 1,1,2,2-Tetrachloroethane & 8,600 & $\mathrm{D}$ & 50 & & 720 & $\mathrm{D}$ & 10 & $U$ & 240 & DJ \\
\hline Tetrachloroethene & 29 & & 10 & $U$ & 29 & & 10 & $U$ & 26 & \\
\hline Toluene & 10 & $\mathrm{U}$ & 10 & $\mathrm{U}$ & 10 & $\mathrm{U}$ & 10 & $\mathrm{U}$ & 10 & $\mathrm{U}$ \\
\hline 1,1,1-Trichloroethane & 10 & $U$ & 10 & $\mathrm{U}$ & 10 & $\mathrm{U}$ & 10 & $\mathrm{U}$ & 10 & $U$ \\
\hline 1,1,2-Trichloroethane & 440 & DJ & 10 & & 210 & DJ & 10 & $U$ & 170 & \\
\hline Trichloroethene & 1,200 & DJ & 18 & & 4,300 & $\mathrm{D}$ & 10 & $\mathrm{U}$ & 7,300 & $\mathrm{D}$ \\
\hline Vinyl chloride & 3,200 & $\mathrm{D}$ & 1,300 & $\mathrm{D}$ & 32 & & 5 & $\mathrm{~J}$ & 25 & \\
\hline Xylenes (total) & 10 & $\mathrm{U}$ & 10 & $\mathrm{U}$ & 10 & $\mathrm{U}$ & 10 & $\mathrm{U}$ & 10 & $\mathrm{U}$ \\
\hline
\end{tabular}




\section{TABLE C.21b (Cont.)}

\begin{tabular}{|c|c|c|c|c|c|c|c|c|c|c|}
\hline \multirow{3}{*}{$\begin{array}{l}\text { Compound } \\
\text { Acetone }\end{array}$} & \multicolumn{10}{|c|}{ Concentrations $(\mu g / L)$ in Groundwater } \\
\hline & \multicolumn{2}{|c|}{ JBPM-3B } & \multicolumn{2}{|c|}{ JBPM-4A } & \multicolumn{2}{|c|}{ JBPM-4B } & \multicolumn{2}{|c|}{ JBPM-5A } & \multicolumn{2}{|c|}{ JBPM-5B } \\
\hline & 10 & $\mathrm{U}$ & 10 & $\mathrm{U}$ & 10 & $\mathrm{U}$ & 10 & $U$ & 10 & $\mathrm{U}$ \\
\hline Benzene & 10 & $\mathrm{U}$ & 10 & $\mathrm{U}$ & 10 & $\mathrm{U}$ & 10 & $\mathrm{U}$ & 10 & $U$ \\
\hline Bromodichloromethane & 10 & $\mathrm{U}$ & 10 & $\mathrm{U}$ & 10 & $\mathrm{U}$ & 10 & $\mathrm{U}$ & 10 & $\mathrm{U}$ \\
\hline Bromoform & 10 & $\mathrm{U}$ & 10 & $U$ & 10 & $\mathrm{U}$ & 10 & $\mathrm{U}$ & 10 & $\mathrm{U}$ \\
\hline Bromomethane & 10 & $\mathrm{U}$ & 10 & $U$ & 10 & $\mathrm{U}$ & 10 & $\mathrm{U}$ & 10 & $\mathrm{U}$ \\
\hline 2-Butanone & 10 & $U$ & 10 & $U$ & 10 & $\mathrm{U}$ & 10 & $\mathrm{U}$ & 10 & $\mathrm{U}$ \\
\hline Carbon disulfide & 10 & $\mathrm{U}$ & 10 & $\mathrm{U}$ & 2 & $\mathrm{~J}$ & 10 & $\mathrm{U}$ & 10 & $\mathrm{U}$ \\
\hline Carbon tetrachloride & 10 & $\mathrm{U}$ & 10 & $\mathrm{U}$ & 10 & $U$ & 10 & $\mathrm{U}$ & 10 & $\mathrm{U}$ \\
\hline Chlorobenzene & 10 & $\mathrm{U}$ & 10 & $\mathrm{U}$ & 10 & $\mathrm{U}$ & 10 & $\mathrm{U}$ & 10 & $\mathrm{U}$ \\
\hline Chloroethane & 10 & $\mathrm{U}$ & 10 & $U$ & 10 & $\mathrm{U}$ & 10 & $U$ & 10 & $U$ \\
\hline Chloroform & 10 & $\mathrm{U}$ & 10 & $\mathrm{U}$ & 10 & $U$ & 10 & $\mathrm{U}$ & 10 & $\mathrm{U}$ \\
\hline Chloromethane & 10 & $U$ & 10 & $U$ & 10 & $\mathrm{U}$ & 10 & $\mathrm{U}$ & 10 & $\mathrm{U}$ \\
\hline Dibromochloromethane & 10 & $U$ & 10 & $\mathrm{U}$ & 10 & $\mathrm{U}$ & 10 & $U$ & 10 & $\mathrm{U}$ \\
\hline 1,1-Dichloroethane & 10 & $\mathrm{U}$ & 10 & $\mathrm{U}$ & 10 & $\mathrm{U}$ & 10 & $\mathrm{U}$ & 10 & $\mathrm{U}$ \\
\hline 1,2-Dichloroethane & 10 & $\mathrm{U}$ & 10 & $U$ & 10 & $\mathrm{U}$ & 10 & $\mathrm{U}$ & 10 & $\mathrm{U}$ \\
\hline 1,1-Dichloroethene & 10 & $\mathrm{U}$ & 10 & $\mathrm{U}$ & 10 & $\mathrm{U}$ & 10 & $\mathbf{U}$ & 10 & U \\
\hline 1,2-Dichloroethene (total) & 10 & $\mathrm{U}$ & 10 & $\mathrm{U}$ & 10 & $\mathrm{U}$ & 10 & $\mathrm{U}$ & 10 & $\mathrm{U}$ \\
\hline 1,2-Dichloropropane & 10 & $\mathrm{U}$ & 10 & $\mathrm{U}$ & 10 & $\mathrm{U}$ & 10 & $U$ & 10 & $\mathrm{U}$ \\
\hline cis-1,3-Dichloropropene & 10 & $\mathrm{U}$ & 10 & $\mathrm{U}$ & 10 & $\mathrm{U}$ & 10 & $U$ & 10 & $\mathrm{U}$ \\
\hline trans-1,3-Dichloropropene & 10 & $U$ & 10 & $U$ & 10 & $\mathrm{U}$ & 10 & $\mathrm{U}$ & 10 & $\mathrm{U}$ \\
\hline Ethylbenzene & 10 & $\mathrm{U}$ & 10 & $U$ & 10 & $\mathrm{U}$ & 10 & $\mathrm{U}$ & 10 & $\mathrm{U}$ \\
\hline 2-Hexanone & 10 & $\mathrm{U}$ & 10 & $U$ & 10 & $\mathrm{U}$ & 10 & $U$ & 10 & $\mathrm{U}$ \\
\hline 4-Methyl-2-pentanone & 10 & $\mathrm{U}$ & 10 & $U$ & 10 & $U$ & 10 & $U$ & 10 & U \\
\hline Methylene chloride & 10 & $\mathrm{U}$ & 10 & $U$ & 10 & $U$ & 10 & $\mathrm{U}$ & 10 & $U$ \\
\hline Styrene & 10 & $\mathrm{U}$ & 10 & $\mathrm{U}$ & 10 & $\mathrm{U}$ & 10 & $\mathrm{U}$ & 10 & $\mathrm{U}$ \\
\hline 1,1,2,2-Tetrachloroethane & 10 & $\mathrm{U}$ & 10 & $U$ & 10 & $\mathrm{U}$ & 10 & $\mathrm{U}$ & 10 & $\mathrm{U}$ \\
\hline Tetrachloroethene & 10 & $\mathrm{U}$ & 10 & $U$ & 10 & $\mathrm{U}$ & 10 & $\mathbf{U}$ & 10 & $U$ \\
\hline Toluene & 10 & $\mathrm{U}$ & 10 & $U$ & 10 & $\mathrm{U}$ & 10 & $\mathrm{U}$ & 10 & $U$ \\
\hline 1,1,1-Trichloroethane & 10 & $U$ & 10 & $\mathrm{U}$ & 10 & $U$ & 10 & $\mathrm{U}$ & 10 & $\mathrm{U}$ \\
\hline 1,1,2-Trichloroethane & 10 & $\mathrm{U}$ & 10 & $\mathrm{U}$ & 10 & U & 10 & $\mathrm{U}$ & 10 & $\mathrm{U}$ \\
\hline Trichloroethene & 10 & $U$ & 10 & $\mathrm{U}$ & 10 & $U$ & 10 & $U$ & 10 & $U$ \\
\hline Vinyl chloride & 10 & $\mathrm{U}$ & 10 & $U$ & 10 & $\mathrm{U}$ & 10 & $\mathrm{U}$ & 10 & $\mathrm{U}$ \\
\hline Xylenes (total) & 10 & $\mathrm{U}$ & 10 & $\mathrm{U}$ & 10 & U & 10 & $\mathrm{U}$ & 10 & $\mathrm{U}$ \\
\hline
\end{tabular}

See next page for footnotes. 


\section{TABLE C.21b (Cont.)}

a Sampled by ANL/USGS, analyzed by EA Laboratories, CLP/HSL volatile organics.

b " $\mathrm{A}$ " denotes deep piezometer in nest.

c "B" denotes shallow piezometer in nest.

Data qualifiers:

$\mathrm{U}=$ analyte was analyzed for but not detected; detection limit given.

$\mathrm{D}=$ analyte was identified at given concentration with a secondary dilution factor.

$\mathrm{J}=$ estimated value. 
TABLE C.22 Semivolatile Organics Analyses for Groundwater, May $1994^{\mathrm{a}}$

\begin{tabular}{|c|c|c|c|c|c|c|c|c|c|c|}
\hline \multirow{3}{*}{$\begin{array}{l}\text { Compound } \\
\text { Acenaphthene }\end{array}$} & \multicolumn{10}{|c|}{ Concentrations $(\mu \mathrm{g} / \mathrm{L})$ in Groundwater } \\
\hline & \multicolumn{2}{|c|}{$\mathrm{P}-3$} & \multicolumn{2}{|c|}{ P-9 } & \multicolumn{2}{|c|}{$\mathrm{JF}-53$} & \multicolumn{2}{|c|}{$\mathrm{JF}-63$} & \multicolumn{2}{|c|}{ JF-73RE } \\
\hline & 10 & $\mathrm{U}^{*}$ & 10 & $\mathrm{U}$ & 10 & $U$ & 10 & $U$ & 10 & Ut \\
\hline Acenaphthylene & 10 & $\mathrm{U}^{*}$ & 10 & U & 10 & $\mathrm{U}$ & 10 & $\mathrm{U}$ & 10 & $U_{+}$ \\
\hline Anthracene & 10 & $\mathrm{U}^{*}$ & 10 & $\mathrm{U}$ & 10 & $\mathrm{U}$ & 10 & $\mathrm{U}$ & 10 & Ut \\
\hline Benz[a]anthracene & 10 & $\mathrm{U}^{*}$ & 10 & $U$ & 10 & $U$ & 10 & $\mathrm{U}$ & 10 & $U_{+}$ \\
\hline Benzo[a]pyrene & 10 & $U^{*}$ & 10 & $\mathrm{U}$ & 10 & $\mathrm{U}$ & 10 & $\mathrm{U}$ & 10 & $\mathrm{U}_{+}$ \\
\hline Benzo[b]fluoranthene & 10 & $\mathrm{U}^{*}$ & 10 & $\mathrm{U}$ & 10 & $\mathrm{U}$ & 10 & $\mathrm{U}$ & 10 & $\mathrm{U}_{+}$ \\
\hline Benzo[g,h,i]perylene & 10 & $\mathrm{U}^{*}$ & 10 & $\mathrm{U}$ & 10 & $\mathrm{U}$ & 10 & $\mathrm{U}$ & 10 & $U_{+}$ \\
\hline Benzo[k]fluoranthene & 10 & $U^{*}$ & 10 & $\mathrm{U}$ & 10 & $\mathrm{U}$ & 10 & $\mathrm{U}$ & 10 & $\mathrm{U}_{+}$ \\
\hline Benzylbutylphthalate & 10 & $\mathrm{U}^{*}$ & 10 & $\mathrm{U}$ & 10 & $\mathrm{U}$ & 10 & $U$ & 10 & $\mathrm{U}_{+}$ \\
\hline Bis(2-chloroethoxy)methane & 10 & $\mathrm{U}^{*}$ & 10. & $\mathrm{U}$ & 10 & $\mathrm{U}$ & 10 & $U$ & 10 & $\mathrm{U}_{+}$ \\
\hline $\mathrm{Bis}(2$-chloroethyl)ether & 10 & $\mathrm{U}^{*}$ & 10 & $\mathrm{U}$ & 10 & $\mathrm{U}$ & 10 & $\mathrm{U}$ & 10 & $\mathrm{U}_{+}$ \\
\hline Bis(2-chloroisopropyl)ether & 10 & $\mathrm{U}^{*}$ & 10 & $\mathrm{U}$ & 10 & $\mathrm{U}$ & 10 & $U$ & 10 & $U_{+}$ \\
\hline Bis(2-ethylhexyl)phthalate & 10 & $\mathrm{U}^{*}$ & 10 & $\mathrm{U}$ & 10 & $U$ & 10 & $U$ & 10 & $\mathrm{U}_{+}$ \\
\hline 4-Bromophenyl phenyl ether & 10 & $\mathrm{U}^{*}$ & 10 & $\mathrm{U}$ & 10 & $\mathrm{U}$ & 10 & $U$ & 10 & $\mathrm{U}_{+}$ \\
\hline 9H-Carbazole & 10 & $\mathrm{U}^{*}$ & 10 & $\mathrm{U}$ & 10 & $\mathrm{U}$ & 10 & $U$ & 10 & $U_{+}$ \\
\hline 4-Chloro-3-methỳlphenol & 10 & $\mathrm{U}^{*}$ & 10 & $\mathrm{U}$ & 10 & $\mathrm{U}$ & 10 & $U$ & 10 & $\mathrm{U}_{+}$ \\
\hline 4-Chloroaniline & 10 & $\mathrm{U}^{*}$ & 10 & $\mathrm{U}$ & 10 & $\mathrm{U}$ & 10 & $\mathrm{U}$ & 10 & $\mathrm{U}_{+}$ \\
\hline 2-Chloronaphthalene & 10 & $\mathrm{U}^{*}$ & 10 & $\mathrm{U}$ & 10 & $U$ & 10 & $\mathrm{U}$ & 10 & $U_{+}$ \\
\hline 2-Chlorophenol & 1 & $\mathrm{~J}^{*}$ & 10 & $\mathrm{U}$ & 10 & $\mathrm{U}$ & 10 & $\mathrm{U}$ & 10 & $\mathrm{U}_{+}$ \\
\hline 4-Chlorophenyl phenyl ether & 10 & $\mathrm{U}^{*}$ & 10 & $\mathrm{U}$ & 10 & $\mathrm{U}$ & 10 & $\mathrm{U}$ & 10 & $U_{+}$ \\
\hline Chrysene & 10 & $\mathrm{U}^{*}$ & 10 & $\mathrm{U}$ & 10 & $\mathrm{U}$ & 10 & $\mathrm{U}$ & 10 & $\mathrm{U}_{+}$ \\
\hline Di-n-butyl phthalate & 10 & $\mathrm{U}^{*}$ & 10 & $\mathrm{U}$ & 10 & $\mathrm{U}$ & 10 & $\mathrm{U}$ & 10 & $\mathrm{U}_{+}$ \\
\hline Di-n-octyl phthalate & 10 & $\mathrm{U}^{*}$ & 10 & $\mathrm{U}$ & 10 & $\mathrm{U}$ & 10 & $\mathrm{U}$ & 10 & $\mathrm{U}_{+}$ \\
\hline Dibenz[a,h]anthracene & 10 & $\mathrm{U}^{*}$ & 10 & $\mathrm{U}$ & 10 & $\mathrm{U}$ & 10 & $\mathrm{U}$ & 10 & $U_{+}$ \\
\hline Dibenzofuran & 10 & $\mathrm{U}^{*}$ & 10 & $\mathrm{U}$ & 10 & $\mathrm{U}$ & 10 & $U$ & 10 & $U_{+}$ \\
\hline 1,2-Dichlorobenzene & 10 & $\mathrm{U}^{*}$ & 10 & $\mathrm{U}$ & 10 & $\mathrm{U}$ & 10 & $\mathrm{U}$ & 10 & $U_{+}$ \\
\hline 1,3-Dichlorobenzene & 10 & $\mathrm{U}^{*}$ & 10 & $\mathrm{U}$ & 10 & $\mathrm{U}$ & 10 & U & 10 & $U_{+}$ \\
\hline 1,4-Dichlorobenzene & 10 & $\mathrm{U}^{*}$ & 10 & U & 10 & $U$ & 10 & $\dot{U}$ & 10 & $U_{+}$ \\
\hline 3,3'-Dichlorobenzidine & 10 & $\mathrm{U}^{*}$ & 10 & $U$ & 10 & $\mathrm{U}$ & 10 & $\mathrm{U}$ & 10 & $U_{+}$ \\
\hline 2,4-Dichlorophenol & 10 & $\mathrm{U}^{*}$ & 10 & $U$ & 10 & $\mathrm{U}$ & 10 & $\mathrm{U}$ & 10 & $U_{+}$ \\
\hline Diethylphthalate & 10 & $U^{*}$ & 10 & U & 10 & $\mathrm{U}$ & 10 & $\mathrm{U}$ & 10 & $U_{+}$ \\
\hline 2,4-Dimethylphenol & 10 & $\mathrm{U}^{*}$ & 10 & $U$ & 10 & $\mathrm{U}$ & 10 & $\mathrm{U}$ & 10 & $U_{+}$ \\
\hline Dimethylphthalate & 10 & $\mathrm{U}^{*}$ & 10 & $\mathrm{U}$ & 10 & $\mathrm{U}$ & 10 & $\mathrm{U}$ & 10 & Ut \\
\hline 2,4-Dinitrophenol & 25 & $\mathrm{U}^{*}$ & 25 & $\mathrm{U}$ & 25 & $U$ & 25 & $\mathrm{U}$ & 25 & U+ \\
\hline 2,4-Dinitrotoluene & 10 & $U^{*}$ & 10 & $U$ & 10 & $U$ & 10 & $\mathrm{U}$ & 10 & $U_{+}$ \\
\hline 2,6-Dinitrotoluene & 10 & $U^{*}$ & 10 & $\mathrm{U}$ & 10 & $U$ & 10 & $\mathrm{U}$ & 10 & $\mathrm{U}_{+}$ \\
\hline Fluoranthene & 10 & $U^{*}$ & 10 & $\mathrm{U}$ & .10 & $U$ & 10 & $\mathrm{U}$ & 10 & $\mathrm{U}_{+}$ \\
\hline
\end{tabular}


TABLE C.22 (Cont.)

\begin{tabular}{|c|c|c|c|c|c|c|c|c|c|c|}
\hline \multirow{3}{*}{ Compound } & \multicolumn{10}{|c|}{ Concentrations $(\mu \mathrm{g} / \mathrm{L})$ in Groundwater } \\
\hline & \multicolumn{2}{|c|}{$P-3$} & \multicolumn{2}{|c|}{ P-9 } & \multicolumn{2}{|c|}{$\mathrm{JF}-53$} & \multicolumn{2}{|c|}{ JF-63 } & \multicolumn{2}{|c|}{ JF-73RE } \\
\hline & 10 & $U^{*}$ & 10 & $\mathbf{U}$ & 10 & $\mathrm{U}$ & 10 & $\mathrm{U}$ & 10 & $U_{+}$ \\
\hline Hexachlorobenzene & 10 & $\mathrm{U}^{*}$ & 10 & $\mathrm{U}$ & 10 & $\mathrm{U}$ & 10 & $\mathrm{U}$ & 10 & $U_{+}$ \\
\hline Hexachlorobutadiene & 10 & $U^{*}$ & 10 & $\mathrm{U}$ & 10 & $\mathrm{U}$ & 10 & $\mathrm{U}$ & 10 & $\mathrm{U}_{+}$ \\
\hline Hexachlorocyclopentadiene & 10 & $\mathrm{U}^{*}$ & 10 & $\mathrm{U}$ & 10 & $U$ & 10 & U & 10 & $U_{+}$ \\
\hline Hexachloroethane & 10 & $\mathrm{U}^{*}$ & 10 & $\mathrm{U}$ & 10 & $U$ & 10 & $\mathrm{U}$ & 10 & $\mathrm{U}_{+}$ \\
\hline Indeno[ $[1,2,3-c, d]$ pyrene & 10 & $U^{*}$ & 10 & $\mathrm{U}$ & 10 & $\mathrm{U}$ & 10 & $\mathrm{U}$ & 10 & $U_{t}$ \\
\hline Isophorone & 10 & $U^{*}$ & 10 & $\mathrm{U}$ & 10 & $\mathrm{U}$ & 10 & $\mathrm{U}$ & 10 & $\mathrm{U}_{+}$ \\
\hline 2-Methyl-4,6-dinitrophenol & 25 & $\mathrm{U}^{*}$ & 25 & U & 25 & $U$ & 25 & $U$ & 25 & $U_{+}$ \\
\hline 2-Methylnaphthalene & 10 & $\mathrm{U}^{*}$ & 10 & $\mathrm{U}$ & 10 & $\mathrm{U}$ & 10 & $\mathrm{U}$ & 10 & $U_{+}$ \\
\hline 2-Methylphenol & 10 & $\mathrm{U}^{*}$ & 10 & $\mathrm{U}$ & 10 & $\mathrm{U}$ & 10 & $\mathrm{U}$ & 10 & $\mathrm{U}_{+}$ \\
\hline 4-Methylphenol & 10 & $\mathrm{U}^{*}$ & 10 & $U$ & 10 & $U$ & 10 & $\mathrm{U}$ & 10 & $U_{+}$ \\
\hline Naphthalene & 10 & $\mathrm{U}^{*}$ & 10 & $U$ & 10 & $U$ & 2 & $\mathrm{~J}$ & 10 & $U_{+}$ \\
\hline 2-Nitroaniline & 25 & $U^{*}$ & 25 & $\mathrm{U}$ & 25 & $\mathrm{U}$ & 25 & $\mathrm{U}$ & 25 & $\mathrm{U}_{+}$ \\
\hline 3-Nitroaniline & 25 & $\mathrm{U}^{*}$ & 25 & $U$ & 25 & $\mathrm{U}$ & 25 & $\mathrm{U}$ & 25 & $U_{+}$ \\
\hline 4-Nitroaniline & 25 & $\mathrm{U}^{*}$ & 25 & $\mathrm{U}$ & 25 & $\mathrm{U}$ & 25 & $U$ & 25 & $U_{+}$ \\
\hline Nitrobenzene & 10 & $U^{*}$ & 10 & $\mathrm{U}$ & 10 & $\mathrm{U}$ & 10 & $\mathrm{U}$ & 10 & $\mathrm{U}_{+}$ \\
\hline 2-Nitrophenol & 10 & $\mathrm{U}^{*}$ & 10 & $\mathrm{U}$ & 10 & $\mathrm{U}$ & 10 & $\mathrm{U}$ & 10 & $U_{+}$ \\
\hline 4-Nitrophenol & 25 & $U^{*}$ & 25 & $\mathrm{U}$ & 25 & $\mathrm{U}$ & 25 & U & 25 & $U_{+}$ \\
\hline N-Nitroso-di-n-propylamine & 10 & $\mathrm{U}^{*}$ & 10 & $\mathrm{U}$ & 10 & $\mathrm{U}$ & 10 & $U$ & 10 & $U_{+}$ \\
\hline N-Nitrosodiphenylamine & 10 & $\mathrm{U}^{*}$ & 10 & $\mathrm{U}$ & 10 & $\mathrm{U}$ & 10 & $\mathrm{U}$ & 10 & $U_{+}$ \\
\hline Pentachlorophenol & 25 & $\mathrm{U}^{*}$ & 25 & $\mathrm{U}$ & 25 & $\mathrm{U}$ & 25 & $\mathrm{U}$ & 25 & $U_{+}$ \\
\hline Phenanthrene & 10 & $\mathrm{U}^{*}$ & 10 & $\mathrm{U}$ & 10 & $\mathrm{U}$ & 10 & $\mathrm{U}$ & 10 & $\mathrm{U}_{+}$ \\
\hline Phenol & 10 & $\mathrm{U}^{*}$ & 10 & $\mathrm{U}$ & 10 & $\mathrm{U}$ & 10 & $\mathrm{U}$ & 10 & $U_{+}$ \\
\hline Pyrene & 10 & $\mathrm{U}^{*}$ & 10 & $\mathrm{U}$ & 10 & $U$ & 10 & $U$ & 10 & $U_{+}$ \\
\hline 1,2,4-Trichlorobenzene & 10 & $\mathrm{U}^{*}$ & 10 & $\mathrm{U}$ & 10 & $\mathrm{U}$ & 10 & $\mathrm{U}$ & 10 & $U_{+}$ \\
\hline 2,4,5-Trichlorophenol & 25 & $\mathrm{U}^{*}$ & 25 & $\mathrm{U}$ & 25 & $\mathrm{U}$ & 25 & $U$ & 25 & $\mathrm{U}_{+}$ \\
\hline \multirow[t]{2}{*}{ 2,4,6-Trichlorophenol } & 10 & $\mathrm{U}^{*}$ & 10 & $\mathrm{U}$ & 10 & U & 10 & $\mathrm{U}$ & 10 & $U_{+}$ \\
\hline & \multicolumn{8}{|c|}{ Concentrations $(\mu \mathrm{g} / \mathrm{L})$ in Groundwater } & & \\
\hline Compound & \multicolumn{2}{|c|}{$\mathrm{JF}-83$} & \multicolumn{2}{|c|}{ JF-173 } & \multicolumn{2}{|c|}{ JF-71 } & \multicolumn{2}{|c|}{$\mathrm{JF}-81$} & & \\
\hline Acenaphthene & 10 & $\mathrm{U}$ & 10 & $\mathrm{U}$ & 10 & $\mathrm{U}$ & 10 & $\mathrm{U}$ & & \\
\hline Acenaphthylene & 10 & $U$ & 10 & $\mathrm{U}$ & 10 & $\mathrm{U}$ & 10 & $\mathrm{U}$ & & \\
\hline Anthracene & 10 & $\mathrm{U}$ & 10 & $\mathrm{U}$ & 10 & $\mathrm{U}$ & 10 & $\mathrm{U}$ & & \\
\hline Benz[a]anthracene & 10 & $\mathrm{U}$ & 10 & $\mathrm{U}$ & 10 & $\mathrm{U}$ & 10 & $\mathrm{U}$ & & \\
\hline Benzo[a]pyrene & 10 & $\mathrm{U}$ & 10 & $\mathbf{U}$ & 10 & $\mathbf{U}$ & 10 & $U$ & & \\
\hline
\end{tabular}


TABLE C.22 (Cont.)

\begin{tabular}{|c|c|c|c|c|c|c|c|c|}
\hline \multirow{3}{*}{$\begin{array}{r}\text { Compound } \\
\text { Benzo[b]fluoranthene }\end{array}$} & \multicolumn{8}{|c|}{ Concentrations $(\mu \mathrm{g} / \mathrm{L})$ in Groundwater } \\
\hline & \multicolumn{2}{|c|}{ JF-83 } & \multicolumn{2}{|c|}{ JF-173 } & \multicolumn{2}{|c|}{$\mathrm{JF}-71$} & \multicolumn{2}{|c|}{ JF-81 } \\
\hline & 10 & $\mathrm{U}$ & 10 & $\mathrm{U}$ & 10 & $\mathrm{U}$ & 10 & $\mathrm{U}$ \\
\hline Benzo[g,h,i]perylene & 10 & $\mathrm{U}$ & 10 & $\mathrm{U}$ & 10 & $U$ & 10 & $\mathrm{U}$ \\
\hline Benzo[k]fluoranthene & 10 & $\mathrm{U}$ & 10 & $U$ & 10 & $U$ & 10 & $\mathrm{U}$ \\
\hline Benzylbutylphthalate & .10 & $U$ & 10 & $U$ & 10 & $\mathrm{U}$ & 10 & $U$ \\
\hline Bis(2-chloroethoxy)methane & 10 & $\mathrm{U}$ & 10 & $\mathrm{U}$ & 10 & $\mathrm{U}$ & 10 & $\mathrm{U}$ \\
\hline Bis(2-chloroethyl)ether & 10 & $\mathrm{U}$ & 10 & $\mathrm{U}$ & 10 & $U$ & 10 & $\mathrm{U}$ \\
\hline Bis(2-chloroisopropyl)ether & 10 & $\mathrm{U}$ & 10 & $U$ & 10 & $\mathrm{U}$ & 10 & $\mathrm{U}$ \\
\hline Bis(2-ethylhexyl)phthalate & 10 & $\mathrm{U}$ & 2 & $\mathrm{~J}$ & 3 & $\mathrm{~J}$ & 2 & $\mathrm{~J}$ \\
\hline 4-Bromophenyl phenyl ether & 10 & $\mathrm{U}$ & 10 & $U$ & 10 & $\mathrm{U}$ & 10 & $\mathrm{U}$ \\
\hline 9H-Carbazole & 10 & $\mathrm{U}$ & 10 & $U$ & 10 & $\mathrm{U}$ & 10 & $\mathrm{U}$ \\
\hline 4-Chloro-3-methylphenol & 10 & $\mathrm{U}$ & 10 & $U$ & 10 & $\mathrm{U}$ & 10 & $\mathrm{U}$ \\
\hline 4-Chloroaniline & 10 & $\mathrm{U}$ & 10 & $\mathrm{U}$ & 10 & $U$ & 10 & $\mathrm{U}$ \\
\hline 2-Chloronaphthalene & 10 & $U$ & 10 & U & 10 & $\mathrm{U}$ & 10 & U \\
\hline 2-Chlorophenol & 10 & $U$ & 10 & $U$ & 10 & $\mathrm{U}$ & 10 & $\mathrm{U}$ \\
\hline 4-Chlorophenyl phenyl ether & 10 & $\mathrm{U}$ & 10 & $U$ & 10 & $\mathrm{U}$ & 10 & $\mathrm{U}$ \\
\hline Chrysene & 10 & $U$ & 10 & $U$ & 10 & $\mathrm{U}$ & 10 & $\mathrm{U}$ \\
\hline Di-n-butyl phthalate & 10 & $\mathrm{U}$ & 10 & $\mathrm{U}$ & 10 & $\mathrm{U}$ & 10 & $\mathrm{U}$ \\
\hline Di-n-octyl phthalate & 10 & $\mathrm{U}$ & 10 & $U$ & 10 & $\mathrm{U}$ & 10 & $\mathrm{U}$ \\
\hline Dibenz $[a, h]$ anthracene & 10 & $U$ & 10 & $U$ & 10 & $U$ & 10 & $\mathrm{U}$ \\
\hline Dibenzofuran & 10 & $U$ & 10 & $\mathrm{U}$ & 10 & $\mathrm{U}$ & 10 & $\mathrm{U}$ \\
\hline 1,2-Dichlorobenzene & 2 & $J$ & 10 & $\mathrm{U}$ & 10 & U & 10 & $\mathrm{U}$ \\
\hline 1,3-Dichlorobenzene & 10 & $\mathrm{U}$ & 10 & $\mathrm{U}$ & 10 & $\mathrm{U}$ & 10 & U \\
\hline 1,4-Dichlorobenzene & 10 & $\mathrm{U}$ & 10 & $\mathrm{U}$ & 10 & $\mathrm{U}$ & 10 & $\mathrm{U}$ \\
\hline 3,3'-Dichlorobenzidine & 10 & $\mathrm{U}$ & 10 & U & 10 & $\mathrm{U}$ & 10 & U \\
\hline 2,4-Dichlorophenol & 10 & $\mathrm{U}$ & 10 & $U$ & 10 & $\mathrm{U}$ & 10 & $\mathrm{U}$ \\
\hline Diethylphthalate & 10 & $\mathrm{U}$ & 10 & $U$ & 10 & $\mathrm{U}$ & 10 & $\mathrm{U}$ \\
\hline 2,4-Dimethylphenol & 10 & $\mathrm{U}$ & 10 & $U$ & 10 & $\mathbf{U}$ & 10 & $\mathrm{U}$ \\
\hline Dimethylphthalate & 10 & $\mathrm{U}$ & 10 & $U$ & 10 & $\mathrm{U}$ & 10 & $\mathrm{U}$ \\
\hline 2,4-Dinitrophenol & 25 & $\mathrm{U}$ & 25 & $U$ & 25 & U & 25 & $\mathrm{U}$ \\
\hline 2,4-Dinitrotoluene & 10 & $\mathrm{U}$ & 10 & U & 10 & $\mathrm{U}$ & 10 & $U$ \\
\hline 2,6-Dinitrotoluene & 10 & $\mathrm{U}$ & 10 & $\mathrm{U}$ & 10 & $\mathrm{U}$ & 10 & $\mathrm{U}$ \\
\hline Fluoranthene & 10 & $\mathrm{U}$ & 10 & $\mathrm{U}$ & 10 & $\mathrm{U}$ & 10 & $\mathrm{U}$ \\
\hline Fluorene & 10 & $U$ & 10 & $\mathrm{U}$ & 10 & $\mathrm{U}$ & 10 & $\mathrm{U}$ \\
\hline Hexachlorobenzene & 10 & $U$ & 10 & $\mathrm{U}$ & 10 & $\mathrm{U}$ & 10 & $\mathrm{U}$ \\
\hline Hexachlorobutadiene & 2 & $\mathrm{~J}$ & 10 & $\mathrm{U}$ & 10 & $\mathrm{U}$ & 10 & $\mathrm{U}$ \\
\hline Hexachlorocyclopentadiene & 10 & U & 10 & U & 10 & $U$ & 10 & U \\
\hline Hexachloroethane & 57 & & 10 & $U$ & 10 & $\mathrm{U}$ & 10 & $\mathrm{U}$ \\
\hline
\end{tabular}


TABLE C.22 (Cont.)

\begin{tabular}{|c|c|c|c|c|c|c|c|c|}
\hline \multirow{3}{*}{$\frac{\text { Compound }}{\text { Indeno[1,2,3-c,d]pyrene }}$} & \multicolumn{8}{|c|}{ Concentrations $(\mu \mathrm{g} / \mathrm{L})$ in Groundwater } \\
\hline & \multicolumn{2}{|c|}{ JF-83 } & \multicolumn{2}{|c|}{ JF-173 } & \multicolumn{2}{|c|}{ JF-71 } & \multicolumn{2}{|c|}{ JF-81 } \\
\hline & 10 & $\mathrm{U}$ & 10 & $\mathrm{U}$ & 10 & $\mathrm{U}$ & 10 & $\mathrm{U}$ \\
\hline Isophorone & 10 & $\mathrm{U}$ & 10 & $\mathrm{U}$ & 10 & $\mathrm{U}$ & 10 & $\mathrm{U}$ \\
\hline 2-Methyl-4,6-dinitrophenol & 25 & $U$ & 25 & $\mathrm{U}$ & 25 & $\mathrm{U}$ & 25 & U \\
\hline 2-Methylnaphthalene & 10 & $U$ & 10 & $U$ & 10 & $\mathrm{U}$ & 10 & $\mathbf{U}$ \\
\hline 2-Methylphenol & 10 & $U$ & 10 & $U$ & 10 & $\mathrm{U}$ & 10 & U \\
\hline 4-Methylphenol & 10 & $\mathrm{U}$ & 10 & $U$ & 10 & $\mathrm{U}$ & 10 & $\mathrm{U}$ \\
\hline Naphthalene & 10 & $\mathrm{U}$ & 10 & $\mathrm{U}$ & 10 & $U$ & 10 & $\mathrm{U}$ \\
\hline 2-Nitroaniline & 25 & $\mathrm{U}$ & 25 & $\mathrm{U}$ & 25 & $\mathrm{U}$ & 25 & $\mathrm{U}$ \\
\hline 3-Nitroaniline & 25 & $U$ & 25 & $\mathrm{U}$ & 25 & $\mathrm{U}$ & 25 & $\mathrm{U}$ \\
\hline 4-Nitroaniline & 25 & $\mathrm{U}$ & 25 & $U$ & 25 & $\mathrm{U}$ & 25 & $\mathrm{U}$ \\
\hline Nitrobenzene & 10 & $\mathrm{U}$ & 10 & $U$ & 10 & $\mathrm{U}$ & 10 & $U$ \\
\hline 2-Nitrophenol & 10 & $\mathrm{U}$ & 10 & $\mathrm{U}$ & 10 & $\mathrm{U}$ & 10 & $\mathrm{U}$ \\
\hline 4-Nitrophenol & 25 & $\mathrm{U}$ & 25 & $U$ & 25 & $\mathrm{U}$ & 25 & $\mathrm{U}$ \\
\hline N-Nitroso-di-n-propylamine & 10 & $\mathrm{U}$ & 10 & $U$ & 10 & $\mathrm{U}$ & 10 & $U$ \\
\hline N-Nitrosodiphenylamine & 10 & $\mathrm{U}$ & 10 & $\mathrm{U}$ & 10 & U & 10 & $\mathrm{U}$ \\
\hline Pentachlorophenol & 25 & $\mathrm{U}$ & 25 & $\mathrm{U}$ & 25 & $\mathrm{U}$ & 25 & $\mathrm{U}$ \\
\hline Phenanthrene & 10 & $U$ & 10 & $\mathrm{U}$ & 10 & $\mathrm{U}$ & 10 & U \\
\hline Phenol & 10 & $\mathrm{U}$ & 10 & $U$ & 5 & $\mathbf{J}$ & 10 & U \\
\hline Pyrene & 10 & $U$ & 10 & $U$ & 10 & $\mathrm{U}$ & 10 & $\mathrm{U}$ \\
\hline 1,2,4-Trichlorobenzene & 4 & $\mathrm{~J}$ & 10 & $\mathrm{U}$ & 10 & $\mathrm{U}$ & 10 & $\mathrm{U}$ \\
\hline 2,4,5-Trichlorophenol & 25 & $U$ & 25 & $U$ & 25 & $\mathrm{U}$ & 25 & $\mathrm{U}$ \\
\hline 2,4,6-Trichlorophenol & 10 & $\mathrm{U}$ & 10 & $\mathrm{U}$ & 10 & $\mathrm{U}$ & 10 & $\mathrm{U}$ \\
\hline
\end{tabular}

a Sampled by ANL, analyzed by EA Laboratories, CLP/HSL semivolatile organics.

Data qualifiers:

$\mathrm{U}=$ analyte was analyzed for but not detected; detection limit given.

* = internal standard area counts were outside QC limits.

$\mathbf{J}=$ estimated value.

+ = surrogate recoveries were outside QC limit(s). 
TABLE C.23 Inorganic Analyses for Groundwater, May $1994^{\mathrm{a}}$

\begin{tabular}{|c|c|c|c|c|c|c|c|c|c|c|c|c|}
\hline \multirow{3}{*}{$\begin{array}{c}\text { Analyte } \\
\text { Aluminum }\end{array}$} & \multicolumn{12}{|c|}{ Concentrations $(\mu \mathrm{g} / \mathrm{L})$ in Groundwater } \\
\hline & \multicolumn{2}{|c|}{$\mathrm{P}-3(\mathrm{~T})^{\mathrm{b}}$} & \multicolumn{2}{|c|}{$P-3(D)^{b}$} & \multicolumn{2}{|c|}{$\mathrm{P}-4(\mathrm{~T})$} & \multicolumn{2}{|c|}{ P-4(D) } & \multicolumn{2}{|c|}{$\mathrm{P}-9(\mathrm{~T})$} & \multicolumn{2}{|c|}{$\mathrm{P}-9(\mathrm{D})$} \\
\hline & 799 & & 28.0 & $\mathrm{U}$ & 25,500 & & 3,180 & & 2,690 & & 30.3 & B \\
\hline Antimony & 20.0 & $\mathrm{U}$ & 20.0 & $\mathrm{U}$ & 20.0 & $\mathrm{U}$ & 20.0 & $U$ & 20.0 & $\mathrm{U}$ & 20.0 & $\mathrm{U}$ \\
\hline Arsenic & 36.6 & & 27.3 & & 4.4 & B & 4.0 & $\mathrm{~B}$ & 1.2 & B & 1.0 & $\mathrm{U}$ \\
\hline Barium & 64.5 & B & 37.2 & B & 290 & & 311 & & 25.1 & B & 18.2 & B \\
\hline Beryllium & 1.0 & $U$ & 1.0 & $U$ & 4.7 & B & 2.1 & $\mathrm{~B}$ & 1.0 & $U$ & 1.0 & $\mathrm{U}$ \\
\hline Cadmium & 3.0 & $U$ & 3.0 & $\mathrm{U}$ & 34.1 & & 33.1 & & 3.0 & $\mathrm{U}$ & 3.0 & $\mathrm{U}$ \\
\hline Calcium & 13,000 & & 13,200 & & 309,000 & & 327,000 & & 21,000 & & 20,800 & \\
\hline Chromium & 7.0 & $\mathrm{U}$ & 5.0 & $\mathrm{U}$ & 7.0 & $\mathrm{U}$ & 5.0 & $U$ & 7.0 & $\mathrm{U}$ & 5.0 & $\mathrm{U}$ \\
\hline Cobalt & 7.0 & $U$ & 7.0 & $\mathrm{U}$ & 114 & & 117 & & 7.2 & $\mathrm{~B}$ & 7.0 & $U$ \\
\hline Copper & 3.0 & $\mathrm{U}$ & 3.0 & $\mathrm{U}$ & 98.7 & & 55.1 & & 3.0 & $U$ & 3.0 & $U$ \\
\hline Iron & 9,820 & & 4,070 & & 5,890 & & 1,110 & & 3,130 & & 22.3 & B \\
\hline Lead & 1.6 & B & 1.0 & $\mathrm{U}$ & 92.2 & & 38.6 & & 2.6 & B & 1.0 & $U$ \\
\hline Magnesium & 65,500 & & 69,000 & & 103,000 & & 110,000 & & 3,550 & B & 3,120 & B \\
\hline Manganese & 384 & & 285 & & 1,480 & & 1,520 & & 22.6 & & 1.0 & $\mathrm{~B}$ \\
\hline Mercury & 0.2 & $\mathrm{U}$ & 0.2 & U & 0.4 & & 0.2 & $U$ & 0.2 & $U$ & 0.2 & $\mathrm{U}$ \\
\hline Nickel & 12.0 & $\mathrm{U}$ & 26.8 & B & 84.2 & & 75.0 & & 12.1 & B & 12.0 & U \\
\hline Potassium & 44,800 & & 48,000 & & 5,410 & & 5,870 & & 799 & B & 305 & B \\
\hline Selenium & 1.0 & UW & 1.0 & UW & 1.0 & UW & 1.0 & UW & 1.0 & UW & 1.0 & UW \\
\hline Silver & 4.0 & $\mathrm{U}$ & 4.0 & U & 4.5 & B & 6.6 & B & 4.0 & $U$ & 4.0 & $U$ \\
\hline Sodium & 33,000 & & 35,300 & & 83,700 & & 88,500 & & 8,300 & & 8,560 & \\
\hline Thallium & 1.0 & $\mathrm{U}$ & 1.0 & UNW & 1.0 & UW & 1.0 & UNW & 1.0 & UW & 1.0 & UNW \\
\hline Vanadium & 5.0 & U & 5.0 & $\mathrm{U}$ & 5.0 & U & 5.0 & $U$ & 5.0 & $\mathrm{U}$ & 5.0 & $\mathrm{U}$ \\
\hline Zinc & 55.6 & & 36.4 & & 1,680 & & 1,760 & & 16.6 & $\mathrm{~B}$ & 12.6 & $B$ \\
\hline
\end{tabular}


TABLE C.23 (Cont.)

\begin{tabular}{|c|c|c|c|c|c|c|c|c|c|c|c|c|}
\hline \multirow{3}{*}{$\begin{array}{c}\text { Analyte } \\
\text { Aluminum }\end{array}$} & \multicolumn{12}{|c|}{ Concentrations $(\mu \mathrm{g} / \mathrm{L})$ in Groundwater } \\
\hline & \multicolumn{2}{|c|}{$J F-43(T)$} & \multicolumn{2}{|c|}{$\mathrm{JF}-43(\mathrm{D})$} & \multicolumn{2}{|c|}{$\mathrm{JF}-53(\mathrm{~T})$} & \multicolumn{2}{|c|}{$\mathrm{JF}-53(\mathrm{D})$} & \multicolumn{2}{|c|}{$\mathrm{JF}-63(\mathrm{~T})$} & \multicolumn{2}{|c|}{ JF-63(D) } \\
\hline & 140 & B & 28.0 & $\mathrm{U}$ & 133 & $\mathrm{~B}$ & 43.0 & & 368 & & 111 & $\mathrm{~B}$ \\
\hline Antimony & 20.0 & $\mathrm{U}$ & 20.0 & $\mathrm{U}$ & 20.0 & $U$ & 20.0 & $\mathrm{U}$ & 20.0 & $\mathrm{U}$ & 20.0 & $U$ \\
\hline Arsenic & 5.2 & $\mathbf{B}$ & 2.4 & $\mathrm{BN}$ & 1.2 & BW & 1.0 & $\mathrm{U}$ & 2.6 & B & 2.1 & B \\
\hline Barium & 22.1 & B & 24.7 & $\mathrm{~B}$ & 113 & $\mathrm{~B}$ & 117 & B & 182 & B & 187 & B \\
\hline Beryllium & 1.0 & $\mathrm{U}$ & 1.0 & $\mathrm{U}$ & 1.0 & $\mathrm{U}$ & 1.0 & $\mathrm{U}$ & 1.0 & $\mathrm{U}$ & 1.0 & $\mathrm{U}$ \\
\hline Cadmium & 3.0 & $\mathrm{U}$ & 3.0 & $U$ & 4.8 & B & 3.0 & $\mathrm{U}$ & 3.0 & $U$ & 5.1 & \\
\hline Calcium & 13,400 & & 14,000 & & 39,100 & & 39,600 & & 97,400 & & 98,700 & \\
\hline Chromium & 5.0 & $U$ & 5.0 & $U$ & 73.3 & & 5.0 & $\mathrm{U}$ & 7.0 & $\mathrm{U}$ & 5.0 & $\mathrm{U}$ \\
\hline Cobalt & 12.4 & B & 9.9 & B & 13.5 & B & 14.0 & B & 11.3 & B & 10.6 & $\mathrm{~B}$ \\
\hline Copper & 3.0 & $\mathrm{U}$ & 3.0 & $\mathrm{U}$ & 3.0 & $U$ & 3.0 & $U$ & 3.0 & $U$ & 3.0 & $U$ \\
\hline Iron & 4,440 & & 3,080 & & 18,100 & & 17,200 & & 21,600 & & 22,100 & \\
\hline Lead & 1.5 & B & 1.0 & $\mathrm{U}$ & 1.0 & $U$ & 1.0 & $U$ & 10.6 & & 1.0 & $\mathrm{U}$ \\
\hline Magnesium & 3,950 & B & 4,110 & B & 12,300 & & 12,900 & & 18,000 & & 18,900 & \\
\hline Manganese & 387 & & 380 & & 969 & & 935 & & 788 & & 825 & \\
\hline Mercury & 0.2 & $\mathrm{U}$ & 0.2 & $U$ & 0.2 & $\mathrm{U}$ & 0.2 & $\mathrm{U}$ & 0.2 & $\mathrm{U}$ & 0.2 & $\mathrm{U}$ \\
\hline Nickel & 12.0 & $U$ & 12.0 & $\mathrm{U}$ & 396 & & 390 & & 21.8 & B & 29.7 & B \\
\hline Potassium & 1,080 & B & 1,140 & B & 1,060 & B & 1,050 & B & 1,810 & B & 1,920 & B \\
\hline Selenium & 1.0 & $\mathrm{U}$ & 1.0 & $\mathrm{U}$ & 1.0 & UW & 1.0 & $U$ & 1.0 & UW & 1.0 & UW \\
\hline Silver & 4.0 & $\mathrm{U}$ & 4.0 & $\mathrm{U}$ & 4.0 & $\mathrm{U}$ & 4.0 & $U$ & 4.0 & $U$ & 4.0 & $\mathrm{U}$ \\
\hline Sodium & 7,920 & & 8,310 & & 11,200 & & 11,500 & & 41,500 & & 42,300 & \\
\hline Thallium & 2.0 & UW & 2.0 & UN & 1.0 & UW & 1.0 & UNW & 1.0 & UW & 1.0 & UNW \\
\hline Vanadium & 5.0 & $\mathrm{U}$ & 5.0 & $\mathrm{U}$ & 5.0 & $\mathrm{U}$ & 5.0 & $\mathrm{U}$ & 5.0 & $U$ & 5.0 & $\mathrm{U}$ \\
\hline Zinc & 6.0 & U & 9.7 & $\mathrm{~B}$ & 67.2 & & 82.4 & & 15.8 & B & 12.4 & B \\
\hline
\end{tabular}


TABLE C.23 (Cont.)

\begin{tabular}{|c|c|c|c|c|c|c|c|c|c|c|c|c|}
\hline \multirow{3}{*}{$\frac{\text { Analyte }}{\text { Aluminum }}$} & \multicolumn{12}{|c|}{ Concentrations $(\mu \mathrm{g} / \mathrm{L})$ in Groundwater } \\
\hline & \multicolumn{2}{|c|}{$\mathrm{JF}-73(\mathrm{~T})$} & \multicolumn{2}{|c|}{ JF-73(D) } & \multicolumn{2}{|c|}{$\mathrm{JF}-83(\mathrm{~T})$} & \multicolumn{2}{|c|}{$\mathrm{JF}-83(\mathrm{D})$} & \multicolumn{2}{|c|}{$\mathrm{JF}-173(\mathrm{~T})$} & \multicolumn{2}{|c|}{$\mathrm{JF}-173(\mathrm{D})$} \\
\hline & 215 & & 104 & $\mathbf{B}$ & 501 & & 45.6 & B & 143 & B & 43 & B \\
\hline Antimony & 20.0 & $\mathrm{U}$ & 20.0 & $\mathrm{U}$ & 20.0 & $\mathrm{U}$ & 20.0 & $\mathrm{U}$ & 20.0 & $\mathrm{U}$ & 20.0 & $U$ \\
\hline Arsenic. & 4.3 & $\mathbf{B}$ & 4.6 & B & 63.8 & & 78.6 & $S$ & 12.3 & & 7.2 & $\mathrm{BN}$ \\
\hline Barium & 87.3 & $\mathrm{~B}$ & 94.7 & B & 61.4 & $\mathrm{~B}$ & 68.2 & B & 125 & B & 109 & B \\
\hline Beryllium & 1.0 & U & 1.0 & $U$ & 1.0 & $\mathrm{U}$ & 1.0 & $\mathrm{U}$ & 1.0 & $\mathrm{U}$ & 1.0 & $\mathrm{U}$ \\
\hline Cadmium & 4.0 & $\mathrm{~B}$ & 3.0 & B & 3.0 & $\mathrm{U}$ & 3.0 & $\mathrm{U}$ & 5.2 & & 3.0 & $\mathrm{U}$ \\
\hline Calcium & 93,200 & & 93,800 & & 33,800 & & 34,300 & & 31,600 & & 32,600 & \\
\hline Chromium & 9.8 & $\mathrm{~B}$ & 5.0 & $U$ & 7.0 & $\mathrm{U}$ & 5.0 & $\mathrm{U}$ & 5.0 & $\mathrm{U}$ & 5.0 & $\mathrm{U}$ \\
\hline Cobalt & 7.0 & $\mathrm{U}$ & 7.0 & $U$ & 13.7 & B & 22.1 & B & 7.0 & $U$ & 10.4 & B \\
\hline Copper & 3.0 & $U$ & 3.0 & $U$ & 3.0 & $U$ & 3.0 & $U$ & 3.0 & $U$ & 3.0 & $\mathrm{U}$ \\
\hline Iron & 3,960 & & 2,200 & & 818 & & 19.0 & B & 21,500 & & 17,300 & \\
\hline Lead & 1.0 & $\mathrm{U}$ & 1.0 & $U$ & 1.0 & $U$ & 1.0 & $U$ & 1.5 & B & 1.0 & $\mathrm{U}$ \\
\hline Magnesium & 6,620 & & 6,620 & & 18,300 & & 19,000 & & 6,050 & & 6,220 & \\
\hline Manganese & 262 & & 233 & & 127 & & 125 & & 785 & & 802 & \\
\hline Mercury & 0.2 & $\mathrm{U}$ & 0.2 & $U$ & 0.2 & $U$ & 0.2 & $\mathrm{U}$ & 0.2 & $U$ & 0.2 & $\mathrm{U}$ \\
\hline Nickel & 462 & & 464 & & 22.9 & B & 39.8 & B & 12.0 & $U$ & 12.0 & $\mathrm{U}$ \\
\hline Potassium & 2,220 & B & 2,270 & B & 460 & B & 356 & B & 1,390 & B & 1,450 & B \\
\hline Selenium & 1.0 & UW & 1.0 & $U$ & 1.7 & BW & 2.2 & BW & 1.0 & UW & 1.0 & UW \\
\hline Silver & 4.0 & $U$ & 4.0 & $U$ & 4.0 & $\mathrm{U}$ & 4.0 & U & 4.0 & $\mathrm{U}$ & 4.0 & $\mathrm{U}$ \\
\hline Sodium & 17,900 & & 18,600 & & 18,200 & & 18,800 & & 25,500 & & 26,400 & \\
\hline Thallium & 1.0 & UW & 1.0 & UNW & 1.0 & UW & 1.0 & UNW & 2.0 & UW & 2.0 & UN \\
\hline Vanadium & 5.0 & $U$ & 5.0 & $\mathrm{U}$ & 5.0 & U & 5.0 & $\mathrm{U}$ & 5.0 & $U$ & 5.0 & $U$ \\
\hline Zinc & 79.7 & & 69.2 & & 25.6 & & 27.6 & & 12.5 & $B$ & 15.6 & B \\
\hline
\end{tabular}


TABLE C.23 (Cont.)

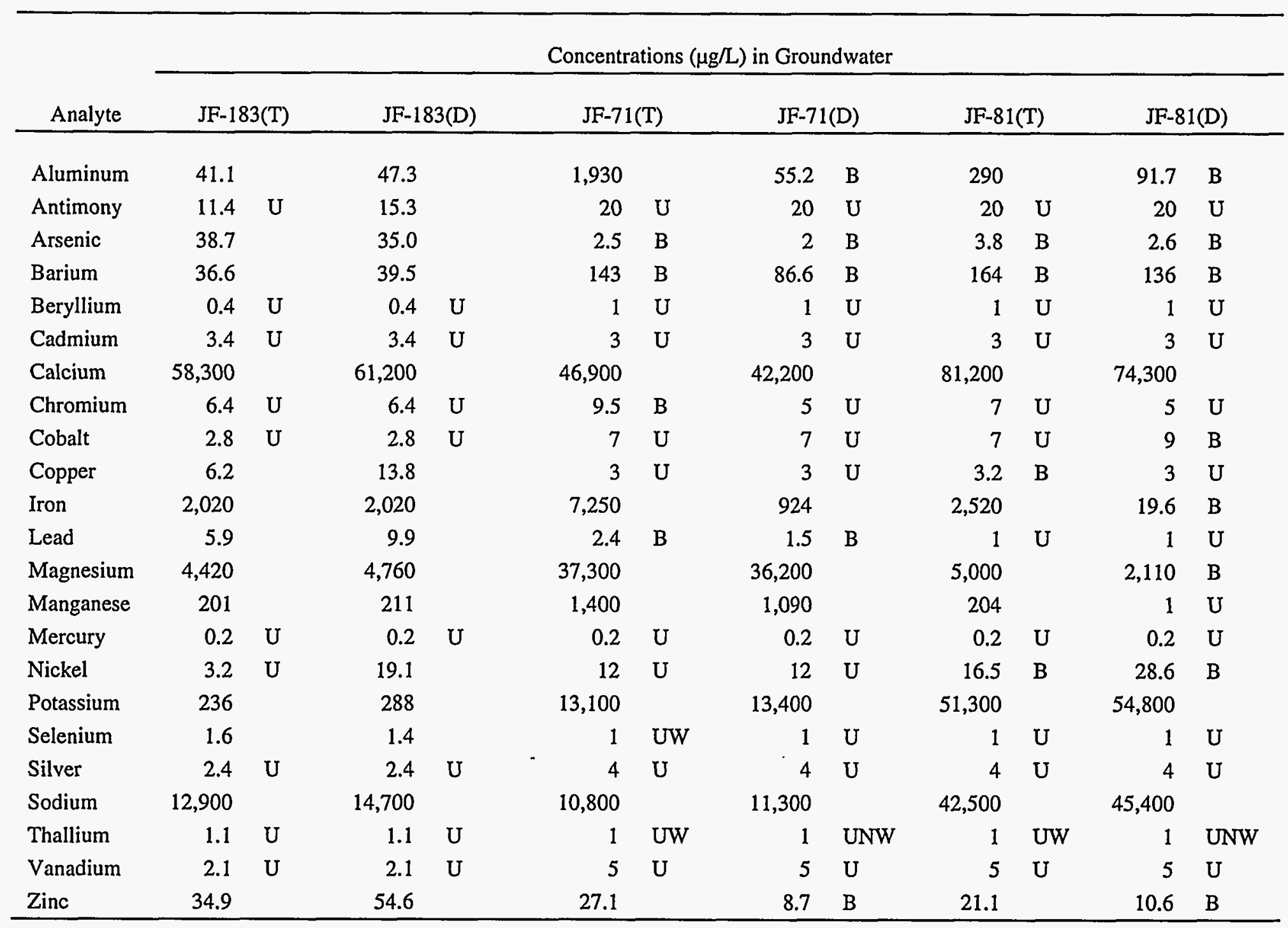

See next page for footnotes. 


\section{TABLE C.23 (Cont.)}

a Sampled by ANL, analyzed by EA Laboratories, CLP/TAL metals. Wells JF-173 and JF-183 sampled in June and December 1994, respectively.

b $\mathrm{T}=$ total; $\mathrm{D}=$ dissolved.

\section{Data qualifiers:}

$\mathrm{U}=$ analyte was analyzed for but not detected; detection limit given.

$\mathrm{B}=$ between IDL and CRDL.

$\mathrm{W}=$ postdigestive spike for furnace AAS analysis was out of control limits.

$\mathrm{N}=$ spiked sample recovery is not within control limits.

$\mathrm{S}=$ reported value is determined by the method of standard additions. 
TABLE C.24 General Chemistry Analyses for Groundwater, May 1994a

\begin{tabular}{|c|c|c|c|c|c|c|c|c|c|c|}
\hline \multirow{3}{*}{$\begin{array}{r}\text { Analyte } \\
\text { Alkalinity }\end{array}$} & \multicolumn{10}{|c|}{ Concentrations $(\mathrm{mg} / \mathrm{L})$ in Groundwater ${ }^{b}$} \\
\hline & \multicolumn{2}{|c|}{ TH4 } & \multicolumn{2}{|c|}{ P-1 } & \multicolumn{2}{|c|}{ P-2 } & \multicolumn{2}{|c|}{ P-3 } & \multicolumn{2}{|c|}{ P-4 } \\
\hline & 252 & $(+)$ & 28.4 & $(t)$ & 22.7 & $(+)$ & 338 & $(+)$ & 34.0 & $(t)$ \\
\hline Bicarbonate & 249 & & 28.4 & & 22.7 & & 338 & & 34.0 & \\
\hline Bromide & 0.10 & $\mathrm{U}$ & 0.10 & $\mathrm{U}$ & 0.10 & $\mathrm{U}$ & 0.10 & $U$ & 1.2 & \\
\hline Carbonate & 3.6 & & 0.40 & U & 0.40 & $U$ & 0.40 & $\mathrm{U}$ & 0.40 & $U$ \\
\hline Chloride & 4.9 & & 1.6 & & 11.0 & & 22.0 & & 1,100 & \\
\hline Cyanide & $\mathrm{NA}$ & & NA & & NA & & 0.01 & $U$ & 0.01 & $\mathrm{U}$ \\
\hline Fluoride & 0.10 & $\mathrm{U}$ & 0.10 & $U$ & 0.10 & $U$ & 0.61 & & 0.10 & $U$ \\
\hline Nitrate & 0.10 & $\mathrm{U}$ & 0.77 & & 1.2 & & 0.74 & & 0.10 & $U$ \\
\hline Nitrite & 1.2 & & 0.58 & & 0.10 & $\mathrm{U}$ & 3.7 & & 0.10 & $\mathrm{U}$ \\
\hline Orthophosphate & 0.10 & $\mathrm{U}$ & 0.10 & $U$ & 0.10 & $\mathrm{U}$ & 0.10 & $\mathrm{U}$ & 0.10 & $\mathrm{U}$ \\
\hline $\mathrm{pH}$ (SI units) & 8.1 & $(t)$ & 5.7 & $(t)$ & 6.4 & $(t)$ & 6.8 & $(+)$ & 5.6 & $(t)$ \\
\hline Phosphate, total & 0.78 & & 0.05 & $\mathrm{U}$ & 0.05 & $\mathrm{U}$ & 1.5 & & 0.05 & $\mathrm{U}$ \\
\hline Sulfate & 22.0 & & 83.0 & & 74.0 & & 120 & & 100 & \\
\hline TDS & 293 & & 117 & & 146 & & 484 & & 2,360 & \\
\hline $\begin{array}{l}\text { Total organic } \\
\text { halogens }(\mu \mathrm{g} / \mathrm{L})\end{array}$ & NA & & NA & & 7.4 & & NA & & 6,900 & \\
\hline & \multicolumn{10}{|c|}{ Concentrations (mg/L) in Groundwater ${ }^{b}$} \\
\hline Analyte & \multicolumn{2}{|c|}{ P-9 } & \multicolumn{2}{|c|}{$\mathrm{JF}-43$} & \multicolumn{2}{|c|}{ JF-53 } & \multicolumn{2}{|c|}{ JF-63 } & \multicolumn{2}{|c|}{ JF-73 } \\
\hline Alkalinity & 22.1 & $(t)$ & 58.8 & $(t)$ & 51.1 & $(t)$ & 27.0 & $(t)$ & 137 & $(t)$ \\
\hline Bicarbonate & 22.1 & & 58.8 & & 51.0 & & 27.0 & & 137 & \\
\hline Bromide & 0.10 & $\mathrm{U}$ & 0.10 & $\mathrm{U}$ & 0.10 & $\mathrm{U}$ & 5.2 & & 0.10 & $\mathrm{U}$ \\
\hline Carbonate & 0.40 & $\mathrm{U}$ & 0.40 & $\mathrm{U}$ & 0.40 & $\mathrm{U}$ & 0.40 & $U$ & 0.40 & $\mathrm{U}$ \\
\hline Chloride & 4.9 & & 6.2 & & 160 & & 250 & & 140 & \\
\hline Cyanide & 0.01 & $U$ & NA & & 0.01 & $U$ & 0.01 & $U$ & 0.01 & $U$ \\
\hline Fluoride & 0.10 & $U$ & 0.10 & $\mathrm{U}$ & 0.10 & $\mathrm{U}$ & .0 .10 & $\mathrm{U}$ & 0.10 & $\mathrm{U}$ \\
\hline Nitrate & 0.79 & & 0.10 & $\mathrm{U}$ & 0.10 & $\mathrm{U}$ & 0.10 & $\mathrm{U}$ & 0.10 & $\mathrm{U}$ \\
\hline Nitrite & 0.10 & $\mathrm{U}$ & 0.10 & $\mathrm{U}$ & 0.10 & $\mathrm{U}$ & 0.10 & $U$ & 0.10 & $U$ \\
\hline Orthophosphate & 0.10 & $\mathrm{U}$ & 0.10 & $\mathrm{U}$ & 0.10 & $\mathrm{U}$ & 0.10 & $\mathrm{U}$ & 0.10 & $\mathrm{U}$ \\
\hline $\mathrm{pH}$ (SI units) & 6.3 & $(+)$ & 6.2 & $(t)$ & 6.5 & $(t)$ & 5.9 & $(t)$ & 6.6 & $(+)$ \\
\hline Phosphate (total) & 0.05 & $\mathrm{U}$ & 0.05 & $\mathrm{U}$ & 0.05 & $\mathrm{U}$ & 0.06 & & 0.05 & $U$ \\
\hline Sulfate & 70.0 & & 17 & & 8.8 & & 65.0 & & 22.0 & \\
\hline TDS & 102 & & 107 & & 304 & & 741 & & 426 & \\
\hline $\begin{array}{l}\text { Total organic } \\
\text { halogens }(\mu \mathrm{g} / \mathrm{L})\end{array}$ & NA & & 7.7 & & 2,300 & & NA & & 23.0 & \\
\hline
\end{tabular}


TABLE C.24 (Cont.)

\begin{tabular}{|c|c|c|c|c|c|c|c|c|c|c|}
\hline \multirow{3}{*}{$\begin{array}{r}\text { Analyte } \\
\text { Alkalinity }\end{array}$} & \multicolumn{10}{|c|}{ Concentrations $(\mathrm{mg} / \mathrm{L})$ in Groundwater ${ }^{\mathrm{b}}$} \\
\hline & \multicolumn{2}{|c|}{ JF-83 } & \multicolumn{2}{|c|}{$\mathrm{JF}-173$} & \multicolumn{2}{|c|}{$\mathrm{JF}-52$} & \multicolumn{2}{|c|}{$\mathrm{JF}-62$} & \multicolumn{2}{|c|}{$\mathrm{JF}-72$} \\
\hline & 51.1 & $(+)$ & 55.3 & & 331 & $(+)$ & 274 & & 376 & $(+)$ \\
\hline Bicarbonate & 51.1 & & 55.3 & & 331 & & 274 & & 151 & \\
\hline Bromide & 0.10 & U & 0.75 & & 0.41 & & 0.4 & & 0.1 & $\mathrm{U}$ \\
\hline Carbonate & 0.40 & $U$ & 0.4 & $\mathrm{U}$ & 0.6 & & 0.8 & & 2.4 & \\
\hline Chloride & 110 & & 56 & & 4.3 & & 4.7 & & 5.2 & \\
\hline Cyanide & 0.01 & U & 0.01 & $\mathrm{U}$ & $\mathrm{NA}$ & & NA & & 0.01 & $\mathrm{U}$ \\
\hline Fluoride & 0.10 & $\mathrm{U}$ & 0.1 & $\mathrm{U}$ & 0.1 & $\mathrm{U}$ & 0.1 & $U$ & 1.5 & \\
\hline Nitrate & 1.2 & & 0.1 & $\mathrm{U}$ & 0.48 & & 0.1 & $\mathrm{U}$ & 0.1 & $\mathrm{U}$ \\
\hline Nitrite & 0.10 & $U$ & 0.1 & $\mathrm{U}$ & 1.2 & & 0.1 & $\mathrm{U}$ & 0.1 & $\mathrm{U}$ \\
\hline Orthophosphate & 0.10 & $\mathrm{U}$ & 0.1 & $\mathrm{U}$ & 0.1 & $U$ & 0.1 & $\mathrm{U}$ & 0.35 & \\
\hline $\mathrm{pH}$ (SI units) & 6.0 & $(t)$ & 6.3 & & 7.2 & $(t)$ & 7.4 & & 11.7 & $(t)$ \\
\hline Phosphate, total & 0.05 & $U$ & 0.05 & $\mathrm{U}$ & 0.63 & & 0.69 & & 0.05 & $\mathrm{U}$ \\
\hline Sulfate & 59.0 & & 38 & & 0.75 & & 0.94 & & 19 & \\
\hline TDS & 743 & & 237 & & 411 & & 355 & & 370 & \\
\hline $\begin{array}{l}\text { Total organic } \\
\text { halogens }(\mu \mathrm{g} / \mathrm{L})\end{array}$ & 120 & & 9,500 & & NA & & 5 & $\mathrm{U}$ & NA & \\
\hline & \multicolumn{10}{|c|}{ Concentrations $(\mathrm{mg} / \mathrm{L})$ in Groundwater ${ }^{b}$} \\
\hline Analyte & \multicolumn{2}{|c|}{ JF-82 } & \multicolumn{2}{|c|}{ JF-51 } & \multicolumn{2}{|c|}{$\mathrm{JF}-61$} & \multicolumn{2}{|c|}{$\mathrm{JF}-71$} & \multicolumn{2}{|c|}{$\mathrm{JF}-81$} \\
\hline Alkalinity & 200 & $(+)$ & 377 & $(+)$ & 219 & $(t)$ & 330 & $(+)$ & 320 & $(t)$ \\
\hline Bicarbonate & 8.3 & & 375 & & 2.9 & & 330 & & 8.8 & \\
\hline Bromide & 0.1 & $\mathrm{U}$ & 0.46 & & 0.1 & $\mathrm{U}$ & 0.28 & & 0.53 & \\
\hline Carbonate & 134 & & 1.7 & & 102 & & 0.7 & & 224 & \\
\hline Chloride & 15 & & 51 & & 77 & & 17 & & 180 & \\
\hline Cyanide & 0.01 & $\mathrm{U}$ & NA & & NA & & 0.01 & $\mathbf{U}$ & 0.01 & $U$ \\
\hline Fluoride & 0.22 & & 0.1 & $\mathrm{U}$ & 0.73 & & 0.1 & $\mathbf{U}$ & 0.1 & $\mathrm{U}$ \\
\hline Nitrate & 0.1 & $\mathrm{U}$ & 0.1 & $\mathrm{U}$ & 0.1 & $U$ & 0.1 & $\mathbf{U}$ & 0.1 & $\mathrm{U}$ \\
\hline Nitrite & 0.1 & $\mathrm{U}$ & 10 & & 0.1 & $\mathrm{U}$ & 3.4 & & 0.1 & $U$ \\
\hline Orthophosphate & 0.1 & $\mathrm{U}$ & 1.2 & & 0.1 & $\mathrm{U}$ & 2.4 & & 0.1 & $\mathrm{U}$ \\
\hline $\mathrm{pH}$ (SI units) & 11.2 & $(+)$ & 7.6 & $(t)$ & 11.4 & $(+)$ & 7.2 & $(t)$ & 11.3 & $(+)$ \\
\hline Phosphate, total & 0.05 & $\mathrm{U}$ & 1.6 & & 0.05 & & 3.6 & & 0.4 & \\
\hline Sulfate & 15 & & 19 & & 9.5 & & 11 & & 1.4 & \\
\hline TDS & 253 & & 431 & & 723 & & 355 & & 414 & \\
\hline $\begin{array}{l}\text { Total organic } \\
\text { halogens }(\mu \mathrm{g} / \mathrm{L})\end{array}$ & NA & & $\mathrm{NA}$ & & $\mathrm{NA}$ & & NA & & 1,800 & \\
\hline
\end{tabular}

See next page for footnotes. 


\section{TABLE C.24 (Cont.)}

a Sampled by ANL, analyzed by EA Laboratories. Well JF-173 sampled in June 1994.

b Units are $\mathrm{mg} / \mathrm{L}$, except where indicated.

Data qualifiers:

$U$ = analyte was analyzed for but not detected; detection limit given.

$(+)=$ holding time was not met.

$\mathrm{NA}=$ not analyzed. 
TABLE C.25 Pesticide and PCB Analyses for Groundwater in the Surficial Aquifer, May $1994^{2}$

\begin{tabular}{|c|c|c|c|c|c|c|c|c|c|c|c|c|}
\hline \multirow{3}{*}{$\frac{\text { Compound }}{\text { Aldrin }}$} & \multicolumn{12}{|c|}{ Concentrations $(\mu \mathrm{g} / \mathrm{L})$ in Groundwater } \\
\hline & \multicolumn{2}{|c|}{$\mathrm{P}-3$} & \multicolumn{2}{|c|}{ P-9 } & \multicolumn{2}{|c|}{ JF-53 } & \multicolumn{2}{|c|}{ JF-63 } & \multicolumn{2}{|c|}{ JF-73 } & \multicolumn{2}{|c|}{$\mathrm{JF}-83$} \\
\hline & 0.05 & $\mathbf{U t}_{+}$ & 0.05 & $\mathrm{U}_{+}$ & 0.05 & $U_{+}$ & 0.05 & $\mathrm{U}+\mathrm{N}$ & 0.05 & $\mathrm{U}_{+}$ & 0.05 & $\mathrm{U}+$ \\
\hline alpha-BHC & 0.05 & $U_{+}$ & 0.05 & $\mathrm{U}_{+}$ & 0.05 & $\mathrm{U}_{+}$ & 0.05 & $\mathrm{U}_{+}$ & 0.05 & $\mathrm{U}_{+}$ & 0.05 & $\mathrm{U}_{+}$ \\
\hline alpha-Chlordane & 0.05 & $U_{+}$ & 0.05 & $\mathrm{U}_{+}$ & 0.05 & $\mathrm{U}_{+}$ & 0.05 & $\mathrm{U}_{+}$ & 0.05 & $\mathrm{U}_{+}$ & 0.05 & $\mathrm{U}_{+}$ \\
\hline Aroclor 1016 & 1.0 & $U_{t}$ & 1.0 & $\mathrm{U}_{+}$ & 1.0 & $U_{t}$ & 1.0 & $U_{t}$ & 1.0 & $U_{+}$ & 1.0 & $\mathrm{U}_{+}$ \\
\hline Aroclor 1221 & 2.0 & $\mathbf{U}_{+}$ & 2.0 & $\mathrm{U}_{+}$ & 2.0 & $U_{+}$ & 2.0 & $U_{+}$ & 2.0 & $\mathrm{U}_{+}$ & 2.0 & $\mathrm{U}_{+}$ \\
\hline Aroclor 1232 & 1.0 & Ut & 1.0 & $\mathrm{U}_{+}$ & 1.0 & $U_{+}$ & 1.0 & $U_{+}$ & 1.0 & $\mathrm{U}_{+}$ & 1.0 & $\mathrm{U}_{+}$ \\
\hline Aroclor 1242 & 1.0 & Ut & 1.0 & $\mathrm{U}_{+}$ & 1.0 & $\mathrm{U}_{+}$ & 1.0 & Ut' & 1.0 & $\mathrm{U}_{+}$ & 1.0 & $U_{+}$ \\
\hline Aroclor 1248 & 1.0 & $\mathrm{U}_{+}$ & 1.0 & $U_{+}$ & 1.0 & $\mathrm{U}_{+}$ & 1.0 & $U_{+}$ & 1.0 & $\mathrm{U}_{+}$ & 1.0 & $\mathrm{U}_{+}$ \\
\hline Aroclor 1254 & 1.0 & $\mathrm{U}_{+}$ & 1.0 & $\mathrm{U}_{+}$ & 1.0 & $U_{+}$ & 1.0 & $\mathrm{U}_{+}$ & 1.0 & $\mathrm{U}_{+}$ & 1.0 & $\mathrm{U}_{+}$ \\
\hline Aroclor 1260 & 1.0 & $\mathrm{U}_{+}$ & 1.0 & $\mathrm{U}_{+}$ & 1.0 & $U_{t}$ & 1.0 & $\mathrm{U}_{+}$ & 1.0 & $\mathrm{U}_{+}$ & 1.0 & U+ \\
\hline beta-BHC & 0.05 & $\mathbf{U}_{+}$ & 0.05 & $\mathrm{U}_{+}$ & 0.05 & $\mathrm{U}_{+}$ & 0.05 & $\mathrm{U}+$ & 0.05 & $\mathrm{U}_{+}$ & 0.05 & $\mathrm{U}_{+}$ \\
\hline $4,4^{\prime}-\mathrm{DDD}$ & 0.10 & U+ & 0.10 &.$U_{+}$ & 0.10 & U+ & 0.10 & Ut & 0.10 & $\mathrm{U}_{+}$ & 0.10 & $\mathrm{Ut}_{+}$ \\
\hline $4,4^{\prime}-\mathrm{DDE}$ & 0.10 & $\mathrm{Ut}$ & 0.10 & $\mathrm{U}_{+}$ & 0.10 & $\mathrm{U}_{+}$ & 0.10 & $\mathrm{U}_{+}$ & 0.10 & $\mathrm{U}_{+}$ & 0.10 & $U_{+}$ \\
\hline 4,4'-DDT & 0.10 & Ut & 0.10 & $\mathrm{U}_{+}$ & 0.10 & Ut & 0.10 & Ut & 0.10 & $\mathrm{U}_{+}$ & 0.10 & $U_{+}$ \\
\hline delta-BHC & 0.05 & Ut & 0.05 & U+ & 0.05 & U+ & 0.05 & Ut & 0.05 & $\mathrm{U}_{+}$ & 0.05 & $\mathrm{U}_{+}$ \\
\hline Dieldrin & 0.10 & Ut & 0.10 & Ut & 0.10 & $\mathrm{U}_{+}$ & 0.10 & $U_{+}$ & 0.10 & $\mathrm{U}_{+}$ & 0.10 & $U_{+}$ \\
\hline Endosulfan I & 0.05 & Ut & 0.05 & $\mathrm{U}_{+}$ & 0.05 & $\mathrm{U}_{+}$ & 0.05 & $U_{+}$ & 0.05 & $\mathrm{U}_{+}$ & 0.05 & $U_{+}$ \\
\hline Endosulfan II & 0.10 & Ut & 0.10 & U+ & 0.10 & $\mathrm{U}_{+}$ & 0.10 & $U_{+}$ & 0.10 & $\mathrm{Ut}_{+}$ & 0.10 & $U_{+}$ \\
\hline Endosulfan sulfate & 0.10 & $U_{+}$ & 0.10 & $\mathrm{Ut}_{+}$ & 0.10 & $\mathrm{U}_{+}$ & 0.10 & $U_{+}$ & 0.10 & $\mathrm{Ut}_{+}$ & 0.10 & $\mathrm{U}_{+}$ \\
\hline Endrin & 0.10 & Ut & 0.10 & $U_{+}$ & 0.10 & $U_{+}$ & 0.10 & Ut & 0.10 & $U_{+}$ & 0.10 & $\mathrm{U}_{+}$ \\
\hline Endrin aldehyde & 0.10 & Ut & 0.10 & Ut & 0.10 & $\mathrm{U}_{+}$ & 0.10 & U+ & 0.10 & $U_{+}$ & 0.10 & $\mathrm{U}_{+}$ \\
\hline Endrin ketone & 0.10 & Ut & 0.10 & Ut & 0.10 & $\mathrm{U}_{+}$ & 0.10 & $\mathrm{U}+\mathrm{N}$ & 0.10 & $U_{+}$ & 0.10 & $\mathrm{U}_{+}$ \\
\hline gamma-BHC & 0.05 & $U_{+}$ & 0.05 & $\mathrm{U}_{+}$ & 0.05 & $\mathrm{U}_{+}$ & 0.05 & $\mathrm{U}_{+}$ & 0.05 & $U_{+}$ & 0.05 & $U_{+}$ \\
\hline gamma-Chlordane & 0.05 & $U_{+}$ & 0.05 & Ut & 0.05 & $\mathrm{U}_{+}$ & 0.05 & Ut & 0.05 & $\mathrm{U}+$ & 0.05 & $\mathrm{U}_{+}$ \\
\hline Heptachlor & 0.05 & $\mathrm{U}_{t}$ & 0.05 & Ut & 0.05 & $\mathrm{U}_{+}$ & 0.05 & $\mathrm{U}+\mathrm{N}$ & 0.05 & $\mathrm{U}_{+}$ & 0.05 & $U_{+}$ \\
\hline Heptachlor epoxide & 0.05 & $\mathrm{U}+$ & 0.05 & Ut & 0.05 & $\mathrm{U}_{+}$ & 0.05 & $\mathrm{U}_{+}$ & 0.05 & $\mathrm{U}+$ & 0.05 & $\mathrm{U}_{+}$ \\
\hline Methoxychlor & 0.50 & $U_{+}$ & 0.50 & $U_{+}$ & 0.50 & $\mathrm{U}_{+}$ & 0.50 & $U_{+}$ & 0.50 & $\mathrm{U}_{+}$ & 0.50 & $\dot{U}_{+}$ \\
\hline Toxaphene & 5.0 & $\mathrm{U}+$ & 5.0 & $\mathrm{U}+$ & 5.0 & $\mathrm{U}_{+}$ & 5.0 & $\mathrm{U}_{+}$ & 5.0 & Ut & 5.0 & $\mathrm{U}_{+}$ \\
\hline
\end{tabular}

a Sampled by ANL, analyzed by EA Laboratories, CLP/TAL metals.

Data qualifiers:

$\mathrm{U}=$ analyte was analyzed for but not detected; detection limit given.

$+=$ surrogate recoveries were outside QC limit(s).

$\mathrm{N}=$ spike and duplicate recovery of percent RPD were outside control limits. 
TABLE C.26 Explosive Compounds Analyses for Groundwater in the Surficial Aquifer, June 1994a

\begin{tabular}{|c|c|c|c|c|c|c|c|c|c|c|c|c|c|c|c|c|}
\hline \multirow{3}{*}{$\begin{array}{l}\text { Compound } \\
1,3-\mathrm{DNB}\end{array}$} & \multicolumn{16}{|c|}{ Concentrations $(\mu \mathrm{g} / \mathrm{L})$ in Groundwater } \\
\hline & \multicolumn{2}{|c|}{$\mathrm{P}-3$} & \multicolumn{2}{|c|}{$\mathrm{P}-4$} & \multicolumn{2}{|c|}{$\mathrm{P}-9$} & \multicolumn{2}{|c|}{$\mathrm{JF}-53$} & \multicolumn{2}{|c|}{$\mathrm{JF}-63$} & \multicolumn{2}{|c|}{$\mathrm{JF}-73$} & \multicolumn{2}{|c|}{$\mathrm{JF}-83$} & \multicolumn{2}{|c|}{ JF-173 } \\
\hline & 0.62 & $\mathrm{U}$ & 0.62 & $U$ & 0.62 & $\mathrm{U}$ & 0.62 & $\mathrm{U}$ & 0.62 & $\mathrm{U}$ & 0.62 & $U$ & 0.62 & U & 0.62 & $\mathrm{U}$ \\
\hline 2,4-DNT & 0.43 & $\mathrm{U}$ & 0.43 & $U$ & 0.43 & $\mathrm{U}$ & 0.43 & $\mathrm{U}$ & 0.43 & $\mathrm{U}$ & 0.43 & $\mathrm{U}$ & 0.43 & $U$ & 0.43 & $\mathrm{U}$ \\
\hline 2,6-DNT & 1.2 & $\mathrm{U}$ & 1.2 & $\mathrm{U}$ & 1.2 & $\mathrm{U}$ & 1.2 & $\mathrm{U}$ & 1.2 & $U$ & 1.2 & $\mathrm{U}$ & 1.2 & $\mathrm{U}$ & 1.2 & $\mathrm{U}$ \\
\hline HMX & 1.1 & $\mathrm{U}$ & 1.1 & $U$ & 1.1 & $U$ & 1.1 & $\mathrm{U}$ & 1.1 & $\mathrm{U}$ & 1.1 & $U$ & 1.1 & U & 1.1 & $\mathrm{U}$ \\
\hline NB & 0.45 & $\mathrm{U}$ & 0.45 & $\mathrm{U}$ & 0.45 & $\mathrm{U}$ & 0.45 & $\mathrm{U}$ & 0.45 & $\mathrm{U}$ & 0.45 & $\mathrm{U}$ & 0.45 & $\mathrm{U}$ & 0.45 & $\mathrm{U}$ \\
\hline $\mathrm{RDX}$ & 1.7 & $\mathrm{U}$ & 1.7 & $\mathrm{U}$ & 1.7 & $\mathrm{U}$ & 1.7 & $\mathrm{U}$ & 1.7 & $\mathrm{U}$ & 1.7 & $\mathrm{U}$ & 8.5 & & 1.5 & \\
\hline TETRYL & 1.9 & $U$ & 1.9 & $\mathrm{U}$ & 1.9 & $\mathrm{U}$ & 1.9 & U & 1.9 & $\mathrm{U}$ & 1.9 & $U$ & 1.9 & $\mathrm{U}$ & 1.9 & $\mathrm{U}$ \\
\hline $1,3,5-\mathrm{TNB}$ & 0.86 & $\mathrm{U}$ & 0.86 & $\mathrm{U}$ & 0.86 & $\mathrm{U}$ & 0.86 & $\mathrm{U}$ & 0.86 & $\mathrm{U}$ & 0.86 & $\mathrm{U}$ & 0.86 & $U$ & 0.86 & $\mathrm{U}$ \\
\hline 2,4,6-TNT & 1.3 & $\mathrm{U}$ & 1.3 & $\mathrm{U}$ & 1.3 & $\mathrm{U}$ & 1.3 & $U$ & 1.3 & $\mathrm{U}$ & 1.3 & $\mathrm{U}$ & 1.3 & $U$ & 1.3 & U \\
\hline
\end{tabular}

a Sampled by ANL, analyzed by EA Laboratories.

Data qualifier:

$\mathrm{U}=$ analyte was analyzed for but not detected; detection limit given. 
TABLE C.27 Radiochemistry Analyses for Groundwater, June $1994^{\text {a }}$

\begin{tabular}{cccccccc}
\hline & \multicolumn{7}{c}{ Concentrations $(\mathrm{pC} / \mathrm{L}$ ) in Groundwater } \\
\cline { 2 - 8 } Analyte & $\mathrm{P}-6$ & $\mathrm{JF}-53$ & $\mathrm{JF}-63$ & $\mathrm{JF}-73$ & $\mathrm{JF}-83$ & JF-173 & JF-173 (Dup) \\
\hline & & & & & & \\
Gross alpha $^{\mathrm{b}}$ & $0.81 \pm 0.45$ & $1.1 \pm 0.7$ & $0.5 \pm 0.6$ & $1.1 \pm 0.7$ & $0.91 \pm 0.58$ & $0.29 \pm 0.56$ & $0.27 \pm 0.48$ \\
Gross beta $^{\mathrm{c}}$ & $2.2 \pm 0.7$ & $2.6 \pm 1.0$ & $3.3 \pm 1.3$ & $2.9 \pm 1.1$ & $2.7 \pm 1.0$ & $1.5 \pm 0.9$ & $3.0 \pm 1.1$ \\
\hline
\end{tabular}

a Sampled by ANL, analyzed by Data Chem Laboratories.

b Gross alpha results relative to $\mathrm{Pu}-239$.

c Gross beta results relative to $\mathrm{Sr}-90 / \mathrm{Y}-90$. 
$D-I$

APPENDIX D:

CHARACTERIZATION OF THE TOXIC BURNING PITS AREA 


$$
\text { D-2 }
$$




\section{APPENDIX D: \\ CHARACTERIZATION OF THE TOXIC BURNING PITS AREA}

Site characterization sampling activities were conducted by Argonne National Laboratory (ANL), the U.S. Environmental Protection Agency Emergency Response Team (EPA ERT), and Roy F. Weston, Inc., at the J-Field Toxic Burning Pits (TBP) area from 1993 to 1995 to fill in data gaps and to supplement the data generated by previous investigators. Some of the data gaps are summarized below:

- Previous soil-gas data showed contamination at the edges of the surveyed areas, an indication that soil-gas contamination extends for unknown distances beyond the surveyed areas. Additional data were needed to determine the extent of this contamination.

- Previous surface soil sampling locations at the J-Field areas of concern (AOCs) were inadequate to characterize the nature and extent of contamination to the degree needed for human health and ecological risk assessment. Some areas with a potential for contamination had not been sampled.

- Subsurface sampling was inadequate to characterize soil contamination at depth in the TBP area.

- Little sediment and surface water sampling had been conducted in the adjacent marsh. Such sampling was especially needed in the marsh near the TBP area, where preliminary thermal imagery suggested that groundwater discharge to surface water could be a significant contaminant migration pathway.

- Existing monitoring wells were not designed to detect the presence of dense, nonaqueous-phase liquids (DNAPLs). Such information was especially needed at the TBP area, where previous data showed the presence of groundwater contamination by volatile organic compounds (VOCs) at levels suggesting the possible presence of DNAPLs.

This appendix summarizes the analytical results of the sampling conducted between 1993 and 1995 to complete the site characterization. The results are presented by environmental medium (i.e., soil gas, soil, sediment, surface water, and groundwater). 
Sediment samples and most of the soil samples collected and analyzed as part of the ongoing remedial investigation (RI) of the site were required to undergo both a "gross" chemical warfare agent (CWA) screen and a low-level CWA screen before being released to either on-site or off-site analytical laboratories. The CWA screening protocol is detailed by Sci Tech Services, Inc. (1992). None of the sediment and soil samples collected from the TBP area contained CWA. Surface water and groundwater samples were not required to undergo CWA screening.

The laboratory analytical data and some of the on-site analytical data for samples collected in the TBP area between January 1993 and June 1995 are presented in Appendix C. A complete quality assurance review of all of the laboratory results reported in Appendix $\mathrm{C}$ was performed. Some soil and sediment sample analyses exceeded holding times because of laboratory error and/or the time lag between sample collection and the completion of the CWA screen. Data qualifiers from the analytical laboratory and ANL data validation activities are footnoted and described for each data set in Appendix C.

\section{D.1 SOIL GAS}

Both active and passive soil-gas monitoring points were used to conduct soil-gas surveys at the TBP area. Active soil-gas monitoring techniques can be used only in areas of unsaturated soil conditions. Because of shallow groundwater conditions and the presence of surface water in portions of the area of interest, passive soil-gas monitoring techniques were used to monitor soil gas in both saturated and unsaturated conditions. In addition, the EPA ERT established a dense grid of active soil-gas monitoring points in the only portion of the TBP area thought to be suitable for the installation of a soil-vapor extraction (SVE) system. The results of these soil-gas surveys are summarized below. A complete description of the sampling methodologies and results for the passive soil-gas monitoring studies are presented by Prasad (1993) and Prasad and Martino (1994). The results of the active soil-gas investigation are detailed by Roy F. Weston, Inc. (1994).

In 1993, passive soil-gas monitoring was conducted with EMFLUX soil-gas collection devices at four locations: sampling points SG-1 and SG-2 in the marsh downgradient and east of the main burning pits, SG-3 in the southern main pit, and SG-4 south of the main pits area (Prasad 1993) (Figure D.1). The SG-1 sample had the highest average emissions of TCLEA $\left(1,127 \mathrm{ng} / \mathrm{m}^{2} / \mathrm{min}\right)$, TRCLE $\left(1,139 \mathrm{ng} / \mathrm{m}^{2} / \mathrm{min}\right), 12 \mathrm{DCE}\left(377 \mathrm{ng} / \mathrm{m}^{2} / \mathrm{min}\right)$, and $112 \mathrm{TCE}\left(203 \mathrm{ng} / \mathrm{m}^{2} / \mathrm{min}\right)$. The SG-3 sample had the highest emission of TCLEE $\left(202 \mathrm{ng} / \mathrm{m}^{2} / \mathrm{min}\right)$ and a relatively high emission of TCLEA $\left(678.5 \mathrm{ng} / \mathrm{m}^{2} / \mathrm{min}\right)$. A low emission of toluene $\left(29.8 \mathrm{ng} / \mathrm{m}^{2} / \mathrm{min}\right)$ was detected in the SG-2 sample, and low emissions of halogenated compounds were found in the SG-2 and SG-4 samples.

In February 1994, an EMFLUX passive soil-gas survey was conducted at 63 locations in the marsh east and south of the TBP area and in other areas too saturated to allow active soil-gas monitoring (Figure D.1). The highest emission of TRCLE $\left(537 \mathrm{ng} / \mathrm{m}^{2} / \mathrm{min}\right.$ ) was measured at 


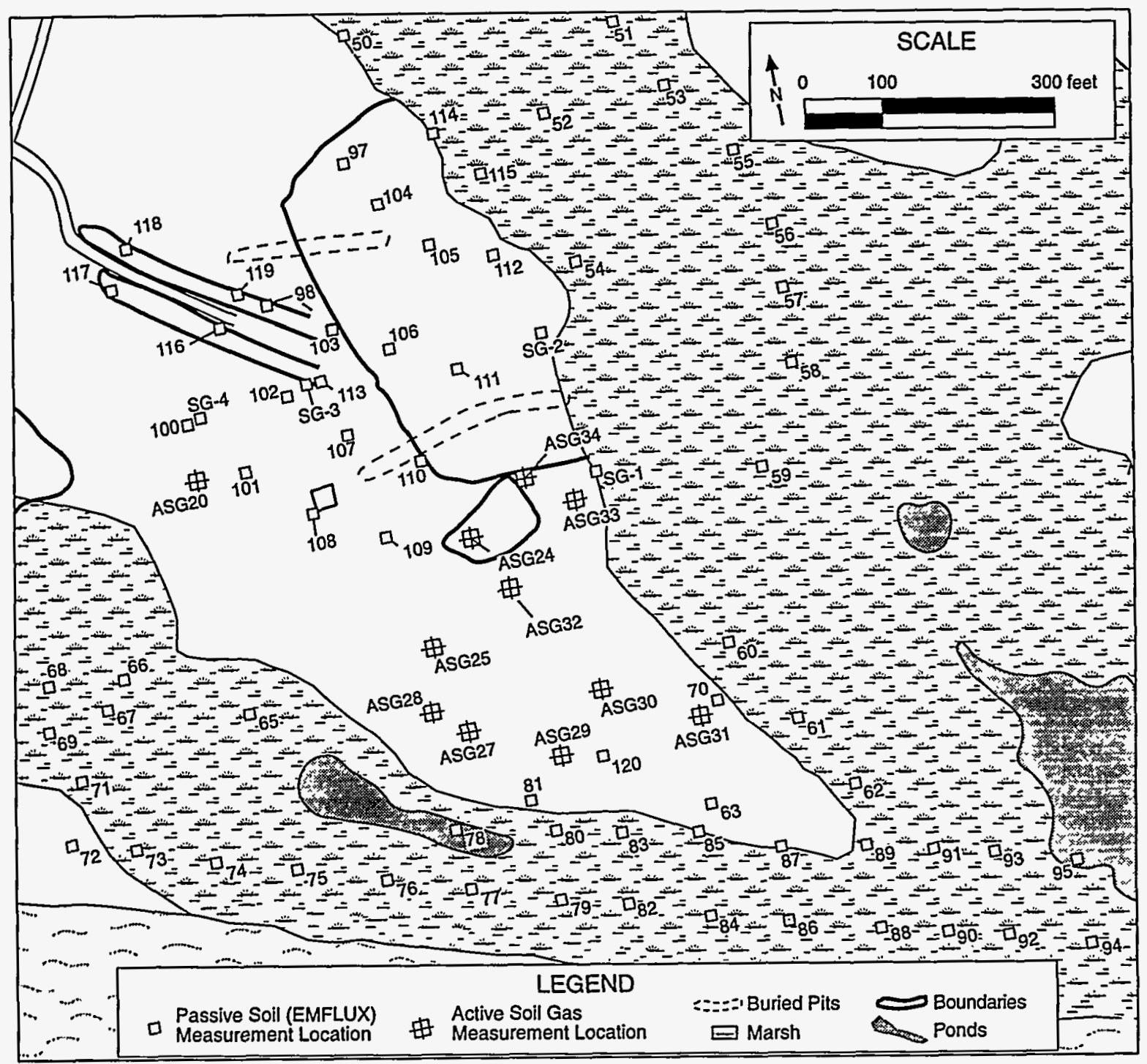

FIGURE D.1 Location of Passive and Active Soil-Gas Measurements at the TBP Area: 1993-1994

sampling point 113, near sampling point SG-3 of the 1993 survey. The second highest TRCLE emission $\left(84.7 \mathrm{ng} / \mathrm{m}^{2} / \mathrm{min}\right)$ was detected at sampling point 95 , on the southwestern edge of the pond within the marsh, southeast of the main burning pits. Emissions of TRCLE at 16 sampling locations ranged from 1.3 to $537 \mathrm{ng} / \mathrm{m}^{2} / \mathrm{min}$, clustering in two areas: around the two main burning pits and the pushout area and near the southeastern end of the TBP area peninsula.

In addition to the passive soil-gas studies, the EPA ERT conducted active soil-gas sampling at 58 locations in the southeastern part of the site (Roy F. Weston, Inc. 1994) (Figure D.2). Samples were analyzed on-site with a Microsensor Technology model P200 gas chromatograph. Fifty soil-gas 


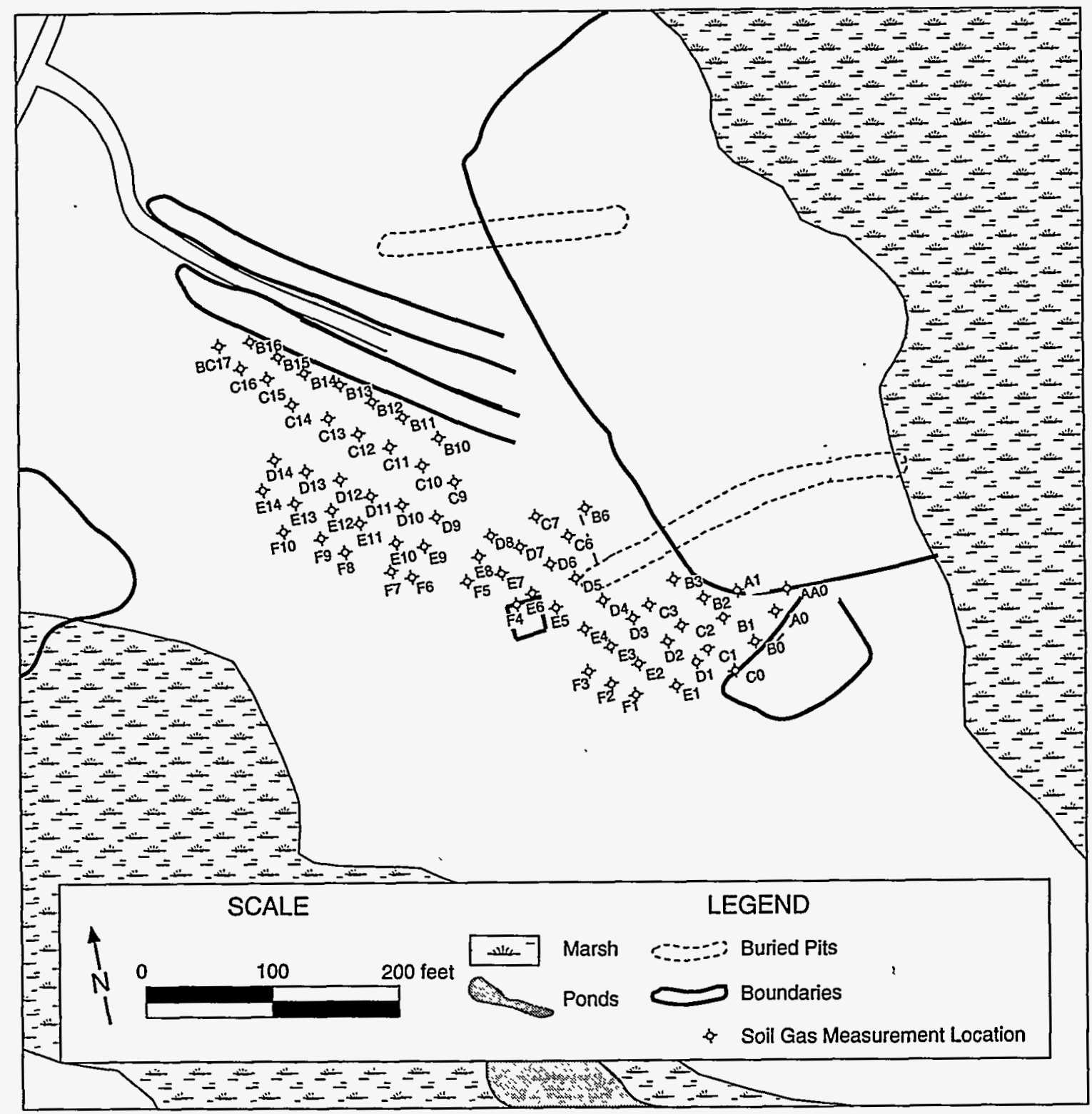

FIGURE D.2 Locations of Active Soil-Gas Sampling at the TBP Area (Source: Modified from Roy F. Weston, Inc. 1994)

samples and two ambient-air field blanks contained no detectable levels of the target compounds. The target compounds include 11DCE, TRCLE, isooctane, 12DCE, chloroform, m-xylene, o-xylene, toluene, and carbon tetrachloride. Eight soil-gas samples (B12-B15, C10, C15, D8, and F5) and one ambient-air field blank contained low levels of TRCLE $\left(<2.2 \mathrm{mg} / \mathrm{m}^{3}\right)$, and one sample (D8) contained a low level of TCLEE $\left(0.29 \mathrm{mg} / \mathrm{m}^{3}\right)$. No other compounds were detected (Roy F. Weston, Inc. 1994). The detection of TRCLE at these six locations is not conclusive because that chemical was detected in the field blank sample.

In 1994, a Sentex Scentograph Plus II portable gas chromatograph was used for active soil-gas sampling at 11 locations (ASG20, ASG24, ASG25, and ASG27-ASG34; Figure D.1). 
Again, TRCLE was found in the field blank. Low levels of TRCLE ( $0.03 \mathrm{ppm}), 12 \mathrm{DCE}(0.04 \mathrm{ppm})$, $\mathrm{m}$-xylene $(0.04 \mathrm{ppm})$, and toluene $(0.16 \mathrm{ppm})$ were detected at ASG33, but duplicate and triplicate measurements did not indicate the presence of these compounds. No detectable levels of the target compounds were found at the other locations.

\section{D.2 SOIL SAMPLING}

ANL has conducted soil sampling from 1993 to 1995 at the TBP area of J-Field as part of the RI. Surface and subsurface soil samples were collected in four of the five burning pits, in areas outside of the burning pits, and in pushout areas. ${ }^{1}$ Both intrusive and nonintrusive methods have been used to characterize surface soils at the TBP area.

Soil samples up to a depth of $1 \mathrm{ft}$ were collected from outside of the burning pits and analyzed for constituents in the on-site analytical suite (OSAS), as specified in Table D.1. Those samples were designated as OT1 to OT20 and OT29 to OT32. ${ }^{2}$ Sample numbers OT5 and OT21 to OT28 were not used. Additional, nonintrusive samples were analyzed in situ by field-portable X-ray fluorescence. Those samples were designated as XRTBP1 to XRTBP45, XRHE1 to XRHE11, XRSP1 to XRSP9, XRSP-mound, XRSP-mound A, and XRSP-mound B.

Soil samples collected after December 1993 were analyzed with a modified analytical suite, specified in Table D.2. The sample analytical protocol was changed for the following reasons:

1. In some cases, the detection limit for a number of inorganic contaminants was higher than acceptable risk-based concentrations.

2. The analytical suite in the OSAS is not as expansive as the Contract Laboratory Program's (CLP's) target compound list (TCL)/target analyte list (TAL) analytical suite.

3. Because sample collection was proceeding without the draft final work plan having been approved by EPA, it was determined that all samples collected after December 1993 would be analyzed by using analytical methods known to be acceptable to regulatory authorities.

1 Pushout areas are areas where residuals remaining after open burning/open detonation were deposited to prepare the burning pit(s) for the next operation.

2 The letter "O" in "OT" signifies on-site analytical suite, and the letter "T" signifies the TBP area. 
TABLE D.1 Summary of On-Site Analytical Methods and Corresponding Analytes

Analytical Method

Headspace analyses

Soil-gas analyses ${ }^{\mathrm{b}}$

Gas chromatography, gas chromatography/mass spectrometry

Colorimetric immunoassay

Colorimetry

$\mathrm{X}$-ray fluorescence (both field-portable in situ methods and laboratory methods)

$\mathrm{HNu}$

MicroTox

MICKIT

Analyses of general parameters for soil, sediment, surface water, and groundwater
Analyte Groups ${ }^{\mathrm{a}}$

VOCs

VOCs and some SVOCs, including phthalates

VOCs and SVOCs

TPHs, PAHs, PCBs, and pentachlorophenol

Nitroaromatics-explosives, PCBs, BTEX

Metals

VOCs

Total toxic chemicals

Different bacterial types

Some physical and chemical parameters for each environmental medium

a $\mathrm{BTEX}=$ benzene, toluene, ethylbenzene, and xylenes; $\mathrm{PAHs}=$ total polyaromatic hydrocarbons; $\mathrm{PCBs}=$ polychlorinated biphenyls; SVOCs = semivolatile organic compounds; TPHs = total petroleum hydrocarbons; VOCs = volatile organic compounds. In analyte groups denoted as "total," individual parameters in the group are not measured, only the sum of contributions from all parameters.

b Includes both active and passive soil-gas analytical methods.

Samples analyzed with the modified OSAS (Table D.2) include samples collected from pushout areas (designated CLP-1 to CLP-9) and samples collected from the burning pits. Samples from the burning pits were designated as follows:

- VXBOR for samples collected from the methylphosphonothioic acid (VX) burning pit,

- HBOR for samples collected from the mustard burning pit,

- TBSPBOR for samples collected from the southernmost areas of the stillvisible burning pits, 


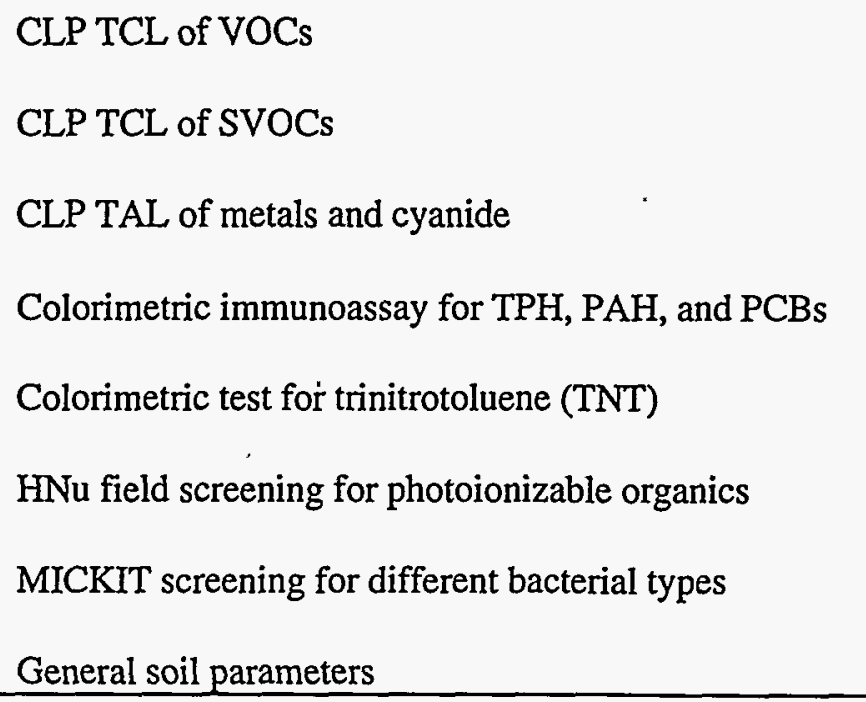

- TBNPBOR for samples collected from the northernmost areas of the stillvisible burning pits, and

- FTBOR for samples collected from an area thought to be part of a "filled trench" east of the northernmost still-visible burning pit.

Additional surface and subsurface soil samples were collected during 1995 in the TBP area. The samples included borings in the VX pit (VXBOR3 to VXBOR5), the northern burning pit TBNPBOR2 and TBNPBOR3), and the mustard pit (HBOR4) and surface soil samples collected from the high explosive (HE) demolition ground, which overlaps the southern portion of the pushout area (TBDG1 to TBDG5), and near the square pit (SQPS1 to SQPS9). Samples collected at these locations were analyzed for various parameters including VOCs, SVOCs, metals, cyanide, explosives, PCBs and pesticides, TPHs, CWA, and dioxin/furans. Laboratory analytical results for the soil samples collected after December 1993 are included in Appendix C. Laboratory analytical results of soil samples collected by Weston in and around the main pits in January 1993 are also included in Appendix C.

\section{D.2.1 Non-Burning-Pit Soil}

\section{D.2.1.1 In Situ X-Ray Fluorescence}

Field-portable X-ray fluorescence (XRF) was used to try to identify "hot spots" in the TBP area. Accuracy and precision for the instrument used (Model 9000 manufactured by TN 
Technologies of Round Rock, Texas) depend on such factors as soil/contaminant heterogeneity, operator error, and instrument error. In general, instrument error (and detection limits) can be reduced by increasing the "count" time used for the elements of interest. Instrument error is reported at the culmination of each scan as an element-specific result coupled with an element-specific standard deviation based on counting statistics. An element reading greater than 10 times the standard deviation is considered to be present at the concentration reported. An element reading less than 3 times the associated standard deviation is considered to be below the detection limit of the instrument. Results between 3 and 10 standard deviations can be interpreted less definitively; that is, the element may be present, but the concentration reported is semiquantitative at best. As noted, the standard deviation can be reduced by increasing the count time (increasing the count time by a factor of four will cut the detection limit in half).

A systematic sampling grid was not used to guide the selection of XRF sample sites because of the presence at the TBP area of dense vegetation, scrap metal, demolition debris, and (potentially) unexploded ordnance (UXO). Instead, sample sites were selected on the basis of field judgment, which incorporated the following criteria:

- Field XRF candidate sites had to be visible from a distance to ensure that the site was visually clear of potential UXO.

- Candidate sites were located within or near inferred contamination sources, such as burning pits, pushout area, or storm-water drainage features.

- Because the XRF 9000 is a "near" direct reading instrument (that is, results are available after the completion of each run, approximately 700 seconds in this case), the XRF operator was prompted to delineate contaminated soil areas in proximity to XRF sample sites with elevated readings.

Forty-four locations were monitored in situ with the field-portable XRF instrument near the TBP and pushout area (XRTBP series, Figure D.3). The results indicate the presence of elevated concentrations of a number of heavy metals, especially in the pushout area. XRF measurements at 11 locations in the HE demolition ground south of the pushout area (XRHE series, Figure D.3) detected no elevated metal concentrations. Elevated levels of zinc, lead, and titanium were also detected in some samples collected near the square pit (XRSP series, Figure D.3). Analytical results for the nonintrusive soil sampling are summarized in Table D.3.

\section{D.2.1.2 Soil Sampling}

In December 1993, 23 soil sample locations outside of the burning pits were selected randomly with a triangular grid system (OT series sample locations, Figure D.4). Samples were 


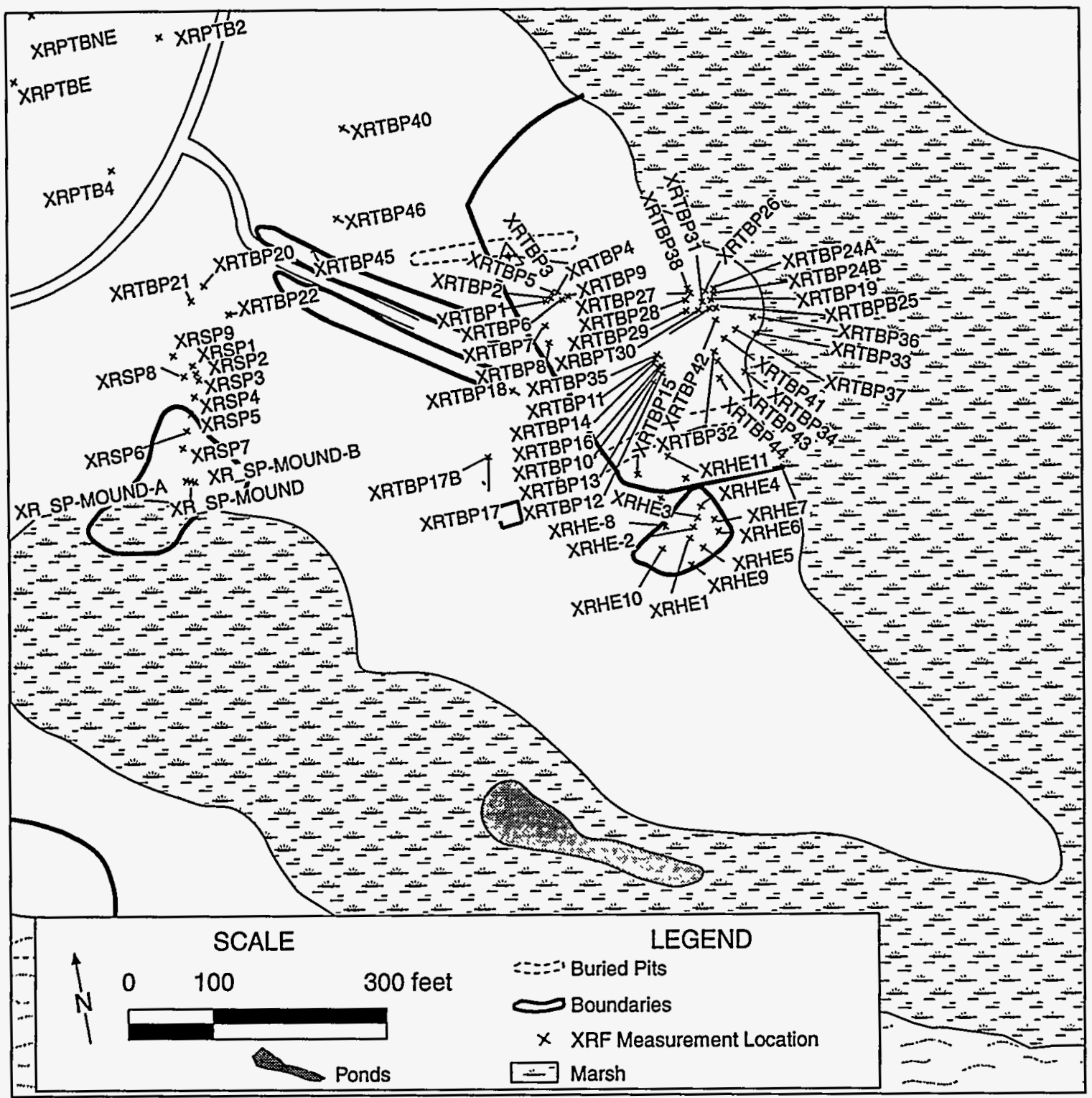

FIGURE D.3 Locations of In-Situ X-Ray Fluorescence Measurements at the TBP Area

generally collected from depths of 0-6 in. ("A" samples) and 6-12 in. ("B" samples). These samples were analyzed by the on-site methods outlined in Table D.1. In January 1994, nine additional soil sampling locations in the pushout area were selected by a combination of field judgment, fieldportable XRF metals analyses results, and UXO clearance procedures (CLP-1 through CLP-9, Figure D.4). In general, the CLP series pushout area soil samples were collected at sites shown by field-portable XRF to have elevated levels of metals and in areas sufficiently clear of UXO to allow samples to be safely collected to an approximate depth of $4 \mathrm{ft}$. Laboratory and some field analytical results for these sample sets are presented in Appendix C.

During 1995, near-surface soil samples were collected near the HE demolition ground south of the mustard burning pit (TBDGS1 through TBDGS5) and the square pit area southwest of the 
TABLE D.3 Results of the Field-Portable X-Ray Fluorescence Analysis at the TBP Area ${ }^{a}$

\begin{tabular}{|c|c|c|c|c|c|c|c|c|c|c|c|}
\hline \multirow[b]{2}{*}{ Sample Number } & \multicolumn{11}{|c|}{ Concentration $(\mathrm{mg} / \mathrm{kg})$} \\
\hline & $\begin{array}{c}\text { Chromium } \\
+3\end{array}$ & $\begin{array}{c}\text { Chromium } \\
+5\end{array}$ & Potassium & Calcium & Titanium & Manganese & Iron & Cobalt & Nickel & Copper & Zinc \\
\hline Detection limit & 90 & 263 & 161 & 70 & 55 & 203 & 111 & 101 & 63 & 44 & 35 \\
\hline XRTBPI & 378 & $N^{c}$ & 3,446 & 2,610 & 1,477 & ND & 7,391 & ND & ND & 173 & 513 \\
\hline XRTBP2 & 352 & 349 & 4,202 & 8,367 & 1,773 & ND & 13,736 & ND & ND & 560 & 741 \\
\hline XRTBP3 & 261 & ND & 3,809 & 1,733 & 2,037 & ND & 10,451 & ND & ND & 182 & 619 \\
\hline XRTBP4 & 128 & ND & 4,011 & 3,270 & 2,086 & ND & 10,215 & ND & ND & 354 & 760 \\
\hline XRTBP5 & 238 & ND & 3,563 & 4,518 & 1,604 & ND & 8127 & ND & ND & 205 & 646 \\
\hline XRTBP6 & 364 & ND & 5,425 & 7,610 & 2,331 & 304 & 15,536 & ND & ND & 360 & 1,306 \\
\hline XRTBP7 & 168 & ND & 5,616 & 5,957 & 2,461 & ND & 12,062 & ND & ND & 243 & 593 \\
\hline XRTBP8 & 273 & ND & 5,503 & 8,025 & 2,143 & ND & 12,917 & 190 & ND & 188 & 645 \\
\hline XRTBP9 & 268 & ND & 5,428 & 5,837 & 2,287 & 308 & 10,384 & ND & ND & 410 & 1,129 \\
\hline XRTBP10 & 216 & ND & 4,943 & 10,301 & 1,550 & ND & 7,241 & ND & ND & 450 & 1,459 \\
\hline XRTBP11 & 176 & ND & 7,460 & 10,540 & 1,915 & 275 & 9,338 & 163 & ND & 777 & 2,206 \\
\hline XRTBP12 & 355 & ND & 3,326 & 3,195 & 1,123 & ND & 7,337 & ND & ND & 490 & 1,070 \\
\hline XRTBP13 & 312 & ND & 4,023 & 17,146 & 1,547 & ND & 15,618 & ND & ND & 635 & 614 \\
\hline XRTBP14 & 390 & ND & 4,776 & 12,355 & 1,307 & ND & 10,684 & 166 & ND & 631 & 238 \\
\hline XRTBP15 & ND & ND & 8,356 & 30,285 & 2,600 & 810 & 10,496 & 184 & ND & 2,377 & 4,217 \\
\hline XRTBP16 & 436 & ND & 3,896 & 7,262 & 909 & ND & 8,636 & ND & ND & 552 & 1,034 \\
\hline XRTBP17 & 245 & ND & 6,567 & 1,691 & 2,090 & ND & 8,079 & ND & ND & ND & 77 \\
\hline XRTBP17 DUP & 203 & ND & 6,558 & 1,587 & 2,229 & ND & 8,016 & ND & ND & ND & 75 \\
\hline XRTBP18 & 197 & ND & 5,204 & 6,362 & 2,158 & 282 & 14,853 & ND & ND & 430 & 2,351 \\
\hline XRTBP19 & 188 & 638 & 3,492 & 733 & 4,151 & 452 & $25,31 l$ & 363 & ND & 534 & 734 \\
\hline XRTBP20 & 204 & ND & 8,226 & 1,247 & 2,514 & ND & 12,854 & ND & ND & 90 & 108 \\
\hline XRTBP21 & 254 & ND & 7,812 & 1,270 & 2,867 & 376 & 9,332 & ND & ND & 152 & 245 \\
\hline XRTBP22 & 251 & ND & 7,065 & 1,192 & 2,032 & ND & 8,859 & ND & ND & 83 & 131 \\
\hline XRTBP24A & ND & ND & - $\quad 5,007$ & 1,083 & 19,272 & ND & 42,180 & 331 & ND & 290 & 900 \\
\hline XRTBP24B & ND & 643 & 3,344 & 667 & 7,958 & 688 & 27,942 & 426 & ND & 528 & 1,017 \\
\hline XRTBP25 & 132 & 524 & 3,965 & 942 & 3,838 & 383 & 13,329 & 285 & ND & 155 & 402 \\
\hline XRTBP26 & ND & $\cdot 870$ & 4,771 & 1,233 & 4,805 & 758 & 48,056 & 601 & 125 & 370 & 5,889 \\
\hline XRTBP26 DUP & ND & 1,268 & 4,624 & 1,254 & 4,077 & 977 & 47,429 & 564 & 158 & 420 & 5,783 \\
\hline XRTBP27 & 228 & 632 & 4,788 & 2,658 & 3,523 & 756 & 42,714 & 699 & 105 & 504 & 7,055 \\
\hline XRTBP28 & ND & 494 & 7,066 & 5,529 & 4,319 & 728 & 24,618 & 418 & 66 & 553 & 4,184 \\
\hline XRTBP29 & ND & 597 & 6,084 & 2,445 & 3,530 & 795 & 25,580 & 421 & ND & 772 & 3,993 \\
\hline XRBPT30 & 152 & 651 & 5,870 & 1,698 & 2,866 & 580 & 27,970 & 369 & ND & 486 & 1,225 \\
\hline XRTBP3I & ND & 870 & 6,275 & 1,810 & 6,445 & ND & 27,660 & 404 & ND & 488 & 931 \\
\hline XRTBP32 & ND & 750 & 5,102 & 1,962 & 10,478 & ND & 45,261 & 396 & ND & 3,355 & 5,068 \\
\hline XRTBP33 & 249 & 847 & 5,171 & 2,561 & 3,646 & ND & 23,631 & 301 & ND & 844 & 4,127 \\
\hline
\end{tabular}


TABLE D.3 (Cont.)

\begin{tabular}{|c|c|c|c|c|c|c|c|c|c|c|c|}
\hline \multirow[b]{2}{*}{ Sample Number } & \multicolumn{11}{|c|}{ Concentration (mg/kg) } \\
\hline & $\begin{array}{c}\text { Chromium } \\
+3\end{array}$ & $\begin{array}{c}\text { Chromium } \\
+5\end{array}$ & Potassium & Calcium & Titanium & Manganese & Iron & Cobait & Nickel & Copper & Zinc \\
\hline Detection limit & 90 & 263 & 161 & 70 & 55 & 203 & 111 & 101 & 63 & 44 & 35 \\
\hline XRTBP34 & ND & 883 & 3,639 & 2,070 & 4,257 & ND & 11,994 & ND & ND & 222 & 1,546 \\
\hline XRTBP36 & ND & 756 & 5,204 & 5,667 & 3,018 & ND & 20,126 & ND & ND & 375 & 3,609 \\
\hline XRTBP37 & ND & 1,224 & 3,203 & 4,440 & 923 & ND & 7,330 & ND & ND & ND & 1,125 \\
\hline XRTBP38. & ND & 802 & 6,548 & 10,890 & 2,622 & 306 & 18,024 & ND & ND & 306 & 3,640 \\
\hline XRTBP39 & 164 & ND & 3,567 & 673 & 1,069 & ND & 6,696 & ND & ND & 49 & 200 \\
\hline XRTBP40 & ND & ND & 7,029 & $I, 666$ & 2,031 & ND & 9,729 & ND & ND & ND & 109 \\
\hline XRTBP40 DUP & ND & ND & 10,286 & 1,402 & 4,052 & ND & 14,771 & 128 & ND & 72 & 96 \\
\hline XRTBP41 & 143 & ND & 3,791 & 19,640 & 516 & 2,180 & 6,676 & ND & 82 & 254 & 8,799 \\
\hline XRTBP42 & ND & ND & 7,346 & 6,474 & 3,057 & 421 & 16,498 & ND & ND & 316 & 2,694 \\
\hline XRTBP43 & ND & ND & 7,556 & 6,816 & 3,781 & 285 & 13,865 & 200 & ND & 245 & 4,209 \\
\hline XRTBP44 & ND & 365 & 8,058 & 4,563 & 4,639 & 384 & 15,107 & ND & ND & 1,067 & 1,054 \\
\hline XRTBP45 & 7,206 & 10,432 & 9,849 & 7,807 & 2,986 & 1,225 & 63,134 & 672 & ND & 22,384 & 3,001 \\
\hline
\end{tabular}


TABLE D.3 (Cont.)

\begin{tabular}{|c|c|c|c|c|c|c|c|c|c|c|c|c|}
\hline \multirow{2}{*}{$\begin{array}{c}\text { Sample } \\
\text { Number }\end{array}$} & \multicolumn{12}{|c|}{ Concentration (mg/kg) } \\
\hline & Arsenic & Selenium & Strontium & Zirconium & Molybdenum & Mercury & Lead & Rubidium & Cadmium & Tin & Antimony & Barium \\
\hline Detection limit & 25 & 17 & 14 & 3 & 4 & 29 & 14 & 5 & 86 & ND & 32 & 9 \\
\hline XRTBPI & ND & ND & 23 & 473 & 6 & ND & 354 & ND & ND & ND & ND & 347 \\
\hline XRTBP2 & ND & ND & 53 & 539 & 8 & ND & 536 & 15 & ND & ND & 48 & 547 \\
\hline XRTBP3 & ND & ND & 33 & 810 & 7 & ND & 659 & ND & ND & ND & 70 & 419 \\
\hline XRTBP4 & ND & ND & 41 & 521 & 5 & ND & 520 & ND & ND & 84 & 49 & 643 \\
\hline XRTBP5 & ND & ND & 31 & 384 & ND & ND & 530 & ND & ND & ND & 42 & 406 \\
\hline XRTBP6 & ND & ND & 59 & 404 & ND & ND & 1,185 & ND & ND & ND & 112 & 2,763 \\
\hline XRTBP7 & ND & ND & 51 & 761 & ND & ND & 1,084 & 19 & ND & ND & 52 & 361 \\
\hline XRTBP8 & ND & ND & 60 & 505 & 7 & ND & 1,070 & 18 & ND & ND & 76 & 434 \\
\hline XRTBP9 & ND & ND & 52 & 488 & 10 & ND & 519 & 14 & ND & ND & 64 & 444 \\
\hline XRTBP10 & ND & ND & 58 & 395 & 5 & ND & 613 & 15 & ND & ND & 33 & 396 \\
\hline XRTBPII & ND & ND & 86 & 424 & ND & ND & 796 & 18 & ND & ND & 37 & 431 \\
\hline XRTBP12 & ND & ND & 32 & 123 & ND & ND & 398 & ND & ND & ND & 33 & 416 \\
\hline XRTBP13 & ND & ND & 47 & 457 & ND & ND & 572 & 15 & ND & ND & 51 & 304 \\
\hline XRTBP14 & ND & ND & 35 & 459 & 9 & ND & 1,028 & ND & ND & ND & 66 & 649 \\
\hline XRTBP15 & ND & ND & 112 & 342 & ND & ND & 822 & 23 & ND & ND & ND & 381 \\
\hline XRTBPI6 & ND & ND & 42 & 234 & 6 & ND & 427 & ND & ND & ND & 47 & 287 \\
\hline XRTBP17 A & 48 & ND & 37 & 612 & 7 & ND & ND & 23 & ND & ND & ND & 184 \\
\hline XRTBP17 DUP & 57 & ND & 41 & 591 & 7 & ND & ND & 16 & ND & ND & ND & 178 \\
\hline XRTBPI8 & 16 & ND & 39 & 421 & ND & ND & 180 & 16 & ND & ND & ND & 237 \\
\hline XRTBP19 & ND & ND & 29 & 252 & 9 & ND & 11,664 & 25 & ND & 54 & 379 & 458 \\
\hline XRTBP20 & 42 & ND & 39 & 616 & 8 & ND & 77 & 30 & ND & ND & ND & 214 \\
\hline XRTBP21 & 41 & ND & 33 & 575 & ND & ND & 86 & 24 & ND & ND & ND & 241 \\
\hline XRTBP22 & 30 & ND & 38 & 562 & 13 & ND & 23 & 24 & ND & ND & ND & 205 \\
\hline XRTBP24 A & ND & ND & 57 & 318 & ND & ND & 19,862 & ND & ND & 173 & 1,249 & 622 \\
\hline XRTBP24 B & ND & ND & 36 & 232 & 9 & ND & 8,298 & 19 & ND & 75 & 407 & 423 \\
\hline XRTBP25 & ND & ND & 42 & 352 & ND & ND & 7,696 & 14 & ND & ND & 296 & 314 \\
\hline XRTBP26 & ND & ND & 52 & 266 & ND & ND & 21,536 & ND & ND & 131 & 727 & 411 \\
\hline XRTBP26 DUP & ND & ND & 48 & 247 & ND & ND & 21,102 & ND & ND & 144 & 798 & 397 \\
\hline XRTBP27 & ND & ND & 50 & 387 & ND & ND & 10,061 & ND & ND & ND & 350 & 600 \\
\hline XRTBP28 & ND & ND & 59 & 427 & ND & ND & 9,435 & ND & ND & 65 & 370 & 643 \\
\hline XRTBP29 & ND & ND & 58 & 424 & 7 & ND & 7,292 & 27 & ND & 64 & 292 & 900 \\
\hline XRBPT30 & ND & ND & 49 & 401 & 5 & ND & 6,602 & ND & ND & ND & 220 & 439 \\
\hline XRTBP31 & ND & ND & 63 & 495 & ND & ND & 10,601 & ND & ND & 107 & 589 & 1,084 \\
\hline XRTBP32 & ND & ND & 59 & 422 & ND & ND & 5,144 & ND & ND & 98 & 228 & 1,248 \\
\hline XRTBP33 & ND & ND & 60 & 352 & ND & ND & 5,947 & ND & ND & ND & 273 & 785 \\
\hline XRTBP34 & ND & ND & 27 & 167 & ND & ND & 1,385 & ND & ND & ND & 81 & .434 \\
\hline
\end{tabular}


TABLE D.3 (Cont.)

\begin{tabular}{|c|c|c|c|c|c|c|c|c|c|c|c|c|}
\hline \multirow{2}{*}{$\begin{array}{c}\text { Sample } \\
\text { Number }\end{array}$} & \multicolumn{12}{|c|}{ Concentration $(\mathrm{mg} / \mathrm{kg})$} \\
\hline & Arsenic & Selenium & Strontium & Zirconium & Molybdenum & Mercury & Lead & Rubidium & Cadmium & Tin & Antimony & Barium \\
\hline Detection limit & 25 & 17 & 14 & 3 & 4 & 29 & 14 & 5 & 86 & ND & 32 & 9 \\
\hline XRTBP36 & ND & ND & 69 & 240 & ND & ND & 4,915 & ND & ND & ND & 125 & 298 \\
\hline XRTBP37 & ND & ND & 43 & 299 & ND & ND & 25,256 & ND & ND & ND & 91 & 141 \\
\hline XRTBP38 & ND & ND & 57 & 312 & ND & ND & 4,406 & ND & ND & ND & 165 & 569 \\
\hline XRTBP39 & 38 & ND & $2 I$ & 221 & 6 & ND & 20 & 14 & ND & ND & ND & 103 \\
\hline XRTBP40 & ND & ND & 40 & 544 & 6 & ND & 38 & 28 & ND & ND & ND & 121 \\
\hline XRTBP40 DUP & ND & ND & 49 & 728 & ND & ND & 33 & ND & ND & ND & 28 & 187 \\
\hline XRTBP41 & ND & ND & 73 & 86 & ND & ND & 1,107 & ND & ND & ND & 52 & 66 \\
\hline XRTBP42 & ND & ND & 63 & 381 & 5 & ND & 799 & ND & ND & ND & 40 & 187 \\
\hline XRTBP43 & ND & ND & 68 & 501 & ND & ND & 1,410 & 36 & ND & ND & 95 & 691 \\
\hline XRTBP44 & ND & ND & 60 & 537 & 6 & ND & 818 & 35 & ND & ND & 66 & 385 \\
\hline XRTBP45 & ND & ND & 96 & 463 & 9 & ND & 303 & ND & ND & ND & 65 & 210 \\
\hline
\end{tabular}

a Standard script indicates that metal is present at less than 10 times but greater than 3 times the standard deviation of counting statistics. Bold italic script indicates that the metal is present at greater than 10 times the standard deviation of counting statistics.

b Samples XRFTBP23 and 35 were not measured.

c ND $=$ Not detected. 


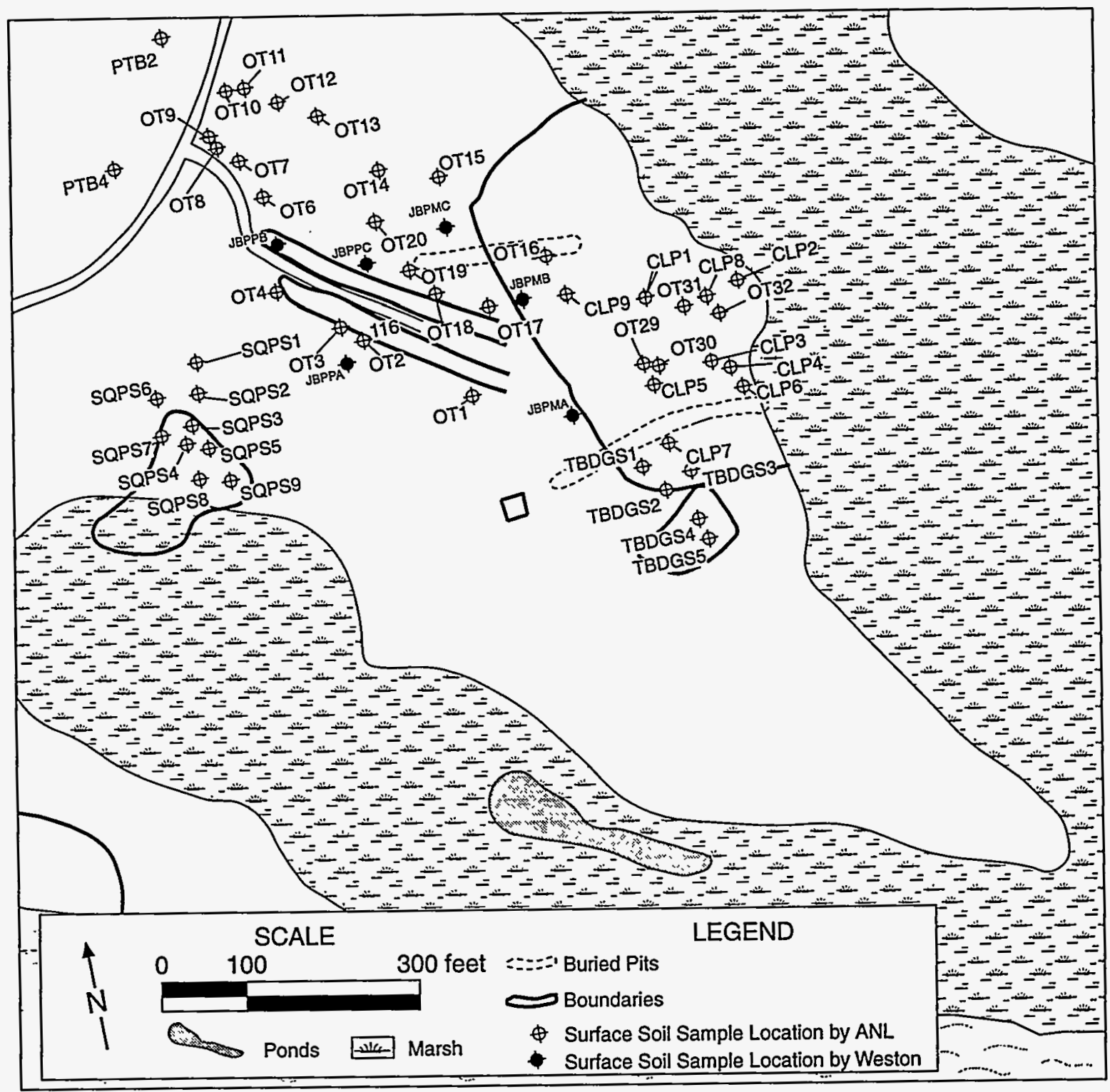

FIGURE D.4 Locations of Surface Soil Samples Collected at the TBP Area since 1993

main burning pits (SQPS1 through SQPS9) (Figure D.4). These samples were analyzed mainly for TAL metals and cyanide. Some organic analyses were performed on selected samples at these areas. The laboratory analytical results for these samples are also presented in Appendix C.

Organic Compound Analyses. In general, most of the non-burning-pit soil sampling locations did not contain VOCs or SVOCs above the detection limits of the analytical methods employed. TRCLE was detected at concentrations ranging from 100 to $600 \mu \mathrm{g} / \mathrm{kg}$ in samples collected from locations OT1, OT2, OT3, OT29, and OT31. TRCLE was also detected in the two 
samples collected from OT30 at concentrations of $1,800 \mu \mathrm{g} / \mathrm{kg}(0-6 \mathrm{in}$.$) and 2,800 \mu \mathrm{g} / \mathrm{kg}(6-12 \mathrm{in}$.). The compound TCLEA was detected at location OT30 at concentrations of $800 \mu \mathrm{g} / \mathrm{kg}(0-6 \mathrm{in}$.) and $2,500 \mu \mathrm{g} / \mathrm{kg}$ (6-12 in.). TCLEE was detected at concentrations ranging from 100 to $1,000 \mu \mathrm{g} / \mathrm{kg}$ in samples collected from locations OT1, OT2, OT16, OT30, OT31, and OT32. One sample collected from location CLP-4 contained three VOCs at concentrations greater than $1 \mathrm{mg} / \mathrm{kg}$. Sample CLP-4 (24-48 in.), the deepest sample collected at this location, contained TRCLE, TCLEE, and TCLE at concentrations of $3,100,1,500$, and $5,600 \mu \mathrm{g} / \mathrm{kg}$, respectively. The laboratory VOC results for the CLP series soil samples are presented in Table C.13b of Appendix C.

Field laboratory analyses performed on the OT series soil samples for selected SVOCs and pesticides generally detected very few compounds. The SVOC 2,4,6-trichloroaniline was the most widespread compound detected during the field semivolatile analysis. This compound was used at APG to manufacture impregnating material used to treat clothing (Nemeth 1989). Concentrations of 2,4,6-trichloroaniline ranged between 200 and $7,900 \mu \mathrm{g} / \mathrm{kg}$ in samples collected at locations OT1, OT4, OT11, OT15, OT16, OT29, OT30, and OT31. Phenol was detected at a concentration of $100 \mu \mathrm{g} / \mathrm{kg}$ in sample OT4A. Petroleum was detected at a concentration of $4,000 \mu \mathrm{g} / \mathrm{kg}$ in sample OT1A. Esters were detected in samples OT3B ( $4 \mathrm{mg} / \mathrm{kg})$, OT4B (1 mg/kg), OT8A (1 mg/kg), OT12A (11 mg/kg), OT14A ( $2 \mathrm{mg} / \mathrm{kg})$, and OT19A ( $3 \mathrm{mg} / \mathrm{kg})$. No other compounds were detected during the field semivolatile analyses.

The results of the CLP laboratory analyses performed on the soil samples collected in January 1994 indicate that most samples contained SVOCs below the method detection limits. Some samples contained low levels, almost always below the contract-required quantitation limit (CRQL), of several phthalates and SVOCs related to fuels. The complete laboratory data set for these semivolatile analyses is presented in Table C.14b.

In addition to the VOC and SVOC analyses conducted on the non-burning-pit soil samples, field tests were performed for PAHs, TPHs, PCBs, and TNT on selected OT series soil samples and all CLP series soil samples. The results of these analyses are presented in Table C.17 and summarized here.

PAHs were detected at concentrations between 1 and $10 \mathrm{mg} / \mathrm{kg}$ in several soil sample locations in the pushout area, including locations CLP-2 (24-48 in.), CLP-3 (0-6 in. and 6-24 in.), and CLP-6 (6-24 in.). PAHs were also detected in one sample outside of the pushout area (OT15B, located north of the VX burning pit, Figure D.4) at a concentration between 10 and $100 \mathrm{mg} / \mathrm{kg}$.

TPHs were detected at between 10 and $100 \mathrm{mg} / \mathrm{kg}$ in pushout area soil samples CLP-2 (24-48 in.), CLP-3 (0-6 in.), CLP-4 (6-24 in. and 24-48 in.), CLP-5 (6-24 in.), and CLP-6 (6-24 in.). A soil sample collected from CLP-5 (24-48 in.) contained a TPH concentration greater than $100 \mathrm{mg} / \mathrm{kg}$. TPHs were also detected in sample OT15B, located north of the VX burning pit, with a concentration between 10 and $100 \mathrm{mg} / \mathrm{kg}$. 
PCBs were detected in two samples in the pushout area, CLP-1 (0-6 in.) and CLP-3 (0-6 in.), with a concentration between 1 and $10 \mathrm{mg} / \mathrm{kg}$. Section D.2.2.3 further discusses the occurrence of PCBs in the TBP area.

TNT was detected in three samples at two locations in the pushout area. The soil sample collected from CLP-1 (6-24 in.) contained TNT at a concentration of $0.96 \mathrm{mg} / \mathrm{kg}$. Two samples collected from CLP-5 contained TNT above the detection limit: $1.95 \mathrm{mg} / \mathrm{kg}$ at $6-24 \mathrm{in}$. and $1.672 \mathrm{mg} / \mathrm{kg}$ and $0.991 \mathrm{mg} / \mathrm{kg}$ in a duplicate at $24-48 \mathrm{in}$.

Organic compound analyses were performed on a limited number of soil samples collected in 1995 outside the TBP. Seven samples (SQPS4, SQPS5, SQPS8, SQPS9, TPDGS3, TPDGS4, and TPDGS5) were analyzed for explosives-related compounds. Nitroglycerin was detected at a concentration of $15.3 \mathrm{mg} / \mathrm{kg}$ in sample TPDGS4. No other explosives-related compounds were detected. In addition, samples from the square pit area were analyzed for VOCs and SVOCs. Low concentrations (up to $38 \mu \mathrm{g} / \mathrm{kg}$ ) of acetone, methylene chloride, and carbon disulfide were detected in samples SQPS5 and SQPS8. Benzo(k)fluoranthene was detected at a concentration of $42 \mu \mathrm{g} / \mathrm{kg}$ in sample SQPS5. No other VOCs or SVOCs were detected in these samples. The results of the VOC, SVOC, and explosives laboratory analyses performed on the soil samples collected in 1995 are presented in Tables C.13d, C.14d, and C.18, respectively.

Inorganic Compound Analyses. Although significant concentrations of organic compounds were not found to be widespread in the soil samples collected outside of the burning pits, unusually elevated concentrations of inorganic compounds, particularly arsenic, copper, lead, zinc, cadmium, and beryllium, were detected in a number of the soil samples. The results of laboratory $\mathrm{XRF}$ and CLP analyses for these metals in the non-burning-pit soil samples are summarized in Table D.4. For comparison, Table D.4 also includes a summary of EPA Region III risk-based concentrations for industrial soil and mean background concentrations. Table D.4 also lists the maximum concentration of selected inorganics detected in the near-surface soil by ICF Kaiser Engineers (1995). In several soil samples, concentrations of copper, cadmium, lead, and zinc exceeded the lower bound and sometimes the upper bound of the concentration ranges of the ecological criteria. In many cases, the concentrations of cadmium, lead, beryllium, and arsenic, as listed in Table D.4, also exceeded the EPA Region III risk-based concentrations for the protection of human health. For example, in the CLP series of soil samples, all collected from the TBP pushout area, lead concentrations exceeded the $400-\mathrm{mg} / \mathrm{kg}$ risk-based criterion in 16 of the 22 samples. Arsenic concentrations exceeded the $1.6-\mathrm{mg} / \mathrm{kg}$ risk-based criterion in all 22 samples. Beryllium concentrations exceeded the risk-based criterion in four samples collected from the TBP pushout area. Antimony concentrations exceeded the risk-based criterion in one sample collected from the TBP pushout area. 
TABLE D.4 Analytical Results for Selected Metals in Soil

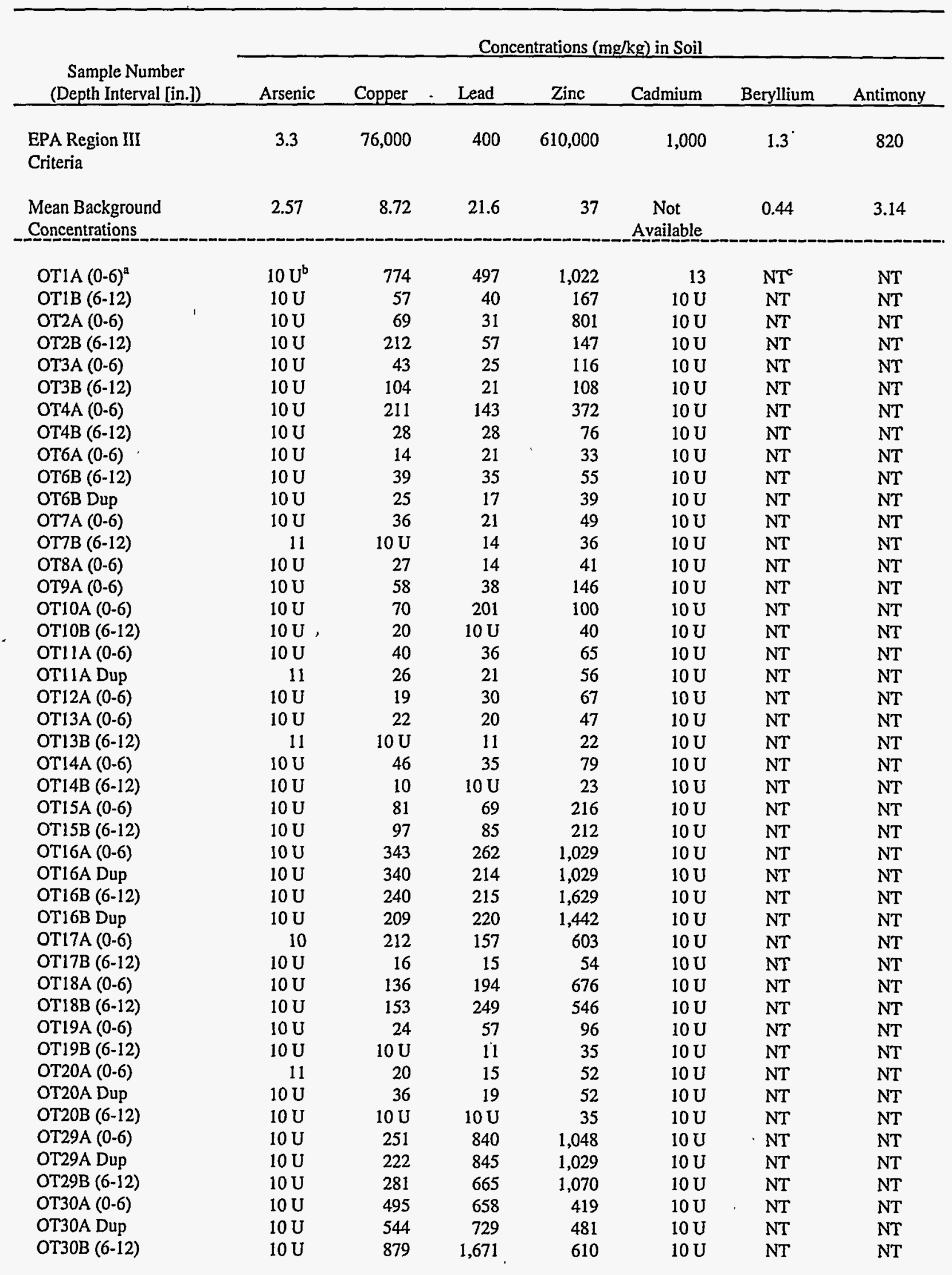


TABLE D.4 (Cont.)

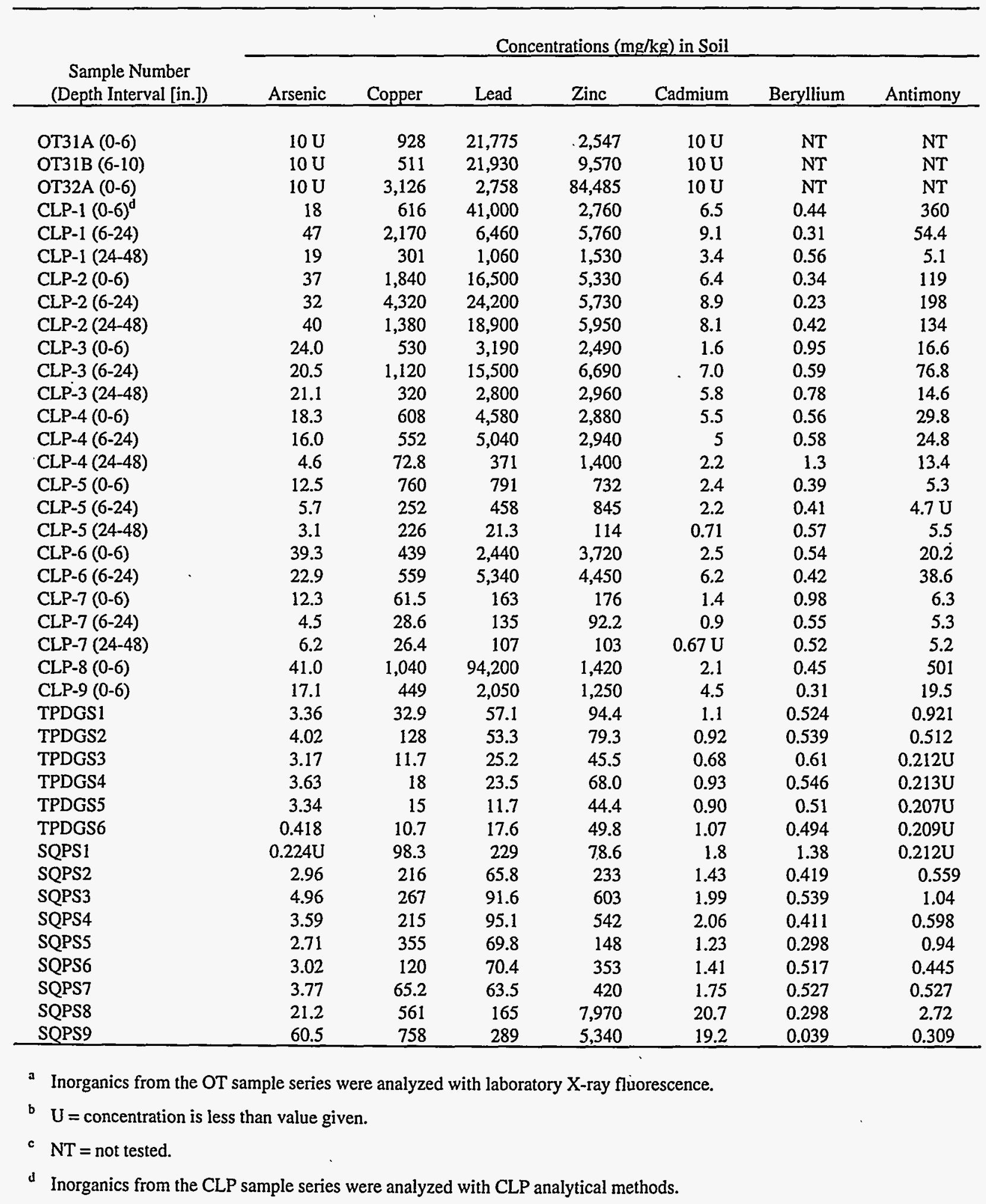


Lead concentrations from pushout area samples, with concentrations as high as $94,200 \mathrm{mg} / \mathrm{kg}$ (CLP-8, 0-6 in.), were highest from samples collected from the upper $2 \mathrm{ft}$ of soil. The highest arsenic concentration $(41 \mathrm{mg} / \mathrm{kg}$ ) was also found in sample CLP-8 (0-6 in.). The highest beryllium concentration was detected in sample CLP-4 (24-48 in.). The highest antimony concentration was detected in sample CLP-8 (0-6 in.). The laboratory analytical results for inorganic compounds, including cyanide, are presented in Table C.15b for the CLP series soil samples.

Soil samples were collected from two other areas outside of the burning pits, the HE demolition ground south of the pushout area and around the square pit (TPDGS series and SQPS series), for analysis of metals and cyanide. The complete laboratory results of these inorganic analyses are presented in Table C.15d.

The inorganic analytical results of the soil samples collected near the HE demolition ground were significantly lower than those detected in samples collected further north in the pushout area (Table D.4), although these two areas overlap. The only result significantly above the calculated background (Table D.4) was copper, found at a concentration of $128 \mathrm{mg} / \mathrm{kg}(20.2 \mathrm{mg} / \mathrm{kg}$ background concentration) in sample TPDGS2. No cyanide was detected in these samples.

Nine surface soil samples were collected near the square pit. It is suspected that burning activities took place in this area. Elevated metals concentrations were detected in many of these samples, though all were below the concentration detected in the pushout area (see Table D. 4 for selected metals). No cyanide was detected in these samples.

\section{D.2.1.3 Other Soil Sampling Activities}

As part of the TPB area pilot remediation study performed by the EPA ERT (Roy F. Weston, Inc. 1994), soil samples were collected from approximately half of the soil-gas sampling locations over a two-day period. Samples were collected at depths of 2,4 , and $6 \mathrm{ft}$ at locations $C 2$, F3, C13, B16, B10, D11, and C7; at depths of 2 and $4 \mathrm{ft}$ at locations D1, D5, D7, F4, D9, F6, E10, $\mathrm{F} 8, \mathrm{E} 12, \mathrm{D} 13, \mathrm{~F} 10, \mathrm{E} 14, \mathrm{~B} 17, \mathrm{C} 15, \mathrm{~B} 14, \mathrm{~B} 12, \mathrm{C} 11, \mathrm{C} 9, \mathrm{C} 6, \mathrm{D} 3, \mathrm{C} 0$, and A0; at $4 \mathrm{ft}$ only at locations $\mathrm{G} 23, \mathrm{G} 3$, and G4; at $6 \mathrm{ft}$ only at location G1; and at $2 \mathrm{ft}$.only at location B6 (see Figure D.2 for sample locations). Samples were analyzed on-site with a Microsensor Technology, Inc., Model P 200 gas chromatograph.

Concentrations of compounds that were detected in soil samples, such as chloromethane, methanol, ethyl alcohol, furan, isobutyl acetate, and acrolein, were also detected in the blanks. Dimethylamine and 111TCE were detected in sample F4 at 1.83 and $2.6 \mathrm{mg} / \mathrm{kg}$, respectively. Detectable levels of target compounds were not found in any of the other samples collected (Roy F. Weston, Inc. 1994). 
Additional information on non-burning-pit soils was also collected as part of the focused feasibility study (FFS). One of the FFS treatability studies included an evaluation of soil washing and electrokinetics for the removal of inorganics (metals) (Peters 1995). Soil samples were collected from the pushout area and from an area upgradient of the burning pits to evaluate the feasibility of using soil washing for the removal of inorganics. In general, samples were composited over a depth interval of $4 \mathrm{ft}$ into a "worst-case" and a "representative" sample on the basis of the results of the CLP series soil samples collected from the pushout area. In addition, one sample was collected from an area at J-Field designated as a "background" sample. One of the testing protocols involved analyzing soils from the worst-case and average samples with the toxicity characteristic leaching procedure (TCLP). The results of the TCLP tests for five metals are summarized in Table D.5. Both the worst-case and the representative soil samples from the pushout area exceeded the TCLP threshold of $5.0 \mathrm{mg} / \mathrm{L}$ for lead (Peters 1995).

\section{D.2.2 Burning Pit Soil}

ANL collected soil samples from four of the five pits in the TBP area during May 1994. The sampling locations (Figure D.5) were selected on the basis of results of a detailed geophysical investigation conducted in the summer of 1993 (Daudt et al. 1994), interpretation of aerial photographs, archival sampling results, and soil-gas sampling results. For example, sampling locations in the southern main pit were near the EMFLUX® monitoring point that showed the greatest soil-gas flux rates. A combination of geophysics and aerial photograph interpretation allowed the field sampling team to advance sample boring VXBOR1 directly into the now-buried VX burning pit. Burning pit soil samples were collected at intervals of $2 \mathrm{ft}$ from the surface to a

TABLE D.5 Toxicity Characteristic Leaching Procedure Results for Selected Metals in Soil

\begin{tabular}{lccc}
\hline & \multicolumn{3}{c}{ TCLP Concentrations $(\mathrm{mg} / \mathrm{L})$ by Sample Type } \\
\cline { 2 - 4 } Metal & Worst-Case & Representative & Background \\
\hline Cadmium & 0.09 & 0.085 & 0.02 \\
Copper & 5.6 & 6.9 & 0.22 \\
Lead & 230.6 & 113.2 & 0.48 \\
Zinc & 58.0 & 46.2 & 0.31 \\
Arsenic & 0.023 & 0.025 & 0.038 \\
\hline
\end{tabular}

Source: Peters (1995). 


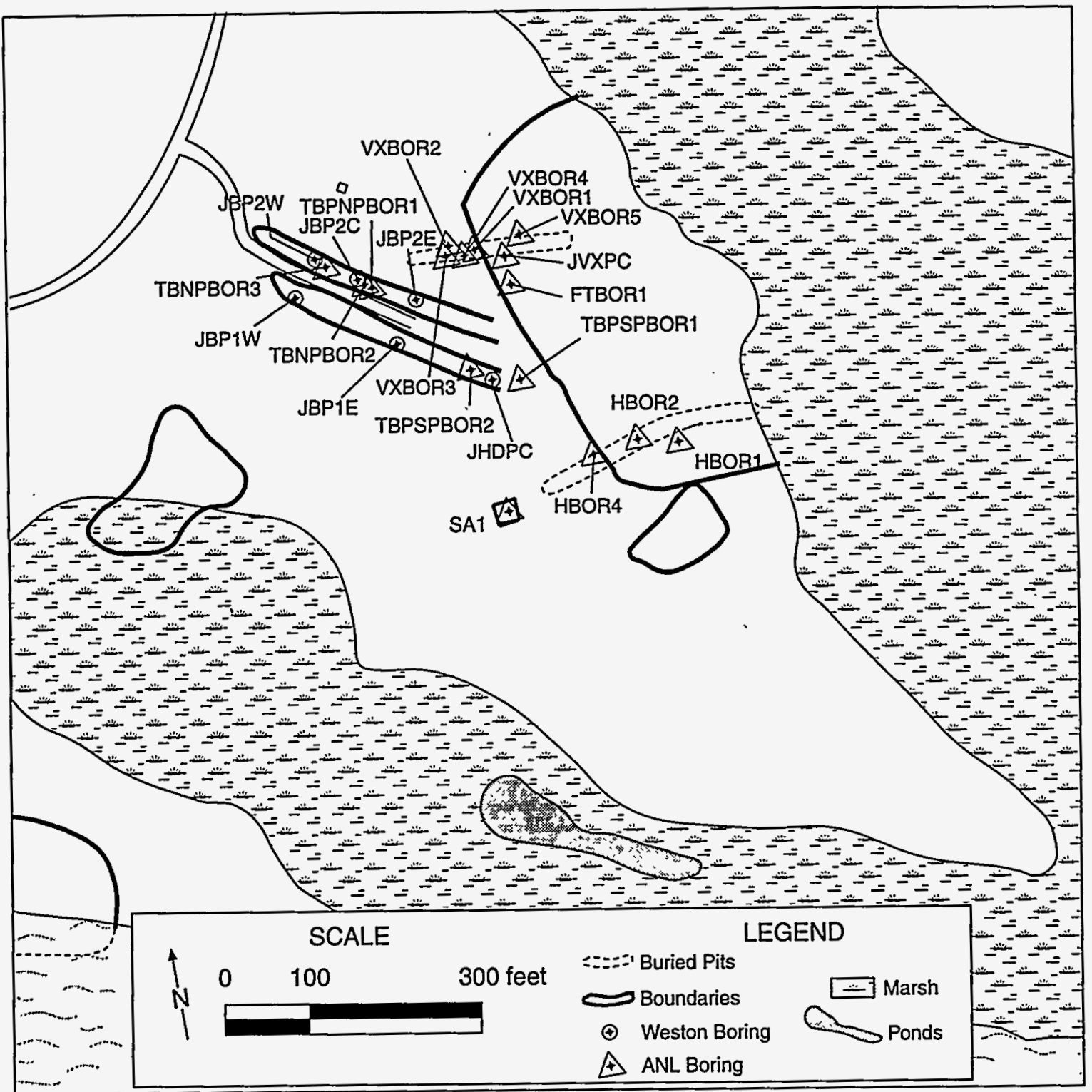

\section{FIGURE D.5 Locations of Soil Borings at the TBP Area}

approximate depth of $10 \mathrm{ft}$. In some cases, conditions allowed the field team to collect samples to depths up to $12 \mathrm{ft}$. Burning pit soil samples were analyzed for a subset of the parameters listed in Table D.2.

On the basis of the 1994 sample analytical results and a more detailed geophysical survey conducted in January 1995 (Davies et al. 1995), additional soil borings were advanced in the northern main burning pit, the VX burning pit, and the mustard burning pit during June 1995. Soil samples were collected at intervals of $2 \mathrm{ft}$ to depths up to $14 \mathrm{ft}$. Selected samples from these borings were analyzed for VOCs, SVOCs, metals, PCBs and pesticides, TPHs, CWAs, explosives, cyanide, and dioxin/furans. 
In addition to the burning pit soil samples collected by ANL in May 1994 and June 1995, subsurface soil samples were collected in and around the main pits by Roy F. Weston in January 1993 and analyzed for VOCs, SVOCs, metals, pesticides, and PCBs. The results of the laboratory analyses of soil samples collected from the main pits during these sampling rounds are presented in Appendix $\mathrm{C}$ and are summarized below.

\section{D.2.2.1 Volatile Organic Compounds}

Elevated levels of VOCs were detected in several soil samples collected from the TBP area. The highest total concentrations of VOCs, including vinyl chloride, methylene chloride, 12DCE, TRCLE, TCLEE, TCLEA, and xylenes, were detected in a number of soil samples collected from the southern main pit (Table D.6). In particular, the soil boring designated TBSPBOR2 contained levels of TCLEA that increased an order of magnitude in each depth interval sampled. TCLEA was detected at concentrations of $14,130,4,600,24,000$, and $220,000 \mu \mathrm{g} / \mathrm{kg}$ at depth intervals of $0-2$, 2-4, 4-6, 6-8, and 8-10 ft, respectively. In addition, in the interval of 8-10 ft for TBSPBOR2, 12DCE, TRCLE, and TCLEE were detected at concentrations of $8,400,21,000$, and $2,500 \mu \mathrm{g} / \mathrm{kg}$, respectively. EPA Region III guidelines for VOCs within industrial soils are also presented in Table D.6 for comparison.

Similar compounds were detected at even higher concentrations in subsurface samples collected by others from the southern main pit. For example, a sample collected at a depth of $6 \mathrm{ft}$ from soil boring JHDP-C, located in the southern main pit, contained 3,270,000 and 263,000 $\mu \mathrm{g} / \mathrm{kg}$ of TCLEA and TRCLE, respectively.

The presence of similar contaminants in sample TBSPBOR2, located about $35 \mathrm{ft}$ northwest of soil boring JHDP-C in the southern main pit, and the much lower concentration of contaminants in TBSPBOR1 (Table D.6), located $25 \mathrm{ft}$ southeast of JHDP-C, suggests the presence of a localized "pocket" of VOC-contaminated soil in the southern main pit. This pocket of contamination may extend to the east where soil samples collected from JBPM-A (Figure D.5), sampled to a depth of $1 \mathrm{ft}$, contained elevated concentrations of VOCs, including $26,000 \mu \mathrm{g} / \mathrm{kg}$ TRCLE.

Elevated levels of chlorinated VOCs were also detected in boring TBNPBOR3, located in the western portion of the northern main burning pit. Elevated VOCs related to fuel were also detected at this location. High concentrations of ethylbenzene $(6,600 \mu \mathrm{g} / \mathrm{kg})$, toluene $(4,200 \mu \mathrm{g} / \mathrm{kg})$, and total xylenes $(46,000 \mu \mathrm{g} / \mathrm{kg}$ ) were detected at the depth interval of $6-8 \mathrm{ft}$ at this location. Chlorinated solvents, including chlorobenzene (up to $23,000 \mu \mathrm{g} / \mathrm{kg}$ ), were also detected at this location, though at generally lower concentrations compared to the southern main burning pit.

Soil samples collected from the mustard burning pit and the VX pit were found to contain much lower levels of VOCs. In general, VOCs in most samples were less than the detection limit 
TABLE D.6 Analytical Results for Selected Volatile Organic Compounds in Southern Main Pit Soil

\begin{tabular}{|c|c|c|c|c|c|c|c|}
\hline \multirow[b]{2}{*}{$\begin{array}{l}\text { Sample Number } \\
\text { (Depth Interval [ft]) }\end{array}$} & \multicolumn{7}{|c|}{ Concentrations $(\mu \mathrm{g} / \mathrm{kg})$ in Soil ${ }^{\mathrm{a}}$} \\
\hline & $\begin{array}{c}\text { Vinyl } \\
\text { Chloride }\end{array}$ & $\begin{array}{l}\text { Methylene } \\
\text { Chloride } \\
\end{array}$ & $\begin{array}{l}\text { 12DCE } \\
\text { (total) }\end{array}$ & TRCLE & TCLEE & TCLEA & $\begin{array}{c}\text { Xylene } \\
\text { (total) }\end{array}$ \\
\hline $\begin{array}{l}\text { EPA Region III } \\
\text { Criteria }\end{array}$ & 1.5 & 380 & 31 & 260 & 55 & 14 & $1,000,000$ \\
\hline \multicolumn{8}{|l|}{ TBSPBOR1 } \\
\hline$(0-2)$ & $12 U$ & $4 \mathrm{~J}$ & 86 & 50 & $12 U$ & 49 & $12 U$ \\
\hline (0-2 Dup) & $12 \mathrm{U}$ & $12 \mathrm{U}$ & 170 & 37 & $12 \mathrm{U}$ & 100 & $12 \mathrm{U}$ \\
\hline$(2-4)$ & $12 \mathrm{U}$ & $12 \mathrm{U}$ & $71 \mathrm{~J}$ & $12 U$ & $12 U$ & $8 \mathrm{~J}$ & $12 U$ \\
\hline$(4-6)$ & 19 & $12 U$ & 68 & $4 \mathrm{~J}$ & $12 U$ & $9 \mathrm{~J}$ & 16 \\
\hline$(6-8)$ & 180 & $12 \mathrm{U}$ & 4,400 & 370 & $12 \mathrm{U}$ & $7 \mathrm{~J}$ & $12 \mathrm{~J}$ \\
\hline$(8-10)$ & 16 & $12 \mathrm{U}$ & 1,500 & 550 & 41 & 600 & $12 U$ \\
\hline$(10-12)$ & $12 \mathrm{U}$ & $12 \mathrm{U}$ & $11 \mathrm{~J}$ & 12 & $12 \mathrm{U}$ & 280 & $12 U$ \\
\hline \multicolumn{8}{|l|}{ TBSPBOR2 } \\
\hline$(0-2)$ & $12 \mathrm{U}$ & $12 \mathrm{U}$ & $12 \mathrm{U}$ & $12 \mathrm{U}$ & $12 U$ & 12 & $12 \mathrm{U}$ \\
\hline (0-2 Dup) & $12 \mathrm{U}$ & $12 \mathrm{U}$ & $12 U$ & $12 \mathrm{U}$ & $12 U$ & $2 \mathrm{~J}$ & $12 \mathrm{U}$ \\
\hline$(2-4)$ & $12 \mathrm{U}$ & $12 \mathrm{U}$ & $12 U$ & $12 \mathrm{U}$ & $12 \mathrm{U}$ & 130 & $12 \mathrm{U}$ \\
\hline$(4-6)$ & $120 \mathrm{U}$ & $120 \mathrm{U}$ & $120 \mathrm{~J}$ & 350 & $25 \mathrm{~J}$ & 4,600 & $120 \mathrm{U}$ \\
\hline$(6-8)$ & $120 \mathrm{U}$ & $120 U$ & 460 & 1,200 & 140 & 24,000 & $120 \mathrm{U}$ \\
\hline$(8-10)$ & $120 \mathrm{U}$ & $120 \mathrm{U}$ & $8,400 \mathrm{~J}$ & $21,000 \mathrm{~J}$ & 2,500 & 222,000 & $120 \mathrm{U}$ \\
\hline
\end{tabular}

a $\mathrm{U}=$ concentration less than value given; $\mathrm{J}=$ estimated value.

of the analytical methods employed. For example, in the most contaminated samples from the mustard pit, TCLEA, 12DCE, and TRCLE were detected at concentrations of 480 (estimated), 450 , and $450 \mu \mathrm{g} / \mathrm{kg}$, respectively. This sample was collected from boring HBOR4 at a depth of $12-14 \mathrm{ft}$ and is thought to reflect migration of groundwater from the southern main burning pit. VOCs related to fuels were also detected in soil samples collected from the VX burning pit with concentrations up to $2,900 \mu \mathrm{g} / \mathrm{kg}$ (ethylbenzene in VXBOR4, 4-6 ft). One sample location approximately $150 \mathrm{ft}$ north of the VX burn pit (JSDP-C) was found to contain high concentrations of VOCs, including $15,200 \mu \mathrm{g} / \mathrm{kg}$ TCLEA at a depth of $4 \mathrm{ft}$. The complete VOC data sets for the soil borings in the main pits are included in Tables C.13a through C.13d.

\section{D.2.2.2 Inorganic Compounds}

Inorganic compounds were detected at concenträtions above background levels in several samples collected from the burning pits. Near-surface soil samples $(<4 \mathrm{ft}$ ) contained elevated 
concentrations of a number of inorganic compounds, including arsenic and lead. Table D.7 includes the analytical results for selected metals from the soil borings TBSPBOR1 and TBSPBOR2. These results illustrate the general decrease in metal concentrations with depth seen throughout the TBP area. Lead concentrations ranged from 10 to $831 \mathrm{mg} / \mathrm{kg}$ in these two borings, with the highest lead concentration occurring in a duplicate sample collected from soil boring TBSPBOR1 ( $0-2 \mathrm{ft})$, which is located adjacent to the pushout area (Figure D.5). Arsenic concentrations in soils from these two borings ranged from 1.4 to $28.2 \mathrm{mg} / \mathrm{kg}$. The highest arsenic concentration within these two soil borings was again in the depth interval of $0-2 \mathrm{ft}$ for soil boring TBSPBOR1.

The highest arsenic concentrations detected at the TBP area were found in the northern main pit. Arsenic was detected in samples collected from depth intervals of 0-2, 2-4, 4-6, 6-8, and 8-10 $\mathrm{ft}$ in boring TBPNPBOR1 at concentrations of $1,440,2,290,247,199$, and $16.7 \mathrm{mg} / \mathrm{kg}$, respectively. Arsenic concentrations in the samples from the remaining burning pit borings ranged from 1.5 to $316 \mathrm{mg} / \mathrm{kg}$.

The two highest lead concentrations were detected in the samples collected from the interval of 0-2 ft for soil borings TBNPBOR2 (4,790 mg/kg) and HBOR1 (4,960 mg/kg). Lead concentrations in the remaining burning pit borings ranged from 13.8 to $3,230 \mathrm{mg} / \mathrm{kg}$.

Three soil samples were collected from the two borings (TBNPBOR2 and TBNPBOR3) installed in the northern main burning pit in 1995 and analyzed for TCLP metals. The samples collected from the interval of $0-2 \mathrm{ft}$ in each boring exceeded the TCLP threshold of $5.0 \mathrm{mg} / \mathrm{L}$ for lead. The third sample, collected from the depth interval of 2-4 $\mathrm{ft}$ in boring TBNPBOR3, had a significantly lower concentration (1.62 vs. $45.7 \mathrm{mg} / \mathrm{L}$ ). The complete laboratory inorganic data sets for the soil borings are included in Tables C.15a through C.15d.

\section{D.2.2.3 Polychlorinated Biphenyls}

Soil samples collected by Weston in the TBP area in January 1993 were submitted for laboratory analysis of PCBs. Soil boring samples collected by ANL in May 1994 were analyzed for PCBs on-site by immunoassay test methods. Selected soil boring samples collected by ANL in June 1995 were also submitted for laboratory analysis of PCBs. The results of these analyses are presented in Tables C.16a, C.16b, and C.17.

PCBs have been detected, mainly in the near surface $(<4 \mathrm{ft})$, in the southern and northern main burning pits and also in the pushout area. The concentrations of PCBs in soil typically decrease with depth, as indicated by the immunoassay results for samples collected from soil borings TBSPBOR1 and TBSPBOR2 (Table D.8). The areal distribution and concentrations of soil samples with detected levels of PCBs are plotted in Figure D.6. Two samples were found to contain PCBs in concentrations above $10 \mathrm{mg} / \mathrm{kg}$. These samples were TBSPBOR1 (0-2 ft) and JBP1-E (0-2 ft). 
TABLE D.7 Analytical Results for Selected Metals in Southern Main Pit Soil

\begin{tabular}{lrrrrrrr}
\hline & \multicolumn{7}{c}{ Concentrations (mg/kg) in Soil } \\
\cline { 2 - 7 } $\begin{array}{c}\text { Sample Number } \\
\text { (Depth Interval [ft]) }\end{array}$ & Arsenic & Beryllium & Cadmium & Copper & Lead & Antimony & Zinc \\
\hline & & & & & & & \\
TBSPBOR1 & 28.2 & 0.43 & 2.1 & 277 & 650 & 6.2 & 757 \\
$(0-2)$ & 20.2 & 0.38 & 3.0 & 366 & 831 & 6.0 & 1,240 \\
$(0-2$ Duplicate) & 9.7 & 0.54 & 3.2 & 151 & 204 & $2.9 \mathrm{U}^{\mathrm{a}}$ & 450 \\
$(2-4)$ & 8.9 & 0.50 & 1.0 & 71.1 & 116 & 4.6 & 192 \\
$(4-6)$ & 6.5 & 0.52 & 1.5 & 36.3 & 38.8 & 2.8 & 79.6 \\
$(6-8)$ & 6.8 & 0.40 & 0.79 & 24.8 & 58.8 & $2.9 \mathrm{U}$ & 61.3 \\
$(8-10)$ & 3.0 & 0.32 & 0.57 & 10.3 & 10.0 & $2.8 \mathrm{U}$ & 38.1 \\
$(10-12)$ & & & & & & & \\
& & & & & & & \\
TBSPBOR2 & 5.4 & 0.27 & 0.95 & 72.4 & 28.2 & $2.8 \mathrm{U}$ & 97.0 \\
$(0-2)$ & 4.5 & 0.28 & 0.7 & 55.7 & 22.5 & $2.7 \mathrm{U}$ & 77.4 \\
$(0-2$ Duplicate) & 4.9 & 0.49 & $0.51 \mathrm{U}$ & 19.4 & 9.6 & $2.9 \mathrm{U}$ & 48.7 \\
$(2-4)$ & 1.4 & 0.23 & $0.49 \mathrm{U}$ & 6.8 & 11.0 & $2.8 \mathrm{U}$ & 17.8 \\
$(4-6)$ & 1.9 & 3.0 & $0.50 \mathrm{U}$ & 7.2 & 11.8 & $2.8 \mathrm{U}$ & 23.0 \\
$(6-8)$ & 1.5 & 0.37 & $0.50 \mathrm{U}$ & 11.0 & 16.2 & $2.8 \mathrm{U}$ & 44.5 \\
$(8-10)$ & & & & & &
\end{tabular}

a $U=$ concentration less than value given.

Aroclor 1248 was found at a concentration of $143 \mathrm{mg} / \mathrm{kg}$ in JBP1-E (0-2 ft). A duplicate sample collected from the same depth interval contained $14.9 \mathrm{mg} / \mathrm{kg}$ Aroclor 1248 . This discrepancy may indicate laboratory errors. However, a composite soil sample collected in 1986 from the southern main pit detected Aroclor 1248 at a concentration of $230 \mathrm{mg} / \mathrm{kg}$ (Nemeth 1989). Samples collected in the depth interval of 2-4 ft in soil borings TBSPBOR1 and JBP1-E contained less than $10 \mathrm{mg} / \mathrm{kg}$ Aroclor 1248.

\section{D.2.2.4 Other Analyses}

Results of laboratory analysis for SVOCs performed on the soil boring samples collected in January 1993, May 1994, and June 1995 are listed in Tables C.14a through C.14d. In general, most samples did not contain SVOCs above the method detection limits. However, residual fuels were present in some borings, and significant concentrations of PAHs were detected in these borings. The highest SVOC concentrations were found in the VX pit borings, with samples collected from VXBOR4 at a depth of 2-6 ft having the greatest concentrations, including 2-methylnaphthalene 
TABLE D.8 Analytical Results for Polychlorinated Biphenyls and Total Petroleum Hydrocarbons in Southern Main Pit Soil

\begin{tabular}{|c|c|c|c|c|c|}
\hline \multicolumn{3}{|c|}{ TBSPBOR1 } & \multicolumn{3}{|c|}{ TBSPBOR2 } \\
\hline \multirow[b]{2}{*}{$\begin{array}{c}\text { Depth } \\
\text { Interval (ft) }\end{array}$} & \multicolumn{2}{|c|}{$\begin{array}{l}\text { Concentration } \\
(\mathrm{mg} / \mathrm{kg})\end{array}$} & \multirow[b]{2}{*}{$\begin{array}{c}\text { Depth } \\
\text { Interval (ft) }\end{array}$} & \multicolumn{2}{|c|}{$\begin{array}{l}\text { Concentration } \\
(\mathrm{mg} / \mathrm{kg})\end{array}$} \\
\hline & PCBs & TPHs & & PCBs & TPHs \\
\hline $0-2$ & $10 U 1^{a}$ & $100 \mathrm{U} 10^{\mathrm{b}}$ & $0-2$ & $10 G^{c}$ & 100U10 \\
\hline $2-4$ & $1 \mathrm{U}^{\mathrm{d}}$ & 100U10 & $2-4$ & 10U1 & $10 \mathrm{U}$ \\
\hline $4-6$ & $1 \mathrm{U}$ & $10 \mathrm{U}$ & $4-6$ & $1 \mathrm{U}$ & $100 \mathrm{G}$ \\
\hline $6-8$ & $1 \mathrm{U}$ & $100 \mathrm{U} 10$ & $6-8$ & $1 \mathrm{U}$ & $100 \mathrm{G}$ \\
\hline $8-10$ & $1 \mathrm{U}$ & $100 U 10$ & $8-10$ & $1 \mathrm{U}$ & 100U10 \\
\hline $10-12$ & $1 \mathrm{U}$ & 100U10 & & & \\
\hline
\end{tabular}

a $10 \mathrm{U} 1=$ concentration less than $10 \mathrm{mg} / \mathrm{kg}$ but greater than $1 \mathrm{mg} / \mathrm{kg}$.

b $100 \mathrm{U} 10=$ concentration less than $100 \mathrm{mg} / \mathrm{kg}$ but greater than $10 \mathrm{mg} / \mathrm{kg}$.

c $\mathrm{G}=$ concentration greater than value given.

d $U=$ concentration less than value given.

$(53,000 \mu \mathrm{g} / \mathrm{kg})$, phenanthrene $(32,000 \mu \mathrm{g} / \mathrm{kg})$, and benzo(k)fluoranthene $(3,100 \mu \mathrm{g} / \mathrm{kg})$. Ten other PAHs with concentrations above $1,000 \mu \mathrm{g} / \mathrm{kg}$ were detected in the VX pit borings. A high concentration $(47,000 \mu \mathrm{g} / \mathrm{kg})$ of di-n-butylphthalate was also detected in boring VXBOR4 at 2-4 ft. Lower concentrations of PAHs (up to $2,100 \mu \mathrm{g} / \mathrm{kg}$ ) were detected in boring TBNPBOR3 in the northern burn pit.

Samples were collected for laboratory analysis of TPHs during the June 1995 soil sampling. The results of the TPH analyses indicate concentrations as high as $35,400 \mathrm{mg} / \mathrm{kg}$ from the depth interval of 2-4 ft in boring VXBOR4 located in the middle of the VX pit, $666 \mathrm{mg} / \mathrm{kg}$ in boring VXBOR5 located in the pushout area of the VX pit, and $19,000 \mathrm{mg} / \mathrm{kg}$ in boring TBNPBOR3 located in the northern burning pit. Again, this reflects the presence of residual fuels from the burning operations. The results of the TPH analyses are included in Table C.19.

Immunoassay methods were used to analyze the May 1994 soil boring samples for TPHs (Table C.17). TPHs were detected in the southern and northern main pits, the VX burn pit, and the mustard burning pit. The TPH results for the two southern main pit soil borings are shown in Table D.8. TPHs were detected in 7 of 11 samples from the southern main pit at concentrations between 10 and $100 \mathrm{mg} / \mathrm{kg}$. In two samples from TBSPBOR2 (6-8 and 8-10 ft), TPHs were detected 


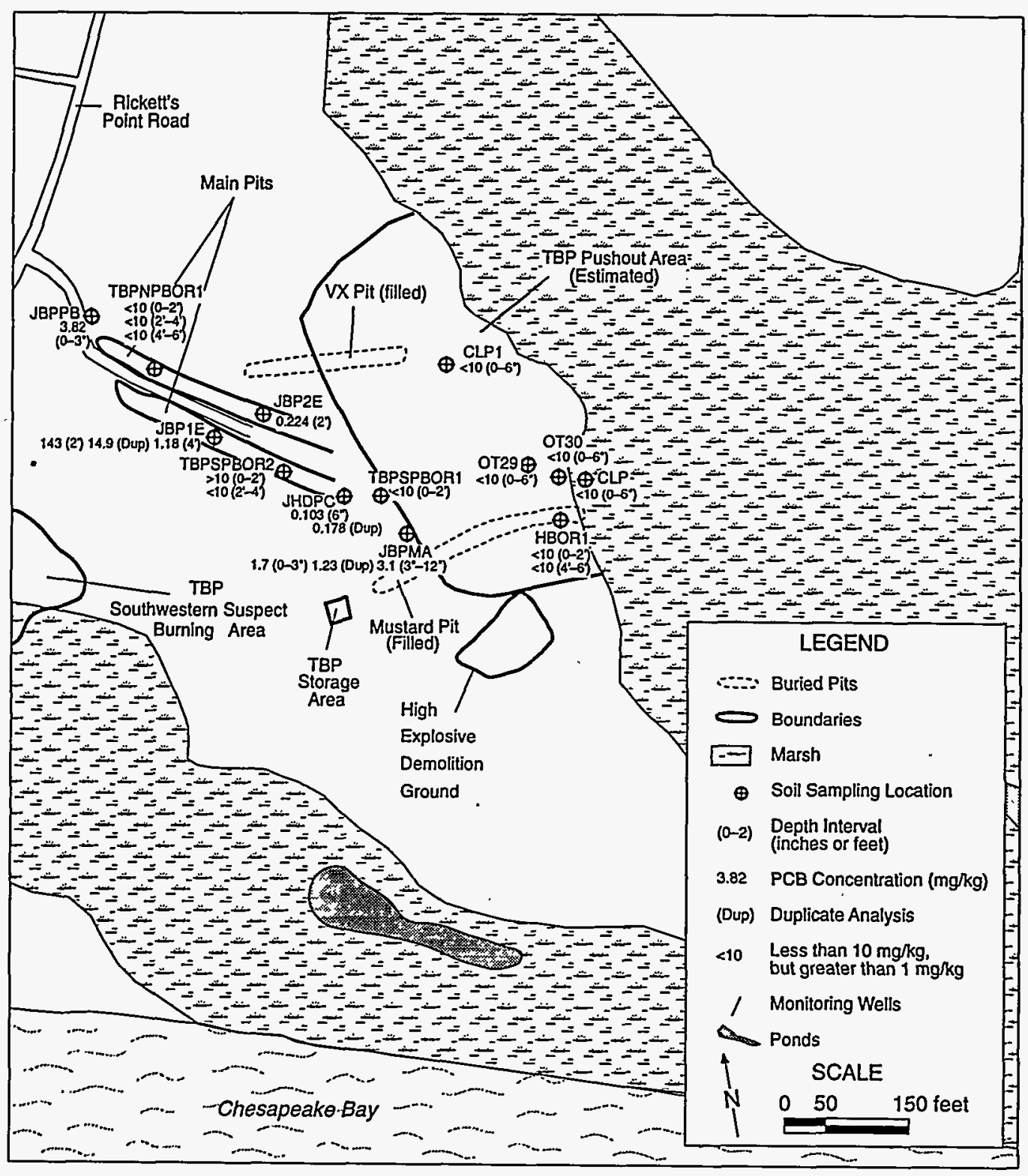

FIGURE D.6 Distribution of Polychlorinated Biphenyls at the TBP Area

at concentrations above $100 \mathrm{mg} / \mathrm{kg}$. Elevated levels of TPHs were also found in the upper $6 \mathrm{ft}$ of soil boring TBNPBOR1. TPH concentrations greater than $100 \mathrm{mg} / \mathrm{kg}$ were detected in all but one sample collected from soil borings VXBOR1 and VXBOR2. The sample from the depth of 8-10 ft in VXBOR 2 contained only between 10 and $100 \mathrm{mg} / \mathrm{kg}$. Two soil samples collected from HBOR 1 in the mustard burning pit (depth intervals of 0-2 and 8-10 ft) also contained TPHs at concentrations between 10 and $100 \mathrm{mg} / \mathrm{kg}$.

Soil samples from the May 1994 soil borings were also analyzed for PAHs with immunoassay methods. Three samples from soil boring VXBOR1, collected from the depth intervals 
of 4-6, 6-8, and 8-10 ft, contained PAHs at concentrations greater than $10 \mathrm{mg} / \mathrm{kg}$. These sample locations correlate with samples exhibiting relatively high concentrations of TPHs and SVOCs. PAHs were also detected in two samples from soil boring TBSBOR1 (0-2 and 4-6 ft) at concentrations between 1 and $10 \mathrm{mg} / \mathrm{kg}$. The results of these immunoassay tests are included in Table C.17.

Additional laboratory analyses for explosives, cyanide, pesticides, CWA degradation products, and dioxins were performed on selected soil samples collected from the burn pit borings in June 1995. Only one sample (VXBOR4, 2-4 ft) contained an explosives-related compound $(1,670 \mu \mathrm{g} / \mathrm{kg}$ pentaerythritol tetranitrate). Cyanide was detected in two samples collected from soil boring TBNPBOR3 at concentrations of $40.8 \mathrm{mg} / \mathrm{kg}(2-4 \mathrm{ft})$ and $11.1 \mathrm{mg} / \mathrm{kg}(4-6 \mathrm{ft})$. Cyanide was not detected below $8 \mathrm{ft}$ at this location. A low concentration of cyanide $(2.63 \mathrm{mg} / \mathrm{kg})$ was also detected in boring VXBOR4 at 2-4 ft. Several pesticides, including 4,4'-DDD, 4,4'-DDE, alpha-BHC, and eldrin ketone were detected at low concentrations $(<5 \mu \mathrm{g} / \mathrm{kg})$ in two samples from VXBOR5. However, higher levels of 4,4'-DDD $(78.8 \mu \mathrm{g} / \mathrm{kg})$ and 4,4'-DDE $(18.2 \mu \mathrm{g} / \mathrm{kg})$ were detected at the depth interval of 2-4 ft in VXBOR3. A CWA degradation product, 1,4-dithiane, was detected in two samples from VXBOR5 at concentrations below $0.5 \mathrm{mg} / \mathrm{kg}$. Low concentrations of two CWA degradation products, diisopropylmethyl phosphonate $(0.01-0.09 \mathrm{mg} / \mathrm{kg})$ and 1,4-dithiane $(0.59-2.65 \mathrm{mg} / \mathrm{kg})$, were detected in soil samples from boring HBOR4 at depths of 6-8, 8-10, and $10-12 \mathrm{ft}$. Low concentrations (up to $0.32 \mu \mathrm{g} / \mathrm{kg}$ ) of several dioxins and furans were detected in VXBOR4 (2-4 ft). Octachlorodibenzo-p-furan $(0.1 \mu \mathrm{g} / \mathrm{kg}$ ) was also found in VXBOR5 (4-6 ft). Dioxins and furans were also detected in a sample collected from boring TBNPBOR3 (4-6 ft), at concentrations ranging between 0.070 and $4.3 \mu \mathrm{g} / \mathrm{kg}$. The laboratory results for the explosives, cyanide, pesticide, CWA degradation products, and dioxins analyses are included in Tables C.16 through C.20, respectively.

\section{D.3 SEDIMENT}

Sediment samples were collected during April 1994 from eight locations in the marsh south and east of the main pits at locations designated SEDBOR1 through SEDBOR8 (Figure D.7). Samples were collected at 2-ft depth intervals from the sediment surface to a depth of about $10 \mathrm{ft}$. However, at many of the locations sampled, a 4- to 6-ft vegetative layer precluded the collection of a sediment sample near the surface. Samples were analyzed for a subset of the parameters given in Table D.2. The sediment sample analytical data are included in Tables C.7 through C.12 and are summarized here.

VOCs were not detected in most of the sediment samples. Acetone was detected in a number of samples and laboratory blanks. Toluene was detected in two samples collected from SEDBOR2, located adjacent to the pushout area (Figure D.7), at concentrations of $150 \mu \mathrm{g} / \mathrm{kg}$ (3-5 ft) and $20 \mu \mathrm{g} / \mathrm{kg}(5-8 \mathrm{ft})$. The VOC 2-butanone was detected in two sediment samples, SEDBOR2-1 


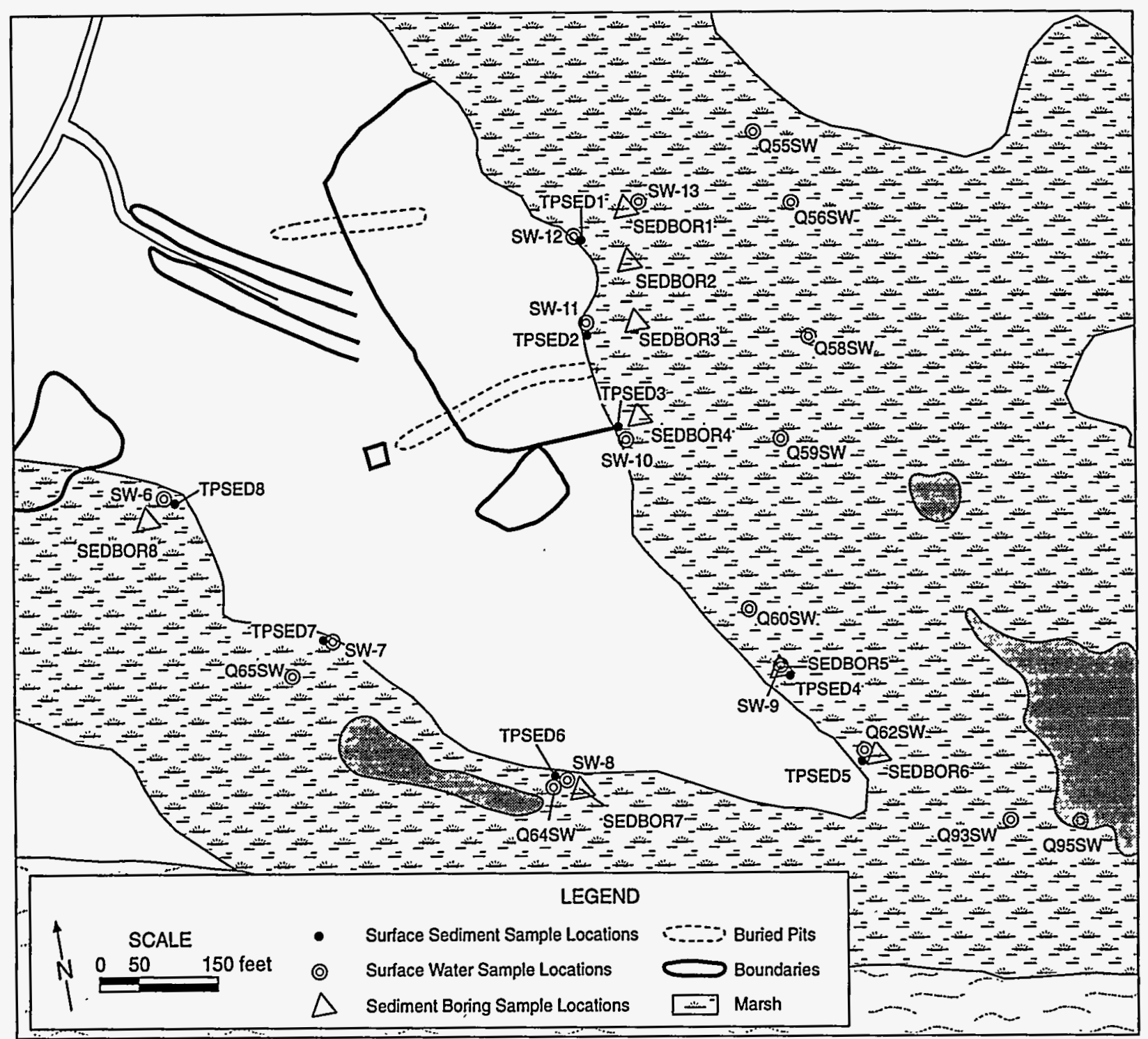

FIGURE D.7 Locations of Surface Water and Sediment Samples and Sediment Borings near the TBP Area

(3-5 ft, $150 \mu \mathrm{g} / \mathrm{kg}$ ) and SEDBOR7-4 (8-10 ft, $180 \mu \mathrm{g} / \mathrm{kg})$. Chlorinated solvents were detected in two sediment borings, SEDBOR3 and SEDBOR4, located to the east and hydraulically downgradient of the TBPs (Figure D.7). Three chlorinated VOCs were detected in the sediment sample SEDBOR3-1 (6-8 ft): TRCLE, $170 \mu \mathrm{g} / \mathrm{kg}$; 12DCE (total), $89 \mu \mathrm{g} / \mathrm{kg}$; and 1,2-dichloroethane, $18 \mu \mathrm{g} / \mathrm{kg}$. Three chlorinated VOCs were also detected in sample SEDBOR3-2 (8-10 ft): TRCLE, $91 \mu \mathrm{g} / \mathrm{kg}$; TCLEA, $31 \mu \mathrm{g} / \mathrm{kg}$; and 112TCE, $10 \mu \mathrm{g} / \mathrm{kg}$. Five chlorinated VOCs were detected in sediment sample SEDBOR4-1 (5-8 ft): 12DCE (total), 2,200 $\mu \mathrm{g} / \mathrm{kg}$; TCLEA, $99 \mu \mathrm{g} / \mathrm{kg} ; 112$ TCE, $76 \mu \mathrm{g} / \mathrm{kg}$; vinyl chloride, $54 \mu \mathrm{g} / \mathrm{kg}$; and TRCLE, estimated $12 \mu \mathrm{g} / \mathrm{kg}$. The compound 12DCE (total) was detected at a concentration of $360 \mu \mathrm{g} / \mathrm{kg}$ in sediment sample SEDBOR4-2 (8-10 ft). 
The samples collected from the sediment borings were also analyzed for CLP TCL SVOCs. In general, SVOCs were not detected in the sediment samples. Di-n-butylphthalate and bis(2-ethylhexyl)phthalate, common laboratory contaminants, were detected below the CRQL in a number of samples. Phenol was detected below the CRQL in sediment samples SEDBOR2-3 (8-10 ft) (estimated at $53 \mu \mathrm{g} / \mathrm{kg}$ ) and SEDBOR6-1 (2-4 ft) (estimated at $70 \mu \mathrm{g} / \mathrm{kg}$ ). SEDBOR7-1 (2-4 ft) was the only sediment sample containing SVOCs above the CRQLs. Twelve SVOCs related to petroleum fuels were detected in this sample at concentrations ranging between about 120 and $2,300 \mu \mathrm{g} / \mathrm{kg}$. Nine of these compounds were also detected in sediment sample SEDBOR7-3 (6-8 ft), with estimated concentrations between 46 and $180 \mu \mathrm{g} / \mathrm{kg}$. A complete listing of the SVOC results for the sediment borings is presented in Tables C.8a and C.8b.

Concentrations of metals and cyanide were much lower in the sediment samples than in the pushout area soils. For example, lead was detected above $20 \mathrm{mg} / \mathrm{kg}$ in only three sediment samples: SEDBOR1-2 (8-10 ft), $20.6 \mathrm{mg} / \mathrm{kg}$; SEDBOR2-1 (3-5 ft), $318 \mathrm{mg} / \mathrm{kg}$; and SEDBOR4-1 (5-8 ft), $61.6 \mathrm{mg} / \mathrm{kg}$.

Field analysis for PAHs, TPHs, PCBs, and TNT were conducted with immunoassay and colorimetric methods on the uppermost sample collected from each sediment boring. Results of these analyses are presented in Tables C.10 and C.11. PAHs and PCBs were not detected in the sediment samples, although SEDBOR7 was not analyzed for PAHs. TPHs were detected above $100 \mathrm{mg} / \mathrm{kg}$ in the interval of $6-8 \mathrm{ft}$ for SEDBOR3 and at concentrations greater than $10 \mathrm{mg} / \mathrm{kg}$ and less than $100 \mathrm{mg} / \mathrm{kg}$ in SEDBOR2 (3-5 ft), SEDBOR4 (6-8 ft), SEDBOR5 (2-4 ft), and SEDBOR7 (2-4 ft). In addition, TNT was detected at concentrations greater than $0.7 \mathrm{mg} / \mathrm{kg}$ in SEDBOR $3(6-8 \mathrm{ft}$ ) and SEDBOR $6(2-4 \mathrm{ft})$.

\section{D.4 SURFACE WATER}

Surface water samples were collected from 17 locations in the marsh areas south and east of the burning pits. The surface water locations SW- 6 through SW-13 in Figure D.7 have been monitored at various times since 1993. Surface water samples from these locations were analyzed for VOCs, SVOCs, pesticides/PCBs, and metals by CLP methods. They were also analyzed for CWA degradation products. Results of these analyses are summarized in Tables C.2 through C.6.

Several other surface water locations were monitored only once as part of the February 1994 EMFLUX@ soil-gas study (Prasad and Martino 1994). These locations (Q55SW, Q56SW, Q58SW, Q59SW, Q60SW, Q62SW, Q65SW Q93SW, and Q95SW) are also depicted on Figure D.7. Surface water samples were collected during the soil-gas study at considerable distance from the shoreline; this was possible because the marsh surface was frozen. These samples were analyzed for VOCs only. 
In general, pesticides, $\mathrm{PCBs}$, and SVOCs were not detected in the surface water samples collected from the TBP area. CWA degradation products were detected in one sample (SW-10) in April 1993. The compounds diisopropyl methylphosphonate, dithiane, and 1,1-oxathiane were detected at concentrations of $0.45,2.49$, and $12.2 \mu \mathrm{g} / \mathrm{L}$, respectively. Sampling point SW-10 is in the general area where the former mustard burning pit exited into the marsh (Figure D.7).

A number of inorganic compounds were also detected in surface water samples, particularly from locations near the pushout area (sampling locations SW-11 and SW-12). All surface water samples were unfiltered. For example, during the latest sampling event in May 1994, copper (total) was detected at locations SW-11 and SW-12 at concentrations of 525 and $105 \mu \mathrm{g} / \mathrm{L}$, respectively. Total lead was detected at the same locations at concentrations of 1,590 and $169 \mu \mathrm{g} / \mathrm{L}$, respectively, during the May 1994 sampling (Table D.9).

Perhaps the most significant surface water quality result was the presence of VOCs in a number of surface water samples. Analytical results for selected VOCs are summarized in Table D.10. A subset of chlorinated VOCs was consistently detected in surface waters adjacent to the pushout area. The VOCs 12DCE, TRCLE, and TCLEA were detected in parts-per-million concentrations at surface water sample location SW-10 during a number of sampling episodes. In addition, VOCs (including cis-12DCE, TCRLE, 112TCE, and TCLEA) were detected in the open pond (sample Q95SW) located some distance from the burning pits (Figure D.7). Sample Q95SW was collected near a groundwater discharge point, as inferred from a thermal imagery study conducted by the U.S. Geological Survey (USGS).

\section{D.5 GROUNDWATER}

Groundwater samples were collected from all of the previously existing monitoring wells at the TBP area (except for wells JF41 and JF42) and from two new wells, JF173 and JF183, installed and sampled since the initiation of the RI. The locations of the TBP monitoring wells are shown in Figure D.8. Each of the well clusters JF4, JF5, JF6, JF7, and JF8 consists of three wells screened in the surficial aquifer, the confining unit, and the confined aquifer. The existing wells were sampled in May 1994. Well JF173 was sampled in June 1994, and well JF183 was sampled in December 1994 during a pump test.

Well JF173 was installed by ANL in an attempt to sample DNAPLs, which, on the basis of the concentrations of chlorinated VOCs found in the groundwater, could be present in the TBP area. The well was constructed differently from other wells in the TBP area in that the screened interval was placed at the boundary between the confining layer (unit $B$ ) and the surficial aquifer to collect DNAPLs that may have migrated downward to the base of the surficial aquifer. The construction specifications for well JF173 are detailed by Patton (1994). 
TABLE D.9 Analytical Results for Selected Metals in Surface Water Samples Collected in May 1994

\begin{tabular}{lrrrr}
\hline & \multicolumn{4}{c}{ Concentrations $(\mu \mathrm{g} / \mathrm{L})$ by Sample ${ }^{\mathrm{a}}$} \\
\cline { 2 - 5 } \multicolumn{1}{c}{ Metal } & SW-7 & SW-10 & \multicolumn{1}{c}{ SW-11 } & SW-12 \\
\hline & & & & \\
Arsenic & $2.4 \mathrm{~B}$ & $6.4 \mathrm{~B}$ & 36.3 & 18.2 \\
Cadmium & $3.0 \mathrm{U}$ & $3.0 \mathrm{U}$ & $4.0 \mathrm{U}$ & $4.0 \mathrm{U}$ \\
Calcium & 35,800 & 106,000 & 98,700 & 33,800 \\
Chromium & $5.0 \mathrm{U}$ & $5.6 \mathrm{~B}$ & 64.8 & $8.0 \mathrm{~B}$ \\
Copper & $3.0 \mathrm{U}$ & $3.0 \mathrm{U}$ & 525 & 105 \\
Iron & 21,100 & 3,470 & 128,000 & 13,000 \\
Lead & 2.1 & 6.5 & $1,590 \mathrm{~S}$ & 169 \\
Magnesium & 44,500 & 28,500 & 110,000 & 68,900 \\
Mercury & $0.20 \mathrm{U}$ & $0.20 \mathrm{U}$ & 1.7 & $0.20 \mathrm{U}$ \\
Zinc & $11.8 \mathrm{~B}$ & $18.4 \mathrm{~B}$ & 4,040 & $968 \mathrm{E}$ \\
\hline
\end{tabular}

a $\mathrm{B}=$ detected in blank; $\mathrm{E}=$ estimated; $\mathrm{S}=$ reported value determined by method of standard additions; $\mathrm{U}=$ undetected.

Well JF183 was installed to serve as a prototype for a prospective groundwater extraction system in the TBP area. Like well JF173, well JF183 was installed so that the bottom of the well rests on the base of the surficial aquifer. Well JF183 is also screened in the surficial aquifer. However, well JF183 was installed with a greater screened interval (from 13-39 ft below ground surface) than other surficial aquifer monitoring wells in the TBP area so that the well could serve as a pumping well for the aquifer test. The construction specifications for well JF183 are detailed by Quinn (1995).

Water levels and water quality in wells JF173 and JF183 have been measured by using a Solinst ${ }^{\circledR}$ Interface Meter on several occasions. The Solinst meter allows the operator to determine the presence of a medium less conductive than water (such as a DNAPL layer). To date, no DNAPLs have been detected in either of the newly installed monitoring wells.

In addition to the site monitoring well network, the USGS installed 10 piezometers in the marsh east of the pushout area in March 1994 (Figure D.8). The piezometers were sampled once by ANL and the USGS as part of the RI in September 1994. 
TABLE D.10 Summary of Volatile Organics Analyses for Surface Water (April 1993, February and May 1994)

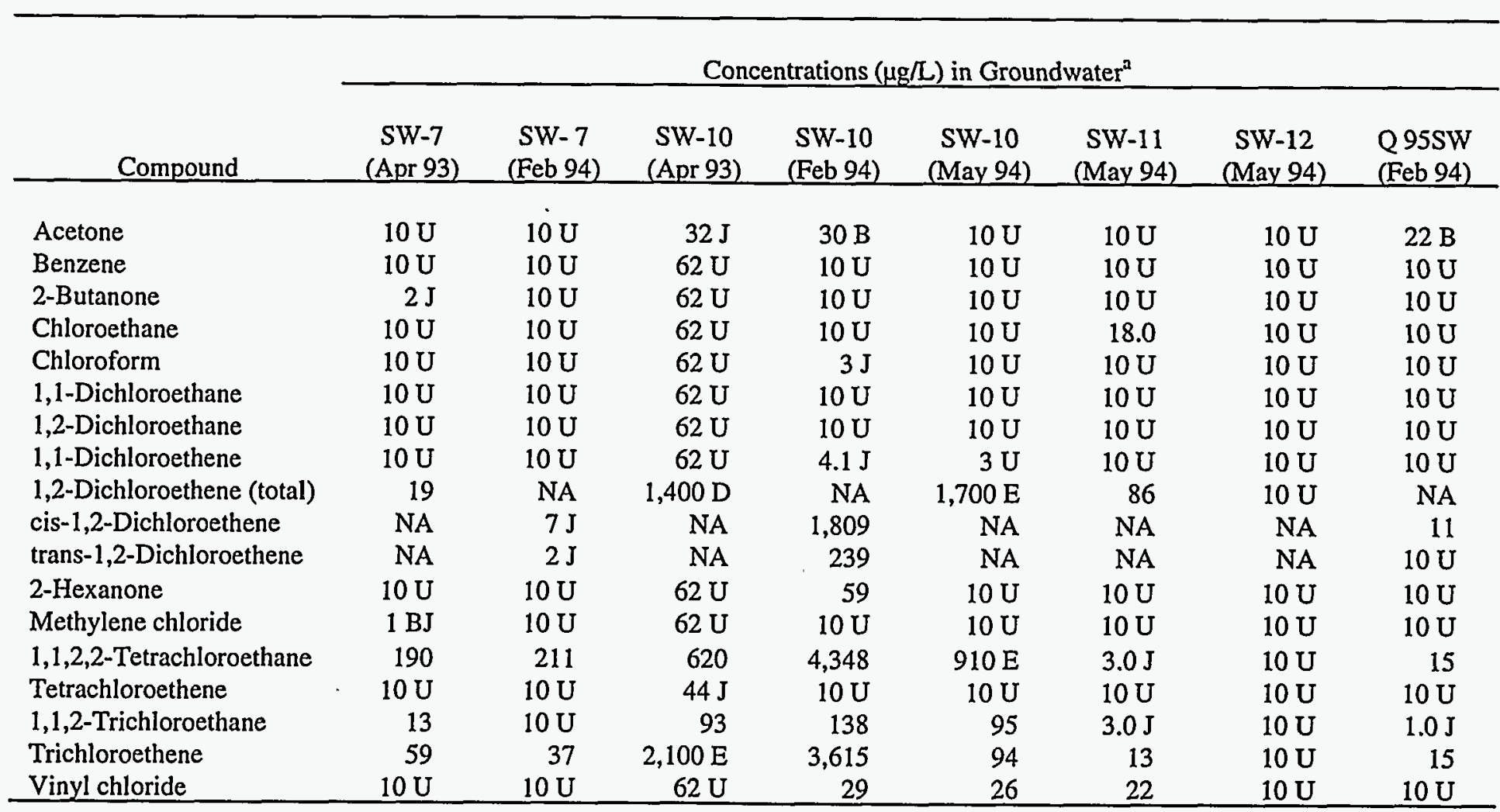

a $\quad B=$ detected in blank; $\mathrm{D}=$ dilution; $\mathrm{E}=$ analyte concentration exceeded calibration limit, concentration estimated; $\mathrm{J}=$ less than detection limit, concentration estimated; $U=$ undetected; $N A=$ not analyzed. 


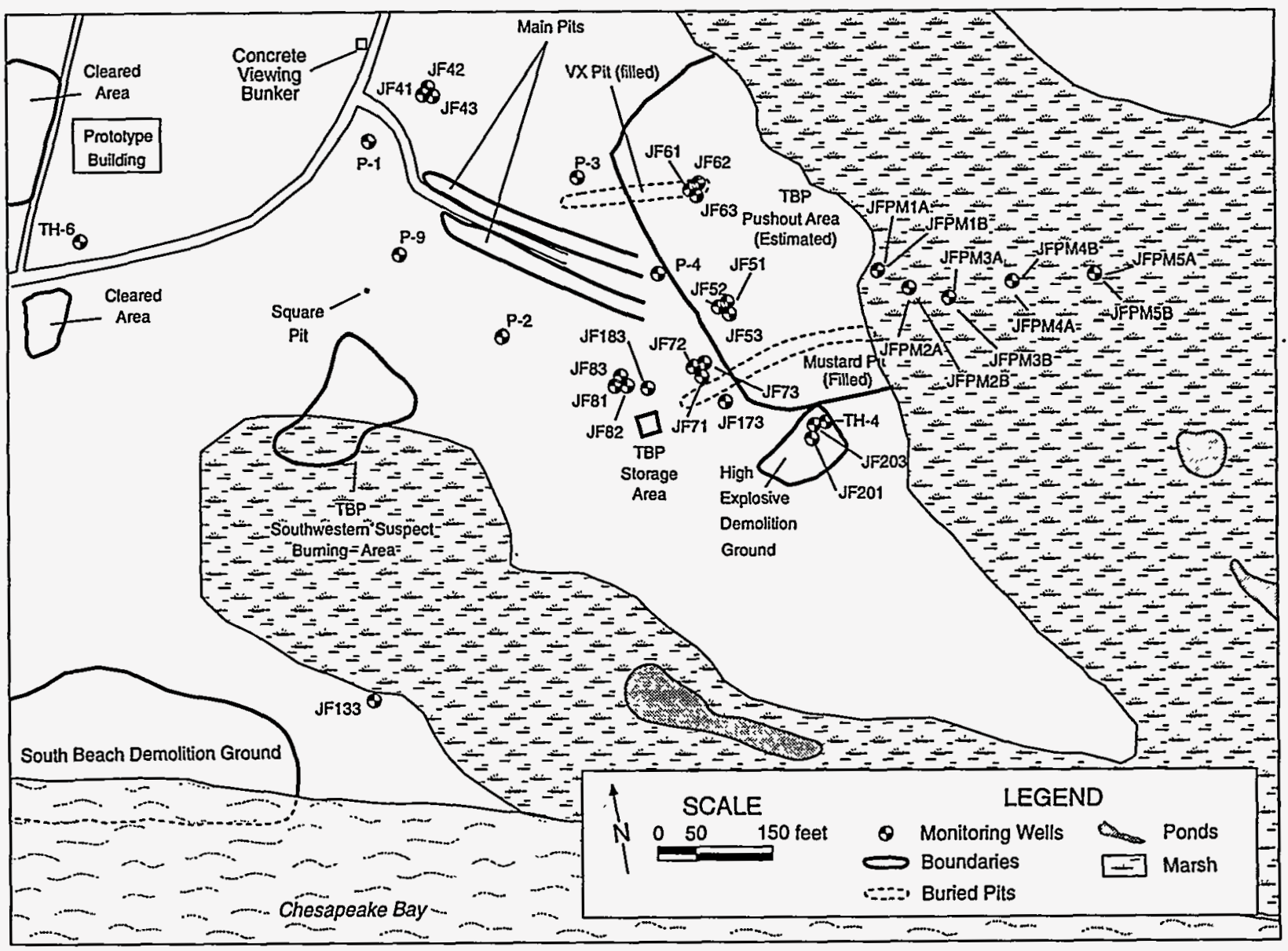

FIGURE D.8 Potential Contamination Sources at the TBP Area

Groundwater samples from the monitoring wells and piezometers were generally analyzed for the parameters in the CLP analytical suite outlined in Table D.11. Many of the wells and piezometers, however, were sampled and analyzed for a subset of the analytes in the CLP analytical suite. The results of the 1994 groundwater sampling at the TBP area are presented in Tables C.21 through C.27 and are discussed below.

Laboratory analyses for TCL VOCs were performed on groundwater samples from all site monitoring wells and piezometers sampled in 1994. The VOC analytical data for the TBP area monitoring wells are presented in Table C.21a and are summarized in Table D.12. VOCs were not detected in the wells upgradient of the main pits (wells P-1, P-2, and JF43). However, VOCs were detected in many of the monitoring wells located between the main pits and the marsh.

The most frequently detected contaminants in the monitoring wells sampled in 1994 were TCLEA, 12DCE (total), TCLEE, TRCLE, and vinyl chloride. The sample collected from well JF83 


\title{
TABLE D.11 Contract Laboratory Program Analytical Suite
}

\author{
CLP TCL of organic compounds \\ CLP TAL of metals \\ Chemical agent degradation products \\ Explosives and related compounds \\ Total organic halides \\ Total organic carbon \\ Conductivity $^{\mathbf{a}}$ \\ Major cations and anions ${ }^{\mathrm{a}}$ \\ Radioactivity (gross alpha and gross beta) \\ a For water samples only.
}

contained the most elevated concentrations of TCLEA and TRCLE $(160,000$ and $21,000 \mu \mathrm{g} / \mathrm{L}$, respectively). The sample collected from well P-4 contained the highest level of 12DCE (total) in any monitoring well, with a concentration of $13,000 \mu \mathrm{g} / \mathrm{L}$.

VOCs have been detected in the wells screened in the confining unit and in wells screened in the confined aquifer. The compounds detected in the deeper units include 1,1-dichloroethene, 1,2-dichloroethane, 12DCE, acetone, methylene chloride, TCLEE, TRCLE, and vinyl chloride. The compound 12DCE, for example, was detected in the confining unit at concentrations of 3,62 , and $170 \mu \mathrm{g} / \mathrm{L}$ in wells JF72, JF52, and JF82, respectively. The compound TRCLE was also detected in the confining unit at concentrations of 9 and $1,500 \mu \mathrm{g} / \mathrm{L}$ in wells JF52 and JF82, respectively.

The compound 12DCE was detected in the confined aquifer at concentrations of 650 and $190 \mu \mathrm{g} / \mathrm{L}$ in wells JF51 and JF81, respectively. The compound TRCLE was detected at concentrations of 850,6 , and $1,600 \mu \mathrm{g} / \mathrm{L}$ in wells JF51, JF61, and JF81, respectively.

The 10 recently constructed marsh piezometers were installed as 5 two-piezometer clusters; the deeper piezometer in each cluster is identified with an " $\mathrm{A}$ " suffix, and the shallower one with a " $B$ " suffix. Table D.13 summarizes some of the pertinent piezometer construction data, including the elevation of the top of each piezometer casing, the amount of casing to the top of the screened interval, and the elevations of the top and bottom of the screen. The locations of the piezometers are shown in Figure D.8. . 
TABLE D.12 Analytical Results for Selected Volatile Organic Compounds in Groundwater $1994^{\mathrm{a}}$

\begin{tabular}{|c|c|c|c|c|c|c|c|c|c|c|}
\hline \multirow[b]{2}{*}{ Compound } & \multicolumn{10}{|c|}{ Concentrations $(\mu \mathrm{g} / \mathrm{L})$ in Groundwater, ${ }^{b}$ by Well } \\
\hline & TH-4 & $\mathrm{P}-1$ & $\mathrm{P}-2$ & $\mathrm{P}-3$ & $\mathrm{P}-4$ & $\mathrm{P}-9$ & $\mathrm{JF} 43$ & JF51 & JF52 & JF53 \\
\hline Benzene & $10 \mathrm{U}$ & $10 U$ & $10 \mathrm{U}$ & $4 \mathrm{~J}$ & $4 \mathrm{~J}$ & $10 \mathrm{U}$ & $10 \mathrm{U}$ & $10 \mathrm{U}$ & $10 \mathrm{U}$ & $10 \mathrm{U}$ \\
\hline Carbon tetrachloride & $10 \mathrm{U}$ & $10 \mathrm{U}$ & $10 U$ & $10 U$ & $10 \mathrm{U}$ & $10 \mathrm{U}$ & $10 \mathrm{U}$ & $10 U$ & $10 U$ & $10 \mathrm{U}$ \\
\hline Chlorobenzene & $10 U$ & $10 U$ & $10 \mathrm{U}$ & 170 & $10 \mathrm{U}$ & $10 \mathrm{U}$ & $10 \mathrm{U}$ & $10 U$ & $10 \mathrm{U}$ & $10 \mathrm{U}$ \\
\hline Chloroform & $10 U$ & $10 \mathrm{U}$ & $10 U$ & $10 \mathrm{U}$ & $10 \mathrm{U}$ & $10 \mathrm{U}$ & $10 \mathrm{U}$ & $10 \mathrm{U}$ & $10 \mathrm{U}$ & $10 \mathrm{U}$ \\
\hline 1,2-Dichloroethane & $10 \mathrm{U}$ & $10 \mathrm{U}$ & $10 U$ & $10 U$ & $10 \mathrm{U}$ & $10 \mathrm{U}$ & $10 \mathrm{U}$ & $10 \mathrm{U}$ & $10 \mathrm{U}$ & $10 \mathrm{U}$ \\
\hline 1,1-Dichloroethene & $10 \mathrm{U}$ & $10 \mathrm{U}$ & $10 \mathrm{U}$ & 27 & $6 \mathrm{~J}$ & $10 \mathrm{U}$ & $10 U$ & $6 \mathrm{~J}$ & $10 \mathrm{U}$ & $10 \mathrm{U}$ \\
\hline 1,2-Dichloroethene (total) & $10 U$ & $10 \mathrm{U}$ & $10 U$ & $1,100 \mathrm{D}$ & $13,000 \mathrm{D}$ & $10 \mathrm{U}$ & $10 \mathrm{U}$ & $650 \mathrm{D}$ & 62 & $2,200 \mathrm{D}$ \\
\hline 1,1,2,2-Tetrachloroethane & $10 U$ & $10 \mathrm{U}$ & $10 U$ & $4 \mathrm{~J}$ & $3,500 \mathrm{D}$ & $10 \mathrm{U}$ & $10 \mathrm{U}$ & $10 \mathrm{U}$ & $10 \mathrm{U}$ & $550 \mathrm{D}$ \\
\hline Tetrachloroethene & $10 \mathrm{U}$ & $10 \mathrm{U}$ & $10 \mathrm{U}$ & $2,400 \mathrm{D}$ & 19 & $10 U$ & $10 \mathrm{U}$ & $10 \mathrm{U}$ & $10 \mathrm{U}$ & $7 \mathrm{~J}$ \\
\hline Toluene & $10 \mathrm{U}$ & $10 \mathrm{U}$ & $10 \mathrm{U}$ & $6 \mathrm{~J}$ & $10 \mathrm{U}$ & $10 \mathrm{U}$ & $10 U$ & $10 U$ & $10 \mathrm{U}$ & $10 \mathrm{U}$ \\
\hline 1,1,2-Trichloroethane & $10 U$ & $10 \mathrm{U}$ & $10 U$ & $10 \mathrm{U}$ & 68 & $10 \mathrm{U}$ & $10 \mathrm{U}$ & $10 \mathrm{U}$ & $10 \mathrm{U}$ & 58 \\
\hline Trichloroethene & $10 \mathrm{U}$ & $10 \mathrm{U}$ & $10 U$ & $390 \mathrm{D}$ & $1,800 \mathrm{D}$ & $10 U$ & $10 \mathrm{U}$ & $850 \mathrm{D}$ & $9 \mathrm{~J}$ & $390 \mathrm{D}$ \\
\hline Vinyl chloride & $10 \mathrm{U}$ & $10 \mathrm{U}$ & $10 U$ & $570 \mathrm{D}$ & 74 & $10 \mathrm{U}$ & $10 \mathrm{U}$ & $10 U$ & 30 & 41 \\
\hline Xylenes_total) & $10 U$ & $10 \mathrm{U}$ & $10 U$ & $3 \mathrm{~J}$ & $10 \mathrm{U}$ & $10 U$ & $10 \mathrm{U}$ & $10 \mathrm{U}$ & $10 \underline{U}$ & $10 \mathrm{U}$ \\
\hline
\end{tabular}




\begin{tabular}{|c|c|c|c|c|c|c|c|c|c|c|c|}
\hline \multirow[b]{2}{*}{ Compound } & \multicolumn{11}{|c|}{ Concentrations $(\mu \mathrm{g} / \mathrm{L})$ in Groundwater, ${ }^{b}$ by Well } \\
\hline & JF61 & JF62 & JF63 & $\mathrm{JF} 71$ & $\mathrm{JF} 72$ & JF73 & JF81 & JF82 & JF83 & $\mathrm{JF} 173$ & $\mathrm{JF} 183$ \\
\hline Benzene & $10 \mathrm{U}$ & $10 \mathrm{U}$ & $10 U$ & $10 U$ & $10 U$ & $10 U$ & $10 \mathrm{U}$ & $10 \mathrm{U}$ & $6 \mathrm{~J}$ & $10 U$ & $3 \mathrm{~J}$ \\
\hline Carbon tetrachloride & $10 \mathrm{U}$ & $10 \mathrm{U}$ & $10 \mathrm{U}$ & $10 \mathrm{U}$ & $10 U$ & $10 \mathrm{U}$ & $10 \mathrm{U}$ & $10 \mathrm{U}$ & $10 U$ & $10 \mathrm{U}$ & $3 \mathrm{~J}$ \\
\hline Chlorobenzene & $10 \mathrm{U}$ & $10 \mathrm{U}$ & $10 \mathrm{U}$ & $10 \mathrm{U}$ & $10 \mathrm{U}$ & $10 \mathrm{U}$ & $10 \mathrm{U}$ & $10 \mathrm{U}$ & $10 U$ & $10 \mathrm{U}$ & $10 \mathrm{U}$ \\
\hline Chloroform & $10 \mathrm{U}$ & $10 \mathrm{U}$ & $9 \mathrm{~J}$ & $10 \mathrm{U}$ & $10 \mathrm{U}$ & $10 \mathrm{U}$ & $10 U$ & $10 U$ & 44 & $10 U$ & 12 \\
\hline 1,2-Dichloroethane & $10 \mathrm{U}$ & $10 \mathrm{U}$ & $10 \mathrm{U}$ & $10 U$ & $10 \mathrm{U}$ & $10 \mathrm{U}$ & $10 U$ & $10 \mathrm{U}$ & $6 \mathrm{~J}$ & $10 \mathrm{U}$ & 5 \\
\hline 1,1-Dichloroethene & $10 \mathrm{U}$ & $10 U$ & $10 \mathrm{U}$ & $10 U$ & $10 U$ & $10 \mathrm{U}$ & 28 & 11 & 12 & $10 \mathrm{U}$ & 17 \\
\hline 1,2-Dichloroethene (total) & $10 \mathrm{U}$ & $10 U$ & $44 \mathrm{DJ}$ & $10 \mathrm{U}$ & 3 & $1,400 \mathrm{D}$ & 190 & $170 \mathrm{D}$ & $4,100 \mathrm{DJ}$ & $1,400 \mathrm{D}$ & $10,000 \mathrm{D}$ \\
\hline 1,1,2,2-Tetrachloroethane & $10 \mathrm{U}$ & $10 \mathrm{U}$ & 50 & $10 \mathrm{U}$ & $10 U$ & $12,000 \mathrm{D}$ & $10 \mathrm{U}$ & $10 \mathrm{U}$ & $160,000 \mathrm{D}$ & $12,000 \mathrm{D}$ & $39,000 \mathrm{D}$ \\
\hline Tetrachloroethene & $10 \mathrm{U}$ & $10 \mathrm{U}$ & 32 & $10 \mathrm{U}$ & $10 \mathrm{U}$ & 170.0 & 34 & 17 & $1,100 \mathrm{E}$ & 170.0 & 8,300 \\
\hline Toluene & $10 \mathrm{U}$ & $-10 \mathrm{U}$ & $10 \mathrm{U}$ & $10 \mathrm{U}$ & $10 \mathrm{U}$ & $10 \mathrm{U}$ & $10 \mathrm{U}$ & $10 U$ & $10 \mathrm{U}$ & $10 \mathrm{U}$ & $10 \mathrm{U}$ \\
\hline 1,1,2-Trichloroethane & $10 U$ & $10 \mathrm{U}$ & $10 U$ & $10 \mathrm{U}$ & $10 \mathrm{U}$ & $10 \mathrm{U}$ & $10 \mathrm{U}$ & $10 \mathrm{U}$ & $990 \mathrm{E}$ & $10 U$ & $600 \mathrm{D}$ \\
\hline Trichloroethene & $6 \mathrm{~J}$ & $10 U$ & $680 \mathrm{D}$ & $10 \mathrm{U}$ & $10 \mathrm{U}$ & $5,800 \mathrm{D}$ & $1,600 \mathrm{D}$ & $1,500 \mathrm{D}$ & $21,000 \mathrm{D}$ & $5,800 \mathrm{D}$ & $13,000 \mathrm{D}$ \\
\hline Vinyl chloride & $10 \mathrm{U}$ & $10 U$ & 12 & $10 \mathrm{U}$ & $10 \mathrm{U}$ & 13.00 & $10 \mathrm{U}$ & 23 & 34 & 13.00 & 68 \\
\hline Xylenes (total) & $10 \mathrm{U}$ & $10 U$ & $10 \mathrm{U}$ & $10 \mathrm{U}$ & $10 \mathrm{U}$ & $10 \mathrm{U}$ & $10 \mathrm{U}$ & $10 U$ & $10 \mathrm{U}$ & $10 \mathrm{U}$ & $\cdot 10 \mathrm{U}$ \\
\hline
\end{tabular}

a All wells sampled in May 1994 except JF-173 and JF-183, which were sampled in June and December 1994, respectively.

b $D=$ sample diluted; $\mathrm{J}=$ estimated value; $\mathrm{U}=$ analyte was analyzed for but not detected, detection limit given. 


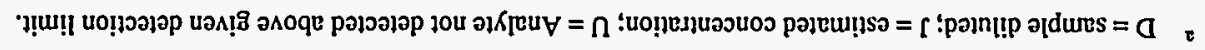

\begin{tabular}{|c|c|c|c|c|c|c|c|c|c|c|}
\hline n $0 \mathrm{I}$ & ก OI & nol & n 01 & nOI & $S \tau$ & IS & $\tau \varepsilon$ & a OOE'l & $a 00 z^{\prime} \varepsilon$ & 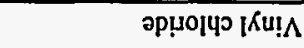 \\
\hline noI & n OI & nol & n 0 I & ก OI & a $00 \varepsilon^{\circ} L$ & noI & $a 00 \varepsilon^{\prime} t$ & 81 & [a $00 z^{\prime} 1$ & 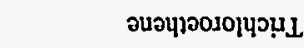 \\
\hline noI & $\Omega$ OI & nol & noI & ก 01 & $0<I$ & nol & ra oIz & OI & s $₫$ olt & 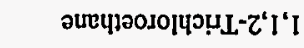 \\
\hline ก OI & ก OI & noI & ก OI & n OI & $9 z$ & noI & 62 & nol & 62 & 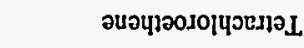 \\
\hline ก ol & ก OI & noI & n $0 \mathrm{I}$ & nol & ra $0 b z$ & noI & $a 0 z L$ & os & $a 009^{\prime} 8$ & 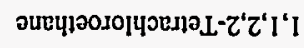 \\
\hline ก OI & 几 OI & nol & noI & n oI & वO0t'I & r 9 & $a 006^{4} \mathrm{I}$ & a $006^{\circ} \mathrm{L}$ & $\triangle 000^{\circ} L \varepsilon$ & 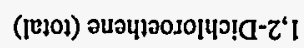 \\
\hline$\Omega 0 I$ & n OI & n OI & n OI & $\Omega 01$ & $\lceil 9$ & noI & Is & $r \tau$ & $t z$ & 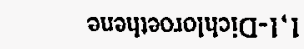 \\
\hline nol & ก OI & nor & $\Omega 01$ & noI & nol & nol & $\Omega 0 I$ & n 01 & ก 01 & 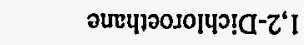 \\
\hline n OI & n ol & n OI & n OI & ก OI & ZI & noI & $L Z$ & $r t$ & $\varepsilon I$ & 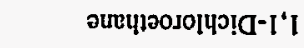 \\
\hline n OI & nol & n 0 I & nol & noI & nor & noI & noI & noI & $\varepsilon l$ & шนојолорРว \\
\hline$\Omega$ OI & $\Omega 0 I$ & l $\tau$ & n OI & $\Omega 0 I$ & nor & noI & $\Omega 0 \mathrm{I}$ & ก OI & noI & әpџIns!p uoqreכ \\
\hline 几 OI & n 01 & ก OI & noI & nol & ก 01 & noI & กoI & noI & $\{z$ & อuจzuอg \\
\hline gSWdAr & VSWdAI & $a b W d d[$ & VDWdAS & gEWdH & VEWdAI & gzgdAr & $\forall Z W d A I C$ & gINddf & VIWdAI & DO^ \\
\hline \multicolumn{11}{|c|}{ 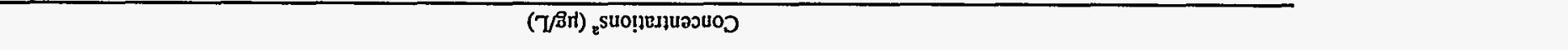 } \\
\hline$\tau t^{\prime} 9-$ & Zt.SI- & $8 I^{\prime} \mathrm{s}-$ & $8 \mathrm{I}^{\circ} \mathrm{ZI}-$ & $\angle t^{\prime} S^{-}$ & $80^{\circ} \mathrm{OI}^{-}$ & $\operatorname{OS}^{\prime} \mathcal{E}-$ & $9 t^{\circ} 6^{-}$ & $82^{\circ} 1^{-}$ & $8 \tau \cdot 5$ & 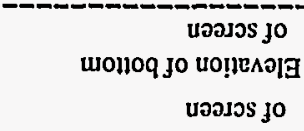 \\
\hline $26^{\circ} b^{-}$ & Z6. EI- & $89^{\circ} \varepsilon-$ & $89^{\circ} \mathrm{II}^{-}$ & $\angle \sigma^{\prime} \varepsilon^{-}$ & $86^{\circ} 8^{-}$ & $00^{\circ} z^{-}$ & $96^{\circ} \mathrm{L}-$ & $\tau \tau^{*} 0$ & $8 L^{\prime} \varepsilon-$ & 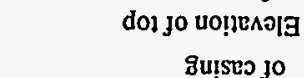 \\
\hline $80^{\circ} \mathrm{t}$ & $80^{\circ} t$ & $\tau \varepsilon \cdot \varsigma$ & 乙E' $\mathrm{s}$ & $\varepsilon 0^{\circ} \mathrm{S}$ & $20^{\circ} \mathrm{S}$ & $00{ }^{\circ} \mathrm{s}$ & to's & $z z^{\prime} \varsigma$ & $z z s$ & do1 jo นo!̣องอา \\
\hline gSWdAI & VSWdAS & GtWdad & $\forall \triangleright W d A r$ & gEWdGr & $\forall E W d A \Gamma$ & gZgdHr & $\forall Z W d \exists r$ & gIWdar & VIWdAI & Jopunend \\
\hline
\end{tabular}

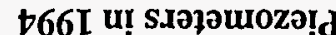

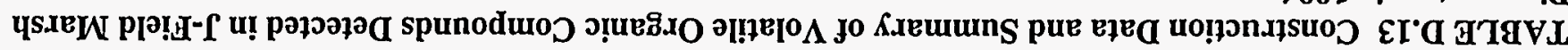


The piezometers were sampled in September 1994 and analyzed for TCL VOCs only. The results of the marsh piezometer groundwater sample analyses are presented in Table C.21b and are summarized in Table D.13.

Many of the same contaminants detected in the monitoring wells were also detected in the piezometers. For example, the compounds TCLEA, 12DCE, TCLEE, TRCLE, and vinyl chloride were detected in piezometers $1 \mathrm{~A}, \mathrm{BB}, 2 \mathrm{~A}, 2 \mathrm{~B}, 3 \mathrm{~A}$, and 4B. At least two compounds were detected at higher concentrations in the marsh piezometers than in any of the TBP monitoring wells. Samples from piezometer $1 \mathrm{~A}$, the deeper piezometer located closest to the marsh edge (Figure D.8), contained the highest concentrations of $12 \mathrm{DCE}$ and vinyl chloride $(37,000$ and $3,200 \mu \mathrm{g} / \mathrm{L}$, respectively) of any groundwater samples collected in the TBP area during 1994. In general, the VOCs were detected at higher concentrations in the piezometer screened at a greater depth (the " $A$ " series piezometer) than in the associated piezometer screened at a shallower depth interval (the " $\mathrm{B}$ " series piezometer). For example, 12DCE (total) was detected at concentrations of 37,000 and $7,900 \mu \mathrm{g} / \mathrm{L}$ in piezometers $1 \mathrm{~A}$ and $\mathrm{IB}$, respectively. No VOCs above the detection limit were found in piezometers $3 \mathrm{~B}, 4 \mathrm{~A}, 5 \mathrm{~A}$, or $5 B$.

TAL metals were detected at elevated concentrations in a number of the groundwater samples collected from the TBP area. Both dissolved and total TAL metal samples were collected and analyzed; the results for each well sampled are presented in Table C.23. Results for selected metals are summarized in Table D.14; the federal primary and secondary drinking-water standards (40 Code of Federal Regulations Parts 141 and 143) maximum contaminant levels (MCLs) are included for comparison.

Arsenic was detected above the MCL in both the total and dissolved samples collected from wells P-3 (36.6 and 27.3 $\mu \mathrm{g} / \mathrm{L}$, respectively) and JF83 (63.8 and $78.6 \mu \mathrm{g} / \mathrm{L}$, respectively). Cadmium was detected above the MCL in both the total and dissolved samples from well P-4 (34.1 and $33.1 \mu \mathrm{g} / \mathrm{L}$, respectively). In addition, mercury was detected above the $\mathrm{MCL}$ in the total sample collected from well P-4 (0.40 $\mathrm{g} / \mathrm{L})$. Lead, commonly detected at elevated levels in the pushout area soils, was not detected above the MCL in any groundwater sample.

SVOC, PCB, and pesticide analyses were performed on selected wells in the TBP area. SVOCs were not detected above the CLP CRQL in any of these wells except for well JF83. Indeno (1,2,3-c,d) pyrene was detected at $57 \mu \mathrm{g} / \mathrm{L}$, which is above the CRQL, in well JF83 (see Table C.22). No pesticides or PCBs were detected in any of the TBP area wells sampled for these compounds (see Table C.25).

Explosive compounds were detected in two of the TBP area wells sampled for those analytes. The compound RDX was detected at concentrations of 8.5 and $1.5 \mu \mathrm{g} / \mathrm{L}$ in wells JF83 and JF173, respectively. No other explosive compounds were detected in the groundwater samples (see Table C.26). 
TABLE D.14 Analytical Results for Selected Inorganics in Groundwater, $1994^{\mathrm{a}}$

\begin{tabular}{lrrrrrrrr}
\hline & & \multicolumn{7}{c}{ Total Metal Concentrations $(\mu \mathrm{g} / \mathrm{L})$, by Well $^{\mathrm{c}}$} \\
\cline { 3 - 9 } \multicolumn{1}{c}{ Metal } & MCL $^{\mathrm{b}}$ & \multicolumn{1}{c}{$\mathrm{JF43}$} & $\mathrm{JF} 83$ & $\mathrm{JF73}$ & \multicolumn{1}{c}{$\mathrm{JF63}$} & $\mathrm{JF53}$ & $\mathrm{JF}-173$ & $\mathrm{JF}-183$ \\
\hline & & & & & & & & \\
Arsenic & 50 & $5.2 \mathrm{~B}$ & 63.8 & $4.3 \mathrm{~B}$ & $2.6 \mathrm{~B}$ & $1.2 \mathrm{BW}$ & 12.3 & 38.7 \\
Cadmium & 10 & $3.0 \mathrm{U}$ & $3.0 \mathrm{U}$ & $4.0 \mathrm{~B}$ & $3.0 \mathrm{U}$ & $4.8 \mathrm{~B}$ & 5.2 & $3.4 \mathrm{U}$ \\
Calcium & - & 13,400 & 33,800 & 93,200 & 97,400 & 39,100 & 31,600 & 58,300 \\
Chromium & 50 & $5.0 \mathrm{U}$ & $7.0 \mathrm{U}$ & $9.8 \mathrm{~B}$ & $7.0 \mathrm{U}$ & 73.3 & $5.0 \mathrm{U}$ & $6.4 \mathrm{U}$ \\
Copper & 1,000 & $3.0 \mathrm{U}$ & $3.0 \mathrm{U}$ & $3.0 \mathrm{U}$ & $3.0 \mathrm{U}$ & 3.0 & $3.0 \mathrm{U}$ & $6.2 \mathrm{U}$ \\
Iron & 300 & 4,440 & 818 & 3,960 & 21,600 & 18,100 & 21,500 & 2,020 \\
Lead & 50 & $1.5 \mathrm{~B}$ & 1.0 & 1.0 & 10.6 & $1.0 \mathrm{U}$ & $1.5 \mathrm{~B}$ & 5.9 \\
Magnesium & - & 3,950 & 18,300 & 6,620 & 18,000 & 12,300 & 6,050 & 4,420 \\
Mercury & 2 & $0.20 \mathrm{U}$ & $0.20 \mathrm{U}$ & 0.20 & 0.20 & $0.20 \mathrm{U}$ & $0.20 \mathrm{U}$ & $0.20 \mathrm{U}$ \\
Zinc & 5,000 & $6.0 \mathrm{U}$ & 25.6 & 79.7 & 15.8 & $67.2 \mathrm{U}$ & $12.5 \mathrm{~B}$ & 34.9 \\
\hline
\end{tabular}

a All wells sampled in May 1994 except JF-173 and JF-183, which were sampled in June 1994 and December 1994, respectively.

b $\mathrm{MCL}=$ maximum contaminant level, Federal Primary and Secondary Drinking Water Standards; "_" = no MCL value set.

c $\mathrm{B}=$ reported value is less than the contract-required detection limit but greater than the instrument detection limit; $\mathrm{U}=$ analyte was analyzed for but not detected, detection limit given; $\mathrm{W}=$ post-digestion spike for furnace AAS was out of control limits.

Several of the surficial monitoring wells (JF53, JF83, JF73, JF63, and JF173) were monitored for gross alpha and beta radioactivity. The highest levels of radioactivity detected in these wells were $1.7 \pm 0.8 \mathrm{pCi} / \mathrm{L}$ gross alpha and $3.5 \pm 1.2 \mathrm{pCi} / \mathrm{L}$ gross beta. For perspective, the Code of Maryland Regulations (COMAR 26.08.02) requires gross alpha and gross beta radioactivity values to be below 15 and $50 \mathrm{pCi} / \mathrm{L}$, respectively, for community water systems. The radioactivity values detected for the wells sampled at the TBP area are all below these values (see Table C.27).

\section{D.6 SUMMARY}

As determined by previous investigators, including the USGS, U.S. Army Environmental Hygiene Agency, Princeton Aquascience, and U.S. Army Toxic and Hazardous Materials Agency, VOCs have been the most frequently detected contaminants in the different media sampled at the TBP area. The more recent sampling events associated with the RI have identified many of the same 
Groundwater quality data collected during past investigations suggested the presence of a significant source(s) of VOC contamination in the TBP area. Groundwater data from the 1994 sampling efforts confirmed the presence of VOCs in TBP area groundwater. Although the active soil-gas monitoring performed by EPA did not locate a significant contamination source, passive soil-gas and soil sample data confirmed the presence of significant VOC contamination in the southern main pit. Passive soil-gas and surface water data indicate that VOCs have migrated to surface water east and south of the main pits.

VOCs were also detected in subsurface soil samples collected from within several of the pits. The highest VOC levels were from the southern main pit. In many cases, the same suite of VOCs was detected in soil-gas samples, subsurface soil samples, groundwater samples, and surface water samples, indicating contaminant migration. VOCs have also been detected in surface water monitoring points located some distance into the marsh from the burning pits, indicating groundwater flow under the marsh to discharge areas. Groundwater chemical data from the piezometers installed in the marsh east of the main pits indicate that the groundwater contains more VOCs in the deeper piezometer within the nest, supporting this contaminant migration interpretation.

PCBs and elevated metal concentrations, most notably arsenic and lead, were detected in soil samples collected from the main pits and the pushout area. In some cases, lead concentrations in pushout area soils were so elevated that they failed the TCLP test for lead. Lead, copper, and chromium were also detected in several of the unfiltered surface water samples collected from locations in the marsh near the pushout area. Soil samples collected from the burn pits and pushout area were found to contain significant amounts of petroleum hydrocarbons from the incomplete combustion of fuels in the burn pits. Low concentrations of dioxin-related compounds were also detected in the subsurface soils.

\section{D.7 REFERENCES FOR APPENDIX D}

Daudt, C.R., et al., 1994, Environmental Geophysics at J-Field, Aberdeen Proving Ground, Maryland, ANL/ESD/TM-77, Argonne National Laboratory, Argonne, IIl.

Davies, B.E., et al., 1995, Phase II Environmental Geophysics at J-Field, Aberdeen Proving Ground, Maryland, ANL/ESD/TM-97, Argonne National Laboratory, Argonne, Ill.

ICF Kaiser Engineers, 1995, Reference Sampling and Analysis Program at the U.S. Army Aberdeen Proving Ground, Soil, Sediment, and Surface Water Reference Data Report, prepared for U.S. Army Environmental Center, Aberdeen Proving Ground, July. 
Nemeth, G., 1989, RCRA Facility Assessment Report, Edgewood Area, Aberdeen Proving Ground, Maryland, 39-26-0490-90, U.S. Army Environmental Hygiene Agency, Waste Disposal Engineering Division, Aberdeen Proving Ground, Md.

Patton, T., 1994, Installation of Well 173 at J-Field Aberdeen Proving Ground, Maryland, TU-2/ANL/APG/J-F/RI, Rev. 1., Argonne National Laboratory, Argonne, Ill., March.

Peters, R., 1995, Feasibility/Treatability Studies for Soil Washing and Solidification/Stabilization at J-Field, Aberdeen Proving Ground, Maryland, TU-18/ANL/APG/J-F/RI-FFS, Argonne National Laboratory, Argonne, III., May.

Prasad, S., 1993, EMFLUX(R) Soil-Gas Investigation of J-Field Toxic Burning Pits and Prototype Building Areas, Aberdeen Proving Ground, Maryland, TU-1/ANL/APG/J-F/RI, Argonne National Laboratory, Argonne, Ill., Sept. 30.

Prasad, S., and L. Martino, 1994, EMFLUX(R) Soil-Gas Investigation of J-Field Toxic Burning Pits and Riot Control Pit Areas, Aberdeen Proving Ground, Maryland, TU-9/ANL/APG/J-F/RI, Argonne National Laboratory, Argonne, Ill., May.

Quinn, J., 1995, Pump Test of Well 183 at J-Field, Aberdeen Proving Ground, Maryland, TU-17/ANL/APG/J-F/RI, Argonne National Laboratory, Argonne, Ill., April.

Roy F. Weston, Inc., 1994, Phase I Final Report Toxic Pits Pilot Remediation Study, J-Field, Gunpowder Neck, Aberdeen Proving Ground, Roy F. Weston, Inc., Abingdon, Md., July.

Sci Tech Services, Inc., 1992, Screening Procedure for the Trace Level Analysis of Potentially Contaminated Soil Samples Using DAAMS(R) Technology and Gas Chromatography, Final Report, prepared by Sci Tech Services, Inc., Abingdon, Md., for U.S. Army Environmental Research and Development Center, Aberdeen Proving Ground, Md., Dec. 


\section{APPENDIX E:}

ECOLOGICAL RISK ASSESSMENT MODELING METHODS 


\section{APPENDIX E:}

\section{ECOLOGICAL RISK ASSESSMENT MODELING METHODS ${ }^{1}$}

Quantitative ecological risk assessments typically employ tissue analysis and toxicity testing to evaluate contaminant exposure and effects. However, these approaches require destructive sampling of biota, and such sampling is not possible for many of the species that occur at J-Field. The large size of such species as the white-tailed deer makes specimen collection, tissue analysis sampling, and toxicity testing impractical. Other species, such as the bald eagle, are protected by federal and state laws and cannot be sacrificed for laboratory analysis. Thus, a modeling approach was employed to estimate contaminant uptake in selected biota at the site.

\section{E.1 MODELING APPROACH}

Uptake modeling was conducted for eight receptor species: (1) mallard, (2) American robin, (3) American kestrel, (4) red-tailed hawk, (5) white-footed mouse, (6) eastern cottontail rabbit, (7) white-tailed deer, and (8) red fox. Uptake models were developed for the eight species to estimate contaminant movement from environmental media to each species and to estimate a daily contaminant dose that each species might receive if it used the Toxic Burning Pits (TBP) area. For each species, a conceptual food chain model was developed that identifies contaminant sources, exposure routes, and food chain (or web) relationships. Mathematical equations were then developed following U.S. Environmental Protection Agency (EPA) guidance (EPA 1993) to describe contaminant movement along the exposure routes and between the physical and biological compartments of each model. Each model incorporated species-specific information on diet, body weight, home range, and food ingestion rates. Principal uptake routes considered in the models were ingestion of food and water and incidental ingestion of soil.

\section{E.2 CHARACTERIZATION OF EXPOSURE SETTING}

\section{E.2.1 Contaminants and Media of Concern}

The focused feasibility study (FFS) addresses the contamination present in the surface soils at the TBP area. The uptake modeling evaluated all contaminants identified as final contaminants of ecological concern for surface soils (i.e., depth range of 0-24 in.) at the TBP area. Drinking water

1 Much of the information included in this appendix is taken from Hlohowskyj et al. (1996). 
sources for modeled receptors used the calculated exposure point concentrations for surface water at the TBP area.

\section{E.2.2 Ecological Receptors}

A wide variety of organisms may occur in the TBP area. The eight species selected for dose modeling have been observed at the site or have been reported for other nearby areas of Aberdeen Proving Ground (APG), are considered likely to use the site, and represent the major terrestrial vertebrate trophic levels for the site. The American robin was selected because it is an omnivorous species that forages on a combination of vegetation and invertebrates that could occur on or in contaminated soils at the site. The American kestrel is a small hawk whose diet consists primarily of terrestrial invertebrates, small mammals, and birds. The red-tailed hawk represents the top avian predator at the site; this species feeds largely on small mammals. The white-footed mouse represents small mammals that feed on a combination of invertebrates and vegetation and that serve as prey for receptors that consume small mammals. The eastern cottontail represents small herbivorous mammals, and the white-tailed deer represents large herbivorous mammals. The red fox, which feeds on a combination of vegetation, invertebrates, birds, and mammals, represents carnivorous mammals at the site. The grassy and disturbed portions of the TBP area contain suitable foraging habitat for each receptor species.

\section{E.2.3 Exposure Pathways}

The exposure pathways from the soil to each receptor included food-chain transfer of contaminants, incidental ingestion of contaminated soil, and intake of contaminants through drinking water. Although the principal medium of concern for the TBP area is soil, detectable concentrations of many of the contaminants of environmental concern (COECs) identified for surface soil were also present in water and sediment within or bordering the TBP area; terrestrial fauna at the site could use the nearby surface water as a drinking water source. Exposure pathways to each receptor are shown in Table E.1.

\section{E.2.4 Exposure Point Concentrations}

The exposure point concentration represents the environmental concentration of a contaminant in a particular medium to which an ecological receptor would be exposed at a site. For this FFS, the exposure point concentration was estimated as the 95\% upper confidence limit (UCL) of the arithmetic mean of the concentrations reported for the TBP area. The use of the 95\% UCL as the exposure point concentration is consistent with EPA Region III guidance for conducting ecological risk assessments (Davis 1994). It is also the same general approach used in determining the exposure point concentration in human health risk assessments (EPA 1989). The 
TABLE E.1 Exposure Routes Evaluated for Ecological Receptors at the TBP Area

\begin{tabular}{|c|c|c|}
\hline Receptor & Medium & Exposure Route \\
\hline Mallard duck & $\begin{array}{l}\text { Surface water } \\
\text { Sediment } \\
\text { Soil }\end{array}$ & $\begin{array}{l}\text { Surface water } \rightarrow \text { invertebrates } \rightarrow \text { ingestion } \rightarrow \text { duck } \\
\text { Surface water } \rightarrow \text { incidental ingestion } \rightarrow \text { duck } \\
\text { Sediment } \rightarrow \text { invertebrates } \rightarrow \text { ingestion } \rightarrow \text { duck } \\
\text { Sediment } \rightarrow \text { incidental ingestion } \rightarrow \text { duck } \\
\text { Soil } \rightarrow \text { vegetation }- \text { ingestion } \rightarrow \text { duck } \\
\text { Soil } \rightarrow \text { incidental ingestion } \rightarrow \text { duck }\end{array}$ \\
\hline Red-tailed hawk & Surface water & $\begin{array}{l}\text { Soil } \rightarrow \text { vegetation } \rightarrow \text { mammals } \rightarrow \text { ingestion } \rightarrow \text { hawk } \\
\text { Soil } \rightarrow \text { vegetation } \rightarrow \text { bird } \rightarrow \text { ingestion } \rightarrow \text { hawk } \\
\text { Soil } \rightarrow \text { invertebrates } \rightarrow \text { bird } \rightarrow \text { ingestion } \rightarrow \text { hawk } \\
\text { Soil } \rightarrow \text { vegetation and invertebrates } \rightarrow \text { bird } \rightarrow \\
\quad \text { ingestion } \rightarrow \text { hawk } \\
\text { Soil } \rightarrow \text { vegetation } \rightarrow \text { mammal } \rightarrow \text { snake } \rightarrow \\
\quad \text { ingestion } \rightarrow \text { hawk } \\
\text { Soil } \rightarrow \text { invertebrate } \rightarrow \text { snake } \rightarrow \text { ingestion } \rightarrow \text { hawk } \\
\text { Surface water } \rightarrow \text { ingestion } \rightarrow \text { hawk }\end{array}$ \\
\hline \multirow[t]{2}{*}{ American kestrel } & Soil & $\begin{array}{l}\text { Soil } \rightarrow \text { invertebrates } \rightarrow \text { ingestion } \rightarrow \text { kestrel } \\
\text { Soil } \rightarrow \text { invertebrates } \rightarrow \text { snake } \rightarrow \text { ingestion } \rightarrow \text { kestrel } \\
\text { Soil } \rightarrow \text { vegetation } \rightarrow \text { mammal } \rightarrow \text { ingestion } \rightarrow \text { kestrel } \\
\text { Soil } \rightarrow \text { vegetation } \rightarrow \text { bird } \rightarrow \text { ingestion } \rightarrow \text { kestrel } \\
\text { Soil } \rightarrow \text { invertebrates } \rightarrow \text { bird } \rightarrow \text { ingestion } \rightarrow \text { kestrel } \\
\text { Soil } \rightarrow \text { vegetation and invertebrates } \rightarrow \text { bird } \rightarrow \\
\quad \text { ingestion } \rightarrow \text { kestrel }\end{array}$ \\
\hline & Surface water & Surface water $\rightarrow$ ingestion $\rightarrow$ kestrel \\
\hline \multirow[t]{2}{*}{ American robin } & Soil & $\begin{array}{l}\text { Soil } \rightarrow \text { invertebrates } \rightarrow \text { ingestion } \rightarrow \text { robin } \\
\text { Soil } \rightarrow \text { vegetation } \rightarrow \text { ingestion } \rightarrow \text { robin } \\
\text { Soil } \rightarrow \text { incidental ingestion } \rightarrow \text { robin }\end{array}$ \\
\hline & Surface water & Surface water - ingestion - robin \\
\hline \multirow[t]{2}{*}{$\begin{array}{l}\text { White-footed } \\
\text { mouse }\end{array}$} & Soil & $\begin{array}{l}\text { Soil } \rightarrow \text { vegetation } \rightarrow \text { ingestion } \rightarrow \text { mouse } \\
\text { Soil } \rightarrow \text { invertebrates } \rightarrow \text { ingestion } \rightarrow \text { mouse } \\
\text { Soil } \rightarrow \text { incidental ingestion } \rightarrow \text { mouse }\end{array}$ \\
\hline & Surface water & Surface water $\rightarrow$ ingestion $\rightarrow$ mouse \\
\hline \multirow[t]{2}{*}{ Eastern cottontail } & Soil & $\begin{array}{l}\text { Soil } \rightarrow \text { vegetation } \rightarrow \text { ingestion } \rightarrow \text { rabbit } \\
\text { Soil } \rightarrow \text { incidental ingestion } \rightarrow \text { rabbit }\end{array}$ \\
\hline & Surface water & Surface water $\rightarrow$ ingestion $\rightarrow$ rabbit \\
\hline \multirow[t]{2}{*}{ Red fox } & Soil & $\begin{array}{l}\text { Soil } \rightarrow \text { vegetation } \rightarrow \text { mouse } \rightarrow \text { ingestion } \rightarrow \text { fox } \\
\text { Soil } \rightarrow \text { invertebrate } \rightarrow \text { bird } \rightarrow \text { ingestion } \rightarrow \text { fox } \\
\text { Soil } \rightarrow \text { vegetation } \rightarrow \text { bird } \rightarrow \text { ingestion } \rightarrow \text { fox } \\
\text { Soil } \rightarrow \text { invertebrate/vegetation } \rightarrow \text { bird } \rightarrow \text { ingestion } \rightarrow \text { fox } \\
\text { Soil } \rightarrow \text { invertebrate } \rightarrow \text { ingestion } \rightarrow \text { fox } \\
\text { Soil } \rightarrow \text { vegetation } \rightarrow \text { ingestion } \rightarrow \text { fox } \\
\text { Soil } \rightarrow \text { incidental ingestion } \rightarrow \text { fox }\end{array}$ \\
\hline & Surface water & Surface water $\rightarrow$ ingestion $\rightarrow$ fox \\
\hline \multirow[t]{2}{*}{ White-tailed deer } & Soil & $\begin{array}{l}\text { Soil }- \text { vegetation }- \text { ingestion }- \text { deer } \\
\text { Soil } \rightarrow \text { incidental ingestion } \rightarrow \text { deer }\end{array}$ \\
\hline & Surface water & Surface water $\rightarrow$ ingestion $\rightarrow$ deer \\
\hline
\end{tabular}

Source: Hlohowskyj et al. (1996). 
calculated 95\% UCL serves as an estimate of the reasonable maximum exposure (RME), which is defined as the maximum exposure reasonably expected to occur at a site (EPA 1989).

The 95\% UCL of an individual contaminant in a particular medium was calculated for each area of concern with data collected during the remedial investigation (Yuen et al. 1996) by using the following equation:

$$
95 \% \mathrm{UCL}=X+t(s / \sqrt{n})
$$

where

$$
\begin{aligned}
X= & \text { arithmetic mean of the characterization data, } \\
t= & \begin{array}{l}
\text { one-tailed } t \text {-statistic value with } n-1 \text { degrees of freedom and a } \\
\text { significance level of } P<0.05,
\end{array} \\
s= & \text { arithmetic standard deviation of the characterization data, and } \\
n= & \text { sample size. }
\end{aligned}
$$

The calculated $95 \%$ UCL was used as the RME exposure point concentration for modeling contaminant uptake unless the calculated $95 \%$ UCL exceeded the maximum reported concentration or was less than $80 \%$ of the maximum concentration. In such cases, the maximum reported concentration was used as the RME exposure point concentration. Thus, the RME concentration of each COEC at each area of concern was estimated by medium by using either the $95 \%$ UCL or the maximum reported concentration of the COEC. The RME concentrations used for modeling contaminant uptake by receptors at the TBP area are presented in Table E.2.

\section{E.2.5 Exposure Factors}

Exposure factors are the species-specific physiological and life history parameters that directly affect contaminant uptake. Physiological parameters include body weight; surface area; metabolic rate; assimilation efficiency; and rates of food, water, soil, and sediment ingestion. Life history parameters include home range, diet composition, and seasonal activity. These parameters are analogous to the standard exposure factors used to model contaminant uptake in human health risk assessments. 
TABLE E.2 Exposure Point Concentrations of Contaminants of Ecological Concern for the TBP Area

\begin{tabular}{|c|c|c|c|}
\hline \multirow[b]{2}{*}{ Contaminant } & \multicolumn{3}{|c|}{ Exposure Point Concentration (Maximum Value) } \\
\hline & Surface Water $(\mu \mathrm{g} / \mathrm{L})$ & Sediment $(\mu \mathrm{g} / \mathrm{kg})$ & Soil $(\mu \mathrm{g} / \mathrm{kg})$ \\
\hline \multicolumn{4}{|l|}{ Metals } \\
\hline Aluminum & $18,000^{2}$ & $26.9 \times 10^{6 a}$ & $22.6 \times 10^{6}$ \\
\hline Antimony & 32.9 & 15,900 & 501,000 \\
\hline Arsenic & $36.3^{\mathrm{a}}$ & $14,100^{2}$ & $1.4 \times 10^{6}$ \\
\hline Barium & 559 & $927,000^{a}$ & $1.6 \times 10^{6}$ \\
\hline Beryllium & $-{ }^{b}$ & 1,050 & 1,380 \\
\hline Cadmium & $13.4^{\mathrm{a}}$ & $7,040^{a}$ & 35,500 \\
\hline Chromium & $64.8^{\mathrm{a}}$ & $80,200^{\mathrm{a}}$ & 878,000 \\
\hline Cobalt & 104 & 9,000 & 108,000 \\
\hline Copper & 525 & $515,000^{2}$ & $4.32 \times 10^{6}$ \\
\hline Cyanide & - & - & 120,000 \\
\hline Iron & 181,100 & $35.6 \times 10^{6 a}$ & $154 \times 10^{6}$ \\
\hline Lead & $1,590^{\mathrm{a}}$ & $1.8 \times 10^{6 \mathrm{a}}$ & $94.2 \times 10^{6}$ \\
\hline Magnesium & 228,000 & $5.1 \times 10^{6 a}$ & $3.9 \times 10^{6}$ \\
\hline Mercury & $1.7^{\mathrm{a}}$ & $1,710^{2}$ & 3,600 \\
\hline Nickel & $116^{\mathrm{a}}$ & $35,200^{2}$ & 84,500 \\
\hline Potassium & $38,700^{2}$ & $1.6 \times 10^{6 a}$ & $1.5 \times 10^{6}$ \\
\hline Selenium & 3.4 & 927 & 7,120 \\
\hline Silver & 7.6 & 3,740 & 41,900 \\
\hline Sodium & 958,000 & $1.8 \times 10^{6 \mathrm{a}}$ & 521,000 \\
\hline Zinc & 4,040 & $3.4 \times 10^{6 \mathrm{a}}$ & $17.8 \times 10^{6}$ \\
\hline \multicolumn{4}{|l|}{ VOCs and SVOCs } \\
\hline Acetone & $32^{\mathrm{a}}$ & 200.0 & 20.0 \\
\hline Benzene & - & - & 100 \\
\hline Benzo(b)fluoranthene & - & - & 1,250 \\
\hline Benzo(k)fluoranthene & - & - & 1,250 \\
\hline 2-Butanone & - & 200.0 & 37.0 \\
\hline Chloroform & - & - & 50.0 \\
\hline 1,1-Dichloroethene & - & - & 100.0 \\
\hline Diethyl phthalate & - & - & 2,000 \\
\hline Fluorene & - & - & 1,250 \\
\hline Hexachlorobenzene & - & $360.5^{c}$ & 3,100 \\
\hline m\&p-Xylene & - & - & 50.0 \\
\hline 2-Methylnaphthalene & - & - & 1,250 \\
\hline 2-Methylphenol & - & - & 1,250 \\
\hline 4-Methylphenol & - & - & 1,250 \\
\hline
\end{tabular}


TABLE E.2 (Cont.)

\begin{tabular}{|c|c|c|c|}
\hline \multirow[b]{2}{*}{ Contaminant } & \multicolumn{3}{|c|}{ Exposure Point Concentration (Maximum Value) } \\
\hline & Surface Water $(\mu g / L)$ & Sediment $(\mu \mathrm{g} / \mathrm{kg})$ & Soil $(\mu \mathrm{g} / \mathrm{kg})$ \\
\hline \multicolumn{4}{|l|}{ VOCs and SVOCs (Cont.) } \\
\hline N-Nitrosodiphenylamine & - & - & 1,250 \\
\hline 1,1,2,2-Tetrachloroethane & $4,348.0$ & 23.0 & $2,500.0$ \\
\hline 2,4,6-Trichloroaniline & - & - & 7,900 \\
\hline \multicolumn{4}{|l|}{ Pesticide/PCB } \\
\hline Aroclor 1248 & - & - & 570.0 \\
\hline \multicolumn{4}{|c|}{ Chemical Warfare Agent/Degradation Product } \\
\hline Nitroglycerin & - & - & 15,300 \\
\hline \multicolumn{4}{|c|}{ a Not a COEC for the indicated medium. } \\
\hline \multicolumn{4}{|c|}{$\mathrm{b}-=$ Contaminant was not detected in the medium. } \\
\hline c Exposure point concentrat & $5 \%$ UCL. & & \\
\hline
\end{tabular}

Several data sources were used to obtain species-specific exposure factors, particularly the Wildlife Exposure Factors Handbook (EPA 1993) and the references cited therein. Other sources included the open scientific literature (Journal of Mammalogy, Auk, Wildlife Management, Transactions of the American Fisheries Society, and Journal of Herpetology). Table E.3 presents the species-specific exposure factors used to estimate contaminant uptake for vertebrate receptors at the TBP AOC. When species-specific exposure factors were unavailable, factors were estimated by using empirically derived allometric equations (EPA 1993) or by using exposure factors from related species.

\section{E.3 DESCRIPTION OF THE CONTAMINANT UPTAKE MODEL}

The contaminant uptake model was used to estimate the applied daily dose (ADD) that each receptor would receive for each contaminant, on the basis of the concentrations of those contaminants in the media and food items ingested by the receptor. Specifics of the contaminant uptake model relevant to the FFS are presented as follows. Additional information regarding the development and use of the contaminant uptake model for the TBP area, as well as other areas of concern at J-Field, is presented by Hlohowskyj et al. (1996). 
TABLE E.3 Species-Specific Exposure Factors Used to Model the Applied Daily Dose for Ecological Receptors that Use the TBP Area

\begin{tabular}{|c|c|c|c|c|c|c|c|c|}
\hline Species Parameter & Mallard & $\begin{array}{c}\text { American } \\
\text { Robin }\end{array}$ & $\begin{array}{c}\text { American } \\
\text { Kestrel }\end{array}$ & $\begin{array}{c}\text { Red-Tailed } \\
\text { Hawk }\end{array}$ & $\begin{array}{c}\text { White-Footed } \\
\text { Mouse }\end{array}$ & $\begin{array}{l}\text { Eastern } \\
\text { Cottontail }\end{array}$ & $\begin{array}{l}\text { White- } \\
\text { Tailed Deer }\end{array}$ & Red Fox \\
\hline Body weight (g) & 1,134 & 77 & 121 & 1,219 & 21 & 1,189 & 49,333 & 4,690 \\
\hline Home range (ha) & 580 & 0.8 & 131 & 697 & 0.06 & 3.8 & 16.2 & 699 \\
\hline Site use factor & 0.01 & 1.00 & 0.03 & 0.01 & 1.00 & 0.96 & 0.22 & 0.01 \\
\hline $\begin{array}{l}\text { Normalized } \\
\text { ingestion rate }(\mathrm{g} / \mathrm{g}-\mathrm{d})\end{array}$ & 0.05 & 1.52 & 0.31 & 0.09 & 0.45 & 0.34 & 0.017 & 0.06 \\
\hline $\begin{array}{l}\text { Normalized water } \\
\text { ingestion rate }(g / g-d)\end{array}$ & 0.06 & 0.14 & 0.12 & 0.06 & 0.09 & 0.1 & 0.07 & 0.15 \\
\hline Soil diet fraction (\%) & $2.0^{\mathrm{b}}$ & 0.8 & 0 & 0 & 2.0 & 2.0 & 2.0 & 2 \\
\hline Diet components & $\begin{array}{l}75 \% \\
\text { invertebrates/ } \\
25 \% \\
\text { vegetation }\end{array}$ & $\begin{array}{l}60 \% \\
\text { vegetation } \\
\text { (fruit)/40\% } \\
\text { invertebrates }\end{array}$ & $\begin{array}{l}33 \% \\
\text { invertebrates/ } \\
32 \% \text { small } \\
\text { mammals/ } \\
30 \% \text { birds/ } \\
5 \% \text { herpeto- } \\
\text { fauna }\end{array}$ & $\begin{array}{l}79 \% \text { small } \\
\text { mammals } / 13 \% \\
\text { herpetofauna/ } \\
8 \% \text { birds }\end{array}$ & $\begin{array}{l}58 \% \\
\text { invertebrates/ } \\
42 \% \\
\text { vegetation }\end{array}$ & $\begin{array}{l}100 \% \\
\text { vegetation }\end{array}$ & $\begin{array}{l}100 \% \\
\text { vegetation }\end{array}$ & $\begin{array}{l}65 \% \text { mammals/ } \\
17 \% \text { vegetation/ } \\
14 \% \text { birds/ } \\
4 \% \text { invertebrates }\end{array}$ \\
\hline
\end{tabular}

a For additional details regarding species-specific exposure factors used for uptake modeling, refer to Hlohowskyj et al. (1996).

b Sediment ingestion. 


\section{E.3.1 Model Assumptions}

Because of the limited availability of species-specific data, the following assumptions were made in modeling contaminant uptake to ecological receptors in the TBP area:

- The home range of each modeled receptor was centered on the area of concern.

- Consistent with EPA (1993) guidance, the home range included both daily activity and foraging ranges.

- All foraging activities of each receptor were constant and uniformly distributed over the receptor's entire home range.

- Contaminant uptake by biota does not significantly affect the environmental concentration of contaminants.

- When site-specific plant or invertebrate tissue concentrations were not available, published or estimated transfer factors were used to predict tissue concentrations.

- Contaminant assimilation was assumed to equal metabolizable energy assimilation efficiency; if that efficiency was unknown, complete (100\%) contaminant assimilation was assumed between trophic levels.

\section{E.3.2 Model Equations}

Equations used to predict contaminant uptake via root uptake by plants, through ingestion of contaminated food and water, and through incidental ingestion of soil are described in the following subsections.

\section{E.3.2.1 Root Uptake by Plants}

Information on contaminant concentrations in vegetation is important because vegetation is the principal food for herbivorous species and the base of the food chain for omnivorous and predatory terrestrial species. Contaminant concentrations in aboveground plant tissue at J-Field were measured directly by tissue analyses, and the measured tissue concentrations were used in uptake models that included a plant ingestion pathway (Hlohowskyj et al. 1996). If measured tissue data 
were unavailable for a specific contaminant, the aboveground plant tissue concentration was modeled by using the following equation:

$$
C_{p}=C_{s} \times \mathrm{SPTF}
$$

where

$$
\begin{aligned}
C_{p} & =\text { concentration of contaminant in plant tissue (mg/kg dry weight [DW]), } \\
C_{s} & =\text { exposure point concentration of contaminant in soil, and } \\
\text { SPTF } & =\text { soil-to-plant transfer factor for contaminant from soil (unitless). }
\end{aligned}
$$

This approach considers root uptake as the principal uptake pathway for terrestrial vegetation. The SPTF is expressed as the ratio of the contaminant concentration in milligrams per kilogram in aboveground plant tissue to the contaminant concentration in milligrams per kilogram in dry soil. When available, SPTFs from the Strenge and Peterson (1989) database were used. Alternatively, the SPTF was estimated by following McKone's (1993) approach:

$$
\operatorname{SPTF}_{i}=7.7 \times K_{o w}^{-0.58} \text {, }
$$

where $K_{o w}$ is the contaminant-specific octanol-water partition coefficient (unitless). This approach applies only to organic contaminants and was not used to estimate uptake of inorganic contaminants. The SPTF values for COECs in the TBP area are presented in Table E.4.

\section{E.3.2.2 Incidental Ingestion of Soil}

No methods estimate soil ingestion rates without determining insoluble ash weights of gastrointestinal contents, food items, soils, and scats. The Wildlife Exposure Factors Handbook (EPA 1993) provides estimates of the percent of soil in the diets of bird, mammal, and reptile species. For species for which no soil ingestion information was available, a default value of $2 \%$ of the total food ingestion was used. These values were used in the following equation to estimate contaminant uptake from incidental soil ingestion:

$$
\mathrm{ADD}_{s i}=\left(C_{s} \times F S \times I R_{\text {total }} \times F R\right) / B W
$$

where

$$
\mathrm{ADD}_{s i}=\text { applied daily dose from incidental ingestion of soil (mg/kg-d), }
$$


TABLE E.4 Soil-to-Plant Transfer Factors (SPTFs) Used to Model the Applied Daily Dose for Ecological Receptors that Use the TBP Area,

\begin{tabular}{|c|c|c|c|}
\hline Contaminant & $\begin{array}{c}\text { SPTF } \\
\text { (unitless) }\end{array}$ & Contaminant & $\begin{array}{c}\text { SPTF } \\
\text { (unitless) }\end{array}$ \\
\hline Metals & \multicolumn{3}{|c|}{ VOCs and SVOCs (Cont.) } \\
\hline Aluminum & 0.00018 & 2-Butanone & $1.00^{c}$ \\
\hline Antimony & 0.011 & Carbon disulfide & 0.676 \\
\hline Arsenic & 0.01 & Chloroform & 0.704 \\
\hline Barium & 0.15 & $4,4^{\prime}-\mathrm{DDD}$ & 0.00253 \\
\hline Beryllium & 0.00047 & 1,1-Dichloroethene & 0.836 \\
\hline Cadmium & 0.55 & Diethyl phthalate & 0.367 \\
\hline Chromium & 0.0075 & Fluorene & 0.0362 \\
\hline Cobalt & 0.0094 & Hexachlorobenzene & 0.00918 \\
\hline Copper & 0.13 & m\&p-Xylene & 0.126 \\
\hline Cyanide & 13.5 & 2-Methylnaphthalene & 0.00569 \\
\hline Iron & 0.004 & 2-Methylphenol & 0.704 \\
\hline Lead & 0.068 & 4-Methylphenol & 0.742 \\
\hline Magnesium & 0.13 & N-Nitrosodiphenylamine & 0.150 \\
\hline Mercury & 0.38 & 2,4,6-Trichloroaniline & $1.00^{c}$ \\
\hline $\begin{array}{l}\text { Nickel } \\
\text { Selenium }\end{array}$ & $\begin{array}{l}0.06 \\
1.30\end{array}$ & Pesticide/PCB & \\
\hline Silver & 1.50 & Aroclor 1248 & 0.00454 \\
\hline \multirow[t]{2}{*}{ Zinc } & 0.4 & & \\
\hline & & \multicolumn{2}{|c|}{ Chemical Warfare Agent/Degradation Product } \\
\hline VOCs and SVOCs & & Nitroglycerin & $0.885^{d}$ \\
\hline Acetone & 13.3 & & \\
\hline Benzene & 0.576 & & \\
\hline Benzo(b)fluoranthene & 0.00304 & & \\
\hline Benzo(k)fluoranthene & 0.00304 & & \\
\hline
\end{tabular}

a Source: Strenge and Peterson (1989), unless otherwise noted.

b Only final COECs for surface soils are included.

c No specific SPTF was available. A transfer factor of 1.00 , which assumes that the concentration in vegetation will equal the soil concentration, was used.

d Burrows et al. (1989). 


$$
\begin{aligned}
C_{s} & =\text { exposure point concentration for soil at the } \mathrm{AOC}(\mathrm{mg} / \mathrm{kg}), \\
F S & =\text { fraction of soil in diet (as percentage of diet on DW basis; unitless), } \\
I R_{\text {total }} & =\text { food ingestion rate on DW basis }(\mathrm{kg} / \mathrm{d}), \\
F R & =\text { fraction of total food intake from } \mathrm{AOC}, \text { and } \\
B W & =\text { body weight of receptor }(\mathrm{kg})
\end{aligned}
$$

Species-specific ingestion rates were obtained from the Wildlife Exposure Factors Handbook (EPA 1993) or the scientific literature, or they were estimated by using allometric equations developed by Nagy (1987) for predicting ingestion rates of some birds, mammals, and herpetofauna as a function of body weight (in grams).

The equations used for birds were as follows:

$$
\begin{aligned}
& I R=0.398 B W^{0.850} \text { for passerines, and } \\
& I R=0.301 B W^{0.751} \text { for nonpasserines. }
\end{aligned}
$$

The equations used for mammals were as follows:

$$
\begin{gathered}
\qquad I R=0.621 B W^{0.564} \text { for rodents, } \\
I R=0.577 B W^{0.727} \text { for herbivores, and } \\
I R=0.235 B W^{0.822} \text { for omnivorous (nonrodent) and carnivorous species. }
\end{gathered}
$$

For herpetofauna, food ingestion allometric equations were available only for iguanid lizards, and these were used for all herpetofauna, as necessary. The equations were as follows:

$$
\begin{gathered}
I R=0.019 B W^{0.841} \text { for herbivores, and } \\
I R=0.013 B W^{0.773} \text { for insectivores. }
\end{gathered}
$$

\section{E.3.2.3 Ingestion of Drinking Water}

Contaminant uptake from the ingestion of contaminated drinking water was estimated by using the following equation (EPA 1993):

$$
\mathrm{ADD}_{d w}=C_{d w} \times F R \times\left(I R_{d w} / B W\right)
$$


where

$$
\begin{aligned}
\mathrm{ADD}_{d w} & =\mathrm{ADD} \text { from drinking water }(\mathrm{mg} / \mathrm{kg}-\mathrm{d}), \\
C_{d w} & =\text { exposure point concentration at drinking water supply }(\mathrm{mg} / \mathrm{L}), \\
F R & =\text { fraction of total water ingestion from contaminated source, } \\
I R_{d w} & =\text { ingestion rate of drinking water }(\mathrm{g} / \mathrm{d}), \text { and } \\
B W & =\text { body weight }(\mathrm{g}) .
\end{aligned}
$$

Drinking water ingestion rates and body weights were obtained from the Wildlife Exposure Factors Handbook (EPA 1993) and the open scientific literature. Body weights were obtained from either field-measured weights or the Wildlife Exposure Factors Handbook (EPA 1993). The proportion of an organism's drinking water obtained from the TBP area was based on the site use factor for that organism.

\section{E.3.2.4 Equations for Ingestion of Food}

Contaminant transport from environmental media to herbivorous receptor species is relatively straightforward, because contaminated vegetation would be the only contaminated food source. For higher trophic level receptors, complex food chains and webs are typical, and modeling contaminant uptake from environmental media to the receptor becomes more complex. Contaminant uptake from ingestion of food was estimated according to EPA (1993) guidance and used the following equation:

$$
\mathrm{ADD}_{f i}=\sum_{k=1}^{m}\left(C_{k} \times D F_{k} \times S U \times N I R_{k}\right)
$$

where

$$
\begin{aligned}
\mathrm{ADD}_{f i} & =\mathrm{ADD} \text { from ingestion of contaminated food }(\mathrm{mg} / \mathrm{kg}-\mathrm{d}) ; \\
m & =\text { number of food items in the diet of the receptor species (unitless); } \\
C_{k} & =\text { contaminant concentration in food item } k(\mathrm{mg} / \mathrm{kg}) ; \\
D F_{k} & =\text { fraction of the total diet represented by food item } k \text { (unitless); }
\end{aligned}
$$




$$
\begin{aligned}
S U= & \text { site-use factor, calculated as the ratio of the area of contamination to } \\
& \text { the home range area (unitless); and } \\
N I R_{k}= & \text { normalized ingestion rate of food item } k, \\
= & \text { [non-normalized ingestion rate }(I R)(\mathrm{g} / \mathrm{d})] \div[\text { body weight }(B W)(\mathrm{g})] .
\end{aligned}
$$

The site-use factor was used to estimate the fraction of the diet obtained from a contaminated area, and this fraction of the diet was considered contaminated. Contaminant concentrations in food items were either based on actual tissue concentrations measured for selected biota at J-Field (Hlohowskyj et al. 1996) or modeled concentrations. For the latter approach, the contaminant concentration in a lower trophic level food item is estimated as follows:

$$
C_{k}=\sum_{1}^{N} \mathrm{ADD}_{k} \times A E
$$

where

$$
\begin{aligned}
C_{k}= & \begin{array}{l}
\text { contaminant concentration }(\mathrm{mg} / \mathrm{kg}) \text { in food item } k \text { resulting from all } \\
\text { appropriate uptake pathways, }
\end{array} \\
\mathrm{ADD}_{k}= & \begin{array}{l}
\mathrm{ADD} \text { to food item } k \text { from all appropriate uptake pathways }(\mathrm{mg} / \mathrm{kg}), \\
\text { and }
\end{array} \\
A E= & \text { assimilation efficiency (\%). }
\end{aligned}
$$

The types and numbers of uptake pathways vary according to food item and may include root uptake, incidental ingestion of contaminated media, and ingestion of drinking water and food.

Because the ADD represents only the dose that a receptor would receive and provides no information on how much of the dose is actually incorporated and could be passed along to other trophic levels, some measure of contaminant assimilation was necessary to more accurately predict contaminant concentration in food items. The assimilation efficiency $(A E)$ reflects the amount of the $\mathrm{ADD}$ that is retained and incorporated into the food item. Contaminant assimilation was estimated by using the metabolizable energy assimilation efficiencies provided in the Wildlife Exposure Factors Handbook (EPA 1993) and assuming that contaminant assimilation is directly proportional to the assimilation efficiency of metabolizable energy. A default $A E$ value of 1.00 (100\% assimilation) was assumed for food items for which no information was available regarding assimilation efficiencies of metabolizable energy. 


\section{E.4 ECOLOGICAL RISK EVALUATION}

After the $\mathrm{ADD}$ was estimated, the potential for adverse ecological effects to the receptor species was estimated by examining the ratio between the ADD and a contaminant-specific benchmark value that represents a safe dose. This ratio is termed the ecological effects quotient (EEQ), and a potential for adverse ecological effects is indicated for values exceeding 1.00 (Davis 1994).

\section{E.4.1 Benchmark Values}

Estimating the EEQ requires the use of benchmark values that represent contaminant concentrations considered to be acceptable ("safe") to biota. Benchmark values are contaminant- and species-specific; typically represent no-observed-adverse-effects-level (NOAEL) concentrations; and may include media concentrations, food concentrations, tissue concentrations, or dose estimates. Benchmark values used for estimating the EEQ were dose estimates given by Opresko et al. (1994). If a benchmark value was unavailable for a given receptor species, a benchmark value was extrapolated by using the following equation (Opresko et al. 1994) if a benchmark value for a closely related species was available:

$$
\mathrm{NOAEL}_{B}=\mathrm{NOAEL}_{A} \times\left(B W_{A} \div B W_{B}\right)^{1 / 3}
$$

where

$$
\begin{aligned}
& \text { NOAEL }_{B}=\text { benchmark NOAEL for target species } B \\
& \text { NOAEL }_{A}=\text { known benchmark NOAEL for closely related species } A \text {, and } \\
& B W \quad=\text { body weight of target }(B) \text { and related }(A) \text { species. }
\end{aligned}
$$

This methodology is similar to that used by EPA in carcinogenicity assessments and reportable quantity documents for adjusting from animal data to an equivalent human dose (EPA 1985, 1988). For some contaminants, an uncertainty factor was applied to make the benchmark value (and resultant risk estimate) more conservative (i.e., more sensitive to contaminant concentrations) as recommended by Davis (1994). For contaminants for which only lowest observed adverse effects levels are available, an uncertainty factor of 10 was used to develop an equivalent NOAEL value, which was then used to develop the benchmark value. 


\section{E.4.2 Environmental Effects Quotient}

The EEQ is calculated with the following equation:

$$
\mathrm{EEQ}=\mathrm{ADD} \div \text { Benchmark } \mathrm{ADD} \text {, }
$$

where

$$
\begin{array}{ll}
\mathrm{EEQ} & =\text { environmental effects quotient, } \\
\mathrm{ADD} & =\text { estimated applied daily dose, and } \\
\text { Benchmark } \mathrm{ADD}= & \text { applied daily dose reported to produce no adverse } \\
& \text { effect in the receptor species. }
\end{array}
$$

Values of the EEQ may vary from 0 to $\infty$, and values greater than 1.0 are considered to demonstrate a potential risk to the receptor from the predicted ADD. Values between 1.0 and 10.0 indicate a potential risk of adverse effects from the estimated ADD, values between 10.0 and 100.0 indicate moderately high potential risk, and values greater than 100 indicate extreme risk from the predicted ADD (Davis 1994). Benchmark values used in modeling the EEQ are shown in Table E.5.

\section{E.5 UNCERTAINTY IN ESTIMATING THE ADD AND EEQ}

A number of uncertainties are inherent in estimating the ADD and the EEQ, and these uncertainties could affect the estimated values of these endpoints as well as the final interpretation and incorporation of the estimates into the ecological risk assessment and remedial decisions for the TBP area. These uncertainties are discussed in the following subsections.

\section{E.5.1 Model Uncertainties}

The principal uncertainties associated with model assumptions relate to (1) estimating contaminant transfer between and assimilation within trophic levels; (2) using a uniform foraging activity over the entire home range of a species; (3) assuming the exposure point concentration is homogeneously distributed across the entire TBP area; and (4) using exposure factor data from geographically different populations, allometric equations, or closely related species. 
TABLE E.5 Species-Specific NOAEL Benchmark Values Used to Estimate the Environmental Effects Quotient

\begin{tabular}{|c|c|c|c|c|c|c|c|c|}
\hline Contaminant & Mallard & $\begin{array}{c}\text { American } \\
\text { Robin }\end{array}$ & $\begin{array}{l}\text { American } \\
\text { Kestrel }\end{array}$ & $\begin{array}{l}\text { Red-Tailed } \\
\text { Hawk }\end{array}$ & $\begin{array}{l}\text { White-Footed } \\
\text { Mouse }\end{array}$ & $\begin{array}{c}\text { Eastern } \\
\text { Cottontail }\end{array}$ & $\begin{array}{l}\text { White- } \\
\text { Tailed Deer }\end{array}$ & Red Fox \\
\hline \multicolumn{9}{|l|}{ Metals } \\
\hline Aluminum & 56.58 & 140.33 & 125.05 & 57.9 & 2.14 & 0.57 & 0.16 & 0.37 \\
\hline Antimony & $--^{a}$ & - & - & - & 0.14 & 0.04 & 0.01 & 0.02 \\
\hline Arsenic & 0.85 & 11.97 & 1.879 & 0.87 & 0.14 & 0.04 & 0.01 & 0.02 \\
\hline Barium & 9.76 & 24.22 & 21.576 & 9.99 & 13.55 & 3.62 & 1.02 & 2.34 \\
\hline Beryllium & - & - & - & - & 1.65 & 0.44 & 0.12 & 0.28 \\
\hline Cadmium & 1.43 & 3.54 & 3.1532 & 1.46 & 0.21 & 0.06 & 0.02 & 0.04 \\
\hline Chromium & 1.01 & 2.51 & 2.2462 & 1.04 & 8.17 & 2.18 & 0.61 & 1.41 \\
\hline Cobalt & - & - & - & - & - & - & - & - \\
\hline Copper & 25.37 & 62.92 & 56.067 & 25.96 & 41.26 & 11.03 & 3.09 & 7.13 \\
\hline Cyanide & - & - & - & - & 15.77 & 4.22 & 1.18 & 2.73 \\
\hline Lead & 1.84 & 4.58 & 4.0819 & 1.89 & 19.94 & 5.33 & 1.49 & 3.44 \\
\hline Mercury & 0.01 & 0.02 & 0.0216 & 0.01 & 0.02 & 0.004 & 0.001 & 0.003 \\
\hline Nickel & 67.06 & 166.33 & 148.88 & 68.63 & 99.68 & 26.64 & 7.47 & 17.22 \\
\hline Selenium & 0.50 & 1.17 & 1.04 & 0.48 & 0.08 & 0.02 & 0.01 & 0.01 \\
\hline Silver & - & - & - & - & - & - & - & - \\
\hline Zinc & 2.82 & 6.99 & 6.2417 & 2.89 & 398.72 & 106.55 & 29.89 & 68.88 \\
\hline \multicolumn{9}{|l|}{ VOCs and SVOCs } \\
\hline Acetone & - & - & - & - & 24.92 & 6.66 & 1.87 & 4.31 \\
\hline Benzene & - & - & - & - & 29.2 & 7.8 & 2.19 & 5.05 \\
\hline Benzo(b)fluoranthene & - & - & - & - & - & - & - & - \\
\hline Benzo(k)fluoranthene & - & - & - & - & - & - & - & - \\
\hline 2-Butanone & - & - & - & - & - & - & - & - \\
\hline Carbon disulfide & - & - & - & - & - & - & - & - \\
\hline Chloroform & - & - & - & - & 37.38 & 9.99 & 2.8 & 6.46 \\
\hline
\end{tabular}


TABLE E.5 (Cont.)

\begin{tabular}{lccccccc}
\hline \multicolumn{1}{c}{ Contaminant } & Mallard & $\begin{array}{c}\text { American } \\
\text { Robin }\end{array}$ & $\begin{array}{c}\text { American } \\
\text { Kestrel }\end{array}$ & $\begin{array}{c}\text { Red-Tailed } \\
\text { Hawk }\end{array}$ & $\begin{array}{c}\text { White-Footed } \\
\text { Mouse }\end{array}$ & $\begin{array}{c}\text { Eastern } \\
\text { Cottontail }\end{array}$ & $\begin{array}{c}\text { White- } \\
\text { Tailed Deer }\end{array}$ \\
Red Fox
\end{tabular}

a $-=$ Not available.

Source: Opresko et al. (1994). 
The transfer and assimilation of contaminants between and within trophic levels is affected by a variety of factors not addressed by the uptake models. These factors include, but are not limited to, the following: (1) contaminant solubility in biological fluids, (2) location of the contaminant in a food item relative to the portion of the food item eaten, (3) species metabolism, (4) contaminant biotransformation, and (5) depuration. For most biota, it is unlikely that the transfer or assimilation of a contaminant is $100 \%$ efficient. Thus, assuming $100 \%$ contaminant assimilation likely overestimates the true degree of contaminant movement and assimilation within food chains. Furthermore, it is not known whether the assimilation efficiency of metabolizable energy is directly proportional to contaminant assimilation, and the use of the assimilation efficiency of metabolizable energy does not take into account contaminant depuration or detoxification.

The assumption that foraging activity is constant over the entire home range is probably inaccurate. Most resources utilized by biota, including food and water, are distributed in a patchy, heterogeneous manner in the environment. Therefore, foraging activity would also occur in a patchy manner. However, the assumption of uniform foraging activity is conservative and should not affect the overall $\mathrm{ADD}$ estimate.

For each COEC, the uptake models use an exposure point concentration that is either the maximum reported concentration reported from the TBP area or the 95\% UCL of all the reported concentrations. The use of either value as the exposure point concentration is consistent with EPA Region III guidance (Davis 1994) and results in a very conservative modeled daily contaminant uptake. For the uptake models, the exposure point concentration is assumed to be present across the entire site, and the EEQ risk estimates represent the potential risk to ecological receptors from a uniform sitewide contaminant concentration. In reality, the exposure point concentrations (maximum or $95 \%$ UCL) are restricted to specific locations within the TBP area, such as the pits and trenches, and concentrations at most locations within the TBP area are much lower than the exposure point concentrations. Thus, the EEQ risk estimates are likely greatly overestimated and the ecological riskbased PRGs are likely overprotective for most, if not all, the contaminants and receptors.

Modeling contaminant doses to ecological receptors requires information on species-specific ecological and physiological parameters, such as ingestion rates, body weight, foraging area, and diet composition. In contrast to data for human health risk assessments, species-specific and population-specific data for the exposure factors are largely unavailable. Therefore, the exposure factors used in this risk assessment were either (1) species-specific but not population-specific, (2) not species-specific but from related taxa, or (3) developed with empirically derived allometric equations. Each of these sources may add uncertainty to the overall risk assessment.

For many ecological receptors evaluated at J-Field, species-specific but not population-specific data were available. For example, some exposure factors used for the tree swallow were derived from populations in Alberta, Canada. Use of species data from populations other than those at J-Field adds uncertainty to the uptake estimates because individuals that inhabit different portions of the total geographic range of the species (e.g., Florida and Wisconsin for the 
eastern cottontail) differ in physiology (e.g., higher metabolic and ingestion rates, smaller body weights) and life history (e.g., larger home range, different diet composition, different habitat use). An attempt was made to limit this type of uncertainty by using data from the geographically nearest populations as well as from populations inhabiting similar habitats.

In the absence of species-specific data, the uptake models used ecological and physiological data from a surrogate species. For example, the leopard frog was identified as an ecological receptor for J-Field, but the exposure factors used to model uptake by this species were for the closely related green frog. Uncertainty is added to the uptake estimate because of differences in physiology and genetics between the receptor and surrogate taxa. This uncertainty is smallest when closely related species (e.g., same genus) are used, and they increase with a decreasing level of taxonomic similarity (e.g., same family but different species). For this environmental risk assessment, the use of exposure factors for surrogate species was limited. The related uncertainty is considered and is not expected to affect the overall risk characterization.

Additional uncertainty is added to uptake modeling through the use of empirically derived allometric equations for estimating body surface area and ingestion rates. For many receptors, no information was available for these parameters, and values were estimated by using reported body weights and allometric equations. These equations were developed with mean values for several species within a taxonomic category, which may be very broad. For example, a relatively specific allometric equation was available for predicting food ingestion rates for rodents from body weight. Uncertainty is added because an individual species will exhibit values different from those predicted by an equation based on several species. In addition, physiological factors usually differ among genders and maturity levels, and predictions from allometric equations do not capture these differences. Uncertainty associated with allometric equations for food ingestion rates is reduced by very high regression coefficients for most of these equations $(>0.900)$, which indicate a very good prediction level.

\section{E.5.2 Risk Estimation}

\section{E.5.2.1 Benchmark Values}

Benchmark values were unavailable for some species and COECs, and the values had to be derived following the approach discussed in Section E.4.1. Developing these values required the use of data from other species. Thus, the uncertainty associated with deriving benchmark values is similar to that for the use of interspecific data in the uptake models. This uncertainty was addressed by using a correction factor to make the EEQ more conservative (Section E.4.2). 


\section{E.5.2.2 Ecological Effects Quotient}

Use of the EEQ for estimating risks to ecological receptors is subject to several inherent uncertainties: (1) the EEQ does not differentiate between long- and short-term effects on biota; (2) it does not consider synergistic or antagonistic interactions among contaminants, which increase or decrease contaminant effects; and (3) the risk estimate is only as good as the estimated ADD, the benchmark values, and their associated uncertainties. The overall risk estimate would be subject to a high degree of uncertainty if the EEQ were the only measure of risk. This uncertainty was reduced by evaluating the results of field studies and media toxicity investigations in a weight-of-evidence approach to estimate the overall risk (Hlohowskyj et al. 1996). The field investigations and biotic surveys provided information on the long-term ecological effects of site contamination, and toxicity testing measured the toxicity of the actual contaminant mixtures to which site biota are exposed.

\section{E.6 REFERENCES FOR APPENDIX E}

Burrows, E.P., et al., 1989, Organic Explosives and Related Compounds: Environmental and Health Considerations, Technical Report 8901, A210554, U.S. Army Biomedical Research and Development Laboratory, Frederick, Md., March.

Davis, R.S., 1994, Region III Interim Ecological Risk Assessment Guidelines, draft, U.S. Environmental Protection Agency, Region III, Philadelphia, Pa., July.

EPA: See U.S. Environmental Protection Agency.

Hlohowskyj, I., et al., 1996, Remedial Investigation Report for J-Field, Aberdeen Proving Ground, Maryland, Volume 2: Ecological Risk Assessment, draft prepared by Argonne National Laboratory, Argonne, Ill., for U.S. Army, Aberdeen Proving Ground, Md., Directorate of Safety, Health, and Environment.

McKone, T.E., 1993, "The Precision of QSAR Methods for Estimating Intermedia Transfer Factors in Exposure Assessments," SAR and QSAR in Environmental Research 1:41-51.

Nagy, K.A., 1987, "Field Metabolic Rate and Food Requirement Scaling in Mammals and Birds," Ecological Monographs 57:111-128.

Opresko, D.M., et al., 1994, Toxicological Benchmarks for Wildlife: 1994 Revision, ES/ER/TM-86/R1, prepared by Oak Ridge National Laboratory, Oak Ridge, Tenn., for U.S. Department of Energy, Office of Environmental Restoration and Waste Management, Sept. 
Strenge, D.L., and S.R. Peterson, 1989, Chemical Data Bases for the Multimedia Environmental Pollutant Assessment System (MEPAS): Version 1, PNL-7145, prepared by Pacific Northwest Laboratory under contract to U.S. Department of Energy, Office of Environmental Audit, Washington, D.C., Dec.

U.S. Environmental Protection Agency, 1985, Reference Values for Risk Assessment, prepared by Syracuse Research Corporation, Syracuse, N.Y., for Environmental Criteria and Assessment Office, Cincinnati, Ohio.

U.S. Environmental Protection Agency, 1988, Methodology for Evaluating Potential Carcinogenicity in Support of Reportable Quantity Adjustments Pursuant to CERCLA Section 102, OHEA-C-073, External Review Draft, Office of Health and Environmental Assessment, Washington, D.C.

U.S. Environmental Protection Agency, 1989, Risk Assessment Guidance for Superfund, Volume I: Human Health Evaluation Manual (Part A), EPA/540/1-89/002, Office of Emergency and Remedial Response, Washington, D.C., Dec.

U.S. Environmental Protection Agency, 1993, Wildlife Exposure Factors Handbook, Volume I, EPA/600/R-93/197a, Office of Research and Development, Washington, D.C., Dec.

Yuen, R., et al., 1996, Remedial Investigation Report for J-Field, Aberdeen Proving Ground, Maryland, Volume 1: Remedial Investigation Results, draft prepared by Argonne National Laboratory, Argonne, Ill., for U.S. Army, Aberdeen Proving Ground, Md., Directorate of Safety, Health, and Environment. 
APPENDIX F:

DETERMINING INTERIM REMEDIAL ACTION COSTS 
F-2 


\section{APPENDIX F:}

\section{DETERMINING INTERIM REMEDIAL ACTION COSTS}

This appendix discusses the methodology and assumptions used to determine the costs of the five final interim remedial action alternatives for the Toxic Burning Pits (TBP) area at J-Field. The costs are itemized by the various components that make up the treatment train (see Tables 7.1, 7.2, 7.3, and 7.4). The cost estimate of each alternative is further subdivided into direct and indirect costs. The cost estimates for Alternative 2 were developed by ICF Kaiser Engineers, Inc. Cost estimates for Alternatives 3 through 5 were developed by Argonne National Laboratory (ANL) using the Remedial Action Cost Engineering and Requirements System (RACER) and contractor estimates.

\section{F.1 ALTERNATIVE 2}

This subsection discusses the methodology and assumptions used to determine the costs of Alternative 2 (in-situ containment, limited excavation, and off-site disposal) developed by ICF Kaiser Engineers, Inc.

The following tasks for Alternative 2 are direct costs: repair/resurface roads; unexploded ordnance (UXO) screening; site clearing; pit excavation, drumming and staging polychlorinated biphenyl- (PCB-) contaminated soil, metals-contaminated soil, and remediation-derived wastes; off-site disposal of PCB-contaminated soil, metals-contaminated soil, and remediation-derived wastes; sampling and analysis; landscape excavated area; remedial action professional labor; remedial design; 2-ft earth cover over site; site stakeout and control; sediment control plans and specifications; perimeter dike with flood protection; beach erosion control; contractor general conditions; and operation and maintenance (O\&M).

All costs were provided by team subcontractors except for UXO screening, sampling and analysis, off-site disposal of soil, contractor general conditions, and O\&M. UXO screening costs were determined from actual costs for UXO screening on previous remediation projects. Analytical costs were based on prices quoted by two independent laboratories that are approved by the U.S. Army Toxic and Hazardous Materials Agency. Off-site disposal and transportation costs are based on quotes provided by several disposal facilities and waste "brokers." Contractor general condition costs are associated with field-related tasks required to execute a contract but are not specific to a technology or restoration task. Contractor general costs include personal protective equipment, per diem, contractor insurance, and bonds. O\&M costs are associated with the upkeep of the soil cover and erosion control méasures. The O\&M costs are for a 30-year period. 
The indirect cost for Alternative 2 is contractor overhead. Contractor overhead includes fringe, legal and accounting, leasing office space, utilities, vehicle leasing, and communications equipment. A Baltimore U.S. Army Corps of Engineers Total Environmental Restoration Contract(TERC-) approved field rate multiplier was used to determine the contractor overhead cost.

The fee for performing the project is $8 \%$ of the sum of the loaded cost (which includes subcontractor and other direct costs), direct, and overhead costs. The total contractor cost of this alternative is the sum of the loaded cost, direct cost, overhead, and fee.

Project management was calculated as a percentage of the total contractor cost and is added to the project estimate to account for the costs associated with contract management, supervision, and oversight. A value of $8 \%$ of the total contractor cost was used for the Alternative 2 cost estimate.

Contingency costs are added to a project for costs that may be incurred as a result of unforeseen conditions. The contingency cost for Alternative 2 was calculated as a percentage of the total contractor cost. A contingency percentage of $10 \%$ was chosen per request of the U.S. Army's Directorate of Safety, Health, and Environment (DSHE), which is within the range recommended by the U.S. Department of Energy's (1990) Office of Environmental Management for projects in the preliminary stage of the remediation process.

The total project cost is the sum of the total contractor cost, project management cost, and contingency cost.

\section{F.2 ALTERNATIVES 3 THROUGH 5}

The costs of most of the components of Alternatives 3 through 5 were estimated by the Center for Cost Engineering of ANL's Decision and Information Sciences Division using RACER. This environmental cost estimating model was developed by the U.S. Air Force to estimate the total cost (both direct and indirect costs) of remedial actions performed under its Installation Restoration Program. RACER is PC-based and can be used to estimate costs for all phases of remediation, which include studies (e.g., remedial investigation/feasibility study and Resource Conservation and Recovery Act feasibility investigation/corrective measures study), remedial design, remedial action, and site work and utilities (Delta Research Corp. 1995). The remedial action costs are also subdivided into costs incurred during the construction/start-up activities and costs incurred during the operation and maintenance phase of the restoration process.

In the RACER model, direct costs are defined as all costs that can be directly attributed to a particular item of work or activity. Indirect costs are defined as those costs that cannot be identified specifically with a particular activity, cannot be charged to a specific element of work, or do not become a permanent part of any facility constructed. Indirect costs, such as contractor general 
conditions, contractor overhead and profit, escalation, contingencies, and project management, are summed separately from the direct costs for each treatment train component. The cost associated with the design of the treatment train (the remedial design) is also separated out but categorized as a direct cost. The total project cost of each alternative is the sum of the direct and indirect costs of the remedial action, contingencies, and project management.

The cost estimating process begins by identifying all components that make up the treatment train, including material transport, waste disposal, and any site work and utilities that are needed to perform the remedial action (e.g., construction/improvement of access roads, extension of overhead electric service). Each component is then modeled using RACER. RACER can model 54 remedial action processes/technologies and 36 site work and utilities activities.

RACER uses a parametric modeling technique similar to the U.S. Air Force's Construction Cost Management Analysis System (CCMAS). The basic concept of RACER is that predefined engineering relationships link primary parameters to detailed quantities. These quantities are then priced using established cost databases. RACER cost models are based on generic engineering solutions for environmental projects, technologies, and processes. The engineering solutions were derived from research, government laboratories, construction management agencies, vendors, contractors, engineering analysis, and historic project information. Design parameters within the cost models are tailored by the estimator to reflect specific project conditions and requirements. The tailored design is translated into specific quantities of work, which are priced by using current price. data. The assembly cost database was developed from the Corps of Engineers' Unit Price Book and supplemented by vendor and contractor quotes.

Included in every treatment train is the Professional Labor model. If a model in the remedial action treatment train includes professional labor tasks, this information is passed to the Professional Labor model instead of accounting for the costs in the remedial action model itself. This method avoids double counting of professional labor tasks, and all professional labor information is consolidated into one model. The model identifies the default labor hours as determined by the remedial action models. However, the user can override these default values to reflect specific project conditions. Professional labor includes activities that provide interpretation of the performance of the remedial action during both the construction/startup and operation and maintenance phases of the environmental restoration process. Typical professional labor activities associated with remedial action construction include oversight of construction activities, permit acquisition, and "as built" drawings. Professional labor activities associated with operation and maintenance include evaluation of sampling and analysis data, comparison of results with project goals, coordination of field activities, and documentation and reporting of all efforts.

RACER has two types of input parameters: required and secondary parameters. Required parameters describe site-specific conditions that impact the overall engineering design and are the minimum amount of information required by RACER to generate a cost estimate. Secondary 
parameters further describe the generic engineering solutions as applied to the specific site requirements. Unlike the required parameters, secondary parameters have defaults that are determined by the model. However, if more detailed information is known, the secondary parameters can be modified to create a more precise and site-specific estimate. The parameters drive the assembly quantities for specific items of work and materials that are part of the engineering design. These quantities are determined at a detailed level, such as engineering manhours by discipline, number of groundwater pumps by size, and cubic yards of soil excavated. Costs of these quantities are then determined using the assembly price data built into the model. The costs are also subdivided in terms of the unit costs for the material, labor, and equipment costs for each assembly. RACER has a great deal of flexibility because it allows the estimator to "fine tune" or customize an estimate (1) by overriding assembly quantities calculated by the model or unit costs derived from the price database or (2) by allowing the estimator to select additional assemblies not originally chosen by the model.

The remedial design cost is calculated by multiplying the direct cost of the remedial action by a design percentage. The purpose of the remedial design phase is to develop detailed designs, plans, specifications, and bid documents for conducting the remedial action. The design percentage can vary from 3 to $10 \%$ depending on the complexity of the remedial action and is applied to the total direct cost of the remedial action treatment train. This is the cost before contractor general conditions, overhead and profit, escalation, project management, and contingencies are added.

After the direct and remedial design costs are calculated, RACER can be used to calculate the indirect costs of the remediation that arise from the contractor general conditions, contractor overhead and profit, project schedule, contingencies, and project management. A separate module calculates the contribution of each component to the total remediation cost. Contractor general conditions are costs for items associated with field-related tasks required to execute a contract but are not specific to a technology or restoration task. These items may include supervision, temporary facilities, personal protective equipment, office trailers, toilets, utilities, permits, photographs, per diem, and contractor's insurance and bonds, among others. Sales tax is normally included in the general conditions module; however, because work at Aberdeen is not subject to sales tax, this item was removed from the cost estimate.

Contractor overhead and profit is another component of indirect cost. As in contractor general conditions, office overhead represents expenses that are not chargeable to any specific project or restoration activity. Office overhead may include items such as home office rent or lease, utilities, communications equipment, salaries of home office employees, and legal and accounting costs. Profit is the amount of money included by the prime contractor and subcontractors in their price as compensation for risk, efforts, and endeavor in undertaking a project.

The project start date and anticipated duration are input to the schedule module to establish the midpoint of the project duration and the escalation factor associated with the midpoint date. An escalation factor is added to the direct costs to account for increases in equipment, material, and 
labor costs from the base year of the RACER model's cost database (January 1995 dollars) that would be incurred over the project period. The model default assumption for escalation is to escalate costs from the database date to the midpoint of the project. This method is common for most types of projects. The approach assumes that the rate of expenditure for the project will resemble a normal distribution (bell curve) and that roughly half of the project costs are spent before the project midpoint and half are spent after. The escalation tables included in RACER are based on the published escalation tables of the Office of Secretary of Defense. The user can override the escalation values calculated by RACER if more pertinent information is available.

RACER calculates a contingency cost as a percentage of the total contract cost, which is the sum of the direct cost, remedial design, contractor general conditions, contractor overhead and profit, and escalation. Contingencies are added to the project estimate to account for cost increases that may occur as a result of unforeseen condition and are based in part on reliability and completeness of data. Contingencies are used to account for "known unknowns" within the current project scope that typically occur during the project. Because the J-Field project is in the preliminary stage of the remediation process, a contingency of $10 \%$ was chosen per DSHE's request. This value is within the range of 10 to $60 \%$ contingency recommended by the U.S. Department of Energy's (1990) Office of Environmental Management for projects at this stage. The value used in this version of the FFS is less than in previous drafts. The site is now better characterized because more data have been obtained and analyzed; therefore, fewer unknowns and changes are expected.

RACER also calculates project management as a percentage of the total contract cost, and it is added to the project estimate to account for the cost paid to government agencies and/or contractors for contract management, supervision, and oversight. A value of $8 \%$ was used to calculate the cost of project management.

Components whose costs were not directly determined by the RACER model were the purchase and construction of a temporary storage facility and the construction of the riprap berm to stabilize the shoreline to the south of the TBP area. These costs were developed outside of the model on the basis of information obtained from the Army Corps of Engineers on a similar soil storage facility recently constructed in Winfield, West Virginia, and ICF Kaiser Engineers (beach erosion control).

Because of the conditions at the J-Field TBP area, the use of Level C personal protection was assumed for all treatment train components. This level of personal protection reduced worker and equipment productivity by $45 \%$ and $25 \%$, respectively. 


\section{F.3 REFERENCES FOR APPENDIX F}

Delta Research Corp., 1995, Remedial Action Cost Engineering and Requirements System (RACER) User Manual, Niceville, Fla.

U.S. Department of Energy, 1990, Cost Estimating Handbook for Environmental Restoration, Environmental Restoration and Waste Management Cost Assessment Team, Rev. 0, Sept. 
G-1

APPENDIX G:

ENGLISH/METRIC - METRIC/ENGLISH EQUIVALENTS 


$$
\text { G-2 }
$$


APPENDIX G:

\section{ENGLISH/METRIC — METRIC/ENGLISH EQUIVALENTS}

TABLE G.1 English/Metric Equivalents

\begin{tabular}{lrl}
\hline \multicolumn{1}{c}{ Multiply } & \multicolumn{1}{c}{ By } & \multicolumn{1}{c}{ To Obtain } \\
\hline & & \\
acres & 0.4047 & hectares (ha) \\
cubic feet $\left(\mathrm{ft}^{3}\right)$ & 0.02832 & cubic meters $\left(\mathrm{m}^{3}\right)$ \\
cubic yards $\left(\mathrm{yd}^{3}\right)$ & 0.7646 & cubic meters $\left(\mathrm{m}^{3}\right)$ \\
degrees Fahrenheit $\left({ }^{\circ} \mathrm{F}\right)-32$ & 0.5555 & degrees Celsius $\left({ }^{\circ} \mathrm{C}\right)$ \\
feet (ft) & 0.3048 & meters (m) \\
gallons (gal) & 3.785 & liters (L) \\
gallons (gal) & 0.003785 & cubic meters $\left(\mathrm{m}^{3}\right)$ \\
inches (in.) & 2.54 & centimeters $(\mathrm{cm})$ \\
miles (mi) & 1.609 & kilometers $(\mathrm{km})$ \\
pounds (lb) & 0.4536 & kilograms $(\mathrm{kg})$ \\
short tons (tons) & 907.2 & kilograms $(\mathrm{kg})$ \\
short tons (tons) & 0.90718 & metric tons $(\mathrm{t})$ \\
square feet $\left(\mathrm{ft}^{2}\right)$ & 0.0929 & square meters $\left(\mathrm{m}^{2}\right)$ \\
square yards $\left(\mathrm{yd}^{2}\right)$ & 0.8361 & square meters $\left(\mathrm{m}^{2}\right)$ \\
square miles $\left(\mathrm{mi}^{2}\right)$ & 2.590 & square kilometers $\left(\mathrm{km}^{2}\right)$ \\
\hline
\end{tabular}

TABLE G.2 Metric/English Equivalents

\begin{tabular}{lrl}
\hline \multicolumn{1}{c}{ Multiply } & \multicolumn{1}{c}{ By } & \multicolumn{1}{c}{ To Obtain } \\
\hline centimeters $(\mathrm{cm})$ & 0.3937 & inches (in.) \\
cubic meters $\left(\mathrm{m}^{3}\right)$ & 35.31 & cubic feet $\left(\mathrm{ft}^{3}\right)$ \\
cubic meters $\left(\mathrm{m}^{3}\right)$ & 1.308 & cubic yards $\left(\mathrm{yd}^{3}\right)$ \\
cubic meters $\left(\mathrm{m}^{3}\right)$ & 264.2 & gallons (gal) \\
degrees Celsius $\left({ }^{\circ} \mathrm{C}\right)+17.78$ & 1.8 & degrees Fahrenheit $\left({ }^{\circ} \mathrm{F}\right)$ \\
hectares (ha) & 2.471 & acres \\
kilograms $(\mathrm{kg})$ & 2.205 & pounds (lb) \\
kilograms $(\mathrm{kg})$ & 0.001102 & short tons (tons) \\
kilometers $(\mathrm{km})$ & 0.6214 & miles (mi) \\
liters $(\mathrm{L})$ & 0.2642 & gallons (gal) \\
meters (m) & 3.281 & feet (ft) \\
metric tons $(\mathrm{t})$ & 1.1023 & short tons (tons) \\
square kilometers $\left(\mathrm{km}^{2}\right)$ & 0.3861 & square miles $\left(\mathrm{m}^{2}\right)$ \\
square meters $\left(\mathrm{m}^{2}\right)$ & 10.76 & square feet $\left(\mathrm{ft}^{2}\right)$ \\
square meters $\left(\mathrm{m}^{2}\right)$ & 1.196 & square yards $\left(\mathrm{yd}^{2}\right)$ \\
\hline
\end{tabular}


G-4 